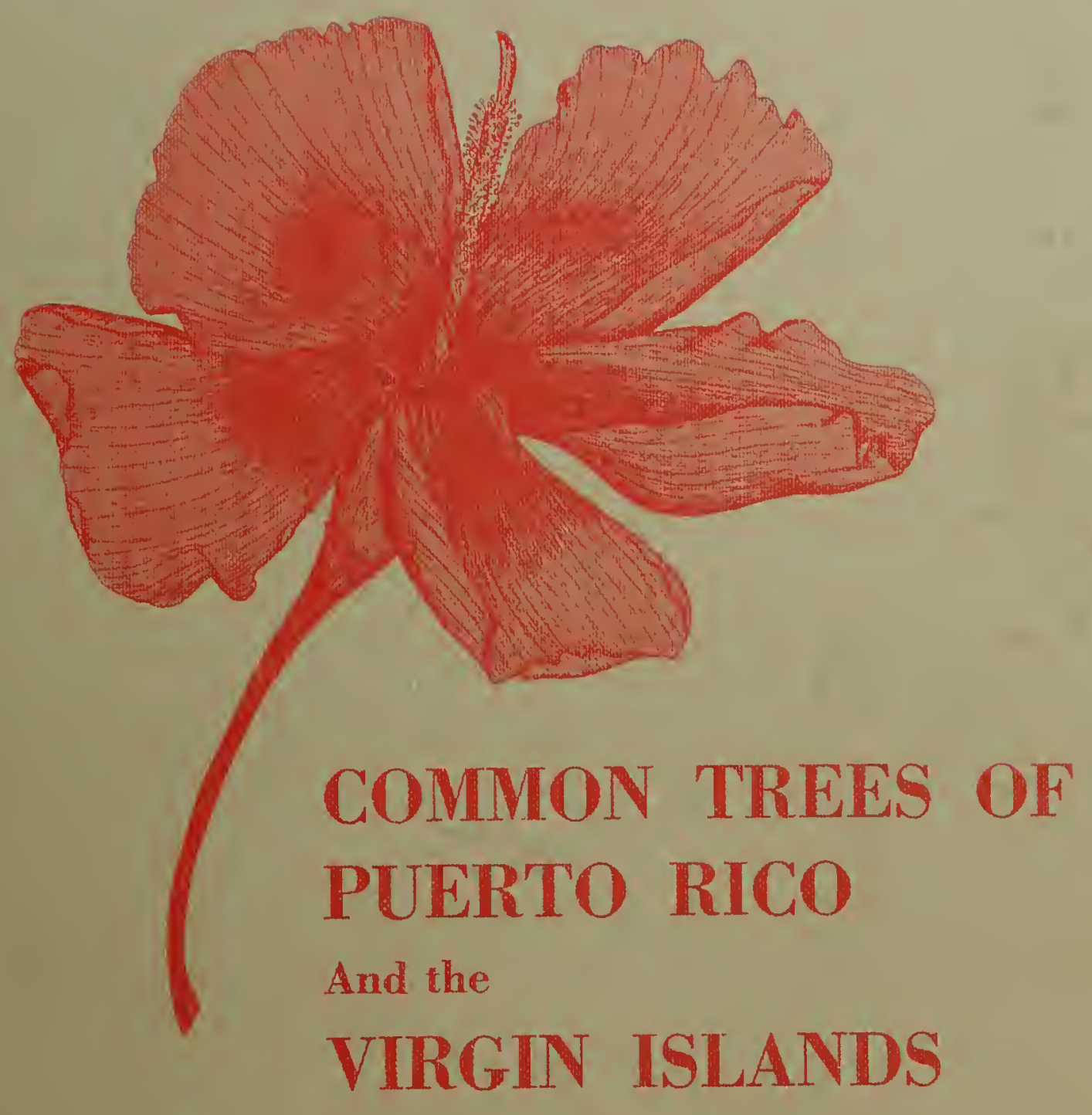

Elbert L. Little, Jr.

Frank H. Wadsworth 



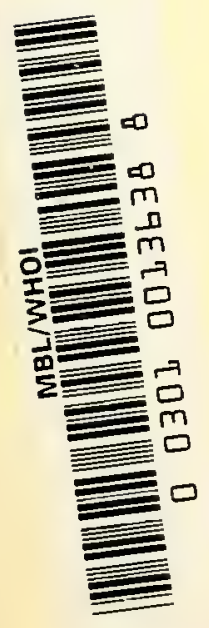




\title{
COMMON TREES OF
}

\section{PUERTO RICO}

AND THE

VIRGIN ISLANDS

\author{
By \\ ELBERT L. LITTLE, JR. \\ Dendrologist, Division of Timber Management Research \\ Forest Service, Washington, D.C. \\ and \\ FRANK H. WADSWORTH \\ Director, Institute of Tropical Forestry \\ Forest Service, Río Piedras, Puerto Rico
}


Library of Congress Catalag Card Number: Agr 64-50 


\section{CONTENTS}

List of tree species with descriptions and illustrations ............ Introduction...

Previous work

Preparation of this book $\ldots \ldots \ldots \ldots \ldots \ldots \ldots$

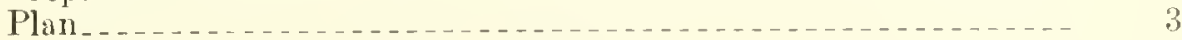

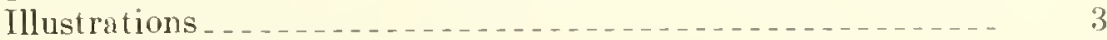

Tree names

Tree descriptions

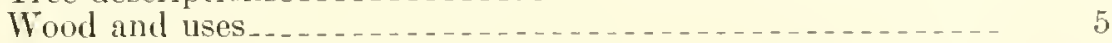

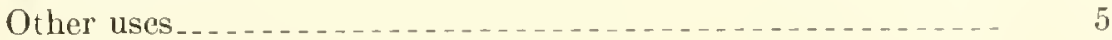

Propagation, growth, and other notes

Distribution

Related species

Explanation of botanical terms 9

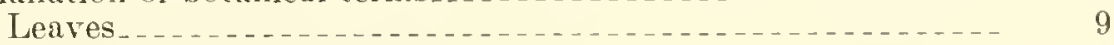

Flower clusters

Flowers . .

Fruits

How to use this book in tree identification 10

Statistical summary _.

Acknowledgments 11

Forests and forestry in Puerto Rico and the Yirgin Islands .

The virgin forests $\ldots \ldots \ldots$

The forests of today $\ldots \ldots \ldots \ldots$

Forest conservation

Literature cited

Special lists

Poisolious trees $\ldots \ldots \ldots \ldots$

Appearance and trunk 19

Colored sap or latex

Leaves_...

Flowers 19

Fruits

Uses

Planting lists 20

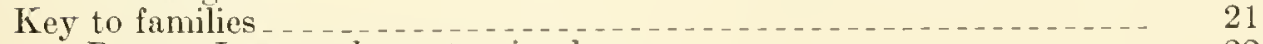

Part 1. Leaves altemate, simple

Part 2. Leaves alternate, compound 25

Part 3. Leaves opposite, simple

Part 4. Leaves opposite, compound 27

Tree species, descriptions and illustrations _................... 28

Index of common and scientific names........ 529 


\section{LIST OF TREE SPECIES WITH DESCRIPTIONS AND ILLUSTRATIONS}

Trec-fern family (Cyatheacene) . .

1. Heterho gigante, tree-fern, Cyathea arborea (L.) J. E. Smith

Yew family (Taxareae)

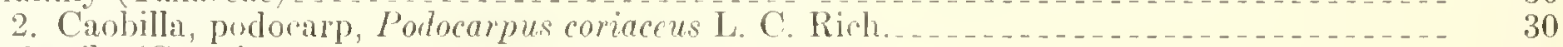

Grass family (Gramineae)

3. Baimbú, common bambo, Bambusa megris Schrad.*.

Palm family (Palmae)

4. Corozo, prickly-palm, Puerto Rico acrocomia, terocomia matia O. F. Cook

5. Palna de coyor, Aiphancs acanthophylla (Mart.) Burret _................... 36

6. Palma de coco, coronut, Cocos nucifera L.*

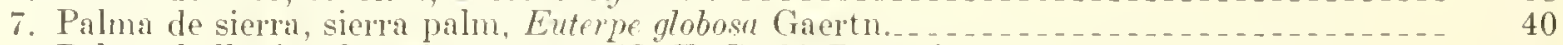

8. Palma de lluvia, Gaussia attenuata (O. F. Cook) Beceari _.

9. Palma real, royal palm, Puerto Rico royalpalm, Roystonca borinquena O. F. Cook

10. Palna de sombrero, Puerto Rico palmetto, Sabal causinum (O. F. Cook) Beceari_... 46

Casuarina family (Casuarinaceae*)

11. Casuariua, Australian heelwood, horsetail rasuarina, Casuarina equisetif lia L. * ..... 48

Pepper family (Piperaceae) .

12. Higuillo, Piper alluncum I.

Chloranthus family (Chloranthaceae)

13. Azafrán, Herlyosmum arboresecns Sw.

Willow family (Salienceae*)

14. Sauce, Humbold willow, Salix humbolitiana Willd.* ${ }^{-} \ldots \ldots$

Elm family (Thareate) _

15. Palo de calrilla, West Indies trema, Trema lamarchiana (Roem. \& Schult.) Blume... 56

16. Guacimilla, false jacocalalu, Florida trema, Trema micrantha (L.) Blume.......... 58

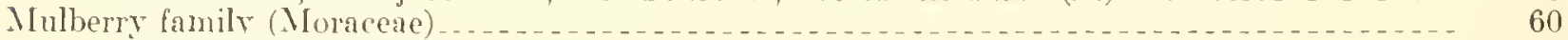

17. Panapén, pana de pepitas, breadfruit, Artocarpus altilis (Parkinson) Fosberg*

18. Jaca, jackfruit, Artocarpus hetroplyllus Lam.*

19. Caucho, Central Anerian rubber, castilla rubber, Castilla elastica Cervantes* ${ }^{*} \ldots$

20. Yagrumo hembra, trumpet-tree, Cecropia peltata L.

21. Palo de goma, India-rubber fig, Ficus clastica Nois. * $\ldots \ldots$

22. Jagüey blanen, shortleaf fig, Ficus laevigata Vahl $\ldots \ldots$

23. Laurel de la India, India-laurel fig, Ficus retusa L.* ${ }_{2} \ldots \ldots$

24. Tagüev colorado, Ficus sintenisii Warb.

Buckwheat family (Polygonaceae)

25. Tvilla, doveplum, Coccoloba diversifolia Jacq.

26. Moralón, Coccoloba pubescens I._._.

27. Ortegón, Coccoloba surartzii Meisn.

28. Ura de playa, seagrape, Coccoloba wifera (L.) L.

29. Calambreña, chicory-grape, Coccoloba venosa L........ 84

30. Triplaris, antree, Triplaris americana L.* *

Four-o'cloek family (Nyctaginaceae)

31. Corcho bobo, Pisonia albida (Heimerl) Britton 88

32. Corcho blanco, water mampoo, Pisonia subcordata Sw.

33. Corcho, black mampoo, Torrubia fragrans (Dum.-Cours.) Standley _._._.

Magnolia family (Magnoliaceae)

34. Jaguïilla, Magnolia portoricensis Bello

35. Laurel sabino, Magmolia splendens Lrban

Annona family (Annonacege) _._.

36. Guanábana cimarrona, wild soursop, Annona montana Macfadyen _............. 98

* Exotic, or introduced. Species (or families) with scientific names followed by an asterisk are not native in Puerto Rico and the Virgin Islands. 
Annona family-Continued

37. Guanábana, soursop, Annona muricata l.**

38. Corazón, custarl-apple, Annona reticulata L.*

39. Anón, sugar-apple, Annona squumosa I.*

40. Ilán-ilán, ylang-ylang, rananya odorata (Iam.) Hook. f. \& Thoms.*

41. Haya minga, Guatteria blainii (Griseb.) (Trban

Laurel family (I aniracene)

42. Guajón, Beilschmiclia pendula (Nw.) Benth. \& Hook. f.

43. Canelilla, Licaria salicifolia (Sw.) Tosterm

44. Palo de misanteco, Culf licaria, Licaria triandra (Sw.) Losterm.

45. I a urel avispillo, Jamaica nectandra, Nectandra coriacea (Sw.) Griseb.

46. Canclón, Ocotca cuncata (Griseb.) Lrban

47. I aurel espada, Ocotea floribunda (Sw.) Mez...

48. Laurel geo, Ocotea le licoxylon (Sw.) Mez

49. Nuez noserda, Ocotea moschata (Meisn.) Mez.

50. Nemocá, Ocotea spathulata Mez.

51. Aguacate, avoeado, Persea americana Mill.*

52. Mago, Hernandia sonora L.

Caper family (Capparidaceae)

53. Burro prieto, Jamaica caper, Capparis cynophallophora $\mathrm{I}$.

132

132

134

134

54. Resedá, horseradish-tree, Moringa oleifera Isam.*

136

55. Palo bobo, Brunellia comocladifolia Humb. \& Bompl.

56. Oreganillo, lleinmannia pinnata L.

57. Icaquillo, Hirtella rugosa Pers.

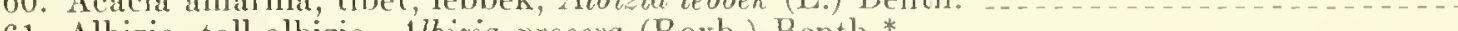

61. Albizia, tall albizia, Albizia procera (Roxb.) Benth.*

62. Guamá, "sweetpea," Inga laurina (Sw.) Willd.

63. Guamá venezolano, Inga quaternata Poepp. \& Endl. * $\ldots \ldots \ldots$

64. Guaba, Inga vera Willd.

65. Zarcilla, tantan, leadtree, Lencaena glanca (L.) Benth.

66. Cojóbana, Piptadenia peregrina (1.) Benth..

67. Cojóba, Pithecellobium arboreum (L.) Lrban.

68. Guamá americano, guamuchil, Pithecellobium dulce (Roxb.) Benth.*

69. Samún, raintree, Pithecellobium saman (Jacq.) Benth.*

73. Casia rosada, pink cassia, Cassia javanica L.*

74. Casia de Siam, Siamese cassia, Cassia siamea Lam.*

75. Flamboyán, flamboyant-tree, Delonir regia (Bojer) Raf.*

76. Algarrobo, West-Indian-locust, courbaril, Hymenaea courbaril L.

77. Palo de rayo, Jerusalem-thorn, Parkinsonia aculeata L *

78. Flamboyán amarillo, yellow flamboyant, Peltophorum inerme (Roxb.) Naves*

79. Cóbana negra, Stahlia monosperma ('Tul.) Crban

80. Tamarindo, tamarind, Tamarindus indica L.*

83. Bucare, swamp immortelle, Erythrina glauca Willd.*.

84. Bucayo gigante, mountain immortelle, Erythrina poepprigiana (Walp.) O. F. Cook*

85. Mata-ratón, mother-of-cocon, Gliricidia sepium (Jacq.) Steud.*

86. Retama, Lonchocarpus latifolius (Willd.) H. B. K.

87. Palo de matos, Ormosia krugii Urban 
Pea subfanily-Continued

8S. Tachuelo, fustic, Pictetia aculcata (Vahl) Urban

89. Pterocarpus, India padauk, Pterocarpus indicus Willd.*

90. Palo de pollo, swamp bloodwood, Pterocarpus officinalis Jacq.

91. Báculo, agati, Sesbania grandiflora (L.) Pers.*

Coca family (Erythroxylaceae)

92. Indio, Erythroxylon areolatum L.

Caltrop family (Zygophyllaceae)

93. GuaÝacán, common lignumvitae, Guaiacum officinale $\mathrm{L}$

94. Guayaćn blanco, holỵwood lignumvitae, Guaiacum sanctum L.

Rue family (Rutaceac)

95. Ten, sea amyris, Amyris elemifera $\mathrm{I}$.

96. I.imón ingrio, lime, Citmus aurantifolia (I.) Swingle**

97. Naranja agria, soul orange, Citrus aurantium L.*

98. Limón de cabro, lemon, Citrus limon (L.) Burm. f.*

99. Toronja, crapefruit, Citrus paradisi Macfadyen*

100. China, sweet orange, ritrus sinensis Osbeck*

101. Aceitillo, yellow-Sinders, yellow-heart, Zanthoxylum flacum Valil

102. Espino rubial, white-prickle, Martinique prickly-ash, Zanthoxylum martinicense (Lam.) DC.

103. Palo rubio, yellow-prickle, yellow prickly-ash, Zanthoxylum monophyllum (Lam.) P. Trilson

Ailanthus family (Simaroubaceae)

104. Guarema, bitterbush, Picramnia pentandra Sw.

Bursera family (Burseraceae)

105. Almácigo, turpentine-tree, gumbo-limbo, Bursera simaruba (I.) Sarg..-

106. 'Tabonuco, Dacryodes excelsea $\mathrm{Vahl}$

107. Masa, Tetragastris balsamifera (Sw.) Kuntze.

Mahogany family (Meliaceate)

10S. Cedro hembra, Spanish-cedar, Cedrela odorata L.

109. Guaraguao, American muskwood, Guarea trichilioides L.

110. Alelaila, chinuberry, Melia azedarach L.*

111. Caoba hondureñ, Honduras malogany, Swietenia macrophylla Kring*.

112. Caoba dominicana, Dominican mahogany, West Indies mahogany, Swietenia mahagoni Jacq. *

113. 'Tinacio, broomstick, Trichilia hirta L.

114. Gaeta, Trichilia pallida Sw.

Malpighia family (Malpighiaceae)

115. Maricao, Byrsonima coriacea (Sw.) DC

116. Marica cimarrón, Byrsonima crassifolia (L.) H. B. K.

Milkwort family (Polygalaceac)

117. Violeta, violet-tree, Polygala cowellit (Britton) Blake

Spurge family (Euphorbiaceac)

118. Achiotillo, Alchornea latifolia Sw.

119. Palo de gallina, Alchorneopsis portoricensis Urban.

120. Sabinón, Croton poecilanthus Urban

121. Varital, Drypetes glauca Vahl.

122. Rascaso, Euphorbia petiolaris Sims

123. Yaití, orsterwood, Gymnanthes lucida Sw.

124. Yanzaillo, on

124. Manzanillo, manchinecl, Hippomane mancinella L.

126. Cedro macho, IIyeronima clusiaides (Tul.) Muell.-Arg.

127. Grosella, Otaheite gooseberry-tree, Phyllanthus acidus (L.) Skeels*

129. Millo, Phyllanthus nobilis (L. f.) Muell.-Arg. -

129. Tabaiba, Sapium laurocerasus Desf.

Cashew family (Anacardiaceac)

130. Pajuil, cashew, Anacardium accidentale L.

131. Mango, Mangifera indica L.*

132. Papayo, Florida poisontree, Metopium toxiferum (L.) Krug \& Urban

133. Jobo de la India, ambarella, Spondias dulcis Parkinson*

134. Jobo, hogplum, yellow mombin, Spondias mombin L.

135. Ciruela del país, purple mombin, Spondias purpurea L.* 
Crrilla family (Cyrillaceae) -.

136. Palo colorado, swamp cyrilla, Cyrilla racemiflora L...

Bladdernut family (Staphyleaceac)

137. Sauco cimarrón, Turpinia paniculata Vent

Soapberry family (Sapindaceae) - . . Cura, Cupania americana I.

139. Neora lora, Matayba dominyensis (DC.) Radlk.

302

140. Quenepa, kinep, Spanish-line, Melicoccus bijugatus Jacq. *

302

141. Jaboneillo, wingleaf soapberry, Sapindus saponaria L.

304

306

142. Selrasuela, Thouinia portoricensis Radlk

305

143. Ceboruquillo, Thominia striata Radlk.

144. Aguacatillo, Meliosma herbcrtii Rolfe.

Buckthorn family (Rhammaceae)

145. Abevuelo, coffee colubrina, Colubrina arborescens (Mill.) Sarg. -

146. Mabí, soldierwood, Colubrina reclinata (L'Hér.) Brongn

147. Bariaco, "ironwood," leadwood, Krugiodendron ferreum (Tahl) T'rban

148. Cascarrova, Sarcomphalus reticulatus (Tahl) Lrban..

149. Notillo, Sloanca berteriana Choisy

Mallow family (Malvaceac) -

150. Emajagua, sea hibiscus, Mibiscus tiliaceus $\mathrm{L}^{*}$ *

151. Maga, Montezuma speciossima Sessé \& Moc.

152. Emajagüilla, otaheita, portiatree, Thespesia populnea (L.) Soland.*

Bombax family (Bombacaceae) Ceiba pentandra (L.) Gaertn

154. Guano, balsa, Ochroma pyramidale (Cav.) Urban .............................. 334

155. Garrocho, Quararibæa turbinata (Sw.) Poir............

Chocolate family (Sterculiaceae) _.

156. Guácima, jacocalalu, Guazuma ulmifolia Lam.

157. Anacagüita, panama-tree, Sterculia a petala (Jacq.) Karst. * .

158. Cacao, chocolate-tree, Theobroma cacao L.* *

Dillenia family (Dilleniaceae)

159. Dilenia, India dillenia, Dillenia indica $\mathbf{L}^{*} \ldots \ldots$

Tea family (Theaceae)

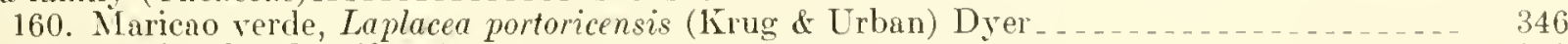

Mangosteen family (Guttiferae) _...

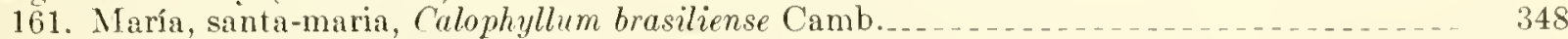

162. Cupéllo, Clusia krugiana Urban $\ldots \ldots \ldots \ldots \ldots$

163. Cupey, wild-mammee, copey clusia, Clusia rosea Jacq.

164. Mamer, mammee-apple, Mammea americana L. . . . . .

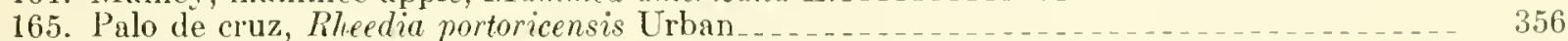

Anat to family (Bixaceae*)

166. Achiote, anatto, Bixa orellana L.* $\ldots$

Cochlospermum family (Cochlospermacene*) _. _ _ _ _ _

167. Rosa imperial, Brazilian-rose, cochlospermum, Cochlospermum vitifolium (Willd.) Spreng.*

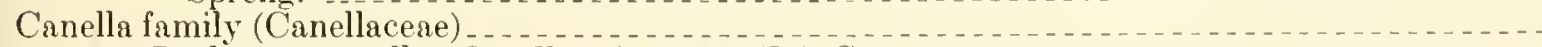

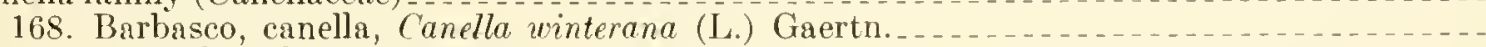

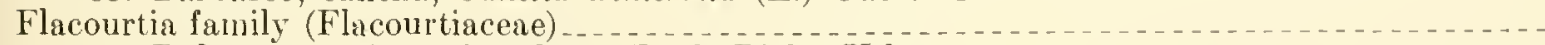

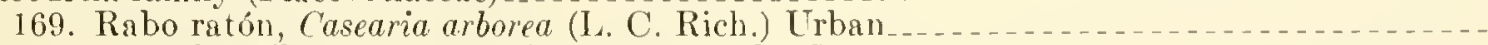

170. Tostado, wild honey-tree, Casearia decandra Jacq.

71. Palo blanco, wild-coffee, Casearia guianensis (Aubl.) Urban

173. Caracolillo, Homalium racemosum Jacq.

Papaya family (Caricaceae*) 174 . Lechosa, papaya, Carica papaya L.*

Cactus family (Cactacene)

175. Sebucán, dildo, Cephalocereus royenii (L.) Britton \& Rose $\ldots \ldots \ldots$

176. Tuna de petate, prickly pear', Opuntia rubescens Salm-Dyck

Nezercon family (Thymelaeaceae)

177. Majagua brava, Daphnopsis philippiana Krug \& Urban $\ldots \ldots \ldots \ldots \ldots$ 
Loosestrife family (Lythraceae)

178. Reina de las flores, queen-of-flowers, Layerstroemia speciosa (L.) Pers. *

Mangrove family (Rhizophoracene)

179. Mangle colorndo, mangrove, Rhizophora mangle L.

Combretum family (Combretaceae).

180. Granadillo, Buchenavia capitata (Tahl) Eichl.

181. Ucar, gregre, oxhorm hucidn, Bucida buceras I.

182. Nangle botón, button-mangrove, Conocarpus erectus $\mathrm{L}$.

183. Mangle blanco, white-mangrove, Laquncularia racemosa (L.) Gaertn. f.

184. Almendra, Indian-almond, Terminalia catappa L.*

Myrtle fumily (Myrtaceae)

185. Limoncillo, Calyptranthes krugii Kisersk.

186. Eucalipto, beakporl encalyptus, Eucalyptus robusta J. E. Smith*

187. Guasábaria, Eugenia aeruginea DC.

188. Pomarrosi, rose-apple, Eugenia jambos L." *

189. Manzana malaya, Malay-apple, Engenia malaccensis L.**

190. Hoja menuda, spiceberry eugenia, Eugenia rhombea (Berg) Krug \& Úrban.

191. Guayabota, Eugenia stahlii (Kiaersk.) Krug \& UTrban

192. Cieneguillo, Myrcia deficra (Poir.) DC

193. Hoja menuda, Myrcia splendens (Sw.) DC

194. Malagueta, bay-rum-tree, Pimenta racemosa (Mill.) J. W. Moore

195. Guaraba, common guava, Psidium guajara L.*

Melastome family (Melastomataceae)

196. Jusillo, Calycogonium squamulosum Cogn

197. Camasey peludo, Heterotrichum cymosum (Wendl.) Irban

198. Camasey, Miconia prasina (Sw.) DC..

199. Verdiseco, Tetrazygia elacagnoides (Nw.) DC.

Ginseng family (Araliaceae)

200. Pollo, Demdropanax arboreus (1.) Decne. \& Planch.

201. Yagrumo macho, mateliwood, Didymopanax morototoni (Aubl.) Decne. \& Planch.....

Myrsine family (Myrsinaceae)

202. Nameruelo, Ardisia oborata Desr

203. Mintequero, Rapanea ferruginea (Ruiz \& Pav.) Mez

204. Bádula, Guiana rapanea, Rapanca guianensis Aubl.

Sapodilla family (Sapotaceae)

205. Lechecillo, Chrysophyllum argenteum Jacq.

206. Caimito, star-apple, Chrysophyllum cainito L.

207. Caimitillo de perro, satinleaf, Chrysophyllum oliniforme L

208. Sanguinaria, wild mespel, willow bustic, Dipholis salicifolia (L.) A. DC.

209. Ausubo, balata, Manilkara billentata (A. DC.) Cher.

210. Níspero, sapodilla, Manilkara zapota (L.) v. Royen*

211. Caimitillo, Micropholis chrysophylloides Pierre

212. Caimitillo verde, Micropholis garciniaefolia Pierre

213. Jácana, Pouteria multiflora (A. DC.)Eyma

214. Tort ugo amarillo, false-mastic, Sideroxylon foetidissimum Jacq.

Swectleaf family (Symplocaceae).

215. Aceit una blanca, candlewood, Symplocos martinicensis Jacq.

Olive family (Oleacene)

216. Hueso blanco, Linnciera domingensis (Lam.) Kínobl.

Dogbane family (Apocynaceae)

217. Alelí, milktree, Plumeria alba L.

218. Frangipani, Plumeria rubra L.*

219. Palo a margo, bitter-ash, Rauvolfia nitida Jacq.

Borage family (Boraginaceae)

220. Palo de vaca, pigeon-berry, Bourreria succulenta Jacq

221. Capá prieto, eapa, Cordia alliodora (Ruiz \& Pav.) Oken

222. Muñeco, Cordia borinquensis Urban

223. Capá colorado, red manjack, Cordia nitula Yahl

224. Moral, white manjack, Cordia sulcata DC. 


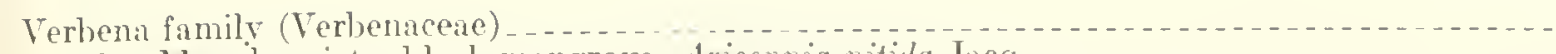

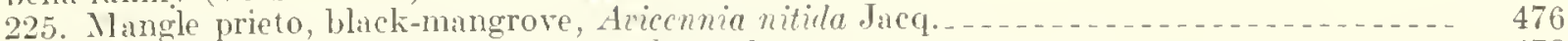

226. Péndula de sierra, Citharexylum caudatum l................................. 478

227. Péndula, pasture fiddlewood, Florida fiddlewood, ritharerylum fruticosum L. . _. _. . _ 480

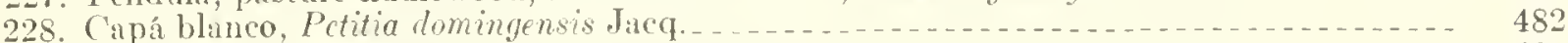

229. Teca, tenk, Tectona grandis L. f. * _ _

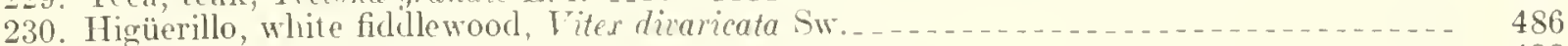

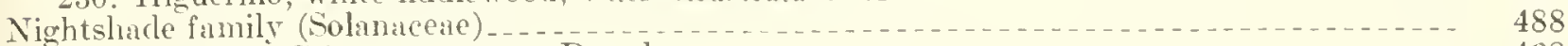

231. Tabacón, Solanum rugosum Dunal _...

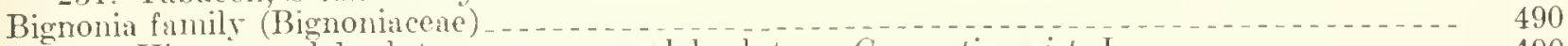

232. Higïero, calabash-tree, common calabasli-tree, Crescentia cujete L._._._._._. 490

233. Jacurunda, Jacaranda mimosifolia D. Don* _...... 492

234. Tulipán africano, African tuliptree, Spathodea campanulata Beanv.*_........... 494

235. Roble cimarıón, Tabebuia haemantha (Bert.) DC.

236. Roble blanco, "white-cedar," Tabebuia heterophylla (DC.) Britton_............... 498

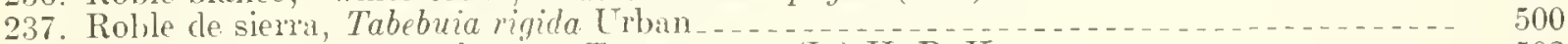

238. Roble amarillo, ginger-thomas, Tecoma stans (L.) H. B. K.

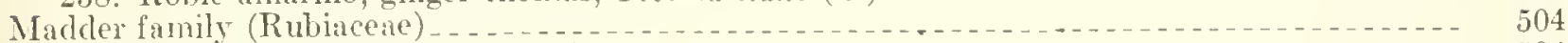

239. Quina, Antirhea obtusifolia UTrban

240. C'afé, coffee, Coffea arabica L.* $\ldots \ldots$

241. Albarilln, Caribbean princewood, Exostema caribaeum (Jacq.) Roem. \& Schult....... 508

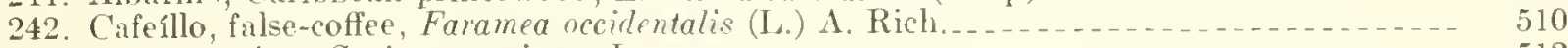

243. Jagua, genipa, Genipa americana L..._ _... _ _...

244. Palo de cucubano, "greenheart," ronghleaf velvetseed, Guettarda scabra (I.) Vent. ... 514

245. Cafeíllo, Ixora ferrca (Jacq.) Benth.

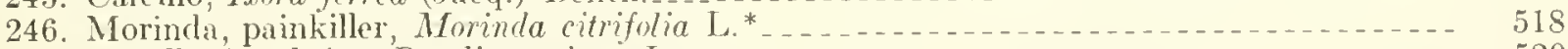

247. 'Tintillo, box-briar, Randia aculeata L.

248. Juan tomás, Rondeletia portoricensis Krug \& Urban _...................... 522

249. Aquilón, Terebraria resinosa (Vahl) Sprague $\ldots \ldots \ldots \ldots \ldots \ldots$

Composite family (Compositae)

250. Carruzo, Clibadium erosum (Sw.) DC. 


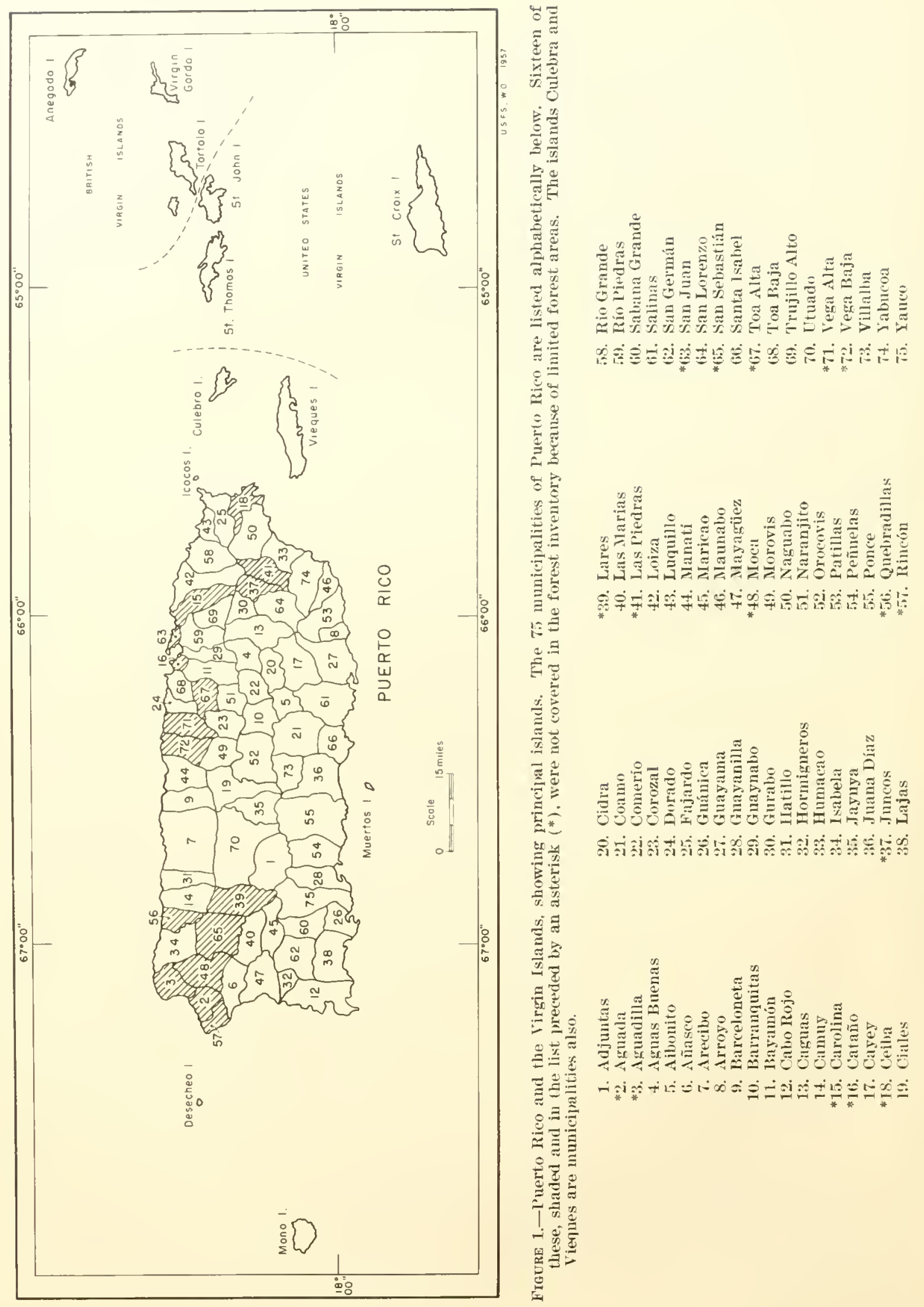




\section{INTRODUCTION}

About 500 species of trees, from the giants of the luxuriant rain forests to the shrubby trees of dry areas and windswept mountain summits, are native to Puerto Rico and the Tirgin Islands, both United States and British (fig. 1). In addition. several hundred tree species from other tropical lands around the world have been introduced into the islands because of showy flowers, handsome foliage, dense shade, valuable timber, delicious fruits, or other values.

Naturally, there have been many requests for a reference book on this subject. In formation about most trees of Puerto Rico and the Virgin Islands has not previously been assembled in nontechnical form, and drawings of some have never been published. Nor are technical botanical floras, forestry publications, and miscellaneous scientific references on this subject generally available.

This book describes in detail 250 of the commoner and more important native and exotic tree species, those most likely to be seen. Identification of each species is aided by a large drawing of the leaves, flowers, and fruit and a description that emplasizes the dist inguishing characteristics. For further identification, 130 additional, related species are mentioned briefly and compared with those illustrated. Thus, 380 species from forest giants down to small trees are included.

The primary purpose of this book, published also in Spanish (R1), is to answer for the people of these and nearby areas of the West Indies, both residents and tourists, the question: What tree is this? Having answered that, it aims to give the more important and interesting facts about the tree. It should be helpful to university sturlents, teachers of high schools, and instructors in youth prourams such as 4-H Chuls, Boy Scouts, and Girl Scouts. It should be a usefil reference in extension and technical assist ance programs, a gricultural research, forestry, and for landowners, landscape architects, and gardeners. Foresters and forestry students in continental United States will find here the descriptions of many common timber trees of tropical America.

For the rapidly increasing number of tourists from continental United States, this reference provides the tree names and answers questions. Public forests, both natura] and managed, are easily accessible by paved highways. The Tirgin Islands National Park contains large forest areas in St. John. 'Teachers, students, and all interested in nature can use this field guide in identification.

This reference will be useful over somewhat larger areas in tropical America because most of the tree species figured are widely clistributed. It will be of ralue also in the other West Indies and in countries bordering the Caribbean Sea not having similar publications.

1 lso this book will be helpful within continental Inited States, notably in southern Florida. More than half of the 250 species selected grow also in sonthern Florida. More than one-fourth, or 65, are in Check List of Native and Naturalized Trees of the United States (19); 42 as native, mostly in the Florida Keys of southern Florida mainland, and 23 as naturalizerl. Two more are shrubs in the United States, and the others are planted in southern Floricka, although some in limited numbers.

Because of their value and interest, 72 species of exotic or introduced trees mostly common through tropical America have been included. While the remaining 178 species illustrated are native in Puerto Rico, only 28 are confined or endemic there. According to their distribution, 101 of these are found also in the Virrin Islands, which have fewer tree species because of their smaller size and lower altitude; 148 are known in other West Indian islands; and 102 grow wild somewhere on the continent, such as in southern Florida, Mexico, Central America, or South America.

Information presented in addition to that required for identification assist s the readers to know the tree better and to judge its suitability for timber, shade, ornament, fruit, or other purposes. These notes include: (1) the size the tree attains at maturity; (2) whether evergreen or deciduous; (3) the normal shape of the crown; (4) the abundance, color, and fragrance of the flowers; (5) the kind of fruit and whether edible or poisonous: (6) the usual period of flowering and fruiting; (7) a brief description of the wood and its uses; (8) other uses of the tree and its products; (9) notes on propagation, growth rate, and site adaptability if available; (10) where the tree grows within Puerto Rico and the Virgin Islands; (11) the geographical distribution, including native home if introluced; (12) other common names listed by country and language; and (13) related mative tree species.

It was not possible to include within one volume an equal number of important though less common tree species. Several hundred additional tree species were recorded by Britton and Wilson (5) as introduced, mostly in small numbers or experimentally, such as in nurseries, experimental forests, arboreta, and gardens. A second volume is planned to describe and illustrate the remaining native tree species and widely planted exotics. 


\section{PREVIOUS WORK}

Preparing this book has alled for full use of the previous work of botanists ind foresters and also for adclitional field investigation. Pnerto Rico and the Virgin Islands, diseovered by Columbus, settled early, and both small and accessible, were among the first areas of tropical Anerica to become well explored botanically. Principal publications on the plants of these islands are listed in the biblingraphies by Britton and Trilson (5) and Otero, Toro, and Pagan (32), the latter containing also a historieal summary.

The nost valuable reference consulted is the descriptive flora of Puerto Rico and the Tirgin Islanis hy Britton and Wilson (5), published in English in 19:3-30. Earlier, in 1943-11, Trban (3\%) wrote a flora of Puprto Rico in Latin and Germatl. In 1883-58 there wis published in Puerto Riro an incomplete flora in spanish by Stall (35), afterwards reprinted in 1936-37. The Virgin Islands have been the subject of other floms, the earliest by Hans Thest in 1793. Another flora of the Virgin Islands by Eggers $(\delta a)$ appeared in 18\%9. Britton (4) puhlished a flora of the United states Tirgin Islands in 1918, a yean a fter their purchise from Demmirk.

Nearly a century ago, José María Fernández ( 9 . pp. 181-215) compiled a list of trees of Puerto Rico in his "Tratado de la Arboricultur"a Cubana," published in Havana in 1867. Entitled "Arlolado de Puerto-Rico," this amnotated list contained about 175 trees arranged by Spanish common names with scientific names for about 100. Introduced, as well as native, species and several shrubs were mentioned. There were notes on size, occurrence, wood including specific sravity, and nses and also lists for special purposes.

Shortly after Puerto Rico became a part of the United States in 1808, studies of the forests beann with a report by Hill (1.3) in 1899 which described 16 important timbers. In 1903 the Lnquillo Division of the Caribbean National Forest, now the Luquillo Experimental Forest, was established from former Spanish crown lands by proclamation of President Theodore Roosevelt. A preliminary list of trees of the Luquillo regrion was prepared soon afterwards by Gifford (10). Murphy (29), of the United States Forest Service, published a list of 292 tree species of Pnerto Rico belonging to 172 genera and 57 families, with notes on size, distribution, wood, and uses by W. D. Brush, Louis S. Murphy, and C. D. Mell. Holdridge and Muñoz (16) described and illustrated seven poisonous trees in an article on the poisonous plants of Puerto Rico. In his manual on propagation of trees and establishment of forest plantations, Gilormini (11) inserted a list of native and exotic trees and shrubs of Puerto Rico with botll Spanish and seientific names.

Much information abont forest trees of Puerto Rico and the Virgin Islands is contained in articles in 'The Caribben Forester and other publications by the Institute of Tropical Forestry. Longwood (2.2.23), of the United States Forest Service, made a special investigation of the woods of Puevto Rico and the Caribbean rearion, including about 70 species in this book.

The agrieultural experiment stations in Puerto Rico and the Virgin Islands have made additional studies of trees. Trolcott (40) tested the resistance of woods to attack by dry-wood termites. Winters and Almeyda (.39) reported on the ornamental trees of Puerto Rico. Fennard and Winters (18) deseribed and illustrated the conmon fruit trees in their publication on fruits and nuts. Poisonous plants of the United States Virgin Islands, several being trees, were described and figured by Oakes and Butcher (.30).

Other important references are mentioned below and listed under Literature Cited. Additional botanical floras and tree publications of various tropical countries, as well as taxonomic monosraplis, have provided useful information for this book.

\section{PREPARATION OF THIS BOOK}

Preparation of an illustrated popular reference on the trees of Puerto Rico wis one of the first projects undertaken when, in 1939, the United States Forest Service heran forest research in Plepto Rico with the establishment of the Tropical Forest Experiment Station, now Institute of Tropical Forestry, in Río Piedras. Leslie R. Holdridge, who was in charge of the project until the end of 1941, male hotanical collections of Puerto Riran trees and supervised the preparation of a few limndred drawings. He wrote two preliminary volumes of "Trees of Puerto Rico" $(14,15)$, published in 194: in hoth English and Spanish, each rolume containing drawings and deseriptions of 50 tree species. These small editions were soon exhausted. It was intended to issue additional palls covering a total of about 600 native and exotic tree species to he followed by a revision printed in a single volume. However, further work was smspended during the war. Identifications of sevcral hundred tree specimens collected mostly by Holdridge and Luis E. Gregory were made by the New Tork Botanical Garden. These specimens were the beginning of the Institute's herbarium.

The present project on the trees of Puerto Rico and the Tirgin Islands was begun by the anthors together in 1950 . The junior author had assisted in the earlier project upon his arrival in Puerto Rico in 1942, while the senior author did some reference work in 1941 . The area was expanded to include the nearby smaller. Tirgin Islands, both United States and British, which have fewer tree species and very few additions.

'The senior" anthor as dendrologist made field trips in Prerto Rico in 1950, 1952, 1954, and 1955. The botanical descriptions were prepared mostly 
by him from trees and living material supplemented by herbarim specimens. On field trips through Puerto Rico and on brief visits to Mona, St. Croix, St. Thomas, St. John, and Tortola, he collected about 1.200 numbers of herbarium specimens of trees. As a result, a few additional island records were obtained and one new tree species was named. An article on the trees of Mona Island (20) was based mainly on his two field trips there. In checking the identifications, he examined the collections from Puerto Rico and the Virgin Islands in the National Herbarim of the United States National Museum, IT ashington, D.C. Sets of specimens have been deposited there and in the herbarium of the Institute of Tropical Forestry and will be distributed to other herbaria.

The junior anthor, Director of the Institute of Tropical Forestry, has conducted forestry investiantious in Puerto Rico continnously since 1942 and has studied many of these tree species in the forests and experimental plots. He has prepared the chapter "Forests and Forestry in Puerto Rico and the Tirgin Islands," checked the descriptions, and contributed notes on wood and uses. Also, he has compiled the data on propagation, growth rate, and site adaptability, and distribution by forest types.

The manuscript was completed in 1955, then translated into Spanish for the Spanish edition, and has been slightly revised in 1962 before publication. The notes on Puerto Rican woods have been expanded to inchude later investigations at the Institute of Tropical Forestry. Also, many common names recorded in recent floras of other countries have been added.

\section{PLAN}

The 250 common tree species of Puerto Rico and the Virgin Islands described and illustrated in this rolume are grouped by plant families in the usual botanical arrangement adopted by Britton and Wilson (5) and within each family alphabetically by scientific names. However, the three large subfamilies of the legume family often accepted as separate families are kept apart. Sixty-eight plant families and 185 genera are represented.

\section{Illustrations}

Facing their respective descriptions, the line drawings show foliage and flowers and usmally also the fruits. Most are natural size (or very slightly reduced), but some have been leduced to $2 / 3$ and a few to $1 / 2$ natural size as indicated. Nearly all were made from fresh specimens in Puerto Rico.

\section{Tree Names}

The heading for the descriptive text of each species contains on the left the preferred common names in Spanish and English, on the right the accepted scientific name, and at top center the family names. In asterisk (*) after the scientific name means that the species (or family) is exotic, or introduced, and not native in Puerto Rico and the Virgin Islands. At the end of the text of eacl species are listed other common names in use and botanical synonyms, the other scientific names used formerly or sometimes now. These names appear also in the Index of Common and Scientific Names. English family names are clerived from an important example, while scientific or I at in family names terminate in "aceae" with few exceptions.

\section{Preferred Common Names}

Common names of trees often vary from place to place, some being applied to more than one mrelated speries, while other species may sometimes lack a distinctive local name. The aintho:s have attempted (1) to record all names commonly applied within this region to each species: (2) to select as a prefer'ed name the one most widely employed locally if not associated more commonly with another species: and (3) to suggest for species with no local common name one extensively used elsewhere. Since Spanish is the language of Puerto Rico, and English that of the Virgin Islands, two names are given for most trees present in both areas.

The Spanish common name in the heading is that preferable for Puerto Rico, based chiefly upon prevalent usage. The selection has been made after consultation with local botanists and with foresters both of the Commonwealth Division of Forests, Fisheries, and Wildlife and of the Institute of Tropical Forestry, United States Forest Service. Personnel of the Division who completed an island-wide forest inventory provided raluable information on usage.

English common names in the heading include those found in the Yirgin Islands or in widespread use elsewhere. These preferred names, many of which were listed by Britton and Wilson (5), were checked in the field with rural inhabitants on different islands. For the 65 species also native or naturalized in the United States, chiefly souther'n Florida, there is added the name accepted by the United States Folest Service in the Check List of Native and Naturalized Trees of the United States (19). For some less known species without local English names, those adopted elsewhere, such as in other. West Inclian islands, in Standardized Plant Names (17), or in commerce, have been accepted. Where two English common names are listed, the first is the local name in the Virgin Islands, and the second is either the Check List name adopted by the United States Forest Service and recommended for the United States or another name also widely employed. If no English name has been selected, the Spanish common name may be suitable or the generic name may serve. 


\section{Other Common Names}

For Prerto Riro and the Tirgin Islands many additional common names were obtained from local residents or taken from references, particnlarly Trban (3\%). Britton and Wilson (5), and Otero, Toro, and Pagán (32). Most of these have been rerified, but several, apparently misapplied, have been omitted. Is no Indian tribes have remained on Puerto Rico since the early Spanish settlement. there are now no separate aboriginal tree names. Howerer, some Spanish names are of Carib Indian origin. Though the Tnited States Virgin Islands belonged to Denmark until purchased by the Inited States in 1917, the tree names were English, and no Danish tree names are now recorded.

Principal common names in use in the New Torld have been compiled from many floras and tree lists of different conntries, and a few added from herbarium labels. These names often differ from country to country or from one island to another and may be in as many as five languages (Spanish, English, French, Dutch, and Portuguese), besides some of American Indian origin. Tariant spellings, aboriginal names, long lists of local names within one country, and Old World names generally have been omitted. Other com. mon names have been grouped hy language and conntries in the following order: Puerto Rico, Tirgin Istands, Spanish, other Spanish-speaking countries in West Indies, and from Mexico to South America: Inited States, Fnglish, British lands, and other English-speaking comntries: French, Haiti, French lands: Dutch West Indies and Surinam: and Brazil. Names in international commerce or lumber trade or so recommended are indicated. Some preferred names of Puerto Rico and the Virgin Islands are repeated under other common names to show usare elsewhere.

In the Mrest Indian islands some tree names are not in the same language of the goreming country, which may have changed one or more times since colonization. Persons migrating from one island to another have brought with them names from different languages. Some common names are colruptions from other tongues, such as French words somewhat modified in British areas. Tarious names have become adopted from Spanish, English, French, and Dutch into creole dialects. Ilso, European colonists often gave to tropical American trees the rell-known names of similar though umelated Old World species.

\section{Scientific Names}

Foresters, botanists, and other scientists use the scientific names in their technical writings and discussions. Being in Latin or Latinized, scientific. names are definite and uniform and regulated by botanists under the International Code of Botanical Nomenclature. Thus, the Latin name of a tree or other plant species in an international language is the same througliout the world.
The scientific name of a species consists of two words: the generic name, which is capitalized, and the specitic epithet. In some species, variet ies are distinguished, being designated by a third word preceded by the abbreviation "var." References and technical publications cite also the author or botanist who first named and described the species, usnally abbreviated if common or long. Where the name has been transferred from one genus or combination to another, the original anthor's name is placerl in pilrenthesis and followed by a second anthor, who made the change.

\section{Botanical Synonyms}

Is some species have borne more than one scientific name, any botanical synonyms common in use, particularly in the West Indies, are listed. For example, a species may hare been descrilsed independently by different botanists, or two species may have been united following later study of additional specimens. Ilso, there may be differences of opinion among specialists whether a variation merits recognition as a variety or separate species or needs no additional name. Included under botanical synourms are those scientific names accepted by Britton and Wilson (5) but afterwards changed becanse of differences in codes of botanical nomenclature or in accordance with monomaphic studies and conservative usage.

\section{Tree Descriptions}

The descriptive text for each species begins with a summary of the main distinguishing characters, which is followed by size and appearance and by botinical descriptions of leaves, flowers, and fruits. Mearurements of trees and their parts are given in the English system of feet and inches. In conversion to the metric system, which is more commonly used in tropical Imerica, these equiralents may be noted : 1 foot is 0.3048 meter, 1 inch is 2.54 centimeters, and $1 / 8$ inch is approximately 3 millimeter's.

\section{Main Distinguishing Characters}

The first paragraph summarizes the outstanding features for easy recognition, particularly leaves, flowers, and fruits. Mention is made of other characters useful in identification, such as distinctive bark or presence of latex or colored sap. Introdnced trees are noted and indicated by ar asterisk after the scientific name.

\section{Size and Appearance}

In the second paragraph the approximate size is given as small (less than 30 feet tall), medium (from 30 to 70 feet tall), or large (more than 70 feet tall). The arerage and maximum heights and trunk diameters represent mature trees in Prerto Rico, though larger trees may have existed in the virgin forests within the island or elsewhere. Trunk measurements are cliameters at breast height (d.b.h.) or 41/2 feet. Trees are classed as 
evergreen if in full leaf throush the vear or deciduous if leafless or nearly so for a brief perioul, such as in the dry season of late winter. Buttresses, or enliured narow outgrowths at the hase of the trumli of larwe trees continumb with lateral roots, are noted if present. Data on shape of crown, branching, and twigs are added for many species. Notes on bark inclucle color of the sul'face and textme, whether smooth or romeh, and if fissured (with many nallow 1 hin aracks) or furrowal (with broal ileep grooves). Is most rees have thin hark less than 1\% inch in thickness, mention is malele of thick hatks. (oblor and taste (also odor if present) are griven for the immer bark, that is, the living tissues exposed by entting beneath the surface, since these details often are liejpful in field identification.

\section{Leaves, Flowers, and Fruits}

Becanse of their importance for iclentification, the leares, flowers, and fruit are described in detail and with measurements for reference. However, characters emphasized in the lirst parang ar are not repated below. Descriptive terms are defined unler the topic "Explanation of Botanical Terms" (p. 9).

Months or seasons of flowering and fruiting, ats far as known, have been compiled from various sonrees. For a few year's persommel of the Inited States Forest Service made field observations of time of flowering and fruting of many Puerto Rican tree speeies, which rere summalized in a card file. Herbarium speeimens collected by personnel of the Forest Selvice at diflerent times of the year have contributed additional dates, as have the floras by Urban (3\%) and stahl (35). Some tree species are cited as flowering and fruiting probably or nearly though the year. This statement means not that a partienlar tree bears flowers and fuits almost continually, but that on almost any date some trees may be found in bearing condition. In individual may have more than one blossoming period during the year. Generally flowering of trees is greatest from March to May. after the start of the spring rains.

\section{Wood and Uses}

The mood is described briefly, including notes on color of sapwood and heartwood, hardness, weight and specific gravity, and durability. These notes are chiefly fiom Puerto Rican specimens supplemented for some species by published descriptions from other areas. Detailed data on wood properties and uses have been condensed from the recent publications by Longwood $(22,2.3)$. The specific gravity values quoted to two deeimal places were based on green volumes and a re slightly lower than other values based on air-dry volumes. Relative resistance of the wood to attack by dry-wood termites has been compiled from Wolcott (40). Tses of the wood are primarily those of Puerto Rico, but special and different uses elsewhere are mentionerl. Most of the native wools are available on] y in limiterl puantities, and none is suffiriently abmelant for export. Nevertheless, als lomewoml repmeted, miny of these woots could le molized in adelitional ways.

\section{Other Uses}

Other purposes served by Puerto Riean trees are notol. Many kinds are planted for fruit, shade, and olmaincunt. Others have bark that yields tannin, fibers, or dyes or lave parts emphoyed in home medicines. Fhaddrand ornamental trees of T'uerto Rico have been listed by Winters and Ameyda (39) and by Martorell (24). The last has prepared also a list of trees that should not be planted because of insect pests or diseases, and these abjections are ineorporated here. Special mention has been malle of the tree speries introduced and hardy in subtropical parts of the United States, ma inly southern Florida and southern California, where they are cultivated for fruit, shatle, and ormament. Simmok and Menninger (36), Meminger (96.29), Morton and Ledin (28), and Barrett (D) have published further information about these. Many trees are classed as honey plants by Ordetx (31) and others, beeause their flowers attract bees and secrete nectar in quantities.

\section{Propagation, Growth, and Other Notes}

Brief notes on propagation, growth rate, and site adaptability of many forest and planted trees have been sumniarized from reeords of the I'nited States Forest Service, and other miscellaneons notes of interest have been added. Further details and methods on propagation of trees in Puerto Rico are contained in the manual on that subject by Gilormini (11). Idditional information on forest management of many Puerto Rican tree species may be found in various articles in The Caribbean Forester.

\section{Distribution}

For each tree species the natural distribution or range is stated, both in Puerto Rico and the United States and British Virgin Islands and also beyond throngh the West Indies and continental tropical Imeriea. Introduced trees, often spreading from cultivation and becoming naturalized, are further designated by mention of their native home.

Names of individual islands belonging to Puerto Rico and the Tirgin Istands where each species is known are recorded, mainly from the published ranges by Britton and Wilson (5) supplemented by the anthors' field records. The first map (fig. 1) shows names and locations of the principal islands. Largest of those mnder Puerto Rico are IIona on the west and Culebra and Vieques on the east. Other small islands of botanical interest noted by Britton and Wilson are Desecheo at the west, Caja de Muertos on the south, and Icacos near the dry northeastern corner. 


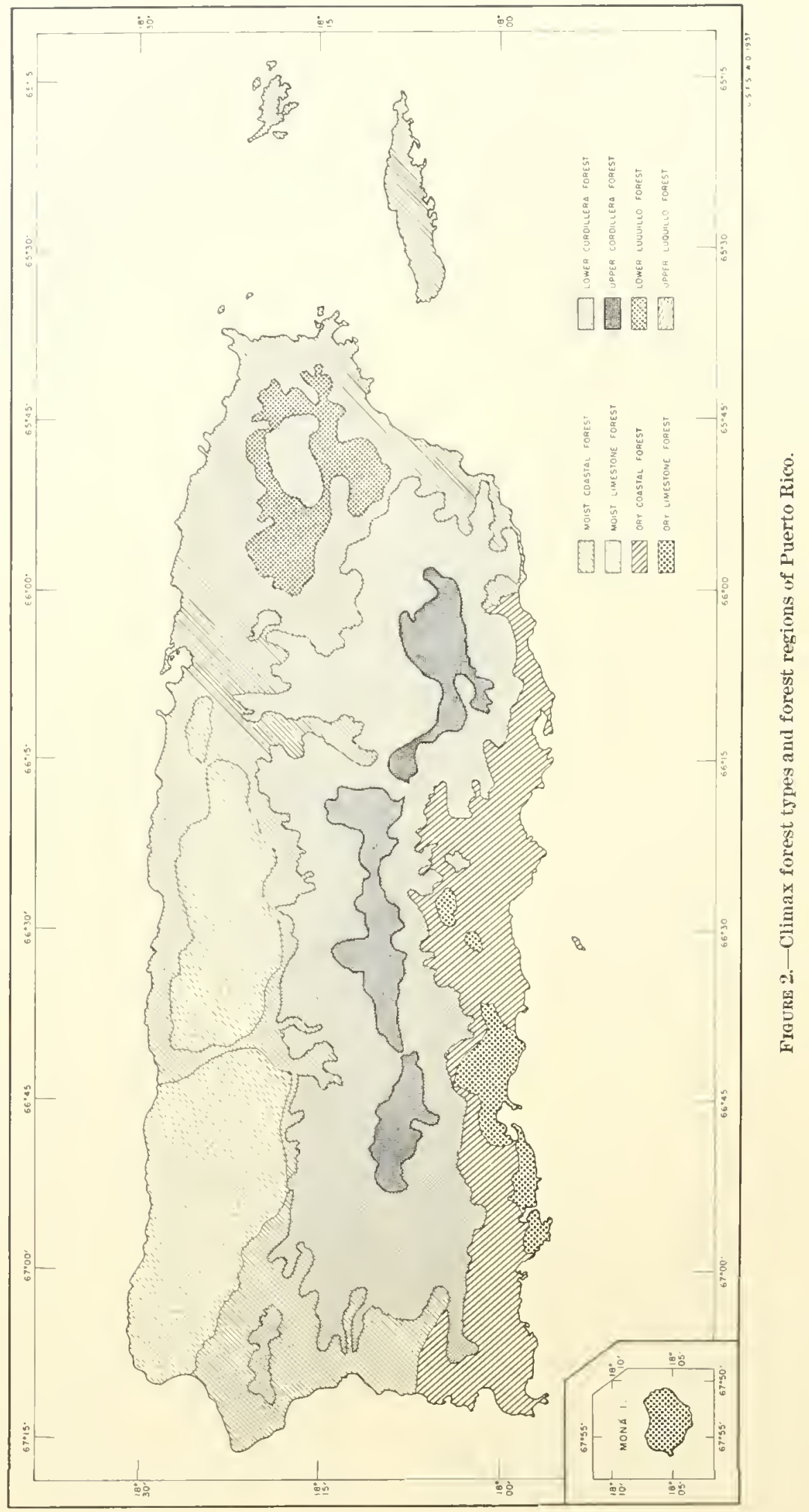


Ocenrence in the Virgin Islands is cited in the following order" st. Croix, st. Thomas, st. John, Tortola, Yirerin Gorda, and Anegada. The first three are the U'nited states Viroin Istands, while the last threa as well as several smaller compose the British Virgin Islands.

Within Puerto Rico the distribution is recorded in wreater detalil by notes on abundance, altitudiual limits, and habitat or site. For many speeies are mentioned the forest recrions or environments, ol ecological regions or provinces. The natural distribution of most native trees tends to be related to ecological regions defined by climate and soil. These eight regions, shown in fignre "2, detine climax forests of distinct types. 'They are deseribed in detail under Forests and Forestry (p.12).

\section{Public Forests}

The public forests in Puerto Rico uncler Federal and Commonwealth administration, shown in figne 3, are widely distributed over the island and contain examples of most common tree species. 'These forests are accessible by highways or' roads, and the personmel in charge can assist in locating and identifying the common trees.

Occurrence of native tree species in the 15 pulblic forests is summarized by alphabetical lists which indicate localities where eximples can be found. Luquillo Experimental Forest, formerly the Caribbean National Forest, is administered by the United States Forest Service. The following 14 public forests are under the Commonwealth Division of Forests, Fisheries, and Wildlife: Aguirre, Boruerón, Cambalache Experimental Forest, Carite, Ceiba, Guajataca, Guámica, Guilarte, Maricao, Río Ibajo, Sall Juan, Susúa, Tolo Negro, and Tega.

\section{Distribution Maps}

One hundred small maps accompanying the drawings summarize the distribution of as many native speeies by mumicipalities within Pnerto Rico, based upon the unpublished forest inventory by the Commonnealth in 1947-1952 and minor additions. Presence is shown by the number on a white background, in accordance with the numbers of municipalities in figure 1 and the accompanying lecrend. This survey covered 59 of the 75 municipalities. The remaining 16 municipalities shown by diagonal shading were omitted because of their limited forested areas, as were two other municipalities on the islands of Culebra and Tieques. Also excluded were the public forests, where other surveys have been made, and the mangrove swamp forests almost wholly within the former.

These incomplete maps show local distribution in much greater detail than would maps based only upon botanical collections, in spite of certain limitations. Some species occur natmrally in additional municipalities containing the same forest environments or regions. Occurrence within a municipality, often limited by enviromment or altitude, is not indianted. On sample plots the trees down to a minimum limit of 3.5 inches riameter at. breast height (d.h.h.) or $41 / 2$ feet were measureet and recorded. However, scattered, less common, and cultivated species were not adequately noted, and probably are present in some municipalities adjalcent to those mapped. Closely related sprecies of a gemus not easily distinguished in the field survey sometimes were glouped together and thus conld not be mapped separately.

Municipalities where an individual species is especially common, that is, among the 10 commonest species in number of trees according to the inventory, are listed by number in the text also.

\section{Distribution Outside Puerto Rico}

Ranges outside Puerto Rico are given for the islands of the WVest Indies in detail and also for continental tropical America. 'These langes are based upon recent botanical floras, tree lists, and monographs supplemented by specimens in the National Herbarium of the T'nited States National Museum. Distribution for many species now is somewhat better known than when summarized by Britton and Wilson (5). Some species have a broad range through the Gieater Antilles (Cuba, Jamaica, Hispamiola, and Pnerto Rico) and Lesser Antilles (Leeward and Windward Islands) to Grenada or Barbados and are present on nearly all the islands except the smallest or those lacking suitable habitats. Thus it has not seemed necessary to list all these islands. Nearly all Puerto Rican tree species native also in the island of Hispaniola are present in both Haiti and the Dominican Republic, which countries are not mentioned individually. For those species not ranging throngh the Lesse ${ }^{\circ}$ Intilles to Grenada, the southernmost island of distribution is recorded.

Islands near the Venezuelan coast of South America, including Trinidad and Tobago and Bonaile, Curaçao, and Aruba of the Dutch West Inclies (WVindward Islands), have the flora of the South American mainland rather than the West Indies. Nearly all native Prerto Rican tree species also on these islands have a brond distribution in the Caribbean area, such as from Bahamas and Cuba to Trinidad and on the continent from Mexico through Central America to Tenezuela or beyond.

The distribution of those species native or naturalized in the United States is given by States, generally only southern Florida, thongh mention is made of introdnced trees planted and hardy in southern Florida and southern California. Southward on the continent the northermmost and southermmost conntries of range limits are stated. Thus, a species recorded from Mexico to Peru and Brazil is native though the comntries of Centra] America and northern South America. Some important cultivated trees are widely distributed 


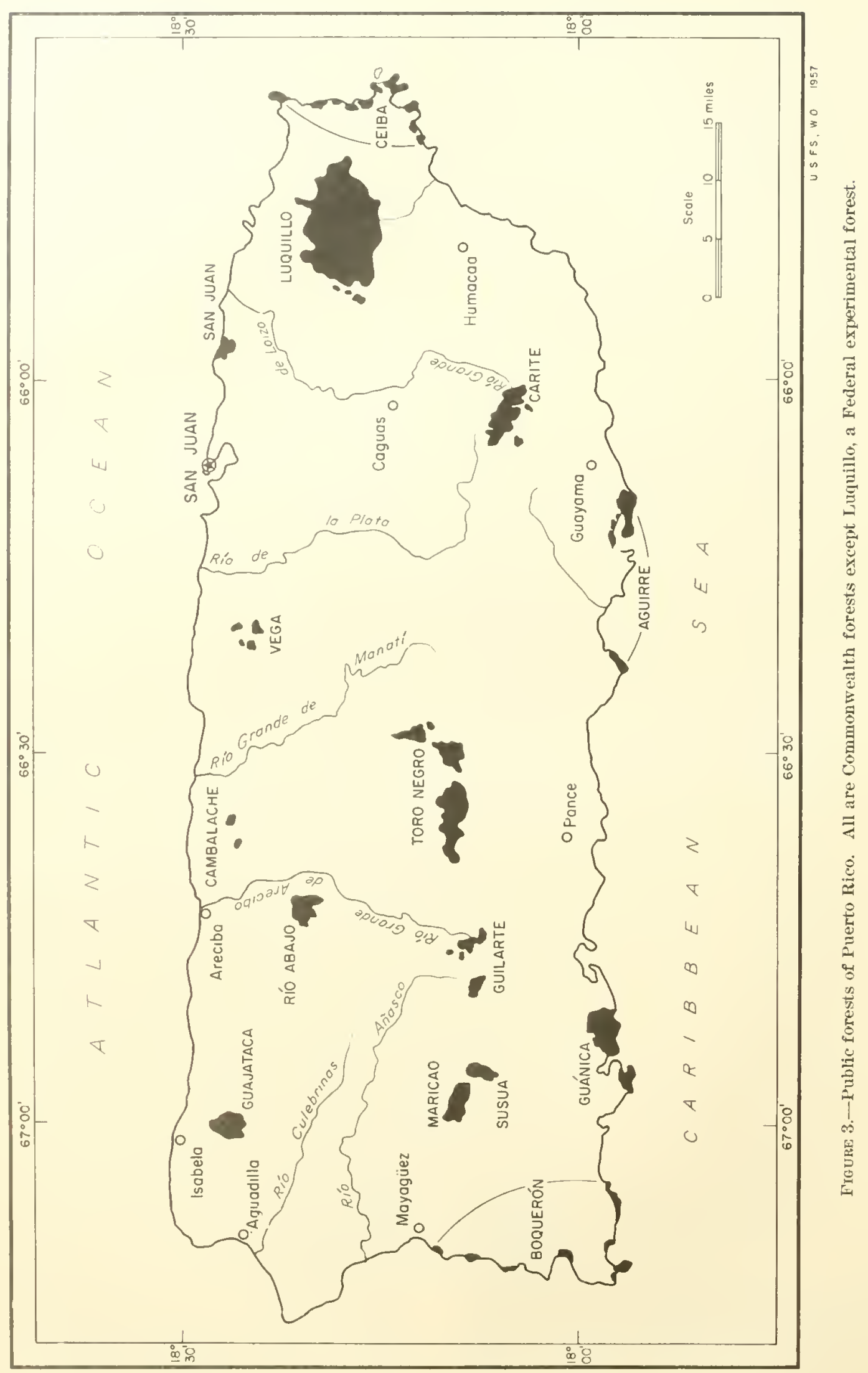


nealy thronghont the tropies, including the old Trorid.

\section{Related Species}

All other native tree species of each genus are mentioned, nsmally moler the first species of the genus or sometimes under a similar one, to aid in further identification. Preferred Spanish and English names are given where known, though some species probably bear the same names or only those of the genus. Distinguishing characters for comparing related species with those figmed have been compiled largely from Britton and Wilson (5). Distribution is given by islands. In the two largest tree genera, Eugenia with 25 native species and $M$ iconia. with 16 , the other species have merely been listed. Keys for identification in these as well as the other genera were published by Britton and Tilson also.

Where no related species are mentioned, all native tree species of the genus, usually only one or two, are illustrated. However, introdnced tree species, shrubs, and herbs have not been cited. Of course, some entire gener'a and 20 families, mostly with few species of small, less important trees, have been omitted.

\section{EXPLANATION OF BOTANICAL TERMS}

Botanical descriptions for the classification and identification on trees are based principally on differences of leaves, flowers, and fruits, and their parts, such as presence or absence, number, arrangement, shape, size, and union or separation. To record thesc details, systematic botanists, or plant taxonomists, have a special teminology of technical words derived from Latin and Greek. defined and illustrated in botany textbooks and floras. In this book, nontechnical terms have been used wherever possible, though some technical terms have been inserted in parenthesis or adopted where there was no clearer equivalent. Principal terms used in this book are explained here, while many are illustrated by the drawings. Thus, it has seemed mmecessiry in include a glossary.

\section{Leaves}

These flat, green organs serving for food manufact ure are very uscul in the identification of trees, usmally present in quantities and of large size. The point on a twig where 1 or more lerves are at tached is the node. In arrangement on the twig, leares attached singly or 1 at a node are alternate. leaves borme in pairs or 2 at a node arc opposite. and leaves inserted 3 or more at a node are whorled. Parts of a leaf are the leafstalk or petiole and the flat expanded part or blude. In some species there we $2(01-1)$ seales at the base of a leaf called stipmes, usually shedding early but sometimes forming distinctive buds at the end of a twig.

In number of blades a lea $f$ with 1 blade is simple, while a compound leaf has usually several blades (rarely only 2) called teaflets, which may or may not have stalks. A leaflet is distinguished from a simple leat by the absence of a bud at the base and by the shedding of the axis. Also, leaflets are in 2 rows along the axis, while simple leaves may be similar lout more often not in 2 rows on the twig. ('omponnd leaves are pinnate or pinnately compomd when the leaflets are inserted along a commom axis and digitate (or palmate) when attached together at the end of the petiole. If the axis has bramclies a leaf may be twice pinnate or bipinnate (1) if branched again the lea $f$ is three times pinnate or tripimate. Pimmate leaves maty be even pimate when the leaflets are paired and end in a pair, and ortd pinnute. when ending in a single leaflet.

Sereral terms describe the shape of leaf blades. I linear leaf has a narrow grasslike blade with edges parallel, and an oblong leaf is broader but with edges also nearly parallel. A I ance-shaped or lanceolute leaf has the form of a lance, several times longer than brond, pointed at apex or tip end, and broadest neal hase, while the reverse shape is oblanceolate. An ovate leaf has an oval shape broadest toward the base, more or less as in an egg, while an obovate leaf is the reverse, broaklest toward apex. An elliptic lea fus an oval shape but broadest in the center. A circular leaf has the blade more or less in form of a circle, while a spatulate leaf is spoon-shaped.

As to margin or edge a leaf blade may be tootherl, lohed, withont teeth, or rolled under. The apex and base of a leaf blade may be long-pointed, short-pointed, or rounded, or the base heartshaped, if with two rounded lobes.

In venation or arrangement of the veins a leaf blade may be parallet-veined, if the veins are closely placed side by side or parallel; pinnatereince. with a single main vein or midrib and lateral veins on both sides somewhat as in a feather: or patmate-veined. when several main veins arise at the base and spread like fingers in a hand.

\section{Flower Clusters}

The gromping of flowers and fruits in clusters (inflorescences) and their location and arrangement often provide characters useful in identification of trees. A flower cluster is terminal when it is at the apex or end of a twig and lateral when borne at the base of a leaf or on the side of a twig. The flowers may be producerl singly, one by one. A spike is a flower clnster with elongated axis bearing stalkless flowers, while a raceme has an elongated axis with stallied flowers, and a punicle is a componnd raceme with branched axis. An umbel has flowers on spreading stalks of equal length attached together at the apex of a larger stalk somewhat like an umbrella. A head bears stalkless flowers on the broad disklike apex of the axis. In a cyme the flower cluster is definite, with the main axis ending in the first flower and with other flowers borne on branches below. 


\section{Flowers}

For classification and identification of trees and other flowering plants, the flowers and fruits, or reproductive organs, are the most important parts. They show the relationships better than the leaves and other vegetative organs, which are less constant and offen vary greatly under different environments. The commoner plant families can be recognized by their eharacteristic flowers. It has seemed desirable, therefore, to describe the flower structure of each tree species in simple terms with measurements.

The flower is a morlified stem bearing four or fetrer groups or eireles of specialized lea ves known as calyx, corolla, stamens, and pistil (or pistils). The calyx, or outermost group, is composed of reduced leaves generally green and called sepals, while the corolle consists of lar reer and usually colored parts known as petals. The eorolla may be regular with equal petals or irregulur with petals of unequal size and may be tubular with the petals united into a tube. The stamens or male organs of the flower have a fitument or stalk and an anther or enlarged, usually yellow, part which bears the pollen, or male elements. Sometimes, the stamens may be replaced by stuminodes, whieh are nonfunetional or sterile stamens, usually small.

In the center of the flower there is usually a single pistil or female organ (sometimes few to many) developed from one or more specialized leaves. The pistil consists of three parts: the ovary or enlarged part at the base, the style or stalk above the ovary, and the stigma. the usually enlarged and often stieky end, which receives the pollen. The ovary contains 1 to many ovules, rounded whitish female elements. The mature ovary is the fruit. while the orvles become the seeds.

In position with respect to the other flower parts, the ovary may be superior or inferior. The superior ocary, the eommon type, is free or separate in the center of the flower and inserted inward from or above the other parts. The inferior ovary is located below the calyx, corolla, and the stamens, which appear to be inserted above. The structure of the ovary, ineluding the number of carities or cells from 1 to several and number and position of the ovules within, is important in classifieation of plant families.

The receptacle is the enlarged base of the flower where the flower parts are inserted. Above the receptacle and inward from the corolla there is sometimes a dish or small part like a eirele or ring, often glandular. The receptacle may form a basal tube or cup called the hypanthinm, which may enclose the inferior ovary or sometimes surround the superior oviry and bear the other parts located above.

Though usually possessing stamens and pistil and thns with both sexes or bisexull. flowers may be of one sex only or unixexum. A male flower has stamens but no pistil, and a female flower has a pistil but no stamens. A species with male and female flowers on the same plant is said to be monopcious. while one with male and female flowers on diflerent plants, which are also male or female, is dioccious. In polygamous species flowers of one sex and bisexual flowers are borne on the same individual.

\section{Fruits}

Developing from mature ovary, the fruit contains the seeds and sometimes other flower parts still attrehed. Present often for longer periods than flowers or also remaining under the trees after falling, the fruits may be especially helpful in identification. Commonly the fruit originates from a single pistil and is simple. A fruit from several pistils in one flower is aggregate (for example, corazón or custard-apple), while one from several nnited flowers often partly from an enlarged fleshy stalk is multiple (for example, higo or fig).

Simple fruits are classed as dry or fleshy (juicy or sucenlent). Some dry fruits do not open to release the seeds (indehiscent), while others open (dehiscent). The akene is a dry fruit not opening and containing a single seed separate from the fruit wall. The nut is also 1 -seeded with a thick hard shell. The pod or legume is a dry 1-celled fruit which splits open usnally along 2 lines (for example, the legume family). The rapsule is a dry fruit of 2 or more cells which opens on as many lines as cells. Fleshy fruits, which do not open, inelude the berry. which usually has several seeds, and the drupe. which has a central stone or hard part containing 1 or more seeds.

\section{HOW TO USE THIS BOOK IN TREE IDENTIFICATION}

Many trees ean be identified by reference to the drawings, descriptions, and distribution notes. However, the illustrations alone may not emphasize differences among closely related speeies not figured. It is helpful to have for comparison the flower's and fruits in addition to foliage becanse many kinds of trees have leaves of similar shape. Often one tree can be found in blossom out of season, perhaps at the edge of a forest, and old fruits may be located on dead branches or on the ground. A ruler and a hand lens are useful in examining the specimen and eomparing it with the description.

If the loeal common name of a tree in Puerto Rico or the Virgin Islands is obtained, such as by asking residents, then the deseription, illustration, and seientific name can be found by consulting the paige listed in the Index of Common and Scientific Names. Sinee common names in other countries and as many as fire languages are included, the Index will be helpful in determining the same species elsewhere.

To avoid errors, identifieation from a common name should always be rerified by inspecting the 
drawing and comparing the specimen with the main distinguishing characters or, if needed, with the detailed description of leares, flowers, and fruits. Otherwise, the use of the same common name for unrelated tree species in different places or misapplication of a name may lead to confusion.

The List of Tree Species with Descriptions and Illustrations will also aid identitication because it lists the species in the usual botanical alrangement with related trees together, alphabetically by scientific names under each plant family. If the family is recognized, names of the examples with page numbers will be found in the List. Iikewise, an unknown tree resembling a known one should be sought in the same family.

The Key to Families serves to place an unknown tree in its plant family. This key includes the 68 families of this book and 20 additional small families represented by only a few native tree species. Each family with two or more species illustrated contains a key to these species for further identification.

The Special Lists may be helpful also in identifying trees with unusual character's or special uses.

For trees not included, reference may be made to Britton and Wilson's (5) flora of Puerto Rico and the Virgin Islands, which contains both keys to species and botanical descriptions. Also botanical specimens of dried pressed twigs with leaves, flowers, and fruits, and with field notes (locality, altitude, date, common name, collector, whether wild or planted, size, abundance, etc.) may be forwarded to large herbaria or universities for identification by specialists.

\section{STATISTICAL SUMMARY}

The 250 species of common trees of Puerto Rico and the Tirgin Islands deseribed and illustrated here are classified into 185 genera and 68 plant families. Of these, 72 species, 38 genera, and 6 families are exotic, or introduced. These genera and families are not represented also by native species of trees or smaller plants. For further identification the 130 additional, related tree species (including $10 \mathrm{introduced)}$ of the same genera are mentioned briefly and compared with those illustrated. Thus, 380 tree species are included for identification. To accomnt for all native tree species recorded by Britton and Wilson (5) in these genera, 22 alditional species of Eugenia and 15.) of Mironin are listed. A second volume is planned to describe and illustrate the remaining native tree species and widely grown exotics in these and other genera and in 20 other families.

Numbers of tree species accepted for an area will depend upon the definition of a tree or minimum size considered. Trees may be refined as roody plants having one erect perennial stem or trunk at least 3 inches (7.5 centineters) in diameter at breast height (d.h.h. or at $4 \frac{1}{2}$ feet or 1.4 meters), a more or less definitely formed crown of foliage, and a height of at least 12 to 15 feet ( 4 meter's).
Accordingly, some small trees often shrubly and not reaching sawlog size have been included.

\section{ACKNOWLEDGMENTS}

Credit is due various persons of the United Nitates Forest Service, past and present, for their assistance in preparing this book and particularly to Leslie li. I Foldridge, who initiated the project, made extensive botanical collections. supervised drawing of numerous ilhustrations (also making a few), and wrote the two preliminary volumes. In those volumes acknowledgment was made to assistance in the preparation of the material by persomel of Trork Projects Administration Offi(-ial Project No. 165-2-36-20.

Most of the black and white drawings were prepared some years a gro by several art ists employed by the Tnited States Forest Service and Work Projects Administration. Francisco Roena Santiago made more than 50 of these. In 1954 to complete this wolume about 50 drawings were made by Edwin C. Rivera S. and 10 by Félix Rosado. Five others were prepared for a similar book on the common trees of Venezuela by the senior author. They are Ceibu pentandra. Terminatio ratappa, and Tecoma stans by Ruby Rice Little and Conorarpus erertus and thicenia nitida by Ellen de Jirgenson. The drawing of Nectandra coriacea was made by .Jane TV. Roller.

Assistance of the New York Botanical Garden in making determinations of the earlier botanical collections is appreciated. Acknowledgment is due the Tnited States National Museum for the privilege of examining the large Puerto Rican and Virgin Islands collections in the Nationa? Herbarium.

Foresters, rangers, and others of both the United States Forest Service and Commonwealth Division of Forests. Fisheries, and Wildlife have assisted the authors in field work and in checking the common names. The authors are deeply indebted to José Marrero, of the Institute of Tropieal Forestry and coathor of the Spanish edition (21), for his review of the manuseript and for his Spanish translation. Credit is due Franklin R. Longwood of the United States Forest Service, for the detailed data on about 60 Puerto Rican woods taken from his publications which appea red while this manuscript was a waiting publication.

Distribution data by municipalities were compiled from the forest inventory of Puerto Rico, which was conducted by the Commonwealth Division of Forests, Fisheries, and Wildlife under the direction of Benjamín R. Seda. From these records the distribution maps were made by Raúl Tharlat C., of the Institute of Tropical Forestry.

Alfonse Nelthropp, of Charlotte Amalie, St. Thomas, has contributed many common names used in the Virgin Islands. Roy O. Woodbury, of the University of Puerto Rico Agricultural Experiment Station, has checked and added to the list of speeies growing also in southern Florida. 


\section{FORESTS AND FORESTRY IN PUERTO RICO AND THE VIRGIN ISLANDS}

The trees native to Puerto Rico and the Virgin Islands, some 500 species, were found at the time of discorery in extensive and luxuliant forests. TVhereas snch forests have subsernently all but disappeared, there is every reason to believe that at the time of Columbus" arrival the dominant vegetation throughout the islands, with the possible exception of a few small marshes, was forest. The reports of early voygenus $(1,8,25)$ all describe the islands as forest covered. Furthermore, in other regions of similar climate and soil the regetation is forest wherever it has not been modified by man. The natural regetation of Puerto Rico, including forests and plant successions, has been described by Gleason and Cook $(12,6)$.

\section{THE VIRGIN FORESTS}

Description of the virgin forests of Pnerto Rico and the Tirgin Islands can now be only very approximate, since few relics remain in Puerto Rico and none in the Tirgin Islands. Wherever partial cutting or complete deforestation has once taken place, even where forests are subsequently allowed to rederelop, the relative albundance of the different species sufters a marked change. The brief description here presented is based upon a study of a few remaining virgin forests in Puerto Rico (38) and upon published descriptions of similar forests in nearby islands, particularly those by Beard (3).

The eight climax forest types or forest regions shown in figure 2 are described below with lists of the common trees. Reference is made printarily to Puerto Rico, and some species mentioned are not in the Tirgin Islands. However, the general character of the regetation there was apparently as here described.

The more important differences in the natura] vegetation of Puerto Rico and the Virgin Islands reflect variations in topography, climate, and soil. The vegetation of the coastal plains was mlike that of the steeper upper slopes, and a still different type of forest clotlied the uppermost peaks. Difleiences in the total amount and seasonal distribution of precipitation produced extreme differences between the forests of the eastern mountains of Puerto Rico and those of the sonthwest coast. Reduced moisture a vililability due to shallow soils, particularly in the limestone regions, is manifest in the growth of trees on such areas. The contrasts annong the various regetative types are striking because of the extreme range of conditions with- in short distances. Elevations range from sea level to 4,398 feet, precipitation from 30 to 180 inches ammally, and soils from deep to very shal. low, and from fine clays to coarse sands.

Along the wind-swept seacoasts was a low scrubby littoral woodland so narrow and so small in area that it is not shown in figure 2. Most of the trees in this woodland were small and of poor form dne to extreme exposure to salt winds. On dry rocky slopes faciug the southern or" soutluwestern coasts, on Anegada, on Mona, and on other smal] outlying islands the littoral woodland assumed the form of cactus scrub. In the more protected locations, particularly on the north coast of Puerto Rico, grew trees of good timber species such as nuría (Catophyllum brastiense), ausubo (1/anitliara bidentata). roble (Tabebuia heterophylla), and tortmo amarillo (sideroxylon foctidissi$m u m)$. One of the most prominent species near the shore was uva de playa (Coccoloba wifera).

Ilong the sliores of protected bays, lagoons, and estuaries in :ur area too restricter to show in figure 2 were dense stands of mangrove, the trees of only four species growing to a height of 60 feet or more. Five public forests bordering the coast, mapped in figure 3 , still contain mangroves. In the water itself was mangle colorado (Rhizophora mangle). On the adjacent area normally subject to tidal flooding were mangle blanco (Laguncularia racemosa) and mangle negro (Avicennia nitida). On the landward side was mangle botón (Conocarpus erectus). The strong durable timbers of mangle colorado and mangle botón were much uséd for construction.

On the coastal plain and lower slopes, up to an elevation of 500 feet or more in Puerto Rico, and to the tops of most mountains of the Virgin Islands grew a dry forest which was largely evergreen but with some deciduous species, particularly in the drier coastal areas. At its best development, on the northern constal plan of Puerto Rico, this forest attained 80 feet or more in height. Elsewleje, in the moist limestone region and on the south coast of Puento Rico, and in the Tirgin Islands, it was apparently shorter, from 40 to 60 feet tall. 'This forest consisted of two tree stories, each composed of distinct species. The lower story constituted a forest within a forest and depended upon the mpper canopy for its existence. The regetation varied in composition from place to place hut it was everywhere a mixture of species. At least 200 tree species were present somewhere within the natmal distribnt ion of this forest. 
Within the area described are four dist inct forest regions or ecological provinces, each giving rise to a distinct type of forest. These regions or provinces, designated as moist coast, moist limestone, dry coast, and dry limestone, are shown in figure 2.

The more common or characteristic species of the moist coastal forest included the following:

Acrocomia media

Nectandre coriacca

Hernandia sonom

Hymenaca courbaril

Andira inermis

Pterocarpus officinalis

Zanthoxylum

martinicense

Calophyllum

brasiticnse

Mammea americana

The moist limestone forest was similar to that along the coast and had many of the same species. The chief differences appear to be due to the drier soils on the well-drained limestone hills and the greater humiclity in the protected areas between the hills, especially in the southern part of this area which is close to the central mountains. The tree species of the moist limestone forest include:

Aiphanes acanthophylla

Gaussia attemata.

Coccoloba diversifotia

Coccoloba pubescens

Licaria saticifolia

Zanthoxylum martinicense

Burserc simaruba

Cedrela odorrata

Hyeronima clusioides

Sapium laurocerasus

Thouinia striata

On the southern, dry side of Puerto Rico the more adverse moisture conditions excluded many of the tree species common on the north side. In their places grew a few other species especially adapted to such conditions. The tree species of the dry coastal forest include:

\section{Coccoloba venosa \\ Capparis cynophallo- phora}

Stahtia monosperma

Lonchocarpus domingensis

Pictetia aculeata

Erythroxylon areolatum

Guaiocum officinale mole hardy replace these. The trees of the dry limestone forest include:

Pisonia albida

Cipparis rynophallophore

Pictetia aculeata

Guaracum officinale

Guaiucum sanctum

Amyris elemifera

Bursera simaruba

Gymmenthes lincide

Thouinia portoricensis

rolubrina arborescens

surcomphalus reticula-

tus.

('phulocerens royenii

Opuntia rubescens

Bucidu buceras

Dipholis salicifolia

Plumeria alba

The coastal forests of Puerto Rico and the Virwin Islands, mlike those of the other Greater Intilles, contained no mahngany (Swietenia mahugomi). Widespread use of the wood and early introduction of the tree to these islands has led to a general impression that this species is natire. However, whereas the yomg trees develop abundantly in Puerto Rico beneath or near planted trees of this species, they are never encountered in native forest at any distance from snch trees. Had the species been native, there would still be young trees throughout the coastal forests of the island without relation to the location of planted trees. It is extremely mlikely that it could ever have been exterminated, since aceitillo (Zanthoxytum f(avm), a tree in greater demand and with much wealer reproductive capacity than mahogany, is still to be found in remote forests.

Typical momntain forests are confined to Puerto Rico, although a small patch of similar but unique forest is found on the top of Sage Mountain. Tortola. Between about 500 to 2,000 feet elevation in the easterm mountains, known as Luquillo Mountains, and to 3,000 feet in the central mountains or Central Cordillera, slightly higher on the south slope than on the morth, was probably the most magnificent forest of Puerto Rico. Much of the original vegetation of this area is described as tropical moist forest : in the wettest areas it is tropical rain forest. At its maximum development this forest reached 110 feet in height, with trees to 8 feet in diameter. Three forest s of dist inct size and composition grew together here, each forming a separate story of vegetation. Throughout the range of this type of forest there were probably about 170 tree species.

Within the mountain area are two forest regions or ecological provinces and corresponding distinct forest types. These provinces are designated as lower Cordillera and lower Luquillo. It is seen in figure 2 that the lower Cordillera province includes both the north and south lower slopes of the central mountains of Puerto Rico and the Sierra de Cavey and also the upper slopes of the discomected Sierra de Atalaya in the northwest. The Luquillo Mountains are separate both geographically and ecologically from the Central Cordillera.

The trees of the lower Cordillera forest include the following:
In the limestone region of the south coast, as on the north coast, excessive soil drainage accentuates the dryness of the environment to a point that some species of trees cannot subsist. Others which are 
Cyathen arborea

Cerropia peltuta

Ocotea louconylon

Orotea moschata

Ilivella rugosa

Inga laurina

Pithcrellobium

arborem

Andira inermis

Ormosia krugii

Iracryodes execlsa

redirela orloruta.

Guarea trictritioides

Byisonima comiacen

Drypetes glanca.

The forest of the lower slopes of the Tuluillo

Mountains is similar in general appearance to that in the Cordillera, but because of rreater precipitation and higher humidity it is somewhat more luxuriant, and several tree species are much more common here than elsewhere. The trees of the lower Luquillo province include the following:

Cyathea arborea

Cecropia peltata

Beilschmiedia pendula

Ocoter lencoxylon

Ocotea moschata

II irtella rugosa

Inga laurina

Andira inermis

Ormosia limugii

Dacryodes excelsa

Tetragastris balsamiferi

Guarea trichilioides

Trichilin pallida

Byrsonima coriarea

The similar forest on Tortola, does not exceed 60 feet in height, apparently because of a somewhat drier climate. It contains many species associated with this forest in Puerto Rico and is dominated almost exclusively by bulletwood (Manitkara bidentata).

Farther up the slopes in Puerto Rico, extending to near the tops of the peaks, was a subtropical rain forest. Here the temperature is lower, and rainfall, ranging from 100 to possibly 200 inches annually, is so abundant as to prodice swampy conditions and highly leached soils. The result was a comparatively poor forest about 60 feet tall and containing about 60 tree species.

This upper mountain forest is distinct in the Cordillera and the Luquillo Mountains primarily because of more moist conditions in the latter. The common or characteristic tree species of the upper Cordillera forest inclinde:

Cyathea arborea

Euterpe globosa

Magnolia portoricensis

Guatteria blainii

Ocotea spathulata
Brmellia

rnmocladifotia

17chomer latifolia

Turpinia paniculata

In the upper Luquillo Mountains the forest is similar to that of the Cordillera, but there are in ardcition a number of species found only on the Larquillo Monntains. The common tree species of the inper Luquillo Forest include the following: ryathea arborea

Eutrpe globosa

Magnolia splendens

Ortotea spathulata

Alchornea lutifolia

Croton poecitanthus

Cyrilla racemiflora

Matayba domingensis

C'7usia lirugiane

Calyptranthes kimgii
Eugenia borinquensis

Calycogonium

syuamulosum

Heterotrichum cymosum

Wicropholis

chrysophylloides

Vicropholis garciniaefolia

Tabebuia rigida
One of the most prominent species in these upper mountain forests is the sierra palm ( $E u$ terpe globosa) which forms extensive, nearly pure stands on mistable soils. In the western part of the Cordillera and near El Yunque peak in the Luquillo Mountains grows Puerto Rico's only arborescent gymnosperm, caobilla (Podocarpus согіaceus).

On Puerto Rico's mountain peaks, above 2,500 feet eleration, the forest is dwarfed to 20 feet or less in height. Little or no valuable timber is present in this forest, but tree species of interest include IV einmennia pinnata and Brunellia comocladifolia.

\section{THE FORESTS OF TODAY}

Writhin the total area of Puerto Rico and the Virgin Islands, approximately $2,335,000$ acres, there are now about 560,000 acres covered by trees. Of this about 280,000 acres are covered by forests or brush. Included here are an estimated 235,000 acres in Puerto Rico and 45,000 acres in the Virgin Islands. Only abont 8,000 acres, slightly more than 1 percent of the forests, are still in rirgin condition.

An estimated 198,000 acres, virtually all in Puerto Rico, are covered by coffee shade. Of this some 125,000 acres bear also coffee trees, the rest being shaded by trees but abandoned as plantations. Another 70,000 acres are woodland pastures, where the trees are more widely spaced but form a light shade. Of this area, 45,000 acres are in Puerto Rico and 25,000 acres in the Virgin Islands. Some 10,000 acres are in orchards, chiefly coconut groves.

\footnotetext{
${ }^{1}$ The estimated areas in this chapter are based upon reports of the Puerto Rico Department of Agriculture and Commerce, the P'uerto Rico Planuing Board, the United States Census, and recent official reports on agriculture in the United States Virgin Islands. Data on the British Virgin Islands are rough approximations, based upon personal observations in the area.
}

\section{Matayba domingensis Clusia krugiana squainulosum}


It is thus seen that more than three-fourths of the land surface of Prerto Rico and the Tiroin Islands is bare of trees. Far more than this has been deforested at one time or another.

The cutting of the forests, done partly to harrest their timber but more generally to elear lans for farming, took place primarily in the 19 th century. It eliminated tree growth from the more fertile and accessible lands. The remaining trees are loeated chiefly on steep slopes, locky mountain summits, or where excessive shallowness, dryness, or wetness of the soil precludes economic farming. Thus the best developed forests have disappeared. Most of the forests remaining are those which reappeared after farming was abandoned on these poor lands.

The remaining forests are nearly all very different from those found by the early vorageurs. The most valuable trees, both as to species and as to size, have been removed. Few trees exceed 12 inches in diameter. Most of these are of species unused for purposes other than fuel, and thus of negligible value. 'These larger trees of inferior' quality tend to suppress the development of any younger trees of more valuable speeies which may be growing beneath them.

A number of the introduced exotic tree species have become naturalized in the forests of the islands, now appearing as though native. Common naturalized species in the humid forests of Puerto Rico include pomarlosa (Eugenio jambos), emajagua (Hibiscus tiliaceus), almendra (Terminatia catappa), bueayo gigante (Erythrina poeppigiana), and tulipán africano (Spathodea campanulata). On the dry sonthwestern coast of Puerto Rico bayahonda (Prosopis jutiflora) has become naturalized in pastures. In the Tnited States Virgin Islands an outstanding naturalized tree in the forests (particularly in St. Croix) is Dominican mahogany (Sroietenin mahagoni) and in pastures, tibet (Albizia lebbeh).

\section{FOREST CONSERVATION}

The trees and forests of Puerto Rico and the Virgin Islands are a valuable asset. The ornamental value of trees around homes along the roadsides and in parks is apparent to all. Tree fruits provide valuable foods and important items of commerce. Forested areas in the mountains or along beaches offer peaceful shady environment for outdoor recreation and on each of the islands constitute important tourist attractions

Not so apparent any mole is the value of the forests for the timber they supply. The best trees have been cut long since, so this contribution from the forest is no longer what it was. The use of wood in construction and chareoal for cooking is declining in the face of substitute materials. However, the forests do continue to supply numerous products, such as posts, which are of utility in farming regions.
The least obvious of the values of our forests is as important as any other, their capacity to conserve soil and water resources. This protective benefit from forest is mexcelled by any other crop. The forest litter reduces surface runoft and erosion. The porous soil beneath forests retains its maximm capacity to absorb rain water-water which may then appear gradually through clear springs rather than in the form of muddy torrents.

The importance of the trees and forests of Puerto Rico and the Virgin Islands is not so mueh a matter of their present contribution as it is a question of what they might contribute. Past cutting of trees and land clearing have reduced these resources to a fraction of their potential. In recognition of the possibility of enhancing local forest lesources, several conservation measures have been taken. I brief history of this activity, confined largely to Prerto Rico, is presented here.

There is little record of actual aceomplishments in forest conservation in Puerto Rico prior to 1900. Sixteenth century Spanish laws, reflecting the scareity of forests in Spain, were generally unrealistic "for the completely forested island of Puerto Rico. Clearing of forests for farming was then needed, rather than preservation of the forests.

Possibly the first indication of official interest in forest conservation within Puerto Rico was a government circular of 1824 recommending that strips of trees be left along and at the source of streams (34). The furst appropriation of public funds for forestry in Puerto Rico is recorded for 1860 (39). Public forest reserves were established in $1876(7)$, and a forest department existed in the colonial government during the rest of that century. The extent and condition of the island's forest resonrces, as deselibed at the end of the century, testify that conservation efforts to that time were not very effective.

The first step toward forest conservation in Puerto Rico during the present century was the proclamation of the Luquillo Forest Reserve in 1903. This area was surveyed in 1916 and proved to contain about 12.400 acres. The United States Forest Service appointed a supervisor to administer this forest in 1917. In the same year the Puerto Rico Forest Service was established and by 1920 was responsible for the protection of more than 26,000 acres of malienated forest lands in the mangroves, at Guániea and Maricao, and on Mona Island.

Forestry activities were materially expanded with the advent of the Civilian Conservation Corps in 1935. Since that time the area of Federal forest lands has increased to about 28,000 acres, and the Commonwealth now administers about another 50,000 acres.

The public forests of Puerto Rico hare been placed under protection, improved, and put to use. Boundaries have been identified and monumented, and roads and ranger stations have been built 


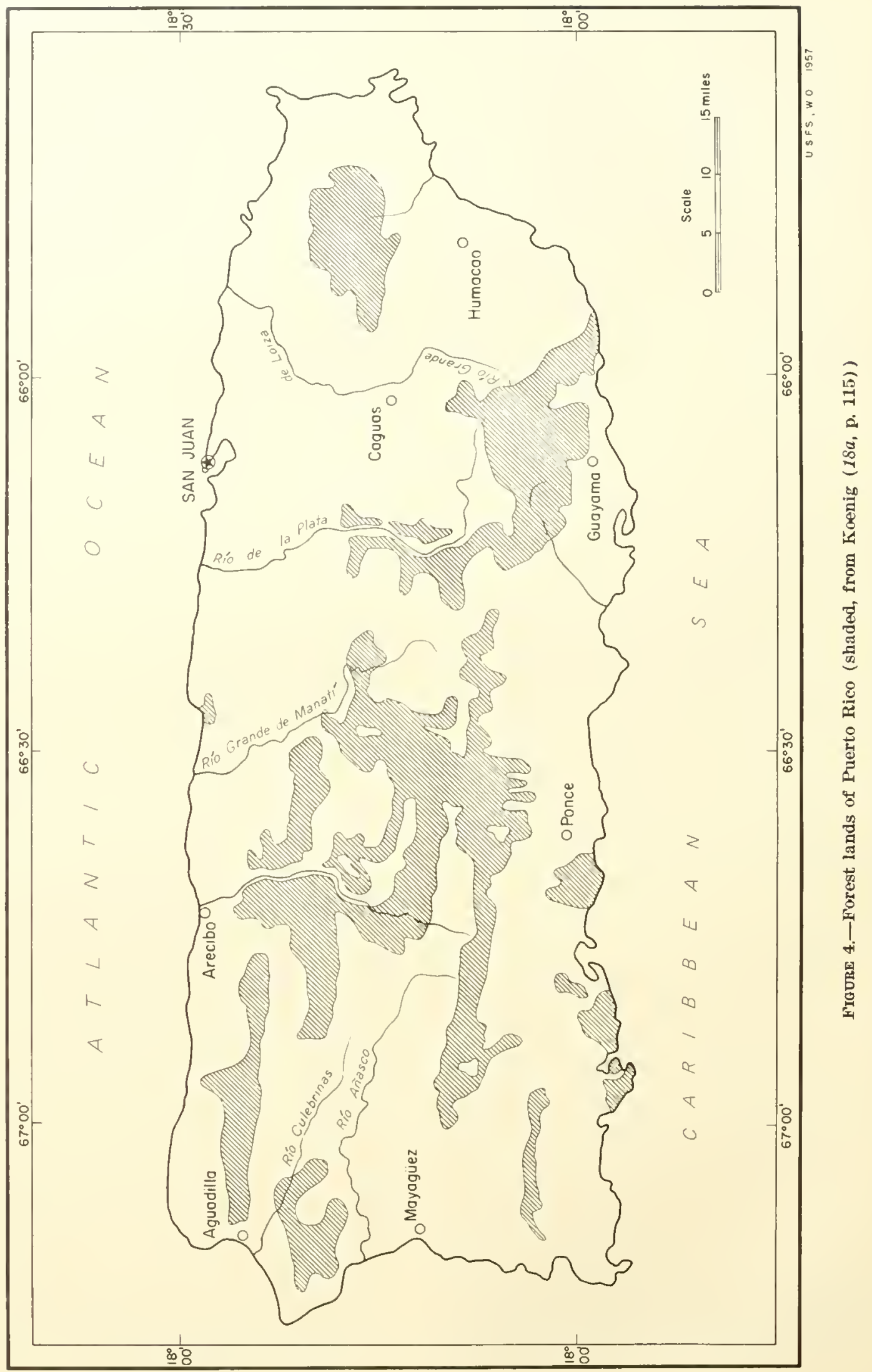


within these forests. About 2,500,000 culbic feet of timber have been remored from the forests in order to harvest mature trees and to eliminate inferior trees. Hbout 7,500 acres of forest have heen improved in this way. In additional 22,000 acres of deforested lands have been planted with trees. Seven recreation areas within these forests have been built for the use of the public. These inprovements represent a total investment of not less than $\$ 15,000,000$.

The Federal and Puerto Rican governments have cooperated in encouraging forestry on prirate lands as well. The Acricultural Extension Service of the University of Pherto Rico and the Federal Soil Conservation Service advise farmers on forestry techniques. The Commonwealth Dirision of Forests, Fisheries, and Trildlife (the successor to the Puerto Rico Forest. Service) and the Tnited States Forest Service cooperate in the production of forest tree nursery stock for distribution to farmers. The United States Forest Service has since 1939 conducted research in forest management and utilization in Puerto Rico, and since 1955 its primary function has been forest research, carried out at the Institute of Tropical Forestry in Río Piedras.

The task of conserving and making productive Puerto Rico"s forest lands (fig. 4) is far from completed. More than 500,000 acres within the island are not well suited to other than forest crops. Present public forest lands under protection and management constitute only about 16 per"cent of this area. Almost none of the private lands are under forest management, and more than half of them are completely deforested. More serions still is that substantial areas of such land are sulject to shifting enltivation, with attendant erosion and sedimentation of reservoirs downstream. The placing of Puerto Rico's forest lands under good management is a task requiring more research, extension, and, in some areas, public acquisition of lands.
In the Virgin Islands a few old laws exist regarding the protection of trees along streams, but in the course of time these islands, both the British and United States, became almost completely deforested to the tops of the momntains. However, in the United States islands extensive secondary forests have developed with the decline in population and agriculture which took place in the past 50 years.

Possibly the ontstanding early development which is of significance to forestry was the introduction of Dominican malogany" (Suietenia mahagoni) into St. Thomas and St. Croix. This introduction, judging by the size of some of the older trees on St. Croix, mist have been made at least 200 years ago, A planting in the hills southwest of ('hristialsted, St. ('mix, has given rise to natural regeneration of mahogany covering some 200 adjacent acres. suggesting that this raluable species might be introduced into secondary forests elsewhere in the islands.

A limited government program of tree planting was carried out in St. Thomas in the early 1930 's, administered from Puerto Rico. Thdoubtedly some of the younger maluganies on that island are a result. Nevertheless, this species is relatively mknown in St. John and Tortola.

I new forestry program is now molerway in the Tnited States Virgin Istands, sponsored by the Federal Government through the Virgin Islands Corporation. Trees are being propagated for cooperative planting on private lands, a sawmill has been set up to utilize mature trees, and new species are being tested as to their adaptability to local growing conditions. Estate Thomas Experimental Forest was established on St. Croix in 1963.

In the British Virgin Islands the Protection of Trees and Corservation of Soil and Water Ordinance of 1954 laid the basis for the protection of areas requiring tree growth as a protection for soil and water resources. That gorermment contemplates initial concentration on the protection of intermittent stream beds by tree planting. 


\section{LITERATURE CITED}

(1) Abbad s Lasierra, Iñigo.

18titj. IIistoria geogriflea, ciril y natural de la isla de San Juan l3autista de luerto Rico. Imprenta y Liberia de Acosta San Juan. 505 ptr.

(2) Ballett, Mary F.

J92if. Common exotic treas of Sonth Florida (Dicotyledons). $41+$ plo. iltus. Gainesville.

(3) Bearil, J. s.

1:49. The natural regetation of the Windward and Leewald Islands, Oxford Forestry Mem. No. 21, 192 p1)., illus.

(4) Piviton, N. L.

19J8. The flura of the American Virgin Islands. BrookIrn Bot. Gird. IIem. 1 : 19-118.

(i) - and Wilson, Percr.

1923-30. Descriftive flora-Spermatoplyta. Botany of Porto Rien and the Virgin Fslands. N.T. Acad. Sci. Sei. Surv. Porto Rico Viroin lslands, $r .5,6$.

(6) Couk, Melvilte T., and Gleason, llenry Allan.

1928. Ecologicat survey of the flora of Polto Rico. Portu Ricul leyt. Igr. Jour. 12:1-139, illus.

(7) Cuba.

1907. Disposiciones rigentes relatiras al serrlcio del Rano de Muntes en la Isla de Cuba, Harana.

(8) I) Irtand, William D.

1920. Forest regeneration in Puerto Rico. Econ. Geog. $\overline{5}: 369-381$.

(4a) Wrecers, 11. F. A

1S79. The flora of St. Croix and the Virgin Islands. [..., Natl. Mlus. Rul. 13. 133 pr.

(9) Fernả udez y Jiménez, José Maria.

1867. Tratidio de la arboricultura cubana $r$ llera arregada de la Isla de Pinos y P'uerto-Rico. $225 \mathrm{pt}$. Habana.

(10) Gifford, Jolin C.

1905. The Linquillo Forest Reserve, Porto Rico, U.S. Dept. Agr. Bur. Forestry Bul. 54, 52 pp., illus.

(11) Gilormini, José A.

1!47. Manual para la propasacion de árboles $r$ el establecimiento de plantaciones forestales en puerto Rico. Ed. 2. 109 pp., illus. Puerto Rico Dept. Agr. Con. Servicio Forestal.

(12) Gleason, IT. A., and Cook, Mel. T.

1927. Plant ecologr of Porto Rico. N.Y. Acad. Sci., Sci. Surv. Porto Rico Virgin Islands $7: 1-173$, illus.

(13) Hill, Robert T.

1899. Notes on the forest conditions of Porto Rico. C.S. Dejt. Agr. Div, Forestry Bul. 25, 45 pp., illus.

(ft) lIoldridge, L. R.

1942-43. Arholes de Puerto Ríco. U.S. Dept. Agr. Forest Serv. Trop. Forest Expt. Sta. Pub. 1, 2, itlus.

(1.)

1942. Trees of Puerto Rico. U.S. Dept. Agr. Forest Serr., Trop. Forest Expt. Sta. Puh. 1, 2, illus.

(16) - and Muñoz MacCormick, Carlos.

1939. Plantas renenosas $r$ de pelos pumzantes de Puerto Rimo. Revista Agr. Puerto Rico 31 : 510-, T22, illus.

(17) Kelser, Harlan P., and Dayton, William A.

1942. Staudardized plant names. Ed. 2, 675 pp. Harrisburg, Pa.

(18) Kennard, William C., and Winters, Harold F.

1960. Some fruits and nuts for the tropics. T.S. Dept. Agr. Misc. Pub. S01, 135 tp., illus.

(18a) Koenig. Nathan.

19.3. A comprehensive agricultural program for Puerto Rieo. 1.S. Dept. Agr. 209 pn., illus.

(19) Iittle, Elhert L., Jr.

1953. Check list of natise and naturalized trees of the Tuited States (including Alaska). U.S. Dept. Agr. (20) Agr. Handlo. $41,472 \mathrm{pp}$.

19.5. Trees of Mona Island. Caribb. Forester $16: 36-53$, illus.
(21) little, Elbert I., .Tr., Wadsworth, Frank IA., and Marrero. Jusé.

1!nit. Irholes comunes de l'nerto Rico e Istas V'írgenes. Eniversilad de Puerto Rico, Rio Piedras, l'nelto Rico.

(2:2) Longwood, Frauklin R.

1!kit. l'verto Rican wools; their machining, seasoning and related chaldacteristics. U.S. Dept. Agr., Agr. Handb. 20., 98 pp., illus.

:3)

1962. l'resent and potential commercial timbers of the Carihhean with siecial reference to the West Indies, the Guimas, and British 11 nduras. U.S. Dept. Agr., Acr. IIandb. 20T, 167 pp., illus.

(24) Martorell, Luis F.

19.33 (1:54). QQue árbol sembraré? Caribb. Forestel $14: 152-160$.

(25) Melgarejo, Juan.

1:14. Memoria 5 descripcion de la isla de San Juan de l'uelto Rico en el año 1582. Bol. Hist. de Puerto Rico $1:-\pi \cdot 91$.

(26) Menuinger, Edwin A.

10.5. What flowering tree is that? A bandbook for the tropies. $1958 \mathrm{Ed} .176 \mathrm{pp}$., illus. Stuart, Fla.

(2T)

1962. Flowering trees of the world for tropics and warn climates. 336 pp., illus. New York.

(2S) Morton, Julia F., and Ledin, R. Bruce. 19.2. to0 plants of south Florida. 134 pp., illus. Coral Gables, Fla.

(29) Murphy, Louis S.

1916. Forests of Porto Rico, past, present and future, and their phrsical and economic derelopment. U.S. Dept. Agr. Bul. 3nt, 99 pp., illus.

(30) Oakes, A. J., and Butcher, James O.

1962. Poisonous and injurious plants of the U.S. Tirgin Islands. U.S. Deft. Agr. Misc. l'ub. 882, 37 pp., illus. (31) Ordetx Ros, Golzalo S.

19:2. Flora apicola de la América tropical. 334 pp., illus. La Ilabana, Cuba.

(32) Otero, José I., Toro, Rafael A., and Pagán de Otero, Lidia.

1945. Catálogo de los nombres rulgares 5 cientificos de algunas plantas puertoriqueñas. Ed. 2. Puerto Rico Tonir. Estación Expt. Agr. Bul. 37, 281 pp.

(33) Puerto Rico.

1860-79. Presupuestos generales de ingresos y gastos corresondicntes a los años económicos 1860-1868 y 187t-1879. San Juan.

(34) Riluos, Francisco.

1868. l'rontuario de disposiciones oficiales del gohierno superior de la isla de Puerto Rico. San Juan. 531 pp.

(35) Stahl, Agustin.

1936-37. Estudios sobre la flora de Puerto Rico. 6 pts. 1883-88. Ed. 2, 3 5., portr. San Juan de Puerto Rico.

(36) Sturrock. Darid, and Menuinger, Edwin A.

1946. Shade and ornanental trees for south Florida and Cuha. 172 pp., illus. Stuart, Fla.

(37) Urban, Ignatius.

1908-11. Flora portorlcensis. Symbolae Antillanae $r$. 4, 771 pn., portr.

(3S) Wadswortl. Frank $H$.

1950. Notes on the climax forests of Puerto Rico and their destruction and conserration prior to 1300. Caribh. Forester 11 : 38-17.

(39) Winters, H. F., and Almerda, N.

1953 (1954). Ornamental trees in Puerto Rico. Caribb. Forester 1t: $97-105$.

(40) Wolcott, George $\mathrm{N}$.

1950. An index to the termite-resistance of woods. Puerto Rico Univ. Agr. Expt. Sta. Bul. 85, 26 pp. 


\section{SPECIAL LISTS}

Common tree species of Puerto Rico and the Virgin Islands with some distinctive character, special feature, or use in common have been grouped together in rarious lists. These lists may be helpful in identification, in locating trees with useful products, and in selecting species for planting. Only those trees outstanding for a particular character or use are included. To save spare the tree species are cited by their numbers, and common and scientific names may be fomnd under" "List of Tree Species with Descriptions and Illustrations" (pp. iv-ix). The additional species mentioned briefly but not illustrated have been omitted.

\section{POISONOUS TREES}

Poisonods tReEs WITH TOXIC FRUITs, sEeDs, oR LEAVES.-65, 66, 74, 81, 82, 83, 84, 85, 110, 124, 125, $130,141,157,168,232$.

Polsonot's Thess with mirtatixg sap.-122, 123, $12+, 125,129,130,132,218$.

\section{APPEARANCE AND TRUNK}

Graxt trees (reaching 100 feet in height, 4 feet in trunk diameter). $-35,69,76,84,89,90,106,108$, $109,111,112,125,136,149,153,180,209$.

LARGE BCTTRESSES.-21, 31, 49, 84, 89, 90, 109 , $111,134,149,153,209$. 179 .

Prop roots (stilt roots) $-20,21,22,162,163$,

UxBRANCHED stex.-1, 3, 4-10 (palm family), 174.

Palms. - $1-10$.

Horizontal BRANCHING. $-3,50,69,70,73,75$, $147,153,155,156,157,163,180,181,181,209,210$, $221,222,223,224,243$.

SPINY TRUNK OR BRANCHES.- $4,5,58,68,70,73$, $77,83,84,88,96,102,103,125,134,153,175,176$, $181,247$.

PEeisixg, SMIOOTH, MIOTTLED BARK.-25, 28, 30, 42, $93,94,105,132,194,195$.

Mangroves (on silt shores).-179, 182, 183, 225.

\section{COLORED SAP OR LATEX}

WHITE OR MILKY S.IP OR LATEX,- $17,18,19,21$, $22,23,24,105,106,120,122,123,124,125,129,130$, $161,174,205-214$ (sapodilla family), 217, 218, 219.

YELLOW OR ORINGE SAP OR LATEX.-162-165 (mangosteen family), 166.

REDDISII S.P OR LATTX.-28, 89, 90, 91, 229.

BLACKISH SAP.- 132 .

\section{LEAVES}

Tert large leaves (mole tham 1 foot long, including compound leares).-1, 1-10 (palms), 17, $19,20,26,51,59,60,61,72,75,81,87,107,108,109$, $110,141,149,154,157,159,167,174,201,229,233$.

SPINY LEATES. - $4,5,77,88,102,103$.

LAATTS REDTCED TO SCALES OR NONE-11, $175,176$.

Fragrant or aromatic liates (with odor when crushed). $-13,42-51$ (laurel family), 95, 96-103 (rue family) , 105, 106, 107, 108, 110, 174, 185, 186, $194,221$.

\section{FLOWERS}

WHITE SHOWY FLOWERS.- $34,35,54,60,62,63$, $64,76,91,96-100$ (citrus), 153, 154, 159, 160, 16t, $188,217,218,221,240,247$.

YELLOW SIOW'Y FLOWERS,-72, 74, 77, 78, 80, 88, $89,115,150,152,167,218,238$

ORAYGE SHOWY FLOWERS.- $75,83,84,150,234$.

Pixk silowy flowers. - $68,69,71,73,81,82,85$, $153,166,178,236$.

RED SHOWY FLOWERS.-30 (fruits), $75,82,84,91$, 1\%1, 189, 218, 234, 235, 237.

BLUE OR P'TRPLE SHOWY FLOWERS. - 81, 86, 93, $110,117,152,166,178,189,230,239$.

Tery fragrint Howers.-34, 35, 40, 54, 58, 60, 70. 73, 96-100 (citrus), 161, 164, 217, 218, 240.

\section{FRUITS}

VerX Laree frutts (more than 6 inches long and 4 inches broad or more than 1 foot long). $-6,17$, $18,37,75,91,164,232$.

FrTIT A BEANLTIE POD.-54, 58-91 (legume family), $217,218,234,235,236,237,238$.

\section{USES}

Timibr trees.-11. 20, 26, 34, 35, 42, 48, 49, 50, $52,60,62,64,69,70,76,79,81,87,93,101,102,105$, $106,107,108,109,111,112,115,118,126,131,134$, $139,144,149,151,153,154,161,164,173,179,180$, $181.184,186,191,196,201,209,211,212,213,214$, $221,228,229,230,236,243$.

Mentcin.l trees (U.S. Pharmacopoeia or Dispensatory ).- $72,80,93,94,97,98,100,158,168$, 194.

EDible wild FrutTs.- 28, 29, 62, 64, 68, 69, 76, $115,116,130,134,164,175,176,188$ (escaped) , 195, $209,213,243$.

EDIble other parts (stems, leaves, flowers, young fruits, seeds).-4, 7, 9, 17, 54, 91, 184. 


\section{PLANTING LISTS}

THEes Grow IN FOREST PLANTATIONS.-11, 52, $111,112,126,161,186,209,221,228,229,230,236$.

Trees For WIXUBlis. $131,12,161,164,189,189,234,236$.

Tries FOR sHoRES (salt resistant).-6, 11, 2S, 150 , $152,161,163,164,181,184,214,218$.

TREES FOR DRY AREIS AND POOR SITES.-11, 54, 60 , 65. 70, 76, 77, 80, 93, 94, 112, 157, 161, 181, 194.

Treis foli WTt ineıs.-?, 11, 1t, 17, 20, 111, 152, $184,186,209$.

TREES FOR LIVIX FENCEPOSTS.- $14,22,54,82,83$, 85, 105. 125, 134, 135, 150, 152, 167.

Cultiyated fliutt trefs.-6, 1 i $, 18,37,38,39$, 51, 80. 96-100 (citrus), 127, 130, 131, 133, 135, 140, 15., $164,174,188,189,195,206,210,243$.

Sih.dDe Trees for COFFeE ANn CACAO.-62, 63, 64, $81,84,200$.
Orxamental trees.- $1,3,6,9,10,11,14,17,18$, $19,20,21,23,26,28,30,39,40,52,54,57,60,62$, (53), 64, 67, 68, 69, 71, 72, 73, 74, 75, 76, 77, 78, 80, 81, $82,83,85,89,91,93,94,105,110,111,112,115,117$, $131,151,152,159,161,163,164,166,167,178,181$, $184,188,189,194,199,206,209,210,218,223,227$, 2.29, 232, 233, 234, 236, 238, $246,247$.

ORNAIENTAL TREES ALSO PRODUCING EFFECTIVE SIANE.-17, $19,21,23,60,62,63,64,68,69,73,74$, $75,76,78,80,83,84,89,105,111,131,163,164,181$, $184,188,206,209,234$.

OrNanertal trees also productNG eDible FRч1тs. $-6,17,28,39,80,131,164,166,184,188$, 206,210 .

ORxaMental tTeEs ALSO PRODUCING VALUABLE TIMBER.-52, $60,69,81,93,94,111,112,131,161$, $164,184,189,206,209,229,236$. 


\section{KEY TO FAMILIES}

When the plant family of a tree is not known, this key to the families of the trees of Prerto Rico and the Vircyin Islands aids identification. Eighty-eight plant families are included, all 75 with native trees and also 13 others with common introduced trees. Of these, 68 families are represented in this volume, 33 by a single species illustrated, however. Additional kers to the remaining 218 of the 250 tree species are inserted in the text under all 35 families with 2 or more species ilinstrated. However, the related species compared briefly and rarious genera of less common trees not mentioned in the text are not keyed.

Some genera have been included in the key to families also. If a plant family has only 1 or 2 genera of native trees, these generic names are cited after the family name. Also, several genera differing slightly from the main charicters of their families have been inserted separately. However, this artificial key may not provide for a few odd genera and extreme variations. Introduced or exotic genera and families are indicated by an asterisk $(*)$.

Keys are outlines or shortcuts for identifying trees or specimens by the process of elimination. Thus, trees are divided into two groups according to one or more pairs of contrasting characters. Each group is divided successively into two smaller groups until the name is reacherl. The name of a particular specimen is found through selection, one by one, of the group which fits and by elimination of the others.

In these indented keys, paired groups are designated by the same letter, single and double, beginning with " $\mathrm{A}$ " and " $\mathrm{A} A$ " at the left of the page and are equally indented by steps. 'The page number refers to the descriptive text, the beginning of the family or' genus listed. 'The 20 small families without page numbers are not mentioned further or represented among the common trees described in this volume.

An unpublished card key to families of West Indian trees by the senior author has served as the basis for this one. Nontechnical characters and those readily observed have been emphasized. The descriptive terms are defined under the topic "Explanation of Botanical Terms" (p.9).
One character used in the key, presence or absence of stipules (one or two scales at the base of a leaf), may be difficult to determine because the stipules sometimes are minute or shed early. Stipules can be examined best in the bud and immature leaves near the stem tip. Upon shedding, the stipules leare a scal, which also may be minute.

Vegetative characters, especially those of leares, are placed first in the key. Some plant families of trees can be recognized or identified by certain combinations of vegetative characters alone. However, many kinds of tropical trees have foliage of similar appearance.

For positive identification of many families, the reproductive characters of flowers, fruits, and seerls are needed. Even when these are lacking, old fruits may be located on dead branches or on the ground, and one tree may be found flowering out of season. Some sterile specimens, those lacking flowers or fruits, can be identified to family by the vegetative characters beginning the key. If not, the key will eliminate many families. Then identification can be continued by consulting the text and drawings for the remaining families.

The key to families is divided into four parts according to the arrangement or position of the leaves and the number of blades. Parts 1 and 2 are for trees with alternate leaves, that is, attached singly or 1 at al point on a twig (node). Parts 3 and 4 are for trees with opposite leaves, that is, paired or 2 at a node, and also those with whorled leaves, 3 or more at a node. Parts 1 and 3 are for trees with simple leaves, with 1 blade, and Parts 2 and 4 , trees with compound leaves, divided into 3 or more blades (ravely only 2 ).

The first step in using this key to families is to place the minnown tree or speciment in one of the four groups listed below. Then continue the key under the part or group on the page cited.

Part 1. Leaves alternate, simple (p. 22).

Part 2. Leaves altermate, compound (p. 25).

Part 3. Leaves opposite, simple (p. 26).

Part 4. Leaves opposite, compound (p.27). 


\section{PART 1. LEAVES ALTERNATE, SIMPLE}

A. Leaves reduced to scales or none.

B. Stems succulent, spiny-Cactus Family (Cactaceae), page 376 .

BB. Stems with slender twigs bearing minute seale leaves 1 at a node-Tamarisk Family (Tamaricaceae; Tamarix*). AA. Leares larger, with flat green blade.

C. Leaves parallel-veined, stems unbranched (very slender branches in bamboo).

D. Leaves grasslike, divided into sheath and blade-Grass Family (Gramineae; Bambusa*), page 32

DD. Leaves palmlike, fan-shaped, very large, with long petiole-Palm Family (Palmae), page 34 .

CC. Leaves with veins forming network or inconspicuous; stems becoming branched.

E. Sap or latex colored.

F. Sap whitish or milky.

G. Stipules present (sometimes minute or shedding early, leaving scar); flowers unisexual.

H. Female flowers with 2 or I style; nodes usually with rings-Mulberry Family (Moraceae), page 60.

III. Female flowers with 3 styles; nodes without rings-Spurge Family (Euphorbiaceae), page 260.

GG. Stipules absent.

i. Leares palmately lobed; flowers mostly unisexual-Papaya Family (Caricaceae;* Carica*), page 37 .

II. Leaves not lobed; flowers bisexual.

J. Corolla of 3-5 separate petals-Cashew Family (Anaeardiaceae), page 28.

JJ. Corolla tubular, of united petals.

K. Stamens opposite corolla lobes; fruit a berry, borne singly-Sapodilla Family (Sapotaceae), page 436.

KI. Stamens alternate with corolla lobes; fruits (drupes or follicles) usually paired, 2 from a flower-

FF. Sap not whitish.

Dogbane Family (Apocynaceae), page 460.

L. Sap orange-Anatto Family (Bixaceae;* Bixa*), page 358.

LL. Sap reddish-Coccoloba wifera, page 82 .

EE. Sap watery.

M. Nodes with rings.

N. Stipules present.

O. Stipules forming sheath around twig-Buckwheat Family (Polygonaceae), page 76.

OO. Stipules enclosing bud, soon shedding.

P. Leaves pinnately veined, elliptie-Nagnolia Family (Magnoliaceae; Magnolia), page 94.

PP. Leaves palmately veined, with $7-11$ main veins froin base, nearly round.

Q. Leaves heart-shaped, not lobed-Mallow Family (Malvaceae; Hibiscus), page 326.

QQ. Leaves very large, umbrellalike, with 7-11 rounded lobes-Cecropia, page 66.

NN. Stipules absent-Piperaeeae (Piper), page 50.

MI. Nodes without rings.

$\mathrm{R}$. Leaves in 2 rows along twig.

S. Leaves with swelling where petiole joins blade-Elaeocarpus Family (Elaeocarpaceae; Sloanea), page 324 .

SS. Leaves without swelling on petiole.

T. Stipules absent; flowers with many pistils often uniting to form I large many-seeded fruit-Annona Family (Annonaceae), page 100.

TT. Stipules present (sometimes mizute or shedding early, leaving scar); flowers with I pistil.

U. Flowers unisexual or mostly so, petals none.

V. Leaves asymmetrical; styles 2; fruit 1-seeded-Elm Family (Ulmaceae; Celtis, Trema), page 56.

VV. Leaves symmetrieal; styles 3; fruit a few-seeded capsule-Spurge Family (Euphorbiaceae), page 260.

UU. Flowers bisexual; petals usually present.

WT. Petals 5, hood-shaped (sometimes none); stamens 5, opposite petals and often within; fruit with 1-4 seeds-Buckthorn Family (Rhamnaceae), page 316.

WW. Petals 3-7, broad (sometimes none); stamens 5 to many; fruit with few to many seeds.

X. Style 1, ovary I-celled-Flacourtia Family (Flacourtiaceae), page 364.

XX. Styles 5, ovary 5-celled-Chocolate Family (Sterculiaceae), page 338.

$R R$. Leaves in more than 2 rows along twig.

Y. Leaves with minute gland dots.

Z. Leaves not aromatic.

a. Gland dots both large and small-Myoporum Family (Myoporaceae; Bontia).

aa. Gland dots uniformly small-Myrsine Family (Myrsinaceae), page 430 .

ZZ. Leaves aromatie, with distinctive odor and taste when crushed.

b. Flowers with numerous stamens but no corolla; odor and taste of eucalyptus-Eucalyptus, ${ }^{*}$ page 398 .

bb. Flowers with few stamens or if many, with petals.

c. Stamens with anthers opening by pores with lids; leaves mostly elliptic with side veins long and curved; odor and taste of spices-Laurel Family (Lauraceae), page 110.

ec. Stamens with anthers splitting open lengthwise.

d. Leaves with odor and taste of citrus; stamens large, separate-Rue Family (Rutaceae), page 218

dd. Leaves with peppery, stinging taste; stamens minute, united into a tube-Canella Family (Canellaceae; Canella), page 362 .

YY. Leaves nithout minute gland dots.

e. Stipules present (sometimes minute or shedding early, leaving scar).

f. Stipule a pointed scale above petiole, persistent-Coca Family (Erythroxylaceae; Erythroxylon), page 210 . 
ff. Stipules outside petiole.

g. Leaves lobed.

h. Leaves with 2 rounded lobes at apex and 13 or 11 veins from heart-shaped base-Bauhinia, page 168.

hh. Leaves deeply palmately lobed with mostly 5 long-pointed, finely toothed lobes-Cochlospermum

Family (Cochlospernaceae; ('ochlospermum*), page 360 .

gg. Leaves not lobed.

i. Leaves long, very narrow, finely toothed-Willow Family (Salicaceae;* Salix*), page 54.

ii. Leaves broad, mostly not toothed.

j. Flowers minute.

k. Flowers unisexual.

1. Leaves with stinging hairs-Nettle Family (Urticaceae; Urera).

11. Leaves without stinging hairs.

m. Female flowers usually without petals, with 3 or 2 styles; fruit a drupe or capsuleSpurge Family (Euphorbiaceae), page 260.

$\mathrm{mm}$. Female flowers with usually 4 petals, 4 stigmas; fruit a berry with 4 nutlets-Holly Family (Aquifoliaceae; Ilex).

kk. Flowers bisesual.

n. Ovary inferior-Ginseng Family (Araliaeeae; Dendropanax), page 426.

nn. Ovary superior-Bittersweet Family (Celastraceae).

jj. Flowers larger, often showy.

o. Fruits 2-5 from a flower, berrylike, black, borwe on an enlarged red disk; flowers yellowOchna Family (Ochnaceae; Ouratea).

oo. Fruit 1 from a flower.

p. Leaves pinnately veined; flowers with cuplike base bearing sepals, 5 petals, and mostly many separate stamens-Rose Family (Rosaceae), page 140.

pp. Leaves palmately veiued (pinnately veined in Quararibafa, page 336), flowers with parts inserted at base, stamens many, united into a column around pistil.

q. Flowers with unbranched style-Bombax Family (Bombacaceae), page 382

ee. Stipules absent.

qq. Flowers with style having mostly 5 branches-Mallow Family (Malvaceae), page 326.

$r$. Seed exposed on 2-lobed, red fleshy base; flowers and fruits not produced; leaves lance-shaped, very narrow, thick, without lateral veins-Yew Family (Taxaceae; Podocarpus), page 30.

rr. Seeds enclosed in fruits maturing from flowers; leaves various.

s. Ovary inferior.

t. Leaves palmately veined, petiole joining blade usually above base-Hernandia Family (Hernandiaceae; Hernandia), page 130.

tt. Leaves pinnately veined.

u. Petals none or minute-Combretum Family (Combretaceae), page 386 .

uu. Petals present.

v. Fruit a drupe less than 1/2 inch long, 1-seeded-Sweetleaf Family (Symplocaceae; Symplocos), page 456.

vv. Fruit larger, various, usually many-seeded-Lecythis Family (Lecythidaceae*).

ss. Ovary superior.

w. Corolla of separate petals or absent.

x. Flowers unisexual.

y. Calyx a cylindrical tube with 4 lobes; corolla abseut-Mezereon Family (Thymeleaceae; Daphnopsis), page 380.

yy. Calyx of mostly separate sepals.

z. Pistils 3, each forming a drupe with 1 curved seed-Moonseed Family (Menispermaceae; Hyperbaena).

zz. Pistil 1.

A. Styles 3 or 2; fruit a capsule or drupe-Spurge Family (Euphorbiaceae), page 262.

AA. Style 1,3-forked; fruit of 3 winged keys-Thauinia portoricensis, page 310.

xx. Flowers bisexual.

B. Flowers minute.

C. Flowers regular.

D. Flowers in long narrow racemes, white; fruit a minute capsule-Cyrilla Family (Cyrillaceae, Cyrilla), page 298.

DD. Flowers in panicles or single; fruit a drupe-Icacina Family (Icacinaceae; Mappia, Ottoschulzia).

CC. Flowers irregular, with 5 unequal petals-Sabia Family (Sabiaceae, Meliosma), page 314.

BB. Flowers larger.

E. Flowers regular.

F. Pistils many, each with 1 style-Dillenia Family (Dilleniaceae, Dillenia*), page 314.

FF. Pistil 1.

G. Flowers with 4 petals, 4 to many long stamens; pistil usually stalked, with short

style or none-Caper Family (Capparidaceae; Capparis, Morisonia), page 132.

GG. Flowers with 5 overlapping sepals, 5 petals, many stamens, and pistil with $2-5$ styles-Tea Family (Theaceae), page 346.

EE. Flowers irregular, with usually 3 petals and 8 stamens united into a tube-MIlkwort Family (Polygalaceae; Polygala, Badicra), page 260.

ww. Corolla of united petals.

H. Stamens separate and distinet.

I. Fruit a drupe-Olax Family (Olacaceae; Schoepfia, Ximenia).

II. Fruit a capsule-Heath Family (Ericaceae; Lyonia). 
HH. Stamens inserted on corolla.

J. Stamens 2-3 times as many as corolla lobes.

K. Flowers unisexual (dioecious), styles 2-6; fruit fleshy, fen-seeded-Ebony Family (Ebenaceae; Diospyros)

KK. Flowers biscxual, style 1; fruit dry, 1-seeded-Snowbell Family (Styracaceae; Styrax). JJ. Stamens as many as corolla lobes or fewer.

L. Flowers regular.

M. Style 1 ; fruit a berry-Nightshade Family (Solanaceae), page 488 .

MI. Styles 2 or divided into 4 forks; fruit a drupe or $1-4$ nutlets-Borage Family (Boraginaccae), page 466 .

LL. Floners irregular, large, with long corolla tube-Bignonia Family (Bignoniaceae; Enallagma). 


\section{PART 2. LEAVES ALTERNATE, COMPOUND}

A. Leaves pinnate, including bipinnate and tripinnate.

B. Leaves bipinnate or tripinnate.

C. Leaves fernlike, coiled at tip when growing, bearing spores in brown dots beneath; stems unbranched-Treefern Family (Cyatheaceae; Cyathea, Hemitelia), page $2 \mathrm{~S}$.

CC. Leares not fernlike; stems becoming branched.

D. Leaflets long-pointed, edges toothed-Melia,* page 246.

DD. Leaflets rounded or short-pointed at apex, edges not toothed.

E. Fruit a pod (legume) with beanlike seeds-Legume Family (Leguminosae), page 142.

EE. Fruit a long 3 -angled capsule with winged seeds-Horscradish-tree Family (Moringaceae; Maringa*), page 134.

BB. Leaves once pinnate.

F. Leaflets parallel-veined, leaves palmlike, very large, with long petiole; stems unbranched-Palm Family (Palmae), page 34 .

FF. Leaflets with veins forming network or inconspicuous; stems hecoming branched.

G. Leaflets deeply divided into narrow segments, white hairy beneath; leaves femlike, almost bipinnateProtea Family (Proteaceae; Grevillea*).

GG. Leaflets not deeply divided or lobed.

H. Stipules usually present; fruit a pod (legume) with beanlike seeds-Legume Family (Leguminosae), page 142.

HH. Stipules absent; fruits and seeds various.

I. Sap whitish or of other color, resinous.

J. Flowers with 1 very short style, stamens twice as many as petals-Bursera Family (Burseraceae), page 258.

JJ. Flowers with $3-5$ stigmas or styles, stamens as many or twice as many as petals-Cashew Family

(Anacardiaceae), page 286.

II. Sap watery.

K. Leaflets with minute gland dots, with citruslike odor when crushed-Rue Family (Rutaceae), page 220. KK. Leaflets without gland dots.

L. Leares with 13-19 lanceolate asymmetrical leaflets, sharply toothed, long-pointed; fruit a walnutWalnut Family (Juglandaceae, Juglans).

LL. Leaves and fruit otherwise.

M. Flowers with $2-5$ pistils or 1 lobed pistil and with $2-5$ styles or stigmas; bark and sap bitterAilanthus Family (Simaroubaceae), page 236.

MII. Flowers with 1 pistil and 1 style.

N. Flowers mostly unisexual, stamens 5-10, separate-Soapberry Family (Sapindaceae), page 302.

YN. Flowers bisexual, with mostly S-10 stamens united into a tube (separate in Cedrela)-Mahogany Family (Meliaceae), page 241.

A. Leaves digitate (palmate) or with 3 leaflets (trifoliolate).

O. Leaflets with minute gland dots, with citruslike odor when crushed-Rue Family (Rutaceae; Amyris, Pilacarpus), page 220.

OO. Leaflets without gland dots.

P. Leaflets 3 .

Q. Stipules usually present; fruit a pod (legume) with beanlike seeds-Erythrina, page 190.

QQ. Stipules absent; fruit a drupe or winged key-Soapberry Family (Sapindaceae), page 302.

PP. Leaflets 5 or more.

R. Flowers minute; fruit a small, slightly fleshy berry, 2-seeded-Cinseng Family (Araliaceae; Didymopanax), paige 426.

RR. Flowers large, with 5 whitish petals; fruit a large oblong capsule with hairy seeds-Bombax Family (Bombacaceae; Ceiba), page 332 . 


\section{PART 3. LEAVES OPPOSITE, SIMPLE}

A. Leaves reduced to scales or needles, opposite or whorled.

B. Leares consisting of minute scales $6-8$ or more in a whorl on wiry green jointed twigs-Casuarina Family (Casuarinacea*;* Casuarina*), page 48 .

BB. Leaves of mintute scales $2-3$ at a node or long needles $2-5$ in a bundle, resinous-Pine Family (Pinaceae; ${ }^{*}$ Cupressus, * Pinus*).

AA. Leaves larger, with flat green blade, opposite or sometimes whorled.

C. Sap or latex colored.

D. Sap whitish or milky.

E. Luaves 3-8 at a node, with petiole longer than the small, nearly round blade-Euphorbin, page 270.

EE. Leaves 2-t at a node, with short petiole and long-or short-pointerl blade-Dogbane Family (Apocynaceae), page 460 .

DD. Sap not whitish.

F. Sap yellow or orange (whitish in Calophyllum)-Nlangosteen Family (Guttiferae), page 318.

FF. Sap of young leaves reddish-Tectona, ${ }^{*}$ page 484

CC. Sap watery.

G. Stipules present (sometimes minute or shedding early, leaving scar).

H. Nories with rings.

I. Stipules forming sheath around twig or paired and persistent.

J. Leares toothed-Chloranthus Family (Chloranthaceae; Hedyosmum), page 52

JJ. Leaves not toothed-Madder Family (Rubiaceae), page 504.

11. Stipules not forming sheath, single, shedding early-Mlangrove Family (Rhizophoraceae; Cassipourea Rhizophora), page 384 .

HH. Nodes without rings.

K. Flowers small, inconspicuous.

I. Petals 4 or 5 , spreading; stamens alternate with petals-Bittersweet Family (Celastraceae).

LL. Petals 5 (sometimes none), lood-shaped; stamens opposite petals and often within-Buckthorn Fam ily (Rhamnaceae), page 316.

KK. Flowers larger, often showy; petals fringed, with narrow stalk.

M. Petals 5; fruit a drupe-Malpighia Family (Mlalpighiaceae), page 256.

M M. Petals mostly 6, sometimes 4 or 5 ; fruit a capsule-Loosestrife Family (Lythraceae; Ginoria, Lagerstroemia*), page 382 .

GG. Stipules absent.

N. Leaves with 3-9 main veins from base, mostly elliptic, side veins curved, many smaller veins straight and, parallel-Melastome Family (Melastomataceae), page 418 .

NN. Leaves with 1 main vein (min̈rib).

O. Leaves coarsely toothed; flowers in a head-Composite Family (Compositae; Clibadium, Eupatorium), page 526.

OO. Leaves not toothed or finely toothed; flowers not in heads.

P. Petioles with 2 glands near blade-Laguncularia, page 392

PP. Petioles without glands.

Q. Oyary inferior.

R. Stamens 10 , petals $5-$ Mouriri (Melastomataceae).

$R R$. Stamens numerous.

S. Petals 4-5, rounded, mostly white; leaves with minute gland dots-Myrtle Family (Myrtaceae), page 396.

SS. Petals 5-7, large, rounded, wrinkled, stalked, searlet or white-Pomegranate Family (Punicaceae;* Punica*).

QQ. Ovary superior, stamens 10 or fewer.

T. Corolla absent or of separate petals; flowers mostly unisexual.

U. Stamens 2-10, separate or united.

V. Ovary exposed, 2-celled; corolla when present of 4 narrow white petals-Olive Family (Oleaceae), page 458 .

VV. Ovary enclosed in calyx tube, 1-celled; corolla absent-Four-o'Clock Family (Nyctaginaceae), page 88 .

UU. Stamens 8 , in 2 sets of 1 , inserted in calyx tube-Mezereon Family (Thymeleaceae; Dophnopsis), page 380 .

TT. Corolla of united petals; flowers bisexual.

TT. Leaves with minute gland dots, aromatic, with citruslike odor when crushed-Ravenia (Rutaceae).

WI $\mathrm{W}$. Leaves without gland dots, not aromatic.

X. Flowers regular, with 5-lobed spreading, waxy, orange or white corolla; fruit a berry-Theophrasta Family (Theophrastaceae; Jaquinia).

XX. Flowers irregular.

Y. Corolla tube short; fruit a drupe or 1-4 nutlets-Verbena Family (Verbenaceae), page 476.

YY. Corolla tube long; fruit a capsule with winged seeds or a berry-Bignonia Family (Bignoniaceae), page 490 . 


\section{PART 4. LEAVES OPPOSITE, COMPOUND}

A. Leaves pinnate (bipinnate in Jacaranda, page 492).

B. Nodes with rings.

C. Leaflets all paired (even pinnate), 4-10, oblique or asymmetrieal, not toothed-Caltrop Family (Zygophyllaeeae; Guaiacum), page 212

CC. Leaflets of odd number (odd pinnate), symmetrical or nearly so, toothed.

D. Leaf axis winged; leaflets rounded at apex-Cunonia Family (Cunoniaceae; If einmannia), page 138.

DD. Leaf axis not winged; leaflets pointed at apex.

E. Leaflets $3-7$, those at base deeply toothed and of ten divided into 3 lobes or leaflets-Honeysuekle Family (Caprifoliaceae; Sambucus).

EE. Leaflets finely toothed, not lobed.

F. Leaflets 5-11, elliptie or ovate, hairless or nearly so-Bladdernut Family (Staphyleaceae; Turpinia), page 300.

FF. Leaflets 11-15, lanee-shaped, densely hairy-Brunellia Family (Brunelliaceae; Brunellia), page 136.

BB. Nodes without rings.

G. Leaflets all paired (even pinnate), 2-8-Matayba, page 304.

GG. Leaflets of odd number (odd pinnate).

H. Leaves with minute gland dots, aromatic, with citruslike odor when erushed-Amyris, page 216.

HH. Leaves without gland dots, not aromatic-Bignonia Family (Bignoniaceae), page 490.

AA. Leaves digitate (palmate) or with 3 leaflets (trifoliolate).

1. Leaflets with minute gland dots, aromatic, with eitruslike odor when erushed- 4 myris, page 216.

II. Leaflets without gland dots, not aromatie.

J. Flowers with short corolla tube; fruit a drupe-l'itex, page 486 .

J.. Flowers with long corolla tube; fruit a long narrow capsule with many winged seeds-Tabebuia, page 496 . 


\section{TREE SPECIES, DESCRIPTIONS AND ILLUSTRATIONS}

\section{TREE-FERN FAMILY (CYATHEACEAE)}

\section{Helecho gigante, tree-fern}

Tree-ferns, among the most beantiful plants of tropical mountains, are common in Puerto Rico. They are readily recognized as ferns by their lacelike fern leaves murolling from a coil at the apex and by the absence of flowers, fruits, and seeds, while their slender unbranclied trumks, leafy only at the smmmit, qualify them is trees.

This species, the commonest of 5 or 6 kinds of trunked ferns reaching tree size in Puerto Rico, is characterized by: (1) slender mbranched brown trunk, scaly but spineless, usually with large oval leaf sears in the upper part and bearing at apex a crown of about 10-18 laree spreading leares: (2) feathery (3-pinnate) leaves mostly 6-10 feet long, the thin blade divided 3 times, ending in a long pointed tip curved downward: and (8) small brown ball-like masses less than $1 / 16$ inch in diameter, borne on the underside of some leaves and producing numerous powdery spores.

A very handsome small evergreen tree to $: 30$ feet or more in height, with trunk:; inches in dianeter and stately crown of graceful leaves, ovate in general outline. This species is spineless throughout, though certain kinds have spiny trunks and leaf axes. There is no conspicnous bud, but usually $1-4$ young mrolling leaves, actually alternate though crowded.

A mature leaf has a light brown axis scaly at base and many yellow-green secondary axes as much as 2 feet long, earh bearing featliery tapering branches less than 6 inches long. The numerous regularly arranged lea fegments are narrowly oblong, $3 / 5$ inch or less in length, rounded at apex, and with the minutely way-toothed edges turned under. The thin segments are yellow green on both sides. A dead leaf soon falls, leaving a large oval scar:

Some older leaves bear minute brown balls or beads (sori) in 2 rows on under surface of segments, composed of numerous spore cases (sporangia) which shed powder"y masses of microscopic spores. [Tuder farorable conditions spores, like seeds, develop into new plants.

Trunks of giant ferns differ from those of most trees in several ways. The smoothish surface is hrown and scaly, often covered below with masses of smaller plants, such as mosses, liverworts, and ferns, and with many small black roots projecting from the enlarged base. Not divided into bark

\section{Cyathea arborea (L.) J. E. Smith}

and wood, the trunk does not grow in diameter. There is a hard black outer layer $1 / 8$ inch or more in thickness and a central white soft pith containing a ring of brown bundles which serve for conduction and strength.

Though not solid wood, the hard trunks are durable and resistant to deciay and termites. Elsewhere, trunks of tree-ferns have served as posts, frameworks of houses, supports for vanilla plants and ot her orchids, and as water hars for drainage along momntain trails. The Carib Indians used the stems to preserve and carry fire, which ean be maintained for hours without snoke or flames.

These luxmriant fems secm to thrive following opening of the areas and const ruction of mountan roads, often growing abundantly along the cut roudsicle banks. One of the most easily accessible areas for viewing these odd plants is along the highway crossing the Luquillo Momtains. Though very omamental in their native mountains, tree-ferns seldom are cultivated in Puerto Rico. It is reported that small plants can be transplanted successfully and garden-grown in moist regions, even at sea level.

In lower and upper mountain forests of Puerto Rico arowing as a small understory tree and especially common in open areas such as ravines, banks, and roadsides. Also recorded from St. Thomas and Tortola, now probably rare on the latter and not observed there in 1954 .

Potrlic Forests.-Carite, Guilarte, Liquillo, Marica, Toro Negro.

RAxGe,-Greater Antilles, St. Thomas, Tortola, and Lesser Antilles in Saba, St. Kitts, Neris, Guadeloupe, Dominica, Montserrat, Martinique, St. Lucia, St. Vincent, and Grenada. Also in Trinidad. Recorded as rare in lowlands of eastern Mexico.

Otuer commox Naszes.- -helecho arbóreo, helecho, palmilla, camarón, camaroncillo (Puerto Rico) : camarón, luelecho árbol, palmera sin espinas (Cuba) ; tree-fern (English).

Several species of trunked ferms of this and related gener:a (Hemitelin and Alsophita) are native in mountain forests of Puerto Rico thougl uncommon to rare and usually not reaching tree size. A related large tree-fem with small spines on the trunk is Cyathea brittoniana Maxon. Inother large tree-fern with leaves only twice pinnate (2pinnate) and with spines is $C$. pubescens Mett. 

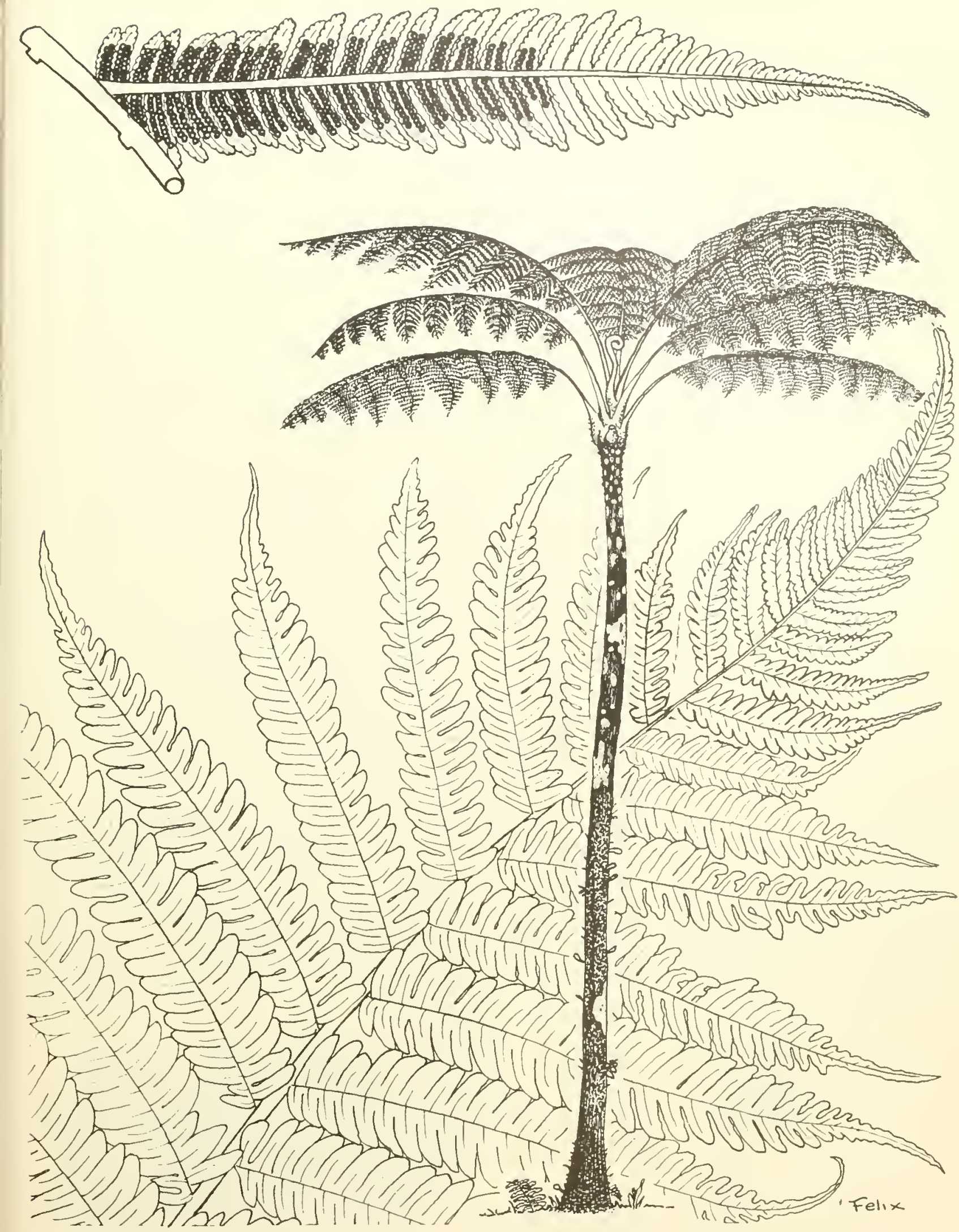

1. Helecho gigante, tree-fern

Cyathea arborea (L.) J. E. Smith Lower leaf surface (above) and upper leaf surface (below), natural size. 


\section{YEW FAMILY (TAXACEAE)}

\section{Caobilla, podocarp}

The only native conifer of Puerto Rico is this medium-sized tree of momntain forests. It is distinguished by the crowded, very narrow, lanceshaped leaves $21 / 2-6$ inches long and less than 1/2 inch wide, long-pointed, leathery, stiff, and without visible lateral veins. There are no true flowers or fruits, but the brown seeds $5 / 16$ inch long are borne sincly and exposed on an enlared 2-lobed red juicy base. Pollen is produced on other or male trees (dioecions) in narrow yellow-green cones $1-11 / 2$ inches long and $1 / 4$ inch in diameter.

An evergreen tree becoming 30 feet high and 1 foot or more in trumk diameter, with narrow to spreading crown. Bark is smoothish and sealy, becoming rough, fissured, shaggy, and peeling off in brown or gray strips about $1 / 4$ inch thiek. Inmer bark is punk, tasteless or slightly bitter. Twigs are green and angled when young, becoming brown and round.

The alternate leares are narrowed and nearly stalkless at base, sometimes slightly curved or sickle-shaped, with edges straight and slightly turned under, the mpper surface dark green and slightly shiny, and lower surface green to yellow green.

Male or pollen-bearing cones are single at base of leares, stallkless and eylindrieal, yellow green, turning brown after pollen is shed. Seeds are also single at leaf bases, naked, small and gray at time of pollination, brown, elliptic, and pointed at maturity. Each seed is attached to a base (receptacle) $3 / 8$ inch long and broad, which is bright red but becoming dark red and which has a stalk 1/4-3/8 inch long. Pollen and seeds are produced nearly through the year.

\section{Podocarpus coriaceus L. C. Rich.}

The saprood is whitish or pinkish, and the heartwond yellowish or brown. The wood is soft, moderitely heary (specifie gravity 0.7), and easily worked. It is suitable for fine cabinetwork and furniture. However, in Puerto Rico the trees are usually small and of poor form and therefore yield little usable wood.

In upper mountain forests of western Puerto Rico, almost confined to the Maricao Forest but also at Cerro Gordo near San Germán. Also rale and local as a shrub 4 feet high in the dwarf forest east of El Yunque summit in the Luquillo Mountains, eastern Pnerto Rico.

Public rorests.-Luquillo, Maricao.

R.inge.-Pnerto Rico, Lesser Antilles on St. Kïtts, Montserrat, Guadeloupe, Dominica, Martinique, and St. Lucia, and Trinidad and Tobago.

Other comion N.umes.- caoba del país (Puerto Rico): podocarp, podocarpus (English, commerce); weedee (Nevis); wild pitch pine (Montserrat); raisinier montagne (Dominica); wild pine (Trinidad) ; lanrier-rose (Guadeloupe).

Botanical srionyr.-Nugeia coriacea (L. C. Rich.) Kíntze.

This coniferous or cone-bearing tree is classed with the gymmosperms, seed plants without true flower's or fruits but with exposed or naked seeds. Conifers, or soft woods, inelude some of the world's most raluable timber trees, such as pines, Douglasfir, spruces, firs, and cedars. Puerto Rico has three other native species of gymnosperms, dwarf shrubby cycads with enlarged undergromd stems and known as maranguey (genus $Z$ amia). 


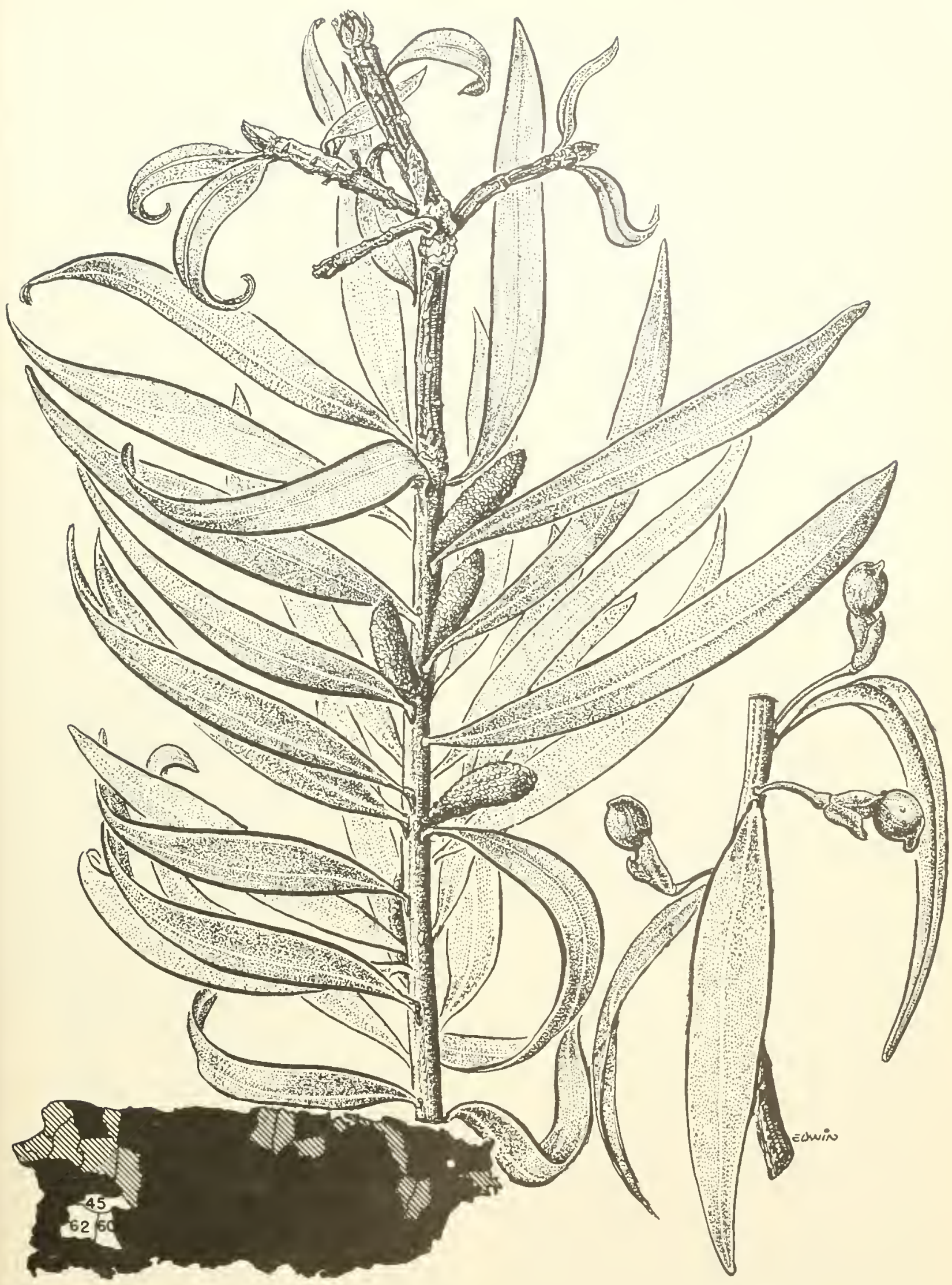

2. Caobilla, podocarp

Natural size

Podocarpus coriaceus L. C. Rich. 


\section{GRASS FAMILY (GRAMINEAE)}

\section{Bambú, common bamboo}

Bamboos, giant introdnced evergreen grasses with clustered, jointed hollow stens and feathery foliage, are so diflerent that they are not likely to be confused with any of her trees. Perhaps they are not trees at all, beciuse they crow in clumps of several stems, like many shmbs. and do not have a single trunk from the base. Their large treelike size and nefulness justify their inclusion here.

The first and by far the commonest of abont 30 exotic species of bambon, this species was introduced into Puerto Rien nore than a century ago and thus is sometimes incorrectly callerl native bamboo. It is diflienlt to distinguish between some of the different speries, as the flowers needed for positive identification are rarely prorluced. Howerer, as a group bamboos are casily recognized by: (1) clusters of several to many slender. tapering, slightly curved stens $2-t$ inches in diameter, dark green to orange, with swollen lings or joints 8-18 inches apart; (2) several rely slender branches spreading horizontally and regularly at the joints: and (3) grass leaves in " rows, consisting of basal sheath around the slender twig and long-pointed blacle with many lateral reins parallel with midrib.

In this species stems (culms) attain 30-50 feet in height and towall the top diverge from the center. The smonth surfice, areen to dark green, becomes orange or yellow in age. From a distance the plant appears like a clump of giant ferns. The slender lateral hranches, about $1 / 4$ inch in diameter, are nearly horizontal and bear wirelike yellow-green twigs. Spines are absent in this species. A horticultural rariety has rariegated stems with rellow and green rertical stripes.

The light green leaf sheaths are $11 / 2-21 / 2$ inches long, closely fitting the twig. Blades are 6-10 inches long and $3 / 4-13 / 4$ inches wide, or as short as 2 inches at base of twig, with rough edges, longpointed at apex and short-pointed where nar'rowed and jointed into sheath. The upper surface of the flat thin blade is green and slightly shiny, the lower surface pale blue green.

The large bamboos bloom only once. Generally, after a long period of many years of growth, many plants growing together flower simultaneously, produce seeds, and then die. Like most other grasses, bamboos have inconspicuons flowers usually light brown or straw colored. The flower cluster (panicle) of this species is composed of slender branches bearing bracted clusters of 3-15 or more stalkless spikelets $1 / 2-3 / 4$ inch long, oblong and pointed, each with several to many flowers (florets) about $3 / \mathrm{s}$ inch long. The flower has 2 narrow scales, 6 stamens with purple protruding anthers, and pistil, producing an oblong grain.

Not divided into bark and wood, the stem is hollow except at the nodes, lightweight, hard, and
Bambusa vulgaris Schrad.*

strong. It completes its height growth from the clustered roots at base in about 3 months, elongating very rapidly as much as 8 inches daily. Nor does it expand in diameter after it is first formed.

I new growing shoot at the outside of a clump is readily distinguished by the absence of branches and by the presence at ench node or joint of a large leaf, with triangular spreading blade. These clasping leaves a]ong the main axis have a very large gray-green sheath 6-12 inches long, extending nearly to the next node and bearing many brown needlelike hairs that stick in the flesh when touched, and a short triangular pointed yellowareen blade $2-3$ inches long and broad, also with a few brown hairs. Toward the apex of the elongating stem the leares are closer together and overlapping.

Bamboos of this and other species have many uses besirles ornament and pasture shade. Their masses of intertwining roots and accumulations of leaf litter check erosion on roadsicle banks and slopes. Poles of various kinds for construction, fences, fenceposts, ladders, tool handles, flagpoles, and stakes are easily made from bamboo. The stems wil] serve as temporary water pipes a fter opening them on one side at each node and removing the partitions. Short pieces are used as pots for seedlings to be transplanted later. Bamboo boards can be prepared by slitting, splitting, and spreading open the stems. and the split pieces woven into baskets. Bamboo stems have been utilized in the manufacture of various articles, including furniture, lattices, fishing rods, picture frimes, lampsharles, mats, and flower vases. This is not the best bamboo becanse the stems are not resistant to rlamage by the bamboo powder-post beetle (Dinoderus minutus (F.)) as are those of certain more recently introdnced species. Also very susceptible to attack by dry-wood termites.

iVith outer scales remored, the tender growing tips of bamboo shoots can be eaten by boiling about one-half hour and changing the water once or twice to remove any bitter taste. There is no distinct flavor except for a slight suggestion of young corn. Bamboo shoots are prepared in meat stews, salads, and other ways.

This species is commonly planted throughont Puerto Rico in moist soil, such as along streams and roadsides and for ornament because of the attractive feathery foliage. Also in St. Croix, St. Thomas, and St. John. Spreading from cultivation but not naturalized as it does not grow ordinarily from seeds. However, in the Lesser Antilles natura] vegetative propagation by breaking and rooting of the fragile short branches occurs.

\footnotetext{
*Exotic, or introduced. Species (or families) with scientific nawes followed bs an asterisk are not native in Puerto Rico and the Virgin islands.
} 
RANGE.-Native of tropical Asia but widely planted throughout the tropies. West Indies from Cuba to Trinidad, and from Mexico to South America. Also grown in sonthern Florida.

Other conmox Names.-bambúa, caña India (Puerto Rico); bambú (Spanish); caña brara, cañambú, pito (Cuba) ; cañaza (Panama) ; common bamboo. feathery bamboo, bamboo (United Stites, English); bambou (French); bamboe (Dutch).

Another generic name formerly employed is Bambos.

\section{PALM FAMILY (PALMAE)}

A. Leares pinnate.

Key to the 7 species illustrated (Nos. 1-10)

B. Spines on trunk and leaf axes.

C. Leaf segnients long-pointed; trunk stout-4. Acrocomin media.

CC. Leaf segments ending in a broad jagged edge as if torn; trunk slender-5. Aiphanes acanthophylla. BR. Spines absent.

D. Leaf sheaths splitting open.

E. Leares mauy, 12-20 feet long: fruit the familiar, large, edible coconut-6. Cocos nucifera*.

EE. Leares severa1, 5-7 feet long; fruits about 1/2 ineh in diameter.

F. Leaf segments spreading flat along axis and not overlapping-7. Euterpe globosa.

FF. Ieaf segments erect and spreading in 2 rows on each side of axis-8. Gaussia attenuata.

DD. Leaf sheaths forming long column at apex of trunk-9. Roystonca borinquena.

AA. Leares fan-shaped-10. Sabal causiarum.

\section{Corozo, prickly palm, Puerto Rico acrocomia}

Corozo, a robust palm and 1 of the 2 Puerto Rican spiny species, is characterized by: (1) the stont straight trumk $8-12$ inches in diameter at base but slightly enlinged and bulging above, bearing rings of long slender black spines; (2) long pinnate leaves $10-13$ feet long with spiny axis and numerous tilted narrow long-pointed leaflets or segments as much as 2 feet long and only $1 / 4-3 / 4$ inch wide: (3) flower clusters $3-5$ feet long, witl spiny stalk and branclyes bearing small pale yellow stalkless flowers, many crowded male flowers $5 / 16$ inch long, and in lower part of branches a few female flowers 3/ inch long: and (4) yellow rounded dry fruits about $13 \%$ inclies in diameter, containing 1 large edible seed.

Easily distinguished from the other native robist species, palma real (Roystonea borinquena O. F. Cook), by the spiny trunk, the much rounder, denser, and mole compact crown composed of many more leaves, the absence of the long columnar green leaf sheaths, and the absence of the unopened rertical leaf in the top.

A medium-sized robust palm becoming 40 feet. tall. The stout unbranched trunk is cylindrical or slightly enlarged above the base to as much as 20 inches in diameter, tapering above and below. The gray trunk has a smooth surface with faint horizontal rings of leaf scars about 2-3 inches apart but is very spiny, especially in the upper part, often sheding some spines below. These black spines ale $2-3$ inches long, sometimes as much as $4-6$ inches. At the apex the evergreen crown is composed of as many as $t 0$ alternate leares, erect, spreading, and drooping.

The leaf segments are not crowcled and arise from the axis tilted or at an angle, rather than flat, and curve downward. They are leathery, parallelreined, and shiny above and dull blue green beneath. Dead leaves liang down and fall off smoothly.

The large drooping flower clusters (panicles)
Acrocomia media O. F. Cook

are subtended by 2 hairy, spiny sheaths (spathes), the outer 4-5 feet long, long-pointed, curved, and shading the axis of flowers, and the immer up to 2 feet long. Male and female flowers are produced on the same branch (monoecious). Branches 4-8 inches long bear crowded male flowers, which have 3 small ovate sepals, a 3 -lobed corolla, 6 stamens at top of corolla tube, and rudimentary pistil. Female flowers are seattered, 2-5 on lower part of a branch, rounded, with 3 small scalelike sepals, 3 overlapping petals, and pistil with 3 -celled ovary and 3 styles.

The rounderl fruit, which changes in color from gleeen to yellow at maturity, has a minute point at apex, a firmly fibrous husk, and a bony inner layer with 3 pores near middle. The single seed 1 inch long has whitish oily contents and is edible. Probably flowering and fruiting nearly through the year.

The rery hard wood from the outer part of the trunk has attractive black markings and has been used for flooring or cut into walking sticks. The hald-shelled seeds are edible, with flaror suggesting coconuts, and yield an oil. They are sometimes carved into rings. The seed oil of a related species is extracted commercially. Though this palm has been suggested as an ormamental, the many spines are objectionable.

Found in fields and woodlands in the coastal forest regions and in the moist limestone region. Also in St. Thomas. Introduced in St. Croix.

Perbic forests.-Cambalache, Carite, Lmquillo, Maricao, Río Abajo, Susúa.

Raxge.-Restricted to Puerto Rico and St. Thomas. Introduced in St. Croix.

O tit e R conson Names.-palma de corozo (Puerto Rico) ; Puerto Rico acrocomia (English). Formerly included in Acrocomia aculeata (Jacq.) Lodd., a related species of the Lesser Intilles from Dominica and Martinque to Grenada. 


\section{PALM FAMILY (PALMAE)}

\section{Palma de coyor}

This slender palm, 1 of the 2 native spiny species, is recognized by: (1) numerous slenter flattened black spines or prickles $1 / 2-21 / 2$ inches long on the slender trunk, the leaf bases and axis and infrequently the under side of blades, and on the axes of flower clusters; (2) about 10-12 erect to spreading pimnate leaves $10-12$ feet long and 3 feet across, the leaflets or secrments ending in a jagred edge as if toln: (3) many small stalkless pale light yellow flowers, male and female, crowded on slender drooping branches of a very spiny curved axis $3-41 / 2$ feet long; and (4) very numerous bright red, cherrylike, flesly fruits $1 / 2^{-5 / 8}$ inch in diameter.

A small to medium-sized palm to 40 feet ligh, evergreen, with slender. straight, erect, unbranched trunk 4-8 inclues in diameter, not tapering. Only slightly enlarged at the base, which bears a mass of spiny prop roots. The light brown trunk has indistinct lings of old leaf sears 3 inches or less apart and bears rings of many flattened black spines 1-2 inches long, pointed downward a little. Spines on old trunks often are fewer or nearly absent. Inside the hard smooth surface of the trunk is a very thin brown layer; next, a thin layer of whitish fibers, then a very hard black woody ring $1 / 4$ inch or more in width, and in the center the soft whitish pith with scattered woody fibers.

Several alternate very large coarse leaves are attached 3 inches or less apart in a terminal cluster at apex of trunk. The stout spiny petiole about 4 feet long, gray to green, is grooved above and enlarged at hase, being attached more than halfway around the trunk, but has no encircling sheath. The blade, about $7-8$ feet long, is composed of many narrow leaflets or segments $2-21 / 2$ feet long and $21 / 2-31 / 2$ inches wide, narrowest at base and widest at end. These altemate segments spread nearly horizontally on both sides of the keeled green axis. Toward apex the segments become shorter and in abont the last 1 foot of blade are in 1 piece not split apart. They are leathery, parallel-veined, green and shightly shiny on upper surface and dull light green beneath. Slender flat-

\section{Aiphanes acanthophylla (Mart.) Burret}

tened black spines about 1 inch long are scattered along lower part of leaf axis, and a few are bome on under side of segments. Old dead leares hang down vertically until they separate smoothly from the trimk.

Curved drooping flower clusters (panicles) are $3-41 / 2$ feet long, borne singly inside base of old leaves. The densely spiny axis has 2 brownish spiny sheaths (spathes), the short outer one less than 1 foot long and 2-pointed, and the imner one long and narrow and very spiny, about as long as the axis and $2 \frac{1}{2}$ inches wide. Many very slender drooping branches about 9 inches long, light yellow and spineless, bear rery numerous stalkless light yellow or whitish male and female flowers (monoecions); the female flowers scattered along lower part of branch, 1 below 2 male flowers. Irale flowers $1 / 4$ inch across consist of 3 minute pointed sepals, 3 widely spreading pointed light yellow petals more than $1 / 8$ inch long, 6 widely spreading light yellow stamens nearly as long as petals, and rudimentary pistil. Female flowers have 3 minute sepals, corolla with 3 pointed light yellow lobes $1 / 8$ inch long, and whit ish pistil less than $1 / 8$ inch long with 3-celled ovary and pointed style.

Fruits are produced in great quantities, several on the lower part of each branch of the axis. They are slightly broader than long, whitish green when immature, tuming to shiny bright red. The thin orange flesh is mealy and tasteless. The single brown seed is rounded, about $7 / 16$ inch in diameter, its surface much pitted. Inside the hard shell is a white edible oily nutmeat, suggesting coconut in taste though much smaller. Flowering and fruiting probably through the year.

Found in the moist limestone forests of Puerto Rico.

Public forests.-Cambalache, Río Abajo.

Raxge.-Known only from Puerto Rico.

OtIIEr common Names.-coyore, coyule, coyola (Puerto Rico) ; coyure rufle-palm (English).

BotaNiCal sYNoxyr.-Bactris acanthophylla Mart. 


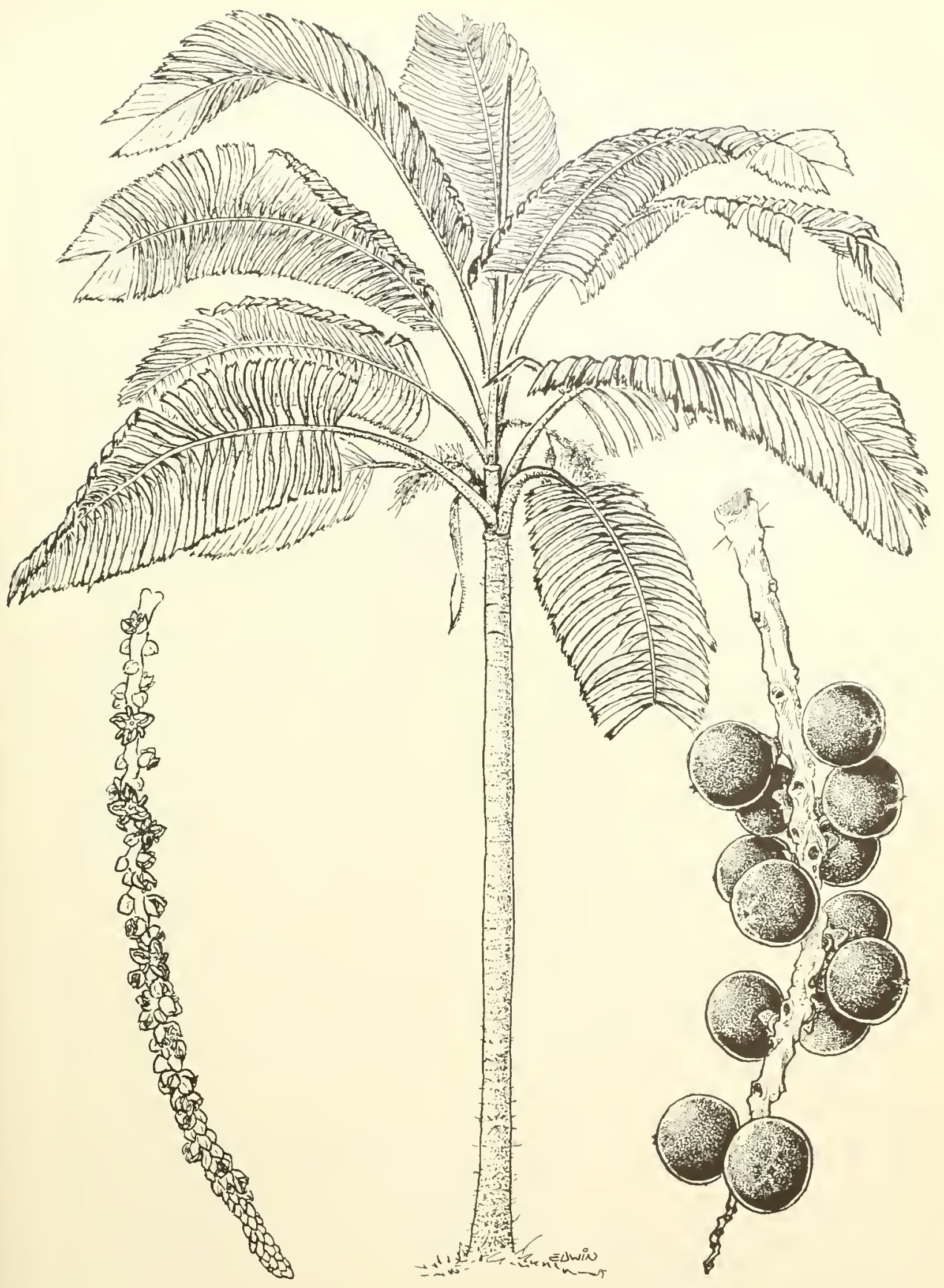


Coconut, the graceful paln lining tropical shores and widely planted for fruit and ornament, is so well known that it has become a symbol of the tropies. Deseriptive features are: (1) the slender often leaning trunk, enlarged at base, ringed above and 8-12 inches in diameter; (2) many pinnate leaves 12-20 feet long with basal sheath of coarse brown fibers, long petiole, and numerous very narrow shiny yellow-green segments spreading regularly in 1 plane on both sides of axis; (3) numerous whitish or pale yellow male and female flowers in branched flower cluster's at leaf bases; and (4) frnit the familiar coconut, egg-shaped or elliptic, consisting of a light brown fibrous husk 8-12 inches long, a hard shell, and 1 very large hollow seed with whitish, oily, edible flesh.

Medium-sized palm, usually 30-60 feet high, sometimes taller. The slender trunk is enlarged to $16-20$ inches in diameter at base, often slightly inclined there, and may be leaning as a result of the constant coastal breeze or after partial uprooting by a hurricane. The gray or brown trunk is slightly cracked. At apex is the relatively broad evergreen crown of alternate, erect, spreading, and drooping leaves.

The basal sheath is nearly 2 feet high on sides of petiole, surrounds the axis, and breaks as the younger leaves expand. The stout yellowish slightly concave petiole is $3-5$ feet long, and the blade $9-15$ feet long and $3-5$ feet wide. The linear leaflets or segments are $2-31 / 2$ feet long and 2 inches wide, shorter toward apex, long-pointed, leathery, parallel-reined, shiny yellow green above, and dull light green beneath. The lowest, dead leaves hang down against the trunk, eventually shedding and forming a smooth ring scar.

Flower clusters (panicles) 3-4 feet long rise from 2 long, narrow, long-pointed sheaths (spathes), the inner about 4 feet long, and bear many slightly fragrant stalkless flowers. A branch about 1 foot long has numerous small male flowers and near the base 1 much larger female flower, which opens later (monoecious). Male flowers $3 / 8^{-1} / 2$ inch long and broad have 3 small, pointed, whitish sepals $1 / 8$ inch long, 3 oblong petals nearly $1 / 2$ inch long, 6 widely spreading stamens, and sterile pistil with 3 styles. Female flowers about $11 / 4$ inch long and broad, rounded or 3 -angled, have 2 broad scales at base, 3 broad round sepals $3 / 4^{-1}$ inch long, 3 rounded whitish or light yellow rounded petals $1-11 / 4$ inches long, and light green pistil $11 / 4$ inches long with 3 -celled ovary and 3 minute stigmas.

The coconut has a bluntly 3 -angled husk $3 / 4-11 / 2$ inches thick, which does not split open. The elliptic or nearly round inner brown fruit with 3 round spots near one end is essentially a seed covered with the hairy hard outer shell. Inside is a slightly sweet oily layer of stored food $3 / 8$ inch thick and a large central cavity containing a watery or milky liquid. This is one of the largest seeds known, surpassed only by the 1 -seeded 2-lobed fruit weighing np to 50 pounds of the double-coconut (Lodoicea maldivica), a tall fan palm of Seychelles in the Indian Ocean. Flowering and fruiting continuously through the year.

Ranking among the 10 most nseful tree species to mankind in the world, coconut is the most important of cultivated palms. The fruits are eaten raw, prepared into candies. or shredded with pastries. When immature, the soft jellylike flesh can be eaten with a spoon. The watery liquid of green fruits and the milky juice of mature ones are pure, unt litious, cool, and refreshing drinks. Known as cocos de agua, these green fruits are sold on city streets. Tuder the name copra the dried white oily part of ripe fruits is marketed in large quantities for the manufacture of soaps and coconut oil, the latter for preparing margarine and other foods and for cooking. Classed also as a honey plant. The sugary sap collected from cut unopened flower clusters is a fresh beverage known as toddy and a source of alcohol.

The trunks serve for posts. Walking sticks have been made from the outer layer or ring of the trunk. The inner part is a very soft, light brown pith with scattered reddish-brown bundles.

The leaves furnish thatch for roofs and shelters and liave been made into lattice screens and fences. Tarious articles, such as norelties, souvenirs, cups, and flower pots, are made from the husks and shells. The shells have also been used for kitchen implements and for high-grade charcoal. In other regions of the world different parts of the plant serve many purposes. Coconut fiber. or coir, is made into mats, ropes, brooms, and brushes.

Certainly coconuts are among the most important trees of Puerto Rico, with plantations or orchards totaling nearly 10,000 acres, mostly along the sandy shores of the island and especially on the northern coast. The trees thrive also in the interior where soil moisture is ample and are hardy in dry climates if irrigated. In plantings for ornament the falling coconnts may be clangerons.

Commonly growing wild along sandy shores and planted as a fruit, ornamental, and shade tree near houses and along streets. Also in Mona, St. Croix, St. Thomas, St. John, and Tortola.

RANGe.-Native land unknown but thonght to be in Malayan or Indo-Pacific region. Now thoroughly naturalized on tropical shores of the world. Naturalized in southern Florida including Florida Feys, through West Indies, and from Mexico to Sonth America. 


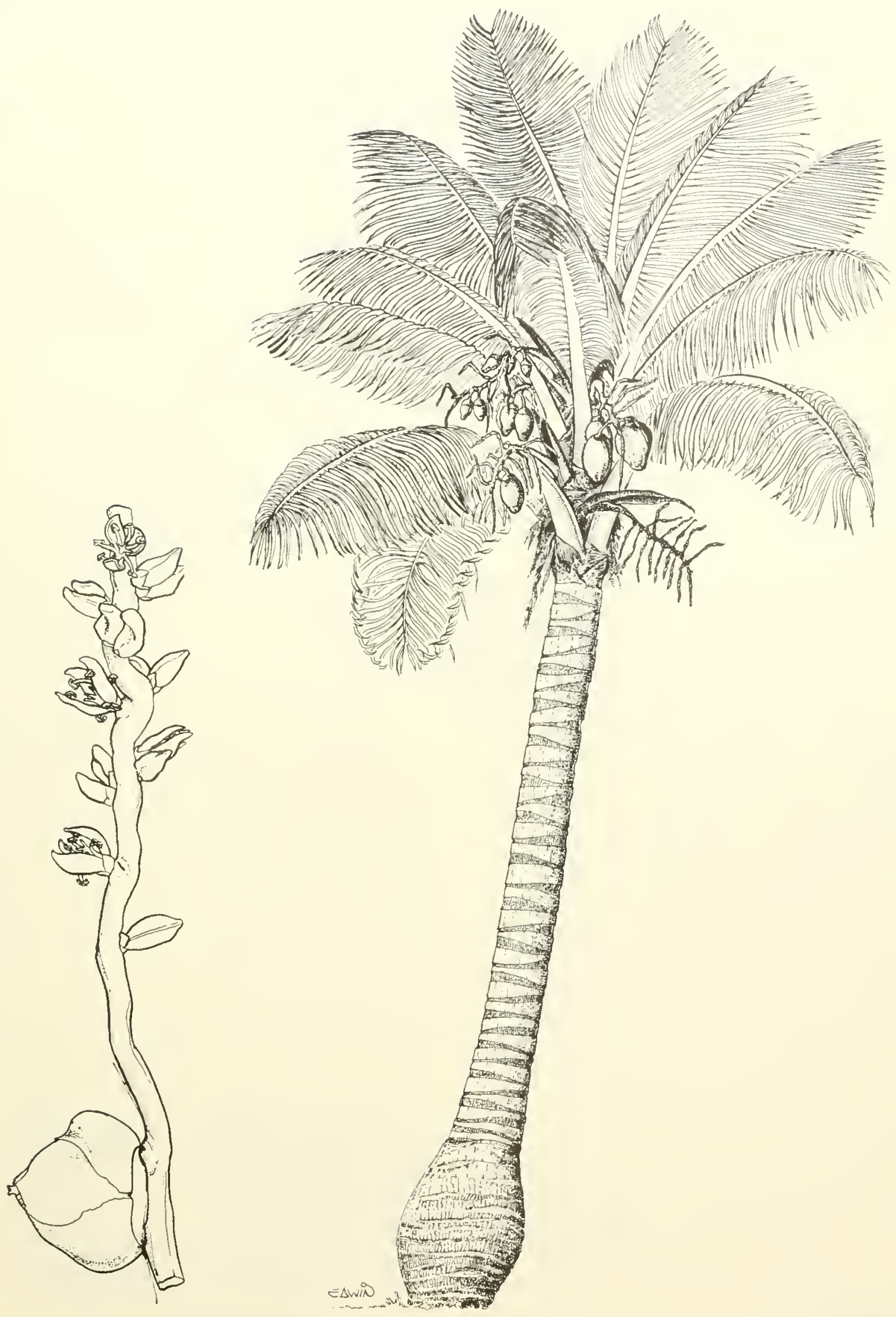

6. Palma de coco, coconut

Cocos nucifera L.

Male flowers and one female flower (lower left), two-thirds natural size. 
This palm has been cultivated so long, so widely disseminated by mankind, and so well naturalized on tropical shores that its origin is lost in antiquity. One belief, now discredited, was that its home was Imerican. Columbus did not find it, and most early Spanish writers in the New World did not mention it. Nevertheless, within a century after Columbus this raluable palm arrived in Prierto Rico. Joseph de Acosta (1539-1600), a Jesuit missionary in Peju from 1571 to 1587 , in his book "Natural History of the Indies," published in 1500 after his return to Spain, stated that he saw a coconnt growing in Puerto Rico. Another Spanish traveler in Puerto Rico in 1599 mentioned the milk of cocomut as "cosmetic for the ladies." In some of the Antilles, however, the coconut apparently was not known until the following centuly. Is early as 1526 , Oviedo mentioned large stands, apparently native, on the Pacifie coast at Burica Point, Costa Rica and Panama.

Otiler common names.- coco, cocotero (Puerto Rico); palma de coco, palmera de coco, coco, cocotero, coco de agua (Spanish) ; coconut, coeomut-palm (Cnited States, English); coco, noix de coco, cocotier (French); coco, cocos, coeospalm, klapperboom (Dutch Trest Indies); coco da Bahia, coqueiro de Bahia, coco da India (Brazil).

\section{PALM FAMILY (PALMAE)}

\section{Palma de sierra, sierra palm}

Palma de sierra, as its name indicates, is the pretty palm which forms the palm forests along upland streams on steep slopes and ridges of the higher peaks of Puerto Rico. It is characterized by: (1) the cylindrical slender erect trunk 4-8 inches in diameter: (2) several pinnate leaves with sheaths about $11 \frac{6}{6}$ feet long at base and blades about 6 feet long and $3-5$ feet across with long narrow segments inserted horizontally on both sides of axis and not overlapping; (3) numerous small white male and female flowers in a oncebranched, drooping, white stalked cluster 3 feet or less in length, attached below the leaves: and (4) round shiny black fruits $1 / 6$ inch in diameter and slightly fleshy. Prop roots covered with tubercles often are present at base.

Small to merlium-sized palm to 50 feet tall with slender tronk of miform diameter and thin narnow everereen erown of several alternate spreading leaves. The smooth gray or light brown trunk has horizontal rings.

The green leaf sheaths clasp the trmk at base. The blade has numerous narrow linear leaflets or segments $20-36$ inches long and $11 / 4-2$ inches wide, long-pointed, leathery, parallel-veined, green to light green on both sides, spreading horizontally and at equal distances on both sides of axis. At apex the segments are shortened. A few dear leares may hang down for a time before shedding and forming a smootly ring sear around the trunk. One to 4 new leaves are prodnced per year.

The narrow flower eluster (panicle) abont 3 feet long is borne below the leaves. By the time fruits mature the oldest leares above have shed, and the attachment of fruit cluster is 6 inches or more below hase of lowest leaf sheath. There are 2 spindle-shaped long-pointed sheaths (spathes), the outer short and the inner long. The white branches of the axis are mostly less than 1 foot long, spreading out at right angles and a fterwards nearly parallel with axis. The small white stalkless flowers are male and female together (mono-

\section{Euterpe globosa Gaertn.}

ecious). Male flowers have 3 overlapping broad sepals, 3 oblong white petals about $3 / 16$ inch long meeting at edges in bud, 6 stamens with rellowish anthers, and a ludimentary pistil. Female flowers have 3 orerlapping blunt sepals, 3 overlapping rounded white petals about $3 / 16$ ineh long, and an oblong ovary.

The fruit has a thin flesh and 1 brown rounded seed 5/16 inch long. Sepals and petals remain attached after fruits fall. In flower and fruit nearly all the year.

In the higher mountains, where this is the only native palm, the leaves or the leaf sheaths, ealled yaguas, are used for thateh. The outer stemwood is sometimes hewn into narrow hoards for sheathing of rural buildings. A portion of the bud of this palm, known as palmillo, can be eaten as a salarl. IIowerel, removal of the bud kills the tree. The edible part consists of the young inner leaf sheaths which form a white eylinder $2-3$ feet long and $3-1$ inches in diameter. These white leaf bases, thongh tender, are almost tasteless as a salad mnless seasoned. Except as a novelty for tourists, the palm bud is doubt fully preferable to cabbage. The fruits are an important food for the Puerto Rican parrot.

In general these palms of the steep momntain slopes are beneficial in maintaining protective cover for the watershed and in preventing soil erosion. This species is now so little utilized, and its growth rate so slow (less than 12 inches in height per year), that it is being gradually replaced by other more useful speeies in the public forests. It may be suitable for ornamental planting.

Common to abundant and forming pure forests in the npper monntain forest region of Puerto Rico, descending in ravines into the lower momntain forests to about 1,500 feet.

Public Forests.-Carite, Guilarte, Luquillo, Maricao, Río Abajo, Toro Negro. 
MtNicipalitTes where egPeCially rOMMON.$1,5,10,13.17,19,22,27,35,36,45,52,53,54,554$ $62.64,70,73$.

Range-Cuba. Hispaniola, Puerto Rico, Lesser Intilles from Saba to Grenada, and Tobago.

Otuer common sumes.-manaclil, patma de manacla. (Dominican Republic): palma boba, palma justa (Cuba); palmiste ì chapelet, macoutouca (ITaiti) : palmiste-montagne (Guadeloupe, Dominica); palmiste frane, chou-palmiste, palmiste blanc (Guadeloupe) ; mountain-palm (Lesser Intilles).

\section{PALM FAMILY (PALMAE)}

\section{Palma de lluvia}

1 graceful tall palm of rugged summits of linestone hills, distinguished by: (1) the slenter, slightly tapering, smooth brown trunk with many prop loots at base: (2) i-j erect to spreading pinnate leaves 4 if feet lon 2 , with wreen sheath \& 12 inches long around trmk, and blade 2-21'2 feet across the many narrow long-pointed leatlets, which depart from the keeled axis at a small angle, apparently in 2 rows on each side, erect and spleading: (3) small stalkless orange and green male and female flowers scattered aloner slemler branches of a emved axis about ; feet long: and (4) numerous bright red or orange-red theshy fruits almost 5/8 inch long, nearly round or slight ly pear-shaped.

I slender pain to 40 feet in height, sometimes taller, with tapering unbranched trunk often slight] y leaning, $6-8$ inches in diameter at base and only 3 inches in diameter at apex, evergreen. It the base of the trunk up to a height of 2 feet are light brown prop roots about $11 / 1$ inches in diameter, bearing numerous short spinelike projections. The smooth brown trunk is ringed, with faint leaf scars 3 inches or less apart. It is relatively soft. composed of a very thin brown outer layer, a thin fibrous whitish layer which is slimhtly bitter, an orange-brown woody ring about $1 / 2$ inch wide, and soft whitish pith with scattered woody strands.

The rather few large coarse leaves a re alternate, their bases overlapping at intervals of 3 inches or less in a narrow terminal cluster at stem apex. At bise of leaf are the green sheath opened on 1 side and a curved stout grooved petiole $1 \frac{1}{2}$ feet or less in length. The crowded, overlapping, narrow leaflets or segments are abont 12-20 inches long and 1-11/4 inches wide, becoming shorter toward apex, leathery, parallel-veined, green, and slightly

\section{Gaussia attenuata (O. F. Cook) Beccari}

shiny on both siales, attached obliquely to the green axis. Ifter turning brown and shedding the leatlats, the axis with leaf base falls, making a smooth s.ar:

Many small flowers are horne stalkjess and scatterer along slender dronping green branches about 6 inches long of the curved and drooping branched chister (panicle) arising insirle sheath of olier leaves. Female flowers about 3/16 inch across have :3 minute broad sepals, :3 fleshy orange spreading petals more than "16 inch long, 6 mimute whitish sterile stamens (staminodes), and pistil composed of areen 3-angled 3-celled ovily more than ${ }^{1 / 16}$ inch long and broad, with stigmas at apex. Male llowers maturing earlier in the same flower cluster (monoecions) are slightly larger, with 3 sepals, $\therefore$ petals less than 2 mm. long. 6 stamens nealy :2 nm. long, and rudimentary pistil.

Fruits change color from sreen to yellow, orange, and red at maturity. The single rounded brown seed is $7 / 16$ inch or less in length. Flowering and fruiting probably through the year, at least in both. Tume and December.

Perhaps of value as an ornamental.

This species is common on the rocky summits and clitls of the moist limestone region and in the hills between San Germán and Lajas. Is these palms are taller than other trees of the jagged hilltops, clusters of palm leares often rise above the forest canopy, conspjenous against the sky. From a distance the leaves appear suspended in midair. since the slender trunk is scarcely risible.

Perala Forest.-C'ambalache.

Raxae- Endemic to Puerto Rico.

()THe: comsox xast.-Puerto Rico llumejalm (English). 


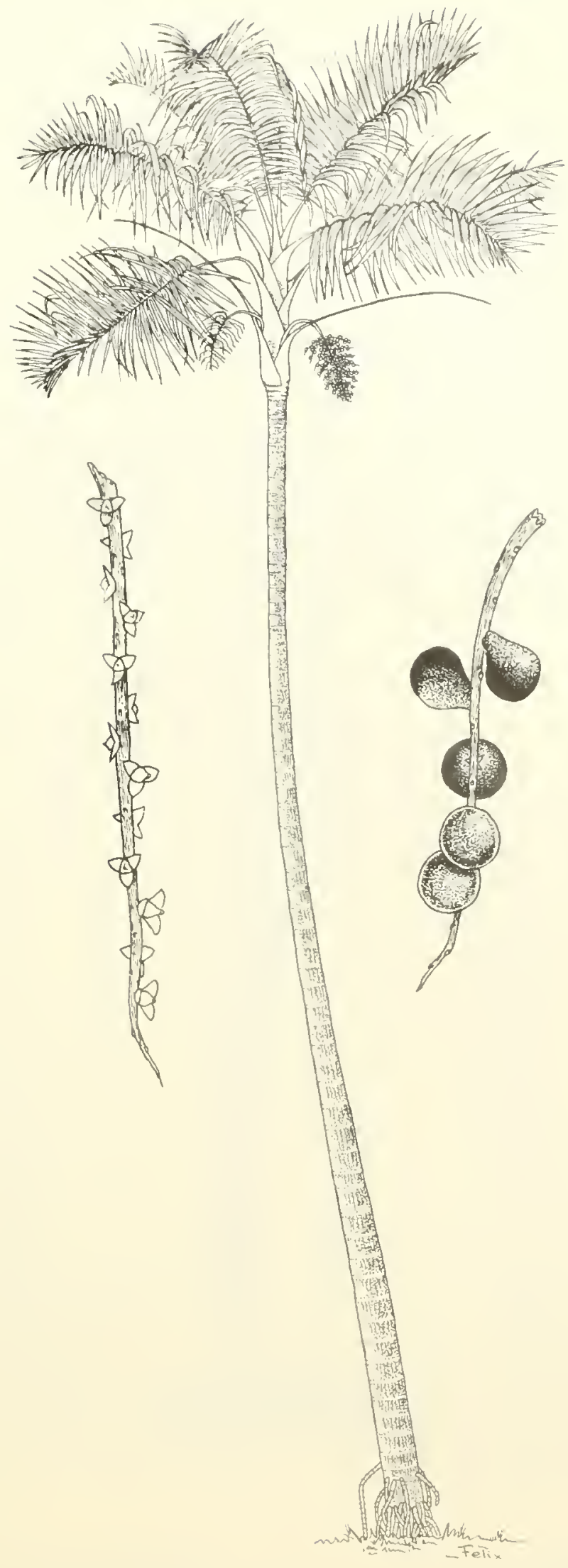

8. Palma de luvia

Gaussiu attenuata (O. F. Cook) Beccari Female flowers (left) and fruits (right), two-thirds natural size 


\section{PALM FAMILY (PALMAE)}

\section{Palma real, royalpalm, Puerto Rico royalpalm}

Roystonea borinquena 0. F. Cook

Puerto Rico royalpalm or palma real is one of Puerto Rion's most characterist ic trees, being a conspicuons feature of the comntrysides and landscapes and efpully at home along city streets. Known to all, it is characterized by: (1) the stont arect trumk 1 - feet in diameter, slightly enlarged and bulging at some distance above the base; (2) a light green narrow column of leaf sheaths about 4 feet high at apex of trunk; (3) large pinnate leares with short petiole above sheath and blade 8-12 feet long composed of many narrow maired segments, and the unfolded youngest leat projecting as a narrow spire above the others: (4) small whitish flowers, male and female, borne in a spreading to drooping twice-branched cluster 3-5 feet long below the leaves; and (5) light brown, elliptie, slightly fleshy fruits about $1 / 2$ ineh long.

This large robust palm becomes $30-60$ feet tall. The gray smoothish trunk usually has a broad base, then is slightly narrowed and swollen for some distance above, and in tall specimens narrowed again toward the apex. There are faint rings of leaf scars at nodes. The evergreen crown is composed of 15 or ferel long, gracefully eurved, spreading alternate leares. The unfolded youngest leaf usually leans slightly towad the east, the direction of the prevailing wind, and thus serres to indicate the directions.

The leaf blade has numerous leaflets or segments 20-36 inclies long and only $3 / 4-13 / 4$ inches wide, long-pointed, leathery, parallel-remed, green, inserted on both sides of axis obliquely by 2 's and in 2 rows on each side, and usually curving downward rather than flat. [pon dying, the oldest leaf falls off promptly, separating smoothly from the trunk at base of sheath.

The flower cluster (panicle) arises below the leaf sheaths from a rery large narrow bud formed by a dark brown boat-shaped sheath (spathe) $3-5$ feet long. Lateral branches 6-12 inches long from main branches 3 feet or more in length bear many stalkless flowers, male flowers opening and falling first, and toward base the female flower buds, genemally 1 between 2 male flowers (monoecions). Male flowers more than $1 / 4$ inch high and nearly $1 / 2$ inch across consist of 3 minute rounded whitish sepals less than 1/16 inch long, 3 bhunt-pointed whitish petals $1 / 1$ inch long, 6-9 spreading stamens with purple anthers, and rudimentary pistil. The smaller female flowers $1 / 8$ inch long and broad have 3 broad whitish sepals less than $1 / 16$ inch long: tuhular corolla $1 / 8$ inch long with 3 pointed lobes and bearing 6 short sterile stamens (staminodes) inside; and pistil of yellow-green rounded ovary with 3 short styles and stigmas on 1 side.

The numerous fruits contain 1 light brown elliptic seed $5 / 16$ inch long, hard but oily. Flowering and fruiting perhaps through the year.

Palma real is a stately ormamental widely planted to heantify streets, parks, and gardens thromghout Puedto Rico. Boards hewn from the hatrder outer part of the trmbs are widely used for sidling and flooring in rural constriction. Ifowrer, they are rery susceptible to attack by dry-mood terinites. The leares are also nsed frequently in construction, less now than fomerly. Fresh leaves are widely displayed hocally for religions services on Palni sunday. The diy blades sore as that th for roofs of barins and houses, and the broad sheaths, known as vaguas, are spread out flat to make sides of buildings. The twisted young leaf segments are woven into chair seats and backs. In important honey plant, the flowers attratet mumerous liees. The fruits are a grood food for hogs.

Palmat real is common in forests. pastures, and river banks almost throughout the island from the wet north flamk of El Yunque to the coastal mangroves and the dry valleys near Guanira. It is found in all but the upper mountains and the dry limestone regions. These palms probably have become nore common following settlement, spreading in clearings, pastures, old fields, and fence rows. Also in Vieques and St. Croix.

Piblic romstr.-Agnirre, Cambalache, Carite, Gua jataca, Guánica, Lurpuillo, Marican, San .Juan, siusúa, Tega.

Raxam-Restricted to Puerto Rico, Vieques, and St. Croix. Introduced at Mona.

Otiner conmox xisies.-palma de yaguas, palma de costa (Puerto Rico) ; mountain-cabbage (St. Croix) : Puerto Rico royalpalm, royalpalm (English).

The generic name honors General Roy Stone (1835-1905), Thited States Army Engineer, who rendered outstanding service to Puerto Rico at the time of the Spanish-American War. Cuban myalpaln (Roystoner regia (H. B. K.) O. F. $\left(\right.$ cook $\left.^{*}\right)$, a related species from Cuba with tall trunk not swollen, has been planted also in Puerto Rico and the Virgin Islands and may have escaped locally. 


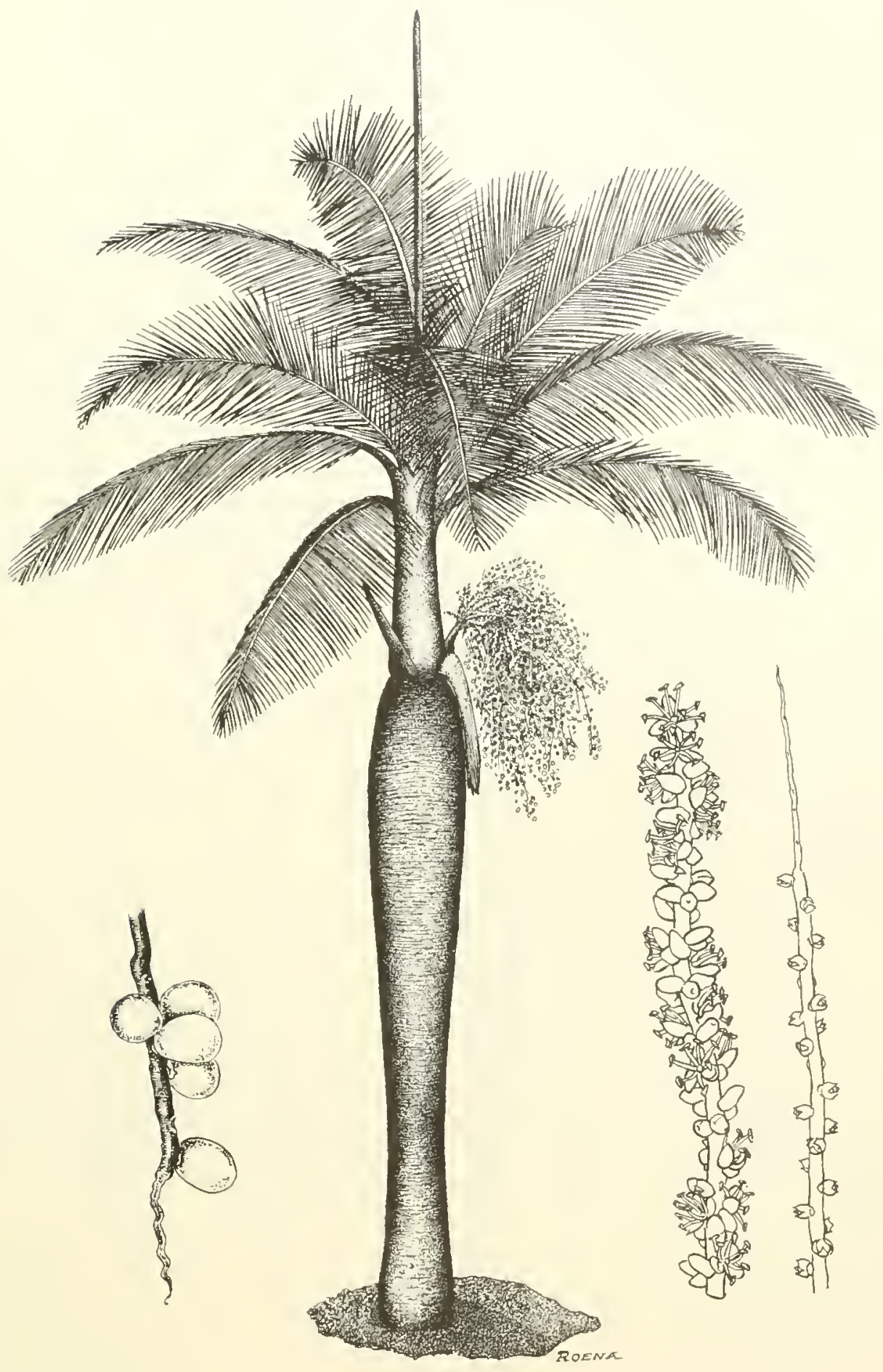

ก. Palma real, rosalpalm, Puerto Rico royalpalu

Roystonca borinquena O. F. Cook Fruits (lower left) and male and female flowers (lower right), two-thirds natural size. 


\section{PALM FAMILY (PALMAE)}

\section{Palma de sombrero, Puerto Rico palmetto}

Palma de sombrem is the only wild Pnerto Rican pahm with both fan-shaped leares and a stout trunk. Its main distinguishing characters are: (1) the stont trunk 1-2 feet in diameter, with the split bases of old petioles langing down a a inst it: (2) large fan-shaped leares with very long petioles $3-5$ feet long and pleated fan-shimperl hluewreen blades 3-t; feet in diameter. with a definite midrib curved downwarl slightly. deeply split from marein to middle into namow segments al temating with threallike fibers in notehes; (3) many small whitish thowers $3 / 16$ inch long in slender, much branched. sprealing chusters at leaf bases longer than pet ioles or sometimes exreedingr the blades: and (4) rommded lown fruits $3 / s^{-1}{ }_{2}$ inch in diameter and slimbly flechy.

small to medimm-sized tree to 30 feet tall with stont unbranched snonthish trunk $1 \frac{1 / 2-21 / 2}{2}$ feet thick at base and $1-2$ feet in diameter, colmmuar or slightly tapering moward, and hoad evergeen erown of many alternate spreading leaves. The trmok is light gray, smoothish or narrowly eracked, with rings and often with a few holes.

The stout blue-green petiole, as long as the blade or longer. has a course brown basal sheath encirding the axis and later splitting apart. Concave. above and decreasing in will above lase from 6 to 2 inches, the petiole is prolonged as an axis or midrib (rachis) nearly half the length of the fanshaped or palmately lobed blarle. Fegments of the blarle are 11/2-21/4 inches wide and as much as 4 feet long, stift and leathery. parallel-remed, dull blue green on both sides eacl split into 2 long pointed strips, with a slender fiber or thread arising from each notch.

The flower chusters (panicles) are up to $8-10$ feet long. There are numerons brown sheaths

\section{Sabal causiarum (O. F. Cook) Beccari}

(spathes) 11/4-21/2 inches long, each bearing a suatl lateral "luster" (panicle) 8 inches or less in length. "The fragrant white stalkless flowers have a white 3-tootherl tubular calyx 1 i6 inch long, 3 nartow white petals more than $1 / 8$ inch long, 6 spreading white stanens less than $3 / 16$ inch long, mited at base, and a narrow whitish pistil more than 1/8 incle long with short. B-celled ovary and stout style.

The numerous smooth fruits (dimpes) have thin flesh and 1 rounded brown seed $3 / 8$ inch or less in diameter. Flowering and fruiting perhaps irregularly dming the year.

Is the common names suggest. Puerto Riean st'aw hats are made from the young leares of this palu, afte' enring, bleaching, and drying. The leall filners are eniployed also for barkets, mats, and hammorks. The older leaves serve as thateh. Ocasionally planted neal homes for the leaves and for ormantent.

Found on coastal plains of northern, western, and southwestern Pnerto Rico, Formerly growinc in wroves on the platean neal Punta Borinquén in the extrema northwest.

Ruxar-- Ipparently native only of Puerto Rico.

()THER romaron xases.-palma de abanico, palna de cogrollo, yarey (Puerto Rico): Puerto Rico hatt-palm (English).

Bermuda palmetto or bulltyre (Sabal bermudunu Bailey: formerly referred to S. bluchburnianm Glazelnook), native of Bermuda, has been introulured on St. Croix and St. Thomas. It is distinguished by the leares. which are areen rather than blue green, and by slightly larger blackish fruits about $5 / 5$ inch in diameter. The leaves are used for the same purposes. 


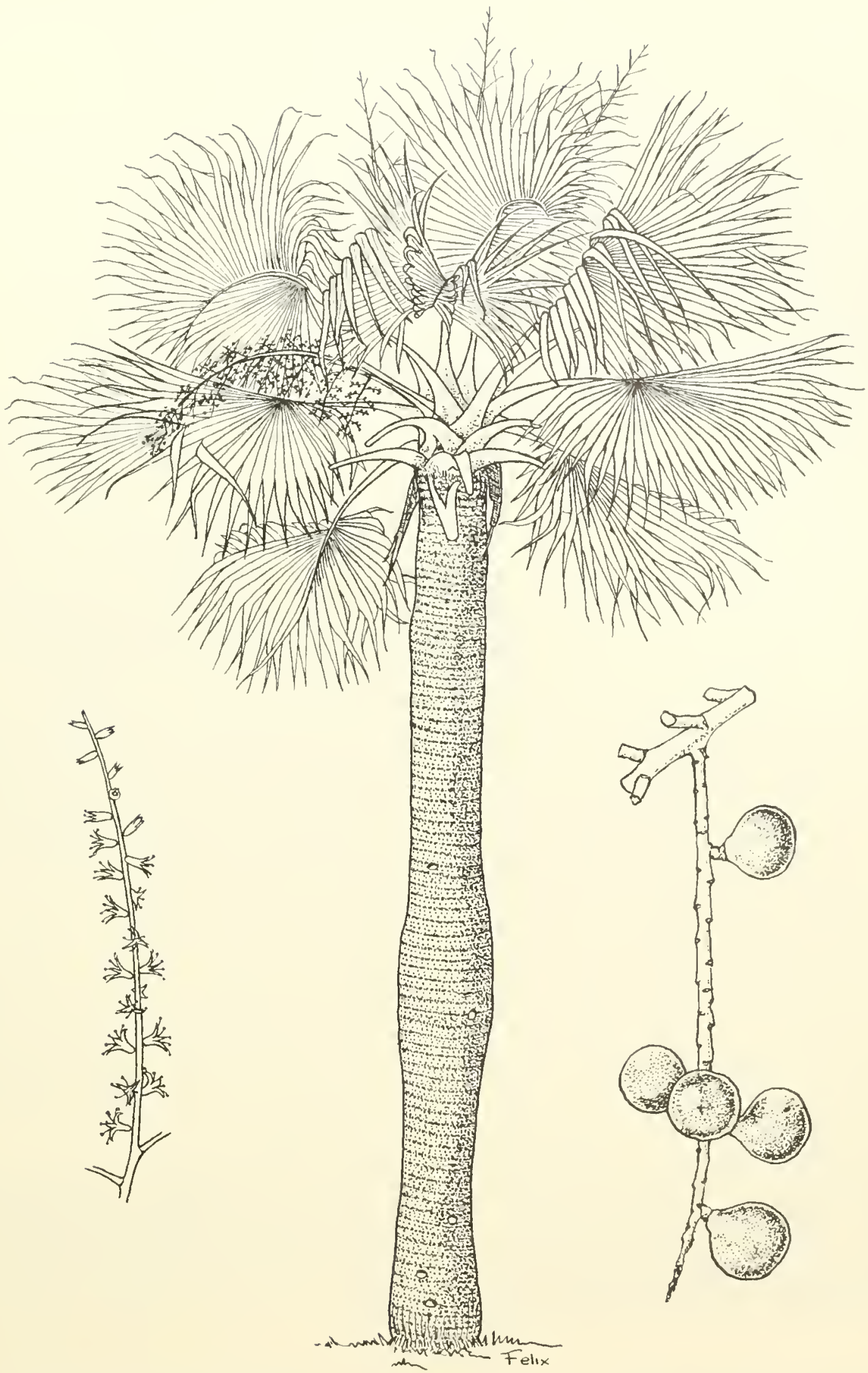

10. Palma de sombrero, Puerto Rico palmet to

sabal rausiarum (O. F. Conk) Bercari Flowers (lower left) and fruits (lower right), natural size. 


\section{CASUARINA FAMILY (CASUARINACEAE*)}

11. Casuarina, Australian beefwood, horsetail casuarina

Casuarina equisetifolia $\mathrm{L} . *$

Itall shemeler introduced tree with a thin crown, chatraterized by: (1) wiry, drooping, dark green, needlelike twigh about 1/32 inch in diameter, jointed and growed, with rings of minnte wrayish scale leaves abont t -3 inch apart: (2) numerous small male and female flowers cruded in inconspicuons linglit buwn ilusters on the sime tree (monoecions), the male flowers in nimow cylindrical telminal clusters $3 / s-3 / 4$ incl long and as much as 1 inch across the stamens, and female flowers in short-stalked buteral hall-like clusters less than $1 / 8$ inch in diameter or $5 / 16$ inch across the spreading dink red styles: and (3) fruit a light brown waty conelike ball $1 / 2-3 / 4$ inch in dimneter.

A rapidly growing medimm-sized everareen tree to lon feet tall and 1-11\% feet in trunk diumeter. 'The bark is light gray brown, smoothish on smill trunks, hecoming jough, furrowed and shangy. and splitting into thin strips and flakes exposing a reddish-brown layer. Inner bark is redlish and bitter or astringent. The wiry drooping twigs ?-1 in inches long are dark green, becoming paler, and the older twigs gray bown and sealy.

Leaves are less than $1 / 32$ inch long, $6-8$ in a ring (whorled) at a joint or node. The twigs remain green and function like leaves in food making and are shed ararlually like leaves.

Iinute male flowers, crowded in rings among the grayish seales, consist of a protruding brownish stamen less than $1 / 8$ inch long with 2 minute frown sepal seales at base. Femile flowers lack sepals but have a pistil about $3 / 16$ inch long with small ovary and threadlike dark red style.

The multiple fruit, gray wreen when immature, is composer of points less than $1 / 8$ inch long and broad, each developing from a flower. In individual fruit has 2 pointed seales that split apart at miturity and release 1 winged light brown seed (akene) about 1/4 inch long $(300,000$ per pound). Flowering and fruting through the gear.

The silpwod is pinkish to light brown, the heartwoml link brown. The fine-textured wood is very hat heary (specific gravity 0.81 ), and very susceptible to attack by dry-rood termites. It is strong, tough, difficult to sa w, but cracks and splits, and is not durable in the ground. Rate of airseasoning is moderate, and amount of degrade is consilerable. Machining characteristics are as follows: planing and turning are fair ; and shaping, boring, mortising, sanding, and resistance to serew splitting are grome. The mood is used in the romind. I'ses inclucle fenceposts and poles, beams but not molerenound, oxcast tongues, char(oil and fuel.

Elsewhere the bark has been employed in tanning, in medicine, and in the extraction of a red or blue-black dye. In sonthern Florida the fruits have been made into novelties and Christmas decorations.

Often propagated by cuttings for street, park, ornamental, and windlineak plantings, it can also be trimmed into hedges. It is used for reforestation because of its adaptability to degraded sites and rapid gowth. Natural regeneration is rare in Puerto Rico because ants consume nearly all the seeds, but in some tropical areas the plants spread rapidly. On protected sandy scacoasts, where this tree is best adapted in this region, diameter growth rates of 1 inch per year are not uncommon. Because some trees have been destroyed by disease in Puerto Rico within recent years, planting for sharle or ornament may not be desirable.

Planted in Pnerto Rico, especially along the coasts and less commonly in the lower mountain regions. Also in Mona, St. (roix, St. Thomas, and St. John.

Raxge- Native of tropical Asia and Australasia but planted and naturalized in varions tropienl and subtropical regions. Southem Florida including Florida Keys, Bermuda, through West Indies from Bahamas and Cuba to Trinidad, and from Mexico to South America.

Other cominon xames.-pino australiano, pino de Australia, pino (Puerto Rico) ; weeping willow (Virgin Islands) : pino, pino de Australia (Spanish) ; ciprés (Cuba, Mexico); sance (Nicaragua): horsetail casuarina, beefwood, horsetail beefwood, horsetail-tree, Anstralian-pine (I'nited States): beefwood (Bahamas); casuarina, whistling-pine (Trinidad and Tobago); Christmas-tree (British Guiana); pin d'Australie (Haiti); filao (French West. Indies); casuarine (Dutch West Indies): cazuarina (Brazil).

Casuarina is not related to the true pines, which are not native in Puerto Rico. The common name pino, of course, is descriptive of the wiry green twigs, which resemble the needle leaves of pines. A few related species introduced from Australia are being tested experimentally in forest plantations. 


\section{PEPPER FAMILY (PIPERACEAE)}

\section{Higuillo}

This almulant small tree or shrul, is easily reconnized hy: (1) the yellow-green, sightly zirzag, finely luaty twigs with enlarged, ringed joints (nodes): (20) the narrowly elliptic, long-pointed, yellow-meen leaves, unequal at base, slightly romgh alove, with long, slightly rurved lateral reins, and arematie or spoiey when rushed: (3) the tiny flowers and fruts erowded in cormber. "urvel, lateral axes 3-t inches long and about $1 / \mathrm{s}$ inch in dianeter: and (t) the perpery taste and odol" of leavers, fruits, and seeds.

An everereen tree to 20 feet in height and $f$ inches in trunk diameter, often hramehing at $\mathrm{ol}^{\circ}$ near hase and with a spreading arown. Tho bark is smooth and gray. Immer lark is whitish and peprery or slightly bitter.

The leaves are alternate, sometimes in 2 rows, with short petioles $1 / \mathrm{s}^{-1 / 4}$ inch long. Leaf hlades are 5-7 inches long and $11 / 0^{-3}$ inches brom, the latse romuder and albont $1 / \mathrm{s}$ iuch longer on 1 side, the edges not toothed, thin, the lower surface pale and soft hairy. Inder a lens, minute lighter dots are risible in the leaves when held aganst the light.

The cordlike. curved flower elusters (spikes) are borne singly opposite a leaf, vellowish but turning to gray green in fruit. The very numerous flowers, each less than 1/32 inch long, consist. of 4 stamens, pistil with 1 -celled ovary and 2 st igmas. and 1 sale (bract). The fruits (dirupes) are pale green, somewhat more than 1/32 inch long, slightly

\section{Piper aduncum L.}

juicy, and contain 1 brown or hlack seed $1 / 32$ inch long. Flowering and fruiting throughont the yest.

The sapwool is whitish and hald and is little userl, although latger trunks sometimus have heen plareel in the formework of comutry homes. Elsewhere the leaves, flowers, and roots have been employed in lome medicines and the peppery froits in siatsoning food.

In forest openingr, roarlsiles, pastures and aluandoned fields, often forming pure thirkets in the moist roast, moist limestone, and lower and upper momtain regions of Puerto Ríco. Also in Vieques.

P'urbic Forests. - Cambalathe, Carite, Guajataleal, Culubarte, Lumuillo, Maricao, Río Mbajo, Susula, Toro Negro.

Ravie-Greater Antilles, St. Timeent, Grenada, Barbados, and Trinidad and Tohago. Also from central Mexico to Pern and Brazil.

Other compon xumes.-lignillo hoja menudat ( Illerto Rico); cordonteillo (Spanish); anisillo. grayuyo, guayuo blanco (Dominican Republic) : platinillo de Cuba, canilla de muerte (Cuba) ; cordoncillo blanen, hiritac (Guatemala): cordoneillo blanco (Nicamana) : Spanish elder, Spanish ella. elcler. ells, eows-foot (British Honduras) : sureau (Haiti) : aperta ruão, matico falso (Brazil).

Besides this species of small tree size, 8 shrubby species of this large tropieal genus are recorded from Puerto Rivo and the Virgin Islands. 


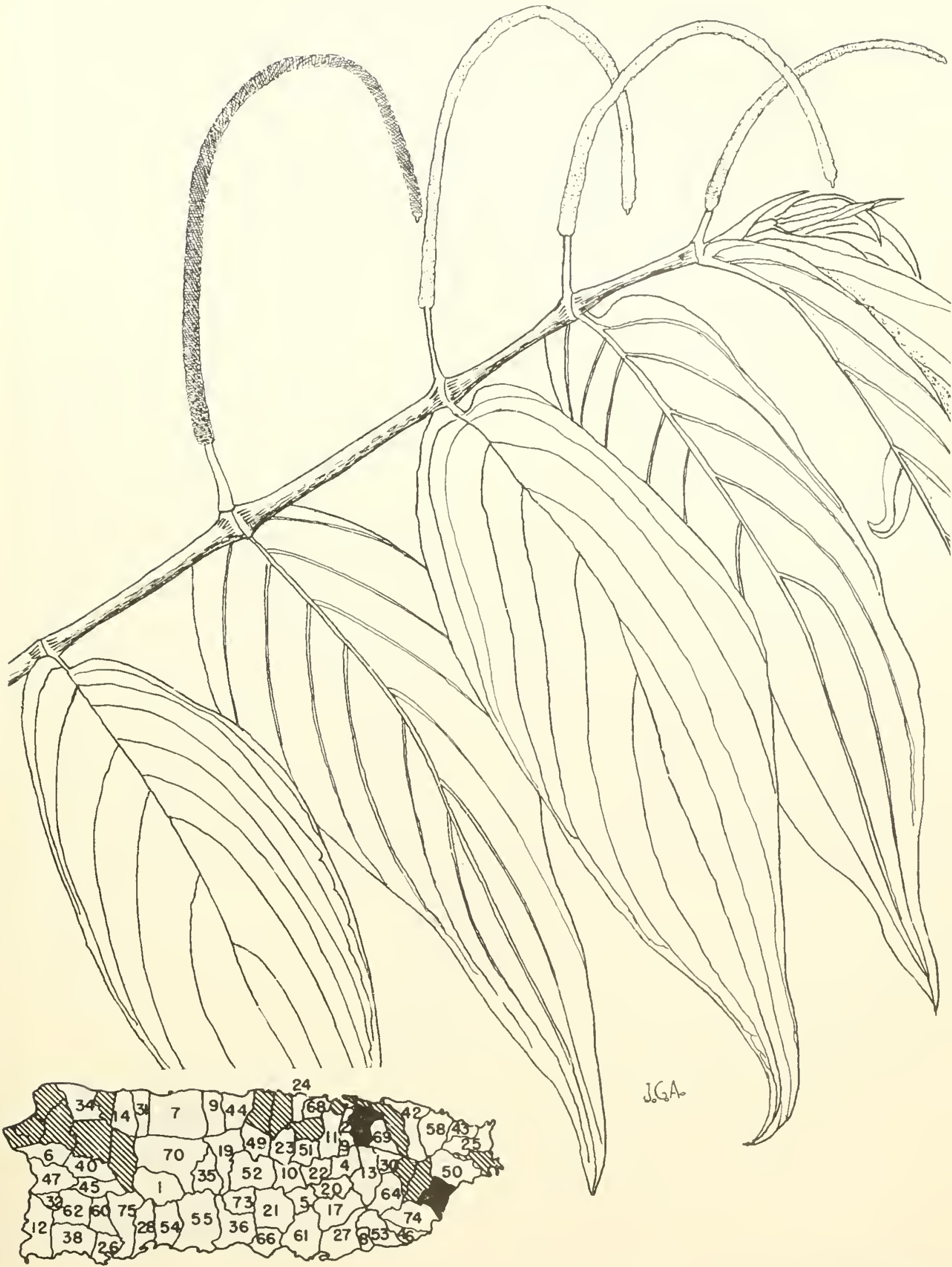

12. Higuillo

Piper aduncum $\mathrm{L}$. 


\section{CHLORANTHUS FAMILY (CHLORANTHACEAE)}

\section{Azafrán}

This distinetive small tree or shrub of the easterm momntains of Puerto Rico is readily identified by the following cluaracters: (1) the leaves, twigs, aid other parts are pleasintly fragrant when crushed: (2) the opposite, elliptic, slightly fleshy, dark green leaves have finely saw-toothed edges, and the petioles of a pair are united at base into an enlarged sheath $3 / 2-1 \%$ inch long allound twig; (B) stalkless small green flowers less than $1 / 8$ incli long. male and female on thiflerent trees (dioecions), the male flowers erowded in narrow cluster's and the female flowers in groups of $2 \mathrm{or}^{\circ} \mathrm{s}$ surrounded hy seales along an axis: and (f) whit ish watery fruits about $3 / 8$ inch in diameter, with 3 fleshy scales on outside.

Iin evergreen thee to 20 feet high and $t$ inches in trunk diameter or shrubby. 'The bark is brown. smoothish and thin, often eovered with mosses and liverworts. Inner bark is light brown or pinkish, and with spicy or bitter taste. The dark green fleshy twigs have enlarged ringed nodes and large pith and are brittle.

Petioles are $1 / 4^{-5 / 8}$ inch long, the leaf blades $1^{3} 4^{-5}$ inches long and 7,2 inches broad, shortpointed at both ends, with the edges slightly turned under.

\section{Hedyosmum arborescens Sw.}

Flower clusters are terminal and lateral. Male flowers are in a stalked eylindrieal eluster (spike) $3 / 4-17$, inches long and 5/16 inch or more in diameter, each flower consisting merely of 1 stamen less than $1 / 8$ inch long and without calyx. The axis (spike) of female flowers is 1-2 mehes long, the Howers composed of 3-angled inferior orary less than 1/s inch long eovered by green tubular base (hypanthium) and bearing minute 3 -toothed calyx at apex.

The fruits are composed mainly of the enlarged fleshy scales, enclosing 2 or 3 individual ?,angled frnits (drupelike) about $1 / 8$ inch long, each from a separate flower and eontaining 1 brown seed. Flowering and fruiting nearly through the year.

The light brown sapwood is hard and is not userl.

In openings in the forests in the upper Luquillo and eastern upper Cordillera regions of Puerto Iico, ascending to near the summits of the peaks.

Penuc forsats.-Carite, Luquillo.

Rivae.-Jamaica, Prerto Rico, and Lesser Intilles from st. Kitts to St. Tincent.

OTIER COMmon vaMes.-bois fragile, bois de leau, bois senti (Gualeloupe). 


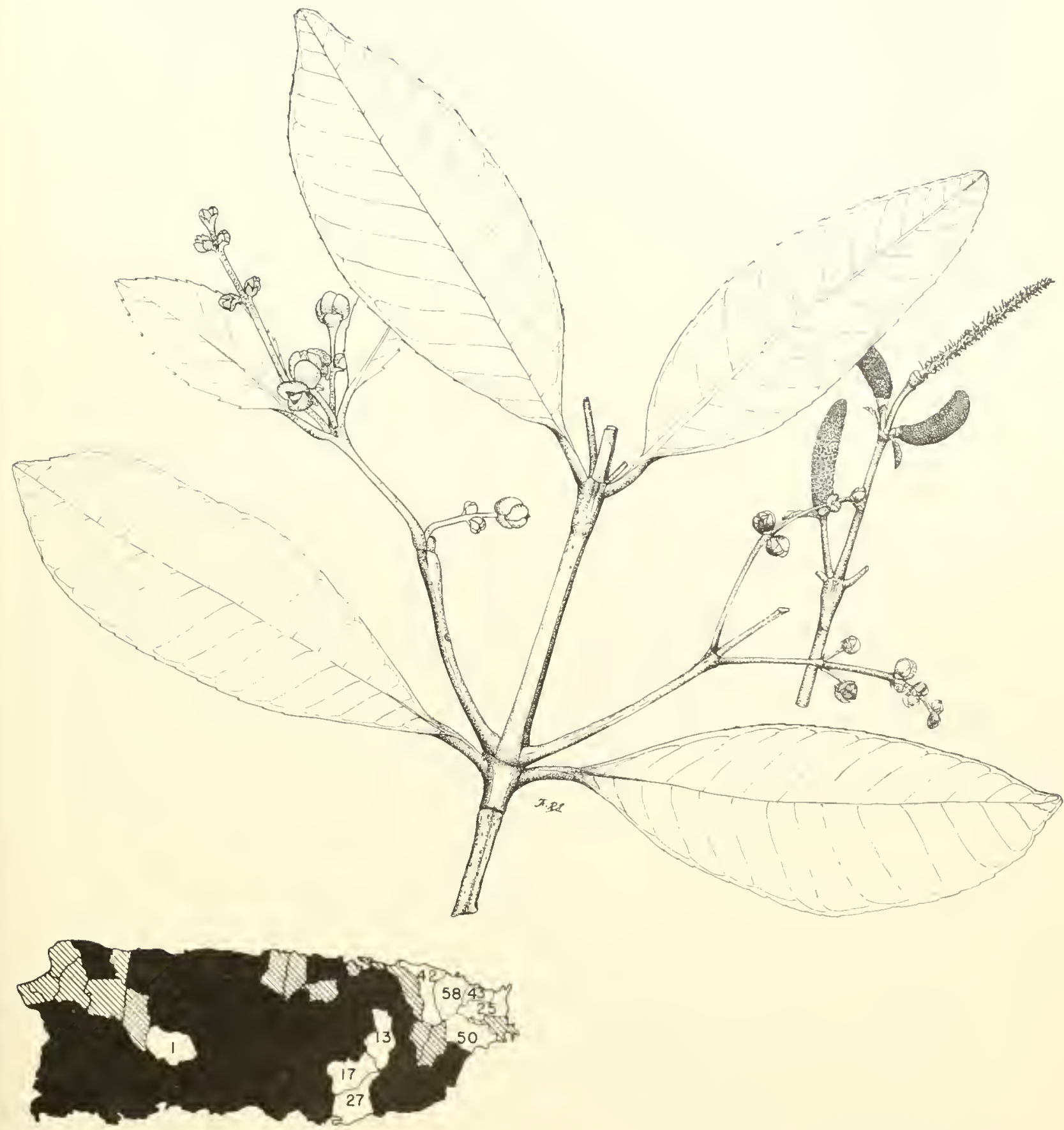

13. Azafrán

Hedyosmum arboreserns SN. 


\section{WILLOW FAMILY (SALICACEAE*)}

\section{Sauce, Humboldt willow}

In exotic ormamental tree easily recognized loy: (1) the very narrow colummar crown with striglit axis: (2) nearly erect branches: (3) slender yellow-green twigs: and (t) the very narrow (linear), long-pointed, finely saw-toothed leares. Ipparently this species does not flower in Puerto Rico.

A small to medimm-sized everoreen tree attaining 20-60 feet in height and 5 inches in trunk diameter. The eray bark is rough and furrowed. Inner bark is pinlish and slightly bitter. The twigs are sometimes pinkish tincred.

The alternate leaves have short slender greenish or pinkish petioles about 1/8 inch long. At base there is a pair of broad. short-pointed, toothed, green scales (stipules) ${ }^{2},-3$ s inch long, clasping the twig. Leaf blades ale $2-5$ inches long and ${ }^{3}{ }_{16}-3 / 6$ inch lroad, short-pointed at base, with lateral veins inconspicnons, papery thin, and dull green on both sides. The foliage has a slight but distinctive odor.

Where present, the flowers are male and female on different trees (dioecious), crowrled with woolly seales in nurrow clusters (catkins) $11 / 4-21 / 2$ inches long, terminal on short twigs. Male flowers consist of 47 stamens above a roolly scale, and female flowers with woolly scale at hase have a pistil composed of 1 -celled ovary and 2 stiomas. Seed capsules nearly $3 / 16$ incla long contain many small seeds with tufts of cottony hairs.

\section{Salix humboldtiana Willd.*}

The sapwood is whitish, and the heartwood dnll glay and reddish. The wood is soft, lightweight (specific gravity 0.4 ), and easy to work. It is not durable and is very susceptible to attack by drywood termites. The wood is used only for posts and fuel in Prerto Rico. Elsewhere it has been cmployed for boxes and in cahinetmaking, and the bark las served in medicine. Baskets and wicker fumiture are male from the slender flexible branches.

The colnmnar form is grown as an ornamental, particularly in cemeteries and also in parks and rardens and in living fences. Also in St. Croix. The species is proparated from cuttings.

RAvge.- Native from central Mexico south to Chile and Argentina. Planted also in southern Florida. Greater Antilles, and in Guadelonpe, Martinique. St. Tincent, and perhaps other Lesser Antilles.

Other connox ranes-mimbre (Pnerto Rico); sauce (Spanish); sauce colorado, mimbre (Colombia) : pajarobobo (Peru) ; sance amargo, sauce chileno (Chile) ; sance criollo, sauce colorado (Argentina): sance criollo, sance blanco ( $\mathrm{T} r u-$ gnay): Humboldt willow, willow (United States, Engisl) : saule (French) : saule, peuplier (Guadeloupe); salgueiro, salso, cholāo (Brazil).

Botanicil sYNoxmu. - Salix chitensis auth., not S. chitensis Molina, a name of uncertain application. 


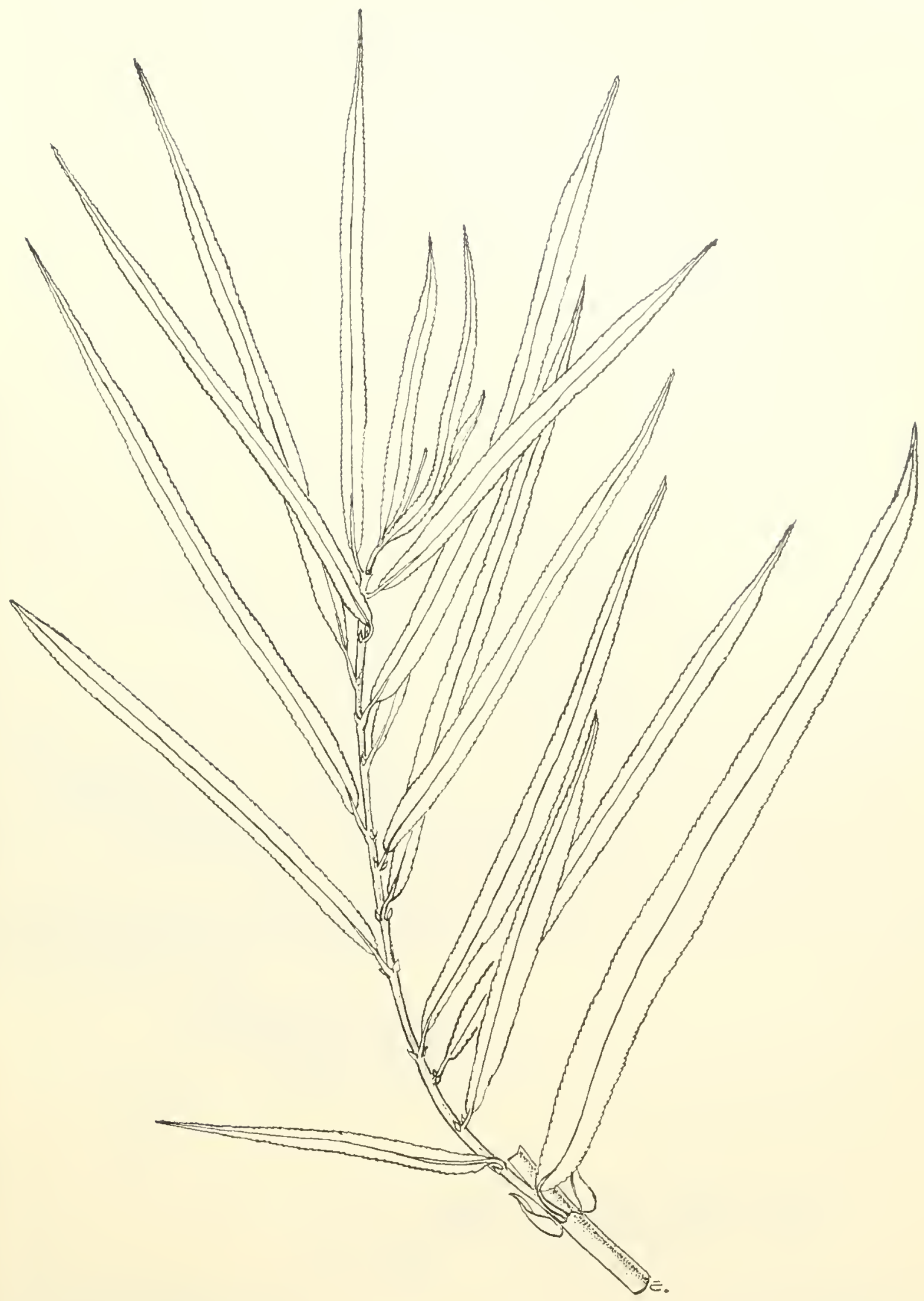

14. Sauce, Humboldt willow 


\section{ELM FAMILY (ULMACEAE)}

Kes to the 2 species illustrated ( Nos. 15 and 16)

A. Leares less than 2 inches long, short-pointed, rough hairy on both surfaces-15. Trema lamarchiana.

Ad. Leaves $3 \frac{1}{2}-6$ inches long, long-pointed, rough hairy above, soft hairy on veins beneath-16. Trema micrantha.

\section{Palo de cabrilla, West Indies trema}

This shrub or small tree of openings in dry areas is characterized by: (1) at thin, rery spreading "lown of horizontal or slightly drooping branches; (ㄴ) small, lance-shaperl leaves usually less than 2 inches long. rongh and hairy on both sides, thick and with the finely raw-toothed edges turned under. with 3 main reins at lasse, and with net work of reins sunken on upper sulface and raised on lower surfince: (3) the leaves in a flat arrangement in 2 rows: and (4) many small greenish flowers and pink fronits $1 / \mathrm{s}$ inch in diameter clustered at bares of leaves.

In everareen shrub or tree to 20 feet in height and 10 inches in trunk diameter. The smoothish liwht brown bark has many tiny warty dots (lenticels) and thin fissures. Inner bark is light brown or pinkish. fibrous and slightly bitter. The slender twigs, green when young and becoming brown, are covered with minnte, stiff, whitish hairs.

The alternite leares have short hairy petioles ${ }_{1} \mathrm{~s}^{1 / 1}$ inch long. Leaf blades are mostly $3 / 4-11 / 2$ inches in length and $1 / 4^{-1 / 2}$ inch in width, sometimes to $31 \%$ inches long and $11 / 4$ inches broad, usually short-pointed at apex, rounded or slightly oblique at base. grreen alove and light green leneath.

\section{Trema lamarckiana (Roem. \& Schult.) Blume}

The hairy flower clusters (cymes) about $3 / 8$ inch acruss hear several short-stalked hairy flower's less thatn $1 / 8$ inch across, mostly male and female togret her" (nonoecious). Nale flowers have 5 sepals, 5 stamens, and rudimentary pistil; female flowers have 5 sepals and pistil composed of ovary with 2 stimmas. The fleshy froits (drupes) contain 1 Inown seed 1/16 inch long. Flowering and fruiting probably through most of the year.

The light brown soft wood is seldom used in Puerto Rico.

In open areas along the edges of forests and along roarlsiles in the sonthwestern part of the lower Condillerat region of Puerto Rico.

Perilile foliests.-Maricao, Susúa.

Raxas-Sontherm Florida including Florida Key\%, Bermuda. Baltamas, Greater Antilles, and Lesicer Intilles from Saba to St. Vincent.

Other conjox vanes. - cabrilla (Puesto Rico): memizo de majagua, menizo cimarrón, majagua, memiso (Dominican Republic); capulí cimarrin, guasimilla (Cuba); West Indies trema (I'nited States): Lamar'k trema, pain-in-back (Bahamas) : mahaut piment (Haiti); orme petites fenilles (French West Indies). 


\section{ELM FAMILY (ULMACEAE)}

\section{Guacimilla, false jacocalalu, Florida trema}

This small tree of open forests is recognized by : (1) open sprealing crown with horizontal and slightly drooping branches: (2) the lance-shaped leaves $31 / 2-6$ inches long, long-pointed at apex, the base with $:$ main veins and slightly leat-shaped and oblique, with fincly saw-toothed edges, rough hairy on upper surface and soft hairy on reins beneath: (3) the leaves arranged thatened in 2 rows on green laliry twigs: and (4) numerous small greenish flowers and romnd orange funits $1 / 8$ inch in diameter borne in lateral clusters at leaf bases.

An evergreen tres to to feet high and 1 foot in trunk diameter. The light brow bark is smoothish with rows of waty lots (lenticels) or becoming slightly fissured. "Inner bark is brownish or pinkish, almost tasteless or slightly bitter.

The leaves are alteruate on short petioles $1 / 4-3 / 8$ inch long with blades 1-21/4 inches broad, slightly thickened, the upper surface green and the lower surface light green.

Flower clusters (eymes) are lateral and branched, 1/2-3/4 inch across, hairy, with nmmerous short-stalked small wreenish flowers less than 1/s inch long. mostly male and female together (monoecions). Male flower's about $1 / 8$ inch across have 5 pointed whitish-ereen sepals. in whitish stamens, and a sterile pistil. Female flowers are composed of a pointed whitish-green sepals and a pistil with green orary and 2 whitish stigmas. The round Heshy fruits (drupes) contain 1 black seed more than $1 / 16$ inch long. Probably in flower and fruit nearly through the year.

\section{Trema micrantha (L.) Blume}

The wood is light brown, soft, lightweight (specifie gravity (1.t), and weak. [sed only for posts :urd fuel in Puerto Riro. The strong fiber in the barlí has lreen employed for cordage.

In openings, cleirings, woodlands and along roatsides in the lower Laquillo and moist coastal legions of eastem Pterto Rico. Also in St. Crois, st. Thomas, Nt. John, and Tortola.

Pubal ronests.-Carite, Lmquillo, Toro Negro.

Raxae-Central and southern Florida and Florida Keys and throughout West Indies from Cuba to Trinidad and Tobaso. Also from central Mexico to Mrgentina and Brazil.

Orier comion names.-palo de cabra, cabra (Puerto licos): memizo cimarón, memiso de paloma, memiso (Dominican Republic) ; guacimilla, guacimilla cimarona, guacimilla boba, capulí cimaron (c"uba) : yaco de cuemo, equipal (Mexico): capulín (Centra] Anerica) : capulín negro (Honduras) : atpulin macho, capulín montes, capulin(cillo. churusco (El Salvador) ; capulín hlanco, jueo, rara blanca (Costa Rica): capulín macho (Panama) : lerraco, raspador, majacua colorada, venaco (Colombia): masaquilla (Venezuela): tortolero, muchichilán (Ecuador); aisegerina, atadijo, rana-caspi (Peru) ; palo-pólrora, afta coloratla (Argentina): Florida trema (United States): Jamaluan nettle-tree (Jamaica); white capulin, wild bay-cerlar (British IIondnlas) : bois re soie (Haiti) : ceriúra (Brazii). 


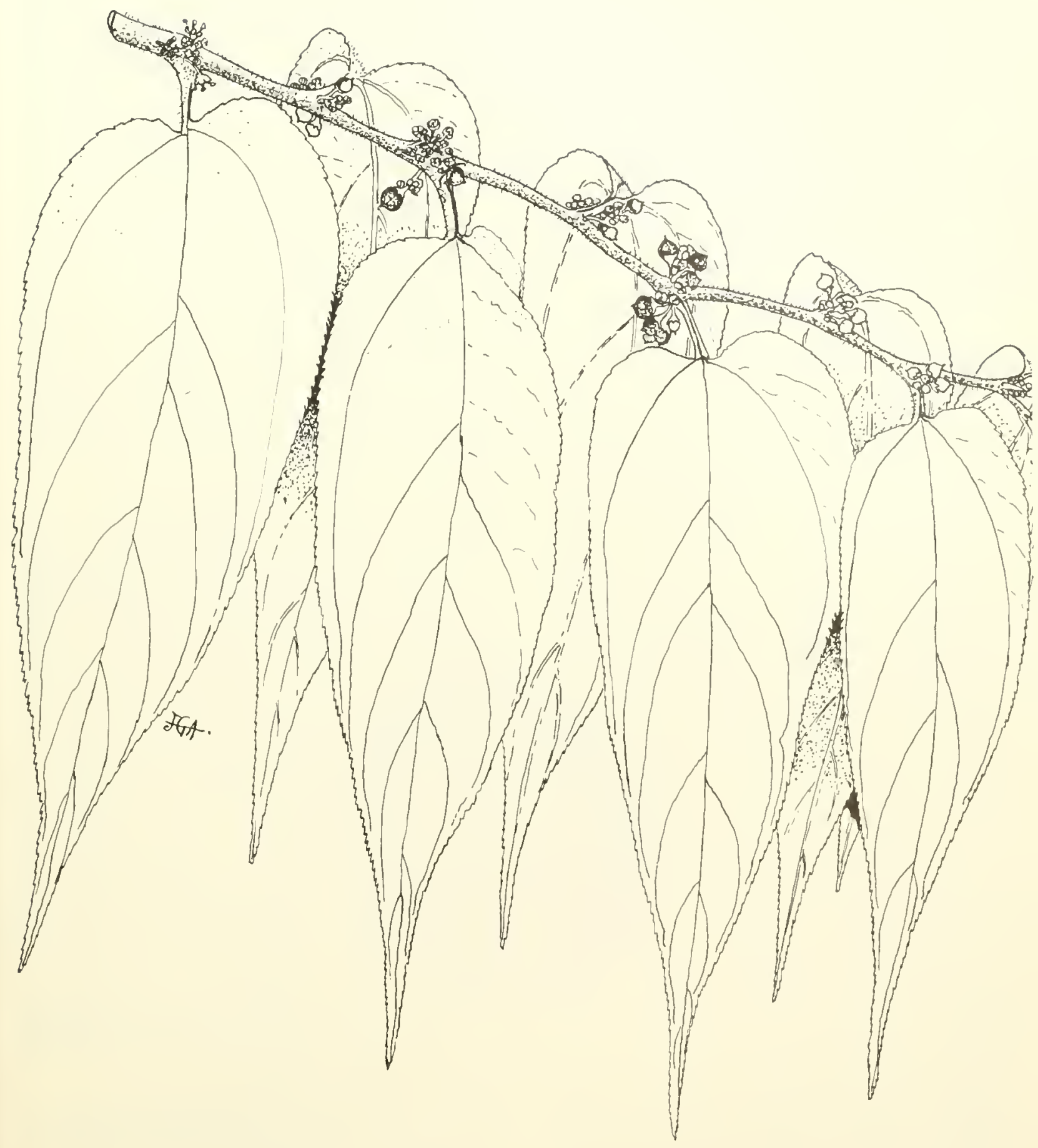

16. Guacimilla, false jacocalalu, Florida trema 


\title{
MULBERRY FAMILY (MORACEAE)
}

\author{
Key to the 8 species illustrated (Nos. 18-24)
}

A. Leares deeply lohed, very large.

B. Jeares umbrellalike, rounded with 7 -11 rounded lobes: jetiole very long-20. Cecropia peltafa.

BB. Leares elliptic, with 7-11 long-pointed lobes; petiole short-17. Arfocarpus altilis.*

A. Leares not lobed.

C. Ieaves luary, oblong, elges with tufts of hairs appearing like minute teeth-19. Castilla elastica.*

CC. Leares hairless or nearly so, edges not toothed.

D. Leares elliptic or obovate, rounded at apex; fruit very large, elliptic or rounded-18. Artocarpus heterophyllus.*

DD. Ieaves various, short-or long-pointed at apex : fruit small, figlike.

E. Leaves with 3 main reins from base, elliptic to diamond-shaped-23. Ficus retusa.*

ED. Leaves with 1 main vein or midrib.

F. Jeaves with f-10 lateral reins on each side of midrib-22. Ficus laevigata.

FF. Leares with many straight, parallel, lateral reins.

G. Leaves abruptly short-pointerl at almex, rounded at base, $4-12$ inches long-21.

GG. Leares short-pointed at both ends, 11/4-3 inches long-24. Ficus sintenisii.

F'icus clastica.*

\section{Panapén, pana de pepitas, breadfruit}

Brearlfruit is a handsome tree planted for its edible fruits and attractive foliage. It is easily reengnized by: (1) the very large, deeply $7-11$ lobed, shing dark green leaves about $11 \%$ (1-3) feet long: (2) the milky juice that exudes from the bark when cut; and (3) the vellowish-green mounder or elliptic fruts +8 inches long. "Two valieties are listinguisherl: panapen being the common seedless variety, and pana de pejitas the variety with seeds.

I medium-sized sprealing evergreen tree to 60 feet himh and 2 feet or more in trunk diameter, with relatively few stout branches. The brown bark is smooth, with warty dots (lenticels). Inmer hark is whitish and almost tasteless, with white, slightly bitter latex. The very stont twigs $1 / 2-1$ inch in diameter ale erreen and minntely hairy, witl rings at norles, and end in a large, pointed, finely hairy bud 5 inches or less in length, formed ly a big scale (stipule) around the developing leaf.

Lenves are alternate on very stont green petioles 1-2 inches long. The leaf blades are elliptic in outline, 9-20 inches arross, the pinnate lobes longpointed, short-pointed at base, slightly thickened, the upper surface nearly hairless except along reins, and the lower surface lighter green and finely hairy at least on veins. The 2 rarieties differ' slightly in leaf slape and hairiness. Ifeares of the seeded variat ion are less deeply lobed, have usually 9 or 11 lobes instearl of the 7 common in the seedless variety, and are more hairy, bristly hairy on veins above and finely and molghly hairy on lower surfare.

Flowers are very numerous and minute, the male and female on the same tree (monoecious) in separite thick, fleshy elusters single at leaf bases on stalks about 2 inches long. The male cluster is a cylindrical or club-shaped soft mass about 5-12 inches long and 1 ineh in diameter, yellowish and tuming brown. Male flowers $1 / 16$ inch long, eonsisting of 2 -lobed calyx and 1 stamen, are crowded on the outside. The female flower cluster is elliptic or romded, about $2 \frac{1}{2}$ inches long and $11 / 2$ inches in diameter or larger, light green. In the

\section{Artocarpus altilis (Parkinson) Fosberg*}

variety with seeds the female flowers are $3 / 5$ inch long and $1 / 16$ inch across, composed of a tubular, conelike and pointed, hairy ealyx projecting $1 / 4$ inch and pistil with a smiken 1-celled 1-owiled ovary and 2 -lobed style. The seedless variety has sterile female flowers projecting only abont 1/32 inch.

The multiple fruits are corered with individual fruits and contain a whitish starchy pulp formed from the enlarged stalk (receptacle). In the seeded variety the fruit surface is composed of greenish conical spinelike projections, each from a single flower, and there are several large brown edible seeds. The seedless variety has a smoothish surface honeycombed with individual fruits about $3 / 16$ inch across. Flowers and fruits are borne throughout the year.

The saprood is light yellow to yellowish brown, and the heartwood colden colored, sometimes flecked with orange. The wood is very soft, lightweight (specific gravity 0.27 ), yet quite firm and strong for its weight. It is very susceptible to attack by dry-wood termites. There are numerous large pores but no growth rings. Rate of airseasoning and amount of degrade are moderate. Machining characteristics are as follows: planing is fair: shaping, turning, boring, and mortising are very poor; sanding is poor; and resistance to screw splitting is excellent.

The wood is little used in Puerto Rico except occasionally for interior partitions. Nevertheless, it is suitable for boxes, erates, light construction, and toys. Surf boards were made from the light wood in Hawaii.

The trees are also attractive for ornament and shade. In periods of prolonged drouglit the leaves have leen cut to provicle forage for cattle. The sticky sap has been used in some places to catch birds.

Fruits are arathered before maturity and roasted or boiled as a starehy vegretable, those of the seedless variety being preferred. Or the young fruits can be sliced and fried. Also, the seeds are boiled or roasted. A dessert and preserves are sometimes 


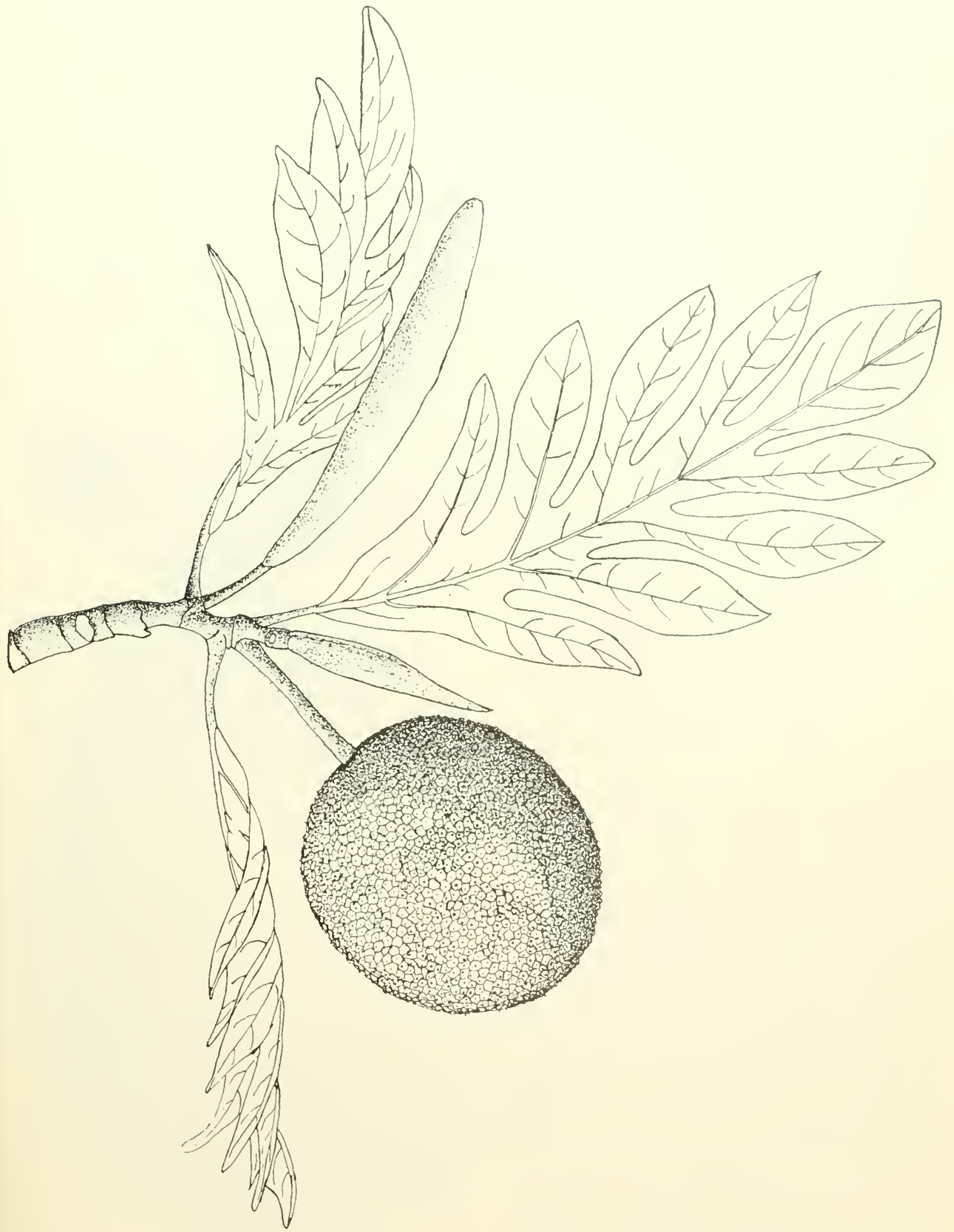

17. Panapén, pana de pepitas, breadfruit

One-third natural size.

Artocarpus altilis (Parkinson) Fosberg

61 
made from the male flower clusters. Elsewhere the fruits have served for fattening hogs.

This tree was introdnced into the West Indies in 1793 from Taliti of the south sea Islands to provile cheap food for slaves. It was claimed that three or fom mature trees conld provide starchy food to support a man thromghout the year. Captain William T3ligh in the ship Providence chartered by the British Covernment brought plants to st. Vincent and Jamaica. This special expedition was undertaken to transport potted plants of the seedless varicty the great distance. In earlier attempt with a cargo of plants on board the ship Bounty failed owing to the famous mutiny a crainst Captain I3lierl in 1789. Abont the same time the French brought a few hreadfruits to other islands of the Trest Indies.

Propagation is ly root cuttings or layering and in the seetled variety by seeds. Frowth is rapid. Widely cultivated around homes almost throughout Pierto Rico and occisionally escaping. I teast common in the upper nountain and dry limestone regions. Also in Mona, St. Croix, St. Thomas, St. folnn, and Tortola.

Roxat.-Native in islands of the Sonth Parific
Ocean. Cirown throughont the tropics, the seederl variety sometimes escaping from cultivation. Planted thromghout the West Indies and in contimental tropical America. Rare in somthern Florida and fruting only at Key West.

Otuer common vames.-árbol de pan, palo de pan, pan, pana (P’uerto Rico, Spanish) : lavapén. mapén. Jombilla, pichones (Puerto Rico) : pana for:atera (neerless variety, Puerto Rico) ; castaña (seeded rariety, Puerto lico): buen pan, allopán, pan de fruta (Dominican Republic): castaño del Ialabar (seeded rarjety, Cuba) ; mazapán, fruta de pan, pan de fruta, castaña (Guatemala) : mazapán (Ilonduras); breadfruit (Lnited States, Enolish): breadnut (seerled variety, English): chataigne (seeted variety, Trinidad): mazapín (British IIonduras) : arbre à pain. fruit à pain (French): arbre véritable (IIaiti): châtaignier, chataimier du pars (seederl variety, French Thest Indles): palu di frut $i$ pan, broodhoom (Dutch Mest Indies) : broodboom (Surinam) ; fructa pão (Brazil).

Botanis. sYoxpus.-Arfocarpus communis J. R. \& G. Forst.. A incisues (Thumb.) L. f.

\section{MULBERRY FAMILY (MORACEAE)}

\section{Jaca, jackfruit}

This cultivated relative of breadfruit is claracterized by: (1) giant, elliptic, rounded or irregular-shaped yellow-green fruits 1-2 feet long and 1/2-1 font in diameter, covered with sharp conical points; (2) milky juice in the bark; and (3) leaves commonly elliptic or oborate, $t-6$ inches long and 2-3 inches broad, dark erreen and slightly shiny, thick and leathery.

A small to medimm-sized evergreen tree to 40 feet in height and 1 foot in trmen diameter. The gray bark is smoothish, becoming rongh, furrowed, and thick (1/2 inch). Inner bark is light brown. gritt y and almost tasteless, yelding tasteless latex. The twigs are gray, with raised rounded leaf scars, ending in a dark green, narrow, pointed, minutely hairy scale (stipule) 1/2 inch or more in length forming the bud.

The leaves are alternate, with stout petioles $1 / 2-3 / 4$ inch long. Leaf blades vary in shape, sometimes oblong or narrow and on young plants and shoots occasionally 2-or'3-lobed.

Iale and female flowers are in different flower clusters, enlarged and fleshy, on the same tree (monoecions). The male cluster on a stalk 2 inches long is stoutly club-shaped, $2-1$ inches long, rellowish rreen, and with oflor like muskmelon, hearing rery many crowded male flowers less than $1 / 16$ inch long. each consisting of a 2 -lobed calyx and 1 stamen. Female flowers, very numerons in the elliptic or rombled female flower clusters, are more than 1/16 inch long, composed of tubular hairy calyx and pistil with 1-celled 1-ovuled ovary, slender sty le, and broader yellow stigma.
Artocarpus heterophyllus Lam.*

The multiple fruits, weighing $20-40$ pounds, have a hard onter covering of the enlarger female flowers, each with a sharp conical point $3 / 8$ inch long and about $1 / 4$ incl across at base. Within is a whitish fibrous pulp containing many seeds ( 80 to a pound), which are irregularly bean-shaped, whitish or light brown, $1 \frac{1 / 4-11 / 2}{2}$ inches long. In fruit nearly through the year.

The wood is yellowish, darkening to brown upon exposure, fairly hard and resistant, taking a gond polish. Little used in Pnerto Rico: elsewhere nsed in cabinetwork and carpentry.

Occasionally planted in gardens, chiefly in the cities and tow of Puerto Rico and Virgin Istands for ornament, shade, or the large edible fruits, though much less common than breadfunit. The fruits, which are eaten cooked as a starchy regetable. have a peculiar flavor and are less palatable than breadfruits.

RaxaE.- Native of tropical Asia from India to Malaya and East Indies. Widely planted in tropial regrions, inchuding southem Florida, West Indies, and continental tropical America.

Other compox rases. - pana cimarona (Puerto Rico): jaca (Spanish): pan de fruta. buen pan, albopán (Dominican Republic) : rima (Cuba) : castaño (Nicaragua) : jaqueira, álbol de pan (Colombia) ; jackfruit, jack (Cnited States, English): cartahar (British Guima): jacuier. (French) : jaca (Brazil).

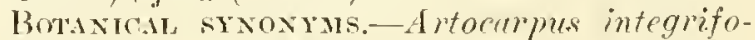
lims anth., not I. f., t. integer anth., not (Thimnb.) Merr. 


\section{MULBERRY FAMILY (MORACEAE)}

\section{Caucho, Central American rubber, castilla rubber}

Castilla elastica Cervantes*

Caucho, including this and 2 related species planted sparingly in Puerto Rico, is easily recognized by: (1) the long, slightly drooping, stout, hairy twigs witl 2 rows of large hairy oblong leaves $10-18$ inches long and 18 inches broad, also drooping: and (2) abundant milky juice in the bark and twigs. The other species are separated mostly by flower and fruit alameters.

A large spreading evergreen tree becoming io feet or more in leight and $1-3$ feet in trunk diameter, with buttresses forming at hase of large trunks. The light brown bark is smonthish. with fine fissures, and thick, often having scars where cut with machetes by curious persons to see the latex drip. Inner bajk is whitish and bitter with latex also bitter. The mbranched twigs are green when young but become hown, mul have a long, narrow, erreen, hairy terminil bud $2-21 \%$ inches long, formed by a many-ridged seale (stipule) that sheds, leaving a diagonal ping scal at each nole.

The altemate leaves are spreading from short stout hairy petioles $1 / 6$ inch long. Leaf blades are oblong hit hroadest beynd the nirldle, shortpointed at apex and heart-shaped at hase, the ed ges with tufts of hairs simnlating minute teeth, thin, green and rongh on upper surface, and light green and soft hairy beneath.

Flowers are male and fenale on the same tree (momecions) but in separate flattened headlike chusters hordered by lows of overlipping sales and borme along the twigs mostly back of the leares. Male clusters are commonily 4 together, $3 /-1$ inch across on stalks ahont 1 jueh long, composed of male flowers with numerous crowded stimens less than $1 / 8$ inch long and no ealyx. Female clusters are single, stalkless or nearly so, forming a greenish-vellow disk $3 / 4$ inch aeross, and hordered by many broad, short-pointed, green, finely hairy, overlapping scales. The erowded female flowers are about $1 / 4$ inch long, with fleshy, minutely hairy, greenish-yellow, tubular, angled calyx surrounding and adhering to the white ovary, which has a yellow-green style and 2- or :-forked protruling stigma.

The multiple fruit is a disk $11 / 2-2$ inches in diameter and $3 / 4-1$ inch thick, bordered by many green overlapping scales from the flower cluster and composed of many crowded individual fruits grown together. Each individual fruit is $1 / 2-3 / 4$ inch long and $1 / 4^{-3} / \mathrm{s}$ inch aeross, bhunt-pointed and lalf within the disk, composed of the fleshy, finely lairy calyx, ehanging color from yellow to green, orange, and red, very juey, almost tasteless but sliglit? sour, soon fermenting and molding, and containing 1 white oblong seed $3 / 8^{-1 / 2}$ inch long. seeds 800 to a pound. Flowering eliefty in spring, and maturing fruits in summer.

The wont is rellow brown, moderately soft, lightweight, and not durable. T'sed in Pnerto Rien chiefly for fuel.

With spectes distribnted on the continent from Mexico to Ecuador, Peru, Bolivia, and Brazil, restillu was formerly an important source of rubber, both from wild trees and plantations. Sone rubber is still olstained from wild trees by cutting or tapping the bark and collerting the latex, which coanulates upon exposure. Cultivation in Trinidarl and Tobago was not commercially suecessful. Iost rubber now comes from plantations of the mrelated Pará rubber tree (IIerea) mative in Brazil. The Indians made mats for blankets and (') thing by beating out the bark.

Planted oceasionally in Prerto Rico, sometimes as a roadiside tree for shade and ornament. Found along the Arecibo-Ltuado, Ciales-Villalba, and Marica-Mayagiez highways. Also grown at St. Thomas. It is a tree of openings in moist forests, prohably light-requiring, and grows rapidly.

RAxGE- Native of Mexico and Central Ameriea sonth to Colombia and Eeuador. In the West Indies introduced into Cuba, Hispaniola, Puerto Rico and St. Thomas, and Triniclad and Tobago. Rarely planted in sonthern Florida.

OTIIER comon Names.-palo de goma, goma, eanchera (Puerto Rico); camcho (Spanish); tirajala (Tominican Republic); árbol del hule (Mexico) ; hule, ule (Guatemala, Honduras) ; nleule, hule, nastate blaneo (Panama) : eaucho nearro (Colombia) : castilla rubber, castilloa rubber, Central American rubber (English); rubber, ule (British Honduras).

Botaxira. synovyrs - Crastilla lactifiua O. F. Cook, C. panamensis O. F. Cook.

The generic name, sometimes spelled Crstilloa. honor's Juan del Castillo (174t-93), Spanish phammeist and economic explorer, who came to Mexico in 1787 . 


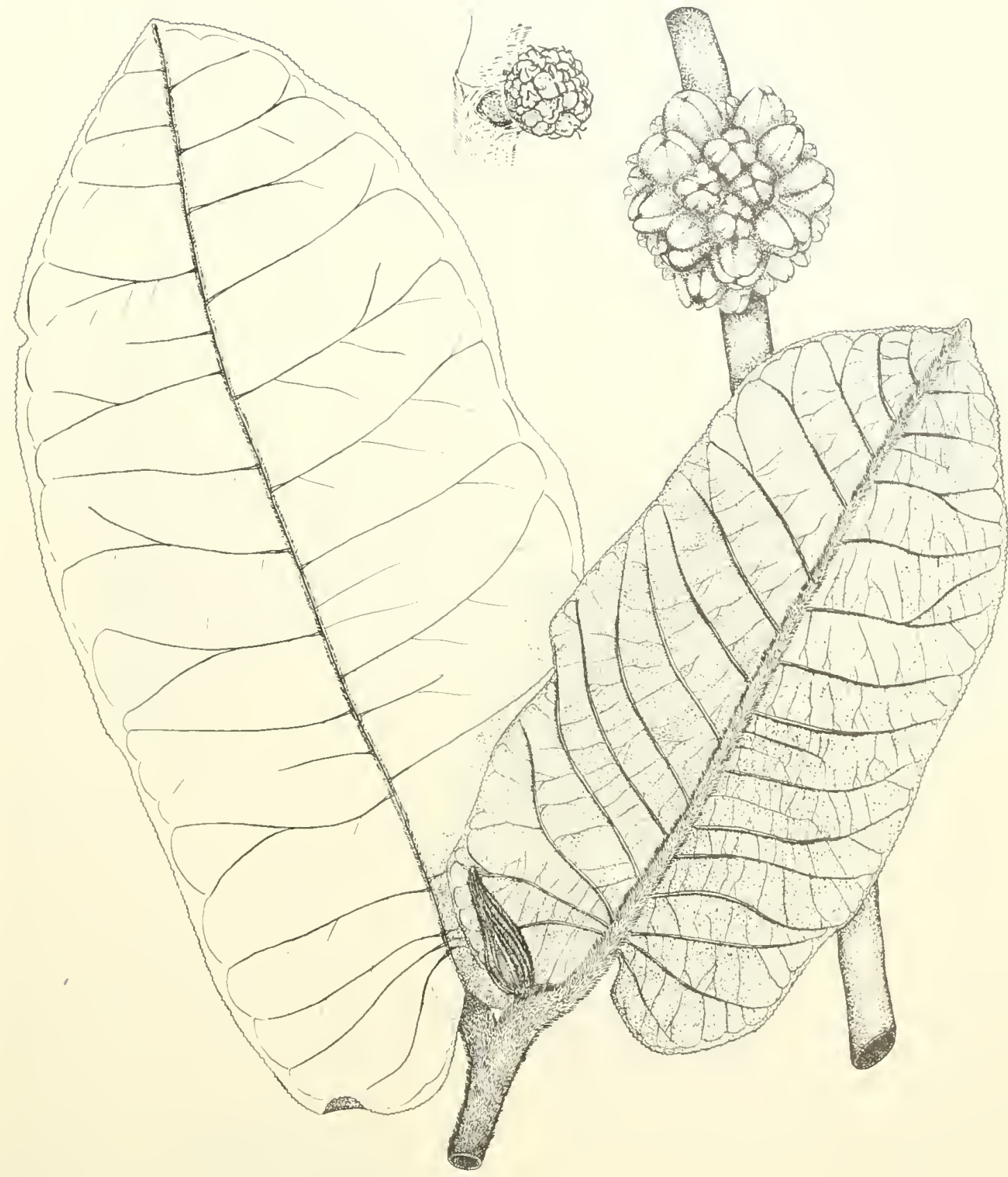

19. Caucho, Central American rubber, castilla rubber

Carlillu rlastira Cerrantes 


\section{MULBERRY FAMILY (MORACEAE)}

\section{Yagrumbo hembra, trumpet-tree}

One of the most abundant trees in Pnerto Rico, this species is easily reogmized by: (1) a rery thin sprealing crown of a few stonl branches arising high on the trmuk and curvine upward: (2) the few very large thick umbrelalibie (peltate) leaves with blades 1-21/0 feet across, composed of $7-11$ large lobes spreading at the end of a stout petiole almost as long; (3) the whitish or silvery undersulfare of leaves readily seen when uptumed hy a herag: and (4) the newer branches hollow exrept for partitions at the norkes.

A medium-sized everereen tree to to feet high and 2 feet in trmb dianeter, deriduous in aleas with a prononnced dry season. Sumetimes dereloping prop roots aromed the base. The graty hark is smooth and thiu, with malow longs and large leaf scars at the nodes or joints $2-1$ mohes apart. Inner bark is pinkish and slightly bitter. with watery latex. 'The smallest branches a le $1^{1}$ inches in dianeter, areen and slightly hairy at apex, becoming gray, with rings at nodes. There is a grimt hud corered hy a larion, pointed, realdish, hairy scale (stipule) 5-io inches lone.

Loaves are alternate but chustered at encls of linames, each on a stont round wrexn petiole 12-20) inches long, enlarged at hase. The leaf blades, roumled in outline, have $7-11$ lobes and veins radiating from the end of the petiole (palmate), the lobes and sinuses rounded. Upper surface is green, slightly rongh, and hairless, and lower surface witl at dense cont of whitish hairs.

Male and female flowers are on rlifferent trees (dioecions) in paired fingerlike rlusters at leat hases. Male flower clnsters have a stalk $2-3$ inches long hearing about 15 narrowly cylindrical pale yellow branches (spikes) $2-31 / 2$ inches long and $3 / 6$ inch in diameter, each on a stalk $1 / 4^{-1 / 2}$ inch long. The rery numerous, tiny, crowded male flowers ale 116 inch long and namow and have a tubilar ealy: and 2 stamens.

Female flower clusters on stalks $2-3$ inclies lonw consist of $2-5$ stalkless, thicker, (rlindrical, gray branches (spikes). The minnte female flowers more than 116 inch long, sunken in the axis, are composed of a tubmlar calyx enchosing ovary and style and an exposed finely branched stjoma. It matmity the branches (mintiple frouts) are $21 / 2-4$ inches long and $3 \leqslant-1 / 2$ inch in diameter, gray and slightly fleshy, dotter with many 1 -seeded minute fruits (about 2200.000 to the poind). The numerous lirown sceds are mote than 1/16 inch long. In flower and fruit probahy thromoh the year.

The wood is whitish, lightweight (specific gravity 0.29$)$, soft, weak, and brittle, but tomgh for its weight. It is not durable and is rery susceptible to attack by dry-woor temites. Lnlike the hollow brames, the main trunk is solic. The rate of airseasoning is rapid, and anomut of clegrade is con-
Cecropia peltata $\mathrm{L}$.

siderable. Machining characteristics are as follows: planing and sanding are good; shaping and tuming are fair; boling is rery poor: moltising is poor: ame resistance to serew splitting is excellent.

In Puerto Rivo the wood is used for manufacture of excelsion: Combined with cement, it is made into a type of insulation board for light interion construction and partitions. The wood whonlt be a suitahle substitute for balsa in mannfacture of toys, motels, ant other products made from molerately heary grades of balsa. Elsewhere the wood has been used for matchsticks, boxes and "lates, interiol hoarding, and paper pulp.

The hollow stem have heen used to make floats for firhnets and life preservers and, when split in two. have sorved as water troughs and gutters. sinbsitutes for cork stoppers have been whittled finom the soft wool. In some comntries the leaves, bark, and latex have been employed in local medi"ine. The fibrous bark of related species was used by Indians for cordage and mats. It is reported that the wool ignites easily from friction and serves as tinder.

Hollow branches of this and relited species elsewhere are inhahited by suall stinging ants which bore holes to reacl the interior. Early naturalists wbserving this constant association imagined that the ants, as parment for the residence furnished, were aggressive in droving away insects or other natural enemies threatening the tree. However, in Juerto lic'o ants are not associated with this species, and the trees thrive.

Ahmdant in open areas and in forests both viryin and cutovel: thoughout Puepto Rico with the exception of parts of the dry coastal and dry limestone regions. Also in Tieques, St. Croix, St. Thomas, St, John, and Tortolit.

The trees propagate naturally and at first grom very rapidly (2-3 inches in dianeter per year) but require nearly full smlioht. The seeds apparently geminate slowly. In Triniclad it was observed that bats eat quantities of the succulent fruits and are the chiet acents of seed dispersal. Birkls also distribute the seeds. This reed tree commonly covers quickly all openings resulting from cutting of trees in the forest. Its open sharle provides a good enviromment for the derelopment of a new forest.

Public folists.-Cambalache, Carite, Guajataca, Guilarte, Lagnillo, Marieso, Río Abajo, Susna, Toro Negro. Vega.

MCNICIPALITIES WHERE FAPFCIALLY COMMON,-1, ․, 10, $14,17,19,22,23,25,27,31,34,35,36,40,43$, $45,49,50,51,52,53,58,59,60,62,64,70,73,74$.

RAxas.-Thmoughont West Indies from Cuba and Iamaica to Trinidad and Tobago. Also from Incatán, Mexico, to Costa Rica and recorded in 
Colombia, Venezuela, and Guians. Planted as an ornanental in southern Floridat.

()THER COMMON N.MAEs-Yagrumo, llagrumo, grayumo lienbra (Puerto Rico); trumpet-wood (Virgin Islands); ragrumo, yagrumo hembra (Dominican Republie) ; yagruma, yagruma hembra (Cuba) : guarumo (Guatemala. Costa Rica, Colombia): igarata (Guatemala): trmmpet-tree, trimpet-wood, pumpwool, snakewood (United States, English); shield-shaped trumpet-tree (United States); pop-a-gun (Barbados); bois canon (Triniclad); wanasoro, congo-pump (Brit- ish Guiana) ; bois trompette (Haiti, Guadeloupe) ; bois canon (Guadeloupe, Martinique); wild papaw (Intch Vest Indies); bospapaja (Surinam).

Botanical srNoxym. - Cecropid aspemima Pittier.

Encrish and French common names refer to the use of the hollow branches for trumpets or other musical instruments. Mlso, children sometimes make flutes from the hollow petioles.

In mrelated tree of generally similar appearance is yagrumo maeho (Didymopanax morototoni (Aubl.) Decne. \& Pl.).

\section{MULBERR Y FAMILY (MORACEAE)}

\section{Palo de goma, India-rubber fig}

Oceasionally planted in Puerto Rico for ornament and shade, this handsome spreading tree is characterized by: (1) an extensive superficial root system and numerous aerial loots about the trunk; (2) abundant milky juice or white latex: (3) large, leathery, oblong or elliptic, shiny green leaves $4-12$ inches long and $2-3$ inches broad, thick and stifl, abruptly short-pointed at apex, rounded at base, and with sides bent upward at midrib; (4) numerous straight, parallel, lateral veins very close together on each side of the midrib and nearly at right angles to it; and (5) oblong gleenishyellow figlike fruits about $1 / 2$ inch long, paired and stalkless at base of leares.

A medium-sized to large everareen tree to 60 feet in height and ? feet in trunk diameter. In India, its native home, it becomes 100 feet tall with a giant fluted trunk, often buttressed at base and with long surface roots. The bark is light gray, smoothish with small horizontal ridges, and thick. Inner bark is reddish and bitter. The cromn of long branches provides dense shade. The stout twigs have faint rings at the nodes. A large, showy, long-pointed, reddish sheath or scale (stipule) 1-2 inches or more in length forms the ontside of the bud and covers each new leat.

The alternate leaves have stout petioles $3 / 4-11 / 2$ inches long. Iteaf blades are lighter colored beneath and much larger on young shoots than on others, not toothed on edges. There is a variation with yellow variegated leaves.

The elliptic multiple fruits (syconia) are covered with a sheath when young that sheds, learing a basal cup. There is a ring and slight pointed opening at apex. Many tiny male and female flowers (monoecious) and seeds are borne inside the slightly fleshy fruits, which are eaten by birds

\section{Ficus elastica Nois.*}

and sometimes by children. Fruiting probably throngh the year.

The sapwood is whitish and moderately hard. The wood is little nsed in Puerto Rico. In native forests and extensive plantations of India this species wis the original commercial source of rubber. However, India rubber has been replaced by Pará rubber (Hevea) from Brazil, which produces higher yiclds and at an earlier age in plantations.

Propagated by cuttings or layers and ardapted to moist regions, where it grows rapidly. IIowever, the many horizontal roots on top of the ground ma be objectionable in street planting. It is reported that the large heary limbs are easily broken by wind. Where native, the plants usually start as air plants (epiphytes) from seeds germinating on other trees, sending down aerial roots to the ground and afterwards strangling and killing the supporting trees.

Planted for ornament and shade along streets and in parks and gardens in Puerto Rico and Tirgin Islands.

Rancie.- Native of tropical Asia from India to Malaya. Widely cultivated in tropical regions, sometimes escaping, and as a potted ornamental in temperate regions. Planted in southern Flor"ida, Cuba, Hispaniola, Puerto Rico and Virgin Islands, Guadeloupe, and Dutch West Indies. Also from Mexico to South America.

Other common vimes.- enucho, higuera (Dominican Repuhlic) : goma elást ica, cancho (Cuba) : amate, hule (Fl Salrador); caucho de la India (Colombia); India-rubber fig, India rubber-plant, India rubber-tree, rubber-plant (United States, English); croutchone (Haiti). 
Like the other wikl and planterl tree species of the same genus (Fing), the commonest of the jagieres of wiln figs of Puerto Rico is recognized by: (1) milky juice, or white latex, which exudes copionsly from "ut or broken parts: (2) arial roots often extending from branches to the ground: (3) prominent long-pointed huds at end of each twig, formed by a seale (stipule) which makes a ring sear: ani (t) small tleshy figlike fruits paired or single at leaf bases, with minute flowers hidden insile. Iagiley blanow is further distinguished by: (1) whitish hats: and (2) leaves with relatively long slemder petioles $3_{4}-2$ inches long and short-pointed ellipt ir to oblongr blates 11/2-6i inches long and $3+31$ inches broad, the $6-10$ hateral veins on each side about $1 ;$ inch apart and nearly at right angles to midrih.

A small to medium-sized sprealing evergreen tree to 60 feet high and 21 feet in trunk diameter. The bark is smoothish, becoming slightly fisenred. The inner latrk is light lowwn, fibrous, and almost tasteless. the white latex also nearly tasteless. Twins are greenish, turning to graty, have faint rings at nodes, and terminite in a long pointed areen scale (stipule) $3 / s-5 / s$ inch long.

Blades of the alternate leaves vary greatly in size and shape and are alyuptly short-pointed at apex and rounded, short-pointed, or slight ly heart shaped at base, often a little thickened. hairless. and not toothed at edges. The upper surface is green to dark green, slight ly shiny, with many tiny dots (raised on a dried leaf), and the lower surface is paler.

As the flowers in this genns are not risible, it appears that the trees have fruits but no flowers. The figlike multiple fruit (svoonimm), actually a compound fruit, corresponds to an enlarced overgrown flower stalk bearing on the inner walls numerous tiny male and female flowers (nonoecious) and the small seeds, each technically a fruit from a single flower. In this species the slightly Heshy roumded fruits ahout $3 / s$ inch in dianeter are liome on slender stalks $1 / 8-3$ inch long. They are greenish. often brown dotted, turning reddish and brownish at nuturity, and edible though tasteless. There are "2 seales $1 / 16$ inch long joined at base and a small pore at apex. Fruits are borne through the year.

The sapwood is whitish, and the heart wood light brown. The wood is foirly lightweight (specific gravity 0.40$)$, soft and tough, and strong for its weight. Severtheless, it is not durable and is very susceptible to attack by dry-roor termites. The late of air-seasoning is slow, and amount of degrade is minor. Machining characteristics are as follows: planing and sanding are good: shaping. turning, boring, and mortising are poor: and resistance to serew splitting is excellent. The wood is nsed for making guitars and $f(r)^{\circ}$ fuel. It is suitahle for hoxes, crates, interior construction, and light anpentry.

The plants make excellent live fenceposts beallase they root so reatily from auttings. Grown ats an orvamental and iharle tree in Puerto Rico aud southern Florida.

Youmg plants of this and some related species commonly start as air plants (epiphytes) high on „ fork of allother tree where birds have dispersed the seeds. Ilter sending slender aerial roots to the ground, the rinelike plant grows rapidly. Its foots nswally unite to form a trunk, sometimes strangling and killing the older tree.

In forests, thickets, fence rows, and roadsides throughout Puerto Rico with the exception of the uppel monntain regions. Also in Mona, Icacos, Culelya, Vieques, St. Croix, St. Thomas, St. John, and Tortola.

P' Bu, rorests.-Aguire, Cambalache, Carite, Gillataca, (iúnica, Guilarte, Luquillo, Maricao, Río Mbajo, sim Juan, Susúa, Toro Xegro, Tega.

Raxcf.-Southern Florida including Florida Keys and thromgh West Indies from laahamas and Cubato Grenada and Barlados.

()THer common simes.-jagüey, jagiley macho. jagioeillo, juginerillo (Puerto Rico) : white fig (Virgin Islands); higuillo (Dominican Republic) : jagrier, jaguicicillo (Cuba); shortlea f fig. wild fig. wild banyan (Lnited states); shortleaf wild fig (Bahamas): fignier (St. Lucia): figuier maudit. figuier blane, fignier banian (Guadeloupe) ; figuier maudit (Martinique).

Butavest syxoxyss.-Ficus lentiginose Vahl, $F$. Ineriguta rar. lentiginosa (Tahl) Urban, $F$. popnetner Tilli., F. Jrecifotia Nutt., F. popminea var. brevifolid (Nutt.) ITarb., F. Taevigato var. brevifolic (Nutt.) Warb.

This is a variable species of wide geographical range, composed of races within Puerto Rico and outside diflering in size of leaves and fruits and in length of fruit stalls. Some taxonomists have distinguished 2 or 3 species and additional varieties. Recently, however, this species has been considered " synonym of $F$. citrifolio Mill., interpreted as a species of broad geographic distribution in tropical Inerica from Florida south to Paraguay.

Besides the 2 native and 2 int roduced species of this genus of figs described and illustrated here. sererial other's have been planted for shade and ornament. Inother species of jagiey or wild fig (Fines trigonata L.; synonyms $F$. crassineria Desf., F. stahli; Wab.) native in Puerto Rico and Tirgin Islands is characterized by stout, hairy twigs, petioles 1/2-11/2 inches long, oblong or ovate leaf blades $3-61 / 2$ inches long and $11 / 2+$ inches broad, usually rounded at both ends, and rounded figlike fruits $3 / 8-5 / 8$ inch in diameter, single or paired on stallis of $1 / 8^{-1 / 4}$ inch. 


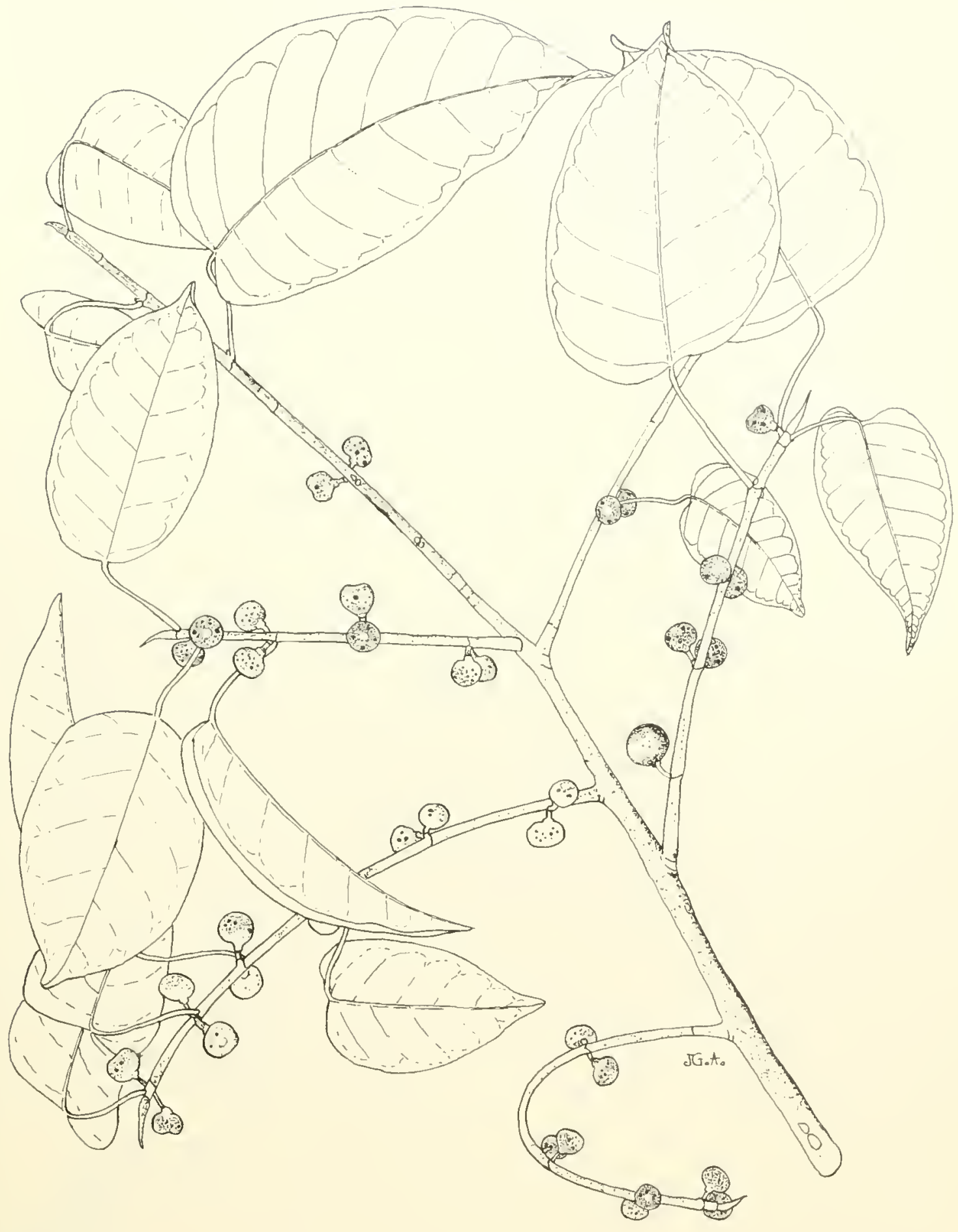

22. Jagiies blanco. shortleaf fig 
On St. Croix still another species of jagiaey or fig (Ficus obtusifolin II. B. K.; synonym $F$. urbunimm Warb.) is native and also planted. It has lare leares with stout petioles $11 / 4_{-}^{-3}$ ) inches long, orate or elliptic blades 5-? inches long, usually rounded at both ends, and rounded figlike fruits about $3 / 4$ inch in cliameter, finely hairy, usnally paired, and almost stalkless with scales $3 / 8$ inch long at base.

\section{MULBERRY FAMILY (MORACEAE)}

\section{Laurel de la India, India-laurel fig}

This large ornamental tree, planted in plazas in Puerto Rico, is distinguished by: (1) a short trunk and very dense globular crown: (2) small, dark green, slightly shiny, thick, leather'y, elliptice leatves $11 / 2-3$ inches long and $5 / 3-11 / 2$ inches broad, with 3 main reins from the base; (3) numerous aerial roots about the trunk or hanging hairlike from the lower branches; (4) milky jnice or white latex which exudes from the bark" or leaves when the tree is injured: and (5) small rounded figlike fruits a bout $5 / 16$ inch in diameter, paired and stalkless at leaf bases.

An evergreen tree to 65 feet high and 3 feet in trunk diameter, the crown often hroader than tall. Bark is smooth and gray. The immer bark is whitish and tasteless, but contains slightly bitter latex. Each gray twig ends in a long-pointed green scale (stipule) $3 / 8$ inch or less in length, which forms the bud.

The leaves are alternate on petioles $1 / 4^{-3} / 8$ inch long. Leaf blades are short-pointed at both ends, and often nearly diamond-shaped (rhomboidal), paler beneath. The 2 lateral reins from the base continue near the toothless margin.

The fleshy multiple fruits (syconia), with an inconspicuous pointed opening at apex, are green, turning yellow or reddish at maturity. There are 3 pointed, finely hairy scales (bracts) $1 / 16$ inch long at base. Inside the fruit are borne many tiny male and female flowers (monoecions) and seeds Fruiting probably through the year.

\section{Ficus retusa L.*}

The sapwood is whitish, and the heartrood is light brown. The wood is medium-weight, hard (specific gravity 0.5), has growth rings, and is very susceptible to attack by dry-wood termites.

Planted in Puerto Rico and the Virgin Istands for ormament and shade. Large specimens are to be found in and around San . Juan and in the plazas of varions torns, particularly in the southeastern part of the island. The dense crowns are frequently trimmed into rounded shapes. Difficulties of propagation have prevented this rapidly growing tree from being planted more commonly. Rooting of cuttings is uncertain but sometimes snceessful. Retter results have been obtained by air layering, or marcottage, in which a fairly large branch can be used. In some places this tree is considered objectionable hecause of its size, the litter of the numerous fruits, or because of a thrips insect, which deforms the foliage and may irritate the eyes of persons beneath the tree.

Rixge.- Tative of India and Malaya but widely planted in tropical regions. Sonthern Florida, Cuba, Hispaniola, I'uerto Rico and Virgin Islands, Lesser Antilles, Trinidad, and Curaçao. Also from Mexico to Chile and Brazil.

Otner commos xames.-jagïey (Puerto Rico); fig (Virgin Islands): laurel de la India (Spanish); laurel, álamo extranjero (Mexico) ; pivijay (Colombia); India-laurel fig, Indian-l a u re"] (United States, Euglish).

Botanical sroxim,-Ficus nitida Thmb., not Blume. 


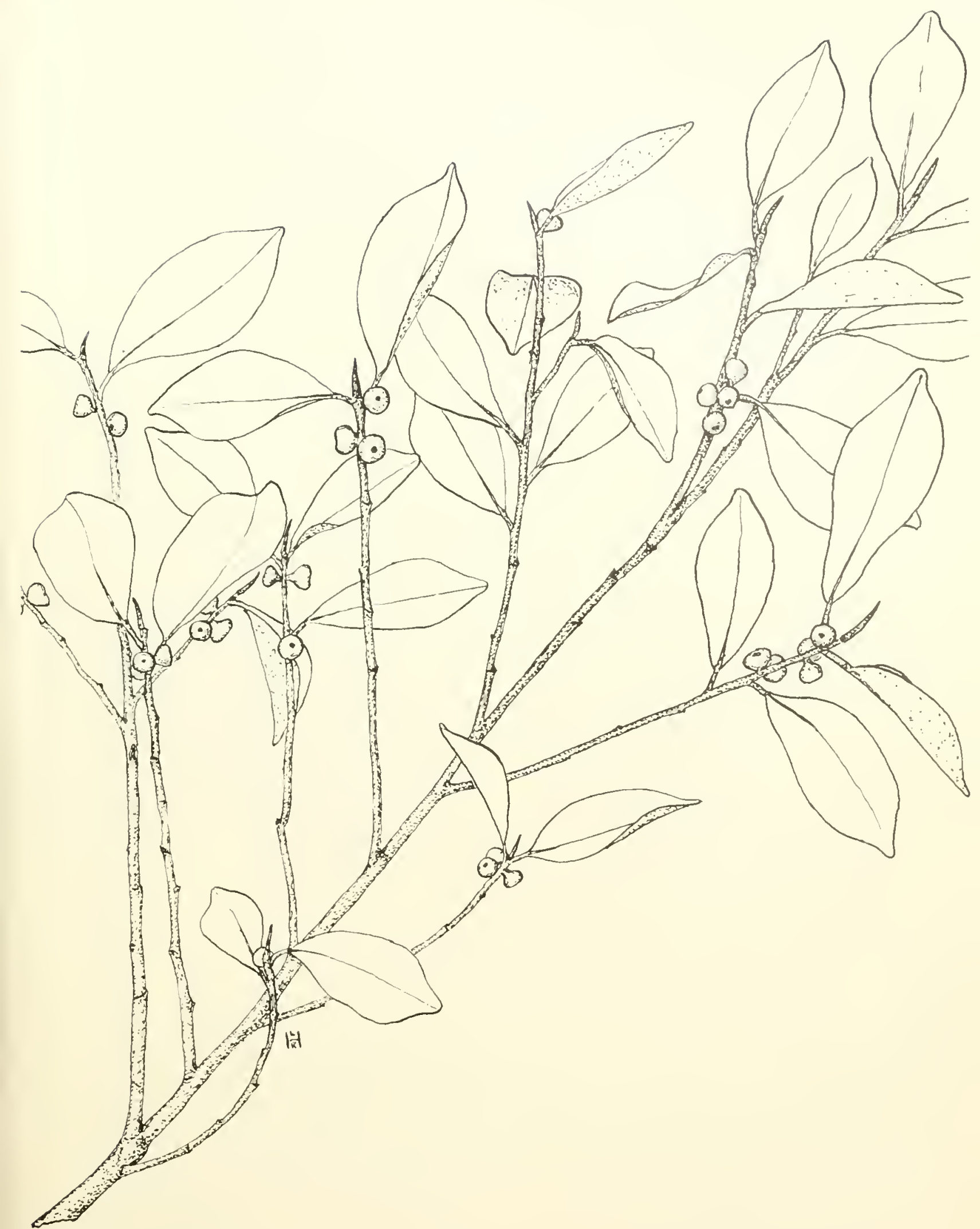




\section{MULBERRY FAMILY (MORACEAE)}

\section{Jagüey colorado}

'This jagiiey or wildfig is distinguished by : (1) small elliptic leaves only $11 / 4-3$ inches long and $5 / 8-11 / 4$ inches hroad, short-pointed at hoth ends, dull reddish when young ; (2) many straight, parallel, lateral reins less than 1/16 inch apart on each side of midrib and nealy at right angles to it : (3) rounded figlike fruits less than ${ }^{1}$ inch in dianeter and on stalks about the same length, mostly paired or single at base of a leaf : and (4) milky juice or white latex.

I small to medium-sized everoreen tree to so feet high (reeorled also to 65 feet) and 1 foot in trunk diameter, with spreading crown. Bark is light grar and smoothish. The whitish inner bark is almost tasteless and contains white latex. Slender brown twigs end in a long-pointed green scale (stipule) $1 / 4-3 / 8$ inch long, which forms the burl.

The alternate leaves have petioles $1 / 4^{-1 / 6}$ inch long. Leal blades are thick and leathery, without teeth, dark green and slightly shiny on upper surface, and yellow green beneath.

The figlike multiple fruits (syconia) are pale green when inmature, becoming pink tinged or reddish and have a slight pointed opening at apex and 2 rounded scales (bracts) 1/16 inch long at base. Numerous minute male and female flowers
Ficus sintenisii Warb.

(monoecious) and seeds are formed inside the slightly fleshy fruit. Probably fruiting through the rear.

The sapwoor is whitish and soft. The wood is soft, fairly lightweight (specific gravity 0.4), weak, and not durable. Tsed for fuel and posts. The broad, aenerally symmetrical dense erown makes this tree potentially an ornamental.

Comnonest in the upper mountain and moist limestone regrions of Puerto Rico, often growing near the summits of limestone hills. Less common in the lower mountain regions.

Punlic roness. - Cambalache, Carite, Guajataca, Guánica, Guilarte, Luquillo, Marieao, Río Ibajo, Susúa, Toro Negro.

Ruxie.-Known only from Puerto Rico.

OthFr commox rames.-jilgüey prieto, jagüey, higuillo prieto (Puerto Rico).

The speeific mame honors P. Sintenis, botanical explorer who marle extensive plant collections on three field trips to Puerto Rico in 1885-87. This species recently has been mited as a synonym of $F$. perforatu L., interpreted as a species of broader range in Bahamas, Greater Antilles, and from Guatemala to Colombia. 


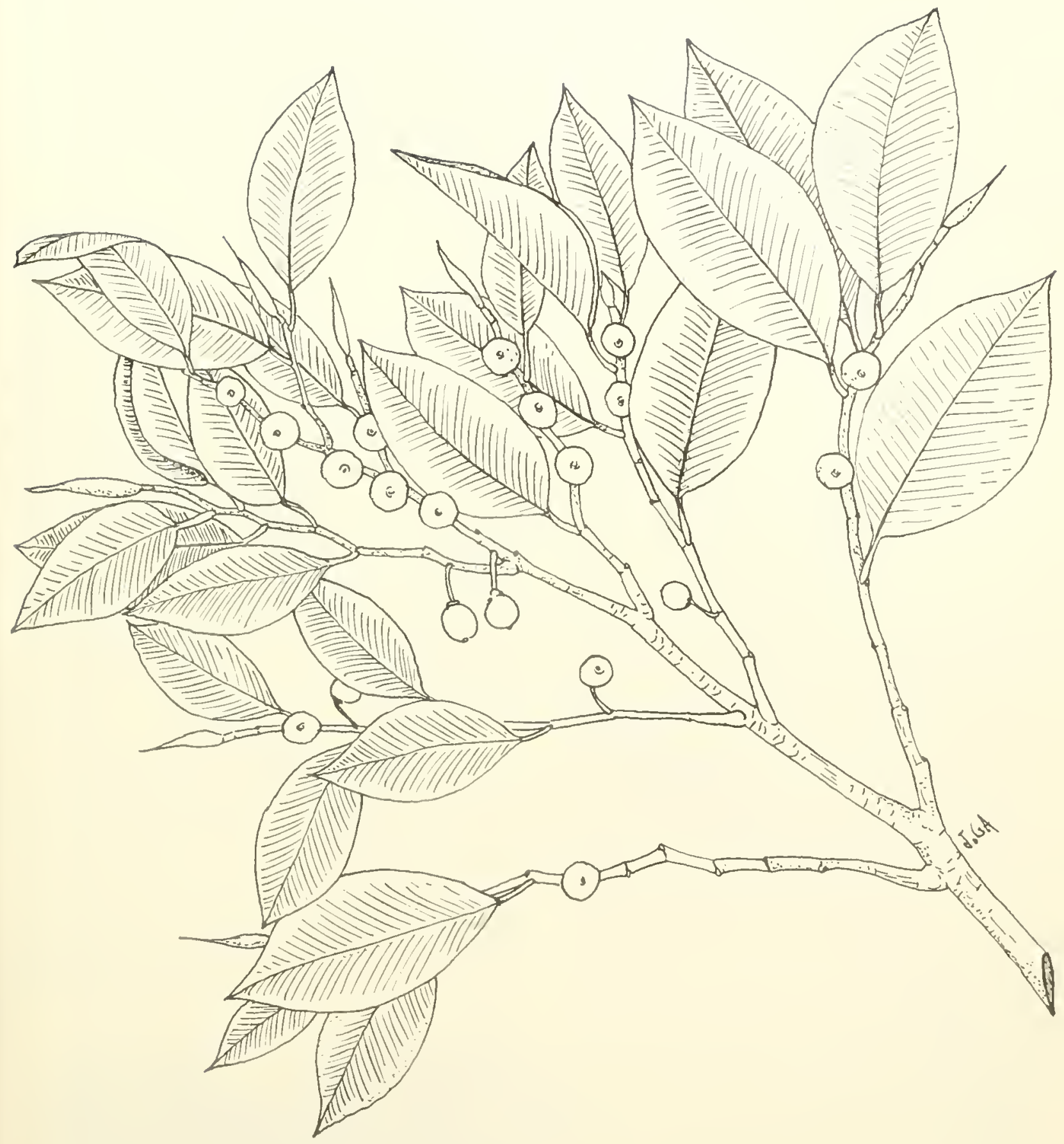




\section{BUCKWHEAT FAMILY (POLYGONACEAE)}

Fey to the 6 species illustrated (Nos. $25-30$ )

A. Leaves rounded or short-pointed at apex, without faint lines; fruits fleshr. without wings.

B. Ieares round or nearly so.

C. Leaves fery large, 1-1\% feet in diameter, aplearing wrinkled with lateral reins deeply sunken-26. Coccoloba pubescens.

C'. Leaves smaller, $21 / 2-1 ;$ inclues long, flat.

D. Leaves longer than broad; veins green, forming prominent network upon drying-27. Coccoloba suartzii.

DD. Leaves broader than long; midrib, larger reins, and young and old leaves often reddish-28. Coccoloba uvifera.

BB. Leares elliptic, about twice as long as broad.

E. Leaves leathery, broadest below middle, mostly rounded at both ends, with edges turned under-25. Coccoloba dirersifolia.

EE. Leaves thin, usuall, broadest above midrle, short- to long-pointed at apex and short-pointed to heartsliaped at base-29. Cocroloba rchosa.

A. Leaves long-pointed, ohlong, with 2-5 faint lines on each side of and parallel with midrib; fruits dry, with 3 showy pink wings-30. Triplaris americana.*

\section{Uvilla, doveplum}

Trees of this genus are recognized by the twigs linged at the nodes with a membranous sheath (ocrea) at the lnase of the leares. This species of limestone forests is characterized by: (1) the distinctive smoothish mottled gray and lonow bark, gray at first but peeling off in short thin flakes exposing brown beneath; (2) twigs ringed at nodes, with rray or brom membranous sheath (ocrea) $1 / 4$ inch long at base of leaves; (3) elliptic to ovate leathery leaves $11 / 2-5$ inches long and $7 / 8-21 / 2$ inches wide, usually rounded at both ends and turned mder at edges: (4) slender flower cluster's with many short-stalked spreading 5-parted whitishwreell flowers $3 / 16$ inch arross: and (5) rounded or egr-shaped dark red or purplish fruits $3 / 8-1 / 2$ inch long, slightly fleshy and edihle.

An everareen, ismally small tree to 30 feet tall and 10 inches in trunk diameter, often with severa] slender trunks and crooked branches. Large trunks may be Juttressed, fluted, or angled. The imner bark is light brown and astringent or bitter. Twigs are areen when young, becoming gray or sometimes brown, and liear alternate leares.

Petioles are $1 / 4-5 / 4$ inch long, light green. Blades are sometimes blunt-pointerl at apex. The upper surface is dark green to green and rull or often shiny, aud lower surface is slightly paler clull areell.

Flower chusters (racemes) are terminal and $1 \frac{1}{2}-$ (i inches long. Flowers are male and female on different trees (dioecions) and have short stalks 1/8 inch or less in length. Male flowers have a short basal tuhe (hypanthium) less than 1/16 inch long: 5 spreading romded whitish-green calyx lobes more than 1/16 inch lone: 8 white spreading stamens at tached to tule; and rudimentary whit ish pistil with ovary and 3 short styles. Female flowers have basal tube, 5 calyx blyes, minute nonfunctional stamens. and pistil with 1-celled ovary $y_{16}$ inch long and:3 spreading styles.

The fruits consist of basal tube (hypanthium) witl calyx lobes at the pointed apex, enclosing 1
Coccoloba diversifolia Jacq.

large brown seed (akene) $1 / 4-3 / 8$ inch long. The soul" and somewhat astringent thin flesh is eaten by birds and children and prepared into jelly. rith flowers or developing fruits nearly through the year.

The whitish or light brown sapwood is hard. The rood is described as dark reddish brown, heary (specific gravity 0.8), strong, and brittle. Employed in Pnerto Rico mostly for posts and yoles. Elsewhere reportedly nsed in cabinetmaking.

Popular for general planting and landseape work in southern Florida. Also a honey plant.

In both the moist and dry limestone forest regions of Puerto Rico. Also in Mona, Tieques, and St. Croix.

Perbic forssts. - Cambalache, Guajataca, Guánica, Susúa, Tega.

MUNICIPALITIES WHERE ESPECIALLY COMMON.$7,9,11,14,24,26,28,38,44,54,55,68,75$.

Raxae.-Southern Florida including Florida Keys, Bahamas, Greater Intilles, St. Croix, and Lesser Intilles.

O THER Commos NAmes.-urerillo (Puerto Rico); uvilla, guayabón, uvilla de sierra, ura cimarona (Dominican Republic) : uvilla, guayacanejo, uverillo, uva de paloma, fruta de paloma (Cuba) : doveplum, pigeon-plum, pigeon seagrape (Tnited States); pigeon-plum (Bahamas) : raisin marron (Haiti).

Formerly referred to Coccoloba laurifolin. Jacq. a species described from Tenezuela.

Besides the 5 species of this genus illustrated here, 6 other's of mostly small trees are natire in forests of Puerto Rico and the Tirgin Islands and are mentioned muder related species. The 2 below are distinguished from that above by the more numerous female flowers 50 or more in along an axis instead of 10-20. Trero de monte (Coccoloba sintenisii Urban), known only from Puerto Rico, has oblong leathery leaves $5-8$ inches long 


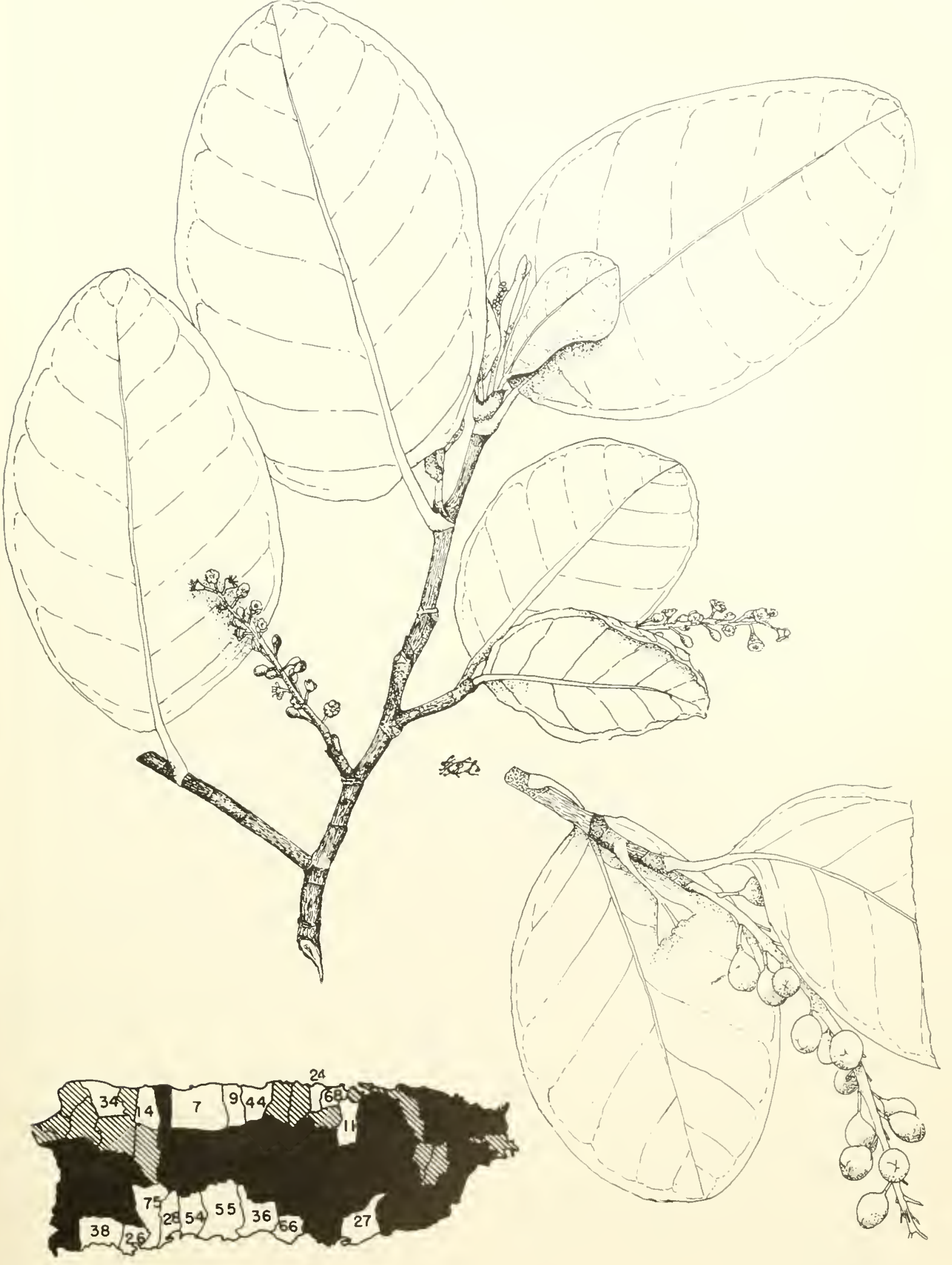

25. Urilla, doreplum

Natural size.

Coccoloba diversifolia Jacq. 
and $31 / 2-5$ inches widle, short-pointed at apex and heart-shaped at base, red flower clusters, and red flowers with stalks $3 / 16$ inch or more in length.

Corcoloba costuta C. Wright. ( $C$. rupicola $\mathrm{Tr}_{\mathrm{r}}$ ban), rare in Puerto Rico but known also from
Cuba and Hispaniola, has broadly ovate to elliptic or rounded leathery leares most $l^{2} \cdot 2-T$ inches long and $2-41 / 2$ inches wide, blunt or lounded at apex, green flower clusters, and green flower's with stalks less than 1/16 inch long.

\section{BUCKWHEAT FAMILY (POLYGONACEAE)}

\section{Moralón}

1 distinctive nedium-sized tree of moist mountain forests in central and western Prerto Rico, easily recomized by: (1) rery large nearly jound leaves 1-11\% feet in diameter (often nearly ? feet on rapidly errowing spronts), broader than long, henrt-shaped and almost stalkless, thick, stitl, and leathery, appearing wrinkled with lateral reins deeply sumen, and tinely hairy beneat h: (2) stout twigs ringed and enlarged at nodes benring at base of leaf a sheath (oclea). split into brown finely hairy rounded lobes about $1,4^{-1 / 2}$ inch long and appearing double; (3) numerous small liught green flowers on short stalks along a stout terminal axis: and (4) rounded fruits $3 / 16^{-1 / 4}$ inch in diameter.

In evergreen tree to 70 feet in height, the trunk becomina 2 feet or more in diameter and slightly buttressed when large, with spreading crown composed of few branches and few leaves. Tound trees and sprouts are erect and unbranched. The Eray bark is smoothish and slightly fissured, the imner bark light brown and slightly bitter. The stout gray twigs have raised dots (lenticels) and are green and minutely hairy when young. Terminal buds are short, rounded, brown, and finely hairy.

The alternate leaves have stout green petioles about '3s inch long, so short that the bases appear to be clasping. Blades are rounded at apex, not toothed at edges, above green and shing and beneath yellow green with the network of reins raised and prominent. Leaves of mature trees found in Hispaniola are reported to be much smaller, as short as $3-4$ inches in length.

'The narrow flower cluster (raceme) 5 -8 inches long consists of a slightly curred light green axis $1 / 8^{-1 / 4}$ inch in diameter, minutely hairy, bearing flowers abont $3 / 16$ inch across, nsmally 2 or 3 together on slender light green stalks abont $1 \mathrm{~s}$ inch long. Flowers are male and female on different trees (dioecions). The male flower consists of a light green euplike basal tube (hypanthium) 1/16 inch long and broad with 5 nearly round whitislgreen calyx lobes 1/16 long; 8 slender white stamens

\section{Coccoloba pubescens $\mathbf{L}$.}

${ }^{1}{ }_{16}$ inch long united into a basal tube nearly as long: and litdimentary pistil composed of light wreen ovary $1 / 16$ inch long and 3 small whitish styles. Female flowers have basal tube, 5 calyx lobes, minute nonfunetional stamens, and pistil with orary $1 / 16$ inch long and 3 styles.

When fruiting, the axis curves downward from the weight of the many fruits which are green and pinkish tinged when immature. consisting of the enlarged basal tube (hypanthium) enclosing 1 shiny brown 3 -angled seed (akene) 3/16 inch long.

The sapwood is whitish, and the heart wood reddish brown with pores malked by dark gum. The very hard, heary wood (specifie gravity more than 1.0) is durable and employed for construction and fumiture. It is resistant to attack by dry-wood termites.

Is a slow-growing ornamental for special plantings, this dist inct ive tree has been introduced sparingly in southern Florida and Cuba.

In the moist limestone forest region and less commonly in the western half of the lower Cordillera recrion of Puerto Rico.

Puble Forests. - Guajataca, Maricao, Río Abajo.

Rixcif.-Ifispaniola, Puerto Rico, Barbuda, Antigua, Montserrat. Nevis, Guadeloupe, Dominica, Martinique, St. Lucia, and Barbados. Planted in southern Florida and Cuba.

Otmbl: common vimes.-hojancha (Dominican Republic); grandleaf seagrape (United States); leather-coat-tree (Babados); raisinier crandesfeuilles, bois rouge, moralón (French West Indies).

Botinicar, smonum.-Coccotoba grandifotia Jaeq.

A related rare species called ortegón (Coccoloba mugosa Desf.) is now known only from the south slope of the Luquillo Mountains but formerly was present also near Gan .Juan. This small tree has the trunk mbranched or with very few branches, similar very large nearly round leares $1-11 / 2$ feet in rliameter but hairless, and reddish flower clusters and fruits. 


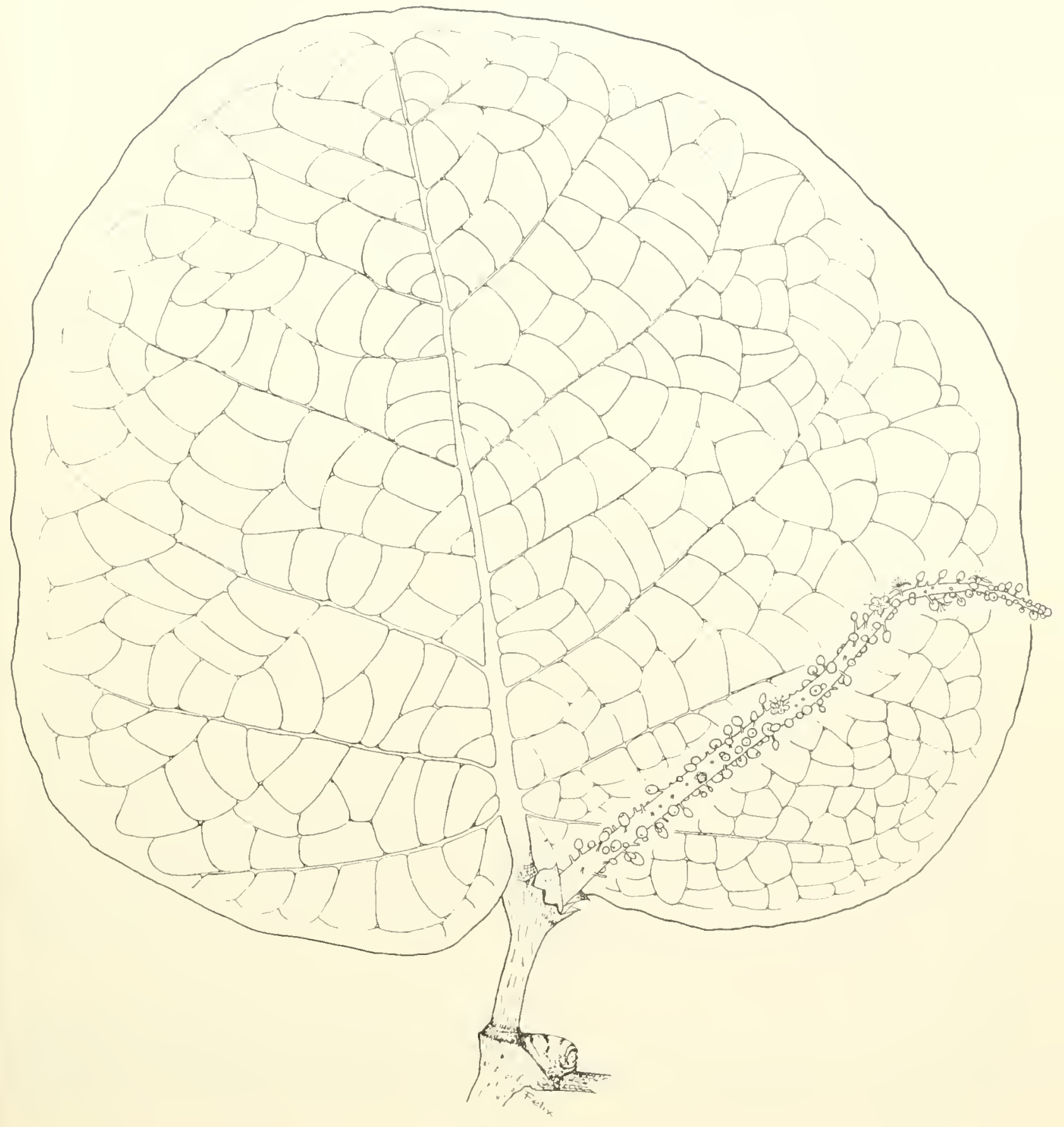




\section{BUCKWHEAT FAMILY (POLYGONACEAE)}

\section{Ortegón}

Distinguishing characters for this species usually of monntain forests, include: (1) shiny green elliptic to broarly orate to rounderl leaf blades generally thick and leat hery, $21 / 2-6$ inches long and - $t$ inches broad, on short stont green petioles; (2) twigs ringed at nodes with a green sheath (ocrea $3 / 3-3 / 4$ inch high at base of young leares: (3) the terminal erect green flowering axis generally stout and 1/3-3/16 inch in diameter, bearing many stalkless greenish 5-parted flowers singly and not crowded; and (t) shightly fleshy green to blackish egg-shaped fruit (akene) $5 / 16$ inch long with calyx lobes at top.

I small to medium-sized evergreen tree commonly to to feet high and 8 inches in trunk diameter, but recorded to 50 feet in height and 3 feet in trunk diameter, with narrow or rounded crown. The bark is gray, smooth to slightly fissured, the brown or pinkish imner bark slighitly hitter and gritty. The stont gray twigs are slightly crooked and bent at the ringed nodes.

Leares are altermate on petioles $3 / 8-3 / 4$ inch long. Blades are blunt-pointed or rommled at apex and rounded or slightly heart-shaped at base, the edges not toothed, shimy green above and a little lighter green beneatls. I'pon drying the minute network of small veins becomes slightly raised and prominent on both surfaces.

The flower eluster (spike) is $t-12$ inches long. lihowers are male and female on different trees (dioecious). The male flower $3 / 16$ inch across has a cuplike scale at base and consists of basal tube (hypanthium) ' $1 / 6$ inch long with 5 widely spreading calyx lobes more than $1 / 16$ inch long, 8 spreading stamens, and rudimentary pistil. In the female flower the stamens are sinall, and the larger pistil has a :-angled 1-celled ovary and ? styles.

The fruit is composed of the basal tube (hypanthinm) $1 / 4$ inch long bearing at apex the 5 calyx lobes more than $1 / 16$ inch long and enelosing a shing dark brown seed 3/16 inch long. Recorled in flower and fruit from Jume to September.

\section{Coccoloba swartzii Meisn.}

The sapwood is whitish and hard. The heary wood (specific gravity 0.7) is used in Puerto Rico chiefly for posts.

In the lower and upper mountain forest regions of Puerto Rico, ascending to dwarf forests of the summits. $A$ lso in moist lowlands of Puerto Rico, Vieques, St. Croix, St. John, and Virgin Gorda.

Perbic forests. - Carite, Guilarte, Luquillo, Maricao, Toro Negro.

Rixge-Dahamas, Greater Antilles, St. Croix, st. John, Virgin Gorda, and Lesser Antilles from Saba to St. Iucia and Barbados.

Otuer comaros vames. - urilla (Puerto Rico); wrillón (Cuba); tie-tongue (Bahamas).

The common form known only from mountains of Puerto Rico and eharacterized by thick leares and stout flowering axis has been distinguished also as a species (Cocroloba borinquensis Britton: C. suetzii f. urbemii (Lindau) Howard).

Three related species may be mentioned here. One called uvera (Coccoloba pyrifolia Desf.), known only from Puerto Rico, has narrowly orate leaves $2-11 / 2$ inehes long and $1-21 / 4$ inches wide, short-pointed or blunt at apex, veins inconspicuous $m$ both sides, and round fruits only $3 / 16$ inch in diameter.

Uverillo (Cocoloba mecrostachya Willd.; synonym C. obtusifolit auth., not Willd.) is a shinb or small tree widely distributed in the drier areas of Puerto Rico and the Virgin Islands and also in Hispaniola. It has small, mostly ohlong or orate leares $11 / 2-21 / 2$ inches long and $5 \%-11 / 4$ inches wide, the apex short-pointed, rounded, or notched, the lase roumded, veins prominent and forming dense network on both sides, and black fruit $1 / 4$ inch long not angled.

Coccoloba krugii I indau, another shrub or small tree of drier areals of P'uerto Rico, Anegada, and elsewhere in the West Indies, has orate leaves 1-? inches long and $5 / 8^{-11 / 4}$ inches wide, rounded at apex and heart-shaped at base, veins inconspicuons (on upper surfice, and 3 -angled fruit $3 / 16$ ineh long. 


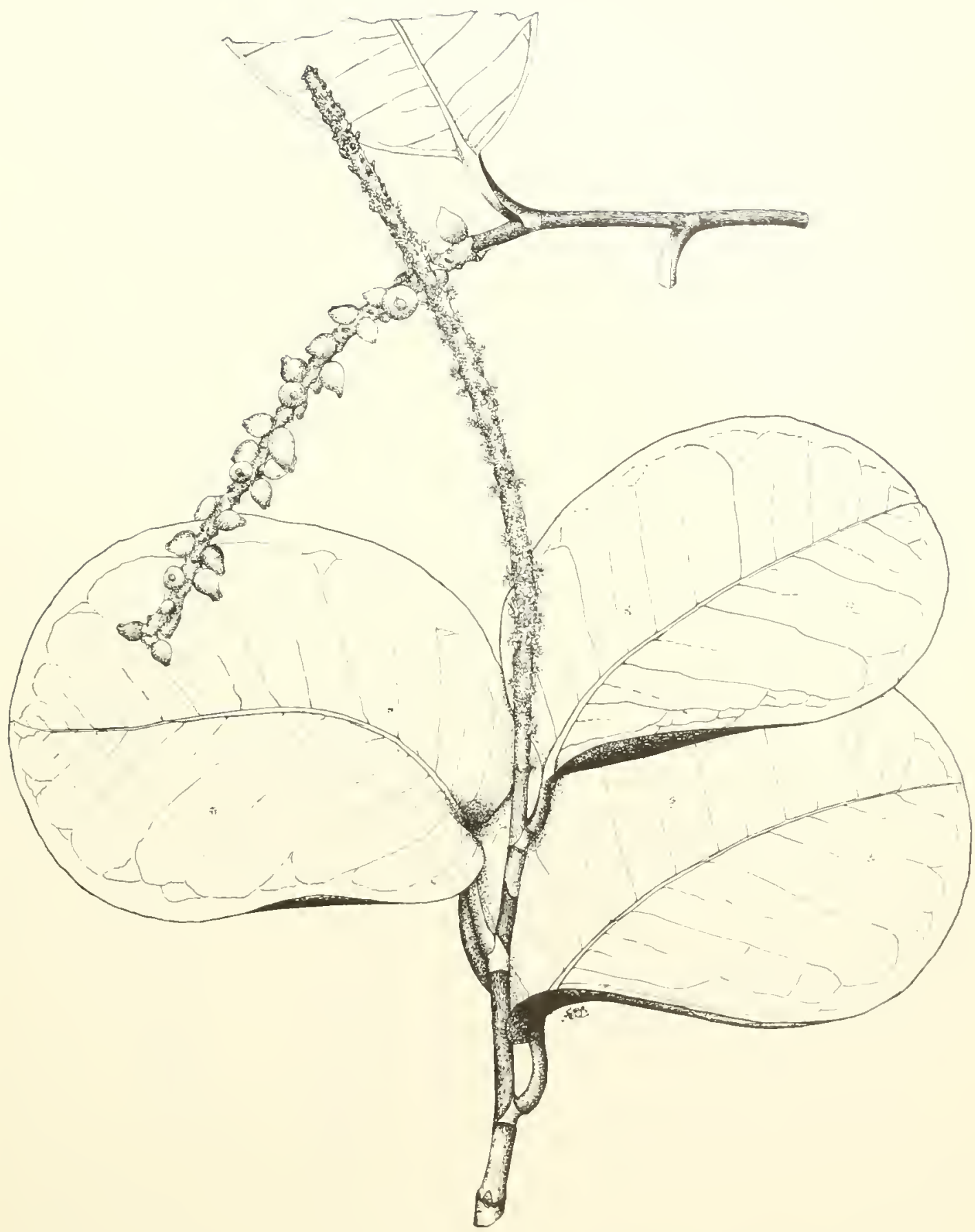




\section{BUCKWHEAT FAMILY (POLYGONACEAE)}

\section{Uva de playa, seagrape}

Csually limited to sandy and roeky seashores and coastal thickets. this familiar small tree or shrub is easily irlentified by: (1) the roumded or kidney-shaped thick and leathery leaves slightly broarer than long, 3-6 inches long and $1-8$ inehes broad, heart-shaped at base, with short petiole and a redidish-brown membranous sheath (oerea) $1 / 4^{-3}$, inch high aroumd stem; (2) midrib, larger reins, and yomg and rery old leaves often reddish; (3) the numerous small whitish or greenishwhite flowers $3 / 16$ inch aeross in narrow terminal and lateral clusters $1-9$ inches long: and ( 1 ) the drooping grapelike clusters of erowded purple fruits about $3 / 4$ inch long, elliptic or egg-shaped, and edible.

Tarying greatly in size from a low prostrate shrub on wind-swept beaches to a small, straggly or wide spreading tree to 30 feet in height and 1 foot in trunk diameter (rarely to $21 / 2$ feet.), evergreen, with rounded crown of few coarse branehes and often branching near base. Sometimes a larger tree in protected or favorable sites. The smoothish thin bark is gray, on large tronks peeling off in small flakes and becoming mottled whit ish. light gray, and light brown. Inner bark is light brown and bit ter. The stout spreading twigs are green and ninutely hairy when young. beeoming glay, with leaf sheatho and ring scars at nodes.

The leares are alternate on petioles $1 / 4^{-1 / 2}$ inch long. The blades, often tmoned on erige remtically, have marwins slightly curvert mnder and are hair. less or nearly so, the upper surface green or blue green and the lower surface paler.

Erect fower elusters (narrow racemes) 1-? inches long have numerons fragrant flowers on short stalks ${ }^{1} 16^{-1}$ s inch long, male and female on different trees (dioecious). The male flower has a. greenish-white hasal tube (hypanthium) 1:16 inch long and broad hearing is spreading rounded white calyx lohes more than in juch long: 8 stamens united at base; and rudimentary pistil. In the female flower the stamens are small, and the larger pistil has a 1 -celled nvary and 3 styles.

The fruit has a thin fleshy eovering (hypanthium ) with calyx at apex, sour or sweetish, and enclosing 1 elliptic seed (akene) ${ }^{3} s$ inch long. Flowering and fruting through the vear.

The sapwood is light brown, and the heartwond is reddish hown. The wool is hard, moderately heary (specifie grarity 0.7 ), and rery susceptible to attack by drowool termites. It takes a fine polish but is little used in Puerto Rico except for posts and fuel. Straight pieces slould be snited for wood turning. Elsewhere, uses for furniture and cabinet work have been reported.
Coccoloba uvifera (L.) L.

The hark eontains tamin, and the astringent roots and bark have heen nsed in medieines elsewhere. West Indian or Jamaiean kino, an astringent red sap exuding or extracted from ent bark. formerly was in commere for tanning and dyeing. - Telly and a rinelike beverage ean be prepared from the fruits, which also are eaten raw. Bunches of funits in eonelike packets formed by rolling the leaves liave been sold on the streets. Early Spanish colonists sometimes used the fresh thick leaves as a substitute for paper, seratehing messages with a pin or other sharp point.

This is one of the first woody speeies to become estahlished on sandy shores, being more hardy in these exposed places and more tolerant of salt than most trees. Fol these reasons it is often planted as an ornamental or windbreak along the coast. Since propagation is from cuttings, female plants should he selected for finits. Also frequently grown in southern Florida in landseaping and as a hedere trimmed to shape. A good honey plant.

Very probably seagrape was the first land plant of America seen by Christopher Columbus, aecorching to Nathaniel L. Britton. That authority, who visited San Salvador (Watling) Istand in 1:M) $T$, reported this to be the most conspicnons plant nearest the ocean. Howerer, that island ap1'allently was not the first discovered.

On nearly all sandy and rocky seashores and coastal thicliets in Prierto Rico, IIona, Desecheo, Icans, Culebra, Vieques, St. Croix, St. Thomas, St. John, Tortola, Mirgin Gorda, and Anegada.

R.Axas.-Wirlely distributed on tropieal American shores. From central and southern Florida, incluring Florida Keys, and Bermuda thronghont Trest Indies from Bahamas and Cuba to Trinidad and Tobago, and Curaçao and Aruba. On Atlant ic eoast of the continent from northern Mexico to Colombia, Tenezuela, and Guianas.

Othel romar xames.-mia de mar, wero (Puerto Rico); grape (Virgin Islands): wa de playa, wa, urero (Spanish): wra de mar, uva caleta (Dominiean Republie); uva caleta (Cuba): papaturro (Honduras, Costa Riea): papaturo extranjero (Niearagua): seagrape (Cnited States, English): seaside-grape (Jamaica, Trinidad, British Guiana); grape (British Honduras) : raisin la mer (Haiti) : raisin bord-de-mer. raisinier bord-de-mer (Guadelompe, French Gminna): zeedreifi, dreifi, dreifi di lamán, seagrape (Duteh West Indies): druif, zeedruif (Surinam). 


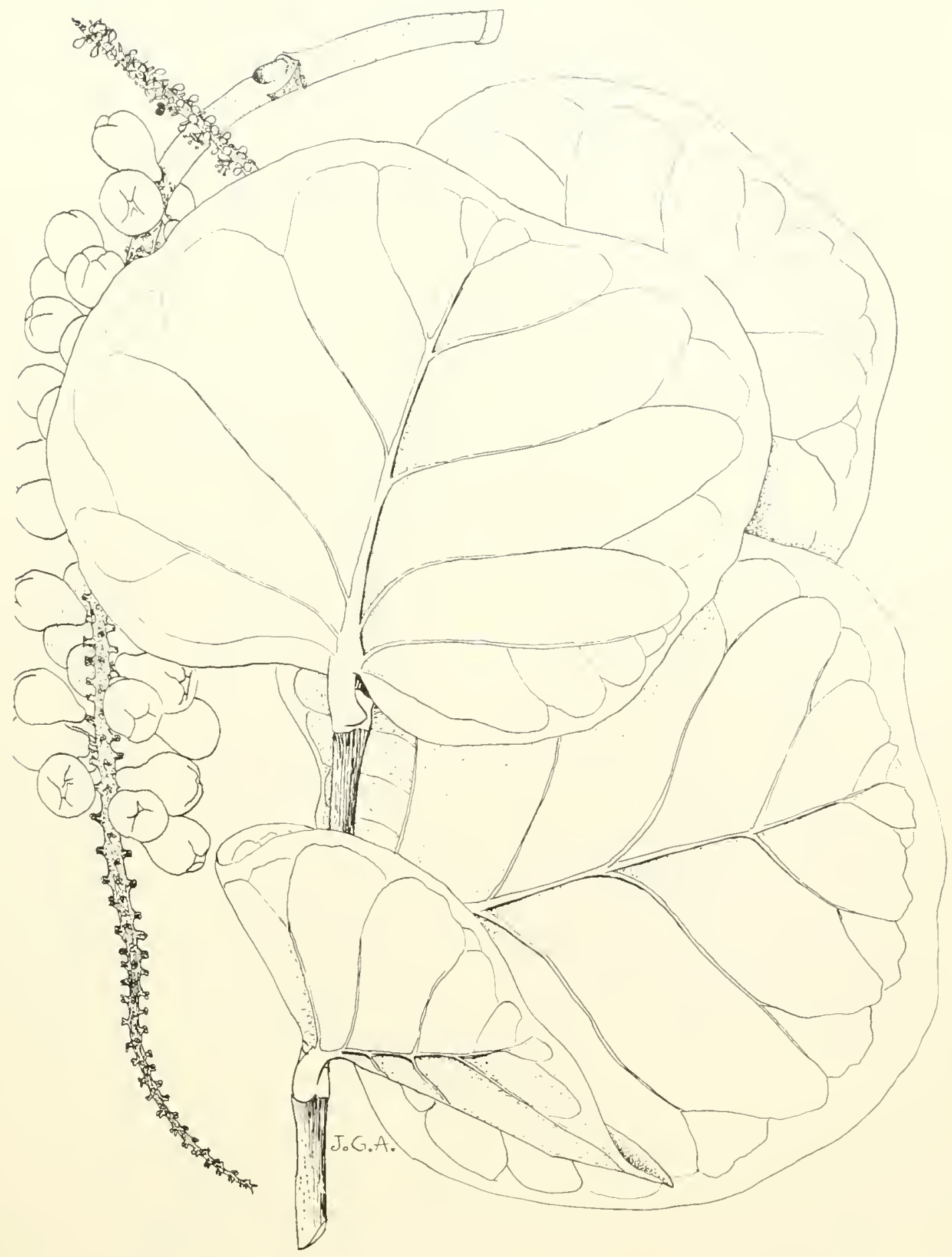

28. Ura de plasa, seagrape

Two-thirds natural size.

Coccoloba urifera (L.) L.

83 


\section{BUCKWHEAT FAMILY (POLYGONACEAE)}

\section{Calambreña, chicory-gape}

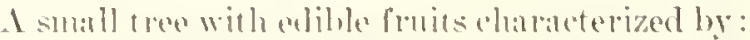

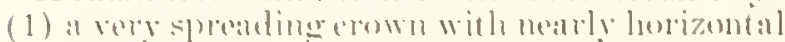

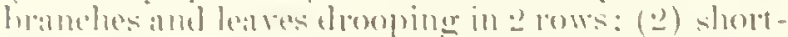

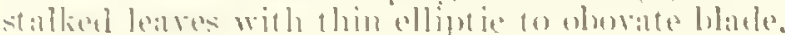

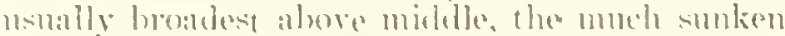

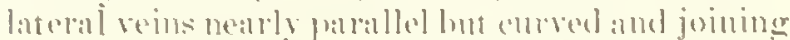

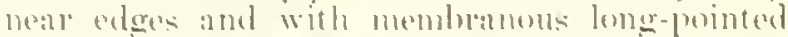

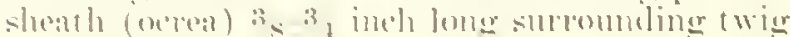

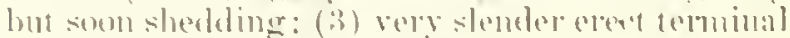
and lateral thewer dusters : 7 inches lontur, with mumerous short-stalked i-partud areenish-yellow thwers more than is ined ateloss, the mate and fomale towers on diflerent treese (dienerions) : and (t) mmmeroms showy lleshy white to pinkish fouts

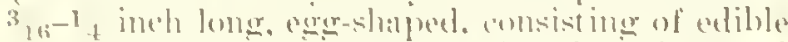

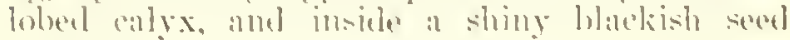
(akene)

I deciduons tree op shrub to sol foet hiorh and is imelos in diamerer. The hrom hark is smonthish with ratsed dets (bentiols), the innel bark pink hrown and slighty bitter. Jwigs ale areon when young, hereming light brown with raised dots (lentieds). with remains of shestl or ring at

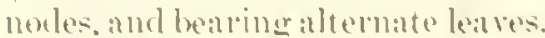

Petioles are ${ }^{1} t^{-1}$ in in loner. brownish areen. Ifter the hasil sheath sinots, the hase remaths at tached. Blades are :31. inches wide. or larere on rapdidy swowing shoots. shore - to bong-pointed alt apex and eratually narrowed to the short-point ed or slightly heart-shaped base. the enteres not toot hed, the muper surfince green and slightly shing, and lower surfate dull green with rased reins.
Coccoloba venosa L.

Flowers an bolne along the axis (spikelike

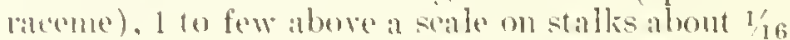
inde long. Hah llower has a 2 -lobed membranous seate about ${ }^{1}$ if inch long at bise. The male flower

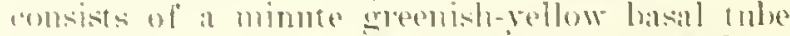
(lypanthimul with s sprealingr aly lohes alout lif ineh bone. s stamens less than is imele long. and pulimentary pistil. The female flower has

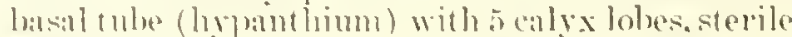
stamens, and pistil with s-angled 1-celled orary amelestyles.

Tha fruit is broadly eareshaped with fleshy calyx lobers, sweet and adible, surrounting the seed (alienc) 18 inch long. Recopded in Hower from Mat to september and in frut in Oet olerer.

The wood is whitish. hard. and little nsed.

In the dry coastal recrion of Puepto Rico. Miso in Jona, Vieques, st. Croix. st. Thomas, St. Jolnt. antel 'Tortolat.

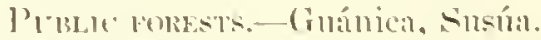

Ravere- Hisprniola, Puevto Ries and Virgin Islands. I exser Intilles from St. Martin somti to Gremida, and 'printidad and 'lobagro. Reported from onmica nealy 200 vears ago, perhaps in error. Mlso in Vencurala ind introduced experimonally in Cuba.

() Tlli: rom grrapes. trible-grape (Virgin Islamds): gumpripo (1) moninioun Repululic): "hecker-grape (Frenadines): hoes-tick-wood (Barbardos): white-errape, small-leaf-arape (Trinidad): sugaly-grape (1)utch West Indies).

Bomaxicas syxomy.-Coceoloba nivee Jace. 


\section{BUCKWHEAT FAMILY (POLYGONACEAE)}

\section{Triplaris, anttree}

This handsome exotic is easily recognized by: (1) its straight tall trunk and narrow columnar crown: (2) smooth motted brown and light gray bark peeling otl' in thin pieces or strips: (3) hollow twigs ringed at nodes and ending in a long, narrow, pointed, pale zreenish or yellowish bud $2-4$ inches long: (4) large oblong long-pointed leaves with many parallel nearly straight lateral veins and with 2 faint lines on each aide of and parallel with minib; (5) snall greenish very hairy Howers. arowded in erect clusters, the male and female on different trees (dioecious); and (6) showy masses of lar gre orld reddish fruits at the top of the crown, about $13 / 4$ inch long, consisting of an elliptic base and 3 oblong pink wings like a small shuttlecock.

A medinm-sizerl to lange evergreen tree becoming 70 feet tall and $1 \frac{1}{2}$ feet in trunk diameter, the trink slightly angled or thited. The bark, where peeled off, exposes a light gray layer beneath. Inner bark is pinkish and astringent. The green to brown stout twigs are often slightly zigzag. The scale (stipule) corering the bud makes a ring scal around the wig npon falling.

The leaves alle alternate on stont, short, flattened petioles $1 / t^{-3 / 4}$ ineh long. Blades are mostly $9-14$ inches long and $21 / 2-5$ inches wide, sometimes only half as larere, short-pointed at hase, not toothed at edges. 'The faint lines parallel with midrib result. from pressure in the bud when the blade is folded under: The npper surface is rlull to shing green and hairless or nearly so, and the lower surface slightly paler dull green and with sattered brown hairs on midrib.

Flower chnsters (spikes and racemes) are lateral at base of leares. $2-8$ inches long, densely light hown hairy, with flowers stalkiess or shortstalkel. Male flowers about $3 / 1$; inch long have a fmmel-shaped, tubular, 6-lobed. hairy calys and

\section{Triplaris americana L.*}

9 spreading stamens. Female flowers have a tubular 3 -lobed calyx, 3 petals, and pistil with 3 -angled ovary and 3 slender styles.

The forut consists of a basal elliptic swollen hairy alyx tulue ${ }^{3} \mathrm{x}$ inch or more in length with 3 reddish or pink-red, membranous, prominently reined wings $1 \frac{1}{4}-1 \frac{1}{2}$ inches long, formed from cally lobes. Inside ale the 3 narow petals and 13 -angled pointed shiny brown seed (akene). At maturity the fruit falls slowly like a parachute, spinning vapilly. Flowering in spring from Februan to May and in fruit in May and Jume.

The whitish saprood is soft. The wood of this or lelaterl speries is reportedly used for construction where native. When cut for fuel, the trunks ale replatered by sprouts.

In the natural environment the hollow twigs are inhubited by ants, usually vicious or ferocious stinging ones.

An omamental in some cities of Pnerto Rico, having heen introduced about 1924 and distributerl a few rears later. Also tested at St. Croix.

Raxar.--Northern South America, originally lescribed from eastern Tenezuela. Planted in southern Florida, Puerto Rico, and other tropical areats.

Other commox xime. - long-john anttree (English).

There is some doubt abont the specific name of the Puerto Rican trees. According to Britton and Wilsm "3 species were introdnced : Tripharis amencona L. from Central Imerica though originally described from Tenezuela. T. caracasana Cham. from Tenezuela, and $T$. cumingiana Fisch. \& Mey. from Panami. 'The Puerto Rican trees appear to be the sane as those planted in the Canal Zone and Cuba under the last named species, which originally was described from Colombia. 


\section{FOUR-O'CLOCK FAMILY (NYCTAGINACEAE)}

Key to the 3 species illustrated (Nos. 31-33)

A. Leares thin or slightly thicliened. rounded or short-pointed at hoth ends, hairy at least when goung; fruits dry. nalrow, with itrows of ototlike glands.

B. Leares about half as broall as long, the lnter surface densels tine hairs-31. Pisonia albirla.

BL. Leaves nearly as broad is long, rusty brown hairy when young but lecoming hairless or nearly so-32. Pisonia subcordata.

A. Leares slightly thickened and succulent, short-pointed at both ends, hairless; fruits fleshy-33. Torrubia fragrans.

31. Corcho bobo

This tree of dry ineas is characterized by: (1) lorittle twigs: ( $(\dot{3})$ opposite elliptic leaves $2-6$ inches long and $1-;$ inches linotd, rounded or short-pointed at both ends, the upper surface slightly shiny green and hairless, and the lower surface paler and densely fine hairy; (3) many fragrant small greenisf flowers in terminal branched clusters when leaves are shed or forming: and (t) mumerous dark brown dry fruits $3 / 6$ inch long and $1 / 16$ inch in diameter, the ipper half with 5 rows of raised glands aud slightly sticky.

1 deciduons, usually small tree to 30 feet in height and 6-12 inches in trmk diameter with spreatding crown, or shrulby. Base of trunk and roots are often enlarged, suggesting an elephant's foot with toes. The bark is whitish gray and smooth. Inner hark is yellow or light brown. grittr, and tasteless. Twigs are light green and finely hairy, becoming light gray.

The leaves have fincly hairy, pale yellow petioles 1/4-11/4 inches long." The blarles are thin or a little thickened and not toothed on edges.

Flowers are male and female on different trees (dioecions) in terminal branehed clusters (ermes) on a stalk alonut 1 inch long. Male flowers are short-stalked, consisting of greenish, finely hairy, 5 -toothed bell-shaped ealyx $1 / \mathrm{s}$ inch long and nsually 8 stamens about $1 / 4$ inch long. Female flowers

\section{Pisonia albida (Heimerl) Britton}

in widely forking branehed clusters have slender stalks $1 / s^{-1 / 4}$ inch or more in length: the greenish. finely hairs, 5-toothed tubular ealyx $1 / 8$ inch long. and pistil with 1-celled, 1-ovuled ovary, style, and stigma.

Fruits (akenes) are numerous in a spreading eluster of widely forking branches $2-31 / 2$ inches long and broad, the whole cluster breaking off together. The tubular ealyx remains outside of the very narrow dark brown 1-seeded fruit. Flowering when leatless or with new leares, from February to May, and matming fruits in late spring.

"The sapwood is vellowish or whitish. The heartwood is yellowish. coarse-textured, with silvery gum in the pores, and moderately soft. Tsed only as fuelwood in Puerto Rico.

It is reported that the sticky fruit clusters fallen on the ground can eause death of young chickens that get tangled in them.

In forests and thickets in the dry coast and limestone regions of sonthern and western Puerto Rico. Also common in Mlona and in Caja de IInertos.

Prtuld folests.-Cruajataca, Guániea, Susúa.

Ringe-Hispaniola, Puerto Rico, Mona, and Cajal de Mluertos.

OTher commox xames.-eoreho blanco, coreho (Puerto Rico). 


\section{FOUR-O'CLOCK FAMILY (NYCTAGINACEAE)}

\section{Corcho blanco, water mampoo}

A medium-sized to lange tree recognized by: (1) opposite, usually lanere, elliptio or nearly romd leaves $21 / 2-8$ (sometimes 10$)$ inches long and nearly as broad, mostly romded at alex and rounded ol often at little heart-shaped at base; (2) gray smooth trunk and branches: (3) numerous greenish flowers erowded in stalked lall-like clusters 1-11/4 inches in diameter, male and female on different trees (dioecious) : and (t) marom dry fruits 3 s-1,2 inch longand more than ${ }^{1 / 16}$ inch in diameter, 10-angled, with 5 rows of rotlike ylands neal a]pex.

This deciduous tree becomes 40-50 feet in height, with short, often thick trunk to $2-3$ feet in diameter, stout branches, and roumded crown. The twigs are green and finely rusty-brown hairy when young, hecoming graly and strint.

The leaves have stout romm pet ioles $1-11 / 2$ inches long. Blades are without teeth on edges, rustybrown hairy when young hut beroming hairless or nearly so, shiny yellow green above and beneath dull light greel with pinkish main veins.

Flowers appearing with new leaves generally in early spring lut sometimes in summer. The terminal and Interal clusters of fragrant finely hairy flowers have stalks 1-2 inches long. Male flowers
Pisonia subcordata Sw.

have bell-shaped, 5-toothed calyx 1/4 inch long amel s-10 longer stamens. Female Howers, less crowded, consist of tubular i-toothed aly about $1 / 8$ inch long and pistil with orary slender style, and mueh branched stigma. The 1-seeded fruits (akenes) are enclosed by the rlub-shaped or $\mathrm{cy}^{2}$ lindrical calyx, gray gleen, matnoing.. zenerally in spring.

Wrod is soft, whitish, lightweight (speeifie gravity about 0.5$)$, porous, and not durable. Ised for net floats for fishing and as fuelwood in Puerto lico and for boxes in Guadelompe.

In forests in the limestone and lower. Cordilleral regions of I'uerto Rico. A race with very latre thin leaves is fornd on limestone. Also in Icacos. ('ulebrita, Vieques, St. ('roix, St. Thomas, St. Jolum, Tortola, and Anegrata.

Pinlar ronests.- Gruajataca, Marieao. Río Abajo.

Rivae.-Pherto Rico and Virom Islands, and Lesser Antilles from Ingrilla and St. Martin south to Guadelompe and Martinique.

Other commos vames.-corcho, palo bobo (Puerto Rico): mampoo, loblolly (Tirgin Islands): mapon (At. Barthélemy): mapon gris (Guadeloupe) ; mappoo (Duteh West Indies). 


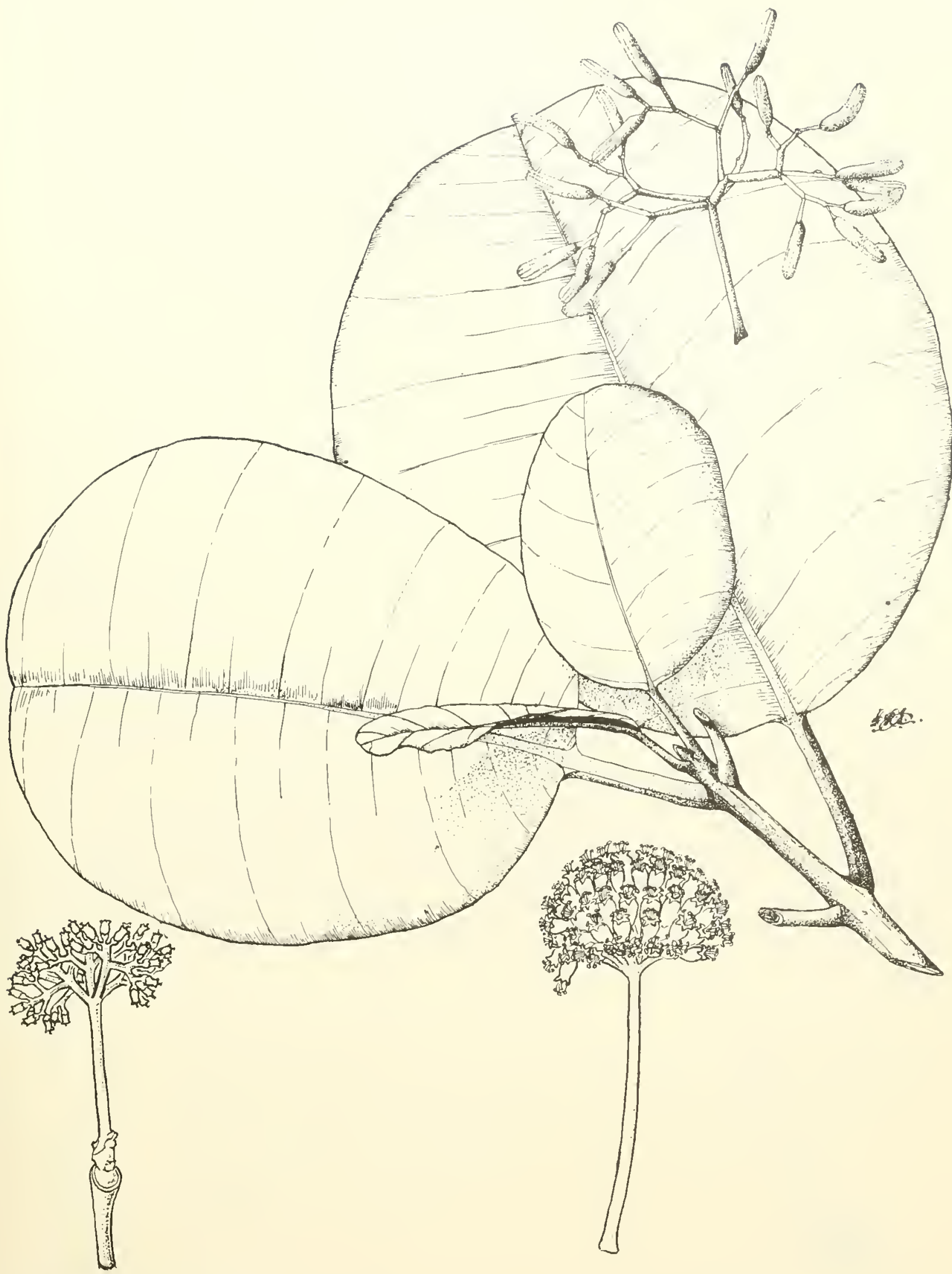

32. Corcho blanco, water mampoo 


\section{FOUR-O'CLOCK FAMILY (NYCTAGINACEAE)}

\section{Corcho, black mampoo}

A small to medium-sized tree characterized by : (1) opposite, obovate or elliptic leares, usmally broadest above milldle, $2-6$ inches long and 1-21\% inches broad, slort-pointed at the apex and gradually narrowed at base to a short petiole: and (2) elustered, cylindrical, fleshy, 1 -seeded fruits $1 \frac{1}{4}-1 / 2$ inch long and $3 / 16$ inch in diameter, red, turning black, corered by the eatyx with 5 teeth at apex.

An evergreen tree : $: 40$ feet high and to 20 inches in trunk cliameter, with rounded crown. The bark is smoot hish, wray or browll. Inner bark is light brown, slightly bitter. Twigs vellow green when young, beroming gray.

The leaves lave yellow-green petioles $1 / 8^{-3} / 8$ inch long and shightly thickened and succulent blades, the edires not toothed, hairless, green or vellow green and slightly shiny above and paler beneatl?.

Flowers are male and female on different trees (dinecions), numerous in stalked, erect, most ly terminal, branched clusters (panicles) 3-t inches long and 11/2-3 inehes broard, short-stalked or stalkless, greenish, minutely hairy, slightly frawrant. Ville flowers have fumel-shaped is-toothed "allyx 3/16 inch long and a-10 longer stanens. Female fowers consist of narrow tubular 5-toothed calyx $1 / 8$ inch long and pistil with ovary, slender strle, and much branched stigma. Flowers and frints appear from early spring to summer.

\section{Torrubia fragrans (Dum.-Cours.) Standley}

The sapwood is whitish and soft. The wood is little used in Puerto Rico and elsewhere has even been considered unsuitable for fuel.

In forests of the moist coast, moist limestone. and lower mount ain regions of Puerto Rico. Also Mona, Icacos, Culebra, St. Croix, St. Thomas, St. Johm, Tortola, and Virgin Gorda.

P'oblic Forests, - Cambalache, Guajataca, Luquillo, Río Abajo, Vega.

Ravae.- Dmost throughout West Indies (except Bahamas) from Cuba and Jamaica to Grenada, Barbados, and Tobago, and in Bonaire, Curaçao, and Lruba. Also in northem South America from Colombia to Venezuela and Guianas.

Other commor vames. - palo de corcho, majagrua de mona, majagua, emajagua (Puerto Rico); perico, palo de perico (Dominican Republic): barrehorno (Cuba); estribo (Colombia); mapoo (At. Lucia, Grenadines); beefwood (Barbados); mapoo (St. Barthélemy).

Botaxichi sroxum.-Pisonia fragrans Dum. (ours.

I seeond species of this genus, known as barrehorno (Tormbia discolor (Spreng.) Britron), is distinguished by the ollong or elliptic leaves rounded at apex and usually smaller, 1-21/2 inches long and $1 / 2-11 / 2$ inches broad. This shrub or small tree is recorded from Puerto Rico and Desecheo. 


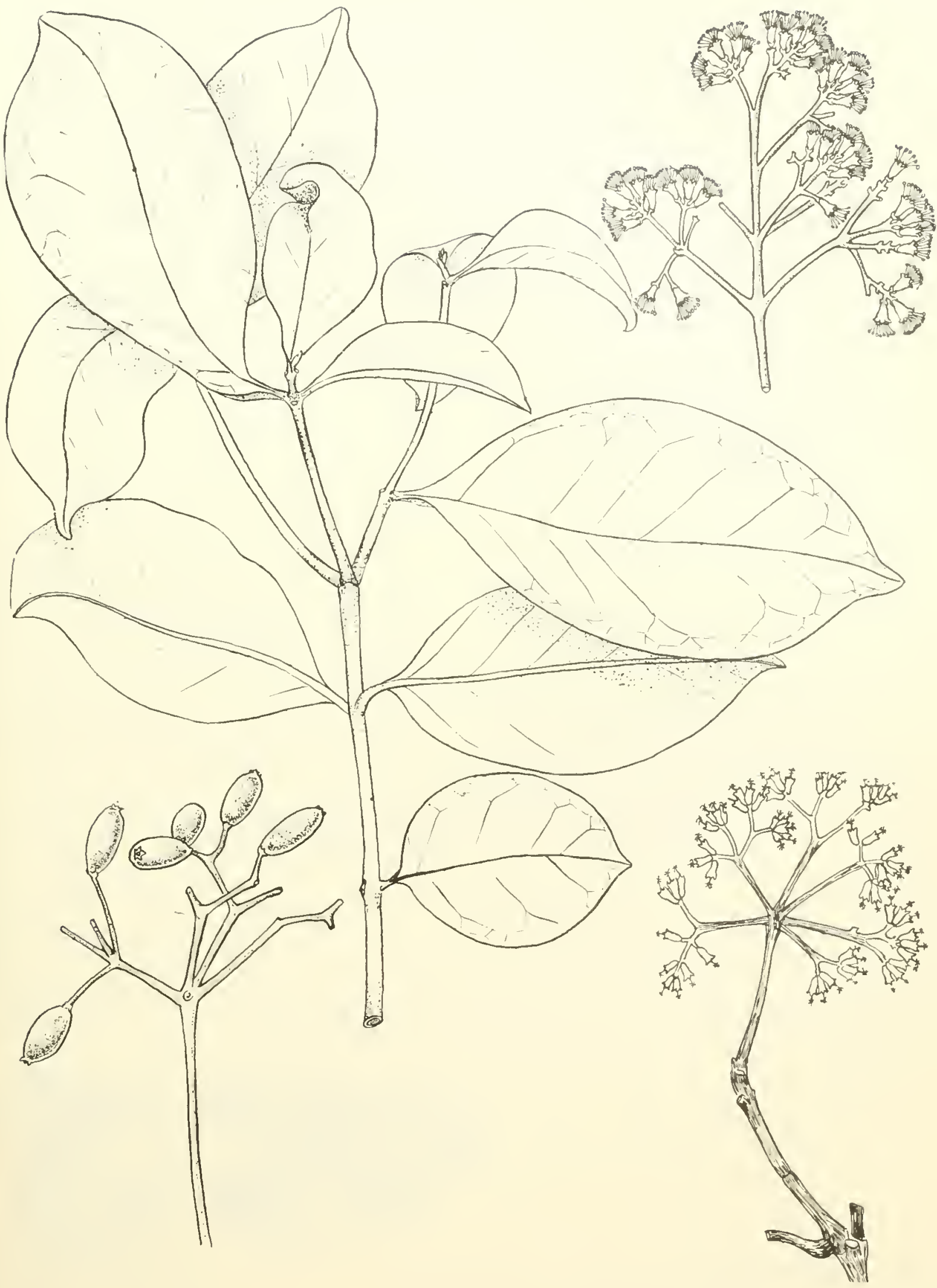

33. Corcho, black mampoo 


\title{
MAGNOLIA FAMILY (MAGNOLIACEAE)
}

\author{
Key to the 2 native species, both illustrated (Nos. $34-35$ )
}

A. Leaves broadly elliptic to nearly round, abruptly short-pointed, hairless-34. Magnolia portoricensis. A. Leaves ovate or elliptic, short- or long-pointed, the lower surface silky gray green with fine hairs-35. Uagnolia splendens.

\section{Jagüilla}

This handsome tree of the central and western momntains of Pnetto Rioro is easily recognized by: (1) slowy, very fragrant, white thowers 20 inches across the 7 or s petals, borne singly and terminal: (2) leathery. broadly elliptio to nearly romm leaves :3-8 inclues long and $2-6$ inches hroad. abrupt ly short-pointed, hent upwark on both sides of midrib. sliglitly hiny, lark green or green on upper surface and paler beneath giving the foliage a grayish cast: (3) hairless twigs ringed at the nodes; (4) folinge and bark with a spicy odor when crusherl, as well as a spiey taste; and (5) long narrow terminal buds.

A medium-sizel to large evergreen tree attaining 70 feet in height and 3 feet in trunk diameter. with narrow crown. The gray balk is smonthish or slightly fissured. heroming rough on large trunks. Inner hark is light brown. The stout green twigs have terminal buds :-:; inches long, rreen but becoming yellowish and tinged with hrown. composed of a pair of scales (stipules) enrosing the new loaf and forming a ring sal. when shed.

The alternate leaves have green petioles $1 / 2-11 / 4$ inches long. Leaf blades have edges without teeth, are roumled at base. stifl, and hairless.

The beantiful. large, spreading flowers bave 3 whitish-green sepals and 7 or 8 white petals, all about $134-21 \%$ inches long. broad and rounded at apex, and slightly thickened. There are numer-
Magnolia portoricensis Bello

ous short-stalked stamens $1 / 2$ inch long. Many ple vellow pistils $1 / 4^{-1 / 2}$ inch long, each with 1 called ovaly and curved style, are sprirally arranged on a central axis 3 inch high.

Fruits are elliptic, conelike, $11 / 2-2$ inches long and 1 inch thick but slightly irregular in shape. Ealch oraly becomes a pod (follicle) and splits open to release 1 or 2 red triangular seeds, which remain attached by fine threads before falling. Flowering and fruiting nearly throngh the year.

The silpwool is light brown. The heartwood when freshly at is olive brown or yellowish green, later hecoming brown. The wood is hard, heary (sperific gravity $0 . \overline{\text { ) }}$, fine-textmed, and spicy fragrant, and is susceptible to attack by dry-wood termites. L'nder the name laurel sabino, the wood is employed for furniture, calinetwork, and similar purposes.

In forests of upper Cordillera region of Puerto Rico. Most of the larger trees have been cut, exrept in the most inaccessible areas.

Public Forests.-Carite, Guilarte, Maricao, Toro Negro.

MTNICIPHATY WHERE ESPECLILY COMMON.-19.

Raxra.---Known only from mountains of Puerto Rico.

OTHER consux xhmes. - buro mauricio, alciba, anonillo, ortegón (Pnerto Rico); laurel sabino (wood, Puerto Rico). 

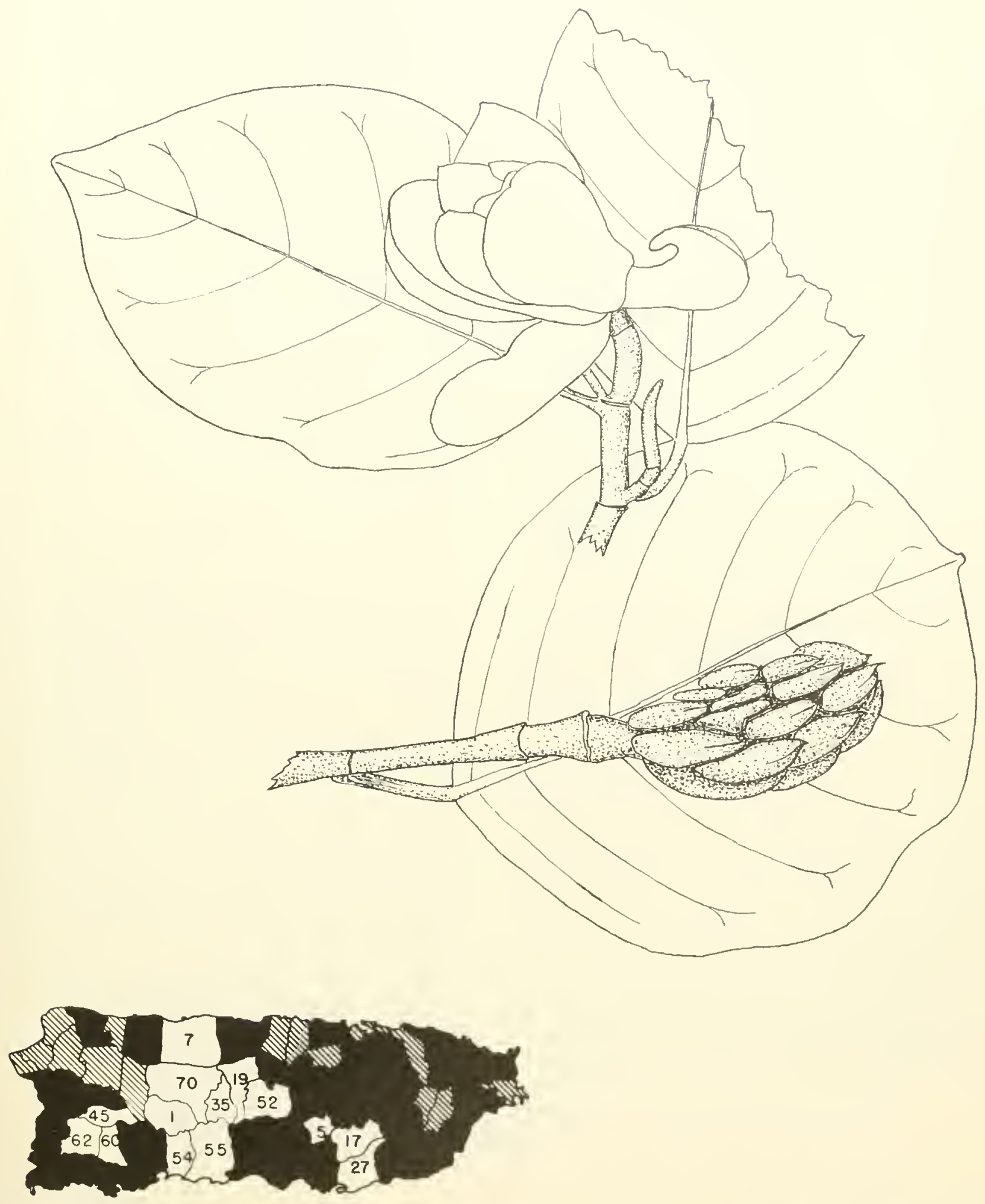

34. Jaguiilla 


\section{MAGNOLIA FAMILY (MAGNOLIACEAE)}

\section{Laurel sabino}

Native only in the Lmquillo Mountains of eastern Puerto Rico, this large tree is characterized by: (1) young twigs and commonly the lower surfines of the leathery, ovate or elliptic leaves silky or satiny gray green with a lense coat of fine hairs giving a gray cast to the crown of the tree: (2) twies ringed at the nodes: (3) prominent narrow long-pointed terminal huds : and (t) large, showy, fragrant, white flowers 3 inches across the 6 or mole petals, single or 2 or 3 together at ends of twigs.

An evergreen tree becoming 75 feet tall and to 4 feet or more in trunk diameter, with narrow crown of dark areen, spicy foliage. The trunk typically produces numbers of new shoots or suckers. Bark is alay, smoothish, slightly fissured or rongh in age, the inner bark light brown, gritty, and slightly bitter. Twigs become green and nearly hairless, then brown. Terminal buds $2-31 / 2$ inches long are covered by a pair of united scales (stipules), silky and aray green, enclosing the new leaf and forming a ring scar upon falling.

The leaves are alternate on silky gray-green petioles $3 / 4-1$ inch long. Isaf blacles are $t-i$ inches long and $2-3$ inches broad, short - or long-pointed at apex and rounded or short-pointed at base, not toothed on edges, thick, and with the upper surface dark green and shiny.

The flowers have 3 whitish-green sepals $11 / 4$ inches long and 6 or more white spreading petals about $11 / 2$ inches long, broad and romnded at apex. Stamens are numerous, about $1 / 2$ inch long, shortstalked. The many pistils are $3 / 8$ inch or less in length, with 1-celled ovary and curved style, spirally arranged in a conelike center $5 / 8$ inch long.

The elliptic conelike fruits are about $1 \frac{1}{2}$ inches long and $7 / 8$ inch thick, greenish, with many pods (follicles), each splitting open and containing usually 2 triangular, red, fleshy seeds more than $1 / 4$ inch long, attached by threads. Flowering mainly from April to September and maturing fruit from spring to winter.

The heartwood is very attractive olive green
Magnolia splendens Urban

when freshly cut, later becoming brown, the sapwood whitish. Growth rings and dark streaks add to the figure. The mood is moderately heavy (specific gravity 0.59 ), hard, moderately strong, with a rharacteristic spicy pungent odor. It is easy to work but susceptible to attack by dry-wood termites. Rate of air-seasoning is rapid, and amount of degrade is minor. Machining characteristics are as follows: planing and sanding are fair: and shaping, turning, boring, mort ising, and resistance to screw splitting all are good.

The wood is used almost entirely for furniture and cabinetwork. Local demand is greater than the limited supply. Other suitable uses are for vencer, plywood, millwork, turning, boat planking, construction, and carpentry.

The spicy leaves have served as a condiment. Possibly this species would be suitable as an ornamental.

Laurel sabino is native to an area where tree growth is so slow that production of the timber is not economical. The average trunk diameter growth rate of $t 6$ trees in the natural forest during a 5-year period was only 0.06 inch per year. The larger trees of the forest are undoubtedly many centuries old. This, plus the fact that propagation for planting elsewhere is difficult because most seeds apparently are sterile, greatly limits the future of this tree. The species will always be preserved within a formally established natural area within the Imquillo Forest, and young trees are being encouraged wherever they appear maturally. Nevertheless, in most areas the old overmature trees are being salvaged more rapidly than they are being replaced by nature.

Restricted to the upper Luquillo Mountains of Puerto Rico, mostly within the Luquillo Forest. Public Forest.-Laquillo.

Ravge.-Known only from eastern Puerto Rico. Otiner common Nanes.-Sabino, bella (Puerto Rico).

BotanicaL SYYoNrar.-Talauma splendens (Urban) McLaughlin. 

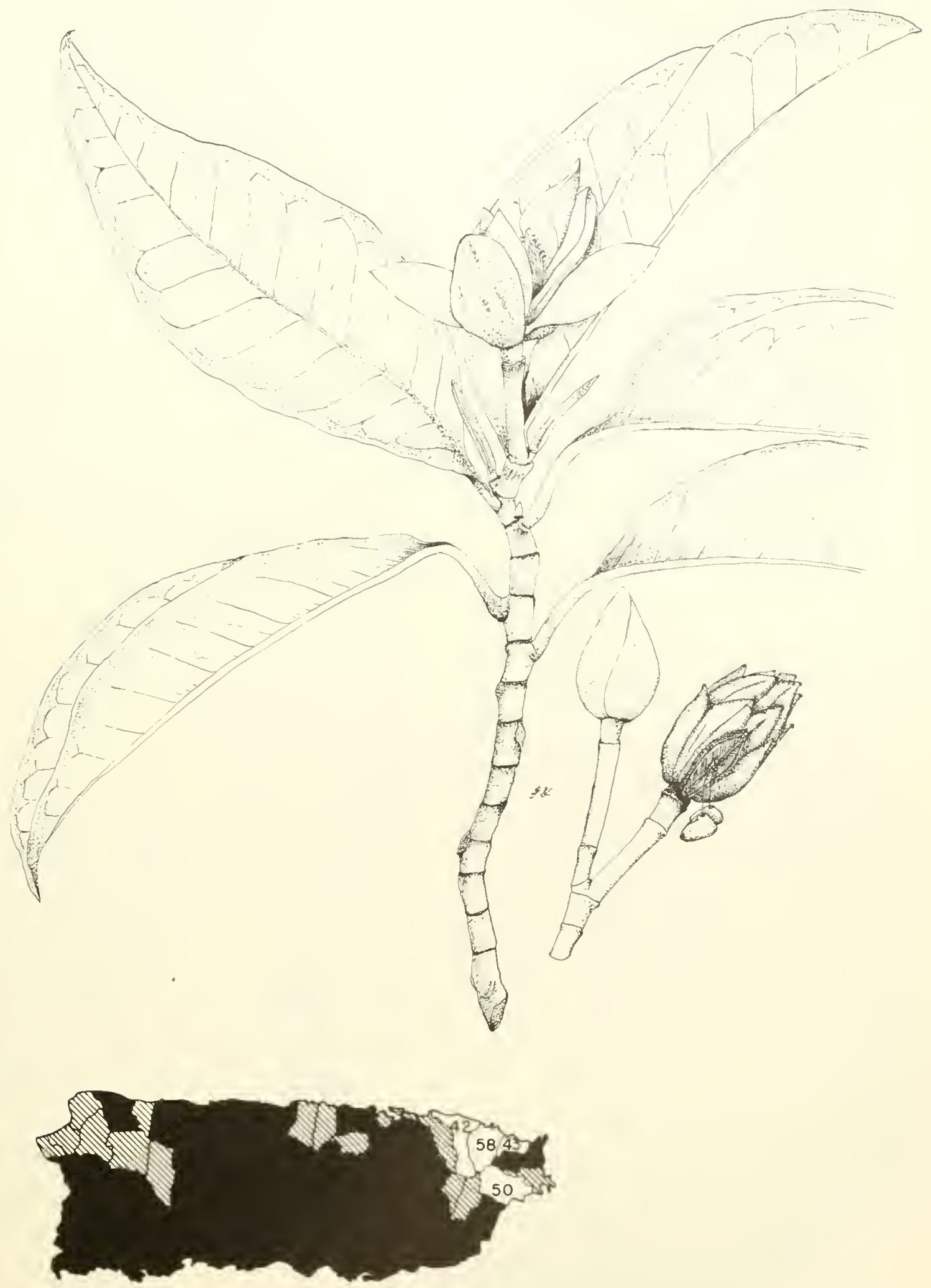

35. Laurel sabino

Two-thirds natural size.

Magnolia splendens Urban 


\section{ANNONA FAMILY (ANNONACEAE)}

Key to the 6 species illustrated (Nos. $36-41)$

1. Fruit 1 from a thurer, from malns pistils mited.

B. Leaves with tiny pockets on lower leaf surface where side veins join midrib: fruits bearing many fleshy spines.

C. Leares hroadest at midlle: fruit with short, straight spines, inedible-36. Annona montana.

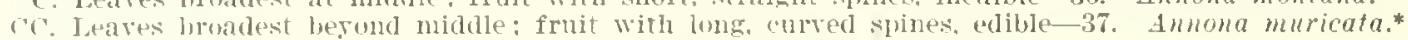

BB. Leares without puckets; fruits smooth, edible.

1). Fruit with network of lines on surface-3s. Anmona reticnlata*

IDD. Fruit comprosed of many runuded tuhereles-39. .1 mona squamosa.*

A. Fruits many from a thwer, separate, inerlible.

E. Ieaves wate to whong. long-pwintml, thin: fruts with lomg stalks- 10 . Cananga odorata.*

EE. leaves oblong. short-jointed or roumled at alex, loithery ; fruits nearly stalkless-11. Guattcria blainii.

\section{Guanábana cimarrona, wild soursop}

Guanábinn cinalrona, a wild speries with inedible fruit, is characterized by: (1) short-stalkerl oblong or elliptic leaves:; 7 inches long and 11, $12-3$ inches wide, abuptly long-pointed at apex and rounded or slort-pointed at base, alternate and in 2 lows: (2) tiny hairy pockets or pits on the lower leaf surfaces where the lateral rems join the midrib: (3) arreenish broad flowers single or pared on older twigs, about 1-13\% inches long, composed of 3 heart-shaperl, broal, short-pointerl, thick fleshy onter petals: and (t) nealy round or eggshaped green to yellowish fruit $21 / 2-5$ inches in diameter, with many short straight fleshy spines and yellowish inedible pulp.

A small deciduous tree to 20 feet in leight, with an irregular spreading crown. The gray or brown bark is smoothish, with raised dots (lenticels), beroming slightly fisured and slightly rough. Inner balk is brown and tasteless. The twigs are brown.

The petioles are 1/4-3/s inch long. Blades are sightly thickened and leathery, the edges withont teeth, shiny dark green above, and paler light green beneath.

The stont flower stalks about $3 / 4$ inch long are borne on older twigs. There are 3 broad. pointed, finely hairy sepals about $3 / 1$ in inch long: 6 concave, fleshy, minutely hairy, weenish petals, the 3 onter petals about $1-13$ s inches loner, meeting by their edges to form the hud, and the $?$ inner petals rounded and stalked, about 1 inch long, less thick and overlapping; very numerous narrow stamens 3/16 inch long. erowded in a rounded mass $1 / 2$ inch in diameter on the conical floral axis; and many narrow separate pistils 3/16 inch long, clowded in a central mass.

The agrresate fruit is composed of the numerous united pistils and is covered with many soft greenish spines about $1 / 8$ inch long, each represent-
Annona montana Macfadyen

ing a style. There are many shiny brown oblong seeds aliont $3 / 4$ inch long. Probably flowering and fruiting most of the rear.

The sapwood is light brown and soft. The wood is used only for fuel. Elsewhere, such as in southern Florida, the tree has been grown as a stock for budding other" species.

In forests of the dry coast and southerm slopes of the Cordillera of Puerto Rico. Also in Vieques and st. Croix.

Perble rorest.--Susuia.

Raxar.-Cuba, Jamaica, Hispaniola, Puerto Rivo and St. Croix, Saba, St. Eustatins, Antigua, Guadeloupe, Martinique, and Trinidad. Also from Tenezuela and Guians to Brazil and Peru. Planted in sonthern Florida.

OTHFR CoMMIN x.4MFs.--guanábana cimarrona, Enanábana de perro (Dominican Republic): guanábana cimarrona. guanábana de loma (Cuba); wnaníbana, turagua (Venezuela): guanábana (Peru) : monntain soursop, wild soursop (United States, English): corossol zombi (Haiti) : boszourzak (Surinam) : araticum apé (Brazil).

1 related native species is coyur or pond-apple ( I moma globru I.), called also corazón cimarmón, a small tree of constal swamps of Puerto Rico and the Tirerin Istands and of wide distribution north to southern Florida. It is distinguished by the smooth, yellowish, egro-shaped fruits. The pale vellow pulp is a lmost tasteless hut can be eaten. The wood, which is very lightweight, has been lised for Hoats of fishing nets and for bottle stoppers.

In addition to the 3 following species of cultivated fruit trees, a few other species of this genus have been introdiced experimentally as fruit trees. The generic name has been spelled Anona also. 


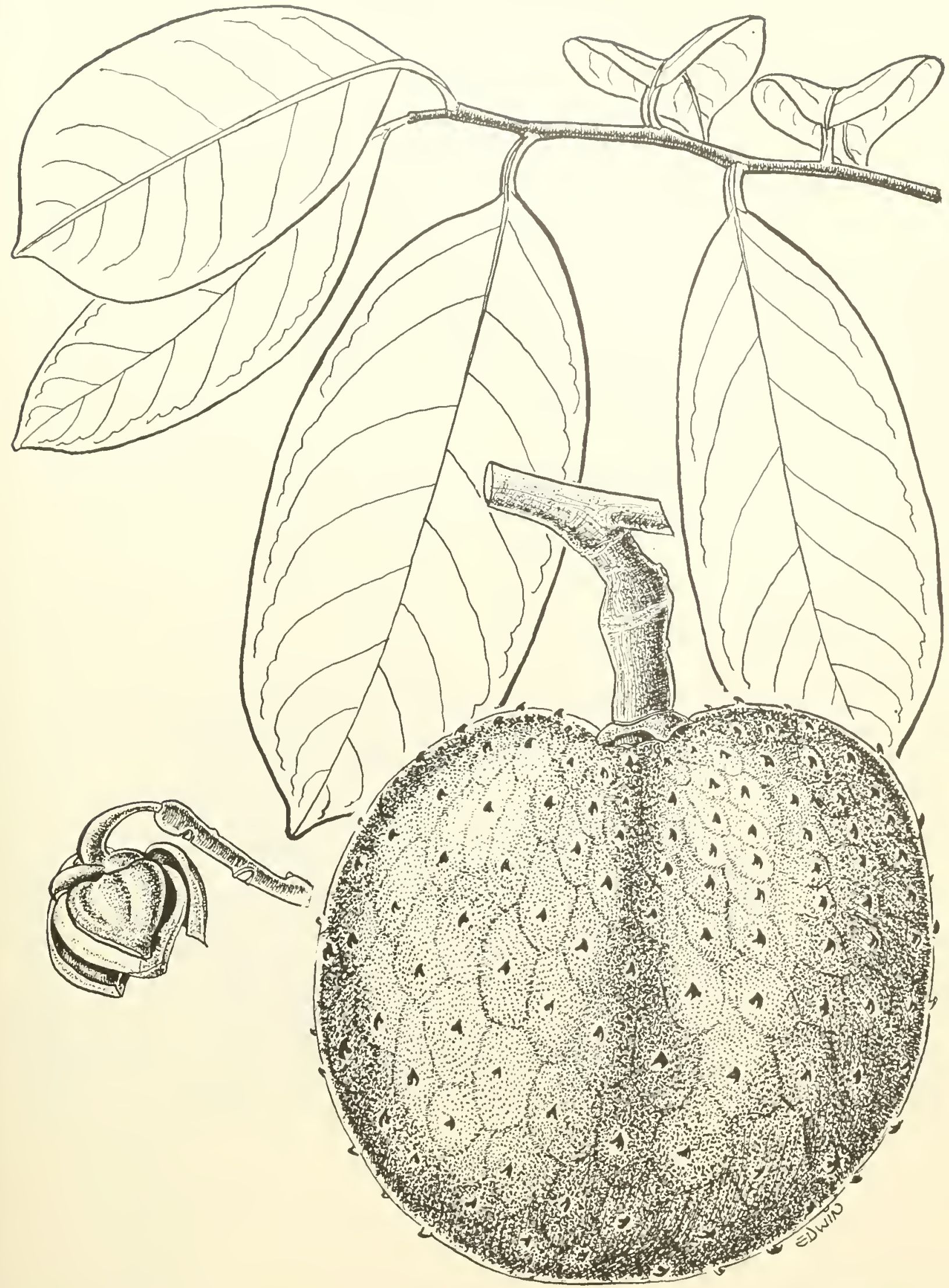




\section{ANNONA FAMILY (ANNONACEAE)}

\section{Guanábana, soursop}

Guanábuna ol soursop, a cultivated and wild fruit tree, is best known by its erlible reen fleshy fruits $6-8$ inches long and about + inches broad. elliptic or exo-shaped, with many cmed fleshy spines. Other distinguishing dhatacters are: (1) the oblong or oborate leares brondest beyond mithle, short-pointed at both ends, slightly thickened and enved up on both siles of midrib, shiny green above and paler beneath, with a strong scent when crusher and alternate in 2 rows: (2) minute round pockets on the lower leaf snrface where the sirle reins join the midrib; and (3) the large, fleshy, pale yellow or sulfur-colored flowers nearly $13 / 4$ inches fong and hroad, inngled from the $?$ heart-shaped concare outer petals, borne singly.

1 small everoureon tree attaining 20 feet in height and 6 inches in trunk diameter. The bark is brown and smoothish, the pinkish inner bark tasteless. 'T'wigs are brown or' gray, hearing minute raiserl dots (lenticels). The shout petioles are $1 / s_{-3}^{-3}$ inch long. and leat blades $21 / 2-6$ inches long and 1-3 imches broal, the edges withont teetl. and hairless or nearly so.

Flowers are terminal or lateral, on stout green stalks $1 / 2-3 / 4$ inch long. and have a st long pungent odor. There are 3 minute and inconspicions broad ween sepals 1/s inch long: :3 pale vellow cuter petals heart-shaped, pointed, concare, nearly 2 inches lona and 1 inch thick, fitting together at edges in bud and rough on outside, 3 smaller, pale yellow, rounded, concare, imner petals nearly 11/2 inches long and less thirk; and a hemisplierical axis bearing vely many crowded stamens $3 / 16$ inch long and mumerous onmapted narow white pist ils $3_{16}$ inch long with sticky stigmas.

The lane, aromatic, fleshy funits (aggregate fruits) weighing as much as $2-5$ pounds are composer of the numerous mited pistils earh ending in a fleshy spine or short base of a spine $1 / 16$ inch
Annona muricata L.*

ol mole in length, which grows from the style. The juicy, slightly sour, creany white, edible pulp contains many shing black or brown oblong seeds $16-5 / g$ inch long, eich developing from a pistil. Filowering commonly from June to October, the fruit ripening mainly in the fall.

The salpwood is whitish, and the heartwood is bown. The wool is soft, lightweight (specific urlavity $(0 . t)$, and not durable. The wood, little used in Prerto Rico, has served elsewhere for ox yokes.

Valuable for the fruits, which are eaten fresh and nsed in making drinks, ice cream, and preserves. Inmature fruts have been rooked as regetables. Leares, flowers, fruits, and seeds have been employed elsewhere in medicines. In insecticide for lice has been male from the leares. Easily polmated from seeds and rapidly growing.

Planted for the fruits and wild or naturalized in thickets, pastures, and along roads throughout Puerto Rico but commonest on the coast and the lowel southern slopes of the Cordillera. Also in Tieques, St. Croix, St. Thomas, St. John, Tortola, and Tirgin Grorda.

Raxie.-Tidely planted and naturalized in tropical regions of America and in western Africa. The native region perhaps is Test Indies though not definitely known. Throughout West Indies except Bahamas and from Mexico to Brazil. Common at Key West but infrequent on mainland of southern Florida.

OTHer COMMION NAMEs- Gruanábana (Spanish) : guanaba (Guatemala, El Salvador); catoche, catuche (Tenezuela) ; soursop (English) ; corossol (Haiti, French Thest Indies) : corossolier (French Gulana) : sorsaka, zuurzak soursap (Dutch West Intlies) : zumzak, (Surinam) : gravióla, guanabano, coração de rainha (Brazil). 


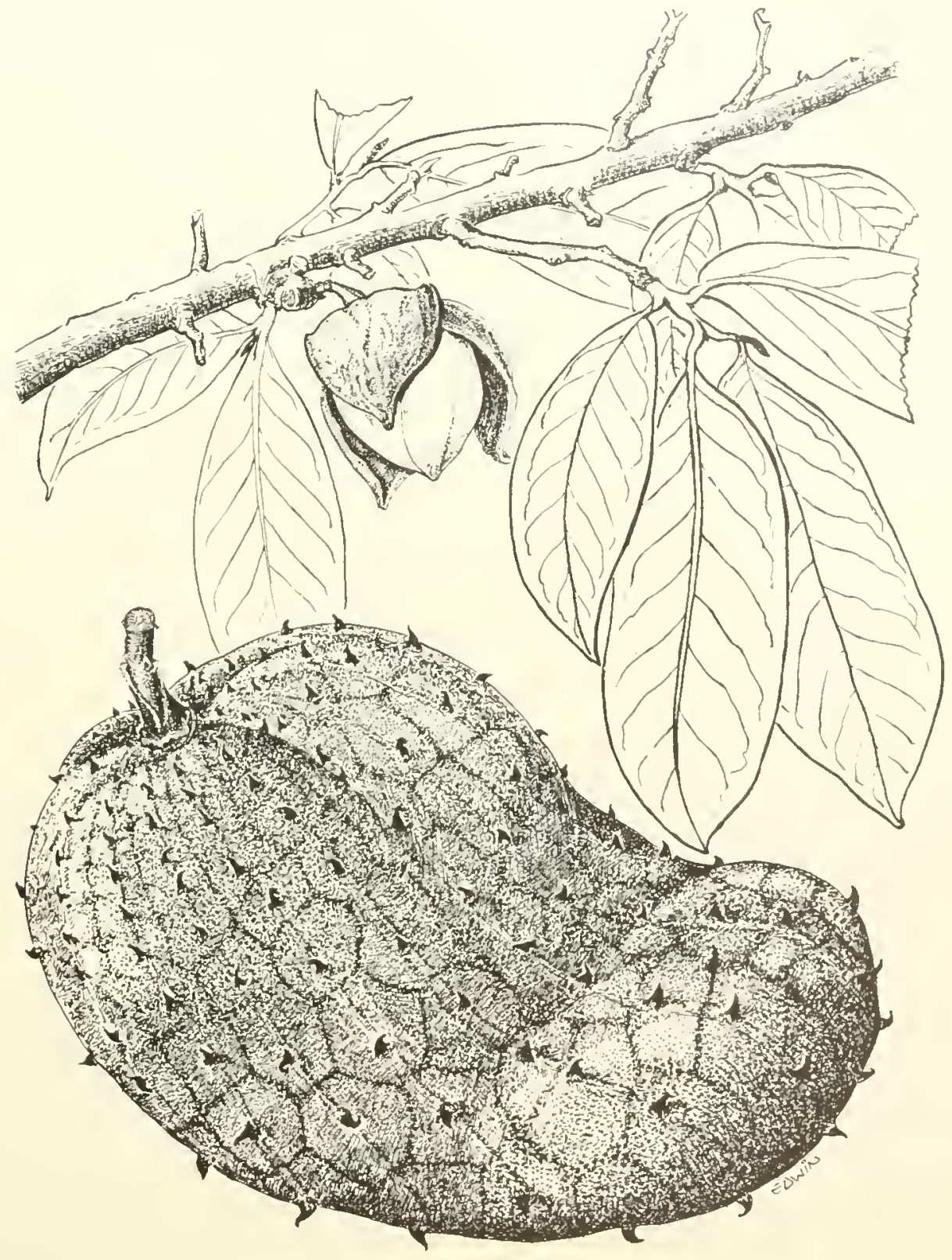

37. Guanábana, soursop 


\section{ANNONA FAMILY (ANNONACEAE)}

\section{Corazón, custard-apple}

Corazón or custarel-apple is a cultivated and escaped fruit tree distinguished by: (1) short-petioled lance-shaped to oblong leaves $31,2-8$ inches long and 1-2 inches wide, long-pointed at apex and short-pointerl at base, alternate and in 2 rows; (2) light green nal row Howers $3 / 4-1$ inch long, with $\therefore$ narrowly oblong fleshy petals not opening widely, nsially a few together in a drooping lateral chnster: and (3) rounded or heart-shaped smooth reddish-hrown fruit $3-5$ inches in diameter", with a network of lines on surface, and with sweet, pale yellow, tallowlike, edible pulp.

A small deriduons tree to 25 feet tall and to 1 foot in trunk rlameter, with a very spreading rrown. The gray or hown bark is smoothish, becoming shallowly furrowed. Inner bark is light. brown, fibrous, anil almost tasteless. Twigs are green and finely hairy when young, becoming brown or criay.

Petioles are $1 / 4-5 / 8$ inch long. The blades, not trothed at edges, ale thin, dull green above and slightly paler or wray green beneath, finely hairy when yomg.

Flower clusters arise from a very short lateral twig hut not at hase of a leaf, the slender flower stalks about 1 inch long. Flowers have a strong fragrance. There are 3 broad, pointed, brownish hairy sepals less than 1/8 inch long: 3 nallow fleshy petals $3 / 1-1$ inch long, less than $1 / 4$ inch wide, and ${ }^{1} \mathrm{~s}$ inch thick, minutely hairy, light green, the inside keeled and pale yellow with purplish or redlish spot at hase, turning brown and falling, and 3 inner petals as minute pointed scales less than 1/ inch long: very many tiny narrow whitish stamens less than is inch long crowded together; and numerons tiny separate pistils $1 / 16$ inch long with hairy greenish ovaries and pale yellow lightly sticky stigmas in a conical central mass.

The base of the fruit is sunken next to the stout salk. The agrregate fruit, formed from many pistils, has a coarse network of rhomboidal or hexaromal markiners which show the individual ovalies. The soft sweet ish erlible pulp arlheres closely to the seeds. There are many oblong shiny dark bown reeds about $1 / 2$ inch long. Recorded in
Annona reticulata L.*

Hower from . Inne to September and in fruit from September to April.

Salpwoor is light bown. The lightweight weak wood is little rsed in Prerto Rico. Elsewhere ox yokes have been made from it.

Thmugh this species is widely cultivated as a fruit tree, other minor uses have been recorded. The pulp is used in lome remedies. The powdered seerls serve as an insecticide to kill lice. A strong fiber can be obtained from the bark. 'The leaves and branches reportedly yield a blue or black dye and have been employed in tanning.

Extensively planted around houses and spreading in roulsides, pastnres, and forests, commonest in the coastal recrions of Pnerto Rico. Also in Vieques, St. ('roix, St. Thomas, St. Johm, and Tortola. It is not known whether this species is nativo here.

Peric folests.-Aguirre, Boquerón, Cambalache, Guajataca, Guánica, Luquillo, Río Abajo, San Inam, Susía.

MUNICIPALITIES WHERE ESPECIALLY COMMON.$11,38$.

RAxge.--Native of tropical America, apparently in Trest Indies and Central America, the botani(al type specimen from. Jamaica. Now widely cultivated as a fruit tree north to southern Florida and spreading or naturalized over tropical America throngh West Indies and from Mexico to Peru and Brazil. Introduced in the Old World tropics and becoming naturalized there.

OTIRr commox Names.-colazón (Spanish); mamón (Dominican Republic); mamón (Cuba); anona (Central America); anonillo, anona colorala (Guatemala): anona colorada (El Salva(nr) : anona de redecilla (Honduras, Nicaragua); anóm, anonillo (Costa Rica): anón (Panama); anón pelón (Colombia) ; chirimoya (Venezuela); custard-apple, bullock-heart. (United States, English) : coeul" de boenf (.Jamaica); cachiman coeur bouf (Haiti) : cachiman coenr-de-boenf (Guadelompe) : kasjoena, custard-apple (Duteh West In(lies): corarãon de boi (Brazil).

Common names in different languages describe the heart-shaped fruit. 


\section{ANNONA FAMILY (ANNONACEAE)}

\section{Anón, sugar-apple}

Anón or sugar-apple, well known for its sweetish edible fruits, is a cultivated tree which also grows spontaneously. Its distinguishing characters are: (1) twigs slightly zigzag, green and densely hairy when young; (2) short-stalked lance-shaper to oblong leaves $2-51 / 2$ inches long and $3 / 4-2$ inches broad, alternate in 2 rows; (3) yellow-green narrow flowers $5 / 8-1$ inch long with "3 narrowly oblong petals, usually a few in a lateral cluster; and (4) nearly round or heart-shaped yellowish-green fruit $21 / 2-4$ inches in diameter, covered with a whitish bloon but soon turning blackish where rubbed and bruised, composed of numerous rounded tubercles or raised segments, with whitish, sweet, juicy, custardlike or creamy pulp.

A small deciduous tree attaining 10-20 feet in height, with broad open crown of irregularly spreading branches. The bark is brown, smoothish to slightly fissured into plates. Inner bark is light yellow and slightly bitter. The twigs become brown with light brown dots (lenticels).

The green hairy petioles are $1 / 4^{-1 / 2}$ inch long. Blades are short- or long-pointed at apex and short-pointed or rounded at base, the sides sometimes slightly unequal, the edges without teeth, inconspicuonsly hairy at least when young, minutely dotted when examined with a lens, thin, dull green to dark green above, and beneath pale blue green and covered with a bloom.

There are 1-4 fragrant flowers on slender hairy stalks in short lateral clusters but not at base of a leaf. The 3 pointed green hairy sepals or calys lobes are about 1/16 inch long: the 3 thick and fleshy onter petals $5 / 2-1$ inch long and $1 / 4$ inch wide, yellow green, slight ly hairy, the inside light yellow and keeled with a purplish or reddish spot at the thin enlarged base, and 3 minute pointed scales as inner petals; very nmmerous crowded white stamens less than $1 / 16$ inch long in a central mass; and many separate pistils $1 / 16$ inch long, with light green ovary and white styles, crowded on the raised axis.
Annona squamosa L.*

The aggregate fruit is formed from the numerous pistils of a flower, which are loosely united, soft, and more distinct than in other species of the genus. Each pistil forms a tubercle, mostly $1 / 2-3 / 4$ inch long and $1 / 4^{-1 / 2}$ inch wide and a separate thin erlible pulp, in which is imbedder 1 oblong shiny blackish or dark brown seed $1 / 2-5 / 8$ inch long. In flower and frmit nearly through the year.

The sapwood is light yellow. The heartwood is brownish. The wood is soft, lightweight, and weak.

The fruit pulp is eaten raw and may be used to prepare drinks or sherbet. The green fruits, seeds, and leaves have insecticidal properties. Elsewhere, the leaves, shoots, and roots have been used in local remedies.

Planted in Puerto Rico for the edible fruits, spraaling from cultivation in roadsides and valleys and also in forests where possibly native. Commonest on the dry coast of Puerto Rico. Also in Vieques, St. Croix, St. Thomas, St. John, Tortola, and Virgin Gorda. Grown more in the Virgin Islands than in Puerto Rico.

Ravge.--Native of tropical America, but the original home uncertain. Named botanically from Jamaica. Now widely cultivated as a fruit tree and spontaneous or naturalized throngh the tropics of the world. Planted or naturalized in southern Florida, including Florida Keys, throughout West Indies, from Mexico to Brazil, and in the Old ITorld.

OTuer common Names.-anón (Spanish) ; saramuya. chirmoya (Guatemala); anona de Guatemala (Nicaragua); anón doméstico, anón de azúcar (Colombia); chirimoya (Ecuador); sugar-apple, sweetsop (Inited States, English); apple-bush (Grenadines) : cachiman cannelle (Haiti); pomme camnelle (Guadeloupe, French Guiana) ; scopappel (Dntch West Indies); kaneelappel (Surinam); at a, fruta de conde, pinha (Brazil). 


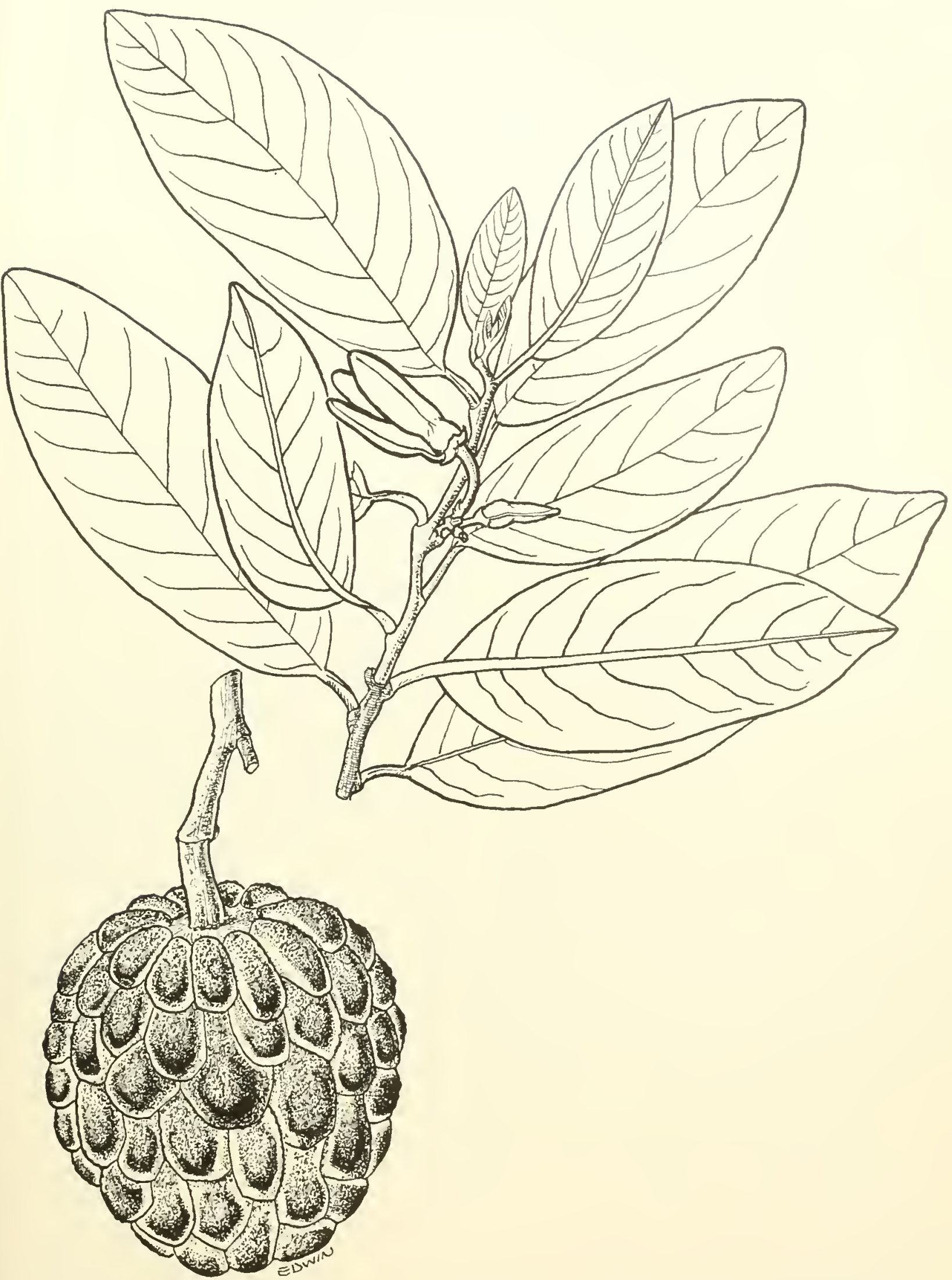

39. Anôn, sugar-apple 


\section{ANNONA FAMILY (ANNONACEAE)}

\section{Ilán-ilán, ylang·ylang}

This East Indian olnamental tree is identified by: (1) branches and twigs drooping and bearing leaves characteristically in 2 rows; (2) thin ovate to oblong leaves long-pointed at apex and romded at base: (B) odd, strongly fiagrant, large though inconspintous, yellow or wreenish-yellow flowers with rery narrow and long-pointed droopiner petals $3-5$ inches long and only $1 / 4^{-1} / 2$ ineh broad, $1-3$ at base of a leaf: and ( 4 ) distinctive fruit "onsisting of $h-15$ sprearling, elliptic, fleshy, green to black berries mostly $3 / 4-1$ inch long, resembling olives, spreading on stalks in al anster $3-1$ inches across, all formed from 1 flower.

A small to medimm-sized evergreen tree attaining 40 feet in height and 1 foot in trunk dimeter, with a spreading crown. Reported to become a large tree in its native lome. The bark is light to dark brown and smonthish, becoming fissured and rough. Inner bark is light brown, fibrous, and slightly bitter. Twigs are light green when young. becoming brown, with slight spicy taste.

The light oreen petioles of the alternate leaves are 1/4-5inch long. The thin blarles are $3-8$ inches long and 11,3 inches wide, the edges withont teeth, slightly shing green alove and dull light irreen beneath.

Flowers are borue in profusion on long slender light green stalks 1-2 inches long seattered along the twigs at leat hases. The ralyx has 3 broad pointed vellow-green lobes $1 / 4$ inch long, spreading and sliglitly turned back: the 6 slightly thickened st rix like petals a le ereen when yomng, turning to areenish yellow and vellow, the inner ? reddish tinged at base inside; very numerons stamens less than 1/s inch long, crowded into a triangular mass, pointed and becoming reddish tinged at apex; and $8-1.5$ separate green pistils crowded in center, less

\section{Cananga odorata (Lam.) Hook. f. \& Thoms.*}

than 1/4 inch long, the stigmas in a sticky mass.

Several fruits developing fiom a flower have almost tasteless flesh and usually tor 5 romoled flat light brown seeds 1 if inch or more in diameter (4i.400 to a pound). In flower and fruit through most of the year.

The salpwod is whitish. The soft wood is not dinable. Where the trees are native, small eanoes and drums have been made from the trmulis.

I valuable rolatile oil, known as oil of ilangilang and employed in perfumes, is the principal product of this tree. It is distilled from the flowers in the Philippines, East Indies, and India. The inhalitants of the East Indies anoint their heads and boulies with the oil or decorate themselves with garlands of the flowers.

()easionally planted as an ornamental and for its fragrance along the coast of Predto Rico and the Tirenin Islands (St. Thomas and perhaps others).

Ruxas.- Native of the Malayan region, ineluding sonthern India, Java. Philippines, Malay Arehipelago, and tropical Pacific islands. Sparingly introduced in other tropical regions and spread from cnitivation. Planted in Cuba, His. paniola. Puerto Rico and Tirgin Islands, Guadelope (recorled as naturalized), and perhaps others of $T^{r}$ est Indies. Mlso in sonthern Florida. a relatively recent introduction in Central America, and in Fontl America.

Otule comaon N.Mes.-ilang-ilang (Puerto Riuro, Virgọin Islands); ilán-ilán, ilang-ilang (Spanish) : carlmia, cananga (Colombia) : ylangylang (Tnited States, English); ylang-ylang ('imadelompe).

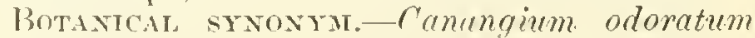
(Lam.) Baill. 


\section{ANNONA FAMILY (ANNONACEAE)}

\section{Haya minga}

A tree of the higher mountains, haya minga is distinguished by: (1) small, leathery, dark green. oblong, flag gant leaves in 2 rows on slightly zigzag blackish twigs which frequently are almost horizontal; (2) the greenish-yellow flowers abont $11 / 2$ inches across the 5 spreading fleshy petals and borne singly on long stalks at base of leares: and (3) clusters of many elliptic berries about $1 / 2$ inch long and $1 / 4$ inch thick from 1 flower.

A medium-sized evergreen tree becoming 20-10 feet in height and 1-11/2 feet in trunk diameter, rarely larger. Sometimes the trunk is buttressed at base and often it is irregular in cross section, much thicker on 1 side. The bark is brown and rough, becoming dark and puplish black. Inner bark is pink with spicy taste. The twigs are mimutely liairy when young.

Petioles of the alternate leaves are only $1 / 8^{-1 / 4}$ inch long. Blades are $11 / 2-3$ inches long and $5 \%$ $11 \mathrm{~s}$ inches wide, stiff, short-pointed or rounded at apex and short-pointed at base, slightly turned under at margins, and beneath yellow green with reins raised.

The flowers have a slight fragrance. Flower stalks are $3 / 4-11 / 2$ inches long. The calvx has 3 triangular lobes $3 / 16$ inch long $t$ urned backwards; the 6 greenish-yellow, elliptic, finely hairy petals are $1 / 2^{-7 / s}$ inch long; there are numerons crowded smal] stamens less than $1 / 16$ inch long in a circular

\section{Guatteria blainii (Griseb.) Urban}

mass $1 / 4$ inch across; and a central group of many small pistils less than $1 / 8$ inch long, each with a 1-celled 1-oruled orary.

'The fruit is composed of a cluster of many nearly stalkless, spreading, short-pointed berries, each containing 1 large shiny brown elliptic seed. Flowering and fruting more than once during the rear.

The saprood is light brown or whitish. The wood is hard and heary (specific gravity 0.8 ). Formerly it was used for construction but now chiefly for posts, since few large trees remain.

In forests of the upper Luquillo and Cordillera regions of Puerto Rico.

Promic Fonests.-Carite, Guilarte, Iuquillo, Maricio, Susúa, Toro Negro.

R.sxce.-Cuba, Iispaniola, and Puerto Rico.

Other conuox xumes.-negta lora, haya (Puerto Rico); yaya (Dominican Republic); purio fangar, purio prieto, ceda (Cuba); bois noir (Haiti).

Botanical syonym.-Cananga blaini $i$ (Griseb.) Britton.

Haya blanca (Guatteria curibaea Urban; syno11 ym Cananga caribaea (Urban) Britton), a relited forest tree of the Luquillo region of Puerto Rico, has larger long-pointed leaves $3-81 / 2$ inches long and $11 / 4-23 / 4$ inches wide. 


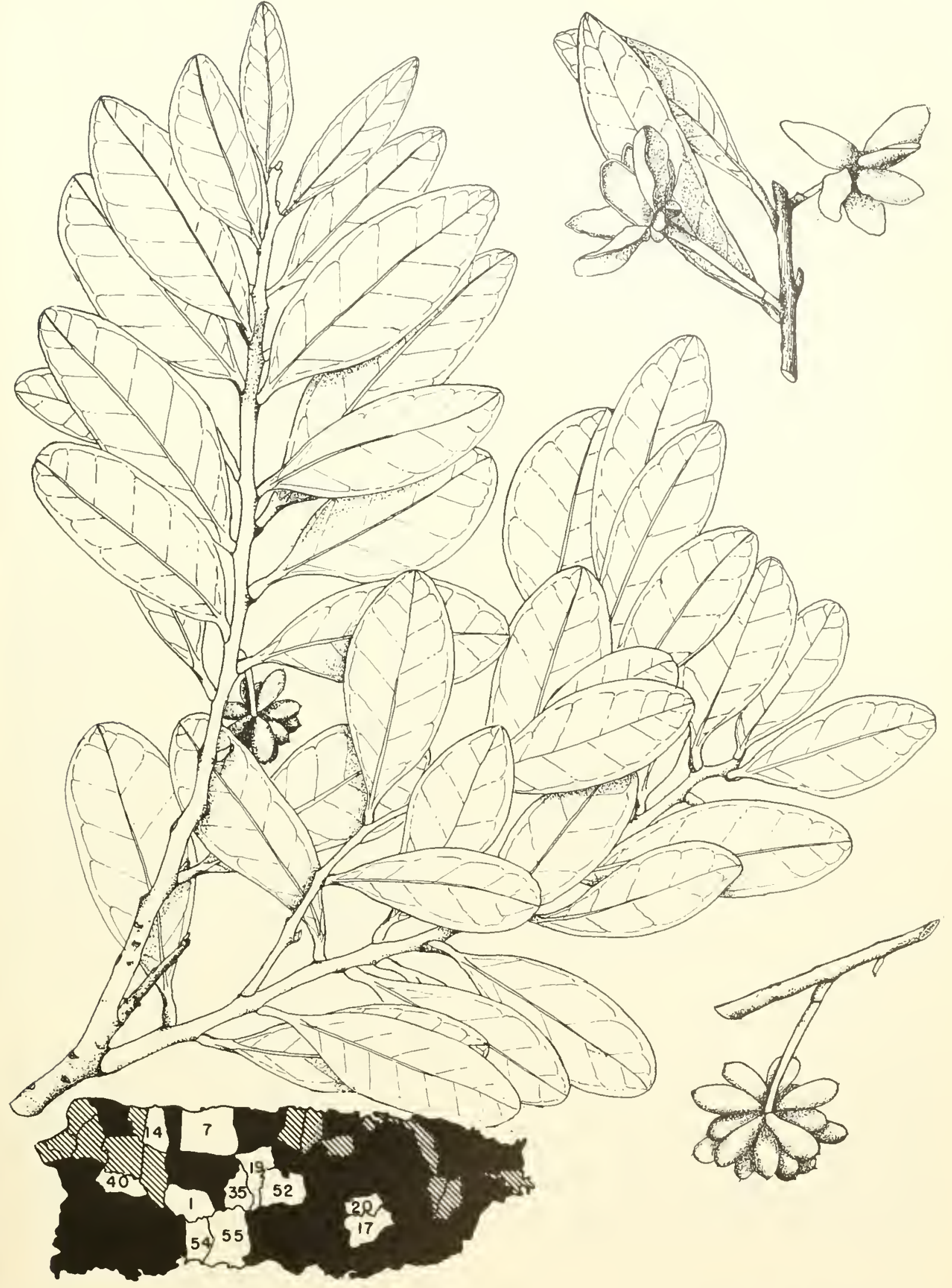

41. Haya minga

Natural size.

Guatteria blainii (Griseb.) Urban 


\section{LAUREL FAMILY (LAURACEAE)}

Ker to the 10 species illustrated (Nos. 42-51)

A. Fruit without a cup at hase.

[3. Fruit elliptic, lubli, 1-1\% inclues long. inedible-12. Beilschmicdia pendula.

13. Fruit pear-shnped or nearly round, sellow green, 4-5 inches long, edible (avoeado)-51. Persca americana.* A. Fruit witl cun at base.

C. Leaves very narrow. lance-shaped-13. Licaria salicifolia.

CC. Leaves broader, mostly elliptia.

D. leaves broadest beluw or near middle, mostlo long-pointed.

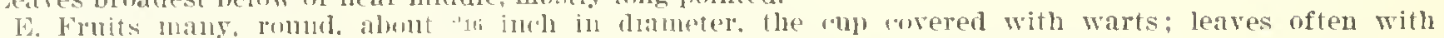

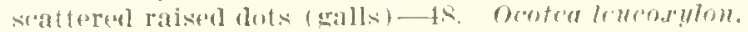

EE. Frnits few or several, $1 / 2$ inch or more in diameter: leares without raised dots.

F. Fruit cup alwut as long as broad.

f. Fruit cup about 1\% inch long and broal-14. Licaria triandra.

(ic. Fruit cul alout 3 if inch lomg amd hroad 45. Nectandra coriacea.

FF. Fruit cul rery short, flat, learing ralex lobes turned lack-17. Ocolca floribunda.

1)D. Leares broadest hepond middle. slurt-pointed or rounded at alpex.

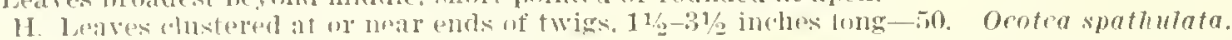

IIII. Ieaves borne singly, 3-7 inches long.

1. Lears with lower surface densels hairs, reddish brown when foung but beeming gray- 16 . Ocoter runcutr.

II. Leares shing wn loth sides, hairless or nearly so, reins mostly reddish tinged near base-49. ocotea moschata.

\section{Guajón}

Distinguished by: (1) spiey foliage, twigs, and hark: (2) bark on large trunks peeling off and exposing rusty reddish-brown inner layers: (3) elliptic. slightly leathery leaves often broadest berond middle, short-pointed at both ends. much perforated by insects on many trees; (4) greenishvellow flowers abont $1 / 8$ inch long and broad, sevel'al in a loose. Iong-stalked, branched, lateral rluster $3-5$ inches long: and (5) the long elliptir bl:ack fruits 1-116 inches long and $1 / 2$ inch in diameter, without a cup at base, fleshy and 1 -seeded. horne singly.

A medium-sized evergreen tree attaining 75 feet in height and 216 feet in trumk dimeter. The dark hrown bark is smoothish and slightly fissured, about $1 / 4$ inch thick, the inmer bark light brown. The twigs are green and minutely hairy when young.

The alternate leaves have petioles $3 / 8-5 / 8$ inch long. Leaf hlades are $31 \%-61 / 2$ inches long and $2-31 / 4$ inches broad, hairless or nearly so at maturity, the edges not toothed, irreen on upper surface, and paler or eovered with a hloom beneath.

The flower cluster's (panicles) have finely hairy branches bearing several short-stalked flowers. The greenish-yellow calyx is finely hairy and has (i) lobes less than 1/16 incl long: there are 9 stamens and additional sterile stamens (staminodes); and pistil of 1-celled, 1-ovuled ovary with short style.
Beilschmiedia pendula (Sw.) Benth. \& Hook. f.

Fruits (berries) are green. turning black at matmrity, fleshy, with 1 large seed. As sone common names slugrest, they resemble small a rocados and olives slightly. Flowering and fruiting from spring to fall.

The sapwood is pale brown, and the heartwood is pinkish brown. The wood is moderately hard, strong. and heavy (specific gravity 0.54). It is very susceptible to damage by dry-wood termites. Rate of air-seasoning is slow, and amount of degrade is minor. Machining characteristics are as follows: planing, shaping, sanding, and resistance to serew splitting are good: tuming and mortising are fair; and boring is poor. 'The wood is used for shipbuilding, general const ruction, flooring, furnitmre, cabinetmaking, and carpentry.

It is reported that the fruits are eaten by hogs and other animals in Cuba.

In lower Luquillo and Cordillera regions of Pnerto Rico. Also in St. Thomas.

Public forests.-Carite, Luquillo.

RAxGe-Greater Intilles, St. Thomas, and Lesser Intilles from St. Kitts to St. Vincent.

Otiler common Nases. - aguacatillo, aguacate cimarrón. cerlro macho (Pnerto Rico); aguacatillo, cigua amarilla (Dominican Republic); aceitunillo, aguacatillo, curavara, mulato (Cuba) ; slogwood, slug-rrood (Jamaica); laurier madame (Dominica).

Botanicai stronm. - II felandia pendula (Sw.) Nees. 


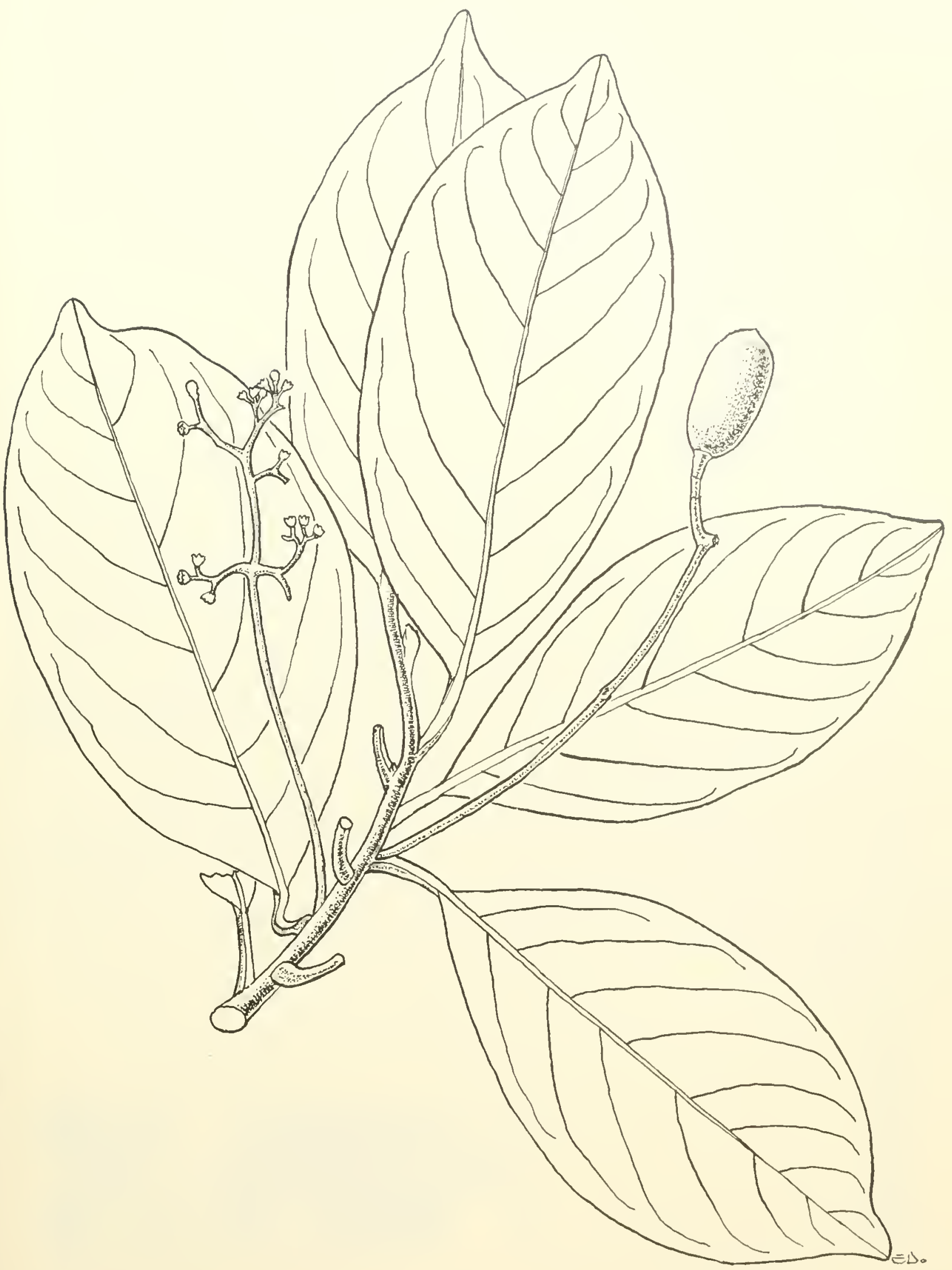




\section{LAUREL FAMILY (LAURACEAE)}

\section{Canelilla}

This species is readily distinguished from other trees of the lanvel family by the narrow leares. Other characters for identifintion include: (1) spicy foliage, twigs, and bark; (2) narrow acute pointed clom on most trees; (3) lance-shaped leathery lea ves, dark green or shing green on upper surface, and gray green and finely hairy beneath: (4) densely redolish-brown hairy young twigs; (5) small, whitish-green hairy flowers more than $1 / 16$ inch long and broad, several in short lateral clusters: and (i) blackish elliptic fleshy fruit $5 / 8$ inch long and $1 / 4$ inch broad, in a spreading gray cup almost. $1 / 4$ inch long and broud, with double rim.

A small to medium-sized evergreen tree to 50 feet high with a straight trunk to 1 foot in diameter. The dark gray or reddish-brown smoothish bark has many small warts (lenticels) and peels off in large irregular flakes 1-6 inches long. Inner bark is light brown. spicy and bitter. Older twigs are slender, brown, and hairless.

The alternate leaves have short reddish-brown hairy petioles $1 / 5-3 / 8$ inch long. Blades a re $13 / 4-41 / 2$ inches long and $1 / 2-1$ inch broad, long-pointed at apex and short-pointed at base, not toothed on edges, the upper surface becoming hairless, and the

\section{Licaria salicifolia (Sw.) Kosterm.}

lower surface remaining finely hairy with a network of many raised small veins.

The small flower clusters (panicles) at leaf bases have several flowers on densely hairy branches. (alyx has o hairy lobes less than $1 / 16$ inch long; theie are 3 stamens with additional sterile stamens (staminodes): and pistil of 1-celled ovary and slender style. The elongate fleshy fruits (berries) have a single large seed. Flowering and fruiting from latter part of February to September.

The sapwood is light brown. The heavy wood (specific gravity 0.8 ) is used only for poles, posts, and fuel in Puerto Rico.

In the moist limestone, dry coast, and lower Cordillera regions, chiefly in western Puerto Rico. Also in Vieques, St. Croix, St. Thomas, St. John, and Tortola.

Public rorests.-Cambalache, Guajataca, Guánica, Maricao, Río Abajo, Susúa.

Rixge.-Puerto Rico and Virgin Islands, and Lesser Antilles from Antigua to Martinique.

Other com Mon Names. - canela, canela del país, canelillo (Puerto Rico) : bois chique, bois fourmi (Guadeloupe).

Botanical SYNoNYM.-Acrodiclidium salicifofium (Sw.) Griseb. 


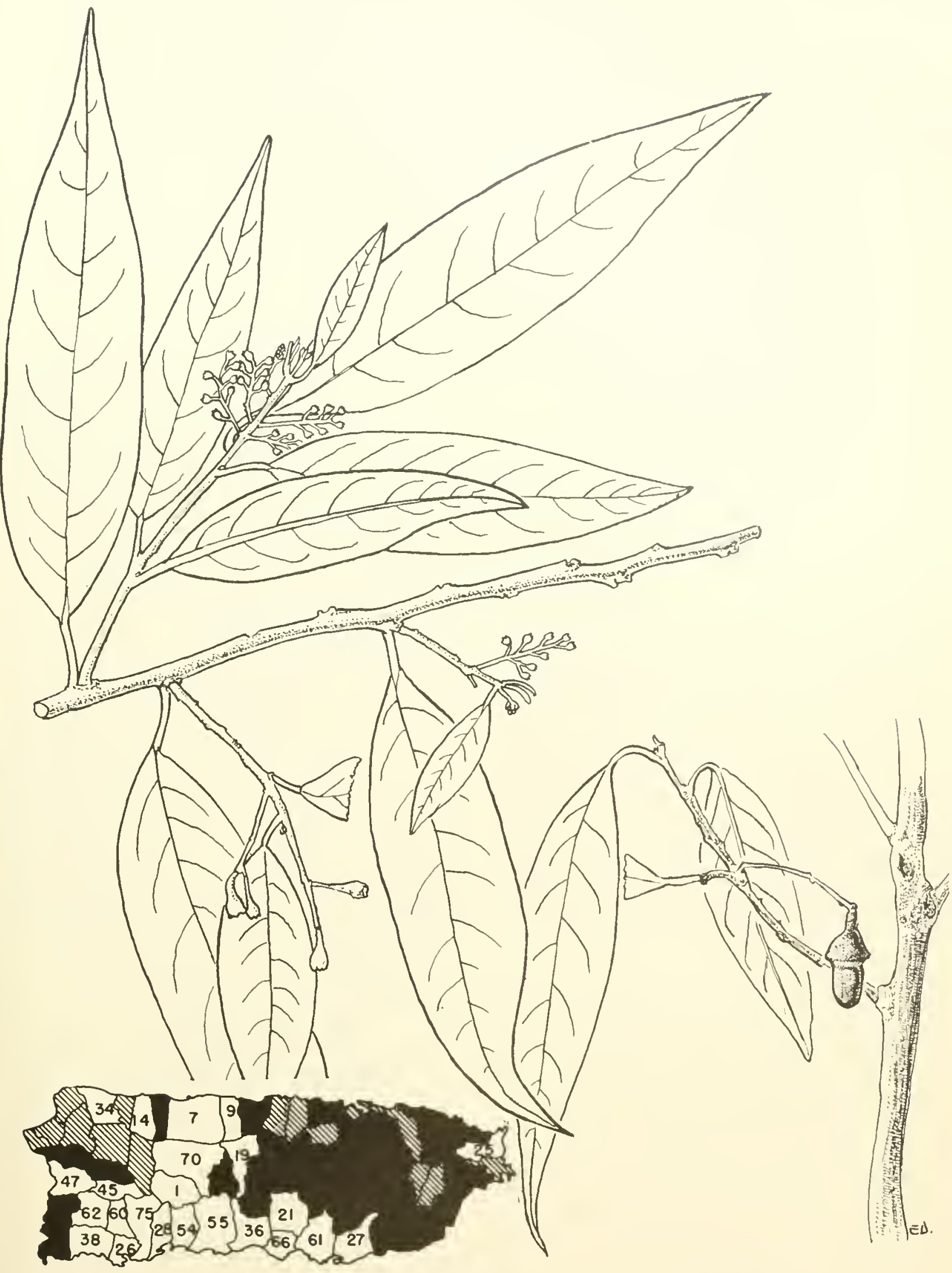

43. Canelilla 


\section{LAUREL FAMILY (LAURACEAE)}

\section{Palo de misanteco, Gulf licaria}

Fonnd lowily in northelu parts of Puerto Rico, this species is chararterized by: (1) spicy foliage, twigs, and bark; (2) twigs reddish when young: (3) narrowly elliptic leaves. slightly thickened, many with a long tapering point and short-pointed at base: (4) the small whitish flowers more than ${ }^{1} 16$ inch lona and broad, many in branched clusters $11 / 2-3$ inches long: and (5) the ellipt ic areen or dark hlue fruits $3 /$ inch or more in length, in a large thick red cup about $1 / 2$ inch long and broad with double rim or margin.

A small everween tree to 30 feet high and 8 inches in diameter with hroad rounded crown. The bark is latrk brown and faky or scaly. The slender twigs are finely hairy and with raised dots (lenticels).

The leaves are altermate on petioles $1 / 4-1 / 2$ inch long. Blarles are:"; inches long and $1-13 / 4$ inches moat. the edges not toothed, shiny dark wreen above, paler beneath.

Flower clnsters (panieles) are terminal and lateral, and hare groups of small flowers on short, slender, hairy stalks. The tubular calyx has 6 lobes: the : stamens are united into a fleshy hairy tube or columm: and the pistil has a 1-celled orary. slender style, and protruding flattened stimma.

\section{Licaria triandra (Sw.) Kosterm.}

The fleshy fruits (berries) are few in a cluster and 1 -seeded. The cup has a second rim about 1/s inch below the edge and is warty. Recorded in flower in May and in frut in May and July.

The wood is described as ash colored or greenish rellow, strong, and hear (specific gravity 0.9 ). Ised for posts in Puerto Rico. Reported as suitable for interior construction and used for matehes and matchboxes in Dominican Republic.

This species has been suggested as a shade tree for southern Florida and Cuba.

In forests of the moist limestone region of Pnerto Rico. Also in Vieques.

PUblic folest.-Guajataca.

Range. - Greater Antilles and Martinique. Also very lare in southern Florida.

OTHer commox xames. - misanteco, palo misanteco (Puerto Rico) ; cigua prieta (Dominican Republic): lebisa, leviza, laurel de loma, laurel blanco (Cuba): Gulf licaria, Gulf misanteca (Tnited States); sweetwood (Jamaica); laurier jaune (Haiti).

BotaNical sYNoxiss. - Misanteca triandra (Sw.) Mez, Acrodiclidium triandrum (Sw.) Lundell, A. jamaicense Nees, Licaria jamaicensis (Nees) Kosterm. 


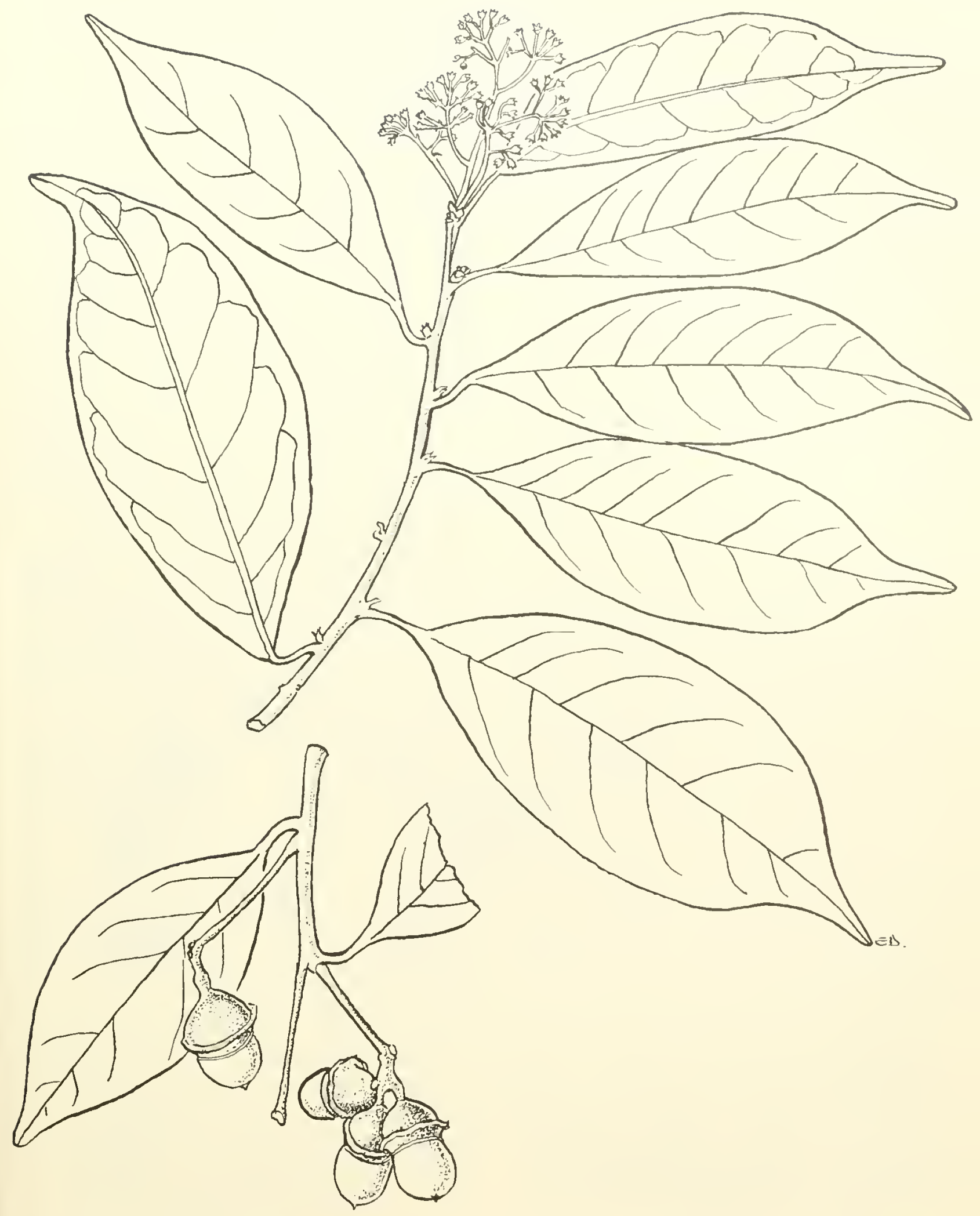

44. Palo de misanteco, Gulf liearia 


\section{Laurel avispillo, Jamaica nectandra}

This tree is distinguished by: (1) spicy leaves, twigs, and bark; (2) shiny green or dark green. leathery, narrowly alliptic leaves usually shortpointed at both apex and hase, pale beneath with a prominent network of reins on both surfaces: (3) small white flowers $3 / \mathrm{s}$ inch or more across, 6-lobed, many or several in lateral clusters with pink or red branches: and (4) romud or elliptic blackish or dark blue fruits about $1 \frac{1}{2}-5$, ineh long, witlı reel cup.

A small evergreen tree attaining 20-30 feet in height and $6-1 \%$ inches in trunk diameter, with a narrow arown. The bark is gray and smoothish. Inner bark is light brown. The slender trigs are green and slightly hairy when young, tuming gray.

T'he leaves are al termate on short petioles $1 / 4^{-1 / 2}$ inch long. Leaf blates are $2-6$ inches long and $3 / 21 / 2$ inches broad, thickener and leathery (as the specific name indicates), often bent upward slightly on both sides of midrib, not toothed on ecloes.

Flower clusters (panicles) are 1-4 inches long. bearing the fragrant flowers on slender stallss $1 / 8-1 / 4$ inch Iong. The calyx los 6 widely spreading, white, finely hairy lohes $1 / 8-3 / 16$ inch long: there ares white stamens: and pistil with 1 -celled orary partly enclosed, style, and broader stigma.

The fleshy fruts (herries) in drooping clusters have 1 redilish-hrown seed. The cup is abont $3 / 16$ inch long and broad. Flowering and fruting probably irregularly through the year.

The sapwool is light brown, the lieart wood dark hown. Elsewhere the worl has been used in earpentry and cabinetwolk and for poles.

Planted for slade in sonthern Florida and ('uba. Reported to he a lioney plant. It is said that eattle eat the fruits.

Common in the moist limestone forest region of northern Puerto Rico. Mlso in Mona, Vieques. St. Croix, St. Thomils, St. Joln, and Tortola.

Pribic romests.-Cambalache, Guajataca.

Ruxge.-Sonthern Florida including Florida keys and thromer West Indies from Bahamas and Cuba to Grenada and Tobago. Also in Mexico (Íneatán Peninsula), British Honduras, and Grmatemala.

Other commox xames.-arispillo, laurel, eigua, laurel cigna (Puerto Rico): pepper cillament (Virgin Islants) : cigua blanca (Dominican Republic) : cigua, siguaray, boniate, lebisa (Cuba): lamel (Mexico): Jamaica nectaudra. Jancerrood, Jamaica ocotea (Inited States): black toreh, sweet torchwoor (Bahamas): sweetwood, eapberry sweetwood, small-leaved sweetwood (Jamajéa) : laurier marbré (Grenada); sweetwood
Nectandra coriacea (Sw.) Griseb.

(British Honduras) : laurier blane (Haiti) ; bois doux négresse, bois violon, bois doux noir (Guadeloupe): sweetwood (Dutch West Indies).

Botaxicil sryox mis.-Ocotea coriacea (Sw.) Britton, O. cotesbyame (Michx.) Sarg.

Five other species of this genns, known also as lamel, are native in moist forests of Puerto Rico, and 2 of these reported also from the Virgin Islunds. Asuatillo (Nectandre antillana Meisn.), of southern and eastern Pnerto Rico and St. Thomas, Jas oblong or broadly lance-shaped leaves 21 -9 inches long and $1-3$ inches wide, longpointed at apex and sliort-pointed at base, hairless except on main vein beneath.

Laurel canelón (Vectandru krugii Mez), of central and western nountains, has the twigs, petioles, loranches of flower clusters, and the flowers rusty hairy: leares ohlong or lance-shaped, 41/2-10 inclies long and 11/4-5iv inches wide, long-pointed at apex and short-pointed or rounded at base, reins smmlien in upper surface and prominent beneath, hairy beneath and also above when young.

Lamel prieto (Nectandra membranacea (Sw.) Griseb.), also called laurelillo, has young twigs rusty hairy and oblong to elliptic leaves $3-10$ inclies long and 1-3 inches wicle, long-pointed at apex and slort-pointed at base, reins sunken in upper surface and prominent beneatl, lairless or slinhtly hairy. This tree, included in "Pnerto Rir'm Wroods." was reported long ago from St. Thomas and st. Croix also.

Lalurel roseta (Nectandra putens (Sw.) Griseb.) bas leares ellipt ic, $3-8$ inehes long and $11 / 4-3$ inches wide. usmally short-pointed at both ends, leathery and witl prominent veins on both sides, and hairless except sometimes with tufts in rein angles beneath; and fruit oblong, nearly 1 inch long, white, with red eup.

Laturel amarillo (Nectandru sintenisiz Mez), also called lamrel macho, has young twigs with short flattened hairs and lance-shaped to elliptic leares 2-8 inches long and 1-3 inches wide, long-pointed at apex, hairless, with few main reins. This tree, listed in "Puerto Rican WToods," was reeorded long ago fiom St. Tliomas also.

I similar tree known also as lamel avispillo (Phorbe elongatu ( $\mathrm{Tahl}$ ) Nees) has been confused with Vectundra corracea. This related mediumsized tree is eonmon in the eastern momtains and northern foothills of Puerto Rico and found also in St. Croix. It has leaves only slightly shiny, without prominent netwolk of veins, and smaller flowers less than $1 / 4$ inch across. The fleshy round or elliptic blackish fruit $1 / 2-5 / 3$ inch long has a 6 -lobed cup formed from the calyx. 


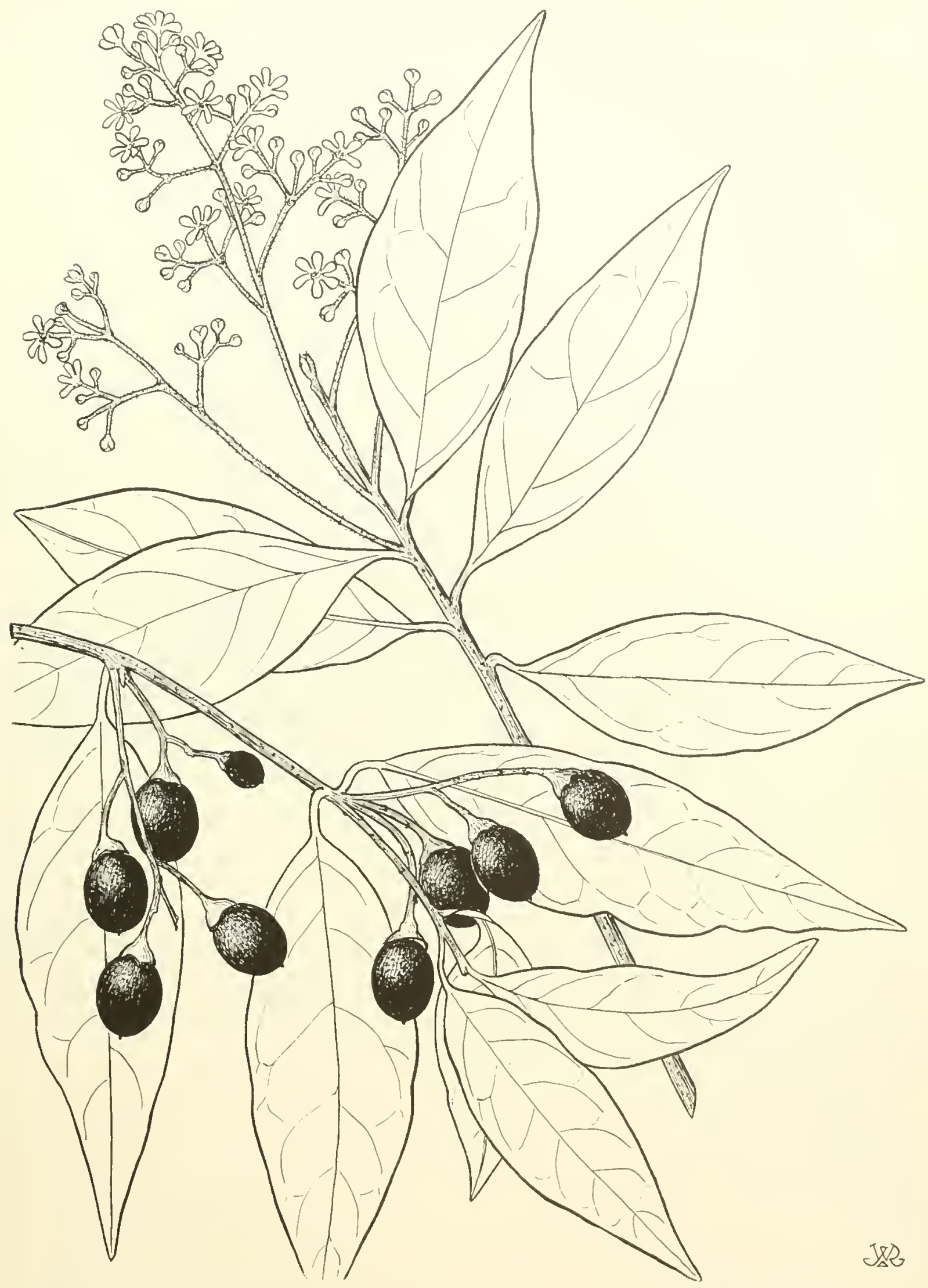

45. Laurel arispillo, Jamaica nectandra 


\section{LAUREL FAMILY (LAURACEAE)}

\section{Canelón}

A distinet lanrel recognized by : (1) dense, symmetrical, narrow, conical (rown; (2) spicy leaves, twigs, and bark: (3) the young twigr, petioles, lower surface of young leaves. flower stalks, and flowers covered with dense, reddish-hown, rusty, or cinnamon-colored laairs: (4) the leathery obovate leaves, hroadest near the abruptly shortpointed apex and gradually narrowed toward the long-pointed, short-stalked base; (5) the spreading yellowish flowers 1/4 inch across in lateral branched clusters: and (i) the elliptic fruts 5 , inch long and $1 / 2$ inch in diameter, with large hemispheric donble-margined cup.

Medimm-sized evergreen tree to 50 feet high and 1 foot in tromk diameter with straight trumk. The hark is brown or gray, smoothish and slightly warty, on lare trunks becoming slightly furowed, rough, and thick (1' inch). Imer batk is brown, spicy and bitter. Fommg twigs are finely hairy and slightly angled, and older twigs are gray and hairless.

The aromatic leaves are alternate on short, stont petioles $1 ;-1 / 2$ inch long. Blades are $4-7$ inches long and 2-31/2 inches broad, thick, not toothed at edges. The upper surface is green or dark green and finely hary or nearly liarless, and the lower surface densely and rery finely hairy, reddish brown when young but becoming gray.

Flower clusters (panicles) are $3-6$ inches long. narrow, with many slightly fraglant flowers on short lairv stalks. There are fi spreading yellowish calyx lobes less than $1 / \mathrm{s}$ inch long: 9 stamens; and pistil of partly enclosed 1-celled orary, style.

\section{Ocotea cuneata (Griseb.) Urban}

and flattened stigma. The fleshy fruit (berry) is 1 -seeded. Flowering from May to September, with fruits nearly through the year.

'The sapwood is whit ish and hard. 'The wood is suitable for construction, but most trees are used for posts.

Forests of the western moist limestone and lower Cordillera regrions of Puerto Rico.

Public rorests.-Guajataea, Marieao, Susúa.

Rivae--Cuba, Hispaniola, and Puerto Rico.

Otuer common vanss.--canela (Puerto Rico) : sasafrás (Dominiean Republie) ; canelón, eanelillo, achetillo, bijote, vencedor (Cuba).

In addition to the is species of this genus deseribed here, 3 others known also as laurel are less common trees in Puerto Rican mountain forests. Palo santo (Ocotea fopniculacea Mez), from the Central Cordillera near Idjuntas, has elliptie leares 2-31' inches long and $1-11 / 2$ inches mide, short-pointed at both ends, stiff, shiny, and hairless.

Lamel de palona (Ocotea portoricensis Mez), called also laurel avispillo and known only from Puerto Rico, has elliptic leaves $2-4$ inches long and $5 / 8-11 / 2$ inches wide. lairless, with callus-like thickenings in rein angles beneath, and has flowers male and female on separate trees (dioecious).

Lilurel canelón (Ocotca wrightii (Meisn.) Mez), of the western Cordillera, has oblong or lance-shaped leares $21 / 2-5$ inches long and 5/8-11/4 inches wide, long-pointed, and densely misty hairy beneath when young. 


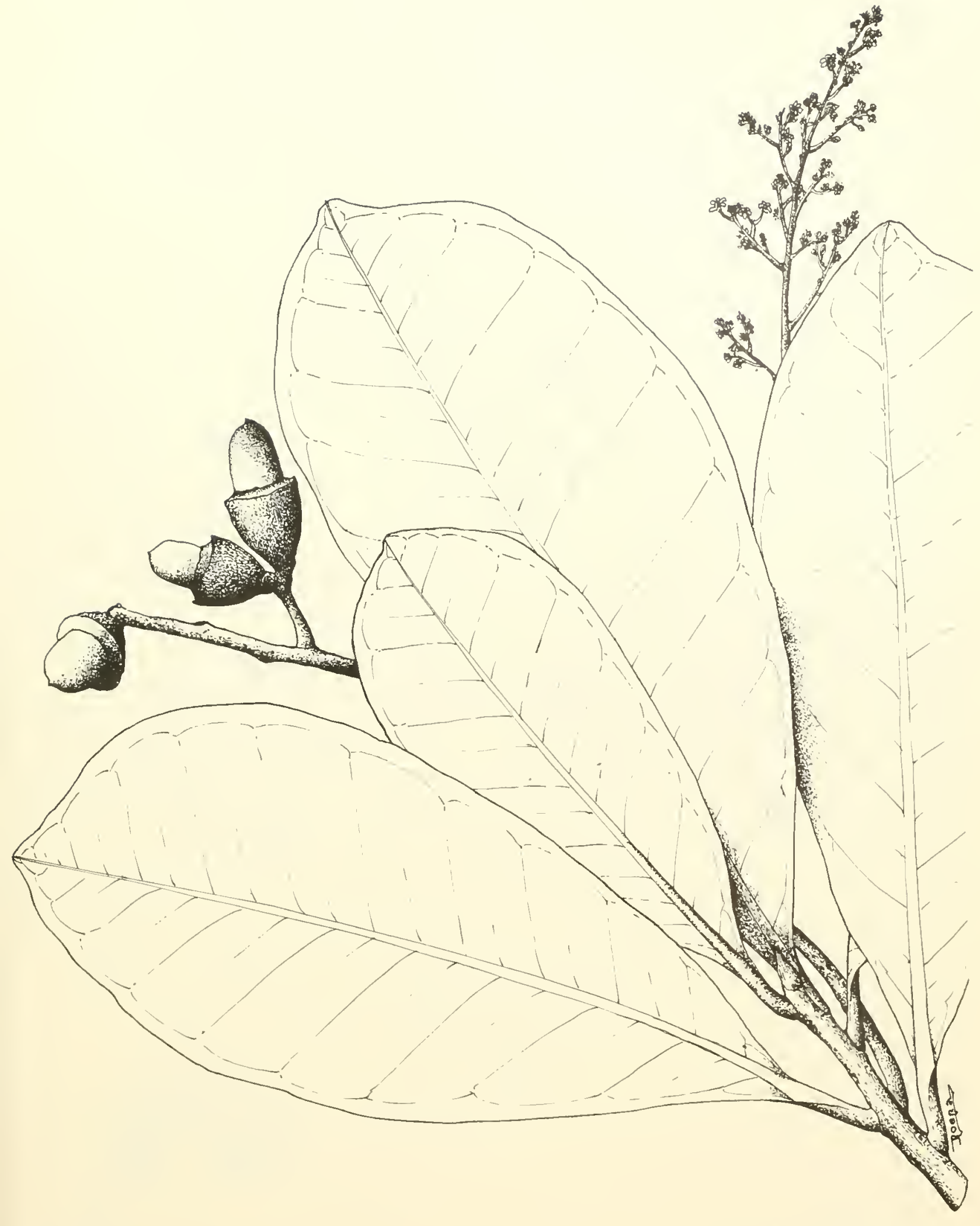




\section{LAUREL FAMILY (LAURACEAE)}

\section{Laurel espada}

Characters distinguishing this species are: (1) long branches spreading outward from the trunk: (2) twigs, hark, and leaves spicy; (3) the lanceshaped or elliptic shiny dark green leaves 2-51\% inches long and $1 / 2-21 / 2$ inches broad, slightly leathery. with long-pointed blumt apex and shortpointed base: (4) nidrib and main lateral reins commonly vellowish white: (5) branched chusters of many small greenish-white flowers $1 / 4$ inch across in lateral branched clusters: and (6) rounded or elliptic black fruits $1 / 2$ inch long with very short, flat, fouble-margined cup bearing the "alyx lobes turned back.

-mall to medium-sized evergreen tree to 60 feet tall and 1 font in trunk diameter. The light brown bark is snoothish; the inner bark also light brown, gritty and spicy to the taste. Twigs are green, sparsely hairy when young.

The alternate leaves have petioles $1 / 8-3 / 6$ inch long. Leaf blades are not toother on erlges. The lower surface of some is dull light green and slightly hairy on midrib and veins.

Flower clusters (panicles) at leaf bases are $1-1$ inches long. with finely hairy branches. The short-stalked hairy flowers are male and female on diflerent trees (dioecious), the calyx with 6

\section{Ocotea floribunda (Sw.) Mez}

spreading greenish-white lobes less than $1 / 8$ inch long. Male flowers have 9 stamens and a rudimentary pistil. Female flowers have small sterile stamens (staminodes) and pistil with 1 -celled ovary partly enclosed, style, and broad flat stigma. The fleshy fruits (berries) have 1 rounded brown seed 3 sinch in diameter. Flowering from October to December and maturing fruits from February to . July.

The rood is described as rose white, lightweight, and easily worked. It is used mostly for posts and fuel and occasionally as lumber in farm buildings in Puerto Rico. In Cuba it is employed for interiors in rural construction.

Forests of the lower mountain regions of Puerto Rico. Also in St. John and Tortola.

Probic romess.-Carite, Fuajataca, Luquilio, Río Abajo.

R.suc.-Greater Antilles, St. John, Tortola, lesser. Intilles fron Guadeloupe to Grenada, and Trinidad. Also in Tenezuela and Guianas.

Ormer commox xumes.-lamel (Puerto Rico): laurel, laurel blaneo (Dominican Republic) : boniato laurel, lebisa (Cuba); black sweetwood, black candlewood (Jamaica); laurier puant (Haiti) : bois toux (Guadelompe). 


\section{LAUREL FAMILY (LAURACEAE)}

\section{Laurel geo}

One of the commonest laurels, this species is characterized by: (1) spicy foliage, twigs, and bark: (2) a very dense romnded crown: (3) elliptic leathery leaves $t_{-9}$ inches long and $11 / 2-31 / 2$ inches broad, the apex short-, long-, or bluntpointed, the base short-pointed or rounded, slightly shiny dark ereen on upper surface and paler beneath, often with scattered raised dots, which are insect galls; (t) brancherl clusters of numerons small yellow flowers $3 / 16$ inch across near ends of twigs: and (5) very many round black fruits $5 / 16$ inch in diameter, in a red or brown cup $3 / 8$ inch long covered with light brown warts.

A small to medium-sized everoreen tree to so feet high and 10 inches in trunk diameter. The bark is brown or cray, smonthish or hecoming slightly fissured. Inner bark is light brown, with bitter spicy taste. Twigs are green and finely hairy when young, becoming brown, slightly ingled.

The leaves are altemate on petioles $3 / 8-3 / 4$ inch long. Blarles are hairless or nearly so and not tuotherl on edges. Insect galls forming suittered raised dots on the upper leaf surface are sufficiently "haracteristic of this species to serve in identifieation.

Flower clnsters (panicles) are $2-6$ inches long, broad and mueh branched, single at leaf bases and appearing terminal, the branches green, angled. and finely hairy. The rery many fraglant. almost stalkless flowers are male and female on different trees (dinecions), the aly with o spreading ve]low or pale yellow lobes more than 1 ' 16 inch long. Male flowers have 9 stamens and a rudimentary pistil. Female flowers have minute sterile stamens (staminodes) and pistil with 1-celled. 1-ornled ovary partly enclosed, style, and broader stioms.

The fruits (herries) have thin flest which is bitter and spicy, covering the nearly round seed about Is inch long. Flowering and fruiting irregularly through the year.

\section{Ocotea leucoxylon (Sw.) Mez}

The sapwood is pale rellowish brown or cream colored, and the heantwood uniform light golden brown without figure. The wood is moderately soft, lightweight (specific gravity 0.45), moderately strong, and easily worked. It is not durable and is susceptible to attack ly dry-wood termites. Rate of air-seasoning is moderate, and amount of degrade is considerable. Machining characteristics are as follows: planing. shaping, turning. mortising, and resistance to screw splitting are good: and boring and sanding are fair.

The wood is used mainly for posts but also in carpentry and construction. It is suitable for inexpensive arades of furmiture and eabinetwork and for interior trim, general earpentry, light construction. boxes and crates, plywond, sheathing. and concrete forms. A general utility wood in Tobago. Formerly macle into shingles in . Tamaica.

In Dominican Republic it is reported that the fruits are an important food for hogs.

Widely distributed in forests of the moist coast, moist limestone, and lower mountain regions of Puerto Rico. Also in St. Thomas and Tortola.

Peble ronests.-Cambalache, Carite, Guajataca, Guilarte, Inquillo, Maricao, Susúa, Toro Negro, Vega.

MTNICIPALITIES WIERE EsPECIALLY COMIION.$2.2,62$.

Rixce-Greater Antilles, Lesser Antilles from Montserrat to Grenada, and Trinidad and Tobago.

Otner commox vimes.-cacaillo, lanrel, lanrel geo-geo, geo, geo-geo (Puerto Rico) ; false arocado (At. Thomas): cigna lanrel, cigua bola (Dominican Republic) ; boniato, curabara, judio, hojancha. patabán de monte (Cuba): whitewond, loblolly sweetwood (Jamaica): dickmood, black-cedar (Trinidad and Tobago): lamrier (IIaiti); bois doux jame. Jois doux piment, lanier fine, lamier madame (Guadeloupe); laurier noir (Martinique). 

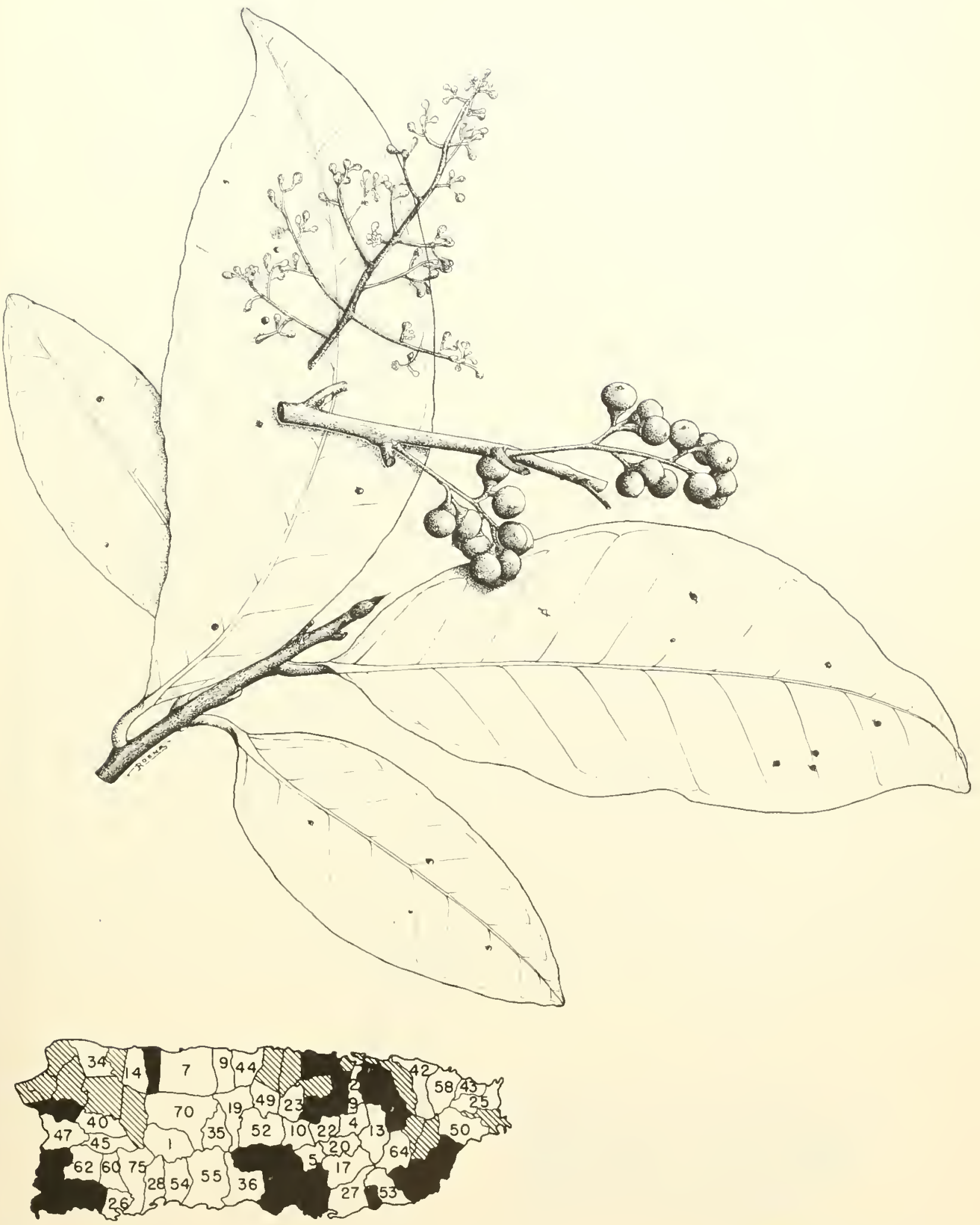

4S. Laurel geo 


\section{LAUREL FAMILY (LAURACEAE)}

\section{Nuez moscada}

Known only from Puerto Rico, this aromatic tree is characterized by: (1) spicy foliage, twigs, and bark: (2) prononnced buttresses: (3) shortstalked, leathery, obovite or elliptic leaves mostly widest bevond the middle. blunt-pointed or ronnled at anes and short-pointed at base, shiny on both sides. datk green on upper surface and yellow green to brownish areen beneath with raised reius on lower" surface mostly tinged reddish near the base; (4) yellowish flowers abont 1,4 inch across, rusty-brown hairy, in lateral clusters shorter than the leaves; and (5) large elliptic fruits to 11,4 inches in length, with lemispherical double-margined cup.

I linge evergleen tree to 80 feet in height and $21 / 2$ feet in trunk dianeter, with a compact narow crown and buttresses to 3 feet high and 2 feet broat. The brown bark is smoothish, becoming fissured and slightly rough. Inner bark is reddish brown, with slightly spicy odor and taste. The brown twigs are finely hairy when young.

The alternate leaves luve stout petioles $1 / \mathrm{s}^{-3} / 8$ inch long and blades $3-6$ inches long and $1 \frac{1}{2}-31 / 2$ inches broad, not toothed at edges. The mpper surfare is hairless and has slightly sunken veins, and the lower surface is hairless or nearly so.

short-stalked flower's are borme in branched chusters (panicles). Calyx has 6 hairy lobes more than $1 / 8$ inch long: there are? stamens: and pistil has 1 -celled ovary with style. The fleshy fruit (bery) contains 1 large seed. Flowering from

\section{Ocotea moschata (Meisn.) Mez}

spring to fall, the fruits maturing from winter to summer.

The sapwood is yellowish to light brown, and the heartwood extremely rariable, from mediun brown to dark brown with irresular darker brown to black streaks or patches. The mood is hard and heary (specific glarity 0.59) and has medium to fine texture. It takes a high polish but is very susceptible to attack by dry-rood termites. Rate of air-seasoning is rapid, and amount of degrade is minor. Machining cliaracteristics are as follows: planing is fair; shaping, turning, boring, and resistance to screw splitting are good; and mortising and sanding are excellent.

This attractive timber formerly was much used for cabinet work. It is recommended for turning. furniture, cabinetmaking, and novelty items and should be suitable for light and heary construction, bridge timbers, heary crating, and packing boxes. The fruits are used for medicinal purposes.

Forests of the lower mountain region of Puerto Rico, commonest in and near the transition to the upper mountain forests.

Prisla ronesti:-Carite, Guilarte, Inquillo, Toro Negro.

R.sae.-Known only from mountains of Puerto Rico.

Other common vames.- - hemocá, nuez moscada (imarrona, nuez moscada matho, nuez moscada del país (Puerto Rico). 


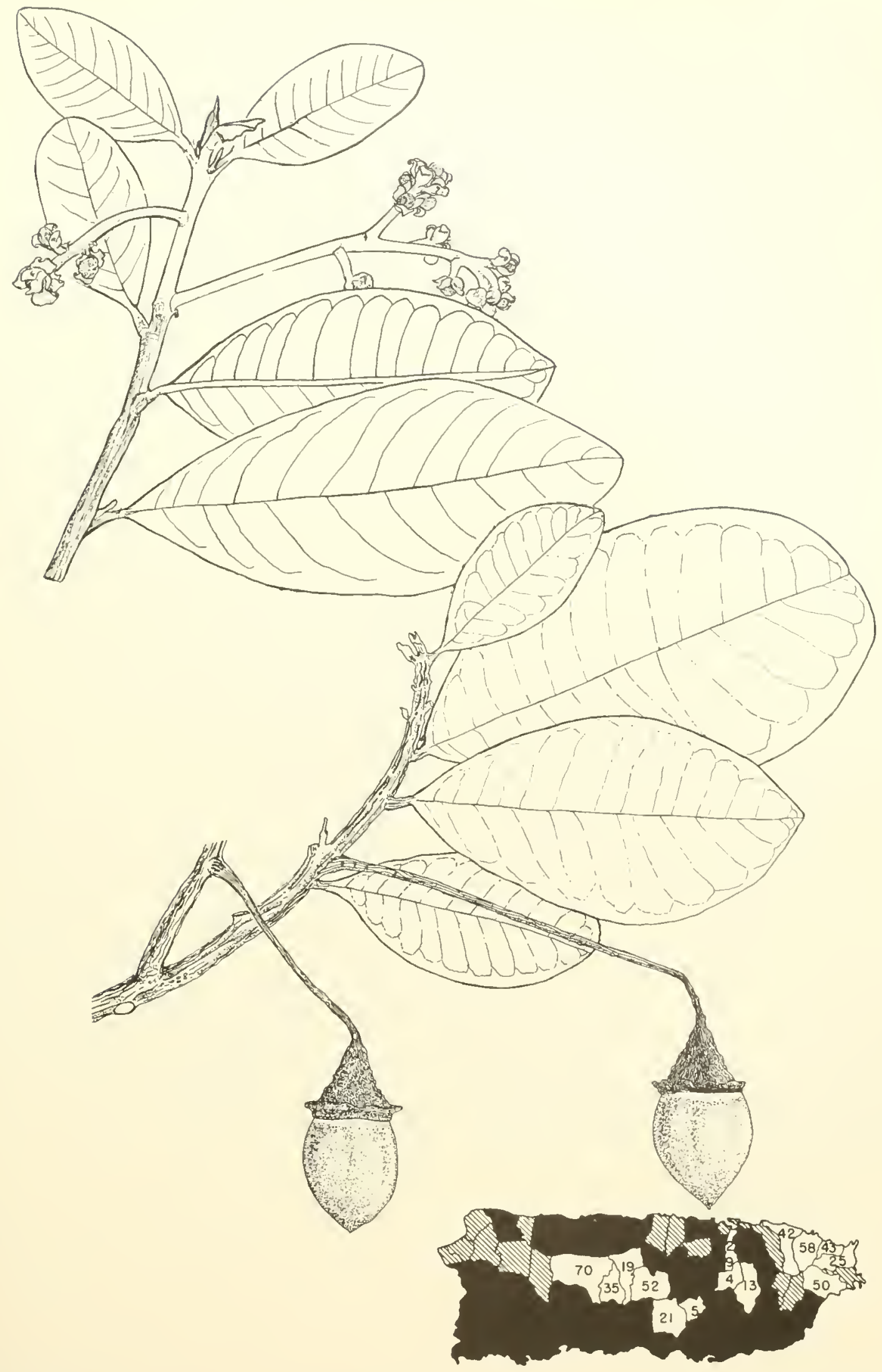

45. Nuez moseada 


\section{LAUREL FAMILY (LAURACEAE)}

\section{Nemocá}

This species of the eastern and centra] mountains is identifier by: (1) branches forming distinct. horizontal layers: (2) narrow buttresses at base of large trunlis; (3) spicy leares, twigs, and bark; $(t)$ lea ves cinstered it or near ends of twigs, shing: and leathery, spoon-shaped (spatulate) or obovate, $11 / 2-31 \frac{1}{2}$ inches long and $3 / 4-11 / 2$ inches broad, widest beyond middle; (5) greenish-yellow, rusty hairy fowers abont 1/4 inch broad, in lateral clusters shorter than the leaves: and (b) large round or elliptic fruits $7 / 8-11 / 4$ jnches long with shallow double-margined cup.

I small or medium-sized evorgreen tree to 45 fect high and $1 \frac{1}{2}$ feet in trunk diameter. The gray or brown bark is sealy, becoming thick and fissured on larger trunlis. Inner bark is light brown and sliglitly spicy and bitter.

Though crowded at ends of the brown twigs, the leaves are alternate. Petioles are short, only $1 / 8-1 / 4$ inch long. The blades are blunt-pointed or rounded at apex and long-pointed at base, with edges turned muder. Tpper surface is dark green, with slightly sunken midrib and slightly raised lateral veins, and the green lower surfice with raised veins.

Flower clustcrs (panicles) are in the cluster of leaves, 1-2 inches long, branched and hairy, bearing several short-stalked flowers. The calyx has 6 widely spreading hairy lobes about $1 / \mathrm{s}$ inch long; there are 9 stamens: and pistil with 1-celled ovary partly enclosed and style.

The fleshy fruit (berry), green when immature, has 1 large seed and a brown cup $3 / 8^{-1 / 2}$ inch high. Flowering and fruiting perhaps irregularly through the year.
Ocotea spathulata Mez

Nemocá is the most unusual and perhaps the nlost attractively figured commercial wood of luerto Rico. The miform sapwool is yellowish brown near the outside and pinkish brown towald the wide interior. The highly variegated heartwood ranges from light pinkish brown to rellowish brown ant greenish brown and has dark brown to black stripes. spots, or irregular lines. The wook is hard, heary (specific gravity 0.62), finetextured, and strong, but rery susceptible to attack by dry-mod termites. It is moderately difficult to work but polishes satisfactorily. Rate of airseasoning and amount of decrrade are moderate. Machining claracteristics are as follows: planing is fair: shaping, turning, boring, sanding, and resistance to screw splitting are good; and mortising is excellent.

The wood is used for furniture, but few remaining trees ale lare enough to produce lumber of rood size. It is suitable for furniture, cabinetmaking, paneling, tumery, boat planking, farm implements, handles, heary construction, and bridges.

Forests of the upper Luquillo and upper $\mathrm{Cor}^{*}$ dillera regions of Puerto Rico, ascending into the dwarf forests on summits of the peaks in Sierra de Luquillo and Sierra de Cayer.

Pcbic forests.-Carite, Luquillo, Toro Negro. Raxge.-Known only from Cuba and Puerto Rico.

Other conmon vames.- nemocá macho, nuez moscada macho, nemocá cimmarrón, canelillo (Pnerto Rico). 


\section{LAUREL FAMILY (LAURACEAE)}

\section{Aguacate, avocado}

A guacate, the well-known fruit tree planted and sometimes growing as if wild, is characterized by : (1) shiny yellow-green pear-shaped or nearly round fruits about $4-5$ inches long and $3-4$ inches in diameter, with oily green and yellow flesh and 1 very lare seed: (i) elliptic, slightly thickened leaves crowded neal ends of twigs, slightly aromatic when crushed, 31/2-7 inches long and 2-31/2 inches broarl, long-or short-pointed at apex and short-pointed at base; and (3) numerous greenishyellow flower's abont $3 / 8$ inch across the 6 calyx lobes in many lateral branched clusters.

A small to medium-sized deciduous tree attaining 15-30 feet in height and 11,3 feet in trunk dianeter, with straight axis and symmetrical narrow or rounded crown, old trees frequently leaning. The bark is brown or alay, slightly rough and fissured. Inne! bark is ol'ange brown, slightly spicy and gritty to the taste. Twigs are green, angular, and finely hairy, becoming brown.

The leaves are alternate on yellow-green petioles 1/2-11/4 inches long. Blades are withont teeth on edges. the upper surface green to dark green, slightly shiny. liairless or nearly so, and the lower surface dull gray green, finely hairy on reins.

The flower cluster's (panicles) near ends of twigs and shorter than leaves bear finely hairy flowers on short hairy stalks when trees are leafless or nearly so. There are 6 widlely spreading, greenishyellow, narrow, hairy sepals about $3 / 16$ inch long; greenish-yellow stamens more than $1 / 8$ inch long and 3 smaller sterile stamens (staminodes); and whitish-areen pistil with 1 -celled 1-ovuled ovary and slender style.

The heavy fruits (berries), bome singly, hang down and bend the twigs by their weight. Inside the thin leathery skin is the edible thick soft flesh somewhat like butter. The brown elliptic or eggshaped seed is about $2-21 / 4$ inches long and up to 2 inches in diameter. Flowering from. Tanuary to April or May and maturing fruits from late June to October.

The sapwood is whit ish and the heartwood light brown. The wood is moderately soft, heavy (sperific gravity 0.6$)$, brittle, not durable, susceptible to attack by dry-wood termites, and seldom used.

\section{Persea americana Mill.*}

The nutritions fruits are eaten raw as a vegetable or salacl, usually with salt added. They can be adcled to somps and in lirazil are made into ice cream. Hogs, other domestic animals, and wild animals are fond of the fruits. Commercial oils, such as a substitute for olive oil and oil for the hair, have been extracted from the pulp, which is reported to have an oil content of about 14 percent. The seeds yield a reddish-brown dye for marking "lothing. Sonne parts of the plant, such as leaves, seeds, fruit rind, and bark, have been employed in folk medicines. The frigrant flowers are attractive to bees and make this tree a honey plant.

Many laces, varying in size, shape, color, and quality of fruit and time of ripening, are in cultiration. Propagation is from seed or, for the superior varieties, by budding.

Planted nearly thronghout Pnerto Rico, most commonly on the coast and in the moist limestone and lowei mountain regions. Also in Vieques, St. Croix, St. Thomas, St. Joln, and Tortola.

R.INGE.-Native of tropical America, probably Mexico and Central America and not West Indies. Widely planted and escaping or naturalized in tropical and subtropical comntries throughout the world, including sonthern Florida and Florida Keys (grown commercially also in sonthern California ), throughout West Indies, and from Mexico to Sonth America.

OTHER commox xumes.-pear, apricot (Virgin Islanls) : aguacate (Spanish); palto, cura (Colombia): palta (Ecuador, Peru, Chile, Argentina): luira-palto (Peru); a vocado, alligatorpear (ITnited States, English); avocado-pear (Triniclad and Tobago): pear, butter-pear (British Honduras): arocat, avocatier (French): zaboca (Haiti); awacati, advocaat, pear-tree (Dutch West Indies); advocaat (Surinam): abacate, abacateiro (Brazil).

Botanical synonyas.-Persea persea (L.) Cockerell, P. gratissima Gaertn. f.

A related species of the momntains of central and western Puelto Rico is known as canela (Persea hrmgii Mez). This native tree has smaller elliptic leaves $1 \frac{1}{2}-4$ inches long, hairy beneath, and much smaller rounded inedible fruits. 


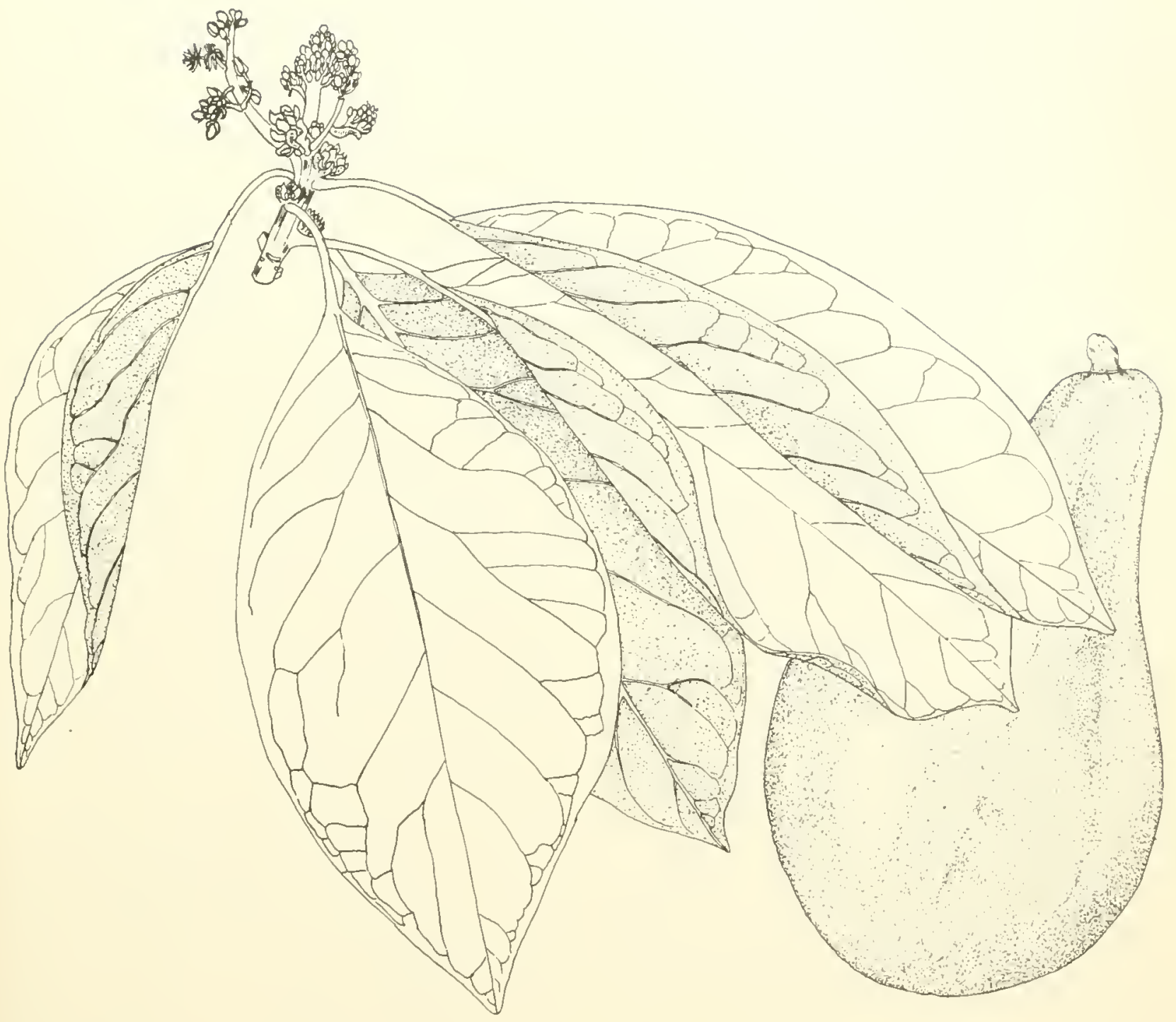




\section{HERNANDIA FAMILY (HERNANDIACEAE)}

\section{Mago}

This tree with handsone foliage is easily recognized by: (1) larere, ovate, slightly shiny, dark ereen latases with loner petioles attacherl $1 / 2-1$ inch above base of blate: (2) broad leaf hlades 7-12 inches long and $4-5$ inches wirle, lomgr-pointer at apex and lomeled at base with s main reins, 2 on each sirle of mithih: (3) inconspicuous areenishwhite flowers finely glay hairy, less than $1 / 6$ inch long. borne in lonierstalked hiteral chusters: and (4) elliptic fruits 1-1 1/4 inches loner inside a rounderl, hollow, wreen ish-yellow, lleshy case about - inches in tiameter.

A large evergreen tree becoming 60 feet high ant : feet in diameter, thick trumks with small buttresses. The light hrown birk is smoothish. slightly fiswred, with small corky warts. Immer hark is light bown, sliglutly mucilarinous ant bitter. The stout twigs are green and minutely hairy.

The leaves are alternate on light areen, minutely hairy petioles $6-10$ inches loner, nearly as long as the blades. Surromding the end of the petioles. the blades (peltate) are withont teeth on margin, slighty thickened, hairless or nearly so, and light areen heneath.

Flower clusters (crmes) are lateral, 5-8 inches long, :-6 inches aross, somewhat flattened, with linht green, finely way hairy branches. Several to many Howers are borne usually ? together, 2 male and 1 female (monoecious), albove 4 greenish-white bracts 1/4-3/8 inch long. Male flowers on stalks $1 / 8$ inch or more in length are nearly $3 / 8$ inch long and broad. consisting of usually 6 slightIy thickened greenish-white sepals more than $1 / 4$ inch long and is stamens each with 2 glandlike yellow sterile stamens (staminodes) at hase. Female flowers stalkless, nearly $1 / 2$ inch long and $3 / 8$ inch across, consist of a cuplike base $1 / 8$ inch lone aromel lower part of the inferior 1-celled ovary nearly $1 / 4$ inch long, wsmally 8 slightly thickened greenish-white sepals $1 / 4$ inch long in 2 sets of 4 earl, $t$ glandlike vellow sterile stamens (staminolles), and curved style $1 / 4$ inch long with large lobed stimma.

The swollen case around the fruit (formed from the cuplike base) is about 1/16 jnch thick, has an opening about $1 / 2$ inch in diameter, is sometimes tinered with red, and at maturity has a pleasant mellow odor like ripe apples. The single fruit
Hernandia sonora L.

(drupe) within is 3-1 inch broad, hard, blackish. with usmally is longitudinal ridges, and 1-seeded. Flowering and fruiting reported at rarions times luring the vear.

Sapwoud and heartwoor are indistinguishable, both aray y white with faint olive-(o)lored streaks and mmerous hare darlier pores. The wool is lim. soft. lirrlitweight (specific gravity 0.29 ), of low strength, and aisily worked. It is very susreptible to attack by dry-wood temites and other insects am to deray. Rate of ar-seasoning is lapid. and amount of degrade is minor. Machining characteristics are as follows: planing and smoling are poor: shaping, turnine, boring, and mortising ane ver poor: and resistance to screw prlitting is axcellent. Suitable uses are light boxes, crates, fishing floats, temporary boarding, interior construction, and as a substitute for heavier" gridles of gllano (balsa). IInwerer, scarcity limits the use in Puerto Rico.

(crasionally planted in the tropics and in subtropical Europe as an ormamental. Easily propawated from seed and arows fairly rapidly if not in dense shade. It is reported that the sap has been used as a depilatory, removing hairs from the face painlessly.

In forests and along streams in the moist coastal region of Puevto Rico. Also infrerment in cultivation as an orlamental and shade tree. Trees may he seen alonir the highway to El Iunque south of Mameyes and on the roat between Marica and Mayagiiez.

Pubirr Fonest.-Luquillo.

Raxre.-Cuba, Hispaniola, Puerto Rico, and Lesser Intilles from St. Kitts to St. Vincent and Barbados. Ilso from Mexico to Costa Rica and from Colomlia to Ecuador. Planted in other tropical and subtropical areas, including southern Florida.

Otilir common xhmes. - matra (Dominican Republic) ; hoja tamal, mano de lein, tambor (Honduras): aguacatillo (Guatemala, Costa Rica): jack-in-the-box (Barbados).

1 closely relate 3 species (II cmandia guianensis Lubl.) formerly not considered distinct is found from Trinidad and Tenezuela to the Fuianas and northern Brizil. It is called cocojolo in Tenezuela, toporite in Trinidad, and jack-in-the-box in British Guiana. 


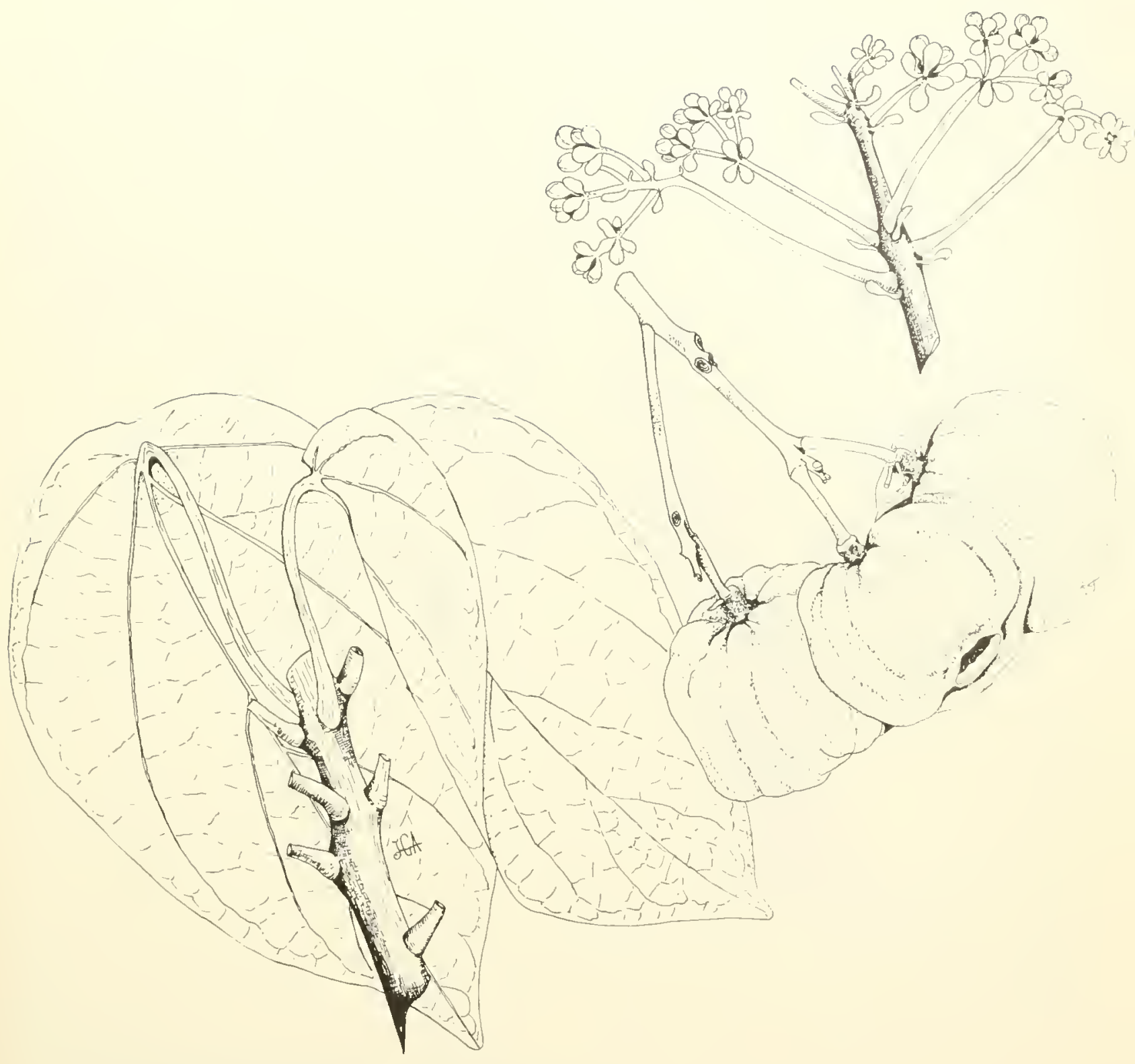




\section{CAPER FAMILY (CAPPARIDACEAE)}

\section{Burro prieto, Jamaica caper}

This mall tree or shrub of constal thickets is identified by: (1) minnte brown seales on young trigk, petioles, mnder side of leaves, flower stalks, flowers, and fruits: (2) elliptic, slightly leathery leaves short-pointed at apex and base, shiny yellow green on ulper surface and silvery brown beneath: (3) purplish flowers about $3 \frac{1}{4}$ inch across or 2 inches across the long, spreading, brushlike stamens, borne in clusters at or near ends of twigs; and (t) long, narrowly eylindrieal, light brown pods about है $(t-12)$ inches long and $5 / 16$ inch in diameter, hanging downward. exposing the bright red inne?" wall upon opening.

In evergreen tree or shrub attaining 10-20 feet in height, with dense compact crown. The dark yray or brown bark is smooth and thin, becoming fissured. Inner bark is light brown, with spicy taste like horseradish. The slender twigs are sijvery brown and angled, becoming gray.

The leares are borne singly (alternate) and have pet inles $1 / 4-1 / 2$ inch long. Leaf blades a re commonly $2-4$ inches long and $3 / 4-11 / 4$ inches broad, sometimes much longar on young plants or young shoots, the enlges slightly turned under. Different races vary in leaf sizes and shape.

Flower clnsters (corrmbs) are lateral but appearing terminal, about 2 inches long, with few to several fragrant flowers near end of an angled scaly lmown stalk. Flower buts are slightly 4:mgled. There are 4 pointed sepals $3 / 5$ inch long, finely sealy on outside and hairy on inside; 4 ellijutic purplish petals $1 / 2$ inch long, finely scaly on ontside: many purplish stamens $1 \frac{1 / 4}{-11}$ o inches long, with yellow anthers, widely spreading but som withering: and sealy, narrowly eylindrical, 1 -celled osary $3 / 16$ inch long inchiding the flat stigma, at end of stalk about 1 inch long.

The long-stalked pods, slightly narrowed between the seerls, split open irregularly to expose the many ellipt ic shiny brown seeds $1 / 4$ inch long. Diflerent trees in flower and fruit at various times thronghout the year.

The sapwood is lingt brown. The heartwood is described as yellow, tinged with red, hard, and heary. I'sed only for posts and fuel in Puerto Rico. Elsewhere occasionally cultirated in parks and as a street tree. It is reported that the roots and leaves have been employed medicinally.

In thickets, chiefly in the dry coastal region of Puerto Rico. Also in Mona, Desecheo, Icacos, Culebra, St. Croix, St. Thomas, St. John, and Tortola.
Capparis cynophallophora $\mathbf{L}$.

\section{PCblic Forest.-Guánica.}

RAxGF.-Southern Florida including Florida Kieys and Thest Indies from Bahamas and Cuba throngh Lesser Antilles. Also in southern Mexico and Central America sonth to Panama. Cultivated ontside the natural range.

Other common Names.-bejuco inglés, sapo (Puerto Rico); mostacilla, carbonero, ciguarayo, palo diablo (Cuba); olivo, frijol (Dominican Republic); zic (Guatemala); cndureee maíz (Nicaragna ); Tamaica caper, capertree, zebrawood (United States); black-willow (Bahamas, Jamaica): bois sénegal, bois cacá, bois d'argent (Haiti) : bois noir (Guadeloupe).

Botanical stwongm.-Capparais jumaicensis Jacq.

Five more species of this genus are native in pnerto Rico and the Virgin Islands. Known as burlo and caper, these shrmbs or small trees are characteristic of thickets in the dry coastal regions. Linguam (Capparis indica (L.) Fawc. \& Rendle) is the only other species with minute seales on the twigs, under side of leaves, and flowers. It differs from the species described above in its flowers with short 4 -lobed calyx only $1 / 8$ inch long and petals hairy as well as scaly.

The ot her 4 species have hairless leares and lack the minute seales. Palinguán or limber caper (Cuppuris flexuosa (L.) L.) has usually narrow, linear or elliptic leaves $2-41 / 2$ inches long and $3 / 8-2$ inches broad, blunt or notehed at apex, and romded or narrowed at base.

Sapo or rat-bean (Capparis baducca I.) has larye elliptic or oblong leaves 4-12 inches long and $11 / 2-31 / 2$ inches wide, short-pointed at apex, and romded at base, and small flowers less than 1/2 inch long with the stamens no longer than the petals.

The remaining 2 species have broader pods not marrowed between the seeds. Burro or broadleaf caper (Capparis cocrolobifolia Mart.) has stifl, leathery, broadly elliptic leares $2-41 / 2$ inches long and $1 \frac{1}{4}-3$ inches wide, rombled or notched at apex, and usually heart-shaped at base; and the fruit oblong, flattened, $1-7$ inches long and $1 \frac{1}{4}$ inches wide.

Burro blanco (Capparis portoricensis Urban) has elliptic leaves $11 / 2-41 / 2$ inches long and $1-2$ inches broad, rounded or short-pointed at apex, short-pointed at base; and the short elliptic fruit only $1 \frac{1}{4}-21 / 2$ inches long and about $3 / 4$ inch wide. 



\section{HORSERADISH-TREE FAMILY (MORINGACEAE*)}

\section{Resedá, horseradish-tree}

This ornamental planted tree is characterized by: (1) feathery or fernlike foliage of 3-pinnately compound leaves 1-11\% feet long composed of numerous thin elliptic leaflets $1 / 4-5 / \%$ inch long and $1 / 8-3 / 8$ inch broad; (2) many showy fragrant white flowers $3 / 4$ inch or more aeross the 10 spreading sepals and petals, slightly irregular, in lateral clusters 4-8 inches long; (3) large, 3-angled, brown seed rapsules $7-14$ inches long and 3 - 1 inch broad, hanging dow: and (4) roots with odor and taste of horseradish.

I small deciduous tree to 30 feet high and to 10 inches in trunk rlianeter, with speating brittle loranches. The whitish-oray bark is smonthish, fissured and waty ol colky, beeoming mollo. The twigs are finely hairy and green, beroming brown.

The alternate leaves have slender, finely hairy. green and redklish-tinged axes, the lateral ones pared. Laflets are paired except for terminal one and have minute stalks less than $1 / 16$ inch long. The blades are rom ded or blunt-pointed at apex and short-pointed at base, the edges not toothed, creen and almost hairless on upper surface, and paler and hairless beneath.

Sprealing or drooping flower clusters (panicles) have many minutely hairy flowers on slender lairy stallis. "The basil cup' (hypanthimm) 1/s incli long and broad hears 5 mequal white sepals almut ${ }^{2}$ inch long: there are sunequal white petals $3 s-5$ inch lone: 5 stamens alternating with a smaller sterile stamens (staminodes): and pistil of 1-celled ovary and slender st vle.

The seed capinles with longitudinal ridges split open aloug the 3 angles. There are many seeds about 1 inch long, composed of 3 whitish papery wings aromed a dark brown rombled center $1 \frac{1}{2}$ inch or less across. Flowering and fruiting through most of the year.

The soft wood is little nserl in Puerto Rico, but the thick soft roots are a spicy condiment. It is reported that the corliy bark ean be made into mats. Root extracts, bark, ant gum exuding from the trunk have been employed in some places in medicines.

Ben oil, elsewhere extracted commereially from the seeds of this and a related species, is a lubricant for watches and other fine mechanisms and a base
Moringa oleifera Lam.*

for perfumes and is said to be both edible and merlicinai. In some localities the young pods, voung leaves, and flowers are eaten cooked like stringlueans and greens. Leaves and twigs have been cut as fodder in India. The flower's are a sonrce of honer.

Grown chicfly as an ornamental and in fences and hedges. The plants are propagated by seeds and cutings and coppice vigorously. Though spectacular for the abundant white flowers and long seed capsules, this irregularly shaped tree with weak, easily broken branches is not so attractive mhen old. Moreover, in Puerto Rico it is very susceptible to attack by termites and for this reason not recommended as an ornamental. It is reporterl that this tree is the only tree in gardens of conthem Florida that flowers every day of the year.

Widely planted for ormament and along roadsicles and escaping from cultivation in Puerto Rico, especially in the coastal regions. 1lso in Tieques, St. Croix, St. Thomas, St. John, and Virgin Gorda.

R.unge- - Native of East Inrlies, southeastern Isia, and India, but now widely distributed through the tropics. Planted and escaped or maturalized in sonthern Florida including Florida Keys (planter also in southem California) and throughout. West Indies from Bahamas and Cnba to Trinidad and Tobago and Curaçao. Also from Mexico to Peru, Paraguay, and Brazil.

Otner commor NAMEs.-ben, ángela, jazmín flancés (Puerto Rico): moringi, palo de abejas, libertad (Dominican Republic); paraiso francés palo jeringa, ben (Cuba): paraíso de España, palláso (Central America) : perlas, paraíso blaneo (Guatemala); teberinto, terebinto (El Salvador) ; jacinto (Panama) : ángela (Colombia); horseladish-tree, drumstick-tree (Inited States, English): maranga calalú (British Honduras); saijhan. St. Joln (British Guiana) ; benzolivier, ben oleifere (Haiti): maloko (Guadeloupe); benbom, salaster. orengga, moriengo, brenolli, orselli (Dutch West Indies); peperrortelboom (Surinam).

BotaNiCaL SYYonYMS.-Moringa moringa (L.) Millsp., M. pterygosperma Gaertn. 


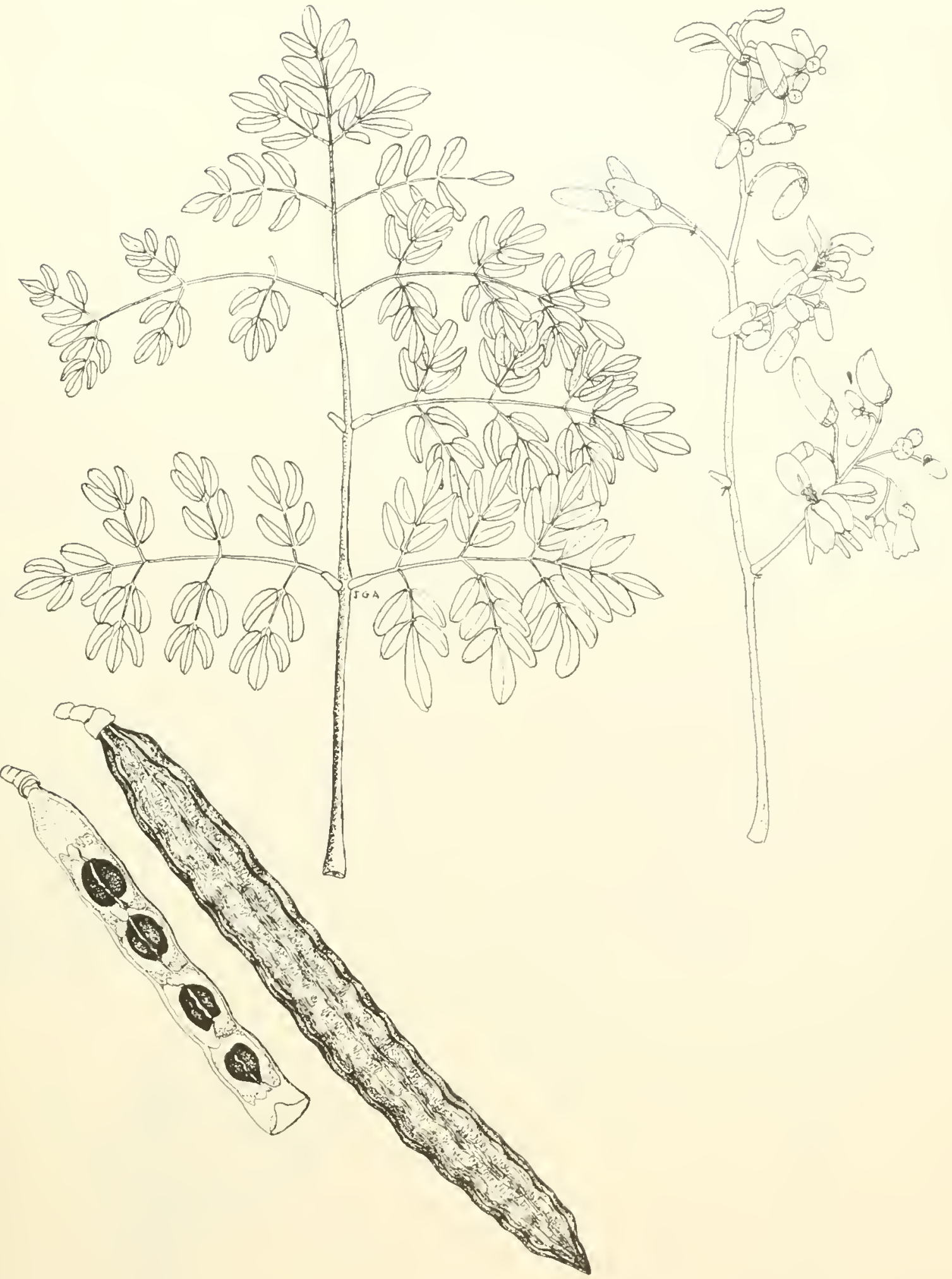

j4. Resedá, horseradish-tree 


\section{BRUNELLIA FAMILY (BRUNELLIACEAE)}

\section{Palo bobo}

This distinctive small to medium-sized tree of mountain forests, the only West Indian representative of its small family, is recognized by: (1) the opposite pinnate leaves: (2) 11-15 (sometimes to 23) oblong, lance-shaperl, long-pointed leaflets 2-5 inches long and 1-11\% inches broad, with sawtoothed edges, also pairerl except at end: (3) stout greenish twigs with rings at noles, finely rustybrown hairy, as are the leaf axes and flower clusters.

In everoreen tree attaining 15-25 feet in height and to $f$ inches in trunk diameter, with thin, open, spreading crown. I3ark on small trunks is smoothish and grats. Inner bark is light brown and slightly bitter.

The leaves are (i-15 inches long. Leaflets are almost stalkless, rounded and oblique at base. The upper' surface is green and almost hairless, and the lower surface gray green and finely hairy and with raised rust $y$-hrown hairy veins.

Flower clusters (panicles) are lateral, branched, and $2-5$ inches long and broat. The numerous short-stalked small flowers alont $3 / 16$ inch long and broad are greenish yellow, some flowers containing both sexes and also male and female on different
Brunellia comocladifolia Humb. \& Bonpl.

trees (polygamous). The calyx is deeply divided, with 5 pointed lobes about $1 / 8$ inch long, rustybrown hairy: corolla none; stamens $8-12,1 / 8-3 / 16$ inch long, inserted at base of a lobed disk; pistils 5 , separiate, 1/s inch long, hairy, each with 1-celled ovary, style, and stigma.

The fruits are star-shaped, $1 / 4$ inch across, of 5 or fewer podlike parts (follicles) each about $3 / 16$ inch long, bristly, lusty-brown hairy, splitting open, and containing 1 or 2 brown seeds. Flowers are formed in spring and summer, and fruits mature in summer.

The wood is light brown, hard, and lightweight (specific gravity 0.3). [Tsed only for fuel in Plierto Rico.

Forests of the upper Cordillera region of Puerto Rico, up to 4,000 feet elevation or higher.

Pubuic Fonests.-Carite, Guilarte, Luquillo, Maricao, Toro Negro.

RANGe.-Greater Antilles, Guadelompe, and Tenezuela and Colombia.

Other conmox Names.-cabra (Puerto Rico); guásima de pinares (Cuba) ; yuco riñón, berraco, jolo macho de tielra fría (Colombia): WestIndian-sumae (Jamaica), bois Mabel (Haiti). 


\section{CUNONIA FAMILY (CUNONIACEAE)}

\section{Oreganillo}

A small tree or shrub of dwarf forests at high elevations on mountain peaks, recognized by: (1) opposite pinmate leares 3-6 inches long with boodly winged axis and usually ?-17 stalkless elliptic toothed leaflets, paired except for the terminal one: (2) paired rounded stipules about $1 / 4$ inch long and broad, forming a rounded narrow bud but shedding early, leaving ringed scars at nodes: (3) numerous minute white flowers tinged with pink, in narrow erect lateral clusters 2-31/2 inches long: and (4) many narow 2-lohed brown seed capsules ${ }^{3}$ if inch long.

An evergreen tree or shrub to 20 feet in height and 6 inches in trunk dianeter. The dark lorom hark is smoothish, inner bark light brown and bitter, and reportedly exudes a resin. The brown twigs are densely bristly with yellow hairs when ronng, becoming blackish.

The leaves have a short hairy petiole. Leaflets are $1 / 2^{-1}$ inch long and $1 / 4^{-5} / 8$ inch broad. shortpointed at hase, rounded at apex, with margins slightly turned under, stiff, alove dark green with midrib and lateral veins sunken, and beneath light ween with laily midrib.

The flowers are 3/46 inch long and broad across the stamens and are borne on short slender stalks along a hairy axis (raceme). There are 4 or 5 minute pointed sepals, 4 or 5 white petals about $1 / 16$ inch long but falling eally, $8 \mathrm{or}^{\circ} 10$ white stamens more than $1 / 8$ inch long, and pist il less than $1 / 8$ inch
Weinmannia pinnata L.

long with 2-celled ovary and 2 white styles. Seed capsules have sepals remaining at base and 2 pointed styles at apex and contain minute hairy seeds. Flowering mainly from Iugust to October.

The sapwood is whitish, and heartwood reddish hrom. The hard, heary wood is not used in Prerto Rico. Elsewhere the bark has been employed in tanning.

In dwarf forests on mountain peaks in the upper Laquillo and upper Cordillera regions of Puerto Rico mostly above 3,000 feet elevation.

Pinlic forests.-Lmquillo. Toro Negro.

Rsxre.-Widely distributed in momtain forests at high elevations from sonthern Mexico to Peru. Brazil, and Veneznela. Also Greater Antilles and Lesser Antilles from St. Kitts to St. rincent.

OTHer comMon NAMrs.-tamarindo de loma (Dominican Repullic): sabicú marañón, sabicú de pinares (Cuba): loro, lorito (Costa Rica): encinillo, arenillo (Colombia); saisai, curtidor (Teneznela) : bastand brazilleto, wild brazilletto (Jamaica) : bois tan rouge (Guadeloupe); bois siffleur (Martinique).

A variable, widely ranging species with varieties differing in hairiness, number of leaflets, and ot her characters. 'This is the only West Indian representative of its family and of a genus common in momntain forests at high elevations in the Andes of soutl tmerica. 


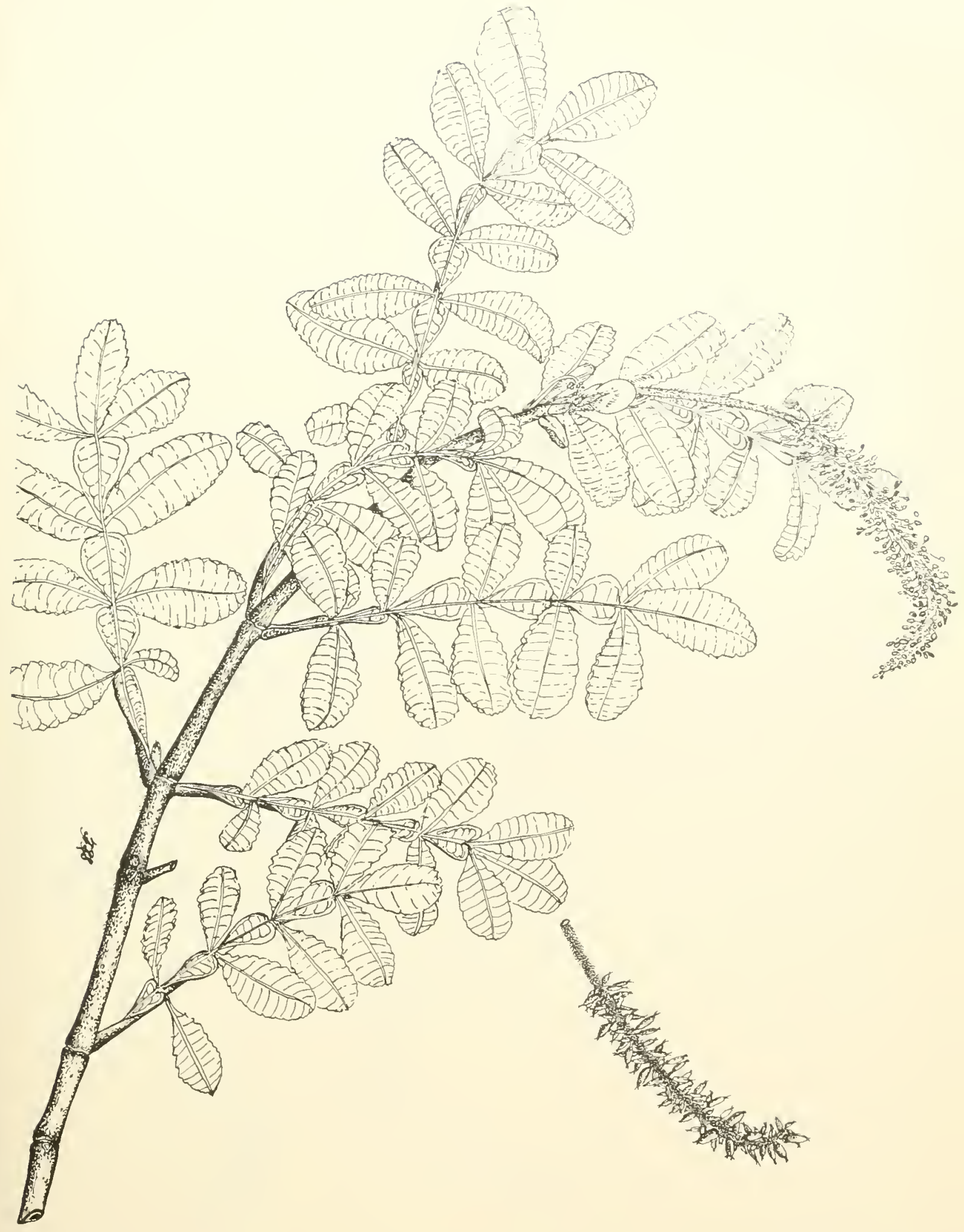




\section{ROSE FAMILY (ROSACEAE)}

\section{Icaquillo}

This small tree of monntain forests in Puerto Rico only is identified by: (1) ovite, long-pointed, shiny green, hairy leaves with veins much sunken in upper sulface and raised beneath, spreading in 2 rows on long, slender, sparsely branched, bristly hairy twigs; (2) pink and red flower's 7 's inch loner with 5 petals, a few or several in clusters almost hidden under the end leaves of a twig; and (3) dark red, elliptic, slightly flattened, 2-pointed, Heshy fruits 1,5 , inch long.

In everoreen tree generally less than 20 feet high and:; inches in trunk diameter. The bark is rray and smooth, inner bark hrown and tasteless.

The altermate leaves are stalkless or with very short hairy petioles less than 1 is inch long. Leaf blades are $1 \frac{1}{2}-31 / 2$ inches long and $3 / 1-1 \frac{1}{2}$ inches broad, romded or slinhtly heart-shaped at base, with ederes turned under, the upper surface bristly hairy on midrib, and the lower surface paler and bristly hairy on veins.

Flower cinsters (racemes) are terminal or lat(eral. 11\% inches or less in length, with few flowers on slender hairy stalks 1/4-1/2 inch long. The hairy hatial tube (hyjanthium) is about 1 s inch long and broat: there are 5 pinkisl hairy sepals $3 / 16$ inch long; 5 elliptic red petals more than $1 / 4$ inch long,

\section{Hirtella rugosa Pers.}

slightly spreading: 3 long red stamens $3 / 4$ inch long; and pistil consisting of hairy 1-celled ovary laterally placed and slender style attached near base.

The fruits (drupes) are finely harry, composed of thin, almost tasteless, juicy flesh and 1 brownish stone $3 / 8$ inch long. Flowering and fruiting nearly thronghout the year.

The sapwood is light brown. The wood is hard, strong, and heary (specific gravity 0.9), but because of the small size of the trees is little used exrept for posts and fuel.

An mnderstory tree in forests of the lower mountain regrions of Puerto Rico.

Prisic Fonfsts-Carite, Guilarte, Luquillo, Maricao. Toro Negro.

R.txge.-Momntains of Puerto Rico only.

Otier common names.-hicaquillo, jicaquillo, jumilla (Puerto Rico).

The other native species of this genus (IIirtella triandra. Sw.) is distinguished by the narrower, lince-shaped to elliptic leares very long-pointed at apex and short-pointed or rounded at base, the veins not sunken. It is found in moist forests but not confined to the mountains. 


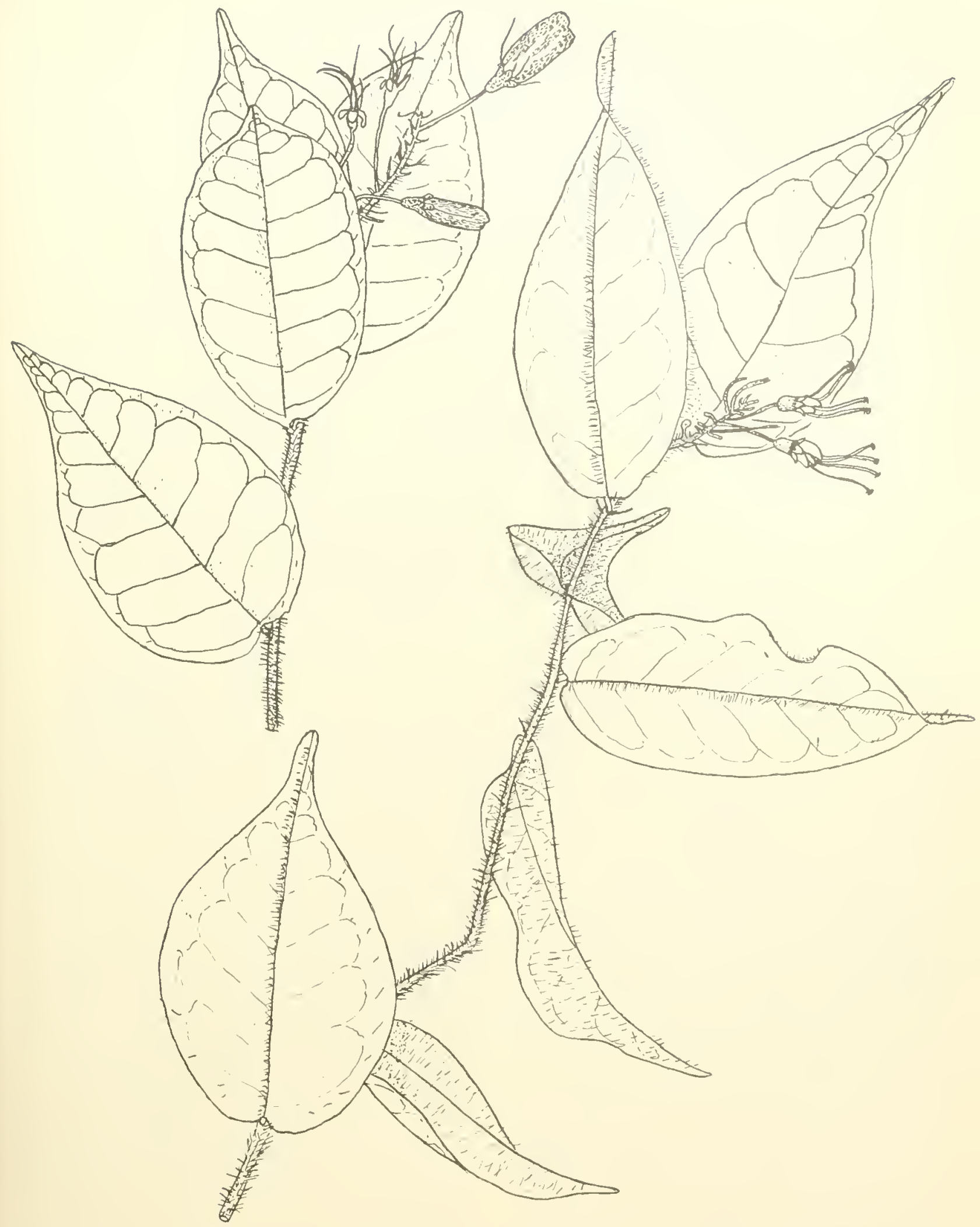

57. Icaquillo

Natural size.

Hirtella rugosa Pers. 


\section{LEGUME FAMILY (LEGUMINOSAE)}

Key to the 3 subfamilies

A. Flowers regular, with 10 to many long, spreading stamens, separate or united at base; petals meeting by edges in hud : leaves bipinnate (fimmate in Inga)-Nimosa subfamilf (Mimosoideae; Mimosaceae), this page below.

A.t. Flowers irregular, with 10 or fewer stanens, often united petals overlapping in bud.

R. Flowers only slightly irregular; the 5 petals separate, the largest petal innermost in bud; leares piunate or lipinnate, sometimes of "z leaflets or simple-Cassia subfamily (Caesalpinioileae; Caesalpiniaceae), lage $16 \times$.

BB. Flowers very irregular, lueanlike or butterfly-shaped; the 5 petals heing the standard (largest and ontermost in bud), 2 wings, and 2 slightls united forming the keel; leares pimate, sometimes of 3 leaflets-Pea Subfamily (Lotoideae; Fabaceae), page list.

\section{MIMOSA SUBFAMILY (MIMOSOIDEAE; MIMOSACEAE)}

Key to the 13 species illnstrated (Nos. 58-70)

A. Leares pinmate. the leaflets in pairs.

B. Leaf axis winged; leaflets hairy; pods nearly cylindrical, 4-angled-64. Inga vera.

IBR. Leaf axis rylindrieal, not winged : leatlets hairless or nearly so; porls thattenel.

C. Ieaflets 4 (sometimes only 2) 62 . Inga laurina.

CC. I.caflets usually 6 or 8 (sometimes 4 ) -63. Inga quatcrnata.*

AA. Leaves bipinnate.

D. Leaflets very narrow, less than $1 / 8$ inch wide, relatively long.

E. Twigs with paired spines at nodes; lateral axes (pimnae) 1-6.

F. Lateral axes 1 or sometimes 2 pairs, each with 12.25 pairs of leaflets $1 / 4-5 / 8$ inch long; spines brown or gray-70. Prosopis juliflora.*

FF. Lateral axes 2-6 pairs, each with $15-25$ pairs of leaflets $1 / s_{-3 / 16}$ inch long; spines whitisb-58. Aeaeia farnesiana.*

EE. Twigs not spiny; lateral axes (pinnae) 3 to many pairs.

G. Lateral axes no more than I0 pairs.

H. Lateral axes 3-10 pairs, each with $10-20$ pairs of gra -green leaflets $5 / 16-5 / 8$ inch long-65. Leucaena glavea.

HH. Lateral axes 8-10 pairs, each with 20-10 pairs of shiuy, dark green leaflets $3 / 8$ inch long-67. Pitheccllobium arboreum.

GG. Iateral axes 2(1-35 pairs, earb with 30-100 pairs of minute leaflets 1/8 inch or less in length-66. Piptadenia peregrina.

DD. Leaflets more than $1 / 4$ inch hroad, less than 4 times as long as broad.

1. Leaflets 2 pairs-bix. Pitherellobium dulre.*

I1. Luaflets many, lateral axes (pinvae) $2-7$ pairs.

J. Lea flets slightly diamond-shaped, asymmet rical-69. Pithecellobium saman.*

JJ. Leaflets oblong, rounded at apex.

$\mathbf{K}$. Leaflets oblique or asymmetrical at base.

L. Lateral axes $2-4$ pairs, each with $4-3$ pairs of leaflets $3 / 4-13 / 4$ inches long; the flat pods strawcolored, more than 1 inch broad-60. Albizia lebbek.*

LL. Lateral axes 4-t pairs, each with $6-14$ pairs of leaflets; the flat pods rich red, turning to brown, less than $3 / 4$ inch broad-fif. Albizia procera.*

KK. Leaflets symmetrical, rounded at both ends, with tiny point at apex-59. Adenanthera pavonina.*

\section{Aroma, sweet acacia}

A spiny shrub or small tree of dry areas, characterized by: (1) the conspicnous paired whitish spines (stipules) at nodes on the slightly zigzag twigs: (2) twice pinnate (bipimnate) leaves $2-4$ inches long, with 2-6 pairs of lateral axes (pinnae), each with 10-25 pairs of narrow (linear or oblong) stalkless leaflets $1 / 8^{-3 / 16}$ inch long; (3) very fragrant flowers in bright yellow balls (heads) about $1 / 2$ inch across the numerous stamens, on lateral stalks: and (4) dark brown to blackish pods $11 / 2-3$ inches long and $3 / 8-1 / 2$ inch broad, straight or slightly curved, $1-3$ on a stalk.

A deciduous shrub usmally less than 10 feet high or sometimes a small tree, much branched and spreading. The bark is dark brown and smoothish. The twigs are dark brown with light colored dots (lenticels) and with paired spines $1 / 8-3 / 4$ inch or more in length.

Often the alternate leaves are crowded on short spmr twigs and appear to be more than 1 at a node. The slender hairy axis hears a minute round

\section{Acacia farnesiana (L.) Willd.*}

gland. The thin green leaflets sometimes as much as $5 / 16$ inch long are short-pointed at apex, rounded at base, and hairless or sometimes hairy around edges.

Flower heads are borne 1-3 together on hairy stalks $3 / 4-11 / 2$ inches long and composed of numerous narrow flowers about $1 / 4$ inch long ending in very many yellow threadlike stamens. The tubular" 5 -toothed calyx is $1 / 16$ inch long; the tubular 5 -tonthed corolla is $1 / 8$ inch long; there are many threadlike stamens almost 1/4 inch long: and pistil $3 / 16$ inch long of narrow ovary and slender style.

The pods are thick and only slightly flattened and only a little narrowed between the seeds, contain sweetish pulp, and open late. There are several brown seeds, elliptic and slightly flattened, $5 / 16$ inch long. Recorded in flower from November to February. The fruits remain attached after maturing.

The sapwood is yellowish and the heartwoor reddish brown. The wood is hard and heary 


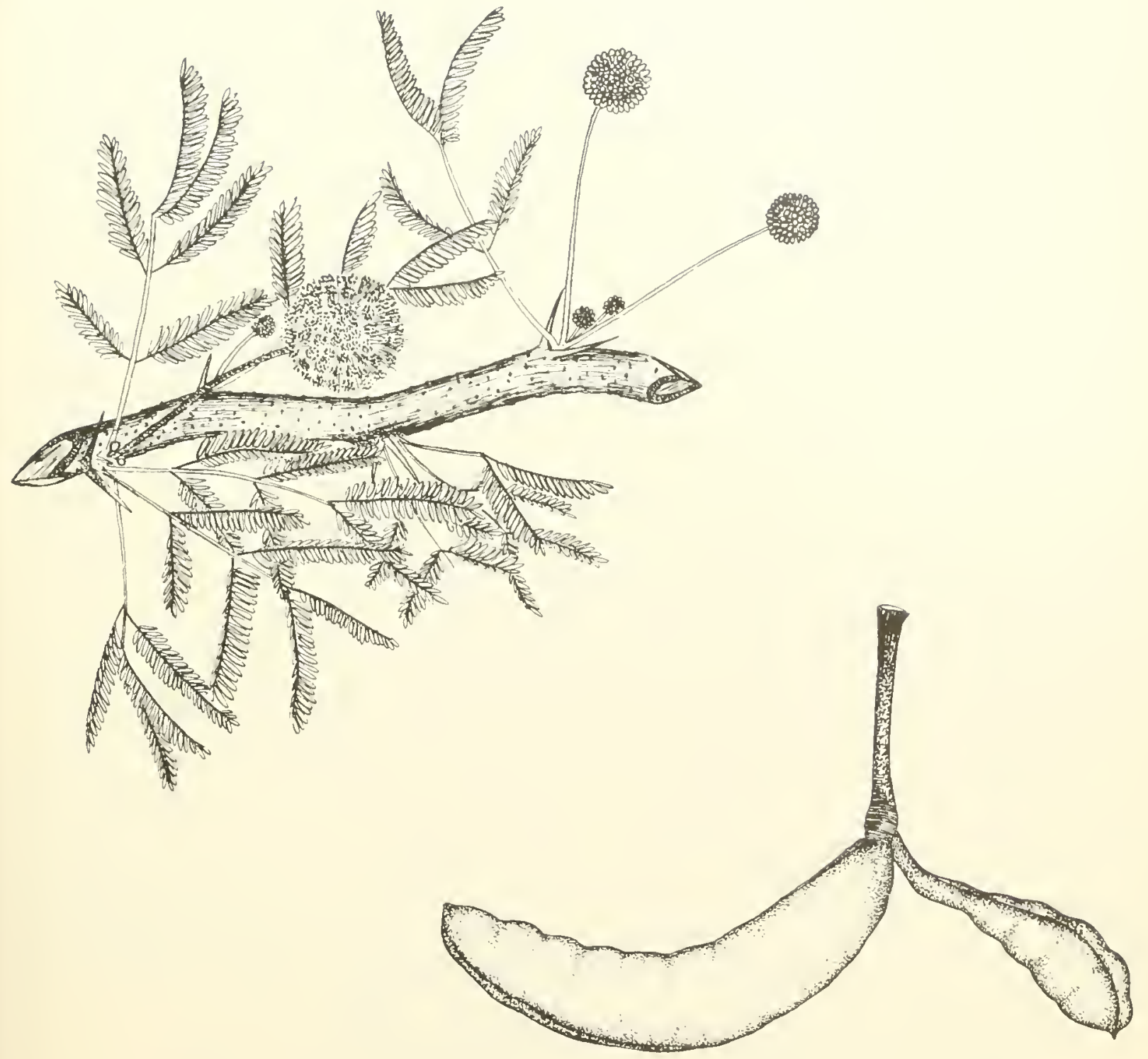


(specific gravity O.S). Tsed only for fuel in Pllevto Riun beraiue of the small size but elsewhere serving for tool hambles and firm implements.

The shubs are occisionally eultirated around homes and in warlens as ormamentals and in India for herlgres:

() ne of the principal products of this species is the perfume distilled from the flowers, known commercially as "cassie flowers." In sonthern Furope the shrubs are cultivated for this purpose. Likewise, in tropical Imerica the flowers. after drying in the shate are placed between linens to perfume them or put in clothes cabinets. The flowers are visited by hees. The leares and pods are browsed by livestock. The bark and astringent pods, which are high in tamin content, are nsed in taming, and the porls also in making ink and a hlack dye. The flowers, green fruits. bark, roots, and leaves have also been employed in local remedies. Mucilage ean be prepared from the gum which exudes from the trunk and whin resembles gum alabic, obtaned from an Ifrican species of the same genus. The sticky juice of the pods has serred to mend broken china.

In thicliets and forests in the dry coastal and dry limestone legions of Puerto Rico. Also oceasionally planted in gardens. Also in Vieques, St. ('roix, st. Thomas, St. Joln, Tortola, and Virgin Gorda.

Pumalc Fumests.-Guániea, Maricao, Susúa.

Raxw- Widely distributed in tropical America and spread by eultivation and naturalization. Sonthwestern border of [Tnited States (Texas, Arizona, and (allifornia) and Mexico to Chile and Argentina. Also through Test Indies from Bahamas and Cular to Trinidad and Tobago and ("uracin and Iruba. Naturalized in southeastern Thited States (Florida to Lonisiana). Also naturalized in Old World tropies.

This species spreads rapidly and may appear to be uative in areas where it was brought in many years ago. In most of the West Indies perhaps introduced and naturalized. IIowever, it has been accepted as native in Cuba. The type botanical specimen was collected in the Dominican Republic.

Otuer comrox s.mes.-casha, cassia (Tirgin Islands) ; aroma, aromo (Spanish) : cambrón (Dominican Republic): aroma amarilla (Cuba); huisache, quisache, binorama, subinche (Mexico): espino blanco, espinal, subín (Guatemala); eachito do aromo, espino, subín (Honduras); espino blanco, espino ruco (El Salvador): eachito de aromo (Nicaragua); pelá, eluji cimarrón, uña de cabra (Colombia) ; euji aromo, pauji (Venezuela); huaranga (Perm): espino blaneo (Bolivia); espinillo (Lruguay, Irgentina) ; sweet acaeia, cassie, huisache (United States): aroma, cashia, opoponax (Bahamas); cassie-flower (Jamaiea); cuntich, cashaw (British Honduras) : casha, eassie (St. Barthélemy) : acacia odorant (Guadeloupe) : casha (Dutch Virest Indies) ; esponjeira (Brazil).

Botaxical sryonm.-Tachellia firmesiana (L.) Wight \& Arn.

1 few other speeies of acacia, characterized by twice pinnate leaves and mostly paired spines, are luative $n$ introduced trees and shrubs. Acacia undosa or spineless acacia (Acacia muricata (L.) Willd.) is a small tree with no spines. leaflets 8-16 pairs on each axis, and many small whitish flowers along an axis.

Suma-eatechu (Acucia sumu (Roxb.) Inurz), an Old World tree introduced on St. Croix, has leaflets 10-40 pairs on eacl axis and small whitish flowers along an axis.

The others have small yellow flowers in balls. Tamariudo silvestre or steel acacia (.tcacia macracunthr Humb. \& Bonpl.; synonyms A. macracanthoides Bert., Poponux macracanthoides (Bert.) Britton \& Rose), of the Virrin Islands, has leaflets 15-40 pairs on each axis and pods somewhat Hattened.

Twisted acacia or cassia (Acacia tortuosa (L.) Willd.; syllonym Poponar tortuosa (L.) Britton \& Rose), of the Virgin Islands, has leaflets 10-20 pairs on each axis and pods nearly eylindrieal.

Goma a rábiga or gum-arabic (Acacia nilotica (L.) Delile*), from Ifriea, is sometimes planted for ornament and is reported to be naturalized locally. It has $10-30$ pairs of leaflets on each axis and narrow flattened pods narrowed between the seeds.

Anegada acaeia (Acacia anegadensis Britton: symonym Fishlockia anegadensis (Britton) Britton \& Rose), known only from the island of Anegada, has leaves with only 1 pair of lateral axes, each with 1 or 2 pairs of leaflets.

\section{LEGUME FAMILY (LEGUMINOSAE) MIMOSA SUBFAMILY (MIMOSOIDEAE; MIMOSACEAE)}

\section{Peronías, jumbie-bead}

This introduced tree. loeally natmralized, is identified by: (1) the large twice pimnate (bipinnate) leaves $1-2$ feet or more in length, composed of numerous oblong thin leaflets romded at both ends and with a tiny point at apex: (2) the erect narlow flower clusters $4-\bar{i}$ inches long, containing numerous erowded, small, pale yellow flowers $1 / 4$ inch aeross; and (3) the shiny scarlet lens-shaped seeds
Adenanthera pavonina $\mathrm{L}^{*}$

$3 / 8$ inch in diameter and nearly $1 / 4$ inch thick, borne in pods $6-10$ inches long.

A medium-sized decidnons tree to 40 feet high and $1 \frac{1}{2}$ feet in trunk diameter, with spreading crown. The brown bark is smoothish with many small fissures. Inner bark is light brown. Twigs are stout and green. 

The main axis of the alternate leaves is green, tinged with brown, with $2-5$ pairs of lateral axes (piunae), and the latter each bearing 11-21 leaflets. The leaflets also are altermate on short stalks less than $1 / 8$ inch long and with blades $3 / 4-13 / 4$ inches Inng and $3 / 8^{-7 / 8}$ inch broad, edges not toothed, minutely and very inconspicuonsly hairy on both sides, dull green on upper surface, and blue green beneath.

Flower clusters (racemes) are lateral and terminal, slender and unbrancled, with many small flowers on stalks about $1 / \mathrm{s}$ inch long. The tiny light green calyx 1/16 inch long is bell-shaped, 5toothed; the 5 spreading, narrow, pointed, petals $1 / 8$ inch long; 10 stamens a little longer than petals, pale yellow with browl anthers; and pistil $3 / 16$ inch long with light green 1 -celled ovary and slender style.

The dark brown pods are $1 / 2-3 / 4$ inch broad, curved, somewhat fleshy, flattened between seeds, splitting into 2 parts and twisting upon opening. The several showy seeds (about 1,600 to a pound) adhere to the opened pods. Flowering usually from late summer to winter (August to January), the fruit maturing in fall and winter and remaining attached for some time.

The sapwood is light brown and hard. Heartwood is reddish. The wood is hard, heary (specific gravity 0.6-0.8), strong, and durable. It is used as roumiwood or fuel. Elsewhere the rood has been employed in construction and cabinetwork and is the source of a red dye.
This is a shade tree and ornamental in Puerto Rico. In Malaya grown as a shade tree for plantation crops. 'The shiny bright colored seeds after softening in boiling water serve as beads in necklaces and novelties.

Naturalized in the coastal and moist limestone regions of Puerto Rico. Also in St. Thomas, St. John, and Tortola.

Publat Forests.-Cambalache, Guajataca, Maricao, Río Abajo, Vega.

RANGE.-Native of tropical Asia, first described from India. Planted and naturalized in other tropical regions including West Indies from Cuba and Jamaica to Trinidad and Tobago. Grown in southern Florida and California. Cultivated in Dutch West Indies and Sonth America from Venezuela to Brazil but very rare in Central America.

Other commos vames.-coralitos, coral, mato colorado, palo de mato, peronías chatas (Puerto Rico): Circassian-bean, coquelicot (Virgin Islands); coralitos, peonía (Dominican Republic); coralín, coral, coralillo (Cuba); sandal beadtree, red sandalwood, Circassian-bean, Circassian-seed (UTnited States) ; red sandalwood, Circassian-seed (.Tamaica, Trinidad); l'église (Grenadines); jumbie-bead (Trinidad) ; buckbead (British Guiana ) ; réglisse, arbre à réglisse, arbre à graines réglisse, corail végétal (Guadeloupe) ; pau tento. tento carolina (Brizil).

\section{LEGUME FAMILY (LEGUMINOSAE)}

\section{MIMOSA SUBFAMILY (MIMOSOIDEAE; MIMOSACEAE)}

\section{Acacia amarilla, tibet, lebbek}

A common introduced roadside tree of the drier areas, acacia amarilla is characterized by: (1) twice pinnate leaves (bipinnate) 6-16 inches long, with 2-4 pairs of lateral axes and with many oblong leaflets $3 / 4-13 / 4$ inches long and $3 / 8-5 / 8$ inch broad, romded at both ends and very oblique at base; (2) quantities of many fragrant creamcolored flowers clustered together at end of a lateral stalk in a rounded mass $2-3$ inches across the many threadlike, spreading, whitish to yellow stamens tipped with light green; and (3) flat, broad, straw-colored pods 48 inches or more in length and $1-11 / 2$ inches broad, usually present in quantities.

A medium-sized decicluous tree $20-40$ feet high and to $11 / 2$ feet in diameter or larger, with spreading crown of thin foliage. The gray bark is smoothish, becoming fissured or rough, the inner bark pink and bitter. The twigs are greenish, becoming gray or brown.

The alternate leaves have a greenish or yellowbrown leaf axis bearing a small elliptic gland on upper side near base and $2-1$ pairs of lateral axes

\section{Albizia lebbek (L.) Benth.*}

(pinnae), each with 4-9 pairs of leaflets. Leaflets have very short stalks less than $1 / 16$ inch long and thin blades, with the midrib not in center and sometimes a second prominent vein from base, the edges not toother, dull green above, and beneath light green and sometimes minutely hairy. The terminal leaflets are broadest above middle (obovate).

Rounded clusters (umbels or heads) of many spreading sholt-stalked narrow flowers are borne at the end of lateral stalks $11 / 2-4$ inches long, singly or 2-4 together, each flower on a short slender hairy stalk almost $1 / 4$ inch long. The individual flower $1 \frac{1}{4}-11 / 2$ inches long to end of stamens has a tubular 5-toothed hairy calyx $1 / 8$ inch long, narrow tubular white corolla $5 / 16$ inch long including 5 pointed lobes hairy at end; many threadlike spreading stamens united into a tube near base, whitish turning yellow, and light green toward tip; and pistil of narrow ovary and threadlike style.

The seed pod, short-pointed at both ends, contains a row of several seeds and is swollen and de- 


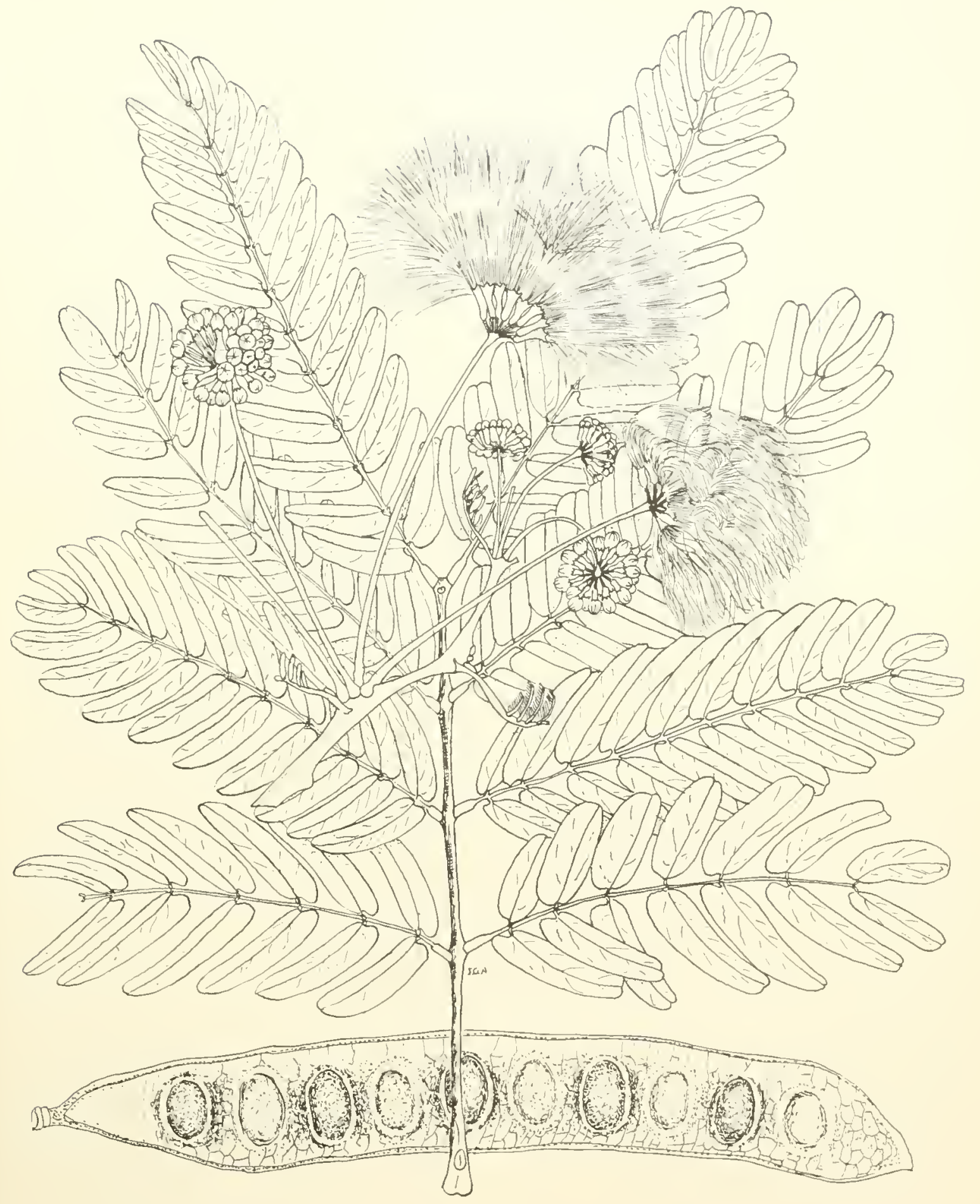

60. Acacia amarilla, tibet, lebbek 
pressed a round earl seet. The oblong flattened hrown seerls are ${ }^{3}$ s inch long. Jouls are produred in great quant it ies, loner persistent on the branclies, late in opening, remaining after the leaves are shed. Flowering from April to september and with fruits nearly thromgh the year.

The sapword is whit ish, and the heart wood light vellowish brown to light brown. The wood is inolerately hard, coarse-crlained, strong, and fairly durable. It seasons well and works and polishes easily. In Puerto Rico used only for fuel and posts. Elsewhere the wood has been employed for fumiture, paneling, ventering, turnery, and general construction. The bark has served in tanning, and a few parts of the tree in medicines.

Propagated rearlily from seed, the trees urow well in dry areas, where they are sufficiently hardy to berome naturalized. Reported to be tolerant of salt spray and suitable also near seashores.

Panted for shade and ornament a loner roarlsides and around houses, and naturalized in pastures and on hillsides in the moist and dry coastal regions of Puerto Rico. Also in Culebra. Tieques, St. Croix, st. Thomas, st. John, and Tortola.

R.x.e.-Native probably of tropical Asia including India and Bumma but now widely planted and naturàlized througl the tropics. Southem
Florida including Florida Kés, Bermuda, and thronghout West Indies. Also from British Honduras throurh Central America and South America to Brazil.

Otner common Names.-lengua de mujer, lengua viperina, casia amarilla, acacia, aroma, amor platónico (Puerto líico) : woman's-tongue, tibettree (Virgin Islands) ; charhá (Dominican Republic); algarrobo de olor, aroma francesa, forestina, "abellos de ángel, músico (Cuba) : acacia, can juro (El Salvador') ; pisquín, muche, carbonero de sombrio, guarmuche, dormilón (Colomhia); barba de caballero, samán (Teneznela); lebbek, lebbek albizia (United States) : koko (United States, commerce): tibet-tree, woman's-tongue, siris-tree (English) : black-ebony (Bermuda) : singer-tree, whistling-bean (Bahamas); shack-shack. WestIndies-ebony, East-Indian-walnut (Trinidad): tcha-tcha, bois noir" (Haiti); vieille fille (Guadeloupe) : barba di junkuman (Dutch West Indies) : coração de negro (Brazil).

The peculiar rattling sound produced by the continual movement of the dry pods in the wind is the origin of the common nime of woman's-tongue (lengua de mujer) and in Cuba the more pleasant one. músico (musical).

The generic name is spelled also Albizzia.

\section{LEGUME FAMILY (LEGUMINOSAE)}

\section{MIMOSA SUBFAMILY (MIMOSOIDEAE; MIMOSACEAE)}

\section{Albizia, tall albizia}

This exot ic tree of relatively recent introduction is planted along roadsides and in gardens. It is identified by: (1) twice pimnate leaves (bipinnate) 1-2 feet lon: with many oblong leaflets reddish in color when first produced, $3 / 4-11 / 2$ inches long and $5,6^{5}, 9$ inch wide, short-pointed at both ends and very oblique at base: (2) showy flowers numerous in whitish balls with many spreading stamens about 7 s inch across: and (3) thin flat pods 3-7 incles long and nearly $3 / 4$ inch broad, rich red but turning to brown, containing a central row of 6-12 elliptir flattened areen-brown seeds about $1 / 4$ inch long. From acicia amarilla (Albizia lebbek (L.) Benth.*) it differs in having smaller flowers and seed porls and in the larger number of lateral axes in the leat $f-7$ pairs.

1 rapidly wrowing deciduous tree becoming 30-60 feet tall with straght trunk 1-2 feet in diameter, few branches, and spreading thin crown. 'The bark is smoothish, varying from very light. brown to whitish or light greenish gray. Inner bark is soft and pinkish with a strong, peculiar, bitter, astringent, and irritating taste. The stout twigs are greenish brown, with many small longitudinal ridges.

The vellow-green axis of the alternate leaves hears an elliptic gland $1 / 2$ inch long on upper side ne:ur the enlarged base and 4-7 pairs of slender

\section{Albizia procera (Roxb.) Benth.*}

lateral axes (pimnae). There are $6-14$ pairs of leaflets with short stalks $1 / 16$ inch long on each lateral axis. The thin leaflet blades with the side nearer axis much broader, not toothed on edges, the upper surface dull green, and the lower surface pale gray green and inconspicuously hairy.

Flowers are borne on several lateral axes (racemes) 3-9 inches long near the end of a twig. In indiridual flower is stalkless and nearly $3 / 8$ inch long, including the stamens, and has a greenish 5 -toothed calyx tube about $1 / 8$ inch long; a whitish narrow corolla nearly $1 / 4$ inch long including tube and 5 pointed hairy lobes; many white threadlike spreading stamens about $7 / 16$ inch long, united into a tube in lower part; and pistil with small narrow ovary and threadlike style.

The pods, long-pointed at both ends, contain fi-12 seeds and have an enlarged dark spot ontside each seed. I ater they split open along 1 side to expose the papery walls and release the seeds. At matmity the large masses of red pods against the green foliage are showy, and then the brown dead open pods remain on the tree for some time, until the whole twig bearing the pods is shed. These pods and fallen leaves make modesimble litter in lawns and gardens. Recorded in flower in August and September and in fruit from. January to.June.

The sapwood is whitish to light yellow, and 


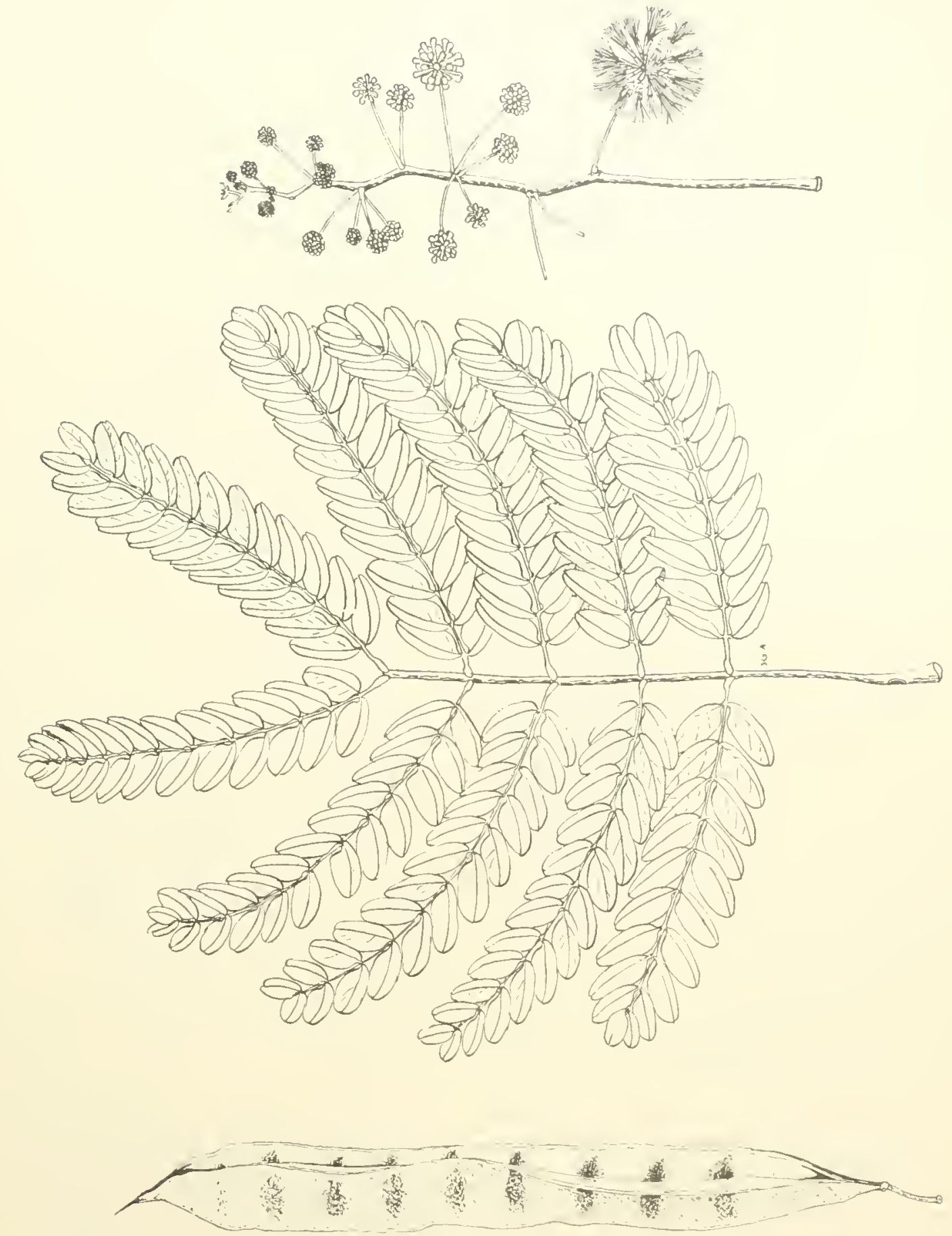

61. Albizia, tall albizia

Albizia procera (Roxb.) Benth Leaf, one-third natural size. Flowers (above) and pod (below), two-thirds natural size. 
heartwood is light brown to light chocolate brown. The worl is moderately harl and is resistant to attack by dry-wood termites. Tised for shade and fuel. In India the woorl has been employed for construction and agricultural implements.

Introlneed by the Commonwealth Forest Service in 102t and sparingly planted in Prerto Rico, such as along roadsides for sharle and fenceposts in the dry areas and in gardens. The propagation of this species for fam plantings was ineleased during the $1940^{\circ} \mathrm{s}$ becaluse it wis considered a promising rapid-growing fuel wood species for the coastal and lower mountain regions. The trees may be raised from seed or enttings. However, most of the trees have suffered sererely fiom a fmurns disense which causes dieback or death. For this reason the species is no longer propagated. Listed from st. Thomas more than a century ago.

River.- Native of tropieal Asia from India to China and to Anstralia. Apparently an nneommon introduced tree in the Ameriean tropies. Sometimes planted in southern Florida.

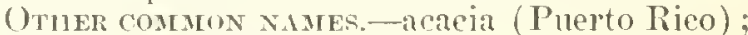
tall albizia, white siris (English).

\section{LEGUME FAMILY (LEGUMINOSAE)}

\section{MIMOSA SUBFAMILY (MIMOSOIDEAE; MIMOSACEAE)}

\section{Guamá, "sweetpea"}

Guama. which is commonly used for coffee shade, is characterized by: (1) alternate pinnate hairless leaves with leaflets usmally 2 pairs (sometimes 1 pair), green to dark green, elliptic ol ovate, the outermost leaflets nsually considerably larger than the first pair, shightly thickened, nearly stalkless, and with a minute round gland on the wingless axis between each pair; (2) many white brushlike flowers with numerous spreading stamens and 1 inch across on an axis $3-6$ inches long: (3) flat pods $21 / 2-41 / 2$ inches long and $3 / 4-11 / 4$ inches thick, slightly curved and with raised border; and (4) whitish bark with prominent horizontal dark lines (lenticels).

A medium-sized evergreen tree 50-70 feet high and $1 \frac{1}{2}$ feet in trmuk diameter, with a rounder dense crown of dark green foliage. The inner lark is reddish and slightly bitter. The twigs are green when young, tmining brown, with many raised dots (lenticels).

Leaves are mostly $3-8$ inches long, the slender green axis 1-4 inches long. Leaflet blades are 2-t inches long and 1-2 inches wide, blunt- or short-pointed at apex. short-pointed and slightly oblique at base, slightly shiny above, pale green beneath, not toothed on edges.

Flower clusters (spikes) are lateral or terminal, single or paired, many slightly fragrant stalkless flowers being bolne on a slender axis. The individual flower, about $5 / 8_{-3 / 4}$ inch long to end of the stamens, has a greenish tubular 5 -toothed ealyx less than 1/8 inch long: greenish funnel-shaped tubular 5-lobed eorolla more than $1 / 4$ inch long; many spreading white threadlike stamens $5 / 8-3 / 4$ inch long, united into tube in lowel part; and pistil $5 / 8$ inch long composed of slender ovary and threadlike style. Often the flower cluster is deforned and much branched as in a witches'-broom.

The pods are $1 / 8^{-3 / 16}$ inch thick, rounded at both ends, green when immature, turning brown, almost without edible pulp around the several seeds, not splitting open. Flowering and fruiting throngh the year.
Inga laurina (Sw.) Willd.

The sapwood is whitish, and the attrative heartwood pale reddish brown, often streaked with darker brown. The wood is moderately hard, moderately heary (specific gravity 0.62), coarsetextured, strong, tough, and easily worked. It is very suseeptible to decay and to attack by drywood termites. The rate of air-seasoning is lapid, and amount of degrade is moderate. Machining characteristies are as follows: planing, turning, boring, mortising, and resistance to screw splitting are good: shaping is fair : and sanding is excellent.

The wood is suitable for fumiture, eabmetwork, tool handles. interior trim, general and heavy construction, erates, boxes, and flooring and has been recommended for veneer and plywood. However, in Puerto Rico it is seldom used except for fuel, chareoal, and fenceposts.

The trees are planted extensively for coffee shade and elsewhere for shade for cacao also. This is an important honey plant.

Forest and collee plantations in the moist coast, moist limestone, the lower mountain, and the upper Cordilleria regions of Puerto Rico. Also in Vieqnes, St. Croix, St. Thomas, St. John, Tortola, and Virgin Gorda.

Prblic forests.-Cambalache, Carite, Guajataca, Guánica, Guilarte, Luquillo, Maricao, Río Ibajo. Susúa. Toro Negro, Tega.

Municlpalities Where espectally COMMON.-6. $47,53,59$.

RAxae-- Vest Indies from Hispaniola and Pnerto Rico and Virgin Islands to Grenada and Barbados and Trinidad, and in northeastern Venezmela (Snere). Also from westem Mexico (Jalisco and Gnerrero) and Guatemala to Panama. Introduced into Cuba for coffee shade.

OTHER COMMON NaMes.-Spanish-oak, pomshoek (Virgin Islands) ; jina (Dominiean Republic) ; guamá de Puerto Rico (Cuba) ; palal (Guatemala); eujinicuil, paternillo, chapernillo (El Salvador): glavo (Panama); sackysae (Trinidad) : Spanish-oak (Montserrat, Barbados); pois doux, pois doux blane (Guadeloupe) : pois doux (Martinique). 

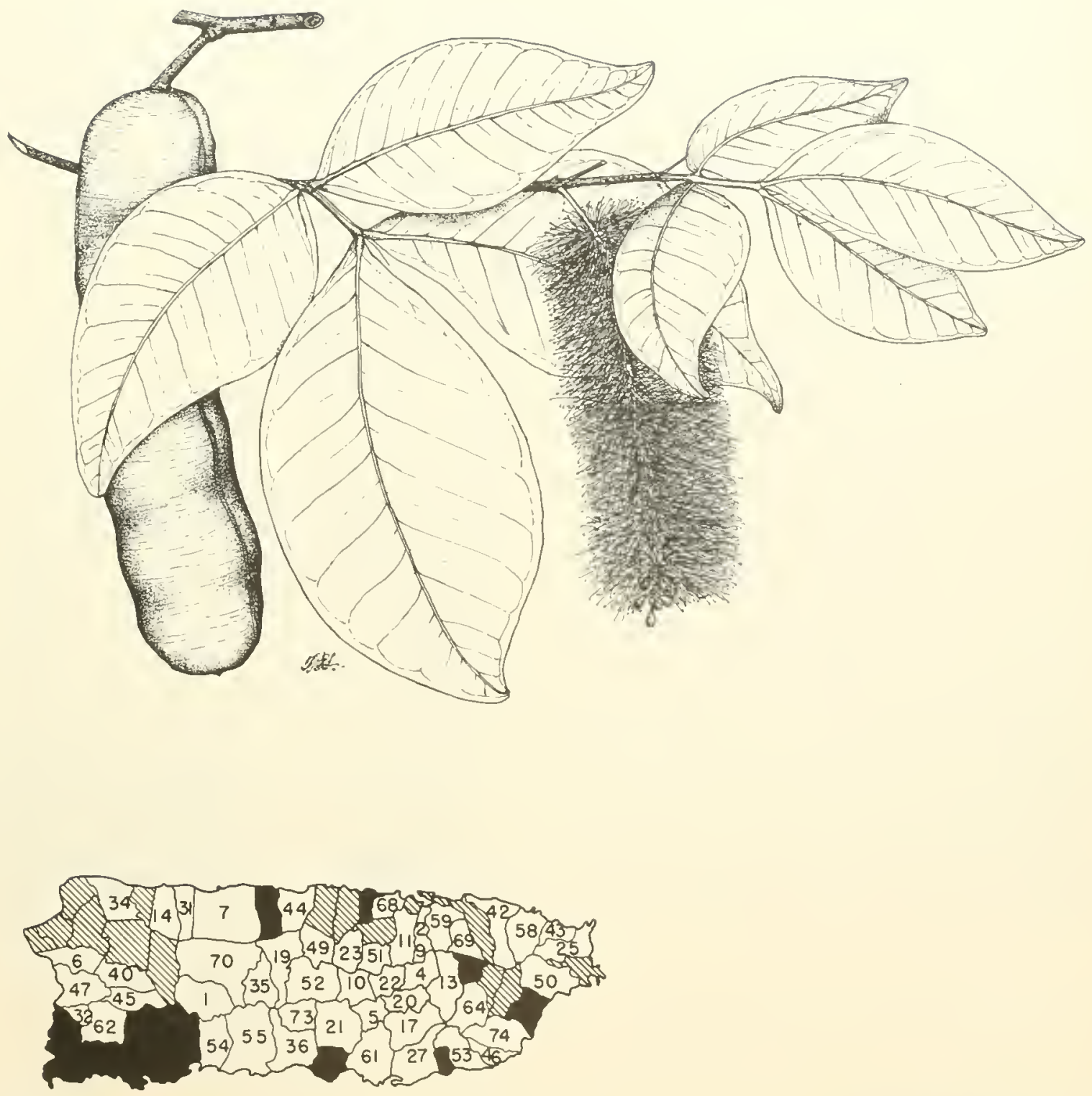

62. Guamá, "sweetpea" 


\section{LEGUME FAMILY (LEGUMINOSAE)}

\section{MIMOSA SUBFAMILY (MIMOSOIDEAE; MIMOSACEAE)}

\section{Guamá renezolano}

A rapidly orowing spreading tree with a dense rown, relaterl to the native guaba and guamá and introluced for roffee shade, characterized by: (1) alternate pimate leaves with usmally 3 or 4 pairs (sometimes 2 ) of obovate to oblong. nearly hairless. stifl, slightly leather'y leaflets, $21 / 2-6$ inches long, beconing larer toward apex, shortstalked, and with a round raised gland $1 / 16$ inch across on the wingless axis bet ween each pair of leatlets: (2) the lonse ball-like flower cluster about ¿ inches aross the many spreading threadlike white stamens, the numelous individual flowers on stalks $1,-3$ inch long: and (3) fruit a flattened but thick pod $1-6$ incties long and 1-13/8 inches broad with raised horder, and often a little curved.

A small to medium-sized evergreen tree, reachind a height of 25 feet and trunk diameter of 3 inches or nuore at age of ahout 5 years. When older. attaining a height of 30 feet and a diameter of 10 inches. Bark brown, snooth at first, ridged slightly later. The inner bark is light brown and lightly bitter. 'The twigs are dark brown and finely lairy when young.

Leares are $i-1 \dot{2}$ inches long. with a brownishureen or brown axis $21,6-6$ inches long, finely hairy, not wingerl. and ending in a point beyond last pair of leatlets. The leaflets have short st out stalks about. 's inch long. Isaflet blades are 1-31/2 inches wille. mostly short-pointed at both ends and broadest above middle, not toot hed, nearly hair]ess except on reins, above yellow green to green and sightly shiny, and beneatly dull light green.

Flower clusters (umbels) are borlue at the end of a lateral stalk 1/2-1 inch long, usually 2 clusters at base of a leat. The narrow tubular light green alyx of the slightly flagrant flowers is $3 / 16$ inch long. s-tonthed and finely laniry: the narrow tubular whitish-green corollis aboit $3 / 8$ inch long, 5tonthed, and finely hairy; the numerous white stamens are $\pi / s-1$ inch long including the tube
Inga quaternata Poepp. \& Endl.*

mearly half the length and spreading $3 / 4$ inch across: and the pistil about $\mathrm{z} / \mathrm{s}$ inch long consists of namo orary and threadlike style.

The pols are about $1 / 2-5 / 2$ inch thick, mostly momled at both ends with a narow point at apex and stalk at hase, light green, tuming brownish, heroming hairless, and do not split open. There are sereral oblong seeds about $3 / 4$ inch long in a thin white sweetish pulp. This whitish pulp is erlille but too thin for the pods to be of commer"ial importance. Probably flowering and fruiting irregularly through the year. Flowers collected in . Inly and Angust.

The whitish sapwood is hard. The tree has been used only for coffee shale and fue] in Puerto Rico to date, mainly because of relatively recent int roduction.

Introduced about 1930 and distributed by the luerto Rico Forest Service for coffee shade, this tree was it first thought to be immune to attack by hormiguilla, an insect pest on the related native species. It has since proved susceptible: but as the tree is very adaptable, survives well, provides a low shade at early age, and is very easily propicated. it probably will continue to be used for this purpose. Now found in coffee plantations in the upper and lower Cordilleri regions and in the moist limestone region.

Rixge-Couthern Mexico and Guatemala to Ecrlatol', Perm, and Brazil.

Other Comion rames.-bribri (Panama); shimbillo ('Peru).

Botantcal synoxyms.-Inga roussoviana Pittier, I. speriosissima Pittier.

Besides the 2 native and 1 introduced species described here, a few other species of Inga have been planted for coffee sharle. Guamá peludo (Ingu fustuosa Willd.*), flom Venezuela, is easily reconnized by the reddish-hairy twigs and large flat pods up to 12 inches long and $2 \frac{1}{2}$ inches wide, also reddish hairy. 


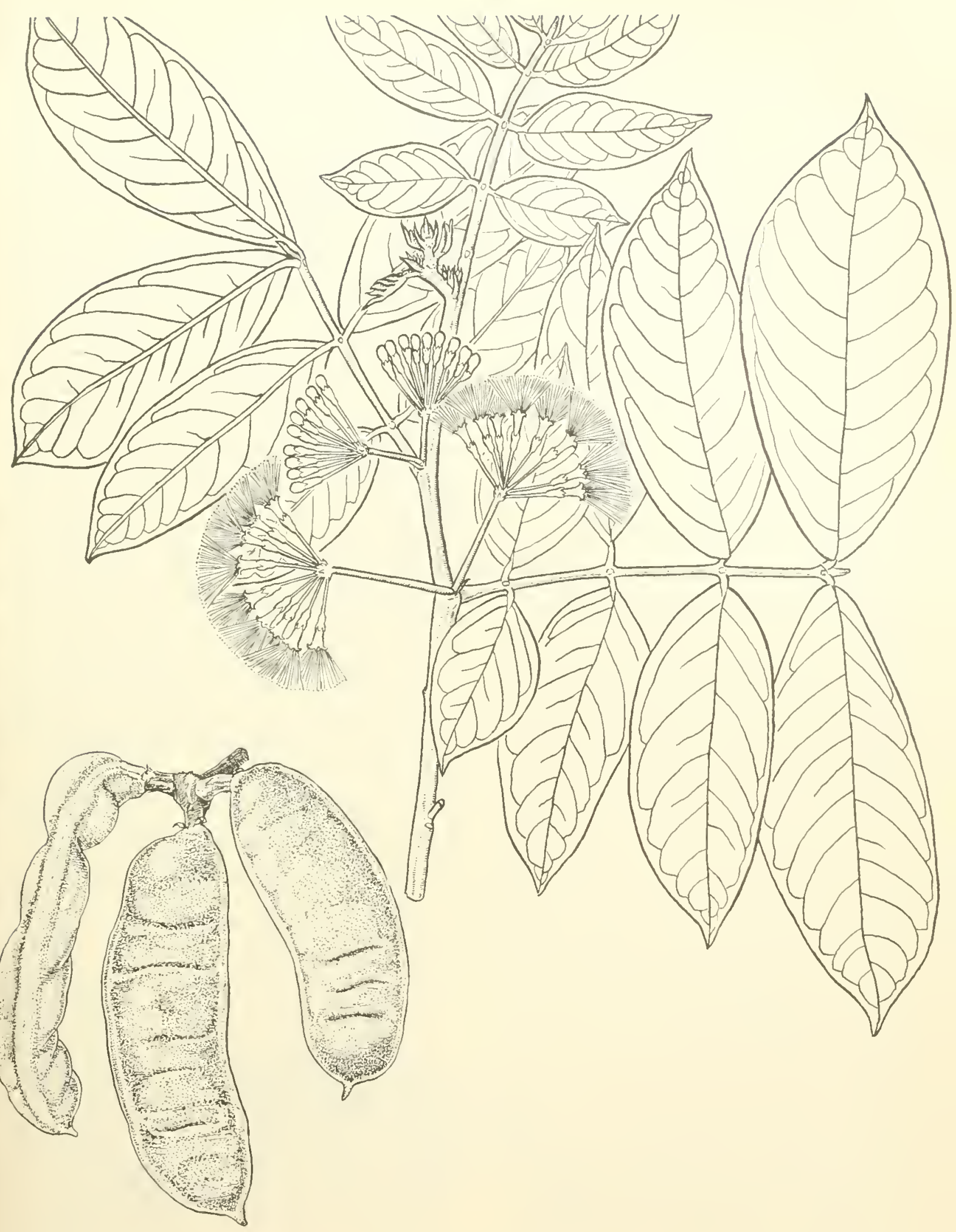




\section{MIMOSA SUBFAMILY (MIMOSOIDEAE; MIMOSACEAE)}

\section{Guaba}

Guaba, the commonest coflee sliade tree and also native or naturalized in wet forests, is easily distinguished by: (1) alternate pimate hairy leaves with $: 5$ pairs of elliptic to oblong, stalkless, slightly drooping leaflets on a winged axis bearing a mimute round yellow-green gland between each pair; (2) lateral clusters of several large whitish flowers with long thearlike stamens $21 / 2-3$ inches long and $3-31 \%$ inches across but soon witting: (3) hairy pole $4-6$ inches long and $1 / 6-5 / 8$ inch in diameter, nearly cylindrical but 4 -ribbed and with 2 broad longitudinal grooves, and containing white sweetish edible pulp.

Medium-sized evergreen tree becoming $40-60$ feet tall and 1-11/2 feet or more in trunk diameter (recorded to 3 feet). with very widely spreading crown of long branches and thin foliage. The bark is gray brown, smoothish but becoming finely fissured. Inner bark is pinkish to brown and slightly bitter. 'Twigs are brown and tend to zigzag, with light colored dots (lenticels), and densely brown hairy when young.

The leares $\bar{i}-12$ inches long are borne in 2 spreading rows on a twig. The axis $21 / 2-7$ inches long is brown hairy, with a green wing $1 / 4-3 / 4$ inch broad between each pair of leaflets. Leaflets are $2-6$ inches long and 1-23/4 inches wide, larger from base toward apex, long-pointed at apex and shortpointed at base, not toothed, thin and slightly convex, the upper surface arreen. lower surface light green, and both surfaces slightly hairy especially on veins, and also slightly shiny.

Flowers do not open at the same time, but usually only 1 or 2 daily in each chuster. It dawn the Hower is fully expanded, but during the day the stamens and style wither. Flower clusters (spikes) are single or pained at base of a leaf, consisting of several stalkless flowers crowded near the end of a hairy green axis 1-21/ inches long. An individual flower with stamens fully expanded is white and $21 / 2-3$ inches long and $3-31 / 2$ inches across. I few hours later the flower is greenish, less than 3/4 inch loner to end of corolla and $5 / 16$ inch across corolla lobes, with the twisted pale yellow stamens drooping $11 / 2$ inches or less below. The brownish-green finely hairy tubular calyx is cylindrical, $7 / 36^{-1 / 2}$ inch long, and 5 -toothed, often splitting on 1 sicle; the greenish-yellow corolla rensely brown hairy, composed of a narrow cylindrical tube about $5 / 8$ inch long and 5 spreading lobes $1 / 8$ inch long; the mumerous spreading white threadlike staneus are united into a tube inside corolla ; and the white pistil is more than $21 / 2$ inches long with narrow ovary and very slender style.
The pod is densely brown hairy and slightly curved, few-seeded, not splitting open, with calyx remaining at base. In flower and fruit through the year, but most fr'uits appearing in the fall.

The sapwood is whitish, and heartwood pale brown to golden brown with longitudinal streaks or patches of darker brown often shaded with green or yellow. The wood is moderately hard, moderately heavy (specific gravity 0.59), strong. and tough. It is very susceptible to attack by drywood termites and other insects and to decay in contact with the ground. Rate of air-seasoning is rapid, and amount of degrade is moderate. Machining characteristics are as follows: planing, turning, boring, mort ising, sanding, and resist ance to screw splitting are good: and shaping is poor.

The wood is used almost solely for posts, fuel, and charcoal. However, it is suitable for utility furniture, boxes, crates, light construction, and general carpentry.

On lower slopes and along streams this tree grows very rapidly, producing coffee shade within 3 years and growing in trunk diameter at a rate somet imes exceeding 1 inch per year. Also a honey plant.

Common in active and abandoned coffee plantations throughout Puerto Rico except in the upper mountain, dry coastal, and dry limestone forest regions. Commonest at the northern base of the lower Cordillera, lower Luquillo, and moist limestone regions.

Public Forests,-Carite, Guajataca, Guilarte, Luquillo, Maricao, Río Abajo, Susúa, and Toro Negro.

MUNicipalities Where fspecially COMMON.$1,5,6,8,19,21,27,32,35,42,43,46,47,50,53,58$, $61,70,73$.

R.snge.-Jamaica, Hispaniola, and Puerto Rico. Also introduced in Cuba and Guadeloupe and perhaps elsewhere for cotfee shade.

Other comiron names.-guaba del país, guaba nativa (Puerto Rico) ; guamá (Dominican Republic); guaba (Cuba); pois doux, pois sucrin, sucrier, sucrin (Haiti); pois doux, pois doux poilu (Guadeloupe); pois doux à paille (Guadeloupe, Martinique).

Named from material collected in Jamaica, this species is the one upon which this large genus was based. It has been reported also from Mexico, Central America, and northern South America but not by authors of the most recent floras.

Botanical srnony.-Inga inga (L.) Britton. 


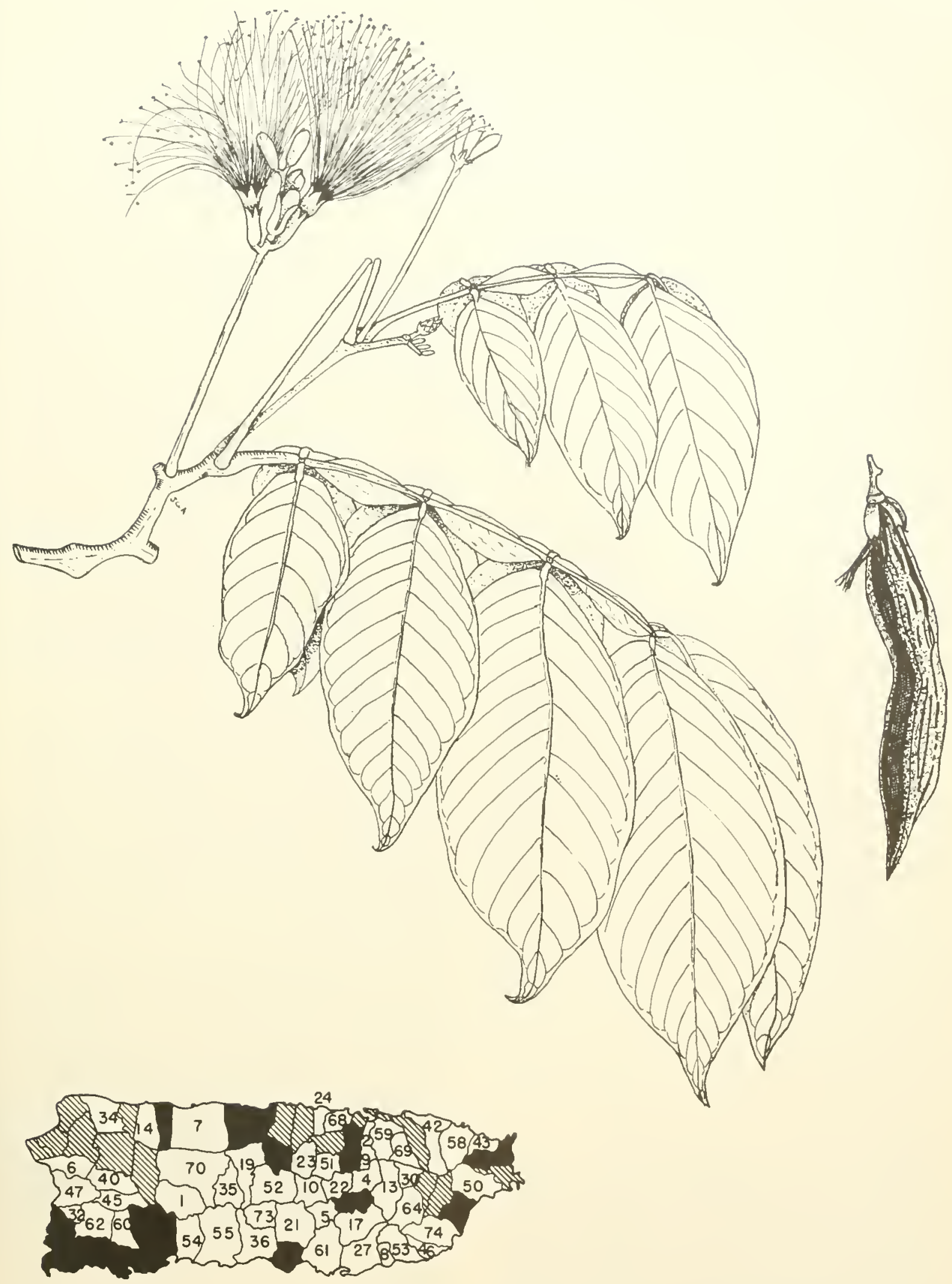

64. Guaba

Two-thirds natural size.

Inga vera Willd. 


\section{MIMOSA SUBFAMILY (MIMOSOIDEAE; MIMOSACEAE)}

\section{Zarcilla, tantan, leadtree}

I small tree or shrub common along roadsides and in old fields in the dry areas, characterized by : (1) alternate twice pinnate leaves (bipinnate) 4-8 inches long, with 3-10 pairs of lateral axes (pinnae), each with 10-20 pairs of stalkless narrowly oblong or lance-shaped cray-ureen leaflets $5 / 16^{-5 / 8}$ inch long and less than $1 / 8$ inch wide; (2) flowers rery numerous in whitish round balls $3 / 4-1$ inch across the spreading threadlike stamens: and (3) usually many clustered dark brown pods $t-6$ inches long and $5 / 5-3,4$ inch wide, flat and thin, with raised bordes.

A rapidly growing decidnous spreading tree $15-25$ feet high and $2-4$ inches in diameter or larger. The bark is gray or brownish gray and smooth with many dots or wasts (lenticels). In. ner bark is light green or light brown and slightly bitter: Twigs are gray green and finely hairy, becoming brownish gray.

The gray-green leaf axes and lateral axes have swellings at bases. Leaflets ane short-pointed at apex and oblique at the short-pointed base, thin, and gray green but slightly paler beneath. They fold upward together at night.

The flower heads are bolme on stalks $3 / 4-11 / 4$ inches long in terminal chusters (racemelike) at ends of twigs or lateral and composed of many narrow stalkless flowers in a whitish round bail a bout $3 / 8-1 / 2$ inch across corollas in bud stage. Each individual flower" 516 inch or more in length has a tubular, greenish-white hairy, 5-toothed calyx more than 1/16 inch long: 5 narow greenish-white haijy petals nearly $3 / 16$ inch long: 10 threadlike white stamens about $5 / 16$ inch long; and slenderstalked pistil nearly $1 / 4$ inch long with narrow green hairy ovary and white style.

The pods are narrowed into a stalk at base, slort pointed at apex, and minntely hairy. They hang down nstually many in a chster and split open on hoth sides at maturity. In a rentral row are many flattened, ohlong, pointed, shiny hrown seeds $5 \% 16$ inch long (10,000 to a pound). Flowering and fruiting nearly throngh the year.

The sapwood is light rellow. Heartrood is yellow brown to dark brown. The hard, heary wood (specific crarity 0.7) is used for fuel in Puerto Rico.

The seeds, after' softening in boiling water, are trung as beads into necklaces, bracelets. decorations on hats, and cmriosities for tomrists in the Tircrin Islands and other localities. In the Philippines the youmg pods have heen cooked as a regetable and the seeds prepared as a cotlee substitute. The bask and roots reportedly have been employed in home remedies. Bees obtain pollen from the flowers. In the Virgin Islands branches from trees along roadsicles frequently are cut for live-
Leucaena glauca (L.) Benth.

stock feed, especially in the dry season.

The leaves and pods are poisonous to horses, domkers, and mules and, when eaten, cause these animals to shed their hair, especially that of the mane and tail (or even hooves if browsing is prolonged, it is reported). Hogs are similarly affected, losing the hair along the spine, and rabbits ase poisoned also. However, cattle, goats, and sheep can browse the foliage without ill effects. The poison is concentrated in the seeds and young leaves.

The trees are easily plopagated from seeds or cuttings and coppice well. Like weeds they readily invade cleared lands and frequently form dense pure thickets. This species has been nsed in some cotuntries for coffee shade, caca shade, and hedges. Being hajdy it can be planted in pastures, to be followed afterwards by timber trees. In some areas the trees have been managed for fuel or charcoal on a sholt rotation of 6 or 7 years between cuttings. In the Far East this legume is grown to rebuild the soil and as a forage crop.

In roadsides, abandoned pastures, and thickets, in the dry limestone and dry coastal regions of Pnerto Rico. Mlso widespread in Mona, Vieques, St. Croix, St. Thomas, St. John, Tortola, and Virgin Gorda.

Pundic forests.-A guire, Cambalache, Guajataca, Guánica, Maricao, Río Abajo, Susúa, Vega.

MITNICIPNITIES WIIERE ESPECLILLY COMMON.$26.38,54,55,75$.

RAxGE.-Throughont Test Indies from Bahamas and Cuba to Trinidad and Tobago and from souther'n Mexico to northern South America. Naturalized beyond the original range north to southern Texas and southerm Florida (also planted in Califormia) and in Besmuda and sonthward to Chile and Brazil. Also maturalized in the Old World tropics.

OTner COMnox vames-tamarindillo, hediondilla, acacia, acacia palida (Puerto Rico); wild tamarind, wild taman (Virgin Islands); lino, granadino, granadillo bobo, lino criollo (Dominican Republic); aroma blanca, aroma mansa, aroma boha (cuba): guaje, uaxim (Mexico): barba de león (Guatemala): panelo (Colombia) : leadtree, white popinac (United States) : jumbie-bean, wild mimosa, acacia (Bermuda) : jumbie-bean, jimbay, cowhush (Bahamas) : wild tamarind (Guenadines, Trinidad, Britisl Honduras): shack-shack, Test Indies mimosa (Trinidad): arains de lin pays (Haiti): bois-lolo, monval (St. Barthélemy, Guadeloupe): macata (Gruadeloupe); macata blanca (Martinique); tumbarabu, mimosa, tantan (Dutch Trest Indies).

Botanical srvonis.-Leucalena leucocephata (I,am.) de IVit. 

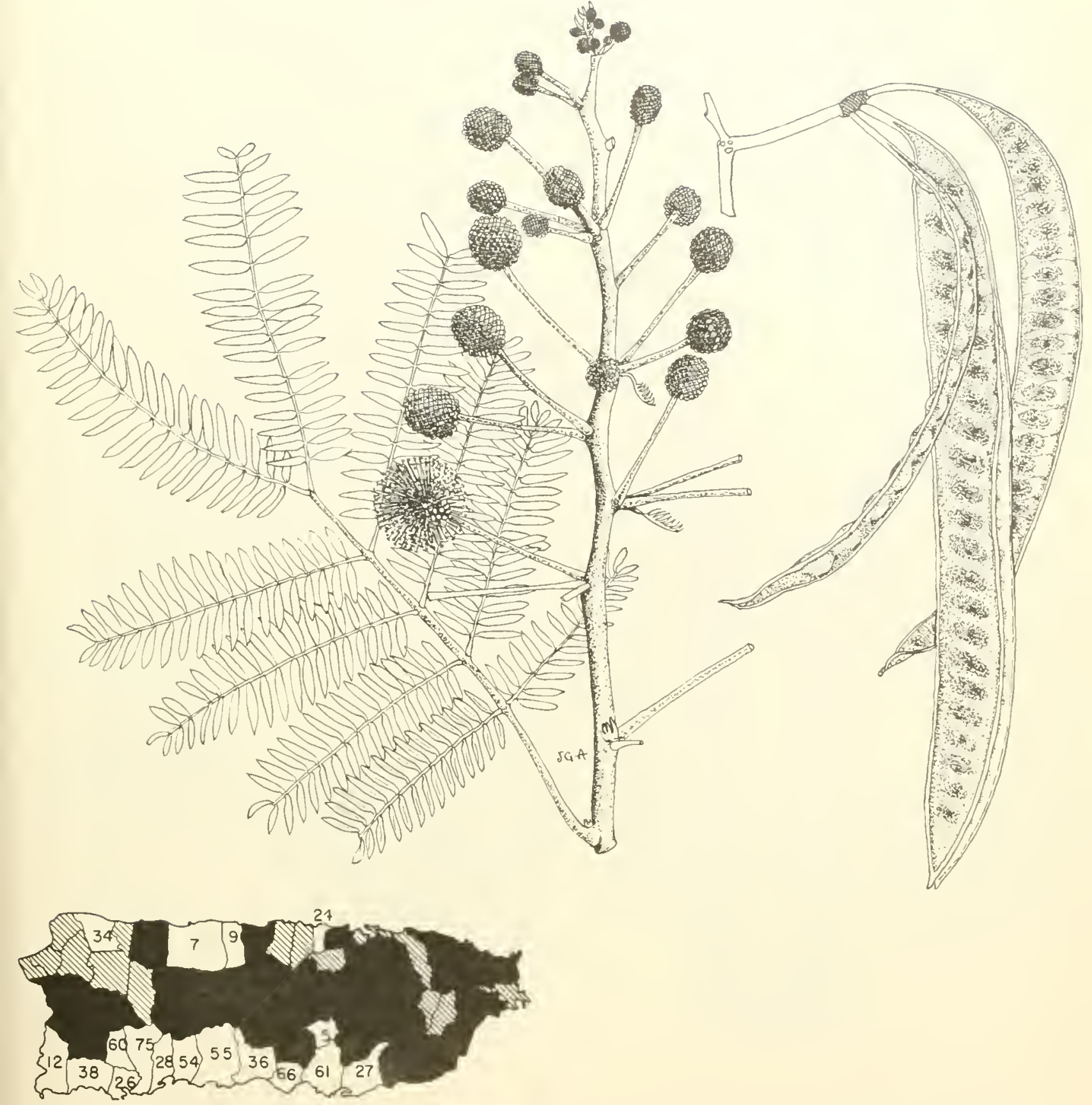

65. Zarcilla, tantan, leadtree 


\section{LEGUME FAMILY (LEGUMINOSAE)}

\section{MIMOSA SUBFAMILY (MIMOSOIDEAE; MIMOSACEAE)}

\section{Cojóbana}

This small to medium-sized tree is eharacterized by: (1) feat thery, twice pinnate lea ves (bipinnate) with minute nalrow leatlets $1 / 8$ ineh or less in length: (2) smatl flowers numerons and crowded in whitish-vellow balls $3 / 8-1 / 2$ inch in dianeter, several in stalked lateral elusters: (3) brown flat and thin pods $3-8$ inches long and about $5 / 8$ inch hroad. slimlitly narrowed hetween the seeds, and finely scaly; and (4) very rough, gray, brown, or blackish birk on larger trees, thiek, cleeply furrowed, and with proniment warts or irregular ridges.

A decirluous tree becoming 2()$-40$ feet high and 8 inches or more in trunk diameter, generally much smaller, with thin widely spreading erown of attractive fine foliagre. (O)ter bark is gray or dark brown, with lines of growth, and inner bark light and dark brown streaked, soft, and bitter. The brown twigs are minutely haily.

The altermate leaves 6-9 inches long have a light brown, finely hairy axis hearing 1 oval reddish gland near base and msually 2 near apex. There are alout 20-35 pairs of lateral branehes (pinnae), each with about 30-100 pairs of stalkless, narrow (linear), slightly hairy leaflets, which are shortpointed at apex and oblique at base, green above and paler beneath. 'Thus, each leaf has at least a few thousand leaflets.

'The flower elusters (heats) are lateral, several together on slender hairy stalks $1 / 2-1$ inch long and bearing mumerons stakless flowers. Each flower is more than $1 / 4$ long when the stamens are fully expanded. The bell-shaped 5-toothed ealyx is $1 / 16$ ineh long and minutely hairy; the white corolla 1/s ineh long, with tube and 5 short lobes, finely hairy on outside: 10 stamens more than $1 / 4$
Piptadenia peregrina (L.) Benth.

inch long: and the pistil has a 1-eelled ovary with slender style about $1 / 4$ inch long.

The pods have raised edges and split into 2 parts. There are several rounded, very thin, flat seeds nearly $1 / 2$ inch in diameter. Flowering from March to dine. Pods present most of the year.

The sapwood is whit ish to light brown, and the leartwoor dark brown or reddish brown. The wood is extremely hard, heary (specific gravity $0.8)$ strong and durable, hit diffienlt to work. Tsed ehiefly for posts in Puerto Rico. The thick bark is rieh in tannin and has been employed in tanneries of Velieznela.

A narcotie smuff ealled "cojoba" was prepared from the finely ground seeds by the Indians of Hispaniola and Tenezuela and adjacent parts of Brazil. It was used in religious ceremonies. Recently this narcotic has been studied chemieally and tested for possible medieinal applications.

In woodlancls and hillsides in the eoastal and lower mountain regions of Puerto Rico.

PI bu. IC fonests.- Cambalache, Marieao.

Raxer.-Hispaniola, Puerto Rico, Dominica, St. Tincent, Grenada, and Trinidad (donbtfully native). Reported from Jamaiea, apparently in error. Also Veneznela, British Guiana, and Brazil.

OTHer common numes.- cojobillo, cojoba, cojobo (Pnerto Rico); eojoba (Dominiean Republie): yopo (Colombia) ; cojoba, niopa, niopo, yopo, curub (Venezuela); saramnal yoke, eohoba (Trinilad) : bois galle, bois l'écorce, cenf de ponle (Haiti) ; paricá (Brazil).

Botuical sroxys.-Viopa peregrina (L.) Britton \& Rose. 


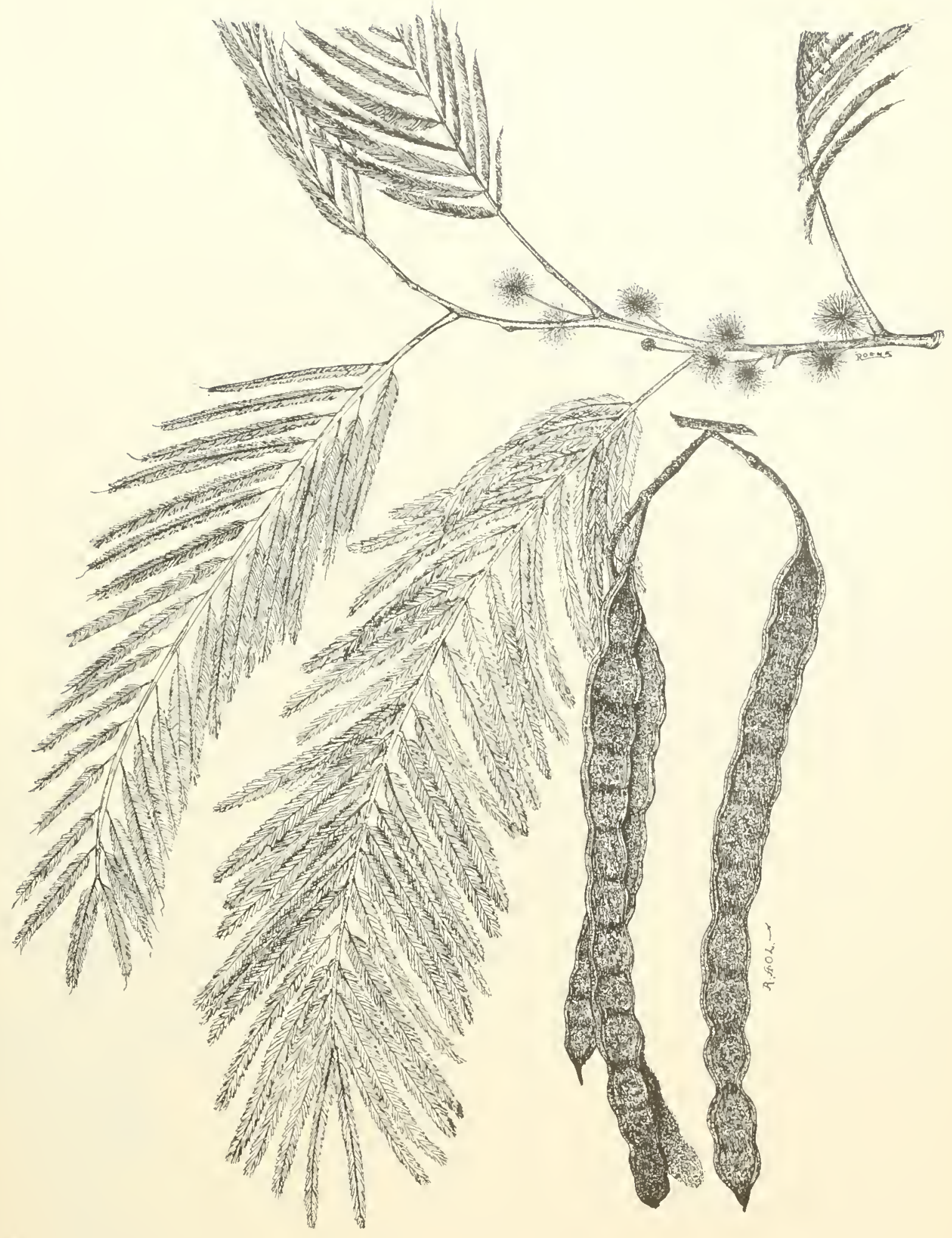

66. Cojóbana

Two-thirds natural size.

Piptadenia peregrina (L.) Benth. 


\section{LEGUME FAMILY (LEGUMINOSAE)}

\section{MIMOSA SUBFAMILY (MIMOSOIDEAE; MIMOSACEAE)}

\section{Cojoba}

This handsone tree with shiny, dark green, featherr foliage is further characterized by: (1) twice pinnate leaves (bipinnate) with numerous mall namow leaflets about $3 \dot{s}$ inch long and less than $1 / \mathrm{s}$ inch wirle: (2) the many flowers in a whit ish ball more than 1 inch in diameter acrose the stamens: and (3) the conspicuons red ports $21 / 2-1 ;$ inches long and $3 / s$ inch in diameter, curverl r eoiled, splitting open, twisting, and exposing the several blark elliptic seerls that hang on short threads.

I small to medium-sized evergreen tree attaining 30 -50 feet in beight and 1 foot in trunk diamster. The bark is rray and smoothish. Inner bark is whitish and hitter. 'The hrown twigs are tinely brown hairy when yomuger.

Thic latres are alternate, 5-12 inches long, with areenish axes minutely brown bairy. The main axis hat $\mathrm{x}-16$ pairs of lateral branches (pimae), with a dot grand at hase of each pair, each luanch healling :-1)-to pail's of stalkless leaflets. Leallets are oblomer or lance-shalped, short-pointed. rblique at base, thin, hairless, paler beneath.

'There ale 1-,") flower' clusters (hearls) at hase of a leat or at a node back of leaves, on stalks $11_{2} \rightarrow 3$ indhes lomg, containing numerous stalkless Howers. The hell-shaped 5-tootherl ealyx is about lis ind lomer the tubular whitish corolla nearly $3 x$ inch loner. including the 5 lohes: the many, very - lender", whitish stamens are about 5is inch long, mited into a tube below: and the pistil has a finely hairy 1-relled ovary wh slender style.

The pords are borne singly or sometimes paired. They ane shightly ronghened. minutely hairy, and nalrowed between the seeds. The alliptic seeds "hatuge from shiny to dull black in color. Flower-

\section{Pithecellobium arboreum (L.) Urban}

ing in spring, the pods matming in summer, and flowering and fruiting again in aut umn.

The sapwond is whitish and hard. Heartrood is dark red or reddish brown, sometimes figured ol with darker streaks, resembling mahogany. The wood is heary (specific gravity 0.7), strong, durable, and takes a fine polish. An excellent timber" suited for heavy and interior construction, ralinetwork, furniture, posts, and rossties. Reportedly employed at one time for bobbins in cottom mills.

Is an attractive olmanental and shade tree with commercial wood, this tree is worthy of more extensive cultivation. Also a honey plant.

Chiefly along streams and at the base of cliffs in the moist limestone region and ascending into the lower Cordillera region in western Puerto Rico.

Public forests.-Cambalache, Guajataca, Mari(ao, Río Abajo, Susúa, Vega.

Raxge-Cuha, Jamaica, Hispaniola, and Puelto Rico. Also in southem Mexico and Central America to Costa Rica.

Other common N.MYes.-cojóbana, cojobanilla, rajola, tamarandillo (P'uerto Rico); abey, abey hentura (Dominican Republic) ; molvuro, moruro rojo, moruro prieto, sabicú, sabicú moruro (Cuba) ; plumillo (Guatemala); barba de jolote (Honduras); a giiijote (El Salvador) ; tamarindo (Costa Rica): wild tamarind, chabark (Jamaica); wild tamarind, black tamarind, red tamarind, zoprilote, barlia jolote (British Honduras); collier, poison lasinette (Haiti).

Botaxicul synoryus.-Cojoba arborea (L.) Britton \& Rose, Strmmen arboren. (I.) Ricker.

The creneric name has been spelled also Pitherotobium. 


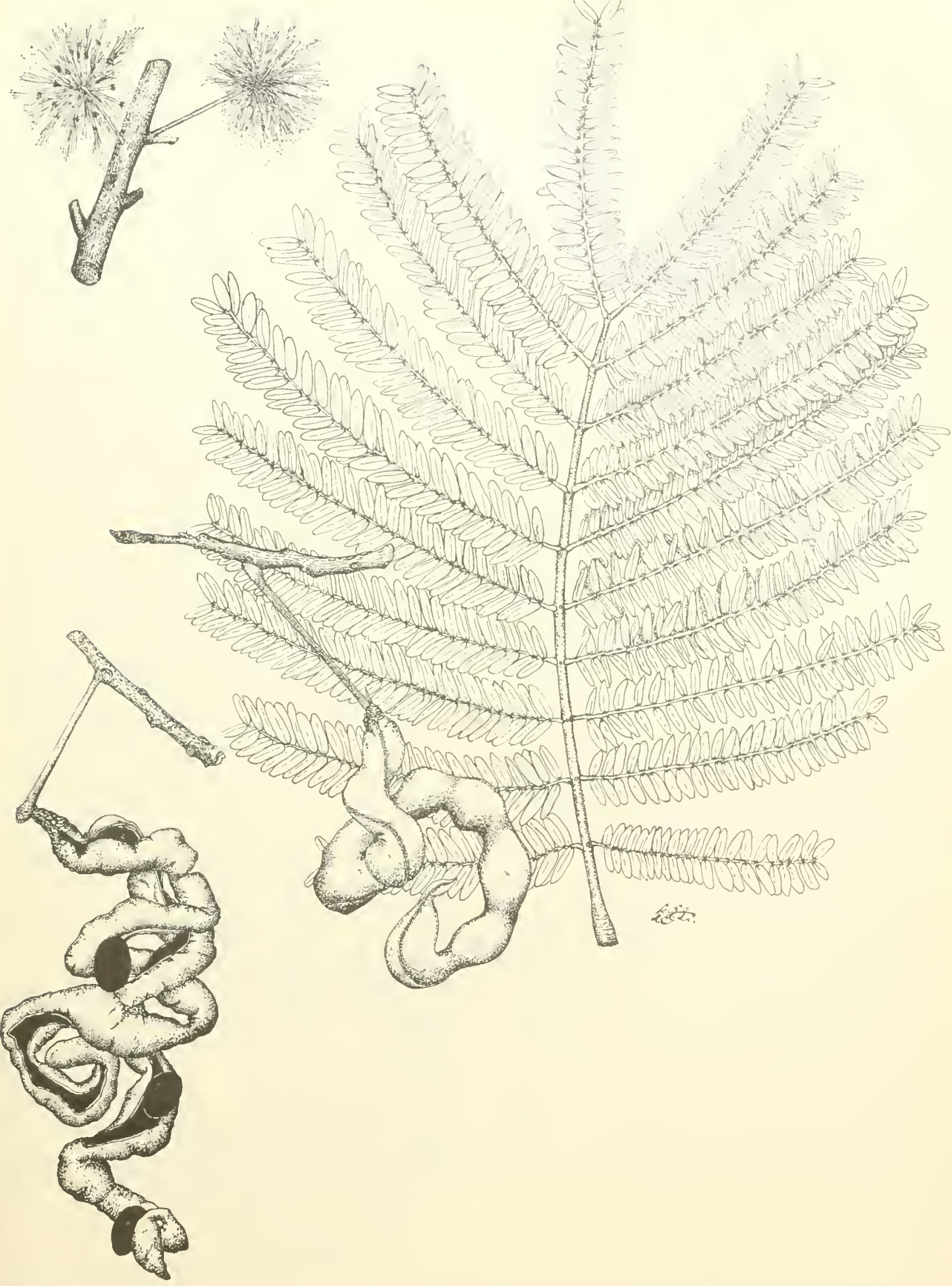

ti7. Cojoba 


\section{MIMOSA SUBFAMILY (MIMOSOIDEAE; MIMOSACEAE)}

\section{Guamá americano, guamuchil}

This introduced tree planted for shade and ornament along highways and streets and around houses is distinguished by: (1) usually a pair of slender sharp spines (stipules) $1 / 16^{-5 / 8}$ inch long at base of each leaf or sometimes spineless; $(2)$ twice pimate leaves (bipinnate) with 2 lateral axes, each with 2 nearly stalkless ollong or ovate leaflets: (i) sniall creamy white flowers in many small ball-like heads $3 / 8$ inch across in slender drooping terminal or lateral axes: and (4) culved or coiled pink to brown pods 4 -5 inches long, narrowert between the seeds, and splitting open on botly sides to loosen several shiny black seeds mostly corered by pink or whitish pulp, which is edible.

A small to medium-sized tree $30-50$ feet in height and 1-2 feet in trunk dimmeter, or shrubby, with trunk and branches often crooked, and broad sprearling crown. Nearly evergreen but shedding the old leares as new ones appear. The bark is light griy, smoothish, becoming slightly rough and furrowed. The thick inner bark is light hown and bitter ol astringent. Twigs are slender and drooping, greenish and slightly hairy when youmg, becoming glay, covered with many small whitish dots (lenticels).

The alternate leaves have a rery slender green petiole $1 / 4-11 / 2$ inches long with minute round gland near apex and the 2 lateral axes (pinnae) only $1 / s^{-1 / 4}$ inch long. The 4 thin or slightly thickened leatlets are $1,2-2$ inches long and $3 / 16-5 \%$ inch wide, romnded at ipex, the oblique base romnded $\mathrm{Ol}^{*}$ short-pointed, not toothed on edges, hairy or hairless, full pale green above and light green beneath. New growth is pink or redish.

The flower clusters (heads) are short-stalked, each corered with whitish hairs and composed of about 20-20 clensely hairy flowers. The flower has a tubular hairy s-toothed calyx about $1 / 16$ inch long, a funnel-shaped tubular hairy 5-toothed corolla about 1/s inch long, about 50 spreading long threadlike stamens mited into a short tube at base, and pistil with hairy ovary and threadlike style.

The pod is $3 / 8-5 / 8$ inch wide, slightly flattened, and inconspicuously hairy. The flattened seeds (4.000 to a ponnd) are about $3 / 8$ inch long and hang down inside the pulpy mass (aril) as much as $3 / 1$ inch long. Recorded is flowering from .January to May and in fruit from February to July.

Sapwod is yellowish, and heartwood yellow ish or reddish brown. The wood is moderately soft,

\section{Pithcellobium dulce (Roxb.) Benth.*}

heavy, strong, and durable. It takes a high polish but is brittle and not easily worked.

In Puerto Rico the wood is used only for posts and fuel, but elsewhere it is employed for general construction. The bark, which contains about 25 percent tannin, is havested in Mexico. It also yields a yellow dye and is an ingradient in home remedies. I mucilage can be made by dissolving in wates the transparent deep reddish-brown gum which exudes from the trunk.

This attractive species makes a good highway and street trze, especially in dry areas, growing rapidly and enduring drought, heat, and shade. It withstands close blowsing and prining and is suitable for fences and hedges also. Formerly it was a popular street tree in southern Florida, where it was susceptible to hurvicane damage and did not recover well.

The thick, pink, sweetish acid pulp around the seeds can be eaten or prepared into a drink like lemonade. Livestock and wild animals browse on the pods under the trees. Also a honey plant.

Along roads and in towns throughout Puerto Rico. Introdnced also into St. Croix.

Raxae--Mexico (Lower California, Sonora, and Chihuahua southward) through Central America to Colombia and Tenezuela. Introduced in southern Florida, Cuba, Jamaica, Puerto Rico, and St. Croix. Widely planted and naturalized in tropical regions, including the Old Trorld.

Other common vames.-gmamuche (Mexico, commerce) ; inga dulce (Cuba); guamúchil (Mexico): jaguay, shahuay, madre de flecha (Guatemala) ; mongollano, guachimol, espino, guayacán blanco (El Salvador); mochiguiste (Costa Rica): gallinero, chininango, tiraco, chancán (Colombia); yacure, guamo blanco, guamacho (T'enezuela); blackbead, apes-earing (United States) gramuchil. Manila-tamarind, Madras-thorn (English); bread-and-cheese (British Guiana).

This species was named and described botanically in 1795 from Coromandel, India, where it had been introduced. The specific name, meaning sweet, doubtless refers to the edible seed pulp.

I related native shrub or small tree of coastal thickets is uña de gato or catclaw blackbead (Pithecellobium unguis-cati (L.) Benth.), known also as rolón, escambrón colorado, and catclaw. This species with yellowish or pinkish flowers is native from sonthern Florida to northern Sonth America. 


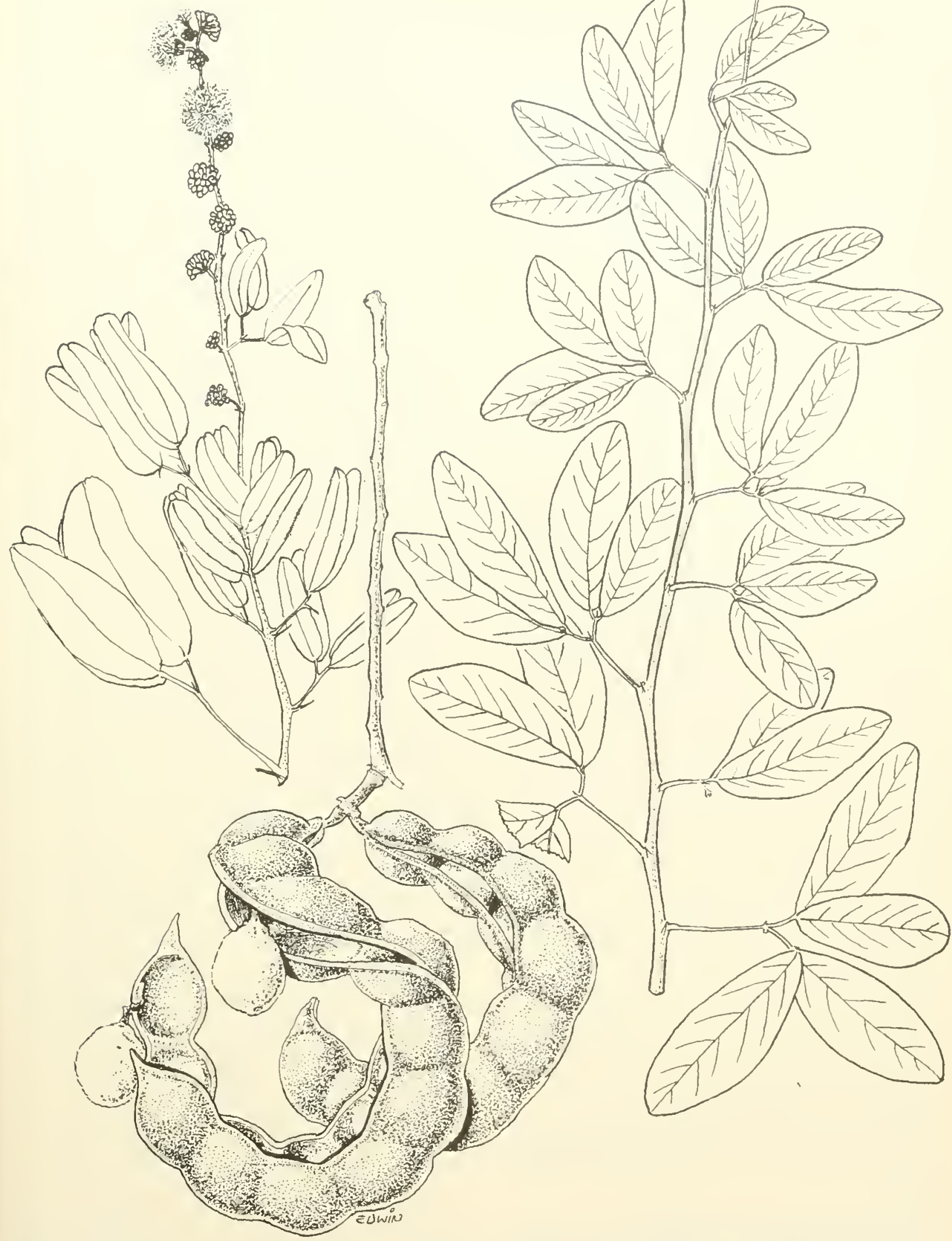




\section{MIMOSA SUBFAMILY (MIMOSOIDEAE; MIMOSACEAE)}

\section{Samán, raintree}

This well-known heaut iful shade tree reaches lan're size both in trunk diameter and in a very broald arched crown. It is further iclentified by: (1) twice pinnate leaves (bipinnate) with many nearly dianourl-shaped leaflets $3 / 4-11 \%$ inches long and $3 / 5-3 / 1$ inch bromd, the sides unequal, the onter leaflets considerably larger than the others, and the pairs of leaflets folding together at night and on cloudy days; (2) delicate flowel heads $21 / 2$ inches across and $11 \%$ inches high, a mass of $111-$ melous threallike stamens pink in outer half and white in inner half: and (3) flattened brown or blackish porls $t-8$ inches lone, about $5 / 8^{-3} / 4$ inch wide, and $1 /$ inch thick, straight or a little curved, with sweet ish pulp, late in splitting open.

An evergreen tree attaining $00-65$ feet in height. with a relatively short stout trunk up to 4 feet in diameter. Crown of long. stout. horizontal branches is brourler than tall, becoming 100 feet or mole across. The gray bark is rontrh, furrowed into long thin plates or corky ridges. Inner bark is pink or liorlut brown, bitter. The stout greenisl] twigs are minutely lairy.

The alternate leit ves are about 10-16 inches long. The axis and 2-6 pairs of branches (pinnae) are green and finely hairy with swelling at base of each and a gland dot on axis where branches join. Each branch (pinua) bears $6-16$ paired stalkless leaflets with a gland dot between each pair. Branches toward apex are longer and with more leaflets. Leaflet blades are blunt and with a minute point at apex, short-pointed at base, the edges not toothed, slightly thickened, the upper surface shiny green and with reins raised a little, and the lower surface paler and finely hairy.

Several flower clusters (heads or umbels) are lateral near end of a twig, each on a green hairy stalk 216-1 incles long and composed of many narow tubular flowers, pinkish, tinged with green, short-stalked. 'The narrow creen calyx is tubular, about $1 / 4$ inch long, 5 -toothed, and finely hairy: the nalrow piuk and greenish-tinged corolla 3/8-1/2 inch long is also tubular, 5-lobed, and finely hairy; the many stamens mited in tube near base have spreading, very long, threadlike filaments about $1 \frac{1}{2}$ inches long and dotlike antliers, soon wilting and shriveling: and the pistil consisting of 1-celled light green ovary $3 / 1$; inch long and a threadlike pinkish st vle 1-11'tinches long.

The hard seed porl have a raised border. They contain several ohlong reddish-brown seeds about 5'́n inch long (about 2.500 to a pound). Flowering from spring to fall. fruiting from fall to winter.

The sapwook is thin and rellowish, and the healt wood clark chocolate brown when freshly cut, becoming attractive light to golden brown with

\section{Pithecellobium saman (Jacq.) Benth.*}

clarker streaks. The wood is soft, lightweight (specific aravity (1.44), of medium to coarse texture, and fairly strong. It is durable to very duratble in respect to decay and resistant to dry-wood termites. It takes a beantiful finish but is often cross-grained and difficult to work. The rate of a ir-seasoning is moderate, and amount of degrade is consiclerable. Machining characteristics are as follows: planing, mortising, sanding, and resistance to screw splitting are good; shaping and borinc are fair: and turning is poor.

Elsewhere the wood has been employed occasionally for furniture, interior trim, and general construction. It is snitable also for boxes and crates, velleer, plywood, and paneling. In Central Anerica cross sections of thick trunks have served is wheels of ox carts.

The trees in Puerto Rico are valued mainly for shade and beauty. The nutritions pods are relinherl by cattle, hogs, and goats and have a flavor like licorice, which some persons like. A honey plant. In a few countries samán has been employed as shade in plantations of coffee and cacao, though less at present than formerly. Because of their enormous growth the trees compete heavily for water and soil nutrients, injuring the shrubs.

Easily propagated from seed and cuttings and of rapid growth. Cattle disseminate the seeds in pastures. A famous giant in Trinjdad more than 100 years old wis measuled as 8 feet in trunk diameter, 147 feet high, and 187 feet in spread. Sonmetimes trees become topheavy and dangerous along highways and near houses. The many surface roots may also be objectionable. Perhaps better suited to dry rather than moist localities, being of smaller size in arid places.

Cultivated along highways and streets and planted and naturalized as a pasture shade tree in both the moist and diy coastal regions and in the lower Cordillera region of Puerto Rico. Also in St. ('roix, St. Thomas, St. John, and Tortola.

Range. - Native from Mexico (Yucatan Peninsula ) and Guatemala to Peru, Bolivia, and Brazil. Widely planted and naturalized elsewhere in continental tropical America from Mexico sonthward, throughout the West. Indies (except Bahamas), and in Old World tropics. Grown also in soutlern Florida.

OTHER COMMON NAMEs.--domilón, guango (Puerto Rico) ; licorice, giant tibet (Virgin Islands); samán (Spanish); alga rrobo, algarrobo lel país (Cuba) : algarrobo (Mexico, Guatemala) : cenicero (Guatemala, El Savador, Costa Rica); carreto, zorra (El Salrador) : samaguare, campaño, genízaro (Colombia) : lara, urero, carabalí (Tenezuela) ; Inacamayo-chico (Peru) ; raintree, saman (English) ; guango (Jamaica) ; cow-tama- 


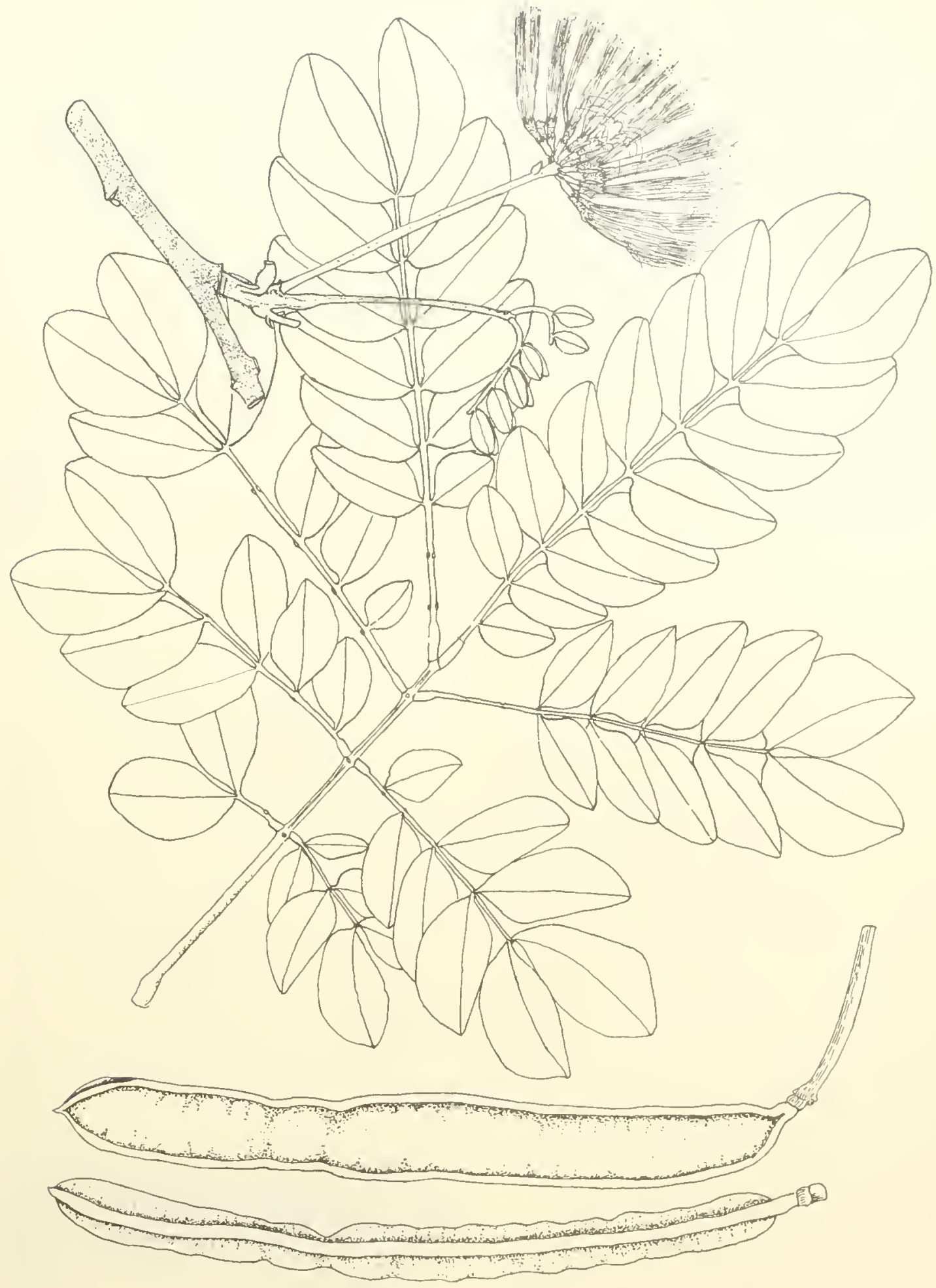

6.). Samân, raintree

Pitheccllobium saman (Jaeq.) Benth.

Two-thirds natural size. 
rind (Grenadines, Trinidad); French tamarind, gnango (British (iuiana); monkeypod (Hawaii); arbre à pluie (French); gouannegonl (Haiti); samana (Guadeloupe).

I30TANICAL SYNoXYMS.-Samanea suman (Jacq.) Merrill, Enterolobium samun (Jacq.) Prain.

The Spanish word "samán" and the specific name are from the South American aboriginal name. Several origins of the English word raintree and its French equivalent have been given. Early travelers reported that the trees mysteriously pro- duced rain at night and would not sleep underneath. Others observed the grass to be greener beneath the trees during droughts. Another explanation was that the rain was excreta of cicada insects inlubiting the trees. More plausible is that the leaflets close up at night and in clondy and rainy weather, indicating the approach of rain and also letting rain fall through the crown to the grass beneath. The Spanish name dormilón refers also to the movements of the leaflets suggesting sleep at niglit.

\section{LEGUME FAMILY (LEGUMINOSAE)}

\section{MIMOSA SUBFAMILY (MIMOSOIDEAE; MIMOSACEAE)}

\section{Bayahonda, mesquite}

A small flit-topped spiny tree or shrub of dry areas recognized by: (1) slightly zigzag green to brown twigs with paired stont brown or gray spines at the enlarged nodes: (2) leaves twice pinnate (bipinnate) with 1 or sometimes 2 pairs of literal axes (pinnae), each with 12-25 pairs of almost stalkless narrow leaflets $1 / 4^{-5 / 8}$ inch long: (3) many small pale yellow flowers about $3 / 16$ inch long, crowded and almost stalkless in narrow drooping chusters 2-4 inches long; and (4) light rellowich-brown, flattened lnt thick pods 49 inches long and $5 / 16^{-1 / 2}$ inch wide, and not splitting open.

Decidnous, 20-30 feet high, with a short crooked trunk to $1 \frac{1 / 2}{2}$ feet in diameter, and with broad erown of very thin spreading foliage. The gray or brown balrk is rough and furrowed, thick and becoming slightly sliagry. the imner bark yellowish, fibrous, and slightly bitter. The spines (stipules) are $1 / t^{-1}$ inch or more in length.

The leaves, mostly borne on very short twigs along larger ones, often are crowded though act ually alternate. They are 3-6 inches long, with slender green leaf axes. Blades are narrow (linear-oblong), ${ }^{1} 16^{-1 / 8}$ inch wide, rounded at both ends or minntely pointed at apex, slightly oblique at base, thin, and dull blue green on both sides.

Flower chusters (spikes) are lateral, often on twigs back of leares. Flower buds are yellow green. The greenish-yellow tubular calyx is less than 1/16 inch long, bell-shaped, and 5-toothed: there are 5 narrow greenish-yellow petals $1 / 8$ inch long, hairy on inside: 10 spreading yellow-orange stamens with browu anthers, less than $3 / 16$ inch long; and pistil 3/16 inch long with hairy light green ovary and slender whitish curved style.

The pods are about $3 / 16$ inch thick and slightly curved or straight. The brown seeds $1 / 4$ inch long are imbedded in a whitish slightly sweet pulp, which can be eaten. Flowering and fruiting through much of the year, chiefly in the summer and fall.

The thin sapwood is light yellow, and the heartwood yellowish to dark brown. The wood is mod-

\section{Prosopis juliflora (Sw.) DC.*}

erately hard, heavy (specific gravity 0.8), tough and strong, easy to work, resistant to decay, and durable in the ground but susceptible to attack by dryood termites.

I'sed in Puerto Rico only for fenceposts and crossties. Elsewhere the rood has served for rehicle parts, rural carpentry, furniture, and formerly even paving blocks. It is a superior fuel and makes charcoal of high quality. An amber gum resembling gum arabic exudes from the trunk and, when dissolved in water, becomes a mncilage. The bark has been employed in taming.

The nutritions pods are browsed by livestock and eaten by children. Cattle are partly responsible for the extensive invasion of pastures by this tree. Indians of Mexico and sonthwestern United States ground the pods into meal as a staple food for baking and for mixing with water as a beverage. This is an important honey plant, and bees commonly are seen around the flowers, which are not fragrant.

Naturalized in thickets and dry forests in the dry limestone and dry coastal regions of southern Pierto Rico, commonly invading pastures. Occasionally planted for ornament. Also in Mona, st. Croix, St. Thomas, and Tortola.

Prbuic forests.-I guirre, Guánica, Susía.

MIUNiCIPALITIES WHERE ESPECIALLY COMIMON.12. 38.

R.AxGE.-Including its geographic varieties native from southwestem United States (Texas to Kansas, Ttall, and California) sonth through Ifexico and Central America to Colombia and Venezuela and perluaps naturalized sonthward. Through West Indies, apparently introduced and naturalized, from Bahamas and Cuba to Barbatos and Trinidad and in Bonaire, Curaçao, and Aruba. Also naturalized in Hawaii and old Wrorld tropics.

This species seems to be very much at home in Puerto Rico and otler islands of the West Indies even though not native. The locality of the botanical type specimen is Jamaica, though an 


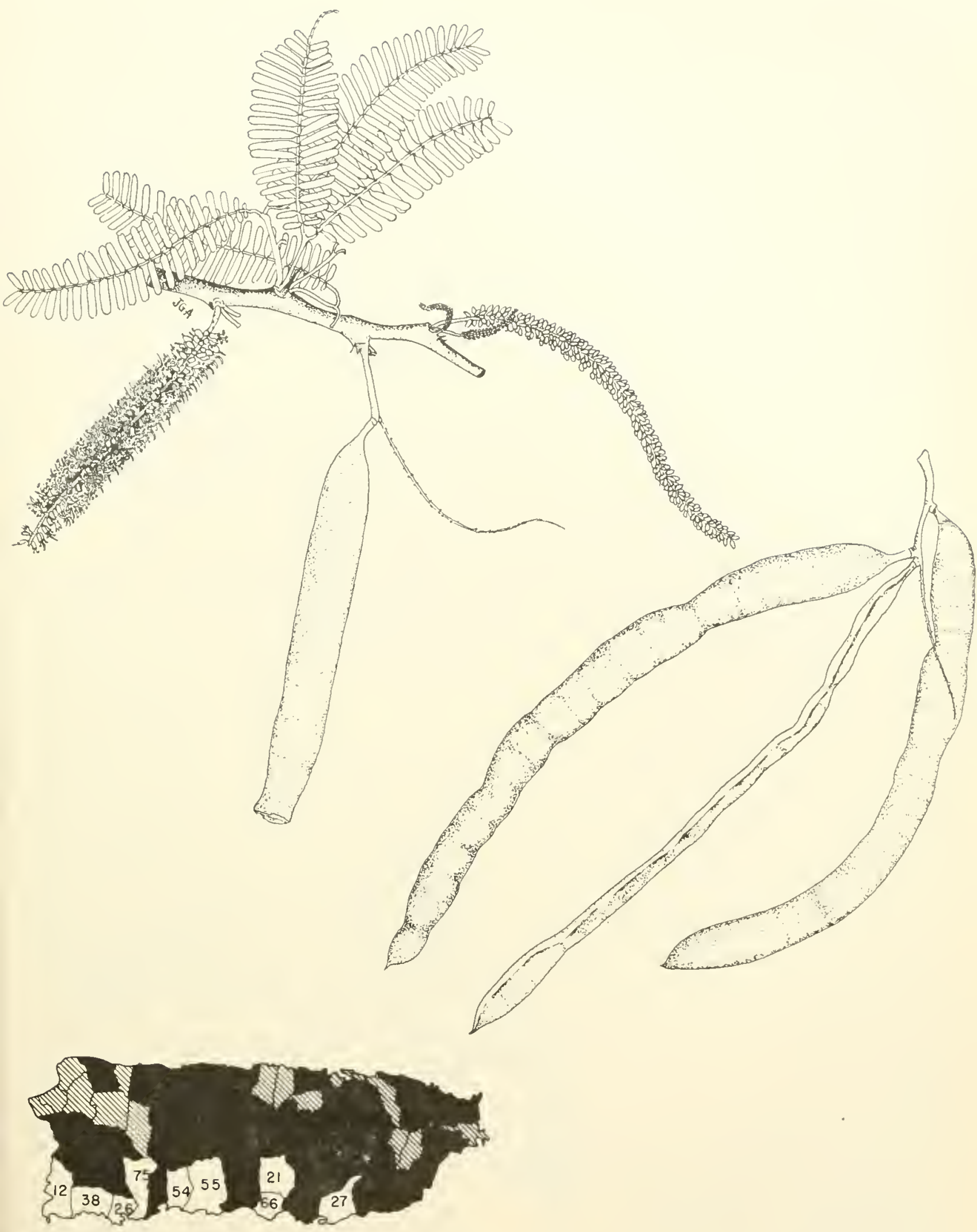

70. Bayahonda, mesquite 
authority on the flora of Juma ica wrote 2 centuries ate that this suredies was introduced there from the iontineut.

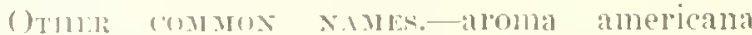
(Presto Rivo) ; alerarrobo (Tirgin Islands) : bayahomla (1)ontinican liepublic) ; mesquite, gratapaná, (:เ mblón, algaluobo del Brasil (Cuba);

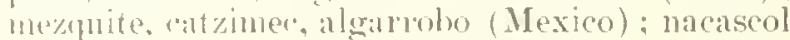
(Cuatemala); alearrobo (Londuras): carbón (El salvador) ; acacia (le Catarina (Nicaragua) ; aromo, manca-eaballo (Panama) ; trupillo, mancacallallo (Colombia); cují yaque, cují negro, cují "arora, "ují, yaque (Tenezuela); mesquite (United States, Bahimals) ; cashaw (Jamaica) ; nesquittree (Trinidacl); bayahon, bayarone (IIaiti); indju, "pui, cuicla, kuigi (Dutch West Indies).

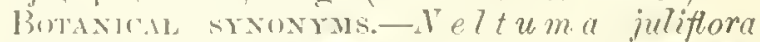
(Nw.) Riaf., Prosopix chitensis auth., not P. chilensis (Mol.) Stmutz. 'The last is a closely related suecies of Chile and Irgentina to Peru.

\title{
LEGUME FAMILY (LEGUMINOSAE)
}

\section{CASSIA SUBFAMILY (CAESALPINIOIDEAE; CAESALPINIACEAE)}

\section{A. Leares simple or of a leaflets.}

\author{
Key to the 10 species illustrated (Nos. 71-80)
}

B. Leaves simple, witl 2 rounded lohes at alrex-71. Rauhinia monandra.*

BB. Leaves of 2 leaflets, paired, long- or short pointed at apex-76. Hymenaca courbaril.

Ad. Leaves compound, of several to many leaflets.

C. Loavis once pinnate.

D. Leaflets mostl. more than 2 inches long, owate and broadest toward base.

F. Leaflets with short, green stalks $1 / 3-1 / 4$ inch long, without black dots-72. Cassia fistula.

EE. Leaflets with very short. red stalks 16 inch long, with scattered raised black dots on lower surface7!). Stahlia monospcrma.

DD. Leaflets less tian 2 inehes long, mostly oblong, with edges nearly parallel.

F. Leaflets srmmetrical.

G. Leaflets short-pointed or ronded at apex-73. Cassia jaranica.*

GG. I.eaflets rounded with bristle-tip at avex-74. Cassia siamea.*

FF. Leaflets oblique at base and slight] 5 assmmetrieal-8(). Tamarindus indica.*

CC. Leaves lipinnate.

H. Leaves consisting of a spine and 1 or 2 fairs of dronping yellow-green strips (lateral axes) 1/8 inch broad bearing numerous small leaflets $1 / 30$ inch long, which shed eariy-77. Parkinsonia aculeata.*

HH. Leaves regularly branched, not spiny, with $10-30$ pairs of lateral axes (pinnae), each with numerous lea flets and featherlike.

I. Leaflets less than $3 / 8$ inch long: coung twigs and leaf axes greenish, finely hairy-75. Delonix regia.*

II. Leaflets $1 / 2-3 / 4$ inch long; young twigs and leaf axes with dense coat of reddish-brown hairs-78. Pcltophorum inerme.*

\section{Mariposa, butterfly bauhinia}

This cultirated ormamental small tree is easily recognized $\mathrm{hy}:$ (1) the odd, somewhat rounder leaves divided aloont $1 / 3$ their length into 2 romded lobes slightly suergesting a cow's hoof and with 13 o) 11 radiating main veins from the heart-shaped base: (2) the rery large and showy flowers $21 \% 2-3$ inches across, with 5 slender-stalked, narrow, spoon-shaped pink petals dotted with red (1 petal mostly red) : and (:i) the flat pods about 8 inches long. 1 incl broad, and $1 / s$ inch thick, with a long narrow point at apex, twisting as they split open.

A small evergreen tree or sometimes a shrub growing 10-30 feet high and to 1 foot in trunk diameter. The bramches are widely spreading. Bark of small trunks is smootl with dots (lenticels) and whitish gray. Inner bark is whitish and tasteless. Foung twigs are finely hairy.

The alternate leaves have long hairy petioles $1-2$ inches lon $x$. I eaf blades a re mostly $2-1$ inches long and $2-+1 / 2$ inches broal or sometimes larger, with the edges not toothed and a short bristle $1 / 8$ inch long between the 2 lobes, very thin, the upper surface light green and hairless, and the lower surface pale gray green and finely hairy.

Flower clusters (racemes) are terminal and mbranched, with few male and bisexual flowers on
Bauhinia monandra Kurz*

green hairy stalks about $1 / 2$ inch long (polygamons). The rery narrow, tubular, stalklike, minutely hairy basal tube (hypanthium) is $1-1 \frac{1}{4}$ inches long and only $1 / 8$ inch broad; the calyx is $3 / 4-1$ inch long, pointed in bud, finely hairy, splitting along 1 side as the flower opens; the 5 unequal petals are 11/2-2 inches long; only 1 slender stamen $11 / 2$ inches long and sterile stamens (staminorles) reduced to scales about 1/8 inch long: and the very slender pistil with stalk about 1 inch long adhering to tube and $11 / 2$ inches long beyond, with a hairy 1-celled ovary and long eurved style: in male flowers the pistil is rudimentary.

The pods split open with force, twisting into 2 parts and scattering the many seeds. The shiny black seeds are elliptic, flat, and $3 / 8$ inch long. Flowering and fruting nearly through the year.

The sapwood is whit ish and hard, and the heartwood recorded as brown. Whood used only for fuel in Puerto Pin. One use reported in Jamaica is as a roadsicle "ince plant: after pollarding, the long pliable branches are arranged into the framework of a fence.

Planted in Puerto Rico for the large ornamental flower's suggestive of orchids or butterflies and the odd-shaped leaves. Escaped from cultivation 


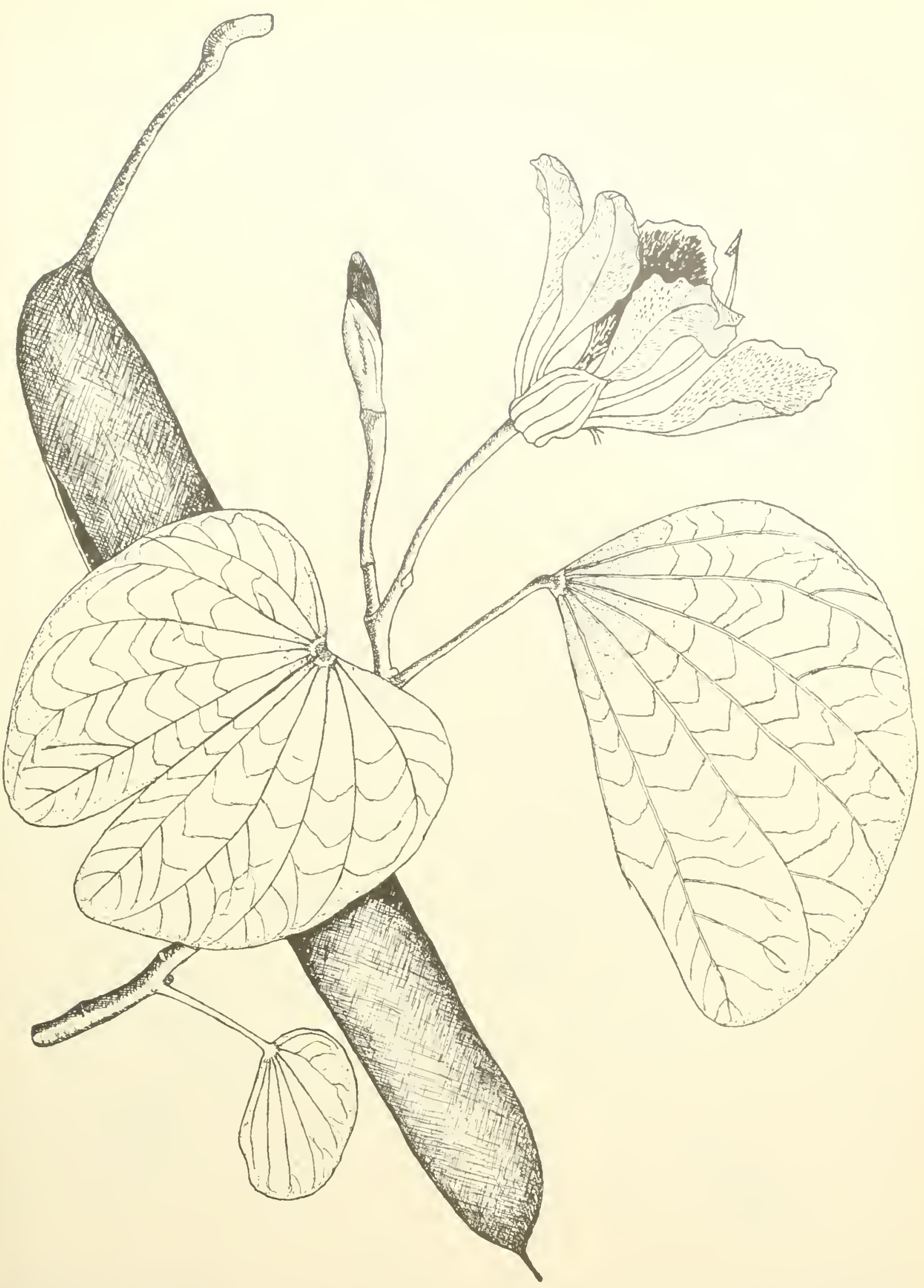

71. Mariposa, butterfly bauhinia 
and naturalized in roadsides, thickets, and river banks in the coastal, linestone, and lower mountain regrons. Ilso in Vieques, St. Croix, St. Thomas, St. Jolm, and Tortola.

R.xac.- Native of southeastern Asia, originally described from Burmat. Planted and escaped or naturalized throumhout the Trest Indies from Cuba and Tamaiea to Babbulos and Trindad. Cultivated in southern Florida. Also introduced in northern South America from French Guiana to Colombia, in El Salvarlor, and perhaps elsewhere.

Otner conuox xumes, - flamboyán blanco, seplina, varital villable, alas de ángel, baujinia (Puerto Riro): Napolenn's plume, poor man's orchid, bauhinia (Virơin Islands) ; flamboyán extranjero, famboýn embano, pata de vaca (Dominican Repmblic): caseo de mulo, pata de vaca (Cuba) : mape (Tenezuela) : butterfly bauhinia, butterfly-flower, pink bauhinia, pink orchidtree
(T'nited States); Jernsalem-date, butterfly-flower (.Tamaica): denx jumelles, caractére des hommes (Iaiti); vlinderbloem (Dutch West Indies).

Botanical synosyas.-Buuhinia kappleri. Sagot. Caspareopsis monumdra (Kurz) Britton \& Rose.

The specific name refers to the odd single stamen which, however, is not restricted to this species. The ?-lobed leaf characteristic of the genus corresponds to a leaf with 1 pair of leaflets partly inited.

A few related speries of shrubs or small trees have been introduced as ornamentals. Palo de orquideas, poor man's oredid, or Bucldhist hauhinia (Bauhinia variegata. L.*; synonym Phanera vritgata (L.) lienth.), has large variegated orchicllike flowers with stamens and the leaves divided to the middle into 2 lobes.

\section{LEGUME FAMILY (LEGUMINOSAE)}

\section{CASSIA SUBFAMILY (CAESALPINIOIDEAE; CAESALPINIACEAE)}

\section{Cañafístula, golden-shower}

This familiar planted tree occasionally escaping from cultivation is identified by: (1) the large even pinnate leaves $12-16$ inches long, with $8-16$ paired, larige, very thin, ovate leaflets $3-6$ inches long and $13 / 4-23 / 4$ inches brond; (2) long drooping chisters of long-stalked, beantiful, golden yellow flowers? inches across the 5 widely spreading petals: and (3) very long crlindrical blackish pods 15-24 inches long and ahont $3 / 4$ inch in diameter.

I medium-sized deciduons tree reported to become 50 feet tall and 11/2 feet in trunk diameter, usually much smaller, with strainht axis, horizontal and spreading branclies, and an open erown of thin foliage. The bark is smooth and grar becoming scaly and reddish brown. The dark green twigs are minutely hairy.

The alternate leaves are composed of 8-16 leaflets with short stalks $1 / 8^{-1 / 4}$ inch long, loosely arranged along the slender, finely hairy, green axis. Leaflet blades are short-pointed at both ends, not toothed on edges, green and hairless on upper surface, and paler and minutely hairy beneath.

'The flower' clusters (racemes), terminal and umhranched, 8-24 inches or more in length, bear several to many lix, slightly fragrant flowers on very slender, neaty horizontal, green stalks 11/4-2 inches long. There are s yellow-meen finely hairy sepals 5/16 inch lonar 5 stalked nearly equal, bright. yellow petals $1-1 \frac{1}{4}$ inch long, elliptie and with veins: 10 stamens, 3 of which have very long filaments, soon falling; and slender, curved, minutely hairy, green pistil $11 \frac{2}{2}$ ineh long with stalked. slender, 1 -eelled ovary and style.

The pods, which hang downward, do not split open but have many cross walls, each containing a single seed embedded in dark brown sweetish
Cassia fistula L.*

pulp. The seeds are shiny, light brown, and flattened. Flowering and fruting nearly through the year.

The reddish wood is very hard, heary (specific gravity 0.9$)$, strong, and durable. Suited as a construction wood and used also for cabinet and inlay work, farm implements, and posts.

Ii Puerto Rico the trees are valued prineipally as omamentals for the showy golden flowers. However, the trees are very susceptible to attack by scale insects.

The drug cassia fistula, a mild laxative, is obtained from the sweetish pulp of the seed porls, which are sold in local markets for this purpose. The medicinal properties were known even by the ancient Egvptians. Flowers, seeds, and bark have been employed also in medicine, and the bark in tanning.

Along highways and streets and around houses chiefly in the moist and dry coastal regions of Puerto Rico. Sometimes escaping and naturalized. Also in Vieques, st. Croix, St. Thomas, and St. John.

R.inge.- Native of tropical Asia. Widely cultivated and locally naturalized in the tropics including West Indies and continental tropical Imerica. However, in many places it is less common than related species known by the same common names. Cuba, Jamaica, Hispaniola, Puerto Rico and Virgin Islands, Lesser Antilles, and Trinidad. A common ornamental in southem Florida and planted also in Bermuda.

OTHER COMMON NAMES,-cañafístula, cañafístola (Spanish) ; golden-shower, golden-shower senna, shower-of-gold, Indian laburmum, pudding-pipe- 


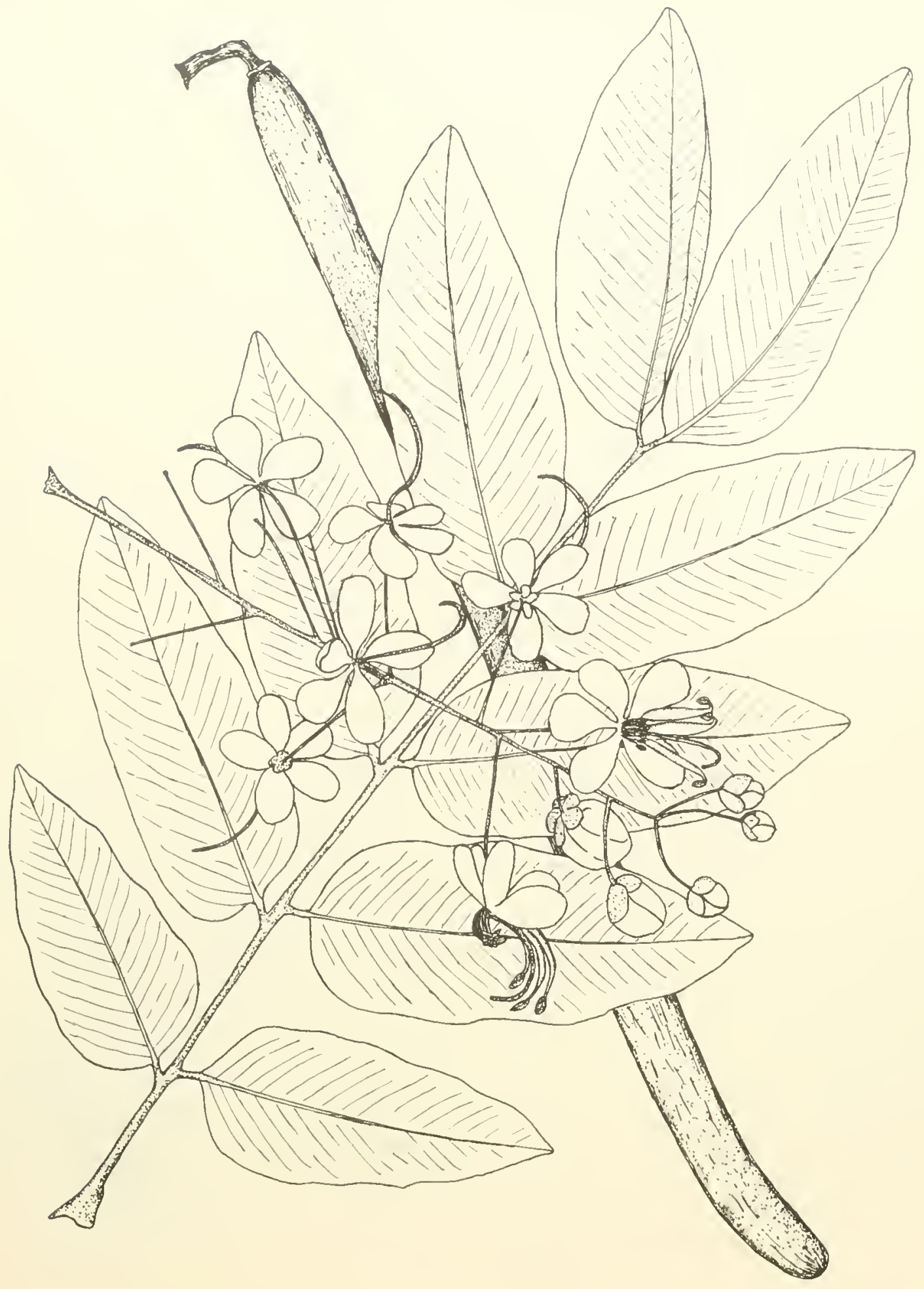

72. Cañafistula, golden-shower 
tree (United States, English); cassia-stick-tree (Jamaira): Inclian labrumum, purgeing eassia (Trindiarl); casse (Haiti); canéfice, canéficier, ("asse-hal hitant (Cimadelompe).

Cañatístula comarmón or pinkshorer cassia (' 'assiu grundix L. f.) is a related tree species of southwestern Puerto Rico and elsewhere planted and locally naturalized. It has reddish or purplish flowers and leaves less than 12 inches long with 11-10 oblong leaflets usually less than 2 inches long. Several native species of this genus are shrubs or herbs.

\section{LEGUME FAMILY (LEGUMINOSAE)}

\section{CASSIA SUBFAMILY (CAESALPINIOIDEAE; CAESALPINIACEAE)}

\section{Casia rosada, pink cassia}

This enltivated ormamental and shade tree diffors from related speries. such as cañafístula, in having a speatimg arched crown and clusters of beantiful lare fragrant flowers, bright pink insteal of reilow. The leaves are even pinnate, mostly $8-15$ inches long, with usually 16-20 (sometimes as few as 10 or mp to : 80 ) paired oblong leaflets $11_{2}-{ }^{-1}{ }_{4}$ inclies loner and $5 / 8-1$ inch broad. The very long. slender, cylindrical, dark brown pods are $16-20$ inches long and $5 / \%$ inch in diameter and (lo not split open.

A medimm-sized. generally deciduous, tree 40 feet or more in height and 1 foot or more in trunk diameter, the trunk oceasionally witly a few stout, diuk uray. spine-tipped branches $2-4$ inches long, aml with willespread crom of thin foliage. The graly bark is smoothish and thin, with many thin fi-cires. Inner bark is light brown and slightly bitter. The long slightly drooping twigs are green aml mimitely hairy.

The leaves are ajternate, enmmonly spreading in -2 rows. The leaflets are regularly arranged on short stalks 1is inch long, nearly equal in size, mostly in pairs along the slender, green, finely hairy axis. baflet blades are short-pointed or rounded at apex, and thim minutely and inconspicmomsly hairy on botlu sides, dull green above and gray green beneath.

Flower clusters (panicles) are lateral, $5-9$ inches long and broad, containing many lare rosescenterl flowers ahout 2 inches across, each on a long. slender, dark red, finely hairy stalk $1-11 / 2$ inches long and slightly curved upward. There are 5 concave, pointed. dark red, finely hairy sepals

\section{Cassia javanica L.*}

1/4 inch long, greenish tinged inside: 5 spreading oblong pink petals 1-11/4 inches long, short-stalked at base and rounded at apex, minutely hairy, with reddish veins but the color of petals fading to whitisl, with age: 10 yellow stanens, 3 about $11 / 2$ inches long and with a swelling beyond middle, and 7 about 1/o inch long: and 1 slender. curved, reddish pistil $1 \frac{1}{4}$ inches long, consisting of stalk, nanow 1-celled owary, strle, and stigma.

The pods, which hang downward, contain numerous rounded and flattened shiny brown seeds $1 / 4$ inch in diameter, each in a separate disklike pulpy compartment, 1,600 to a pound. Flowering mainly from May to July and occasionally through the summer and fall.

'The soft wood with whitish sapwood is not generally used in Puerto Rico.

1 fast-growing tree of relatively recent introduction to Puerto Rico but increasing in popularity and certain to beeome commoner.

Planted along streets and in yards, chiefly in the larger cities of Puerto Rico. Also in Virgin Islands.

RAxGe- Native from eastern Himalayas of India to Malaya. Planted for ornament in various tropical regions. Introduced in southern Floricla.

Other Conmon Nanes. - acacia rosada (Puerto Riro): nodding cassia (Virgin Islands); pink cassia, apple-blossom cassia, apple-blossom senna, pink-and-white shower, Javanese cassia, jointwood, jointwood senna (English).

Botanical srovim.-Cassia nodosa Hamilt. 


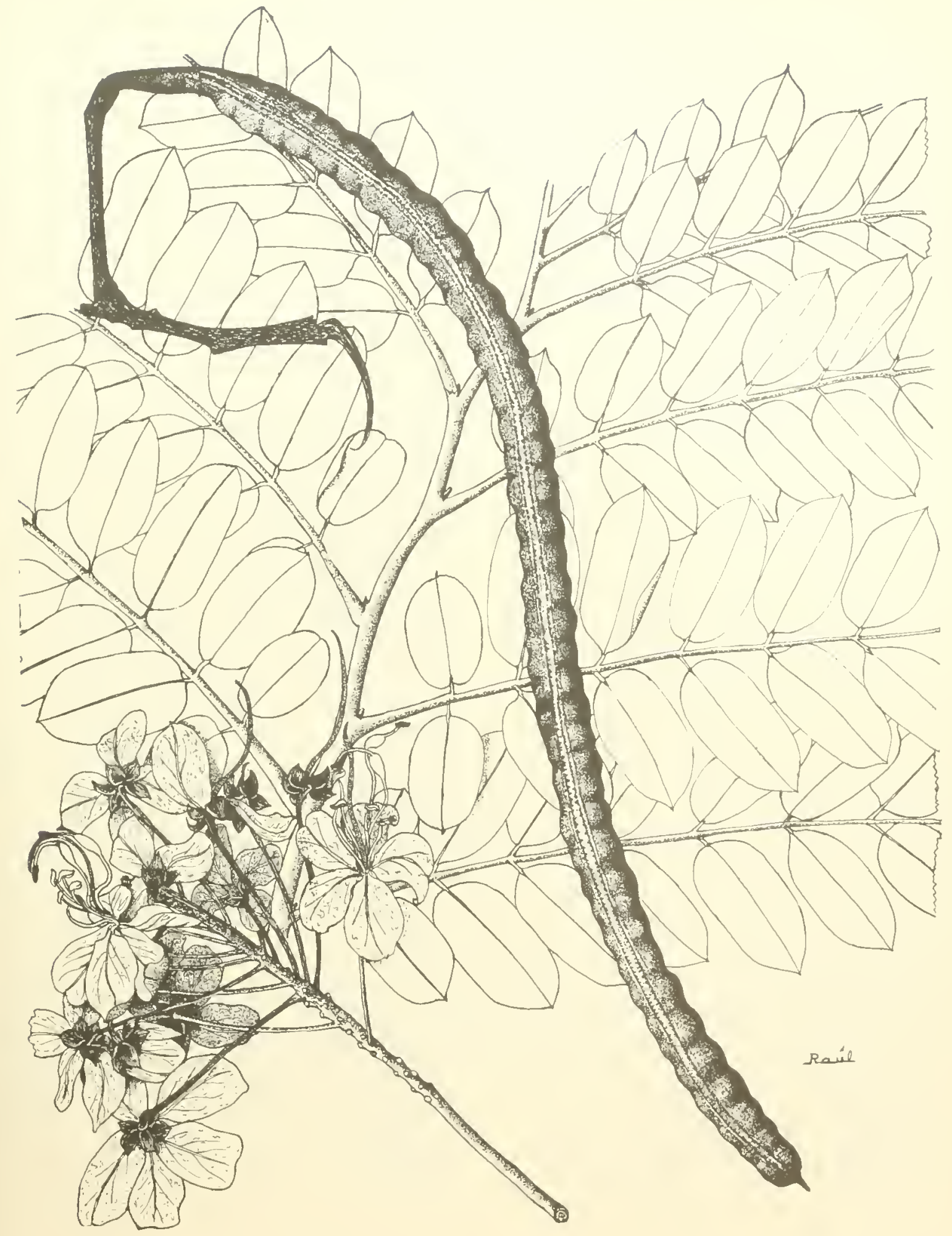

73. Casia rosada, pink cassia

Cassia javanica L.

Two-thirds natural size. 


\section{LEGUME FAMILY (LEGUMINOSAE)}

\section{CASSIA SUBFAMILY (CAESALPINIOIDEAE; CAESALPINIACEAE)}

\section{Casia de Siam, Siamese cassia}

This introdnced tree commonly planted along highways and in windbreaks is characterized by: (1) a generally erect crown, not spreading like most similar species; (2) eren pimate leares $9-13$ inches long, with 1:-2.2 paired oblong or lanceshaped leaflets rounded at both ends and slightly shiny green above; (3) the erect large terminal clinsters of numerous brinht yellow flowers $11 / 4$ inches across the 5 romuded petals: and (t) the many long, narow, flat, dark brown pods which split open to release the seeds.

1 medium-sized evergreen tree to 60 feet in height and 1 foot in trunk rliameter or sometimes larger, with straight axis. The bark is gray or light brown, smoothish but beconing slightly fissured. Inner bark is light brown, oritty and tasteless. The twigs are greenish and minitely hairy when young, turning brown.

The alternate leaves bear leaflets in pairs along the slender, grooved, green and reddish-tinged axis on short stalks $1 / 5$ inch long. The leaflet blarles are almost all the same size, $11 / 4-3$ inches long and $1 / 2^{-7}$ inch broad, with a tiny bristle tip, the edges withont teeth, thin, the upper surface almost hailless, and the lower surface gray green with minute hairs.

Flower chusters (panicles) are branched, 8-12 inches long and 5 inches broad, with many, almost regular flowers on straight, yellow-green, finely hairy stalks 1-11/4 inches long. There are 5 conrave, pointed, greenish-rellow, finely hairy semals "is inch long: 5 spreading, nearly equal, yellow petals $5 / 8-3 / 4$ inch long, short-stalked: 7 stmens of different lengths and in smaller sterile stamens: and a pistil with pale green, minutely hairy, 1-celled ovary and enrved style.

The pods, so numerons that they sometimes give an unticly appearance to the tree, are 6-10 inches long, about $1 / 2$ inch broad, and $1 / 16$ inch thick. stifl, and often slightly curved. They split up the sides into 2 parts, releasing the many flat, shinv, dark hinwn seeds $5 / 16$ inch ]ong and 16,000 to a pound. In flower and fouit throughout the year.

The supwoml is light brown and morlerately: latrl. The heartwool is dark brown and streaked and hard. The wood, which is very susceptible to
Cassia siamea Lam.*

ittack by dry-mood termites, is used locally as a grood fuel and for posts. Flsewhere employed for construction, funiture, tumery, and similar purposes. Tamnin has been extracted from the bark.

In Puerto Rico and the Tirgin Islands the principal uses of the trees are for ormament, shade. and windbreaks. They form good windbreaks becanse they retrin a deep closed crown. This species is a relatively recent introduction in Puerto Rico but now widespread as a result of distribution of quantities of seedlings by the government. It was brought to Jamaica before 1837 and in cinadelonpe has heen planted as shade for coffee and cacalo. The trees are propagated by seeds, wow very rapidly in full sunlight, and are suitable for fuel within in few years. However, they are rery susceptible to attick by scale insects.

The seeds, ports, and foliage are toxic to hogs and canse death quickly after being eaten. As hous relish the poisonons leaves, farmers in Pnerto Rico have suffered losses. Trees blown orel or broken by storms inclease the danger. Thus, swine and perhaps other livestock should he kept away from these trees.

Commonly planted along highways and streets and in parks and yards in both the moist and dry coastal regions, the moist limestone region, and in the lower mountain regions of Puerto Rico. Also common, especially in windbreaks, in St. Croix. St. Thomas, and St. John.

Raxae.-Native of East Indies, Malaya, India, and Ceylon but spread by cultivation. First described from Siam, as the common and scientific mames indicate. Tridely planted through ITest Indies in Crrenter Antilles and many of Lesser Intilles to Trinidad and escaped and naturalized locally. Less enmmon in sonthern Florida and from Guatemala to northern Sonth America.

OtIER Comion xames.-casia amarilla, casia, ('alsia siamea (Puelto Rico) ; yellow cassia (Virgin Islands): flambollán amarillo (Dominican Republic); casia siamea (Cuba): Siamese senua, ciamese shower, kassod-tree (I'nited States): Siamese cassia, kassod-tiee, Bombay blackwood (English) : casse de Sian (Guadeloupe).

BOTANICALs Y N N Y M.-Sciacrssia siamea (lam.) Britton. 


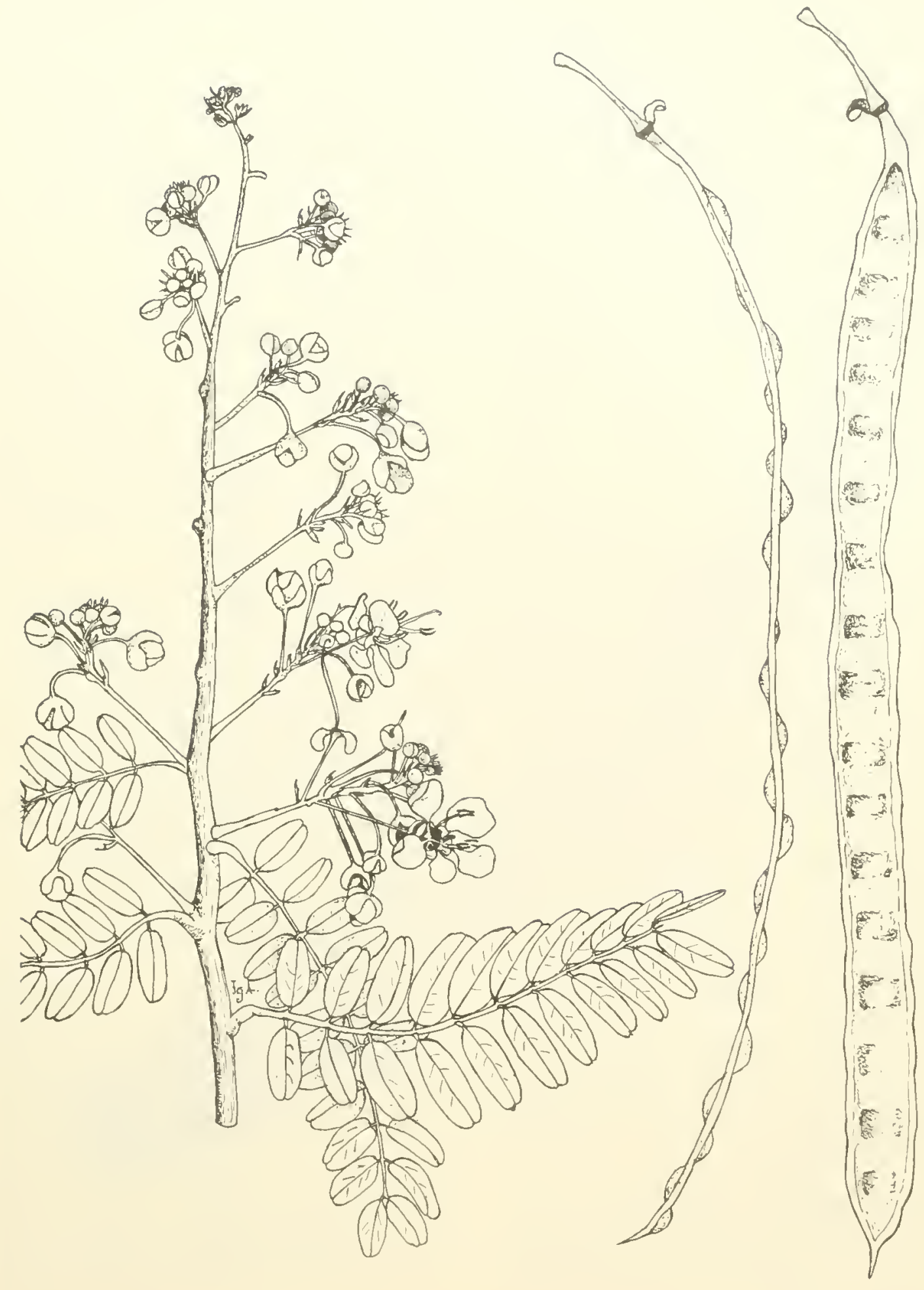




\section{CASSIA SUBFAMILY (CAESALPINIOIDEAE; CAESALPINIACEAE)}

\section{Flamboyán, flamboyant-tree}

Flamboyan, the widely spreading tree which forms arohes of shade along Puerto Rico's highways and which is covered with hilliant masses of large orange-red Howers mostly from May to ofuly or August, is known to all, visitors and residents alike. Fven when the flame-colored blossoms are allisent, the feathery foliage and the giant, flat, blackish or dark liown pods resembling machetes nuke illentification easy.

This small to medium-sized decidnons tree be(a)mes 20 -5) feet hiorl and 2 feet in trunk diameter, laroe truks buttressed and angled towarl base. The gray-brown bark is smoothish, sometimes slightly" aracked, and with many dots (lenticels). Inner lank is light brown and tasteless. Long, nearly horizontal Iranclues form a broad Hat-topped "1own of thin foliage wider than the tree's height. The stont twigs are greenish and finely hairy when young, becoming brown.

The alternate leives are $8-20$ inches long and twice pinnate (bipinnate). Along the light green, slightly hairy axis are $10-25$ pairs of slenter feathery hranches (pinnae) 2-5 inches long, each healling $1:-40$ pairs of very small oblong leatlets $3 / 16^{-3} s$ inch long and $1 / 8$ inch wide. 'The numerous leatlets al'e stalkless, roumderl at base and apex, not tootherl, thin, very minutely hairy on botls sides, green on upper surface and paler beneath.

Several flower clusters (racemes) 6-10 inches long are borne laterally near the end of a twig, each with loosely aringed, slightly fraglant Howers. The flowers are 4 inches across, on slender stallis 2-3 inches long. Calyx consists of i pointed. finely hairy sepals abont 1 inch long. irreen ontside and reddish with yellow border within: 5 unequal petals $2-21 / 2$ inches long and $3 / 4-11 / 4$ inches wide, with a very long, slencler, hairy stalk. broadly spoon-shaped, rounded but broader than long, slightly way-margined or crisp, widely extended and bending backwards before falling: 4 petals are orange red or almost scarlet, while 1 which is longer" and narrower than the others is whitish inside with red spots and streaks: the 10 stamens about 13/4 inches long are slender and red. hairy towarl base: and the pistil has a hairy 1 relled ovary abont 1/2 inch long and slencler style alout 113 in hes long.

The porls are hard, 14-20 inches long, 2-21/4 inches wide, and $1 / 4$ inch thick, finally splitting into 2 parts. There are many obloner mottled brown seeds albout $3 / 4$ inch long and $1 / 4$ inch broad, abut ano to the pound. The onspicuous pods

\section{Delonix regia (Bojer) Raf.*}

hang down and remain attached most of the year, even when the trees are leafless.

The sapwood is light yellow, and the heartwood is vellowish brown to light brown. The wood is soft, heary (specific gravity 0.8 ), coarse-grained, weak and blittle, and very susceptible to attack by dry-mood termites. The large pods as well as the wood are used for fuel.

Widely planted along highways and streets and in parks and gardens of both moist and dry areas almost throughout Puerto Rico for the spectacular flowers and for the shade of the broad branches. Along high ways the trees often are hearily pruned except for the leaning side forming the arch. Also a live fencepost. Sometimes escaping from cultiration and becoming natmalized. Also in Mona. St. Croix, St. Thomas, St. John, and Tortola.

Propagated easily from seed and of rapid growth. Since the wood is weak, trees are often broken by strong winds. After the lea ves a re shed, the trees are less attractive with their conspicnous pods remaining on the bare branches and with the prominent tumnels and nests of the termites which commonly attack this species. A caterpillar, or defoliating insect, occasionally attacks the trees and eliminates the leares completely. Another objectionable feature is the surface root system which sometimes breaks sidewalks and walls. Because of these undesirable characteristics some authorities classify flamboyan among the trees which should not be planted.

RAxGe.- Native of Madagrascar. One of the most extensively planted ormamental trees in tropical and subtropical regions throughout the world and locally esciping or naturalized. Southern Florida including Florida Keys, southem Califormia (planted), Bermuda, and thronghout. West Indies. Also from Mexico to Brazil.

OTHer Comyon vamrs-flamboyán rojo, flamboýn colorado (Puerto Rico); flamboyant, giant, giant-t ree (Virgin Islands); flamboyán (Dominican Republic, Colombia, Tenezuela) ; framboyán. flamboyant (Cuba): árbol de fuego, tabuchín (Mexico); árbol del fuego, flor de fuegro (Central Imerica): acacia, framboýn, guacamayo (Guatemala); guacamaya, poinciana (Honduras) ; guaamaya (El Salvador); clavellino, flor de paro (Colombia) ; flamboyant, josefina (Tenezuela); flamboyant-tree (British Guiana); flamboyant, royal poinciana, flame-tree (United States, English): flamboyant (French): flamborant, Julytree (1)utch Viest Indies) : flimboyant (Brazil).

Botavical smony.-Poinciuna regia Bojer. 


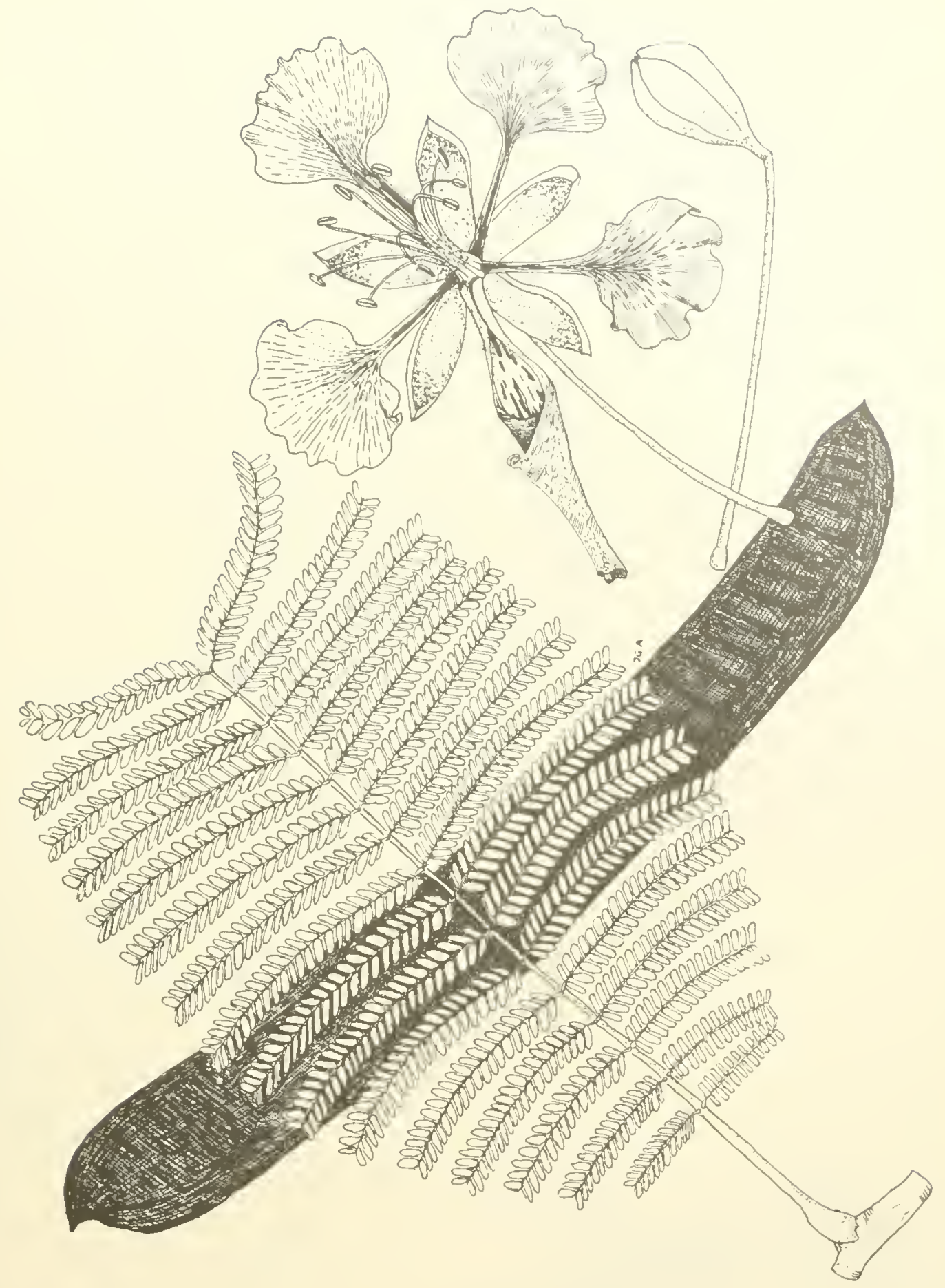

75. Flamboðán, flamboyant-tree

Delonix regia (Bojer) Raf.

Flower and bud, two-thirds natural size; leaf and fruit, one-third natural size. 


\section{CASSIA SUBFAMILY (CAESALPINIOIDEAE; CAESALPINIACEAE)}

76. Algarrobo, West-Indian-locust, courbaril

This handome large tree is charteterized by: (1) compound leaves consisting of 2 almost stalkless, very unequal-siderl, ohlong, shiny green leaflets $2-4$ inchss long and $3 / 4-11 \%$ inches broad, shortor !ong-pointed at apex am lounded at base, and sightly thickenen or heathery; (2) the large spreadiug whitish flowers abont $1 \frac{1}{1}$ inches across, nomerous in erent terminal clusters with stont branches: and (3) the erect, large, oblong, rough, dark brown pods $2-t$ inches long, about $11 / 2-2$ inches wide, more tlan 1 inch thick, with edible pulp.

A nsually evergreen spreading forest tree to 65 feet in heirht and 4 feet in dianneter or larger, sometimes with huttresses. I3ark is smoothish and grar, beroming 1 inch or more in thickness. Inner birk is light pinkish brom. 'The stont branches form a romblerl, widely spreading crown. The twigr are stout, lown, and umbeh ficsured.

The alternate leaves have a petiole 1 inch long. Leaflet blades are shiny green to dark green on upper surface, dull yellow green and slightly brownish tinged on lower surfare, not toothed on erleses, hairless, and show many lighter gland dots when examined with a lens against the light.

The flower "lusters (panicles) are about $4-6$ inches high and lroad, and flattened. The bellshaped, gray-green, finely hoiry, thick basal tube (hypanthim) is 3 inch long and broad; there are 5 sightly thickened, gray-green, hairy sepals $1 / 2-5 / 8$ inch long: the 5 thin white petals are elliptic, $5 / 8-3 / 4$ inch long and a little unequal, covered with minute glind dots: the 10 stamens $1 \frac{1}{4}$ inches long have white filaments and red anthers: and the pistil consist of a stalk projecting beyond the tube, a flattened 1-celled ovary less than 3 's inch long, and a very slencler enred style 1 inch long.

The pods are thick-walled, hard, conta in pockets of sum, and do not open. There are few to several oblong, flattened, dark red seeds about 1 inch long imbedded in the thick pale yellow pulp. This sweet and mealy or powdery pulp is edible, thongh it has an umpleasant odor, and mixed with water forms a drink. The large seeds weigh about 120 to a pound. Flowering from early spling to fall, and pods remaining on the tree awhile after maturity.

The thick sapwood is whitish to gray brown. Heartwood is rark or reddish brown, often with blackish streaks. The wood is very hard, heary (specific gravity 0.7), mostly medimm textured and lisually with interlocked glain. It is very strong. tough, durable, vely resistant to attack by drywood termites, and slightly difficult to work. Rate of air-seasoning is moderate and amount of de-
Hymenaea courbaril L.

Erade is considerable. Machining charncteristics are as follows: planing is fair"; turning is excellent ; shaping, boring, mortising, sanding, and resistance to screw splitting are good.

In important Imerican timber species producing wood of good quality but of limited quantity in Puerto Rico. Here clasced as for furniture and sometimes compared with malogany. Mlso used in carpentry, general construction, and for wheels and cogs. Eisewlyere employed in shipbuilding and for railway crossties, posts, looms, cart wheels, and balls. The wood should be attractive as veneer, plywood, cabinetwork, interior trim, and turnery.

The roots and trunk yield a pale yellow or reddish resinlike gum known commereially as South Imerican copal. The gum exudes and forms hard homps which heome buried in the soil at the base of a tree. Sometimes as much as a barrel of gum has been found around the roots of a large tree or at the site of a former tree. The gum is used mainly in valuish but also for incense and local medicines. I honey plant.

Indians made canoes from the smooth hard thick bark by stripping in one piece the bark of a large tree, sewing the ends together, waterproofing the seams with gum or resin, and inserting wooden crosspieces. The barls has been used in medicines also,

Efforts to nse this species for reforestation in Puerto Rico have shown it to be unadapted to degraded sites and generally of slow growth. Shade is required at first if the trees are to produce. stridirht trunks. Trees underplanted in a forest near Rio Piedras attained heights ranging up to 20 feet after 13 years. Plantings in the open. for shade and ornamental purposes, produce attractive spreading trees more rapidly. This makes a good roadside shade tree, but locations near houses should be a voided beenuse of the malodorous fruits.

scattered in forests, pastures, and along roadsides in the moist and dry constal and limestone regions of Puerto Rico. 1lso in Vieques, St. Croix, St. Thomas, St. John, and Tortola.

Promic monests.-Cimbalache, Gmajataca, Luquillo, Maricao, Río Aba jo, Susúa.

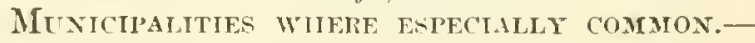
$25,30,32,42,59,69$.

R.xige.-Throughout IVest Indies from Cuba and Jamaica to Trinidad and Tobago. Also from central Mexico to Peru, Bolivia, Brazil, and French Guiana. Rarely planted in southern Florida.

Other Common NAMEs.-TTest-Indian-locust, locust (Tirgin Islands); algarrobo (Spanish): 

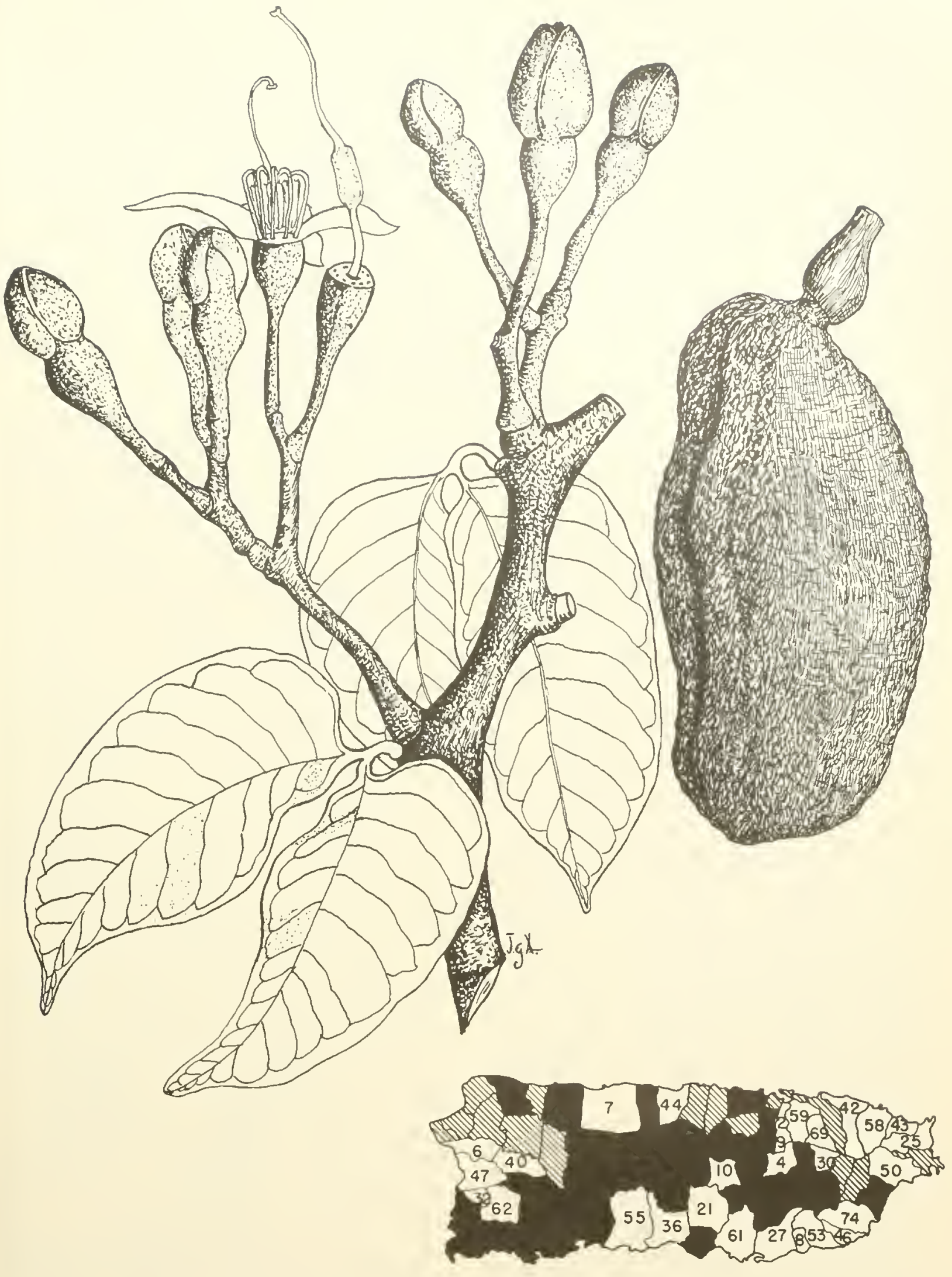

76. Algarrobo, West-Indian-locust, courbaril

Natural size

IIymenaca courbaril L. 
(coubaril (enmmerce, English) : curbaril, caguairán, algarrobo de las Antillas (Cuba); guapinol, cumpinol, copinol (Mexico, Central Imerica); muapinal, nazareno (C'olombia) ; corobore (V'eneZulclal): (opal (Ecuador): courbaril (Peru); locust (British Trest Indies, British Guiana); Wrest-Indian-locust, stinking-toe (J a m a i c a) : stinking-toe (Trinidad) ; locust, guapinol (British Honduras); courbaril, simiri, locust (British (tuiana); courbaril (Guadeloupe, Martinque, French (ruiana); locust (Dutch IVest Indies); rode locus, locus, loksi (Surinam) ; jutahy, jatobá (Brazil)

The specific epithet is taken from an American Indian name, combaril. Early Spanish settlers in the New World gave the name algarrobo to this and other trees of the legume family suggestive of the related Old World carob tree with the same Spanish name (Ceratonia siliqua L.*). The latter, introduced experimentally in St. Croix, has pimate leaves with \pm-10 elliptic leaflets and flat porls $1-12$ inches long with edible pulp.

\section{LEGUME FAMILY (LEGUMINOSAE)}

\section{CASSIA SUBFAMILY (CAESALPINIOIDEAE; CAESALPINIACEAE)}

\section{Palo de rayo, Jerusalem-thorn}

Small spiny tree characterized by: (1) smooth vellow-mreen or blue-green bark, branches, and twigs: (2) specialized leaves consisting of a terminal spine and 2 or 4 long yellow-green drooping strips bearing numerous small leaflets $1 / 8-3 / 16$ inch long which shed early; (3) showy golden-yellow flowers $3 / 4$ inch or more across the 5 petals, in loose lateral (lusters (racemes) 3-8 inches long: and (4) brown pod $2-4$ inches long and $1 / 4$ inch or more in diameter, narrowed between the seeds.

Shrub or small tree 10-20 feet tall, often branching near ground, with very open crown of spreading branches and very thin drooping foliage, green throughout the rear, though appearing leafless after the leaflets fall. The bark is smoth and rery thin, yellow green or blue green but becoming brown and fissured or scaly on large trunks. Imner bark is green and slightly bitter. The slender, slightly zigzag, green twigs are minutely hairy when young. They have paired short spines (stipules) at norles bordering the linger spine $3,-3 / 4$ inch or more $i n$ length, which ends the leaf axis. These spines may remain on the branches and trunk in gloups of 3 or singly.

The alternate leaves actually are twice pimate (bipinnate). consisting of a very short main axis ending in a spine and 1 or 2 pairs of droopiner lateral axes $4-12$ inches loner and 1 , inch broad, flat. and slightly thickened. Each drooping strip or streamer bear's $20-: 0$ pairs of thin, oblong, green, lecidnous leaflets and functions as a leaf after the leaflets fall.

Several sightly beanlike fragrant flowers are lorne on slender stalks. There is a short calyx tube with 5 narow yellow-brown lobes $3 / 16$ inch loner. turned downward: i nearly round petals $3 / 1 / 2$ inch long, yellow, tinged with nmange, and hary at base, the upper petal slightly larger, redspotted, and turning red in withering: 10 stamens 1't inch long with green filaments and brown anthers: and reddish-tinged pistil $1 / 4$ inch long with hairy 1-celled ovary and slender style. The
Parkinsonia aculeata L.*

long-pointed pods contain usually $2-5$ oblong dark bown seeds $3: 8$ inch long (5,600 to a pound). With flowers and pods throughont the year.

The saprood is yellowish and thick, and heartwood light or reddish brown. The wood is moderately hard and heary (specific gravity 0.6), and brittle, used locilly only for fue].

Sometimes grown in fences and as a spiny living hedge. The foliage and pods are browsed by livestock. Elsewhere an infusion of the leaves has served in lome medicines.

() ften planted as an ormamental along roads and escaping from cultivation or naturalized, chiefly in the Iry coastal region of Puerto Rico. Also in Vieques, St. Croix, St. Thomas, St. John, Tortola, and Virgin Gorda.

RAxre.-Widely distributed in tropical Americal native of 'Texis. Arizona, and Mexico and possibly elsewhere but cultivated, spreading, and becoming naturalized from southern United States (Florida and Georgia to Texas and California) south to Irgentina and in the Old World tropics. Ilso thromghout West Indies, probably introdured, and planted in Berumda.

O) Tif.r comsion Nisles.-flol de rayo, flor de milyo (Puerto Rico) : lluvia de oro, acacia, acacia de los masones, cambrón, siempre-viva (Dominican liepulblic) : junco marino, espinillo (Cuba); paloverde (Mexico) : retama (Mexico to Colombia) : sulfato, sulfatillo, palo de rayo (Guatemala): sulfato (El Salvador) : acacia de agiiijote (Nicaracua) : yabo, sauce, sauce espino, goajiro (Colombia): espinillo, paují, cují extranjero (Venezuela) ; mataburro (Peru); cina-cina (Iruguay. Arrentina): Jerusalem-thom, horsebean, paloverde, Mexican paloverde, retama (United States): Jerusalem-thorn (English); horsebean (Bahamas) : Jerusalem (British Guiana) ; madam naiz, madam yass (Haiti) ; arrête-boenf (Guadeloupe, Martinique); boonchi strena, wonder-tree (Dutch Trest Indies). 


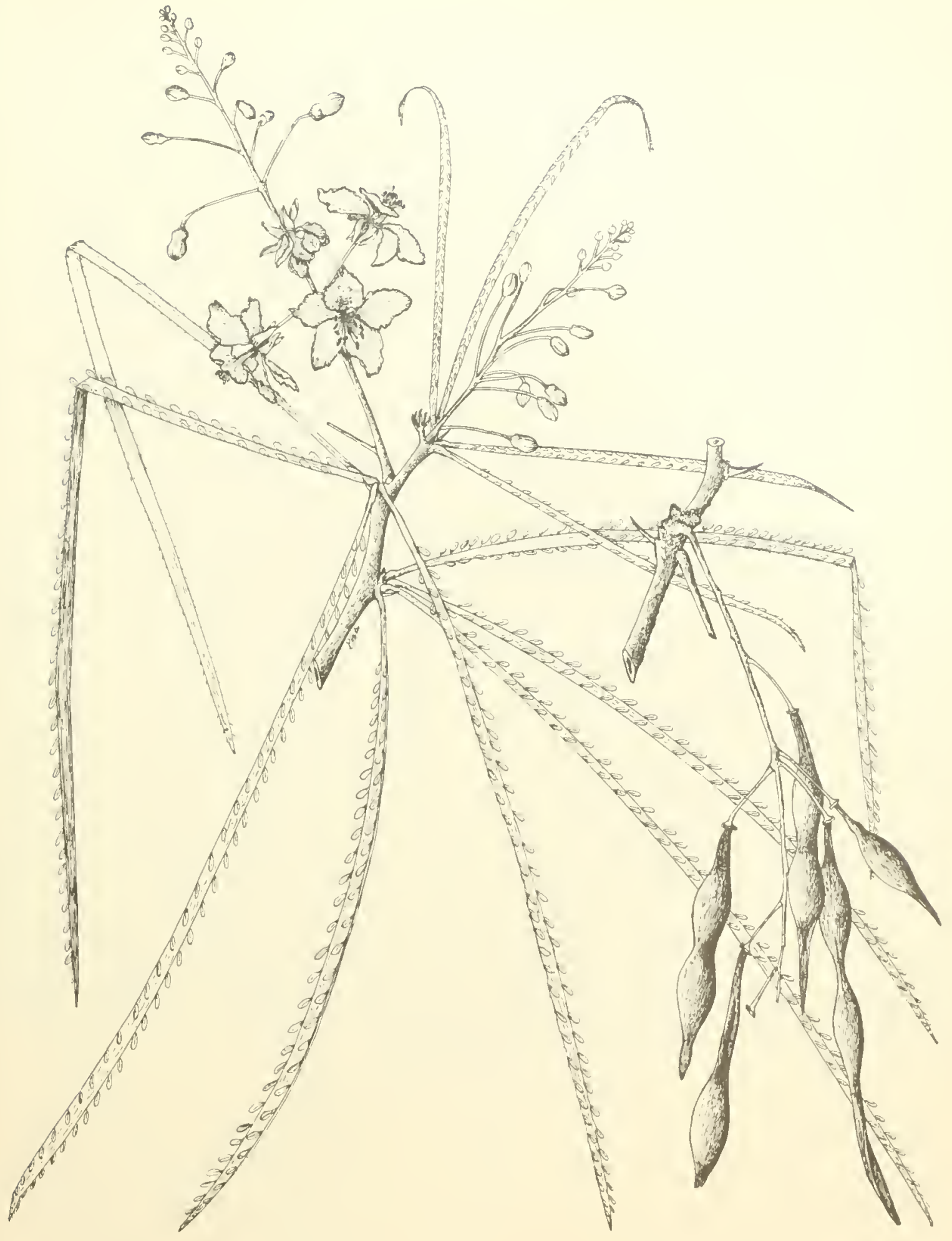

77. Palo de rajo, Jerusalem-thorm 


\section{LEGUME FAMILY (LEGUMINOSAE)}

\section{CASSIA SUBFAMILY (CAESALPINIOIDEAE; CAESALPINLACEAE)}

\section{Flamboyán amarillo, yellow flamboyant}

This handsome ornamental and shade tree, a relatively re:ent introduction to Pureto Rico, is characterized by: (1) the feathery or fernlike, twice pinnate leaves (bipimmate) $s-16$ inches long, with numerous paired small oblong leaflets $1 / 2^{-3 / 1}$ inch long and $1 / 4-3 / 8$ inch loroad: (2) the dense coat of rility or reddish-brown hairs on young twigs, leaf axes, branches of Hower clusters, and flower buds; (3) many showy rusty-yellow flowers with 5 roumled petals, in kirge chusters; and (4) conspicuous, broad, flat and winged pods, reddish but turning to d:uk reddish brown, $21 / 2-11 / 2$ inches long and $1-13 / 3$ inches broad.

A medinm-sized to la rge evergreen tree 30-65 feet in height and $1 \frac{1}{2}$ feet or more in trunk diameter, graceful and with spreading branches and dense foliage. MIost of the trees here are not old enough to have reached large size, the maximum elsewhere being about 109 feet. Bark on small trees is smoothisls, with dots and lines (lenticels), light gray, becoming brown and furrowed. The inner bark is light brown and bitter.

The alternate leaves consist of a main axis and 14-30 paired lateral axes (pinnae), each bearing 16-32 paired leaflets. Leaflets have very short stalks about ${ }^{1}$. inch long, are rounded and s!ightly notched at apex and rounded and oblique at base. the edges not toothed, thin, the upper surfare green and hairless, and the lower surfice paler and finely hairy.

Flower clusters (panicles) are terminal and widely branched, nearly 1 foot long. The calyx of the fragrant flowers is more than $3 / 8$ incly long. with short tube and 5 rusty-lorown hairy lobes; the 5 nearly equal, stalked, rounded petals $5 / 3-3 / 4$ inch long have wary, finely toothed margins and

\section{Peltophorum inerme (Roxb.) Naves*}

are bright yellow with a brown hairy stripe on ontside: 10 stamens with orange anthers and filaments brown hairy at base; and pistil with a hairy 1-celled ovary, slender style, and broad flat stigma.

The oblong pods are short-pointed at both ends, wing-margined, with 1-4 flat seeds (5,600 to a pound), and do not split open. Flowering from spring to fall (April to September) and fruiting chiefly in the winter.

The sapwood is whitish and hard. To the present the wood is used locally only for fuel.

Grom for the ornamental flowers and attractive reddish fruits and as a street or shade tree in the larger cities in Puerto Rico and also in St. Thomas. Though a fairly new introduction, this species is increasing in popularity and being planted more extensively $\boldsymbol{y}$ ft is propagated from seed and grows rapidly. The floyers attract bees. The trees are reported to be shallow rooted and subject to damage by strong winds.

River.-Native in Ceylon, southern India. Malaya, East Indies, Philippines, and northern Australia. Widely cultivated through the tropies though apparently not yet introduced in many parts of the New World. Recorded as planted in southern Florida, Puerto Rico and St. Thomas, Guadeloupe, Trinidad and Tobago, Guatemala, Panama, Venezuela, and British Guiana.

Otifer common vames.-yellow flamboyant, yellow poinciana (English): peltophorum, zapatero (Trinidad): palissandre (Guadeloupe).

Botaxical sYxoxyms.-Caesalpinia fermiginea Decne., C. inermis Roxb., Peltophorum ferrugineum. (Decne.) Benth., P. roxburghii (G. Don) Degener. 


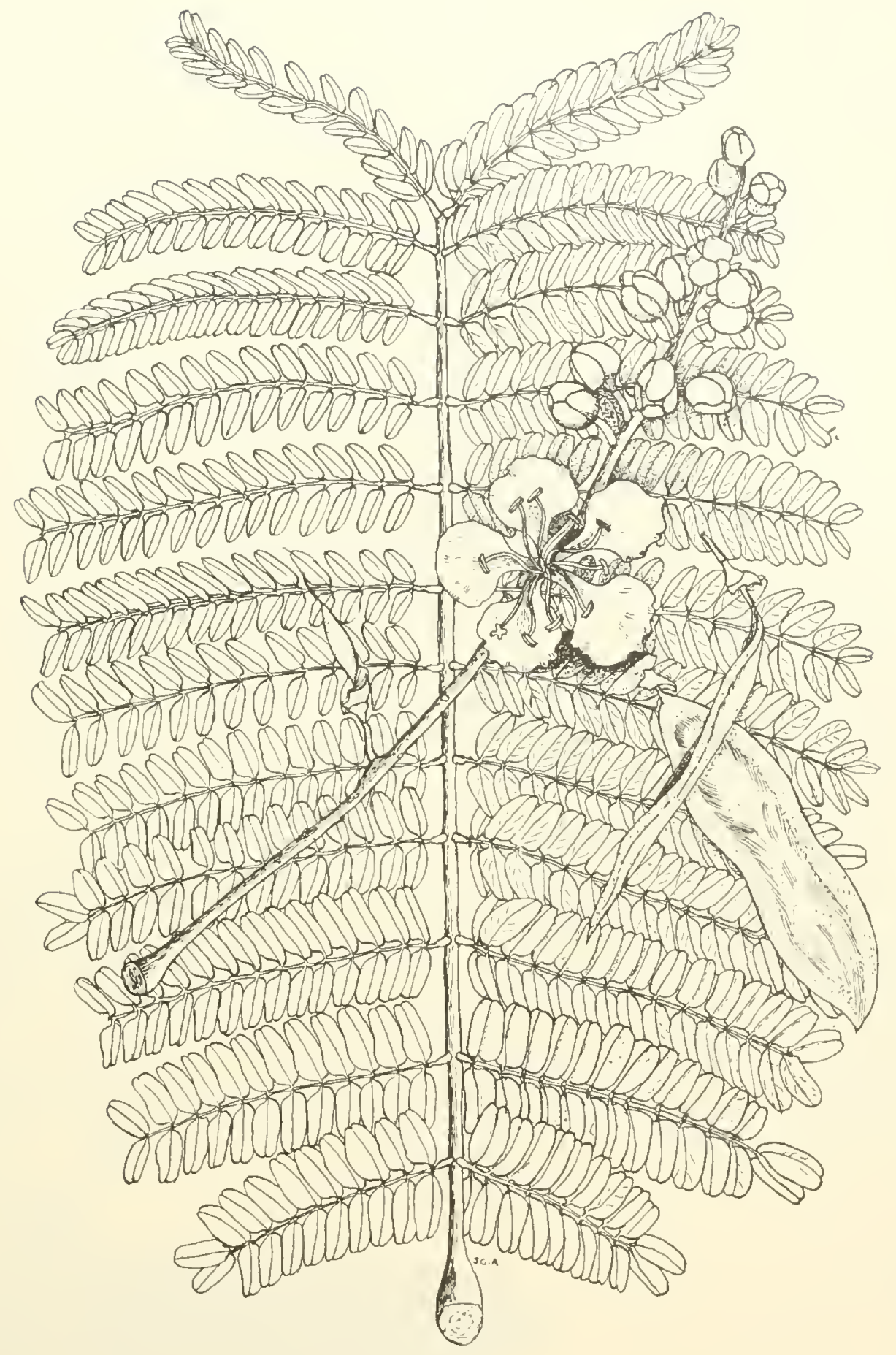

78. Flambosán amarillo, fellow tlambosant 


\section{LEGUME FAMILY (LEGUMINOSAE)}

\section{CASSIA SUBFAMILY (CAESALPINIOIDEAE; CAESALPINIACEAE)}

\section{Cóbana negra}

This tree of coastal forests of southwestern and southeastern I'nerto Rico is easily identified by: (1) the pinnately compound leaves with $6-12$ opposite lance-shaped to ovite leatlets $11 / 4-31 / 2$ inches long and $1 /, 11 /$ inches broarl, on red stalks with scattered black raised dots (glands) on lower surface: (2) the chusters of pale yellow flowers about $1 / 2$ inch arross the 5 petals : and (3) the odd, elliptic, thick and fleshy, red pods 2 inches or less in length, not splitting open.

I medimm-sized everom tree $25-50$ feet in heiwht and 1-11\% feet in trunk diameter. [Tsully small, becanse the large trees have heen ent. Bark on small tumks is dark gray and smoothish, becoming rough, much furmowed, and thick on large trunks. Inner bark is light lnown and bitter. The twigs are bruwn and latirless, with raised gray dots (lenticels).

The leaves are altermate, $1-7$ inches long, with a rellow-hown axis and with stalks of individual leaflets 1/1; inch long. Ieaflet hlades are shortpointed at apex, rounded and slightly oblique at base, the edges slightly wary, thichened and leatherr, shiny on upper surfice and dull beneath.

Flowej clnsters (racemes) are terminal and lat. eral. :-6 inches long, unbranched, and the flowers with short stalks ${ }_{4}^{\prime}$ inch long. The fommel-shaped base (hypanthium) is about $1 / 6$ inch long and hroat; there ale of slightly hairy sepals $1 / 4$ inch long: 5 slightly hairy (japillose) petals $3 / 8-1 / 2$ inch long; 10 stamens; and pistil with 1-celled oviry and slender courved style.
Stahlia monosperma (Tul.) Urban

The pods are about $11 / 8$ inches broad and $3 / 4$ inch thick, with odor of ripe apples, light bromn tasteless flesh, and 1 large seed. Flowering in spring and early summer (February to June) and maturing fruits in summer and fall.

The sapwood is light brown, and the heartwood is dark brown. The rood is rery hard, heary, strong, durable, and resistant to attack by drywood termites.

Snited for furniture, although considered hard for this purpose. Mostly used for construction in the past. Becanse of the denand of this raluable wood, large trees have beeome searce. Perhaps this species could be planted both for shade and wood.

Generally found in low areas and near mangrove in the dry-coastal region of Puerto Rico enst to Ceiba. Also Tieques.

Putilic Folisst.--Boquerón.

Raxae.-Folmerly known only from Puerto Rico and Tieques bit in recent years found also in eastern I ominican Republie near Macao.

Otiner comzox vayes.- cóbana, polisandro (Puerto Rico) : coabanilla (Dominican Republic).

Botixichl sryoxym. -Stahlin maritima Bello.

The generie name stahtin honor's Agustim Stahl (18t2-1917), phrsician and botanist of Baymón, Puerto Rico, who wrote "Estudios sobie la Flor"a de Pnerto Rico" (1883-88, second edition 1986-37), an unfinished publication on the plants of the island. This is the only species of the genus. 


\section{LEGUME FAMILY (LEGUMINOSAE)}

\section{CASSIA SUBFAMILY (CAESALPINIOIDEAE; CAESALPINIACEAE)}

\section{Tamarindo, tamarind}

This well-known handsome planted tree, whose solu pods are used in a refreshing doink, is characterized by: (1) a generally dense crown of foathery, pinnate leaves $2-11 / 2$ inches long, with 10-1s pairs of oblong blue-green leafl $35 / 5-7 / \mathrm{s}$ inch long and $1 / \mathrm{s}^{-1 / 4}$ inch hroad; (2) showy flowers about 1 inch across, pale yellow tinged with red, sereral in terminal and lateral chusters (racemes) $11 / 2-6$ inches long; and (3) the gray, rongh, thick pork $11 \%-5$ inclies long, containing dark brown edible pulp around the seeds. Showy when in full bloom, the flowers giving yellowish color to the tree.

A medium-sized tree to 40 feet high and with usually a short trunk to 3 feet in diameter or larger, with a ronnded crown of dense fine foliage, except on very dry sites. The bark is longh, much fissured, gray or brown, and thick. Inmer bark is brownish, gritty, and slightly bitter in taste. The twigrs are green and minntely hairy when youmg, turning aray or brown.

The leaves are alternate. Leaflets are almost stalkless and cloce tourether along a slender pale green axis, romnded at both ends and oblique at base, not toothed, thin, blue green above and slightly paler beneath, folding against axis at nieht.

The flowers are slightly irregular sluaped, delicate, and on slender stalks. Flower buds are dark red. The narrow, pale green basal tube (hypanthium) is $3 / 16$ inch long: there are 4 pale yellow semals $1 / 2$ inch long: 3 pale yellow petals with red veins, keeled and bronder toward the finely wary apex, the 2 onter ones 5 is inch long and central petal $3 / 8$ inch long, 2 other petals reduced to minute scales: 3 greenish stamens $1 / 2$ inch long, united by filaments to middle, and 2 minute sterile stamens : and a green beanlike pistil $5 / 8$ inch long with stalked 1-celled ovary and enrved style.

The heavy, often curred pods are about $11 / 2-t$ inches long, $3 / 4^{-1}$ inch wide, and $3 / s^{-5} / 8$ inch thick, slightly comstricted between the seeds, with a brittle onter shell, and not splitting open. I'sually 3 or + flattened shiny hrown seeds $5 / 8$ inch long are imbedded in the dark brown, fibrous pulp, which is edible though very sour. Seeds 400 to a pound. Flowering mainly from spring to fall and fruiting from winter to spring.

\section{Tamarindus indica L.*}

The supwood is light yellow and moderately soft, and the small heartwood dark purplish brown. The woor is described as very hard, heavy (specific gravity 0.9), and takes a fine polish. It is st rong and durable, although very susceptible to attack by dry-wood termites.

The wood is used chiefly for fuel and is reported to generate oreat heat. In other places where the species is sufficiently common, the wood is employed for constuction, tool handles, furniture, and articles in woodturning but is considered very difficult to work. Good charcoal for gurtpowder formerly was manufactured from it.

Candy and preserves, as well as the beverage, are prepared from the edible ports. The young tender sour fruits have been cooked for seasoning meats, and the young leares and flowers reportedly ronsmued as food. IBesides making the trees ormamental, the flowers attract bees and are an important sonrce of honey. However, the litter of the porls is oljectionable in street planting. In India the trees are planted on forest frebreaks becaluse the ground underneath usually is bare.

The fruit pulp is employed in home medicine and formerly was oflicial as the source of a laxative. It contains sugar as well as acetic, tartaric, and citric acids and is antiscorbutic. Decoctions from flowers, seeds, young leaves, and bark of the plant have been nsed medicinally also. A yellow dye has been obtained from the leaves.

Planted in Puerto Rico mainly for the fruits and ormament and shade and occasionally naturalized. Fairly common aromed houses, along roads, and on hillsides in the coastal regions, mainly on the dry coast. Also in Vieques, St. Croix, St. Thomas, St. John, and Tortola.

R.sxcE. - Native of the Old World tropics but widely planted and naturalized in tropical and subtropical regions and introduced into the New World at a very early date. Cultivated and often naturalized throughiout Trest Indies and from Mexico to Brazil. Planted also in southern Florida inchding Florida Keys and in Bermuda.

OTIER COMMON NAMES. - taman, tamarindade (Virgin Islands); tamarindo (Spanish); tamarind (United States, English); tamarin, tamarinier, tama rindier (French): tamarijn, tamarind (Dutch West Indies); tamarinde (Surinanı); tamarindo (Brazil). 


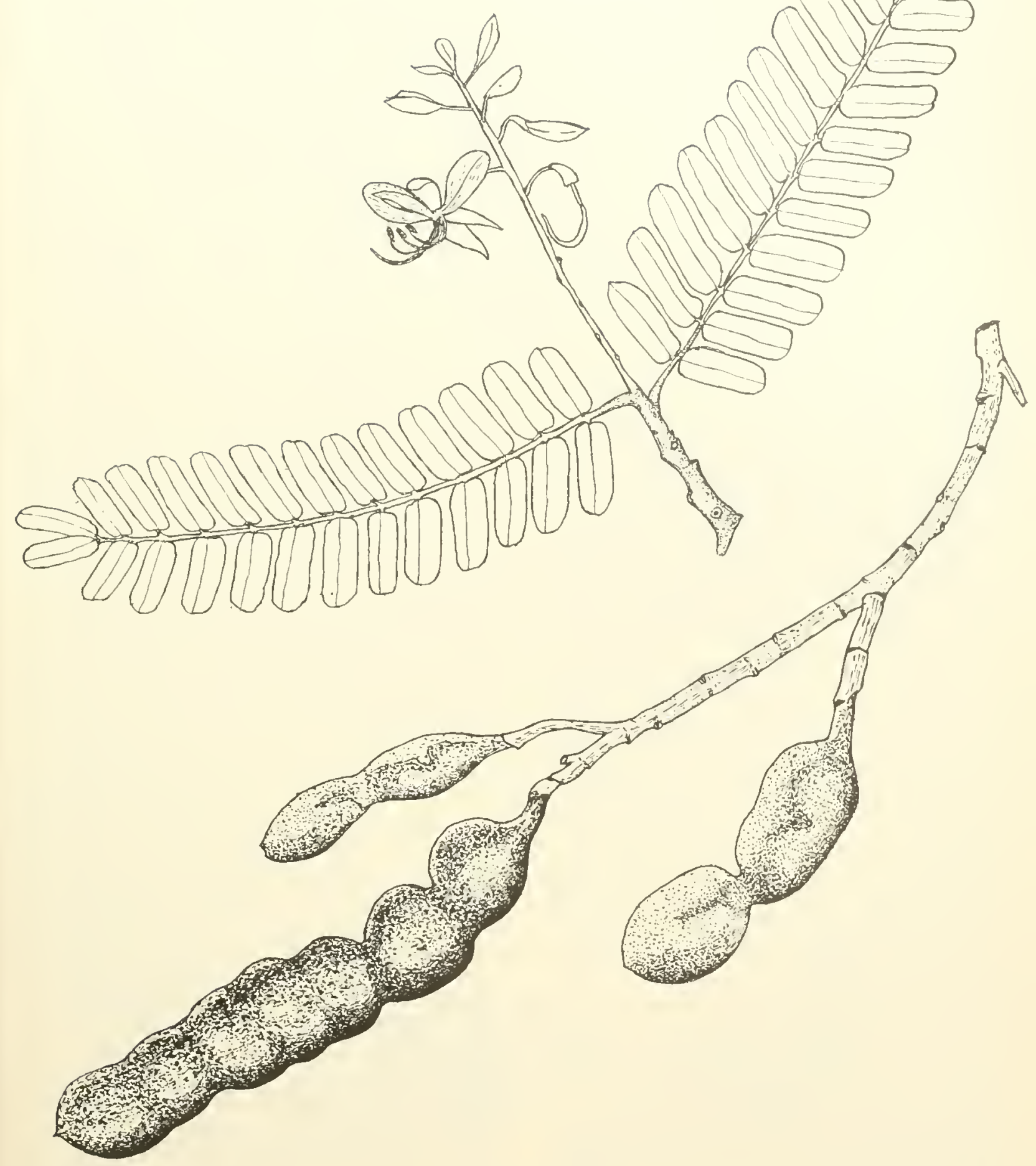

so. Tamarindo, tamarind 


\section{PEA SUBFAMILY (LOTOIDEAE; FABACEAE)}

A. Leares with 3 leaflets.

Kisy to the 11 spercies illustrated (Nos. 81-91)

B. Leaflets with 3 main reins from hase, short-pointed at apex.

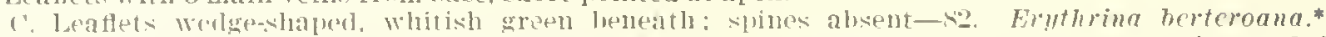

(1). Leaflets broadly ovate, nearly straight at hase: spines often seattered on twigs and branches-SH. Erythrina porppigiana."

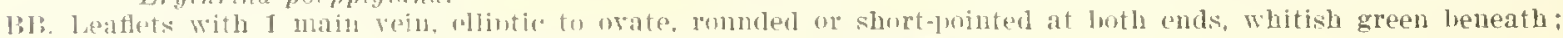
spines seattered on twigs and branches-S3. Erythrina glanca.*

Ad. Leaves pinnate.

I). Leaflets rounded, $3 / 5-3 / 4$ inch long and broad, with fellowish sping or bristle tip: twigs spiny-88. Pictetia aculeratu.

DI). Leaflets larger, longer than hroad, not sjing; twigs not spins.

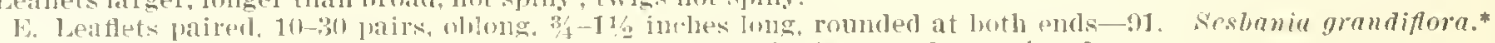

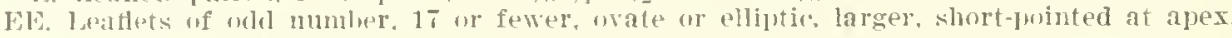

F. I.eares less than 1 foot long.

G. Leaflets paired exe(p)t at end: saj waters.

I. Leaflets $5-9$, wimally $T$. with stout stallis $1 / 4-1 / 4$ inch long-86. Lonehorarpus latifolius.

HH. J.eatlets $\mathbf{i}$-13 ur mre, with slender stalks.

I. Leafots shontle shing grem un npler surface, 2-5 inebes long-s1. Andira inermis.

II. Leatlots luhl green, mostly less than 2 inches long-85. Gliricidia sepimm.*

GG. Leaflets all attached singly, not pairel ; sap dark red.

J. Leafletswate S!). Ptrorarpus imdirus.*

J.J. Leaflets elliptic to wblong-ik). Pfrocarpus offirinalis.

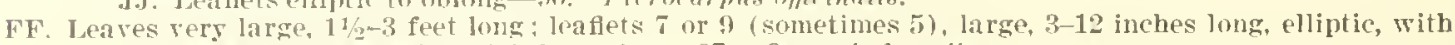
many parallel lateral reins slightls snnken-87. Ormosia krugii.

\section{Moca, cabbage angelin}

This attractive tree is easily recognized in flower by the showy masses of pink to purple pea-shaped flowers $7 / 1$ inch long. Other distinguishing chararters are: (1) the rongh light gray bark, which has an umpleasant cabbagelike odor when cut; (2) alternate pimate leaves with $i-13$ oblong or elliptic short- or long-pointed, thin, slightly shiny green leaflets; and (3) the distinctive stalked elliptic or egg-shaped green pod $1-1 \frac{1}{2}$ inches or more in length, containing 1 poisonous seed and not splitting open.

1 medium-sized deciduous tree becoming 20-50 feet tall and 6-12 inches in trunk diameter, sometimes larger, erect in the forest but in the open mucli branched and with dense rounded spreading crown. 'The bark $1 / 4-3$ 's inch thick is much fissured and scaly. Inner bark is light brown, sometimes with slightly bitter taste. The stout twigs are wreen and finely hairy when young, becoming brown or gray.

The leaves $6-16$ inclies long have a green axis enlarged at hase, bearing there when young 2 narrow pointed areen to brown scales (stipules) 1/s-1/2 inch long. I eaflets, paired except at end, have short green stalks $1 / 8-1 / 4$ inch long and 2 narrow pointed green scales $1 / 16^{-1 / 8}$ inch long at base. The blades are 2-5 inches long and 1-2 inclies broad. romderl at base, not toothed at edges. turner up a little at midrib, pale and very slightly sliny or dull beneath, varying in color from yellow green through green to brownish green.

Flower clusters (panicles) are broad and much branched, 6-12 inches long, terminal or sometimes also lateral, the greenish branches finely hairy, bearing numerous almost stalkless flowers, which

\section{Andiva inermis (W. Wright) H. B. K.}

al'e dark red to deep pink in bud. The bell-shaped alys tube is $3 / 16$ inch long and broad, minutely 5 -toothed at the almost even top, pinkish tinged, finely hairy; there are 5 usually pink petals $7 / 16$ incli long, all narrowed and stalked at base, a broad ronnded standarr, 2 wings, and 2 keel petals: 10 white stamens, 1 free and $?$ united into a tube about $2 / s$ their length: and long-stalked pistil nearly $1 / 2$ inch long. including flattened light green hairy 1-celled ovary and curred slender white style.

The thick pods (drupes) are slightly fleshy outside and hard within, weighing about 20 to the pound. Recorled in flower in winter (.Tanuary and February) and summer (May to September) and in fruit mainly from summer to December.

sapwood is light brown. The highly figured, decorative heartwood varies from yellowish brown to dark reddish brown with sharply contrasting hands of light and dark fibers. The wood is hard, fairly heary (specific gravity 0.63), coarse-textured, easy to work, and finishes well. It is susreptible to attack by dry-wood termites but reported to he durable in contact with the ground. Rate of air-seasoning and amount of degrade are moderate. Machining characteristics are as follows: planing. turning, and sanding are excellent: shaping is fair; and boring, mortising, and resistance to screw splitting are good.

Formerly and potentially for high-grade furniture and cabinetwork in Puerto Rico, the wood is now utilized chiefly for posts and poles because of the small dimensions available. Uses elsewhere are fancy turned articles including billiard-cue butts, umbrella handles, and canes, also heary construction, bridge timbers, carpentry, vehicles, piling. and boats. 


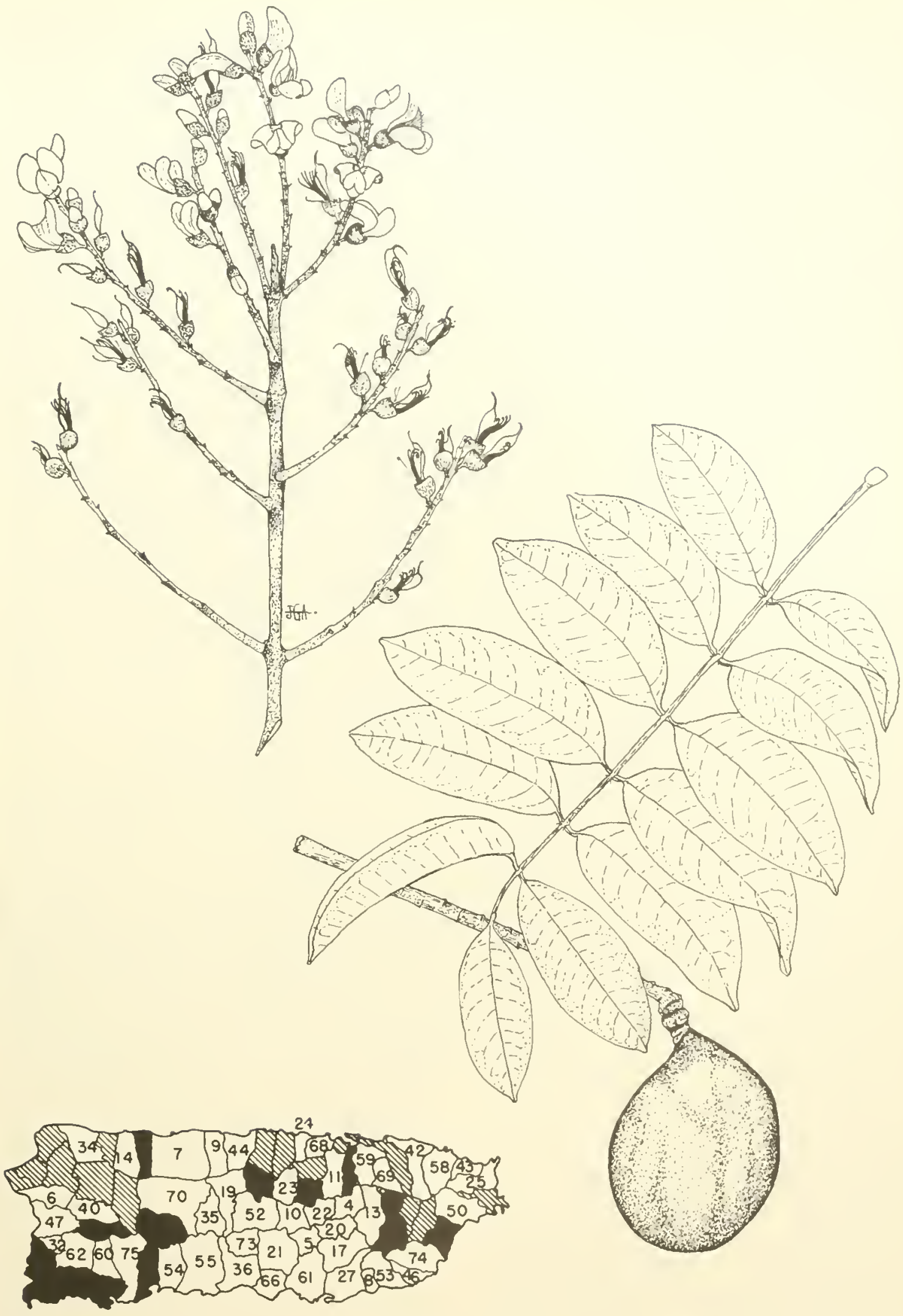

s1. Moca cabbage angelin

Andira inermis (W. Wright) H. B. K. 
Planted occasionally for coffee shade. This spe"ies lus been testerl in reforestation in Puerto Rico but was abandoned because of very slow growth. It also suflered heary losses when field mice cut stems of many seedlings. Nevertheless, the adaptability of this species to a wide rariety of sites and its capacity to prouluce larere crops of fruits which are dispersed by animals have made it one of the most widespreal trees of Puerto Rico.

The bark and seeds, reportedly poisonous and in large doses eausing death, have been employed in other places as a rermifuge, purgative, and narcotic. It is said that smoke from the rood is injurious to the eyes.

IIandsome and very showy when in flower, this species has been planited for ornament and sharde in some countries. Is the flowers are much risited by honey bees, the tree is an excellent honey plant.

Comnion in all regrions of Puerto Rico except the upper mountains. Commonest on the lower southern slopes of the Cordillera. Fomm in woodlands, along roalsides, fence rows, river banks, and in pastures. Ilso in Vieques, St. Croix. St. Thomas, Nt. John, and Tortola.

Promic Fonests.-I guire, Cambalache, Carite,

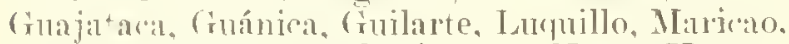
Rín Lba jo. Sin . Juan, Susúa, Toro Negro, Tega.

MUNITHALTES WHERE ESPECIALLY COMMON.$6,8,9,28,32,42,44,46,47,50,53,60,61,69,70,73$.

R.syge.-Through West Inrlies from Cuba and
Tamaica to Trinidad. Collected at Bahia Fonda Key, Florida, and introduced in southern Florida. Also from central Mexico (Michoacán) south to Peru, Bolivia, and Brazil, and in western tropical Ifriea.

Oruer common names.-moea blanca (Puerto Rico) ; dog-almond, dog-plum, false-mahogany (Tirgin Islands) : palo de burro (Dominican Republic); yaba, yaba colorada, moca (Cuba); maca colorarla, paeay, macayo, cuilimbuea, moca, yaba (Mexico); almenrlro (Central America); almendro cimarrón, guacamayo (Cuatemala); guacamayo (Honduras); almendro macho, almendro de lío, almendro montés, alnendro real (El Salva(lor) : cocú, carme asada (Costa Rica) ; cocí, pilón, arenillo, quira (Panama) ; congo, guayacán congo, palo de seca, majagra uallina, peloto (Colombia); pilón, chirai, trompillo (V'enezuela); motón (Ecuador): angelim. angelim da varzea (Peru); ajunado (Bolivia) : cabbage angelin, cahbage-bark (Tnited States); angelin (English, commerce): calbage-bark (English): black-plum (Tobago): cornwood, carbón, chaperno (British Honduras): luatseed, horaro (British Guiana): bois palmiste (IIaiti): angelin, bois olive (Guadeloupe, Martinique); angelin palmiste (Guadeloupe): reddie. mode kabbes (Surinam): angelim norcequeira (Brazil).

BotaniCal sY NoNYas.-Indira jumaieensis (IV. Wright) Urban, Geoffroya inermis W. Wright.

\section{LEGUME FAMILY (LEGUMINOSAE)}

\section{PEA SUBFAMILY (LOTOIDEAE; FABACEAE)}

\section{Bucare enano, machette}

This small introduced tree used as a living fence is recognized by: (1) alternate leaves with 3 werge-shaped leaflets about as broad as long, short-pointed at apex and rery broad at base, dull light arreen alove, and whit ish areen beneath: (2) howy masses of coral pink to red flowers about 3 inclues long but rery narrow, only $1 / 4$ inch broad. resembling a machete or sword in shape, many borne in erect unbrancher clusters; and (3) the dark brown pod 1-6 inches long, rery long stalked and very long pointed, slightly flattened and much narrowed between the oblong seeds, which are bright orange red. From related species of the same grenus in Pnerto Rico, bucare enano is distinguished by the absence of spines on twigs and trunks, though the trmk rarely may be spiny. (A spiny form oceurs in Central I merica.)

$\Lambda$ recidunus small tree becoming 20-25 feet high and 1 foot in diameter, with branching trunk and broad sprearling thin crown. The bark is brown, smoothish, slightly warty and becoming shallow furrowed. Inner liark is about $1 / 2$ inch thick, light yellow, slightly soft, and almost tasteless. The

\section{Erythrina berteroana Urban*}

stout twigs are shiny wreen when young, becoming gray.

The leaves 6-14 inches long have light green round petioles : $8-6$ inches long. enlarged at base. Leaflet stalks are $3 / s-1 / 2$ inch long with minute green glands at base. Leatlet blades are $2-5$ inches long and $13 / 4^{-5}$ inches wide, broadly ovate and often nearly diamond-shaped, not toothed on edires, thin. with ; main reins from base. The leaflets often are turned upward on edge, exposing the lower surfaces, which are eovered with a whitish hloom.

The attractive large flower's usually appear with the new leaves. In erect terminal flower cluster (raceme) 5-10 inches long bear's many nearly horizontal sholt-stalked flowers successively shorter toward apex. The irregular flower has a tubular green calyx $3 / 4-1$ inch long, opened on 1 side at apex and ob-enrely toothed: corolla of 5 unequal petals, the corsl-pink to red standard 3 inches long and folded, and + very small petals $3 / 8-7 / 16$ inch long. 2 wings and 2 keel petals hidden inside: 10 siglitly unequal stamens about $21 / 2$ inches long. united into a tule most of the length with the an- 


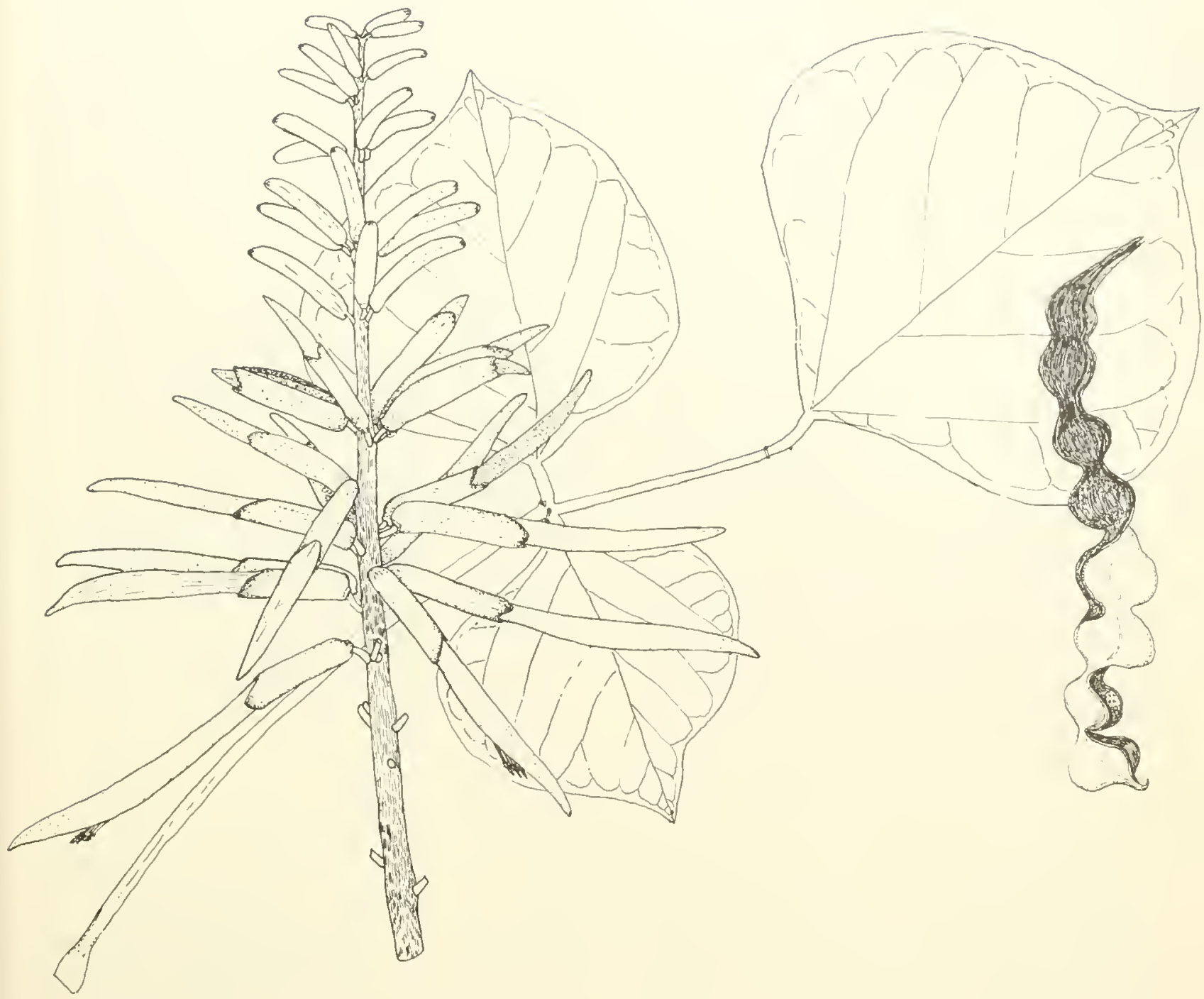


thers protruding: and rery narrow finely hairy pistil $21 / 4$ inches long with stalked ovary and narlow style.

The porl resembles a string of beads in its elliptic swellings about $3 / 8 \mathrm{inch}$ across outside each seed and constrintions between these seeds. The enrved opened porls with seeds attached remain on the tree after maturity. Sereral oblong seeds nearly $3 / 8$ inch long are rery eonspicnons when exposed on the opened edges of the thin-walled pod. Flowering in winter and spring (January to April) and maturing fruit in spring ( I pril-Nay).

The wood is whitish, soft, light weight (speeific Gavity 0.3$)$, and weak. It is seldom used for other than fuel in Puerto Rico. Elsewhere it has been employed as a substitute for cork and for carving toys and figures.

Posts root readily, so the tree is a common live fencepost, ehiefly in the moist coastal and lower Cordillera lesions. Also in Tirgin Islands. The plants ale propagated also hy cuttings. Besides living fenceposts and hedges, the trees have been grown as support for the vines in vanilla plantations. However, severe attacks by defoliating insects make the speeies undesirable for this purpose. Ioung branches and leaves are a favorite food of rabbits. Cattle eat the young twigs and leaves. Becruse of the showy Howers this species is wrown for ormament in ajulition to sharle and has been introdluced into Florida.

In Guatemala the Hower buds, young leaves, and young twigs are conked and eaten like string beans, though it is thought that eating quantities induces sleep and may be injurious. The poisonous seeds of this and other species have heen strung into bracelets, necklaces, and novelties. Though perhaps toxic ol nareotic, parts of the tree have been employed in home remedies. It is reported that the ernshed branches serve as fish poison and that the bark yields a yellow dye.

Raxge--Southern Mexico and Guatemala to Panama and Colombia. Also in Cuba and Hispaniola, perhaps introduced long ago, and naturalized in Puerto Rico. Planted in southern Florida and Tirgin Istands and in the Old World tropies.

OTHER common vames. - machete, bueayo enano, bneayo sin espinas (Puerto Rico): machete (Virgin Islands); piñon (Dominiean Republic); piñón de pito, piñón de cerca, bueare (Cuba) ; pito, pitón (Guatemala, Honduras, El Salvador); miche, machetillos, coralillo (Guatemala); elequeme (Niearagua); gallito, pernilla de casa (Panama); pito de peronilla, peronilla, peronio, mata caina (Colombia): coralbean (English); brueal (Haiti).

Machete, a common name, is suggested by the flowers with standard petal shaped like a machete biade and the calyx forming the handle. The common name piñón de pito in Cuba refers to the use of the flowers by small boys in making whistles or flutes. The corolla placed in a hollow petiole serves as a reed.

Besides the 3 species described and illustrated here, 2 other species of bueare are native, and a few others have been introduced. Piñón espinoso (Erythrina eggersii Krukoff \& Moldenke; synonym $E$. horrida Eggers, not DC.), native only in Pnerto Rico and the Virgin Islands, is distinguished by the spines on the reins of leaflets and by the narrow red flowers nearly 2 inches long.

Another speeies, known as coraltree or common coralbean (Erythrina corallodendrum L.), has leares nearly spineless and narrow coral-red flowers $2-21 / 4$ inches long.

\section{LEGUME FAMILY (LEGUMINOSAE)}

\section{PEA SUBFAMILY (LOTOIDEAE; FABACEAE)}

\section{Bucare, swamp immortelle}

This exotic tree, found in pastures and along roadsides in northeastern Puerto Rico, is characterized by: (1) scattered small spines on twigs and stout spimes on branches and trunk, at least when young; (2) alternate leaves with 3 slightly leathery leaflets elliptic to ovate in shape, rounded or short-pointed at apex and base, shiny yellow green to dark green above and whit ish green and finely hairy beneath; (3) mmerous clusters of large and broad, showy, pea-shaped, orange or salmoneolored flowers, several ereet near the end of a drooping axis; and (4) flattened pod 6-10 inches long and $5 / 8$ inch wide, and containing $3-12$ brownish or blackish poisonons seeds. The whitish mdersumfaces of leaves make the tree recognizable at a distance.

$A$ deciduons tree $30-50$ feet high and 2 feet in trunk diameter, sometimes larger, with broad crown of whitish-green foliage. The bark is light

\section{Erythrina glauca Willd.*}

brown, smoothish but becoming rough and shallowly furrowed. Small trunks have stout spines $3 / 8^{-3 / 4}$ ineh high, a few spines or warts often persisting on large trunks. Inner bark is as much as 1 inch thick, light brown, soft, and almost tasteless or slightly bitter. The stout twigs are light green and finely hairy when young, becoming gray, with seattered sharp spines $1 / 8$ inch or more in length and with raised leaf sears.

The leaves are 8-12 inches long, the light green round petioles $2+4$ inches long, enlarged at base. Leaflets have stout stalks $3 / 8$ inch long, with round gleen glands $1 / 16$ inch in diameter at base. Leaflet blades are $21 / 2-6$ inches long and $11 / 2-31 / 2$ inches wide, not toothed on edges, in vertical position or folding together at night.

Flower clusters (racemes) are 4-8 inches long, the finely hairy axis drooping and bearing erect flowers near the end on stout, dark red and green- 


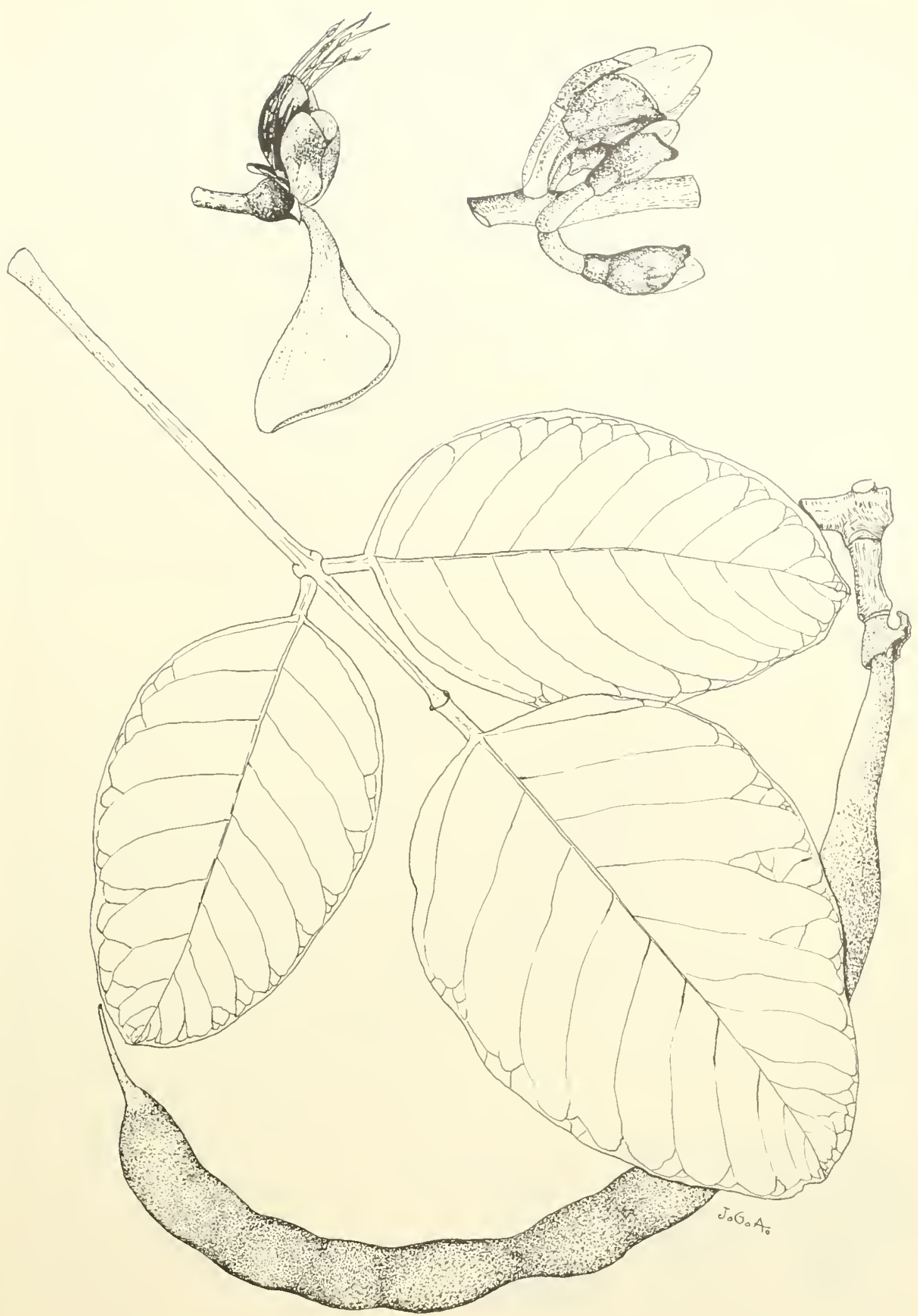

83. Bucare, swamp immortelle

Two-thirds natural size.

Erythrina glauca Willd. 
ish-tinged stalks 3/s-3/1 inch long. The bell-shaped calyx abont $5 /$ inch long is dark red, tinged with erreen, irregularly :;-lobed, and finely hairy; there are 5 slingtly thickened and succulent petals, the large obuvate, folded, orange-red standard $21 / 4-$ $23 / 4$ inches long and stalked at base, 2 orange-red wings vellow at base and 1 ineh long, and 2 united pale yellow keel petals 11\% inelhes long: 10 stamens 2-21/4 inches long with brown anthers and pale yellow-green fleshy filaments, 9 mited into a tube and 1 separate: and eurved pale yellow-green pistil about 2 inches long, with a stalked narrow hairy ovary and emred style. The distanee across an open flower may be as meh as 4 inches but only to inch in the marrow dimension. The poisonons seeds are abont $5 / 8$ inch long. Flowering in winter and early spring (Jamiary to March) and with matme frnit in spring.

The heartwood is light yellow to yellowish hrown and moderately soft. The lightweight wood is weak, not durable, and searcely snitable for limber.

Trees have been planted in pastmes and along roadsides and fences and are ornamental as well as shade trees. T'ses in other comtries inchude shade for eaca and coffee and living fenceposts. Propagated by cuttings.
Found near Bayamón, Rio Piedras, and Cagnas, Pnerto Rieo. Also reeorded from St. Thomas more than a century ago but not now planted there.

Ravae- Native probably from Guatemala to Peru, Bolivia, Brazil, and V'eneznela, the original lange extended by cultivation. Also introduced in West Indies in the Greater Antilles, Guadeloupe, Martinique, St. Vincent, and Trinidad and Tobago, Planted also in sontherm Flovida, British Honduras, and in the Old World tropies. Where native, this species forms pure forests characteristie of swamps and stream valleys.

Othez comalon numes.-bueayo (Pnerto Rico); piñón franés, búcare, piñón del eauto (Cuba); gniliqneme (Honduras); ahuijote, ahuejote (El Salvador); poró (Costa Rica); gallito, pito, palo bobo, palo santo (Panama) ; eámbulo, bícaro, cantagallo, písano, písamo ralentado (Colombia); bucare, ceibo, anaueo (Venezuela); palo prieto, malre de eacao (Eeuador); amasisn (Peru); bois immortelle (United States); swamp immortelle, bucare, boeare (Jamaica); boeare immortelle, water immortelle ('Trinidad and Tobago) ; sandcoker, oronoque, eck-tree (British Guiana) ; bois immortel, immortel blane (Guadeloupe, Martinique) : sniña, assacú-rana (Brazil).

\section{LEGUME FAMILY (LEGUMINOSAE)}

\section{PEA SUBFAMILY (LOTOIDEAE; FABACEAE)}

\section{Bucayo gigante, mountain immortelle}

This introduced sharde tree of coffee plantations and roadsides may be recognized by: (1) beantiful masses of showy orange-red flowers in late winter, when the trees are leafless, the large pea-shaped flowers $11 / 2-2$ inches long, erect on nearly horizontal axes; (2) the trmuls and branches often with stont spines: (3) alternate leaves with 3 broadly ovate thin leaflets, short-pointed at apex and very broad pointed or nearly straight at base, green on both sides; and (4) straight, cylindrical, dark brown pod 5-10 inches or less in length and about $5 / 8$ inch wide, long-stalked at base and long-pointed at both ends.

A large deeidnous tree attaining 30-70 feet in height and 2-4 feet in trunk diameter, with spreading erown. The bark is greenish brown or gray brown, smoothish or slightly funcowed, warty or spiny. Inner bark is thiek, becoming $3 / 4$ ineh or more in thickness, whit ish, and slightly bitter. The stont twigs are light green and minutely hairy when young, beeoming greenish gray, with raised leaf sears, and often with seattered spines $1 / 16$ inch or more in length.

Leaves are 8-12 inches long, ineluding the light green finely hairy petioles $21 / 2-8$ inehes long. Leaflets have stalks $1 / 4^{-5 / 8}$ inch long with 2 green cuplike glands about $1 / 8$ ineh long at base of lateral leaflets and 2 more glands below terminal leaflet.

\section{Erythrina poeppigiana (Walp.) O. F. Cook ${ }^{*}$}

The thin leaflet blades are $21 / 2-7$ inches long and 2-6 inches wide, or larger on rapidly growing shoots, not toothed at edges, with 3 main veins from base, green and dull or nearly so on npper surface, and slightly lighter dull green beneath.

Horizontal flower cluster's (racemes) 4-8 inehes long bear a few open flowers, which fall soon after opening, and many narrow flower bnds progressirely smaller toward apex. Thus, the ground under a tree beeomes orange red too. The flowers are $11 / 2-2$ inches long and about half as wide. The enp-shaped ealyx is $3 / 16^{-3} / 8$ inch long, reddish at the top and greenish below, not toothed; 5 orangered petals, the large orange standard $11 / 4-11 / 2$ inches long, elliptie, keeled, short-pointed, and spreading, 2 short elliptic wings $1 / 2$ ineh long, orange red but yellow toward base, and 2 united keel petals 11/4-11/2 inches long, orange red but yellow toward base, enclosing the stamens; 10 stamens $1 \frac{1}{4}-1 \frac{1}{2}$ inches long, 9 united into a light yellow tube and 1 separate, the anthers brown; and narrow greenish pistil about $1 \frac{1}{2}$ inehes long inelnding stalked ovary and style. There is some variation in flower color, a few trees having pale yellow-orange blossoms and others rarely seen with scarlet petals.

'The pod eontains several brown kidney-shaped beanlike seeds $5 / 8$ ineh long, which are poisonous. 
In Pnerto Rico flowering usually from Jamuary to March, sometimes also in Angrist, the fruits maturing from February to May

The wood is whitish, soft, perishable, and little nsed in Puerto Rico.

Formerly the trees were widely planted in Puerto Rico for collee shade. Now, however, they are not reeommended for that purpose. They grow to large size, larger than desirable for coffee sharle and thus may compete with the crop beneath. The weak branches are easily broken by strong winds or hurrieanes. The trees are grown also as ormamental and shade trees.

Centuries ago this speeies was transported over the Imerian tropics from its home in lower slopes of the Ancles as a shade tree for coffee and cacao plantations and pastures and for living fences. In some countries, espeeially in the Andes, this is still a popular eoflee shade tree.

The bark, twigs, and seeds of various speeies of this genus are more or less toxic. They have provided drugs and medicines locally and have been employed also to stupefy fish. It is reported that the flowers of this species have been eaten in soup and salad.

Chiefly in coffee plantations in the lower Cordil- lera and moist limestone regions of Puerto Rico. Ilso in St. Thomas.

MUNICIIIATY WHERE ESPECLLLY COMMON. - 73. Range- Native probably from Venezuela to Panama, south to Ecuador, Peru, Bolivia, and Brazil. Now extensively planted and naturalized in tropical America north to Guatemala and introdneed into the Greater Antilles, Guadeloupe, Martinique, and Trinidad and 'Tobago. Cultivated also in the Old World tropics and recorded from southern Florida.

OTHER com Mon Names.-bueare gigante, bucare, búcar, bricayo, palo de boya (Pnerto Rico); bumatell (St. Thomas); brueal, amapola, mapola (Dominican Republic); piñón de sombra, bucare (Cuba) ; pito extranjero (Guatemala, El Salva(jor); písamo, saivo, cachimbo, eámbulo, pito grigante (Colombia); bneare, ceibo (Venezuela) ; bombón (Eeuador); amasisa (Peru) ; saibo (Bolivia) ; ananca (United States); mountain immortelle, bois immortelle (Jamaiea, Trinidad); ananea immortelle, cocon-mamma, coffee-mamma (Trinidad) : bois immortel (Haiti) ; bois immortel, immortel jaune (Gnadeloupe); mulungú (Brazil).

BotaNiCaL SYNONYM.-Erythrina micropteryo Poepp.

\section{LEGUME FAMILY (LEGUMINOSAE)}

\section{PEA SUBFAMILY (LOTOIDEAE; FABACEAE)}

\section{Mata-ratón, mother-of-cocoa}

Mata-ratón, a small introduced tree commonly planted in fence rows and for ormament, is distinguished by: (1) odd pinnate leaves 6-16 inches long with i-17 ovate, elliptic, or lance-shaped leaflets: (2) numerous showy whitish-pink or purplish-tinged pea-shaped flowers about 3/4 ineh long in lateral clusters along old branehes when leafless or along branches back of leaves; and (3) flat blackish pods +6 inches long.

A small deciduous tree or shrub, becoming 25 feet tall and 8 incles in trunk diameter, with irregular spreading crown of thin foliage. The bark is gray or light brown, smoothish to slightly fissured. İner bark is whitish and almost tasteless. Young twigs are light green and finely hairy, the older twigs light brown.

The alternate leaves have slender yellow-green finely hairy axes. Leaflets, paired except the terminal one, have hairy stalks abont $3 / 16$ inch long. The thin leaflet blades are $11 / 4-21 / 2$ inches long and $5 / /-11 / 4$ inches wide, short- to long-pointed at apex, rounded or short-pointed at base, not toothed at edges, dull green above, and gray green and slightly hairy beneath.

The numerous lateral flower clusters (racemes) $2-5$ inches long are many flowered. The attractive flowers have a slender green stalk and a bel]shaped light green calyx tinged with red, $1 / 4$ inch

\section{Gliricidia sepium (Jacq.) Steud.*}

long and broad, minutely 5 -toothed at apex; the butterfly-shaped eorolla about 5/8 inch long consists of 5 whitish-pink or purplish-tinged petals, the broad standard turned baek and yellowish near base, 2 ollong enrved wings, and 2 united petals forming a keel; 10 whitish stamens $5 / 8$ ineh long, 9 united in a tube and 1 separate; and pistil $5 / 8$ inch long, with stalked narrow red ovary and whitish bent style.

The pods are yellow green when immature, turning blackish, $1 / 2-5 / 8$ inch wide, short-stalked at base and short-pointed at apex, splitting open at maturity. There are 3-8 flat, elliptic, shiny, blackish seeds $3 / 8$ inch long (2,000 to a pound). Flowering in winter and spring (December to May), the fruit maturing from winter to summer.

The sapwood is light brown and the heartwood dark brown, turning reddish brown on exposure. The wood is hard, heavy, strong, and considered durable in the gromnd as posts. It is used chiefly for this purpose in Pnerto Rico because promptly set posts generally sprout and take root, lasting indefinitely. Elsewhere the wood has been employed for railroad ties and heavy construction. Pretty and taking a good polish, it should be suitable for furniture and small articles.

This tree is a popular ornamenta] or hedge plant, being readily propagated from cuttings as well as 


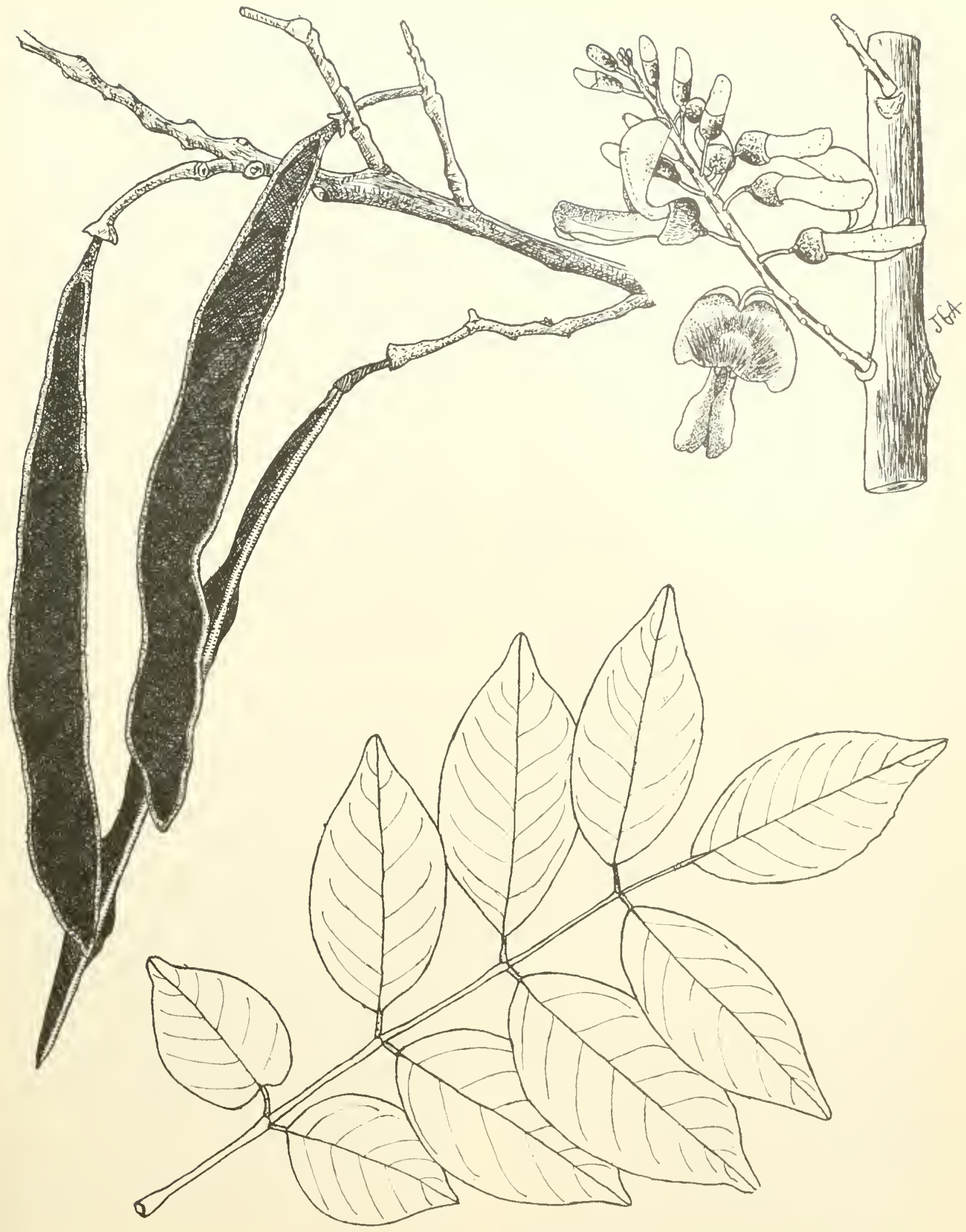

85. Mata-ratón, mother-of-cocoa 
seed and growing rapidly. However, an objection to further planting of this species in Puerto Rico is that the foliage often is attacked by an aphid or plant louse. These tiny insects spread and multiply rapidly, secreting a sweet liquid which attracts ants and causes growth of a black fungus or sooty mold over the leaves. Many blackened leaves fall, and automobiles parked beneath the trees may be damaged by the liquid.

As the eommon nane mata-ratón (mouse killer) sugrests, the toxic sceds, bark, leares, and roots are used to poison rats, mice, and other rodents. Inother use of the freshly crushed leares is in poultices in home remedies. The leares are reported to be nutritions for cattle and also to be poisonous for horses and logs. The flowers, thongh not fragrant, are visited by bees and are a source of honey. In a few countries the flowers are fried or boiled and eaten.

The names madre de cacao and nother-of-cocoa, applied to this species is some areas, indicate that the trees are grown also as shade trees in cacao plantations. Before the Spanish conquest, the Iztec Indians of Mexico had observed that cacao grew well under these trees, which they named cacahnanantl or mother of cacao. These trees have nodules on their roots containing nitrogenfixing bacteria which emrich the soil.

Inother use of mata-ratón is support for vanilla vines. In a few countries the trees, though not evergreen, have been planted for coflee shade.
In Puerto Rico this species is common along roads, in fence lows and as an ornamental in the moist and dry coastal regions, the moist limestone region, and lower momtain regions. It may be naturalized locally. Niso planted occasionally in St. Croix, Nt. Thomas, and Tortola.

Ruxac.-Native from Mexico to Colombia, Tenezuela, and Guianas. Introdnced and becoming naturalized in West Indies from Cuba and Jamaica to Lesser Antilles, Trinidarl, and Curacao. Planted also in southern Florida and in South Imerica sonth to Brazil. Also introduced into the Old Torld tropies, including Africa and sonthern Isia and recorded as naturalized in the Philippine Islands.

Otier common xames.-madle de cacao (Puerto Rico); pea-tree (Tirgin Islands); mata-ratón, malle de cacao (Spanish); piñón de Cuba (Dominican Republic) ; piñón amoroso, piñón florido, bien restida, piñón violento (Cuba); cacahmananche, cocoite (Mexico); madera negra (Honduras, Costa Rica, Panama) ; madriado, madrial, cacaguance, cacagua (Honduras); palo de hierı, cacalunanance (El Salvador); madriado (Nicaragua) : bala, balo (Panama); St. Tincent plum, quick-stick (Jamaica); Nicaragua cocoa-shade, marlura (Trinidad); quick-stick (British Guiana) : lilas étranger (Haiti); glicicidia, gliceridia (Guadeloupe): yerba di tonka, mataratôn, ratonera (Dutch Trest Indies).

Botanical sy ronym-Crlinicidia maculata $(\mathrm{H}$. B. K.) Stend.

\section{LEGUME FAMILY (LEGUMINOSAE)}

\section{PEA SUBFAMILY (LOTOIDEAE; FABACEAE)}

\section{Retama}

This uncommon though widely distributed tree is characterized by: (1) alternate pinnate leares with 5-9, usually 7 , elliptic leaflets on thick stalks, 2-6 inches long, pale light green and finely hairy beneath, paired except at end; (2) numerois crowded purple pea-shaped flowers $5 / 36$ inch long in lateral clusters which usually are several together near end of twigs; and (3) the distinctive light brown oblong flat ports $11 / 2-4$ inches long and $5 / x_{-1}$ inch wide, short-pointed at both ends, very thin and like parchment, 1-3-seeded but not splitting open, often produced in large numbers and rather conspicuous.

A small to medium-sized deciduous tree 15-30 feet high and $1-8$ inches in trunk diameter with spreading crown. The bark is gray to brown, smoothish, becoming slightly fissured. The light. brown inner bark is slightly bitter. The brown twigs are finely hairy when young.

The leaves are $7-14$ inclies long, with finely hairy green axis and leaflet stalks $1 / 8^{-1 / 4}$ inch long. Leaflet blades are $11 / 4-23 / 4$ inches wide, mostly shortpointed at apex but varying from blunt to long-

\section{Lonchocarpus latifolius (Willd.) H. B. K.}

pointed, rounded or short-pointed at base, the edges not toothed, thin or rery slightly thickened, above green to dark green and hairless, and beneath pale light green and finely hairy.

Flower clnsters (racemes or panicles) are $2-41 / 2$ inches long at base of leaves, the axis usually finely brown hairy and the flower stalks abont $1 / 16$ inch long, also hairy. The flowers have a bell-shaped 5-toothed calyx $1 / 8$ inch long, finely brown hairy; dark reddish-purple to green ish-purple corolla of 5 stalked petals about $1 / 4$ inch long, the lounded standard notched at apex and finely brown hairy on ontside, 2 oblong wings, and 2 elliptic slightly united keel petals; 10 stamens $1 / 4$ inch long with filaments mited; and pistil with narrow brown hairy ovary and bent style.

The minutely hairy pod is thickened and darker brown around the fiat seeds, which are brown, kidney-shaped, and $t / 16$ inch long. Recorded in flower from March to Jume and in fruit nearly through the year.

The sapwood is whitish and the heartrood reddish. The wood is hard, heary (specific gravity 


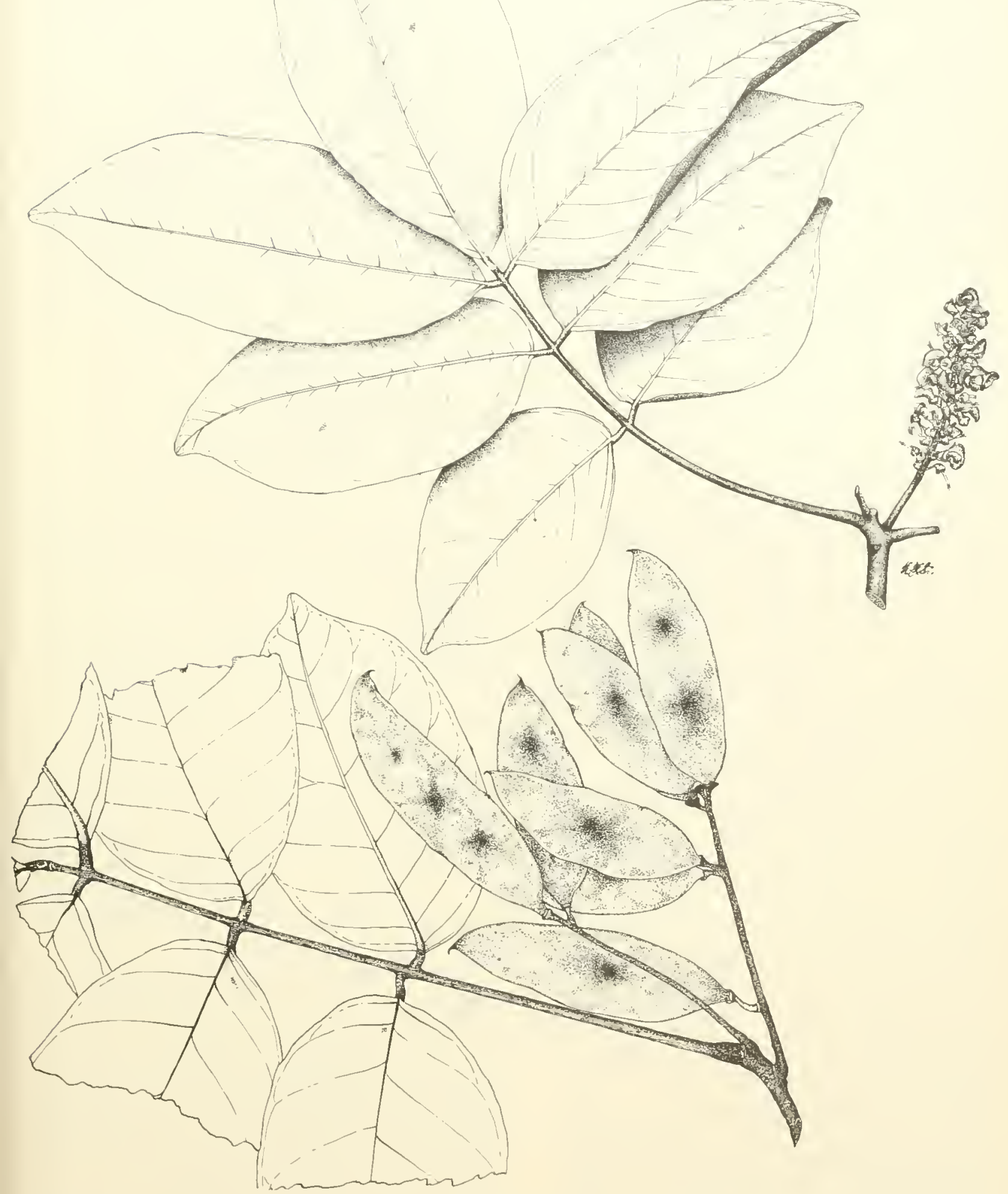

86. Retama

Two-thirds natural size.

Lonchocarpus latifolius (Willd.) H. B. K. 
0.6), strong, and reported to be durable. Used chiefly for fue] or fenceposts in Puerto Rico. In Cubr the word is employed for piling.

Planted as an ornamental in sonthern Florida and Cuba. Also a honey plant. The root and fruit reportedly have insecticidal properties.

Along streams and in young forests in the moist vastal, moist limestone, and lower mountain forest regions of Puerto Rico.

Priblic forests.-Cambalache, Guajataca, Lilsquillo, Sustía.

RAsGe.-Through West Indies from Cuba and Jamaica to Grenada and Trinidad. Also from southern Mexico (Tabasco), Guatemala, and British Honduras to Colombia, Tenezuela, the Guianas, and Brazil. Introduced in southern Florida and Cuba.

Otimer commox sames.-palo hediondo, forteventura, genogeno, palo seco (Pnerto Rico); guamá de costa, frijolillo amarillo, guamá macho (Cuba); mataboy (Guatemala); cincho (Hon- duras): guapaste, cuapaste (Nicaragua); coto (Costa Rica); acurutú, mahomo, jebe (Venezuela); savonette (St. Lucia); white savonette, savonette jaune (Trinidad) ; lancewood (United States); swamp dogwood, dogwood (British Honduras); dogwood (Canal Zone); savonette grand bois, savonnette grandes feuilles, savonnette rivière (Guadeloupe, Martinique).

Two other species of this genus are native and a few others have been planted experimentally. Genogeno (Lonchocarpus domingensis (Pers.) DC.), of western and southern Puerto Rico, has leathery pods deeply narrowed between the seeds, long-pointed leaflets lairy beneath, and twigs finely hairy.

Geno (Lonchocarpus glaucifolius Urban), known only from western Puerto Rico, has narrow leathery pods not or only slightly narrowed between seeds, leaflets whit ish beneath and notched at apex, and twigs hairless.

\section{LEGUME FAMILY (LEGUMINOSAE)}

\section{PEA SUBFAMILY (LOTOIDEAE; FABACEAE)}

\section{Palo de matos}

1 tree of mountain forests characterized by : (1) clean, light tan, smoothish bark: (2) young twigs finely brown lairy; (3) very large pimnate leaves $11 / 2-3$ feet long, consisting of 7 or 9 (sometimes 5 ) stout-stalked, large, elliptic, dull green leaflets with abrupt minute point at rounded apex, paired except at end; (4) many pea-shaped dark violet flowers 5 ' inch long in terminal or lateral clusters; and (5) brown pod $11 / 2-4$ inches long, deeply narrowed between the rounded seeds, which are $3 / 8$ inch in diameter and shiny scarlet red usnally with 1 or more black spots.

A medium-sized evergreen tree 30-60 feet high and to 2 feet in trunk diameter, with broad crown. The bark becomes scaly on large trees. Twigs are stout and greenish. Young leaves, branches of flower clusters, calyx, and pods are finely brown hairy.

The alternate leaves have a stont green axis keeled above and swollen at base. The green leaflet stalks are $3 / 8-5 / 8$ inch long. longer on the terminal leaflet. Blades are 3-12 inches loug and $11 / 2-8$ inches wide, the base rounded or shortpointed, not toothed on edges, st rongly pinnately reined with many parallel lateral veins slightly sunken, slightly thickened, the upper surface dull green, and the lower surface paler and inconspicuonsly fine hairy, especially on the veins.

Flower clusters (panicles) are 6-12 inches long, branched, and many-flowered. The short-stalked flower has a brown hairy bell-shaped calyx more than 3/s inch long, including unequal pointed teeth ; 5 dark violet petals about $5 / 8$ inch long, including broad romnded standard spotted with white or yel-

\section{Ormosia krugii Urban}

low, 2 wings, and 2 keel petals; 10 separate and unequal stamens; and pistil $5 / 8$ inch long with flattened brown-hairy 1-celled ovary and slender curved style.

The brown pods are $5 / 8_{-3 / 4}$ inch wide, slightly keeled, long-pointed at both ends, and with calyx remaining at base. There are $1-5$ seeds, rounded but slightly flattened. Recorded in flower from September to November and in fruit from May to November.

The sapwood is yellowish, and the heartwood a uniform salmon color with occasional darker streaks. The wood is somewhat coarse-textured, of medium weight (specific gravity 0.50 ), with indistinct growth rings, and large open pores. It is very susceptible to damage by dry-wood termites. The rate of air-seasoning is slow, and amount of degrade is moderate. Machining characteristics are as follows: planing, shaping, sanding, and resistance to screw splitting are good; turning, boring, and mortising are fair.

The wood is used chiefly for fuel in Puerto Rico. However, it should be suitable for furniture, millwork, construction, boxes, crates, and general carpentry.

Becanse of the rapid growth and vigorous sprouting of the trees in secondary forests, efforts are being made to find a better use for the wood. Apparently the trees are shallow rooted and easily blowl over, as many are leaning or prostrate. Possibly suited for shade or ornament.

Found in secondary forests in the lower Luquillo and lower Cordillera forest regions of Puerto Rico. 


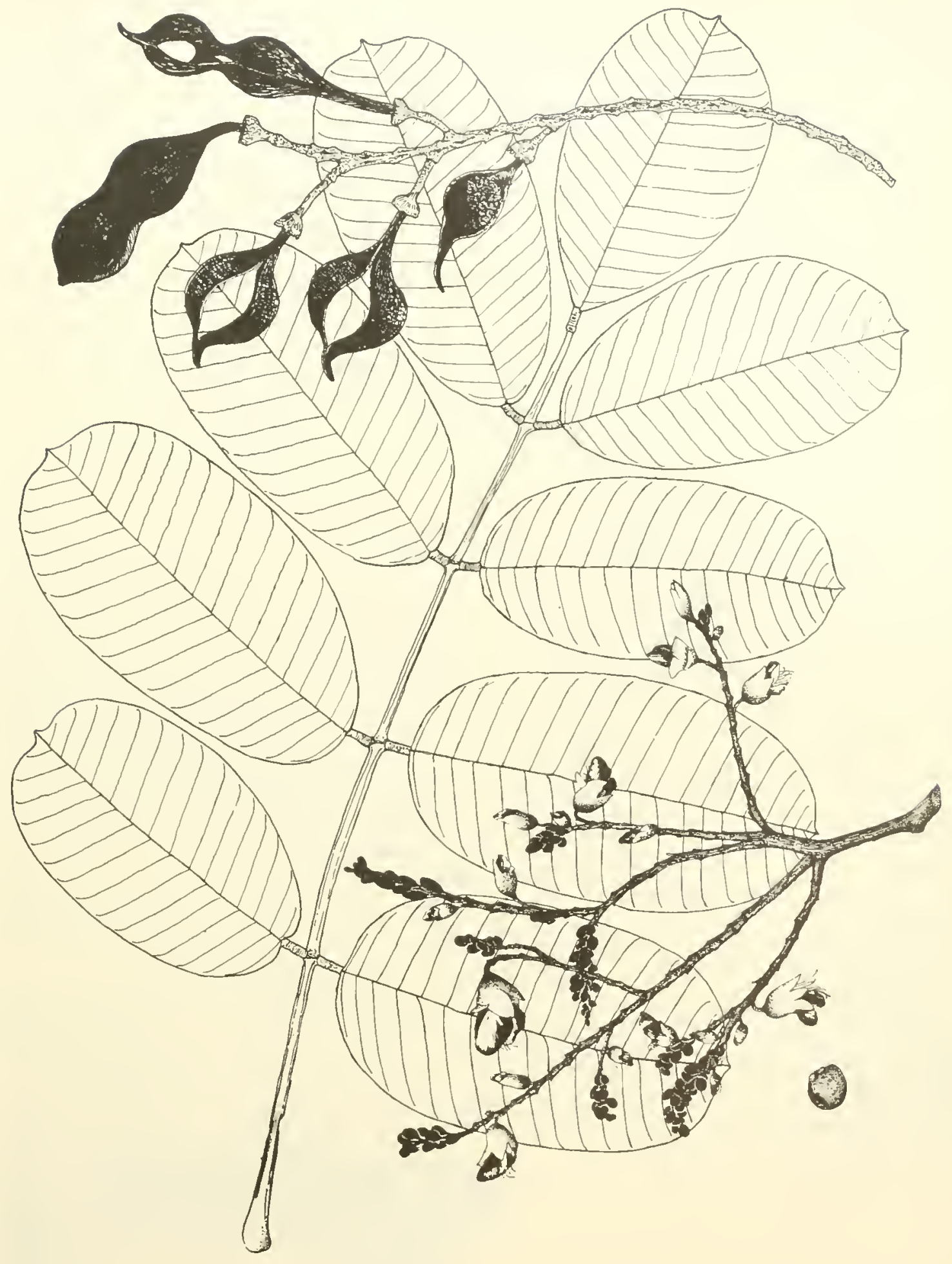

87. Palo de matos

Two-thirds natural size.

Ormosia krugii Urban 
Pernic fonests.-Carite, Guilarte, Luquillo, Toro Negro.

R.sxge.-Hispaniolal (Haiti and Dominican Republic), Inerto Rico, Guadeloupe, and Dominica.
Otiler commox vames.-matillo, mato, palo de peronías, peronía (Puerto Rico) : peronía, palo de peronía (Dominican Republic); malcaconier (Dominiea).

\section{LEGUME FAMILY (LEGUMINOSAE) PEA SUBFAMILY (LOTOIDEAE; FABACEAE)}

\section{Tachuelo, fustic}

This small tree of dry areas is easily identified by: (1) spiny branches, manally several from the bise: (2) odd pinnate leaves $2 \frac{1}{2}-41 / 2$ inehes long with 9-25 rounded or ohovate leaflets $3 / 8-3 / 4$ inch long and broad, alnost stalkless. each bealing a yellowish spiny or bristle tip $1 / 16^{-1 / 4}$ inch long at apex: (3) quant it ies of showy, hright yellow, peashaped flowers 3/4-1 inch long, several together in a lateral cluster; and (t) narrow flattened brown pod $3 / 4-2$ inches long and $1 / 4$ inch wide, 2-6jointed.

A deciduons tree or shruh 10-20 feet high and to $s$ inches in trunk diameter or larger. Formerly reported to 30 feet tall, but now rarely seen that size because most large individuals have been cut. Bark of shrubs is brown or gray and smooth with spines remaining, on larger trinks separating in large flakes. Inner balk is vellowish and slightly bitter. The slender twigs a pe brown or green and fincly hairy when young.

The alternate leaves have at base a pair of slender spines (stipules) $3 / 16^{-1 / 2}$ inch long, brownish but green when young, and a slender finely hairy axis. Leaflets are notched or nearly straight at the spiny tip, rounded or slightly notched at base, hent up on both sides of midrib and curved down at tip, not toothed on edges, slightly thickened, finely hairy when young but hecoming nearly hairless, and green and slightly shiny on both surfaces.

Flower elusters (ricemes) are $1 \frac{1}{2}-3$ inches long,

\section{Pictetia aculeata (Vahl) Urban}

with flowers on slender stalks. The bell-shaped green calyx 1/1-3/8 inch long is unequally 5 -toothed; there are 5 petals $3 / 4-1$ inch long, narrowed into stalks at base, the bright yellow standard nearly round and curved backward, 2 bright yellow oblong wings, and 2 pale yellow petals forming the lieel; 10 stamens 3/4-1 juch long, 9 united into a tube and 1 separate; and green ish pistil consisting of stalked, narrow, hairy, 1-celled ovary and slender curved style. The slightly curved pod is finely hairy and does not split open. Flowering and fruiting nearly through the year.

The sapwood is light brown, and the heartwood dark brown. Resembling lignumvitae, the wood is extremely hard, heary (specific gravity 0.8), and durable. Used in Puerto Rico only for fenceposts, since la rger sizes are not now arailable, formerly also for larger poles.

Because of the numerous attrative yellow flowers which beatify the countrysicle, this speeies is suitable as an ormamental for dry areas. Sometimes grown as a living fencepost.

Coastal thickets and pastures in the dry coastal and dry limestone regions of Puerto Rico. Also in Culebra. Vieques, St. Croix, St. Thomas, St. John, Tortola, Virgin Crorda, and Anegada.

Public forests.-Aguire, Guániea.

Municipalities WHere espeClally COMLON.-$21,26,28,36,55,66,75$.

Ranre.-Puerto Rico and Virgin Islands and reported from Iispaniola. 


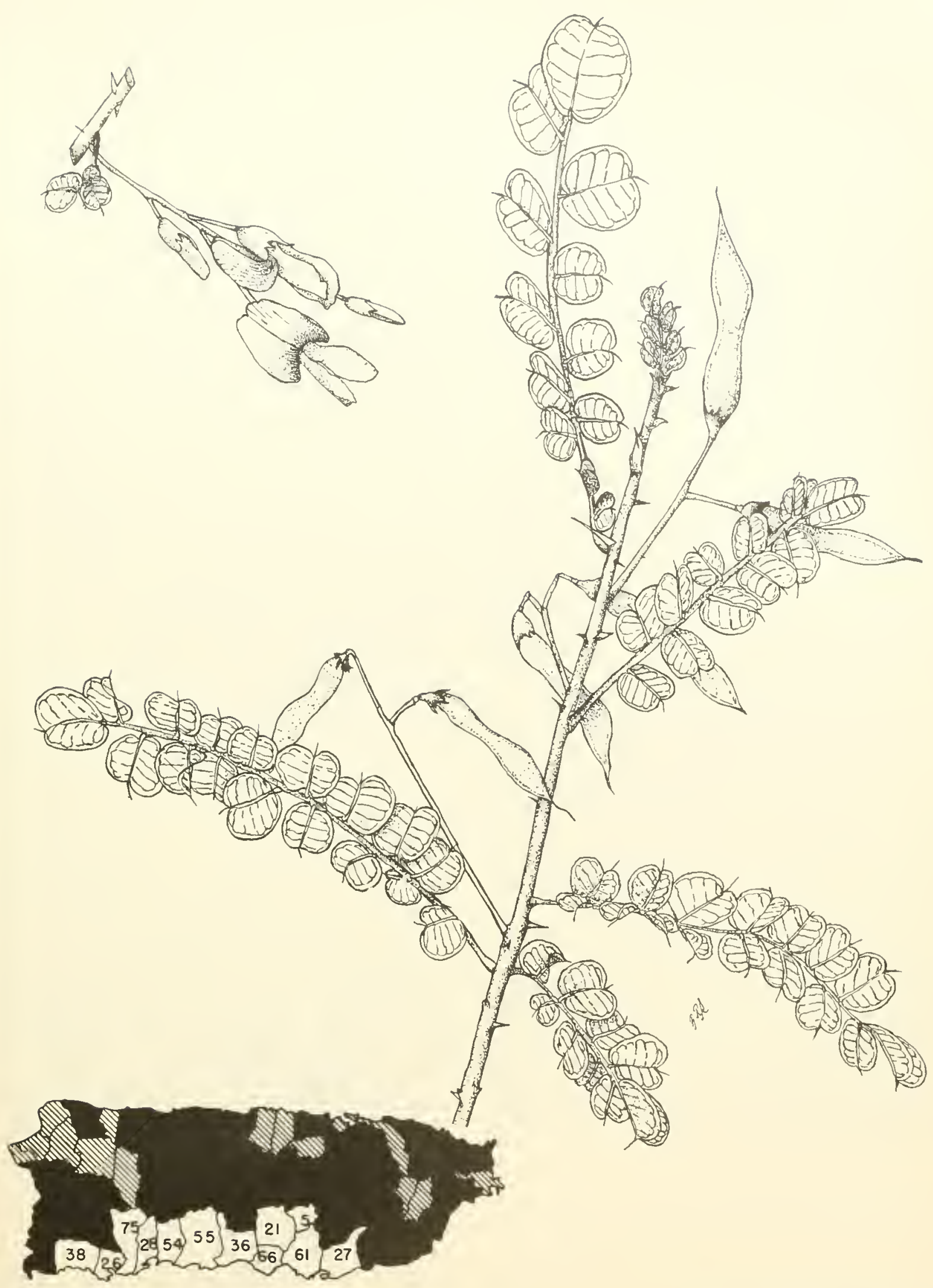

88. Tachuelo, fustic

Pictetia aculeata (Vahl) Urban Natural size. 


\section{LEGUME FAMILY (LEGUMINOSAE)}

\section{PEA SUBFAMILY (LOTOIDEAE; FABACEAE)}

\section{Pterocarpus, India padauk}

An introduced handsome ornamental, shate, and timber tree, distinguished by: (1) a broad crown of long drooping branches, some nearly touching the ground; (2) reddish latex sparingly produced in the cut bark; (3) pinnate leaves alternate in "2 rows with nsmally $i-11$ ovate, thin, shiny, green to yellow-green alternate leaflets, longpointerl at apex; (4) many showy, yellow peashaped flowers nearly 3 / inch long, produced in lateral clusters: and (5) nearly round brown pod 11/4-11/2 inches in diameter, flattened and bordered by a broad thin wing, stalked at base and with pointed style at 1 side.

A spreading medium-sized tree 50 feet high and 1 foot in trunk diameter, or larger. Essentially evergreen but nearly leafless for a short period in spring when old leaves are falling and new leaves forming. The bark is light brown and finely fissured. Inner lark is light brown and reddish brown streaked, astringent, and yielding a small amount of red latex, sticky and bitter, when cht. Twigs are green when young, becoming light brown, hairless except at apex.

The slightly drooping leaves about 9-16 inches long have a slender green axis enlarged at base, and the leaflets have stalks about $1 / 4$ inch long. $\quad \Lambda$ few short leaves have only :3-5 leaflets. Leaflet blades are $21 / 2-5$ inches long and $11 / 2-21 / 2$ inches wide, the edges not toothed, turned up a little at midrib, shiny green to yellow green above and dull sreen beneath.

The fragrant flowers are borme on slender green stalks in clusters (racemes and panicles) $4-7$ inches long. The slightly irregular bell-shaped green calyx is $5 / 16$ inch long, pointed at base and $1 m$ equally 5 -toothed at apex, and minutely hairy; the 5 yellow petals $5 / 8-3 / 4$ inch or less in length are stalked at base, becoming crinkled, the romnded stanclard $5 / 8$ inch wide and rolled backward, 2 wings, and 2 smaller paler keel petals barely united on sides; 10 stamens about $3 / 8$ inch long,

\section{Pterocarpus indicus Willd.*}

united by the whitish filaments into 2 groups of 5 each : and green hairy pistil $\pi / 16$ inch long, consisting of stalked narrow ovary and tapering style.

The winged pods have a roughened wrinkled enlargement near the center enclosing 1 or 2 small seeds but do not split open. Flowering in June and July and maturing fruits in summer to September.

The reddish hard woor is an excellent timber in southem Asia, known as padauk or Burma-rosewood. It is listed among the most raluable timbers in the Philippines, where it is called narra. Uses include construction, furniture, musical instruments, and eart wheels.

Lignum nephriticum (Latin for kidneywood) was the wood of this Philippine species and of kidneywood (Eysenhardtin polystachya (Ortega) Sarg.) from Mexico. It was known throughout Europe from the 16th to early 18th centuries for its reputed dinretic properties but is no longer employed in medicine. Howerer, infusions of the wood are fluorescent, and this odd response to light may have been associated with remedies. Cups made from the wood and chips of wood impart to water a beautiful blue and yellow color, which changes in light and shadow.

Classed among the finest tropical shade trees, this species is oceasionally planted in Puerto Rico for shade and ormament. Introduced by the United States Forest Service in 1924, it is still limited to a few streets and patios, chiefly in the metropolitan areas. A honey plant.

Ravae-Philippines to Java, Sumatra, southern China, Burma, and Andaman Isands of India and introduced in southern India. Planted elsewhere in the tropies for shade, such as in southern Florida, Cuba, Puerto Rico, and Trinidad.

Otuer comuon numes.-India padank, Burmacoast padauk, Burma-rosewood (English) ; rosewood (Trinidad). 


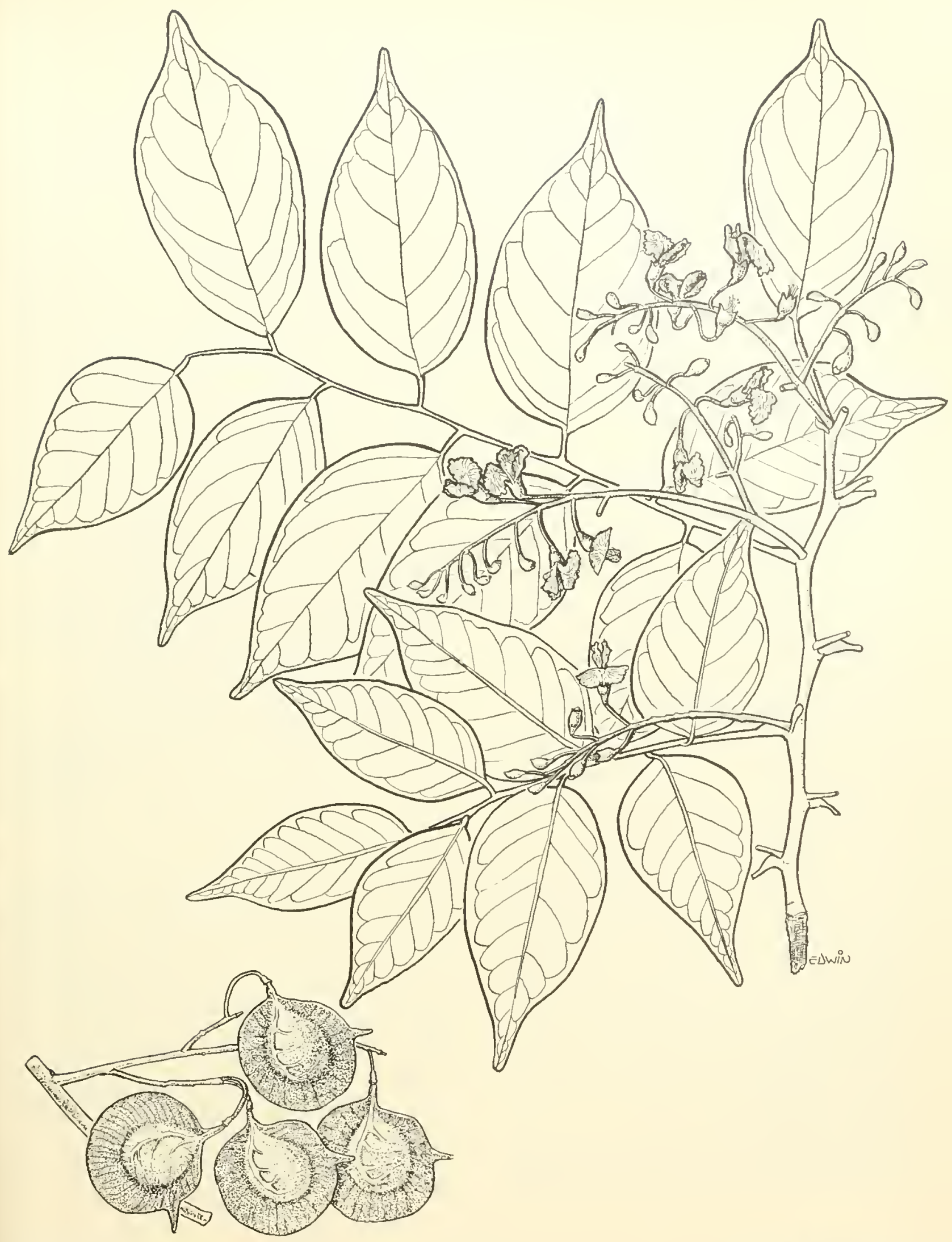




\section{PEA SUBFAMILY (LOTOIDEAE; FABACEAE)}

\section{Palo de pollo, swamp bloodwood}

Large tree of swamp forests and stream borders in mountains, easily recognized by the enormous narrow planklike buttresses extending high mp trunk and horizontally a long roots and by the dark blood-red latex in bark. ()ther distinguishing characters are: (1) alternate pinnate leaves with i-9 elliptic to oblong long-pointed shiny areen altermate leatlets: (2) clusters of yellow peashaped flowers $1 / 2^{-5 / 4}$ inch long and broad; and (3) flat, irregularly romded, dark brown winged pods $11 / 2-2$ inches in diameter.

In evergreen tree $50-90$ feet tall and $2-3$ feet in trunk diameter above buttresses. Trunks often are curved or crooked and fluted. The rery mominent buttresses on large trees sometimes rise to 15 feet in height and may be $2-5$ feet wide at base, often extending ontward along roots a distance of 10 feet. These buttresses, frequently 4 large ones to a tree with smillel ones between, and scarcely 1 inch wide, renerally curve suakelike along the forest floor. Bark of trunk and buttresses is smoothish light brown, beeoming finely and thinly fissured and scaly. Inner bark is liglit brown, with dark blood-red streaks in inner part, slightly bitter, containing bitter latex. Twigs are green or reddish green, hecoming brown.

Leaves are $(:-16$ inches long. the axis reddish when young but turning brownish green, slender but emlarged at base and with 2 hasal narrow pointed green scales (stipules), which shed early. Leaflets have stont green stalks $1 / 8-3 / 16$ inch long and thin or only slightly thickened blades 2-1; inches long and $11 / 4-21 / 2$ inches wide, rounded at base, not toothed on edges, shiny green above, and beneath a little lighter and shiny or dull.

Flower clusters (panicles or racemes) are mostly $21 / 2-6$ inches long, lateral at base of leaves, with many loosely arranged short-stalked fragrant flowers, the branches finely hairy. The bellshaped calyx $1 / 4$ inch long has 5 imequal shortpointed teeth: 5 yellow petals about $1 / 2$ imeh long with narrow stalklike bases, the broad rounded standard reddish tinged or dark jed near base, or reported sometimes to he violet tinged, also 2 wings, and 2 keel petals: 10 stamens about $5 / 16$ inch long, united into a tube about half their length: and pistil more thin $5 / 16$ inch long, composed of long stalk, flattened 1 -celled ovary, and short slender style.

The pod, green when immature, turning to dark brown, is short-stalked with calyx at base, $11 / 2-2$ inches in diameter, oblique or asymmetrical, with
Pterocarpus officinalis Jacq.

few prominent reins, with wing around edge brous on 1 side, not splitting open, 1 -seeded. Recorded in flower from February to September and in frut from A pril to November.

The sapwood is whitish to light yellow. The wood is lightweight (specific gravity 0.3 ), very soft, and weal. It stains easily in drying, is subject to decay, and susceptible to attack by drywood termites.

The wood has been used in Puerto Rico for floats for fishnets. At me time pieces of the thin buttresses served as pans in washing or panning for gold. The resin or wmm, which soon solidifies from the latex, fomerly was exported in large quantities from Colombia to Spain for medicinal use under the name sangre de drago as a hemostatic and also as an astringent. The trees have been planted for slade and ormament in southern Florida and Cuba and might be suitable for the same purposes in Puerto Rico.

Grows in swamp forests, chiefly on the landward side of mangrove but also in swamps and along streambanks in the lower Luquillo forest region up to about 1,500 feet elevation. Common in swampy areas on the sontheast coast near Humacao.

Prrulc forests.-Luquillo, San. Juan.

MUNTCI'ALITY WHERE ESPECILIY COMNON.-33.

Raxae-- Tamaiea, Hispaniola, Puerto Rico, Guadeloupe, Dominica, Martinque, St. Lucia, St. Tincent, and Trinidad. Also in continental tropical America from sontheastern Mexico (Yucatán) and British Honduras to Colombia, Ecuador, Tenezuela, Guianas, and Brazil. Introduced in Cuba and sonthern Florida.

Otrier Conmon ximes.--sangre de drago (Puerto Rico, Spanish): drago (Dominican Republic, commerce); sangregado (Guatemala, Nicaragua, Costa Riea) ; sangre, conee (Honduras) ; chajada amarilla, sangrillo (Costa Riea); bloodwood (Panama) ; sabroso (Colombia) ; sangrito, cacú, lagunero, mucutena (Venezuela) ; bambulo (Ecuador); swamp bloodwood (Trinidad); kaway, swamp kaway (British Honduras): bloodwood, corkwood (British Guiana); bois pâle (Haiti); mangle médaille, palétuvier, sang dragon (Guadeloupe); montouchi de savane (French Guiana); bebé, bebé hoedoe, watrabebé, wata gwe-gwe (Surinam) ; mututy (Brazil).

Botanical synorvi.-Pterocarpus draco L. (in part). 


\section{LEGUME FAMILY (LEGUMINOSAE)}

\section{PEA SUBFAMILY (LOTOIDEAE; FABACEAE)}

\section{Báculo, agati}

An introduced ornamental, spreading from cultivation, this tree is distinguished by: (1) alternate, even pimate leaves with $10-30$ pairs of oblong leaflets $3 / 4-11 / 2$ inches long and $1 / 4^{-1 / 2}$ inch wide, rounded at both ends, and very shortstalkerl: (2) giant white or bright red, flattened, pea-shaped flowers $21,2-4$ inches long, 2-5 hanging in a stalked cluster at hase of a leaf ; and (3) light brown pods 120-18 inches fong and only 5 in inch wide, flattened but slightly 4 -angled, long-pointed at both ends, and stalked at base.

Rapidly growing, short-lived, deciduons small tree attaining 15-25 feet in height and 6-12 inches in trunk dianeter, with thin crown of few branches. The gray bark is $1 / 2$ incl or more in thickness, rough, and furrowed into thick plates. Inner bark is pink and slightly bitter. The young twigs are finely hairy.

Ieaves are $6-14$ inches lone, with finely hairy axes enlaroel at hase. 'The leatlets have very short hairy stalks less than $1 / 6$ inch long and thin blades with apex roum or minutely notched with very ting point, with base :ounded but slightly unequalsided, pale green, and nearty hairless except when young.

Flower clusters (racemes) shorter than the leaves have $2-5$ flowers with umpleasant odor, commonly white but red in one variety, which is illustrated. The bud is somewhat mired. The large bell-shaped whitish calyx is nearly 1 inch long, slightly 2-loberl with s shallow teeth: the corolla of a white or red fleshy petals $210-1$ inches long, stalked at base, the oblong spreading standard shorter than the others and curred back, 2 curved wings, and 2 united curved keel petals; 10 curved stamens, ? united into a tube and 1 separate; and pistil of stalked rery narrow orary and slender style. The pods hang down and split open to release many elliptic brown seeds $3 / 16$ inch long. Flowering and fruiting throughout the year.

The wood is whitish, soft, and lightweight. It is weak and seldom used.

\section{Sesbania grandiftora (L.) Pers.*}

In India and elsewhere in southern Asia uses have been found for other parts of the tree. The flowers, tender green pods, and young leaves are eaten, such as in salads, curries, soups, and fried. Ieaves and young sloots are fed to cattle also. The bark vields a fiber, and gum with red and yellow coloring principles has been obtained from the pinkish white sap exnding from the cut trunk. Extracts of leaves and flowers and of the bark have been employed medicinally.

The name báculo (walking-stick) perhaps was sllggested by the odd, very long and narrow pods. Other names, gallito and cresta de gallo (cockscomb), are descriptive of the shape and color of the flowers in the red-flowered variation. Flowerind when small and only 2 years old.

Planted as an olmamental in gardens and escaping from cultivation in roadsides and thickets and perhaps naturalized locally in Puerto Rico, Tieques, St. Croix, St. Thomas, and St. Johm.

RANor.- Native from India to East Indies, Philippines, and northern Australia. Widely though sparingly distributed by cultivation and oceasionally spontaneons or naturalized in southen Florida, through most of the West Indies from Bahamas and Cuba to St. Tincent and Trinidad, and from southern Mexico through most countries of Central Imerica to South America.

Otuer com Mox xames.-gallito, cresta de gallo, a arat $\mathrm{(Pnelto} \mathrm{Rico)} \mathrm{;} \mathrm{jack-in-the-beanstalk} \mathrm{(Vir-}$ gin Islands) : gallito (Dominican Republic); crestal de gallo, gallito blanco, gallito colorado, zapatón blanco, zapatón rojo, paloma (Cuba); pico de flamenco (Mexico); choncho (El Salvador); cobreque (Nicaragua); gallito (Venezuela); agati, agati sesbania, Australian corkwoodtree (I'nited States); agati, flamingo-bill (Bahamas): pois vallier (Haiti); colibri végétal, papillon, fleur-papillon (Guadeloupe) ; tigertongue (Dutch West Indies).

Botaxicar sroxim.-Agati grandifiora (L.)
Desr.
This genus is represented also by 3 native
species of shrubs. The generic name formerly was
spelled also Sesban. 

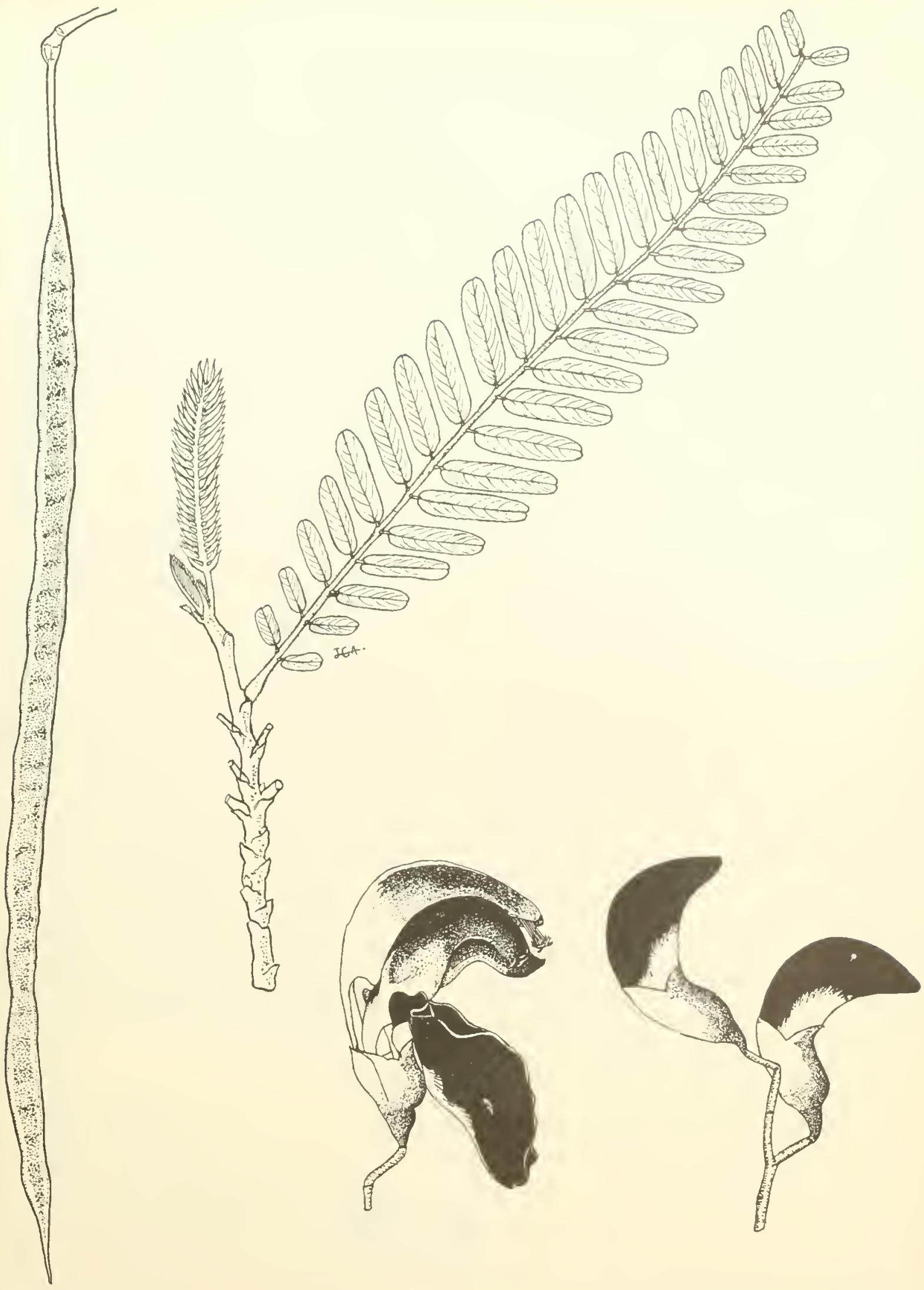

91. Bâculo, agati

Two-thirds natural size.

Sesbania grandiflora (L.) Pers. 


\section{COCA FAMILY (ERYTHROXYLACEAE)}

\section{Indio}

I small tree or shrub of dry areas characterized by: (1) short-stalked elliptie leaves $1 \frac{1}{2}-3$ inches long and $34-11 \%$ inches broad, minutely notched at rounded apex and with '2 fant lines nealy parallel with midrib and more prominent on lower surface: $(2)$ small whitish flowers $3 /$ inch across, sprelal together in lateral clusters mostly before the leaves or at base of new leaves: and ( 5 ) fleshy red oblong frits $5 / 16^{-3 / 5}$ inch long, 1 -seeded.

A decirnous tree or shrub s-20 feet high and 2-6 inches in trunk diameter. The gray bark is fissured and sealy, inner bark red and slightly bitter". Twigs gray, the short lateral twigs often with old seales where leaves and flowers were borne.

The leares are altermate but sometimes close together on slort latera] i wigs. Petioles are $3 / 16^{-}$ 1/1 inch long and slender, with a pointed suale (stipule) 1/s inch long inside base. blacles are broadly short-pointed at hase, not toothed on edgres, with 2 faint lines nearly parallel with midrib but converging with it at both ends, thin, dull dark green above, and pale whitish green beneath.

Several fragrant flowers derelop from a lateral bud on $t$ wig, each on a slender stalk $1 / 8^{-1 / 4}$ inch long. There is a 5 -toothed green calyx less than 1/16 inch long; 5 white rounded spreading petals $1 / 8$ inch long, each with a minnte 2 -lobed seale on inner side: 10 stamens $1 / 16^{-1 / 8}$ inch long, united into a tube in lower part; and pistil about $1 / \mathrm{s}$ inch long with 3-celled green ovary and 3 styles. Some flowers have long stamens and short styles, while others have short stamens and long styles. Collected in flower in different months from October to June. The fruits (drupes) are green when immature but tum red and have thin flesh and 1 large seed.

\section{Erythroxylon areolatum $\mathrm{L}$.}

The sapwood is light brown and hard. Heartwood is rivh rerldish hown the generic name means red wood) or chocolate brown, with oily appearance, very fine-grained, and very hard. The wood is heary, strong, and highly durable but available only in small sizes.

It is reported that the leares contain a small amount of cocaine. This dlug is obtained from the leaves of coca (Erythroxylon coca Lam.), a related speries of the Indes of Per'u and Bolivia.

Characteristic of thickets and forests on hills from Ponce to Caloo Rojo, the dry coastal and dry limestone regions of Puerto líeo. Also in Mona and doubt fully recorded from st. Thomas.

Pundic Forests.-Cruajataca, Guánica.

Ravge. - West Indies in Bahamas, Cuba, Jamaica, Hispaniola, Puerto Rico, and Mona. Also in southern Mexico (Tabaseo to Yrucatán), Guatemala, El Falvador, British Honduras, and Honduras. Reported from northern South America, probably in error.

Other commox samis.-palo de hierro, cocaina falsa, muerto, hierro negro (Puerto Rico); piracua, fruta de paloma, arabo (Dominican Republic); arabo carbonero, arabo jiba, arabo real (Cuba); limoneillo (Guatemala): thin-leaf erythroxylon (Bahamas); redwood (Jamaica); redwood, lidge redwood, swanp redwood (British Fonduras): poirier, arabo (Haiti).

This genus is represented by 3 additional species of shrubs or small trees, and another species is a low shrub. Jiba (Erythroxylon brevipes DC.) has nearly stalkless oloviate leares less than 1 inch long. Ratón ( $E$. rotundifolium I unan) has similar leaves with petioles $1 / 8^{-1 / 4}$ inch long. E. mufum. Cav, has oblong leaves $21 / 2+$ inches long, slightly thickened, with prominent network of reins. 


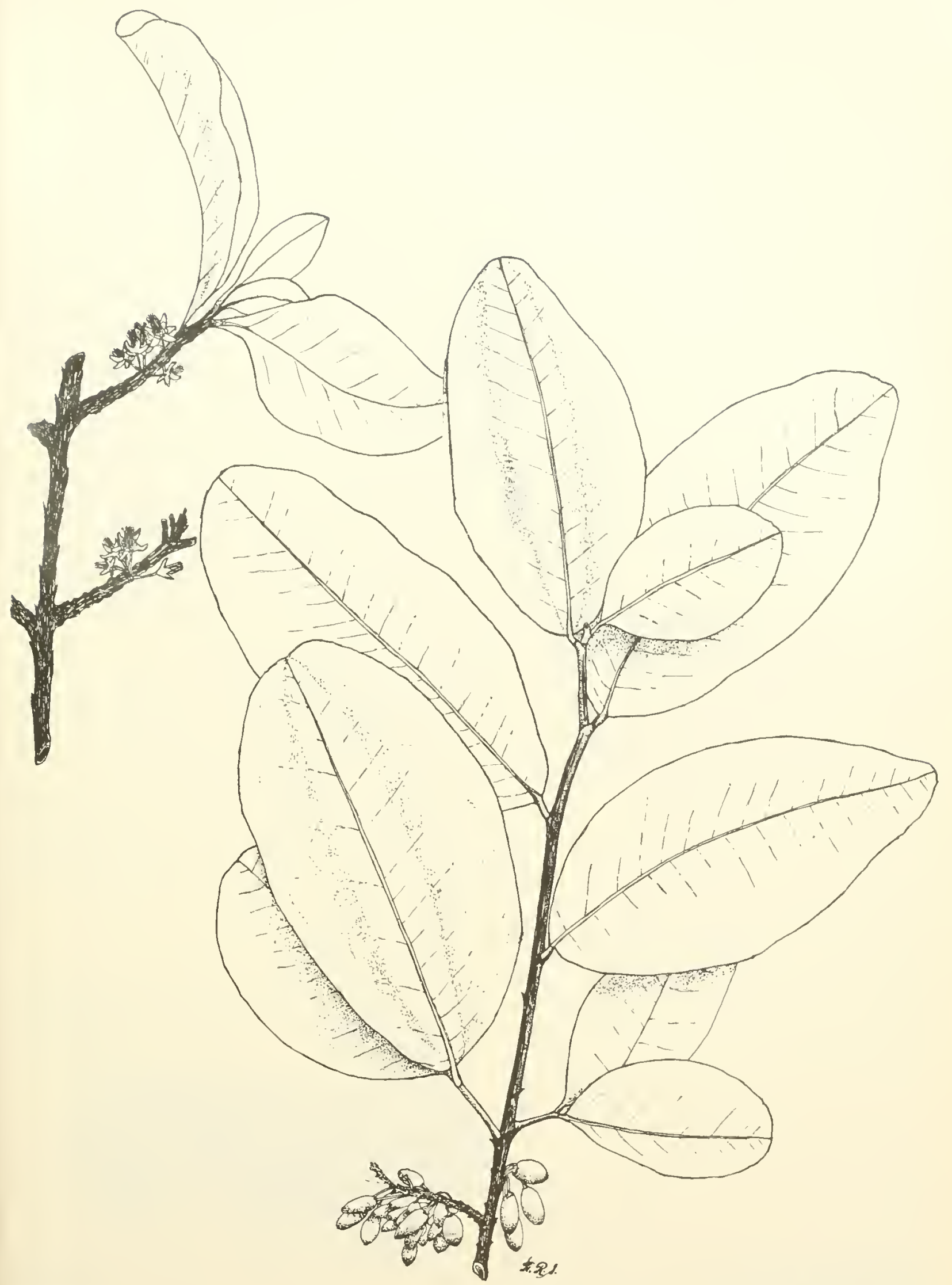

92. Indio

Natural size.

Erythroxylon arcolatum L.

211 


\section{CALTROP FAMILY (ZYGOPHYLLACEAE)}

Key to the 2 native species, both illustrated (Nos. 93-94)

A. Leaflets mostly 4, sumetimes 6; fruits mostly flattened, heart-shaped at ajex-93. Guaiacum offeinale. AA. Leaflets mostly 6-10; fruits deeply 5- or 4-angled or winged, pointed at apex-24. Guaiacum sanctum.

\section{Guayacán, common lignumvitae}

A handsome small evergreen tree with a dense rounded rown and atak green foliage, easily reeognized by: (1) light brown bark smoothish and mottled, peeling off in thin scales; (2) opposite even piunate leaves with mostly 4 or 6 stalkless, oblique, broadly elliptic or obovate leathery leaflets; (3) several to many deep to pale blue flowers with o petals minutely hairy on the onter surface, spreading starlike $3 / 4-7 / 8$ inch across in showy terminal and lateral clusters shorter than the leares; and (4) flattened orange-brown capsules $3 / 4$ inch long and broad, heart-shaped and slightly winged, attached at nalrowed end.

A tree 15-30 feet high, with a short trunk 4-18 inclies in diameter. The bark scales are $1-2$ inches across and mon falling expose smoothish gray brown spots beneath. Imner bark is light brown and bitter. The green twigs, turning to sray, have enlarged ringed nodes and are nuch branclied and widely forking.

Leaves are 11/2-?, inches loner, with green axis and at base paired minnte luary scales (stipules) which shed early. Leaflets are $3 / 4-2$ inches long and $1 / 2-11 / 4$ inches wide, romder or sometimes blunt-pointed at both base and apex, broadest on the sicle toward base of leaf, slightly thickened and often tumed under at edges, hairless, and dark green or olire green on both sirles, slightly shiny above. 'The lowest pair of leaflets is at the base of axis beside the twig, while the pair of leaflets at apex is largest.

Many pretty, faintly fragrant. flowers are clustered together (umbellike) on slender minutely hairy stalks $3 / 5-1$ inch long. There are 5 broad rounded finely bairy sepals nearly $1 / 4$ inch long: 5 spreading deep to pale blue petals nearly $1 / 2$ inch long, narrowed at base and rounded at apex, minutely hairy on outer surface; 10 stamens abont 5/16 inch long, with blue filaments and yellow anthers; and stalked pistil 1/4 inch long, with flattened usually 2 -celled orary and pointed style.

The flattened capsules minutely pointed at the heart-shaped apex are green when immature, turning orange brown. They split open to discharge 2 or 1 seed $1 / 2$ inch long, brown with a red fleshy covering (aril). Flowering and fruiting from early spring to fall.

The narrow saprood is pale yellow. Heartwood is dark greenish brown or nearly black. Lignumvitae is one of the heariest commercial roods (specifie aravity about $1.2-1.3)$. It is extremely hard, of very fine uniform textme, with highly interlocked grain, growth rings clearly defined, and characteristic oily feel cansed by the unique resin content. The wood is difficult to season and work but takes a fine polish. The heartwood is very
Guaiacum officinale L.

durable and very resistant to decay. It is rery resistant to attack by dry-wood termites, but the salpwood is susceptible.

The self-]ubricating resinons wood is so valuable that it is sold by weight, though not now of commercial importince in Puerto Rico. It is famed for its special use in bearings and bushing blocks for propeller slafts of steamships. It serves also for pulley slieares, deadeyes, and as a replacement for metal bearinas in roller mills. Other uses include bandsaw guides, awning rollers, furniture casters, mallets, bowling balls, and turned novelties.

Tnder the name lignmmitae (Latin for rood of life), the extract of this wood formerly was official in medicine as a stimulant and to increase perspiration. Earlier it was thought to be a cure for tarions diseases, haring been introduced in Europe about 1508. Also employed medicinally was gua lac resill, which exudes from hark and sapwood, reddish brown in color but changing to blue or blue green.

The trees occasionally are planted as omamentals for the masses of blue flowers, which are rare in the tropics, and for the handsome dark green foliage. However, their growth is slow, so slow that forest plantings in Puerto Rico by the Forest Serrice lave been discontinued in faror of other species. Bees visit the flowers.

Forests, thickets, and pastmres in the dry coastal and dry limestone regions of Pnerto Rico from Guayma to Cabo Rojo. Also in Culebra, Vieques, St. Croix, St. Thomas, and St. John. Reported to be nearly exterminated on Virgin Islands except in cultivation.

Purlic rorest.-Guánica.

Municipalittes WHEle especialle COMMON.12,66 .

Ruxre.- West Indies from Bahamas and Greater Antilles to Martinque in Lesser Antilles and in Bonaire, Curaça, and Aruba. Also in Panama, Colombia, Tenezuela, and British Guiana. Planted in southern Florida, Bermuda, Trinidad and Tobago, Surmam, and elsewhere in tropical America.

Other comson Names-guayaco (Puerto Rico); lignumvitae (Virgin Islands); guayacán (Spanish); palo santo (Cuba, Venezuela); guayacán negro (Cuba) ; guayacán de playa, guayacán colombiano, guayico (Colombia); lignmuitae, common lignumvitae (United States, English, commerce); gaiac (French, commerce); gaïac franc, gaïc mâle (Haiti) ; bois saint (Martinique); wayacá, pokhout (Dutch WTest Indies); guaiaco, pau santo (Brazil).

The generic name is also spelled Guajacum. 

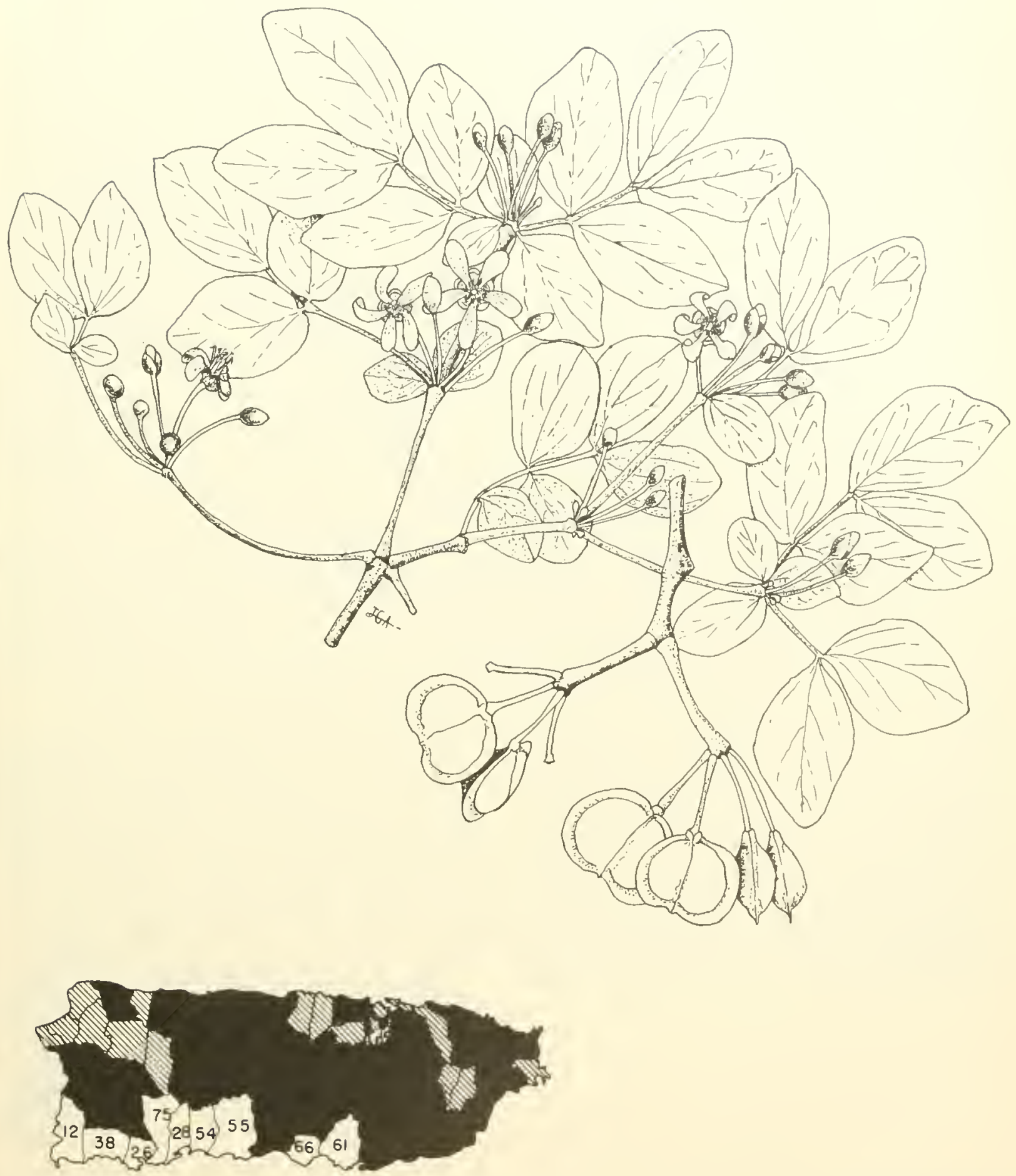

93. Guayacán, common lignumvitae 


\section{CALTROP FAMILY (ZYGOPHYLLACEAE)}

\section{Guayacán blanco, holywood lignumvitae}

A small tree of dry areas characterized by: (1) hark rleeply fissmed rertically; (2) opposite, even pinmate leaves with mostly $6-10$ stalkless, (H) hique, elliptic or obovate leaflets ending in a mimute point, with several veins from base: (3) blue flowers o's inch across the 5 spreading hairless petals, usually a few in terminal clusters shorter than the leares; and (4) rellowish or orange capsule $5 / 8$ inch long, deeply 5 - or 4 -angled or winged.

An evergreen tree 1 ir-30 feet high with short stont trunk 8 inches or more in diameter, and dense round crown of spreading or drooping branches. 'The light gray bark is rough. Imner bark is light brown and slightly bitter. Sapwood is light yellow and rery hard. The light gray twigs are enlarged at nodes, slightly angled, and green and minutely hairy when young.

The leaves $21 / 2-31 / 2$ inches long have paired minute hairy seales (stipules) at base and a green minutely hairy axis. Leaflets are 5/8-1 inch long, $3 / 8-3 / 4$ inch wide, short-pointed at base, rounded and minntely pointed at apex, not toothed on edges, broadest above middle and on the side toward base of leaf, slightly thickened and leathery, hairless, and green on both sides. During the hottest part of the day the paired leaflets often fold toget her.

Flowers are bone on slender minutely hairy stalks $3 / 1-1$ inch long attached between the nppermost pair of leaves. There are 5 blunt-pointed slightly hairy sepals $1 / 4$ inch long; 5 blue petals $5 / 16^{-3 / 8}$ inch long, narrowed at base and in part 2 -lobed at apex; 10 stamens nearly $1 / 4$ inch long; and stalked pisti] $1 / 4$ inch long, the ovary with 5 or 4 angles and cells and ending in pointed style.

Seed capsules are 5/8 inch long and $1 / 2$ inch across the angles, broadest near the short-pointed apex, containing dark brown or black seeds about $3 / 8$ inch long, each with a scarlet fleshy covering
Guaiacum sanctum L.

\section{(aril). Flowering and fruiting from spring to} fall.

Sapwood is light yellow and very hard, and heartwood becoming greenish or brown on exposure. The wood has clearly defined growth rings, is resinous with a characteristic odor, rery hard, very heary (specific gravity about 1.1), and rery durable. It resembles the wood of common lignumvitae (Guaiacum officinale L.) and has similar uses but is less valuable. Like its relative this species of lignumvitae formerly was official in medicine for similar purposes.

Sometimes planted as a handsome blue-flowered ornamental in Pnerto Rico, southerm Florida, and elsewhere.

In thickets and forests in the dry coastal and dry limestone regions of Puerto Rico from Ponce to Cabo Rojo. Also in MIona.

PÚlic Forest.-Guánica.

Ravge-Florida Keys, Bahamas, Cuba, Hispaniola, Pnerto Rico, and Mona. Also in Mexico (Yneatán), Guatemala, Honduras, and Nicaragua. Recorded from Bonaire, Curaçao, and Iruba, perhaps in cultivation. Planted in southern Florida, Trinidad, and elsewhere in tropical America. (The botanical type specimen came from Puerto Rico.)

OTHer common Names.-guayacán de rera, guayacancillo (Pnerto Rico); vera, guayacancillo (Dominican Republic, Cuba); guayacán blanco (Cuba); guayacán (Mexico, Guatemala, Nicaragua): palo santo (Mexico); holywood lignumvitae, rouglibark lignumvitae, lignumvitae (United States); lignumvitae (English, commerce); bois saint, gaïac blane, gaïac femelle (Haiti); wayaka slimarón, beera, boeloebarie, wajakaa maatsjoe (Dutch West Indies).

BotaNiC.AL SYNONYM.-Guaiacum guatemalense Planch. 


\section{RUE FAMILY (RUTACEAE)}

Key to the 9 species illustrated (Nos. 95-103)

A. Leares opposite, with usually 3 (sometimes 1 or 5) long-pointed leaflets-95. Amyris elemifera.

AA. Leaves alternate.

B. Leaves simple.

C. Leares elliptic, with many minute rounded teeth on margin, petiole usually jointed with blade; flowers large, white; fruit a rounded or elliptic juicr berry (citrus).

D. Leares small, 11/2-3 inches long; fruit elliptic $1 \frac{1}{2}-21 / 2$ inches long (lime)-96. Citrus aurantifolia.* DD. Leaves and fruit larger.

E. Petiole broadly winged.

F. Leares mostls long-pointed at apex; fruit round, roughened, orange, bitter, inedible (sour orange) -97 . Citrus a urantium.*

FF. Leaves rounded at botl ends (or blunt-pointed at apex) ; fruit round, smooth, large, pale jellow grapefruit-in. Citrus paradisi*

EE. Petiole almost wingless or narrowl winged.

G. Petiole almost wingless; fruit elliptic, blunt-pointed or tubercled at both ends, the surface often rongh and wrinkled, yellow (lenon)- is. "itrus timon**

GG. Peliole narrowly winged; fruit round, smooth, orange (sweet orange)-100. Citrus sinensis.*

CC. Leaves with margin not tootled, somelimes slightly wavr, petiole not jointed with blade; flowers and BB. Leaves pinnate. fruit very small-103. Zanthoxylum monophyllum.

H. Leaflets 5-9, elliptic, margin willout teeth or very finely wary; not sping-101. Zanthoxylum fanum. HH. Leaflets 7-19, oblong to lance-shaped, margin very finely wavy; spiny-102. Zanthoxylum martinicense.

\section{Tea, sea amyris}

Amyris elemifera L.

A small tree or shrub characterized by: (1) dense rounded crown of compact pale green foliage; (2) opposite compound leaves with usually ? (sometimes 1 or 5 ) orate or lance-shaped, longpointed leaflets $1-21 / 2$ inches long and $1 / 2-11 / 2$ inches broad, slightly leathery, slightly shiny yellow green, and with many gland dots: (3) many small, greenish-white, $t$-parted, spreading flowers about $3 / 16$ inch across; $(4)$ many small round black fluits about 1/4 inch in diameter; and (5) twigs, leares, and fruits with slight citrus odor when crushed.

An evergreen tree commonly 10-20 feet high and 3-6 inches in trunk diameter. The bark is smoothish and gray, becoming rough with deep furrows and rectangular plates. Inner bark light brown, with slight citrus spicy taste. The twigs are yellow green when young, becoming gray.

The leaves are $2-4$ inches long. The leaflets, on slender stalks 1/8-1/2 incl long, are short-pointed or rounded at base, the edges withont teeth or minutely wavy.

Flower clusters (panicles) are terminal and lateral, much branched, 11/2-2 inches long and broad. The short-stalked flowers have a minute 4-lobed calyx; 4 gland-dotted spreading petals; 8 stamens; and pistil of 1-celled orary and broad stigma. The fruits (drupes) are covered with a bloom, gland-dotted, with thin flesh and 1 brown seed. Flowering and fruiting irregularly during the year, recorded in flower from Narch to October.

The sapwood is whitish, and the heartwood light yellow. The wood is very resinous with strong odor, very hard, fine-grained, heavy (specific grarity 1.0-1.1), and strong. It takes a good polish, is very durable, and definitely repellent to dry-wood termites.
Used chiefly for posts in Puerto Rico. Formerly also employed for furniture and fuel. If available in quantities and larger size, the wood might be valuable. As common names in different languages indicate, torches are made from the resinons wood. The tree yields a fragrant resin.

Widely distributed in thickets of the dry limestone and dry coastal regions of Puerto Rico. Also in Mona, Desecheo, Icacos, Culebra, Vieques, St. Croix, st. Thomas, St. John, and Anegada. On Mona the species is becoming less common owing to extensive browsing of its bark by goats.

Peblic Forestrs.-Guajataca, Guánica, Susúa.

MUNiCIPALITIFs WHERE ESPECIALLY COMMON.$26,28,55,75$.

RANGE-Central and southern Florida including Florida Keys, Bahamas, Cuba, Jamaica, Hispaniola, Puerto Rico and Virgin Islands, and Lesser Antilles from St. Martin to St. Vincent, Grenadines, and Grenada. Also Central America in Guatemala, British Honduras, Honduras, and El Salvador. Reported from Venezuela, apparently in error:

Otiler comion names.- c u a b i l l a (Puerto Rico) : candlewood, torchwood (Tirgin Islands) ; guaconejo, palo de tea (Dominican Republic); cuabilla, cuaba de costa (Cuba) ; chilillo, pimienta, taray (Honduras) ; roldán, melón (El Salavdor) ; sea amyris, torchwood, candlewood (United States); white torch (Bahamas); amyris-wood, torchwood (Jamaica); waiki-pine (British Honduras); bois chandelle (French) ; bois chandelle b]anc, bois pini, bois flambeau (Guadeloupe).

The Spanish name tea means torch. This is not the shrub called tea in English.

Teilla (Amyris balsamifera L.), a related species of southwestem Puerto Rico. has 3-7 leaflets and larger elliptic fruits $1 / 4^{-1 / 2}$ inch long. 


\section{Limón agrio, lime}

Serepal speeies of citrus (cenus Citrus) natice in sonthern Asia are "ultivated for their wellknown edible fruits. Characteristies for identifi(ation of the gromp are: (1) aromatic, ghandular everween shrubs and small trees with distinctive spicy odor and taste of crushed parts; (2) green twirs mostly with sharp brown-tipped green spines $1{ }^{1}-1$ inch long, single at base of leaves; (3) alteruate leathery leaves, green to dark green and mostly elliptic, with many minnte rounded teeth on margin and numerous timy gland dots visible against the light: (4) petiole jointed with blade (except in 1 species) and usually winged; (i) fragrant white (sometimes purplish-tinged) flowers with $t$ - $i$ spreading, sightly fleshy, glandlotted petals $3 / 4-2$ inches across; and (6) rounded or elliptic vellow or orange fruits (berry or hesperidium), green when immature, composed of an aromatic peeling, S-15 rells with many pointed juicy sace, and several to many whitish seeds.

Lime is distinguished from the other kinds of citrus frouits by: (1) the small elliptic fouit $11 / 2-$ $21 / 2$ inches long and 1-2 inches in diameter, pointed or rounderl at apex, smooth, areen but tuming to areenish yellow, with thin peeling $1 / 16$ inch thick, ank witli very sour green flesh: (2) small white thowers only $1 / 2-1$ inch across the + or 5 petals; and (3) small dull areen, elliptic leaves commonly romeled or blunt-pointed at apex and with nallowly winged petioles.

An evergreen aromatic and glandular slumb or small tree to 20 feet high, with irregular butnehes. The brown bark is smoothish, inner bark pale yellow and bitter: The green to dark green twigs, angled when young, have short sharp spines, usmally $1 / 8-5 / 8$ inch long. green and tipped with brown, solitary at base of the alternate leares.

The green petioles $3 / 8-3 / 1$ inch long are jointed with blade. The sumall thick and leathery blade is $11 / 2^{-3}$ inches long and $3 / 4-13 / 4$ inches wide, sometimes to 4 inches long and $21 / 4$ inehes broad, rounded at base, the edges with many minute rounded teeth, and with mumerous tiny gland dots visible against the light. [pper surface is dull green, and lower surface is dull light green.

Flowers, only slightly fragrant, are produced in clusters of $2-7$ on short stalks at base of a leaf. The white sancer-shaped ealyx is about $3 / 16$ inch across and less than $1 / 8$ inch high, with 4 or 5 teeth: 4 or 5 white oblong gland-dotted petals about $1 / 2$ inch long: $20-25$ white stamens $1 / 2$ inch long. separate at base, with yellow anthers; and pistil $3 / 8$ inch long on a whitish disk, consisting of green romded ovary with 9-12 cells, stont whitish style, and yellowish rounded stigma.

The fruit (berry or hesperidium) has a few whit ish elliptic pointed seeds about $3 / 5$ inch long, with brownish-red eaps at end. Flowering in spring to July, later than the other species of
Citrus aurantifolia (L.) Swingle*

citrus, and maturing fruit in summer and fall. The hard wood with whit ish sapwood is little used locilly. When pruned back, the plants make a grood fence. Also a honey plant.

The fruit is picked and shipped green. It is utilized extensively in refreshing drinks and for seasoning foods. The West Indian islands of Montserrat and Dominica produce quantities of lime fruits and lime juice for export. The fruit is the man source of citric acid for the dyeing industry and medicinal use, and lime oil is extracted from the rind. The bottled juice, which is rich in vitamin $C$, has been carried on ships as a means of preventing seury. I tea or tonic has been prepared from the leaves.

(ultivated and escaping or matmalized, chiefly at low elevations, in Puerto Rico and Mona. St. Croix, St. Thomas, St. John, and Tortola.

Raxar.- Native of East Indian Arehipelago but introduced into the New Forld more than 400 years ago. Widely eultivated and natmalized in tropical and subtropical regions, including southern Florida and Florida Keys, Trest Indies, and from Mexico to South America.

Other commox Names. - TTest Indian lime (Tirgin Islands): lima (Spanish); lima boba (Dominican Republic) : limón eriollo, lima agria (Cuba): lima chica (Mexico); limón (Central Imeriea); lima agria (Tenezuela): limón sutil (Eeuador): limón agrio (Peru) : lime, West Indian lime (English); lime-leaf-plant (Grenadines): citron (Haiti); eitron commun (Guadeloupe): lamunehi, lemoen (Duteh Wrest Indies).

Botaxical stroxym.-Citrus lima Lunan.

Sweet lime or limón dulce (citron doux in French) apparently is a variation or hybrid of lime or limón agrio and not botanically distinet, though it has been recognized by some authors as a speejes (Citmes limetta Risso). It has a rounded wreenish-yellow fruit $21 \frac{2}{2}$ inches in diameter, with whitish of greenish-tinged flesh which is slightly sweet or insipid. Sometimes planted as a fruit tree in Puerto Rico and elsewhere in tropical Anerica. though not ranking highly among the citus fruits hecamse of the weak flavor.

Besides the 5 citrus species deserihed and illustrated here, a few others are less frequently cultivated. Mandarin orange, tangerine, or mandarima (Citme retimlata Blaneo; symonym $C$. nobitis auth., not Lour.) has orange rounded fruits 2-3 inches in diameter, broader than long, with loose peel and easily separable segments.

Pummelo, shadkloek, or pomelo (Citmes grandis (L.) Osbeck*) has large yellow fruits round or slightly pear-shaped, 5-6 inches in diameter.

Citron or cidra (Citms medira L.*), usually slurubby, has large yellow fruits oblong or elliptie, 5-8 inches long. and about 2 inches in diameter, with very thick peel and small pulp. 


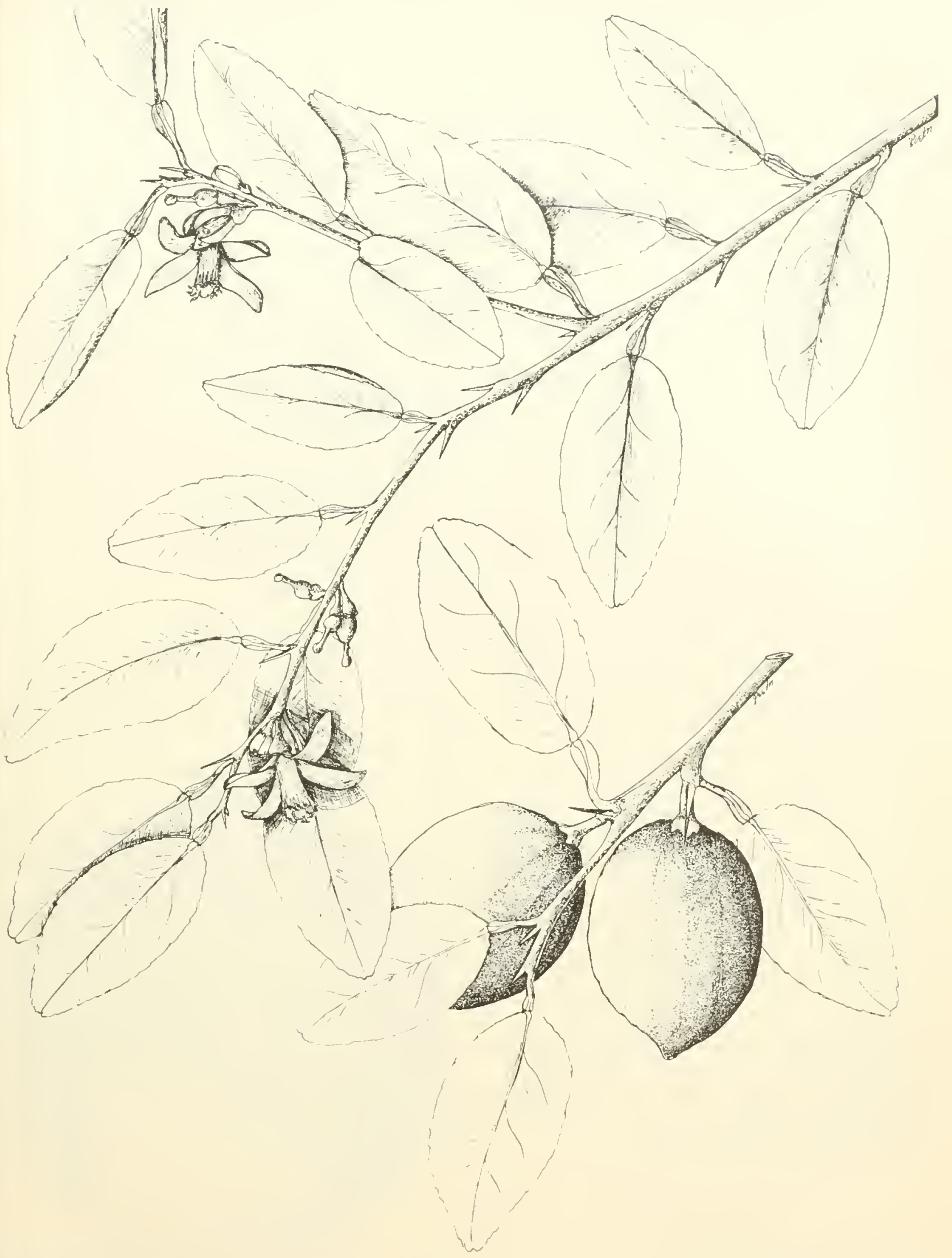




\section{RUE FAMILY (RUTACEAE)}

\section{Naranja agria, sour orange}

Sour orange differs from the other citrus fruits in: (1) the round orange or reddish-orange fruit $21 / 2-41 / 2$ inches in liameter, often broader than long, more or less roughener, with thick peeling, and hollow pulpy core, which is bitter and too sour to be elilule: (2) strongly fragrant large white flowers with usually 5 petals; and (3) leaves ovate, more or less longr-pointed at apex and tapering or rounded at base, the petioles with broad wings $3 / 8-5 / 8$ inch across.

A small aronatic evergreen tree 15-30 feet high, with rounded crown. The hark is brown and smoothish, the inner bark light brown and bitter. Twigs green, angled when young, with sharp spines lecoming $1 \mathrm{inch}$ long.

Leaves are alternate on petioles $3 / 4-11 / 2$ inches long. Blades are jointed with petiole, ovate, $21 / 2-$ $51 / 2$ inches long and $11 / 2-1$ inches wide, with many minute rounded teeth at edges, a little leathery, with numerous tiny grand dots, alove green and slightly sliny, and beneath pale light green. The leaves have a pleasant scent.

There are 1 to few fragrant large white flowers at base of a leaf. Calyx is light green and 4-5toothed; usually 5 narrowly oblong white glanddotterl petals about 3/4 inch long: $20-21$ stamens united into tulue in lower half; and pistil on a disk with 9-12-celled ovary, style, and rounded stigma.

The fruit (berry or hesperidimu) rind, $1 / 4-3 / 8$ inch thick, is bitter and aromatic, and the flesh has bitter walls. The whitish seeds are flattened, marked with ridged lines, and about $1 / 2$ inch long (1,600 to a pound). Flowering throughout the year.

The heartwood is whitish to light yellow, hard and fine-grained, with prominent growth rings. It is reported that the wood is like that of sweet orange or china ( $C$ itrus sinensis L.*) and perhaps is suitable for the same purposes. In Cubat the wood is used to make baseball bats.

\section{Citrus aurantium L.*}

The peeling with pulp of this species is the principal source of ortuge marmalade and is sometimes candied and, when fresh, yields an essential oil. The juice serves for seasoning foods, such as soups and meats, and sometimes as an orangeade drink when sweetened with sugar. I perfume, oil of neroli, is produced in southern Europe from the petals. In home medicines the juice is an ant iseptic and hemostatic, and a decoction of the lea ves induces sweating. The peel and its oil have been used medicinally as a source of ritamins. This is a honey plant also.

Being resistant to the root rot disease of citms fruits, this species is employed, especially in the United States, as the stock for budding the other species.

Cultivated in Puerto Rico and spontaneous after planting and naturalized, chiefly in the lower mountain and moist limestone forest regions. A hybrid or variety of the Seville orange, which has sweet juice, is grown in Puerto Rico also. St. Croix, St. Thomas, and probably other's of the Virgin Islands.

Pubuc Forests.-Carite, Guajataca, Luquillo, Río Abajo, Toro Negro.

Raxge:-Native of southeastem Asia. Widely planted and naturalized in tropical and subtropical regions. Naturalized in southeastem United States (Georgia and Florida), Bermuda, through West Indies, and from Mexico to Argentina.

OTIER COMMON NAMES.-naranja agria, naranja ácida (Spanish); naranja cajera (Tenezuela); naran jo amargo (Argentina) : sour orange, Seville orange (United States, English) ; bitter" orange (Bermuda, Jamaica); bigarade orange (Jamaica) ; orange sûre (Haiti); orange sûre, orange amere, orange grosse-peau (Guadeloupe); bois d"oranger, naranga (French Guiana); laraha, laraha zier (Dutch West Indies) ; laranja da terra, laranja amaroga (Brazil).

Botanical syonyms.-Citme vulgaris Risso, C. bigaradia Loisel. 



\section{RUE FAMILY (RUTACEAE)}

\section{Limón de cabro, lemon}

Lemon is separated from the other kinds of citrus fruits by: (1) the very sour vellow ellintic fruit $21 / 4-4$ inches loug and $11 / 2-31 \%$ inches in diameter, blunt-pointed or tubercled at both ends, and the surface often rongh and wrinkled; (2) flower's $11 / 4-2$ inches broad with 4 or 5 whitish petals purplish tinged on outside; and (3) leaves with apex pointed and with almost wingless petiole.

A small aromatic everoreen tree attaining 10-20 feet in height and 4 inches in trunk dianeter or larger, the trunk slightly angled, witl long irregular sprearling branches. The bark is brown or gray and smooth to finely fissured, the light brown inner bark slightly bitter. The green twigs usually have a short stout spine at base of leaf.

The alternate leaves have petioles $1 / 4-1 / 2$ inch long, jointed with blade. Blades ale oblong to elliptic, $21 / 2-41 / 2$ inches long and $11 / 1-21 / 4$ inches wide, short-to long-pointed at apex and romided at base, with many minute rounded teeth at edges. thick and leathery, and with numerous gland dots. The upper surface is green or dark green and slightly shing, and the lowel surface dull light green. Toung leaves are reddish.

Flowers are single, paired, or few at base of a leaf, slightly fragrant, some hisexinal and some male, the buds reddish or purplish tinged. There is a euplike $4-5$-toothed light green and purplish calyx about $1 / 4$ ineh high and broad ; 4 or 5 slightly fleshy, gland-dotted petals $3 / 4$ incl long, and curved back on the onter side: $20-40$ stamens $5 / 8$ inch long with fleshy white filaments slightly united at base and with yellow anthers; and pistil on basal disk with 7 -11-celled ovary tapering to the stout style.

The fruit (berry or hesperidimn) has a thick peeling $1 / 4^{-3 / 8}$ inch thick and rery sour, pale yellowish flesh. The elliptic whitish seeds about $3 / 8$ inch long are pointed at 1 end. Flowering
Citrus limon (L.) Burm. f.*

in spring and with fruit in summer and fall. The wood is light brown and hard.

The juice is made into lemonade drinks, sweetened with sugar and serves to season foods. The fruit is mole crenerally consumed in the United States than in Latin Lnerica. In home medieines the juice is antiseptic and arrests bleeding, a decoction produces sweating, and the root has been employed also. The lime juice of the old sailing vessels, a preventative of scurvy, eame partly from this species. I emon oil, from the fruit peel, is official in the United States Phamacopoeia as a flavoring agent. A honey plant.

Formerly planted as a fruit tree and naturalized in Puerto Rico, chiefly in the lower mountain and moist limestone forest regions. Also in the Tirgin Islands.

Prbulc Forests.-Carite, Luquillo, Maricao, Río Abajo, Toro Negro.

R.uxge.-Perhaps from southeastern Asia, the origin meertain and perhaps relatively recent, possibly hybrid. Now widely cultivated and naturalized in tropical and subtropical regions. Bermula. West Indies, and from southern Florida and southem Califomia and Mexico to South Ameriea. It is reported that this species was first introduced into the New Torld at Hispaniola by Columbus in 1493 .

Orher commox vames.-limón (Spanish); linón agrio (Dominican Republic, Mexico); Jimón francés, cidra (Culba) ; limonero (Mexico, Colombia): limón real (Central America, Ecuador); limón común (Nicaragua); limón criollo, limón francés (Venezuela) ; lemon (Lnited States, Engrlish): limon (French); citronnier, limon france (Haiti); lamoentsji, lammehi dushi (Dutch West Indies).

Botwicat sroxis.-Citme limonum Risso. Formerly referred also to Citmu limonia Osbeck, Canton lemon, which is a different Chinese hybrid. 


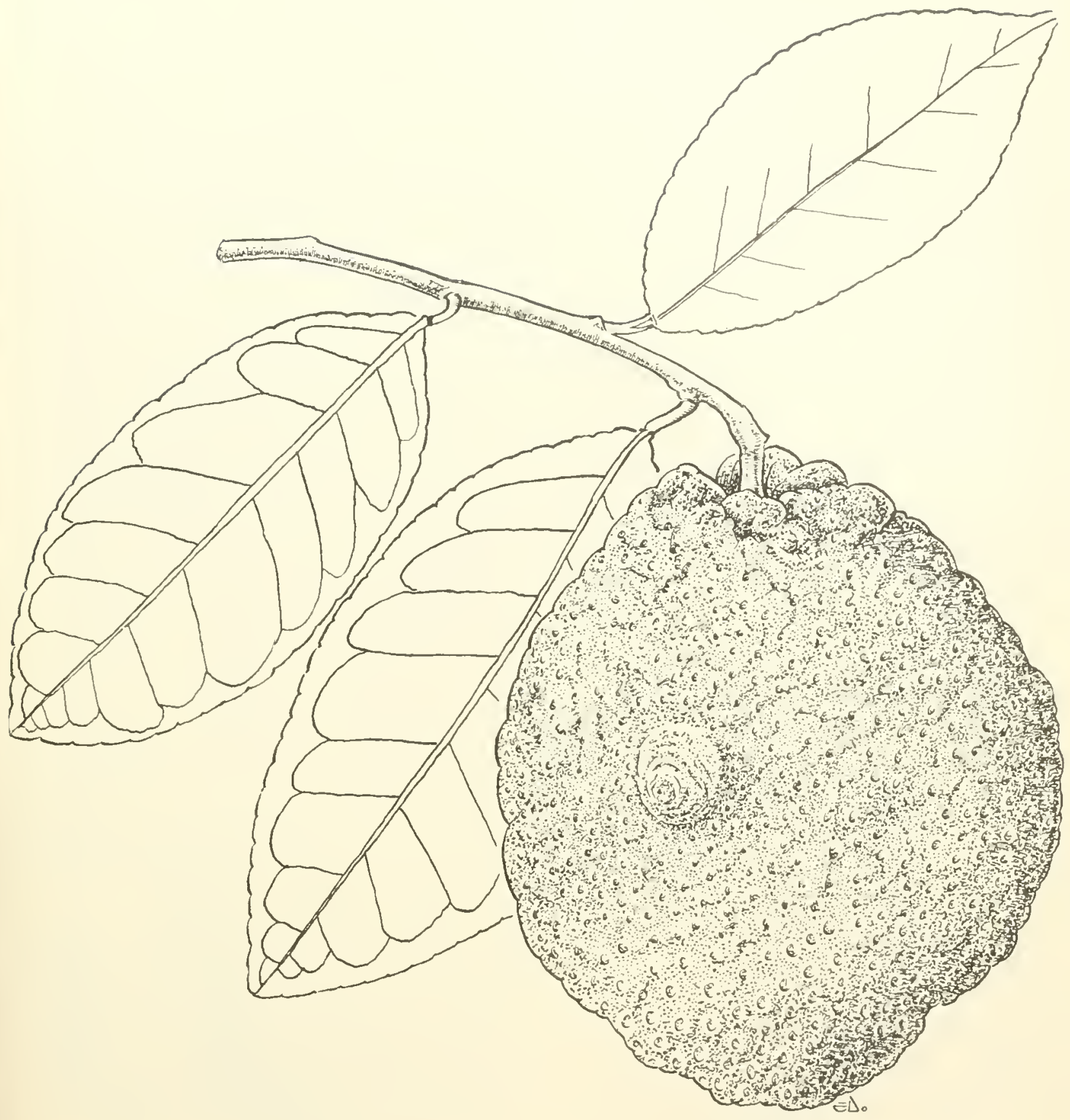

98. Limôn de cabro, lemon

Citrus limon (L.) Burm. 1 . 


\section{RUE FAMILY (RUTACEAE)}

\section{Toronja, grapefruit}

Grapefruit is recognized among the eitrus funit trees by: (1) the large round finit, which is pale yellow at maturity, $31 / 2-5$ inches in diameter, smonth, with flesh usually light yellow, sometimes pink, the taste sweet and acid and bittel combined: (2) frogrant large white flower's $1-13 / 4$ inclies across the + petals; and ( 3 ) leaves elliptic, lounded at both ends (or blunt-pointed at apex) and petiole usually broadly winged.

A small aromatic evergreen tree becoming 15-20 feet high and 6 inches in trumk diameter, sometimes larger, with rounded spreading crown of regular branches. The hark is smooth cray brown, imer bark light vellow and slimhty bitter. The green twigs usnally have short slender and flexible spines single at nodes, the leaves also alternate. romug 1 wigs and leaves are hairless or nearly so.

The petiole is $1 / 4-1$ inch long, the wing $1 / 4-1 / 2$ incl, wille. I3lade in $3-6$ inches long and $13 / 4-3$ inches wide, jointed to petiole, with many minute romnded teeth at edges, slightly leathery, and with numerous tiny gland dots, above shiny dirk irreen, and beneat li dull light green.

Flowers are solitary or 2-6 in a lateral cluster (raceme). The cup-shaped calyx is irregularly 5 -tonthed, about $3 / 16$ inch high and $1 / 4$ inch or more across; there are 4 oblong white fleshy petals $3 / 4$ inch or more in length: $20-25$ stamens mited into tube in lower part; and pistil on a disk with round 11-14-celled ovary.

The fruit (berry or hesperidium) has a whitish peeling $3 / 16-3 / 8$ inch thick. Walls of the flesh are hitter. The numerous whitish elliptic pointed seeds are about $1 / 2$ inch long. Flowering in the spring and fruiting in the fall, the mature fruits persisting unt il May.

The sapwood is whit ish to light yellow, and the heartwood light yellow to yellowish brown. The hald, fine-grained wood with growth rings clearly defined is used chiefly for fuel.

Grapefruit, a breakfast favorite, is marketed in Pnerto Rico eithel fresh or as camed sections or juice. The tree is an attractive omamental and honey plant as well as fruit tree.

\section{Citrus paradisi Macfadyen*}

This is one of the commonest citrus species in P'uerto Rico, heing grown in plantations, chiefly in the moist coastal region. Formerly it was the most important fruit grown commercially on the island for shipment in fresh form to the United States. Now the plantations are mostly abandoned becanse competition destroyed the export market. Scattered trees are to be found in the moist limestone and lower mountain regions. Also in the Virgin Islauds.

R.uxge.-Apparently of relatively recent origin in cultivation in the West Indies and not found wild in Asia. Planted extensively in subtropical areas of southern I'nited States in Florida, Texas, Arizona, and California. Also grown through Test Indies, from Mexico to Sonth America, and in the Old World tropies.

Other common x.MuEs.-toronja (Spanish); grapefruit (Central America); greifruta (Colombia): grapefruit (United States, English); chadèque (Haiti) : pamplemonsse, grapefruit (Guadeloupe); grapefruit (Dutch West Indies).

Botaxical syoxya.-Citrus maxima (Burm.) Merr. var. uvicarpa Merr. \& Lee.

$\mathrm{B}_{\mathrm{y}}$ some authors the grapefonit is placed as a variety of pummelo, shaddock, or pomelo, Citrus grandis (L.) Osbeck* (C.maxima (Bum.) Merr., C. decumana (L.) L.). The latter has larger thick-skinned frnits 5-6 inches in diameter or slightly pear-shaped, with the juicy particles large and easily separable, large rongh yellowish seeds, larger leaves with broadly winged heart-shaped petioles, and very large flowers.

It is thought that grapefuit originated in the West Indies as a mutation of pummelo or possible hybrid of that species with sweet orange. Apparently it was first described in 1750 as the forbiclden fruit of Barbados. In 1814 the English name grapefruit first appeared in a Jamaican book, which attributed the derivation to the resemblance in flavor to the grape. The species was named botanically from Jamaica in 1830. 


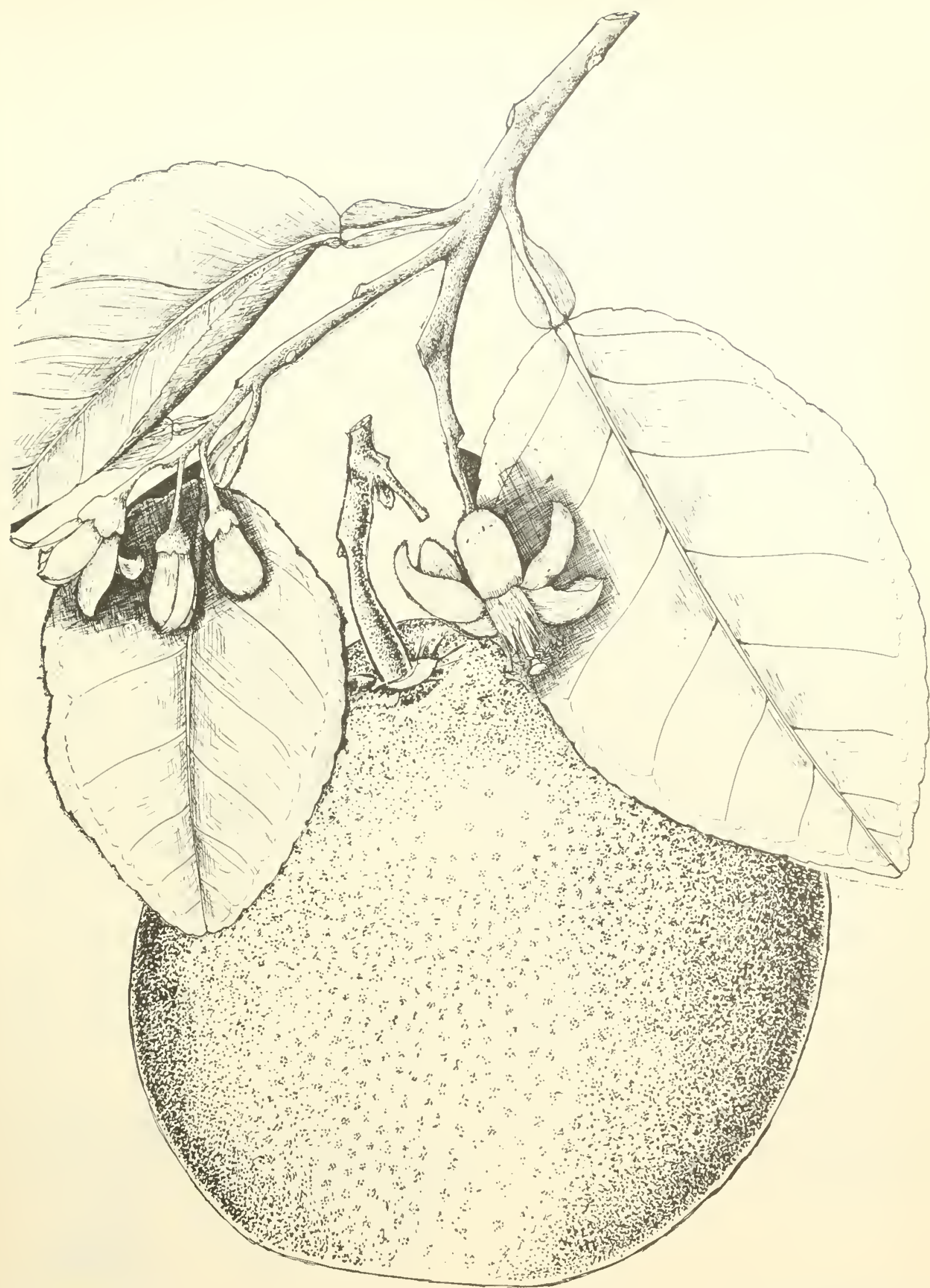

99. Toronja, grapefruit 


\section{RUE FAMILY (RUTACEAE)}

\section{China, sweet orange}

Sweet orange, or orange, the lest known and most popular of the citrus fruits, is distinguished by: (1) the familiar, usually smooth oramge round fruit, mostly $21 / 2-31 / 2$ inches in cliameter, with sweetish orange-colored flesh; (2) very fragrant white flowers with usually 5 petals about $11 / 4-11 / 2$ inches across; and (3) leares oblong to elliptic or wate, short-pointed or rounded at both ends, and with narowly winged petiole.

In evergreen small tree becoming 20-30 feet tall and 6-10 inches or more in trunk diameter, witl rounded crown. The bark is brown and finely fissured, the immer bark yellowish and slightly bitter. The light green angled twigs usmally have 1 slender sharp spine $1 / 8$ inch long at a node.

The alternate leaves have a green petiole $3 / 8-3 / 4$ inch long, jointed to the blade. The leaf blade is $21 / 2-6$ inches long and $11 / 4-31,2$ inches wide, the edges usually with many minute roumled teeth, slightly leathery and with numerous tiny gland dots, above dark green to yellow green and slightly shiny, and leneath dull light green.

Flowers are lateral, 1-6 at base of a leaf. There is a greenish-white broad saucer-shaped calyx 1 /s inch high and 5-toothed: wsually 5 white ellipt ie petals $1 / 2-7 / 5$ inch long. gland-clotted and slightly fleshy, spreading and turned back; 20-25 white stamens 1/2 inch long with brown anthers, nnited into ling at base: and on whit ish disk a pistil 5/8 inch long with 10-13-celled yellow-green rounded oviry, slender style, and rounded stigma.

The familiar sweet ish orange fruit (berry) has a smooth usually thin peeling less than $1 / 4$ inch thick, orange at matmity (but the fruit is sometimes consumed wlile still green), and solid center of orange-colored juicy flesh which is sweet or sometimes slightly sour. Seeds are white and wrinkled. The navel orange is a variety distinguished by the fruit apex not completely corered by the outer rind but with additional small segments or cells and usually is seedless. Flowering in spring and maturing fruits in the fall, but in some areas the fruits may persist on the trees into the following May.

\section{Citrus sinensis Osbeck*}

The wood is light yellow, hard, strong, and tough, and rery susceptible to attack by dry-wood termites. Its uses inchudes canes and virious small articles, such as manicure sticks.

The orange, with its high vitamin $\mathrm{C}$ content, is one of the most popular tropical fruits. Quantities of the sweetish juice are canned in Puerto Rico for export. The peel yields an essential oil when presserl and sometimes is candied. Orange oil is official in the Tnited States Pharmacopoeia as a flavoring agent.

Grown extensively as a fruit tree in Puerto Rico, where it is one of the most important fruits and also a gond honey plant. 'The trees are also omamental. Found throughout the island but chiefly in coffee plantations in the lower Cordillera and moist limestone regions. Also in Mona, St. Croix, and St. Thomas, and probably otlers of the Virgim Islands. Oceasionally escaping from cultivation or naturalized.

Prbuic forests.-Cambalache, Carite, Guajataca, Guilarte, Luquillo, Maricao, Río Abajo, Toro Negro.

II NICIPAITTIES WIIERE ESPECLALLY COMMON.$5,6,8,21,32,47,61,70,73$.

Ravge.-Probably originally mative of China, Tietnam, or other sontheastern Isiatic regions but no longer known as truly wild. Widely cultivated in tropical and subtropical regions, eseaping, and becoming natmralized. Bermuda, throughout Trest Indies, and subtropieal United States from Florida to California, sonth to Argentina.

Otuer concmon names.-china dulce (Puerto Rico) ; naranja, naranja dulce (Spanish) ; naranja de China (Dominiean Republic, Cuba, Nicaragua) : naraujo, naranjo común, clino dulce (Venezuela) ; sweet orange, orange (Tnited States, English); orange donce (French); sinasappels (Dutch West Indies).

The scientific name and apparently also the Puerto Rican common name refer to the conntry of origin. Formerly known as Citmes aurantium L., a name now restricted to the sour orange. 

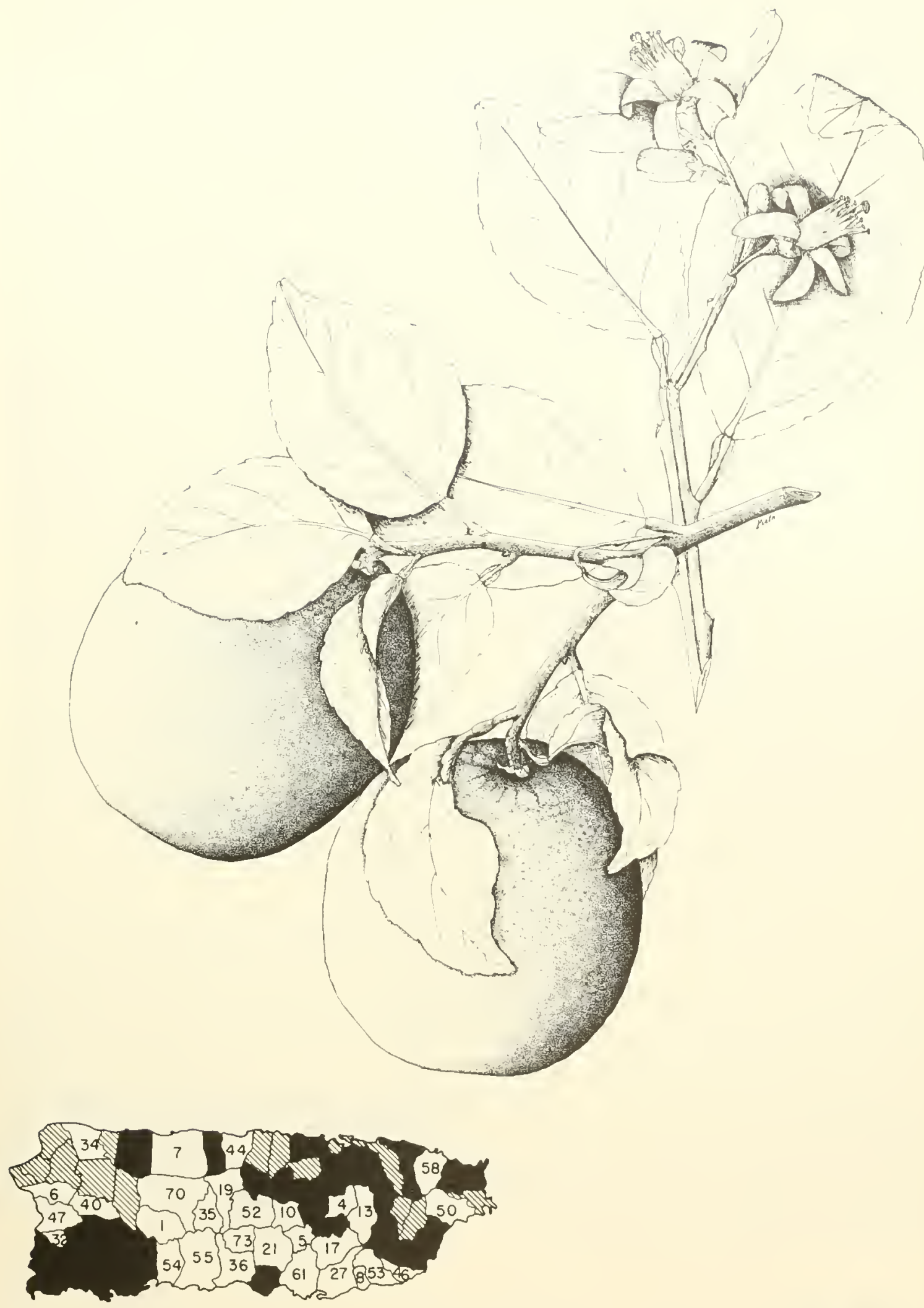

100. China, sweet orange

Two-thirds natural size.

Citrus sinensis Osbeck 


\section{RUE FAMILY (RUTACEAE)}

101. Aceitillo, yellow-sanders, yellowheart

Folmerly one of Puerto Rico's most villuable timbers, this now scarre tree is distinguished by : (1) the pinnate leaves with mostly 5-9 nearly stalliess elliptic leaflets rounderl or short-pointed at apex and base, the ellues without teeth or very finely way, and with mimute gland dots: (2) trunk and twigs not spiny as in relater species: (:) small yellowish 5-parted spreading flowel's $1 / 4$ inch arross: and (4) the dry fruits of 1 or 2 dark hrown ports $1 / 4$ ineh long.

I small to nedimm-sized deeidnous tree :20)-50 feet high and :3-16 inches in trunk diameter or a shrub. The bark is smonthish, slimtly fissured. light eray, and thin. Inner bark yellowish, with citrus spiry taste. The twigs are stout, gray, and finely gray hairy with minute star-shaped hairs when young.

The leaves are altemate and $4-10$ inches long. Leaflets are pairerl except for the ent one, 1-: inches long and 1/2-11/2 inches broad, thin, with minute star-shaped hairs when yomg but becoming almost hairless, and slightly shing erreen at matmrity.

The much branched flower clusters (panicles) are terminal and 2-5 inches long and broad. The many short-stalked fragrant flowers are male and female on diflerent trees (dioecious). Sepals 5. minute, covered with gray star-shaped hairs, petals 5 ; male flowers with 5 stamens about as long as petals: and female flowers with pistil of mostly 2-lobed 2-relled ovary (or.1-3-celled) and mostly 2 -lobed stigma.

The fruits are of 1 or 2 stalked pods (follicles), splitting open and containing 1 nearly rombl shiny black seed $1 / 8$ inch long. Flowering mainly with the new leaves or from winter to smmmer and with frnit from spring to fall.

The saljwood is whitish to light yellow, and the heart wood yellow to yellowish brown. The wood is very hard, heary (specific glavity 0.9), strong, fine-grained, with clearly defined growth rings. and with odol of coconuts or oil. It las a satiny luster, takes a fine polish, and is resistant to attack by dry-wood termites.

This beantiful decorative wood has been prized for cabinetmaking, fine furniture, paneling, inlaid work, veneer, and turnery. Other uses are backs of hand mirrors and hairbrushes. Wood figured with wavy grain is converted into veneer for hand-

\section{Zanthoxylum flavum Vahl}

some furniture and paneling. It is reported that Puerto Rico formerly produced the finest West Indian satinwood, both in quality and color, but exports ceased with exhaustion of the supply. Logs of figured wood commanded very high prices by the cubic foot or by weight. Even the stmmps and roots were removed and shipped from Puerto Rico as late as 1020 .

This species can be planted for shade as well as its fine wood. It is also a loney plant, the flowers attract ing bees.

Protected forests in the serpentine and dry and moist limestone regions of western Puerto Rico, now rare. Planted experimentally in the Guajataca Forest, this species is proving slow growing. Trees 15 years old are scarcely 3 inches in diameter. Reported many yeals ago from Bordeanx Hills, St. John, and possibly now extinet there.

Peralc monests.-Cambalache, Guajataca, Guánica, Maricao.

R.Angr-lower Florida Keys (nearly extinct), Bermuda, Bahamas, Cuba, Jamaica, Hispaniola, Puerto Rico, and Lesser Antilles from Anguilla to St. Incia. Ilso lecorded from Bonaire.

OTuler common Names.-espinillo (Dominican Republic); aceitillo (Cuba); yellowheart, satinwood, yellowheart prickly-ash, yellowwood (UTited States); Test Indian satinwood, satinwood (Encrlish, commerce): .Tamaican satinwood, vellow-sanders (Jamaiea): noyer, bois noyer (Guadeloupe): kalabarie (Bonaire).

Botanical sronma.-Fagara flava (Vahl) Krug \& Urban.

This genus, whose name frequently is spelled Tanthorylum, has 2 additional native tree species and 2 of shrubs besides the 3 figured here. Another species of espino lubial ( $Z$ anthoxylum caribaenm Lam.; synonym Fagara caribaea (Lam.) Krug \& Urban) in southern and western Puerto Rico has pinnate leaves with $7-13$ elliptic leaflets romded at apex and with wavy-toothed margins.

Alfiler (Zanthoxylum punctatum Vahl; synonym Fagare trifoliata Sw.), a spiny shinb or small tree of southwestern Puerto Rico, Mona, and St. Croix, has pinnate leaves with obovate or elliptic leaflets, usually 3 or sometimes as many as 7 or even 19, with variable apex, and relatively few small 3-parted flowers in lateral clusters. 

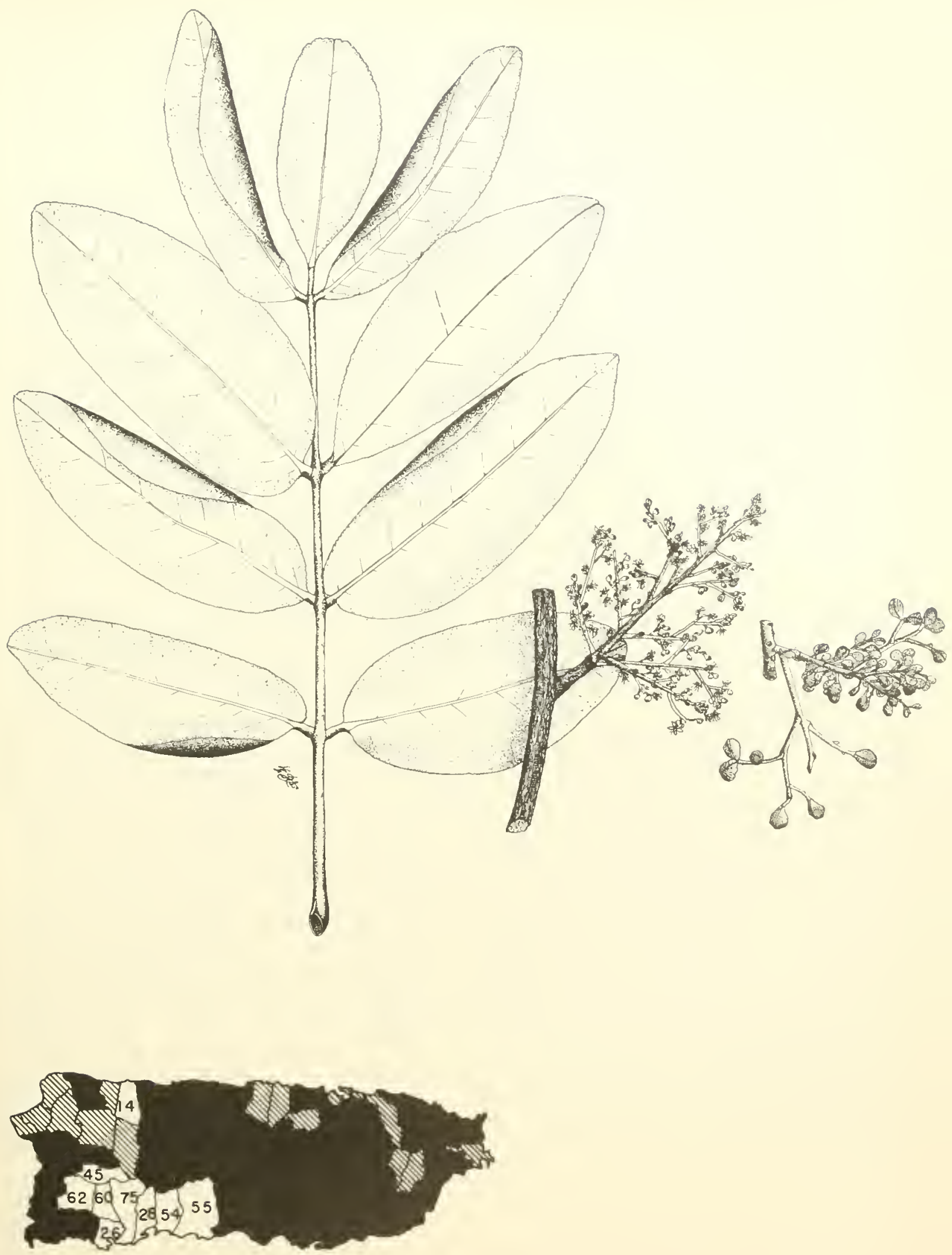

101. Aceitillo, yellow-sanders, yellowheart 


\section{RUE FAMILY (RUTACEAE)}

\section{Espino rubial, white-prickle, Martinique prickly-ash}

\section{Zanthoxylum martinicense (Lam.) DC.}

This medium-sized tree is characterized by: (1) the very stout conical spines $1 / 4-1$ inch long and broal on the smoothish light gray trunk and usually smaller spines on the twigs; (2) the pinnate leaves with $7-1$ ) stalkless oblong to lanceshaped leatlets $11,-5$ inches long and $1 / 2-11 / 2$ inches hoad, very finely way mangined, and with minute gland dots; (3) many small greenish-white 5-parted flowers 3/16 inch long and broad: and (4) the dry firuits, deeply 5-parted, 1/t inch long and 5/16 incli broad, dark biown.

In evergreen tree becoming 20-65 feet in height and 18 inches in trunk chiameter, with thin spreading crown. The bark is smoothish, light gray, about $1 / 1$ inch thick, with spines on larger trees becoming 2 inches long and hroad. Inner bark brown. with ritus spicy taste and also slightly gritty. The twiers are gray, stout, brittle. minutely bristly hairy when yomng, usually spiny with many stoit gray spines $1 / 16^{-1 / 3}$ inch long.

The alternate leaves an 6-12 inches long, the axes and midribs finely hairy and often spiny. The leaflets are short-pointed to rounded at apex, slightly ohlique at base, thin, upper surface green and hairless, lower surface paler and minutely lairy on veins.

Flower cluster's (panicles) are termina] and lateral, much branched, 2-6 inches lonx and broad, bearing many almost stalkless flowers, male and female on difl'erent trees (dioceions). There are 5 minute sepals: 5 spreading petals; in male flowers 5 stamens longer than petals: and in female flowers a pistil with deeply 5-lobed 5-celled ovary and 5-lobed stigma. The fruits are deeply 5-parted, each part (follicle) splitting open and with 1 nearly round shiny black seed $1 / 8$ inch long. Flowering and frut ing from spring to fall.

The sapwood is whitish, and the heartwood light yellow to light yellowish brown. The wood is of mediun weight (specific glavity 0.46 ), hard, of medim to fine textmre, witl growtl rings clearly defined, but without distinetive figure. It is very susceptible to attack by dry-mood termites and other insects and is noi durible where exposed. The rate of all-seasoning is rapid, but the amomnt of degrade is considerable. Machining characterist irs ane as follows: planing, shaping, boring, and mort ising are fair; turning and sanding are poor; and resistance to screw splittiug is good.

Becalnse of the small size of the remaining trees, the wood is seldom used. It is suitable for boxes, crates, general anpentry, low-grade fumiture, liglat construction, concrete forms, and similar uses.

This species requires overhead light and grows rapidly. In Trinidad it spreads naturally and vigorously in elearings. It has been grown for sliade in Cuba and sontlem Florida, though the spines may be objectionable for this purpose. Ilso a honey plant.

Widely distributed in the coastal, limestone, and lower mountain forest regions of Puerto Rico. Also in Vieques, St. Croix, St. Thomas, St. John, and 'Tortola.

Prubic Forests.-Cambalache, Carite, Guajataca, Gúniea, Guilarte, Luquillo, Marieao, Río Abajo, Susúa, Toro Negro, Vega.

MUNICIPALTIES WIIERE ESPECIALLY COMMON.$14.20,30,40.42, \pm 7,68,69$.

Ruxae.-Througliout West Indies from Cuba and Jamaica to Trimidad and Tobago.

Other conzroN Names. - cenizo, espino, espinosil, aýú (Puerto Rico); pimo macho (Dominican Republic); ayúa, ayúa amarilla, bayúa (Cuba) : prickly-yellow, yellow Ilereules (Janaica) : Mantinique prickly-ash (English); lepine gommier (st. Lucia); lepine (Dominica); lépinet (Trinidad): yellow-prickle (Tobago); bois piné (Haiti); lépiné jaune, lépuni jamne, lépineux jame (Guadeloupe, Martinique); yellow-prickle (Dutel West Indies).

Boraxical sroxym.-Fagara martinicensis Lam. 

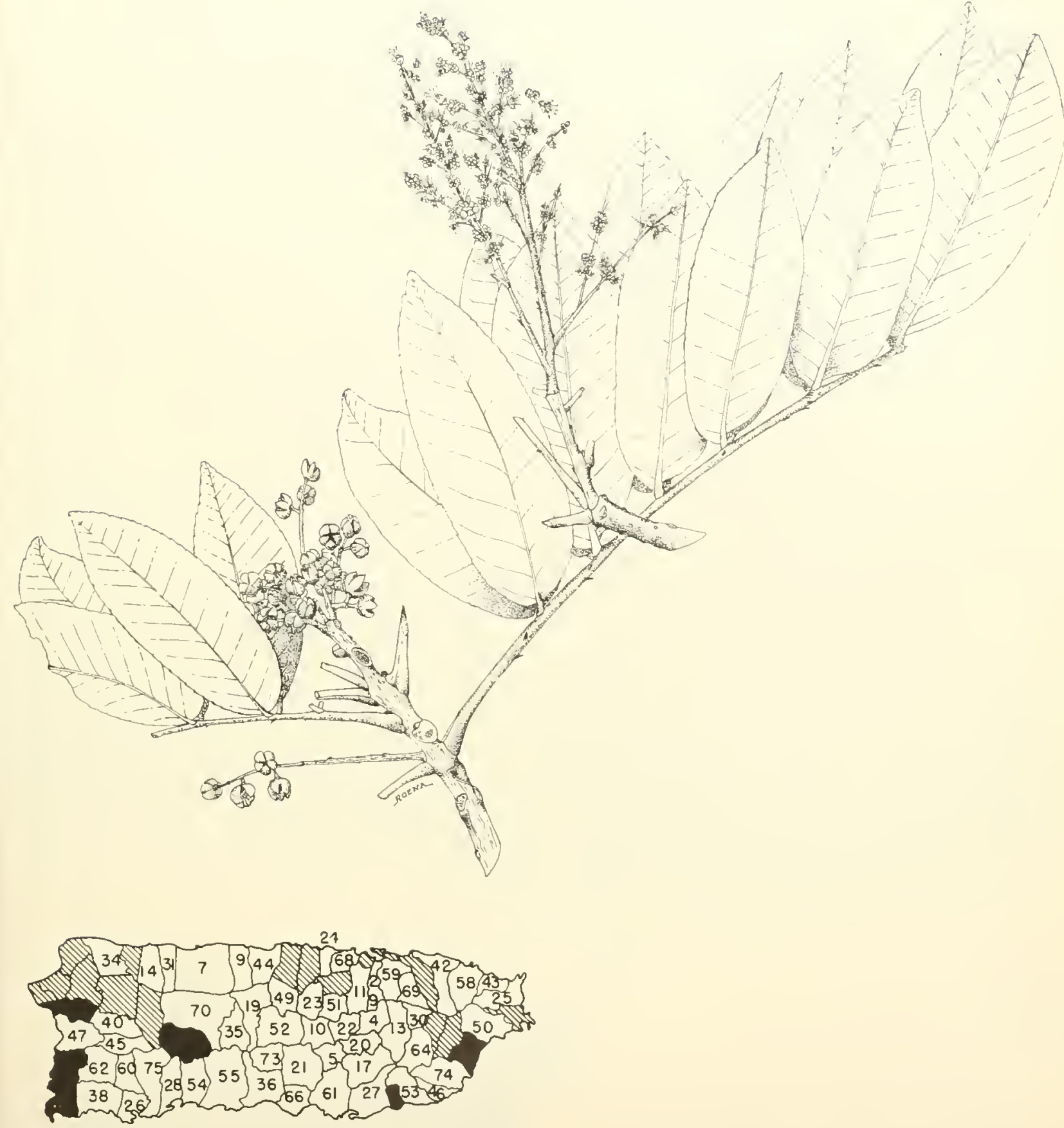

102. Espino rubial, white-prickle, Martinique prickly-ash

Zanthoxylum martinirense (Lam.) DC. Two-thirds natural size. 


\section{RUE FAMILY (RUTACEAE)}

\section{Palo rubio, yellow-prickle, yellow prickly-ash}

An aromatic small tree or shrub, generally with spiny trigs and trunk, further characterized by: (1) short-stalked simple leaves with elliptic blades $11 / 4-t$ inches long and $1 / 2-2$ inches broad, or sometimes larger, usually short-pointed at both ends, with mmerous minute gland dots, slightly spicy when crushed; (2) many small whitish 5-parted flowers abont $3 / 16$ inch across in terminal or lateral branching clusters 1-2 inches long; and (3) 1-3 rounded light green fruits $3 / 16$ inch long from a flower, each splitting open to release 1 rounded shiny black seed. The simple leaves (or single leaflets) easily distingnish this from other species of the genus, which have pinnate leaves.

A decidnous tree attaining 15-25 feet in height, or shrubby, with spreading crown. The gray to brown bark is smoothish with rertical fissures, often bearing many stout pyramidal spines $1 / 2-3 / 4$ inch high and 1 inch or more in rertical length along the trunk. Immer bark is deep yellow, with a bitter spicy taste. The green twigs, becoming brown, frequently have scattered stout spines $1 / 8$ inch or more in length.

The alternate leaves have slender petioles $1 / 4^{-1 / 2}$ inch long. Blades are slightly thickened, the edges sometimes slightly wary, hairless, green and slightly shiny above and paler beneath.

Branches of the flower cluster (panicle) often are minutely hairy when yomg. Flowers apparently are mostly male and female on different trees (dioecions). Female flowers have 5 minute pointed sepals, 5 narrow white petals less than $1 / 8$ inch long, and pistil more than $1 / 16$ inch long with deeply 2- or 3-lobed, 2- or 3-celled ovary and 2 or 3

\section{Zanthoxylum monophyllum (Lam.) P. Wilson}

styles. Male flowers hare 5 stamens about as long as petals. From each female flower are formed 1-3 rounded podlike fruits (follicles) longer than broad, each covered with tiny gland dots and 1 -seedled.

The sapwood is light yellow and the heartwood dark brown. 'The wood is very hard, heavy (specific gravity 0.76 ), tough, fine-textured, and has growth rings. It takes a good polish but is selGom used becanse of the small size of the trees.

Distribnted chiefly in western Puerto Rico in the coastal and limestone forest regions. Also in Tieques, St. Croix, St. Thomas, and St. John.

Punlic forests.-Guánica, Susńa.

Municipalities wiere especially COMMON.$12,36,38$.

Raxce.-Hispaniola, Pnerto Rico and Virgin Islands, and Lesser Antilles from Montserrat to St. Lucia and Barbados and in Trinidad, Bonaire, and Cnraçao. Also in Veneznela, Colombia, and Costa Rica.

Other comion names. - enrubio, espino, mapurito, espino rubial, espino blanco, carubio, rubia (Puerto Rico) : yellow-prickly (Virgin Islands); pino macho (Dominican Republic); lagarto, lagarto negro, lagarto amarillo (Costa Rica) ; bosú, bosía, concha de paneque, paneque (Venezuela); yellow prickly-ash (English); yellow harklis (Barbados); lépuni jaune, lépiné jaune, bois noyer (Guadeloupe, Martinique); bossoea, kaubaati (Dutch West Indies).

Botaxical sYNonYi.-Fagara monophylla Lam. 


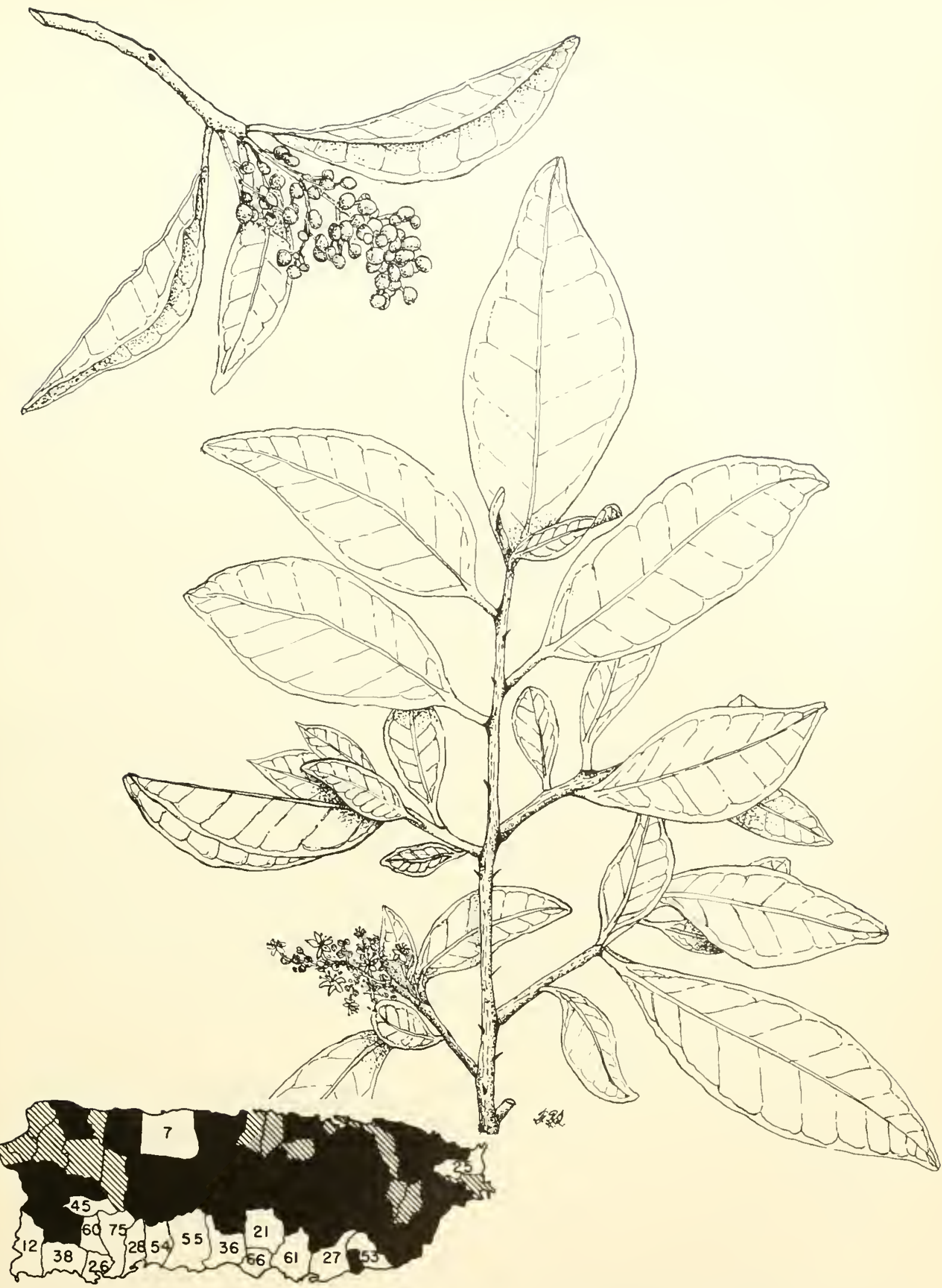

103. Palo rubio, yellow-prickle, yellow prickly-ash Natural size.

Zanthoxylum monophyllum (Lam.) P. Wilson 


\section{AILANTHUS FAMILY (SIMAROUBACEAE)}

\section{Guarema, bitterbush}

A small slender tree or shrub characterized by: (1) the showy or ornamental red or scarlet fruts $3 / 8-5 / 8$ inch long, in grapelike terminal elusters, turning to black; (2) leaves with 5-9 elliptic to arate, mostly long-pointed leaflets $11 / 2-5$ inches long and 1-2 inches broad: (3) minute green and reddish-tinged 5-parted flowers 1/8 ineh long and broad; and (4) the leaves, cray twigs, bark, fruits, and seeds very bitter.

An evergreen tree or shrub to 20 feet high and 4 inches in trumk diameter. Bark on small trunks is gray and smooth. The inner lark is brown and bitter. Young twigs, very young leaves, and flower stalks are covered with minute grayish pressed hairs.

The alternate leaves are 5-12 inches long, the axis green or reddish tinged. The leaflets have short stalks $1 / 8$ inch long and are short-pointed or sometimes oblique at base, not toothed at edges, slightly thickened, almost hairless at maturity, slightly shiny green on upper surface and somewhat paler beneath.

Male and female flowers are on different trees (dioecions) in branched terminal clusters (panicles) $3-7$ inches long. The flowers have 5 narrow sepals and 5 narrow petals about 1/16 inch long. Male flowers have 5 stamens, and female flowers a pistil with 2 - or 3 -celled ovary and 2 or 3 stigmas.
Picramnia pentandra Sw.

Berrylike fruits, borne on slender red stalks, are round to elliptic, $3 / 8^{-5 / 8}$ inch long, somewhat juicy inside, with $1-3$ shiny brown seeds $1 / 4-3 / 8$ inch long. Flowers and fruits produced nearly through the year.

The whitish, hard, heary wood is little used in Puerto Rico, becanse the trees are too small.

The leaves and bark have been employed medicinally in Cuba against fevers. In southern Florida and Cuba the small trees have been grown as hardy ormamentals. A honey plant.

In secondary forests in the coastal and limestone regions of Puerto Rico. Also in Tortola and reported from St. Thomas.

Public forests.-Cambalache, Guánica, Río Abajo.

RAXGe,-Southern Florida including Florida Keys, Bahamas, Cuba, Jamaica (?), Hispaniola, Puerto Rico and Tortola, St. Martin, St. Barthélemy, Antigua, Montserrat, Gradeloupe, Dominica, Martinique, St. Lucia, and Tobago. Also in Colombia and Venezuela.

Other common names.- hueso (Puerto Rico); agnedita, palo de peje, palo de pez (Dominiean Republic); agnedita, roble agalla, quina del país (Cuba): bitterbush, Florida bitterbush (United States); doctor-bar' (Tobago); bois poison, raillant garçon (Haiti); bois poison, bois montagne (Guadeloupe); wild-coffee (Dutch West Indies). 


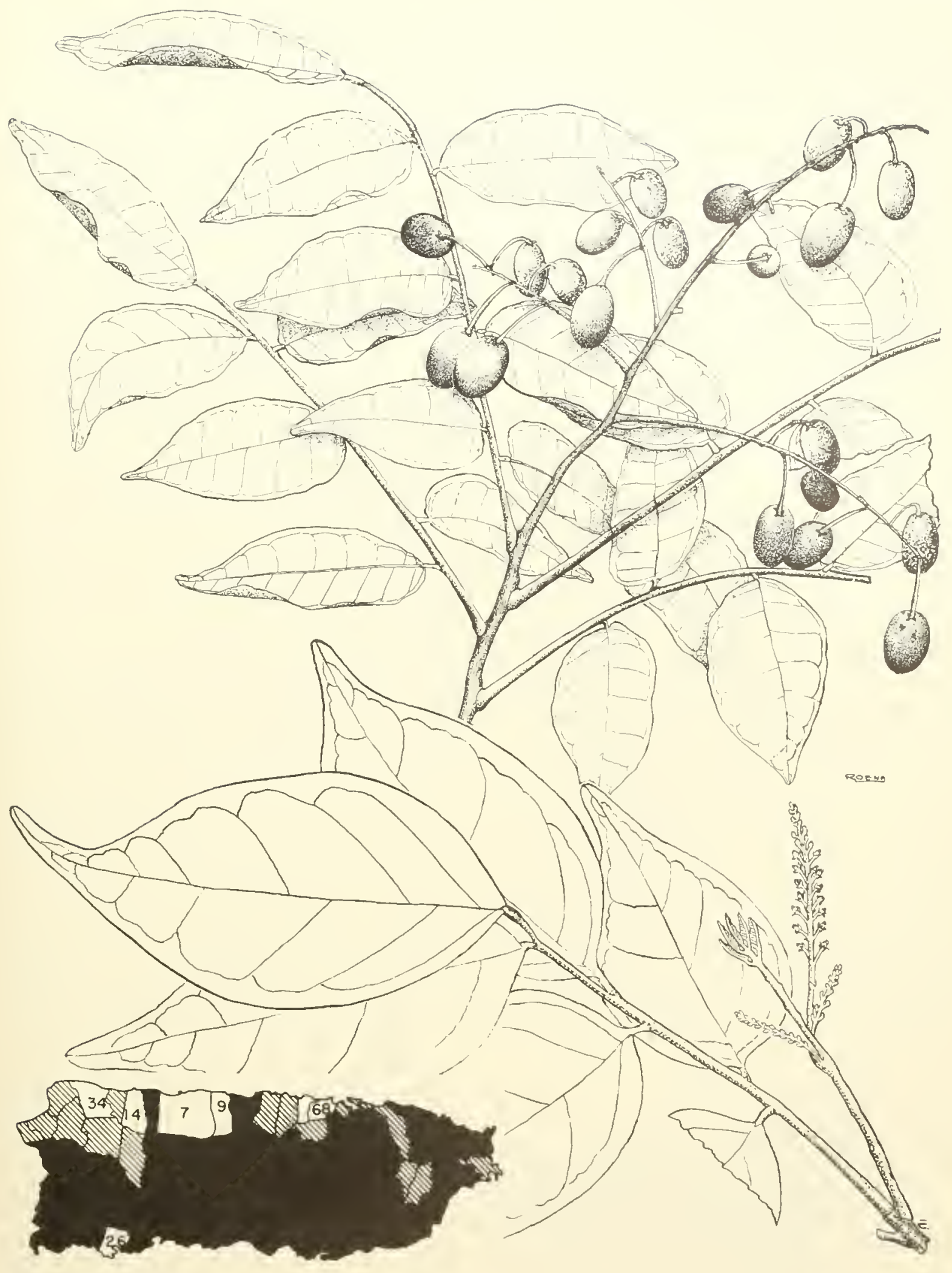

104. Guarema, bitterbush

Natural size.

Picramnia pentandra Sw. 


\section{BURSERA FAMILY (BURSERACEAE)}

Fey to the 3 native species, all illustrated (Nos. 105-107)

A. Leatlets asymmetrical at base, less than 3 inches long; flowers i-parted-105. Bursera simaruba.

AA. Leaflets symmetrical at base, $21 / 2-T$ inches long.

B. Leaflets short-pointed or rounded at both ends; flowers 3-parted-106. Dacrlodes excelsa.

BB. Leaflets long-pointed at apex, short-pointed at base; flowers 4-parted-107. Tetragastris balsamifera.

105. Almácigo, turpentine-tree, gumbo-limbo

This spreading aromatic tree is easily recognized by the smooth reddish-brown or coppercolored bark, which peels off in papery flakes and exposes the greenish-brown layer beneath. Other distinguishing characteristies are: (1) a grayish resin with taste like turpentine which exudes from ents in the bark; (2) the slightly pungent or turpentine odor of clushed leaves and fruits and cut twigs: (3) the pimate leaves with 5 or 7 (sometimes 3 ) oblong to ovate leaflets $1 \frac{1}{4}-3$ inches long, abruptly short-pointed at apex and broad and oblique at base, and (4) the many small whitish or yellowish-green 5-parted flowers about $3 / 16$ inch across.

A medium-sized deciduous tree $20-10$ feet high with relatively thick trunk 1-2 feet or more in diameter, large spreading crooked branches, and thin foliage. The bark is about $1 / 2$ inch thick, the inner bark whit ish or reddish, soft, and almost tasteless. Twigs are brownish green, becoming light brown.

Leaves are alternate and $4-8$ inches long. The leaflets are paired except for the end one, shortstalked, oblong to ovate, $3 / 4-11 / 2$ inches broad, slightly thickened, edges not toothed, mostly hairless, green or dark green and slightly shiny above, and paler beneath.

Flower clusters (panicles) are terminal and lateral, branched and narrow, and 2-6 inches long. The flowers on slender, usually short stalks are mostly male and female on different trees or some flowers bisexual (polygamous). Calyx is 5 -tootherl; petals 5: stamens 10; and pistil with 3-eelled orary, short style, and 3-lobed stigma.

The fruits (drupelike) are diamond-shaped, slightly 3 -angled, pointed at both ends, about 1/2 inch long and $5 / 6$ ineh broad, dark pink, splitting into 3 parts, with usually one 3 -angled whitish seed $3 / 5$ inch long. Flowers and fruits appearing usually in spring before or with the new leares, sometimes in summer.

Both sapwood and heartwood are a miform cream to light brown color, though turning bluish gray beeanse of sap-staining. 'The wood is lightweight (specific gravity 0.29 ), fine-textured, soft, weak, with strong odor, the growth rings absent or indistinct. It is very susceptible to attack by dry-nood termites and other insects and is very perishable. Sap stain develops in freshly cut logs mless milled immediately and the lumber is dipped in an antistain solution before piling. Rate of air-seasoning is rapid, and amount of degrade is minor. Machining characteristies are as follows: planing and sanding are good; shaping, turning,
Bursera simaruba (L.) Sarg.

and mortising are rery poor; boring is poor; and resistance to screw splitting is excellent.

The wood is suited for boxes, erates, cement forms, interiol carpentry, light construction, firewood, and chareoal. Other products made elsewhere are matehes, match boxes, toothpicks, and utility plywood.

The aromatie resin known as Chibou, Cachibon resin, or Gomart resin, has been employed in domestic medicines and as glue, vamish, coating for eanoes, and incense. A tea subst itute has been prepared from the leaves.

The trees are used in Puerto Rico chiefly for living fenceposts, being easily propagated from cuttings and posts. They are also planted atong road. sides and in hedges and ean serve also as living telegraph poles. Because of the attractive colored bark, the trees hare been planted as ornamentals in dry soils of southern Florida, where they are also native.

Native to the soils derived from limestone in Puerto Rico but seen as a fence row and roadside tree in the coastal and lower mountain legions. Also in Mona, Desecheo, Ieacos, Culebra, Vieques, St. Croix, St. Thomas, St. John, and Tortola. A few trees of this speeies in the thorn serub at the eastern end of St. Croix are the eastermmost trees in United States territory.

Public Forests. - A guirre, Cambalache, Guajataea, Guániea, Marica, Río Ibajo, Susúa, Vega.

MUNICIPALITIES WHERE EsPECIALLY COMMON.$7,8,9,11,12,14,21,23,24,25,26,28,32,36,38$, $44,54,55,61,66,68,75$.

Raxge.-Sonthern Florida ineluding Florida Keys and almost throughout West. Indies from Bahamas and Cuba to Trinidad and Tobago and Curaço and Aruba. Also from Mexico to Colombia, Yenezmela, and British Guiana.

Otuer common NAMEs.-West-Indian-bireh, gommier (Virgin Islands); almácigo (Spanish, commeree) : indio desnudo (Spanish) ; almácigo blaneo, almácigo colorado (Dominiean Republic); almácigo. almácigo colorado (Cuba); mulato, palo mulato, ehaca, palo retinto (Mexico); jiote, palo jiote (Mexico, Gnatemala, Honduras, El Salvador) ; chino, chinacahnite, palo chino, ehaca, chicchiea, palo pulato (Guatemala) ; chinacuite, jenequite, chino, pato chino, copón, palo mulato, torehwood (Honduras); jiñocuabo, jiñicuite (Nicalagua); jiñote, сaraña, jiñoeuavo (Costa Rica); almácigo, carate (Panama); almácigo, caratero, guácimo, resbalo nono (Colombia); jobo pelón, caraña, pellejo de indio, mara, cucheme, palo de 


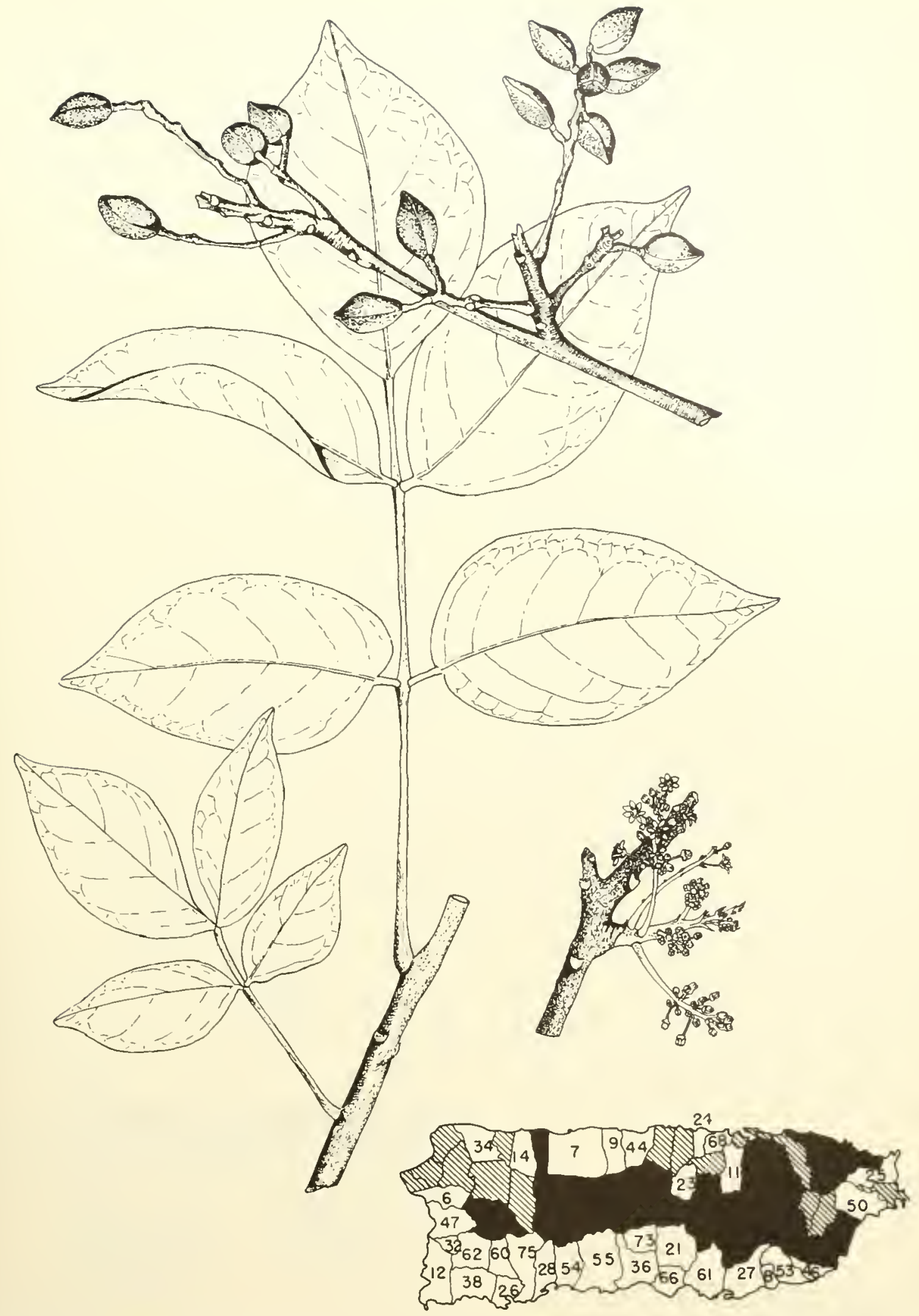

105. Almácigo, turpentine-tree, gumbo-limbo

Two-thirds natural size.

Bursera simaruba (L.) Sarg. 
incienso (Tenezuela): gumbo-limbo (United States, commerce); gum-elemi, Trest-Indian-birch (Tnitel States); gumtree (Bahamas) ; red-birch, Trest-Indian-birch, turpentine-tree, incense-tree, mastic-tree (Jamaica); gommier maudit (St. Lncia); gomme mombin (Grenada): birch-gum (Barbados) : turpentine-tree (Grenadines); peeling-bar'k rommier, naked-Indian, Indien nue, dryland gommier (Trinjdad); naked-boy (Tobago); hirch, red gombo-limbo, hukup, chaca, palo chino, palo jiote (British Honduras); chioné, gommier blanc (Haiti) ; gommier rouge (Guadeloupe, Martinque); gommier, gommier barrière (Guadeloupe) : paaloe sieja doesji, paaloe sieja maatsjoe, sieja blanko, gumtree, balsam-tree (Dutch West Indies).

Botinichi srowars. - Bursera gummifera L., B. ovalifolia (Schlecht.) Engler, Elaphrium simameba (L.) Rose.

The English name gumbo-limbo is a col'uption of the Spanish name goma elemi meaning gum resin.

\section{BURSERA FAMILY (BURSERACEAE)}

\section{Tabonuco}

Usually a very large erect tree, rising above the forest canopy and distinguished at a distance on the monntainsides by its size and dark green foliage. Tabonuco is further recognized by: (1) the smooth whitish bark, peeling off in thick flakes and exuding streaks of fragrant whitish resin from cuts: (2) the pinnate leaves with $5-7$ elliptic leaflets $21 / 2-5$ inches long and $11 / 4-3$ inches broad, producing characteristic fragrance when crushed; and (3) oblong fleshy brown fruits 1 inch long and $1 \%$ inch broad. Because of its abundance, size, and good form, this was one of the most valuable trees of Puerto Rico's original mountain forests.

Tabonuco reaches 100 feet or more in height, is evergreen, and lias an elongated crown. Britton and Tilson in their flora called it "the most majestic tree" of Puerto Rico. The trunk becomes $3-5$ feet or more in diameter and is slightly enlarged at the base, sometimes with short broad buttresses giving the appearance of an elephant's foot. The bark is thin (about $1 / 4$ inch thick) and reddish brown on rapid-gnowing young trees. 'The resin, which is an amber liquid when fresh and becomes white and hard after exposure to the air, is inflammable. The inner bark is brown, gritty, and has a turpentine taste. 'Twigs are brown and slightly warty.

Leaves are alternate and 6-10 inches long. The short-stalked leaflets, paired except for the end one, are elliptic, short-pointed or rounded at apex and base, not toothed on edges, slightly thickened, hairless, dark green on upper" surface, and green beneath.

Flower clusters (panicles) are lateral and much branched, 3-8 inches long. The small greenish flowers about $3 / 16$ inch across are male and female on different trees (dioecions). Calyx is cupshaped, 3 -toothed; petals 3 , less than $1 / 8$ inch long, spreading; stamens 6 , short, inserted at base of thick disk; and pistil of female flowers with ovary, short style, and stigma.

The fruit (drupe) resembles an olive and is 1 seeded. Flowering and fruiting nearly through

\section{Dacryodes excelsa Vahl}

the year, but most fruits produced from July to October.

The narrow saprood is grayish, and the heartwood uniform brown with pinkish cast when first cut, turning pinkish brown when seasoned and later lustrous brown when exposed. The wood is moderately heavy (specific gravity 0.53), moderately hard, tough, and strong, of fine to medium uniform texture, with roey and interlocked grain and ripple marks, lacking growth rings, and with high luster. It is very susceptible to attack by dry-wood termites and is only slightly resistant to decay. Rate of air-seasoning is rapid, and amount of degrade is minor. Machining characteristics are as follows: planing, shaping, mortising, sanding, and resistance to screw splitting are good; and turning and boring are fair. The wood cuts and saws easily but rapidly dulls saws and other tools. It stains well, finishes beautifully with varnish or lacquer, and resembles mahogany.

Tabonico has been utilized in Puerto Rico more because of its availability in quantity and in large sizes than becanse of its wood quality. It is extensively used as a substitute for mahogany in furniture. Besides all types of furniture, it serves for cabinetwork, interior trim, general construction, carpentry, and rehicle and truck bodies. Elsewhere it is made into crates, boxes, shingles, and small boats. The wood should be suitable also for soft-drink cases, fruit and regetable containers, and decorative veneer. The Caribs of Dominica still hollow the trunks into dugout canoes, one of which was found washed on the eastem shore of Mona Island in 1953. The resin was formerly widely employed for torches, as incense in religious ceremonies, to calk boats, and for medicinal purposes.

Because of the limitations of the wood, the difficulty of successfully transplanting seedlings bare-rooted, and the mediocre growth rate of forest trees, efforts by the govermment to increase tabonuco artificially in the public forests have been abandoned. On the other hand, young trees 

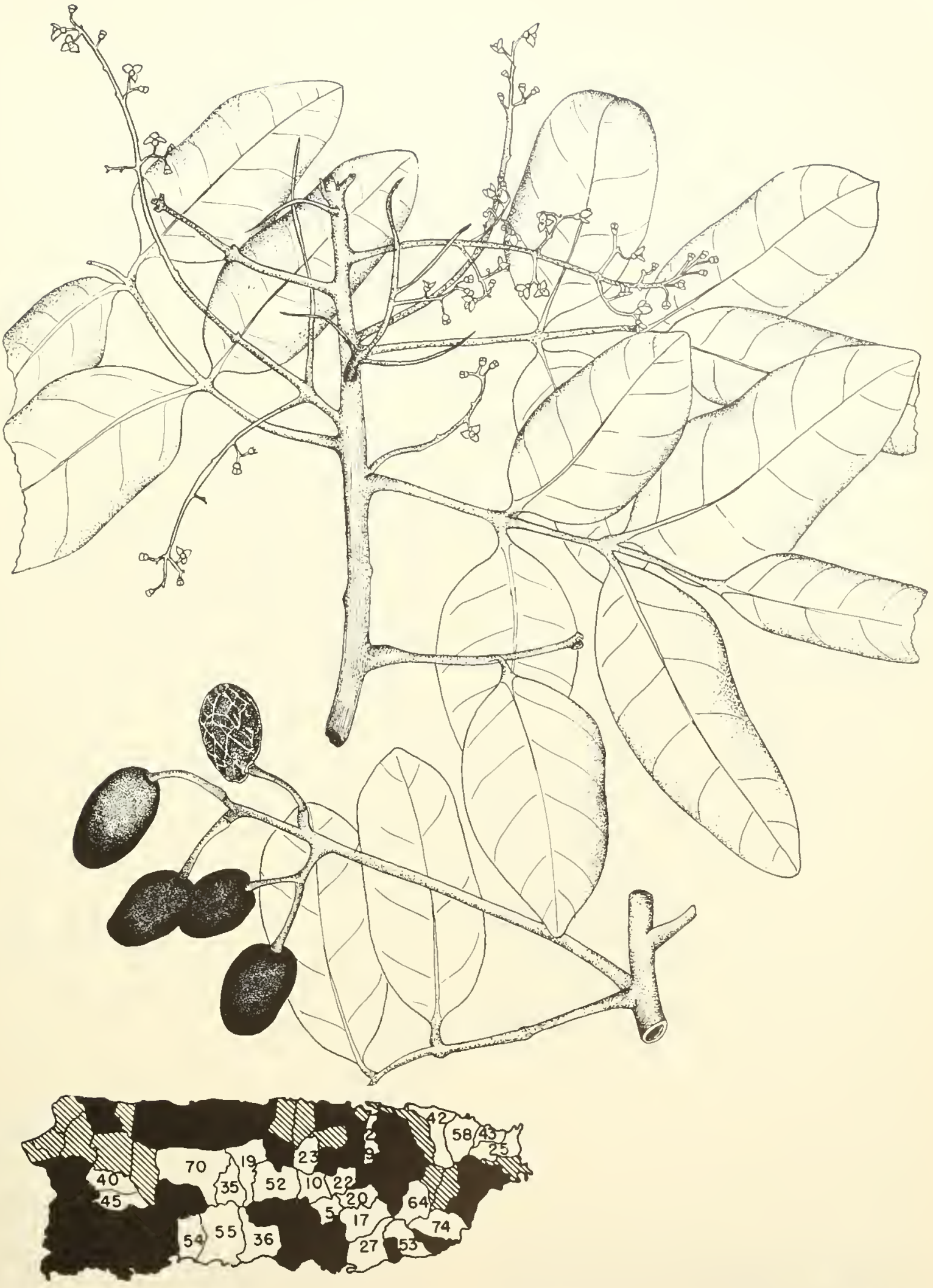

106. Tabonuco

Two-thirds natural size.

Dacryodes excelsa Vahl 
which appear naturally within the public forests in some places are being protected and cared for.

Formerly distributed widely in the lower Lilquillo and lower Cordillera forests, where it was the dominant tree. Beeause this speeies does not. readily reinvade open or eutover areas, it has disappeared from all but the least disturbed forests. Now chiefly limited to the remaining virgin or protected rain forest of the lower slopes of the Luquillo M.tountains but also remaining in several smaller isolated areas in the lower Cordillera.

Prblic forests.-Carite, Guilarte, Luquillo, Marieao, Toro Negro.
MUNICIPALITIES WIIERE ESPECIALLY COMMON.$10,27,52,58,64,70$.

Raxce.-Puerto Rico and Lesser Antilles from St. Kit ts to Grenada.

Other comion NAMEs.-gommier blanc (Dominiea) : candlewood (English); gommier (commerce, St. Lucia, St. Vincent, and Grenacla); grommier blane, gommier montagne, bois eochon (Guadeloupe, Martinique); gomnier, gommier à eanot (Guadeloupe).

Botaxicul srxonys.-Dasryodes hexandra (Hamilt.) Griseb., Pachylobus hexandrus (Hamilt.) Engler.

\section{BURSERA FAMILY (BURSERACEAE)}

\section{Masa}

This large tree is eharacterized by: (1) pinnate leaves with 5-9 (commonly 7 ) lanceolate to elliptic, abruptly short-pointed, darli green leaflets : $;-7$ inches long, in pairs except for end one, longpointed at apex, short-pointed and symmetrical at the base, fragrant when crushed, and with prominent translucent venation; (2) several to many small, t-lobed, whitish and meenish flowers about $3 / 16$ inch long are bome in terminal and lateral clusters: and (3) romeled fruits $3 / 4-1$ inch in diameter in grapelike clusters.

In evergreen tree attaining 50-80 feet in height and 1-11/2 feet in trunk diameter. Bark smoothish, slightly fissured or flaky, and gray, the inmer bark brown and bitter. Twigs stout, gray brown, finely hairy when young.

The alternate leaves are $7-18$ inehes long. The leaflets have stalks $1 / 4$ incl long (end one to 1 ineh) and blades $3-7$ inches long and $11 / 4-23 / 4$ inches broad, not toothed on edges, slightly thickened, dark green and slightly shiny above, paler and with raised reins beneath.

Flower clusters (panicles) are terminal and lateral, bramehed, 2- 7 inches long. The slightly fragrant small flowers are male and female on different trees or some flowers containing both sexes (polygamous). Calyx is 4-lobed, greenish; eorolla 4-lobed, whitish, brown tinged, the lobes not spreading: stamens 8 ; and pistil with 4-eelled ovary, short style, and 4-lobed stigma. Fruits (drupes) are 2-4-celled, with 2 seeds in each cell. Flowering and fruiting throughout the year.

The sapwood is whitish, becoming yellowish brown, while the heartwood is light reddish brown, becoming orange brown with darker streaks. The wood is heavy (specific gravity 0.63), hard, tough, strong, of uniformly fine texture, of irregular to

\section{Tetragastris balsamifera (Sw.) Kuntze}

very loey grain, with indistinct growth layers, and fragrant. Rate of air-seasoning is rapid, and amount of degrade is minor. Machining characteristics are as follows: planing and resistance to screw splitting are fair; shaping, turning, boring, and sanding are good: and mortising is excellent. The wood is susceptible to attack by dry-wood ternites but generally durable to very durable in contact with the ground.

In Puerto Rico the rood is used for furmiture, cabinetwork, paneling, interior construction, and oars. It is suitable also for millwork, light and heary construction, and flooring. Now it is not sufficiently eommon in large sizes to be an important timber locally. However, the species regenerates readily in the forest, grows rapidly, and is of grood form, and therefore may become import. ant.

Found in little-disturbed forest in the lower mountaill, moist limestone, and moist and dry coastal regions of Puerto Rico. Also St. Croix.

Public forests.-Cambalache, Carite, Guajataca, Guániea, Luquillo, Marieao, Río Abajo, Susúa, Toro Negro.

Municipalities Where especially COMMon.$14,30,49,60$.

Range--Hispaniola, Puerto Rico, St. Croix, and Guadeloupe. Reported from Cuba, probably in error.

Other common names.--palo de aceite (Puerto Rico) ; abey, amacey, abey hembra (Dominican Republic); bois cochon (Haiti) ; gommier, gommier encens (Guadeloupe).

Botanical syonyms.-Hedwigia balsamifera Sw., Tetragastris balsamifera var. lanceifolia. Swart. 


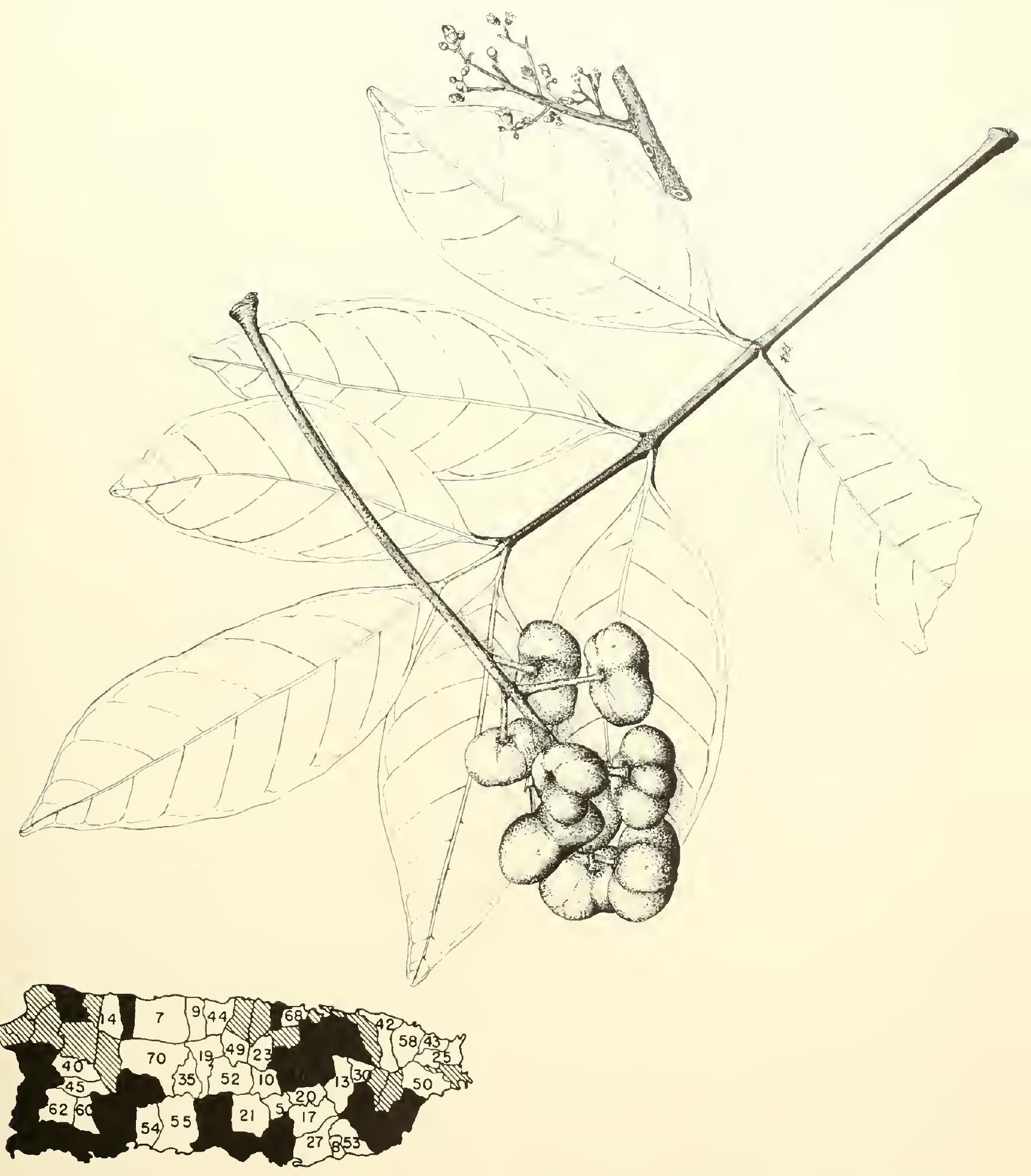

107. Masa

Two-thirds natural size.

Tetragastris balsamifera (Sw.) Kuntze 


\section{MAHOGANY FAMILY (MELIACEAE)}

Key to the 7 species illustrated (Nos. 10S-114)

A. Leares bipinnate, leaflets with toothed margins-110. Melia azedarach.*

AA. Leaves pinnate; leaflets not toothed.

B. Leaflets all paired (even pinnate), assmmetrical.

C. Leaflets mostly many, 10 or more.

D. Leaflets 10-16 (sometimes 30), veins not sunken; flowers and fruit 5-parted-108. Cedrela odorata.

DD. Leaflets \& 20, reins sunken; flowers and fruit 4-parted-109. Guarea lrichilioides.

C. Leaflets 4-12.

E. Leaflets $21 \%-6$ inehes long-111. Swietenia maerophylla.*

EE. Leaflets 1-21/2 inches long-112. Swietenia mahagoni.*

$B B$. Leaflets of odd nmmber (odd limate).

F. Leaflets 7-21, symmetrical, about equal in size, veins slightly sunken-113. Trichilia hirta.

FF. Leaflets 3 or 5 (sometimes 7 ), asymetrical, the erid leaflet largest and lowest leaflets smallest; veins much sunken, causing a wrinkled appearance-114. Trichilia pallida.

\section{Cedro hembra, Spanish-cedar}

Cedrela odorata L.

This native tree with valuable aromatic wood is distinguished by : (1) the alternate, long. even pinnate leaves 1-2 feet or more in length with 10-22 paired lance-shaped, oblong, or ovate leaflets longpointed at apex and obliqne at the rounded or short-pointed base: (2) many narrow yellow-green flowers $1 / 4^{-3} / 8$ inch long, appearing tubular but with 5 narrow petals, in long lones spreading terminal clusters: (3) brown elliptic seed capsules about 1-13/4 inches long and $3 / 4$ inch in diameter, splitting widely into 5 parts and releasing many long-winged seeds: and $(t)$ the odor of garlic in flowers, crnshed leaves, and cut twigs, and garlic taste in twigs and bark.

A large deciduous tree 40-100 feet high and 1-3 feet in trunk diameter, sometimes with slight buttresses at base, and with large rounded or tall crown. The gray or brown bark is thick, becoming rough and furrowed. Inner bark is light brown to pinkish with bitter taste of garlic. The stout gray-brown twigs have raised brown dots (lenticels) and laroe prominent rounded leaf scars.

The leaves have a greenish-brown round axis bearing the leaflets on slender stalks $1 / 8^{-3} / 8$ inch long. Leaflet blades are $2-6$ inehes long and $1-21 / 2$ inches wide, slightly curved, not toothed on edges, thin, hairless, green and slightly shiny on upper surface and inll green beneath. The lateral veins, which often are slightly smiken in upper surface, commonly are rearly parallel with midrib for a minute distance at base before forking at a wide angle.

The flower clusters (panicles) 6-16 inches long bear many flowers on slender, usually hairless branches. Flowers have a calyx more than $1 / 16$ inch long in form of cup, irregularly toothed and split on 1 side, hairless; yellow-green corolla about $5 / 16$ inch long, appearing tubular but with 5 narrow oblong petals, minutely hairy on outside, united to the disk like a tube; 5 stamens with filaments attached on the narrow columnar disk, shorter than petals; and also on the disk the pistil $1 / 8$ inch long including 5-celled ovary, style, and rounded stigma.
The woody seed capsule is rounded at both ends. It has a central 5-angled axis with broad apex, to which are attached many long-winged seeds $3 / 4$ inch long, about 18,000 per pound. Flowering from June to August, the fruits maturing and remaining on the tree in fall and winter.

Sapwood is whitish to light brown, the heartwood light brown to reddish brown with prominent growth rings (semi-ring-porons). The wood resembles mahogany (caoba) but has the characteristie fragrant odor of Spanish-cedar (cedro) and a bitter taste. It is soft, lightweight (specific gravity 0.45 ), strong, easily worked, and takes a smooth polish. It is durable, resistant to dry-mood termites, and not attaeked by other insects. Rate of air-seasoning is rapid, and amount of degrade is minor. Machining elharacteristics are as follows: planing, shaping, mortising, and sanding are good: turning is fair; and boring is poor.

Spanish-cedar or cedro (Cedrela) inchnding 7 or more speeies with similar woods is widely distribnted in the New World from West Indies and Mexieo south to Argentina (except Chile). It is the most import ant timber for local nse in tropical America, the lumber being used extensively for \{reneral construction, carpentry, and suitable for many other purposes. This fine cabinet wood is preferred for' furniture, cabinetmaking, carpentry, doors and windors, interior trim, shelves, carved figures, etc. Being resistant to insects and aromatic, the wood is a favorite for chests and wardrobes. Elsewhere it is used also for veneer, plywood, and boat parts. In the past, quantities were exported to the United States and other countries for cigarboxes, but now little is used for this purpose. Indians made dugout canoes from the trunks and paddles from the wood. The astringent bark has been employed in liome remedies.

This and related species are commonly grown in tropical America as handsome shade trees along streets and highways. in parks, and pastures, and in plantations of coffee and cacao. Also a honey plant.

Because of the valuable wood the native trees of this species have been reduced to scattered remote 


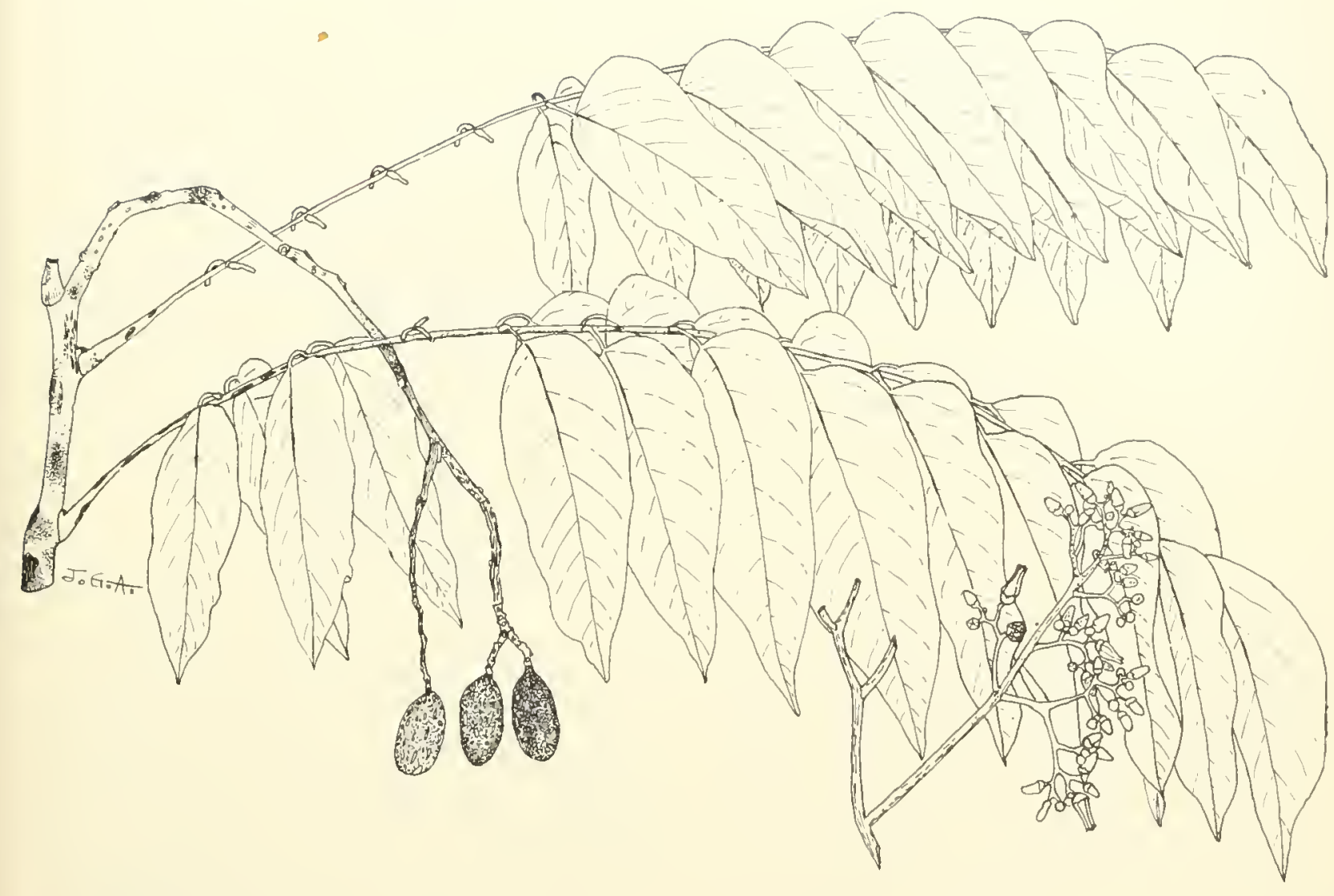


areas in Puerto Rico, chiefly in the moist limestone and lower Cordillera forest regions. In the Cordillerin restricted chiefly to steep rocky areas with soils in the Mfucara croup or in associated wel]drained rocky soils. In a few experiments the native seed has not produced promising forest plantations.

Seed from continental America formerly remarded as a distinct species, cedro español or Mexican-cedar (Cedrela mexicana M. I. Roem.), has also been tested in Puerto Rico. Though widely planted in the public forests for timber, most of the trees became chlorotic and died for reasons not understood. Nevertheless, a few trees grew very lapidly. The handsome shade trees commonly seen along roadsides are from imported seed

Public forests.-Carite, Guajataca, Guilante, Maricao, Rín Abajo, Toro Negro.

RANGE.-TVidely distributed in wet forests of low elevations in tropical America. Sative apparently through West Indies in Greater Antilles and Lesser Antilles to Trinidad and Tobago, the range spread by cultivation. Also native in contimental tropical America from Mexico (Sinaloa and San Luís Potosi southward) to Ecuador, Peru, Brazil, and Guimas. Introduced into southem Florida and the Old World.
Other comion vanes.-cedro, cedio oloroso, cedro del país, cedro hembra del país, cedro mexicano, cedro español (Puerto Rico); cedro (Spanish, commerce); cedro luembra (Dominican Republic, Cuba); ceslro macho (Cuba); cedro colorado, culche (Mexico) ; cedro real (El Salvador): cedro amargo, cedro blinco, cedro dulce, cedro colorado, cóbano (Costa Rica); cedro amareo (Panama) ; cedro blanco, cedro oloroso, cedro caba, cedro clavel (Colombia); cedro amargo, certro amarillo (Venezuela); cedro de Castilla (Ecuador); cedro colorado (Peru); spanish-cedar, West-Indies-cedar, Mexican-cedar, Central-American-cedar, South-American - cedar (English); cigarbox - cedar, cigarbox cedrela (United States); cedar, Jamaican-cedar, Honduras-cedar (Jamaica) : redcedar, acajou (Dominica, Trinidad) ; cigarbox-cedar, cedar (Trinidad) ; redcedar (Tobago); cedar (British Honduras); redcedar, cedir, kurana (British Guiana) ; acajou *onge (French); cèdre, cèdre espagnol (Haiti) ; acajou amer, acajou sent $i$, acajon ì muebles, acajou pays (Guadeloupe) ; acajon (Dutch West Indies) ; leli (Curaço): ceder (Surinam); acajú, cedro vermetho (Brazil).

Botanical syNovins. - Cedrela sintenisii C. DC., C. mexicana M. J. Roem.

\section{MAHOGANY FAMILY (MELIACEAE)}

\section{Guaraguao, American muskwood}

Large tree of moist forests distinguished by: (1) a dense crown of large, altemate, even pinnate leaves with 8-20 or more paired, elliptic to oblong, glossy, dark green leaflets, with sunken veins giving a slightly corrugated appearance: (2) the apex of the woody leaf axis continuing to grow like a stem and forming new leaflets at the tip after the other leaflets are matme; (3) many t-parted greenish-white flowers $3 / 8-5 / 8$ inch across; and $(4)$ the reddish-brown seed capsules borne in narrow grapelike clusters, nearly round, $5 / 8-3 / 1$ inch in diameter but narrowed at base, covered with many raised dots (lenticels), and splitting into 4 parts, with 4 or fewer reddish seeds.

An evergreen tree of the forest canopy 40-75 feet tall, with straight clear trunk (forked low in open grown trees) 1-3 feet in diameter, a few larger, becoming fluted when large, and with a widely spreading crown. The bark is rongh, with many longitudinal fissures, brown with a reddish tinge, thick ( $3 / 8$ inch or more). Inner bark is pinkish and slightly bitter. Twigs are brown and stout, with many raised dots (lenticels).

The leaves are $8-24$ inches long on stont round brown woody axes. The leaflets, borne on short stalks $1 / 8$ inch long, are $5-7$ inches long and $11 / 2^{-}$ $21 / 2$ inches broad, short-pointed at apex and base,
Guarea trichilioides L.

edges not toothed, slightly thickened, dark green on upper surface and paler beneath.

Flower clusters (panicles) are borne laterally, branched but narrow, $4-12$ inches long. The numerous fragrant short-stalked flowers are spreading and minutely hairy. 'The calyx is 4-lobed; there are 4 hairy petals $1 / 4$ inch long; white stamen tube $1 / 4$ inch high with 8 anthers inside top; and pistil $3 / 16$ inch high on a disk with 4-celled ovary, style, and stigma. The seeds are $3 / 8^{-1 / 2}$ inch long. Flowers and fruit are produced over most of the year.

The sapwood is whitish to hrownish, and the very attractive heartwood pinkish to red, turning light reddish brown. The wood is of medium weight or moderately heary (specific gravity 0.51), hard, strong, tough, medium-textured, straight-grained, sonewhat brittle, and aromatic when green though odorless when seasoned. Rate of air-seasoning is slow, and amount of degrade is moderate. Machining characteristics are as follows: planing, shaping, turning, mortising, and resistance to screw splitting are good; boring is fair; and sanding is excellent. The wood is resistant to attack by d $1 \mathrm{y}$-wood termites and is durable in the ground.

This pretty wood makes fine furniture and cabinets, since it resembles mahogany and Spanish- 


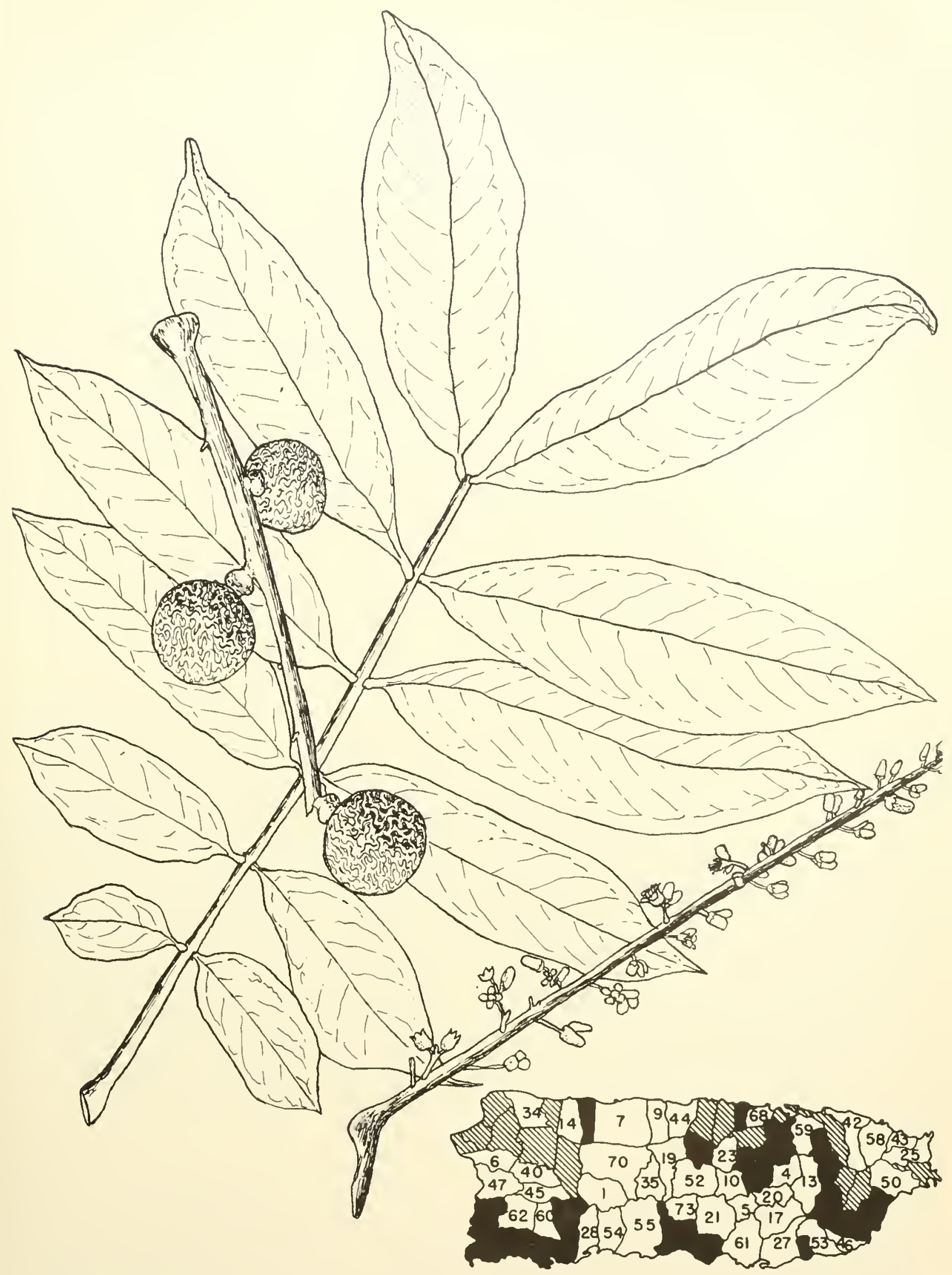

109. Guaraguao, American muskwood 
cedar and takes a high polish. It is used also for construction, carpentry, implements, and cooperage.

Planterl as a hardy small shade tree in southern Florida. Elsewhere the leaves and roots have served in home medicines.

This species is one of the commonest trees of moist forests and cotlee plantations of Pnerto Rico. It regenerates abundantly and withstands forest shade. 'Trees which come up in cofl'ee plantations are sometimes left unt il they can be harvested for their wood, although the shade is generally considered too dense for coflee culture. Test plantations established by the government show this species to be slower in growth than broadleaf mahogany, so the Jatter has been substituted where adapted. The trees are suitable for shade as well as wood.

Distributed throughout the lower mountain, moist limestone, and moist coastal regions of Puerto Rico. Also St. Croix.

Pcruic forests. Cambalache, Carite, Guajataca, Guilarte, Luquillo, Maricao, Río Abajo, Toro Negro, Vega.

II NIPIPALATIES WHERE ESPECTALY COMMON.-5, $6,7,21,40,42,43,47,50,53,61,70,73$.

Range-Cuba, Hispaniola, and Puerto Rico and St. Croix. Also in Trinidad and from Costa
Rica and Panama sontl to Argentina and Brazil. Introdnced in southern Florida.

OTHER romyox ranes.-cabirma santa, cabirma, cedro macho (Dominican Republic); yamao, yamagua (Cuba) ; carbonero, manu (Costa Riea) ; cedro macho (Panama, Colombia); trompillo (Colombia, Tenezuela, Bolivia); bilibili, mestizo, trompeto, zambo cedro (Colombia); cedro dulce, cedrón. cabimbo, shupárai (Tenezuela) ; fruta de loro (Ecuador) ; latapi, latajoicaspi, atapio, requía (Peru); cedrillo (Argentina) : American muskwood (United States) ; redwood (Trinidad) ; karaba-balli, buck vomit (British Guiana): bois rouge (Haiti); bois pistolet (Guadeloupe, Martinique): bois bale (French Guiana): doifiesirie (Surinam): gitó, cedrohy, atauba (Brazil).

Botanleal sroony.-Guarea guara (Jacq.) P. Wilson.

Guaraguaillo (Guarea ramiflora Vent.), known also as guaraguao macho, is the other native species of this genus. It is a small tree, common and widely distributed in mountain forests only in Puerto Rico. The pinnate leares $2-7$ inches long have 2-6 long-pointed objong leaflets 3-S inches long with prominent reins on both sides. The few flowers borne in lateral clusters are pink.

\section{MAHOGANY FAMILY (MELIACEAE)}

\section{Alelaila, chinaberry}

This popular introduced tree, planted for its showy chusters of pale purplish 5-parted spreading flowers and for the shade of its dense, dark green foliage, is further characterized by: (1) leaves twice pinnate (bipinnate), composed of many thin lance-shaped to ovate leaflets 1-2 inches long, which are long-pointed and saw-toothed on the edges (or some lobed) and which has a characteristic bitter taste and pungent odor when erushed: and (2) the clusters of nearly round, yellow poisonous frnits about $5 / 2$ inch in diameter, conspicuous when the tree is leafless.

A small to medinm-sized deciduous tree becoming 20-50 feet tall and 1-2 feet in trunk dianeter, with crowded, abruptly spreading branches forming a hemispherical or flattened crown. The bark is dark or reddish brown, becoming furrowed. Inner bark is whitish, slightly bitter and astringent. The twigs are green and hairless or nearly so.

The leares are alternate and $8-16$ inches or more in length and may be in part three times pinnate (tripinnate). The numerous short-stalked leaflets are borne in pairs along the slender green branches of the leaf axis but single at the ends. These leaflets are $3 / 8-3 / 4$ inch broad, with the base shortpointed and mostly 1 -sided. They are thin, hair- less or mearly so, and dark green on the upper surface and paler below.

Branched flower chusters (panicles) $4-10$ inches long are laterally attached and long-stalked. The numerous showy fragrant flowers on slender stalks are about $3 / 8$ inch long and $5 / 8-3 / 4$ inch across. There are 5 greenish sepals 1/16 inch long; 5 pale purplish or lilac-colored petals $3 / 8$ inch long, narrow, spreading and shightly tumed back; nsmally 10 stamens on a narrow violet $t$ ube $5 / 16$ inch long: a pale green pistil 5/16 inch long with disk at base, 3-6-celled orary, and long style.

The fruits or berries (drupes) are smooth but becoming a little shriveled, and slightly fleshy but with hard stone containing 5 or fewer narrow dark brown seeds $5 / 16$ ineh long. These fruits are bitter and have poisonons or narcotic properties. Flowering throughout the year in Pnerto Rico, and the old slightly wrinkled yellow fruits generally present.

The sapwood is yellowish white, and heartwood light brown to reddish brown and attractively marked. The wood is moderately soft, weak and brittle, and very suscept ible to attack by dry-wood termites. In Puerto Rico the rood is used for fuel. Uses of the wood elsewhere include tool handles, cabinets, furniture, and cigarboxes. 


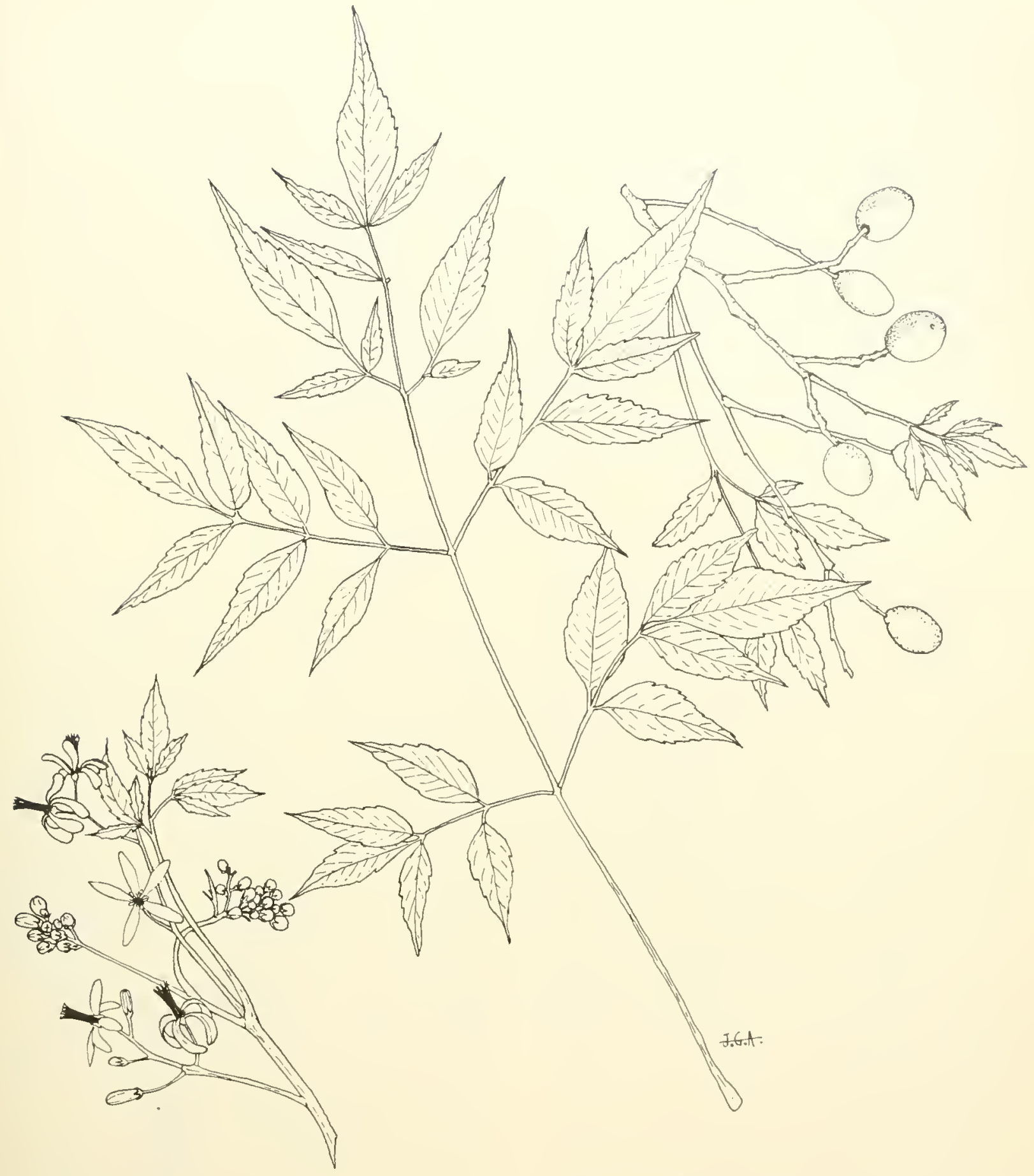

110. Alelaila, chinaberry

Two-thirds natural size.

Melia azedaraeh $\mathbf{L}$ 
Extensively planted for ornament and shade. This attractive tree is easily propagated from seed and cuttings, sprouts from stumps, and grows rapid]y. However, it is short-lived; and the brittle limbs are easily broken by the wind.

This species is poisonous and has insecticidal properties, the leaves and dried fruits having been used to protect stored clothing and other articles against insects. Various parts of the tree, including fruits, flowers, leaves, bark, and roots, have been employed medicinally in different. countries. The berries are toxic to animals and have caused deaths of pigs. In oil suitahle for illumination was extracted experimentally from the berries. The hard, angular, bony centers of the fruits, when remored by boiling, are dyed and strung as beads. In parts of Asia this is a sacred tree.

In Puerto Rico planted and locally naturalized in the coastal and lower mountain regions. Commonly planted and escaping in the Tirgin Islands. Vieques, St. Croix, St. Thomas, St. John, and Tortola.
Raxae- - Native of sonthern Asia, probably from Iran and Ifimalaya to China, but cultirated and naturalized in tropical and subtropical countries over the world. Bermuda and throughout West. Indies. Mlso from sonthern United States and Mexico south to Argentina and Brazil.

Hardy also in warm temperate regions, this tropical species is naturalized in southeastem Tnited States and grows north to Virginia and Oklalioma and west to California.

Otuer common names.-lilaila, pasilla (Puerto Rico): lilas (Tirgin Islands) ; paraíso (Spanish); alilaila, lik, lilayo, violeta (Dominican Republic); jacinto (Panama); alelí (Tenezuela); flor de paraíso (Peru) : chinaberry, chinatree, pride-ofChina, pride-of-fndia, umbrella chinaberry, umhrella-tree (United States); hoop-tree, West-Indian-lilac, bead-t ree (Jamaica) ; chinaberry, WestIndian-lilac (Trinidad); paradise-tree (British Honduras) ; lilas (Haiti); lilas, lilas du pays (Guadeloupe) : lilas des Indes (French Guiana); alelí, anesita, lilac (Dutch Trest Indies); cimnamomo (Brazil).

\section{MAHOGANY FAMILY (MELIACEAE)}

\section{Caoba" hondureña, Honduras mahogany}

Mahogany, the world's premier cabinet wood and probably the most valuable timber tree in tropical America, was not originally known from Pnerto Rico and the Virgin Islands, but 2 species have been widely planted. Honduras mahogany is recognized by: (1) usually dense crown of shiny green leares, which are eren pinnate and 8-16 inches long with 6-12 paired, mnequal-sided leaflets $21 / 2-6$ inches long: and (2) erect egg-shaped or pear-shaped seed capsules $41 / 2-7$ inches long and about 3 inches in diameter, splitting upward from the base into 5 parts. Leaves and fruits are much larger than in West Indies mahogany (Swietenia mahagoni Jacr.).

A medium-sized to large decidnons tree 60 feet or more in height with clear, straight, erect trunk to 2 feet or more in diameter, becoming buttressed at base. The bark is rough, deeply fissured into flat scales, light brown, and about $1 / 2$ inch thick, the inner bark dark reddish and bitter. The stont brown twigs hare many raised dots (lenticels).

The alternate leaves have a slender round yellow-green axis ending in a narrow dead point, bearing leaflets on short stalks less than $1 / 4$ inch long. Blades are 1-21/4 inches wide, elliptic to oblong, short-pointed at base and abruptly longpointed at apex, noticeably broader on side toward axis, not toothed on edges, slightly thickened or leathery, green to dark green and slightly shiny on upper surface, and paler beneath.

Flower chusters (panicles) 46 inches or more in length at base of new leaves bear many small,

\section{Swietenia macrophylla King*}

short-stalked, fragrant, greenish-yellow flowers nearly $1 / 2$ inch across. The light green calyx $1 / 16$ inch high is 5 -toothed; there are 5 oblong, slightly concave, greenish-yellow petals $1 / 4$ inch long, greenish-yellow stamen tube nearly $1 / 4$ inch long, bearing inside apex 10 tiny brown stamens between as many teeth; and pistil $3 / 16$ inch long with oringe-red basal disk, light green rounded 5celled ovary, style, and broad flattened stigma. A few flowers ha ve parts in 4's.

The seed capsules are borne on long stout stalks, thick-walled and heary, and the large, 5-angled axis remains on the tree. The numerous flat, longwinged, brown seeds are $3-31 / 2$ inches long and $3 / 4-1$ inch broad, about 900 to the pound. Flowers borne in May and June, and seeds produced generally in the late fall.

The thin sapwood 1-2 inches wide is yellowish white. The heartwood is pinkish when freshly cut, later becoming light reddish brown with a rolden luster. The wood is moderately lightweight (specific gravity $0.5-0.6$ ), strong, of medium to fine uniform texture, with interlocked grain and attractive figure, and growth layers indistinct. It is one of the easiest woods to work and takes an excellent polish. Rate of air-seasoning is rapid, and amount of degrade very minor except when tension wood is present. Machining characteristics are as follows: sanding is excellent; planing, shaping, turning, boring, mortising, and resistance to screw splitting are good. The heartwood is resistant to decay and generally is resistant to at- 


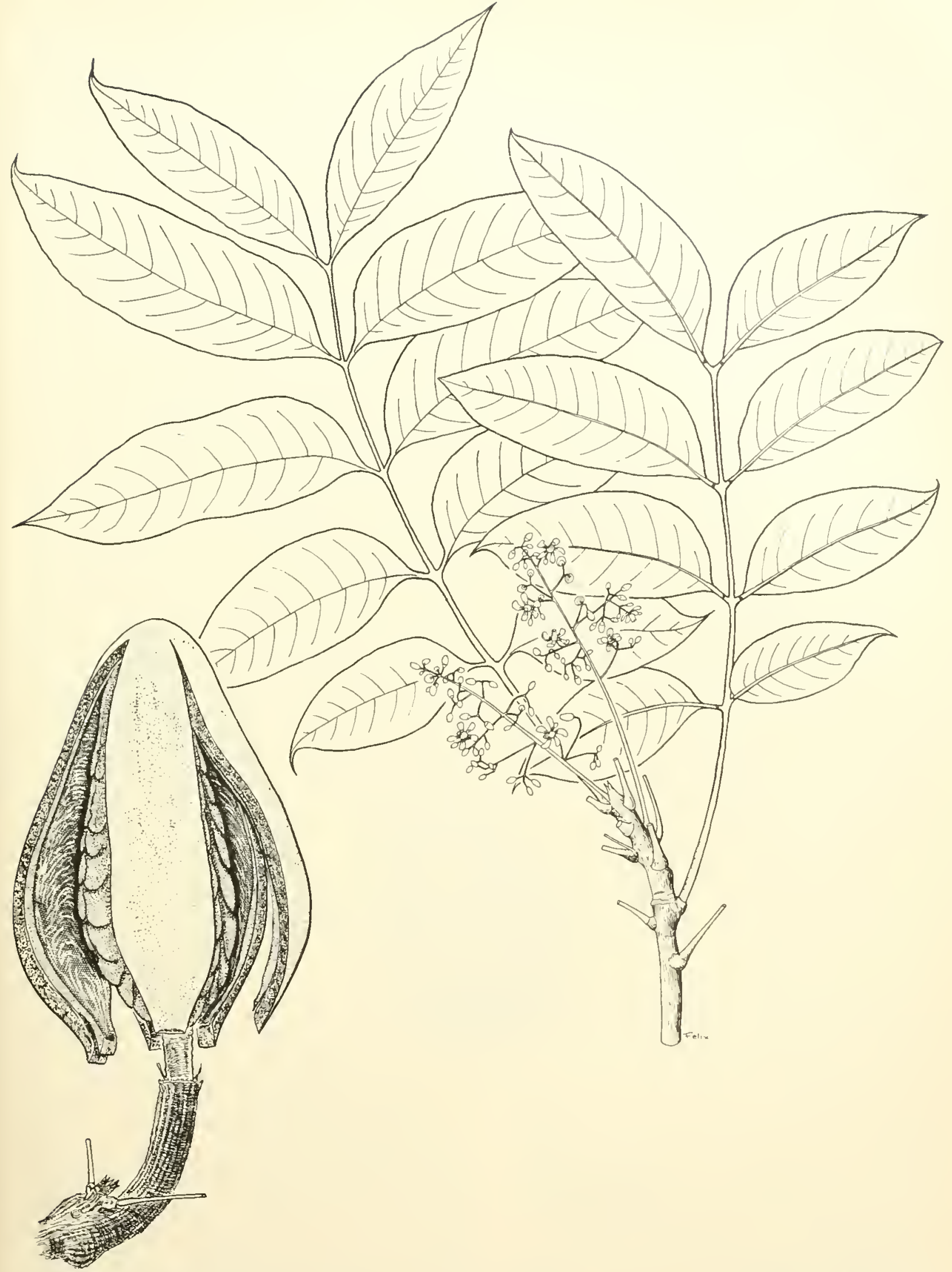


tack by dry-woorl termites, but the sapwond is rerr susceptible to decay and inserts. From West Indies malhogany the wood dillers in being mole open-grainerl, lighter in weight, and softer.

'This is one of the commonest woods for furniture manufacture and cabinetmaking in Plerto IRico, being imported in large quant ities from $1 / \mathrm{x}^{\mathrm{x}}$ ico as ronch lumber. limited amounts of small logs come from local plantations also. Other uses mostly elsewhere includs face reneer, interior trim, paneling, burial caskets, interiors of boats and ships, turning, musical instruments, molds. dies, and pattermnaking.

This species is now much more important commercially than Wrest Indies mahogany, because of its more extensive range in Central and Fonth America and its relayed utilization. British I Ionduras was established as a colony for the prized timbers of mahogany and logwood. Timber" exported from other tropical Imerican countries is often designated by the country of origin, for example, Brazilian malougany.

With struight tall trunk and few branches, this is a handsome street and sloade tree in tropical comntries, also producing raluable timber. The balk is high in tannin content. Ilso reponted to be a honey plant.

Planted extensively in the mblic forests of Puevto Rico and as a shade tree in patios and along roarlsides in Pnerto Rico and St. Croix and perhaps others of the Tirgin Islands. One of the most promising species for forestry on welldrained deep solls in the lower mountain and moist limestone regions of Puerto Rico. It withstands sharle, grows papidly, and produces a tree of gond form.

Pumic ronests.-Cambalache, Carite, Guajataca, Guilarte, Luruillo, Maricao, Río Mbajo, Susúa, Toro Negro.
Raxfe.-Southem Mexico (Oaxaca, Veracruz, Tabaseo, and lucatún Peninsula sonthward), Atlantic slope of Central Imerica from British I IonJuras to Panami, and in Colombia. Terezuela, and port ions of upper Amazon region in Peru, Bolivia, and Brazil. [util alout 1923 it was not known from the Lmazon region, where a large supply of timber necurs in the virgin forests. Introdiced into sonthem Florida, Puerto Rico and Virgin Islands, Cuba, Trinidad and Tobago, India, and other tropical areas.

Other commox xumes.-caoba de Honduras (Puerto Rico); broadleaf mahogany, bigleaf mahogany, Central American mahogany (Tirgin Islands): caoha, caoba hondureña (Spanish); chacalte (Guatemala) ; cals americana (Colombia); aguano (Peru); mahogany, IIonduras mahogany, British Houduras mahogany, Venezuelan mahogany, Peruvian mahogany, Brazilian mahogany (United States, English, commerce); acajoil Imérique (French, commerce): malogany IIonduras (Guadeloupe, Martinique); acajou du Ionduras (Guadelompe).

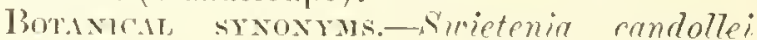
Pittier" (caobal renezolana. Venzuelan mahogany), S. betizensis Luntell, S. Frution ii Gleason \& Panshin. S. tessmumnii Harms.

What is believer] to be a matural hybrid between this and the following species (Suietenia macrophylla $\times$ mahagoni) is found in St. Croix. Where trees of the 2 species have been planted together, some of the seedlings are intermediate in appearance. The intermediate is known locally as medimmleaf malogany becanse the leaflet widt h is between that of the parent species. In preliminary experiments the plants grow rapidly and apparently show hybrid rigor. Also, the wood is of high quality like that of the second species.

\section{MAHOGANY FAMILY (MELIACEAE)}

\section{Caoba dominicana, Dominican mahogany, West Indies mahogany}

\section{Swietenia mahagoni Jacq.*}

Trest Indies mahogany is commonly planted in Puerto Rico and the Tirgin Islands though not native. This first-rliscovered species of mahogany, the world's premier cabinet wood, is easily recognized by: (1) its distinctive leaves, alternate and even pinnate, $4-7$ inches long, bearing $t-10$ paired sliny green leaflets, ovate to lance-shaped, $1-21 / 2$ inches long and $1 / 2-7 \%$ inch broad, longpointed and very conspicuously unequal-sided; and (2) the odd, exr-shaped or pear-shaped, dark brown erect seed capsules $21 / 2-4$ inches long and $11 / 2-2$ inches in diameter, hard and thick-walled, splitting 11 ward from the base into 5 parts and releasing many flat long-winged seeds.

A medium-sized to large deciduous tree with maximum size $40-60$ feet in height and $3-41 / 2$ feet in trunk diameter. The trunk is usually short and has swollen or buttressed base when large, and produces a spreading, much-branched erown. Bark on small trees is smoothish, slightly fissured, and gray, beeoming dark reddish brown and sealy on large trunks. The inner bark is pink and bitter. Foung twigs are pale red, becoming brownish oray with many raised dots (lenticels).

Leaflets are borne along a slender yellow-green axis on slender stalks fess than $1 / 4$ inch long. These leaflets have the inner ol" upper edge rounded at base but edges not toothed, are slightly thickened or leathery, shiny green above and paler beneath, and have a reddish-brown midrib.

The flower clusters (panicles) are lateral, 2-6 inches long, and branched. Several to many small 

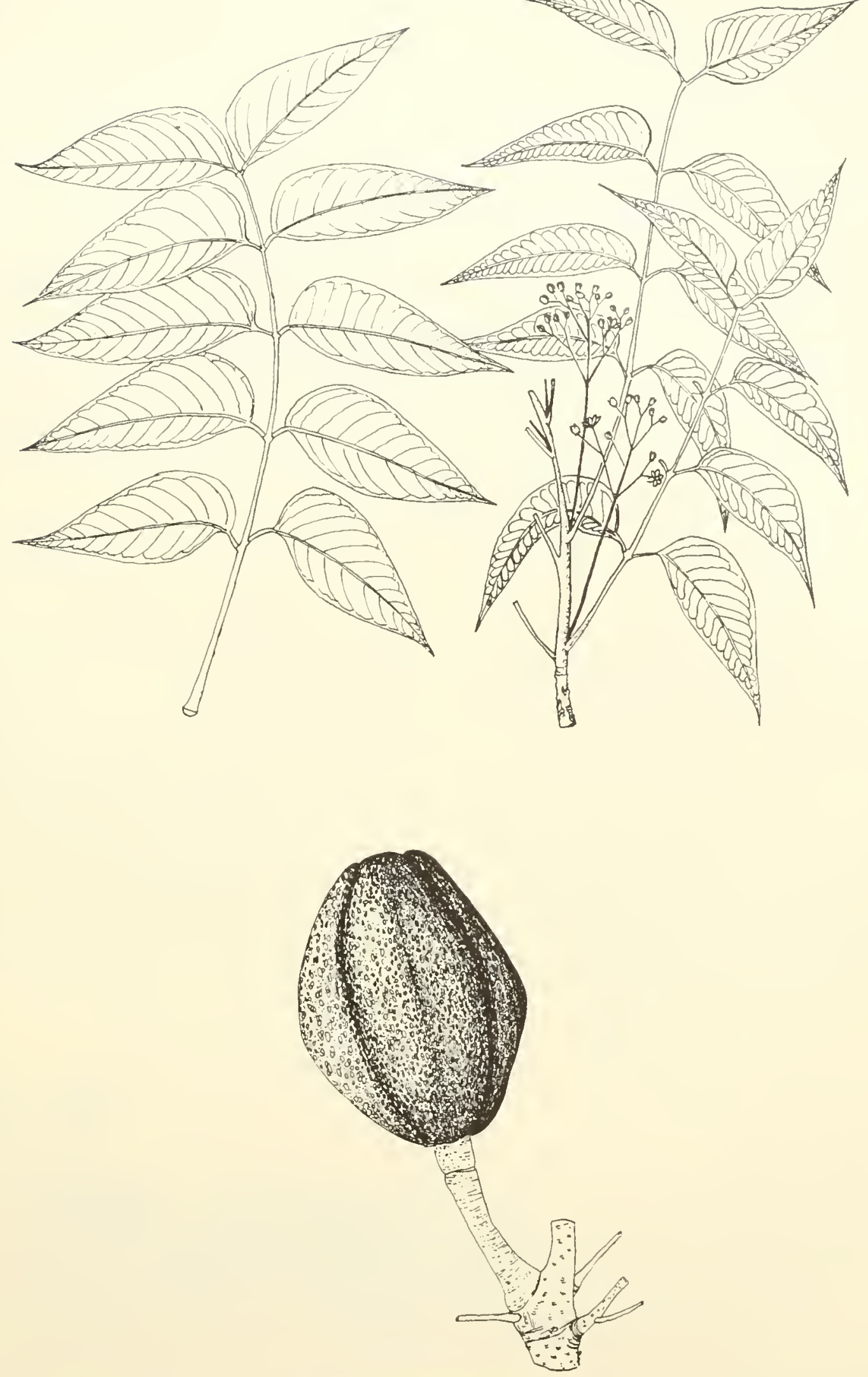

112. Caoba dominicana, Dominican mahogany, West Indies mahogany

Swietenia mahagoni Jaeq. Two-thirds natural size. 
greenish-yellow flowers, 5-parted, spreading, and it juch across, are borne on short stalks. There are 5 minute sepals, 5 whitish or ycllow spreading petals $1 / 8$ inch long, 10 stamens inside a short tube I/s inch long, and pistil on a disk and composed of a s-celled ovary, stvle, and flattened stigma.

The fruts are horne on long stalks, and the lare 5-angled axis remains attached. The light lurwn seeds are about $2-21 / 4$ inches long and $1 / 2$ inch broad, approximately 3,200 to a pound. Flowers are borne mainly from March to July in Puerto Rico, and mature fruits are present chiefly in the winter.

The sipwood is whitish or yellowish. The heart wood is reddish, pinkish, or yellowish when freshly cut, gratually turuing dark rich reddish hrown. The wood is moderately hard, heary (specifie aravity $0.7-0.5$ ), and strong. It is rery resistant to decay and to attack by dry-wood termites.

The wood is used chicfly for furnitme, cabinetmaking, interior finish, and vencers, heing easily worked and taking a beantiful polish. It formerly was employed in shipbuilding, construction, and for beams. Ronts and stumps of large trees are especially prized for their inegular wary grain. Considered superior in quality and durbility to the wood of Honduras mahoginy. The astringent bitter bark has been used in medicine.

Planted as a street and shade trec hecanse of the at tractive spherical erown and ilense shade. Often grown in southern Florida where also native. Reported to he a honey plant.

The oldest surviving use of mahogany by European colonists is said to be in the cathedral at Santo Domingo (Ciudad Trujillo), Dominican Republic, completed in 1550 . It contains much alved mahogany woodwork still in fine condition after more than four centuries in the tropies and a lough-hew mahogany cross bearing the dite 1514 , the rear construction was begun. The Dominican Republic has selected the mahogany flower for its national emblem.
Test Indies mahogany was introduced into Puerto Rico and the Virgin Islands more than 200 ycars ago. Fine old trees reently cut near Guayama on the south const of Puerto Rico ranged up to 52 inches in trunk diameter, one near Ponce measured 50 inches, and some in St. Croix are more than 50 inches. A number of small plantings were made by Dr. Agustín Stahl near Aguadilia, 'Toa Alta, anil Manatí about 50 years ago. More extensive forest plantations have been established on both public and private lands within the pasti 25 years. This species has proven better adapted to "dry rocky sites than Honduras mahogany. Trees 20 ycal's old near San Germán areraged 5 inches in dimeter and 35 feet in height. The abundance of young trees developing beneath and near the plantations may be partly responsible for the popmlar misconception that the tree is native. Planted also in Mona, St. Croix, St. Thomas, St. John, and Tortola.

Public rorests.-Cambalache, Guajataca, Guániea, Luquillo, Maricao, Río Abajo, Susúa.

R.was.--Nitive in southem Florida including Florida Keys, Bahamas, Cuba, Janaica, and Hispaniola. Introduced in Puerto Rico and Virgin Islands, Bermuda, throughout Lesser Antilles, Trinidad and Tobago, and Curaça, south to Sonth America and clsewhere in tropical regions, and naturalized locally.

OTHER Comion NAMEs.-Caoba, caoba de Santo Domingo (Puerto Rico, Spanish) : small-leaf mahogany, mahogany (Virgin Islands); caobilla (Cuba): West Indies mahogany, West Indian mahogany, mahogany (United States, English, commerce): madiera (Bahamas); Spanish malogany (St. Yincent, Trinidad and Tobago); acajou (Haiti); mahogany petites feuilles (Guadeloupe, Martinique); mahogany, mahogany du pays, acajou de Saint Domingue (Guadeloupe); mahok (Dutch West Indies); mahoni (Surinam).

\section{MAHOGANY FAMILY (MELIACEAE)}

\section{Tinacio, broomstick}

A small tree or shrub of dry areas characterized by: (1) a rounded crown of dense foliage; (2) alternate pimnate leaves with $7-21$ lanceshaped to elliptic leaflets slightly oblique at base with sunken veins above; (3) several to many small greenish-white or pale yellow, 5-parted flowers about $3 / 1$, inch long and broad in branching clusters at leaf bases; and $(t)$ rounded greenishbrown seed capsules $3 / s^{-1 / 2}$ inch in diameter, finely hairy, splitting widely into 3 parts and exposing usually 3 or:ange-red seeds.

Decidhous, 15-20 feet high with trunk 4-6 inches in diameter, elsewhere a tree to 50 fcet in height.
The brown or gray bark is rough, fissured and scaly or furrowed, and the whitish inner bark is bitter. The twigs are green and finely hairy when young, becoming brownish.

Leares are $6-12$ inches or more in length, the slender round green axis bearing leaflets on short lateral stalks $1 / 10^{-1 / 4}$ inch long. Leaflet blades are $1-41 / 2$ inches long and $1 / 2-11 / 2$ inches wide, bluntly long- or short-pointed at apex, the side toward apex of axis broader at the rounded or shortpointed base, not toothed at edges, thin, above slightly shiny green to dark green, and beneath paler and often slightly hairy. 

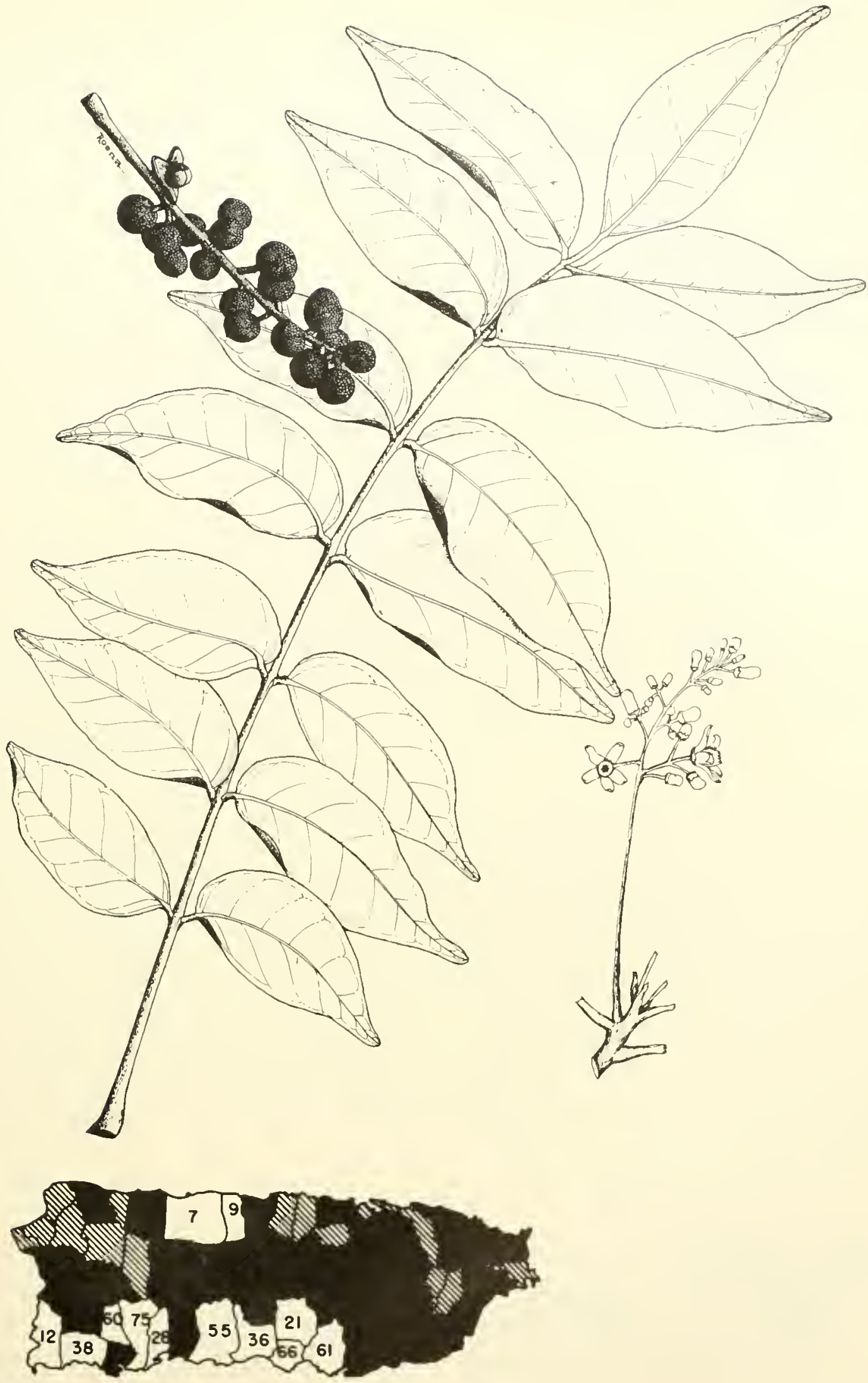

113. Tinacio, broomstick 
The nar'ow flowel clusters (panicles) $1 \frac{1}{2}-7$ inches long are near ends of twigs. the individual fower stalks about 1 is inch long and jointed below mirlile. 'Ilhe slightly fracrant cup-shaped to spretuling flowers hice a light green minute 5-ivined atyx less than 1/16 inch long: 5 greenishwhite ar pale yellow oblong petals $3 / 16$ inch long; 10 stamens ${ }^{1}$ s incl long, wit ly white hairy filaments flattened and united loward base: and on a yellow disk the liwht wreen pistil more than $1 / 8$ inch long incluling rounded hairy 3-celled orary, style, and rounderl stimna. The elliptic seeds are $5 / 16$ inch long, with fleshy coats. Flowering and fruitingr wer most of the year.

The sapwood is light brown and heartwood reddish brown with darker reins. The rood is described as resembling cedro (Cedrela) in color, moderately ligletweight (specific gravity 0.5). Heart wood very resistunt and silpwood resistant to attack by dry-wood termites.

Ised chiefly for posts and fuel in Puerto Rico. Broom handles lave been made from young stems. In Tenezuela oar's or paddles (canaletes) were made from the wood, which was recommended as suitable for interior finish, furniture, implements, and plywood. Planted for shade and ornament in southern Florida. Also a honey plant.

Open forests in the limestone and coastal (chiefly diy coast) regions of Puerto Rico. Also in Vieques, St. Croix, St. Thomas, and St. John.
Ptourc Forests.-Cambalache, Guánica, Susúa. Raxge.-C"nba, Jamaica, Hispaniola, Puerto Rico and Virgin Islands, and Grenadines and Grenada. Also from Mexico and Tres Marías Islands to Ecuador, Perru, Brazil, and Tenezuela. Introduced in sonthern liklorida.

OTIIR COMNon NMMr.-cabo de hacha, guaita, retamo, palo de anastasio (Puerto Rico); broomwood (Virgin Islands); jojobán (Dominican Republic) ; julrabán, cabo de hacha (C'uba); cabo de hacha, garbancillo, jumay, mapahuite (Mexico) ; mapalnuite, trompillo, cedrillo, cedro colorado (Guatemala) : cedro espino (Honduras) ; cola de paro, jocotillo, cedrillo (El Salvador") : mata piojo (Nicaragua); canalete, cazabito, cedrillo, trompillo, pan de trigo (T'enezucla) ; pata de vaca (Colombia); gajigua (Ecuador); redcedar (British Honduras); mombin bâtard (Haiti); carrapeta (Brazil).

Botanigal sTNONYM.-Trichitia spondioides .Tace.

Bariaco (Trichitio triacantho Urban), called also guaydacin, the thind representative of this genus, is known only from the dry southwestem part of Prerto Rico. This slurub or small tree is easily recognized by the spiny tips of the leaflets. 'The pimnate leaves latve 3-7 obovate or wedgeshaped leaflets $1 / 2-11 / 4$ inches long and $1 / 4-5 / 8$ inch wide, broadest at the spiny 3 -toothed apex.

\section{MAHOGANY FAMILY (MELIACEAE)}

\section{Gaeta}

A small tree, lecognized by: (1) the alternate pinmate leaves with 3 or 5 (or 7 ) ellipt ic leaflets havingr veins sunken and prominent beneath, causing a wrinkled appearance, the end leaflet largest and others pared and smaller toward base: (2) the few 4-parted spreading greenish-white flowers almost $1 / 2$ inch across; and (3) the nearly round seed capsules 3/8-1/2 inch in diameter, light brown and fincly hairy, with 1-3 bright orange-red seeds.

Everereen, commonly 15-30) feet high and $3-6$ inches in trunk diameter. Bark on small trumks is dirk brown, smootle, with many horizontal dots and lines (lenticels), and the inner bark whitish and bitter. The twigs are light to dark brown, with raised dots (lenticels), hairy when young.

'The leaves are $4-9$ inches long. "The leaflets are short-stallied or almost stalkless, $11 / 2-6$ inches long and $3 / 4-21 / 2$ inches broad, short-pointed at apex and base, edges often slightly turned down, slightly thickened, dark green or green on upper surface and paler beneath.

The small flower chuster's (like umbels) are lateral at base of leaves, $3 / 4^{-11 / 2}$ inches long and broad, with slender hairy branches. Flowers are
Trichilia pallida Sw.

finely hairy and slightly fragrant. Calyx is t-toothed: petals $4,1 / 4$ inch long, whitish, minutely hairy: stamens 8 on a cup-shaped stamen tube: and pistil with 3 - or 2-celled ovary, style, and stigma. The few chustered seed capsules split widely into 3 or 2 parts, releasing elliptic seeds $1 / 4$ inch long. Flowering and fruiting nearly throughout the year (March to December).

The wood is hard, heary (specific gravity 0.7), and fine-textured, the sapwood whitish. Though seldom used because of the small dimensions, the wood is very resistant to attack by dry-wood termites.

Tsually an understory tree in forests of the lower mountain and moist limestone regions of Puerto Rico.

Public Forests.-Carite, Guilarte, Luquillo, Susúa, 'Toro Negro.

Raxge.-Cuba, Hispaniola, and Puerto Rico.

Otuer common cimes.-ramoncillo, caracolillo (Puerto Rico) : caracolí, palo amalcgo, almendro, almendrillo (Dominican Republic); siguaraya (Cuba); bois arada, dombou, Marie-Jeanne (Haiti). 


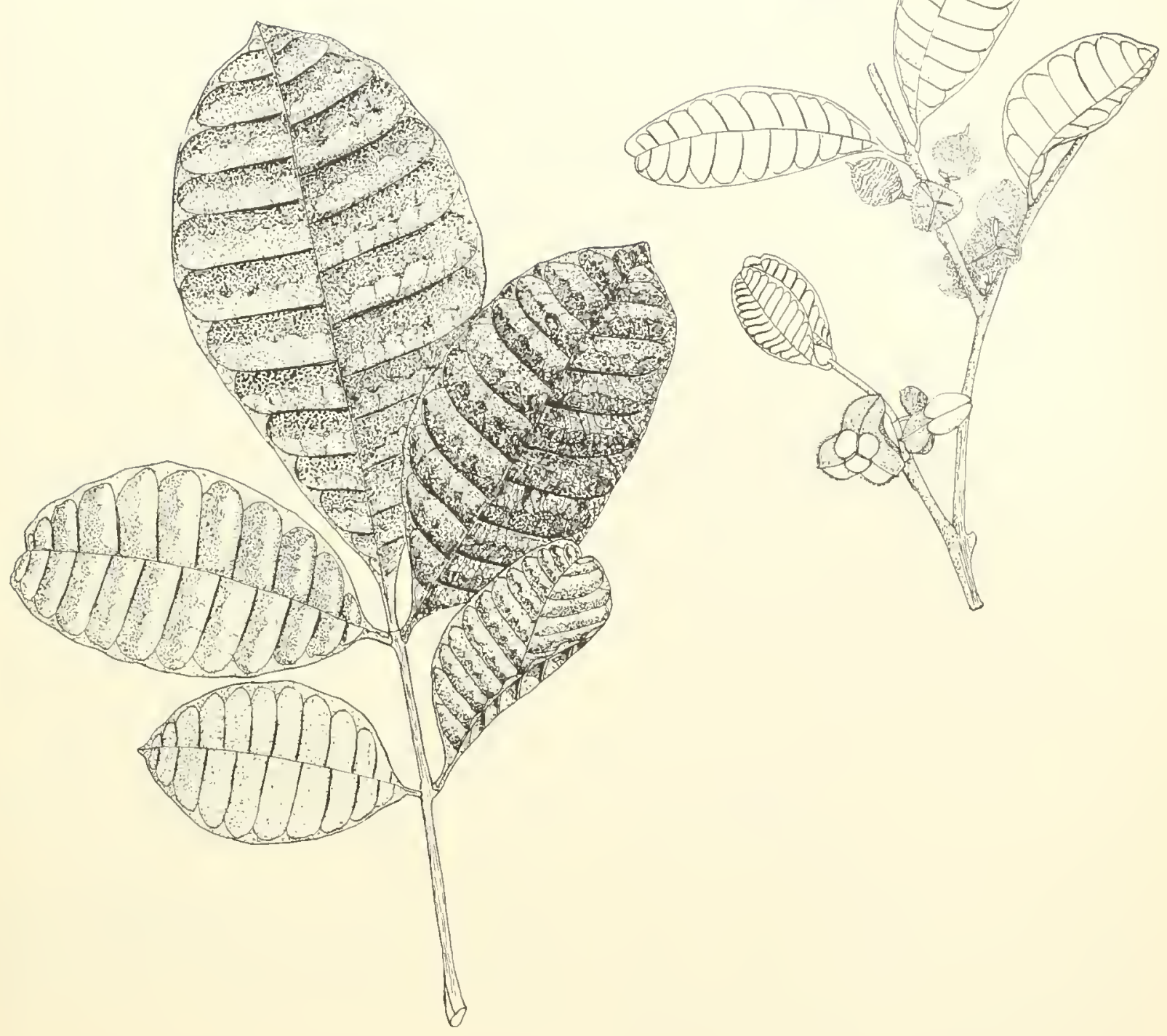
114. Gaeta

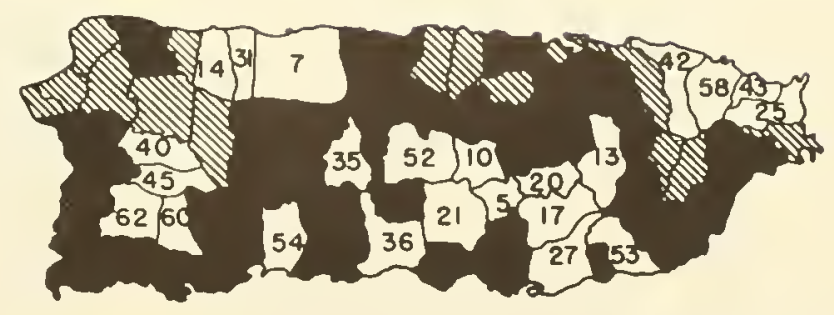

Two-thlrds natural size.

Trichilia pallida Sw. 


\section{MALPIGHIA FAMILY (MALPIGHIACEAE)}

Key to the 2 species illustrated (Nos. 115-116)

A. Leares thin, turuing rich red upou drying, upper surface shiny, midrib lighter in color than blade-115. Byrsonima coriacea.

A. Leaves leathery, with prominent reins, upper surface slightly shiny, lower surface with larger veins often rusty-red hairs-116. Byrsonima crassifolia.

\section{Maricao}

A medium-sized tree with a spreading crown, characterized by: (1) opposite elliptic to lanceshaped leaves $2-5$ inches long and $3 / 4-2$ inches broad, short-pointed or rounded at apex and shortpointed at base, the midrib notably lighter in color than the thin blade, tmming rich red upon drying, a few such leaves on most trees at all times: (2) young twigs and flower stalks covered with fine, rusty-red hairs: (3) flowers showy, yellow, $1 / 2-5 / 8$ inch across with 5 rounded petals narrowed into long stalks; and (4) the nearly romd yellow fruits $3 / 8-1 / 2$ inch in diameter.

An evergreen tree $30-60$ feet tall and $1-11 / 2$ feet or more in trunk diameter. The bark is smoothish, gray, becoming slightly rongh and warty and 1/4-3/4 inch thick. Inner bark is pinkish and bitter.

Petioles are 1/4-1/2 inch long. The upper sulface of the blades is shiny green and hairless, the lower surface lighter green and often slightly hairy on mirlrib and near edges, which are not toothed.

Flower clusters (racemes) are terminal, 2-4 inches long. The many flowers are borne along the erect flower stalks $3 / 8-1 / 2$ inch long and curved downward when young. The calyx $1 / 8$ inch long is 5 -Iobed with 10 oblong glands on ontside: 5 petals, yellow, widely spreading, 1/4 inch long, nearly round but narowed into long stalks; 10 stamens: and pistil with 3 -celled orary and 3 styles. The flowers are slightly fragrant and attract bees. The juicy fruits (drupes) are broader than long and with a large stone, edible, but with a bitter taste. Flowering and fruiting nearly through the year.

The sapwood is gray to reddish brown, and the heartwood is reddish brown with a purplish cast and generally marked by darker stripes with a stippled effect. The wood is moderately hard, heary (specific gravity 0.64), of fine texture and straight to slightly roey grain, and fairly strong but brittle. Its rate of air-seasoning and amount of degrade are moderate. Machining characteristics are as follows: planing, shaping, tmrning, and sanding are grood; boring and mortising are excellent; and resistance to screw splitting is poor. The wood is very susceptible to attack by dry-wood termites and only slightly resistant to decay.

Though few trees are large enough to produce lumber, the wood is recommended for fancy furniture and cabinetwork, turning, flooling, interior trim, and other decorative uses. It is suitable also for general carpentry, heavy construction, plywood, and veneer. Elsewhere it has been made into charcoal. The bark is employed in tanning.

The trees are rather ornamental when in flower and suitable for shade but are seldom planted for

\section{Byrsonima coriacea (Sw.) DC.}

these purposes. 'The seeds are slow to germinate, lying as long as a year on the forest floor before germination. Early growth is rapid.

Common in secondary forests and frequently on lands degraded by farming in the lower mountain, moist coastal, and moist limestone regions of Puerto Rico. Also in St. Croix, St. Thomas, St. Iohn, and Tortola.

Pcburc forests.-Cambalache, Carite, Guilarte, Luquillo, Maricao, Susúa. Toro Negro.

IIUNiCIPALITIES WHERE ESPECIALLY COMMON.29,69 .

Raxge.-Throngh Trest Indies from Cuba and Jamaica to Trinidad and Tobago. Also from Guianas to Colombia and Panama and south to Pesu, Bolivia, and Brazil.

Otiler Comion Names.--doncella (Puerto Rico): peralejo (Dominican Republic) : peralejo de pinar (Cuba); piginjo (Colombia); manteco sabanero, manteco, manteco de agua, chapar'o de chinche (Venezuela): hogberry, locust-tree (Jamaica) ; indano, indano colorado (Peru) ; mauricef (Dominica, Grenada); bois tan (St. Lucia); barka-locust, locust-berry (Barbados); serrette (Grenada, Trinidad); rosewood (Tobago) : hicha (British Guiana); bois tan, mauricef (Guadeloupe, Martinique): hollyhock (Dutch West Indies); holia, moeleri, sabana kwarie (Surinam); pau de costume, pessegueiro bravo (Brazil).

The West Indian tree has been placed in a variety (Byrsonima coriacea (Sw.) DC. var. spicata (Cav.) Niedenzu) often accepted as a species ( $B$. spicatr (Cav.) DC.).

Besides the 2 illustrated here, 4 additional tree species of this genus known also as maricao are native in Pnerto Rico. Palo de cloncella (Byrsonima lucida DC.; synonym B. cuneata (Turcz) P. Wils.) has small spoon-shaped or obovate leares $3 / 4-2$ inches long and flowers with white to red petals.

Two poorly known, doubtfully distinct, local species described from Guanajibo, near Mayaguez, have yellow petals tmming red. They are Byrsonima ophiticola Small, with obovate leares less than 2 inches long, and $B$. horneana Britton \& Small, with obovate leaves $1 \frac{1}{2}-31 / 2$ inches long.

A distinct species rare in dwarf forests and momntain forests of eastern and central Pllerto Rico is almendrillo (Byrsonima wadsworthiz Little). During the preparation of this book, this species was noted as new and ras mamed in 1953. It has elliptic leaves mostly $11 / 2-3$ inches long, slightly thickened, with edges turned under, gray hairy beneath, and flowers with white petals turning pink. 


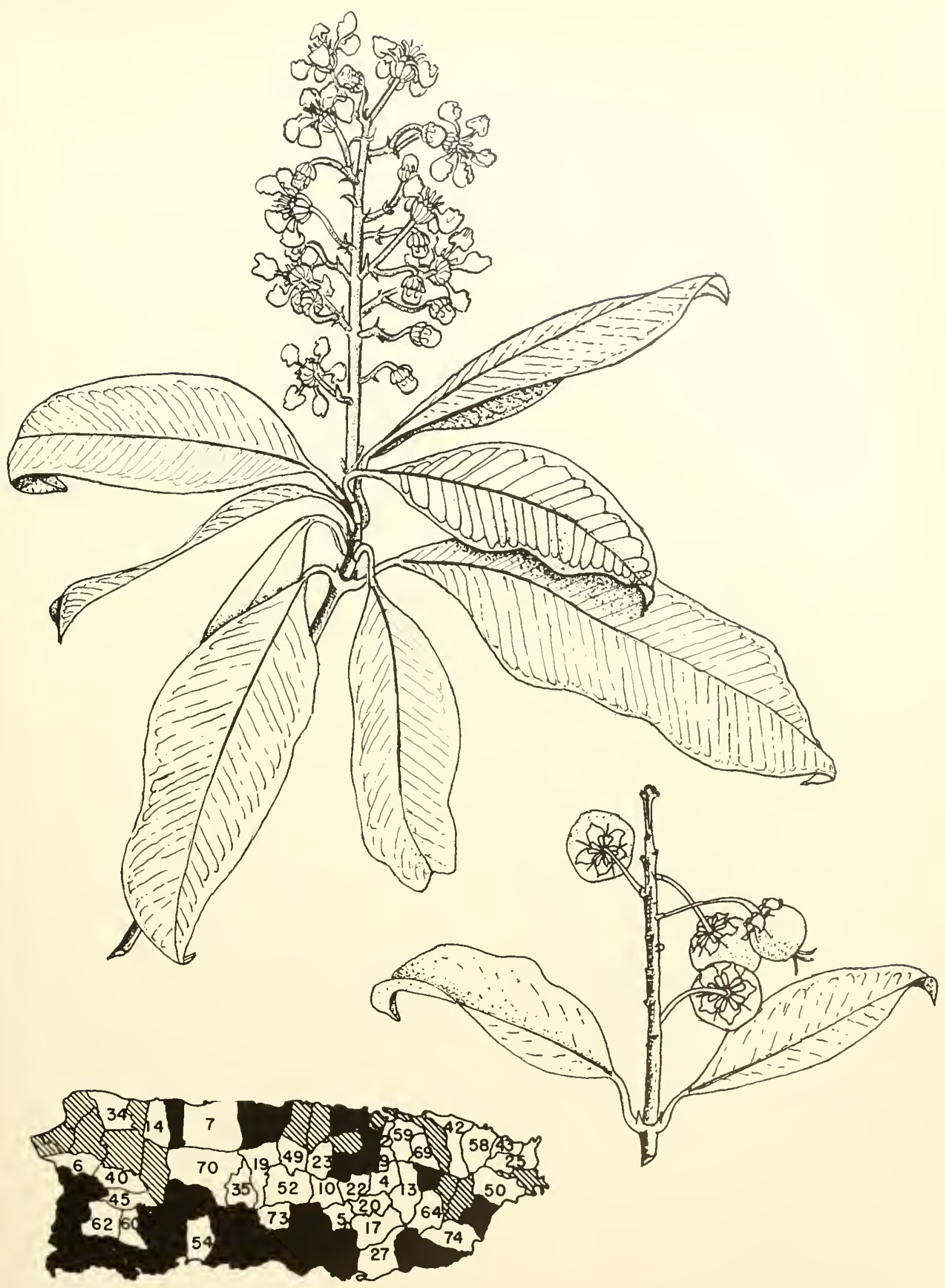




\section{MALPIGHIA FAMILY (MALPIGHIACEAE)}

\section{Maricao cimarrón}

This small crooked tree or shrub of dry forests is thacterized by: (1) opposite, mostly elliptic leaves $21 / 2-5$ inclies long and $1-2$ inches broad, short-pointed at apex and base, leathery and with prominent veins: (2) the roung twigs, flower stalks, pet ioles, and rery young leares corered with finc, rusty-red hairs; (3) the flowers $5 / 8-3 / 4$ inch across with 5 pomded yellow petals narrowed into long stallss, in terminal clusters on stalks which curve downwal; and (t) the nearly round yellow fruts 1 inch or less in diameter, sour but edible.

1 small everereen tree or shrub at taining $15-25$ feet in height and 10 inches in trunk diameter, with open, wide spreading crown. The bark is way to dark brown, becoming thick and very rongh, with irregular large warts. The imer batk, more than $3 / 8$ inch thick, is streaked with pink and red, and is bitter.

The leaves, with petioles $3 / 8-5 / 8$ inch long, are variable in shape and size, edges not toothed, upper surface green, slightly shiny, and almost hairless at maturity, and lower surface light green and with larger veins rusty-red hairy or nearly hairless.

Flower clusters (racemes) are 3-4 inches long. The miny yellow flowers are horne along the erect. moty hairy axis on flower stalks 3/8-1/2 inch long and curved downard, also rusty hairy. The alyx is pale rellow, 1usty hairy, $3 / 16$ inch long, -h-lohed with 10 ohlong ylands at base outside; the 5 bright yellow petals widely spreading, 1/4-3/8 inch long. nearly round but narrowed into long stalks; 10 pale yellow stamens $1 / 8$ inch long; and pale green pistil 1/8 inch long, including s-celled orary with 3 slender styles. The fruits (drupes) are juicy and have a laige stone. Flowering and fruiting from spring to fall.

The reddish-brown wood is hard, heary (specific wravity 0.7 ), strong but brittle, and only moderately durable. Considered suited for construction, though generally too small, and in other places burned for charcoal.

\section{Byrsonima crassifolia (L.) H. B. K.}

The fruits are eaten raw or coolied or prepared in a drink like lemonade and are consumed by hogs and other aninals, domestic and wild. In Mexieo and Central Imerica the trees are planted for the fruits, which are larger and different in appearance. A light brown dye for cotton textiles is extracted from the fruit rind in Guatemala. Becausc of their many golden flowers the plants are classed as ornamentals and have been introduced for this purpose in southern Florida. Also reported to be honey plants. The bark has been employed for tanning and in home remedies.

This species is found chiefly in open forests of the lower ('ordillera forest regions in southwestern and western Inerto Rico.

Peblic forest.-Sisía.

Raxge.-Cuba, Hispaniola, Puerto Rien, St. Martin, Dominica, Barbados, Trinidad, and Curacao. Ilso from southern Mexico to Perm, Bolivia, Paraguay, Brazil, and Guianas. Plinted in southern Florida.

In some parts of its range, such as the savanas of Cuba and the llanos of Colombia and Venezuela, this tree is a common and characteristic shrubby tree on the errassy plains. Some anthors have distinguished virieties of this widely distributed species whose leaves vary in shape, size, and haipiness.

OTher commox ximes - maricao verde, peralejo, peralejo blanco (Puerto Rico): doncela (commerce); peralejo, maricao (Dominican Republic): peralejo, peralejo de sabana (Cuba); nanche, nance, nance agrio, chi, changugo (Mexico); nance, nancite (Central America); chi, tapal (Guatemala) : nancito, cralo (Honduras); nance verde (El Salvador); wild-cherry (Panama); chaparro, chaparro manteca, yuco, peraleja, noro (Colombia): chaparro manteco, chaparro de sabana, manteco, manteco merey, manero (Venezuela): saranna serrette ('Trinidad); craboo, crapoo, wile craboo (British Honduras); huria (British Guiana): sabana kwari moeleidan, hori, sabana mango (Surinam). 


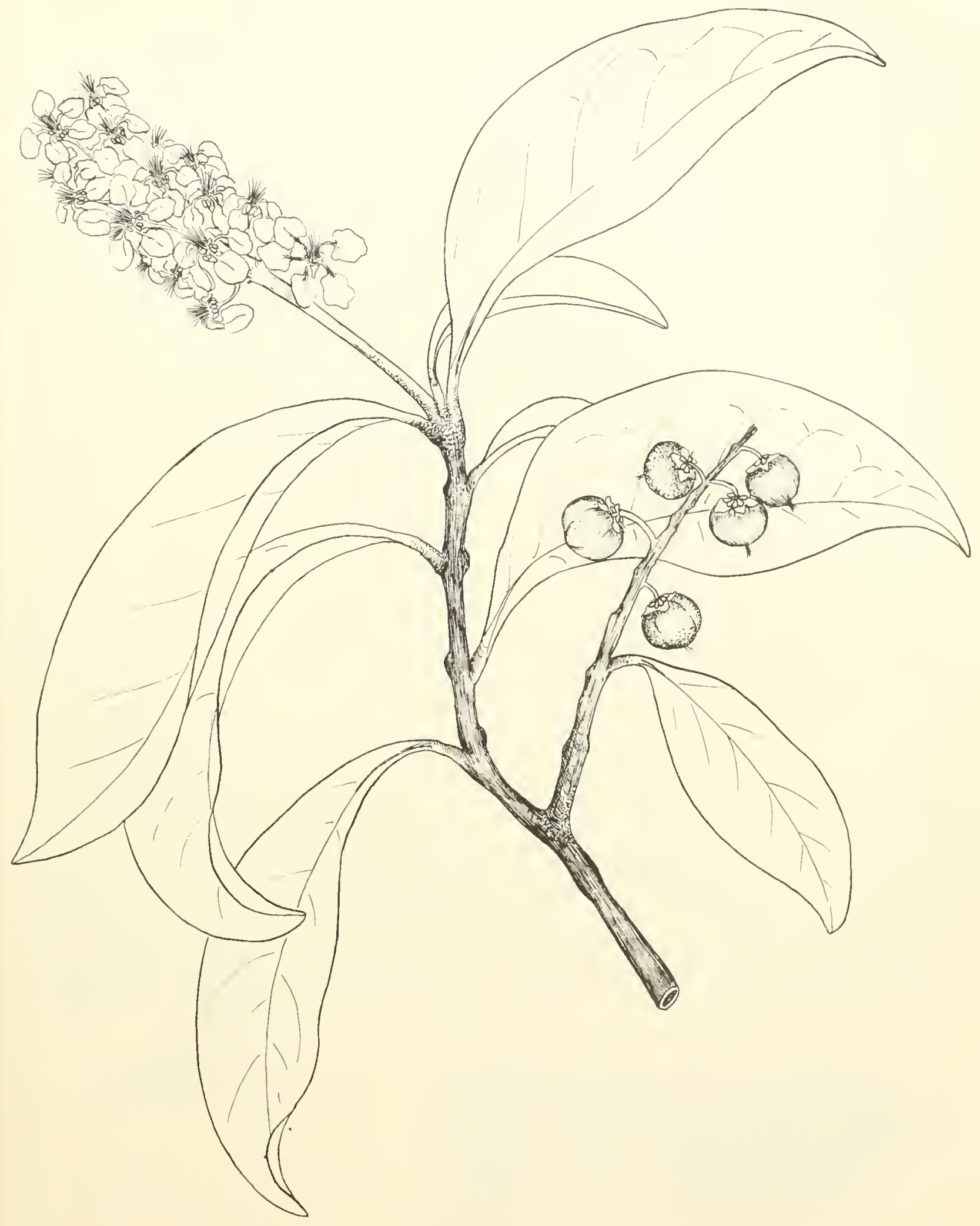

116. Maricao cimarrón 


\section{MILKWORT FAMILY (POLYGALACEAE)}

\section{Violeta, violet-tree}

Native only in Puerto Rico, violeta is well known hy the beantiful masses of riolet-colored Howers about :it inch across, slightly pea-shaped, which cover the tree from February to March or April, generally when leafless. Other distinguishing chanders are: (1) the elliptic yellow-green leaves 2-5 inches long, slightly thickened and leathery, with a peculiar arrangement of many nearly paralle], slichtly raised, thin, lateral veins;

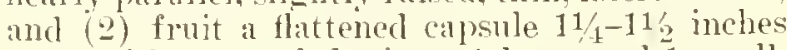
long, with 2 romnded wings, 1 large and 1 small.

I small to merlinm-sized deciluous tree $15-40$ feet tall with trunk $4-8$ inches in diameter, rarely to 65 feet in height and to 2 feet in diameter. The gray bark is smoothish to slightly fissured. inner bark light brown and bitter. The slender, light green twigs are minutely hairy when young.

The leaves are altermate on short petioles $1 / 4-3 / 8$ inch long. Leaf hlades are $1-21 / 2$ inches wide, short-pointed to rounded at both ends, slightly turned under at edges, shiny above and dull beneath.

The flowers appear in profusion when the trees a re leafless or before the old leaves are shed, bome on slender stalks in short lateral clusters ( $r a-$ cemes). Both calyx and corolla are riolet. There are 3 small sepals $1 / 8-3 / 16$ inch long and 2 large elliptic sepals (wings) $9 / 16$ inch long; usually 3 unequal petals about $9 / 16$ inch long, the central petal keeled and enclosing the stamen tube, and sonetimes 2 additional petals $1 / 8$ inch long: 8 stamens nearly $1 / 2$ inch long, mited into a split whitish tube; and pistil consisting of green

\section{Polygala cowellii (Britton) Blake}

rounded 2-celled ovary $1 / 16$ inch long and curved strle $5 / 8$ inch long.

The seed capsule has a large eurved or rounded wing $11 / 4-11 / 2$ inches long on 1 side and a small wing $1 / 2$ inch long on the other and contains $1 \mathrm{or}^{\circ}$ sometimes hairy seeds $5 / 16$ inch long, maturing in March or April.

The yellow or light brown wood is hard and is little used.

'I'he trees are worthy of cultivation as ornamentals for the very showy flowers. They are evidently slow growing.

In forests of hillsides and arroyos, mostly in the sonthern coastal region but scattered also through the moist limestone and lower Cordillera regions of Puerto Rico. Rare on the limestone hills of the northern coast near Toa Baja, Vega Baja, and Arecibo.

Public forest.-Guámica.

Raxise-Known only from Puerto Rico.

Other conmon vares. - árbol de violeta, palo de violeta, palo de tortuga, tortuguero (Pnerto Rico); Puerto Rican violet-tree (English).

Botayical sromyat-Phlebotaenia covellii Britton.

The scientific name honors John Francis Cowell (1852-1915), director of the Botanical Garden of Buffalo, New York, who aided in collecting at Coamo Springs the botanical specimens from which this species was described.

Trees are unusual in this genus. The 4 other Puerto Rican species are herbs. 


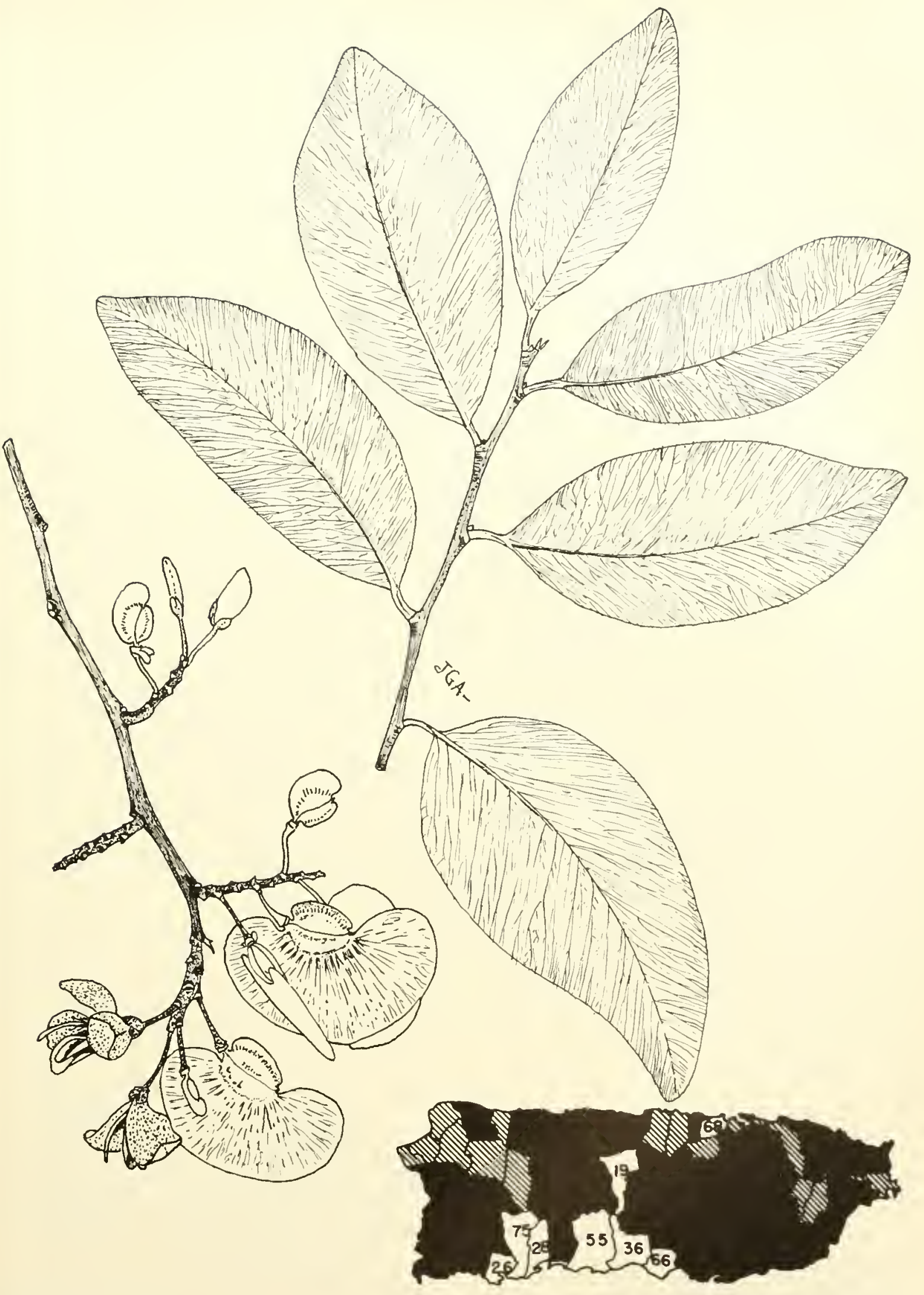

117. Violeta, violet-tree Natural size.

Polygala covollii (Britton) Blake 


\section{SPURGE FAMILY (EUPHORBLACEAE)}

Key to the 12 species illustrated (Nos. 118-129)

A. Leares 3 or more at a node; nodes with rings-122. Euphorbia petiolaris.

A. Leares alternate: nodes without rings.

B. Leaves with 3 main reins from base.

C. Leaves with coarsels saw-tunthed edges and 2 straight lateral veins from romded base-11s. Alchornea latifoliu.

CC. Leares with inconspieuously war-tonthed edges and 2 curved reins from shortpointed base-119. Alchorncopsis portoricensis.

BB. Leaves with 1 main rein or midrib.

D. letiole more than 1 inch long: leaves in more than 2 rows.

E. Leaves with sereral lateral veins at acute angles to midrib.

F. Leaves short-pointed at hase, the edges not toothed; tins dutlike hrown seales on twigs, petioles, and leaf blades.

G. Leaves thick and leathers, sliort-pointed at both ends, petiole silvery hrown-120. Croton poreilunthus.

Gr. Leaves slightly thiokened, rounded or blunt-pointed at hoth ends, petiole usually reddish tingud-126. Hyeromima clusioides.

FF. Lobres hroad at lose, with twotherl edges, without srales, mostle hairless.

11. Leaves short-pwited at apex and ronnded at base-124. Himpomane mancinclla.

111. Leaves abruptly long pointed nt apex and heart-shnped at liase-125. Hura erepitans.

EE. Leares with mang straight, parallel lateral reins almost at right angles to midrib-129. Sapium lauroecrasus.

DD. letiole slon't, less than 3/4 inch long: leaves in "2 rows.

I. Leaves hroadest hesond middle, often with a few teeth toward apex-123. Gymmanthes lucida.

11. Leaves broadest below or near middlo. without tecth.

J. Ieaves many alnng slender deciduons twigs and appearing to be pinnate, orate. 1-3 inches long, on vers short petioles 1's inch long-127. Phyllanthus acidus.*

JJ. Leaves sereral, not appearing to be pinnato. 2-6 inches long, on petioles more than $1 / 8$ ineh long. 15. Leares widels spaeed, lance-shaped, slightly thickened, upper surface slightly shiuy-121. Druprtes glaucu.

IK. Leaves hanging down, (lliptic. thin, upler surface dull green, lower surface pale whitish green-12s. Phyllanthus nobilis.

\section{Achiotillo}

A widely distributed tree distinguished by: (1) reddish-brown smooth bark; (2) long-petioled large yellow-green elliptic leaves with coarsely saw-toothed edges and 2 prominent, long, straight lateral veins at the rounded base, and shortpointed at apex; (3) many small greenish or yellow-areen stalkless flowers, the male on branched lateral axes and the female on nnbranched axes of different trees (dioecious) : and (4) seed enpsules $3 / 8$ inch in diameter, with 2 long styles, 2-seeded.

I medium-sized evergreen spreading tree attaining $: 30-50$ feet in height and $11 / 2$ feet in trunk diameter. The imner bark is whitisl and slightly bitter. The brown twigs, greenish and with groups of tiny star-shaped hairs when young, have raised nearly pomd leaf sears.

The alternate leares have petioles 11/4-21/6 inches long ancl blades +-716 (sometimes to 10 ) inches long and $21 / 2-41 / 2$ inches broad, slightly thickened. and slightly shiny on upper surface. The hase has 2-4 smill glands, and lower surface has minute tufts of hails in vein angles and, when young, seat tered small stal-shaped hairs.

The flower elusters (spikes) are 2-8 inches long, with groups of timy star-shaped hairs on the slender axes. Male flowers are few together, about $1 / 8$ inch long and broad, with ealyx splitting into 3 or 4 lobes and with 8 or fewer stamens. Female flowers single or paired along a drooping axis have a t-lobed calyx $1 / 16$ inch long and pistil with

\section{Alchornea latifolia Sw.}

2 -celled orary less than $1 / 8$ inch long and 2 long styles $1 / 2-3 / 4$ inch long.

Seed capsules are nearly round but slightly flattened, dark red when immature but becoming dark brown, the 2 long brown styles bresking ofl. There are 2 red, tubercled seeds $1 / 4$ inch long. Flowering and fruiting nearly through the rear.

The heartwood is light brown, and the sapwood similar or whitish. 'The wood is firily soft, moderately lightweight (specific gravity 0.39$)$, mocierately strong for its weight, of medium texture, with straight to slightly way grain, and withont wrowth rings. Reddish-brow radial canals appear on the surface as small holes. The rate of air-seasoning and amount of degrade are moderate. Machinine characteristics are as follows: planing is gool: shaping, turning, boring, and nortising are poor: sanding is rery poor and resistance to screw splitting is excellent. The wood is not durable and is rery susceptible to attack by dry-wood temites and other insects.

In Puerto Rico the wood is used for posts and fuel. It is suitable for kite sticks and other small bent parts, boxes, crates, toys, temporary cement forms, and ntility reneer. With preservative treatment it wonld serve for light carpentry and some types of exterior construction.

This rapidly growing tree has been introdnced for shade in southern Florida.

Commonest in the mountain forests of Puerto Rico, including the upper monntain regions, but 


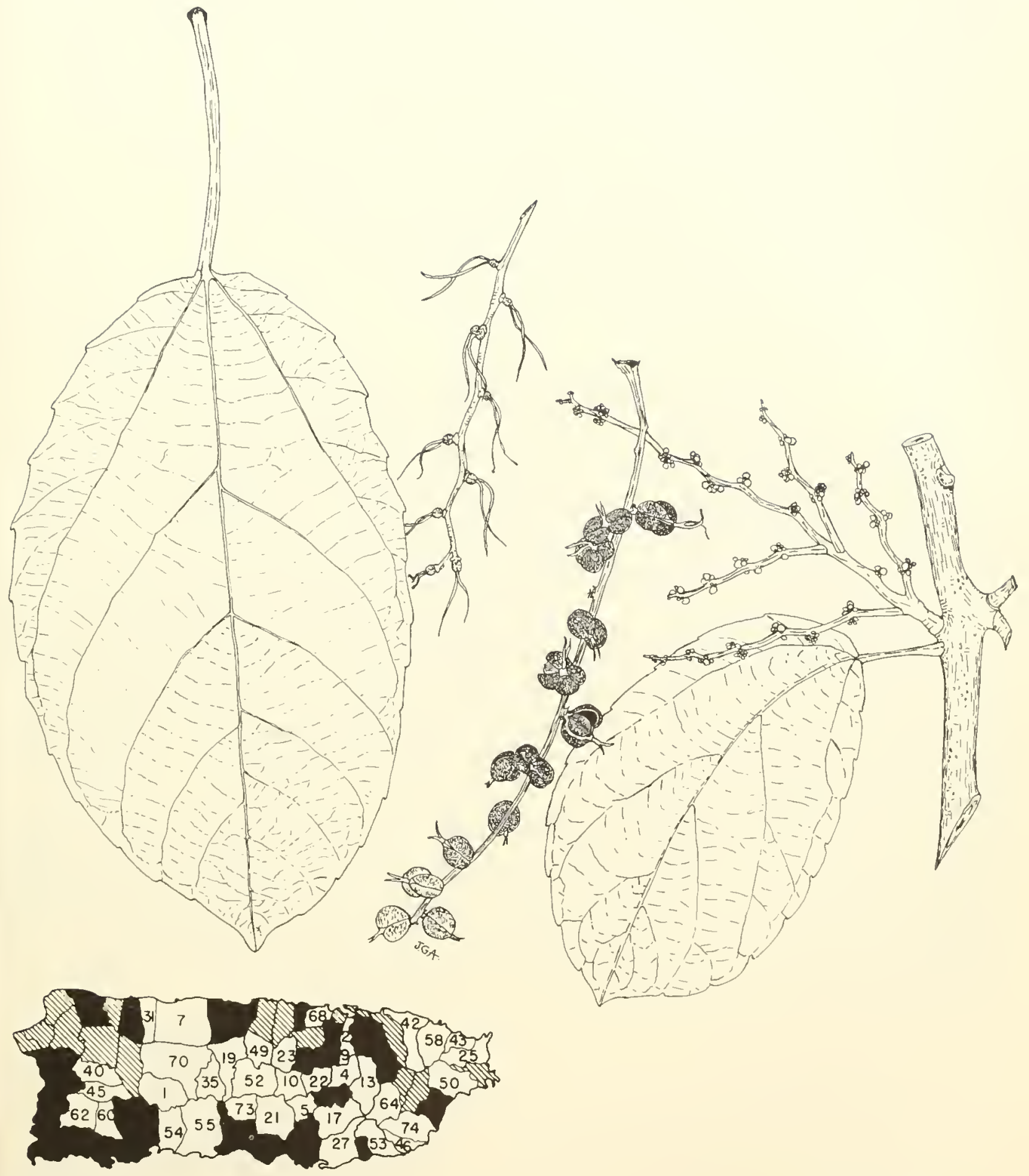

118. Achiotillo 
also in the moist limestone and moist coastal regions. Growing mainly in openings in the forests and along roadsides where there is plenty of light. Also in Tortola.

Public ronests.-Carite, Guilarte, Luquillo, Maricao, Río Abajo, Toro Negro.

MUNICTPAITIES WHERE ESPECIALLT COMMON.$1,4,5,10,19,22,23,35,43,52,58,64$.

Range.-Cuba, Jamaica, Hispaniola, Puerto
Rico, and Tortola. Also from southern Mexico to Panama. Planted in southem Floridla.

OTHer COMMON NaMes.-palo de cotorra (Puerto Rico); aguacatillo (Dominican Republic, Cuba); bacona, chote (Cuba); palo mujer (Mexico); carretón, cajetón (Guatemala); canelito (Honduras); pochote, tambor (El Salvador); dovewood (Jamaica); bois crapaud, bois vache (Haiti).

\section{SPURGE FAMILY (EUPHORBIACEAE)}

\section{Palo de gallina}

This small to medium-sized tree of mountain forests is recognized by : (1) thin, light or yellowgreen, elliptic leaves with 3 prominent reins from base of blade, the midrib and 2 long and curved lateral reins, short-pointed at both ends, and with inconspicuously wary-toothed edges; (2) numerous small greenish or vellow-rreen flowers borne on very short stalks along slender lateral axes $1-3$ together and 1-2 inches long, male and female on different trees (dioecious); and (3) brown seed capsules $3 / 16$ inch in diameter, 3-seeded. Distinguished from achiotillo (Alchornea latifolia $\mathbf{S w}$.) by the smaller and narrower leaves with few lateral reins and with less prominent teeth and by the smaller seed capsules with 3 short styles.

A generally elect evergreen tree 20-50 feet in height and to $1 \frac{1}{2}$ feet in trunk diameter. Bark on small tmunks is smoothish, slightly fissured, and light gray. Innel bark is brownish, with gritty and slightly bitter taste. The light brown twigs are finely hairy when young.

The alternate leaves ha re slender petioles $3 / 4-11 / 4$ inches long and blades $3-51 / 2$ inches long and $13 / 4-23 / 4$ inches broad, slightly shiny.

\section{Alchorneopsis portoricensis Urban}

The flower clusters (narrow racemes) and flowers are minutely hairy. Male flowers $1-4$ together have a calyx splitting into 3 or 4 lobes and have 5-8 (usually 6) stamens. Female flowers have a 4-lobed calyx and a pistil composed of a rounded, finely hairy, 3 -celled ovary and 3 short styles. The seed capsules have 3 whitish seeds $1 / 8$ inch long, the surface with irregular ridges. Flowering and fruiting perhaps nearly through the year.

The sapwood is soft and whitish, and the heartmood is pale brown. The wood is moderately soft, lightweight (specific gravity $0.4-0.5$ ), and perishable. It does not plane well. Used occasionally for fuel.

Forests of the upper and lower mountain regions in the eastern half of Puerto Rico. A lightdemanding tree generally found in openings in the forest, and often in or beside swampy areas.

Prblic forests.-Carite, Luqnillo, Toro Negro.

R.sxge.- Hispaniola and Puerto Rico.

Other common name.-palo de gallina (Dominican Republic). 


\section{SPURGE FAMILY (EUPHORBIACEAE)}

\section{Sabinón}

This tree with watery latex, confined to the eastern mountains of Puerto Rico, is distinguished by : (1) lower surface of leaves, petioles, young twigs, flower stalks, flowers and fruits silvery green or brown, being covered with tiny round silverybrown scales: (2) the leares elliptic, thick and leathery, $3-i$ inches long and $2-3$ inches wide. short-pointed at both ends, the upper surface green to dark green, and slightly shiny; and (B) the many small silvery-brown male and female flowers almost stalkless on a terminal axis $3-\bar{t}$ inches long.

A small or medimm-sized evergreen tree attaining 20-40 feet in height and 10 inches in trunk diameter, with irlegular spreading crown. The bark is smoothish and ninutely fissnred or warty, glay or brown. Inner bark is pink, slightly bitter with a burning taste. There is a small amount of whitish watery or nearly transparent latex. The leaves are alternate on petioles $3 / 4-2$ inches long, the blades not tootherl on edges.

The flower clusters (racemes) have all male flowers, or also a few female flowers at base, or all fenale flowers (monoecious). Male flowers $3 / 8$ inch long and broad hare a gray-green scaly calyx with $3 \mathrm{or}^{4} 4$ deep lobes $3 / 16$ inch long, 5 whitish scaly petals $3 / 16$ inch long, and about 20 whit.ish

\section{Croton poecilanthus Urban}

spleading stamens. Female flowers about the same size have a cup-shaped, gray-green, scaly calyx 3/16 inch long inchuding the 5 short lobes, and pistil with gray-green, scaly, 3-celled ovary and 3 large whitish styles, deeply forked and appearing as 6 , afterwards turning black and remaining attached to fruit.

The seed capsules are nearly round but longer than broad, slightly 3-angled, about $1 / 2$ inch long. It maturity the capsule separates into 3 brown parts, each falling from the axis and splitting open to release a brown seed $3 / 8$ inch long. Flowering and fruiting nearly thronghout the year.

The sapwond is whitish, and the heartwood is light yellow. The wood is moderately hard and moderately heary (specific gravity 0.6). It is used only for posts and fuel.

An understory tree in the upper Luquillo forest region and extending down the slopes into swampy areas and along stream conrses in the upper portion of the lower Luquil]o region of Puerto Rico.

PerLic foliest.-Inquillo.

R.ANGE.-Known only from momtains of eastern P'nerto Rico.

The other native species of this genus inclucte 10 of shrubs and 2 of herbs. 

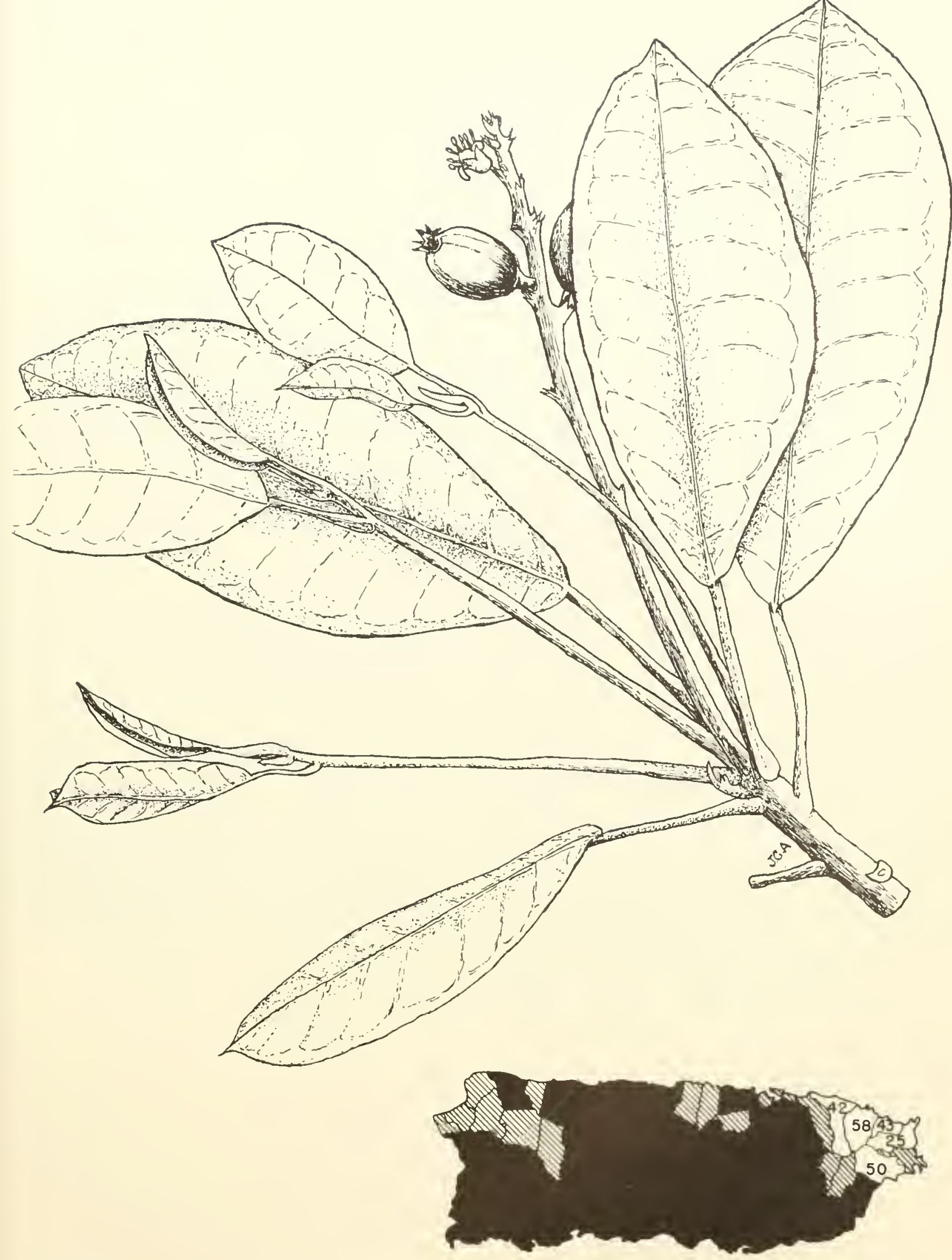


\section{SPURGE FAMILY (EUPHORBIACEAE)}

\section{Varital}

A small to medium-sized understory tree characterized by: (1) smooth whitish or light gray bark: (:2) broadly lance-shaped, dark green leaves, $: 31 / 2-6$ inches long and $11 / 4-2$ inches broad, abruptly long- or short-pointed, usually widely spaced, in 2 rows on horizontal or slightly drooping twigs: (3) small greenish flower's about $3 / 16$ inch across and $1 / 8$ inch high, 1 to several at base of leaves, the male and female flowers on different trees (dioecious); and ( 4 ) whitish elliptic fleshy fruits $5 / 8$ inch long, borne along the branches at base of leaves.

In evergreen tree commonly 10-30 feet high and to $f$ inches in trunk diameter, with spreading branches, reported to reach larger size. The bark has small warts (lenticels). The inner bark is light brown or orange and slightly bitter. Young twigs are green, minutely hairy, becoming gray.

The alternate leaves have petioles $3 / 8-3 / 4$ inch long and hlades often oblique at base, a little thickened, not toothed on edges, slightly shiny on upper surface, and paler beneatl.

Male flower's on short, hairy stalks less than $1 / 4$ inch long have 4-5yellow-green, minutely hairy. spleading sepals, 6-8 spreading stamens, and a broad lobed disk. Female flowers are single $\mathrm{or}^{*}$ paired on short hairy stalks about $3 / 8$ inch long, with 4 wreenish, slightly hairy sepals and pistil

\section{Drypetes glauca Vahl}

with hairy 1-celled ovary and broad stigma. The fruits (drupes) are finely hairy or hairless and 1-seeded. Flowering and fruiting from spring to fall.

The sapwood is whitish and hard. The wood is used for charcoal and posts and in the Lesser Intilles for construction.

Widely distributed in the lower mountain regrions of Puerto Rico. Also reported long ago from St. Croix.

Prblac ronksts.-Carite, Guilarte, Luquillo, Maricao, Toro Negro.

Range--Hispaniola, Pnerto Rico, and Lesser Intilles from St. Kitts to St. Vincent. (Reported also from . Jamaica, perhaps in error.)

Otiler conyox names. - palo blanco, palo de aceituna, cafeíllo (Puerto Rico) ; bois café, café grand bois (Guadeloupe).

Three arlditional species of this genus are trees ol shrubs. Hueso (Drypetes alba Poit.), known also as palo cle raca and cafeíllo, has smaller elliptic whitish fruits less than $3 / 8$ inch long. Cueriduro or Guianaplum (D. laterifiora. (Sw.) Krug \& Urban), native also as far as southern Florida, has romded dark brown fruits $1 / 4-1 / 2$ inch long. Encinilla (I). iticifolia Krug \& Urban), known only from norther'n Puerto Rico, has spiny toothed oblong leaves and elliptic fruits about $3 / 4$ inch long. 


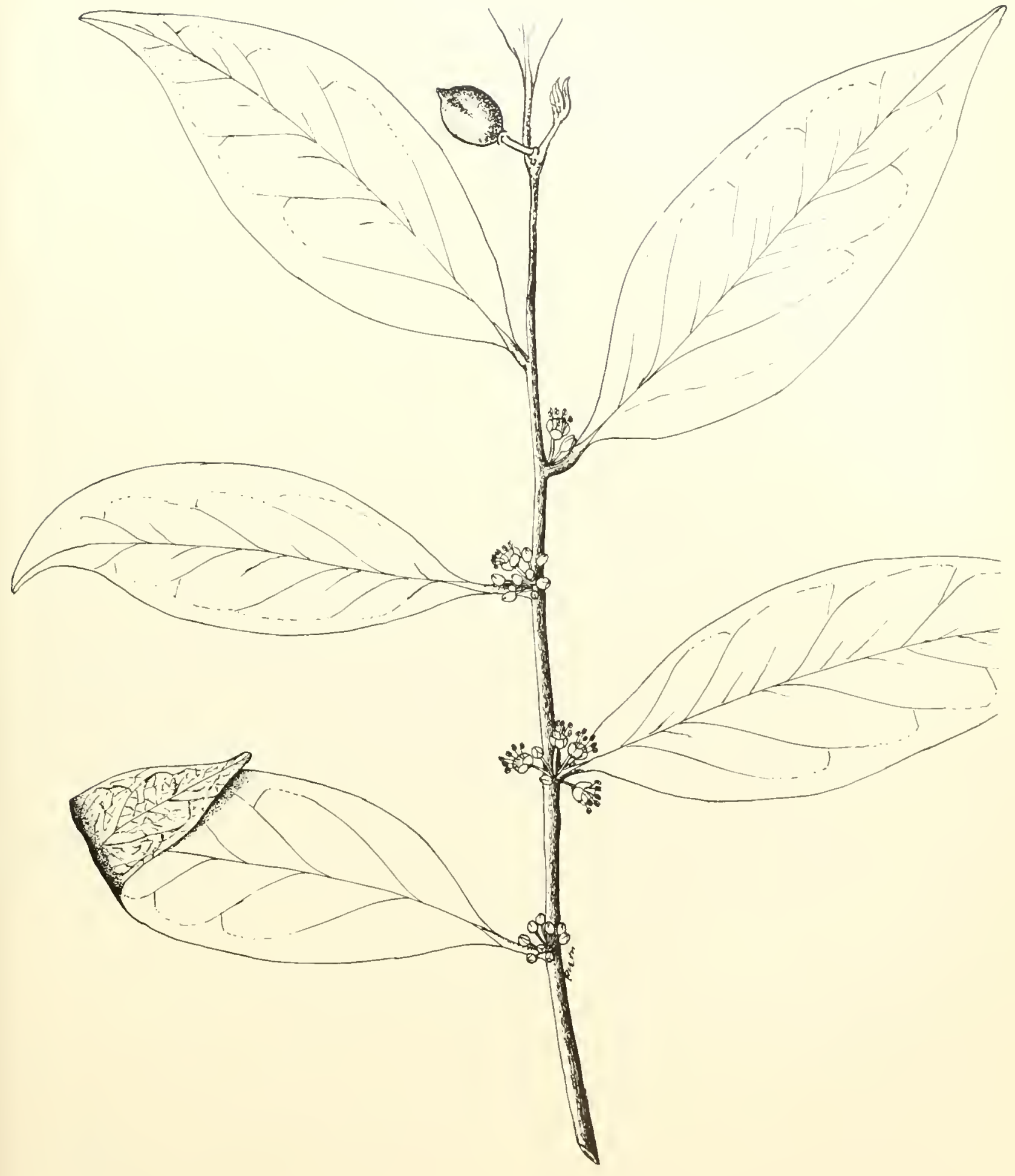




\section{SPURGE FAMILY (EUPHORBIACEAE)}

\section{Rascaso}

A poisonous shrub or small tree of dry and coastal areas with very toxic and caustic whitish latex irritating to the skin and easily recognized by: (1) shiny brown bark peeling off in papery layers and rery thin; (2) jointed twigs bearing 3-8 leaves at the swollen nodes; (3) slender petioles mostly longer than the blades; (4) small, orate or rounded, thin, green leaf blades about $3 / 8-3 / 4$ inch long and broad but slightly wider than long, rounder or minutely notehed at apex and nearly stright or rounded at base. The plants should be known in order to be avoided.

Deciduous and usually growing to 20 feet tall and $2-4$ inches in trunk diameter. The light brown inner bark. though almost tasteless, contains latex which is very irritating to the month. Twigs are light green when young, becoming gray and then dark reddish brown.

Petioles are $1 / 4-1$ inch long, reddish tinged, with glandular scales (stipules) at base. The blades have widely spreading lateral veins, are not toothed on edges, and a re pale beneath.

The inconspicuous minute male and female flowers both on the same plant (monoecions) are borne in a stalked green hemispheric cup (involucre) $1 / 8$ inch long, which has 5 yellowish petallike lobes each with a gland at base. The many male flowers within consist of a single yellow stamen less than
Euphorbia petiolaris Sims

$1 / 16$ inch long. The female flower is a single light green pistil with stalked 3-angled 3-celled ovary and 3 spreading 2 -forked styles.

The smooth 3 -angled capsule splits into 3 keeled parts, each containing 1 egg-shaped white seed 1/8 inch long, pointed and pitted. Collected in flowel in lugust and December.

The wood is little used because of the small size of the tree and the poisonous or caustic latex.

Common in thickets in the dry coastal and dry limestone regions of eastern, southern, and southwestern Puerto Rico. Also in Mona, Culebra, Vieques, St. Croix (?), St. Thomas, St. John, Tortola, Virgin Gorda, and Anegada.

Public forest.-Guánica.

Range.-South Caicos Island in Bahamas, Hispaniola, Puerto Rico and Tirgin Islands, St. Martin, Martinique, and Guadeloupe, and Margarita (Tenezuela).

Other commox names.-indio desnudo (Puerto Rico): broadleaf spurge (Bahamas); palo de leche, palo de yuca (Dominican Republic); bon garçon (Haiti); black mageniel (St. Martin).

Botanical squrus.-Alilema petiolare (Sims) Millsp.

This is the only native tree species of its genus. About 20) related native species are herbs and shrubs, sometimes placed in segregate genera. 


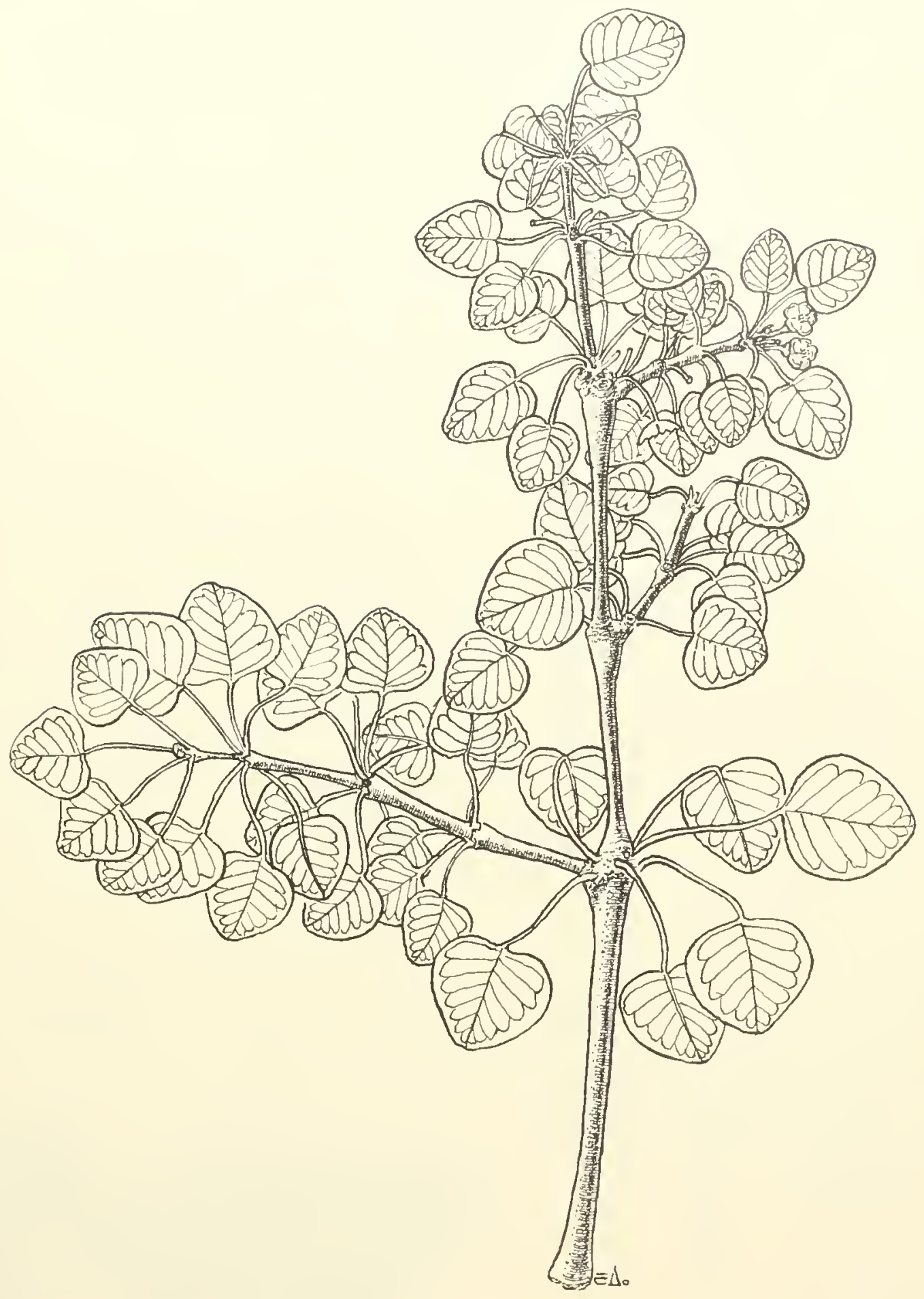




\section{SPURGE FAMILY (EUPHORBIACEAE)}

\section{Yaiti, oysterwood}

This poisonous small tree or shrub is characterized by: (1) poisonous milky juice which may irritate the skin; (2) slightly thickened stift shiny leaves reverse lance-shaped (oblanceolate) to nearly spoon-shaped (spatulate), broadest beyond middle, rounded or blunt-pointed at apex and tapering and long-pointed at base, often with a few small teeth toward the apex; (3) scaly or flaky bark on older trees; and (4) small yellowishgreen lateral flowers, the male numerous along an axis (narow raceme) $1 / 2-1$ inch or more in length and usually 1 female flower at the base (monoecious).

An evergreen tree becoming 30 feet high and 8 inches in trunk diameter, with a narrow crown. The bark is gray or brown, smoothish on young trees with many thin fissures. Inner bark is light brown and slightly bitter. The gray twigs, green when young, have many laised dots (lenticels).

The alternate leaves have petioles $1 / 4^{-1 / 2}$ inch long and leathery blades $1 \frac{1}{2}-31 / 2$ inches long and $1 / 2-11 / 4$ inches broad, green to dark green above and paler beneath. The edges ase slightly turned under, and veins are slightly raised in a prominent net work on the upper surface.

The crowded male flowers are borne 3 above a scale (bract) on the axis, each minute (less than 1/32 inch long and broad) and consisting of a smaller seale and 2-1 stamens. They are faintly fragrant and attract bees. There is 1 female flower (or none or sometimes 2) 1/16 inch long at base of flower cluster, on a stalk $1 / 8$ inch long which lengthens greatly in fruit, and consisting of 3 scales and a pistil composed of greenish 3-celled ovary and 3 styles.

Brown seed capsules, bolne on slender stalks
Gymnanthes lucida Sw.

1-2 inches long, are rounded but slightly 3 -lobed and broader than long, about $3 / 8$ inch in diameter. There are :" or fewer brown seeds $3 / 16$ inch long. Flowering and fruiting from spring to fall.

'The sapwond is whitish or yellowish. The heartwood is light olive, streaked with dark brown. The wood is very fine-grained, very hard, very heary (specific gravity 1.1), takes a fine polish, and is durable.

ITsed in Puerto Rico for fenceposts, the generally small size limiting its values. The wood has been made into varions small novelties, including canes, handles, backs of brushes and mirrors, and omamental articles shaped by woodturning.

The white latex is reported to produce inflammation of the skin upon contact. It is said that smoke from burning wood is irritating to the eyes.

Forests and thickets in both limestone regions of Puerto Rico. Nlso in Mona, Desecheo, Icacos, Culebra, Vieques, St. Croix, St. Thomas, St. John, and Virgin Gorda.

Public ronests-Cambalache, Guajataca, Ginánica.

MUNICIPALITY WHERE FSPECIALLY COMMON.-9. Rivae.-Sonthern Florida including Florida Keys, Bahamas, Greater Intilles, and northern I esser Intilles from St. Eustatius to Antigua and Guadeloupe. Mlso in southeastem Mexico (Tucatán), Guatemala, and British Honduras.

OTHer common NAMEs.- ramón, tabaco (Puerto Rico): talacón, palo de hueso (Dominican Republic) ; yaití, aité (Cuba) ; pij (Guatemala) ; oysterwood, shiny oysterwood, clabwood (United States) ; crabwood (Bahamas, Jamaica); false lignumvitae (British Honduras): bois marbre (Haiti). 


\section{Manzanillo, manchineel}

The deadly manzanillo or manchineel is the most poisonous tree of Puerto Rico and the Virgin Islands and ranks among the most famous poisonous plants in tropieal Ameriea. The attraetive palatable fruits eause serious illiness or even deat $h_{1}$ when eaten. and the milky sap is injurious both externally and intermally. Growing along and near sandy seashore or sometimes inland, this tree is characterized by: (1) irritating milky sap in the leaves, twigs, aid bark; (2) round, yellow-green or yellowish fruits, tinged with red, 1-11/2 inches in dianeter, resembling small apples or guavas (guayabas) but very toxie, often littering the beaches; and (3) the long-stalked, shiny, leathery, vellow-green, ellipt ic leaves with minute wary teeth on edges, the sides bent upward slightly at the yellowish midrib, and with a raised dot (gland) at base of midrib.

An evergreen tree to 40 feet in height and 2 feet in diameter, usually smaller, with widely forking branehes and broad spreading erown. The bark is dark brown or gray, sealy or fissured or with warts, as mueh as $1 /$ inch thiek. Inner bark is light brown or whitish with bitter lasting irritating taste and with poisonous white sap or latex. Twigs are green when young, beconing bromuish gray, and smooth.

The altemate leaves have round vellow-green petioles $11 / 2-2$ inches long. The leaf blades are $2-4$ inches long and 11/4-21/2 inches wide, shortpointed, rounder at hase, shiny on upper surface and dull and paler beneath.

The ineonspicuous greenish male and female flowers are borne stalkless along a glandular greenish terminal axis (spike) $2-4$ inches long (monnecious). Male flowers are in groups of 5 15 each, about $1 / 4$ ineh long, composed of calyx with 2 or 3 lobes and 2 or 3 stamens. Female flowers, 1, 2, or none at base of same axis, about $1 / 8$ inch long and broad, consist of 3-lobed calyx and pistil with 6-8-celled orary and 6-8 eurved short brown styles.

The stalkless fruits (drupes), single or paired but produced in quantities, appear lateral after forking and continued growth of twigs beyond. The sweet-srenter fruit has a sunken spot at end and greenish-white mellow flesh which is palatable and not irritating to the taste though very toxic. A lard stone eneloses 6-8 dark brown seeds 1/4 inch long. Flowering from spring to October, the fruits maturing almost a year later.

The sapwood is light brown or sellowish, and the heartwood dark brown. The wood is fairly hard, mediumweight (specific gravity 0.5 ), and strong, taking a good polish. Though reported to be rlurable, it is very susceptible to attaek by drywood termites. The wood has been employed for furniture, cabinetwork, interior finish, and con-
Hippomane mancinella $\mathrm{L}$.

struction. Though the poisonons sap adds diffirulties to logring and handling lumber, the trees "an be wirdled in advance or the hark can be burned ofl or charred before felling.

The eaustic milky sap is partieularly irritating to the eves and mouth, causing prolonged pain. It also produces severe inflammations and blisters on the skin of some persons. However, in some places it has been employed in local medicines. Caribs poisoned their arows with this toxio liquid. As smoke from hurning parts of the tree causes inIlammation of the eves, the wood should not be used for fuel. It is reported that lain water dripping from the leaves is injurions. It has been claimed that a person who rested or slept under the of these trees would lie injured, blinded, or eren killed, hut these exargerated reports are erroneons. Classed as a honey plant, the honey remolted to be nontoxic.

Early explorers, who discovered this tree along beaches, ate the attractive, aromatic, tempting fruits, which resembled wild apples or crab apples, with disastrous and sometimes fatal results. In 17.in, a royal ordinance prescrilsed destruction of al] manzanillo trees at St. Barthéleny. However, as recently as 1940, during the late war, famished survivors of a sunken ship were poisoned by eating these fruits after landing their lifeboat on an uninlabited beach there. Taken promptly to a hospital, they recovered after a few days. Mbout 188. these fruits poisoned 54 German seamen at Curacao, causing the deatli of 5 and serious illness of the others.

Two persons were hospitalized at St. Thomas in 19.it after consuming these dangerous fruits. Prompt treatment includes eausing romiting and use of a stomach pump.

Livestock have also been affected and should not be confined in areas with these trees. The fruits have poisoned hogs. Cattle have suffered skin irritation from contact with the plants.

Perhaps the wide distribution along tropical shores, ineluding small islands, resulted from dissemination of the fruits by oeean eurrents. Near settements the eradieation of these dangerons trees has been undertaken, for example, in southern Florida.

Fortumately this species is Joenl and not very common in Prerto Rico. However, it is distributed also through the Virgin Islands, being eommonest on St. Croix.

The trees grow in eoastal woods and thickets, sometimes singly, along and near sandy seashores and on rocky eliffs in both wet and dry areas around the islands. They are less common inland along streams. In the Virgin Islands they are found oecasionally along roadsides, fences, and ditehbanks, in pastures and waste grounds, and around houses. Puerto Rico, Desecheo, Mona, 
Icacos, Culebrn, Tieques, St. Croix, St. John, St.

Thomas, and Tirgin Gorda.

Prolic rorest.-Guánica.

RAxiE-Chiefly along shores in southern Florida including Florida Keys and thronghout Trest Indies from Balamas and Cuba to Trinidad and Tobago and in Bonaire, Curaçao, and Amba. Also Atlantic and Preific consts of Mexico and Central America to Colombia, Ecuador, and Tenezuela. ( )n Revillagigedo, Galapagos, and other islands.

OTHER COMMON NAMEs.-poison-guava, manchioneel (Tiroin Istands) : manzanillo (Spanish, commerce): manzanillo de costa, pinipiniche (Cuba); manzanillo de playa (Costa Rica); manzanillo de playa, limoncillo (Venezuela); manchineel (Tnited States, English); mancinillier (French); maximilier (Guadeloupe, Martinique) : mangeniel, manzalinja, manzanilla (Dutch Test Indies).
The English name manchineel is a corruption of the Spanish word manzanilla (little apple), from which the Latin scientific name also is derived. This genus has only one species.

Symptoms and treatment of manzanillo or manchineel poisoning in the Grenadines have been summarized by Richard 1 . Horrard ${ }^{1}$ as follows:

"Serions nausea and diarphea are usually followed by slock and hy an appalling muschlar weakness. Sloughing off of mucous membranes occurs within a day or two if even a small quantity of the fruit is eaten. The juice of the tree or the fruit in the ere will cause violent conjunctivitis and nsually temporary blindness. Arrowroot is considered the best antidote for this poison in the Grenalines. A suspension of arrowront starch is giren in liberal doses when the fruit has been eaten and poultices of arrowront starch are applied to external burns from the juice of the manchineel."

\footnotetext{
${ }^{1}$ Howard, Richard A. The regetation of the Grenadines, Trindwarl lslands, British West Indies. Harrard Univ. Gray Herbarium Contrib. 174, 129 pp., illus. 1952.
}

\section{SPURGE FAMILY (EUPHORBIACEAE)}

\section{Molinillo, sandbox, hura}

This handsome lare tree, with sap and seeds both poisonous, planted along highways and in pastures and wild, is recognized by: (1) a globular crown of dense folinge: (2) the trunks and branches usually with many blackish spines $3 / 5^{-3 / 4}$ inch long on the smoothish light brown bark; (3) heart-slaped leares with blades curved up at the midrib, 5-8 inches long and 4-5 inches broad, abruptly long-pointed, with or without teeth on edges, and with long round green petioles about as long as the blades: (4) copious watery or slightly whitish latex, which is very irritating and poisonous: and (5) the large dark brown seed capsule $21 / 2-31 / 2$ inches in diameter and $11 / 4^{-11 / 2}$ inches high, groored into abont 15 sections.

Decidnous or nearly so, to 80 feet in height, with straight trunk 2-4 feet or more in diameter. The thick bark forms a sheath around the base of each spine. Inmer bark is light brown, irritating to the taste.

The leares are altemate on the stont green to bromn twigs. Blades are slightly thickened, dark green and slightly shiny above and paler beneath, in a variation hairy, especially on the veins beneath.

Male and female flowers are borne on the same tree (monoecions), the former numerous in a terminal crowded chister (spike) 1-2 inches long and $3 / 1$ inch in diameter at the end of a slender green stalk $21 / 2-4$ inches long and resenbling a short ear. of corn. Individual male flowers are $3 / 26$ inch long and $1 / 8$ inch broad, dark red, consisting of a cuplike calyx and $8-20$ stamens in 2 or 3 rings on the central column. Female flowers, also dark red,

\section{Hura crepitans L.}

are single and lateral near ends of twigs, on stout stalks $1 / 2-1$ inch long, and include a cup-shaped calyx $1 / 2$ inch long and broad and a pistil, the ovary of about 15 cells inside the calyx, a long tubular style $3 / 4-11 / 2$ inches long, and a prominent enlarged and flattened stigma $1 / 2-11 / 4$ inches across, including about 15 narrow lobes.

The sped capsule is flattened and sunken in the center. When dry it splits and explodes violently with a lond noise, scattering the hard 1-seeded sections at a distance. The brown seeds are rounded and flattened, 3/4-1 inch long and broad. Flowering from winter to summer, the fruit maturing in spring and summer.

The sapwond is whitish to light yellow, and the heartwood is pale yellowish brown, pale olive gray, or dark brown. The wood is moderately soft, moderately light weight (specific gravity 0.38 ), brittle, fine-textured and often with interlocked grain. Air-seasoning is rapid but moderitely difficult witl warping. The rood is very susceptible to attack by dry-wood termites and variable in durability:

In Pnerto Rico the rood is used chiefly for fenceposts and fuel. Elsewhere it is used for general carpentry, interior construction, boxes, crates, vencer, plywond, furniture, joinery, and poles. Formerly, dugont canoes were hollowed from large trinks.

The canstic, poisonous latex causes inflammation or eruption upon contact with the skin of some persons and is very irritating to the eyes, reportedly causing temporary blindness. It makes the tree mpopular with wood cutters. The juice has 


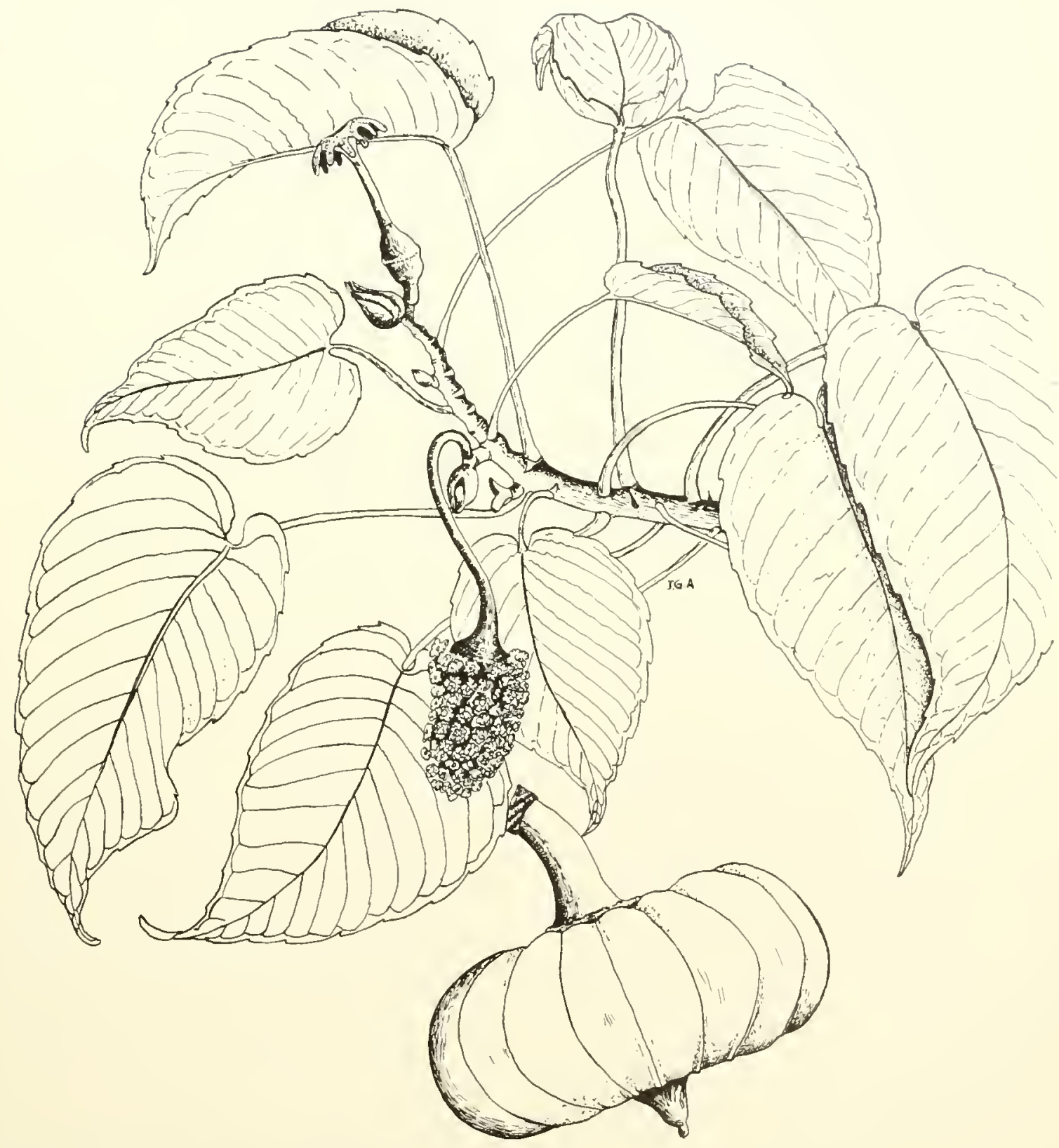

125. Molinillo, sandbox, hura 
heen used to stmpefy fish. The seeds are toxic to humans and livestock and have been employed in poisoning animals and in merlicine, lout such use is dangerons. Then exploding, the mature seed eapsules may injure or frighten persons and livest ock.

In some tropical areas, incluling sonthern Florida, the trees are planted for sharle. However, the poisonons sap makes the trees ol,jectionable around liouses. Joung trees grow laipidly but require plenty of light. Windstorms damage the trees.

Common as a roarlside shade tree and living fence along the moist coast of P'nerto Rico, mostly east of San Juan. Occasionally elsewhere on the island, planted and wild. Through the Virgin Islands scattered in moist forests and pastures and planted along fence rows and for shade. St. Croix, St. Thomas, St. John, and Tortola.

Rasul. - Thromeh West Indies from Cuba aur Jamaina to Trinidad and Tobago and on the emutinent from Costa Riea sonth to Peru, Bolivia. Brazil, and Guianas. Planted also in sonthern Florida and sonthern California, Bahamas, and Dutch Trest Indies. Cultivated and oceasionally naturalized in Old World tropics.

Otinel commos ximes.-javilla (Punto Rico); monkey-pist ol (Virgin Islands) ; habillo, habilla, jabillo, jabilla (Spanish); salvadera, haha (Cuba) ; tronador, nme (Panama) : ceibo amarillo, ceiba de leche, acnapar, tronarlor, castañeto (Colombia); ceiba, ceiba blanca, ceiba habillo (Veneznela) : catalnu (Peru) ; ochohó (Bolivia); lura (commerce); hura, hura-wood, possumwood, sandlox, sindbox-tree (United States, English); monkey-pistol, possumtree (English); monkey llinner-bell (British Guiana); sablier (French); arbre an diable (Haiti); bois du diable (Martinique); zandkokerboom, sandbox-tree (Dutch Vest Indies); possentrie (Surinam); assaeú (Brazil, commerce) ; catáluá, areeiro (Brazil).

The English nume sandbox and French name sablier refer to the early use of the hollowed out shell of immature seed capsules to hold sand, employed in blotting ink before blotters came into use. Paper weights have been made by filling the capsules with learl, but the capsules may come apart on drying.

A closely related species of jabillo ( II ura potyandru Baill.), ditlering in the white male flowers with more numerous stamens in a column $3 / 8-5 / 8$ inch long, is native from Mexico to Costa Rica.

\section{SPURGE FAMILY (EUPHORBIACEAE)}

\section{Cedro macho}

This medim-sized tree limited to Puerto Rico is characterized by: (1) a very miform, dense. bright green cromn, pyramidal on young trees; (2) twigs, petioles, branches of flower elusters, and Ilowers corered with tiny dotlike brown seales, which are less conspicuous on both leaf surfaces: (3) the elliptic leares blunt-pointed or rounded at both ends with wary and often recurved edges, slightly jointed and bent where the blade is attacherl to the usmally reddish-tinged petiole: and (4) numerous minnte yellowish-green flowers less than 1/s inch long in lateral branched elusters, male and female on different trees (dioecions).

Evergreen tree to 70 feet in height and 3 feet or morte in trunk diameter. The bark varies from scaly to fissured and lough, from gray to dark brown, and becomes more than $1 / 4$ inch thick. Inner bark is brown or reddish and slightly bitter. Twigs are light brown.

The leares are alternate on petioles $1 / 2-11 / 2$ inches long and have slightly thickened blades $21 / 2-5$ inches long and $11 / 2-3$ inches broad. The upper surface is oreen and slightly shiny, and the lower surface paler and with midrib often hairy.

Flower eluster's (panicles) $1-4$ inches long bear

\section{Hyeronina clusioides (Tul.) Muell.-Arg.}

flowers almost stalkless along the branches. Male flowers have a ('mp-shaped, 3-5-toothed scaly calyx. a hairy disk, and $3-5$, nsmally 5 , spreading stamens. Female flowers have a cup-shaped sealy ealyx and a pistil with 2 -celled ovary and 2 or 3 - forked styles. The nearly round fruits are less than 1/s inch long, reddish to blackish, slightly lleshy, and 1 -seeded. Flowering mainly in smmer and fall and in fruit from late summer to winter.

The salpwood is light brown, the heartwood rich reddish brown. The wood is hard, heary (specific wravity 0.8), finishes well, and takes a good polish. It is susceptible to attack by dry-rood temites. The wood has been employed both for furniture and constrution. It is considered heary for the former nse but is very attractive.

Distributed in Puerto Rico chiefly in the moist limestone and western lower Cordillera regions.

Purric Forests.-Cambalache, Carite, Guajataca, Guilarte, Maricao, Río Abajo, Toro Negro.

Raxie.- Known only from Puerto Rieo.

The generic name also is spelled IIieronyma. Reports of this species from. Jamaiea and from Dominiea to Trinidad refer to $I I$. jumaicensis Lrban and $I I$. caribaed Urban, respectively. 


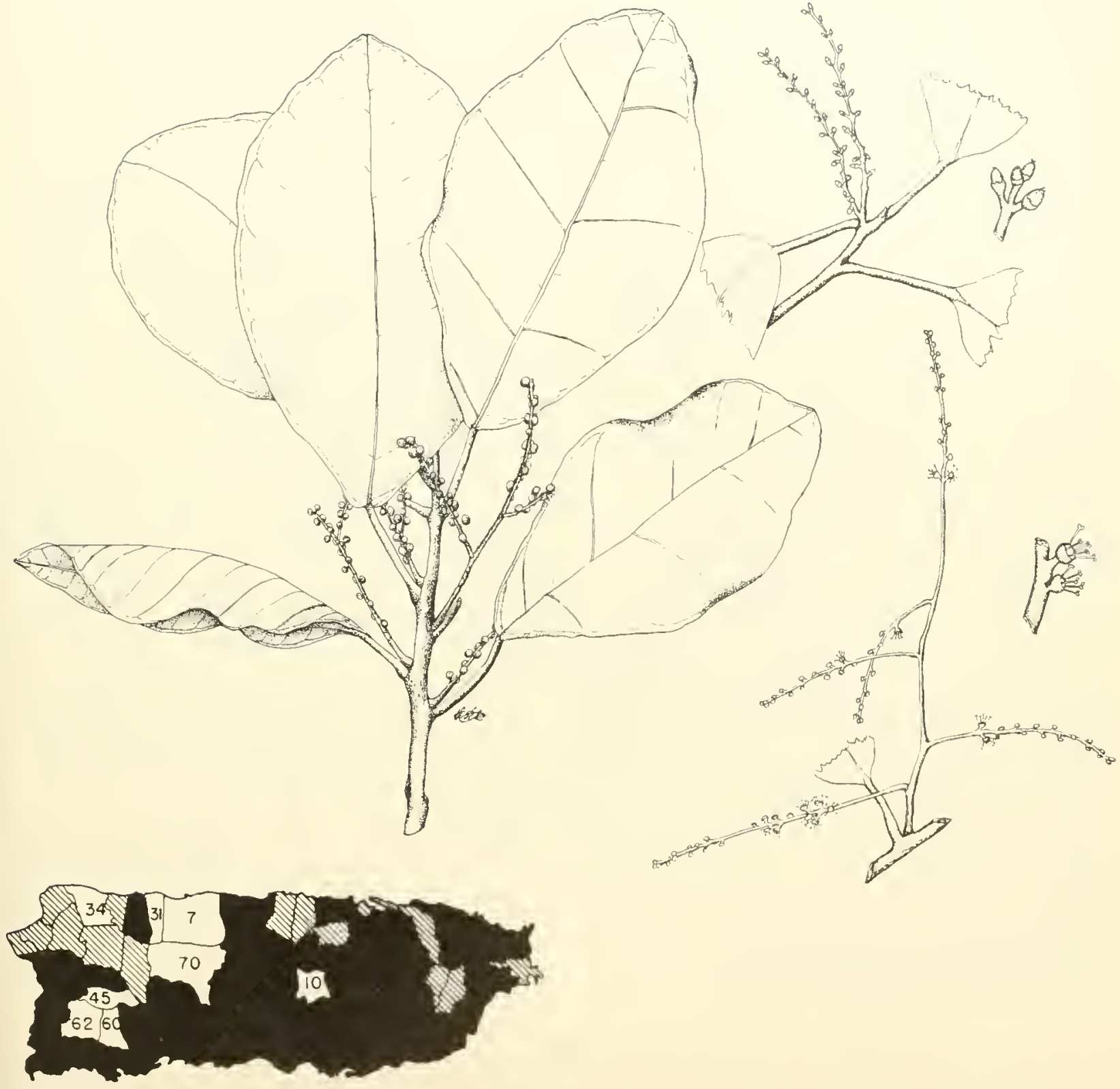

126. Cedro macho

Hyeronima clusioides (Tul.) Muell.-Arg. Two-thirds natural size. 


\section{SPURGE FAMILY (EUPHORBIACEAE)}

\section{Grosella, Otaheite gooseberry-tree}

A small tree cultivated for its edible sour fruits. It is distinguished by: (1) the light yellow juicy berries $3 / 4-\pi / 8$ inch in diameter, somewhat rounderl but broader than long and slightly 8 - or 6 -angled, suggesting a diminutive squash, hanging down in clusters from the branches: $(2)$ the simple leares altermate in 2 rows along slender deciduous twigs and appearing to be pimmate, orate, $1-3$ inches long and $3 / 4-11 / 4$ inches broad, short-pointed at apex and rounded at base, on short petioles $1 / 8$ inch long; (3) stout twigs rough from rounded raised trig scars; and (4) flowers minute and reddish or pink, t-parted and $1 / 5-3 / 16$ incli across, usually clustered along slender axes back of leaves.

A spreading deciduous tree attaining $20-30$ feet in height and 6 inches in trunk diameter. The greenish-gray bark is fissured and slightly scaly. Inner bark is pink and almost tasteless. 'The conspicuous persistent twigs are $1 / 2$ inch or more in diameter, brownish gray, green and slender at apex.

The leaves hang down from green or pinkishtinged trigs 6-12 inches long which appear to be axes of pinnate leaves and which shed from the stont twigs like leares. Blades are thin, green and slightly shiny above, and beneath pale blue green with a bloom. At base of each leaf are 2 minute pointed scales (stipules).

Flowers are bome mostly on slender leafless axes (panicles) 2-5 inches long, several clustered together on short stalks. Male and female flowers are mixed in the same clusters (monoecious) and have 4 spreading caly $x$ lobes about $1 / 16$ inch long but lack petals. There are 4 stamens also in male flowers, and in female flowers a pistil with 4-or 3 -celled ovary and 4 or 3 styles.

Frnits hang down in clusters, several along a slender drooping axis. The fruit contains a brownish stone with few seeds. Flowering and fruiting nearly through the year, fruiting chiefly in April and August.

The heartwood is reddish brown, moderately laard, fine-grained, of medium weight (specific gravity 0.6$)$, strong, tough, and fibrous. It is sairl to be durable and to take a good polish but, seldom being available, is little used.

\section{Phyllanthus acidus (L.) Skeels*}

Widely planted in tropical regions for the juicy sour fruits, which can be eaten raw but usually are made into jelly, preserves, candy, and pickles. The root and seed have been used in medicines. Introduced into the Wrest Indies in 1793.

Cultivated and also spreading along roadsides and waste places, chiefly in the coasta] regions of Puerto Rico. Also in St. Croix, St. Thomas, St. John, and Tortola.

RANGe.-Native of tropical Asia and perhaps also East Indies but extensively introduced and spontaneous and sometimes naturalized in tropical regions. Southern Florida, through West Indies from Bahamas and Cuba to Trinidad, Mexico, Central America, and South America.

Otrier common sanes. - cereza amarilla, cerezo agrio, grosella blanca (Puerto Rico); grosella (Spanish) ; guinda, pimienta (El Salvador); grosella de Nicaragua (Nicaragua); cerezo agrio, cereza (Venezuela); Otaheite gooseberry-tree, Otaheite-gooseberry, star-gooseberry, West-Indian-gooseberry, gooseberry-tree, jimbling (United States, English); wild-plum (British Fonduras); wild gooseberry (British Guiana); sybilline (Haiti); surelle (St. Barthélemy); pomme surelle (Guadeloupe) : gooseberry (Dutch TTest Indies) ; goesberie (Surinam); roselle (Brazil).

Botavicul srvosyus.-Phyllanthus distichus (L.) Muell.-Arg., Circe disticha L., C. acida (L.) Merr.

This species is botanically mrelated to the true gooseber'y, which is a prickly bush (Ribes grossuTaria L., family Saxifragacea) grown in temperate regions and having fruits with similar flavor.

The genus sometimes divided into several, is represented also by 2 native tree species, 1 of which is illustrated here, and by 6 species of herbs and shrubs. Jagüerillo (Phyllanthus juglandifolius Willd.; synonyms $P$. grandifolius auth., not L., Isterandra grandifolia auth.), known also as tobillo and gamo de costa, is a small tree with larger oblong or lance-shaped leaves $2-6$ inches long. 


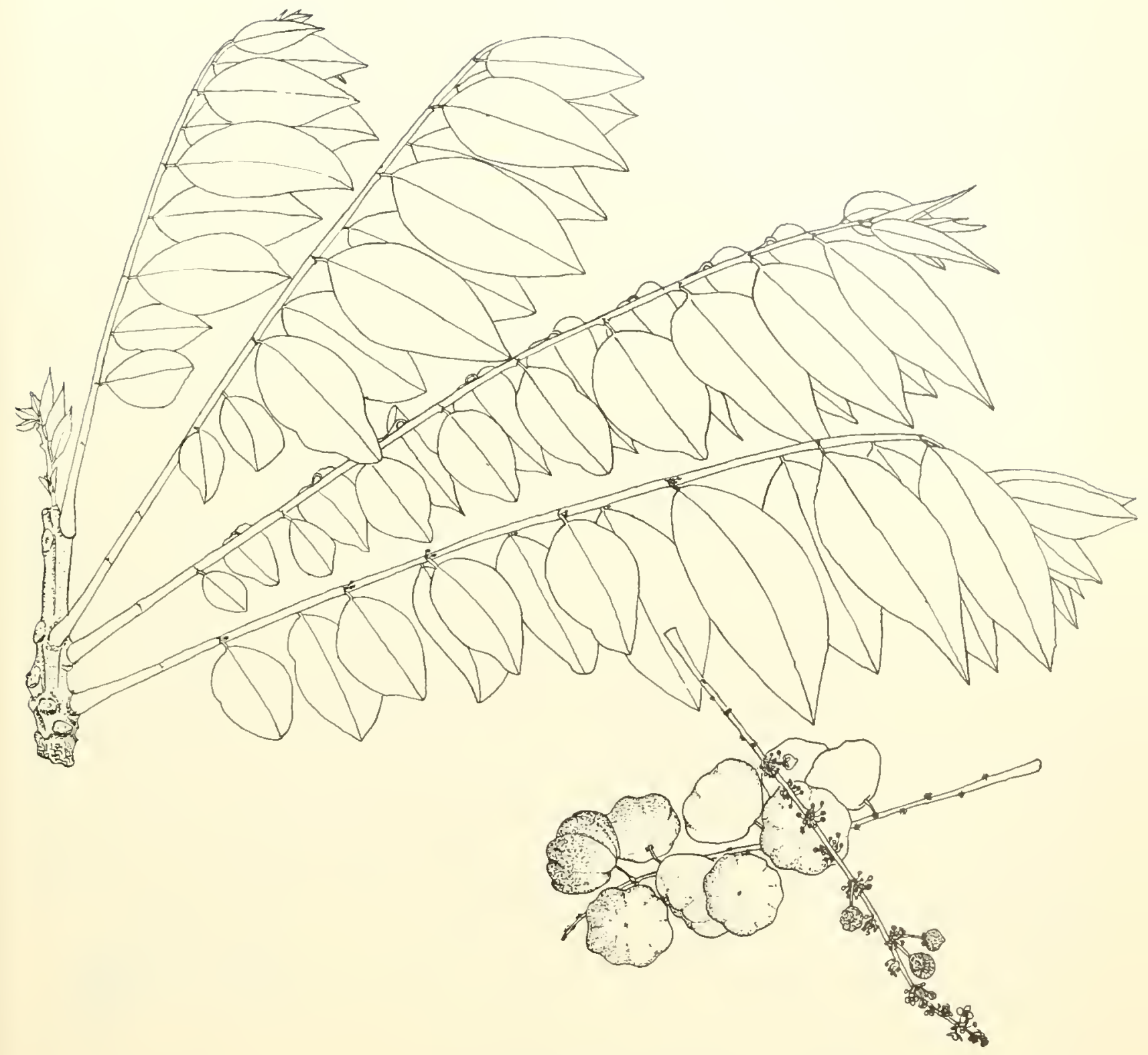




\section{SPURGE FAMILY (EUPHORBIACEAE)}

\section{Millo}

Millo is a small tree distinguished by : (1) dark brown twigs with numerous eonspicious, raised, light brown, warty dots (lenticels), the altemate leaves hanging down in 2 lows: (2) thin narrowly elliptic leaves $2-5$ inches long and $3 / 4-13 / 4$ inehes broad, short-or long-pointed at both ends, above dull green or dark green and beneath pale whitish green: (3) tiny 4-parted green flowers, male and female on different trees (dioecious) in lateral clusters scattered along the twig; and (1) greenish seed eapsules $5 / 16$ inch in diameter, rounded but broader than long, with 5 or 4 peculiar narrow 2-forked styles remaining flattened on apex, slightly fleshy but splitting into 5 or 4 dark blue segments, each 2 -seeded.

A deeidnous tree $2 \%-40$ feet high and to 8 inches in trunk diameter, with ilregular spreading erown. The bark is light aray, smoothish but becoming slightly fissured and scaly, exposing the brown bark beneath. Inner bark is pinkish and slightly bitter.

The leaves have short thin petioles $1 / 8^{-1 / 4}$ inch long and at base a pair of pointed seales (stipules) $1 / 16$ inch long.

The male flowers less than $1 / \mathrm{s}$ inch across are bome on threadlike stalks about $3 / 16$ inch long. many elustered together at a node, consisting of 4 sepals less than $1 / 16$ inch long and $t$ stamens of the same length. The small but larger female flowers have stalks $1 / 4-1 / 2$ inch long, ealyx nearly $3 / 16$ ineh across the 4 lobes which are timned downward, and pistil of rounded 5- or t-eelled ovary $1 / 16$ inch in diameter with 5 or 4 styles mnited at base, bent down ward, each with 2 -forked stigma. The brown seeds are $1 / 8$ inch long. Flowering and fruiting nearly through the year, chiefly in the spring and early summer. Often flowering when leafless.

\section{Phyllanthus nobilis (L. f.) Muell.-Arg.}

The light brown sapwood is hard. Heart rood is hownish, sometimes pinkish and heary (specific gravity 0.9$)$. The wood is used only for posts and finel.

Widely distributed in thickets and the understory of forests in the coastal, moist limestone, and lower mountain regions of Puerto Rico. Also in St. Thomas, St. John, and Tortola, and recorded from St. Croix.

Prible ronests.-Cambalache, Guajataca, Lilquillo, Susúa.

Raven- Tridely distributed in tropieal America. Through West Indies in Cuba, . Tamaiea, Hispaniola, Puerto Rico and Tirgin Islands, Lesser Intilles from Saba to Grenada, and Trinidad. Ilso from Mexico to Eeuador, Peru, Brazil, Guianas, and Venezuela.

Otuer common NuMes. - amortiguado, palo de millo, higuillo, avispillo, siete-eneros, yuquillo (Puerto Rico) : false gooseberry (Virgin Islands); palo amargo (Dominican Republic); graicaje, azulejo, llorón (Cuba) : nistamal (El Salvador): carillo (Niearagua) : pintureso, yayo (Colombia) : cuarataro (Tenezuela) : chaquirillo (Eenador): neariviro (T'eru) : hastard hog-ber'y (Jamaiea): clawherey, lamon macho (British Honduras); mille branches, bois diable, acomat bâtard (Guadeloupe) : goosebery (Duteh Wrest Indies); boskoffie (Surinam).

BoTANICAl, SYXONYMS.-Margaritarin nobitis L. f., M. nobitig rar. antillana (A. .Juss.) Stehlé \& Quentin, Phyllanthus antillanus (A. Juss.) Muell.-Are.. P. nobilis var. antillanus (A. Juss.) Muell.-Al'g. 


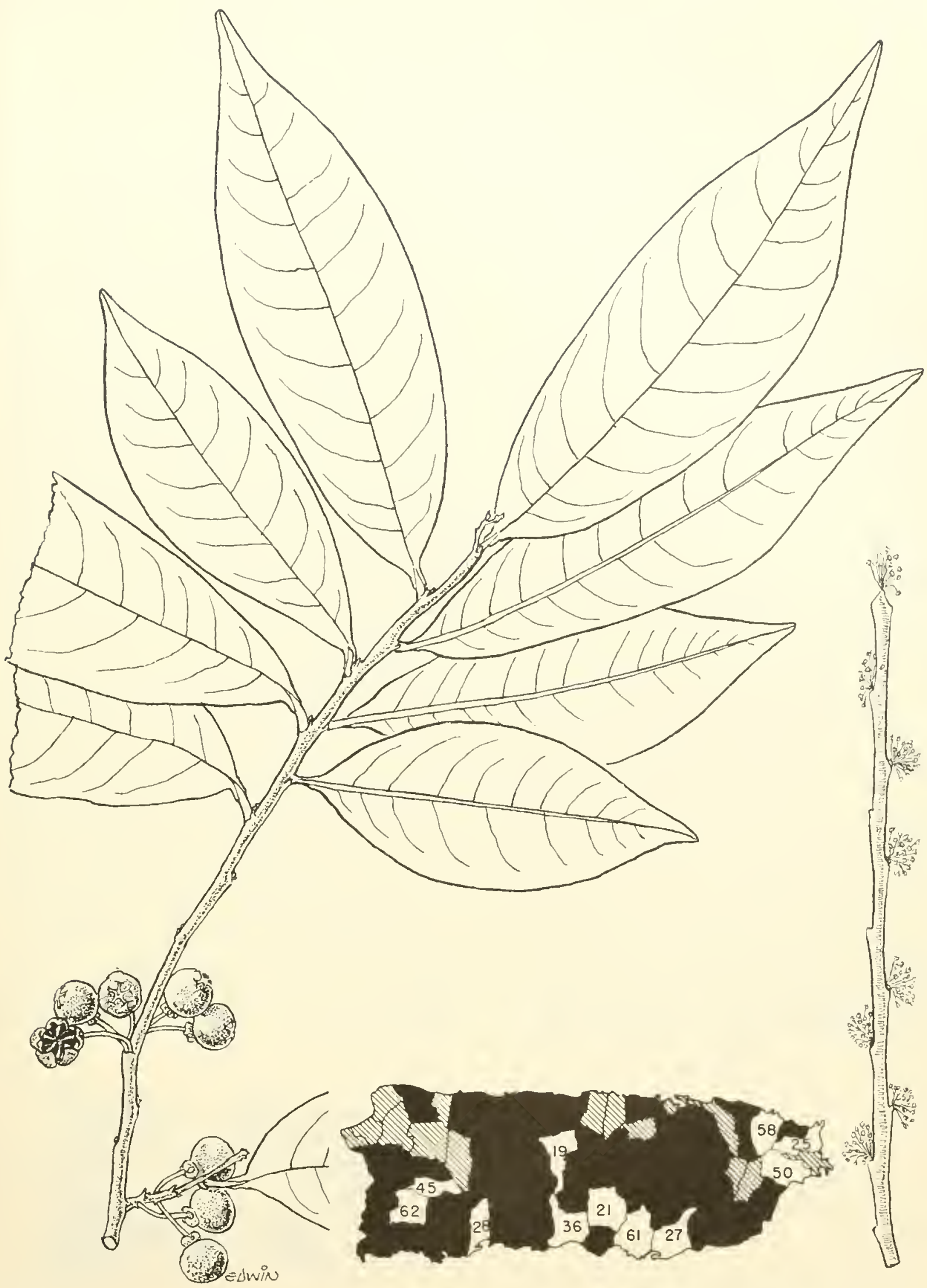




\section{SPURGE FAMILY (EUPHORBIACEAE)}

\section{Tabaiba}

A medium-sized poisonous tree of moist forests confined to Puerto Rico, easily recognized by : (1) abundant irritating and poisonous milky juice; (2) the oblong or elliptic dark green leaves, slightly thickened and shiny, with many straight parallel lateral reins almost at right angles to midrib and 2 raised dotlike glands at upper end of petiole; and (3) the small yellowish-green flowers stalkless on narrow lateral axes $3 / 4-2$ inches long, mostly male with 1 or a few female flowers often present at base (monoecious).

An evergreen tree $20-60$ feet high and to 2 feet in trunk diameter, with a colummar crown. The light brown bark is smoothish or slightly fissured and thin. Inner bark is whitish, its thick white latex calusing a lingering irritation in the mouth when tasted. The twigs are ureen, becoming brown or gray.

The alternate leares have green petioles $1 / 2-11 / 4$ inches long and blades mostly $21 / 2-6$ inches long and $11 / 2-21 / 2$ inches broad, sometimes to 8 inches long and $23 / 4$ inches wide. They are abruptly short-pointed at apex and short-pointed or rounded at base, finely and inconspicuously toothed or almost without teeth, paler and slightly shiny on lower surface.

Near the ends of twigs are located the green flower clusters (spikes). Male flowers, in groups of 3-9 above a broad rounded scale, are about $1 / 16$ inich long and broad, yellow green, and consist of a cup-shaped 2-toothed calyx and 2 stamens. Female flowers when present at hase of axis are borne singly and are long and narrow, $1 / 8-3 / 16$ inch long, green, composed of a cup-shaped 3-lobed calyx and pistil with ovary and 3 styles.

The seed capsules are nearly round or slightly 3 -angled, about $3 / 8$ inch in diameter, green, tu rning

\section{Sapium laurocerasus Desf.}

brown, slightly fleshy but becoming dry, with 3 white seeds about $1 / 4$ inch long. Flowering and fruiting from spring to fall.

The sapwood is whitish, and the heart wood light brown or light yellow. The wood is soft, lightweight (specific grarity 0.38), mostly fine-textured except for many large pores, with grain frequently tightly interlocked, and without risible growth rings. Rate of air-seasoning and anount of degrade are moderate. Machining characteristics are as follows: planing is excellent; shaping and tmrning are fair; boring and mortising are poor'; sanding is rery poor; and resistance to screw splitting is root. The wood is very susceptible to attack by dry-wood termites and other insects and to decay. Sap-staining fungi discolor freshly cut wood if it is neither dipped in fungicide nor dried promptly.

Though cut occasionally for posts, the wood is unpopular becanse the caustic latex injures the skin. It is suitable for boxes, crates, interior construction, paper pulp, and plywood. Latex of related South American species has been a minor source of pubber.

In forests of the lower and upper mountain and moist limestone regions of Puerto Rico. Also reported long ago from St. John but not seen in flower there. Sterile specimens possibly of this species were collècted at Tortola in 1954.

Public Forests.-Carite, Guilarte, Lnquillo, Río Abajo, Toro Negro.

MUNicipalities Where hapecially COMMON.$1,10,35$.

Ravae.-Known definitely only from Puerto Rico.

Other common xames.-manzanillo, lechecillo (Puerto Rico). 


\section{CASHEW FAMILY (ANACARDIACEAE)}

Key to the 6 species illustrated (Nos. 130-135)

A. Leares simple.

B. Leares elliptic or ohovate, ronnded at loth ends or slightly notehed at apex-130. Anacardium occidentale.

BB. Leares lance-shaped, long-pointed at both ends-131. Mangifera indica.*

Ad. Leares pinnate.

C. Leaflets usualty $5(3-7)$, ovate. blunt-pointed or minutely notched at anex; sap poisonous to the touch-132. Uetopium toriferum.

CC. Leaflets $0-25$.

1. Leaflets mostly lance-shaped. long- or short-pointed at apex, with short stalks about $1 / 3$ ineh long.

F. Iseaflets ineonspicuously toothed-133. Spondias duleis.*

El. Leaflets not torthel-134. spondias mombin.

DD. Leaflets elliptic, lounded or short-jointed at apex, almost stalkless-135. Spondias purpurea.*

\section{Pajuil, cashew}

Known for its cashew nuts and fruits, this small tree of sandy areas on the north const of Puerto Rico, sometimes planted, is identified by: (1) a dense irregular crown of obovate or elliptic, dull blue-green, leathery leaves $21 / 2-6$ inches long and $13 / 4-3$ inches broad, rounded at both ends or slightly notched at apex, with the edges turned moler and with prominent sunken lateral veins nearly at right angles to the midrib: (2) many fragrant pinkish flower's about $3 / 8$ inch long, with 5 very narrow petals, short-stalked and crowded toward ends of terminal branched clusters; and (3) the very odd fruits consisting of a sliny gray-brown kidiney-shaped or bean-shaped nut (edible only when roasted), about $1-1 \frac{1 / 4}{4}$ inches long on a yejlow or reddish, fluitlike, enlarged, pen r-shaped stalk or false fruit alout $13 / 1-3$ inches long and 13/4-2 inches broad, juicy and edible, thus appearing as if the nut glows outsicle the fruit. The nut shell contains a cilust ic poisonous oil which blisters or birms the skin.

An evergreen tree to 20 feet high and 6 inches in trunk diameter, ol often shrubby. The light gray to brown bark is smoothish, becoming slightly fissured. The whit ish to reddish-hrown inner bark is thick, bitter, and astringent, and contains a milky juice, and larger trunks yield a gum. Twigs are yellow green and finely hairy when young, becoming light gray, stiff, and erooked.

The alternate leaves have broad yellow-gleen petioles $1 / 4^{-1 / 2}$ inch long. Leaf blides slightly thickened, pale beneath.

The widely sprenting flower clusters (panieles) are $4-19$ inches long and nearly as broad. Flowers are male and bisexual on the same tree (polygamous). Calyx is mole than 3/16 inch long, light. green and finely hairy, narrowly 5-lobed nearly to base: the 5 pinkish petals yellow green at first are $3 / s^{-1 / 2}$ inch long. long-pointed, spreading and curved backward, and minutely hairy ; 10 or fewer stamens, 1 much longer than the others, slightly united at base; and in bisexual flowers a pistil on a disk with l-celled ovary and slender curved st vle on 1 side.

"The nuts, which are the true fruits, are attached at end, dry, and do not split open. Inside the poisonous shell is 1 large curved seed nearly 1 inch long, the edible cashew nut. As the nut matures,
Anacardium occidentale $\mathrm{L}$.

the stalk (receptacle) at base enlarges rapidly within a few days into a fleshy fruitlike structure hroblest at apex, popularly known as the fruit. This thin-skinned edible cashew "f frut" has light yellow spongy flesh, which is very juicy and pleasantly arde and slightly astringent when eaten raw lut highly astringent when green. Flowering from February to May, the fucuit maturing from April to Auguist.

The wool is whitish, brownish, or pinkish, of medium hathess, medium weight (specifie gravity (1.5), moderately strong, and easy to work but susceptible to attack by dry-wood termites. Thongh little used in Puerto Rico, the wood has been employed elsewhere locally in construetion and carpentry, including boatbuliling, yokes, huls, etce, and for charcoal. The hark has served in taming. Mucilage repellent to insects and varnish have been made from the gum, which is sinilar to grmm arabic, and an indelible ink from the milky sap.

The tree is ralued primarily for the nuts and fruits. Roasted cashew nuts are an item of world commerce. In roasting, the poisonous oil of the shell is removed by heat, but the caustic fumes and thops of oil may b]ister the skin and intlame the eves if care is not exercised. The "fluits" are eaten fresh or in preserves and have been employed in preparation of wine and rinegar.

Cardol oil, the poisonous, thick, black, very acrid oil of the shell of the nut, has been used medicinally and to preserve book bindings, carved wood, and similar articles against insects. A nutritious oil similar to olive oil has been obtained from the seeds. The bark has been the source of medicines also. As the flowers are attractive to bees, this species has been classed also among the honey plants.

Living fences have been made from the trees, which sometimes are grown for olnament. The plants mature at a very early age and are shortlived, flowering and fruiting as early as the second or third or sometimes the first year after sowing. 'Through the tropics the trees are grown in plantations for the nuts and "fruits," but they are semiwild or naturalized in many regions. In the Vircrin Islands the trees are uncommon but widely planted for shade and fruit, such as around houses, 


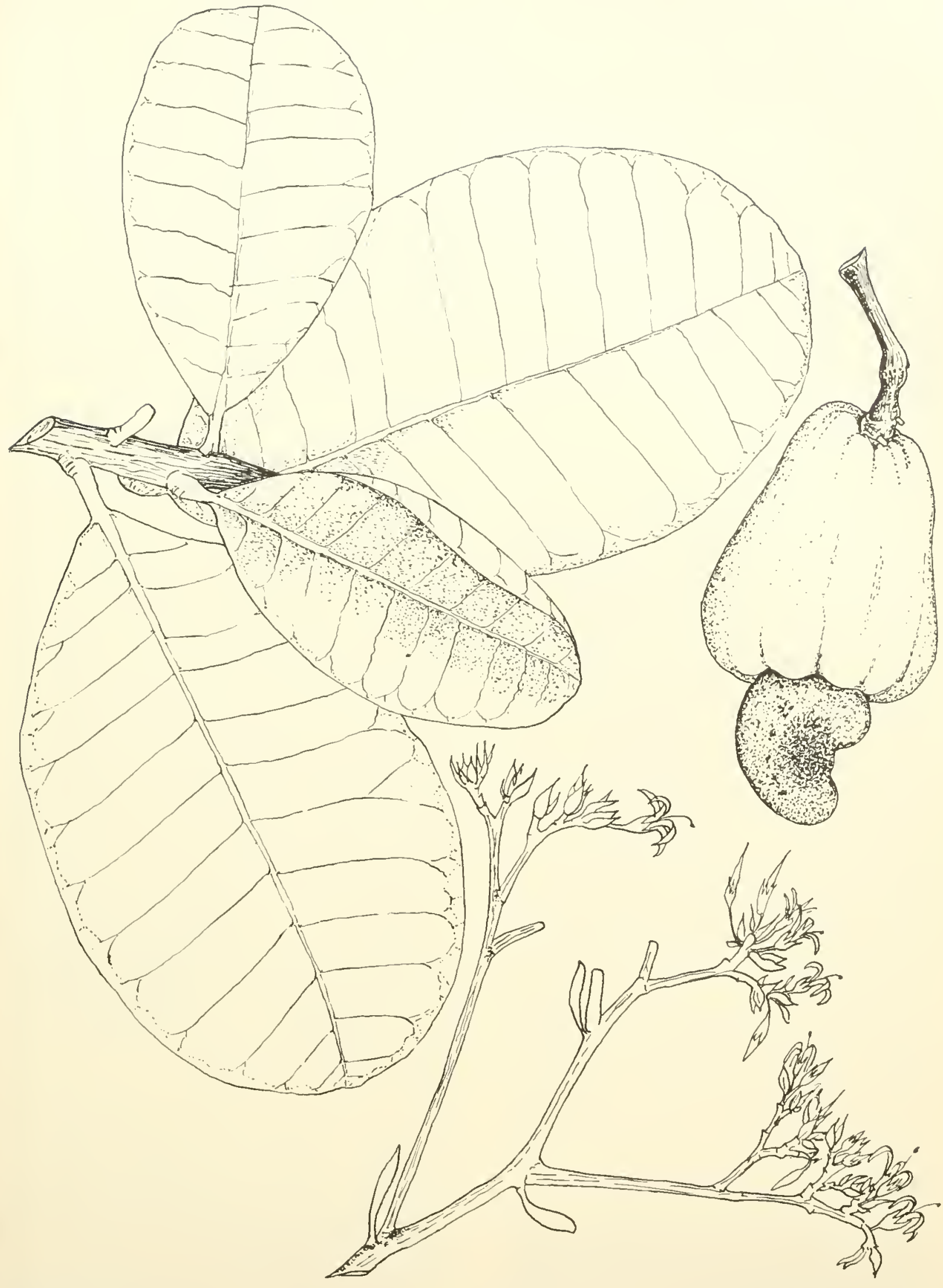


along poads, and in waste rrounds.

Limiterl to the moist coastal region of Prerto Rieo, chiefly on the white sands between Bayamon and Aquadilla. Also in Culebra, Tieques, St. (roix, st. Thomas, St. John, Tortola, and Virgin Gorda.

RAxre-Thronghout West Indies, except Bahamas, from Cuba to Trinidad and Dutrh West Indies. Mlso from southern Mexico to Peru and Brazil, the range extended through cultivation and naturalization. Planted also in southern Florida. Cultivated and naturalized in Ifrica, India, and elsewhere in the Old Workd tropies.

It has been suggested that Indians from South
Imerica may have brought this species to the Trest Indies in pre-Cohmbian times.

Other comyon Nistes. - c a j u il, malañón (Puerto Rico) ; maranón (Spanish) ; cajuil (Dominican Republic); jocote marañon (Guatemala, Honduras, El Salvador); nerey (Colombia, Venczuela) : caju, casu (Peru) : cashew, cashew-nut, cashew-apple (United States, English) ; acajou, noix d"acajou, pomme d"acajou, pommier d"acajou (French); pomme cajou (Guadeloupe); acajou à pomme, noix d'acajou (French Guiana): cashu, palu cli cashupete, kasjoe, cashew, cherry (Dutch TTest Indies); kasjoe, bosehkasjoe, mereke, orvi (Sminam) ; caju, cajueiro (Brazil).

\section{CASHEW FAMILY (ANACARDIACEAE)}

\section{Mango}

This popular introduced fruit and sharle tree, bearing one of the finest tropical fruits, hardly requires lescription. It is characterized by: (1) a very dense round crown and stont trunk: (2) large, leathery, dark green, lance-shaped or narrowly ollong leaves long-ponted at both ends or short-pointed at base, drooping in conspicuous red-brown chisters when first prodnced; (3) $\mathrm{mm}$ merous small yellow-green to pink s-parted flowers about $1 / 4$ juch across in lares showy terminal clusters; and (4) the familiar large, elliptic, yellow fruits with edible flesh and a larore seed in a mass of fibers.

A medimm-sized to large evergreen tree attaining 20-65 feet in height with trmk to 3 feet in diameter. The brown hark is smoothish, with many thin fissures, and thick, hecoming darker. rough, and scaly or furrowed. Inmer hark is light brown and bitter. A whit ish latex exudes from cut twigs, and a resin from cuts in the trunk. The stont $t$ wigs are pale green and hairless.

The altemate leaves have petioles $1 / 2-11 / 2$ inches long and swollen at base. Leaf blades are 6-12 inches long and $11 / 2-3$ inches broad, curved upward from midrib and sometimes with edges a little wavy.

Large branched flower chusters (panicles) are 6-8 inches or more in length, with reddish hairy branches. The short-stalked fincly hairy fracrant flowers are partly male and partly bisexual (polygamons). The yellow-green calyx $1 / 16$ inch long is deeply n-lobed: there are 5 spreading petals more than $1 / \mathrm{s}$ inch long, pink but tmung reddish : 5 stamens, 1 fertile and + shorter and sterile, borne on a disk; and some flowers have a pistil with 1-celled orary and slender lateral style.

The large aromatic fruits (drupes) on hanging stalks are mostly $3-41 / 2$ inches long, slightly narrowed toward apex and a little flattened, soft at maturity. The yellow flesh is thick and juicy, the seed $21 / 2-31 \%$ inches long. flattened, and weighing about an ounce. Flowering mainly in winter and
Mangifera indica L.*

spring (recorded from November to July) and maturino frolits mostly from May to September.

'The sapwood is eream colored or light brown, and the heart wool pale yellow or brown and often with darker spots and inegular lines. The wood is harl, molerately heary (specific sravity 0.62), tougl. strong, and medium-textured and has straight to way grail, many large pores, and growtl rings. Rate of air-seasoning is moderate, and amount of derrade minor. Machining characteristics are as follows: planing, shaping, and turning are fair: boring, mortising, and resistance to screw splitting are good: and sanding is poor. The wood works easily but with only fair results. It is susceptible to attack by dry-wood termites.

In Prerto Rico the wood has been msed occasionally for meat chopping-blocks as well as for fuel. Elsewhere it has been emploved for furniture, carpentry, flooling, construction, boxes and crates, carts, plywood. and dry cooperage. Beantiful furniture has been made from a variety with streaked wood.

This is perhaps the most popular fruit through tropical America. Though usually eaten raw, mangos are also cooked or made into preserves or juice. Numerons improved varieties with larger and less fibrons fruits have been developerd. These superior varjeties, propagated regetatively by budding or grafting, shonld replace the common minproved fibrous mangos which are grown from seeds.

Mango is an excellent hardy shade tree. It is also among the important honey plants, secreting quantities of nectar, and the flowers reportedly are edible. Lirestock eat the fruits. The seeds, flowers, bark, leaves, and resin have been employed medicinally, and the bark and leares yield a yellow dye. I few persons have skin sensitive to the sap, which produces a lash aromd the mouth and on the face.

Widely planted as a fruit tree and shade tree around houses and along highways and commonly 


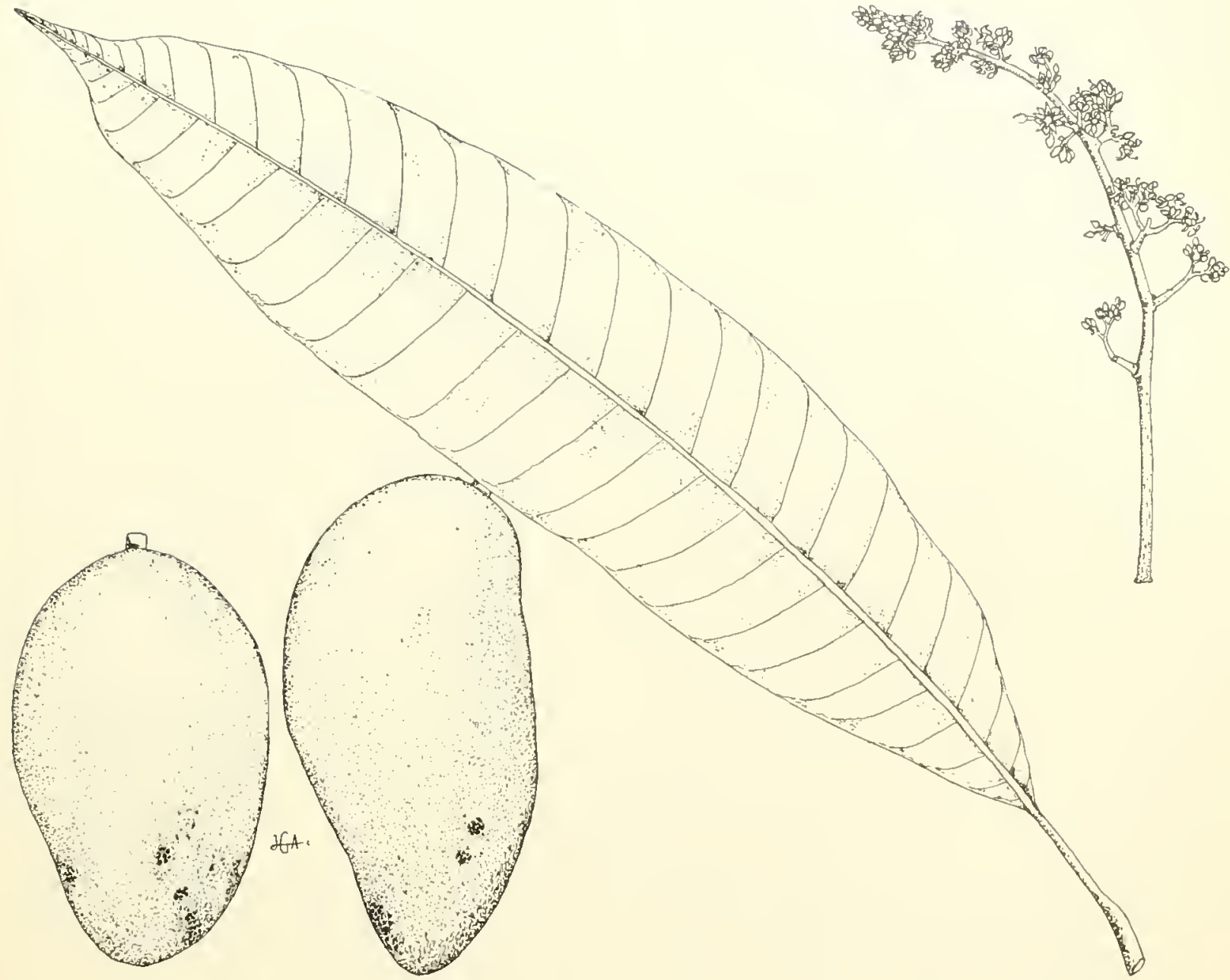


escaping from cultivation and naturalized almost throughout Puerto Rico with the exception of the mangrove, dry limestone, and upper mountain regions. Through the Tirgin Islands commonly planted and also spontaneous except in the drier areas. Mona, ('ulebra, Tieques, St. Croix, St. Thomas, St. Joln, and Tortola.

R.s.ve. - Native of tropical Asia probably from India east to Vietnam. Planted and escaped from cultivation thoughout the tropies, ineluding sonthern Florida and Florida Kérs, Trest Indies, and from Mexico to Peru and Brazil. Grown also in southern California.
Though the exact date of introduction into the New World is uncertin, mango reportedly reached Mexien and [Brazi] before the end of the 17 th century. Shout 17 t2 this fruit was first introduced into the Trest Indies at Barluados from lirazil and in 1782 reached om inaca. It is thought that mangos liave heen cultivated by man for 4,000 years.

Other common Numes.-mango, mangó (Spanish); mango (United States, English); mangue, manguier (French); mangot, mangotine (Guadeloupe): mangego, minggaboom (I)utch); manja, liajanna manja, bobbie manja (Surinam); manga, mango, mangueira (Brazil).

\section{CASHEW FAMILY (ANACARDIACEAE)}

\section{Papayo, Florida poisontree}

This small tree related to poison-ivy of the Inited States, with caustic sap poisonous to the toucl, is abundant in Mona lut uncommon in Puerto Rico. It is characterized by: (1) smoothish light gray lark mottled with yellow to brown spots; (2) a broad rounded crown of widely spreading stout branches; (3) pimate leares with usually 5 (3-7) mostly orate leathery leaflets blunt-pointed or sometimes minutely motched at apex and nearly straight at base on yellow-green axes and leaflet stalks; (4) many small 5-parted meenish flowers about $3 / 16$ inch across in branched fateral elusters; and (5) numerous elliptic or oblong fruits $3 / 8^{-1 / 2}$ inch long and $1 / 4$ inch in diameter, green tuming to orange brown at maturity.

An evergreen tree 15-20 feet in height and 6-i2 inches in trumk diameter. The distinctire bark peels off in thin scales or flakes, exposing the yellow to brown thin inner layer. Inner bark is pinkish. The stout twigs are brown with many raised orangre-brown dots (lenticels), finely hairy mhen young. The poisonous watery sap tmins black upon drying.

The alternate leaves chustered near ends of twigs are 6-11 inches long and have leaflet stallis $1 / 4-1$ inch long. Leaflets are paired except the terminal one. Leaflet blades are $1 \frac{1}{2}-33 / 4$ inches long and $1-21 / 2$ inches broad, not toothed at edges, above shiny green, and beneath yellow green and slightly shing or dull. Some leaflets have scattered black dots composed in part of black dried sap at injured places.

The slender, narrow flower clusters (panicles) at base of leaves are 6-10 inches long, bearing flowers on short stalks. Flowers are mostly male and female on different trees or partly bisexual (polygamous). There are 5 rounded sepals 1/32 inch long, 5 yellow-green elliptic petals less than $1 / 8$ inch long and with dark lines within, 5 stamens $1 / 16$ inch long, and pistil (rudimentary in male flowers) on a disk, consisting of 1-celled ovary, short style, and slightly 3-lobed stigma.

\section{Metopium toxiferum (L.) Krug \& Urban}

Fruits (drupes) retain the sepals at base and have 1 seed about $1 / 4$ inch long. Pigeons feed upon the great quantities of fruits on Miona. Recorded witl flowers in February and with fruits in summer and fall.

Sapwool is yellowish or light brown, and heartwool dark brown streaked with red. The hard, heary wood is easily worked, takes a fine polish, and is reporter to be dumable. It is litule used in Puerto Rico but has served elsewhere for fenceposts.

'This species is of interest primarily as a poisonous tree to be aroided and to be recoginized in areas where found. The genus is closely related to that of the well-known poison-ivy ind poison-oak (Toxicortemtron or Phuss) in the Cnited States. The sap of all parts of the plant is irritating to the skin of many persons and often produces a painful rash or swelling upon contact with leaves or twigs. For example, men clearing land where this tree grows have suffered inflammation of the skin.

Sometimes the trees are seen as ornamentals in southern Florida, where they may have persisted from the original forest. A resinous gum from the bark is said to have medicinal properties. Also a honey plant.

In forests and thickets of the dry limestone region and rare in the moist limestone region of Puerto Rico. One of the commonest trees of IIoma. Absent from Culebra, Vieques, and Tirgin Islands.

Public forest.-Cambalache (very rare).

R.xig.-Gouthern Florida including Florida Keys, through Bahamas, Cuba. Hispaniola, Mona and Puerto Rion, and Anguilla in Leeward Islands.

OTHER conmox sames.-almendrón, c e d ro prieto (Puerto Rico): guao de costa (Cuba) ; Florida poisontree, poisonwood, West Indies poisontrce (I'nited States): poisontree, poisonwood (Bahamas): mancenillier (Haiti). 


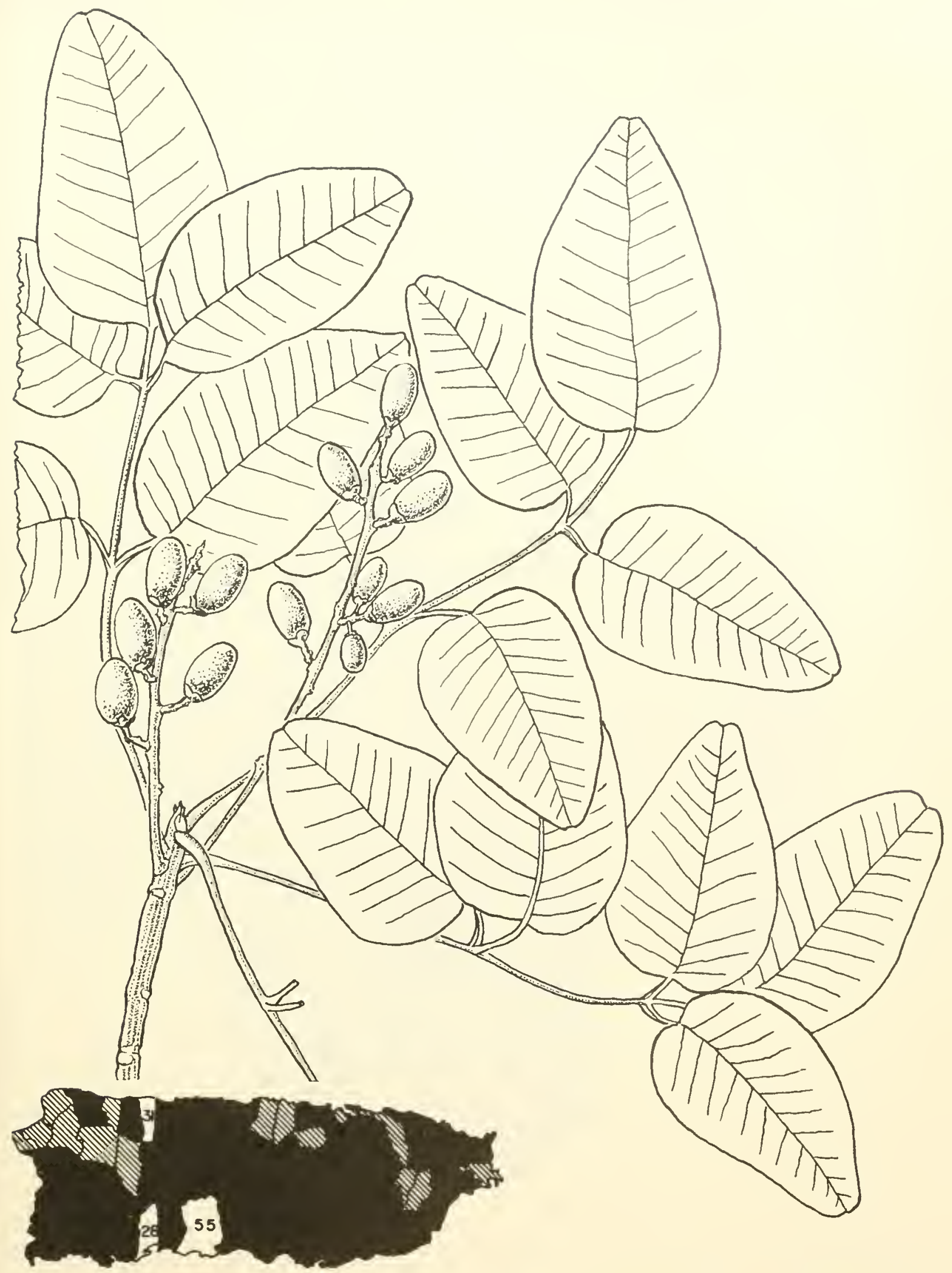




\section{CASHEW FAMILY (ANACARDIACEAE)}

\section{Jobo de la India, ambarella}

This exotic fruit tree is characterized by: (1) pinnate leaves 8-12 inches long with 11-23 shortstalked, lance-shaped or oblong leaflets $11 / 2-21 / 2$ inches long, thin and long-pointed, the edges inconspieunusly toothed and turned under: (2) numerous small, fragrant, whitish, 5-parted flowers nearly $1 / 4$ inch across in branched terminal clusters: and (3) large elliptie or rounded yellow fruits $2-1$ inches long and 2 inches in diameter, sour and edible.

I small to medium-sized deciduous tree reaching $20-10$ feet in height and $11 / 2$ feet in trunk diameter, with few stout branches and stout twigs. The bark is smooth and greenish and exudes a lesinous juice.

The leaves are alternate. Iseaflets have stalks less than $1 / 8$ inch long and blades paired except the terminal one, $5 / 8-1$ inch broad, short-pointed at base.

The flower clusters (panicles) are 8-12 inches long, the flowers on stalks about $1 / 16$ ineh long. Flowers are male or female and bisexual on the same tree (polygamous). The small ealyx is 5 -lobed: the 5 whit ish petals less than $1 / 8$ ineh long are spreading and bent downwards; there are 10 stamens; and the pistil on a disk has an orary with 5 styles.

The thick-skinned fruits (drupes) are borne 2-10 in a drooping cluster. They have a pleasant odor and flavor suggesting apples. The large fewseeded stone $1-11 / 2$ inches long has stiff spinelike projections into the yellow juicy pulp. In fruit through most of the year.

\section{Spondias dulcis Parkinson*}

The saprood is whitish to light yellow, and the heartwood is light brown. The wood is moderately soft, lightweight, and not durable.

The fruits are made into preserves as well as eaten fresh. Plants are propagated readily by cuttings.

Grown for its fruits in Puerto Rico, ehiefly in the coastal regions. Also in St. Croix, St. Thomas, and St. John.

Ravar.- Native of Society Islands in the South Pacific but planted in various tropical regions and relatively uncommon in the New World. Cultivated in southern Florida, through TVest Indies from Cuba and Jamaica to Trinidad and Tobago, and from Guianas and Venezuela to Brazil.

Though introduced into Jamaiea as early as 1782 , this has not become a popular fruit tree in the West Indies.

Other comron names.-eítara (Puerto Rico) ; poinme eythère (Virgin Islands) ; jobo de la India, manzana de oro (Dominiean Republic); ciruela dulee, manzana de Otahití, jobo de la India (Cuba) ; jobo de indio (Venezuela) ; manzana de oro (Eeuador) ; ambarella, golden-apple, vi-apple, Otaheite-apple (English); Otaheite-plum (Jamaica); pomme eythere (French); mombin espagnol, lobe (Haiti) ; prune cythère (Guadeloupe, Martinique); pomme de Cythère (Curaçao, Surinam) ; fransi mope (Surinam); cajá manga, imbuzeiro (Brazil).

Botanical Synonyus.-Spondias Sonner., S. dulcis Forst. f. 


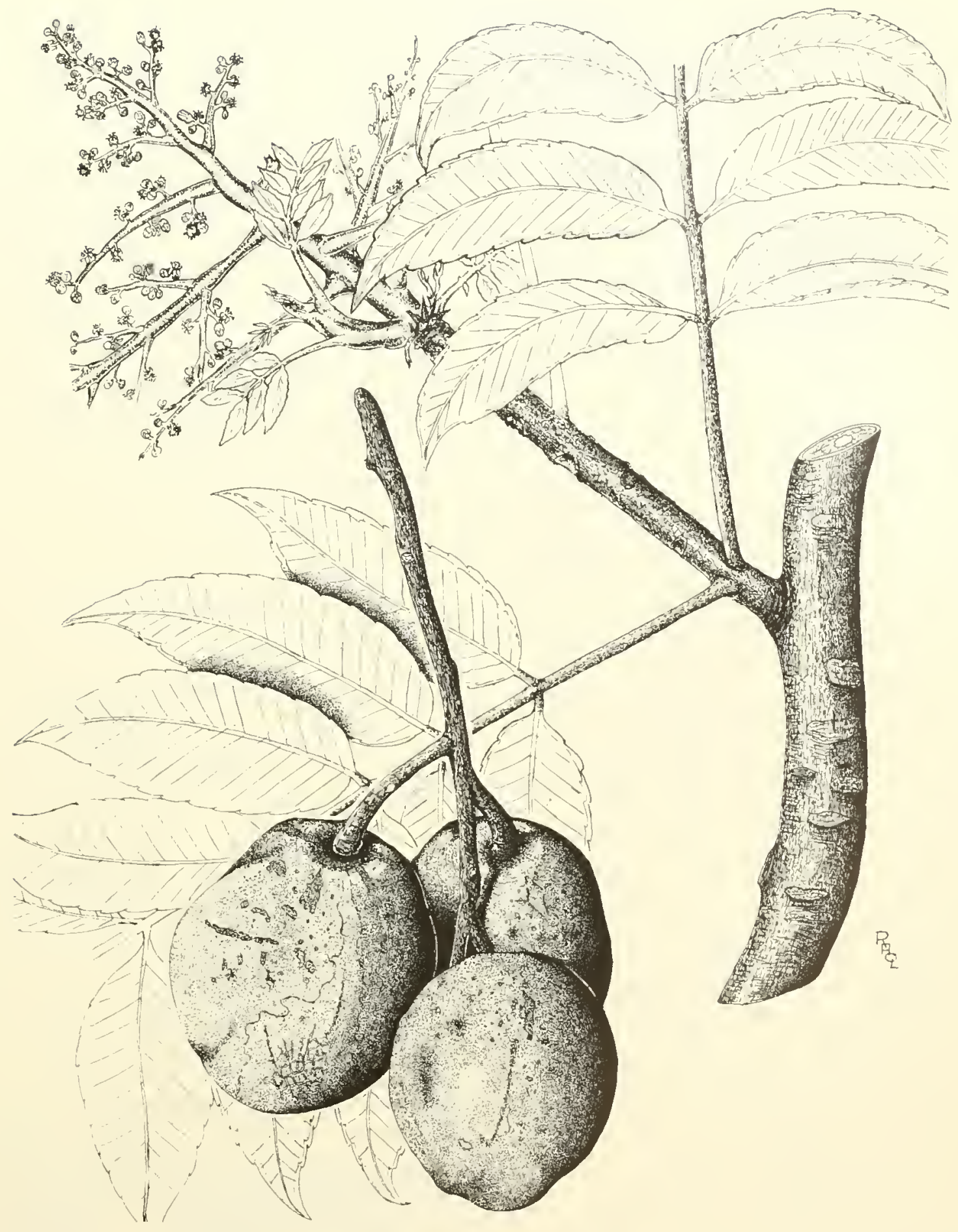




\section{CASHEW FAMILY (ANACARDIACEAE)}

\section{Jobo, hogplum, yellow mombin}

Jobo, which grows wild and is planted as a fence row tree and for its fruit, is recognized by: (1) numerous spinelike projections $1 / 4-3 / 4$ inch long on the thick, corky bark of the trunk; (2) a very spreading yellow-green crown, usually with few nearly horizontal branches; (3) pinnate leaves 8-16 inches or more in length with 9-19 asymmetrical ovate or lance-shaped, short or long-pointed, thin leaflets; (4) numerous small, fragrant, yellowish-white, 5-parted flowers nearly $1 / 4$ inch across in showy branched terminal clusters; and (5) clusters of yellow, cylindrical, soft, juicy fruits $11 / 4-11 / 2$ inches long and $3 / 4-1$ inch in diameter, edible though inferior.

A small to medium-sized decidnous tree to 60 feet in height and $2 \frac{1}{2}$ feet in tmink diameter. The whitish-brown or gray bark is smoothish except for numerous spinelike projections $1 / 4-3 / 4$ inch high, becoming rough and furrowed. Inner bark is light pink and slightly bitter. A resin exudes from cuts. The stont twigs are hairless or finely hairy.

The alternate leaves have slender and finely hairy axes. The leaflets are more or less paired except for the terminal one, on stalks $1 / 8^{-1 / 4}$ inch long. Leaflet blades are $2-4$ inches long and $1-13 / 4$ inches broad, short-pointed or rounded and oblique at base, the edges not toothed or slightly wary, yellow-green on upper surface and paler beneath.

The spreading flower clusters (panicles) are 612 inches or more in length, with flowers on short stalks $1 / 16$ inch or more in length. Flowers are male or female and bisexual on the same tree (polygamous). The minute hairy calyx is 5-lobed; there are 5 yellowish-white petals nearly $1 / 8$ inch long, spreading and curved back; 10 stamens; and pistil on a disk, composed of ovary and 4 styles.

The pleasantly odorous fruits (drupes) have a thin yellow edible flesh with slightly sour pungent taste and a large few-seeded stone about 1 inch long. Flowering chiefly from winter to summer and maturing fruits from summer to winter.

The sapwood is whitish or cream colored, and the heartwood similar when first cut but tuming golden brown. Sap-staining fungi in seasoning often turn the wood to a blue-gray color. The wood is soft, lightweight (specific gravity 0.41), with straight to slightly interlocked grain, coarse texture, and numerous pores. It is tough and strong for its weight. Rate of air-seasoning and amount of degrade are moderate. Machining characteristics are as follows: planing is excellent; shaping, turning, boring, and mortising are poor; sanding is fair; and resistance to screw splitting is good. The wood is perishable and very sus-
Spondias mombin $\mathrm{L}$.

ceptible to attack by dry-wood termites and other insects.

In Puerto Rico the wood serves for fenceposts and fuel. It is used also for soft-drink cases, packing boxes, and matches. It will produce pulp for white paper and utility plywood and could be utilized for cheap furniture and light construction where protected. Other uses elsewhere are as a cork substitute and for charcoal, and the bark as an astringent.

The trees are planted as living fenceposts and for shade and ornament, being readily propagated by cuttings and fast glowing when not in deep shade. The fruits can be eaten, though inferior to the smaller fruits of purple mombin ( $S$ pondias purpurea L.), and serve to fatten hogs and cattle. A honey plant.

Along roadsides and fence rows and in pastures and forests in the coastal, moist limestone, and lower mountain regions of Puerto Rico, perhaps naturalized rather than native. Also in St. Croix, St. Thomas, St. John, and Tortola.

Public forests. - Aguirre, Cambalache, Carite, Guajataca, Luquillo, Maricao, Río Abajo, San Juan, Susúa, Vega.

MUNiCIPALities Wiere EsPectally COMMON.$8,25,30,44$.

RANGE.-Throughout West Indies except Bahamas and from sonthern Mexico to Perl and Brazil, in part cultivated or naturalized. Planted in sonthern Floricla. Also in Old World tropics, perhaps introduced.

OTHER DOM MoN NAMEs.-jobillo, jobo gusanero, jobo vano, jobo de perro (Puerto Rico); jobo (Spanish, commerce); ciruela amarilla (Dominican Republic, Cuba, Mexico, Ecuador) ; jobo de puerco, jobobán, ciruela (Dominican Republic); jobo hembra (Cuba); jocote jobo, jobo jocote (Guatemala); ciruela de monte, jocote (Honduras) ; jocote, jocote de jobo, ciruela de jobo, jocote montanero (Nicaragua); hogplum, wildplum (Costa Rica, Panama); jobo blanco, jobo colorado, jobo de castilla (Colombia); cuajo, guama zapatero (Venezuela); yellow mombin, hogplum (United States); hogplum (English); Bequia-plum (Bequia); hoba, hmbn, plum-bush (British Guiana); mombin, monbin (French); mombin franc, myrobalane (Haiti); mombin fruits jaunes, prune mombin, prune Myrobolan (Guadeloupe); prunier mombin, nonbinier (French Guiana); macaprein, hoba, yellow-plum (Dutch West Indies); mopé (Surinam, commerce); moppé, monbe, hooboo (Surinam); cajá, cajá-mirim, cajá seira (Brazil).

Botanical symonYm.-Spondias lutea $\mathrm{L}$. 


\section{CASHEW FAMILY (ANACARDIACEAE)}

\section{Ciruela del pais, purple mombin}

Occasionally planted in fence rows and for its edible fruits, this small tree, frequently with gnarled branches, is characterized by : (1) pinnate leaves 4-8 inches long with 9-25 almost stalkless, elliptic, thin, yellow-green leaflets, $3 / 4-11 / 2$ inches long, rounded or short-pointed at apex, shortpointed and slightly oblique at base, with edges slightly wary toothed; (2) small red or pink 5 -parted flowers less than $1 / 4$ inch across, in lateral clusters: and (3) the yellow or purplish-red, cylindrical, slightly sour, edible fruits $1-11 / 4$ inches long.

A small spreading deciduous tree to 30 feet hich, with thick trunk to 1 foot in diameter, or sometimes shrubby. The bark is brown or gray, smoothish, soft, and thick, becoming rougl and warty on large trunks. Inner bark is whitish and brown streaked, soft, and astringent. The large branches are brittle and easily broken. The stout twigs are green with brown dots (lenticels), becoming brown.

The leaves are altemate and with slender, angled, finely hairy, yellow-green axes. Leaflet blades are more or less paired except for terminal one, $1 / 2-1$ inch broad, nearly hairless, and dull or slightly shiny.

The branched flower clusters (panicles) are short and finely hairy and bear few flowers on stalks about $1 / 8$ inch long when the trees are leafless or nearly so. Flowers are male or female and bisexual on the same tree (polygamous). The minute calyx is 5 -lobed; there are 5 petals about $1 / 8$ inch long; 10 stamens; and pistil on a disk, with usually 5 -celled ovary and 3 or 4 shor't styles.

The short-stalked fruits (drupes) have yellow, juicy and edible pulp and a large stone $1 / 2-3 / 4$ inch long, which is fibrous on the outside, and contain 5 or fewer: seerls. Flowering in spring and maturing fruits in summer.

The wood is whitish, soft, lightweight, and brittle. It is seldom used, though elsewhere the ash has been employed in soapmaking.

The fruits, which resemble plums (ciruelas) and have a similar flavor, are eaten raw or sometimes cooked and produce wine and other alcoholic drinks. They serve also to fatten hogs and cattle.
Spondias purpurea L.*

In parts of Mexico and Central America this species is one of the most important fruits. The sour young shoots and leaves sometimes are eaten raw or cooked and are browsed by animals.

Grown commonly as living fenceposts, the trees are easily propagated from cuttings and seeds. They are handsome with their small flower's and showy fruits when leafless. Elsewhere the trees have been employed to support cultivated orchids.

In fence rows, along highways, and near homes in the coastal regions, commonest and largest and in a narrow strip along the base of the southern side of the Cordillera of Puerto Rico. Probably naturalized rather than native. Also in St. Croix, St. Thomas, and St. John.

R.s.as.-Planted and naturalized throughout Trest Indies except Bahamas. Native of tropical continental America and widely distributed from central Mexico to Peru and Brazil, spread through cultivation. Planted in southern Florida. Also introduced into the Old World tropics.

OTHER conmon vames.-cimela, jobillo, jobo francés (Puerto Rico); purple-plum (Virgin Islands); ciruela, ciruelo (Spanish): jobo, ciruela morada, cirmela sanjuanera (Dominican Republic) ; ciruela colorada, cirnela campechana (Cuba) ; jocote (Mexico, Central America); jocote de invierno, jocote jobo, jobo, pitarrillo (El Salvador): jocote común (Nicaragua); jobito (Costa Rica): wild-plum (Costa Rica, Panama); hobo colorado, ciruelo colorado (Colombia); hobo, ciruela colorada (Ecuador); ajuela ciruelo (Peru) : purple mombin, red mombin, hogplum, Spanish-plum (United States, English) ; Jamaicaplum (Trinidad); jobo (British Honduras); cironelle (Haiti): prune d'Espagne, prune du Chili (Guadeloupe, Martinique); prune rouge, prune jaune, mombin ronge (Guadeloupe) ; noba, makka pruim, redplum, Jamacia-plum (Dutch Trest Indies); imbuzeiro, cajá, ciroela (Brazil).

Botaxical srowrus. - Spondias mombin L. (1759, not 1753), S. cirouella Tussac, S. purpurea L. forma luter (Macfadyen) Fawcett \& Rendle. The yellow-fruited form has been separated from the purple-fruited form by some authors as a species (S. cirouella Tussac). 


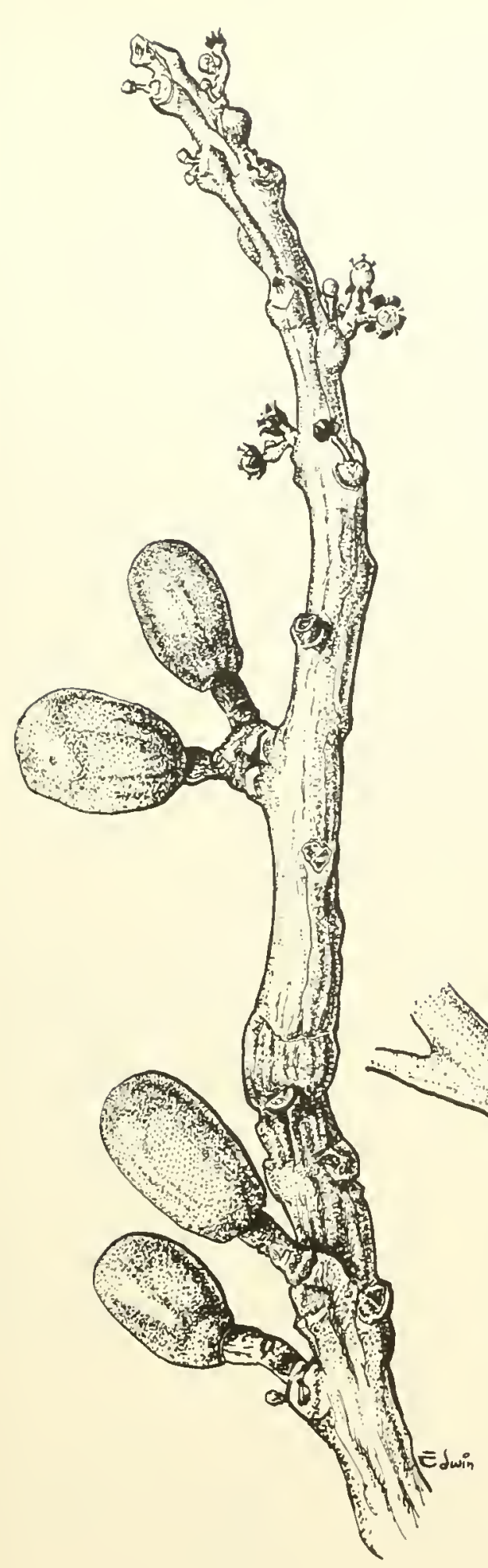




\section{CYRILLA FAMILY (CYRILLACEAE)}

\section{Palo colorado, swamp cyrilla}

Palo colorado, a large tree common in the higher mountains, is characterized by: (1) leathery, lance-shaped to narrowly elliptic leaves $11 / 2-31 / 2$ inches long, blunt and nimutely notched at apex, usually turning red before falling; (2) reddishbrown, smoothish thin bark on the large crooked and twisted trunks which splits off in thin plates or scales, becoming whitish pink, spongy at base of tree; (3) leaves confined chiefly to the top of a many-branched crown, which resembles a broom in appearance: and (4) numerous crowded, small, white, 5-parted flowers 1/8 long in rery narrow lateral flower clusters 3-6 inclies long and only $3 / 8$ inch broad.

This evergreen tree generally becomes 50 feet high and 3 feet in diameter, rarely 60 feet in height and 6 feet in trunk diameter. On exposed mountain ridges and summits it may be small or shrubby. The bark on small trunks does not have the reddish-brown color noted above but is gray to brown, smoothish and minutely fissured. The inner bark is reddish to brown and bitter. Young twigs a re brown, turning gray.

The alternate leaves have petioles $1 / s^{-1 / 2}$ inch long. The leaf blades are variable in form and size, commonly $3 / 8-1$ inch broad, sometimes smaller, pointed at base, with edges curved under. They are green and shiny on upper surface and pale green on lower surface.

One to 10 flower clusters (spikelike racemes) on a twig are located below most of the leaves. They bear numerous short-stalked flowers $3 / 16$ inch across and spreading slightly. There are 5 short, pointed sepals; 5 pointed petals $1 / 8$ inch long, white or also tinged with pink; 5 stamens; and pistil with a 2-celled ovary, short style, and 2 stigmas.

The many small, dry, egg-shaped fruits (drupes) $1 / 8$ inch long are pink to red ind contain 2 or 3 light lnown seeds. Flowering and fruiting probably during most of the year.

The sapwood is light brown, and the seasoned heartwood attractive dark reddish brown. This very hard, moderately heary wood (specifie gravity approximately 0.53 ) has fine uniform texture, heavily interlocked grain, and prominent annual growth rings. The rate of air-seasoning is very slow, but degrade is exceptionally severe, and shrinkage is very high. Becanse of severe warping, air-dry lumber is unfit for most commercial uses. Machining characteristics are as follows:
Cyrilla racemiflora $\mathrm{L}$.

planing and resistance to screw splitting are excellent; shaping, turning, boring, and mortising are grool: and sanding is fair. The wood is susceptible to dry-wood termites.

In Puerto Rico the wood is seldom used except for fuel, becallse of the great warping in seasoning. Also, the large, very old trunks are short, often crooked, and usually hollow. However, in Cuba the handsomely colored wood has been made into furniture. The spongy bark at the base of trunk is absorbent, pliable, and astringent and has been recommended as a styptic.

Sometimes planted in the Unired States as an ormamental because of the graceful white flower chuster's and showy autumnal coloration of the foliage. The flowers produce dark honey, and in Cuba the hollow trumks serve as beehives.

Widely clistributed in the forests of the upper nountain regions of Puerto Rico, chiefly in the Luquillo Mountains. The wild parrots native only in the Luquillo Mountains nest in these hollow trees.

Pululc forests.-Carite, Luquillo, Maricao, Toro Negro.

RAvcr.-Southeastern United States (near coast from southeastern Virginia to Florida and southeastern 'Texas), Greater' Antilles, and Lesser Antilles in Guadelompe, Martinique, and St. Vincent. Also in southern Mexico (Oaxaca) and British Honcluras and from Venezuela to Guianas and northern Brazil.

Accolding to its musual northward distribution, this species is one of the hardiest native trees of Prerto Rico in resistance to cold. Growing wild north to sontheastern Virginia, it has been cultivated farther north in eastern United States to New England. Over most of the wide range a small tree or shrub of swamps and river banks but in the monntains of the Greater Antilles it becomes a large tree.

Other comion Names.-colorado (Puerto Rico) ; granado, palo colorado, sabina macho (Dominican Republic); barril, clavellina, llorona, yanilla (Cuba); piojillo, piojito (Venezuela); swamp cyrilla, American cyrilla, leatherwood, southern leatherwood, titi, white titi (United States) ; bloodwood, beetwood (Jamaica); warimiri (British Guiana) ; bois couché, olivier montagne (Guadeloupe).

Botanical syonym.-Cyrilla antillana Michx. 


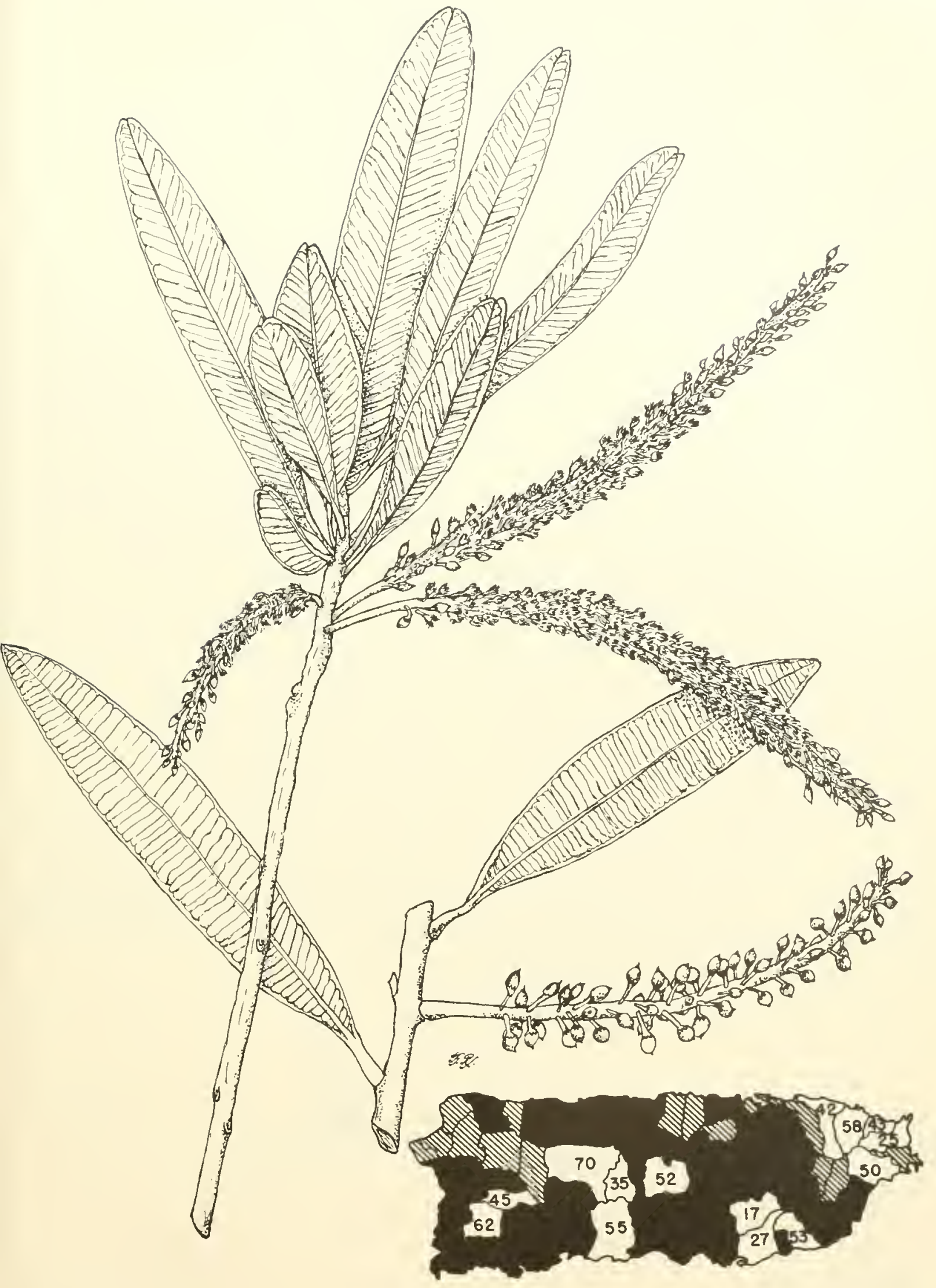




\section{BLADDERNUT FAMILY (STAPHYLEACEAE)}

\section{Sauco cimarrón}

This small or medium-sized tree is characterized by: (1) opposite pinnate leaves with 5-11 elliptic or ovate leaflets also paired except for the terminal one, the edges minutely sa w-toothed; (2) numerous small 5-parted greenish-white flowers about $1 / 4$ inch across in a large broad, branched, terminal cluster; and (3) nearly round or slightly 3 -lobed fruits $1 / 2-3 / 4$ inch in diameter, mostly on long, slender, spreading stalks.

An evergreen tree commonly less than 30 feet high and 6 inches in trunk diameter with an open crown, hairless throughout except for young twigs and young leaves. The gray bark is much fissured and thin. Inner bark is brown and almost tasteless. The brown twigs are stout and slightly fissured.

The leaves, 5-10 inches long, have a slender light green or pinkish-tinged axis, and the leaflets have sloort stalks $1 / 8-3 / 8$ inch long. Leaflet blades are $11 / 2-4$ inches long and $1 / 2-23 / 4$ inches broad, mostly short-pointed at apex and rounded or short-pointed at base, the saw-toothed edges often way, thin or very slightly thickened, green and often shiny on upper surface, light green beneath.

Flower clusters (panicles) are mostly 6-12 inches long and nearly as broad and have long, slender, horizontally spreading, light green branches bearing many short-stalked fragrant flowers. The calyx consists of 5 light green unequal elliptic sepals less than $1 / 8$ inch long, remain-
Turpinia paniculata Vent.

ing on fruit; there are 5 white rounded petals more than 1/8 inch long; 5 whitish stamens $1 / 8$ inch long; and pistil 1/8 inch longr on a lobed disk with 3lobed, 3-celled ovary and 3 united styles which often remain on the fruit as points or hooks.

The rounded fruits are broader than long and slightly 3-angled, turning from green to brown, dry but not splitting open, 3-celled. There are 3-6 shiny light brown elliptic seeds $1 / 4$ inch long. Flowering chiefly in spring (February to June), the frovits maturing in summer and fall (July to October).

The sapwood is whitish and hard. The heartwood is moderately resistant to attack by drywood termites. Reported to be brittle, the wood is used only for fuel.

Lower and upper mountain forests of Puerto Rico, ascending to summits of peaks. Also in Tortola.

Punlic forests,-Carite, Gnajataca, Guilarte, Luquillo, Maricao, Toro Negro.

MUNICIPALITY WHERE ESPECIALLY COMMON.-10.

Ranoe,-Cuba, Hispaniola, Puerto Rico and Tortola. Also from southern Mexico and Guatemala to Panama.

Otiler Common names.-sauquillo, lilayo, eugenio (Puerto Rico) ; cedro hembra (Dominican Republic); saúco cimarrón, roble güira, serrucho (Cuba); cedrillo (E] Salvador); cajeta, tinta (Guatemala). 


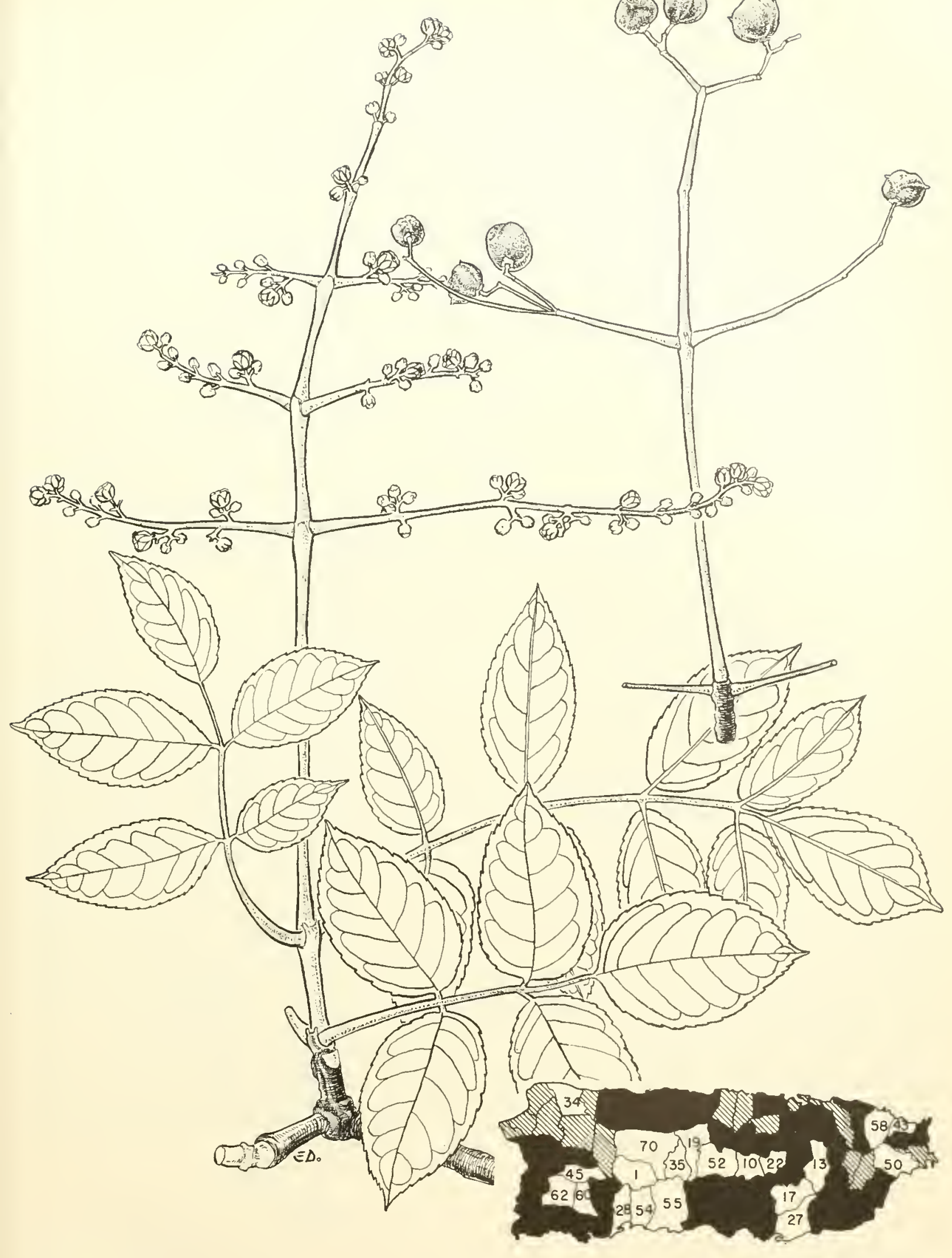




\section{SOAPBERRY FAMILY (SAPINDACEAE)}

Key to the 6 species illustrated (Nos. 13S-143)

A. Leares simple, elliptic, the edges finels toothed-142. Thouinia portoricensis.

AA. Leaves compound.

B. Leaflets 3, elliptic or oborate, broadest beyond middle, short-pointed at both ends, toothed on edges-143. Thouinia striata.

BB. Leaflets pinnate, 4 or more (sometimes onls 2).

C. Leaflets $4-8$, not paired, with wary-toothed edges, elliptie, those toward apex largest, rounded or notched at apex-138. Cupania americana.

CC. Leaflets mostly paired, not toothed.

D. Leaflets $2-8$, rounded or blunt-pointed at apex, on slender reddish or dark brown axis; fruit a flattened seed capsule-139. Ifatayba domingensis.

DD. Leaflets long- or short-pointed at both ends, on axis often winged; fruit round, fleshy.

E. Leaflets 4 , the pair at apex larger, fruit $7 / 8-1 \frac{1}{4}$ inches in diameter, edible-140. Melicoccus bijugatus.*

EE. Leaflets usually $6-12$, sometimes only 1 at end ; fruit $5 / 8-1$ inch in diameter, yellow, inedible-141. sapindus saponaria.

\section{Guara}

This tree is characterized by: (1) twigs and leaf axes brown hairy; (2) pimnate leaves with 4-8 alternate elliptic or obovate leaflets, those toward apex largest, rounded or notched at apex, shortpointed at base, with wavy toothed edges, the upper surface shiny green and hairy only on veins, and the lower surface paler and densely soft hairy; (3) numerous small whitish 5-parted flowers $1 / 8$ inch across, in mostly terminal branched clusters: and $(4)$ the rounded seed capsules $1 / 2-3 / 4$ inch long, bluntly 3 -lobed, relvety-brown or rustybrown hairy, splitting into 3 parts and exposing 3 rounded shiny blackish seeds $5 / 16$ inch long, each in an orange cup.

A small to medium-sized evergreen tree attaining $20-50$ feet in height and 10 inches in trmmk diameter with a broadly spreading rounded crown. The gray bark is smoothish or becoming rough and fissured into plates. Inner bark is light brown and slightly bitter. The twigs are stout.

The leaves are alternate, 5-10 inches long, with stout axes. Leaflets have short hairy stalks $1 / 8^{-1 / 4}$ inch long and blades $11 / 2-6$ inches long and $3 / 4-23 / 4$ inches broad and slightly thickened.

The flower chusters (panicles) 4-8 inches long have brown hairy branches. Flowers are male, female, and bisexual (polygamous). There are 5 hairy sepals nearly 1/s inch long; 5 hairy, narrow stalked petals about as long as sepals, each with 2 scales on the outer edges; 8 stamens on a disk; and pistil composed of hairy 3-celled ovary with short style and 3 stigmas.

Seed capsules commonly are many and crowded in terminal branched chusters, short-stalked at
Cupania americana L.

base, opening widely into 3 parts, retaining the 3 seeds attached for some time. Flowering in winter and early spring (December to March) and matmring froits in spring and summer.

The wood is light brown and hard, of medinm weight (specific gravity 0.4). Tery susceptible to attack by dry-rood termites. Used in Puerto Rico chiefly for posts and poles and elsewhere for construction and shipbuilding.

This species has been suggested as an ornamental and shade tree. The seeds and leaves sometimes serve for medicinal pmposes. Also a honey plant.

Forests, especially along streams, in the moist coast, moist limestone, and lower momtain regions of Puerto Rico.

Pribic forests. - Cambalache, Carite, Guajataca, Iuquillo, Maricao, Río Abajo, Susúa, Vega.

RAxGE.-Greater Antilles and in Lesser Antilles only in Dominica, Martinique, and Barbados, and in Trinidad and Tobago. Also in Colombia and Venezuela.

Other common Names.-guara blanca (Puerto Rico); guárana, guara (Dominican Republic); guara, guara común, guárano, guárana macho, guálana hembra (Cuba); guacharaco (Colombia); guará, patillo. zapatero, cabimo, guamo guará, guamo matías (Venezuela) : candlewoodtree (Barbados); maraquil (Trinidad); bois de satanier (Haiti).

A closely related species of guara (Cupania triquetra 1 . Rich.) in Puerto Rico differs in having twigs and seed capsules $\pi$ ith shorter yellowbrown hairs and the seed capsules sharply 3-angled and on longer stalks. 


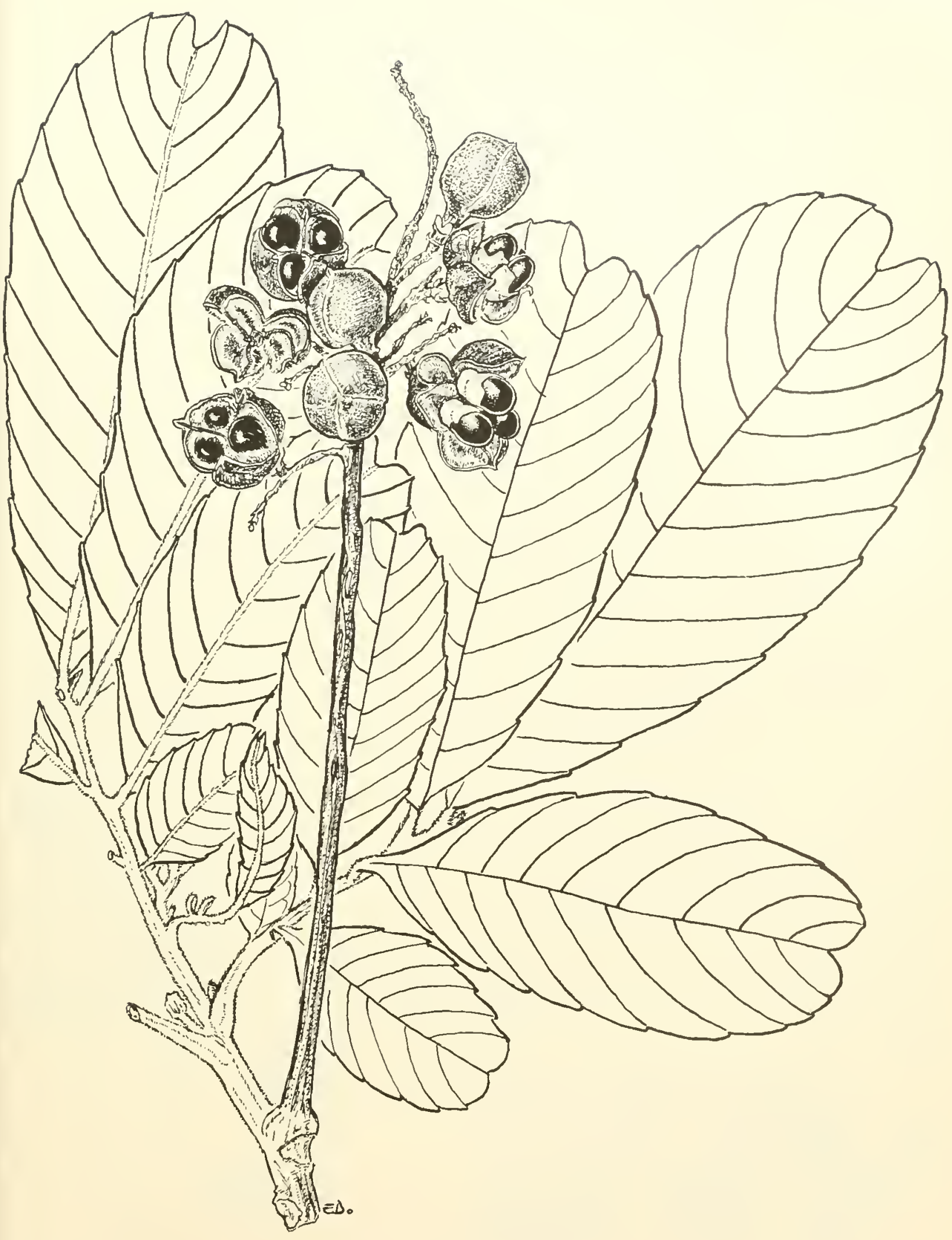




\section{SOAPBERRY FAMILY (SAPINDACEAE)}

\section{Negra lora}

This medium-sized tree of mountain forests is characterized by: (1) pinnate leaves with $2-8$ paired elliptic or lance-slaped stiff and leathery leaflets $1 \frac{1}{2}-31 / 4$ inches long and $1 / 2-11 / 4$ inches broad, on a slender reddish or dark brown axis, rounded or blunt-pointed at apex and shortpointed at base, the upper surface shiny green and with many slightly raised lateral veins, pale or with a brownish cast beneath; (2) minute 4 - or 5 -parted flowers less than $1 / 8$ inch long and broad, numerous in lateral branched flower clusters; and (3) odd, reverse heart-shaped (obcordate) dark brown or blackish seed capsules $1 / 2-5 / 8$ inch long and broad, mostly flattened and less than $3 / 16$ inch thick.

An evergreen tree attaining 30-60 feet in height and $11 / 2$ feet in trunk diameter, with a compact, slightly spreading crown. The bark is dark brown, smoothish, about $1 / 4$ inch thick, often spotted with an orange-red lichen. Inner bark is reddish brown, bitter and gritty. The twigs are reddish brown or dark brown, finely hairy when young.

Some leaves are altemate and others opposite, $3-8$ inches long. Ifeaflets have short stalks $1 / 8-1 / 4$ inch long and blades with minute lighter dots, not toothed on elges.

Flower clusters (panicles) are 1-4 inches long, with finely hairy branches. The numerous hairy flowers are male, female, and bisexual (polygamous). There are 4 or 5 pointed sepals, 4 or 5 smaller petals, 8 stamens on a disk, and pistil with usually 2 -celled ovary, style, and 2 stigmas.

Seed capsules are slightly stalked, hard, commonly 2 -lobed and 2-or 1 -seeded, reported as also 3 -lobed. The shiny black seeds are $5 / 16$ inch long

\section{Matayba domingensis (DC.) Radlk.}

and flat. Flowering and fruiting nearly through the year.

The sapwood is light brown, and the heartwood mniform pinkish brown or reddish brown. 'The wood is attractive, very hard, heavy (specific gravity 0.70 ), strong, fine-textured, of usually irregular and interlocked grain, and has a distinctive foul octor. The rate of air-seasoning is low, and amount of degrade is moderate. Machining characteristics are as follows: planing and resistance to screw splitting are fair; and shaping, turning, boring, mortising, and sanding are good. 'The wood is moderately difficult to saw and dulls cutting edges. It is very susceptible to damage by dry-rood termites and other insects and is not durable.

Chief uses in Puerto Rico are posts and poles, though preservative treatment is recommended. The rood is suitable for furniture, cabinetwork, turnery, interior trim, flooring, handles, agricultural implements, rehicle bodies, and light and heary construction.

Forests of the transition zone between the lower and upper mountain regions of Puerto Rico.

PrTlic Forests.-Carite, Guilarte, Luquillo, Maricao, Toro Negro.

Range.-Cuba, Hispaniola, and Puerto Rico.

Other common Names.- loncella, tea cimarrona, ratón, escoba (Puerto Rico) ; ratón, guara (Dominican Republic); caraicillo, macurije (Cuba).

A second species known as doncella (Matayba oppositifolia (A. Rich.) Britton) has oblong leaflets short - or long-pointed at apex and the leaves opposite. It apparently is rare in mountain forests of Puerto Rico. 

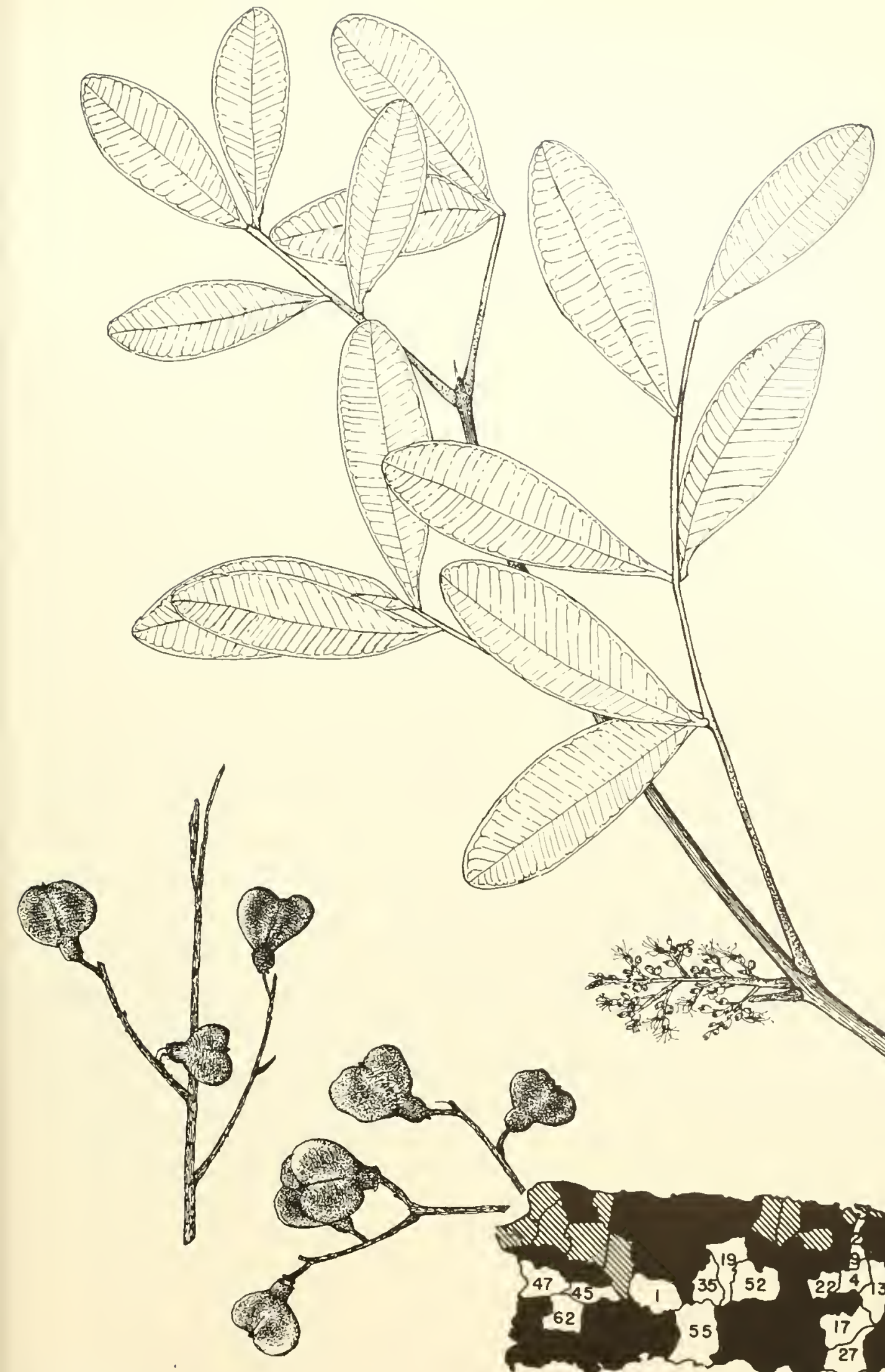

139. Negra lora

Natural size. 


\section{SOAPBERRY FAMILY (SAPINDACEAE)}

\section{Quenepa, kinep, Spanish-lime}

Quenepa is a familiar exotic tree planted for its edible fruit and shade. It is distinguished by : (1) erect form and a dense symmetrical globular crown of dull light green foliage; (2) pinnate leaves with 4 paired elliptic leaflets $3-5$ inches long and $11 / 4-$ $21 / 4$ inches broad, long- or short-pointed at both ends and slightly oblique at base, almost stalkless along an axis sometimes winged; and (3) small greenish-white fragrant flowers about $3 / 16$ inch across, very numerous in terminal branched clusters; and (4) round or elliptic green fruits $7 / 8-11 / 4$ inches in diameter with thm, sweet and acid, juicy flesh and 1 (sometimes 2) large seed.

An evergreen tree becoming 40-60 feet high, with trunk 1-2 feet in diameter, slightly angled and fluted. The bark is gray and smoothish, the inner bark orange brown, gritty, and tasteless. Twigs are bromn or gray, greenish when young.

The alternate leaves are $6-8$ inches long, with light green axis $21 / 2-3$ inches long. Leaflets are thin, not toothed on edges, the pair at apex larger.

Flower clusters (panicles) are 3-6 inches long and broad, with several to many narrow branches. Flowers are mostly male and female on different trees but partly of both sexes (polygamous), on spreading stalks $1 / 4$ inch long. Calyx is deeply 4or 5-lobed, the lobes more than $1 / 16$ inch long; there are 4 or 5 rounded greenish-white petals about 1/8 inch long: $8-10$ stamens on a disk; and pistil composed of 2 - or 3-celled ovary with short style and 2 - or 3-lobed stigma.

Fruits (drupes), borne in clusters, are marketed for their thin flesh, which is gelatinous and slightly fibrous, yellowish to salmon colored, and suggestive of grapes. The pale yellow elliptic seeds

\section{Melicoccus bijugatus Jacq.*}

$3 / 4-11 / 8$ inches long are edible when roasted. Flowering in spring (April to June), the fruits maturing from Jume to September.

The sapwood is light brown, and the heartwood light brown or pale yellow gray. The rood is of medium weight and fairly hard but reportedly not resistant to decay. Elsewhere it has been used in const ruction, interior work, and cabinets.

Besides furnishing fruit and shade, the trees are honey plants, their pleasantly scented flowers attracting bees.

Planted as a fruit and shade tree and along highways in Puerto Rico and escaping from cultivation. Commonest in the dry coastal region. Also in Mona, St. Croix, St. Thomas, St. John, and Tortola.

RAvge- Native of Colombia, Venezuela, and Guianas. Widely planted and escaping or naturalized throughout West. Indies from Bahamas and Cuba to Trinidad and Curaçao. Cultivated also in southem Florida and Califomia, Bermuda, Central America, Ecrador, and perhaps elsewhere in tropical America. Also introduced in Asia.

OTHer COMMON NinMfs.-genip, ginep (Virgin Islands); mamón (Spanish, commerce); mamoncillo (Spanish); quenepa (Puerto Rico, Colombia); limoncillo, quenepa (Dominican Republic); escanjocote (Nicaragua); mamón de Cartagena (Costa Rica); Spanish-lime, genip, mamoncillo (United States) ; genip (English) ; chenet (Trinidad) ; quénépe (Haiti) ; quenette, quenettier, kenepier (Guadelompe); quenette (French Guiana); kenepa, kimmup-tree (Dutch West Indies); knippen (Surinam).

Botanical sYNonm.-Melicocca bijuga $\mathrm{L}$. 


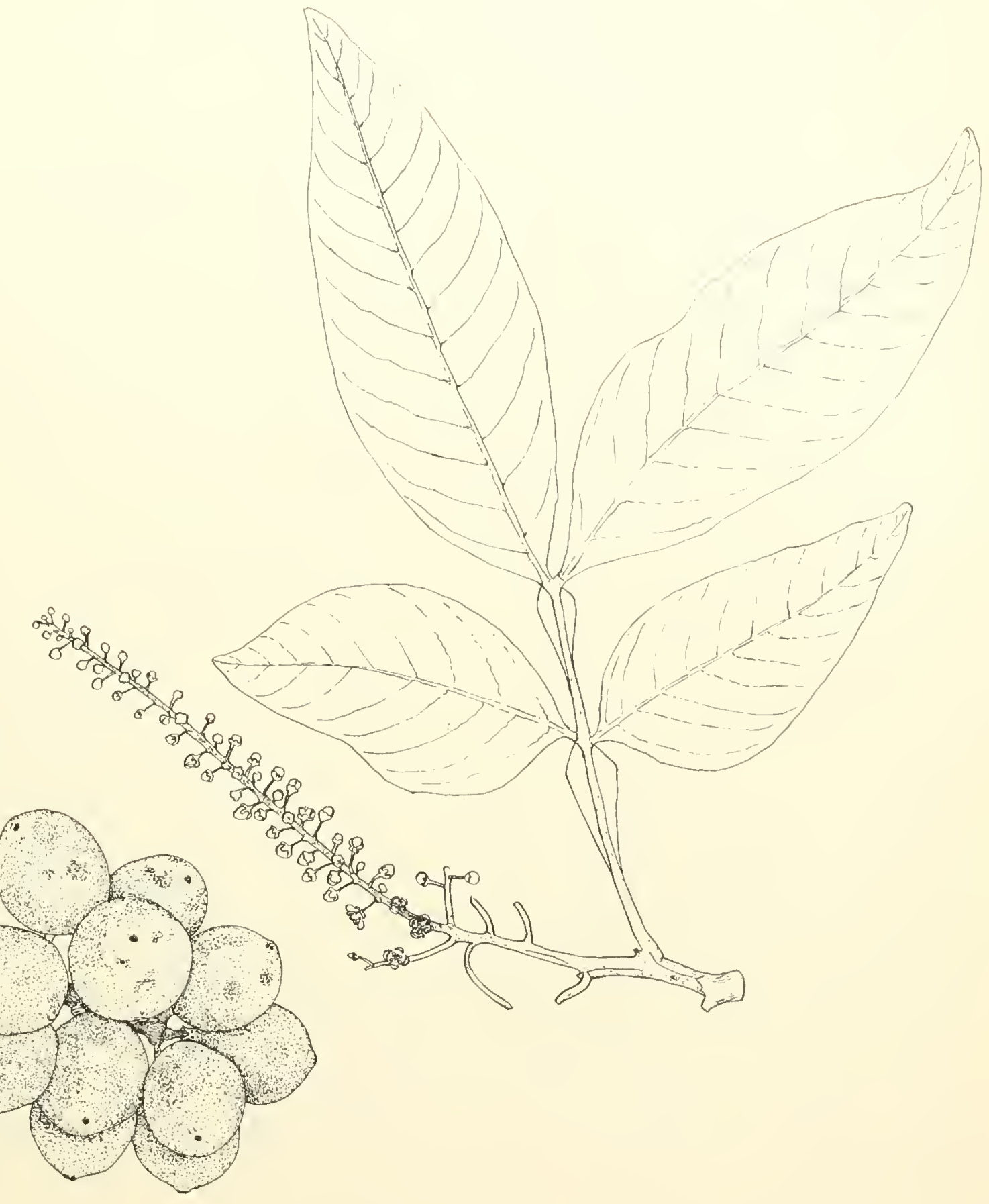




\section{SOAPBERRY FAMILY (SAPINDACEAE)}

\section{Jaboncillo, wingleaf soapberry}

Small to medium-sized tree sometimes planted for shade, characterized by: (1) pinnate leaves 8-16 inches long, with usually 6-12 paired elliptic to lance-shaped dull green leaflets, the green axis often with a wing $1 / 4^{-1 / 2}$ inch wide; (2) very $n u$ merous small 5-parted whitish flowers $3 / 16$ inch across in lar.re branched lateral clusters 6-18 inches long: and (3) shiny brown ball-like berries $5 / 8-1$ inch in diameter, borne singly or sometimes 2 or 3 together, containing yellow, sticky, bitter, poisonons flesh and 1 lound black poisonons seed.

An evergreen tree 20-60 feet high and 1 foot in trunk diameter, sometimes larger, with broad crown. The light gray or brown bark is smoothish and warty, becoming finely fissured and scaly. Imner bark is light orange brown, slightly bitter and astringent. The stont twigs are light gray with raised reddish-brown dots (lenticels), finely hairy when young.

The alternate leares have paired leaflets with ol without a single terminal one. Leaflets are stalkless or nearly so, $21 / 2-6$ inches long and $1-21 / 2$ inches wide, mostly short-pointed at both ends, often oblique and mequal-sided with side toward leaf apex much broader, thin, not toothed on edges, beneath slightly paler and sometimes soft hairy.

The male flowers produced in great quantities seem to fall from the tree almost like rain and litter the gromnd beneath. Flowers are mostly male but some are female or bisexual (polygamous). In male flowers there are 5 spreading sepals abont $1 / 16$ inch long, mequal, the outer 2 being smaller, whitish and tinged with green: 5 white hairy petals rounded and smaller than sepals; 8 light yellow stamens more than $1 / 16$ inch long on a light green disk; and a minute brown nonfunctional pistil. Female flowers have besides the sepals and petals shorter stamens and a greenish pistil more than $1 / 16$ inch long with 3 -celled ovary and slender style.

One or sometimes 2 or 3 fruits derelop from a pistil, the aboltive ones remaining as disklike appendages at base. Inside the translucent yellow flesh is the poisonous seed $3 / 8^{-1 / 2}$ inch in diameter. Branches of the flower cluster (panicle) become hard and woody when the fruits mature.

Sapwood is whitish, and heartwood yellow or
Sapindus saponaria L.

light brown. The wood is hard and heavy (specific gravity 0.8 ), coarse-textured, and not durable when exposed. Used locally for posts and elsewhere employed in carpentry.

The common names lefer to the use of the fleshy fruit as a substitnte for soap. When cut up, the fleshy part, which contains about 30 percent saponin, produces suds abundantly in water.

Crushed seeds serve as a fish poison when thrown into a stream. An insecticide has been made from ground seeds, and medicinal oil extracted also. Other uses of the seeds are as beads in necklaces, as marbles, and formerly as buttons. Infusions of the roots and leaves have been prepared for home remedies. A shade tree and honey plant.

In the dry constal region of Puerto Rico, infrequently planted for shade. Also in Vieques, St. Croix, St. Thomas, and St. John.

Public forest.-Aguirre.

RavoE.-Common and widely distributed in tropical America and spread farther through cultivation. Southern Florida including Florida Keys (mown also in California and Bermuda) and throughout West Indies from Bahamas and Cuba to Trinidad. Also from Mexico to Ecuador, Galapagos Islands, Peru, Argentina, Paraguay, and Brazil. Introduced into Old World tropics.

OTHER COMIION NAMES.-soapberry (Virgin Islands); jaboncillo (Spanish); palo amargo, chorote, mata de chivo (Dominican Republic); guiiril, hniril, jaboncillal (Guatemala); pacón (Honduras) ; pacún (El Salvador) ; pacón, cuyus (Nicaragua); limoncillo (Panama); chumbino, chumbimbo, chocho (Colombia) ; paraparo, pepo (Veneznela) ; jurupe (Ecuador); sulluco (Peru); jisotoúbo (Bolivia); yequiti, casita, palo-jabón (Argentina); wingleaf soapberry, soapberry (United States) ; soapberly (English) ; soapseed Trinidad); soap-tree, soapseed-tree, jabon-ché (British Honduras) ; saronette pays, graine canique, bois savonette (Haiti) ; savonier, savonettier, savonette montagne, bois mausseux, savonette mousseuse (Guadelonpe) ; sa vonetapel (Curaçao) ; sopo sirie (Surinam); saboeiro, saboneteiro (Brazil). 


\section{SOAPBERRY FAMILY (SAPINDACEAE)}

\section{Serrasuela}

This small tree or shrub restricted to dry sonthwestern Puerto Rico is distinguished by: (1) few slender spreading branches and without a definite crown; (2) leathery elliptic leares simple (sometimes compound with 3 leaflets), rounded at apex and short-pointerd at base, the edges finely toothed, shiny green above and pale green and densely soft hairy with prominent veins beneath; (3) many small whitish flowers $3 / 16$ inch across, 4 - or 5 parted, in narrow branched lateral clusters 1-21/2 inches long; and (4) brown narrow key fruits 1/2 $5 / 8$ inch long, usually 3 attached together. This species is closely related to the next species, ceboruquillo (Thouinir strinta Radlk.), a large tree having compound leaves with 8 thimmer leaflets and smaller flowers. Intermediate individuals have been found.

A deciduous tree becoming 15 feet high and 3 inches in trunk diameter. The gray bark is rongh, fissured and divided into thim scaly plates. Inner bark is brownish and slightly bitter. Twigs are brownish green, finely hairy when young, becoming gray.

The altermate leaves have finely brownish hairy petioles $3 / 8-11 \frac{1}{2}$ inches long. The blade is usually simple and 2-4 inches long and 1-2 inches wide, the upper surface nearly hairless except on veins. Sometimes there are 3 stalkless leaflets at end of

\section{Thouinia portoricensis Radlk.}

petiole, the 2 lateral leaflets mich smaller, $7 / 8^{-11 / 2}$ inches long.

The densely hairy flower clusters (thyrses) are attached along the twigs, often at leaf bases. Flowers are male, female, and bisexnal (polygamous), borne on short stalks less than $1 / 8$ inch long. There are 4 or 5 greenish hairy sepals more than $1 / 16$ inch long and rounded at apex; 4 or 5 white petals less than $1 / 8$ inch long; 8 stamens 1/8 inch long on a disk; and pistil $1 / 8$ inch long with hairy 3-celled ovary of 3 nearly separate lobes and 3-forked style rising between lobes.

The dry fruits (samaras), usually 3 developing from a flower, are finely hairy, enclosed 1 seed at hase, and have a long narrow curved wing $3 / 16$ inch wide. Flowering and fruiting nearly through the year.

The sapwood is light brown and hard. The wood is little used.

Forests and thickets of the dry limestone region of southwestern Puerto Rico.

Poiblic forest.-Guánica.

MTNICIPALITIES WHERE ESPECLALLY COMMON.$28,38,54$.

Range.-Confined to sonthwestern Puerto Rico.

Other common Name- -quebracho (Pnerto Rico).

Botanical sYNonym. - Thyana portoricensis (Radlk.) Britton. 


\section{SOAPBERRY FAMILY (SAPINDACEAE)}

\section{Ceboruquillo}

A small to medium-sized tree of Puerto Rico recognized by: (1) compound leaves with 3 elliptic or obovate leaflets, the middle leaflet largest, broadest beyond middle, saw-toothed on edges, and short-pointed at apex and base, the lower surface soft hairy and with prominent veins; (2) small whitish flowers less than $1 / 8$ inch long and broad, 4-parted, numerous, and short-stalked in very narrow clusters $1 \frac{1}{2}-4$ inches long and $3 / 8$ inch wide at leaf bases; and (3) brown narrow winged key fruits $5 / 8^{-3} / 4$ inch long, borne in 3 's.

An evergreen tree to 50 feet in height and 8 inches in trunk diameter, with an erect crown. The bark is gray, rough, broken into thin rectangular scaly plates. Inner bark is light brown and slightly bitter. The brownish twigs are finely hairy, green when young.

The alternate leaves are $\$ 8$ inches long, with leaflets at the end of a minutely hairy petiole $1 / 2-21 / 2$ inches long, the leaflets with short stalks about $1 / 8$ inch long. Leaflet blades are $21 / 2-6$ inches long and 1-3 inches broad, slightly thickened, the upper surface yellow green and hairless except on veins, the lower surface light green and densely soft hairy.

The lateral flower clusters (panicles) commonly

\section{Thouinia striata Radlk.}

have 2 main finely hairy branches. Flowers are male, female, and bisexual (polygamous), borne on stalks less than $1 / 8$ inch long. There are 4 yellow-green hairy sepals less than $\mathrm{I} / 16$ inch long; 4 white narrow hairy petals more than $1 / 16$ inch long, notcherl at apex; 8 stamens on a disk; and pistil composed of hairy 3-celled ovary and slender style 3 -lobed at apex.

The fruits (samaras) are dark brown at the narrow base, slightly hairy, 1 -seeded, with a long light brown wing $1 / 4$ inch broad. Flowering and fruiting from spring to fall.

The sapwood is light brown. The wood is hard, tough, and heavy (specific gravity 0.9). It is used chiefly for posts.

Forests of the moist limestone and lower Cordillera regions in western Puerto Rico.

Public Forests.-Cambalache, Guajataca, Maricao, Río Abajo, Susúa.

Municipalities Where espegially COMMON.-7, $9,23,24,31,34,68$.

Raxge.-Known only from Puerto Rico.

Other CoMmon NAMrs.-quiebra-hacha, quebracha, serrasuela, guabá (Puerto Rico).

Botanical SYNONYMr.-Thyana striata (Radlk.) Britton. 

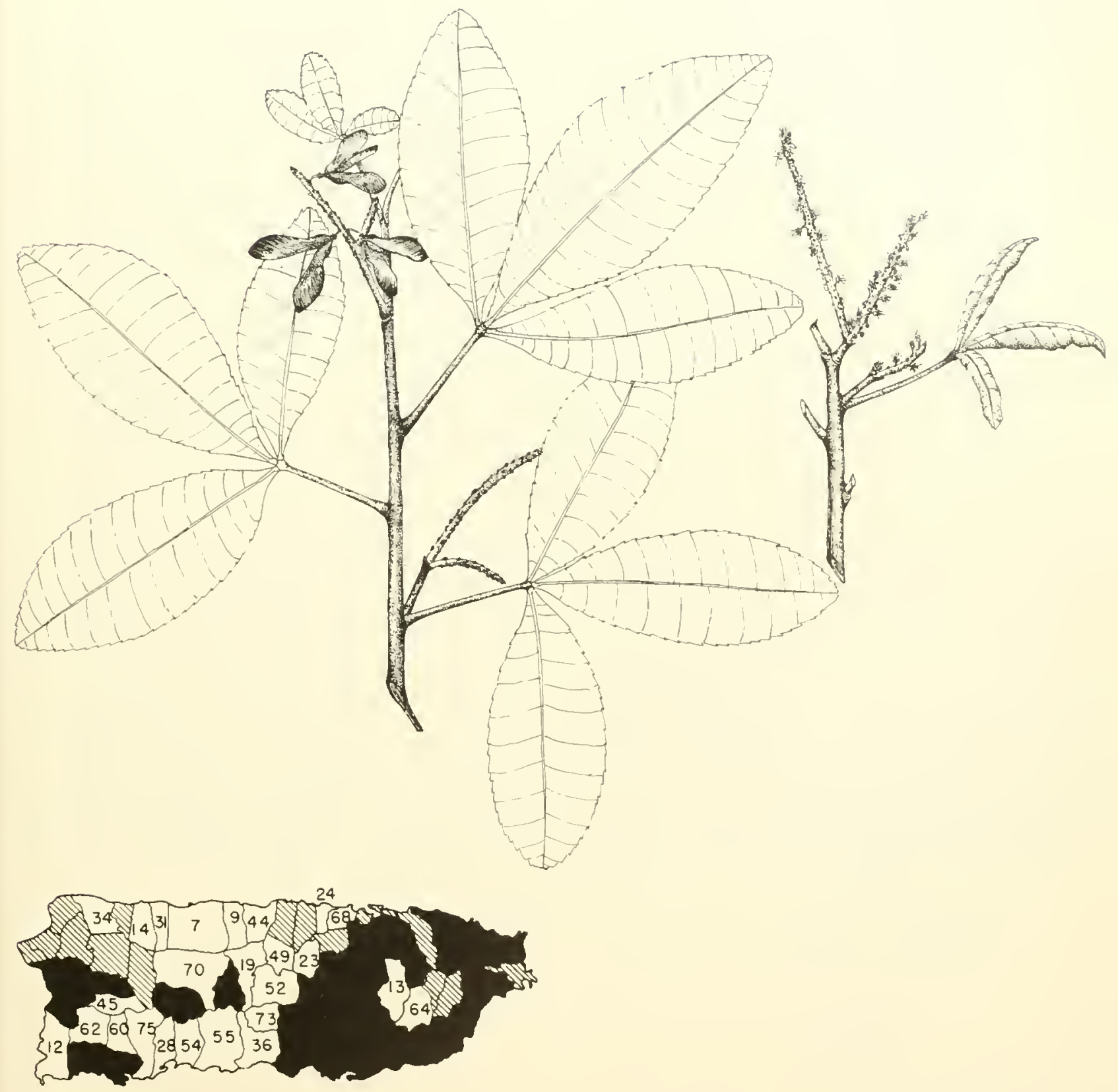

143. Ceboruquillo

Two-thirds natural size.

Thouinia striata Radlk. 


\section{SABIA FAMILY (SABIACEAE)}

\section{Aguacatillo}

A medium-sized tree of momtain forests characterized by: (1) petioles with an enlargement at base and 3/8-11/4 inches long; (2) dark green elliptic leaves mostly broadest beyond the middle, 3-8 (sometimes 10) inches long and 11/2-31/4 (sometimes 4) inches wide, short-pointed or blunt at. apex, short-pointed at base, edges not toothed except on young plants: (3) very numerous minute white 5-parted flowers less than $1 / 8$ inch long and broad in much-branched clusters; and (4) few to many nearly round fruits $5 / 5-3 / 1$ inch long, dark brown, violet, or black, and fleshy.

An evergreen tree reaching $30^{\circ}-60$ feet in height and 2 feet in trunk diameter. The bark is smoothish but slightly warty, gray, and thin, becoming fissured on large trunks. Inner bark is brownish and bitter. The gray twigs, hairless except when yomng, have scatteled redilish-brown, corky warts (lenticels) $1 / 8 \mathrm{inch}$ or less in length.

The leaves are alternate, with the few lateral veins sunken, slightly shiny on both sides, and paler beneath. Young plants produce larger leares.

The branched flower clusters (panicles) are terminal and lateral, 2-8 inches long and broad, and minutely hairy. The flowers have a few minute, hairy, overlapping seales at base. There are 5 rounded overlapping sepals $1 / 16$ inch long, with hairy border, remaining attached at base of fruit; petals 5, white, the outer :3 larger and more than $1 / 26$ inch long and 2 small narrow scales; 5 stamens opposite the petals and mited with them at base, 2 fertile stamens opposite the small petals and 3 sterile (staminodes); and pistil with ovary, style, and 2 minnte stigmas.

Fruits (drupes) are light green when immature, nearly round but longer than broad, have a large 1 -seeded stone, and remain attached for some time.
Meliosma herbertii Rolfe

Flowering and fruiting nearly through the year.

The sapwood is light brown, and the attractive heartwood light brown with darker streaks and often an attrittive orange overcast. The wood is moderately heary (specific gravity 0.42), firm, tough, with moderately coarse texture, straight to frequently interlocked grain, and faint growth lings. It is low in dumbility and very susceptible to attack by dry-mood termites. The rate of airseasoning is moderate, but the amount of degrade is considerable. Machining characteristics are as follows: planing and resistance to screw splitting are excellent; shaping, turning, boring, and mortising are poor ; and sanding is good.

Few trees become large enough for commercial timber. Uses elsewhere include construction and carpentry. 'Though difficult to work, the wood is suitable also for furniture, cabinetwork, paneling, interior trim, and boxes and crates.

Forests of the lower momntain regions of Puerto Rico. Also in Tortola.

Púlic Forests.-Carite, Guilarte, Luquillo, Toro Negro.

Raxge.-Hispaniola, Pnerto Rico and Tortola, and Lesser Antilles from St. Kitts to Grenada. Also in northeastern Venezuela.

OTHER COMMON NAMES.-arroyo, cacaillo, cacao bobo (Puerto Rico) ; cacao cimarrón, cacao bobo (Dominican Republic); gross grain (Grenada); bois violet, graines violettes, graines vertes (Guadeloupe); wild cocoa (Trinidad).

Arroyo (Metiosma obtusifolia (Bello) Krug \& Urban) is a related, less common tree species known only from mountain forests of Pnerto Rico. It has leaves rounded at apex and smaller nearly round fruits about $3 / 8$ inch in diameter. Other common names are cacaillo, cerrillo, ciralillo, and gllayarote. 


$$
\begin{aligned}
& \text { और } \\
& \text { of o ? }
\end{aligned}
$$

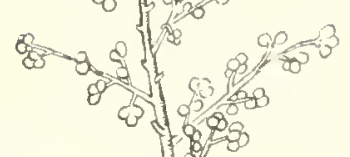

$x$

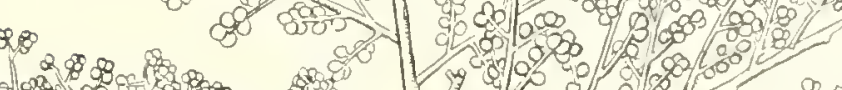

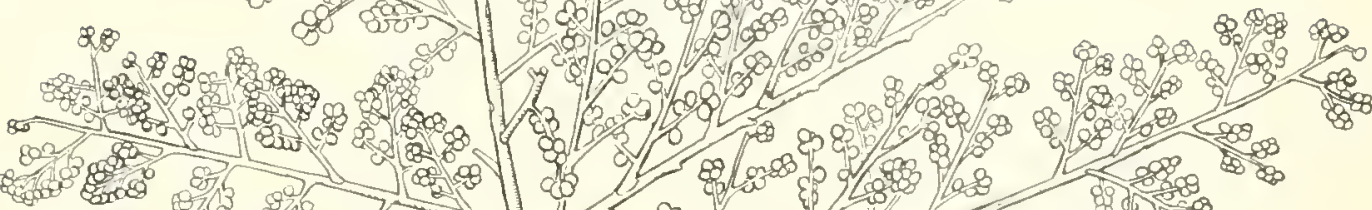
\&

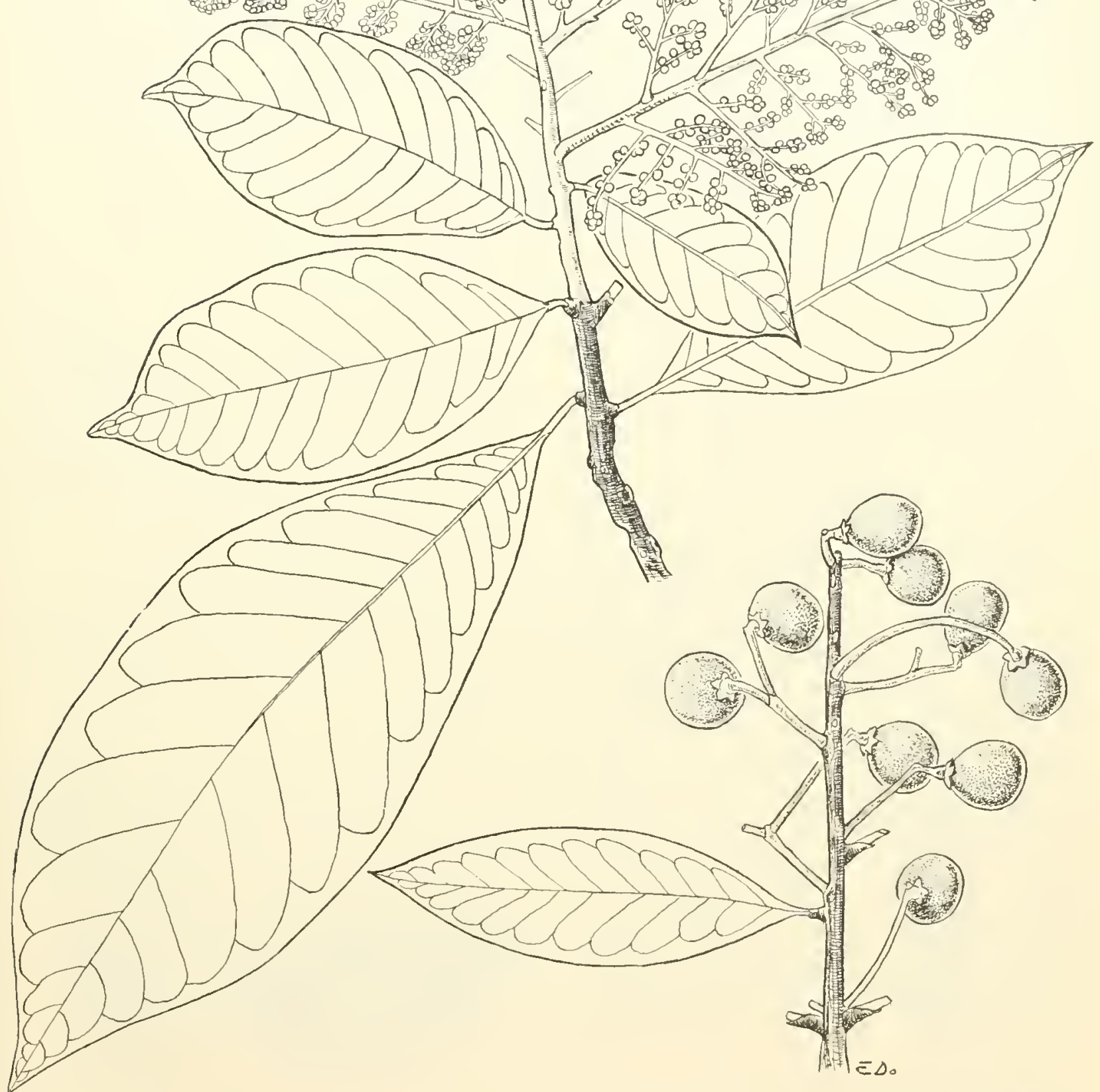




\section{BUCKTHORN FAMILY (RHAMNACEAE)}

Key to the 4 species illustrated (Nos. 145-1 18 )

A. Leares with 1 main rein or midrib, edges not toothed; twigs not spiny.

B. Leares mostls short-pointerl at apex, lateral veins curred and prolonged near margins.

C. Leaves slightly thickened, the lower surface, petioles, and twigs with rusty brown hairs, especially when young-145. Colubrina arborescens.

CC. Leaves thin, the lower surface pale green and minutely hairy-146. Colubrina reclinata.

BB. Leares rounded at both ends and slightly notehed at apex, nearly hairless-147. Frugiodendron ferreum. AA. Leares with 3 main reins from base, edges often minutels toothed; twigs with paired or single spines-148. sarcomphalus reticulatus.

\section{Abeyuelo, coffee colubrina}

This usually small tree is identified by: (1) rusty-brown hairs on young twigs, young leaves, veins or lower surface of mature leares, petioles, and flower cluster's; (2) slightly thickened elliptic leares $11 / 2-6$ inches long and $3 / 4-3$ inches broad, blunt- or short-pointed at apex and rounded at base, with the prominent lateral reins curved and prolonged near margins, the upper surface slightly shiny green and nearly luairless, and the lower surface lighter green and finely hairy; (3) small, spreading, 5-parted, greenish and rusty-brown hairy flowers $3 / 16^{-1 / 4}$ inch across in small lateral clusters; and (4) rounded dark brown or blackish seed capsules about $1 / 4$ inch in diameter, 3 -seeded.

Commonly 10-15 feet high and 2 inches or less in trunk diameter but sometimes 25 feet or more in height, evergreen, with spreading crown. Bark of small trees is brown or gray, smoothish, and thin, peeling off in small thin flakes, on larger trumks becoming fissured. Inner bark is light brown or pink and slightly bitter. Older twigs are gray or redidish brown.

Leaves are altermate in 2 rows and have petioles $1 / 4-1 / 2$ inch long. Blades ale $1 \frac{1}{2}-6$ inches long and $3 / 4-3$ inches broad, not toothed on edges.

Trees planted in moist sites of Puerto Rico are so different in their more vigorous rapid growth that they scarcely seem to represent the same species. They become $40-50$ feet in height and $6-10$ inches in trunk diameter, with long stout nearly holizontal branches bearing 2 rows of large coarse leaves. These much larger leares have stout petioles $3 / 4^{-1}$ inch long and blades $8-11$ inches long and $4-6$ inches wide. The flowers are similar, though the seed capsules may be slightly larger. The drawings illustrate both the typical and largeleaf forms.

Flower clusters are $1 / 2$ inch across or smaller, almost stalkless, with sereral, mostly short-stalked flowers. The short cuplike base (hypanthimm) bears 5 spreading, pointed sepals more than $1 / 16$ inch long, greenish and on outside rusty-brown hairy, and 5 smaller narrow yellow petals folded around the 5 opposite stamens; and the pistil consists of 3-celled ovary covered by the broad disk, a style, and 3 stigmas.

\section{Colubrina arborescens (Mill.) Sarg.}

Seed capsules, borne few to several together along twig mostly back of leaves, are nearly ronnd or slightly 3-lobed, with cuplike base (hypanthinm) in lowest third to half, splitting into 3 parts and separating from base. The shiny black seeds are $1 / 8^{-1 / 4}$ inch long. Flowering and fruiting probably irregularly from spring to fall.

The sapwood is whitish or light brown, the heartwood yellowish brown. The wood is hard, heary (specific gravity 0.7), strong, and durable. Used chiefly for posts in Puerto Rico and formerly for piling because of resistance to decay in water. Elsewhere employed in construction where sufficiently large.

Planted as a shade tree in southern Florida, Guatemala, and El Salvador. Recent forest plantations of this species in the Guilarte Forest contain rapid-growing trees of good form. The shiny seeds of this and related species have been made into necklaces and similar omaments in Jamaica.

Thickets and forests in the coastal and limestone regions, chiefly in the drier areas of Puerto Rico. Also in Mona, Icacos, Vieques, Culebra, St. Croix, St. Thomas, St. John, Tortola, Virgin Gorda, and Anegada.

Public forests.-Boquerón, Cambalache, Guajataca, Guánica, Guilarte, Río Abajo.

MUNICIPALITT WHERE ESPECIALLY COMMON. 19.

RAxge.- Sonthern Florida including Florida Keys and West Indies from Bahamas and Cuba to Antigua and in Barbados. Also southern Mexico, Guatemala, and Honduras, and introduced in El Salvador.

Other comion NAMEs.-corazón de paloma, cuerno de buey (Dominican Republic) : bijáguara, birijagua, fruego (Cuba); cascalata (Mexico) ; coxté, costex, guayabillo (Guatemala) ; chaquirio, chaquira (El Salvador) ; coffee colubrina, nakedwood, wild-coffee (United States) ; common snakebark, bitters (Bahamas) ; greenheart, snake-wood, black relvet, wild ebony, mountain ebony (Jamaica) ; blackbead-tree (Barbados) : bois de fer, bois mabí, bois pelé, bois ferblanc (Haiti).

Botayical synonyas. - Colubrina colubrina (Jacq.) Millsp., C. ferruginosa Brongn. 


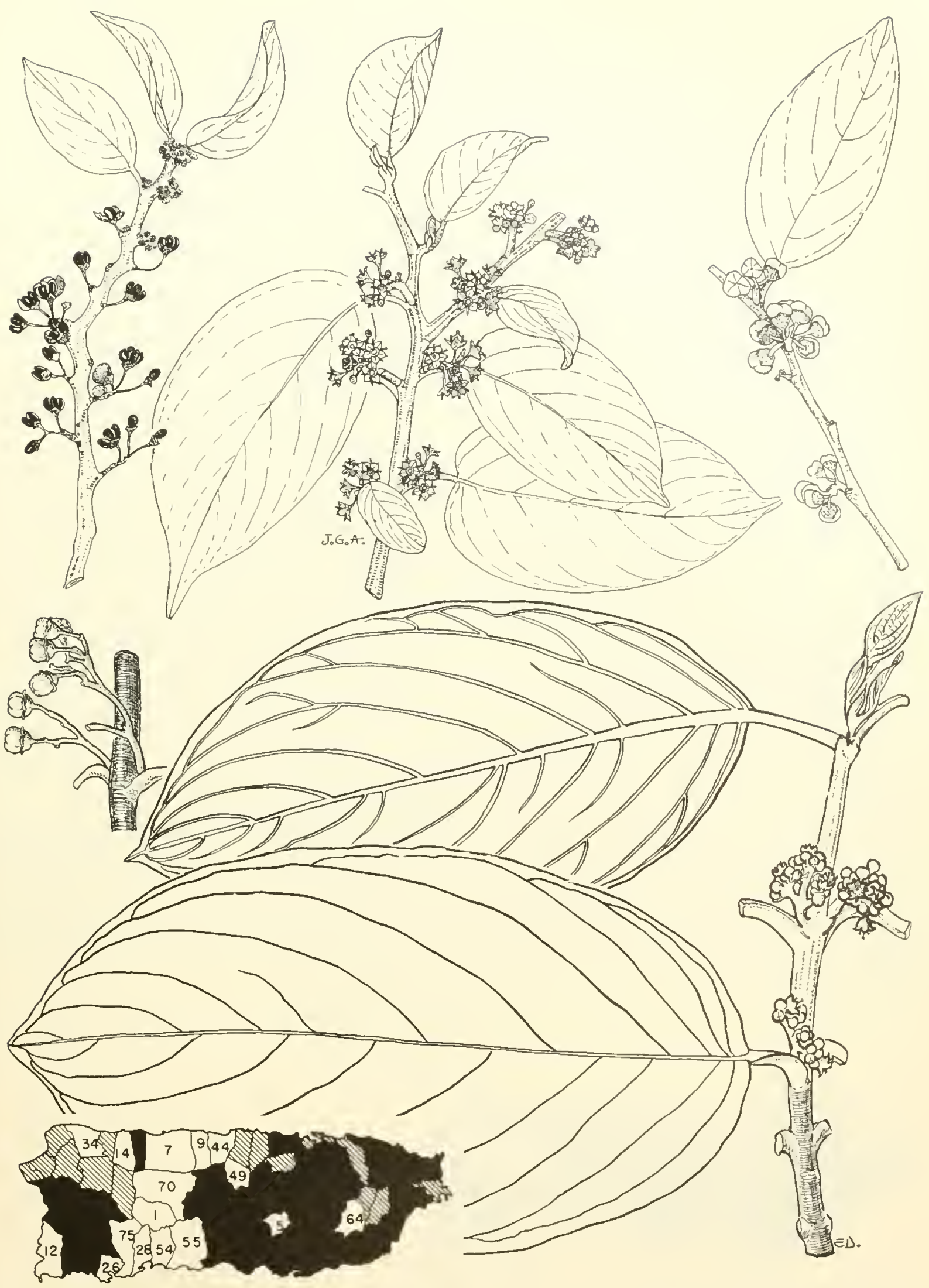

145. Abeyuelo, coffee colubrina

Colubrina arborescens (Mill.) Sarg. Typical form (above) and large-leaf form (below), two-thirds natural size. 


\section{BUCKTHORN FAMILY (RHAMNACEAE)}

\section{Mabí, soldierwood}

This small tree or shrub of dry areas is characterized by: (1) finely hairy brown twigs; (2) thin, ellipt ic leaves $1-3$ inches long and $1 / 9-11 / 2$ inches hroad, short-pointed at apex and rounded at base, with the lateral veins curved and prolonged near margins, green and hairless on upper surface, and pale green and minutely hairy beneath; (3) the surall, spreading greenish 5-parted flowers nearly $3 / 16$ inch across, several in almost stalkless clusters at bases of leaves: and (t) the rounded, slightly 3-angled, reddish-brown seed capsules $1 / 4$ inch in diameter, 3-seeded.

Evergreen, msually 10-15 feet high and less than 4 inches in trunk dinmeter, with spreading crown of thin foliage. The orange-brown bark is smoothish on small trunks but becomes fissured, splitting off in thin seales. Imner bark is light brown and bitter. The twigs are slender.

The alternate leaves have hairy petioles $1 / 4-1 / 2$ inch long. The blades commonly have 2 brown gland dots on the margin near base.

Flowel clusters about $1 / 4$ inch across, hairy. Each flower has a short cuplike base (hypanthium) on which are borne 5 spreading, pointed, greenish sepals mole than $1 / 6$ inch long, hairy on outside, and 5 smaller, narrow, yellow petals folded around the 5 opposite stamens; the pistil has a 3 -celled ovary covered by the broad disk but with style and 3 stigmas protruding.

\section{Colubrina reclinata (L'Hér.) Brongn.}

Seed capsules have a cuplike base (hypanthium) in lowest third and split apart from the base to release the shiny brownish-black elliptic seeds $3 / 16$ inch long. In flower from July to November and in fruit from July to .January.

The sapwood is light brown, and the heartwood dark brown. The wood is hard, heavy (specific gravity 0.8), strong, and reported to be durable. It is used only for posts in Puerto Rico.

From the bark is produced the popular fermented drink "mabí." Elsewhere decoctions from the bitter bark and the leaves have been used in local medicines. The plants have been grown as ormamentals in southern Florida.

Thickets and woods in the dry coastal and dry limestone regions of southwestern Puerto Rico. Also in Culebra, St. Croix, St. Thomas, St. John, Tortola, and Anegada.

Public Forest.-Guánica.

Rasge. - Southern Florida including Florida Keys, Bahamas, Greater Antilles, and Lesser Antilles south to St. Vincent. Also in southern Mexico (Veracruz and Yueatán) and Guatemala.

OTHER COMIMON NAMEs.-palo amargo, mabí (Dominican Republic); jayajabico, carbonero de costa, carbonero (Cuba); soldierwood, naked-wood (United States); smooth snake-bark (Bahamas); bois mabí, bois de fer (Haiti); bois mabí, mambee (Guadeloupe). 


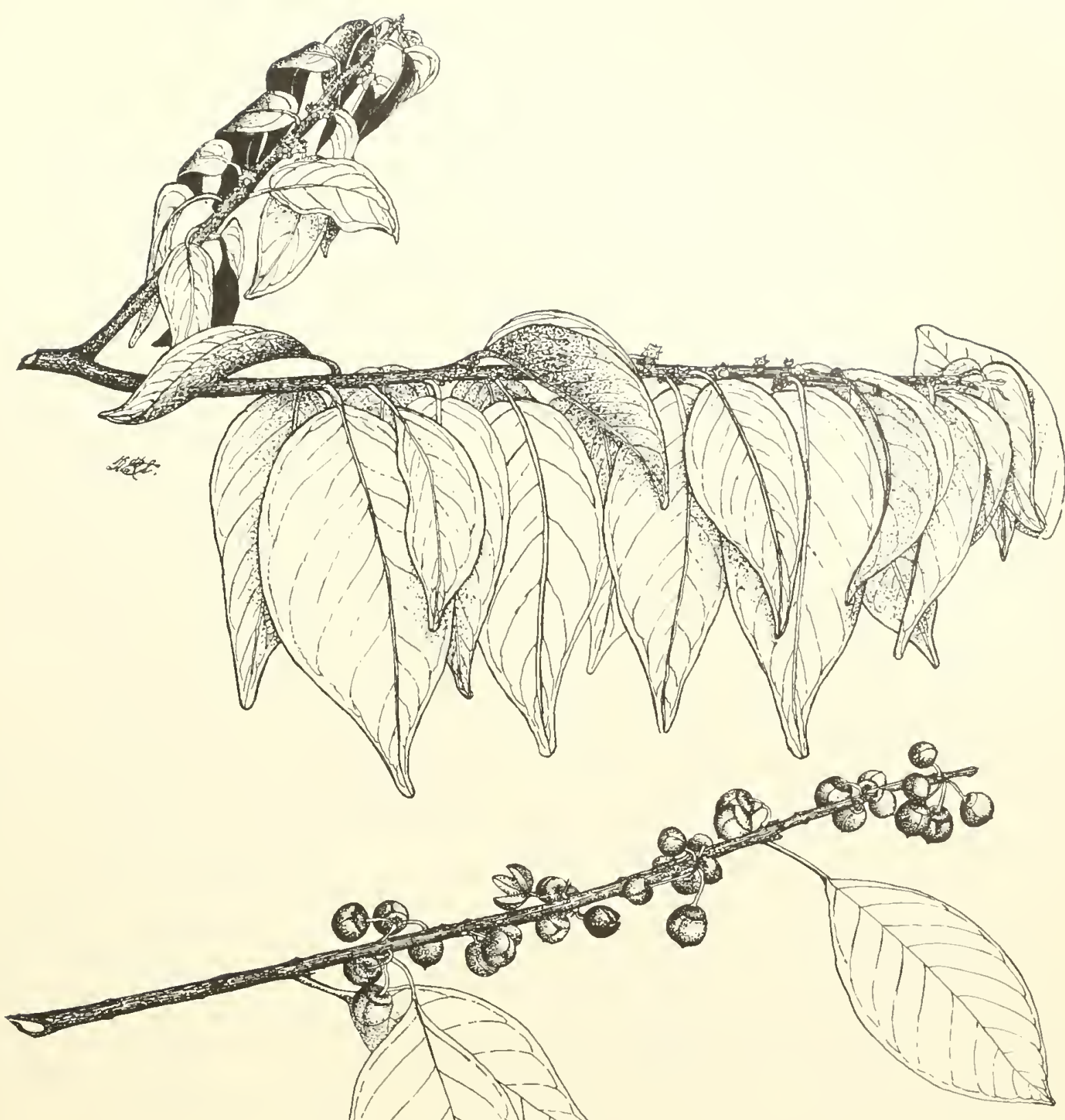




\section{BUCKTHORN FAMILY (RHAMNACEAE)}

\section{Bariaco, "ironwood," leadwood}

One of several similar species with small leaves, this small tree or shrub is characterized by: (1) densely leafy spreading branches in horizontal layers; (2) mostly opposite, nearly hairless, elliptic (sometimes ovate) leaves $3 / 1-2$ inches long and $1 / 2-1 \frac{1}{4}$ inches broad, rounded at both ends and slightly notched at apex, reddish when immature, later green or yellow green, shiny on upper surface and dull beneath; (3) yellow-green 5-parted flowers $3 / 16$ inch across, a few in clusters $1 / 4-1 / 2$ inch long at leaf bases; and (4) elliptic dark brown or black fruits $1 / 4-3 / 8$ inch long.

An evergreen tree or shrub commonly $10-15$ feet high and 2-6 inches in trumk diameter. The gray bark is smoothish or slightly fissured, beconing ridged and sealy on large trunks. Inner bark is reddish brown, slightly bitter. The slender twigs are minutely hairy, gray or light brown, the young green portions bearing the lateral flowers. Raised leaf sears and dots (lenticels) make the twigs slight ly rough.

The leaves have short, finely hairy petioles $1 / 8-3 / 16$ inch long and blades usually slightly thickened, not toothed on edges.

Flower clusters (cymes) have 5 or fewer flowers, each on a stalk abont $1 / 8$ inch long. The short cupshaped base (hypanthium) is less than $1 / 16$ long, bearing 5 spreading pointed yellow-green sepals $1 / 16$ inch long and 5 stamens; the pistil $1 / 16$ inch long bordered by the clisk has ovary, short style, and 2 stigmas. Petals are lacking. The fruits (drupes) are 1-seeded. Flowering and fruiting at different times during the year.

The sapwood is light brown, and the heartwood is orange brown to dark brown, streaked. The wood is exceedingly hard, exceedingly heavy (specific gravity 1.3-1.4), very fine-textured, and very
Krugiodendron ferreum (Vahl) Urban

resistant to decay and to attack by dry-wood termites. Because of the small size of local trees, the wood has little use in Puerto Rico except for posts.

Used elsewhere for cabinetwork, reneer, crossties, and canes. The wood is one of the densest in the world, the heaviest of the native woods in the United States and perhaps also of Puerto Rico.

Thickets and woods in the limestone regions of Puerto Rico, mostly in the south west. Also Mona, Desecheo, Caja de Muertos, Icacos, Culebra, Vieques, St. Croix, St. Thomas, St. John, Tortola, and Anegada.

Pülic forests.-Guajataca, Guánica.

RavaE.-Southern Florida including Florida Keys, Bahamas, Greater Antilles, Lesser Antilles south to St. Vincent and Bequia, and in Bonaire and Curaçao. Also in southem Mexico, Guatemala, British Honduras, and Honduras.

OtHer Conmon names.-espejuelo, palo de hierro, quiebra-hacha (Puerto Rico); ironwood, guatafer, bois de fer (Virgin Islands); quiebrahacha, ciguamo, palo de hierro (Dominican Republic) ; cocruyo, hueso de tortuga, coronel, carey de costa, palo diablo, acero (Cuba); quiebra-hacha (Guatemala) ; leadwood, black-ironwood (United States) ; black-ironwood (Jamaica) ; axemaster, quebracho (British Honduras); bois de fer (Haiti, Guadeloupe) ; manggel cora, ironberry (Dutch West Indies).

The generic name means Krug's tree. This genus of a single species was dedicated to Leopold Krug (1833-98), German consul in Puerto Rico, businessman, botanist, and patron of science, who studied the flora of the West Indies. 


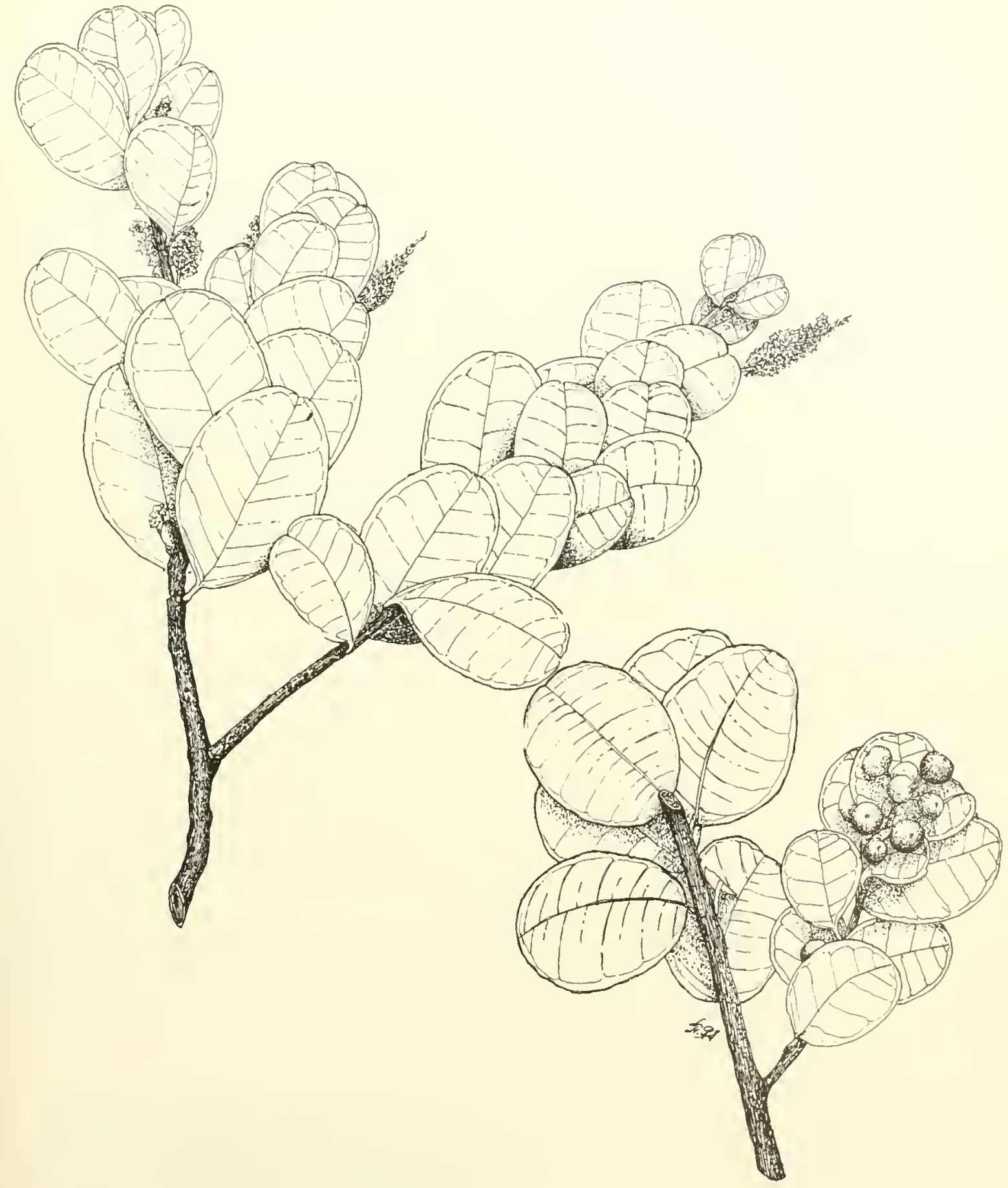




\section{BUCKTHORN FAMILY (RHAMNACEAE)}

\section{Cascarroya}

This small tree of dry forests is distinguished by: (1) small gray or brown spines $1 / 8-3 / 8$ inch long, paired or single at some nodes: (2) densely rusty hairy twigs; (3) mostly small, thickened, st iff and bittle elliptic leaves 1-3 inches long and $5 / 8-2$ inches broad, pounded at both ends, with 3 main veins from base, the lower surfare with prominent network of raised reins and finely soft hairy ; (4) many small yellow-green 5-parted flowers $3 / 16$ inch across, finely and densely hairy, in branched clusters; and (5) elliptic brown fruits $3 / 8-5 / 8$ inch long, with brown hairy base $1 / 4$ inch across.

In evergreen tree or shrub to 20 feet high and 4 inches in trunk diameter. The dark gray or brown bark is smoothish. Inner bark is dark red, gritty, and tasteless. The brown or gray twigs are angled when young.

The alternate leaves have short hairy petioles about $1 / 8$ inch long. Leaf blades are often slightly heart-shaped at base, with edges often minutely toothed and tmrned under, the upper surface green to dark green, dull or a little shiny, finely hairy or becoming nearly hairless, with slightly sunken reins, and the lower surface light green.

The flower clusters (panicles) are mostly terminal, 1/2-21/2 inches long, densely hairy, and bear many crowded, almost stalkless, slightly fragrant flowers less than $1 / 8$ inch long. The conical green hairy base (hypanthimm) 1/16 inch long bears 5 spreading, pointed, yellow-green sepals $1 / 16$ inch long, hairy on ontside, 5 mimute long-stalked concave pale yellow petals $1 / 16$ inch long, and 5 stamens opposite the petals and the same length; and within the yellow-green disk is the pistil $1 / 16$ inch

\section{Sarcomphalus reticulatus (Vahl) Urban}

long composed of a green hairy 3-celled ovary and 3 styles mited below.

The fruits (drupes), a few in a cluster, are slightly longer than broad, light green and tuming to brown, finely hairy or hairless. The large stone encloses 3 or fewer shiny brown flattened seeds. Flowering and fruiting in summer.

The wood is light brown or yellowish, hard, and heavy (specific gravity 0.9). Used in Puerto Rico for posts.

In Dominican Republic hogs and goats eat the fruits. Reported to be a honey plant.

Forests and thickets of the dry limestone region of sonthwestern Puerto Rico. Also in Caja de Inertos, St. Croix, and Tortola.

Puble Fonest.-Guánica.

Range--Hispaniola, Puerto Rico and Virgin Islands, and Lesser Antilles at Barbuda and Long Island near Antigua.

OTHER COMMON rAMEs.-cacao rojo, azufaito, cascarilla, espejuelo (Puerto Rico) ; saona cimarrona, saona de puerco, sopaipo (Dominican Repnblic) ; coquemolle (Haiti).

A related tree species (Sarcomphatus domingensis (Spreng.) Krug \& Urban) has the twigs, leares, and flowers all hairless. It is recorded from the British Virgin Islands, Vieques, and the northeastern end of Puerto Rico.

Another species (Sarcomphalus tayloriz Britton), a shrub or small tree of Mona Island and Bahamas, has obovate leaves less than 1 inch long, bright green on both sides, and notched or rounded at apex. 


\section{ELAEOCARPUS FAMILY (ELAEOCARPACEAE)}

\section{Motillo}

A large tree of mountain forests, recognized by : (1) the mostly large elliptic leaves 6-18 inches long and 3-8 inches broad, short-pointed at both ends and the petioles with a swelling at each end; (2) the pale yellow widely spreading flowers $5 / 8-3 / 4$ inch across, 4 - or 5 -parted, several in lateral clusters; (3) the elliptic brown seed capsules 11/4 inches long, hard and thick-walled, splitting usually into 4 parts and commonly present on ground under trees; and (4) pronounced buttresses at the base of the trunk.

This evergreen tree becomes 100 feet tall, with a straight trunk 2-3 feet in diameter. The smoothish dark gray bark has reddish-brown warts about $1 / 1$ inch long and broad. Inner bark is light brown, with slightly bitter gritty taste. The brown twigs are finely hairy when young.

The altemate leaves have stont petioles $1 / 2-31 / 2$ inches long, green turning brownish. Lea blades vary greatly in size and are thin or slightly thickened, without marginal teeth, nearly hairless, dark green and with slightly sunken veins on upper surface, and green beneath.

Flower clusters (racemes) are unbranched, 2 inches or less in length, with several flowers on slender, finely hairy stalks $1 / 2-3 / 4$ inch long. There are 4 or s pale yellow, pointed, finely hairy sepals $1 / 1-5 / 16$ inch long; no petals; numerous hairy stamens $1 / 4$ inch or less in length, attached on a broad disk; and the hairy pistil $1 / 4$ inch long, consisting of 4-or sometimes 3-celled ovary, style, and $4 \mathrm{or}^{\circ}$ sometimes 3 stigmas.

The 4-parted seed capsules, inconspicuously fine hairy, hard and with walls $3 / 16$ inch thick, release a few rounded or elliptic seeds about $1 / 2$ inch long. Flowering chiefly from spring to fall, with fruits nearly through the year.

The sapwood is yellowish brown, and the heartwood multicolored, varying from yellow brown to pinkish brown or dark brown, sometimes with

\section{Sloanea berteriana Choisy}

darker brown stripes. The wood is very hard, heary (specific gravity 0.80), strong, and mediumtextured, and has growth rings and irregular grain. It is considered hard on tools, is classed as durable, and is susceptible to attack by drywood termites. Its rate of ail-seasoning and amount of degrade are moderate. Machining characteristics are as follows: planing, tuming, mortising, and sanding are good : shaping and boring are excellent; and resistance to screw splitting is poor.

In Puerto Rico the wood has been used sparingly for furniture and also in local construction and for crossties. Lacking attractiveness and uniform color for furniture and cabinetwork, it is snitable for heavy construction, farm implement parts, handles, heary-duty flooring, and boat parts.

Forests of the lower mountain regions of Puerto Rico, A dominant tree in the rain forest, usually glowing in the moist ravines and becoming an emergent tree in the upper story of the forest.

Punlic forests.-Carite, Guilarte, Luquillo, Tolo Negro.

RAxge.-Hispaniola, Puerto Rico, and Lesser Antilles from St. Kitts to Martinique.

OTHer comor Nases.-- cacao motillo, cacaillo, cacao roseta, cacaotillo, roseta (Puerto Rico) ; cacao cimarrón (Dominican Republic); petit coco, châtaignier petit coco, cocoyer (Guadeloupe, Martinique).

Inother species (Sloanea amygdalina Griseb.) is rare in the mountain forest at Maricao Forest in the western Cordillera. This tree has smaller elliptic leaves with blades $21 / 2-6$ inches long, blunt or notched at apex, fewer flowers usually single or no more than 3 together, and smaller seed capsules $5 / 8-1$ inch long, densely covered with short spines $1 / 16$ inch long. It is native also in Hispaniola and Cuba but was not listed from Puerto Rico by Britton and Wilson. 

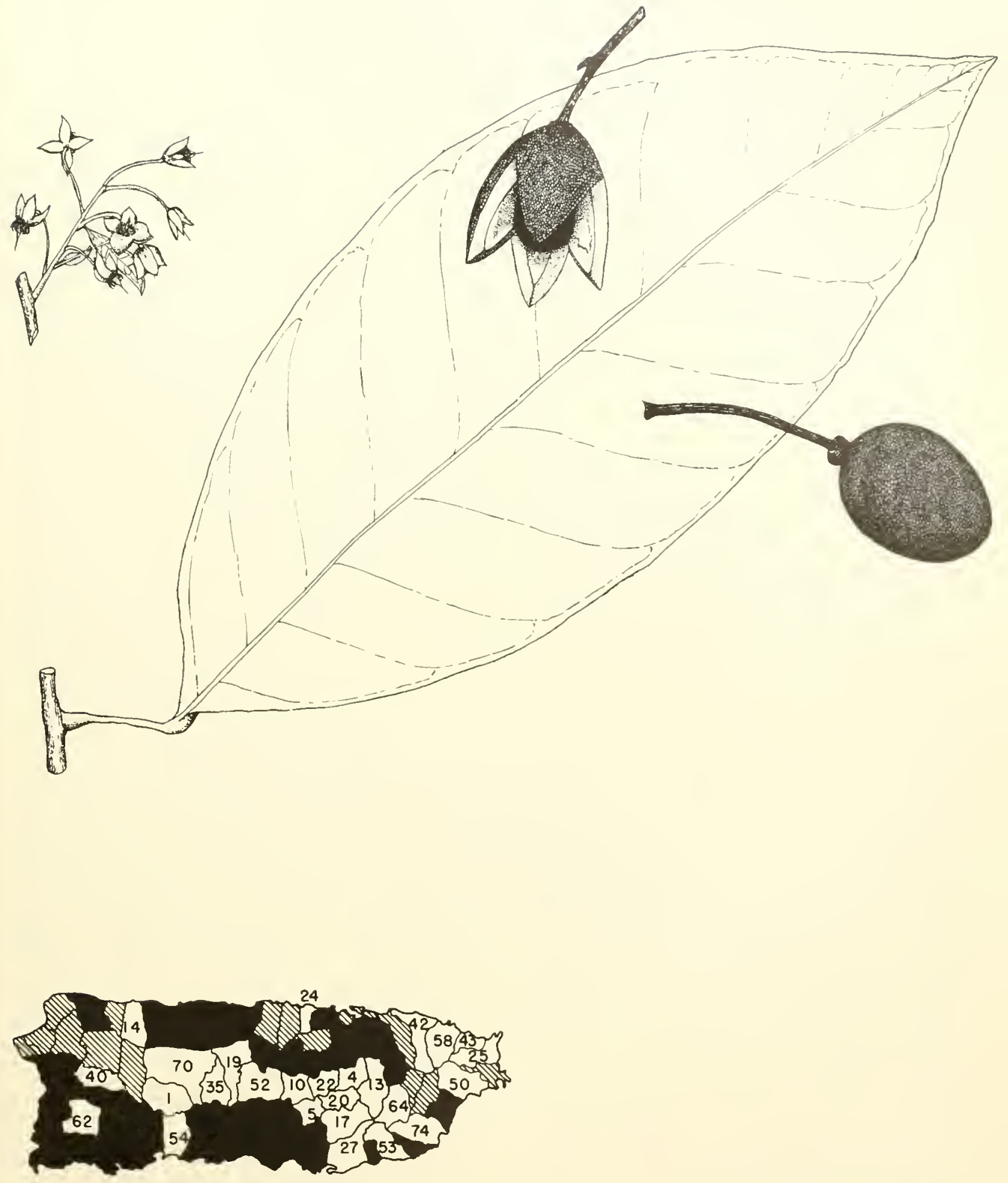

149. Motillo

Two-thirds natural size. 


\section{MALLOW FAMILY (MALVACEAE)}

Key to the 3 species illustrated (Nos. 150-152)

A. Leares with mostly 11 or 9 main reins from base; petioles and lower leaf surfaces densely covered with whitishgray star-shaped hairs; flowers with sellow petals, turning orange and reddish with age-150. Hibiscus tiliaccus.*

AA. Leares with mostly 7 main reins from base, petioles and blades with scattered minute scales.

B. Leaves abruptls long- or short-pointed at apex; flowers with red yetals-151. Montezuma speciosissima.

BB. Leaves long-poiuted at apex; flowers with pale sellow petals, turning to purple-152. Thespesia populnea.*

\section{Emajagua, sea hibiscus}

Hibiscus tiliaceus $\mathrm{L}^{*}$

This small tree or shrub is characterized by: (1) long-petioled, henrt-shaped and nearly round leaves $4-7$ inches long and brond, with mostly 11 or 9 main veins from hase, shiny yellow green and hairless on upper surface; (2) the young twigs, petioles, lower leaf surfaces, calyx, and seed capsules densely covered with whitish-gray starshaped hairs; (3) widely spreading or prostrate crooked branches: (4) the large fumnel-shaped yellow flowers $3-31 / 2$ inches long and broad, turning orange and reddish with age: and (5) the elliptic, gray-grcen, hairy seed capsules $1-11 / 4$ inches long, which split into 5 parts.

An evergreen tree attaining 10-20 feet in height. with a short crooked trumk to 6 inches in diameter and a broad crown. The bark is gray and smooth, the thin inner bark fibrons. The twigs have rings at nodes and become brown and hairless in age.

Leaves are alternate and have petioles $2-5$ inches in length. Leaf b]ades are abruptly short- or longpointed at apex and heart-shaped at base, with edges not toothed, and slightly thickened. There are 2 large short-pointed whitish hairy scales (stipules) 1-11/2 inches long at base of leaf, soon shedding and leaving a ring soar.

A few flowers are borne in terminal branching clusters (panicles) or lateral near ends of twigs, each on a whitish hairy stalk $3 / 4-2$ inches long. At the base of a flower there is a gray-green hairy cup (involucre) $3 / 1$ inch long with usually 9 or 10 narrow pointed lobes. The calyx, also gray-green hairy, is $1-11 / 4$ inches long, tubulal with 5 narrow long-pointed lobes. Petals 5 (greenish tinged in dried specimens), $21 / 2-31 / 2$ inches long, l'ounded but broader on 1 side, with star-shaped hairs on outside. Numerons stamens are on a colnmn abont. 2 inches long united with petals at base. The pistil consists of a densely hairy conical 5-celled ovary with long slender style and 5 broad stigmas.

The long-pointed seed capsules split and break open the calyx and involncre which remain attached. There are many brownish-black seeds $1 / 8^{-3 / 16}$ inch long. Flowering and fruiting through the year.

The sapwood is whitish, and heartwood is dark greenish brown. The wood is moderately soft, porous, and moderately heary (specific gravity 0.6). U'sed chiefly for fuel, sometimes elsewhere for floats or as a cork substitute.

An important use of the fibrons bark, which can be peeled off in long strips, is for cordage. Be- sides ropes, fish nets, mats, and coarse cloth formerly were made from the bark, which even could he enten in times of famine along with the roots and young leaves. Also, the fiber has served for tying tobacco. The trees spront from stmmps and when cut back produce long vigorous shoots from which quantities of ropes can be made. Different parts of the tree have served in home medicines. Also a boney plant.

Grown as an ornamental for the showy flowers. The plants are easily propagated by cuttings and are started in fence rows as living fenceposts. In constal swamps near mangroves, leaning trunks and branches form roots in the mud and aid building the land.

Roadsides, thickets, and swampy areas in the lower mountain regions of Puerto Rico. Also in Mona, Vieques, St. Thomas, and St. John. (Recorded long ago from St. Croix.)

Peblic Forests.-Carite, Guilarte, Luquillo, Río Abajo, Toro Negro.

R.MGE-Seashores throughout the tropics, probably of Old World origin and naturalized in Imerica. Sonthern Florida including Florida Keys, Bermuda, and through West Indies from Bahamas and Cuba to Trinidad and Tobago. Also from Mexico to Peru and Brazil.

Otiler comion nayes. - majagua (Puerto Rico, Spanish): damajagua (Dominican Republic); majagua hembra (Cuba); majao (Honduras) : algodoncillo, mahoe (Panama); sea hibiscus, linden hibiscus, tree hibiscus, mahoe (United States) ; mahoo (English) : seaside majoe (Jamaica, Trinidad and Tobago); mahot (St. Vincent); blue moho, wild cotton (British Honduras); maho, hayuwa (British Guiana) ; coton marron, mahaut franc (Haiti) ; bois flot, bois de liège, grand mahot, mahot gombo (Guadeloupe); bois flot (Martinique); pariti (French Guiana); mabo (Surinam).

Botanical synonym.-Paritium titiaceum (L.) St.-Hil., Juss., \& Camb.

The Spanish common name majagua, of which the English name mahoe is a corruption, is an American Indian word applied in tropical America to several imrelated trees with useful fibrous bark.

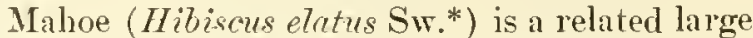
upland tree native in Cuba and Jamaica and introduced into Puerto Rico in experimental forest plantations. It has a tall straight trunk and 


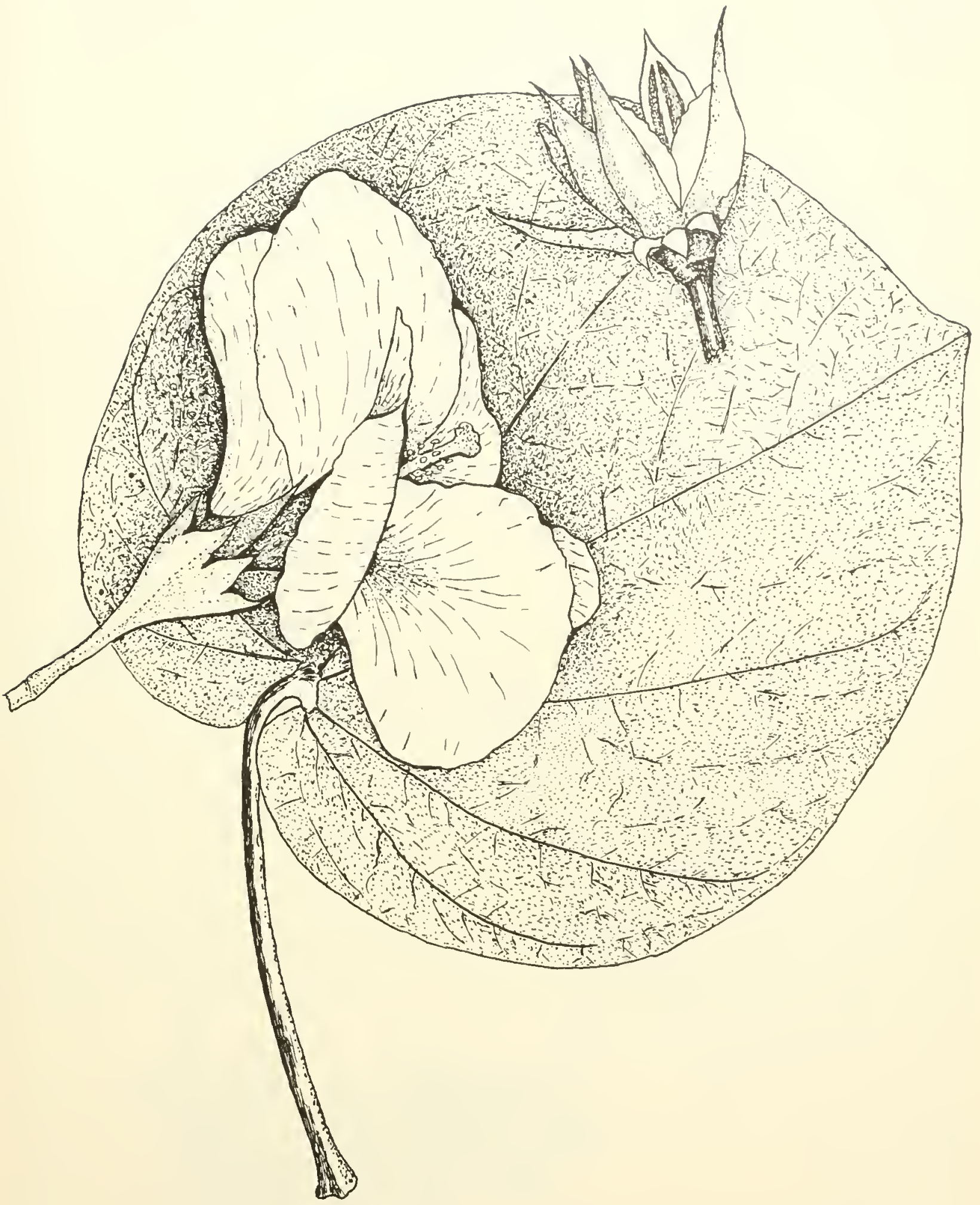


larger flowers about 4 inches long and broad. The petals are dark led at base, changing in color from pink to yellow and red.

This genus is represented also by 10 or more species of native and introduced shrubs and herbs, including the veretable okra (Hibiscus esculentus L.). Amapola ol Chinese hibiscus (H. rosasinersis L.*) is a popular ornamental shrub with purple, rose, or white petals, introduced from tropical Asia.

\section{MALLOW FAMILY (MALVACEAE)}

\section{Maga}

Maga, a widely planted native tree is easily recognized by its very large red spreading flowers $3-31 / 2$ inches long and $31 / 2-5$ inches broad, with 5 rounded overlapping petals. Though generally in flower, identification may be made also by: (1) the long-petioled heart-shaped leaves with blades $41 / 2-9$ inches long and $4-61 / 2$ inches broad and usually 7 main veins from base; and (2) the nearly round pointed green fruit $11 / 4-2$ inches in diameter.

A medium-sized evergreen tree becoming $30-50$ feet tall and 6-18 inches in trunk diameter, formerly larger. The gray or brown bark is rough and relatively thick ( $1 \%$ inch), deeply furrowed on large trunks. Inner bark is light brown, fibrous, and slightly bitter. The stout, warty twigs are green when young, turning brown; young twigs and other green parts have scattered minute brown scales.

The altermate leaves have yellow-green petioles 2-5 inches long. Leaf blades are abruptly long- or short-pointed at apex, heart-shaped at base, with edges not toothed, slightly thickened, green or yellow green above and paler beneath.

Flowers are solitary at leaf bases on stout stalks $4-51 / 2$ inches long, longer than petioles. Though several are formed on a twig, only 1 flower opens at a time. The cup-shaped areen calyx is about $3 / 4$ inch long and broad, slightly thickened, shedding as a ring after flowering, with 3 narrow green scales (bracts) $\frac{5}{8}$ inch long at base falling from the bud. 'The 5 very large petals are $3-31 / 2$ inches long and 2-3 inches bunad, rounded but broader on 1 side, with minute star-shaped hairs on outside. Stamens many, $3 / 16$ inch long, on a whitish column about $23 / 4$ inches long united at base with petals and shedding with them. The pistil is composed of a slightly conical yellow-green ovary about $3 / 3$ inch long and broad, 4 - or 3 -celled, slender white style $21 / 4$ inches long, and 4 or 3 yellow united stigmas $1 / 2-3 / 4$ inch long.

The funits are fleshy or leathery, not splitting open. There are a few brown seeds $1 / 2$ inch long, a veraging about 1,200 to the pound. They lose viability within a month. Flowering and fruiting throughout the year.

The sapwood is light brown, and the heartwood is rich chocolate brown resembling old mahogany. The wood is rather hard, heary (specific gravity 0.7 ), fine-textured, very durable, and very resist-
Montezuma speciosissima Sessé \& Moc.

ant to attack by dry-wood termites. A now scarce furniture wood nsed also occasionally for tumery, musical instruments, posts, and poles.

This tree was formerly widely planted along roadsides and for timber in the public forests. As it proved to be an alternate host of the pink bollworm (Pectinophora gossypiella Saunders), its planting was discontinued in the cotton region. Subsequently, propagation of this species has nearly terminated except for landscaping. Forest plantings stopped when it was found that trees which at first grew straight and rapidly later nearly ceased growth, became excessively branchy, and produced numerous cankerlike defects on the trunk. Trees in plantations on good soils in the moist limestone region averaged 3.6 inches in diameter at an age of 9 years. Another objection to extensive planting even for the flowers is that the trees are very susceptible to a scale insect which deforms trunk and branches and sometimes causes death. In southern Florida and elsewhere the trees have been introduced for ornament and shade.

This handsome tree is Puerto Rico's own and should be a candidate for adoption as the official tree. When originally described, it was confused with Mexican collections by the same Spanish botanists, and the range was erroneously given as Mexico. The scarcely appropriate name for this genus of a single species confined to Puerto Rico honors Montezuma, Aztec ruler in Mexico at the time of the Spanish conquest in 1513 , but the specific name means very beautiful.

Native in the moist limestone forest region of Puerto Rico. Extensively planted on the humid coast, lower Cordillera, and lower Luquillo forest regions. Cultivated also in St. Thomas.

Public forests.-Wild and planted in Cambalache, Guajataca, and Río Abajo. Planted in Carite, Luquillo, and Toro Negro.

MUNICIPALITIES WIIERE ESPECIALLY COMMON.$49,53$.

Ravae.-Native only in Puerto Rico. Planted in St. Thomas, Dominican Republic, Cuba, Jamaica, southern Florida, and British Honduras, and perhaps elsewhere.

OTher Common NaMes.-maga colorada (Puerto Rico); purple haiti-haiti (St. Thomas); tulipán del Japón (Dominican Republic).

Botanical sTNoNYIS.-Thespesia grandiflora DC., Montezuma grandiflora (DC.) Urban, Maga grandiflora (DC.) Urban. 

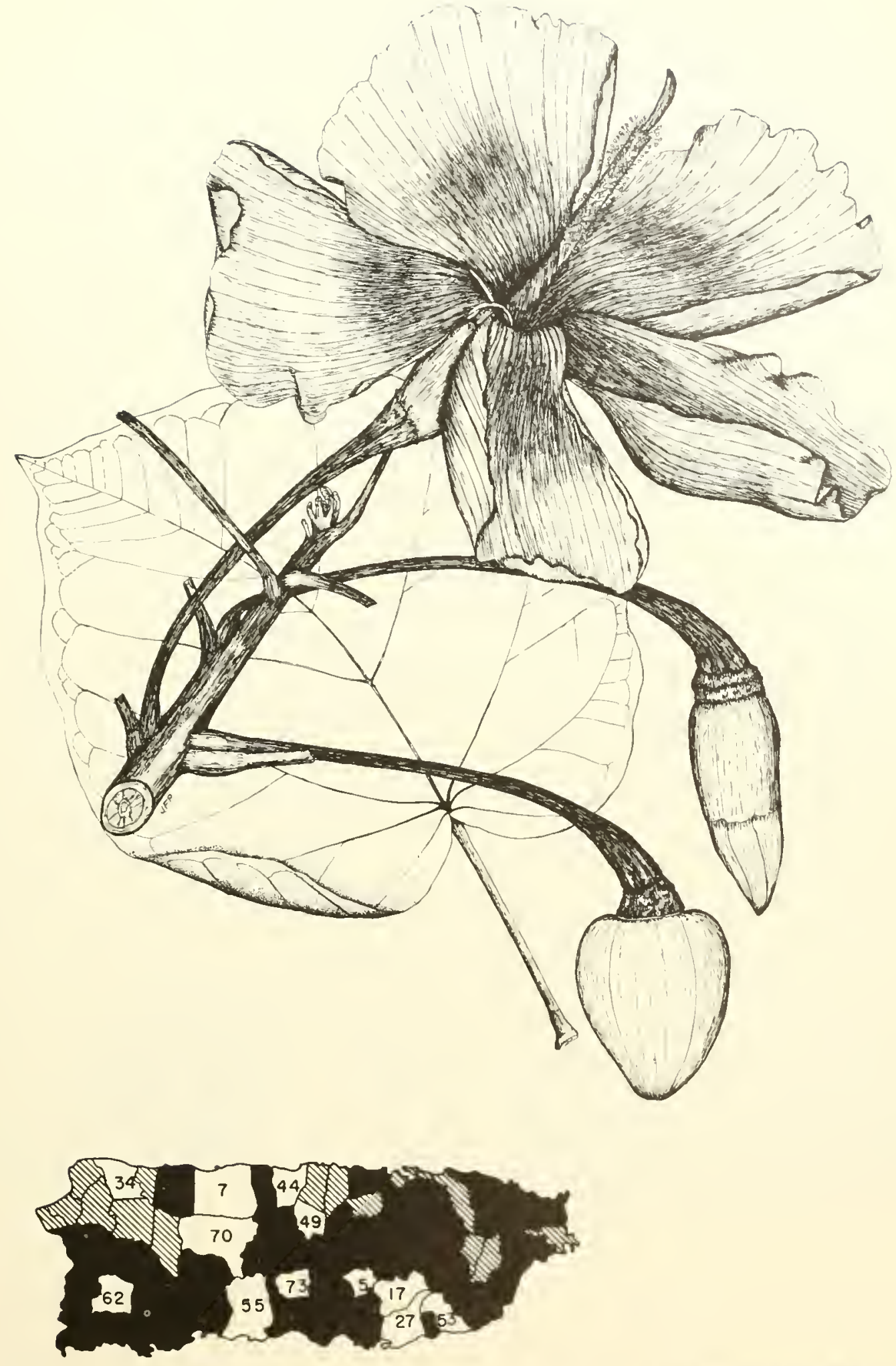

151. Maga

Two-thirds natural size.

Hontezuma speciosissima Sessé \& Moc. 


\section{MALLOW FAMILY (MALVACEAE)}

\section{Emajagüilla, otaheita, portiatree}

This tree ol" shrub of coastal woods, also planted for ornament and shade, is characterized by: (1) large bell-shaped flowers 2 inches long and broad, with 5 overlapping petals, pale yellow but turning to purple, single at leaf bases; (2) dark gray, romeded but flattened, slightly 5-ridged, hard, dry fruits about $1 \frac{1 / 4}{4}$ inches or more in diameter and 3/4 inch high; (3) long-petioled, long-pointed, deeply heart-shaped, dark green shiny leaves with blades $4-8$ inches $\operatorname{long}$ and $21 / 2-5$ inches broad, with usually 7 main veins from base; and $(4)$ tollgh fibrous bark.

An evergreen tree to 30 feet in height and 8 inches in tromk diameter with dense crown, the long spreading lower branches of crowded plants forming dense thickets. The bark is gray and slightly fissured, becoming thick and rough. Inner bark is yellowish and fibrous. The stout twigs are green and covered with very small brown scales when youn r, becoming aray. Petioles, leaf blades, flower stalks, calyx, and fruits have seattered minute inconspicious brown scales also.

The altemate leaves have petioles $2-t$ inches long. Leaf blades are slightly thickened and leathery, lighter beneath, not toothed on edges.

Flowers lateral on a twig, opening 1 at a time, on stout stalks shorter than petioles, $1 / 2-2$ inches long. The cup-shaped green calyx is about $3 / 8$ inch high and $1 / 2$ inch across, remaining at base of fruit, with $3-\tilde{5}$ narrow green scales (bracts) $1 / 2$ inch or more in length on ontside, falling from the bud. The broad. rounded, oblique petals 2 inches or more in length are pale yellow, purplish at base and turning to purple, with minute starshaped hairs on outside. Stamens many, on a column 1 inch long joined to petals at base. The pistil has a 5-celled ovary with slender style and 5 broader stignas.

The fruits, which remain attached for some time but do not split open, contain several brown hairy seeds about $3 / 8$ inch long and $1 / 4$ inch broad. Flowering and fruiting from spring to fall.

The sapwood is light brown, and the heartwood chocolate brown. The wood is moderately soft. mediumweight, durable, and takes a fine polish.

\section{Thespesia populnea (L.) Soland.*}

It is classed as resistant to attack from dry-wood termites. Used in boatbuilding and for fuel and elsewhere in cabinetwork.

Rope has been made from the tough fibrous bark. It is reported that the flowers are eaten as food and that the fruit is employed medicinally for the treatment of skin eruptions.

Planted as a street tree and ornamental and living fencepost. However, this tree is a host of the cotton stainer, a red insect which stains the fibers of growing cotton, and is eladicated in West Indian islands where cotton is an important crop. For this reason, the elimination of this tree from cotton areas of Puerto Rico has been adrocated, and further propagation has been discouraged.

Coistal woods and thicliets along seashores and bolders of mangrove in Pnerto Rico. Also in Mona, Vieques, St. Croix, St. Thomas, and St. John.

R.sve.- Widely distributed on tropical shores, believed to be native in the Old World tropics and planted and naturalized elsewhere. Southern Florida including Florida Keys (planted also in California), Bermuda, and thronghont West Indies from Bahamas and Cuba to Trinidad and Tobago. Ilso occasionally cultivated in continental tropical America from southern Mexico (Yucatán) and British Honduras to Brazil and Chile.

Other comsos rames.-majagüilla, fiescura, jaqueca, palo de jaqueca, clamor, santa maría (Puerto Rico); haiti-luaiti (Virgin Islands); álamo, álamo blanco (Dominican Republic); majagua de Florida (Cuba); frescura (Nicaragua): clemón, algodón de monte (Colombia); cremón (Venezuela) ; macoi (Chile); portiatree, seaside mahoe (United State); seaside mahoe (English) ; cork-tree, Spanish-cork (Bahamas); John-Bull-tree (Jamaica, Bequia); mahot bordde-mer (St. Lucia) ; tuliptree, mahault de Londres (Triniclad) : Spanish-cork, cork-tree (British IIonduras) ; beach maho, maho (British Guiana); grós mahaut (Haiti); catalpa (Guadeloupe); otaheita, palu santu (Dutch West Indies); boschkatoen (Surinam). 


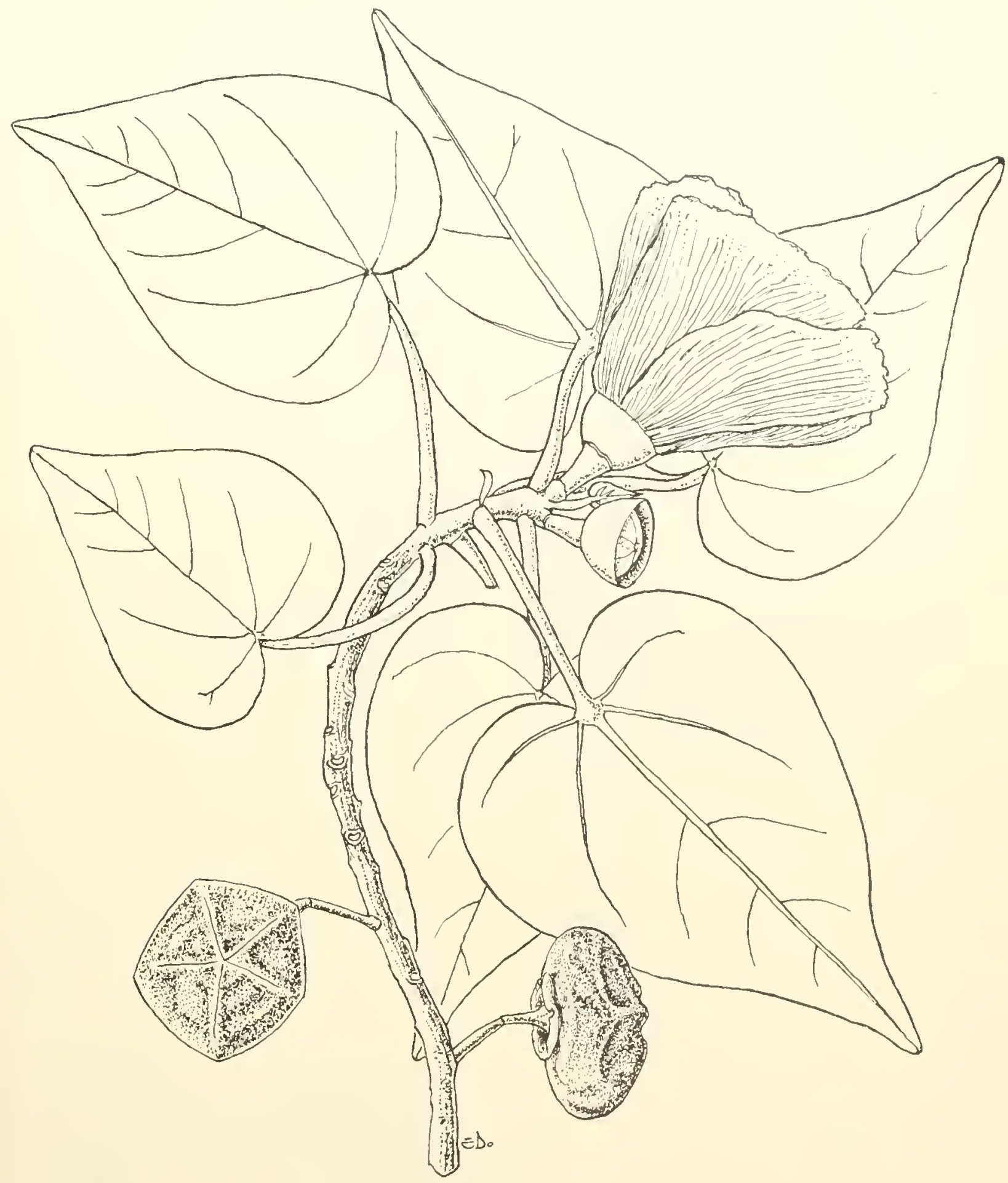




\section{BOMBAX FAMILY (BOMBACACEAE)}

Key to the 3 native species, all illustrated (Nos. 153-155)

A. Leares digitate (palmate), with 5-s lance-shaped or oblong leaflets-153. Ceiba pentandra.

A. Leares simple.

B. Leares with $5-9$ main reins from base-151. Ochroma pyramidale.

BB. Leares with 1 main rein or midrilı-155. Quararibaca turbinata.

\section{Ceiba, silk-cotton-tree}

This giant tree, one of the largest in tropical America, is easily recognized by the massive graygreen or' gray smoothish trunk (spiny when small) which reaches an enormous size of 5-8 feet or more in diameter above the musually large narrow buttresses and by the very broad flat crown of horizontal branches. Other distinguishing characteristics are: (1) the palmately compound leares (digitate) of 5-8 lance-shaped or oblong leaflets 3-8 inches long, drooping from the end of a long petiole; (2) numerons spreading 5 -parted whitish to pink flowers $11 / 4-11 / 2$ inches long and broad; and (3) oblong or elliptic seed capsules :3-6 inches or more in length and 2 inches in diameter, containing many seeds and roolly hairs, the kapok of commerce.

Ceiba is a rapidly growing deciduons tree becoming 80 feet or more in height. The brittresses, 6-12 inches thick, extend horizontally ont from the trunk over the large roots as much as 10 feet and almost as high. Many stout conical spines $1 / 8-1$ inch long are present on branches and small trumks but are mostly absent on large trunks. The thick inner bark is light brown and almost tasteless. The thin crown is commonly broader than the height of the tree. Twigs are stont, green at tip, and becoming gray.

Leaves are altemate, with slender green petioles $3-9$ inches long. The leaflets hang down on short stalks $1 / 8^{-3 / 8}$ inch long and are $3-8$ inches long and $3 / 4-13 / 4$ inches broad, short-pointed at base and apex, not toothed on edges, thin, above bright green to dark green, and beneath dnll green.

Great quantities of flowers are produced in lateral clusters near the ends of twigs in winter or early spring (December to February) though not every year, often while the tree is leafless. Flower stalks are $1-11 / 2$ inches long. The calyx is cupshaped, about $1 / 2$ inch long and broad, with 5-10 shallow teeth. The 5 petals are about $1 \frac{1}{4}$ inches long, whitish to rose colored, and densely brown silky hairy on the outer surface. Five stamens. longer than the petals, are united into a column near the base. The pistil consists of 5-celled ovary, a long style curved near apex, and enlarged stigma.

Seed capsules mature in spring and summer, splitting open along 5 lines. Many rounded black seeds less than $1 / 4$ inch long (about 3,200 to a pound) are imbedded in a dense mass of gray woolly hairs.

The wood is rery light brown but nearly always turned to blue gray by sap-staining fungi,

\section{Ceiba pentandra (L.) Gaertn.}

the sapwood almost the same color and not readily distinguished. It is very soft, exceedingly lightweight (specific gravity 0.23 ), weak, coarse-textmed, and straight-gramed. The rate of air-seasoning and amount of degrade are moderate. The wood machines easily but not satisfactorily. Machining characteristics are as follows: planing, sunding, and resistance to screw splitting are excellent: shaping and boring are poor: turning is very poor: and mortising is fair. Logs and lumber are very susceptible to attack by insects and decay. However, blue-stain can be prevented by dipping the lumber in a fungicide solution soon after sawing.

The wood is seldom used in Puerto Rico althongh sometimes has served for interior sheathing. It resembles heavier grades of balsa (guano) but is twice as strong and could be used similarly. It is suitable for boxes, slack cooperage, toys, light construction, patternmaking, and ntility-grade plywood. Becanse it is easily worked and in spite of lack of durability, the wood has been employed for tubs and basins. Indians made drums of the rood and hollowed out the trunks for dugout canoes of large size.

Trees are occasionally planted for shade and ornament, and young cut branches or cuttings will root when planted. In many tropical towns a giant spreading ceiba occupies the center of the plaza. Classed as a valuable honey plant. It is reported that the leaves are edible when cooked.

Kapok, the woolly or silky hair from the seed pods, is an important product of this species. The harvest is mainly from planted trees in .Jara and the Philippines. A growing tree produces about 600-900 seed capsules or 6-9 pounds of clean floss annually. This fiber is fine, lightweight, and elastic and does not become matted under pressure. Because of these characteristics and its insulating qnalities, kapok is preferred for linings of sleeping bags and was a strategic material in the last war. Another use is for life preservers. In many places kapok has been used locally in stuffing pillows and mattresses, and commercial development has been surgested where the trees are sufficiently common. The fiber is brittle and inflammable and not suitable for spinning into threads. An oil suitable for making soap and illumination has been extracted from the seeds.

Ceiba is seattered and widely distributed in Pnerto Rico along river banks and open hillsides on the coastal plain and in the lower mountain 


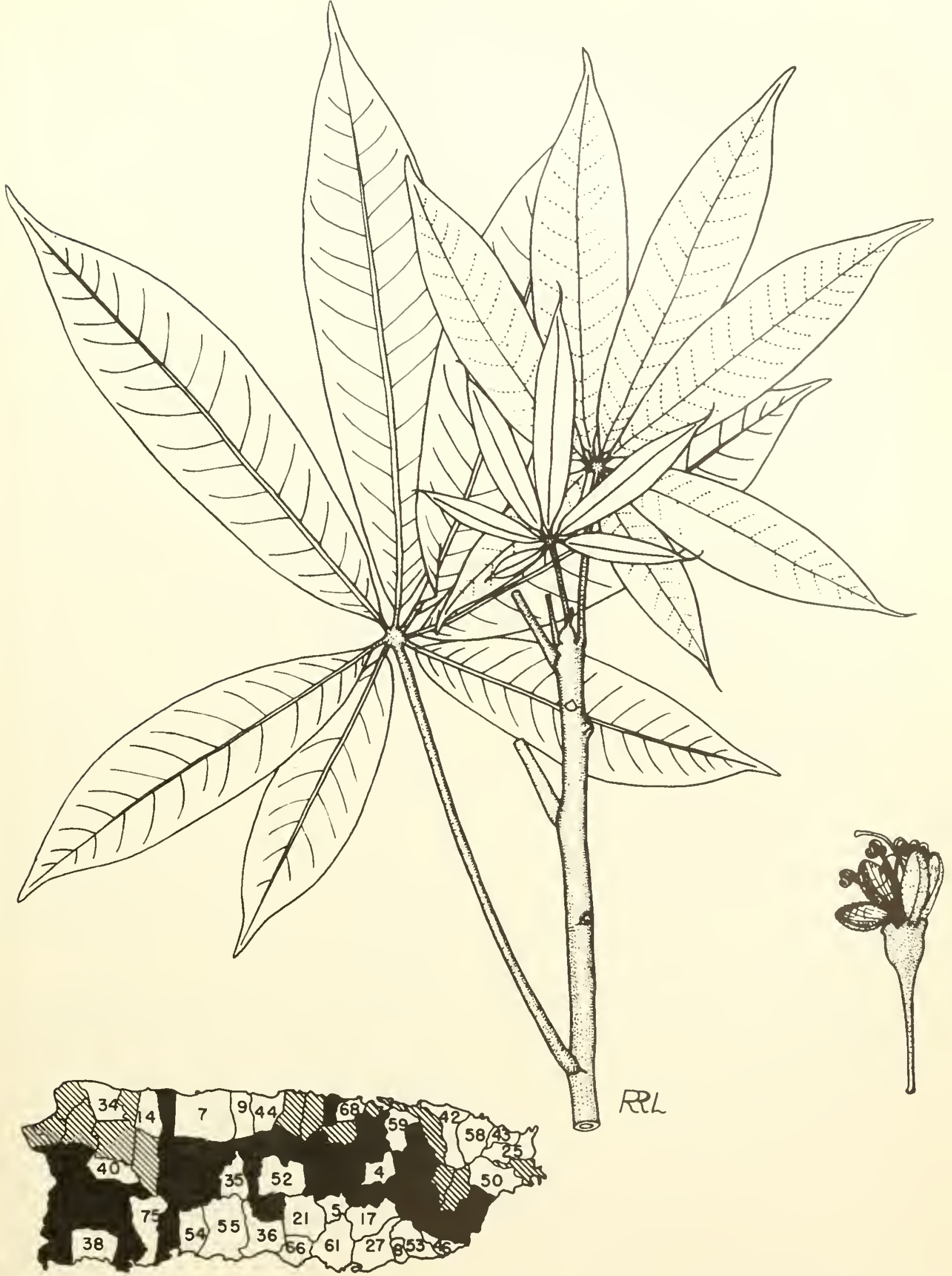

153. Ceiba, silk-cotton-tree 
regions and is commonest in the drier, sonthern areas. Also in Vieques, Nt. Croix, St. Thomas, St. John, and Tortola.

Prblic Forests.-Cambalache, Guajataca, Luquillo, Río Abajo, San Juan, Susúa, Toro Negro, Tega.

Raxge.- Nearly throughout West Indies from Cuba and Jamaiea to Trinidad and Tobago. Introdnced in Bermudia and Bahamas and planted also in sonthern Floricla and California. Widely distributed from Mexico to Ecuador, Brazil, and Guianas. Also in tropical Africa and Asia.

Other commoN NAMEs.-k a pok ( $\mathrm{T}$ i r gin Islands); ceiba, ceibo (Spanish, commerce); pochote (Mexico, Central Imerica); bongo, cotton-tree (Panama) : ceiba de lana, bonga, ceiba de Garzón (Colombia); silk-cotton-tree, kapok

\section{BOMBAX FAMILY}

\section{Guano, balsa}

Balsa, a rery rapidly growing tree known in Puerto Rico as guano, is easily recognized by: (1) an open crown of a few coarse spreading branches; (2) smooth pinkish-gray bark: (3) large, nearly round, heart-shaped leaves 8-16 inches long and broad with $7-9$ main reins spreading from base (palmately veined) and with long petioles: (4) the large, tubular hell-shaped, whit ish and greenish flowers 5 inches long, with 5 petals, borne sincrly; and (i) the odd dark brown erlindrical seed capsules 7-10 inches long and 1-11/2 inches in diameter, covered with light brown wool after opening.

A medium-sized to large evergreen tree, becoming 50-80 feet in height and $21 / 2$ feet in trunk diameter, with slight buttresses when large. Inner benk is fibrons, pinkish, $3 / 4$ inch or less in thickness. The twigs are stont, $1 / 2$ inch in diameter, greenish, rusty-brown hairy when young, with large brownish leaf scars and thick pith.

The alternate leaves have stout reddish-tinged petioles about as long as the blades and 2 broad rounded scales (stipules) $1 / 2$ inch long at base. Leaf blades are short-pointed or slightly 3-pointed (sometimes 5-pointed), edges mostly without teeth, slightly thickened, green and hairless on upper surface and yellow green with minute starshaped hairs on lower surface. Ioung plants have very large leaves with blades as much as 2 feet long and broad.

The flowers are formed on long stout stalks near ends of twigs. They are 3-t inches broad, slightly fleshy, bearing minute star-shaped hairs. The thickened brownish-green calyx has a tube about 2 inches long and 5 large spreading lobes $11 / 2$ inches long, the 2 onter lobes narrow and pointed, 2 lobes very broad and notched, and 1 broad on 1 side. There are 5 whitish petals 5 inches long, broad and rounded at apex and narrow below. The stamen column about 5 inches long has an enlarged terminal pollen-bearing portion of many spirally twisted anthers and surrounds the pistil
(English): cotton-tree (British Honduras) ; lumaka (British Guiana); mapou (Haiti, Guadeloupe) : fromager (commerce, Guadeloupe, Martinique, French Guiana); bois coton, kapokier (French Guiana) : katoenboom, katmbom, kapokboom, silk-cotton-tree (Dutch West Indies); kankantrie, kaddo bakkoe (Nurinam) ; sumauma, mai das arrores, cyyba, mocmayn (Brazil).

Botanlat syoxiss.-Bombax pentandmum L.. Ceiba an fructuosa (DC.) Maza.

Some authors have separated the New Wrorld trees from those of the Old World as a variety or species (Ceiba pentandra (L.) Gaertn. var. caribaea (DC.) Bakh., C. caribaea (DC.) 1. Cher., $C$. occidentulis (Spreng.) Burkill). The Spanish and generic names are from an old Caribbean word which is said to mean boat.

\section{(BOMBACACEAE)}

\section{Ochroma pyramidale (Cav.) Urban}

with its 5-celled, conical ovary, long style $41 / 2$ inches in length, and 5 spirally twisted stigmas.

The seed capsules are 10-angled and grooved and split into 5 parts to expose a mass of tawny-brown, long, soft hails, in which many small dark brown seeds $1 / 8$ inch long are loosely imbedded. Flowers appearing from winter to summer, and fruits and seeds mature in spring and summer.

Balsa is the lightest of commercial woods, weighing less than cork. However, the Puerto Rican guano (specific gravity 0.22 ) is heavier than balsa of major commercial sources. The sapwood, the main source, is whitish, often with yellowish or pinkish hue, and the heartwood is pale brown or reddish tinged. The wood is very soft, weak, and has very coarse, straight, uniform grain. It is absorbent unless treated (frequently with paraffin), warps badly, and requires very sharp tools to work. Also it is perishable, decays and becomes discolored readily, and is very susceptible to attack by dry-rood termites. The rate of air-seasoning and amount of degrade are moderate. Machining characteristics are as follows: planing is good; shaping is poor; turning, boring, and mortising are very poor; sanding is fair ; and resistance to screw splitting is excellent.

Balsa wood was a strategic material in the Second World War, being employed chiefly for liferafts, lifebelts, and similar equipment, and in airplane construction. The best grades were used in making British mosquito bombers. Nearly all the wartime supply came from Ecuador. In the First World War, 80,000 balsa floats were made for a submarine mine barrage 250 miles long in the North Sea.

Peacetime uses elsewhere include insulation, toys, floats for fishnets, and lightweight boxes. Becanse of the insulating qualities, boxes of balsa have been used for shipping cold perishables without ice. The wood can serve as a substitute for cork. The Puerto Rican guano can be used in many ways like the heavier grades of balsa. It is 

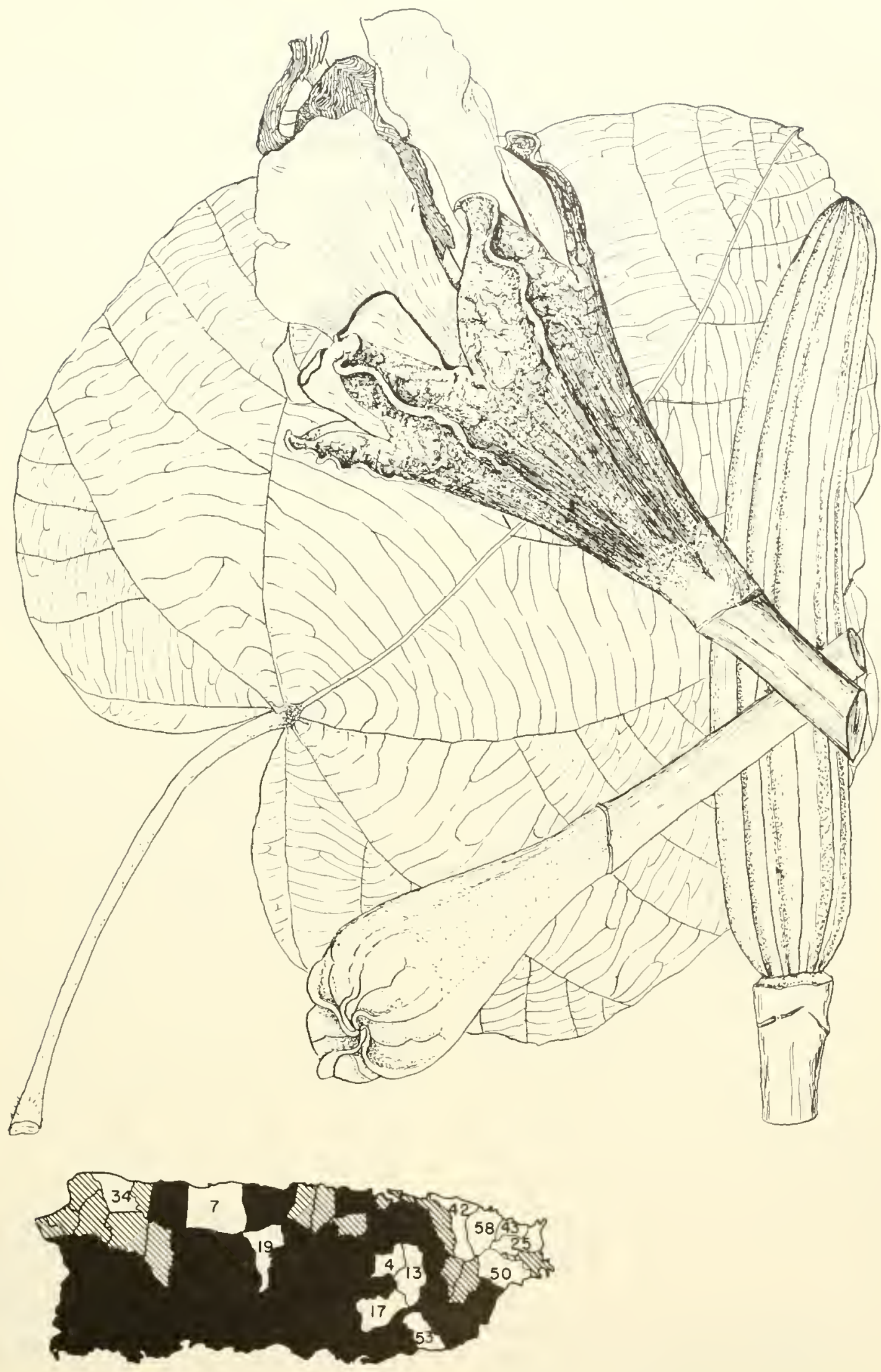

154. Guano, balsa

Two-thirds natural size.

Ochroma pyramidale (Car.) Urban 
suitable for certain types of fruit and regetable containers, novelties, toys, and temporary forms. The Spanish common name balsa, meaning raft and perhaps of aboriginal origin, is associated with the use of the buoyant logs by the Indians for rafts.

The woolly or silky hairs of the seed capsules are employed for stuffing pillows and mattresses, being similar to the kapok fiber's of commerce obtained from the related tree, ceiba. It is reported that these fibers have been used also in felt hats. Ropes have been made from the fibrous bark, which also contains tannin.

The trees are sometimes growil as ornamentals for the large leaves and large flowers, such as in southern Florida.

Scattered in the moist coast, moist limestone, and lower mountain regions of Puerto Rico. Requiring full sunlight, it is confined to open areas, such as roadsides, clearings, and cutover forests, where the wind-borne seeds are widely distributed. Germination is rapid, especially following fire. Trees attain mature size within $6-10$ years, sometimes averaging 10 feet in height growth a year.

Publo forests.-Cambalache, Carite, Guajataca, Luquillo, Río Abajo, Susúa.

RANGE.-Widely distributed in tropical America with minor variations distinguished as species by some authors. Greater Antilles and Lesser Antilles from St. Kitts to Grenada, and Trinidad and Tobago. Also from southem Mexico to Ecuador, Per'u, Bolivia, and Brazil. Planted also in southern Florida and Dutch West Indies.

OTHER Comiron Names.-false cork-tree (Virgin Islands) ; balsa, palo de balsa, balso (Spanish); palo de lana, lana, lanero (Dominican Republic); lamero, ceibón botija (Cuba); corcho (Mexico); lana, cajeto, lanilla, guano, corcho, jujul (Guatemala); guano, tambor (Honduras); algodón (El Salvador) ; gatillo (Nicaragua) ; lana, cottontree (Panama); tucumo, ceiba de lana, lana (Colombia); huampo, topa (Peru); balsa, balsa-wood (United States, English, commerce); corkwood, downtree, bombast mahoe (Jamaica); bois flot (St. Lucia, Dominica, Trinidad and Tobago) ; polak (British Honduras); coton fleurs, mahaudeme (Haiti); bois flot (Guadeloupe, Martinique) : fromager mapou, bois liège, bois pripri, patte lapin, bois lièvre (Guadelompe); balsa (Brazil).

Botanical srnonvis.-Ochroma bicolor Rowlee, $O$. boliviana Rowlee, $O$.grandiffora Rowlee, $O$. lagopus Sw., O. lagopus var. bicolor (Rowlee) Standl. \& Steyerm., $O$. limonensis Rowlee, $O$. obtusa Rowlee, $O$. peruviana Johnst., O. tomentosa Willd., O. velutina Rowlee.

\section{BOMBAX FAMILY (BOMBACACEAE)}

\section{Garrocho}

This small tree is limited to deep shade of moist forests and characterized by: (1) straight erect trunk and axis with horizontal branches attached in circles of 5 or $^{2}$ together at the same point; (2) elliptic leaves 3-9 inches long and $11 / 2-4$ inches broad, short-petioled, slightly thickened, strongly odorous when dry; (3) lateral whitish funnelshaped flowers $3 / 4$ inch long, mostly single and almost stalkless at base of leaves; and (4) rounded, orange, fleshy fruits $3 / 4$ inch in diameter.

An evergreen tree becoming 20 feet in height and 6 inches in trunk diameter. The branches, attached in whorls about $11 / 2-2$ feet apart along the axis, are distinctive of this genus. The graybrown bark is smoothish but finely warty. Inner bark is yellowish and slightly bitter. Twigs are brown, with faint rings where lea ves are borne.

The alternate leaves have petioles $1 / 4-5 / 8$ inch long. Blades are short-pointed at both ends, withont teeth on edges, dark green and slightly shiny with sunken lateral reins on upper surface and dull yellow green beneath. At base of young leaves is a pair of narrow pointed gray scales (stipules) 3/16 inch long, which shed early, leaving a ring scar.

The flowers are attached on very short stalks along the twigs, bear minute star-shaped hairs, and have a peculiar odor. The narrow green calyx tube is $3 / 8^{-1 / 2}$ inch long, slightly and irregularly 2 - or 3 -lobed; there are 5 spreading whitish petals

\section{Quararibaea turbinata (Sw.) Poir.}

more than 1/2 inch long; stamen column $5 / 8$ inch long, with many anther's clustered at apex; and pistil with 2-or 3 -celled ovary, slender style, and enlarged stigma inside the stamen column.

The rounded, orange fleshy fruits are slightly broader than long, with calyx remaining at base, and have 1 or 2 large seeds. Flowers are produced chiefly in spring (February to May), and fruits mature slightly later (February to July).

The sapwood is whitish and hard. The wood is little used in Puerto Rico. Formerly the stems were used for goad sticks, as the Spanish common name indicates. Because of the peculiar branching, small stems could serve as hatracks.

An understory tree of the moist coast, moist limestone, and lower mountain regions of Puerto Rico. Also Vieques, St. John, and St. Croix. Rediscovered in St. Croix in 1954, more than 150 years after an earlier collection there.

Poblic Forests. - Cambalache, Guajataca, Luquillo, Río Abajo.

MUNicipality WHERE ESPECIALLY COMMON.-46. Raxge.-Hispaniola, Puerto Rico, Vieques, St. John, and St. Croix, and Lesser Antilles from St. Eustatius, St. Kitts, and Antigua to Grenada. Also recorded from Surinam.

OTHER COMMON NAMES.- palo de garrocha, asubillo (Puerto Rico); molinillo (Dominican Republic); swizzle-stick-tree (Lesser Antilles) ; millerwood (St. Eustatius). 


\section{CHOCOLATE FAMILY (STERCULIACEAE)}

Key to the 3 species illustrated (Nos. 156-158)

A. Leares deeply 5-lobed, with 5 main reins from heart-shaped base; petiole nearly as long as blade-157. Sterculia apetala.*

AA. Leares not lobed.

B. Leares with 3 or sometimes 5 main reins from the oblique base, with edges finely saw-toothed-156. Guazuma ulmifolia.

BB. Leaves with 1 main vein or midrib, not toothed on edges-158. Theobroma cacao.*

\section{Guácima, jacocalalu}

This tree is recognized by: (1) long widely spreading branches, horizontal or slightly drooping, with the alternate leaves in 2 rows in a flattened arrangement: (2) bark becoming furrowed and rough or shightly shagrey; (3) young twigs covered with minute rusty-brown or light gray star-shaped hairs; (4) the ovate to lance-shaped leaves $21 / 2-5$ inches long and $1-21 / 2$ inches wide, long-pointed, finely saw-toothed, and with 3 or sometimes 5 main veins from the rounded oblique base; (5) small brown-tinged yellow 5-parted flowers in clusters at base of leaves; and (6) fruit round to elliptic, hard, very warty, black, $5 / 8-1$ inch long.

A small to medimm-sized tree to 50 feet high and 2 feet in trunk diameter, with spreading rounded crown. The bark is gray or gray brown, $1 / 4$ inch or more in thickness. Inner bark is light brown, fibrous, and slightly bitter. Evergreen except in areas with long dry sensons. The long slender twigs become dark brown.

The slencler petioles $1 / 4^{-1} / 2$ inch long are covered with minute rusty-brown or light gray star-shaped hairs. Leaf blades are thin, nearly hairless or sometimes densely hairy, green on upper surface and paler beneath. At night the leaves hang vertically.

Branched flower clusters (panicles) aro 1-2 inches long at base of leaves and bear many small, slightly fragrant flowers on minntely hairy stalks. The spreading flowers are about $3 / 8$ inch long and half as broad, consisting of a 2-or 3-lobed rustybrown or light gray hairy calyx less than $1 / 8$ inch long, tmmed back and then greenish, 5 yellow petals each with a slender 2 -forked appendage, and yellowish stamen colımn with about 15 anthers surrounding the pistil, composed of hairy light green 5-celled ovary, style, and 5 united stigmas.

The warty seed capsules, which mature in fall and winter, are 5-celled, open at the apex or irregularly by pores, and contain many seeds $1 / 8$ inch long. Flowering from spring to fall (March to October) and with finuits throughout the year.

This is a variable species with differences in shape and amount of hairiness in the leaves and in shape and method of opening of seed capsules. Some botanists distinguish 2 species, both widely distributed with almost the same range and both occurring in Prerto Rico. Trees in moist areas have nearly hairless foliage with rusty-brown
Guazuma ulmifolia Lam.

hairs, while those in dry areas have densely light. gray hairy foliage and have been separated as a different species ( $r_{x}$. tomentosa H. B. K.).

Sapwood is light brown and heartwood is pinkish to brownish. The wood is moderately soft, lightweight to moderately heavy (specific gravity $0.5)$, easily worked, and not durable. It is very susceptible to attack by dry-wood termites.

In Puerto Rico the wood is used chiefly for posts. $V$ arions uses of the wood elsewhere include general carpentry, interior construction, furniture, barrel staves, boxes and crates, tool handles, gunstocks, shoe lasts, violins, and charcoal for gunpowder.

The trees sometimes serve as shade in pastures. Immature fruits and foliage are browsed by horses and cattle, especially in dry periods, and the fruits are fed to hogs. These mucilaginous green fruits, fresh or cooked, are edible, and it is reported that a beverage can be prepared by soaking the crushed fruits in water. In some areas rope and twine are made from the tough fibrous bark and young stems. The flowers attract bees and are a source of honey. Different parts of the plant are employed in home medicines.

This species is characteristic of openings, st ream banks, clearings, and second growth of disturbed areas and is less common in forests. It requires light, grows rapidly, and is hardy in dry as well as moist areas. Thus, it has been classed as a weed tree. It is reported to be one of the commonest and most widely distributed tree species in Cuba and one of the commonest plants of Central America.

Along stream courses and in thickets, pastures, and forests in the coastal and lower mountain regions of Puerto Rico. Also in Vieques, St. Croix, St. Thomas, St. John, and Tortola.

Public rorests.-Aguirre, Cambalache, Guajataca, Guánica, Lmquillo, Maricao, Río Abajo, Susúa.

MUNICIPALITIES WHERE ESPECIALLY COMMON.$8,21,66$.

RAvgk:-Throughout West Indies (except Bahamas) from Cuba to Trinidad and Tobago and cultivated in Dutch West Indies. Also from Mexico to Ecuador, Peru, northern Argentina, Paraguay, and Brazil.

OTHER COMLION NAMEs.—guácima, guácimo (Spanish); guácima cimarrona (Dominican Republic); guácima de caballo (Cuba); tablote, 

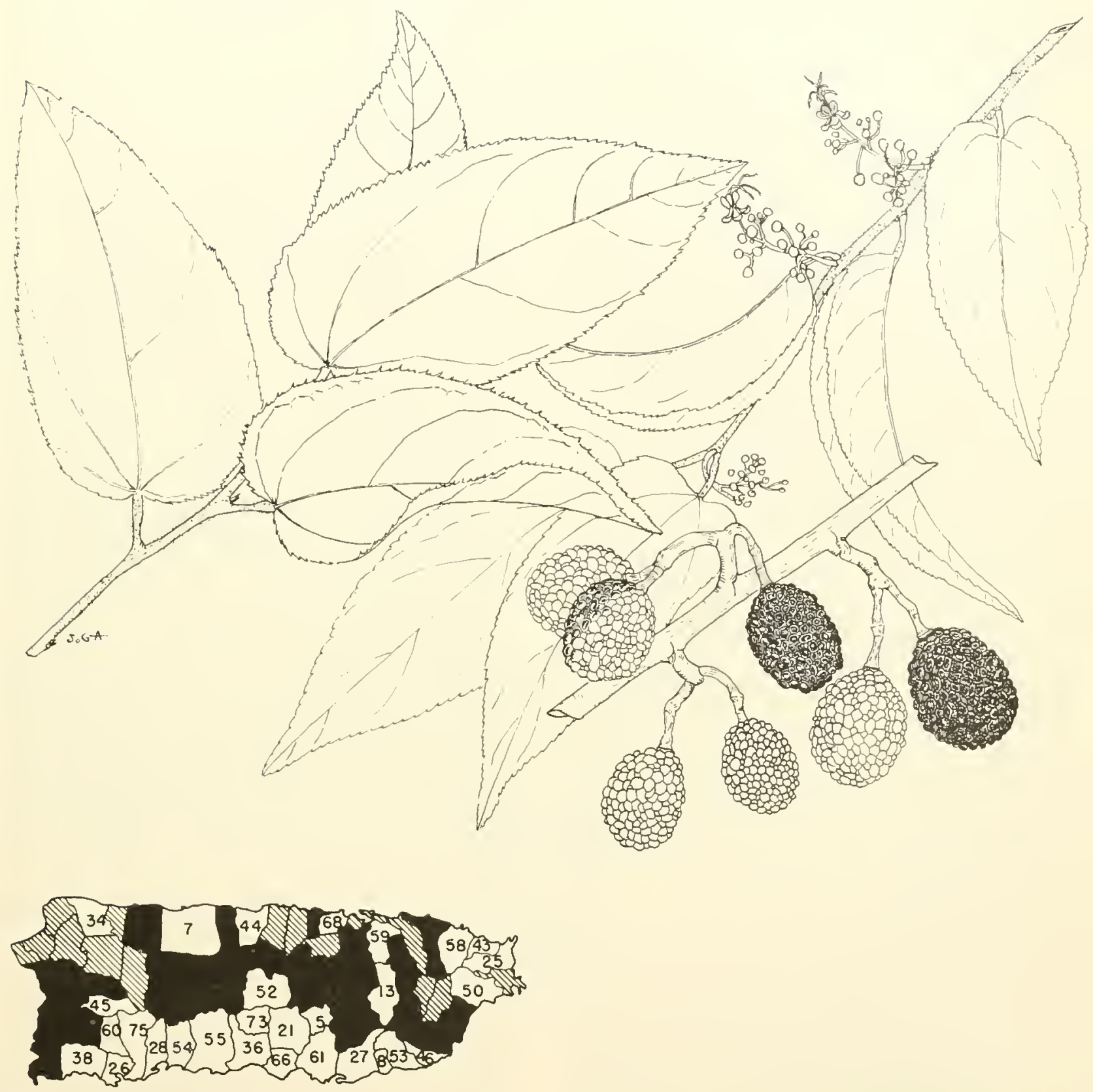

156. Guácima, jacocalalu

Two-thirds natural size.

Guazuma ulmifolia Lam. 
majagua de toro (Mexico) ; tapaculo (Guatemala, El Salvador) ; caulote (Guatemala, Honduras, El Salvador, Colombia) ; contamal (Guatemala); chicharrón (El Salvador); guacimillo (Nicaragua) ; guácino blanco (Costa Rica) ; guácimo de ternero (Panama); iumanasi, papayillo (Perı); coco (Bolivia); cambá-acá, guazuma (Argentina); bastard-cedar (Jamaica, Trinidad); bois d'orme, West-Indian-elm (Trinidad) ; pigeon-wood ('Tobago); bay-cedar, caulote, pixoy (British Hon- duras) ; bois d'orme, orme d'Amérique (French) ; bois de hêtre, hêtre gris, hêtre rert, mahot-hêtre (Guadeloupe) ; goeaazoema (Dutch West Indies) ; nutamba (Brazil).

BotANICAL sYNoNyars. - Guazuma guazuma (L.) Cockerell, G. tomentosa H. B. K., G. ulmifolia var. tomentosa (H. B. K.) K. Schum.

The common name jacocalalu, applied to this species in St. Thomas, is said to be an African word for an edible plant like spinach.

\section{CHOCOLATE FAMILY (STERCULIACEAE)}

\section{Anacaguiita, panama-tree}

This large and handsome, introduced shade tree is distinguished by: (1) a dense broad spreading crown; (2) the abundant foliage of long-petioled, broad, deeply 5-lobed, pleated leaves with thick and leathery blades 8-12 inches long and wide; (3) large clusters of many bell-shaped yellowish flowers tinged with red or purple, 5-lobed and about 5/8 inch long and 3/4 inch across; and (4) the large, dark brown, hard, dry fruits, each of 5 or fewer spreading pods $21 / 2-31 / 2$ inches long, opening widely to release the large black seeds and covered within with stiff needlelike bristles, which penetrate and irritate the skin.

An evergreen tree to 50 feet high. The trunks are commonly 3 feet or more in diameter, developing narrow prominent buttresses taller than broad. The bark is smooth and gray or brown. Inner bark is orange brown, gritty, and tasteless. Young twigs, flowers, and young leaves are thickly covered with brown, much-branched or star-shaped hairs. Older twigs are stont and light gray, with large, nearly round leaf scars.

The alternate leaves have round yellow-green petioles 5-8 inches or more in length. Blades have 5 main veins from the heart-shaped base (palmately lobed), the lobes ovate and short-pointed, not toothed on edges. The green and slightly shiny upper surface becomes almost hairless, while the gray to brownish-green lower surface is densely woolly with minute star-shaped hairs.

Branched flower clusters (panicles) about 8 inches long are borne near the ends of twigs. 'The numerous flowers are partly male or female and partly bisexual (polygamous), with a 5 -lobed calyx but have no petals. Stamens and pistil are borne at the end of a stalk $1 / 4^{-3 / 8}$ inch long, with $7-15$ anthers on a very short tube, and the woolly pistil, when present, consisting of a 5 -celled ovary $1 / 8$ inch in diameter and a style of the same length but curved downward. There are 2-5 elliptic

\section{Sterculia apetala (Jacq.) Karst.*}

seeds $3 / 4$ inch long in each pod (follicle), maturing usually in spring. Flowering in spring and occasionally in summer and fall.

The saprood is whitish, and the heartwood light brown to reddish brown. The wood is lightweight (specific gravity 0.30-.45), soft, spongy, fibrous, coarse-textured, and has growth rings. It works easily but discolors rapidily and is susceptible to decay. Possible nses are interior construction and packing boxes. Large trunks have been hollowed into dugout canoes elsewhere.

The principal value of this species is for shade and ornament, since the rood is seldom used. It is reported that the edible seeds when ground can be made into a bererage and when roasted taste like peanuts. Pigs eat the seeds also. Flowers, leares, and bark have been employed in home medicines. Also a honey plant.

Individual trees have been planted for shade and ornament in various parts of Puerto Rico and in St. Thomas and perhaps others of the Virgin Islands, but the species is not native. 'This species is honored as the national tree of the Republic of Panama and as the origin of that country's name.

Range.-Southern Mexico and Central America to Peru and Brazil. Naturalized in Jamaica and Trinidad. Planted in sonthern Florida, Cuba, Hispaniola, Puerto Rico and Virgin Islands, and elsewhere in the tropics.

Other comion Names, - anacahuita (Dominican Republic); chicha (commerce); anacagiiita, camaruca (Cuba) : bellota (Mexico, Guatemala); castaño (Guatemala, Honduras, El Salvador); panamá (Central America) ; camajurú, camajonduro (Colombia) ; camoruco, pata de danta, sunsún, cacaíto, cacaguillo (Venezuela); panama-tree (English); pistache des Indes (Haiti).

BOTANICAL SYNONYM.--Stercutia carthaginensis Cav. 


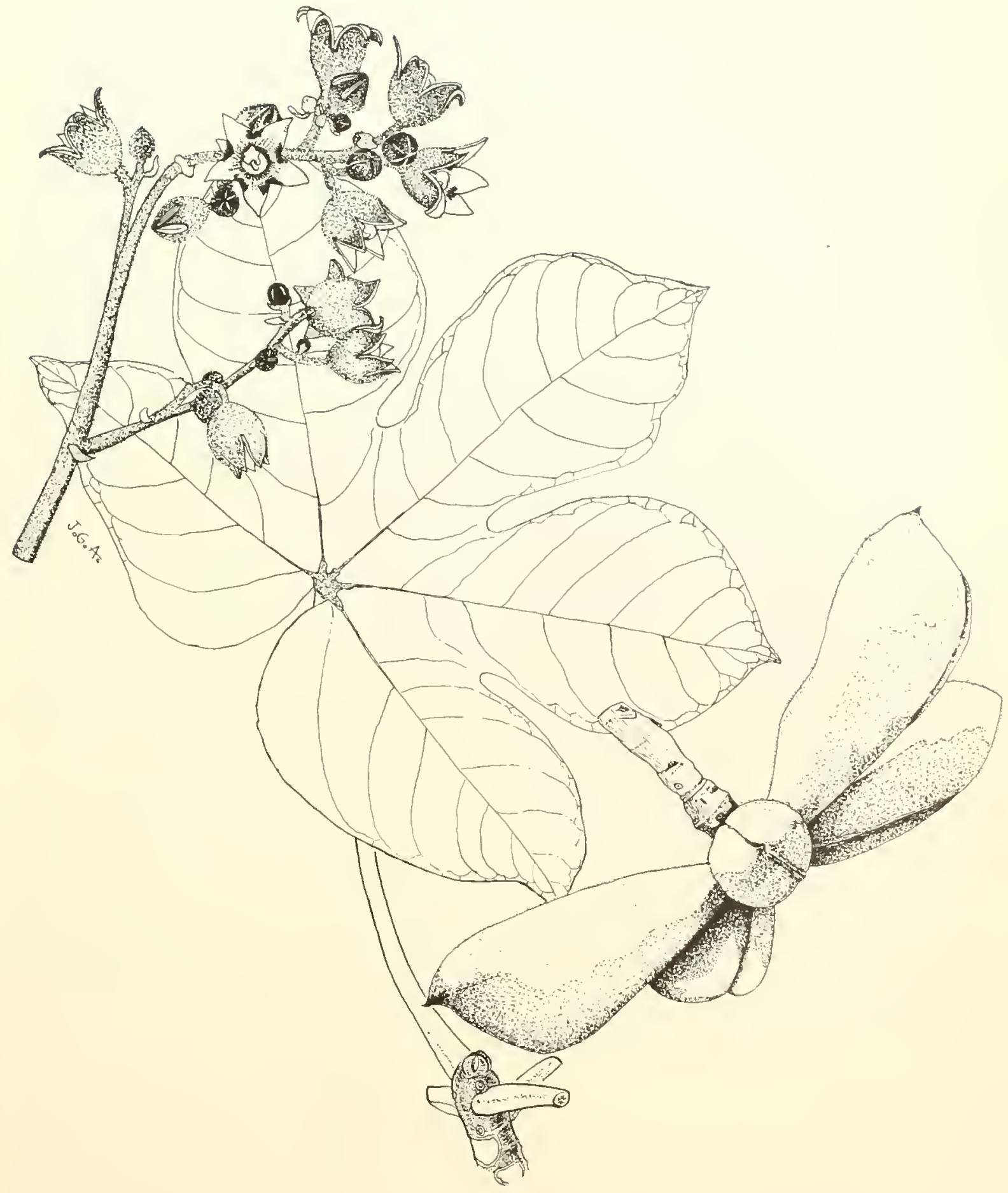




\section{CHOCOLATE FAMILY (STERCULIACEAE)}

\section{Cacao, chocolate-tree}

Cacao, the source of cocon and chocolate, is a small cultivated tree characterized by: (1) low spreading crown; (2) large elliptic or oblong leaves hanging downward, 8-14 inches long and 21/2-41/2 inches broad, long-pointed, broadest above middle, and rounded at base; (3) many flowers in clusters along trunk, branches, and larger twigs, 1 to several on slender pink stalks $3 / 4-1$ inch long, oddly star-shaped, 5-parted, and spreading, 5/8 inch across, whitish, tinged with orange and pink: and (4) the large oblong or egg-shaped, yellow or purplish, fleshy fruits 6-12 inches long and $3-4$ inches thick, pointed, ridged and grooved, and hanging down ward from trunk.

This evergreen tree, cultivated under larger shade trees, becomes 2.5 feet high and 6 inches in trunk diameter. The dark brown bark is fissured and rough, and inner bark is light brown and tasteless. The twigs are brown and minutely hairy when young.

The alternate leaves hang down from petioles 1/2-1 inch long. Blades are slightly thickened, not toothed on edges, green or dark green on upper surface and paler beneath.

Flowers have 5 narrow, pointed, widely spreading pink sepals $1 / 4$ inch long; 5 petals $1 / 4$ inch long, hood-shaped at base, with a very narrow middle part bent backward, and spoon-shaped at apex; 5 short stamens united into a cup at base and with 5 very narrow lobes $1 / 4$ inch high ; and pistil composed of 5-celled ovary, style, and stigma.

In the large 5-celled fruits are many large chocolate-colored or purplish seeds 1 inch or more in length and bitter tasting. There are abont 200

\section{Theobroma cacao L.*}

seeds to a pound. Flowering in summer and fall. Fruits mature chiefly in spring and summer.

The light brown, hard wood is not used in Puerto Rico.

Cacao is planted widely in wet tropical regions for its seeds or "beans," from which cocoa and chocolate are prepared by grinding and roasting. It is one of the best known cultivated plants originating in the New World. The Spanish Conquistadores found it already being cultivated by the Mexican Indians. Besides the main use in Mexico for preparing drinks, the seeds served the natives as money. Sweetened chocolate now is an important ingredient of candies and desserts as well as a popular beverage. Cacao (cocoa) powder and syrup from the seeds are official in the United States Pharmacopoeia, serving as a flavoring agent and concentrated nutriment.

In active and abandoned coffee plantations, chiefly in the western part of the lower mountain regions of Puerto Rico. Cacao is planted to a limited extent also in St. Croix.

Raxge- - Native of sonthem Mexico and Central America and spread by cultivation south to Pern, Bolivia, and Brazil. Introduced and planted throughont the West Indies, mostly on a small scale. Propagation worldwide in moist tropical regions.

OtIIER COMMON NAMES.- cacao (Spanish); cacao, cocoa, chocolate-tree (English); cacao, cacaoyer (French); cacáo, cacateiro (Brazil). Several cultivated varieties have been given descriptive common names. 


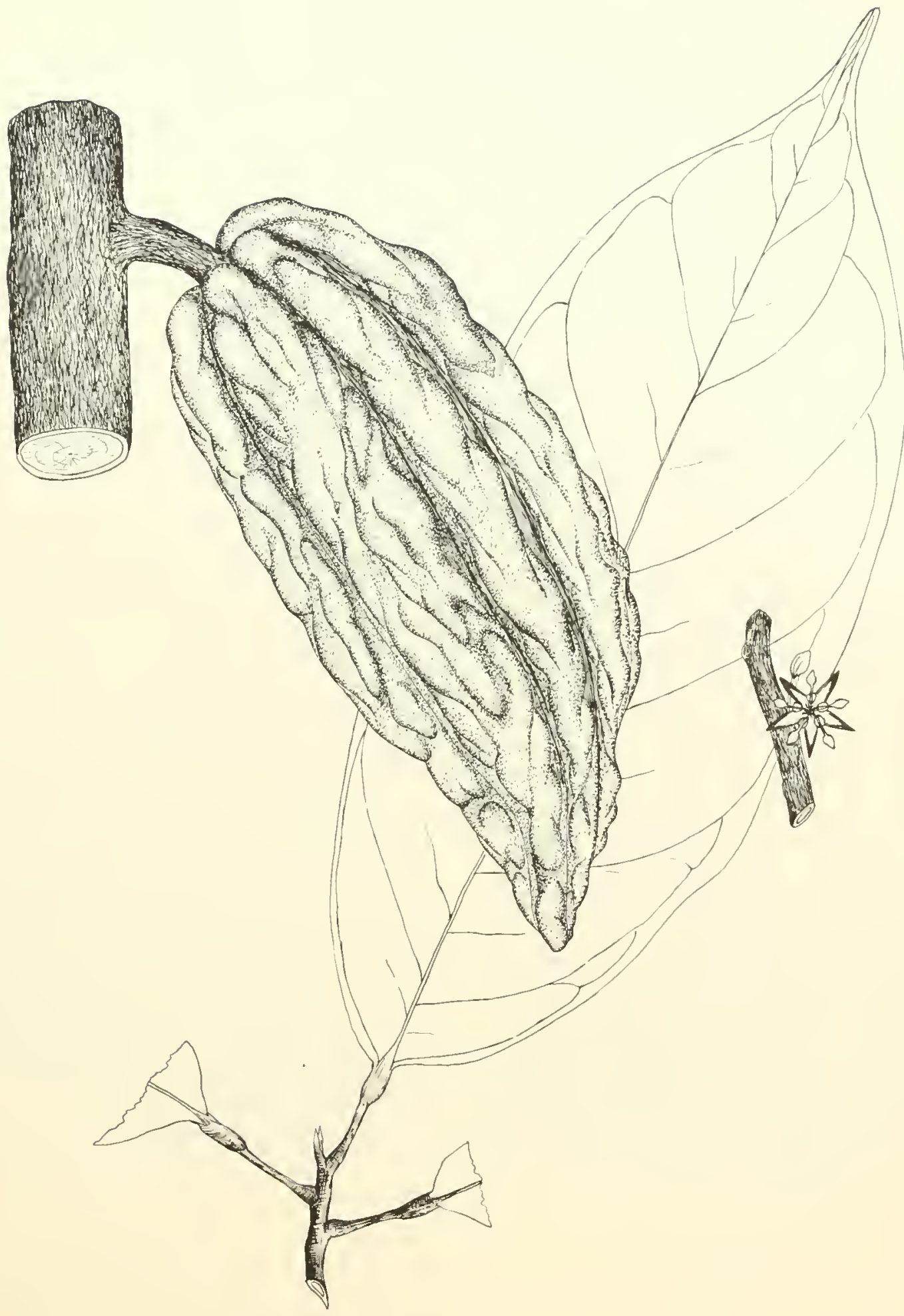




\section{DILLENIA FAMILY (DILLENIACEAE)}

\section{Dilenia, India dillenia}

A showy exotic introduced in gardens as an ornamental shade tree, distinguished by: (1) the symmetrical, usually conical dense crown; (2) large oblong or oblanceolate shiny green leaves with saw-toothed edges and with many straight parallel lateral veins $1 / 4^{-3} / 8$ inch apart leaving midrib at an angle of about 45 degrees and each ending in a tooth; (3) beautiful very large white flowers, with yellow stamens, 8-9 inches across the 5 petals: and (4) large, hard, light green fruits 5-8 inches in diameter, resembling a cabbage head, covered by very thick sepals.

An evergreen tree attaining 50 feet in height with straight trumk to 1 foot in cliameter, with large spreading branches arising a few together along the trunk. The brown bark is smoothish, with faint horizontal ring scars, and becoming slightly scaly. Inner bark is pinkish brown and bitter. The stout brownish-gray twigs have many broad leaf scars and at apex bear crowded alternate leaves and have pointed buds $1 / 2$ inch long, covered with pointed gray silky hairy scales.

The leaves have stout, light green, grooved petioles 11/4-13/4 inches long. Blacles are 6-15 inches long and $21 / 2-6$ inches wide, abruptly longpointed at apex and narrowed toward the shortpointed base, often broadest above middle, above shiny green with midrib and lateral reins slightly sunken, and beneath lighter green with prominent lateral veins which are inconspicnously hairy.

Flowers are borne singly near end of twig on a long stout stalk. There are 5 sprea ding light green sepals, concave and fleshy; 5 spreading obovate white petals about 4 inches long; very numerous curved bright yellow stamens in a globelike mass; and a central ring of about 16-18 crowded but
Dillenia indica $\mathrm{L}^{*}$

nearly separate pistils (carpels), each 1 -celled and bearing a white slender spreading stigma $7 / 8$ inch long, narrow, flat, and pointed, the stigmas spreading as rays in a circle.

The heavy fruits hang down singly, only 1 at the end of a leafy twig. They are rounded but hroader than long and slightly irregular, being shaped by the 5 rounded hard sepals which are more than 1 inch thick at base with whitish flesh, the outer 2 short and the inner 3 tightly overlapping. The sepals do not open but enclose tightly the aggregate fruit of crowded light brown ovaries about 3 inches across, each with thick soft sour walls and containing several light brown flattened seeds $1 / 4$ inch long in transparent gelatinous flesh. Observed in flower in .July and August and with fruits nearly through the year.

The light brown sapwood is slightly soft. The wood is not used in Puerto Rico.

In India the fruit is eaten, the entire fruit being made into jelly or a drink or sometimes cooked as a vegetable. The bulk consists of the very thick sepals, which have a very sour taste. The smaller juicy fruits inside are sour also.

Planted in Puerto Rico as an ornamental and shade tree and experimentally in St. Thomas. Elsewhere in the tropics examples may be seen in botanical gardens.

RaxGe.- Native of tropical Asia from India to Milaya. Introduced into other tropica] regions, sparingly in the New World, including southerm Florida and southern Califormia, Greater Antilles, and Central and South America.

Other common Names.-coca (Dominican Republic); India dillenia, dillenia (United States). 


\section{TEA FAMILY (THEACEAE)}

\section{Maricao verde}

This tree native only in Luquillo Momtains is distinguished by: (1) alternate elliptic leaves $2-41 / 2$ inches long and $7 / 8-13 / 4$ inches wide, rounded at apex and long-pointed at the rery short-stalked base, with slightly wavy-toothed edges, the lower surface with 2 faint lines parallel with midrib, and orange red when new; (2) fragrant showy white Hower's nearly 2 inches across the $6-9$ petals, almost stalkless and single at base of leaves; and (3) oblong dark brown capsule $3 / 4-1$ inch long and 3/8-1/2 inch in diameter, 6-10-ridged, remaining attached after opening.

A medium-sized evergreen tree to 40 feet in height and 11/2 feet in trunk diameter. Bark on old trunks is gray and fissured. The twigs are gray, finely hairy when young. The terminal bud is long and narrow and covered by a hairy scale (stipule).

The dark green leaf blades are often broadest above middle, turned under a little at edges, only slightly thickened, and beneath with prominent veins and paler and sparsely hairy.

The large flowers are very conspicuous and attractive, contrasting with the foliage. A flower

\section{Laplacea portoricensis (Krug \& Urban) Dyer}

has 5 overlapping, unequal, rounded, leathery, finely hairy sepals $3 / 8^{-1 / 2}$ inch in diameter; $6-9$ bright white mequal obovate petals abont $3 / 4$ inch long, some notched, soon falling; more than 100 unequal stamens $1 / 4$ inch long with yellow anthers; and pistil more than $3 / 16$ inch long with broad, rounded, hairy, 6-10-celled ovary and 5 or 6 styles.

The finely hairy capsule splits open along the ridges to release many thin, narrow, winged, brown seeds nearly $1 / 2$ inch long. These old open capsules serve as an aid in identification. Recorded as flowering and with fruits in several months nearly through the year.

This tree perhaps is worthy of trial as an ornamental for its showy flowers. The rood is little used.

Found only in the lower Liquillo forest region. Putrlic forest.-Luquillo.

Raxge.-Restricted to eastern Puerto Rico.

Other commox Names.-maricao, niño de cota (Puerto Rico).

BOTANICAL SYNoNYMS.-Haemocharis portoricensis Krug \& Urban, Wickstroemia portoricensis (Krug \& Urban) Blake. 


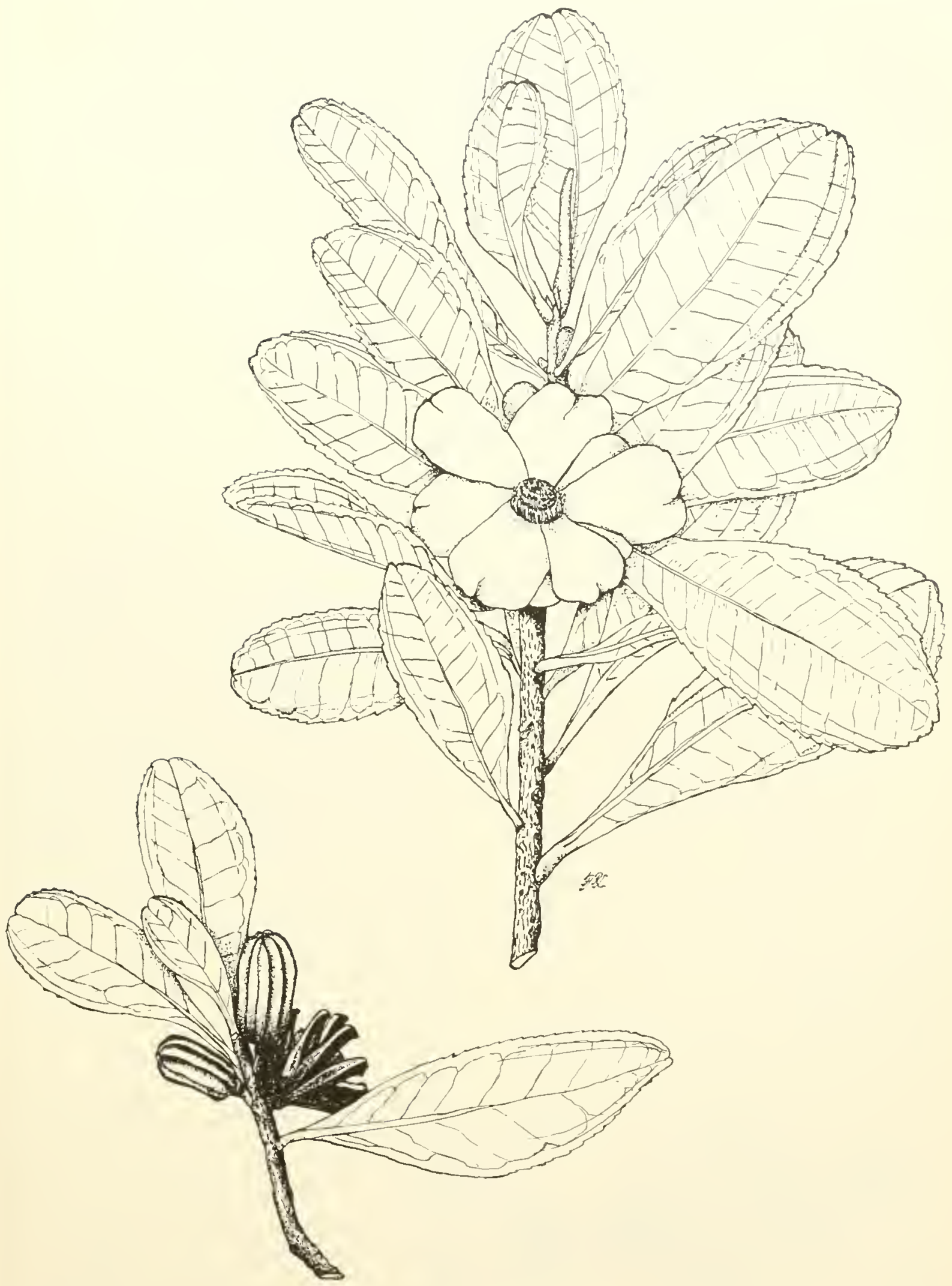




\section{MANGOSTEEN FAMILY (GUTTIFERAE)}

Key to the 5 species illustrated (Nos. 161-165)

A. Leares stiff, ending in long-pointed sharp spine-165. Rheedia portoricensis.

AA. Leaves rounded or notched at apex.

B. Leaves thick, with many straight parallel lateral veins nearly at right angles to midrib.

C. Lateral reins only about $1 / 32$ inch apart; fruit nearly 1 inch in diameter, inedible-161. Calophyllum brasiliense.

CC. Lateral reins more than $1 / 16$ inch apart; fruit 3-10 inches in diameter, edible (mamey) -164. Mammea americana.

BB. Leares rery thick and fleshy, with lateral reins inconspicuous or scarcely visible.

D. Leaves with rounderl apex, the edges rolled under, seed capsules $5 \% 8-3 / 4$ inch in diameter-162. Clusia krugiana.

DD. Leares with rounded or notched apex, the edges slightly turned under; seed capsules 2-21/2 inches in diameter-163. Clusia rosea.

\section{María, santa-maria}

Calophyllum brasiliense Camb.

María, a native and widely planted tree for timber, ornament, and shade, is identified by its dense crown with opposite stiff elliptic leaves $21 / 2-5$ inches long and 11/4-21/2 inches broad, dark green and slightly shiny on upper surface, with very many straight parallel lateral veins only about $1 / 32$ inch apart and nearly at right angles to midrib, and without smaller veins. Other distinguishing characteristics are: (1) numerous small fragrant white flowers $3 / 8^{-1 / 2}$ inch broad in a lateral branched cluster 1-2 inches long; (2) the round, light brown, 1-seeded fruits nearly 1 inch in diameter; and (3) the whitish latex produced in small quantities.

A medium-sized evergreen tree 40-65 feet ligh, becoming larger, and up to $11 / 2$ feet or more in diameter, with straight axis and usually a spreading crown. The bark is light gray and smooth or slightly fissured, becoming spotted with numerous dark protuberances on large trunks. Inner bark is whitish and bitter. 'The twigs are green, 4angled, and minutely hairy when young, becoming gray.

The petioles are $1 / 4^{-3 / 4}$ inch long. Blades are rounded or minutely notched at apex, shortpointed at base, not toothed on edges, and slightly leathery. Some leaves have a rust, or fungus disease, producing on the upper sulface wartlike narrow swellings $1 / 16^{-1 / 4}$ inch long, becoming brown, and corresponding sunken brown areas on lower surface.

Flower clusters (racemes) at leaf bases or on twigs back of leaves are much shorter than the leaves and have several flowers on slender stalks. Flowers are male and bisexual on the same tree (polygamous). There are 4 white rounded and concave sepals, 2 about $1 / 4$ inch long and 2 about half as long, widely spreading and turned back; petals commonly absent (or 1-4, smaller than the largest sepals and white); male flowers have about 40-50 stamens in a prominent orange cluster more than $1 / 4$ inch across and often a rudimentary pistil. Bisexual flowers have $8-12$ stamens and a pistil consisting of round green ovary $1 / 8$ inch in diamoter, 1 -celled with 1 ovule, short bent style, and flattened whitish stigma.
The fruit (drupe) has a hard, dry shell and contains 1 large rounded seed. Flowering chiefly in spring and summer, the fuit maturing from late spring to winter, mostly in the fall.

The sapwood is light brown or whitish, and the heartwood varies from light pinkish to reddish brown, often with fine darker stripes. The wood is hard, moderately heavy (specific gravity 0.55), fairly strong, and coarse-textured, and frequently has interlocked grain. It is moderately durable in contact with the ground but is very susceptible to attack by dry-mood termites. Air-seasoning is slow and very difficult, and the amount of degrade is considerable. Machining characteristics are as follows: planing is fair; shaping, mortising, sanding, and resistance to screw splitting are good; and turning and boring are poor.

María is classed as a construction wood, but the small trees now available are chiefly for posts. The attractive wood resembles mahogany and can be used for many of the same purposes but is somewhat more difficult to season and work. Elsewhere it is used for furniture, cabinetmaking, flooring, shingles, interior construction, shipbuilding, house framing, agricultural implements, handles, vehicles, structural timbers, poles, and crossties.

The latex or resin from the trunk, called bálsamo de maria, has been employed medicinally. The fruits are reported to be good food for hogs, and an oil has been extracted from the seeds.

The tree is widely planted for ormament and shade along highways. When young, its crown may be shaped into a hedge or other forms. The fruits are apparently distributed by bats with the result that dense clumps of seedlings sometimes develop directly beneath coconut palms along the const. Extensively planted in forest areas because of its adaptability to degraded soils and the ease with which it may be established by direct seeding. Seedlings do not survive transplanting well if lifted without a ball of earth. Almost the only valuable tree which grows well on the extremely laterite soils of the western mountains, where it attains 8 inches in diameter in 25 years. 
Introduced for ormament and shade in southern Florida, and in parts of the West Indies planted as shade for coffee and cacao and for windbreaks. In Grenada the trees are windbreaks for nutmeg plantations.

Probably native only in the moist coastal and moist limestone forest regions of Puerto Rico. Now distributed as well througlront the lower Cordillera and lower Luquillo regions with a few trees on the dry coast. Also in Tieques, St. Croix, and St. Thomas.

Public forests.- Native in Cambalache, Guajataca, Río Abajo, and Vega. Introduced into Carite, Guilarte, Luquillo, Maricao, Susúa, and Toro Negro.

MUNICIPALTTES WIERE ESPECIALLY COMNON.$17,34,62,74$.

RANGE.-This species with its geographic varieties also known as species is widely distributed through the West Indies and from Mexico to Peru, Bolivia, Brazil, and Guianas. The rariety in Puerto Rico and the Tirgin Islands, Calophyllum brasitiense var, antillamem. (Britton) Standl., also classed as a species by some author's, langes from Cuba and Jamaica through the Lessel Antilles to
Grenada, is naturalized in Bermuda, and is introduced in southern Florida.

Othel: compor xames.-palo de maría, santa maría, aceite de maría (Puerto Rico); falsemamey (Virgin Islands); santa maría, maría (Spanish); baría, mara, palo maría (Dominican Republic) ; ocuje, ocuje colorado (Cuba) ; barillo, marío, varío (El Salvador); cojón, cachicamo (Venezuela ) ; jacare-úba, lagarto-caspi blanco (Peru) ; santa-maria, Brazil beauty-leaf (Inited States) ; santa-maria (English, commerce); wildmamee (.Jamaica) ; came-marie, damage, dalemarie (Haiti); galba (Guadeloupe, Dominica, Martinique, St. Vincent); galba odorant, calaba. (Guadeloupe): koelarie, mani kwaha, koerahara (Surinam); guanandi, olandi, landi (Brazil).

Botanical synonyms of Calophyllum brasitiense var. antillanum (Britton) Stand1.-Calophyllum crlaba Jacq., not L., $C$. antillanum Britton, $C$. jacquinib Fawc. \& Rendle.

The common name maria is said to be of Carib Indian origin rather than Spanish. A closely related species (Calophyllum lucidum Benth.) or variety known as galba occurs in Trinidad and 'Tobasro, Veneznela, and British Guiana.

\section{MANGOSTEEN FAMILY (GUTTIFERAE)}

\section{Cupeíllo}

This tree with orange or yellow latex is common in upper mountain forests of Puerto Rico. It is characterized by: (1) opposite, very thick, stiff and leathery, oborate dark green leaves, broadest near the rounded apex, gradnally narrowed toward an almost stalkless base, and with edges considerably rolled under; (2) terminal branched chusters of sereral to many spreading yellow flowers about $1 / 2$ inch across, male and female on different trees (dioecions); and (3) round green fleshy seed capsules $5 / 8-3 / 4$ inch in diameter, splitting open and becoming 5 -parted and star-shaped, exposing the orange pulp in which the light brown seeds are imbedded.

A small to medium-sized evergreen tree to 40 feet high and $6-12$ inches in trunk diameter, with a spreading crown of thick branches, sometimes with a few prop roots. The gray bark is smoothish, often covered with mosses, and within is pinkish and slightly bitter, containing orange or yellow latex. Twigs are stout and brownish, ringed at nodes.

The stout broad petioles are only about $1 / 8$ inch long. Blades are $2-5$ inches long, $11 / 2-4$ inches broad, with the reins irconspicuous or scarcely visible on both sides, dark green and often slightly shiny above, and pale yellow green beneath.

The flower clusters (cymose) are $11 / 2-21 / 2$ inches long, the fleshy branches paired, and flower stalks $1 / 8-3 / 8$ inch long. There are 4 sepals about $3 / 16$ inch

\section{Clusia krugiana Urban}

long and 4 oblong yellow petals more than $1 / 4$ inch in length. Male flowers have many stamens $3 / 16$ inch long. Female flower's have pistil $3 / 16$ inch long with 5 -celled ovary and 5 blackish stigmas on top.

The round green fruit retains the calyx at base and 5 stigmas at apex and when split open is $1 \frac{1}{2}$ inches across the 5 lobes. Several light brown seeds $1 / 8$ inch long are imbedded in orange pulp. Flowering and fruiting probably through the year.

The light brown wood is hard and heavy (specific gravity 0.9$)$. As the trunk is seldom straight, the wood is used mostly for fuel.

Common in the dwarf forests on mountain summits in the upper Luquillo and Cordillera forest regions in Puerto Rico.

Public forests. - Carite, Luquillo, Maricao, Toro Negro.

Raxge.-Puerto Rico and Hispaniola (Dominican Republic).

Cupey trepador (Clusia minor L.), a related shrub, small tree, or vine, has fleshy leares with petioles $3 / s^{-3 / 4}$ inch long, and clusters of few flowers with white to pink petals.

Cupeíllo de altura (Clusia gundlachii Stahl), or cupey de altura, a rinelike shrub or sometimes tree known only from Puerto Rico, has fleshy leaves with petioles $1 / 4-5 / 8$ inch long, clusters of many small flowers, and oblong fruits about $3 / 4$ inch long. The fourth native species of this genus is described below. 

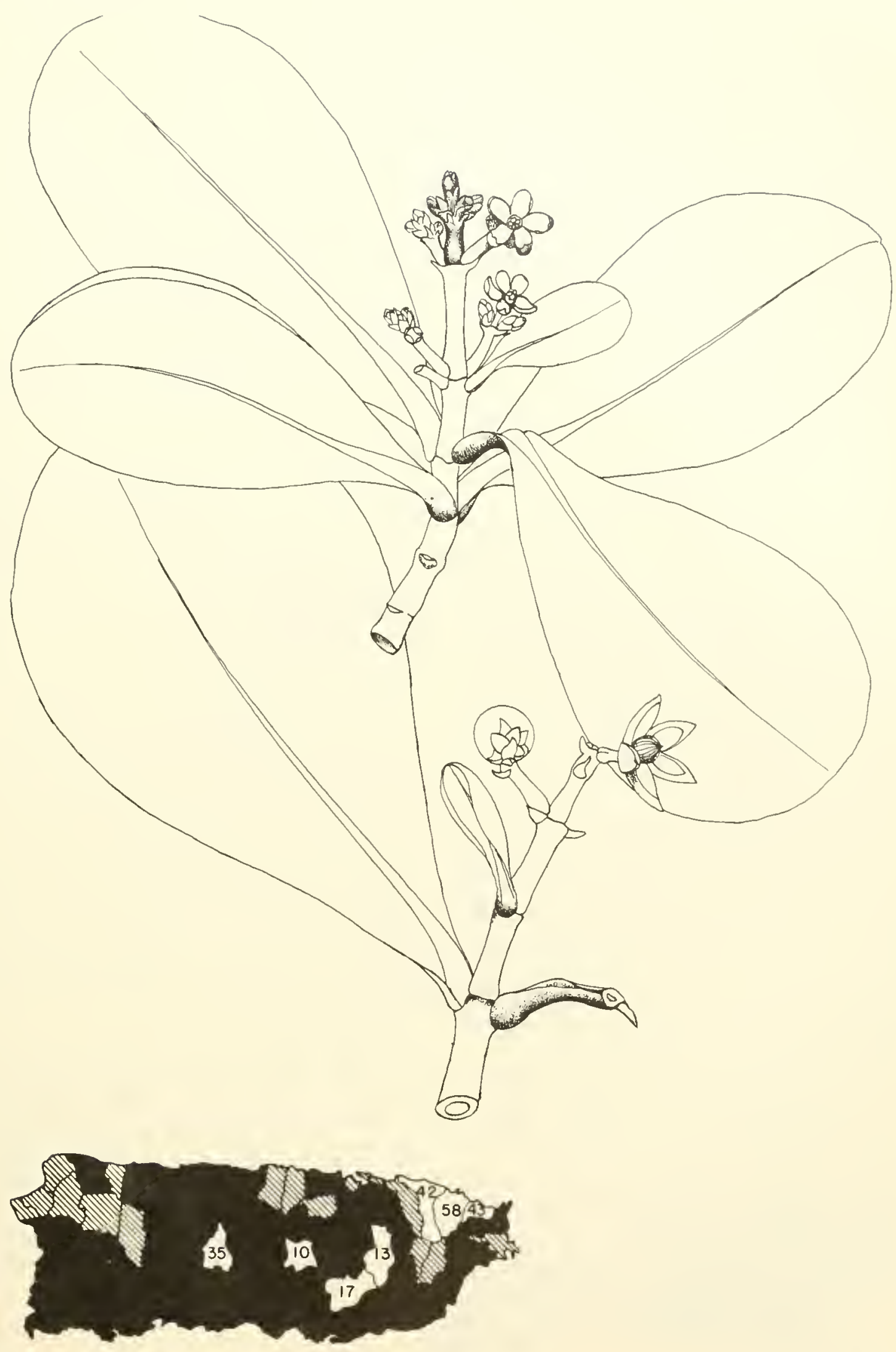

162. Cupeíllo 
A tree with yellow resinous latex easily recognized by: (1) very broad spreading clense crown; (2) opposite, very thick, stiff and leathery, obovate leaves, rounded or slightly notched at apex and gradually narrowed toward the short-pointed base; (3) showy, large, spreading, white flowers about 3 inches across the $6-8$ obovate petals notched at apex, male and female on different trees (dioecious); and (4) nearly round fleshy seed capsules $2-21 / 2$ inches in diameter, yellow green turning brown, splitting into $7-9$ parts and containing many yellow seeds in orange-red pulp.

Medium-sized evergreen tree to 60 feet high and 2 feet in trunk diameter, usually with prop roots at base. Like jagïeyes or matapalos (Ficus spp.), the trees often begin as air plants or epiphytes. the seed germinating in the fork of a tree and sending long aerial roots to the ground. In time these rapidly growing roots come together and encircle the host tree, finally forming a trunk around it and strangling and killing it. The gray bark is smoothish, slightly fissured and warty. Inner bark is pink brown and gritty, with yellow latex. The green twigs ane stout and ringed at nodes.

Petioles are $1 / 2-1$ inch long, green, stout, flattened, and enlarged at base. Blades are $3-6$ inches long and $2-41 / 2$ inches wide, broadest beyond middle, the edges slightly turned under, fleshy and with lateral veins scarcely visible, green to dark green and slightly shiny above and dull yellow green beneath.

Flowers are terminal, 1-3 at end of twig on stalks $1 / 2$ inch or more in length and curved downward. The buds are white, tinged with pink, about $5 / 8$ inch in diameter. There are $4-6$ rounded concave sepals $1 / 2-5 / 8$ inch long, white and tinged with pink, and 6-8 white obovate fleshy petals about 11/4 inches long. Female flowers have a brown ring or cup of sterile stamens and a pistil with $7-9$-celled ovary and green resinous mass of $7-9$ stigmas $1 / 2$ inch across. Male flowers have sepals, petals, and many stamens united in a ring, the inner ones in a resinous mass.

The ball-like fruits are not edible and are considered to be poisonous, though eaten by bats. They are broader than long, changing in color from yellow green to brown at maturity, retaining the sepals at base and flat blackish stigmas in a circle $3 / 4$ inch across at apex. The seeds are $3 / 16$ inch long. In flower or fruit throughout the year.

The heartwood is reddish brown, and the sapwood lighter colored. The wood is hard, heavy (specific gravity 0.67 ), strong, of medium to fine texture, straight-grained, and without growth rings. It is moderately difficult to saw and ma- chine and is very susceptible to attack by dry-wood termites. The rate of air-seasoning and amount of degrade are moderate. Machining characteristics are as follows: planing and boring are fair; and shaping, turning, mortising, sanding, and resistance to serew splitting a re good.

The wood is used mainly for fuel, fenceposts, rural construction, and crossties. It is suitable also for light and heavy construction, cheap furniture, farm implement parts, and tool handles.

The yellow resinous latex of bark, fruit, and other parts of the tree hardens upon exposure and has been used variously, including calking the seams of boats in the Virgin Islands, as plaster, and in medicine.

It is chronicled by Oviedo that the early Spanish conquistadores in the West Indies made playing cards of the thick leaves, drawing the figures and spots with a pin and shuffling these substitutes in their gambling games in the absence of regular cards. Another early use was for writing paper.

By strangling and killing more vahable trees, this species may be classed as a forest pest. However, the leathery leaves and large flowers make it an attractive ormamental. As the heavy foliage is salt tolerant, this tree is suitable for ornamental plantings on exposed ocean front properties.

Common in forests on river banks and hillsides throughout Puerto Rico except in the upper mountain regions. Also in Mona, Desecheo, Vieques, Culebra, St. Thomas, St. John, and Tortola, and recorded long a go from St. Croix.

Public ronests.-Cambalache, Carite, Guajataca, Guánica, Luquillo, Maricao, Susúa, Vega.

MUNICIPAIJTIES WHERE ESPECIALLY COMMON.$11,14,20,30,31,34,45,60,62,69$.

RANGE.-Nearly throughout West Indies from Bahamas and Cuba to Trinidad and Tobago and Bonaire and Curaçao. Very rare in Florida Keys but planted in southern Florida. Also from southern Mexico (Chiapas) to Colombia, Venezuela, and French Guiana.

OtIIER COMmon NAMEs.-pitch-apple, wild-fig, strangler-fig, false-mamey (Virgin Islands); cupey, copey (Spanish); cape, gaque, cucharo (Colombia); copey, tampaco, chuchi copei (Venezuela) ; copey clusia, monkey-apple (United States) ; pitch-apple (Bahamas); balsam-tree, wild-fig (Jamaica); monkey-goblet (St. Vincent) ; Scotch-attorney, Scotchman, matapal (Trinidad) ; parrotapple (Tobago); kufa (British Guiana) ; figuier maudit cimarron (Haiti) ; figuier maudit, figuier marron, abricotier maudit (Guadeloupe); aralie, aralie grande feuille (Martinique); dam machu, cuchiú, kopijk (Dutch West Indies). 


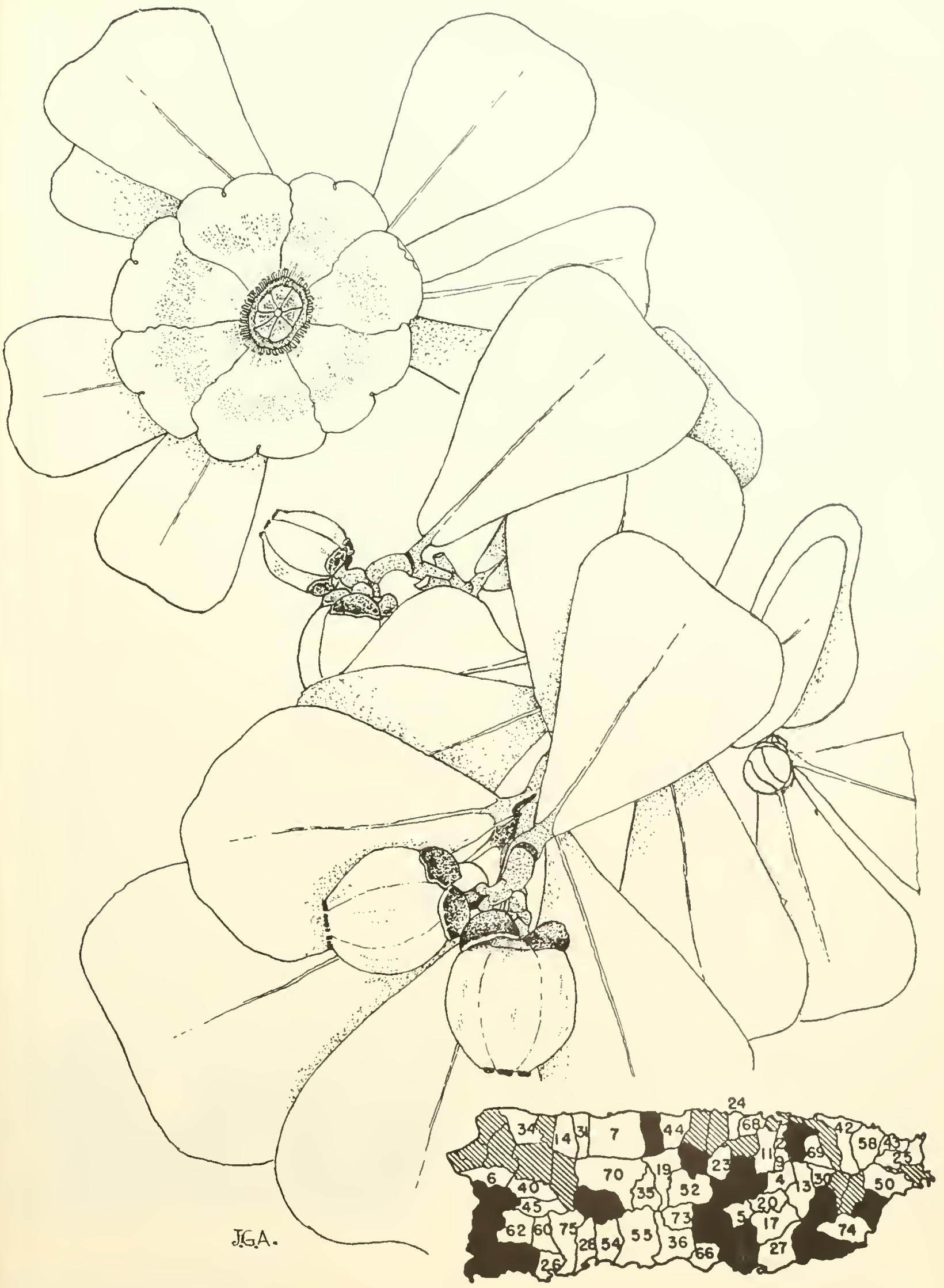




\section{MANGOSTEEN FAMILY (GUTTIFERAE)}

\section{Mamey, mammee-apple}

Mamey, a handsome wild or planted fruit tree, is best known for its brown nearly round edible fruits 3-10 inches in diameter. Other characters are: (1) an erect trunk with rery dense shiny areen columuar crown: (2) bark containing pale yellow latex, which is erident where cut: (3) opposite elliptic leaves $4-61 \%$ inches long and $21 / 4^{-}$ $33 / 4$ inches wide, thickened and leathery, glossy green to dark green above, and with numerous closely arranged, parallel lateral reins; and (4) large fragrant white flowers $1 \frac{1}{2}-2$ inches across the usually 6 spreading petals, borne on twigs mostly back of leaves.

An evergreen tree to 60 feet high and 2 feet in trunk diameter. The brown or gray bark is smoothish to slightly fissured, inmer bark light brown or pinkish and bitter. The stont twigs are green when young, turning brown.

Petioles are $1 / 4-3 / 8$ inch long and stout. Blades are rounded at apex and rounded or short-pointerl at base, turned under slightly at eciges, with reins slightly sumken on upper surface, and yellow green beneath. The leares have gland dots risible with a hand lens against the light.

'The flower's are single or a few together on stout stalks $1 / 1-3 / 4$ inch long, male and female and bisexual (polygamous). The flower bud is whitish green, turning brown, round to ellipt ic, $1 / 2-5 / 8$ long, splitting into 2 sepals about $5 / 8$ inch long. There are $1-6$, usually 6 , obovate spreading white petals $3 / 4-1$ inch long. Male flowers have in the center. numerous small crowded yellow stamens $1 / 2$ inch high and $3 / 1$ inch across, united at base. Female flowers have a pistil composed of 2- or 4-celled orary with short style and usually broadly 2 -lobed stigma.

'The fruit (berrylike) has a thick skin and firm bright yellow or reddish flesh with white sap. There are $2-4$ very large oblong reddish-brown stones or seeds with rough fibrous surface. Observed in flower from May to October and with fruits during most of the year.

The sapwood is light brown, and the heartwood reddish brown. The surface of this attractive wood often is flecked with small dark oily exudations. It is hard, heavy (specific gravity 0.62), strong, medium-textmed, and frequently has irregular and interlocked grain. Air-seasoning is moderate in rate but very difficult, and the amount of degrade is considerable. Machining characteristics are as follows: planing, turning, boring, and mortising are good; shaping and resistance to screw splitting are excellent; and sanding is poor. The rood is rery susceptible to attack by dry-
Mammea americana $\mathrm{L}$.

wood termites but is moderately durable in the ground.

The scattered trees in Puerto Rico serve for fruit, fenceposts, and fuel. Elsewhere the rood is employed for some types of general construction and carpentry and for piling.

The fruits are eaten raw or made into preserves and marmalades. The skin and flesh next to the seeds are bitter. In the French West Indies an aromatic liqueur, known as "eau de créole" or" "crème de Créole," is distilled from the flowers. The gummy latex from the bark and the powdered seeds have been used as insecticides, to extract chiggers and insects from the skin, and to kill ticks and other parasites of dogs and other domestic animals. Then twisted into the shape of a cone, the leaves serve as pots for planting tobacco seedlings and protect the young plants from rootdestroying insects.

The large seeds are reported to be poisonous, though not eaten by lirestock. They are highly toxic to certain types of insects, to fish, and to chicks.

Planted in Puerto Rico and Virgin Islands (St. Croix, St. Thomas, St. John, and Tortola) for the edible fruits and for shade and ornament. A common tree along roadsides and fence rows. Apparently native to the moist coastal forest of Puerto Rico.

MUNicipalities wiIERE especially COMMION.$31,47$.

Raxie.- Native of West Indies. Spread by cultivation over tropical America in southern Florida, Bermuda, West Indies from Bahamas and Cuba to Trinidad and Tobago, and Mexico south to Brazil and in the Old World tropics.

Other COMmon Names.-mamee (Virgin Islands); mamey (Spanish); mamey de Santo Domingo, mamey amarillo (Cuba); zapote mamey, zapote de niño, zapote de Santo Domingo (Mexico); ruri (Nicaragua); mamey de Cartagena (Panama, Ecuador); mata-serrano (Ecuador); mamey, nammee-apple (United States, English); apricot (Dominica); abricot, abricotier (Haiti, Guadeloupe, Martinique) ; abricot des Antilles, abricot de Saint-Domingue, abricot pays (Guadeloupe, Martinique) ; mamie, abricotier, abricotier d'Amérique (French Guiana); mami, mamaya (Dutch TVest Indies); mammi, mamieboom, mamaja (Suriuam) ; abricó do Pará, abricoteiro (Brazil).

The generic name is derived from the native West Indian name. 


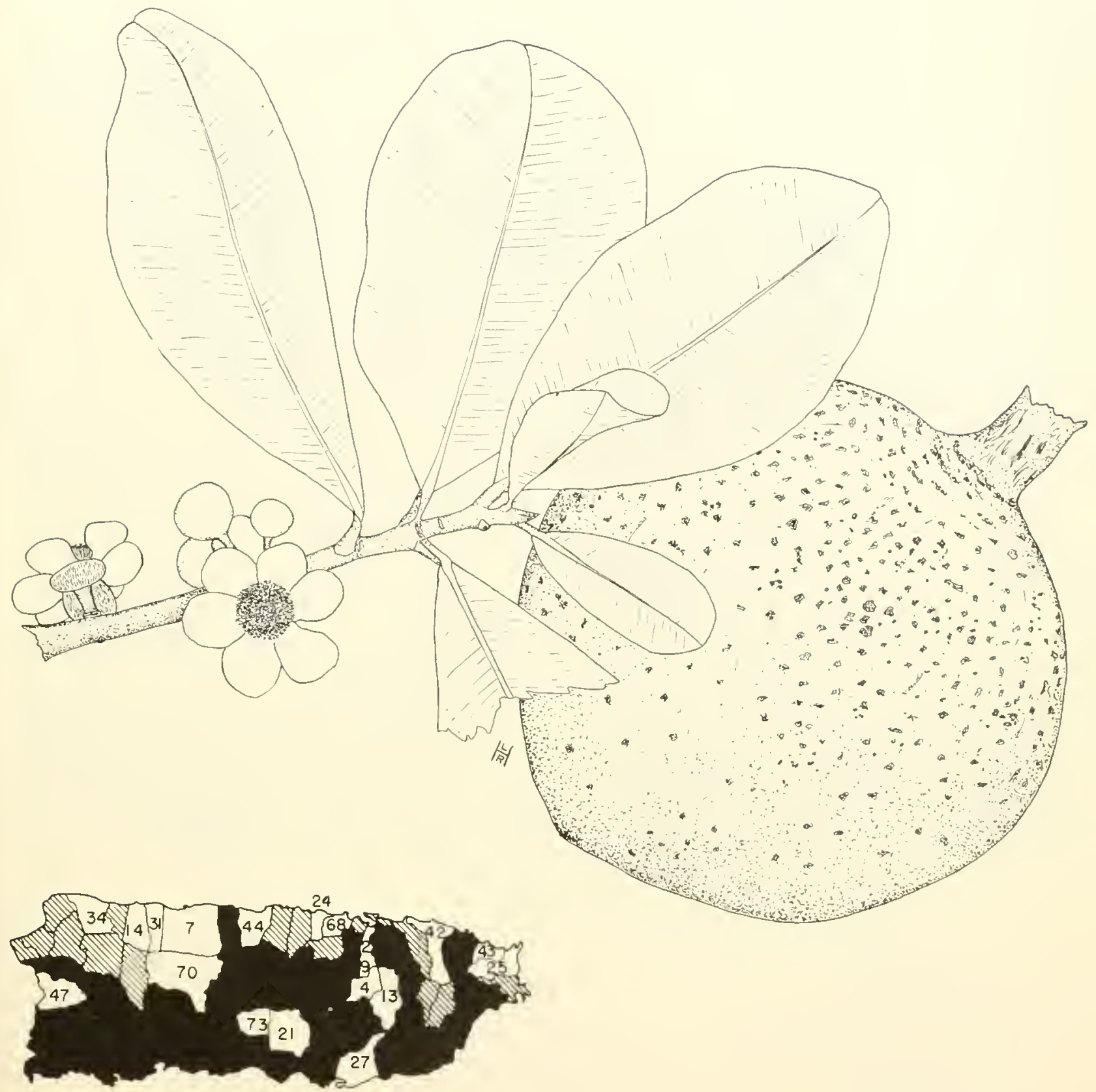

164. Mamey, mammee-apple 


\section{MANGOSTEEN FAMILY (GUTTIFERAE)}

\section{Palo de cruz}

Palo de cruz is easily identified by its opposite, elliptic or" obovate, shiny dark green leaves which are small, thick and stiff, with sunken midrib, and curved downward from the long-pointed base to the long-pointed sharp spine $1 / s^{-1 / 4}$ inch long. Other distinguishing characteristics are: (1) regular opposite branching of twigs at right angles from the axis; (2) pale yellow latex in inner bark, twigs, leaves, and frnits; (3) small, pale yellow, pinkish-tinged flowers about $1 / 4$ inch across, several or 1 at leaf bases; and (4) bright yellow elliptic berry $1-1 \frac{1}{4}$ inches long.

Commonly a small tree to 20 feet high (formerly to 65 feet, according to earlier reports) and 4 inches in trunk diameter, evergreen, with narrow crown of drooping or horizontal branches and dark green foliage. The bark is brown and smooth or slightly fissnred. Inmer bark is reddish, bitter, with pale yellow latex in innermost part. The twigs are green and slightly angled when young, becoming gray and enlarged at nodes.

The leaves have short erect petioles $1 / 4^{-1 / 2}$ inch long and blades $11 / 2-31 / 4$ inches long and $3 / 4-2$ inches broad. Margins are turned under slightly, and the lower surface is light green.

Lateral flowers on stalks about $1 / 4-3 / 8$ inch long are bisexual and male and female on the same or different trees (polygamous or dioecions). There are 2 yellow-green sepals $1 / 1$ inch long; 4 pale yellow petals pinkish at base, $1 / 8^{-1 / 4}$ inch long; stamens about $7-10$ (about 18 stamens around a broad

\section{Rheedia portoricensis Urban}

whitish disk in male flowers); and pistil with rounded pinkish 2 -celled ovary less than $1 / 8$ inch long and 2-lobed flat stigma (sometimes ovary is 3-celled and stigma 3-lobed). The fleshy fruits are pointed and contain usually 2 large seeds. Flowering and fruiting at different times during the year.

The sapwood is very light brown, and the heartwood light brown. The wood is very hard, heavy (specific gravity 0.9 ), and very fine-textured. Because of the small size of this tree its wood is used only for posts.

Forests of the lower Luquillo Mountain region and thickets of the moist and dry coastal regions. Also in Vieques. A handsome small tree of possible ornamental value.

Public Forests.-Carite, Luquillo, Susúa.

RANGe.-Known only from Puerto Rico and Vieques.

Other comion Nase--guayabacoa (Puerto Rico).

Botanicai srovim. - Rheedia acuminata (Spreng.) Planch. \& Tr., not R. acuminata (Ruiz \& Pav.) Planch.\& Tr.

The common name palo de cruz (tree of cross) refers to the branching of twigs at right angles to the straight axis in the shape of a cross.

A second natire species (Rheedia hessii Britton) known only from near Maricao apparently is rare. It has narrowly lance-shaped leaves less than 1 inch long. 


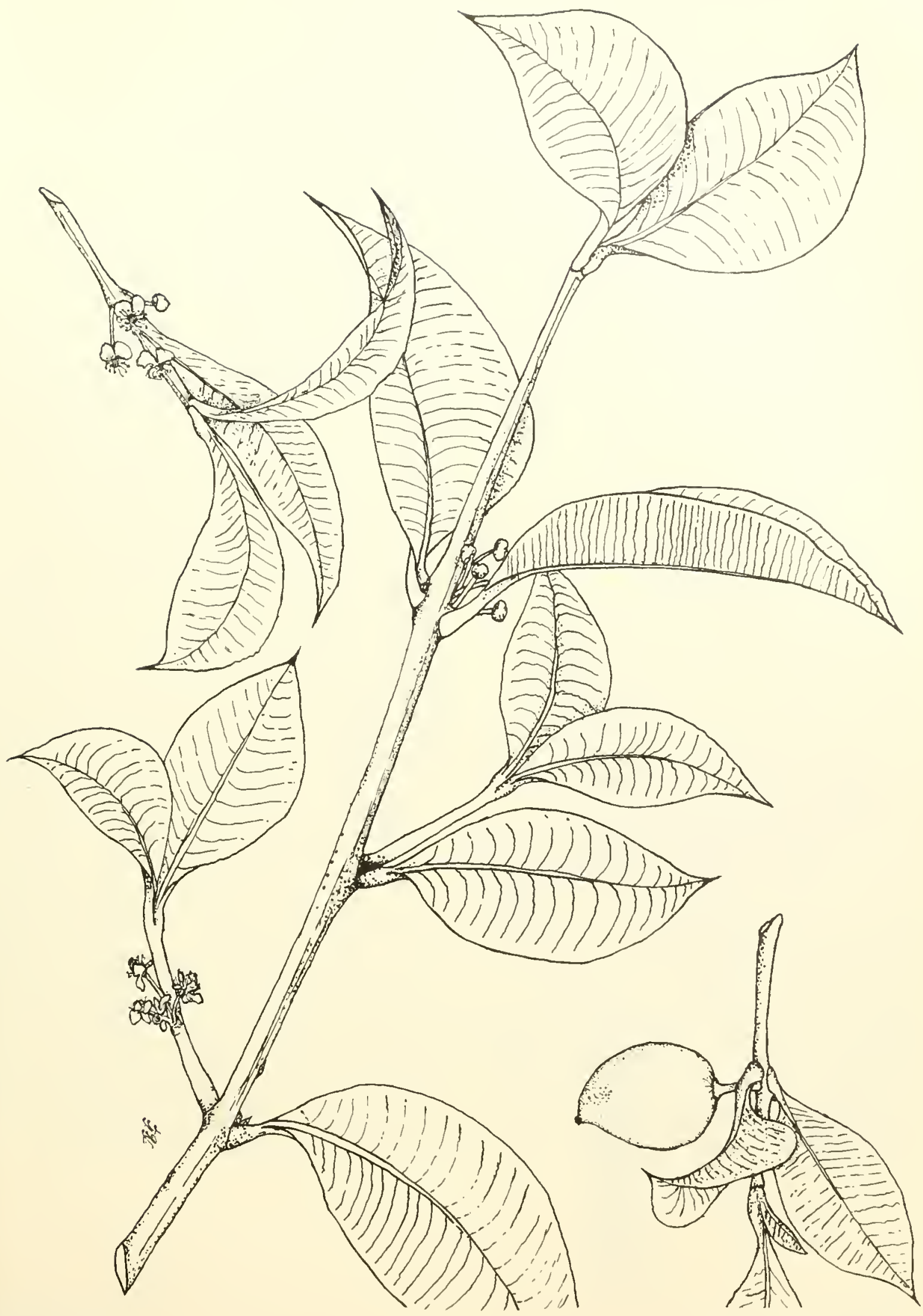

165. Palo de cruz

Natural size.

Rheedia portoricensis Urban 


\section{ANATTO FAMILY (BIXACEAE*)}

\section{Achiote, anatto}

Achiote, or anatto, a small tree planted for the orange-red dye on the seeds, has become naturalized. It is characterized by: (1) thin ovate leaves long-pointed at apex, heart-shaped at base, and long-petioled; (2) large, showy, pinkish or purplish-tinged or whitish flowers $1 \frac{1}{2}-2$ inches across the 5 spreading petals, several or few in terminal clusters; (3) reddish-brown to dark brown, rounded seed capsules 1-11/2 inches long and broad, densely covered with soft prickles up to $1 / 4$ inch long; (4) orange sap in the inner baik; and (5) twigs ringed at nodes.

A small evergreen tree commonly less than 15 feet higl and 4 inches in trme diameter. The bark is light brown and smoothish, with many warty dots (lenticels), or fissured. Inner bark is pinkish toward outside and orange within, and often slightly bitter. The twigs are green and with minute, rusty, reddish-brown scales, becoming dark brown.

The alternate leaves have slender petioles 1-3 inches long. Leaf blades are $31 / 2-71 / 2$ inches long and $21 / 2-41 / 2$ inches broad, thin, with minnte scales when young but becoming hairless or remaining slight ly scaly on lower surface, green or dark green on beneath.

Flower clusters (panicles) are branched, and the fragrant flowers are on scaly stalks. There are 5 brownish-green sepals about $3 / 8$ inch long, covered with reddish-brown seales and soon falling; 5 broad, rounded, pinkish or purplish-tinged ol' whitish petals about 1 inch long; numerons purplish stamens about $5 / 8$ inch long; and pistil $5 / 8$ inch long composed of bristly 1-celled ovary, style, and short 2-lobed stigma.

Seed capsules are somewhat flattened and split into 2 parts. There are many angular seeds about $3 / 16$ inch long, with bright orange-red fleshy seed coat. Flowering mainly in spring and maturing fruits chiefly in summer.

The sapwood is whitish, and the heartwood is light brown or yellowish. The wood is soft,
Bixa orellana L.*

lightweight (specific gravity 0.4), porous, weak, and not durable.

Commercially important for the orange-red dye called anatto. Extracted in the kitchen by boiling the seeds in cooking fat or oil, anatto is nsed to color rice, margarine, butter, cheese, somps, and other foods but adds no flavor. It is a dye for oils, varnishes, and cosmetics also. Indians have painted their faces and bodies with this pigment, which also is reported to give relief from insects.

The conspicuous pinkish flowers and prickly fruits also make this plant an attractive ornamental, and the flowers are a source of honey. Ropes and twine have been made from the fibrous bark, and a gum similar to gum arabic has been obtained from the branches. It is said that fire can be started by friction of two pieces of the soft wood. In some places the seeds and leaves have been employed in domestic medicine.

Grown around houses and occasionally naturalized in nearby thickets on the coastal plains of Puerto Rico. Also in Vieques, St. Croix, St. Thomas, and St. John.

RAvGe- Native of continental tropical America but spread by cultivation and now from Mexico to Argentina and Brazil. Widely planted and naturalized in tropical and subtropical regions of the world. Through West Indies from Cuba and Jamaica to Barbados and Trinidad. Uncommon in cultivation in southern Florida.

Otimer common rames.-achote, bija (Puerto Rico); roucou (Virgin Islands); achiote, achote (Spanish); bija (Dominican Republic, Cuba, Teneznela); chaya, xayau (Guatemala); cuajachote (El Salvador); onoto, onotillo, caituco (Tenezuela); shambu (Peru); urucú (Bolivia. Argentina); annato, annatto, anatto-tree (English) ; roucou (Trinidad and Tobago) ; atta (British Honduras) ; onoto (British Guiana) ; roucou, roucouyer (French); achiot (French Guiana); rucu, roucou (Dutch West Indies) ; roucon, koesoewee (Surinam) ; urucú, achiote (Brazil). 



\section{COCHLOSPERMUM FAMILY (COCHLOSPERMACEAE*)}

\section{Rosa imperial, Brazilian-rose, cochlospermum}

\section{Cochlospermum vitifolium (Willd.) Spreng.*}

This introduced, cultivated omamental is distinguished by: (1) quantities of large, showy, bright yellow roselike flowers $3-4$ inches across, borme in terminal chusters usually when the trees are leafless; and (2) long-petioled, deeply palmately lobed leaves with usually 5 long-pointed toothed lobes. The double-flowered form with many petals grown in Puerto Rico does not mature fruits and seeds.

A small to medium-sized deciduous tree to 25 feet tall and 1 foot in trunk diameter, with relatively few stout branches. The bark is gray, smoothish and becoming slightly furrowed. Inner bark is brown streaked, fibrous, slightly bitter, and yields a gum. Twigs are green when young, becoming browll.

The alternate leaves have petioles $3-7$ inches in length, green and tinged with red, and a pair of minute threadlike stipules at base which soon shed. Leaf blades measure about 4-8 inches long and broad, are heart-shaped at base, and have usually 5 ( rarely 3 or 7 ) spreading lobes, each with a prominent central vein and small teeth along the edges. Upper surface of the thin blades is green to dark green and slightly shiny, and the lower surface lighter gray green, finely hairy to nearly hairless.

Flowers are borme on long stalks in erect spreading terminal chusters (panjeles), sometimes a few on shrubby plants only $3-5$ feet high. There are 5 green to yellow-green sepals $1 / 2-5 / 8$ inch long, the outer 2 pointed and smaller and the inner 3 rounded and broader. In the double-flowered Puerto Rican form there are many widely spreading, rounded, elliptic, bright yellow petals $11 / 2-2$ inches long. Numerous spreading orange stamens $3 / 8-3 / 4$ inch long with curved slender filaments and curved narrow anthers are in the center, but a functional pistil is lacking. Blooming mostly from January to March, during the drier part of the year.

The nore widespread single-flowered form not found in Puerto Rico has only 5 petals about 2 inches long, notched at apex, and in the center of the many stamens a pistil consisting of a green rounded ovary $3 / 16$ inch in diameter, 5-carpeled, and a slender curved yellow style about $1 \frac{1}{4}$ inch long. On wild trees the large elliptic dark brown capsules about 3 inches long and 2 inches in diameter hang down from curved stalks. The inconspicuously hairy, thin-walled capsules split into
5 parts, releasing many dark brown kidney-shaped seeds $3 / 16$ inch long, imbedded in masses of soft cottony white hairs.

The whitish to light brown wood is soft, spongy, very lightweight, perishable, and of little use.

Planted for ornament on the coastal plains of Puerto Rico and in the Virgin Islands, growing rapidly and best in dry areas. Reported to be a honey plant. The trees are propagated easily by cuttings. The more attractive double-flowered form in Puerto Rico, Hispaniola, Dominica, and perhaps a few other islands of the West Indies is preferred for cultivation but apparently is little known elsewhere. Both the normal and doubleflowered forms are grown in St. Thomas. Hedges and living fences can be formed by planting branches and pruning them back.

Elsewhere, rope has been made from the fibrous bark, and the cotton around the seeds is used for stuffing pillows. A home remedy has been extracted from wood and leaves.

Range.-Continental tropical America from western Mexico through Central America and norther'n South America to Ecuador, Peru, Bolivia, Brazil, Guianas, and Trinidad, chiefly in dry forests. Planted for ornament in the West Indies, such as in Cuba and Puerto Rico, and other tropical areas and as far north as southern Florida and southern California.

OTHER COMHON NAMES.-rosa china, emperatriz de la selva, rosa de Maximiliano (Puerto Rico); rose-of-Sharon (Virgin Islands); botija, palo bobo (Cuba); tecomasuche (Mexico, Guatemala, El Salvador) ; rosa amarilla, chumn, cocito, apomo panaco (Mexico); jicarillo (Honduras); cho, pochote, pumpo, pumpumjuche, tecomatillo (Guatemala) ; bombón, tecomasúchil (El Salvador) ; poroporo (Nicaragua, Costa Rica, Panama, Colombia); bombón, catamericuche (Nicaragua); camestolendas, bototo (Colombia, Venezuela); papayote (Colombia) ; bototillo, bototito, botulo (Eucador); huimba, quillo-sisa (Peru); cochlospermum, shellseed (English); rose-of-Peru (Dominica); wild-cotton, pochote (British Honduras); kanakuchiballi, wild-cotton (British Guiana); njoe fodoe (Surinam).

Botanida. SYNonys.-Maximitianea vitifolia (Willd.) Krug \& Urban, Cochlospermum hibiscoides Kunth.

The descriptive specific name, meaning "grapeleaf," recalls the similarity of the leaves to those of cultivated grapes. 


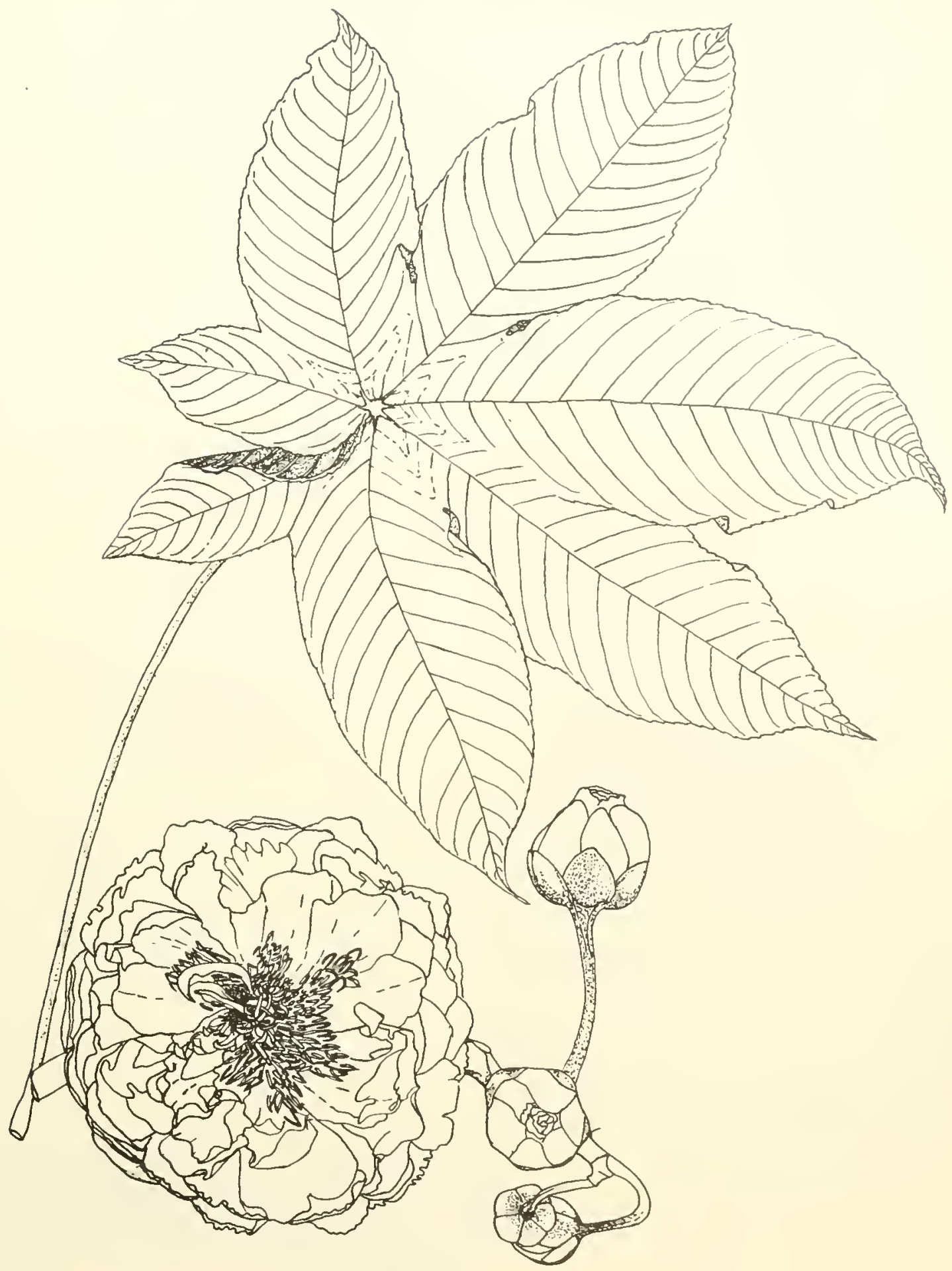

167. Rosa imperial, Brazilian-rose, cochlospermum

Cochlospermum vitifolium (Willd.) Spreng. Two-thirds natural size. 


\section{CANELLA FAMILY (CANELLACEAE)}

\section{Barbasco, canella}

This small tree characteristic of dry areas is identified by: (1) a dense crown of obovate or spoon-shaped, leathery shiny green leaves $11 / 4-31 / 2$ inches long and $5 / 8-1 \frac{1}{2}$ inches broad, romcled at apex and gradually narrowed toward base, aromatic and with peppery stinging taste: (2) small dark red, purplish-tinged flowers $1 / 4$ inch long and broad, several to many in terminal flat-topped clusters shorter than the leaves; (3) round red (or purplish-black) berries about $3 / 8$ inch in diameter: and ( + ) aromatic, gray, smoothish, slightly warty bark with burning or stinging taste.

Ali evergreen tree to 20 feet high and $5-8$ inches in trunk diameter, or shrubby. The thin bark sometimes is fissured. Inner bark is whit ish. The twigs are green at apex, becoming gray, with spicy taste.

The alternate leaves are crowded near ends of twigs, with petioles $1 / 8^{-1 / 4}$ inch long. Leaf blades are broadest beyond middle, with edges slightly turned under, thickened, with few indistinct veins, ininutely gland dotted, and paler beneath.

Flower clusters (corymbs) are branched, about 1 inch long and broad, with fragrant spreading flowers on stalks about $1 / 8$ inch long. There are 3 broad, rounded, blue-green sepals less than $1 / 8$ inch long; 5 elliptic rounded fleshy petals $3 / 16$ inch long, dark red but purplish on outsicle; about 20 red stamens united by filaments and anthers into a tube more than $1 / 8$ inch long; and pistil $3 / 16$ inch long consisting of light green 1 -celled ovary with short style and very slightly 2 -lobed stigma, protruding througl stamen tube. Berries are fleshy, with a few black seeds $3 / 16$ inch long. Flowering and fruiting probably irregularly through the year.

The sapwood is olive brown, and the heartwood blackish. The wood is very hard and very heavy (specific gravity 0.9-1.0). In Puerto Rico it is seldom utilized except for posts because of the

\section{Canella winterana (L.) Gaertn.}

small size of the trees. Uses elsembere have been for plows, poles, and beams.

Canella bark, the wild cinnamon bark of commerce, has served in medicine though rarely at present as an aromatic stimulant and slight tonic and also as a condiment. The leaves have been employed similarly and as a fish poison. The berries are reported to be hot like black pepper. when gathered green and dried. Also a honey plant, the flowers being very rich in nectar. Though this usually is not regarded as a poisonous plant, the leaves and stems were toxic to poultry in feeding trials in St. Croix.

Planted around houses in the Virgin Islands. In southern Florida this is a hardy ornamental shrub grown for the numerous bright red berries borne in spring.

Thickets in the dry coastal and limestone regions of Puerto Rico and also at Cabezas de San Juan at the northeastern corner of the island. Also on Mona, Icacos, Vieques, St. Croix, St. Thomas, St. John, and Anegada.

Public forests.-Guániea, Maricao, Susúa.

Range.-Southern Florida including Florida Keys, Bahamas, Cuba, Jamaica, Puerto Rico and Tirgin Islands, and Lesser Antilles from St. Martin and Barbuda to St. Lucia and Barbados.

Other common names.- canela (Puerto Rico); wild cinnamon, caneel, pepper cinnamon, cilliment-bush (Virgin Islands); canela de la tierra, canelilla (Dominican Republic); cúrbana, picapica, malambo, canela blanca (Cuba); canella, cinnamon canelia (United States) ; canella, wild cinnamon, whitewood bark (English); cinnamonbark (Bahamas) ; canelle poivrée (Haiti) ; canellier blanc, canellier bâtard, bois canelle (Guadeloupe).

Botanical synonyas.-Canella alba Murr., Winterana canella $\mathrm{L}$. 

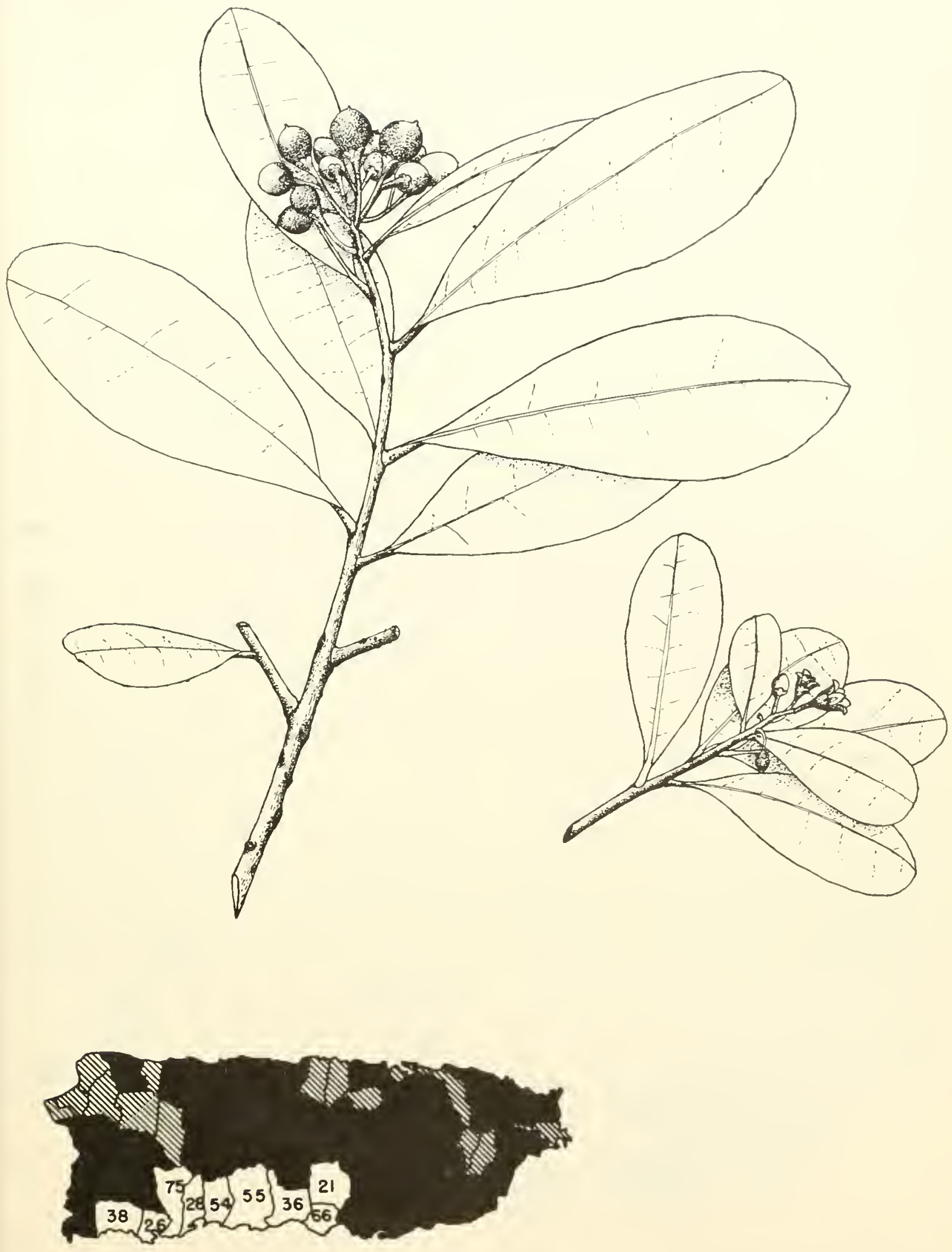

168. Barbasco, canella 


\title{
FLACOURTIA FAMILY (FLACOURTIACEAE)
}

\author{
Key to the 5 species illustrated (Nos. 169-173)
}

A. Flowers in short lateral clusters; fruit a rounded or an elliptic seed capsule.

B. Leares many, evenly spaced on long slender twigs, appearing pinnate; seed capsules $3 / 16$ iuch or less in diameter.

C. Leaves with lower surface gray green, hairy; edges toothed-169. Cascaria arborea.

CC. Leaves green on both surfaces; edges appearing as if without teeth-172. Casearea sylvestris.

BB. Leares few; seed capsules about $\% / 8$ inch in diameter.

D. Leaves less than 3 inches long, hairless; seed capsules round-170. Casearea deeandra.

DD. Leares $2 \frac{1}{2}-51 \%$ inches long, hairy on reins; seed capsules elliptic-171. Casearia guianensis.

Ad. Flowers in long-stalked lateral clusters; fruit of seed capsules resembling dried flowers with 6 or 7 large brown sepals attached-173. Homalium racemosum.

\section{Rabo ratón}

This very common small tree is distinguished by: (1) many crowded lance-shaped or narrowly oblong leaves flattened in 2 rows on long, slender, nearly horizontal or slightly drooping twios; (2) the leaves long-pointed, finely saw-toothed, and the lower surface gray green and covered with minute hairs; and (3) small greenish-white bellshaped flowers $3 / 16$ inch long and broad and seed capsules 3/16 inch in diameter in clusters at leaf bases.

An evergreen tree to 30 feet high and 6 (rarely 10) inches in trunk diameter, or shrubby. The thin gray-brown bark is smoothish. Inner bark is light brown and slightly bitter. The twigs are finely hairy and brown, green when young.

The alternate leaves have short hairy petioles $1 / 8$ inch long and thin blacles $11 / 2-4$ inches long and 1/2-1 inch broad, short-pointed at base, shiny green and almost hairless on upper surface and densely gray-green hairy beneath. Many minute gland dots and lines can be seen when a leaf is examined with a hand lens a gainst the light.

Several to many small flowers are borne in lateral clusters (umbels) about $1 / 2$ inch across at bases of leaves, each on a short, hairy, jointed stalk less than $1 / 8$ inch long. The whit ish or greenish-white, bell-shaped flowers consist of the calyx with 5 finely hairy, spreading lobes about $1 / 8$ inch long; 10 stamens attached to calyx and alternating with smaller hairy sterile stamens (staminodes); and pistil with 1-celled ovary with style and rounded stigma. Seed capsules become reddish and blackish. Flowering and fruiting through the year.

\section{Casearia arborea (L. C. Rich.) Urban}

Saprood is hard and brittle, very light brown. The tree is used chiefly for" posts and fuel in Puerto Rico.

Abundant and widely distributed along roadsicles and in openings, thickets, and forests, in the lower mountain, moist limestone, and moist coasta] regions of Puerto Rico. (Also repolted long ago from St. Thomas, perhaps in error.)

Public Forfsts.-Carite, Guajataca, Guilarte, Isuquillo, Maricao, Río Abajo, Susúa, Toro Negro.

IUNICIPALITIES WHERE ESPECIALLY COMMON.-4, $19,20.27,29,35,40.49,51,52,53,64$.

Ravge.-Cuba, Hispaniola, and Puerto Rico. Recorded from Honduras, Brit ish Honduras, and Costa Rica in Central America. Also in Sonth America from Guianas to Brazil, Bolivia, and Peru.

Other comion names.-rabo junco (Puerto Rico) ; palo de yagua, palo salvaje, cascarita (Dominican Republic); guaguasí, jique, guasimilla (Cuba) ; llajas (Peru).

Two additional species of this genus are native in Puerto Rico besides the 4 illustrated here. Casearia aculeata Jacq., a shrub or small tree of sonthern and western Puerto Rico, has elliptic leaves $1-23 / 4$ inches long, usually hairy beneath and distinguished by spines $3 / 4-11 / 4$ inches long, often branched, on the twigs.

Talantrón (Casearia bicolor Urban), apparently rare, is a tree species known only from the Cordillera near Utuado. It has narrow oblong lenves $3-41 / 2$ inches long and $1-13 / 4$ inches wide, short-pointed at apex and rounded at base. 


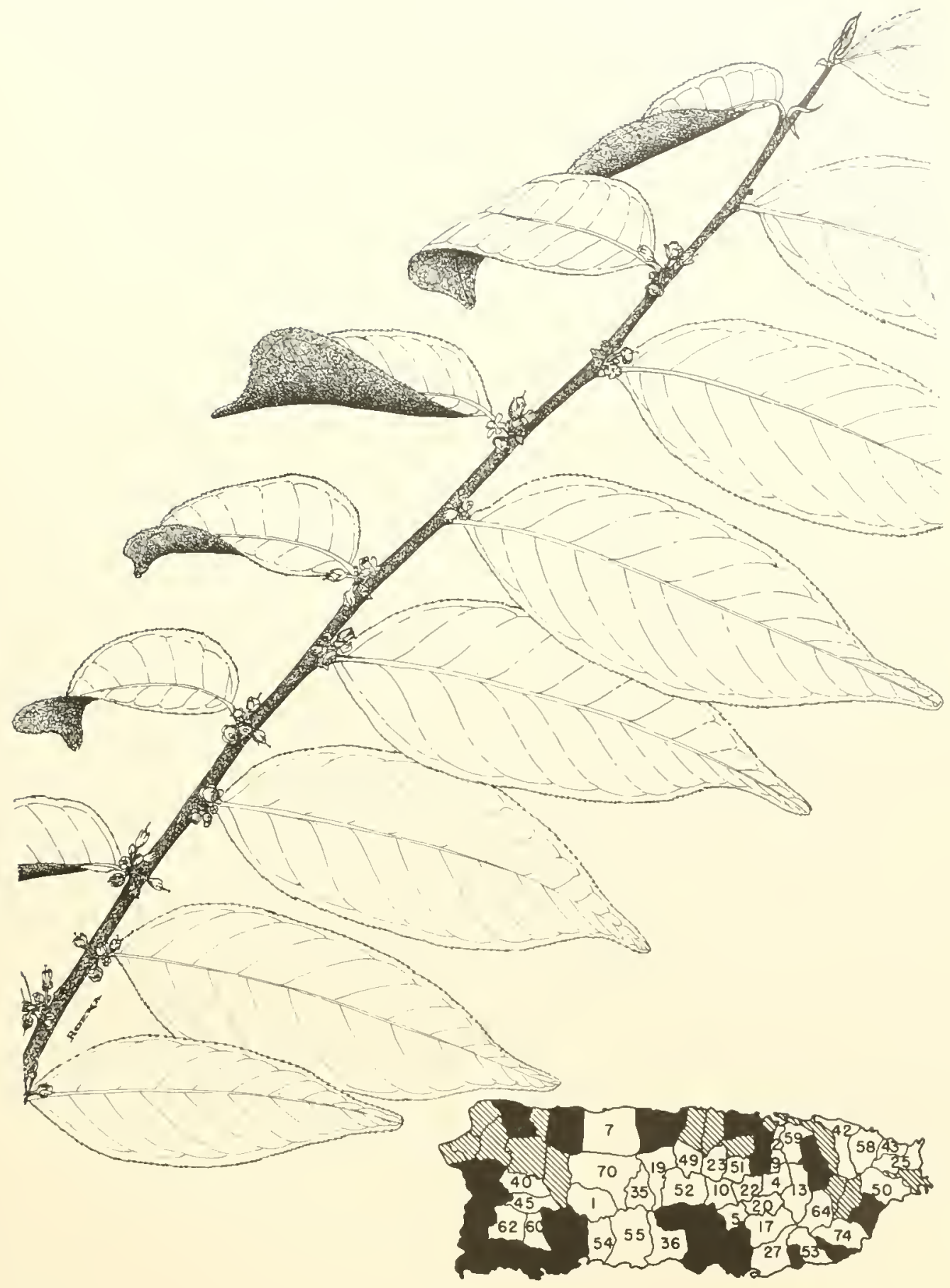

169. Rabo ratón

Natural size.

Casearia arborea (L. C. Rich.) Urban 


\section{FLACOURTIA FAMILY (FLACOURTIACEAE)}

\section{Tostado, wild honey-tree}

This shrub or small tree is characterized by: (1) the small, yellow-green elliptic leaves less than 3 inches long, finely saw-toothed, thin, and sledding in winter; (2) the many small greenish-white flowers $1 / 4$ inch across in clustels about $3 / 4$ inch across at nodes when twigs are leafless; and (3) the round seed capsules $3 / 8$ inch in diameter, pale yellow or brown, edible but almost tasteless.

A deciduous shrub or small tree to 15 feet high and to 3 inches in trunk diameter, with spreading crown. The gray bark is smooth and thin, the imner bark light brown and tasteless. The slender hairless twigs are green when young, becoming bromn.

The alternate leaves have short petioles $1 / 8-1 / 4$ incl long and thin blades $1 \frac{1 / 1-3}{-1}$ inches long and $5 / 8-1 \frac{1}{4}$ inches broad, long- or short-pointed at apex and short-pointed or rounded at base, green on both sides and slightly shiny above, hairless except for inconspicuous tufts of hairs usually in vein angles beneath.

Many finely hairy flowers are bome in lateral flower chusters (umbels) on slender stalks about $3 / 16$ inch long, jointed near base. The calyx is deeply divided into 5 narrow, finely hairy, spreading lobes $1 / 8$ inch long; 10 hairy stamens attached near base of calyx are alternate with smaller hairy sterile stamens (staminodes); and pistil consisting of hairy 1-celled ovary, slender hairy style, and rounded stigma.

\section{Casearia decandra Jacq.}

The fleshy seed capsules are single or sometimes paired on twigs back of the leaves and split into 3 parts. There are 2-4 seeds in the orange-colored flesh. Flowering and fruiting at different times dnring the year.

The light brown, hard sapwood perhaps is used as round wood where the trees are of sufficient size.

The fruits are edible, as the common name cerezo (cherry) indicates, but almost tasteless. $A n$ important honey plant.

Common and widely distributed in thickets and as an understory tree in moist coastal and lower mountain forests in Puerto Rico. Also in Vieques, St. Thomas, St. John, Tortola, and Virgin Gorda. (Reported long ago from St. Croix also.)

Public forests.-Cambalache, Guajataca, Luquillo, Maricao, Río Abajo, Susúa, Toro Negro.

Ravge--Hispaniola, Pnerto Rico and Virgin Islands, throughont Lesser Antilles, Triniclad and Tobago, and Margarita. Also in Costa Rica and northern South America from Colombia and Venezuela to Brazil and Peru.

OTHER COMMON NAMES.- palo blanco, cerezo, gia mausa, cotorrelillo (Puerto Rico); wild-cherry (Virgin Islands); machacomo, tapaculo (Venezuela) ; fortuga caspi, limoncaspi (Peru) ; jumbieapple (Grenadines); wild-cherry (Barbados); pipewood, biscuitwood (Trinidad); bois jaune (Guadeloupe). 


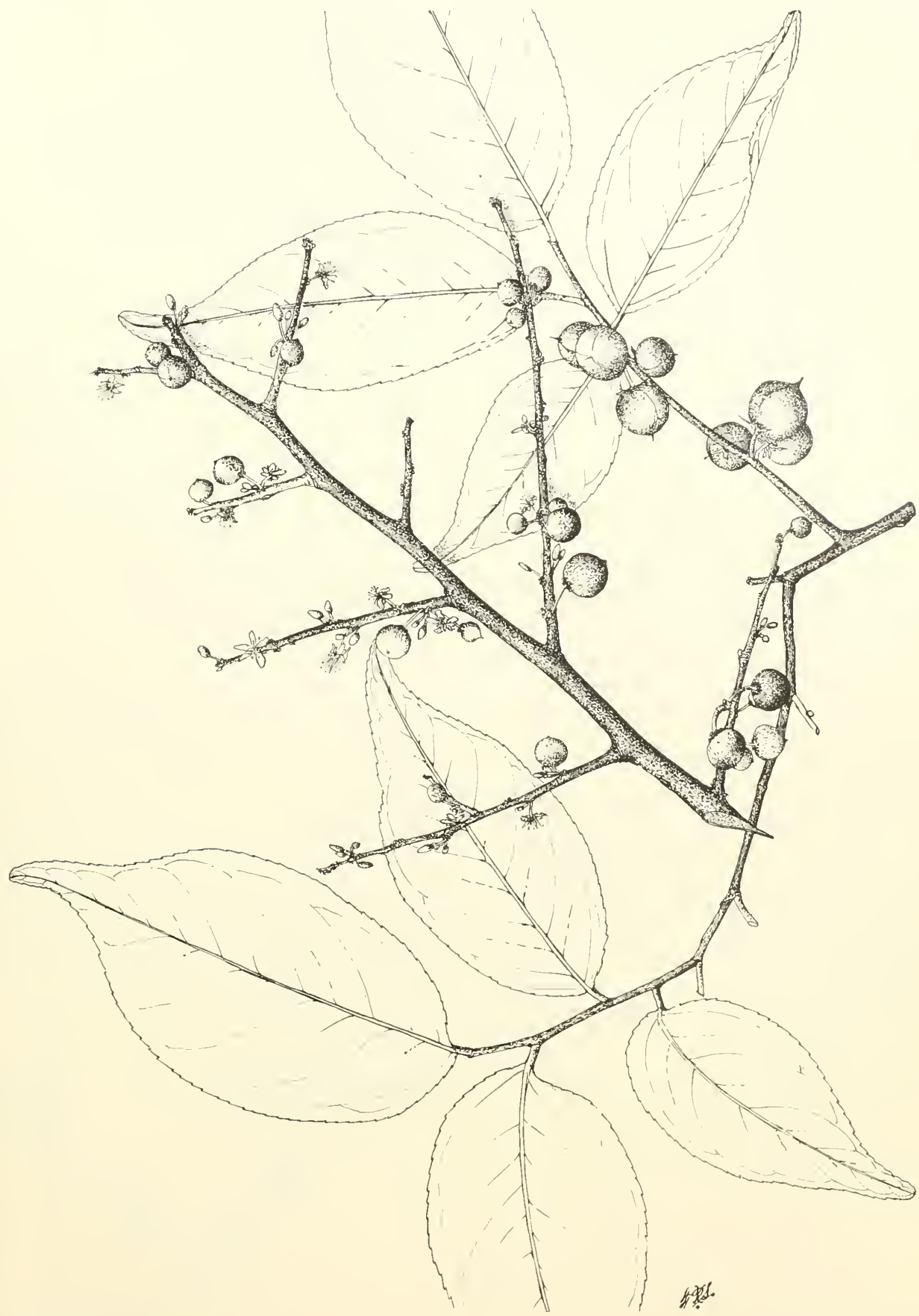




\section{FLACOURTIA FAMILY (FLACOURTIACEAE)}

\section{Palo blanco, wild-coffee}

This small tree is characterized by: (1) thin elliptic or obovate, light green leaves, abruptly short-pointed or rounded at apex, with toothed edges and sunken curved lateral veins, arranged in 2 rows on the twigs: (2) whitish or yellowish spreading flowers $5 / 16$ inch across, several in clusters at leaf bases; and (3) the elliptic fruits nearly $1 / 2$ inch long, splitting into 3 parts.

Evergreen shrub or small tree 15 feet high (reported to 30 feet) and 2 inches or more in trunk diameter, with spreading crown. The smooth thin bark is light gray or whitish, the inner bark light brown and slightly bitter. The twigs are green and finely hairy when young, becoming gray.

The alternate leaves are borne in 2 rows on short green petioles $1 / 4$ inch long. Leaf blades are $21 / 2-$ $51 / 2$ inches long and 11/4-21/2 inches broad, often widest beyond middle, short- or long-pointed at base, hairless except on veins, the lower surface pale green and with raised veins. Numerous mimute gland dots and a few lines can be seen when a leaf is viewed with a hand lens against the light.

Lateral flower clusters (umbels) are composed of several flowers on slender hairy stalks $1 / 8^{-1 / 4}$ inch long, which are jointed below middle. The whitish or yellowish calyx $3 / 16$ inch long consists of 5 widely spreading, finely hairy lobes; there are usually 8 stamens inserted near base of calyx and alternating with smaller hairy sterile stamens
Casearia guianensis (Aubl.) Urban

(staminodes); and pistil composed of 1-celled ovary, style, and rounded stigma.

The elliptic seed capsules, commonly borne singly, are $3 / 8$ inch or more in length, greenish, slightly fleshy. Flowering and fruiting probably through the year.

The sapwood is light brown, hard, and heavy (specific gravity 0.7). Used only for fuel.

Scattered in moist coastal and lower mountain regions in Puerto Rico. Also Vieques, St. Croix, St. Thomas, and St. John.

Punlic forests. - Cambalache, Luquillo, Río Abajo.

Range.-Cuba, Jamaica, Hispaniola, Puerto Rico and Virgin Islands, Lesser Antilles from Antigua to Grenada, Trinidad and Tobago, and Margarita. Also in southem Mexico, Central America, and northern South America in Venezuela and Guianas.

Otimer common names.-cafeíllo, cafetillo (Puerto Rico) ; cafe cimarrón, café de gallina, palo blanco (Dominican Republic); jía amarilla (Cuba); limoncillo (El Salvador); palo de la cruz (Panama); palo blanco (Colombia); punta de ral, palo amarillo, huesito, limoncillo (Venezuela) ; pipewood (Trinidad); kibihidan (British Guiana).

BotaNiCal SYNONYM.-Casearia ramiflora Vahl. 


\section{FLACOURTIA FAMILY (FLACOURTIACEAE)}

\section{Cafeíllo}

This rather common and widely distributed shrub or small tree is recognized by: (1) the shiny green lance-shaped to elliptic leaves longer than $21 / 2$ inches, mostly long-pointed, thicker than those of related species, edges wavy and inconspicuously toothed but appearing as if without teeth, hairless, in 2 rows in a flattened arrangement on long, unbranched twigs; (2) many minute greenish or yellowish-white flowers abont $1 / 8$ inch across, crowded on short stalks at leaf bases: and (3) rounded, red, fleshy seed capsules $1 / 8$ inch or more in diameter, containing usually 3 brown seeds.

Evergreen shrub or small tree 10-15 feet high and to $t$ inches in trunk dianeter, also recorded as up to 65 feet in height, with rounded spreading crown, sometimes several trunks, hairless throughout. The thin gray bark is smoothish with warty dots (lenticels). Inner bark is whitish and tasteless or slightly bitter. The long, slender, nnbranched twigs commonly are horizontal or slightly drooping, green and a fterwards becoming gray.

Leaves are alternate on short green petioles $1 / 4$ inch long. The blacles vary in size as well as shape, $21 / 2-7$ inches long and 1-3 inches broad, mostly with a long narrow point at apex and shortpointed at base, the upper surface with sunken veins, and the lower surface light green. When examined with a hand lens against the light, the leaves show numerous mimute lighter gland dots and lines within the network of reins.

Flower cluster's (umbels) are lateral, about $1 / 2$ inch across, with numerous small greenish or yellowish-white flowers about $1 / 8$ inch across on slender stalks of the same color, $1 / 8$ inch long and jointed near middle. Each flower consists of usually 5 spreading calyx lobes more than $1 / 16$ inch long; about 10 stamens inserted near base of calyx and alternating with sterile stamens (staminodes);
Casearia sylvestris Sw.

and pistil composed of green ovary with short style and 3 -lobed stigma. The rounded, red, Heshy seed capsules split into 3 parts and have usu,lly 3 brown seeds $1 / 16$ inch long. Flowering and fruiting throughout the year.

Sapwood is light brown, heartwood dark brown. The wood is hard, heary, strong, and fine-textured. Classed as fuelwood. Suitable for small handles and elsewhere used in carpentry and for poles.

A honey plant, the fragrant flowers attracting bees.

Very common, especially in open areas, roadsides, and also in forest understory, in moist coastal and lower mountain regions in Puerto Rico. Also in Vieques, St. Croix, St. Thomas, St. John, and Tortola.

Pcblid Forests.-Cambalache, Carite, Guajataca, Luquillo, Río Abajo, Susúa, Toro Negro. Range.-Cuba, Jamaica, Hispaniola, Puerto Rico and Virgin Islands, thronghout Lesser Antilles, and Trinidad and Tobago. Also from sonthem Mexico to Peru, Argentina, Uruguay, and Brazil. Botanical varieties have been distinguished in different areas.

Other common Names.-café silvestre, cafeíllo cimarı́n, palo blanco (Puerto Rico); sarnilla, jía colorada, juba rompehneso (Cuba): guayabillo, palo de cotona (Mexico); corallilo, sacmuda (Guatemala); barredera (El Salvador); sombra cle armado, sombra de conejo (Honduras) ; comida de culebra (Nicaragua) : corta lingua (Panama) ; dondequiera, mahajo (Colombia); tortolito, guayabito, punteral, tacasito, pabito (Venezuela); aratí-timbatí, palo rajaclor, guazat umba, cambagni (Argentina): wild-coffee (Trinidad); wild-sage (British Honduras) ; papelite (Haiti) ; crack-open (Saba); guassatunga (Brazil).

Botanical syionym. - Casearia parviflora auth., not (L.) Willd. 


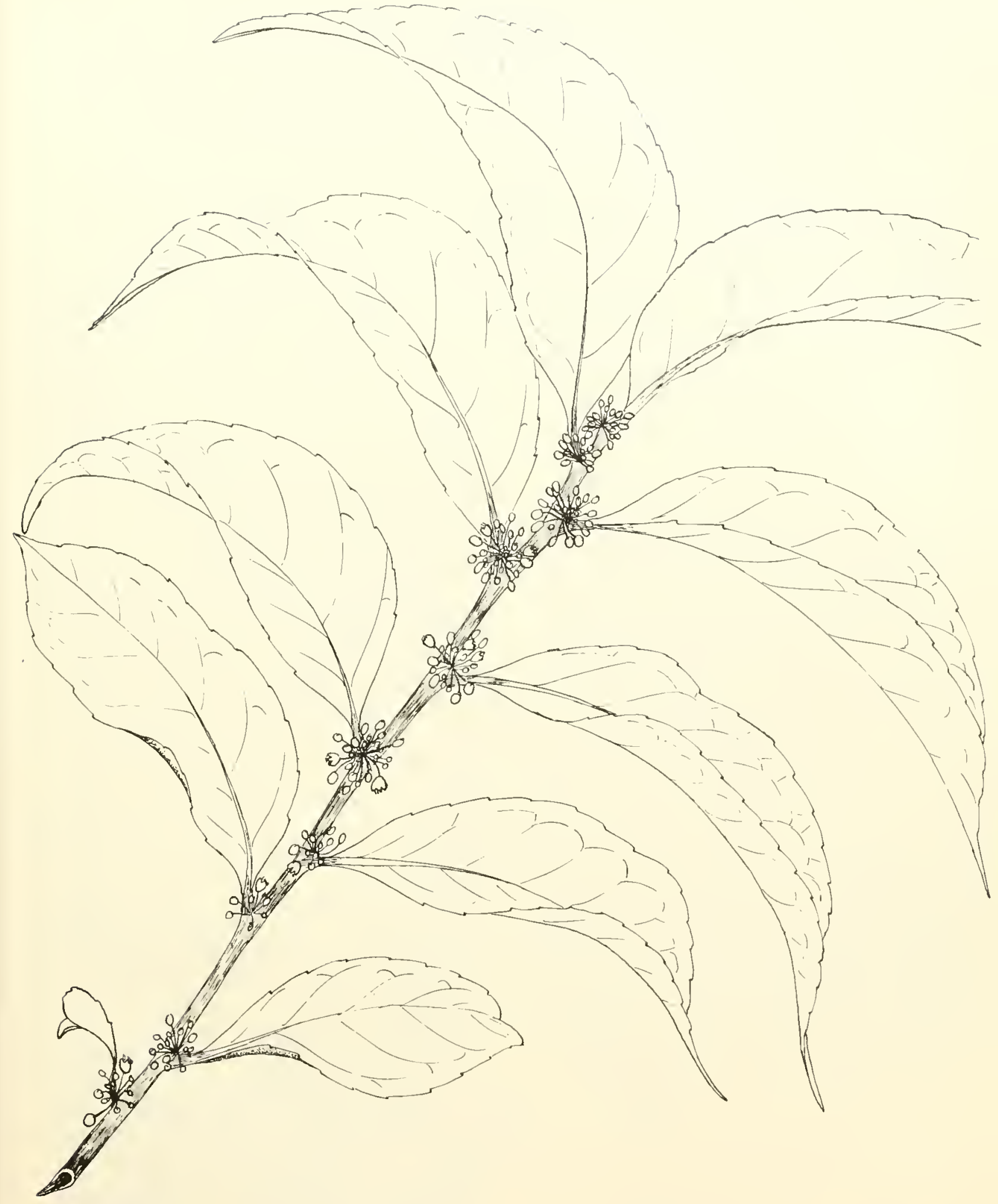




\section{FLACOURTIA FAMILY (FLACOURTIACEAE)}

\section{Caracolillo}

A large tree characterized by: (1) elliptic leaves with wavy-toothed edges, abruptly short-pointed at apex and rounded or short-pointed at base, spreading in 2 rows; (2) the lateral flower clusters 2-6 inches long bearing few to many grayish or pale green, finely hairy, widely spreading flowers $3 / 8^{-1 / 2}$ inch across the 6 or 7 spreading petals; and (3) brown seed capsules resembling dried flowers with dead brown sepals attached. Large trees stand out because of their pale or light green foliage and their white bark.

An evergreen tree to 70 feet or more in height and 2 feet in trunk diameter, with narrow or spreading crown. The light gray to white bark is thin and smooth, becoming slightly fissured and scaly. Inner bark is light brown and bitter. The slender twigs are brown, green when young, hair. less or nearly so.

The alternate leares have short petioles $1 / 8^{-3 / 8}$ inch long. Leaf blades are variable in shape and size, $2-5$ inches long and $11 / 4-21 / 2$ inches broad. thin or slightly thickened, hairless or often with minute tufts in vein angles beneath, shiny green above and beneath dull green and slightly paler.

The usually narrow flower clusters (racemes or panicles) are borne singly at leaf bases and vary greatly in length and in number of flowers. The slender, finely hairy axis has flowers on short stalks about. $1 / 16$ inch long or sometimes 3 on a branch less than 1/4 inch long. The calyx borne on the tubular base (hypanthimm) has 6 or 7 widely spreading, pointed, hairy sepals $1 / 8-3 / 16$ inch long; there are as many spreading petals $3 / 16$ inch long, pointed, and hairy; numerous stamens in groups of mostly $4-6$ opposite the petals and alternate with glands; and the pistil with hairy, half inferior ovary conical at both ends and with 3 styles $1 / 8$ inch long separate to base or partly united.

The seed capsule and spreading sepals fall to-
Homalium racemosum Jacq.

gether. There is usually 1 rounded brown seed more than $1 / 16$ inch long. Flowering and fruiting from spring to fall (April to September).

The attractive golden yellow sapwood merges gradually int o the grayish-brown to reddish-brown heartwood, frequently with irregular darker streaks and patches. The wood is very hard, very heavy (specific gravity 0.77), moderately strong, fine-textured, and with interlocked grain. It is resistant to attack by dry-wood termites. Rate of air-seasoning and amomt of degrade are moderate. Machining characteristics are as follows: planing, shaping, turning, mortising, and sanding are good; boring is excellent; and resistance to screw splitting is very poor.

The wood is used for general construction, although its hardness is a disadvantage. It is suitable for tool handles, sporting and athletic goods, agricultural implements, boat parts, and heavy construction.

Widely distributed in Puerto Rico in forests, thickets, and along streams, in the upper and lower mountain, the limestone, and coastal regions.

Public forests.-Cambalache, Carite, Guajataca, Guánica, Guilarte, Luquillo, Río Abajo, Susúa, Toro Negro.

MuNicipalities WiHere especially COMMION.24,60 .

Raxge.-Greater Antilles and Lesser Antilles from St. Kitts to Guadeloupe and Martinique. Also from Mexico to Venezuela, Surinam, and northern Brazil.

OTHER COMMON NAMEs.-tostado, guajanilla, cereza (Puerto Rico) ; corazón de paloma (Dominican Republic); caramacate, marfil, granadillo de clavo, verdecito (Venezuela); bois de hêtre, acoma blanc, acoma hêtre, acoma franc (Guadeloupe); acomat (Martinique); bietahoedoe (Surinam).

Bota NiCAL SYNONYMS.-Homalium pleiandmum Blake, H. hemistylum Blake, $H$. leiogynum Blake. 


\section{PAPAYA FAMILY (CARICACEAE*)}

Papaya, a familiar small tree with distinctive pungent odor, is widely gromn for its delicious edible fruits and also is naturalized. It is easily recognized by: (1) usually unbranched, soft, succulent trumk with thin milky sap, bearing a cluster of altemate spreading leaves at apex; (2) large long-petioled leaves with palmately 7 - ol 9-lobed blades, deeply cut into smaller long- or shortpointed lobes; (3) male and female flowers whitish or pale yellow, on different plants (dioecious), the narrow tubular male flower's 1-1 1/2 inches long and numerous in branched clusters, and the larger female flowers about 2 inches long, with 5 spreading petals and borne nearly stalkless, single or a few together at base of a leaf; and (4) fruit clustered around the trunk, usually $6-15$ inches long, oblong, obovoid, or rounded, and short-pointerl.

A rapidly growing short-lived evergreen shrub or tree to 20 feet tall, with trunk usually less than 8 inches in diameter (rarely to 24 feet high and 16 inches in diameter) and with a narrow crown. The bark is greenish or grayish brown to light gray, smooth, with prominent broad to nearly horizontal leaf scars. The greenish or yellowish inner bark has a spicy or slightly bitter taste. Because of the soft almost herbaceous stem and short life of a few years, this species is also regarded as a giant perennial herb lather than a tree.

Upper leaves are erect spreading and lower leaves drooping. The stout green petioles are 16-24 inches or more in length, round and hollow. Leaf blades are rounded in outline, 8-24 inches in diameter, slightly thickened and fleshy, dull light green above and beneath pale whitish green and covered with a bloom.

The slender lateral cluster (panicle) of many fragrant male flowers is 6-24 inches long or longer. A male flower has short 5-toothed calyx about $1 / 16$ inch long; whitish corolla of narrow funnelshaped tube about $3 / 4-11 / 4$ inches long and 5 widely spreading narrow oblong lobes more than $1 / 3$ inch long and extending, 1 inch or more across; 10 yellowish stamens inserted in throat of corolla tube, 5 stalkless and 5 short-stalked; and rudimentary narrow pistil about $3 / 8$ inch long. The shortstalked female flowers have 5-toothed green calyx $3 / 16^{-3 / 8}$ inch long, 5 twisted narrom lance-shaped fleshy pale yellow petals about 2 inches long, soon falling; and pale yellow pistil $3 / 4-11 / 4$ inches long with large elliptic or round ovary, 1 -celled with 5 ridges covered with ovules, and 5 spreading stalkless much-lobed stigmas. Rarely perfect flowers with both stamens and a pistil are produced (polygamous).

Several to many short-stalked fruits (berries) hang down from the trunk of a female tree near its summit, turning from green to orange at maturity. The soft orange flesh 1-2 inches thick with milky juice surrounds a large central cavity containing many rounded blackish seeds about $3 / 16$ inch in diameter, which are enclosed in a gelatinous membrane (aril). There are about 8,000 seeds to a pound. In flower and fruit probably through the year.

The whitish or pale yellow wood is very soft, very lightweight, and fleshy. There is a large white pith, and the center of the trunk is hollow except at nodes. The wood is not used.

Papaya is one of the most popular tropical fruits. Races difler in size and shape of fruit. Like large melons, giant papayas may reach 18 inches in length and weigh as much as 20 pounds, while the fruits of wild plants often are small, sometimes only 3 inches long, and bitter flavored. 'This esteemed melonlike fruit is served at the breakfast table or as a dessert, often flavored with juice of limes, but it is also made into preserves and sherbets. The juice is also extracted and canned. Green papayas can be cooked as a regetable like squash.

The milky latex or juice of the fruit, leaves, and other parts of the plant contains the enzyme papain (papaína) which, like pepsin, digests proteins and curdles milk. Thus, papayas when eaten aid in digestion of other foods. Tough meat is made tender by wrapping it in papaya leaves for a few hours, by washing in water containing the juice, or by rubbing the juice on. Or the leaves can be boiled with the meat, but if the time is too long or the juice too concentrated, the meat may fall apart in shreds. Though the tenderizing property of papaya leaves lias long been common knowledge of tropical residents and known also to botanists, only in recent years have meat tenderizers prepared from this plant become available commercially.

Other applications of this enzyme are medicinally to aid digestion in cases of dyspepsia and for clarifying beer. In some areas the seeds, juice, flowers, and leaves have served in home remedies. Also the leaves have been stewed as greens. The male flowers may be a source of honey. It is reported that the leaves have been employed in place of soap for washing delicate fabrics. Children make flutes from the hollow petioles.

Many races vary in size and quality of fruit. The plants are also attractive ornamentals. Through the tropics they grow almost as weeds, bearing fruit the first year from seed and spreading along roadsides and in waste places. Plants are being heavily affected by diseases, especially viruses.

Widely cultivated, escaping, and naturalized in Puerto Rico. Also on Mona, Vieques, St. Croix, St. Thomas, St. John, and Tortola.

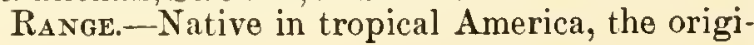




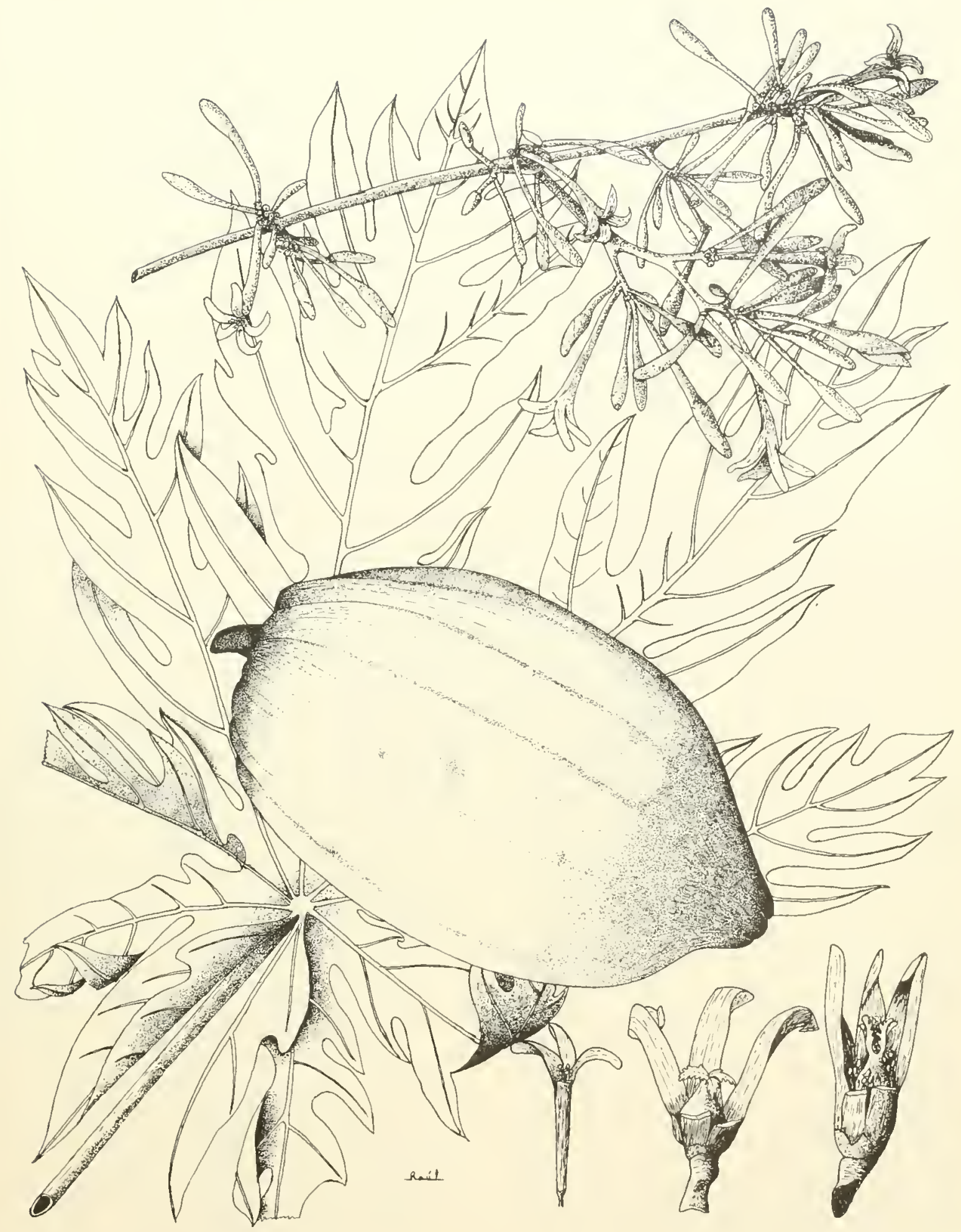

174. Iechosa, papaya 
nal home unknown. Widely cultivated and naturalized in southern Florida, Bermuda, throughout. West Indies, from Mexico to Argentina and Brazil, and in the Old World tropics.

OTHer Common names.-papay, pawpaw (Virgin Islands); papaya (Spanish); fruta bomba
(Cuba) ; melón zapote (Merico) ; papayo calentano (Colombia); lechosa, papaya (Venezuela); papayo, mamón (Argentina); papaya, pawpaw, papaw (United States, English); papaye, papayer (French); papaya, papao, papay (Dutch West Indies); mamão, mamoeiro (Brazil).

\title{
CACTUS FAMILY (CACTACEAE)
}

\author{
Key to the 2 species illustrated (Nos. 175-176)
}

A. Branches columnar, with 7-11 ridges and groores; fruits round, spineless-175. Cephaloccreus royenii. AA. Branches flat, oblong joints or pads; fruits pear-shaped, mostly spiny-176. Opuntia rubescens.

\section{Sebucán, dildo}

This tree cactus of dry areas is easily recognized by : (1) stout erect gray-green columnar branches $21 / 2-4$ inches in diameter with $7-11$ ribs, or ridges, and grooves between the branches and trunk, not woody but soft and succulent; (2) absence of leaves, but with many clusters of several spreading needlelike yellow to gray spines $3 / 8-21 / 4$ inches in length along the ribs; (3) greenish, whitish or purplish-tinged, flowers 2 inches or more in length, tubular and fleshy with many sepals and petals, borne singly and stalkless along ribs near apex; and (4) rounded but much flattened edible red berry up to 1 inch high and 2 inches in diameter, the surface smooth and spineless.

A branched cactus 6-20 feet tall with trunk 4-12 inches in diameter, commonly dividing at 1-2 feet above the base into several branches. As twigs and leaves are absent, there is no definite crown as in other trees. The trunk is reddish brown, smoothish except for rows of spines radiating in clusters and with very thin bark. The surface of the smooth grooves in the branches is covered with a bloom at least when young.

The spines are in clusters, several radiating ont from the central point of attachment (areole), which also bears inconspicuons whitish hairs. Near the rounded apex of branches the ribs bear tufts of longer white hairs about 11/4 inches in length, which are woolly and somewhat shaggy.

The tubular fleshy flowers extend straight and nearly horizontal, opening at night. The flower has an inferior, smoothish, spineless rounded ovary about 1/2 inch long, 1 -celled; a funnelform greenish fleshy tube (hypanthium) with many overlapping oblong, rounded or pointed, whitish or purplish-tinged, fleshy sepals about $3 / 8$ inch long and with about 10 whitish narrow pointed petals $3 / 8^{-1 / 2}$ inch long within; very many white stamens $1 / 4-1 / 2$ inch long attached at the throat and base of the tube; and protruding white fleshy style almost 2 inches long with many narrow stigma lobes.

\section{Cephalocereus royenii (L.) Britton \& Rose}

The ovary develops into the fruit, while the remaining flower parts shrivel and dry, remaining attached. The flattened berry contains red juicy flesh slightly sweet and edible and many small shiny black seeds less than $1 / 16$ inch long. Probably flowering irregularly through the year.

The trunk is composed mostly of soft waterstoring tissues, light green near the surface and yellowish within, juicy and slightly salty in taste. 'The soft wood is a light brown fibrous cylinder with large white rays.

The tree cactus is remarkably well adapted to very dry conditions. The root system is broad and near the surface where water from light rains can be absorbed rapidly. The bulk of the plant is made up of water storage tissue, which retains water absorbed after rains for use over long clry periods. The surface area is greatly reduced through absence of leaves, and loss of water to the air (transpiration) is correspondingly checked. The branches have a very thick skin which also retards evaporation and, being green, at the same time carry on the processes of food manufacture (photosynthesis), normally functions of the green leares. Further, the formidable spines protect the juicy stems from animal life.

Scattered im dry forest on plains and hills at lower elevations in southern and southwestern Puerto Rico and rare at Cape San Juan in the dry extreme northeastern corner. Also on Mona, Desecheo, Icacos, Culebra, and Vieques. Through Virgin Islands on St. Croix, St. Thomas, St. John, Tortola, Virgin Gorda, Anegada, and probably smaller islands.

Public Forest.-Guánica.

Range.-Mona, Puerto Rico and smaller adjacent islands, Virgin Islands, and St. Kitts and Antigua in northern Lesser Antilles.

OTHER COMMON NAMES.-pipe-organ cactus, cactus (Virgin Islands) .

Botanidal sYNONYMS.-Cereus royenii Mill., Pilocereus royenii (L.) Rümpl. 


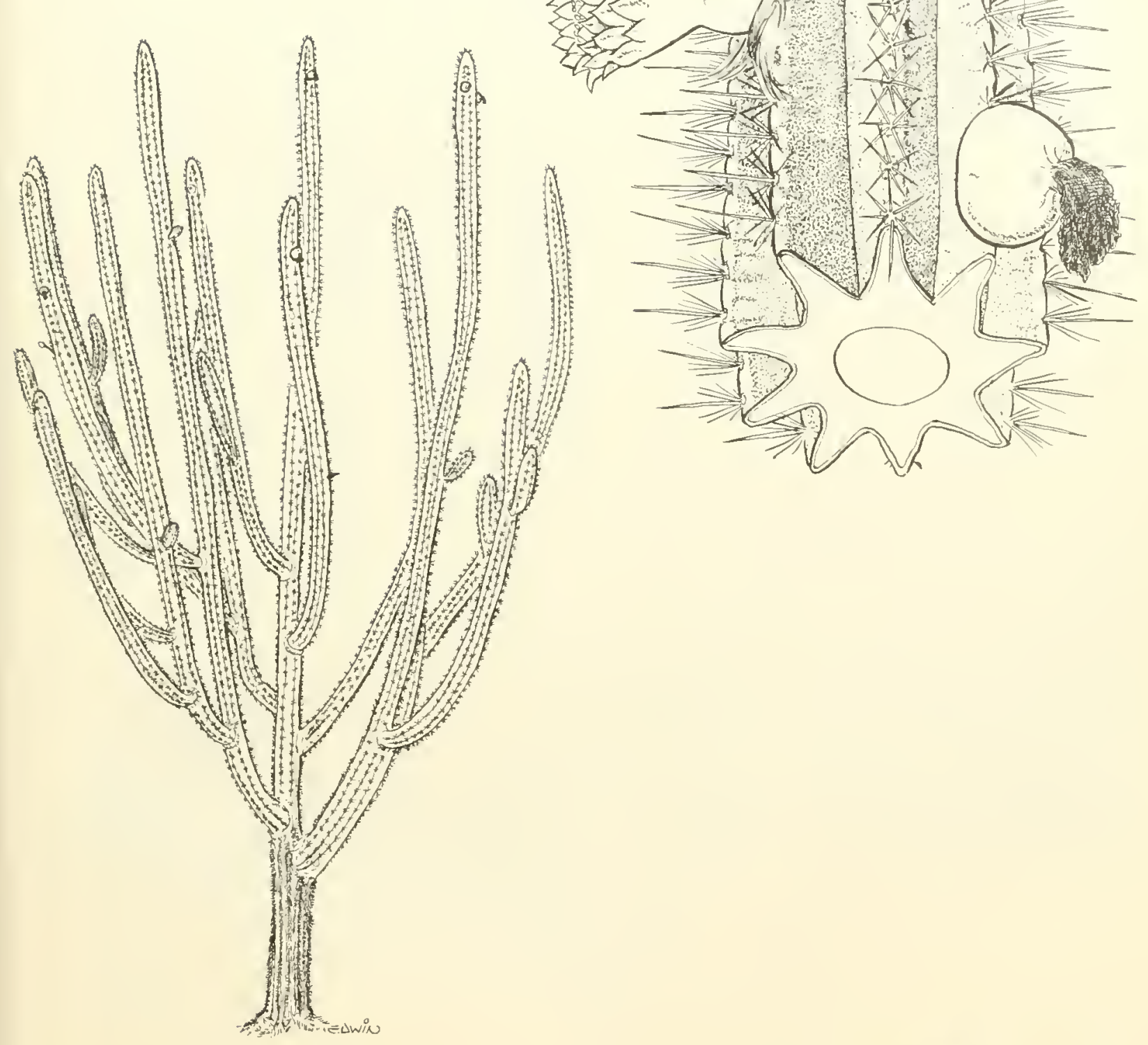
End of branch with flower and fruit (upper right), two-thirds natural size. 


\section{CACTUS FAMILY (CACTACEAE)}

\section{Tuna de petate, pricklypear}

Distinguishing characters of this large treelike cactus are: (1) numerous spines, 1-6 together spreading in a cluster with a tuft of needlelike hirirs at base, or spines sometimes absent; (2) erect rounded fleshy spiny trunk with bark papery or scaly, bearing as branches flat, oblong to obovate, dull gray-green to dark green or reddish-green joints or pads, 6-16 inches long, spiny and fleshy; (3) essentially leafless, the leaves being minute green fleshy scales located singly at base of clusters of spines; (4) orange, red, or yellow flowers $3 / 4$ inch across the many petals, borme on an oblong tubercled spiny green ovary $11 \%-2$ inches long; and (5) red fleshy froit a pearshaped or rounded berry 2-3 inches long, spiny or spineless. A spineless form of this species occurs in Puerto Rico.

A cactus 10-15 feet tall, with trunk 16 inches in diameter, not jointed, erect and umbranched for a few feet. The reddish-brown trunk becomes furrowed and flaky, retaining many gray spines 1-2 inches long in radiating cluster's. There are several stont spiny branches ascending and ending in several spreading to horizontal flat spiny joints. They continue or branch, 1-3 at the end of an older joint. A definite crown of foliage is not present.

The leaves are borne at a cushion (areole) of many small, needlelike, fine, stiff, brown hairs and cluster of spines which corresponds to a node. Thongh the leares fall, the fleshy joints are evergreen and function yearlong like leaves in food manufacture. There are 1-6 needlelike whitish spines 1/4-2 inches long, spreading from a center.

Flowers are borne singly and stalkless on the terminal joints, 1-3 on the edges of a joint, located at the cushions of needle hairs. The largest part of the flower is the inferior tubercled and usually spiny green ovary $1 \frac{1}{2}-2$ inches long and $11 / 4$ inches in diameter. The calyx is composed of many fleshy sepals. The petals are obovate, minutely pointed, and spreading. There are very many stamens about half as long as the petals and a central style bearing the stigma with several rays.

\section{Opuntia rubescens Salm-Dyck}

The fruit is the enlarged ovary, usually spiny. There are many seeds less than $1 / 4$ inch in diameter. Flowering and fruiting nearly through the year:

Beneath the bark is light yellow, soft watery tissue, almost tasteless, and inside is the light yellow, fibrous wood.

As in certain other species of cacti, some fruits proliferate, that is, grow to form new flowers at the ends. Upon falling to the ground, these easily detached ovaries develop roots and grow into new plants around the parent, directly and regetatively, rather than through seeds. Likewise, a joint on the soil can begin a new plant. Vegetative propagation in this manner is more direct and more certain in dry areas than seed germination and establishment of small seedlings.

Like the columnar tree cactus, tuma de petate or pricklypear is adapted to a hot and very dry climate. It has a shallow root system, water storage tissue in the fleshy joints, reduced surface area, and reduced water loss (transpiration).

This species is often an undesirable plant where common. The spineless form has been introduced into cultivation in gardens in Puerto Pico.

Scattered in dry forest on plains and hills at low elevation in southern and southwestern Puerto Rico and rare at Cape San Juan in the extreme northeastern comer. Also on Mona(?), Icacos, Culebra, and Vieques. Through Virgin Islands on St. Croix, St. Thomas, St. John, Tortola, and probably smaller islands.

Public rorest.-Guánica.

Range.--Mona (?), Puerto Rico and smaller adjacent islands, through Virgin Islands, and St. Martin to Guadeloupe in Lesser Antilles.

Otiner comsion Names.-tuna de yagua, tuma (Puerto Rico); tree cactus (Virgin Islands); petites raquettes (Guadeloupe).

BotaniCaL S Y N N Y M.-Consolea mubescens (Salm-Dyck) Lemaire.

This genus of pricklypears is represented by 6 other native species not reaching tree size and by a few others introduced for ornament. 


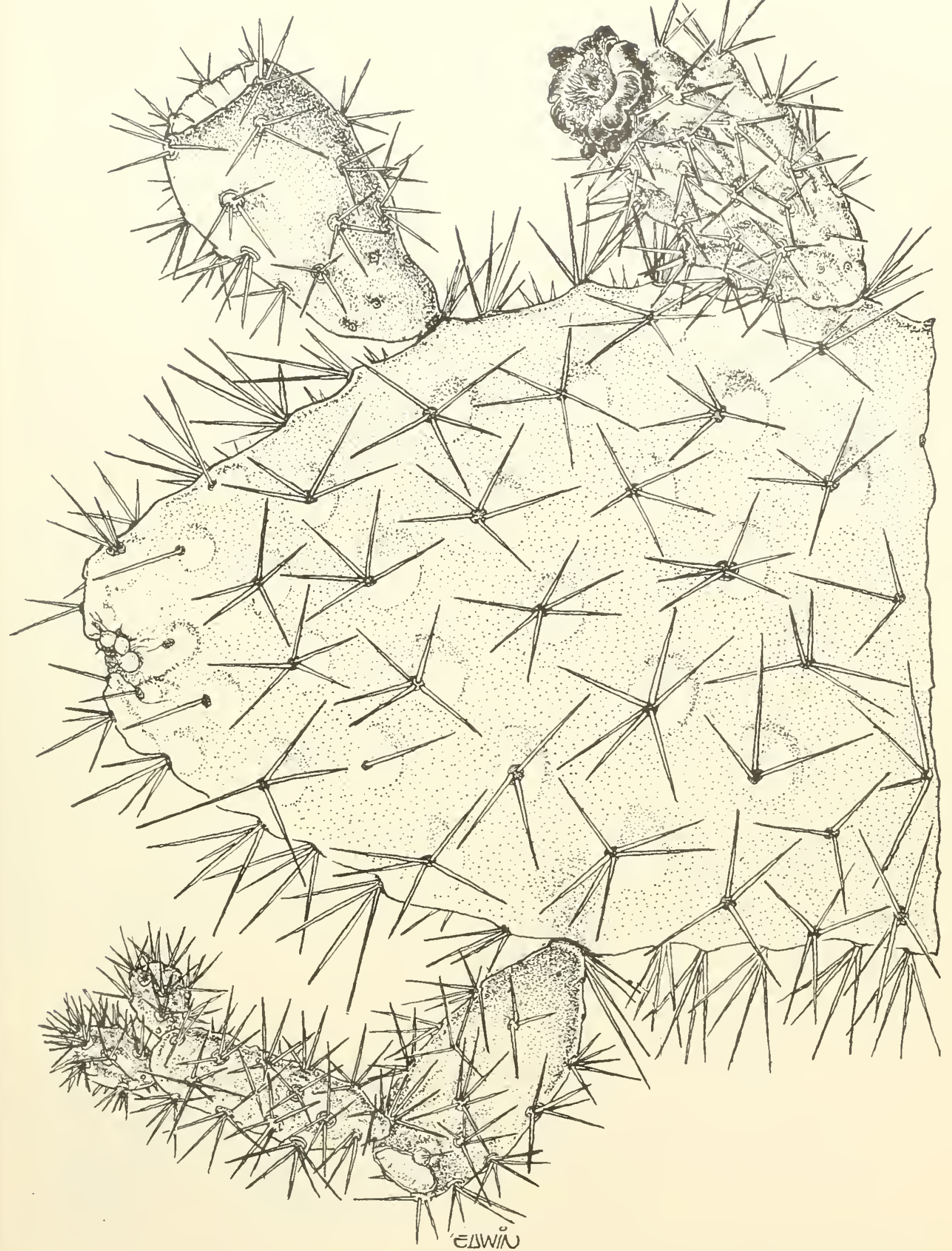




\section{MEZEREON FAMILY (THYMELAEACEAE)}

\section{Majagua brava}

This small Puerto Rican tree with tough, fibrous bark is characterized by: (1) twigs forking into 2 or sometimes 3 equal forks, reddish brown when young and tuning brown; (2) elliptic to oborate, leathery and slightly fleshy leaves short- or longpointed at both ends, clustered together at ends of twigs and at nodes; (3) small fragrant white flowers, several at nodes in stalkless clusters (heads) with hairy scales; and (4) elliptic white fleshy fruits $3 / 8^{-1 / 2}$ inch long, 1 -seeded.

An evergreen tree or shiub 10-20 feet high and 2-4 inches in trunk diameter. 'The bark is gray, smooth or slightly fissured, and thin. Inner bark is whitish, almost tasteless.

The leares appear as if opposite or in clusters of 3 or 4 (whorled). They have petioles $1 / 8-3 / 8$ inch long and blades $21 / 4-4$ inches long and 1-21/4 inches broad, commonly widest beyond middle, edges not toothed, slightly shiny on upper" surface, and pale green beneath.

Flower's are male and female on different plants (dioecious). Male flowers have a white hairy calyx with narrow tube more than $1 / 4$ inch long with 4 lobes less than $1 / 8$ inch long, 8 stamens in 2 sets of 4 each near mouth of tube, and rudimentary pistil. Female flowers are smaller, with a calyx about half as long as in male flowers, with tube and 4 lobes, and pistil with ovary and short style.

\section{Daphnopsis philippiana Krug \& Urban}

The fleshy fruits are borne sereral together or only 1 at a node on very short stalks, green when immature but becoming white. 'The single brown seed is about $1 / 4$ inch long. Flowering and fruiting nearly through the year.

The wood is whitish or yellowish, soft, and little used because of the small size of the tree. The bark has in the past been used for rope.

Known only from the upper Luquillo and Cordillera forests of Puerto Rico.

Public forests.-Carite, Linquillo, Toro Negro.

RaNGE.--Restricted to mountains of Puerto Rico.

Other Common NAMEs.-emajagua de sierra, majagua quemadora, emajagua brava (Puerto Rico).

This genus and family are represented by 2 other tree species. Majagua de sierra or mahout (Daphnopsis americana (Mill.) J. R. Johnston; synonyms D. americana subsp. caribaea. (Griseb.) Ner1., D. caribaea Griseb.), of forests in Puerto Rico, Vieques, and the Virgin Islands and beyond, has slightly smaller flowers in small branched clusters at ends of twigs, and fruits only $1 / 4$ inch long. The other ( $D$. helleriana Urban), known only from 1 collection near Bayamón, has oblong leaves rounded at apex and hairy beneath. 


\section{LOOSESTRIFE FAMILY (LYTHRACEAE)}

\section{Reina de las flores, queen-of-flowers}

Planted for its numerous showy purple flowers, this exotic tree is identified by: (1) the large, loosely branched, terminal clusters 6-18 inches long bearing many beautiful lavender or purple (or on some trees pink) flowers $2-21 / 2$ inches across, with 6 rounded, crinkled and wavy-margined, spreading petals; (2) the aray-brown rounded seed capsules 3/4-11/4 inches in diameter, splitting into 6 parts and shedding many brown winged seeds $1 / 2-3 / 4$ inch long; and (3) the large elliptic leaves abruptly short-pointed at apex and shortpointed at base, opposite or alternate, a ppearing to be in 2 rows on the long, spreading twigs.

A small cultivated tree 15-30 feet high, with trunk to 8 inches in diameter, or larger, and with rounded or widely spreading dense crown. Deciduous only in dry climates. The bark is gray or light brown, smoothish to slightly fissured and scaly. Inner bark is light brown and bitter to the taste.

Leaves appear in 2 rows on the light green twigs as a result of bending of the short petioles $1 / 8-3 / 8$ inch long. Leaf blades are 5-12 inches long and $21 / 2-5$ inches broad, not toothed on edges, slightly thickened, green on upper surface and paler beneath.

Flower clusters (panicles) have stout, finely hairy branches, with individual flower stalks $1 / 4-1 / 2$ inch long. The very showy flowers have a light wreen, cup-shaped, 12-ridged base (hypanthium) $3 / 8$ inch high and nearly $1 / 2$ inch broad, minutely hairy, bearing 6 light green, pointed, thickened, finely hairy sepals $5 / 16$ inch long and widely spreading, 6 stalked nearly round petals $11 / 4$ inches long, and numerous purplish stamens about $3 / 4$ inch long. The pistil consists of a 6 -celled ovary ${ }^{3} 16$ inch in diameter, a slender purplish style about 1 inch long, becoming curved, and small rounded green stigma.

\section{Lagerstroemia speciosa (L.) Pers.*}

The seed capsules are nearly round or elliptic, with dried hypanthimm and sepals attached at hase. The many seeds, about 39,000 to a pound, have a long, mostly narrow wing. Flowering from May through October, the fruit maturing from winter to summer.

The light brown sapwood is hard. An important large timber tree in India, where the wood is preferred for small boats, shipbuilding, and piling. In Puerto Rico the tree is grown in the open primarily for ornament and seldom produces a straight stem.

Occasionally planted for ornament and shade, such as a street tree and in gardens, in Puerto Rico and the Virgin Islands and sometimes escaping from cultivation. Commonly purplish flowered, but a variation with pinkish flowers is also grown.

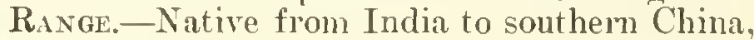
Malay Peninsula, Philippines, East Indies, and northerm Australia. Planted as an ormamental flowering tree and escaping in many tropical lands. Grown in southern Florida and West Indies from Cuba and Jamaica (naturalized) to Puerto Rico and Virgin Islands, Guadeloupe, Martinique, and Trinidad and from Mexico to South America.

OTHER COMmon Nanes. - tree crapemyrtle (Virgin Islands); astromelia, flor de la reina (Venezuela) ; queen-of-flowers, queen-flower, pride-ofIndia, queen crapemyrtle (English); king-offlowers (British Guiana) ; pyimma (commerce).

Botanical sYNonym. - Lagerstroemia flosreginae Retz.

Astromelia or common crapemyrtle (Lagerstroemia indica $\left.\mathrm{L} .{ }^{*}\right)$, a related shrub or small tree from Asia, is a popular ornamental. It has small elliptic leaves 1-2 inches long and showy masses of pink, white, or purple flowers less than $1 \frac{1}{2}$ inches across. 


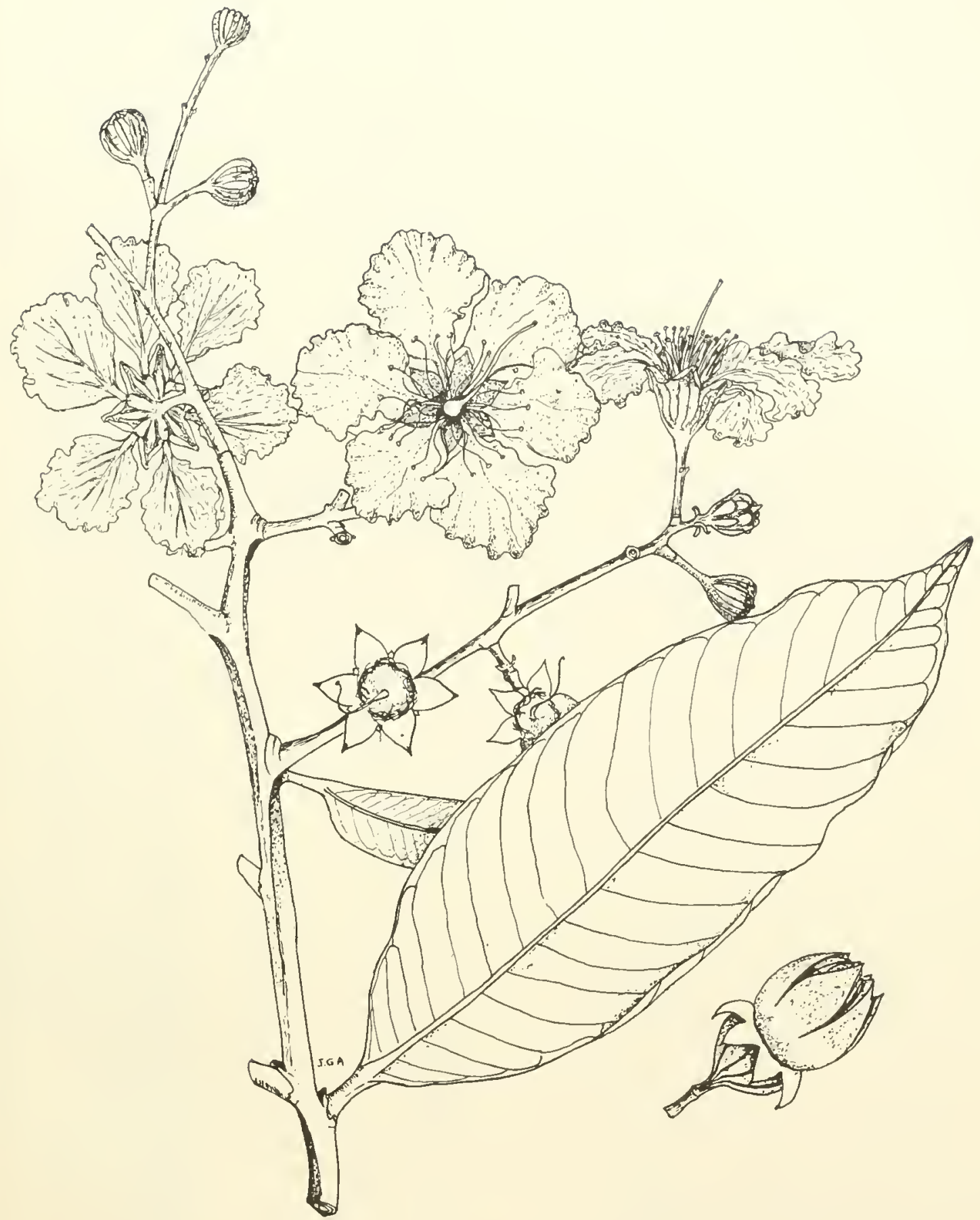




\section{MANGROVE FAMILY (RHIZOPHORACEAE)}

\section{Mangle colorado, mangrove}

This common species on protected muddy seashores is easily recognized by the mass of peculiar, branching, curved and arching stilt roots, enabling the trees to spread in shallow salt and brackish water and form dense, impenetrable thickets at tide level. Other distinguishing characteristics are: (1) the conspicuons, narrow, long, pointed, green terminal buds; (2) the opposite, elliptic, blunt-pointed, shiny green leaves, slightly leathery and fleshy, and yellow green beneath; (3) the pale yellow flower's about $3 / 4$ inch across with 4 widely spreading narow and leathery sepals, usually $2-4$ in stalked lateral chusters; and (4) the unique dark brown fruits about $1 \frac{1}{4}$ inches long and $1 / 2$ inch in diameter, remaining attached, each containing a growing seedling with long narrow podlike first root up to 1 foot long and hanging down.

Commonly a small tree 15-25 feet or more in height, evergreen, with an erect trunk 8 inches or more in diameter. Formerly probably much larger. The hark is gray or gray brown, smooth, and thin on small trunks, becoming furrowed and thick on larger ones. Inner bark is reddish or pinkish, with slightly bitter and salty taste. The stout twigs are gray or brown, bearing several crowded leaves near apex. The bud is $1-2$ inches long, covered with 2 green scales (stipules) around the pair of developing leaves and which make a ring scar on the twig upon sherding.

The slightly flattened petioles are $1 / 2-7 / 8$ inch long. Leaf blades are $21 / 2-4$ inches long and $1-$ $21 / 2$ inches broad, blunt-pointed at apex and shortpointed at base, the edges slightly rolled under.

Flowers are 2-4 together on a forked green stalk altogether $11 / 2-3$ inches long, slightly fragrant. The bell-shaped pale yellow base (hypanthium) less than $1 / 4$ inch long bears 4 widely spreading narrow pale yellow sepals almost $1 / 2$ inch long, leathery and persistent; there are 4 narrow petals $3 / 8$ inch long, curved downward, whitish but turning brown, white woolly or cottony on inner side; 8 stamens; and the pistil consists of a 2 -celled ovary, mostly inferior but conical at apex, with 2 ovules in each cell, slender style, and 2 -lobed stigma.

The single seed germinates inside the conical fruit, forming a long narrow first root (radicle) green except for the brown enlarged and pointed end up to $1 / 2$ inch in diameter. When about 1 foot long, the heary seedling falls and is usually carried by water before becoming firmly rooted. Flowering and fruiting through the year.

The sapwood is light brown, the heartwood reddish brown or dark brown. The wood is hard,
Rhizophora mangle $\mathrm{L}$.

very heavy (specific gravity $0.9-1.2$ ), durable in the soil but susceptible to attack by dry-wood termites.

Ised as roundwood, for posts and poles and excellent for fuel and charcoal. Elsemhere the wood in larger sizes has been employed also for marine piling and wharves, shipbuilding, and in cabinet work. The bark is important commercially in tamning leather, and the leares are rich in tamnin also. A dye and medicines have been obtained from the bark. Fishermen in Puerto Rico preserve their lines with an extract from the l'oots.

Mangrove forests on depositing shores aid in extending the shore line, liolding the black mud in place and gradually advancing on the side toward the ocean. This species with its stilt roots growing in shallow water extends farther seawald than the 3 other species of mangroves.

Common to abundant in mangrove swamp forests over large flat areas of silty or muddy shores in salt and brackish water around Puerto Rico. Forming pure stands on the sea side of such forests and mixed with other mangrove species farther inland. Also in Mona. Vieques, St. Croix, St Thomas, St. John, Tortola, and Inegada.

Public Fonfsts.-Aguirre, Boquerón, Ceiba, Guínica, San Juan.

RAxGE.-Shores of central and southern Florida including Florida Keys, Bermuda, and throughont Trest Indies (excep ${ }^{+}$Dominica) to Trinidad and Tobago and Dutch West Indies. Also on both coasts of continental tropical America from central Mexico south to Ecuador and northwestern Perll and to Brazil. Also in Galapagos Islands, Melanesia, and Polynesia.

OTHER COMrox NAMES.-mangle, mangle zapatero. mangle de chifle (Puerto Rico); mangle (Virgin Islands); mangle, mangle colorado (Spanish): mangle gateador, mangle caballero (Costa Rica); mangle salado (Panama); mangle rojo (Venezuela); mangle injerto (Ecuador); mangrove, red mangrove (United States, English); black mangrove (British Guiana); manglier, manglier rouge (Haiti) ; palétuvier rouge (French, commerce); manglier rouge, mangle ronge, mangle noir, manglier chandelle (Guadeloupe); mangel tan (Dutch West Indies); mangro (Surinam); mangue sapateiro, mangue vermelho (Brazil).

BotaniCAL srNONYMs.-Rhizophora mangle var. samoensis Hochr., R. samoensis (Hochr.) Salroza. 


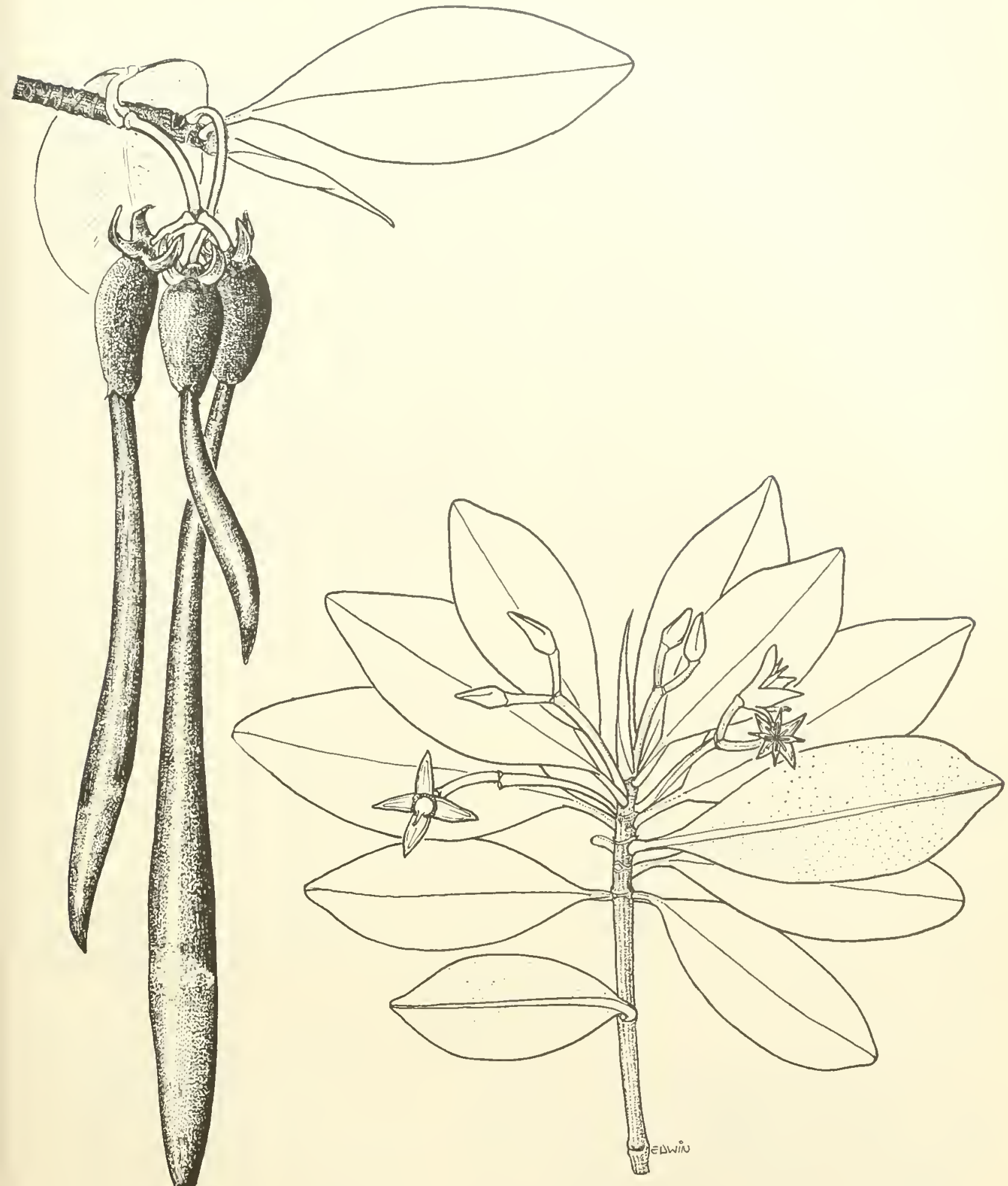

179. Mangle colorado, mangrore 


\section{COMBRETUM FAMILY (COMBRETACEAE)}

Key to the 5 species illustrated (Nos. 180-184)

A. Leaves mostly clustered at ends of twigs; petiole without glands, blade broadest beyond middle; upland trees. B. Leares less than 3 inches long, green or yellow green.

C. Twigs spineless; fruit an elliptic pointed drupe about 7/8 inch long-180. Buchenavia capitata.

CC. Twigs often with paired spines; fruits about $1 / 1$ inch long. with calsx at apex, some deformed as slender hornlike galls $2-3$ inches long-181. Bucila buceras.

BB. Leares 6-11 inches long, turning reddish before falling-1st. Terminalia catappa.*

AA. Leaves erenly spaced along twigs: petiole with 2 glands near the elliptic blade; trees of mangrore swamp forests.

D. Leares alternate, long-pointed at both ends-18:. Conocarpus erectus.

DD. Leares opposite, rounded at both ends-183. Laguncularia racemosa.

\section{Granadillo}

This large, spreading timber tree is characterized by: (1) a striking thin crown composed of a few main, widely spreading nearly horizontal branches: (2) erect clusters of small reverse lanceshaped (oblanceolate) or spoon-shaped (spatulate) yellow-green leaves crowded at ends of short erect twigs from horizontal branches: (3) many small greenish flowers about $1 / 8$ inch across at the end of a lateral stalk, altogether 1-1/2 inches long; and (3) elliptic greenish fruits $3 / 4-7 / 8$ inch long and $1 / 2$ inch in diameter, pointed at both ends and slightly 4-or 5-angled, single or paired.

A tree growing to $60-80$ feet tall and $2-4$ feet in trunk diameter, with straight trunk becoming buttressed at base. Deciduous but with the new yellowish foliage appearing soon after leaf fall in most areas. The light brown bark is smoothish, with many small fissures. The inner bark is yellowish and bitter. The brown to gray twigs, finely rusty-brown hairy when young, have slender leafless areas and shorter stout spurs bearing leaves or leaf scars close together.

The leaves are alternate, though clustered. Petjoles are $1 / 8^{-3 / 8}$ inch long. Leaf blades are $11 / 2-3$ inches long, $1 / 2-11 / 2$ inches broad, rounded at apex and long-pointed at base, broadest beyond middle. the edges flat or rolled under, becoming thickened and leathery, hairless or nearly so when mature, shiny yellow green on upper surface and paler beneath.

Flower clusters (spikes or heads) $1 / 2-3 / 4$ inch long on hairy stalks $1 / 2-1$ inch long are inconspicuons among the new leaves. The crowded, hairy flowers are both bisexual and male (polygamous). The calys is broadly cup-shaped, 5-toothed, 1/16 inch long, soon falling, and there are 10 stamens; and the pistil has an inferior hairy, 1-celled ovary.

Fruits (drupes) borne on a stalk abont 1 inch long resemble an olive, are slightly fleshy and bitter, and contain 1 large stone. Flowering mainly in winter and spring and maturing fruits throngh the vear.

The light rellow to golden-brown heartwood is not clearly separated from the pale yellow sapmood. The attractive, good quality wood is moderately hard, moderately heavy (specific gravity 0.61 , and strong. It has high luster, roey or
Buchenavia capitata (Vahl) Eichl.

straight grain, medium texture, and growth rings marked by niarrow bands of darker pores. The lumber air-seasons rapidly with only a very small amomnt of degrade. It finishes well and takes a high satiny polish. Machining characteristics are as follows: planing, shaping, turning, boring, mortising, sanding, and resistance to screw splitting are good. The heart wood, sometimes found among the timbers of old buildings, is resistant to attack by dry-mood termites and is fairly durable in the gromd, but the sapwood is perishable.

Though not widely used, the wood is highly recommended for furniture and cabinetwork. It is suited also for const luction, framing, flooring, plywood, decorative veneer, interior trim, boatbuilding. boxes and crates, and turnery.

Planted as a shade tree in southern Florida, where it is reported to be hardy and suitable for dry soils and exposed sites. Ċlassed also as an ornamental in Puerto Rico. Requires ample light for good growth. The bark is high in tamin.

A prominent tree of the forest canopy chiefly in the lower mountain and moist limestone regions, descending in some places to the moist coast of Prerto Rico. Also in Tortola.

Pribic Forests.-Carite, Guajataca, Guilarte, Luquillo, Maricao, Susúa, Toro Negıo.

MUNICTHAIJTIES WIIERE ESPECIALLY COMMON.$4,10,11,20,22,29,35,42,43,46,47,50,53,58,61$, $68,70,73$.

Raxae-Cuba, Jamaica, Hispaniola, Puerto Rico and Tortola, Lesser Antilles, and Trinidad and Tobago. Also in Panama and South America from Tenezuela to French Guiana, Brazil, and Bolivia.

Other COMnos sames.-gri-gri, ciruelillo, guaraguao (Dominican Republic); júcaro amarillo, jícaro mastelero, jocuma, jucarillo (Cuba) ; amarillo boj, amarillo, chicharro (Venezuela); yellow olivier (Trinidad); yellow sanders (Tobago); wild olive (Jamaica); bois margot, bois gris-gris (Haiti) ; bois gli-gli, bois gri-gri, bois olivier (Guadeloupe); olivier grand bois, angouchi des sables (French Guiana); matakki, gemberhout, katoelima, toekoeli (Surinam).

Botanical sromy.,-Bucida capitata Vall. 


\section{COMBRETUM FAMILY (COMBRETACEAE)}

A widely spreading timber and shade tree identified by : (1) a broad symmetrical crown of nearly horizontal branches which generally droop near the ends; (2) paired gray spines $1 / 4^{-3 / 4}$ inch long on the twigs of some trees: (3) elliptic leaves $1-3$ inches long and $5 / 8-2$ inches broad, clustered at ends of short erect twigs: (4) small, greenishwhite or light brown flowers stalkless in lateral clusters 1-t inches long; and (5) brownish, somewhat conical fruits about $1 / 4$ inch long with spreading calyx remaining at apex, but some fruits deformed as hormlike galls 2-3 inches long and more than $1 / 8$ inch in diameter.

Evergreen or decidnous medium-sized to large tree 30-60 feet high and to 3 feet in trumk diameter. The bark is brown, fissured and slightly rough or becoming thickened and scaly. Inner bark brown and slightly bitter. The gray twigs, finely hairy when young, are widely forking, consisting of slender leafless portions and shorter stout, spurlike areas bearing leaves or masses of leaf sears.

The leares are alternate on slightly hairy petioles $1 / 4-3 / 4$ inch long. Blades are rounded, shortpointed, or notched at apex and short-pointed at base, often widest berond middle, the edges not toothed, slightly thickened, hairless or nearly so at maturity, green on upper surface and yellow green beneath.

Flower clusters (spikes) are among the leares, unbranched, and bear along the finely hairy graygreen axis or at the end many stalkless flowers, which are $1 / 4-3 / 8$ inch lon $g$ and $1 / 4-1 / 2$ inch broad across the stamens. The base (hypanthium) is less than $1 / 8$ inch long, gray green or light brownish, finely hairy; the bowl-shaped, greenish-white calyx is $1 / 16$ inch long and $3 / 16$ inch across, 5toothed, and finely hairy; there are 10 widely spreading stamens $1 / 8-1 / 4$ inch long; and the pistil with inferior 1-celled ovary and slender hairy style $3 / 16$ inch long.

The fruits (drupes) are irregularly 5-angled, slightly fleshy or dry, narrowed below the calyx, minutely hairy, 1-seeded. Odd, lornlike galls caused by mites commonly develop from some fruits and become many times longer than normal size. Flowering and fruting irregularly through the year.

The sapwood is yellowish or light brown, and the attractive heartwood dark greenish brown with longitudinal stripes resulting from roey grain. The wood is very lard, very heary (specific gravity 0.93 ), very strong, tough, and moderately fine- textured. Rate of air-seasoning and a mount of degrade are molelate. Machining characteristics are as follows: planing is fair; shaping and sanding are good; turning, boring, and mortising are excellent; but resistance to screw splitting is very poor. One of the heaviest available woods of Puerto Rico, it is difficult to work becanse of the high density and hardness. It is durable in contact with the ground, resistant to attack by drywood termites, and takes a fine polish.

This valuable timber is used locally in carts, gates, fences, and rural construction. It is suitable also for heary-duty flooring, workbenches, machinery platforms, and heary exterior construction. Uses elsewhere include marine piling in nonteredo areas, crossties, house posts, bridge timbers, and charcoal.

Folmerly the bark was employed in taming. Also planted as a shade and ornamental tree, especially in constal and dry regions. Conmon in cultivation as a street tree in southern Florida.

In forests of the moist and dry limestone regions and forests along coasts and st reams near the sea in Puerto Rico. Also in Mona, Vieques, St. Croix, St. Thomas, and St. John.

Prblic forests.-Agnirre, Boquerón, Cambalache, Guajataca, Guánica, Río Abajo, San Juan, Susúa.

MUNICIPALITIES WHERE ESPECLAILY COMMON.$12,21,24,26,28,36,38,44,54,55,66,75$.

Range-Upper Florida Keys, Bahamas, Cuba, Jamaica, Hispaniola, Puerto Rico and Virgin Islands, and Leeward Islands to Guadelompe in Lesser Antilles. Also from southem Mexico to Panama and northern South America along the coasts of Colombia, Yenezuela (including Margarita), and Guianas.

OTHER Comion Nases.-guaraguao, gri-gri (Dominican Republic); júcaro, júcaro negro, jucarillo (Cuba); pneté (Mexico); bucida (Colombia); oxhorn bucida, black-olive (United States); black-olive (Bahamas, Jamaica) ; olivebark-tree (Jamaica); bullet-tree, bullywood, bully-tree (British Honduras) ; bois gri-gri, grisgris des montagnes, gué-gué (Haiti); bois gli-gli, bois gris-gris (Guadeloupe); grignon (French Guiana).

Botaxical srovorms.--Buceras bucida Crantz, Terminalia buceras C. Wright.

The scientific name and English common name oxhorn bucida are descriptive of the elongated fruit galls. 


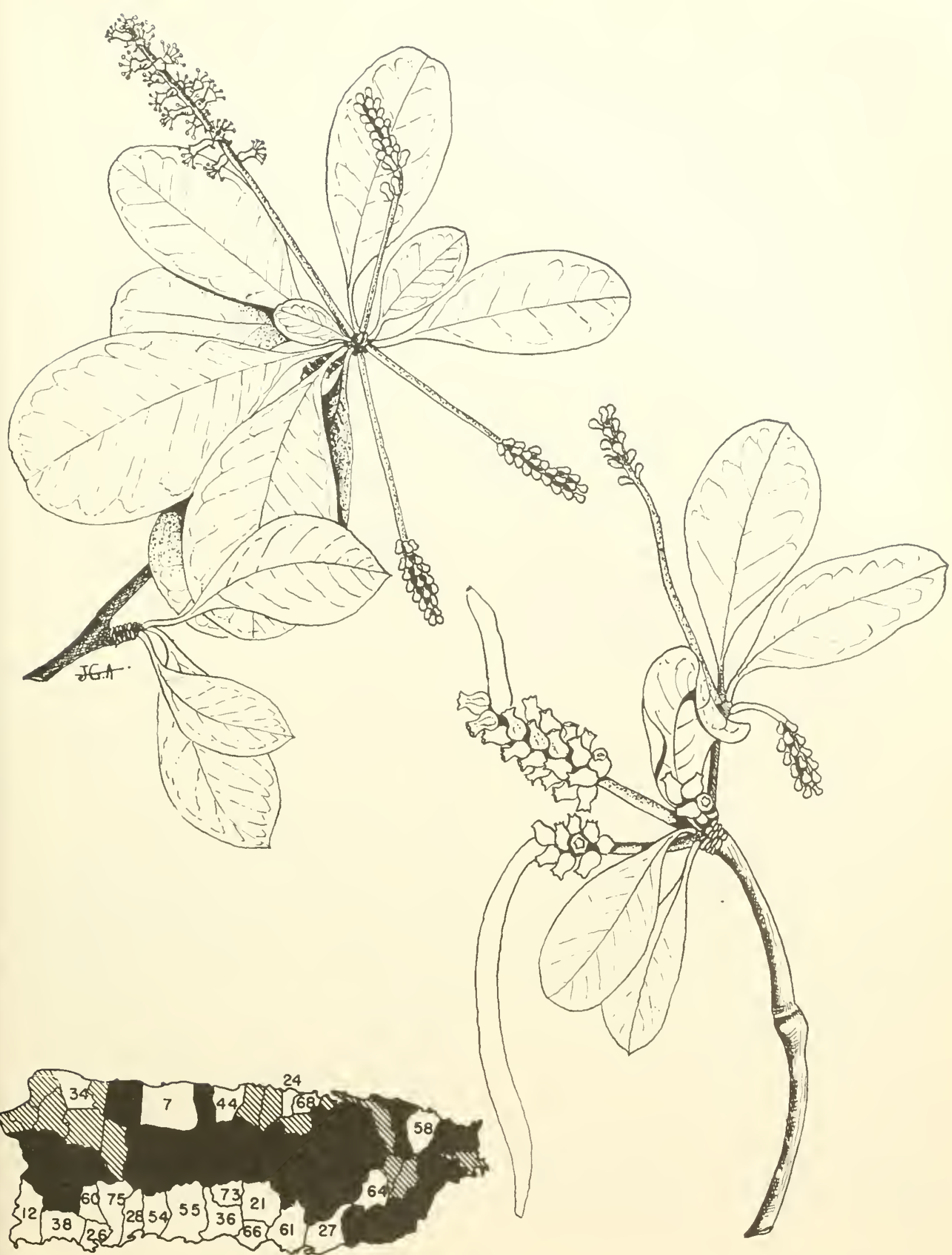

181. Ccar, gregre, oxhorn bucida

Bucida buccras L. 


\section{COMBRETUM FAMILY (COMBRETACEAE)}

\section{Mangle botón, button-mangrove}

Button-mangrove, a tree frequently shrubby in habit and usually on the landward side of tidal mangrove swamp forests, is distinguished as the only mangrove species with altermate leaves. It is further characterized by: (1) leathery and slightly fleshy, lance-shaped or elliptic leaves $1 \frac{1}{4}-3$ inches long and 1/2-11/4 inches broad, long-pointed at both ends, yellow green on both sides; (2) yellow-green angled or winged twigs; (3) minute greenish fragrant flowers less than $1 / 16$ inch across, crowded in balls less than $1 / 4$ inch in diameter in terminal and lateral clusters; and (4) purplishbrown rounded conelike fruits $3 / 8-1 / 2$ inch in diameter, composed of many scalelike single 1 -seeded fruits about $1 / 8$ inch long.

A small evergreen tree to 20 feet in height and 8 inches in trunk diameter, sometimes larger or a low shrub, with spreading crown. Usually hairless throughont, but one variation has silky or silvery hairy foliage. The bark is gray or brown, becoming rough, furrowed, and thick. Imer bark is light brown and astringent and bitter. The twigs are yellow green when young, becoming brown, and with a prominent angle of wing below each leaf.

The leaves have slightly winged, short petioles $1 / 8^{-3 / 8}$ inch long with 2 dotlike glands. Leaf blades are not toothed on edges and usually have several dotlike glands near vein angles on lower surface.

There are commonly several stalked balls or heads of flowers in clusters mostly 1-3 inches long. Flowers are mostly bisexual, but some trees bear heads of male flowers. Bisexual flowers are more than 1/16 inch long, with hairy grayish 2-winged tubular base (hypanthim), cuplike green calyx with 5 lobes, $5-10$ protruding stamens, and pistil of inferior ovary with slender style. Male flowers lack the tubular base (hypanthium) and pistil and have longer stamens.

The dry individual fruits (drupes) are brown, 2 -winged, overlapping and separating at maturity. Flowering and fruiting probably through the year.

The sapwood is light brown, and the heartwood yellow brown. The wood is very hard, very heary (specific gravity 1.0), strong, and finetextured. It takes a fine polish and is said to be generally very durable, although susceptible to at-
Conocarpus erectus L.

tack by dry-mood termites. The wood has been used for fenceposts, crossties, wood turning, and in boatbuilding. It burns slowly and makes good fuel and charcoal.

The bark has served in tamning and medicine, and the leaves contain tamnin also. Elsewhere, it is reported that plants can be propagated from cuttings as living fenceposts. In sonthern Florida the variation with silky or silvery hairy foliage is grown as a handsome ornamental. Plants of this species will grow on dry land away from the seashores.

Mangrove swamp forests on silty shores near salt and brackish water, and sometimes also on rocky and sandy shores around Puerto Rico. Also in Mona, Icacos, Vieques, St. Croix, St. Thomas, St. Jolnu, Tortola, Virgin Gorda, and Anegada.

PUblic Fonests.-Aguirre, Boquerón, Ceiba, Guánica, and Sall Juan.

RAvGE.-Shores of central and southern Florida including Florida Keys, Bermuda, nearly throughout West Indies (except Dominica) from Bahamas and Cuba to Trinidad and Tobago and Dutch Trest Indies. On both coasts of continental tropical America from Mexico south through Central America and northerm South America to Ecuador and Galapagos Islands and to Brazil. Also in western tropical Africa.

Otiner conimon Names.-botoncillo (Puerto Rico): buttonwood (Virgin Islands): mangle botón (Spanish) ; botoncillo, mangle prieto (Dominican Republic) ; yana (Cuba) ; mangle negro, mangle prieto (Mexico); botoncillo (El Salvadol'); marequito, mangle negro, mangle marequita (Costa Rica); zaragosa, mangle piñuelo, mangle torcido (Panama) ; mangle neglo, mangle garbancillo (Colombia) ; botoncillo, mangle botoncillo, mangle lloroso (Venezuela); mangle jelí, jele (E c u a d o r) ; button-mangrove, buttonwood (United States. English) ; manglier (St. Lucia) : buttonbush, botoncillo (British Honduras) ; mangle, palétuvier (Haiti); palétuvier gris (Guadeloupe, Martinique); mangle gris, manglier gris, chêne Guadeloupe (Guadeloupe); mangel, grijze mangel, mangel blancu, witte mangel (Dutch West Indies); mangue, mangue bianco, mangue de botão (Brazil). 


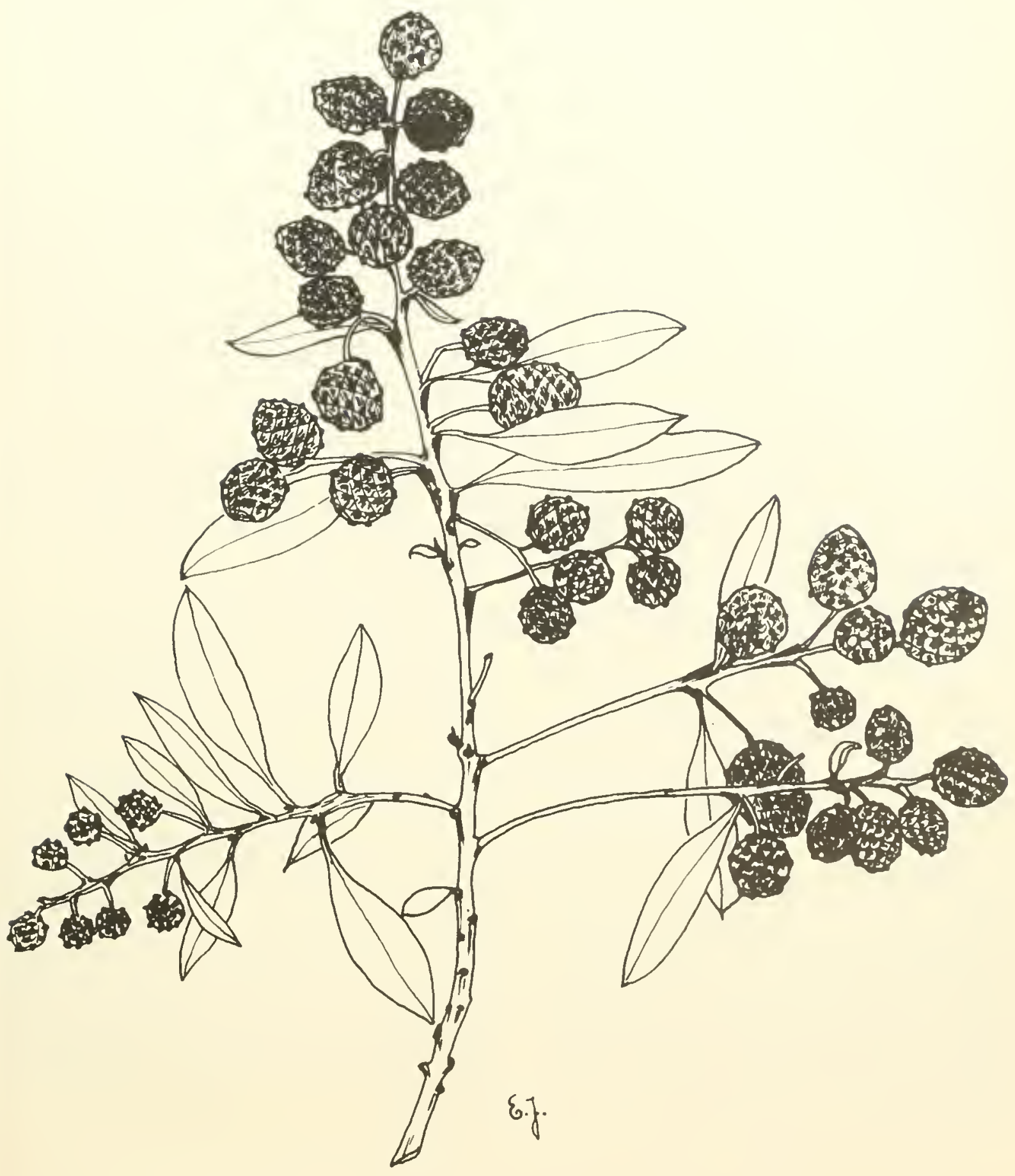




\section{COMBRETUM FAMILY (COMBRETACEAE)}

\section{Mangle blanco, white-mangrove}

One of the 4 species of mangrove swamp forests on brackish silty seashores, mangle blanco is characterized by: (1) opposite, leathery and slightly fleshy, elliptic leaves $11 / 2-4$ inches long and $1-2$ inches broad, rounded at both ends, dull yellow green on both sides and borne on reddish petioles with 2 raised gland dots neal apex; (2) graybrown bark becoming rough and fissured; (3) many small bell-shaped whitish flowers about $3 / 16$ inch long, stalkless in terminal and lateral clusters $1-4$ inches long; and (4) clusters of velvety graygreen fruits $5 / 8-3 / 4$ inch long, slightly pear-shaped (obovoid), flattened and with ridges.

Commonly a small evergreen tree to 40 feet high and 1 foot in trunk diameter, sometimes larger. Many trees consist of a clump of stens which have sprouted after cutting. The inner bark is light brown, bitter and astringent. Twigs are greenish or reddish brown when young but becoming brown, hairless, and thickened at nodes.

The leaves have stout petioles $3 / 8^{-1 / 2}$ inch long. Leaf blades are without toothed edges, visible reins, or hairs.

Flower clusters (panicles) are generally branched and spreading, the fragrant flowers mostly bisexual (or a few male). The minutely hairy, whitish tubular base (hypanthium) is less than $1 / 8$ inch long and broad, bearing 2 minute scales (bracts), 5 spreading blunt-pointed whitish sepals less than $1 / 16$ inch long, and 5 rounded whitish petals $1 / 16$ inch long; there are 10 stamens; and pistil with inferior 1-celled ovary with 2 ovules, slender style, and minutely 2-lobed stigma.

The slightly fleshy fruit (drupe) is minutely hairy, gray green when immature and brownish at maturity, broadest near the apex, which has sepals remaining attached. It floats and is disseminated by water. There is 1 large seed which starts to enlarge and sometimes begins germination within the fruit on the tree or floating in the water. Flowering and fruiting nearly throughout the year.

\section{Laguncularia racemosa (L.) Gaertn. f.}

The sapwood is light brown, and the heartwood yellowish brown. The wood is moderately heavy (specific gravity 0.6), hard, and strong, but not very durable. In Puerto Rico used mainly for posts, fuel, or charcoal, and sometimes for tool handles and similar objects. Elsewhere the wood has served also for construction. The bark contains tannin and has been employed in tanning and medicinally.

A rapidly growing tree which may flower and fruit when less than 2 years old. Also a honey plant.

The most widely distributed of the mangrove species in Puerto Rico. Grows along the silty shores of lagoons and estuaries near the coast. Also in Mona, Vieques, St. Croix, St. Thomas, St. John, and Anegada.

Punlic Forests.-Aguirre, Boquerón, Ceiba, Guánica, San Juan.

RANGE.-Shores of central and southern Florida including Florida Keys, Bermuda, and nearly throughout West Indies (except Dominica) from Bahamas and Cuba to Trinidad and Tobago and Dutch West Indies. On both coasts of continental tropical America from Mexico south to Ecuador and northwestern Peru and to Brazil. Also in western tropical Africa.

Other comion Names.-mangle bobo (Puerto Rico); mangel (Virgin Islands); mangle blanco (Spanish); mangle amarillo, mangle prieto (Dominican Republic); patabán (Cuba); cincahuite (El Salvador); palo de sal, mangle marequita (Costa Rica); mangle amarillo (Venezuela); white-mangrove, white buttonwood (United States, English); green turtle-bough (Bahamas); coil (British Guiana); mangle, manglier blanc (Haiti); palétuvier (French); mangle blanc, manglier blanc (Guadeloupe); akira (Surinam); mangue, mangue branco (Brazil). 


\section{Almendra, Indian-almond}

This familiar tree commonly planted for shade, ornament, and nuts is introduced, rather than native. It is characterized by: (1) horizontal branches in circles at different levels on the trunk: (2) large leathery leaves broadest toward apex (obovate), tmining reddish before falling: (3) many small greenish-white flowers $3 / 16^{-1 / 4}$ inch across in narrow lateral clusters: and (4) elliptic, slightly flattened greenish fruits ibout 2 inches long, each with a bard husk containing a large edible seed or nut.

Tsually a medium-sized tree, to 50 feet in height and 1 foot in trunk diameter, sometimes larger and with slight buttresses. It is evergieen except in areas with a marked dry season. The gray bark is smoothish and thin, becoming slightly fissured. Inner bark is pinkish brown, slightly bitter and astringent. Twios are lrown, finely hairy when young, slender but swollen at leaf scars and the nodes.

The leaves are altemate but crowded togrether near ends of twigs and have stont. finely brown hairy petioles $3 / 8-3 / 4$ inch long. Blades are $6-11$ inches long and $31 / 2-6$ inches broad, abruptly short-pointert or rounder at apex and gradually narrowed toward the romded base. not toothed on edges, slightly thickened, the upper surface shiny green or dark green and hairless, and the lower surface paler and often finely brown hairy.

Flower duaters (narrow racemes) are $2-6$ inches long. with numerous, mostly short-stalked. slightly fragrant finwers, mostly male and a few bisexual flowers near hase (polyoramous). Both kinds have a greenish-white or light brown. hoirv calyx with cup-shaped tube and 5 or 6 pointed. spreading lohes $1 / 16$ long and hearing twice as many small stamens near hase. In addition the bisexual or female flowers, which are stalkless, have a slender style and a narrow basal tube (hypanthium) 3/16 inch long. brownish green and finely hairy, resembling a stalk but containing the inferior 1 -celled ovary.

The fruits (drupes) are ahout 1 inch broad, pointer, slightly flattener and with 1 or 2 narrowly wingerl edges. light brown at maturity. The thin outer layer is slight]y sour and can be eaten. Insicle the hard fibrous huck there is a light brown, thick, hard stone containing an oily seed or nut ahout 11/4 inches long and $3 / 2$ inch broad. somewhat like the true almond. Flowering and fouiting nearly throurh the year.

The heartwood is reddish brown with slightly darker stripes, and the sapwond lighter in coloi. The rood is hard. molerately heavy (specific gravity 0.59), moderately strong, tough, mediumtextured, and with irregular and often interlocked

\section{Terminalia catappa L.*}

grain. It is very suscept ible to attack by dry-wood termites. Rate of air-seasoning is rapid, and amount of degrade is moderate. Machining characteristies are as follows: planing is very poor; shaping, boring, and mort ising are fair: turning is poor; and sanding and resistance to screw splitting ale grood.

Local uses are for posts and fuel. However, this attractive wood if carefully handled in machining would be snitable for millwork, funnitme, veneer, and cabinetwork. Elsewhere it has been recommended for boatbuilding, general construction, brilge timbers, crossties, flooling, and boxes and crites.

The bark, roots, astringent green fruits, and leaves contain tamin and have been used in tanning. A black dye serving for ink has been obtained from bark, fruits, and foliage also. In oil las been extracted from the seeds.

Planted chiefly for shade and ornament and for the edible seeds. and growing rapidly. One of the common roadside trees in Puerto Rico, attractire for its peculial branching and the reddish-tinged old leaves. Trees are extensively planted along sandy seashores, being hardy and salt tolerant, though reportedly not resistant to hurricanes or storm winds. I thrips insect attacks the trees [renerally in autumn and winter, causing the leaves to turn yellowish or whitish and to fall and thus making the leafless trees less suitable for shade.

Taturalized in Puerto Rico, especially on the sandy soils and dunes along the coasts, but extensively planted and escaping from cultivation in rapious places. Also in Mona, Vieques, St. Croix, St. Thomas, St. John, Tortola, and Virgin Gorda.

RANGE.- Native of East Indies and Oceanica and widely planted and naturalized in tropical rerions. Southern Florida including Florida Kiers, Bermuda, and throughout West Indies. Ilso from Mexico to Peru and Brazil.

Other common nimes. - almendro (Puerto Rico, Spanish); almond, Trest-Indian-almond (Virrin Islands) : almendro de la India (Domini(an Reunblir. Cuba, Colombia); alcornoqne (Costa Rica) : almenrlón (Venezuela) : almendro americano (Colombia) ; castaña (Peru) ; Indianalmond, tropical-almond, West-Indian-almond (Lnited States. English): almond (British West Indies, British Honduras, British Guiana) : amandier des Indes, amandier tropical, zammande (Haiti); amandier, amandier-pays (Guadelompe); amandier de Cayenne (Guayana Fran(cesa): manguel, wilde amandel (Dutch West Indies) ; amanda, amandebbom (Surinam); amendoeira, chapéo de sol, guarda-sol, castañola (Bi:azil). 


\section{MYRTLE FAMILY (MYRTACEAE)}

Key to the 11 speeies illustrated (Nos. 185-195)

A. Leares alternate : rorolla absent-1s6. Eucalyptus robusta.*

A. Leares opposite; corclla of 4 or 5 rounded petals.

13. Leaves small, lesis than 2 inches long

C. Leares rounderl at alkx; the short petioles and roung twigs reddish-brown hairy-185. Calyptranthes kruyii.

CC. Leares long-pointed at apex, hairless when mature.

D. Leares bluntly long-pointed, nearly diamond-shaped, dull green, thin, the few lateral veins inconspieuous-120. Eugcnia rhombra.

DD. Leaves ending in long narrow point, ovate or lance-shaped, shinf, slightly thickened, with many prominent side veins-193. Murcia splendens.

BB. Leares laryer, more than 2 inches long.

E. Leares rounded at apex, thick and leathery.

F. Leares with many straight, parallel side reins, edges rolled under; flowers many, very small-194. Pimenta raremosa.

FF. Lores with few side reins: flowers few, large-191. Eugenia stahlii.

EE. Leaves long- or slort-pointed at apex.

G. Leares with sicle veins sunken.

H. Leaves thick, stiff, upler surface shing: petioles and twigs densely reddish-brown hairy; Howers and fruits mans, small-193. Myria defteru.

HH. Leaves slightly thickened, not stiff: twigs and lower leaf surfaces finely hairy; flowers few, large; fruit large, round edible (gnava)-19.5. Psidium guajava.*

GG. Leaves with side veins not sunken.

I. Flowers and fruts small, abont 1/2 incl long and broad-157. Eugenia aeruginea.

II. Flowers large, more than 2 incles broad: fruits more than 1 ineh long. edible.

J. Flowers white: frnits rounded (rose-apple)-188. Engcnia jambos.*

JJ. Flowers purplish red; fruits pear-shaped (Malag-apple)-189. Eugcnia malacensis.*

185. Limoncillo

This shrub or small tree found only in the monntains of Prepto Rico is characterized by: (1) dark brown twigs, crowded, much branched and forking, when young densely rusty reddishbrown hairy: (2) opposite small, obovate, slightly aromatic, leathery leaves almost stalkless, $5 / 8-1$ inch long and $3 / 8-3 / 4$ inch wide, rounded at apex and pointed at base, areen to dark green above and pale light green beneath. with many minute gland dots; (3) each leaf covered until almost full size by 2 odd brownish scales (stipules), which split open at midrib on both sides: (4) white flowers $1 / 2-3 / 4$ inch across the many white stamens, single and stalkless at leaf hases: and (5) round ber'y 1,4 inch in diameter, with ring at apes.

An erergreen shrmb or small tree $8-15$ feet tall and 2-3 inches or more in trunk diameter, with narrow crown. The brown bark is smooth, within whitish or brownish and almost tasteless to slightly bitter. The slender forking twigs are slightly fissured.

The leaves have short reddish-brown hairy petioles $1 / 16$ inch $\mathrm{ol}^{\circ}$ less in length. The thickened stiff blades are hairy when young, the edges turned under, slightly shiny above, and with inconspicuous lateral veins.

Flower buds are rounded and reddish-brown hairy. The flower, about $3 / 8$ inch high, has a reddish-brown hairy cuplike base (hypanthium) enclosing the inferior orary and projecting beyond, bearing the calyx. which splits open as a lid attached on 1 side, + minute white petals less than $1 / 16$ inch long, a ring of spreading white stamens $1 / 4$ inch long, and a green style $1 / 4$ inch long.

\section{Calyptranthes krugii Kiaersk.}

The fleshy fruit is covered with reddish-brown hairs and is greenish when immature. Collected in flower from June to October and with fruit in January.

The sapwood is light brown and hard. The wood is not used because of the small size of the tree,

In the upper mountain forests, including the dwarf forests of the summits of the Luquillo Mountains and also in the Central Cordillera.

Public forests.-Carite, Luquillo, Toro Negro.

RaxgF.-Confined to eastem and central mountains of Puerto Rico.

This genus is represented by 2 more species of small trees or shrubs in Puerto Rico and 3 others in the Virgin Istands. Flower characteristics of this genus include a cuplike base (hypanthium), which upon shedding leaves a ring scar at apex of the round berry funit the calyx which splits open as a lid; and corolla none or of 4 very small white petals. The English generic name lidflower, from the scientific name, refers to the calyx.

Culyptranthes kiaerskovii Krug \& Urban, known only from foliage collected at Tortola, has oborate hairless leaves 1 inch or less in length with blunt or rounded apex and upper surface shiny.

The other species have larger leaves 1-3 inches long. Limoncillo del monte (Calyptranthes sintenisii Kiacrsk.), of moist forests in Puerto Rico and also in Hispaniola, has elliptic long-pointed leaves bright green and faintly shining above and beneath paler, dull, and sometimes slightly hairy; and fruit $1 / 2$ inch or more in diameter.

Pale lidflower (Calyptranthes pallens Griseb.), of St. Croix, St. Thomas, and Mona and wider dis- 


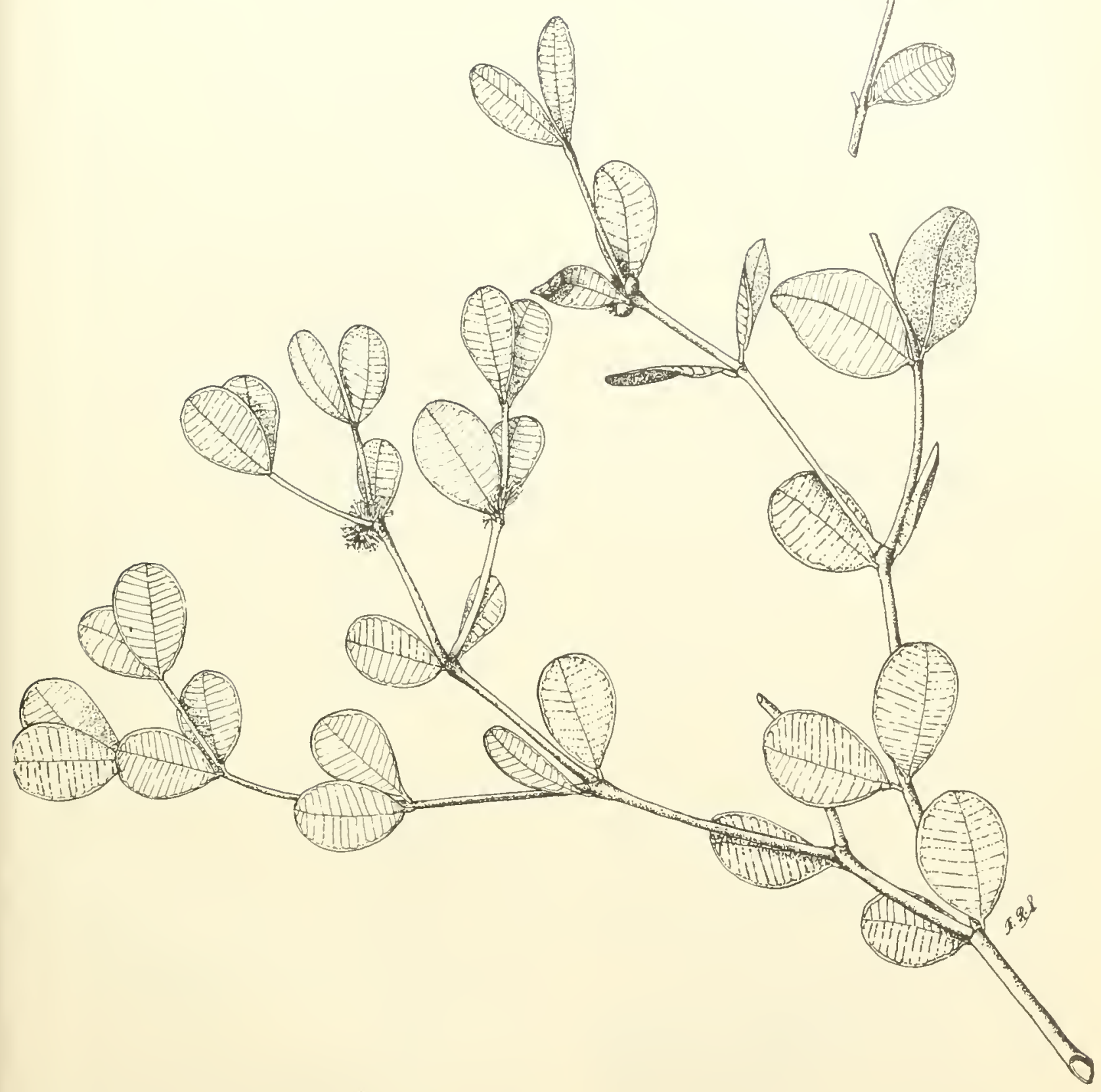


tribution from Guadeloupe to southern Florida, has elliptic long-pointed leaves shiny above and smaller fruit about $3 / 16$ inch in diameter.

Calyptranthes portoricensis Britton, known only from near Maricao in Puerto Rico, has leaves rounded or short-pointed at apex and hairy be- neath when young; dense brown hairs on twigs, flower clusters, and fruits; and fruit about $3 / 16$ inch in cliameter.

Calyptranthes thomasiana Berg, described from St. Thomas, has blunt-pointed oblong or obovate leaves $1-2$ inches long.

\section{MYRTLE FAMILY (MYRTACEAE)}

\section{Eucalipto, beakpod eucalyptus}

This handsome introduced tree, occasionally planted in Puerto Rico, is characterized by: (1) generally very straight axis with thick furrowed bark and narrow to spreading crown of dark green foliage; (2) broadly lance-shaped leaves 4-8 inches long and $1 \frac{1}{4}-21 / 2$ inches broad, mostly slightly curved and unequal-sided from the shortpointed base, with a long tapering point, stiff and leathery, aromatic, with a peculiar spicy resinous odor" (when crushed) and taste; (3) cream-colored flowers with very numerous stamens in a spreading mass $11 / 4$ inches across, sereral borne laterally at the end of a flattened green stalk about 1 inch Jong; and (4) cuplike dark green seed capsules $1 / 2-5 / \%$ inch long and $3 / s$ inch in diameter.

A medium-sized evergreen tree to 90 feet in height and $11 / 2$ feet in trunk diameter. The bark on large trunks is gray on the surface, $1-11 / 2$ inches thick, deeply furpored, reddish brown beneath, fibrous and very soft. The inner bark, about $1 / 4$ inch thick, is fibrous, whitish, and slightly bitter. Twigs are yellowish green and angled when young, becoming round and reddish brown.

The alternate leaves have slightly flattened yellowish-green petioles $1-1 \frac{1}{4}$ inches long. Blades have tonthless edges and many fine, widely spreading, parallel lateral veins and are dark green on upper surface and only slightly paler beneath.

spreading clusters (umbels) of 10 or fewer short-stalked flower's are borne at leaf bases. Flower buds are 1 inch long and $3 / 5$ inch broad, becoming pale yellow and tinged with green, with a long-pointed cap nearly $1 / 2$ inch long formed from calyx or corolla, which becomes detached from the fumnel-shaped base (hypanthium) about $1 / 2$ inch loner. The stamens, $1 / 2$ inch and less in length, with minute anthers, are attached on the rim of the hypanthium in a widely spreading mass abont $1 \frac{1}{4}$ inches across and soon shedding. The pistil is composed of inferior 3-5-celled ovary and straight stout style $3 / 8$ inch long.

Seed capsules, which remain on the tree for some time, have $3-5$ pores sunken below the rim, throngh which numerous minute brown seeds $1 / 16$ inch long sift out. Nearly $2,000,000$ seeds per pound. Flowering and fruiting from late summer to early spring (mostly from August to March).

The sapwood is light brown, and the heartwood salmon to light reddish brown, often mottled with

\section{Eucalyptus robusta J. E. Smith*}

brown streaks and patches. The wood is hard, moderately heavy (specific gravity 0.51), strong, brittle, stiff, elastic, coarse in texture, and fairly straight-grained with some interlocked grain. The late of air-seasoning is moderate but with considerable degrade from warp with very great, uneven shrinkage. Machining characteristics are as follows: planing, shaping, turning. mortising, and sanding are good: boring is fair; and resistance to screw splitting is excellent. The rood is very susceptible to attack by dry-wood termites but is considered durable in the ground.

Uses include underground piling, utility poles, and fenceposts. This species is employed for general construction in Australia, especially in contact with the ground, and should be suitable for the same purpose in Puerto Rico.

Suitable for shade and ornament and also a honey plant. An infusion of the leaves has been prepared for home remedies.

This species grows rery rapidly, 15-year-old trees attaining a diameter of 16 inches and a height of 90 feet. Natural regeneration in Puerto Rico is very rare. Growth is best in the upper and lower momtain regions, above 1,500 feet elevation. As a street tree in California, this tree proved objectionable because the tops were easily broken by strong winds. Planted also in Florida.

Public rorests.-Carite, Guilarte, Luquillo, Maricao, Toro Negro.

RAxGe.- Native of Australia but introduced into many tropical and subtropical lands including West. Indies and from subtropical United States and Mexico south to Argentina and Brazil.

Otuer commos Names.- encalipto del ajcanfor, encalipto de pantano (Puerto Rico); encalyptus (Virgin Islands); ellcalipto común, encalipto achatado (Colombia) : beakpod eucalyptus, eucalyptus (United States); eucalyptus, eucalypt. swamp-mahogany, browngum (English).

BotaNical sYNoNym.-Eucalyptus multifora Poir.

This species seems to be the best adapted of more than 30 species of Eucalyptus which have been introduced experimentally into Puerto Rico from their native home in Australia. Several are being tested by the United States Forest Service in plantations. 


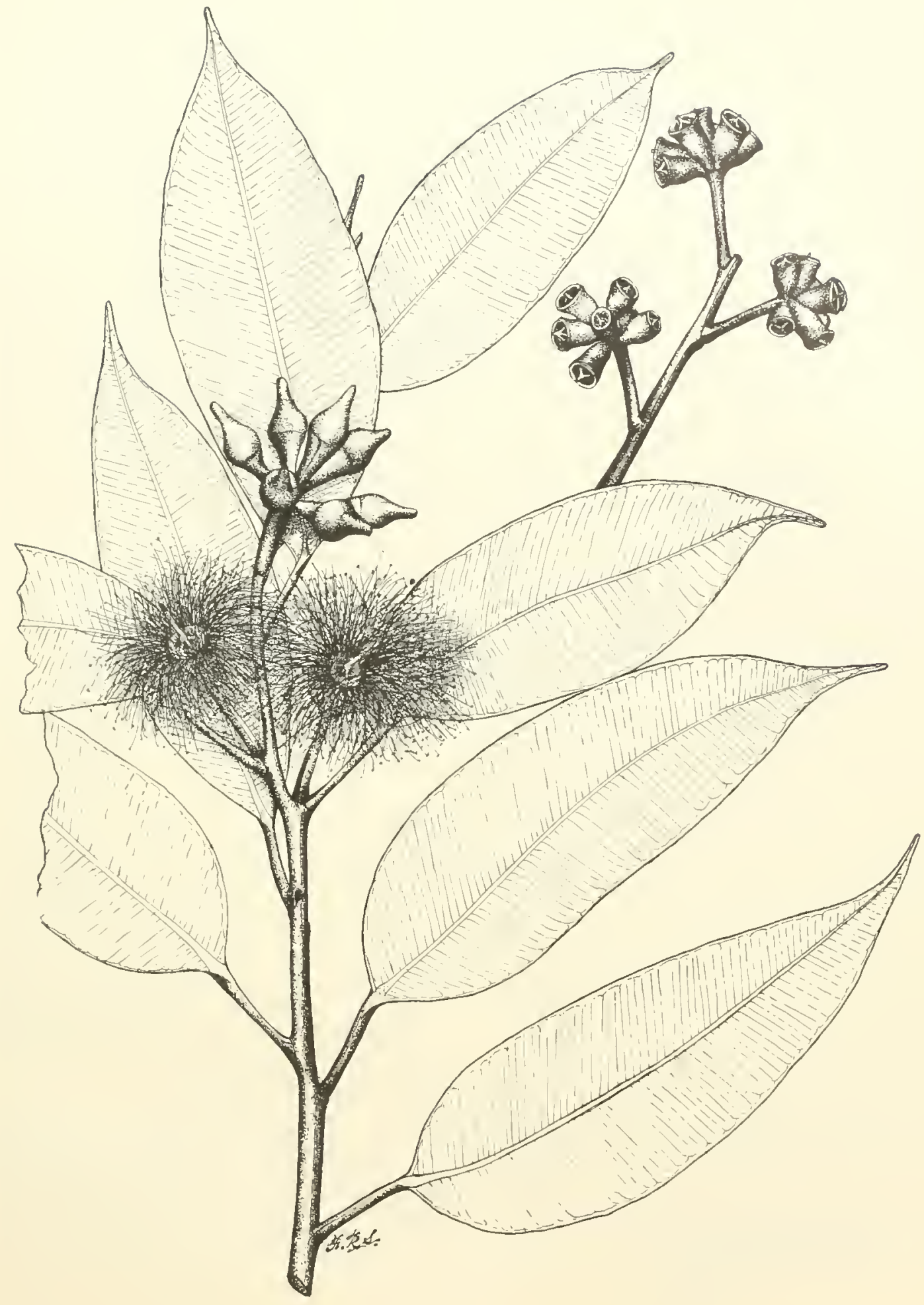




\section{MYRTLE FAMILY (MYRTACEAE)}

\section{Guasábara}

Gusábara, a tree of mountain forests, is distinguished by: (1) light gray to whit ish bark, slightly rough and separating in irregnlar flakes: (2) opposite elliptic long-pointed leaves $21 / 2-41 / 2$ inches long and $11 / 2-21 / 4$ inches broal, with minute gland dots; (3) whitish flowers wearly $1 / 2$ inch across with $t$ petals and many spreading stamens, in lateral clusters at base of leaves: and (t) blackish-purple berry $3 / 8^{-5 / 8}$ inch long, elliptic or rounded, with sepals at apex and reported to be edible.

An evergreen tree $30-60$ feet tall and $8-18$ inches in trumk diameter. Imner bark is brown, woody, and slightly astringent and bitter. Twigs are light brown.

The green petioles are $1 / 4^{-3 / 8}$ inch long. Blades are mostly short-pointed at base, slightly leathery or thin, shiny green above and lighter green beneath, and hairless or nearly so at maturity.

Flower clusters (racemes) are 1-2 inches long, bearing several to many flowers on slender hairy stalks. Flower buds are greenish and hairy, with 2 short united scales or bracts at base. 'The flower' has a greenish hairy cuplike base (hypanthium) less than $1 / 8$ inch long, which encloses the inferior" ovary and hears + greenish rouncled hairy sepals, 2 more than $1 / 8$ inch long and 2 much smaller, 4 white petals about $3 / 16$ inch long, many spreading stamens, and style $5 / 16$ inch long. In flower and fruit nearly through the year.

The sapwood is light brown. The wood is described as hard, strong, and heary. It is little used except for posts and fuel. This species has been listed as suitable for shade and ornament.

In lower mountain forests of Puerto Rico, ascending to nearly 3,000 feet eleration in the Central Cordillera.

Perlat foresrs.-Carite, Lnquillo, Toro Negro.

Ravge.-Cuba, Hispaniola, Puerto Rico, Dominica, Martinique, St. Tincent, and Trinidad. Reported doubtfully from Jamaica nearly a century ago.

Other Common NaMes.- guásara (Dominican Republic); comecará (Cuba); serrette guava (Trinidad) ; brignolle (Haiti).
Eugenia aeruginea DC.

\section{BotaNICAL sYroNrM.-Eugenia domingensis} Berg.

This genus, known in English as eugenia, is perhaps the largest in number of species of small trees or shrubs represented in Puerto Rico and the Virgin Islands. The Spanish name hoja menuda and English name stopper are applied to many species. The group is characterized by flowers mostly few in lateral clusters among the leaves, by 4 or 5 sepals which remain attached at the apex of the usually rounded berry fruit, and by 4 or 5 white petals (red in an introduced species).

Besides the 3 mative and 2 introduced species described and illustrated here, Britton and Wilson (Botany of Porto Rico and the Virgin Islands 6: 33-12. 1925) described 22 other native species and prepared a key for their identification. These species are listed below in alphabetical order by scientific name with any distinctive common names. Eugenia axilluris (Sw.) Willd., grajo, white-stopper eugenia; E. bellonis Krug \& Urban; E. biflora (L.) DC. (E.lancea Poir.), pitangueira; $E$. borueronensis IBritton; E. borinquensis Britton, gua yabota; $E$. confusa DC., cieneguillo, redberry pugenia; $E$. cordato (Sw.) DC.; E. corozalensis Britton; $E$. eggersii Kiaersk., gllasábara; $E$. floribunda West; E. fragrans (Sw.) Willd. (Anamomis fragrans (Sw.) Griseb.), guayabacón; E. ligustrina (Sw.) Willd., palo de muleta; $E$. monticola (Sw.) DC., biriji; E. myrtoides Poir. (E. buxifolia (Sw.) Willd.), anguilla, boxleaf eugenia; $E$. procera (Sw.) Poir.; E. pseudopsidium Jacq., quiebrahaca; $E$. serrasuela Krug \& Urban, serrazuela; E. sessiliflora Vahl; E. sintenisii Kiaersk., murta; E. stewurdsoniz Britton; E. underwoodii Britton; E. xerophytica Britton.

Cerezo de Cayena or pitanga (Eugenia uniflora L.*), also called Surinam-cherry, is planted for its fruit in St. Croix and St. Thomas and recorded as escaping from cultivation. It has ovate shiny dark green leaves 1-2 inches long, flowers mostly single on long stalks, and bright red edible fruits $3 / 8$ inch in diameter. 


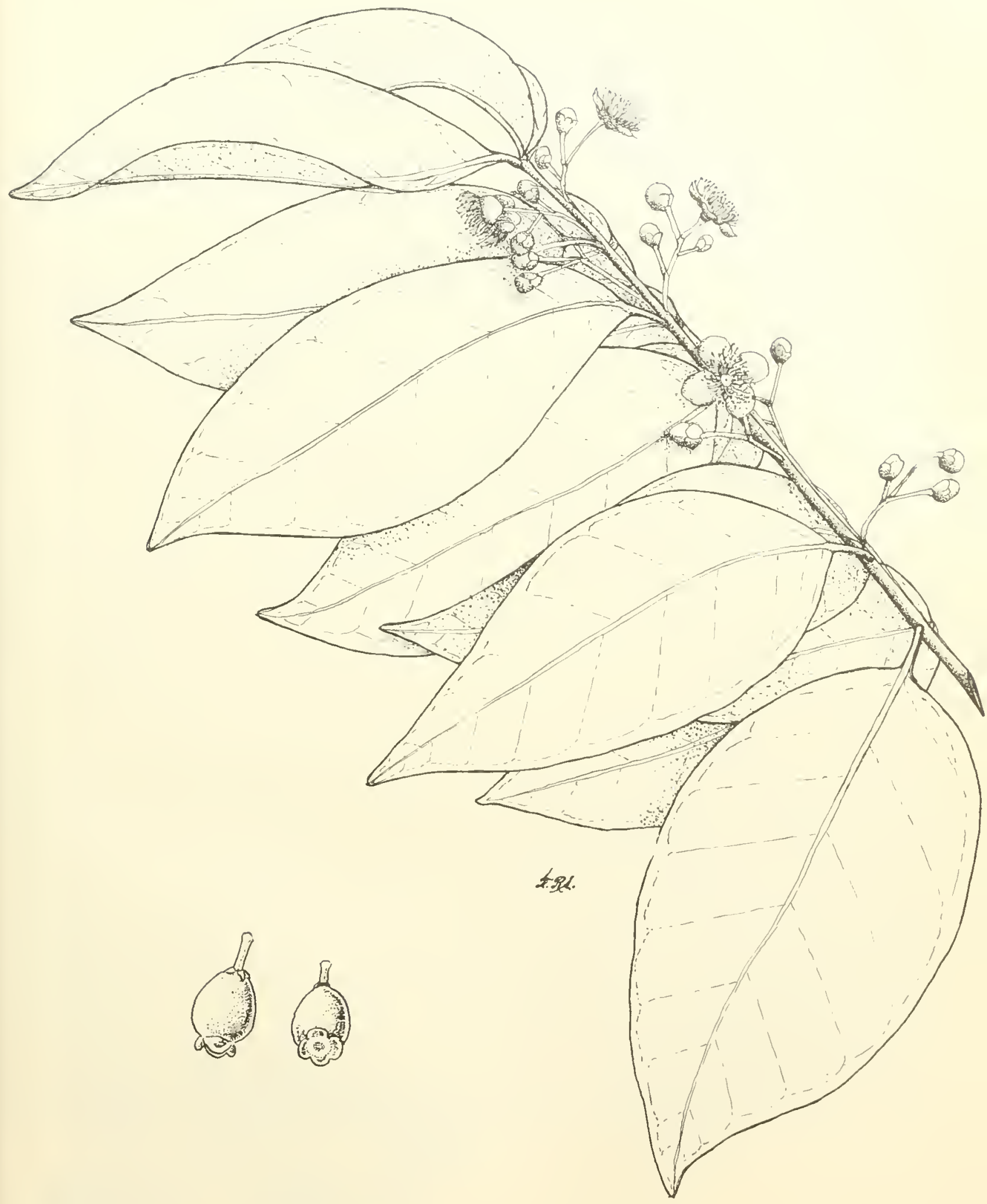




\section{MYRTLE FAMILY (MYRTACEAE)}

\section{Pomarrosa, rose-apple}

A naturalized tree with handsome foliage and edible fruits, rose-apple is clistinguished by: (1) stems frepuently very (rooked and several fiom a single hase: (2) a dense opaque dark crown; (3) opposite, shiny, dark green, lance-shaped, leathery leaves $31 \%-6$ inches long and $5 / 8-13,4$ inches broad, with minute gramel dots visible against the light with a lens: (4) few large rellowish-white 4-petaled flowers in terminal clusters, 3-t inches across the numerous widely sprealing long stamens : and (5) fragrant pale vellowish or pinkish-tinged rounded or elliptic fruits about $1 \frac{1 / 4-11 / 2}{2}$ inches long, with 4 sepals at apex, the slightly sweet, edible flesh with odor and flavor like rose perfume.

A small everereen tree $15-30$ feet tall and $1-8$ inches in trunk lianeter, with a spreading crown. The bown balk is smoothish with many small fissures. The inner bark is whit ish or light brown and astringent. 'Twigs are dark brown, green when roung.

The short petioles are $3 / 16^{-3 / 8}$ inch in length. Leaf blates are rely long-pointed at apex, shortpointed at base, not tootherl on edges, and dull green heneath. (Iften the leares are covered with a black sooty moll fungus which makes them appear even darker.

The flower cluster (corymb) has commonly 4 or 5 flowers. An individual flower is mostly a hrushlike mass of whitish stanens, which are $11 / 4-2$ inches long, with brown dot anthers. The conical pinkish-areen tubulan base (hypanthium) is about $1 / 2$ inch high and wile, enclosing the ovary; there are 4 rouncled hroal sepals $1 / 4$ inch bong, persistent on the fruit; 4 rounded roncure whitish petals about. $5 / 8$ inch long, faintly tinged with green, coarsely gland dotted: and pistil consisting of the inferior 2-celled orary and persistent whitish slender style $13 / 4$ inches iong.

Fruits (berries) have pale yellow firm flesh with littie juice and usually 1 (sometimes 2) rounded brown seed $3 / 8$ inch in diameter in a large cavity. Abont 180 seeds per pound. Flowering and fruiting nearly through the yeats, though infrequently in summer.

The dull hrown wood is hard and heary (specific gravity 0.7). I'sed chiefly as fuel. It is not
Eugenia jambos L.*

durable in the soil and is very susceptible to attack by dry-woor temites. Young branches have been lised for making coarse baskets and barrel hoops. In Cula tobacco poles are made from the branches.

Planted occasionally for ormament, primarily for the showy flowers and handsome foliage and sometimes for windbreaks and shade, rather than for the fruits, which are insipid and not popular. Sometines the fruits are prepared into jellies, preserves, and salarls. I good honey plant. Elsewhere the seeds and roots have been employed in home remedies. The trees reproduce naturally fron seeds, and sprout vigoronsly when cut. The shade beneath pure thickets generally kills out all vegetation.

In the lower mountain, moist coast, and moist linestone reurions of Puerto Rico, locally abundant. spreading like a weed, and forming pure stands or dense thickets, especially along streams. Also in st. Croix, St. Thomas, St. John, and Tortola.

Prasic Forests.-Cambalache, Carite, Guajataca, Guilarte, Luquillo, Maricao, Río Ibajo, Susúa, Toro Negro, Tegra.

MUNICIPALITIES WHERE ESPECIALLY CONHAON.-$4,5,6,7,10,11,13,17,20,22,23,24,25,29,40,43$, $45,42,51,52,59,60,62$.

Rinar. - Native of southeastern tropical Asia but now widely cultivated and naturalized through the tropies, inchuding West Indies and continental tropical America from Mexico south to I3razil. Planted also in Florida and southern California and in Bermuda.

OTIEl COMnON NAMEs.-phum-rose (Virgin Islands) : pomo (Dominican Republic); manzana losa (Cuba): manzana rosa, manzana (Central America): pomarrosa, manzanita de rosa (Colombia): rose-apple (United States, English): pomme rose, pommier rose (French); jambosier (French (ruiana): plum-rose (Dutch West Indies): pommeroos, appelroos (Surinam); jamheiro, jambo amarello (Brazil).

Botanical symoniss.-Jambos jambos (L.) Millsp.. Jumbosa vulyaris DC., Syzygium jambos (L.) Alston, Caryophyllus jambos (L.) Stokes. 


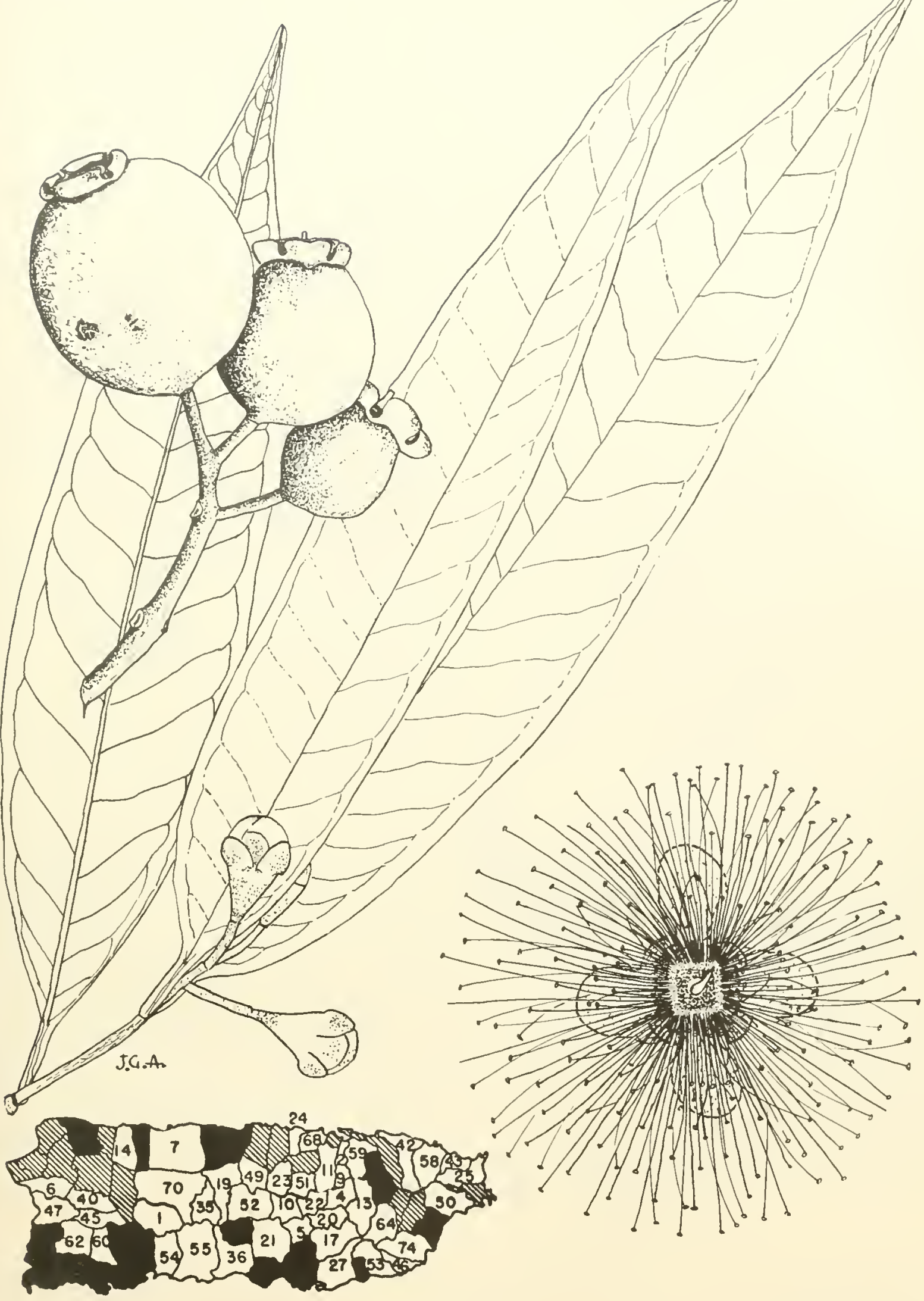




\section{MYRTLE FAMILY (MYRTACEAE)}

\section{Manzana malaya, Malay-apple}

Malay-apple, an exotic tree occasionally planted for n'nament, sharle, and windbreaks, is identified by: (1) an ereet stem and dense conical or columnar erown of dark green foliage; (2) opposite, large, oblong, mostly dark green, leathery leaves, short-stalked, with blades $7-12$ inches long and $3-5$ inehes broad, long-pointed at apex and shortpointed at base: (3) pretty purplish-red or rosepurple flowers composed of a mass of spreading stanens $21 / 2-3$ inches across, like pins in a pin cushion, several elustered together along twigs back of leares and hidden in crown: and (4) red (sometimes pink or whitish) pear-shaped fruits 2-3 inches long and 1-2 inches in diameter, with 4 sepals at apex and the white, slightly sour edible flesh with applelike flavor.

A small to medium-sized evergreen tree 15-40 feet tall and 3-8 inches in trunk diameter, or larger. The bark is light brown, smoothish to slightly fissured. Inner bark is brownish streaked and slightly astringent. The twigs are light brown, green when young, with slightly raised leaf scars.

Petioles are $1 / 0-3 / 4$ inch long, stout, green to brown. Leaf blades are slightly curved upward on both sides of midrib, the lateral veins slightly sunken and conneeted near mar'gins, the upper surface dark green or green and usually slightly shiny, and the lower surface dull light green. Seattered minute gland dots are risible with a lens when the blade is held toward the light.

Several to many odlorless flowers are borne in clusters $4-5$ inches across, almost stalkless on a short branched green lateral axis (eyme or paniele). The flower has a fumnel-shaped, light pulplish-green base (hypanthium) $3 / 4$ inch long and $\pi / 16$ inch wide at top, enclosing the ovary and extending as a broad tube $3 / 16$ inch beyond. There are 4 broad, rounded, thickened, persistent sepals 1/8-3/16 inch long: 4 spreading, rounded, eoncave, purplish-red petals $1 / 2$ inch long; the mass of stamens 1-11/4 inches long, purplish red with yellow dot anthers; and pistil composed of inferior 2-celled ovary and persistent purplish-red straight style about $1 \frac{1}{4}$ inches long. As the stamens fall, the ground under the tree becomes a purplish-red carpet.

The berries have thin soft skin, crisp juiey flesh with pleasant flavor, and 1 large rounded light
Eugenia malaccensis L.*

brown seed about $3 / 4$ inch in diameter. Seeds recorded as to to pound. Flowering and fruiting nearly through the year.

The sapwood is light brown. The rood is deserihed as hard, tough, very heary, but tending to warp, and diffienlt to work. The tree is not suffieiently common for its wood to be mueh used in Puerto Rico or the Virgin Islands.

Widely eultivated elsewhere for the fruits, which are eaten law or also cooked or preserved or used for wine, and for ornament. One author places this among the most beantiful flowering trees of the tropics. It is said that the slightly sour stamens ean be prepared into salads. Easily propagated from seed and of moderately rapid growth.

Malay-apple was introdnced into Jamaica in 1793 from Tahiti by Captain Bligh of the British ship P'ovidence. This, along with breadfruit, was one of several trees brought in to provide inexpensive food for the slaves.

Limited elniefly to urban areas in Puerto Rico, planted around buildings but oceasionally also for windbreaks in rural areas on the moist coast. Also in St. Croix.

Raxge. - Native probably of Malay Archipelago or Malay Peninsula. Widely planted through the tropies, ineluding Trest Indies and continental tropical Ameriea. Uncommon in southern Florida.

OTHER COMMON NAMEs.-pomarrosa malaya, ohia (Puerto Rieo); cajuilito sulimán (Dominiean Republic); pomarrosa de Malaca, pera (Cuba); marañón japonés (EI Salvador); manzana (Costa Riea); marañón de Curaçao, manzana de Faiti (Panama); pomarrosa de Nalaea (Colombia); pomagás, pomagada (Venezuela); Malay-apple, ohia (United States, English); Otaheite-apple (Jamaica, British West Indies) ; pomerac, pomme malae (Trinidad); Freneh-eashew (British Guiana); jamelae (French); pomme de Tahiti, pomme de Malaisie (Guadelonpe); pommerak (Surinam) : jambeiro, jambo enearnado (Brazil).

Botaxical sronyus.-Jambosa malaccensis (L.) DC., Syzygium malaccense (L.) Merrill \& Perry. 


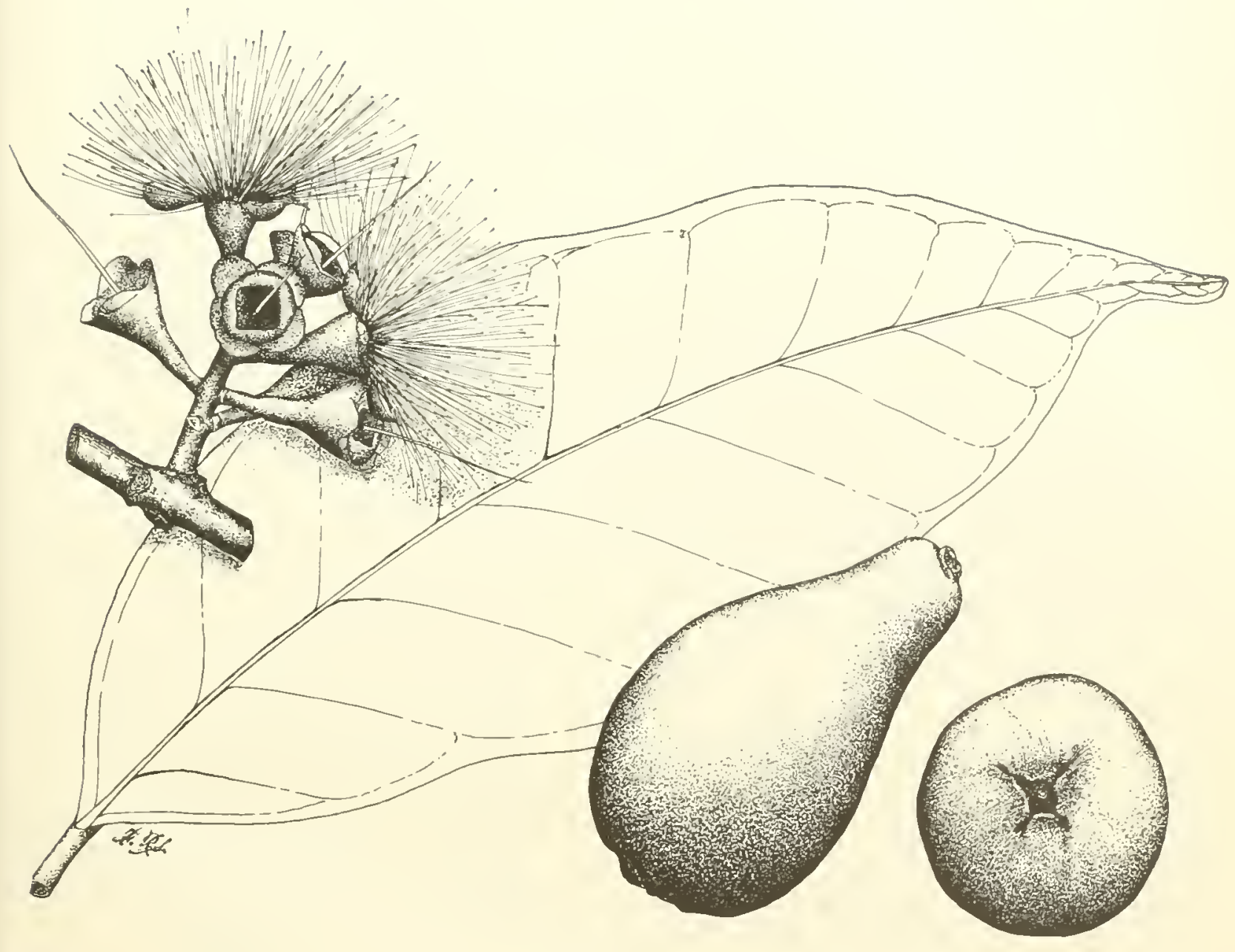




\section{MYRTLE FAMILY (MYRTACEAE)}

\section{Hoja menuda, spiceberry eugenia}

One of sereral known as hoja menuda, this species of dry areas of southwestern Puerto Rico is recognized by the small ovate drooping leaves nearly in the shipe of a diamond (rhomb), as the scientifie name indicates. Other distinguishing characters are: (1) opposite leaves 11/4-2 inches long and 5/8-11/4 inches broad, blunt ty long-pointed at apex and short-pointed at base, lateral veins inconspicuons, and with many gland dots including black dots on lower surface; (2) few to several white flowers with $t$ petals, $1 / 2$ inch across the spreading stamens, in lateral clusters at leaf bases or back of leaves; and (3) rounded red to black berries $3 / 8-5 / 8$ inch in diameter, broader than long, with sepals at apex.

A small erect evergreen tree $20-25$ feet high with trunk 2-8 inches in diameter, or shrubby. The brownish-gray bark is smooth, peeling off in flakes. Inner bark is light brown and slightly bitter. The slender whitish-gray twigs are often drooping.

The petioles are brown yellow, or reddish tinged, 1/8-1/4 inch long. Blades are slightly thickened, leathery, and stiff, not tootheri on edges, dull dark green above and yellow green beneath.

The flower cluster (umbel) without a main stalk is composed of flowers on slender spreading stalks $1 / 4^{-5 / 8}$ inch long. The flower has a short basal tube

\section{Eugenia rhombea (Berg) Krug \& Urban}

(hypanthium) enclosing the inferior ovary, 4 rounded sepals less than $1 / 8$ inch long, 4 white rounded petals $3 / 16$ inch long, many spreading stamens, and style. The fleshy 1 -seeded fruits change color from red to black as they ripen. Recorded with flowers in July and with fruits in January and July.

The light brown wood is very hard and heavy. Recanse of the small dimensions, it is used chiefly for posts, stakes, and fuel. The wood is not durable in the ground.

In cutover dry forests and thickets in the dry limestone region of southwestern Puerto Rico. Also in Desecheo, Mona, Muertos, St. Croix, St. Thomas, and St. Johm.

PCBLIC Forest.-Guánica.

Rixge,-Lower Florida Keys, Bahamas, Cuba, . Tamaica, Hispaniola, Puerto Rico and Virgm Islands, and Lesser Antilles from St. Martin to Gnadeloupe.

Other common names.-guayabilla de costa (Puerto Rico); arrayín (Dominican Republic); mije, guairaje (Cuba); spiceberry engenia, red stopper, stopper (United States); red stopper (Bahamas) : rodwood (Barbuda): myrte, bois myrte (Haiti); merisier (St. Barthéleny); merisier rouge (Gnadeloupe). 


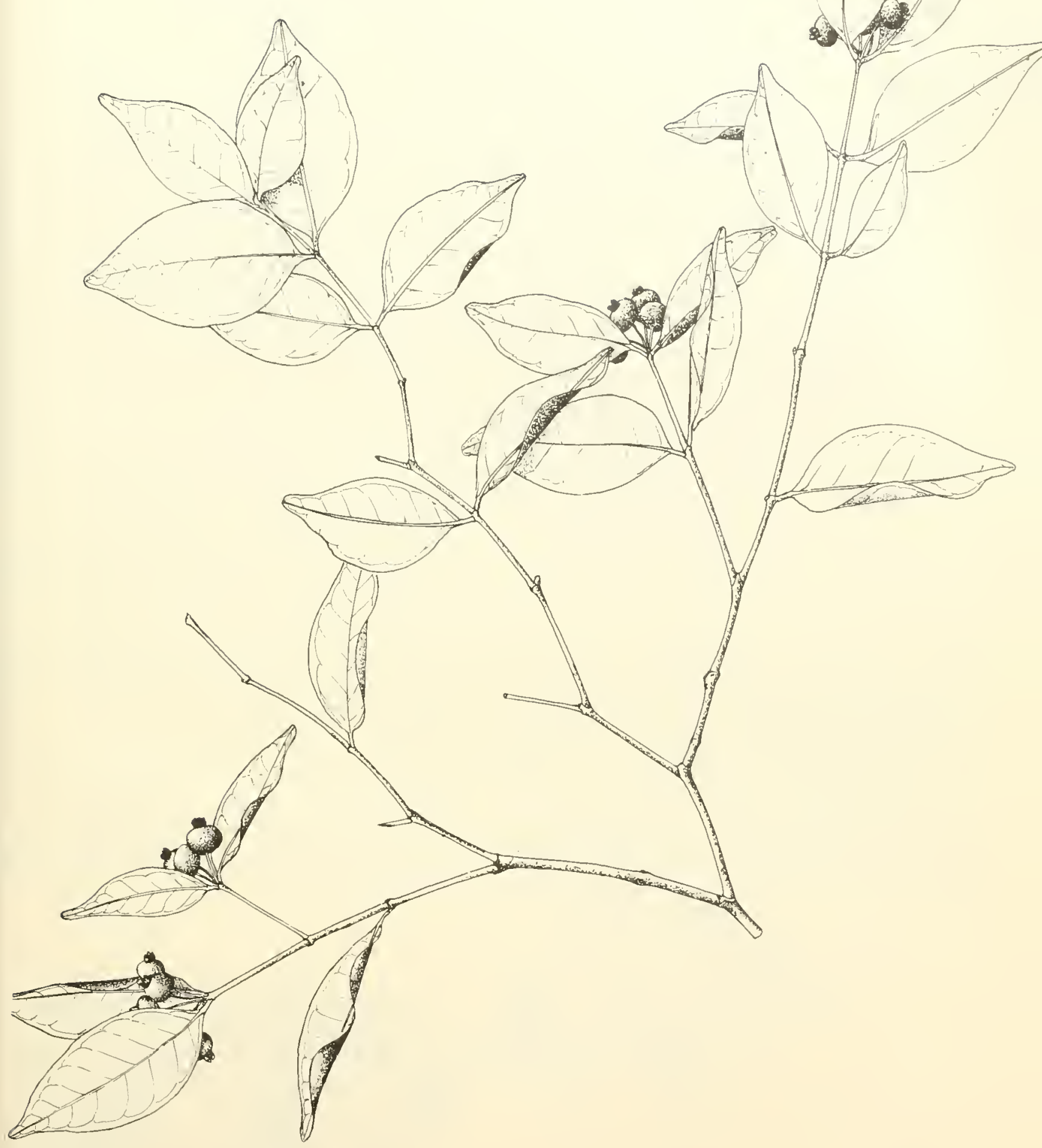

190. Hoja menuda, spiceberry eugenia Eugenia rhombea (Berg) Krug \& Urban Natural size. 


\section{MYRTLE FAMILY (MYRTACEAE)}

\section{Guayabota}

Known only from Puerto Rican mountains, this medinm-sized tree is identified by: (1) erect dense columnar crown; (2) light gray or whitish bark, scaling off in plates: (3) opposite, elliptic, thick and leathery leares $21 / 2-31 / 2$ inches long and 11/121,2 inches broad, ronnded or blunt-pointed at apex and short-pointed at base, with minute gland dots, and on short petioles $1 / 4^{-3 / 5}$ inch long; (4) large spreading white $t$-petaled flowers about $1 \frac{1}{2}$ inches across the numerous stimens, few at or near ends of twigs or singly at noues; and (5) rounded berries $3 / 4-7 / 8$ inch in diameter, with 4 unequal sepals at apex, resembling small guayabas.

An evergreen tree reaching 60 feet in height and more than 1 foot in trunk diameter. The stout twigs are light gray. Leaf blades have margins which may be slightly tumed under, the npper surface green and slightly shiny, the lower surface paler.

Flowers are borne on stout, often flattened, stalks $1 / 2-11 / 4$ inches long. The bell-shaped base (hypanthium) is nearly 1/4 inch long and broad, with $t$ persistent, rounded concave, yellow-green sepals, 2 nearly $3 / 8$ inch long and 2 half as long; there are 4 spreading rounded petals $1 / 2-5 / 8$ inch long: numerons spreading stamens; and pistil with 2-celled inferior ovary and long style.

The fleshy fruit, dark green when immature, is minutely rarty on the surfice, with 1 large irregularly roumded brown seed. Flowering and fruiting nearly through the year except in spring.

\section{Eugenia stahlii (Kiaersk.) Krug \& Urban}

This attractive wood has pinkish-brown sap. wood, gray-brown heartwood, and growth rings marked by narrow darker bands. It is very hard, leavy (specific gravity 0.73 ), tough, strong, finetextured, with irregular grain, and with mild pleasant odor. Rate of air-seasoning and amount of degrade are moderate. Machining characteristies are as follows: planing and mortising are good; shaping, turning, and boring are excellent; sanding is poor: and resistance to screw splitting is very poor. The wood has high but uniform shrinkage during seasoning and is moderately difficult to work because of its hardness. It is very susceptible to attack by dry-wood termites and is reported to be variable in decay resistance.

ITses include general construction, crossties, oxcart tongues, poles, and posts. The wood is suitable also for furniture, cabinetwork, tumery, carving, interior trim, tool handles, farm implements, and boatbuilding.

Commonest in the transition zone between the lower and upper mountain forests of Puerto Rico, between 1,500 and 3,000 feet elevation. Appar. ently a slow-glowing tree.

PUlinic Forests.-Carite, Guilarte, Luquillo, Toro Negro.

MTNICIPALITIFS WHERE ESPECIALLY COMMON.$13,30,44$.

Range.-Mount ains of Puerto Rico only.

Naned for Agustín Stahl (1842-1917), Puerto Rican physician and botanist, who collected specimens of this species. 



\section{MYRTLE FAMILY (MYRTACEAE)}

\section{Cieneguillo}

A small to medium-sized widely distributed tree, chararterized by: (1) twigs, petioles, bucls, and bramehes of flower clusters densely and finely reddislı brown or light brown hairy ; (2) opposite, oblong to elliptic, long-pointed leaves with minute gland lots, thick and stiff and hanging downward. with lateral veins much sunken on the shiny upper surface; (3) masses of fraglant, delicate, small white flowers with 5 petals and numerons spreading stamens $5 / 8$ inch across; and ( $t$ ) oval berry about $1 / 4$ inch long with calyx at apex.

In evergreen tree 10-30 feet tall and to 6 inches in trumk diameter, with sprearling crown. The gray bark is smoothish, becoming slightly cracked and fissured, and the trunk grooved. Inner bark is pinkish and bitter.

Petioles are about 1/4 inch long, and blades 21/2-6 inches long and 1-21/2 inches wide, shortpointed at base, not flat but the sides bent up slightly from the sunken midrib and the apex bent downward, inconspienously hairy on veins and lower surface. The upper surface is shiny vellow green to green with the lateral veins nearly parallel to midrib, and the lower surface dull whitish green with lateral veins much raised. Older leaves and twigs often are partly covered by black masses of sooty mold fungus.

Flower clusters (panicles) $2-4$ inches long and broad are terminal and lateral, those at apex actually at base of leaves and beside the terminal bud, bearing many nearly stalkless flowers on the finely hairy branches, Flower buds are whitish and rounded, about $1 / 8$ inch in diameter. The most conspicuous floral parts are the numerous threadlike curved stamens spreading more than $5 / 8$ inch across, each about $1 / 4$ inch long and ending in a dotlike anther. The whitish hairy tubular base (hypanthium) 1/16 incl long encloses the inferior -celled orary and bears the other parts. There are 5 whitish hairy, rounded and widely spreading sepals about $1 / 8$ inch long and 5 round white petals less than $3 / 16$ inch long, curved backward and near-
Myrcia deflexa (Poir.) DC.

ly hidden by the stamens. In the center of the stamens is a tiny white style. Flowering and fruiting nearly through the year.

'The sapwood is whitish and the heartwood reddish. The rood is hard, heary (specific gravity (0.8), and stlong. It is made into stakes, posts, and handles. Elsewhere it is employed in construction, carpentry, and vehicles.

I shade-enduring understory tree of the lower mountain forests of Puerto Rico, in some places extending into the upper mountain region.

Prblic Forests.-Carite, Guilarte, Luquillo, Marica, Toro Negro.

Range.-Cuba, Hispaniola, Puerto Rico, Lesser Antilles from Guadelompe to Grenada, and Trinidad. Also in Colombia, Tenezuela, Guianas, and northern Brazil.

Other common xames-aquey del chiquito (Dominican Republic); goyavier (Grenada); brésillette, petite-feuille, goyavier quene-de-rat (Guadeloupe).

Botaxicil SYNoNYM.-Myrcia ferminea Berg.

This genus is represented by 4 more native species of small trees in addition to the 2 illustrated here. The group has flowers in terminal and lateral branched clusters; caly $x$ of 5 sepals which remain attached at apex of round or elliptic berry fruit; and 5 white petals. Two species (Myroia berberis DC. and $M$. paganii Krug \& Urban) were recorded from Puerto Rico long ago but have not been collected there in recent years.

Limoncillo del monte (Myrcia citrifolia (Aubl.) Urban), of moist areas in Puerto Rico and the Tirgin Islands, has ovate to oblong leaves $3 / 4-21 / 4$ inches long, blunt or short-pointed at apex, edges turned under, hairless or nearly so, and shiny, and round fruit $1 / 4-3 / 8$ inch in diameter.

Guayabacón (Myrcia leptoclada DC.), of moist forests in Puerto Rico, has elliptic leaves $2-4$ inches long, with long-pointed apex, edges not turned under, and round fruit $1 / 4$ inch in diameter. 


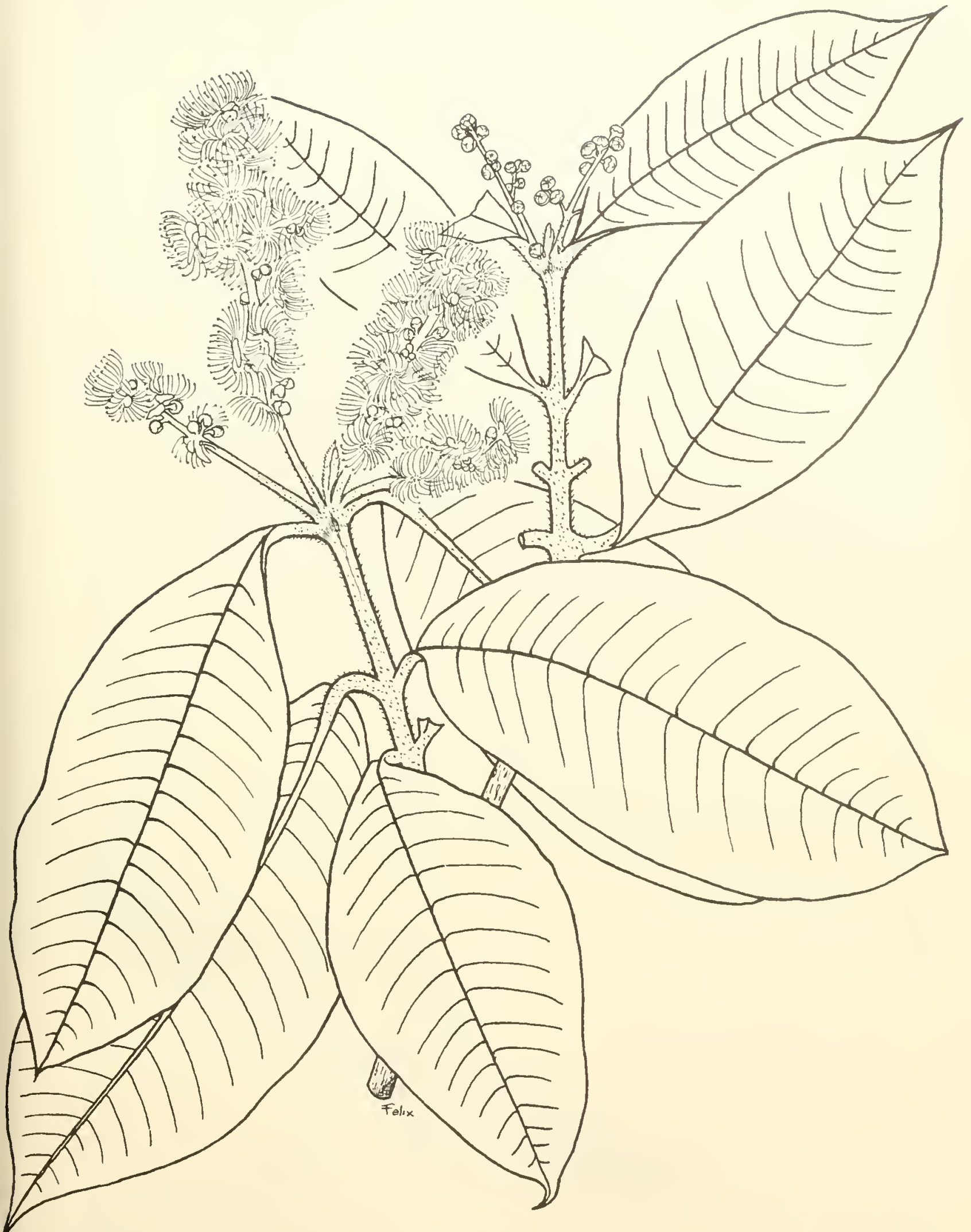




\section{MYRTLE FAMILY (MYRTACEAE)}

\section{Hoja menuda}

This small tree with opposite small leares bearing minute gland dots is easily distinguished from others with the same common name by the very short-stalked leares shiny green to dark green, slightly thickened, with very long tapering point and numerous prominent, straight, nearly parallel lateral veins. Other characters are: (1) numerous small white flowers with 5 rounded petals, about $3 / 8$ inch across the many spreading white stamens, in lateral and terminal clusters mostly $1-11 / 6$ inches long: and (2) elliptic or rounded blackish berries $1 / 4^{-5 / 16}$ inch long, with ring of sepals at apex.

An evergreen tree to 30 feet high and 4 inches in trunk dianeter or often a shrub. The brown or gray bark is rough, fissured, and flaky or divided into many small plates. Inner bark is brown or dark red and slightly astringent and bitter to the taste. The brown twigs are slender and finely hairy.

Petioles are $1 / 16$ inch or less in length and finely hairy. The thin blades are $1-3$ inches long and $1 / 2-1$ inch wide, rounded or short-pointed at base, with smken midrib, edges slightly turned under, beneath paler green and slightly shiny, hairy when young but nealy hairless at maturity.

Flower clusters (panicles) have slender hairy branches. The fragrant flower has a hairy tubular' base (hypanthium) 1/16 inch long and broad, which encloses the inferior 2-celled ovary and bears the other parts; 5 minute blunt-pointed
Myrcia splendens (Sw.) DC.

hairy sepals, 5 white rounded petals nearly $1 / 8$ inch long, hairy on outside: mumerous white stamens nearly $3 / 16$ inch long; and style mole than $1 / 8$ inch long.

The fleshy fruits are green when immature, turning to dark blue or blackish, and have thin flesh and 1 large seed. Elsewhere they are reported to he erlible. Flowering and fruiting nealy throngl the year.

The sanwood is light brown to reddish brown and hard. "The hardwood is used for posts.

Common in forests and openings in moist areas in the lower mountain regions of Puerto Rico. Also in St. Croix and Tortola and reported from St. 'Thomas.

Public forests.-Luquillo, Carite, Maricao.

Rixge.-Cuba, Jamaica (?), Hispaniola, Puerto Rico, St. Croix, Tortola, Lesser Antilles from St. Martin to St. Tincent and Barbados, and Trinidad and Tobago. Also Colombia to Peru, Bolivia, and Brazil.

Other connox Naues.- rama menuda (Puerto Rico) : birchberry, pumchberry (Virgin Islands); arrajuán, comecará, tinajero (Cuba); vicho caspi (Peru): hlack-birch (Montserrat); bois créole (At. Incia); red rodwood (Barbados); wild guara (Trinidad); small-leaf (Tobago); ibbibanaru (British Guiana) ; petit merisier (Guadelonpe); merisier petites feuilles, ti feuilles, bois créole (Martinique); Surinam-cherry (Dutch West Indies); meerilang (Surinam). 


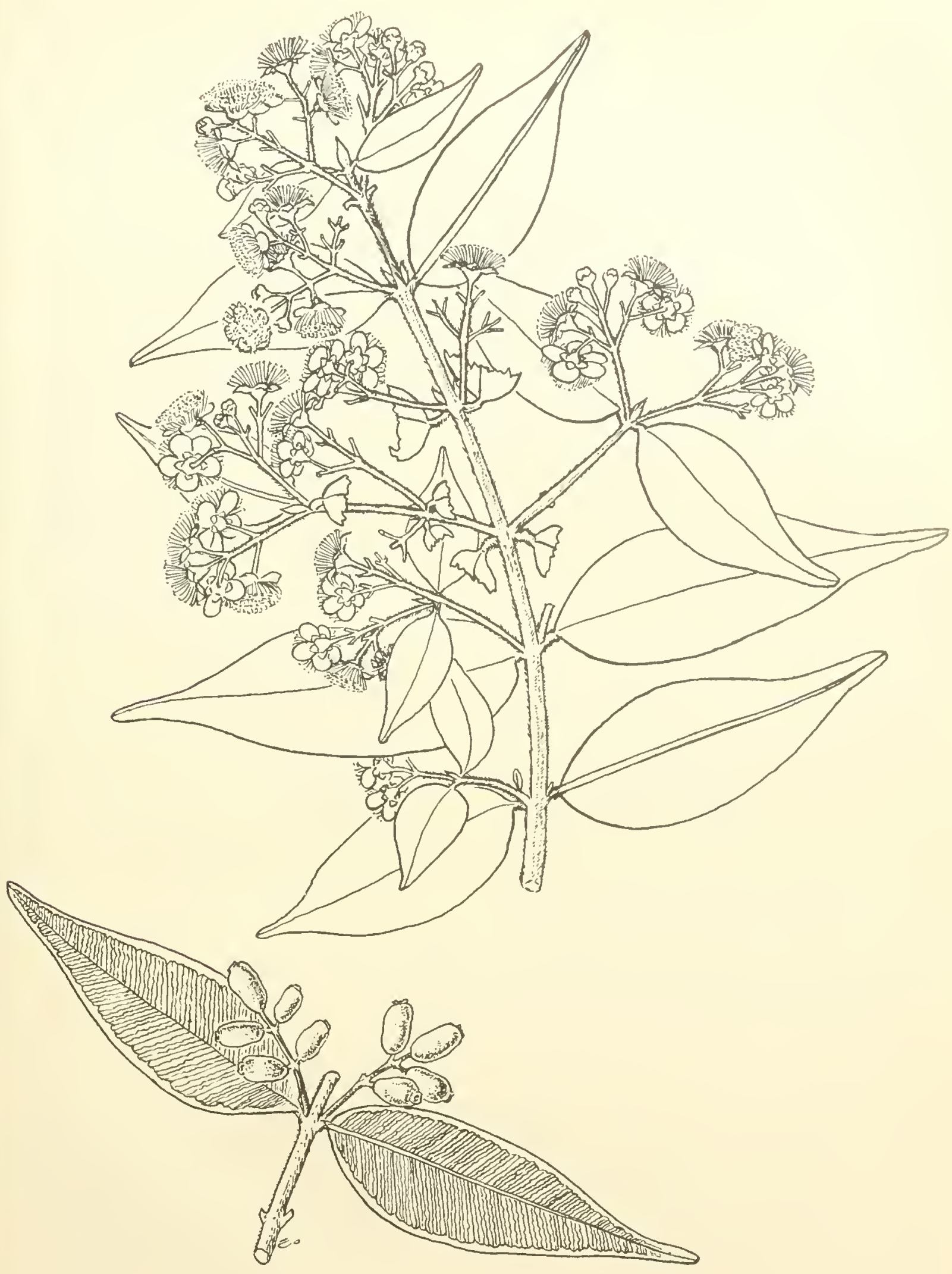


194 Malagueta, bay-rum-tree

The bay-rum-tree or malagueta, including the variety ausú, is native and also cultivated both for the essential oil in its leaves and twigs and for omament and shade. It is easily recognized by the strong pungent odor of the leares when crushed. Other distinguishing characteristics are : (1) erect form with a dense columnar dark green crown: (2) smooth gray to light brown bark peeling off in thin strips exposing lighter gray shades beneath: (3) opposite, elliptic or obovate, mostly small, stiff and leathery leaves rounded at both ends or the apex notched or sometimes shortpointed, with minute gland dots, shiny dark green on uppes" surface and beneath paler or finely gray hairy, with midrib sunken and edges rolled under" (4) white flowers $3 / 8$ inch or more across the 5 petals, several to many in lateral and terminal branched clusters; and (5) the romded or elliptic fleshy black (or finely gray hairy) fruits $5 / 16^{-1 / 2}$ inch in diameter.

This is a variable species with races differing in shape, size, color, and hairiness of leaves, shape and hairiness of fruit, and in amount and quality of oil. One variety called ausí (Pimenta racemosa var. grisea (Kiaersk.) Fosberg) is characterized by finely gray or white hairy coats on under surface of leaves, young twigs, branches of flower clusters, and fmits.

A small to medium-sized evergreen tree to 40 feet high and 8 inches or more in trunk diameter, the trunk often slightly angled and groored, or sometimes shrubby. Inner bark is pinkish and slightly bitter and astringent. The twigs are green or dark green, with gland dots, hairless (or finely gray hairy), and angled when young, becoming brown.

The leaves have short, green, reddish-tinged petioles $1 / 8^{-3} / 8$ inch long and blades $11 / 4-4$ inches long and 1-21/2 inches broad or larger (recorded to 6 inches long), hairless to finely gray hairy beneath.

The flower clusters (cymes) are 1-3 inches long and broad, gland-dotted, and bear fragrant glanddotted flowers on shont stalks. There is a light green tubular base (hypanthium) less than $1 / 8$ inch long and broad, extending beyond ovary; 5 broad, spreading sepals less than $1 / 16$ inch long; 5 white rounded petals more than $1 / 8$ inch long and widely spreading; numerous white stamens $3 / 16$ inch long: and pistil composed of inferior 2-celled ovary and slender, slightly bent, white style $3 / 16$ inch long.

The berrylike fruits have sepals at tached at apex and contain a few brown seeds more than $1 / 8$ inch long. Flowering mainly in spring and summer (April to August) and maturing fruit in late summer and fall (August to October.).

The sapwood is light brown, and the heartwood brownish yed or blackish and mottled. The wood is very hard, very heavy (specific gravity 0.9),
Pimenta racemosa (Mill.) J. W. Moore

strong, tough, durable, and resistant to attack by dry-wood termites. Employed for posts and in carpentry, it is said to split readily and to be excellent for ficel.

The main product is myrcia oil (bay oil) obtained by distillation of the leaves and twigs and which is the important ingredient in bay rum, used in cosmetics and medicines. A yield of more than 1 pound of bay oil has been extracted from 100 pounds of leaves. Bay rum was originally prepured ly distilling the leaves in rum. Compound myreia spirit (bay rmm) is composed of bay oil, olange oil, pimenta oil, alcohol, and water.

Confined chicfly to the dry slopes of the lower Cordillera region of southwestem Puerto Rico, but commercial plantations grow near Adjuntas, Patillas, and Guayama. Also in Vieques, St. John, St. Thomas, and Tortola. Reported long ago from St. Cloix and now planted there. In St. John large forests of this species under management have prodnced oil of superior quality.

Punlic forests.-Carite, Guajataca, Luquillo, Maricao, Susúa.

RAxGe.-Through West Indies from Cuba and Jamaica to Grenada and Tobago. Also in Venezuela and Guianas. Planted in sonthern Florida, Bemmuda, Bahamas, and Trinidad, and in East Indies.

Other common Names.-ausú, limoncillo (Puerto Rico); wild cilliment, wild cimnamon, cinnamon (Virgin Islands); malagueta, ozúa, canelillo (Dominican Republic); pimienta de Tabasco (Cuba) ; bay-rum-tree, West Indian bayberry (English); bayberry-tree, wild cinnamon, wild olive (Jamaica); cinnamon (Montserrat, Grenadines); bayleaf (Barbuda, Tobago); bois d'Inde Français (Haiti); bois d'Inde (Guadeloupe, Martinique, St. Lucia); bay boom (Sminam).

Botanical srNoNyms. - Amomis caryophyllata (Jacq.) Krug \& Urban, Pimenta acris (Sw.) Íostel.

Botanical varietr.-ausú, Pimenta racemosa var. grisea (Kiaersk.) Fosberg (synonyms $P$. acris var. grisea Kiaersk., Amomis caryophyllata var. grise (Kỉaersk.) Ḱrug \& Urban, A. grisea (Kiaersk.) Britton).

The generic name Pimenta is taken from the Spanish name for allspice, pimienta (Pimenta dioica (L.) Meru.*; symonyms $P$. offcinalis Lindl., $P$. pimenta (L.) Cock.). This related species of Cuba, Jamaica, and continental tropical America is sometimes planted in Puerto Rico and the Virgin Islands. It has elliptic or oblong leaves 3-6 inches long and many small white flowers about $5 / 16$ inch across, with 4 petals. The dried green berries $1 / 4$ inch or less in diameter, with a flavor resembling a mixtme of clove, cinnamon, and nutmeg (or all spices), are used as a condiment. 


\section{MYRTLE FAMILY (MYRTACEAE)}

\section{Guayaba, common guava}

Guayaba or guava is a well-known cultivated tree, because of the paste and jelly made from its fruits. It is charaeterized by: (1) shrubby form, the stems seldom straight; (2) smooth reddishbrown bark which is thin and seales off in thin slieets; (3) oblong or elliptie leaves with sunken reins and minute ghand dots; (4) large white flowers about 11 in inches arross the 4 or in large petals, mostly borne singly at leat bases; and (5) rounderl (sometimes pear-shaped) yellow edible fruits $11,-2$ inches in diameter, with 4 or 5 sepals at apex.

Generally a shub or low, widely spreading evergreen tree 10-15 feet high and to 8 inches in diameter. Imner bark is lrown and shightly bitter. Toung twigs are $t$-angled and slightly winged, hairy, and green, beeoming brown.

The leaves have short petioles $1 / 8-1 / 4$ inch long. Iseaf blades are $2-t$ inches long and $1-2$ inches wide, short-pointer or rounderl at both ends, slinhtly thickened and leathery, with edges a little turned under, the upper surface green or yellow green, slightly shiny, almost hairless at maturity, witl the many parallel lateral reins sunken, and lower surface paler, finely hairy, and with lateral reins raised.

The fragrant flowers are scattered on stalks $3 / 4-1$ inch long at base of a leaf. The green finely hairy tubular base (hypanthium) 3/s imeb long and broad eneloses the ovary and bear's the other parts. There are 4 or 5 yellow-green, slightly thickened, finely hairy sepals $3 / 8-5 / 8$ ineh long: 4 or 5 elliptic rounded white petals 5/8-3/4 inch long; and very numerous brushlike spreading stamens with slender white filaments averaging $1 / 2$ inch long: and pistil consisting of the inferior 4 - or 5-celled ovary and slender white style $\% / 16$ inch long.

Cultivated varieties of this variable speeies differ in fruit eharacters. The fruits (berries) have a strong mellow odor at maturity. Within the thin, yellow, slightly sour, edible outer layer

\section{Psidium guajava L.*}

ale numerous yellow seeds more than $1 / 8$ inch long in a juiey, pinkish or yellow pulp. Flowering and fruiting nearly throughout the year.

The sapwood is light brown, and the heartwood brown or reddish. The hard, strong, heary wood (speeifie glavity 0.5 ) has been used for handles and implements.

Commonly eultivated as a fruit tree. The fruits are unusually rich in ritamin C. The outer layer of the fruit is preserved and camned commercially, as is the juice. Guara powder has been prepared from the dehydrated fruits also. Elsewhere the bark has been employed in tanning. Extracts from leaves, bark, roots, and buds have served in folk medieine.

Forming thickets and spreading in pastures, chiefly on the coastal plains but also in the lower mountain regions of Puerto Rico. Mlso in Mona, Tieques, St. Croix, St. Thomas, St. John, and Tortola.

RANGe-Native of tropieal America probably from sonthern Mexico sonth to South Ameriea, the range greatly extenrled beyond through eultivation. Planted and naturalized also in sonthern Floricla including Florida Keys (grown also in California), Bermuda, and throughout West Indies from Balumas and Cuba to Trinidad, and soutl to Brazil. Cultirated in Duteh West Indies. Also introduced in tropical and subtropical regions of the Old World.

Other common NAMes.-guava (Virgin Islands): guayaba, guayava, guayabo (Spanish); guayaba pernlera (Nicaragua); guayabo dulce (Colombia); arazá-puitá (Argentina); common guara, guara (United States); guara (English); wild gurva (British IIonduras) ; goyave, goyariel (French); goyavier à fruits (Guadeloupe); guyaba, goeajaaba, guara (Dutch West Indies); guave, goejaba (Surinam): goiaba, gobiabiera (Brazil). 


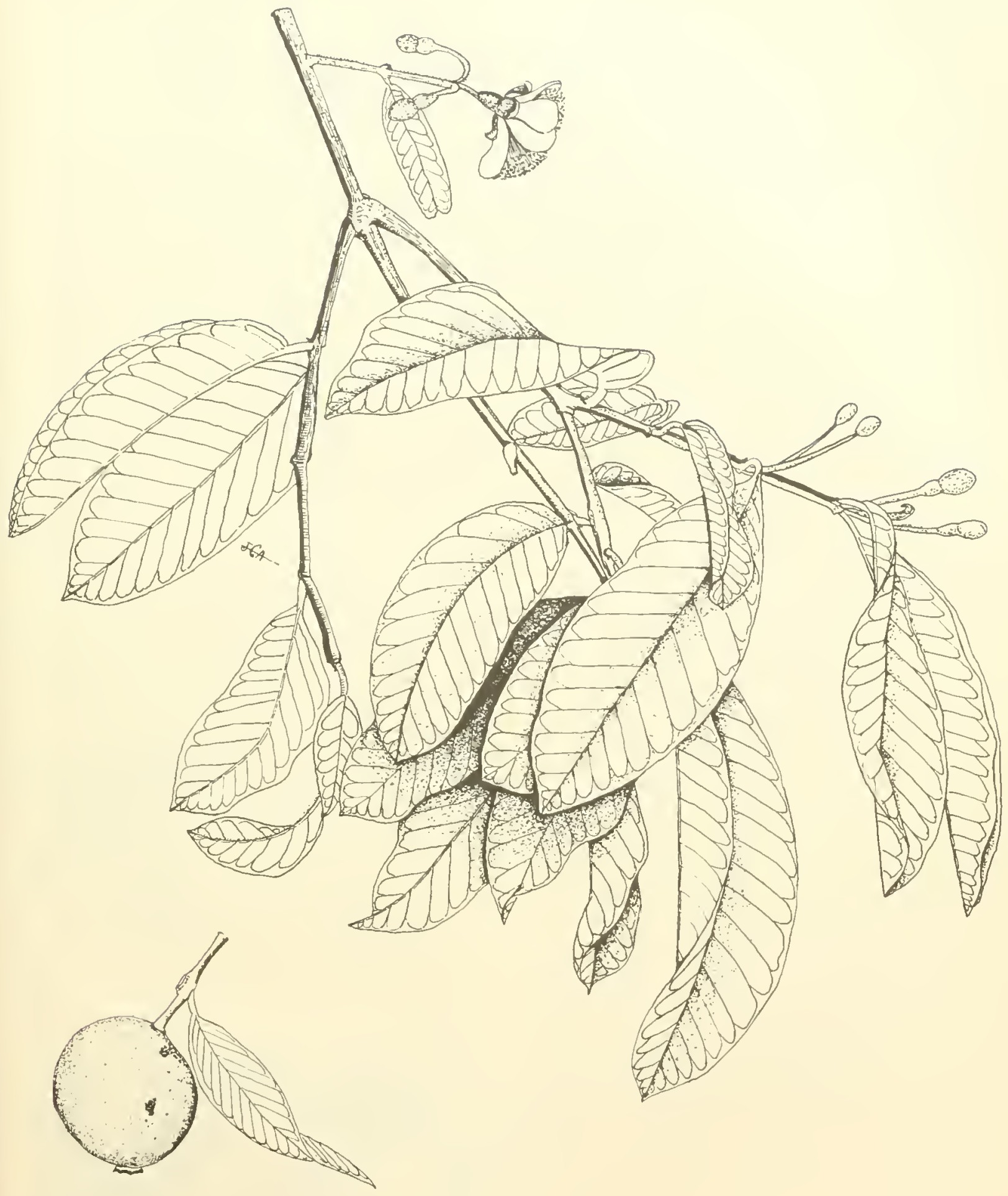




\title{
MELASTOME FAMILY (MELASTOMATACEAE)
}

\author{
Kes to the 4 species illustrated (Nos. 196-199)
}

A. Leaves broadly orate, with 7 main veins from base, reddish tinged above, bristly hairy; petioles and twigs with stickr red hairs-197. Heterotrichum cymosum.

AA. Leaves narrow, elliptic to lance-shaped, with 3 or 5 main veins from base, hairless or soft hairy.

B. Leaves mostly rounded at apex: minute brown scales on retioles, blades, and soung twigs-196. Calycogonium squamulosum.

BB. Leaves long- or short-pointed at apex ; not scaly.

C. Leaves grcen on botll surfaces, hairless or nearly so, edges finely wary-toothed-198. Miconia prasina.

$\mathrm{CC}$. Leaves densely whitish hairy on lower surface; petioles and young twigs light brown, finely scurfy hairy199. Tetrazygia elaeagnoides.

\section{Jusillo}

This medium-sized tree, confined to the mountains of Prerto Rico, is readily distinguished by: (1) the erect twigs frequently with clusters of erect leaves on nearly horizontal brinches; (2) the opposite, elliptic, thick, yellow-green leaves with 3 main reins from base, the 2 lateral veins near the tumed uncler edges; (3) young twigs, petioles, flower stalks, flowers and fruits covered with small brown scales; and ( 4 ) the flowers more than $3 / 8$ inch long and broad and with 4 white petals, usually 3 together on a sliort stalk at base of leaf.

An evergreen tree 30-50 feet high and to 1 foot in trunk diameter, with spreading cromn of nearly horizontal branches and erect, leafy, brown or gray twigs. The bark is brown or gray, smoothish or slightly fissured, the inner bark also brown and almost tasteless.

Petioles are $1 / 1^{-1 / 2}$ inch long, and blades $11 / 4^{-3}$ inches long and $1 / 2-11 / 2$ inches broad, the apex rounded or with a minute point, the base shortpointed. The upper surface is yellow green to green, slightly shiny, with inconspicuous minute dotlike scales, and with sunken midrib, and the lower surface paler yellow green and with minute brown scales.

Flowers are borme at the end of a curved, brown, scaly stalk about $1 / 4$ inch long. The tubular base (hypanthium) and tubular 4 -lobed calyx, both scaly brown, together are about $3 / 16$ inch long and broad. angled and slightly flattened in the bud; there are 4 spreading, white, reddish-tinged petals $1 / 4$ inch long; $S$ stamens; and pistil with inferior 4 -celled ovary and slender style $5 / 16$ inch long.

\section{Calycogonium squamulosum Cogn.}

The ronnded berrylike fruit, with calyx remaining attached, is sealy brown, $3 / 1$ in inch in diameter. It contains numerous minute brown seeds about $1 / 32$ inch long. Flowering mainly in summer and fall (June to October), the fruit maturing in fall and winter.

The sapwood is bright yellow. The attractive heartwood is pinkish brown to pale brown, with widely spaced black streaks. The wood is hard, heary (specific gravity 0.74), strong, fine-textured, with generally straight grain, and without growth rings. Rate of air-seasoning and amount of degrade are moderate. Machining characteristics tre as follows: planing, sauding, and resistance to serew splitting are poor; and shaping, turning, boring, and mortising are good. The wood is very susceptible to attack by dry-wood termites. It is of doubtful durability in contact with the ground, and old forest trees are frequently decayed.

Uses are posts and poles, though preservative treatment is recommended. The wood seems suitable also for furniture, patternmaking, reneer and plywood, farm implements, tool haudles, heavyduty floong, turnery, boat parts, vehicles frames, heary construction, and bridge timbers.

In upper momtain forests in eastern and central Puerto Rico.

Perhic forests. - Carite, Guilarte, Luquillo, Toro Negro.

Raxae.- Knnown only from Puerto Rico.

Otiner conjox xames.-camasey jusillo, camasey negro (Puerto Rico). 

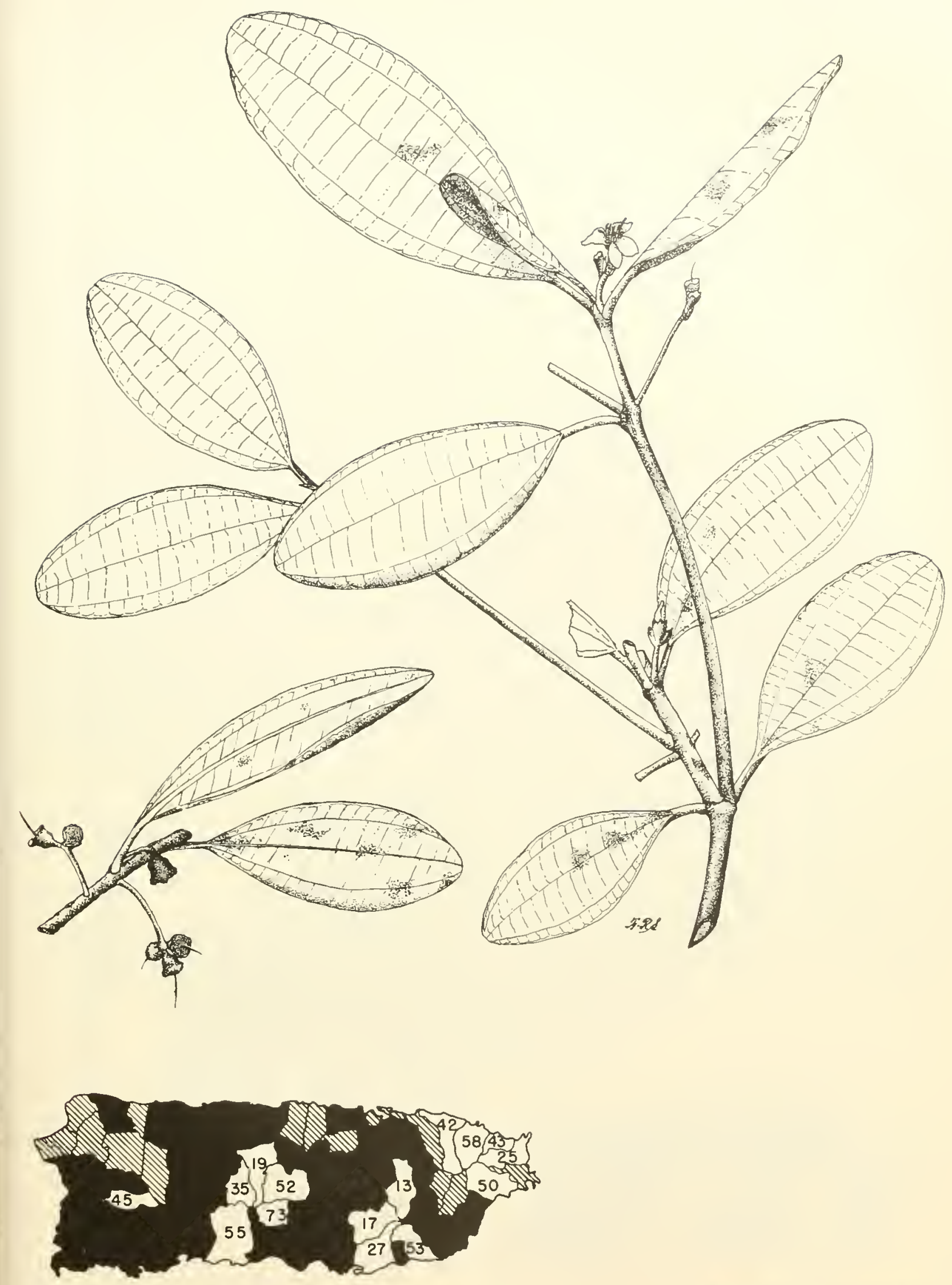

196. Jusillo

Natural size.

Calycogonium squamulosum Cogn. 


\section{MELASTOME FAMILY (MELASTOMATACEAE)}

\section{Camasey peludo}

This distinctive shrub or small tree limited to Puerto Rico is easily recognized by: (1) the straight, bristly, sticky (glandular), red hairs $1 / 16^{-1 / 8}$ inch long (and also dense minute starshaped hairs) on twigs, petioles, flower stalks, flowers, and frnits: (2) the opposite, lonw-petioled, bristly hairy, broadly ovate leaves reddish tinged above, with 7 reins from base: (3) large white flowers $3 / 4$ inch long and broad, with 6-8 spreading petals, several in terminal clusters: and $(t)$ the edible, purplish, very juicy berries $1 / 2$ inch in diameter.

An evergreen tree commonly less than 15 feet high and 3 inches in trunk diameter, sometimes larger, with spreading crown. The brownish-gray bark is smoothish and slightly fissured and thin. Inner bark is light brown and almost tasteless. The twigs are greenish and reddish tinged, becoming brown, with long straight red hairs.

The leares have petioles 11/2-31/2 inches long, and thin but stiff blades $4-7$ inches long and $3-41 / 2$ inches wide (smaller below flowers), long-pointed with slightly heart-shaped or rounded base. The edges are finely toothed and with bristly hairs, the upper surface is green and bristly hairy, and the lower surface yellow green.

Flower clusters (panicles) are branched, 3-5 inches long and broad. The very hairy tubular

\section{Heterotrichum cymosum (Wendl.) Urban}

base (hypanthium) encloses the inferior ovary more than $1 / 8$ inch in diameter and extends $1 / 16$ inch abore; the calyx tube is about $1 / 8$ inch long and $1 / 4$ inch across, widely spreading, with 6-S very narrow, very hairy, green lobes $1 / 4$ inch long; there are $6-8$ spreading white petals tinged with pink, almost 1/2 inch long: twice as many stamens as petals, pink, with yellow anthers; and pisti] composed of inferior. several-celled ovary and slentler, curved style $5 / 16$ inch long.

The berries, roinded with a flattened spreading top of calyx tnbe and lobes remaining, are slightly sweet to the taste. There are numerous tiny light brown seeds. In flower and fruit nearly through the year.

The sapwood is light brown, moderately hard, and medinmmeight (specific gravity 0.6). Because of the small size and spreading form of the tree the wood is little nsed.

Common and widely distributed in open areas, such as roadsides in the mountain forest regions of Puerto Rico.

Public forests.-Carite, Guilarte, Luquillo, Maricao. Río Abajo. Toro Negro.

Rasge.-Known only from Puerto Rico.

Other common names.-pelúa, terciopelo, eamasey de paloma (Puerto Rico). 


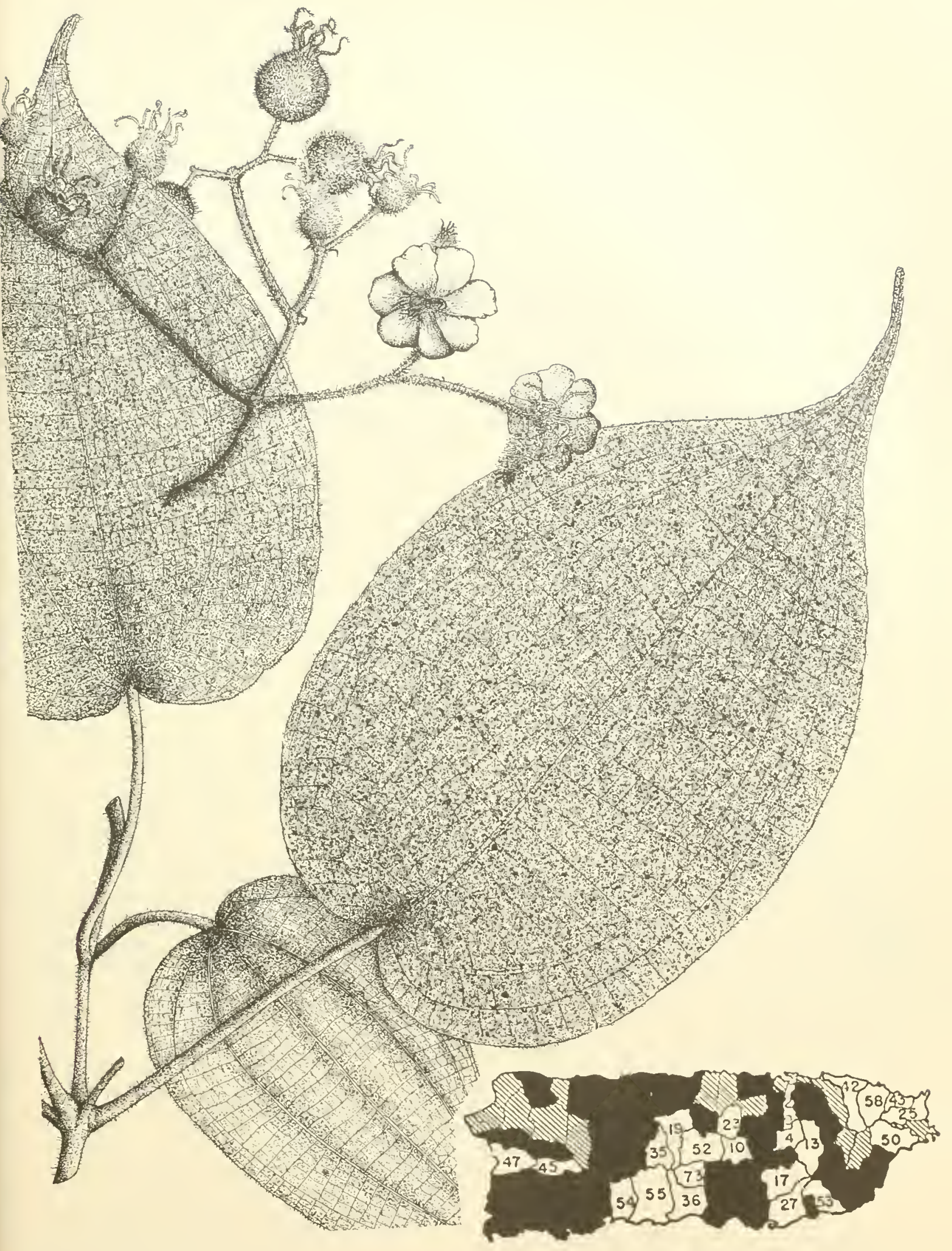

197. Camasey peludo 


\section{MELASTOME FAMILY (MELASTOMATACEAE)}

\section{Camasey}

Camasey (Miconio and related genera) is represented by many species of small trees and shrubs in Puerto Rico. One of the commoner species, this is characterized by: (1) opposite, narrowly elliptie leaves finely wary-toothed, green and slightly shiny on both sides, with 5 main veins, the 2 pains of lateral veins joined to the midrib at different points near base (5-nerved): (2) small whit ish flowers in large terminal elusters with horizontal, pirired, spreading branches; and (3) rounded purplish-blue berries $5 / 16$ inch in diameter.

An evergreen shrub or small tree to 25 feet high and 4 inches in trunk diameter. The bark is smooth, gray, and thin, the inner bark yellowish brown and bitter. The stout gray-brown twigs are minutely hairy with star-shaped hairs when young and with faint rings at nodes.

The leaves bave winged or wingless petioles $1 / 4-1$ ineh long and blades $41 / 2-71 / 2$ inches long and $11 / 2-21 / 4$ inehes broad, the apex long-pointed and base short-pointed, slightly thiekened, usually hairless or nearly so at maturity. The veins are a little sunken on upper surface and raised on the lower surface, which is slightly lighter green.

Flower elusters (panicles) are 3-6 inches long and 2-t inehes broad, with branches covered with minute star-shaped hairs, bearing many stalkless flowers $1 / 4$ ineh long. The tubular base (hypanthium) and slightly o-lobed ealyx are less than 1/s inch long, finely hary; there are 5 small white petals more than $1 / 16$ inch long; 10 spreading stamens with white filaments: and pistil composed of inferior ovary, slender style, and rounded stigma.

The berries are slightly flattened, juicy, edible but slightly somr and almost tasteless. There are many brown seeds about 1/32 ineh long. In flower and firuit nearly through the year.

The sapwood is light brown, and the heartwood is grayish brown. The had, heary wood (spe-

\section{Miconia prasina (Sw.) DC.}

cifie glavity 0.7 ) is little used except as fuel. Not durable as a fencepost.

Common in the moist constal, moist limestone, and lower mountain forests in Puerto Rico. Also in Tortola.

Pcrinc Fonests.-Carite, Luquillo, Río Abajo, 'Tol'o Negro.

RAxaE.-Common and ridely distributed in tropical Imeriea. Cuba, Jamaiea, Hispaniola, Pnerto Rico, and Tortola. Lesser Antilles in Antigua, Montserrat, Guadeloupe, Martinique, and Grenada, and Trinidad and Margarita. Mlso from souther'n Mexico to Peru, Boliva, Paraguay, and Brazil. Botanical rarieties are distinguished in ditlerent parts of the broad range.

Otiler cominon Names, - camasey blaneo (Puerto Rico) ; granadillo bobo, cenizoso (Dominican Republic) : mullaea colorado, mullu caspi (Peru); sarline (Trinidad); waraia (British Guiana); santo, selele bélétére, konorrépie, pintjo (Suri. nam) ; jaeatirão, mondururu preto (Brazil).

This genus has 15 additional native speeies of small trees or shrubs reeorded from Puerto Rico and the Tirgin Islands, found generally in moist areas and known commonly as camasey. Britton and Wilson (Botany of Porto Rieo and the Virgin Islands $6: 6-11,555.1925)$ published botanical descriptions and a key for identification. These species are: Miconia foveolata Cogn., M. impetioluris (Sw.) D. Don, M. laevigata (I.) DC., . . lanata (DC.) Triana, $\boldsymbol{M}$. microcarpa DC., $\boldsymbol{M}$. ottoschulzii Trban \& Ekman, M. pachyphylla Cogn., M. pumetata (Desv.) D. Don, M. pycnoncura Urban, M. racemosa (Aubl.) DC., M. rubiginosa (Bonpl.) DC., M. sintenisï Cogn., M. subcorymbosa Brition, M. tetrandra (Sw.) D. Don, and $M$. thomesiana DC. 


\section{MELASTOME FAMILY (MELASTOMATACEAE)}

\section{Verdiseco}

This small tree is easily recognized by the erect conical crown which is grayish in appearance, the thick furrowed gray bark, and the opposite, mostly small, lance-shaped leaves with 3 main reins from near base to apex and with the lower surface whitish and densely fine hairy. The spreading 4petaled white flowers, $3 / 4$ inch broad and almost as long, are borne in slort, few-flowered terminal clusters, and the fruit is a rounded berry nearly $3 / 8$ inch in diancter, with calyx at apex.

An evergreen tree 20-30 feet high and to 6 inches in trunk diameter, with a crown of thin foliage. The inmer bark is light brown and slightly sour to the taste. Young twigs, petioles, and branches of flower clusters are light brown, finely seurfy hairy. Older twigs are dark brown.

Leaves have petioles $1 / 1^{-1 / 2}$ inch long and blades $11 / 4-3$ inches long and $1 / 2^{-3 / 4}$ inch broad, mostly short-pointed (sometimes blunt-pointed) at both apex and base, thickened, dark green and hairless on upper surface, and whitish, soft hairy beneath. There are many small parallel veins almost at right angles to midrib.

Flower clusters (panicles) branched, 1-2 inches long, the few flowers short-stalked. The tubular base (hypanthium) extends $1 / 8$ inch above the inferior ovary about $1 / 16$ inch long, contracted, scaly hairy, with short spreading calyx tube $3 / 16$ inch in diameter, membranous at edge; 4 broad and
Tetrazygia elaeagnoides (Sw.) DC.

romnded petals $3 / 8$ inch long, narrowed at base, white but fading to pink; 8 slender stamens $1 / 2$ inch long; and pistil with inferior t-celled ovary and slender, slightly curved style more than $1 / 2$ inch long. 'The berry is broader than long and 4lobed, fleshy and containing numerous minute seeds. Flowering and fruiting probably through the year.

The sapwood is light brown and hard. The tree is used chiefly for fenceposts.

Hillsides and cutover lands in the moist limestone forest region in northern and western Puerto Rico. Also in Vieques, St. Croix, St. Thomas, St. John, and Tortola.

Public Forests.-Cambalache, Guajataca, Vega.

MIUNICIPALITY WIIERE ESPEClaLLT COMMON.-11. Range.- Hispaniola and Puerto Rico and Virgin Islands. Also recorded from Montserrat and Martinique.

Other Conmon NaMes, - camasey cenizo, cenizo, (Puerto Rico); kre-kre (Virgin Islands).

Another species (Tetrazygia angustifolia ( $\mathrm{Sw}$.) DC.) is a small tree or shrub through the Virgin Islands, common on St. John, but absent from Puerto Rico. It has narrower lance-shaped leaves, clusters of many small flowers about $1 / 4$ inch long and broad, with yellowish or pink petals, and small blackish berry $3 / 16$ inch in diameter. 

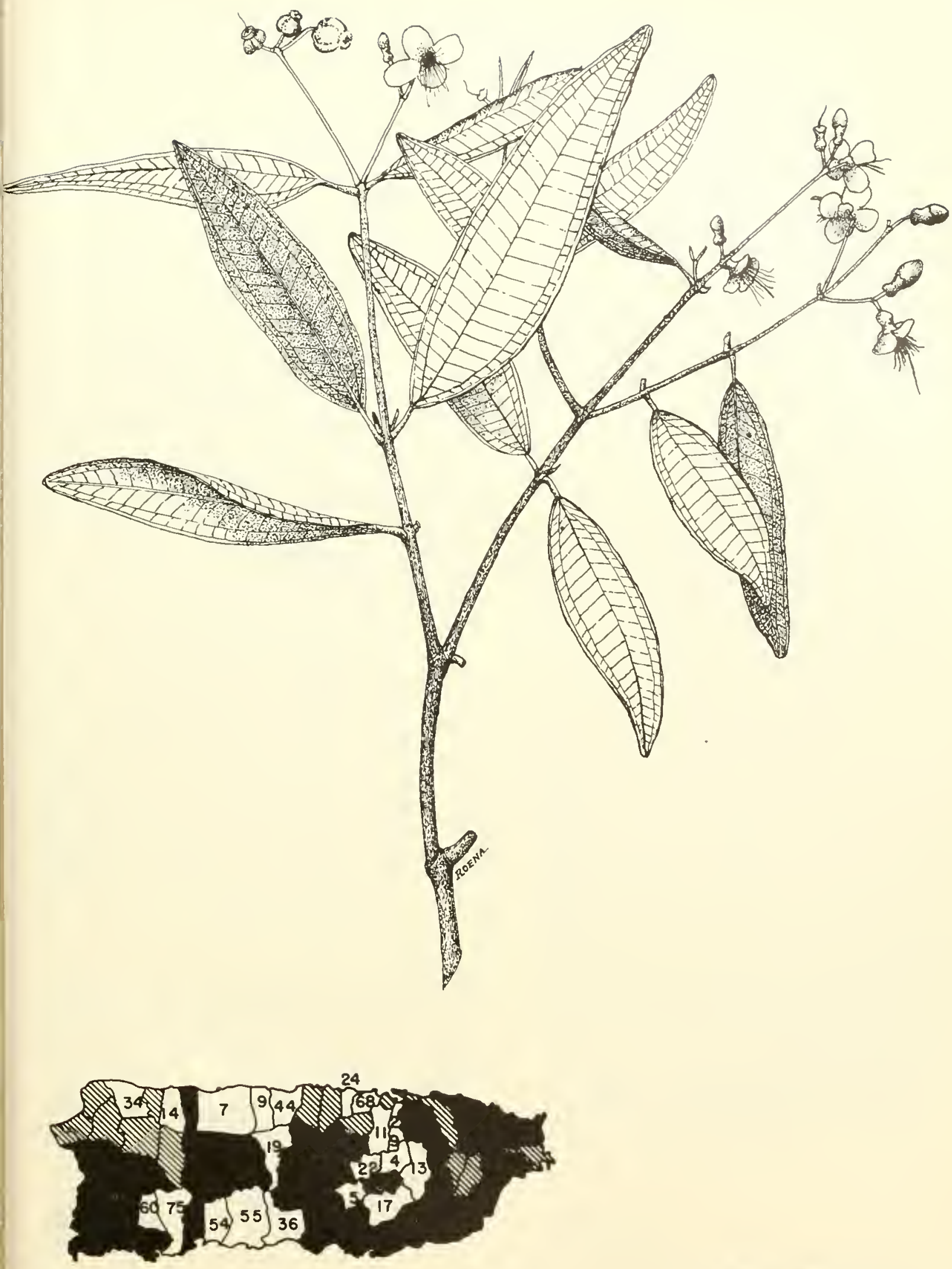

199. Verdiseco

Natural size.

Tetrazygia elacagnoides (Sw.) DC. 


\section{GINSENG FAMILY (ARALIACEAE)}

Key to the 2 species illustrated (Nos. 200-201)

A. Leares simple-200. Dendropanax arboreus.

AA. Leares digitate or lalmately compound, with usually 10 or 11 leaflets-201. Didymopanax morototoni.

\section{Pollo}

A small to medium-sized tree characterized by: (1) mostly long-stalked (to 4 inches) elliptic to ovate leaves, dirk green and slightly shiny above and light green beneath: (2) terminal compound flower clusters of numerous small, usually 5parted, greenish-yellow flowers $3 / 16$ inch across on shortel stalks in ball-like clusters $1 / 2-3 / 4$ inch across, which are bome on long equal stalks along the main axis: and (3) fleshy rounded fruit (berry) abont $1 / 4$ inch in diameter, turning from whitish green to black at maturity.

An evergreen tree to 40 feet or more in height and 1 foot in trunk diameter, with wide spreading rounded crown, hairless throughout. 'The bark is light gray, smooth or warty with raised dots (lenticels) or becoming sliglitly fissured. Inner bark is whitish and tasteless. Twigs are green, turning to gray, slender or stout.

Leaves are alternate, the green petioles mostly long but rarying from very short to very long, $1 / 4-t$ inches. Blades are $2-8$ inches long and $11 / 4-$ $31 / 2$ inches wide, short- to long-pointed at apex and short-pointed to rounded at base, thin to slightly thickened, not toothed on edges, the laternl veins often slightly sumken on upper surface. On young shoots the leares are reported to be often 3-lobed.

Flower clusters (raceme of umbels with compound umbel at apex) are $2-5$ inches long and 2 inches across, the branches about $3 / 4$ inch long and flower stalks about $1 / 8$ inch long, the axis and branches yellow meen. Flower parts usually 5, sometimes 6 or 7 , of each kind. 1 flower consists of a basal tube (hypanthium) about 1/16 inch long and broad, partly enclosing the inferior 5 -celled ovary and bearing the minute 5 -toothed calyx, 5pointed yellow petals more than $1 / 16$ inch long, 5 erect stamens $1 / 16$ inch long, and top of ovary with 5 partly united styles.

The fruits upon drying become 5-angled and contain 5 flattened secds nearly $1 / 4$ inch long, arranged starlike. The styles remain at apex of

\section{Dendropanax arboreus (L.) Decne. \& Planch.}

fruit. Flowering and fruiting nearly through the year.

The sipwood is whitish or yellowish brown. The moderitely soft, moderately light weight wood (specific gravity 0.5) is little used.

Elsewhere a decoction of the leaves and roots has been employed in home medicines. A honey plant.

Widely distributed in the lower mountain and moist limestone regions of Puerto Rico, especially in the coflee plantations of the central and western Cordillera. Also in St. Thomas and 'Tortola.

l'eulic forests.-Cambalache, Guajataca, Luquillo, Maricao, Río Abajo, Susúa, Toro Negro.

MI Xiciphlities Where especially CoNMION.-6, 35 .

RuxGe.-Common and widespread in tropical America. Greater Antilles, St. Thomas, Tortola, st. Tincent. Grenada, and Trinidad. Mexico (Finaloa to Tamaulipas and sonthward) to Colombia. Tenezuela (jncluding Margarita), Peru, and Bolivia. Also planted in southern Florida.

Other common Names.-palo de pollo (Puerto Rico) : ramón de costa, jamón de vaca, lengua de raca, palo de burro (Dominican Republic); víbona, ramón de vaca, ramón de caballo, palo santo (Cuba): mano de oso, mano de león, palo santo, palo de danta, palo guitaro (Mexico); mano de león (El Salvador) ; vaquero (Panama); pana (Tenezuela); galipee, angelica-tree (Jamaica); bois négresse (Haiti).

Botanical sYxonym.-Gilibertia arborea (L.) F. March.

Gongolí (Dendropanax laurifolius (E. March.) Deene. \& Planch.), also called palo de pollo negro, palo de cachumbia, palo de vaca, ríbona, and víbora, is a related tree species known only from moist forests of Puerto Rico. It has the flower clusters spreading and branched (umbels in umbel-like cluster's), the stalks of the branches up to $1 \frac{1}{2}$ inches long. 

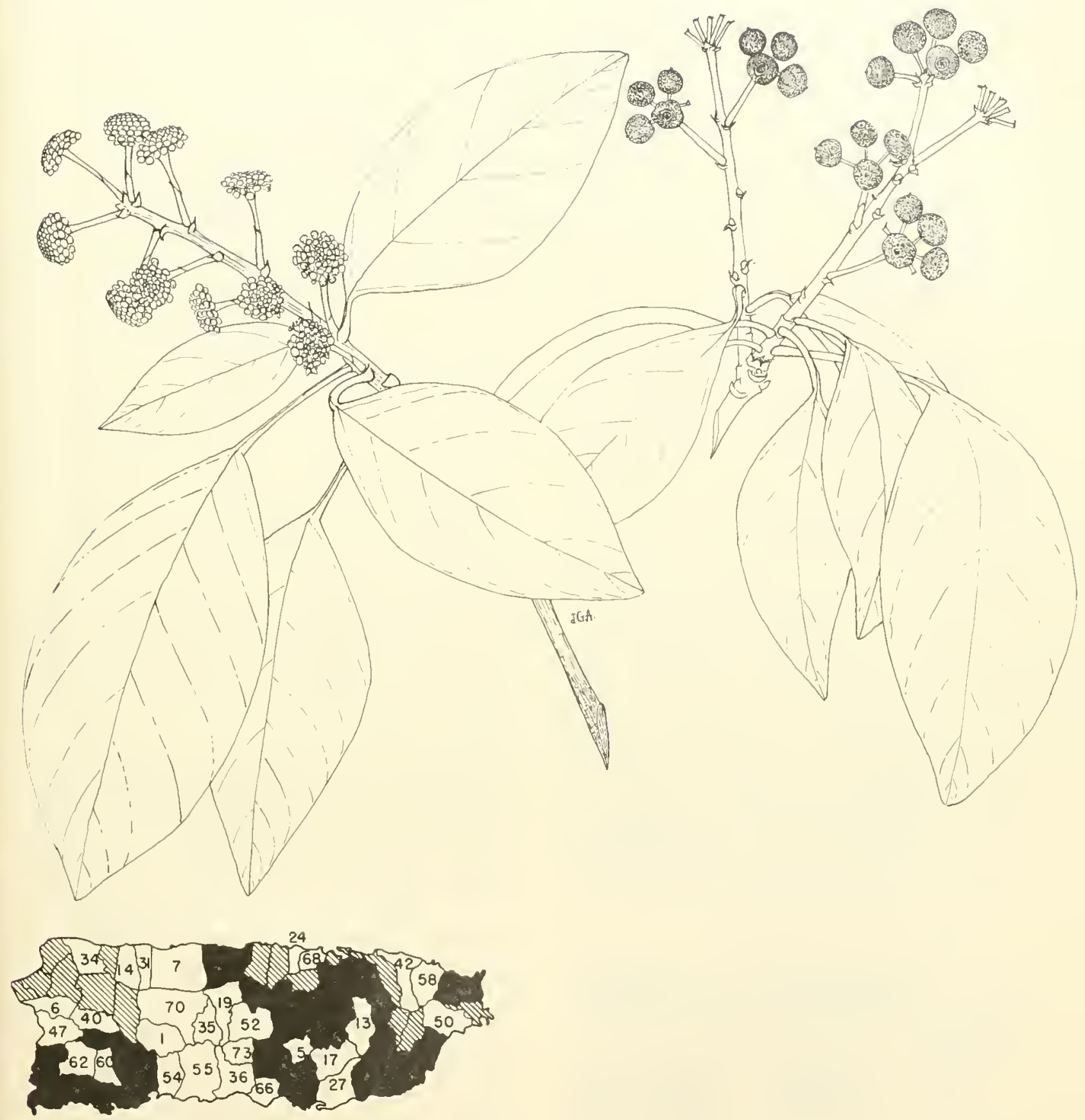

200. Pollo

Two-thirds natural size

Dendropanax arborrus (L.) Deene. \& Planch. 


\section{GINSENG FAMILY (ARALIACEAE)}

\section{Yagrumo macho, matchwood}

A striking tree easily recognized by its distinctive branching, crown, and leares. The smooth, gray, ringed trunk, unbranched below, has a few stont branclies above, bearing in uppermost part a shallow crown like an mubrella formed by the terminal clusters of leaves. The very large leaves are palmately compound, with a long stout round petiole 2 feet or less in length and usually 10 or 11 long-stalked oblong leaflets with blades $10-17$ inches long, long-pointed at apex, and beneath brown or greenish brown with a satiny coat of fine hairs.

Ls the common name suggests, this species resembles yagrumo hembra (Cecropia peltata L.), a botanically unrelated tree. However, in yagrumo hembra the leaves are not compound but merely palmately reined and palmately lobed with rounded lobes and they are whitish rather than brown beneath.

An evergreen tree becoming 60 feet or more in height, with trunk 6-18 inches in diameter, in Puerto Rico usually medium-sized. The gray or light brown bark is smooth with many faint liorizontal rings and large leaf scars about 3 inches apart. Inmer bark is brownish and slightly bitter or spicy in taste. The twigs, petioles, under surface of leaflet blades, flower stalks, and flowers are minutely gray or brown hairy. The few twigs are very large and stout, about $11 / 2$ inches in diameter and finely brown hairy.

Leaves are alternate but closely crowded, with sleatl of 2 hairy pointed scales (stipules) $1 / 4-1 / 2$ inch long at base. It apex of the round green petiole are usually 10 or 11 spreading green leaflet stalks $21 / 2-41 \%$ inches long. Leaflet b]ades are 4 $71 / 2$ inches wide, and rounded or sometimes a little heart-shaped at base, the edges often a little wary, slightly thickened and leathery, above green and hairless. Young leaflets are brown hairy on both surfaces. Howerer, leaflets of young plants are green on both sides and rough hairy above, thim, sometimes saw-toothed on edges, and smaller, with shorter petiole and fewer leaflets ( 7 or more).

Flower clusters (panicled umbels) are lateral, about 1-2 feet long and broad, with branches gray and finely hairy. The very numerous flowers are grouped at ends of branches into numerous small rounded clusters (umbels) less than $1 / 2$ inch across, on spreading flomer stalks $1 / 16^{-3 / 16}$ inch long. The 5-parted finely brownish and gray hairy flower about $3 / 16$ inch across has a minute basal tube (hypanthium) less than $1 / 16$ inch long enclosing the inferior 2 -celled ovary and bearing the minute 5 toothed calyx, 5 white pointed petals more than $1 / 16$ incli long, 5 stamens, and 2 styles.

The fleshy fruit (berry), gray and covered with a bloom, is about $3 / 16$ inch long, $1 / 4$ inch broad, and a little flattened, with 2 styles at apex. It contains 2 oblong flattened brown seeds $3 / 16$ inch long.
Flowering and fruiting nearly throughout the year.

The wood is pale brown or light brown throughout, soft, fairly lightweight (specific gravity $0.36)$, fine-textured, straight-grained, brittle, and has large pith. It is very susceptible to attack by dry-wood termites and other insects and to decay. The l"ate of air-seasoning is rapid, but the amount of degrade is considerable. Machining characteristics are as follows: planing, shaping, mortising, and sanding are good: turning is very poor ; boring is poor; and resistance to screw splitting is excellent.

In Puerto Rico the wood is little used, though it is especially suitable for boxes and crates. Where the trees are more abundant and of larger size, uses include general carpentry, interior construction, and boxes. In Trinidad and British Guiana the wood is made into matchsticks and matchboxes. Other possible uses are utility grade plywood, tors, pulp, and as a substitute for heavier grades of balsa.

Of possible value as an ornamental, growing rapidly and requiring light. The leaves have served in home remedies in other places.

Scattered in forests of the lower mountain moist coast and moist limestone regions of Pnerto Rico. Also in St. Thomas, St. John, and Tortola.

Pinuc forests.-Cambalache, Carite, Guajataca, Luquillo, Maricao, Río Abajo, Susía, Toro Negro, Tega.

MUNICIPALITIES WILRE ESPECIALLY COMMION.$4,6,10,19,20,22,23,27,29,30,40,43,49,51,53$, 58,59 .

RAxGe. - Widespread in wet forests of tropical America. West Indies in Cuba, Hispaniola, Puerto Rico, St. Thomas, St. John, Tortola, Guadeloupe, and Trinidad. Continental tropical America from southem Mexico (Oaxaca) to Bolivia, Argentina, Brazil, and Guianas. Also planted in sonthern Florida.

OTIER Conmox Nunis. - pana cimarrona (Puerto Rico): morototo, mandioquiera (commerce); palo de sable, sablito, yagrumo macho (Dominican Republic) ; zapatón, yagrumo macho, arriero, gavilán, badana, cordobán. padero, papayón (Cuba): chancaro blanco, roble blanco (Mexico) ; costilla de danto (Nicaragua): para, pavilla, probado (Costa Rica) ; mangabé, gargorán, para (Panama); yarmero, yagrume (Colombia) : yagrumo macho, orumo macho, sun-sún, hignerete, tinajero (Tenezuela) ; sacha-uva, anonillo (Peru); guitarrero (Bolivia); ambay-guazú (Argentina); match wood, jeretón (Trinidad) ; mountain trumpet (British Honduras): karohoro, matchwood, morototo (British Guiana) ; arbre de Saint-Jean (French Guiana): morototo, cassavehout, bigi boesie, papajahoedoe, kasabahoedoe (Surinam); morototó, mandioqueira, marupá, matatauba (Brazil). 


\section{MYRSINE FAMILY (MYRSINACEAE)}

Ker to the 3 species illustrated (Nos. 202-204)

A. Leares elliptic to oborate, with flattened or winged petinle; flowers and fruits many in terminal clusters-202. Irisia oborata.

A. Leaves lance-shaped or elliptie, clustered near encls of twigs, with slender petiole; flowers and fruits many in almust stalkless clusters along twigs.

B. Twigs rusty-brown hairy; leares slightly hairs beneath, lance-shaped, short-pointed-203. Rapanea ferruginea.

BB. Twigs hairless; leares hairless, elliptic, rounded or biunt-pointed-204. Rapanea guianensis.

\section{Mameyuelo}

This shrub or small tree is characterized by : (1) elliptic or obovate slightly shiny leaves, leathery and slightly sncenlent, with inconspicuous veins, with mimute gland dots on both sides, blunt-pointed or rounded at apex, often broadest above middle, and gradually narrower at hase to the broad or winged petiole: (2) erect, termina , much branched flower cluster $3-5$ inches long and broad, with very many small greenish flowers $3 / 8$ inch across, with tiny black dots; and (3) many black 1 -seeded fruits $1 / 1^{-5 / 16}$ inch in diameter.

In evergreen shrub or small tree 10-20 feet high and to 4 inches in diameter, hairless throughont. The stout twigs are gretnish when young, becoming light gray. Bark on small trunks is smoothish, gray, and thin, with pinkish, tasteless inner bark.

The alternate loaves have flattened or winged petioles $1 / 1^{-3} / 5$ inch long. Blades are $21 / 2-51 / 2$ inches long and 1-2 inches broad, with edges slightly turned under, areen on upper surface and pales beneath.

The flower cluster (panicle) contains crowded. short-stalked thowers. Calyx is composed of it rounded lobes $3_{16}^{\prime}$ inch long: corolla with short tube and nsually 5 elliptic lobes nearly $3 / 16$ inch long, which are spreading or turned backwards and $3 / 8$ inch across; 5 stamens inserted near base of cololla tube and opposite the lobes: and pistil with 1-celled ovary and short style.
Ardisia obovata Desv.

The numerous berries are round or slightly broader than long, with short point (style) at end, turning from erveen to red to blackish at maturity, with thin dark red flesh and 1 large round brown seed 3/16 inch in diameter. Flowering and fruiting thronghout the year.

The sapwoor is pinkish, and the heartwood is light reddish brown. The hard, heary rood is nsed only for posts in Puerto Rico.

In the moist and dry limestone forests at lower. and midlle elevations in Puerto Rico. In understory tree or shrub. Also T'ieques, St. Croix, St. Thomas, st. John. Tortola, and Virgin Gorda.

Prbuic Forests.-Cambalache, Guajataca, Susúa. Raxge.--Bahamas (North Caicos only), Hispaniola, Prerto Rico and Virgin Islands, and Lesser Antilles from Saba to St. Lucia.

Other connox xuses.-bádula (Puerto Rico); Guadeloupe marlbery (Bahamas).

BOTANICAL STONYIs.-Ardisia guadalupensis Duch., Icucorca guadulupensis (Duch.) Britton.

Inother species of mameynelo (Ardisia glauciHom l'uban; symonym Icacorea glauciflora (Lrban) Britton) is a small tree known only from momntain forests of Puerto Rico. It has larger, elliptic, thick, leathery leaves +8 inches long with prominent netwolk of reins, and many larger flowers about $1 / 2$ inch across. 


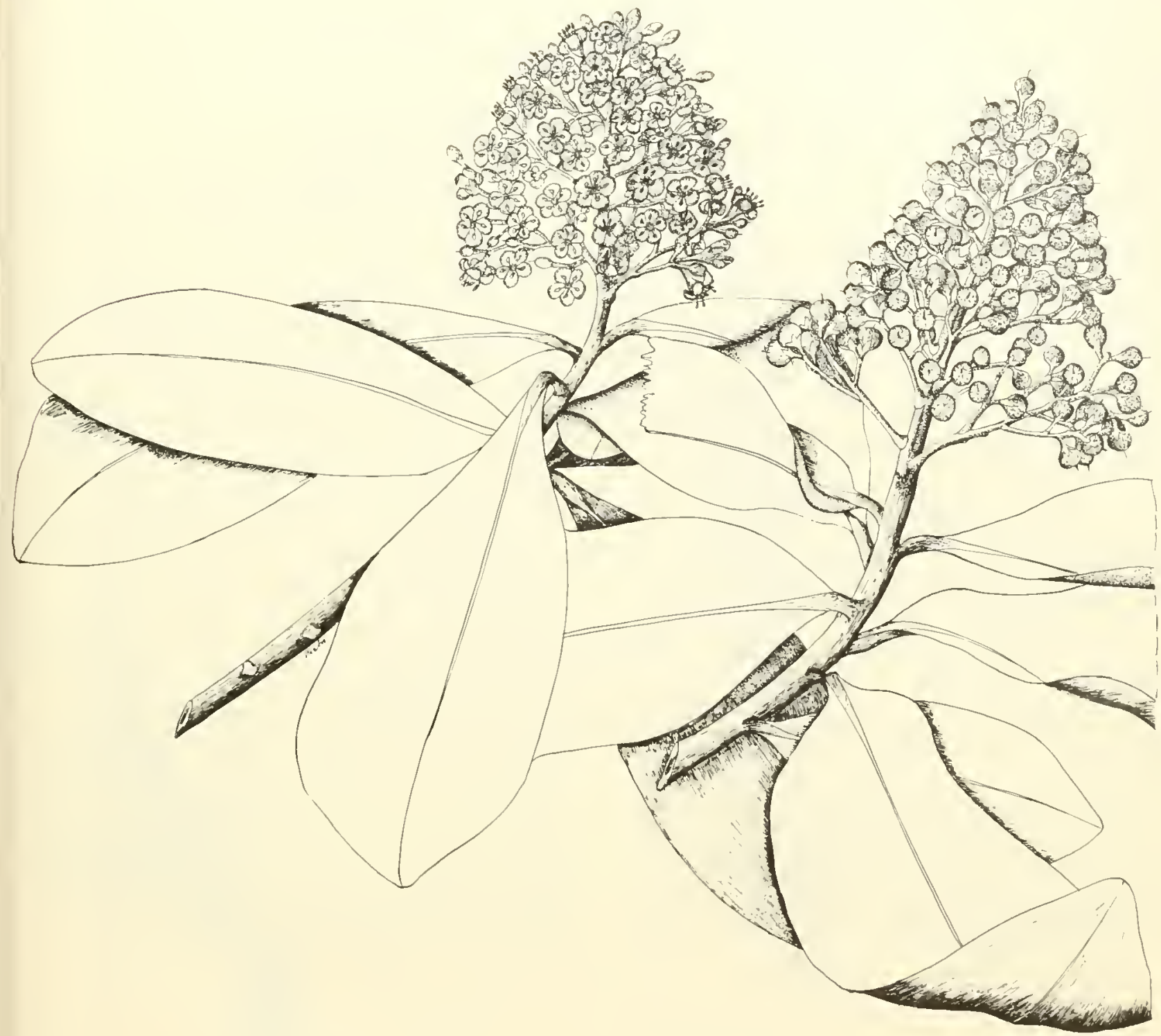




\section{MYRSINE FAMILY (MYRSINACEAE)}

\section{Mantequero}

This common small tree is distinguished by : (1) lance-shaped shiny green leaves numerous and crowded near ends of twigs, with minute gland dots on both sides: (2) long slender twigs, rustybrown hairy, greenish near apex but beeming brown; (3) many inconspicuous small yellowgreen flowers almost stalkless in scaly lateral clusters mostly back of leaves; and (4) numerous round black fruits $1 / 8$ inch or more in diameter, almost stalkless and crowded along the twigs for a few inches.

Small evergreen tree 15-30 feet high and 3-6 inches in trunk diameter, with erect erown. The bark is smooth or slightly fissured, thin, and gray. Inner bark is whitish or light brown, tasteless or slightly astringent, with sticky sap.

Leaves are alternate but close together, with finely hairy petioles $1 / 2-1 / 2$ inch long. Blades are $1 \mathrm{I} / 2-4$ inches long and $1 / 2-1$ inch broad, widest at middle or a little beyond, short-pointed at apex and tapering to the long-pointed base, slightly thickened, and with edges turned mder. The lower surface is paler and usmally slightly hairy.

The spreading flowers about $1 / 5$ inch across are male and female on different trees or some flowers bisexual (polygamo-dioecious). Calyx is deeply 5-lobed; the spreading corolla has 5 narrow, pointed lobes, yellow green with pink dots; 5 stalkless stamens on the corolla and opposite the lobes;

\section{Rapanea ferruginea (Ruiz \& Pav.) Mez}

and pistil composed of 1-celled ovary with short, lobed stigma.

The berries cluange color from green to red to black at maturity and contain purplish flesh and 1 round brown seed less than $1 / 8$ inch long. Flowering and fruiting nearly through the year.

The whitish sapwood, charaeterized by prominent. white rays, is hard and heary (specific gravity 0.7 ). The wood is used chiefly for fenceposts.

In open moist forests in Puerto Rico from near sea level almost to the summit of Cerro Punta, abore 4,000 feet in altitude. Characteristic of openings, clearings, and edges of forests and probably light requiring.

Public Forests.-Carite, Guilarte, Luquillo, Marica, Toro Negro.

RANGE.-Greater Antilles and throughout Lesser Antilles from Saba and St. Kitts to Grenada. Also from Mexico and Central Ameriea to Argentina, Uruguay, and Brazil.

OTIIER Common NANes.-arrayán, arrayán bobo, bádula (Puerto Rico) ; hojita larga, palo de sabana (Dominican Republic) ; camaguiilla (Cuba) ; amatillo (El Salvador); manglillo (Panama) ; espadero (Colombia) ; mauteco, manteco blanco, mantequero, mantequito (Venezuela) ; canelón-puitá (Argentina); bois plomb, bois savanne (Haiti); azeitona brava, azeitona do matto (Brazil). 


\section{MYRSINE FAMILY (MYRSINACEAE)}

\section{Bádula, Guiana rapanea}

This small tree resembles its close relative mantequero (Rupanen fermginea (Rniz \& Pav.) Mez) but is hairless thronghout and has broader leares with mostly ronnded apices and slightly larger flowers and fruits. It is eharacterized by: (1) the elliptie, slightly shinr, green leares elustered at ents of twigs, with minute gland dots on both sides; $(2)$ the long slender twigs, greenish when young, becoming light brown: (3) numerous small greenish flowers almost stalkless in sealy lateral cluster's mostly back of leaves; and (4) many round blue-black funits $3 / 1$; inch in diameter erowded along the twigs for a few inehes.

A small evergreen tiee to 25 feet high and $3-6$ inches in trunk diameter, with straight axis, open and narrow crown, and relatively few unbranched twigs. The thin gray bark is smooth or slightly fissured. Inner bark is reddish or brown, slightly hitter ol almost tasteless.

The leaves. altermate but elose together, have petioles $1 / 4^{-1} / 2$ inch long. Blades are $2-4$ inches long, $3 / 4-13 / 4$ inehes broad, widest at middle or bevond. rounded or blunt-pointed at apex. pointed at base, slightly thickened, and with edges turned under. The lower surface is paler.

Male and female flower's are on different trees or some flowers bisexual (polygamo-dioecious), greenish and more than $3 / 16$ ineh across. The small ealyx is deeply 5 -lobed, dotted with purple; the
Rapanea guianensis Aubl.

spreading corolla with 5 unequal pointed lobes dotted with purple: is stalkless stamens on the corolla and opposite the lobes: and pistil with 1-celled orary and short-lohed stigma. The berries have thin flesh and 1 large brown seed more than $1 / 8$ inch in rliameter. Collected in flower in spring and with fruits in summer.

The light brown, hard, strong wood is used chiefly for posts.

In the moist and dry limestone forests in northern and western Puerto Rico. Also in Tortola.

Pubuc fonests.-Cambalache, Guajataca, Río Abajo, Susúa.

Raxge- - Central and southern Florida including Florida Keys, Bahamas, Greater Antilles, Tortola, Lesser Antilles from Guadeloupe to Grenada, and Trinidad and Tobago. Also in souther'n Mexico, British Honduras, Costa Rica, and South Ameriea from Colombia to Bolivia, Argentina, Brazil, and Guianas.

Otur counos ximes.-mameyuelo (Dominican Republic): camagiiilla (Cuba); chagualito (Colombia); manteeo blaneo, mameycillo, encharo (Venezuela): eanelón (Argentina, commerce); Guiana rapanea, myrsine (United States); myrsine (Bahamas); dakara (British Guiana); fuelle canelle (Haiti): dakara, konaparan, mannie hotieie (Surinam). 

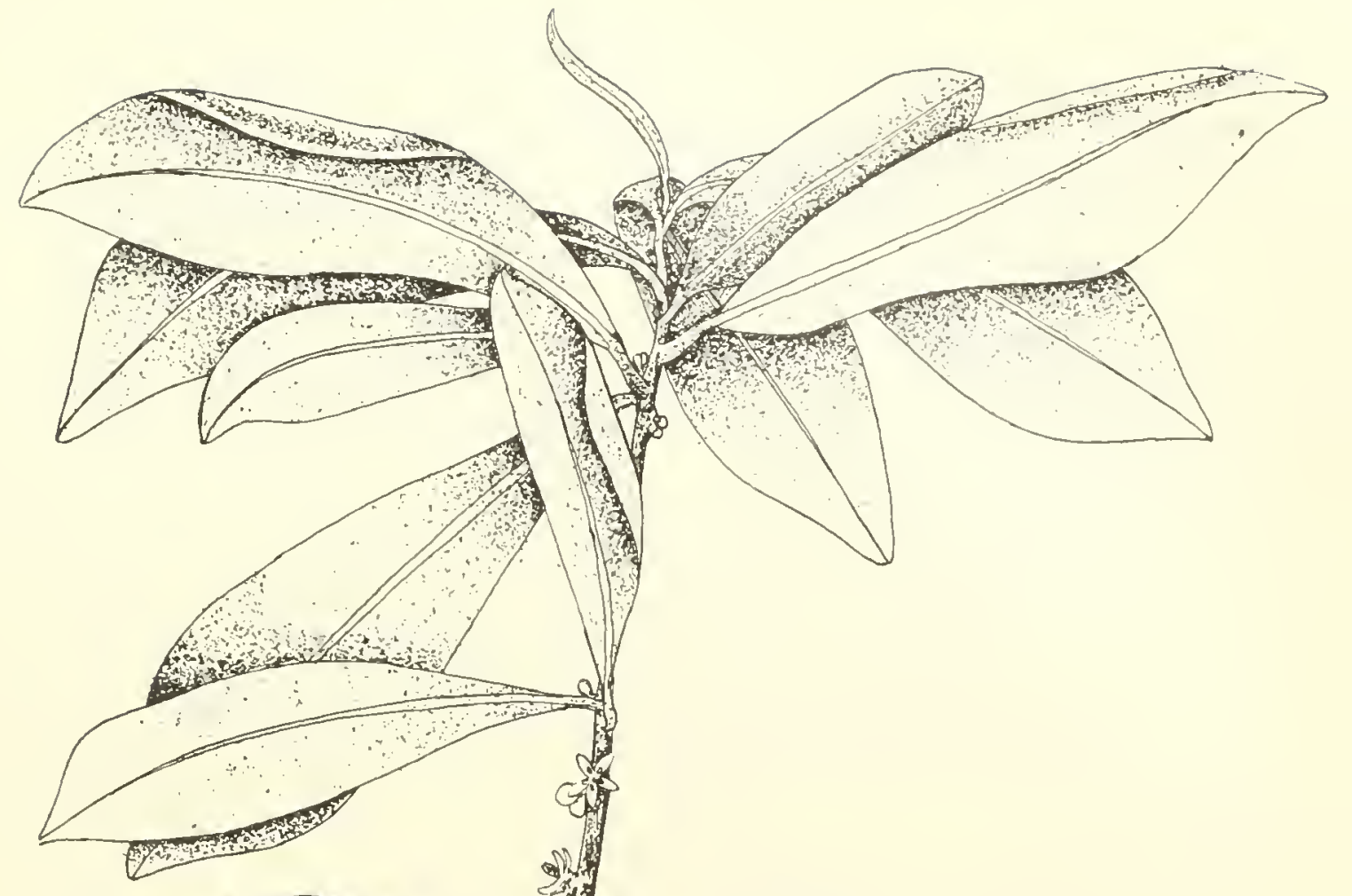


\section{SAPODILLA FAMILY (SAPOTACEAE)}

Key to the 10 species illustrated (Nos. 205-214)

A. Leaves with many straight, parallel side veins nearls at right angle to midrib.

B. Leares small, less than $3 \frac{1}{2}$ inches long; fruits elliptic, inedible.

C. Leaves abruptly short-pointed; the lower surface reddish brown, finely silky hairy-211. Micropholis chrysophylloidcs.

CC. Leares rounded or slightly notched at apex, green on both surfaces, becoming hairless or nearly so-212. Iricropholis garciniaefolia.

BB. Leaves more than 3 inches long; fruits round, edible.

D. Leaves rounded, blunt-pointed, or notched at apex; fruits about 1 inch in diameter-209. Manilkara bidcritata.

DD. Leaves short-pointed; frnits 11/2-3 inches in diameter (sapodilla)-210. Manilkara zapota.*

AA. Leares with several side veins at acute angle to midrib, mostly curved at end.

E. Leaves mostly lance-shaped, long-pointed at both ends, the edges appearing finely wary or wrinkled-208. Dipholis salicifolia.

EE. Leaves broader, mostly elliptic.

F. Leaves with short petiole less than $3 / 4$ inch long.

G. Leares elliptic, broadest near middle, less than 5 inches long.

H. Leaves with lower surfaces gragish or silvery green and often silky hairy-205. Chrysophyllum argenteum.

HH. Leaves with lower surfaces reddish brown or golden silky hairy.

I. Fruit round, sereral-seeded, 2-3 inches in diameter (star-apple)-206. Chrysophyllum cainito.

I1. Fruit elliptic, 1-seeded, abont $3 / 4$ inch long-207. Chrysophyllum oliviforme.

GG. Leaves narrowly elliptic. broadest bejond middle, large, 5-16 inches long-213. Pouteria multiflora.

FF. Leaves with long slender petiole more than $3 / 4$ inch long, often slightly winged torard apex; midrib sellcw-21t. Sideroxylon foetidissimum.

\section{Lechecillo}

Chrysophyllum argenteum Jacq.

This tree with milley sap is characterized by: (1) a spreading low crown; (2) elliptic or oblong leaves with lower surfaces slightly grayish or silvery green and often silky hairy and with lateral veins straight and parallel, almost at right angles to midrib and regularly spaced $1 / 8-1 / 4$ inch apart; (3) small greenish-yellow bell-shaped flowers about $3 / 16$ inch long chustered at leaf bases; and (4) oval or rounded, dark blue, edible berries $3 / 8-$ $3 / 4$ inch long.

An evergreen, usually small tree $15-25$ feet high and 1-8 inches in diameter. Bark on small trunks is smoothish or much fissured, light brown or gray, the inner bark pinkish and slightly bitter. Young twigs are greenish and finely hairy, becoming brown or gray. The bud composed of youngest leaves is brown and finely hairy.

The alternate leaves hine finely hairy petioles $1 / 4-3 / 8$ inch long. Lea f blades are $21 / 2-5$ inches long and $1 \frac{1}{4}-21 / 4$ inches broad, mostly short-pointed at apex and short-pointed or rounded at base, a little thickened. The upper surface is green or dark green, slightly shiny, and hairless or nearly so. The specific name, meaning silvery, describes the lower leaf surface.

Few to several flowers with a peculiar odor are borne together on slender liaily stalks abont $1 / 4$ inch long. There are strounded brownish-green sepals nearly $1 / 8$ inch long, finely brown hairy; a tubular bell-shaped, greenish-yellow, finely hairy corolla $3 / 16$ inch long, with 5 or 6 small rounded lobes; 5 or 6 small stamens on the corolla tube opposite the lobes; and pistil with hairy 6-8-celled ovary, short style, and minutely lobed stigma. The fruit contains 1 large shiny brown seed. Flowering and fruiting probably through the year.

The wood with light brown sapwood is reported to be hard, heavy, strong, tough, and durable. Tsed chiefly for posts in Puerto Rico. Elsewhere utilized in construction and carpentry.

Moist limestone and lower mountain forests in Puerto Rico. Also in St. Thomas and Tortola.

Public Fonests. - Guajataca, Luquillo, Río Ibajo.

Rivge.-Cuba, Hispaniola, Puerto Rico, St. Thomas, Tortola, and nearly throughout Lesser Intilles to Trinidad and Tobago. Also in Venezuela.

Otrier common names. - caimito verde (Puerto Rico) : caimito blanco cimarrón, caimitillo, caimito cocuyo, carabana (Dominican Republic); macauabo (Cuba); milky-iron (Montserrat); star-apple (Intigua, St. Vincent); balata chien (St. Lucia); wild kaimit (Trinidad); petit caimite, ti caimite (Iraiti): bois glu, bois kaki, eaimitier bois (Guadeloupe): bois bonis, petit bonis (Guadeloupe, Martinique).

Botavical sxony. - Chrysophyllum glabrum. Jacq.

Two more species of this genus are native, in addition to the 3 illustrated here. Caimito de pero (Chrysophyllum pauciforum Lam.) is known only from dry areas of Puerto Rico, Vieques, St. Croix, St. Thomas, and St. John. It differs from the species described above in the nearly hairless leaves shiny above, the flower with 5 -celled ovary, and the sliapp-pointed, oblong fruit $3 / 8-3 / 4$ inch long. 



\section{SAPODILLA FAMILY (SAPOTACEAE)}

\section{Caimito, star-apple}

1 handsome tree with milky sap, cultivated for its very sweet, edible, round fruits 2-3 inches in dianeter, erreenish or purplish, and for sharle. It is further iclentified by: (1) its spreading to drooping crown; and (2) pretty, reddish-brown or golden (copper-colored) silky hairy lower surfaces of the ellutic or oblong leaves. T'he small purplishwhite or greenish flowers $1 / 4 \mathrm{inch}$ long are elustered at bases of leaves.

Simall to medinm-sized everorreen tree 20-10 feet high and 2 feet in trunk diameter. with dense crown. The bark is rough, much fissured, and brown. Young twigs, als well as the petioles, which are 1/2-5, inch long, and the flower stalks, are reddish-brown hairy.

The altermate leaves have blarles 3-5 inches long and 11,2-21/4 inches broal, mostly abruptly shortpointed at apex, short-pointed at base, with edges not toothed, and slightly thickened. The upper smrface is dark green, slightly shiny, and hairless.

Flower clusters have numerous small flowers on slender lairy stalks $1 y^{-3}$ inch long. Calyx is eomposed of usually 6 rounded sepals 1/16 inch long, reddish-brown hitiry; the purplish-white corolla, also hairy, is nearly ${ }^{1} / 4$ ineh long, tubnlar and $5-i$ lobed: stamens on the corolla tulbe opposite the lobes: and pistil consisting of hairy i-11-celled ovary with short style and as many small stigma lobes as cells.

\section{Chrysophyllum cainito $\mathrm{L}$.}

The edible berry has a thick, glossy, leathery rind with gummy latex, white jellylike flesh, and sereral thattened brown seeds. The arrangement of rells and seeds like a star in the ent half fruit is the source of the English name star-apple. Flowering in summer and fall, the fruit maturing from late fall to summer. Said not to fruit in the Virgin Islands.

The wood is redlish brown, hard, heary (spe(ific gravity 0.7), strong, and durable. It is snitalle for construction.

The principal value of this tree in Puerto Rico is its fruit and its attractive appearance as an ornamental and shade tree.

Planted and escaping from cultivation in Pnerto Rieo and possibly natire. Also grown in St. ('roix, st. 'Thomas, and St. oohn.

Riscre-Cative in Greater Antilles, the range spread by cultivation throngh tropical America. Now widely planted in sonthern Florida, through West Indies from Cuba to Trinidad and Tobago and from sonthern Mexico to Brazil.

()Ther cominox vames.-eainit (Tirgin Islands) : ramito (Spanish); maduraverde, eamo, caimo morato (Colombia): star-apple, goldenleaf (English) : kaimit, caimite (Trinidad and Tobago) : caïnite, ("aïnitier (French) : sterappel (Curaçao); sterappel, apra (Surinam); cainito (Brizil). 


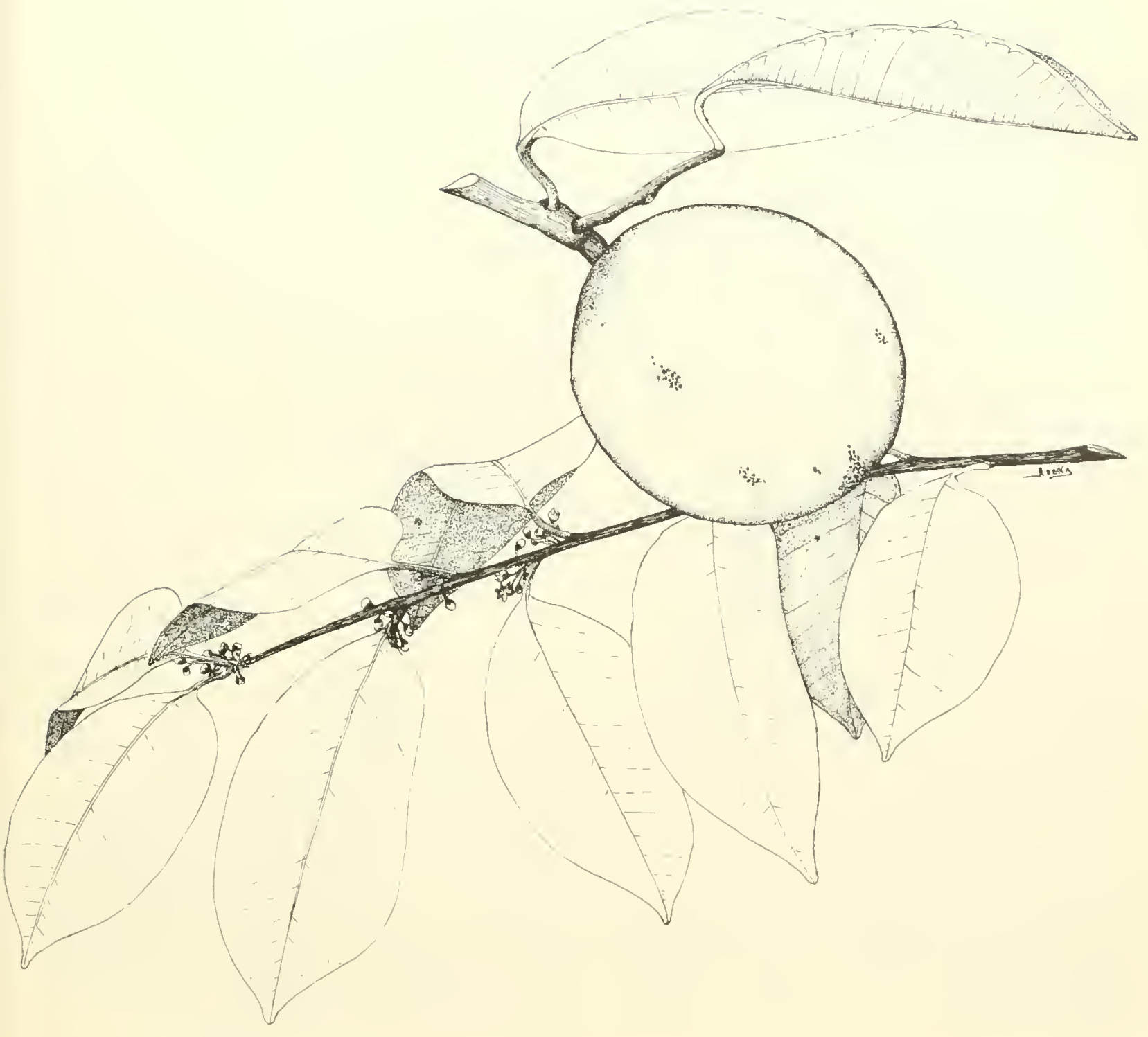




\section{SAPODILLA FAMILY (SAPOTACEAE)}

\section{Caimitillo de perro, satinleaf}

A small tree, with milky sap, resembling starapple or caimito (Chrysophyllum cuinito L.) and easily recognized by the similar elliptic leares with lower surfaces pretty reddish brown (copper colored), finely satiny or silky hairy. It differs in the smaller elliptic dark purple berry about 3/1 inch (to $11 / 4$ inches) long with usually only 1 seed. Other distinguishing characters are: (1) young twigs, buds, petioles, flower stalks, and calyx finely reddish-brown hairy; and (2) the small tubular bell-shaped 5-lobed flowers $3 / 16$ inch long and broad, whitish green, a few together on short stalks at bise of leaves.

An evergreen tree 12-30 feet high with trunk to 1 foot in diameter. 'The gray-brown bark is rough and much fissured into irregular plates and thin scales. Inner bark is light pink and contains milky latex. The slender reddish-brown or rusty young twigs later become light gray.

The alternate leaves have petioles $1 / 4-1 / 2$ inch long. Blades are $11 / 4-3$ inches long and $3 / 4-13 / 4$ inches wide, short-pointed at apex, rounded or short-pointed at base, slightly thickened, above shiny green with inconspicuous reins and hairless except when young.

There are a few flowers chustered together at the base of a leaf on slender reddish-brown hairy stalks $1 / 8-1 / 4$ inch long. The calyx consists of 5 rounded, reddish-brown hairy and greenish sepals more than 1/16 inch long; the whitish-green tubular corolla $3 / 16$ inch long with 5 rounded lobes and bearing 5 minute stamens at apex of tube opposite the lobes; and light green pistil 1/8 inch long with hairy 5-celled ovary, short style, and minutely 5 -lobed stigma.
Chrysophyllum oliviforme $\mathrm{L}$.

The elliptic fleshy fruit resembles an olive, as the specific name indicates. It retains the calyx at base and has a minute style point at apex. The light purple to whitish flesh is sweet ish and edible, but the skin is gummy or rubbery with milky sap. The large seed is shiny light brown. Collected in flower from July to October and with mature fruits in February.

The light brown wood is hard, very heary (specific gravity 0.9), and strong. In Cuba it is used for constriction, beams, and doors and windows.

Planted in sonthern Florida as an ornamental for the beautiful foliage. Jelly can be prepared from the fruits.

The moist limestone region of northern and western Puerto Rico.

Public forests.-Cambalache, Vega.

RANGE.--Southern Florida including Florida Ḱeys, Bahamas, Cuba, Jamaica, Hispaniola, Mona (possibly introdnced), and Puerto Rico.

Otrier comion vaues.-caimitillo, caimito de perro (Dominican Republic); caimitillo, caimito, caimito cimarrón, macanabo (Cuba); satinleaf (United States); satinleaf, saffron-tree (Bahamas) ; caïmite marron (Haiti).

A related species of caimitillo (Chrysophyllum birolor Poir.; synonym $C$. eggersiz Pierre) is called also wild cainit and lechecillo. It has elliptic leares with lower surfaces reddish brown and finely satiny or silky hairy when young but later nearly hairless. It differs from the above species in the flower with 5-9-celled ovary and in the fruit with 1 to few seeds. Besides Puerto Rico, it is found in St. Croix, St. Thomas, and St. John. 


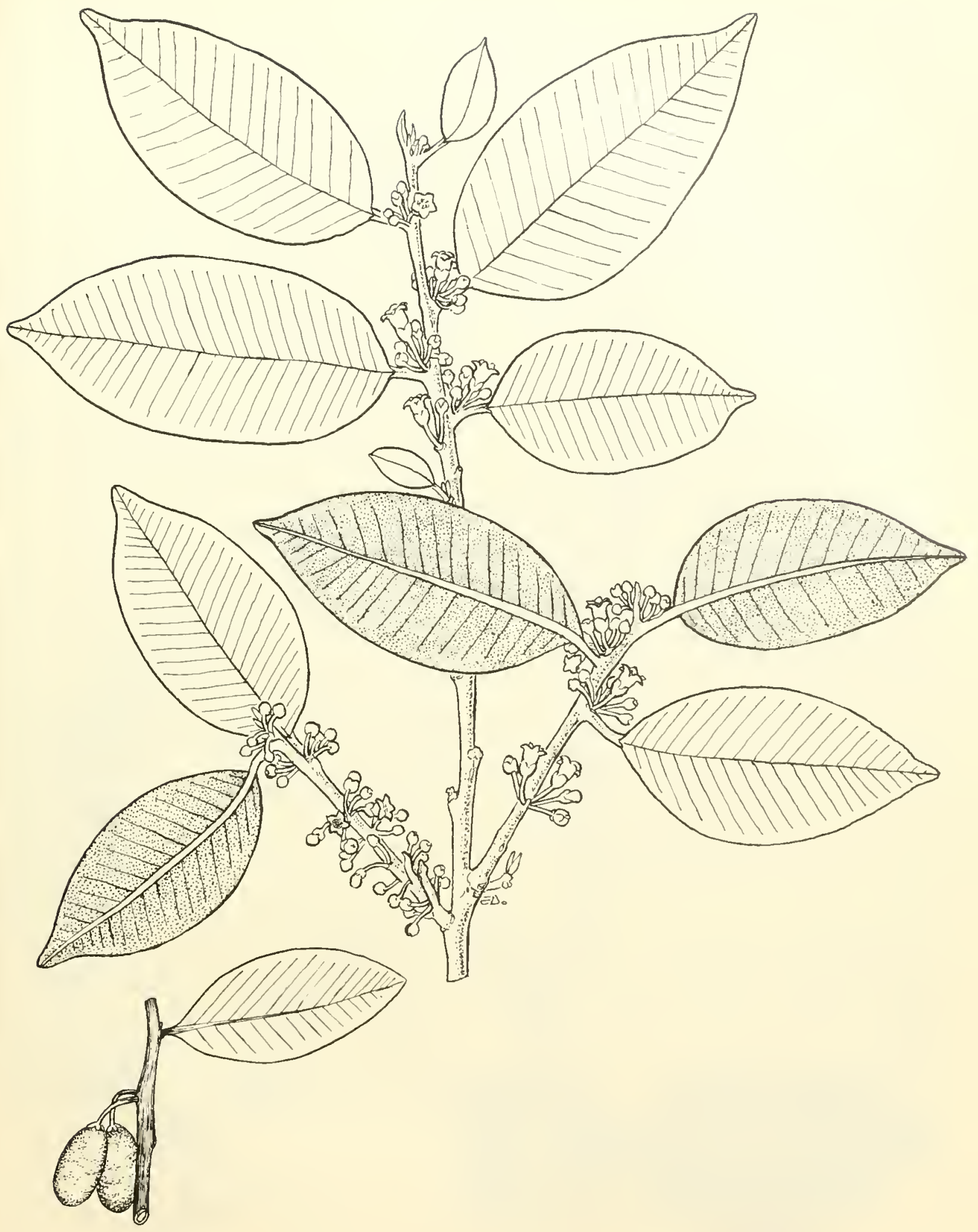




\section{SAPODILLA FAMILY (SAPOTACEAE)}

\section{Sanguinaria, wild mespel, willow bustic}

This small to medium-sized tree with white latex is recognized by: (1) lanee-shaped or narpowly ellipt ic leaves, mostly widest at middle and long-pointed at both ends, the edges appearing finely wary or wrinkled; (2) numerous small whitish-green fragrant flowers, rounded and about $3 / 16$ inch long and broad, borne in erowded lateral clusters along the twigs mostly back of the leares: and (3) many round black berries $1 / 4$ inch or more in diameter along the twigs.

An erergreen tree $30-50$ feet high and to $1-2$ feet in diameter. The brownish-gray bark is smoothish and much fissured, becoming rough and flaky or sealy. Imner bark is pinkish and bitter. The slender twigs are brownish-green hairy when young, becoming gray.

The leaves are erowded but alternate on brown hairy or hairless petioles $1 / 4^{-1 / 2}$ inch long. Leaf blades are $21 / 2-4$ inches long and $3 / 4-11 / 4$ inches broad, slightly thickened, hairy when young, green and slightly shiny on upper surface and paler beneath. Is the seientific name suggests, they resemble willow leaves.

Flower elusters are less than $1 / 2$ ineh across, with each flower on a biown hairy stalk less than $1 / 8$ inch long. The ealyx is eomposed of 5 nearly round, brown hairy sepals less than 1/s inch long: the whitish funnel-shaped corolla has 5 rounded lobes each with 2 small lobes or appendages: 5 stamens on the cornlla tube opposite the lobes and alternating with 5 toothed appendages (staminodes) : and pistil with 5-celled ovary and slender style.

"The fruits mostly single back of the leares are blunt-pointed. sticky inside, and contain usually 1 brown seed less than $3 / 16$ inch in diameter. Flowering ehiefly in early spring and spring (January to May) and maturing fruit in summer and fall.

The sapwood is light brown, and the heartwood reddish brown or dark brown. The wood is hard. very heary (speeifie gravity 0.9), strong, tough.
Dipholis salicifolia (L.) A. DC.

and moderately durable. It has medium-fine texture, fairly straight grain, and a bitter taste. In Puerto Rico used ehiefly for posts. Uses elsewhere include heary construction, bridges, poles, flooling, and crossties.

In British Fonduras the trees though rare reportedly are tapped for chicle. The flowers are attractive to bees.

The moist and dry limestone regions of Puerto Rico. I tree of open areas and probably lightrequining. Also in Mona, Vieques, St. Croix, St. Thomas, St. John, and Tortola.

Punlic Fonests.-Cambalache, Guajataca, and Guánica. 7,9 .

MUNiCIPALITIES WIIERE ESPECIALLY COMMON.-

RANGE.-Sonthern Florida ineluding Florida Keys and nearly through West Indies from Bahamas and Cuba to Dominica, St. Vincent, and Barbados. Also in southern Mexico, Guatemala, and British Honduras.

Other Comion Names.-almendrón (Puerto Rico) : caya colorada (Dominican Republic); euyá, almendrillo, almendro silvestre, carolina, jubilla (Cuba) : xac-chum (Mexico) : willow bustie, bustic, cassada (United States); bustic (commerce) ; bustic, wild eassada, cassada-rood (Bahamas); white bulletwood (Jamaica): sweetwood (Barbuda); bully-tree (Barbados); cháchiga, mijico (British Honduras): acomât rouge, sapotillier marron (Haiti); acomat batârd (Guadeloupe).

Two other species of this genus are native only in mountain forests of Puerto Rico. Tabloncillo (Diphotis bellonis Urban) is a rare large tree known only from the Central Cordillera. It has ovate leaves $3-11 / 2$ inehes long, long-pointed at apex, and larger black berries $3 / 4$ inch long.

Espejuelo (Diphotis cubensis (Griseb.) Pierre: synonym $D$. sintenisiana Pierre), of the central and western mountains, has usually smaller oborate leares $1-21 / 2$ inches long with usually rounded apex, and oblong greenish berries $3 / 8$ inch long. 


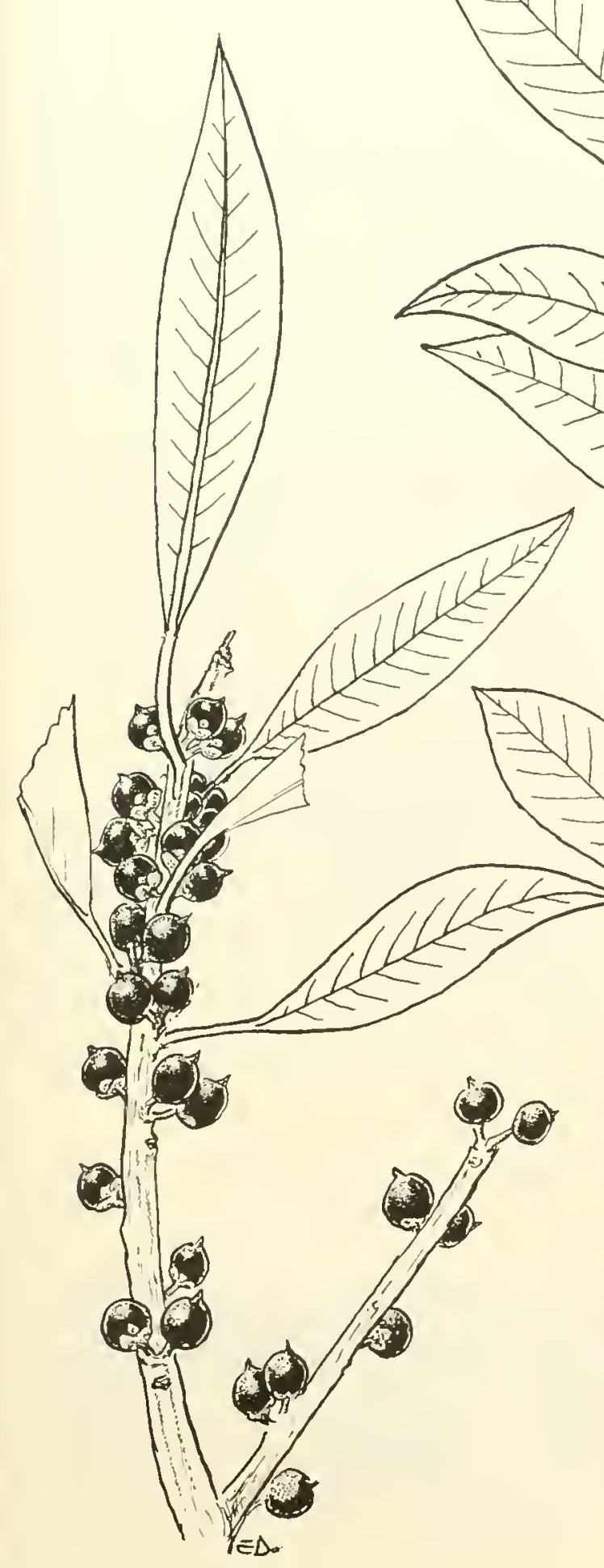

208. Sanguinaria, wild mespel, willow bustic

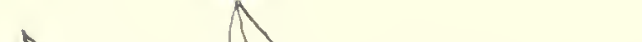


In the past, this large forest tree with milky latex probably was the most important timber of Puerto Rico. It is characterized by: (1) a dense crown of horizontal branches with the foliage appearing in layers; (2) dark green elliptic leaves, often large, the apex varying from blunt-pointed to rounded or notched and base short-pointed, thickened and leathery with edges slightly turned under, with many faint parallel lateral veins; (3) small whitish fragrant bell-shaped flowers in lateral cluster's at leaf bases; and (4) lound or oval, edible fruits $1-11 / 4$ inches long.

An evergreen tree becoming 100 feet tall, with straight trunk to 4 feet in diameter. Large trunks have broad rounded buttresses spreading at base. The thick brown baik is fissured and scaly. Inmer bark is pink and bitter. The stout gray twigs are hairless or minutely hairy when young.

The alternate leaves, frequently darkened by a covering of sooty mold, have petioles $3 / 4-11 / 4$ inches long. Leaf blades are $31 / 2-10$ inches long and $11 / 2-$ $41 / 2$ inches broad, often broadest beyond middle. The midrib is slightly sunken on the dark green upper surface and raised on the light green fower surface.

There are $3-10$ flowers together on stalks about $1 / 2$ inch long. Calyx consists of 6 pointed green sepals $1 / 4$ inch long, minutely hairy or nearly hairless, arranged in 2 series; the whitish corolla slightly longer, with short tube and 6 lobes, each with 2 long narrow appendages resembling additional lobes; 6 stamens on the corolla tube opposite the lobes and alternating with the same number of appendages (staminodes) ; and pistil with 6-10celled ovary and slender style.

The smooth berry has a sweet sticky or gummy pulp and is edible. It contains usually a single shiny blackish seed. Flowering and fruiting perhaps irregularly through the year.

Ausubo is one of the strongest and most attractive commercial woods of Puerto Rico. The sapwood is whitish to pale brown, and the heartwood is light red when cut, turning to dark reddish brown when dry. The wood is very hard, heavy (specific gravity 0.82 ), very strong, fine-textured, with grain usually straight but sometimes coarsely interlocked. The rate of air-seasoning is rapid, and amount of degrade is minor. Machining characteristics are as follows: shaping, boring, mortising, and sanding are excellent; planing is good; turning is poor; and resistance to screw splitting is fair. The wood finishes beautifully, resembling mahogany. It is generally resistant to attack by dry-wood termites, very resistant to decay, and very durable in contact with the ground.

The chief use of this wood in Puerto Rico was for construction timber's. Elsewhere it is utilized for furniture, cabinetwork, crossties, utility poles, tool handles, heavy construction, flooring, and bridges. It is suitable also for shuttles and other textile items, billiard cues, and violin bows.

Formerly named as distinct, this tree of Puerto Rico, St. John, and Tortola is now considered the same as the more widely distributed and commercially important tropical American timber species, balata or bulletwood. The milky latex of this species is the source of balata gum, which is similar to gutta-percha. Trees in northern South America and Panama are tapped for this purpose. In some areas the trees are first destroyed by felling and then bled. The latex is coagulated by heat and smoke over a fire or is dried in the sun. Souvenirs and novelties are made from the girm.

Moist coastal and limestone forests and lower mountain forests in Puerto Rico. Also St. John and Tortola. The trees grow slowly but are tolerant of shade. This species has been listed as worthy of planting for shade and timber.

Publac Forests.-Cambalache, Carite, Guajataca, Luquillo, Río Abajo. There is a very large tree along the Big Tree Trail in the La Mina Recreation Area in the Iuquillo Forest.

MUNICIPALITIES WIIERE ESPECIALIY COMIMON.$13,42,58,74$.

Range.-Hispaniola, Puerto Rico and Virgin Islands, throughont Lesser Antilles to Barbados, Trinidad and Tobago, Panama, and northern South America from Guianas and Venezuela to Peru and northern Brazil.

Otier common Names.-balatá (Spanish); purguo, acaná, pendare (Venezuela); pamashto, quinilla, quinilla colorada (Peru) ; balata (English, commerce); bulletwood, bullet (English); gooseberry (Tobago); bully-tree (Barbados); sapotillier marron, sapotillier noir, bois noir (Guadeloupe); balate (Guadeloupe, Martinique) ; balata franc, balata rouge (French Guiana); bolletrie, balata, parata (Surinam); balata (Brazil).

Botanical synonyms.-Manilkara nitida (Sessé \& Moc.) Dubard, Manilkara balata auth., Manilkara riedleana (Pierre) Dubard, Mimusops bidentata A. DC., Mimusops balata auth., Mimusops sieberi A. DC., Mimusops riedleana Pierre, Mimusops domingensis (Pierre) Huber.

Zapote de costa (Manilkara pleeana (Pierue) Cronq.; synonym M. duplicata (Sessé \& Moc.) Dubard), called also mameyuelo, is a related tree of moist coastal forests known only from Puerto Rico, Vieques, St. John, and Tortola. It has leaves silvery hairy beneath, larger flowers with corolla about $1 / 2$ inch long, and larger fruits $11 / 2-$ $21 / 2$ inches long, broader than long, and 3-8-seeded. 


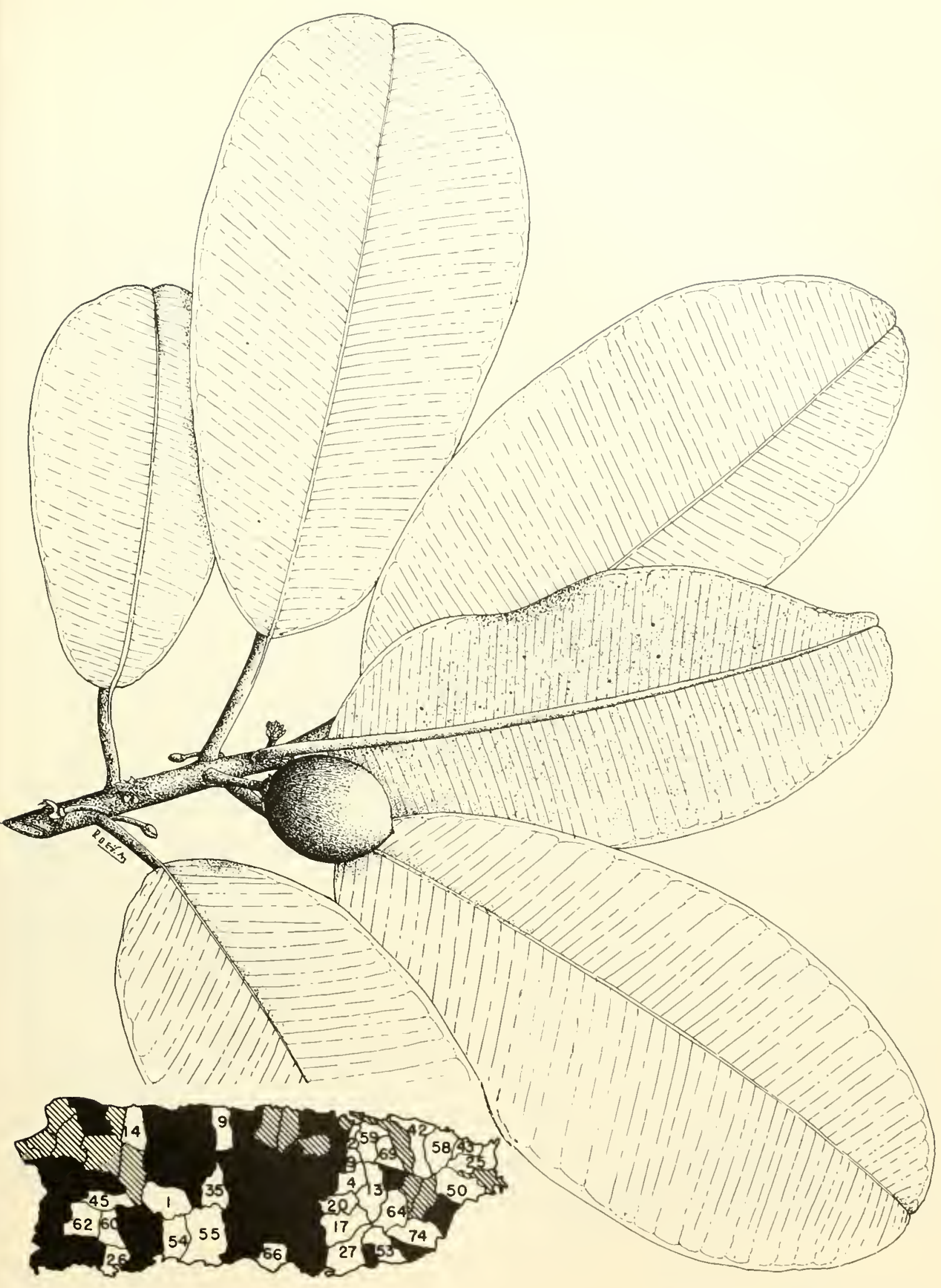

209. Ausubo, balata 


\section{SAPODILLA FAMILY (SAPOTACEAE)}

\section{Níspero, sapodilla}

This exotic tree whose white latex is the main source of chewing gum is cultivated for its wellknown edible fruits. It is distinguished by: (1) elliptic shing green leaves mostly short-pointed at both ends, with indistinct lateral veins close together and nearly at right angles to midrib, on slender petioles clustered at ends of stout twigs though actually alternate; (2) light green cupshaped or bell-shaped flowers about $3 / 8$ inch long and broad, borme singly at leaf bases; and (3) the brown rounded or egg-shaped fruits $1 \frac{1}{2}-3$ inches in dianeter, with sweet brownish flesh and milky sap.

Handsome evergreen tree, in cultivation to 50 feet in height and 20 inches in diameter but becoming more than 100 feet tall in forests, with dense rounded crown of shiny green to dark green foliage. The dark brown bark when eut yields the latex known as chicle. The stout twigs are gray and widely forking.

Petioles are $3 / 8-3 / 4$ inch long, yellow green, and finely brown hairy. Blades are $3-41 / 2$ inches long and $11 / 4-1 \frac{1}{2}$ inches wide, slight ly thickened, shiny green above and dull light grreen beneath.

Flowers are borne on brown hairy stalks about $1 / 2$ inch long and consist of 6 sepals about $5 / 16$ inch long, the outer 3 hrownish hairy, ovate, and bluntpointed and the inner 3 light brownish green and elliptic; light green corolla about $3 / 8$ inch long, forming a tube in lower half and 6 elliptic lobes above: 6 stamens less than $1 / 8$ inch long at apex of corolla tube, opposite the corolla lobes and alternating with toothed lobes (staminodes) nearly $3 / 16$ inch long; and pistil nearly $3 / 8$ inch long with light brown hairy $10-12$-celled ovary and stout green style.

The rough-skinned berry contains $1-5$ or sometimes more flattened elliptic shiny black or brown seeds $3 / 4-1$ inch long with a white sear on inner edge. Flowering and fruiting nearly through the year.

The wood is dark red, very hard and heavy, strong, tough, and durable. Where available, the wood is employed in general and heavy construction, cabinetwork, furniture, tool handles, crossties, carts, rulers, and shuttles.

Chewing gum is made from commercial chicle, which is the condensed latex principally of this species and obtained chiefly by tapping trunks of

\section{Manilkara zapota (L.) v. Royen*}

wild trees in the Yucatan Peninsula of southern Mexico, British Honduras, and Guatemala. Accordiugly, this is one of the most important tree species of liritish Honduras. V-shaped gashes are cut in the bark in the rainy season, and the milky liquid is collected in small vessels. Then the sap is condensed by heating, and the resulting gum kneader with a stick and made into small cakes for export.

Nispero, or sapodilla, is extensively planted over tropical regions of the world for the edible fruits, which are among the most popular in the tropics. and for ormament and shade. Besides being eaten law, the fruits can be made into preserves and syrup.

In Puerto Rico the trees are grown occasionally for fruit and shade around houses at lower elevations, mostly in the drier areas. Also in Mona, St. (roix, st. Thomas, St. John, and Tortola.

R.x.Ge.-Native in sonthern Mexico and Central America south to Costa Rica. Now widely cultivated and recasionally naturalized from southern Florida and Bermuda through West Indies from Bahamas and Cuba to Barbados, Trinidad and Tobago, and Dutch West Indies, from Mexico to Brazil, and in the Old World tropies.

Other comaron names.-mespel (Virgin Islands): níspero (Spanish); sapote (Cuba); zapote, chicozapote, zapote chico, chicle, zapotillo (Mexico) ; muyozapot (El Salvador); sapodilla (Tnited States, English); naseberry (British West Indies); dilly (Bahamas) ; chicle, sapodilla, zapote blanco, zapote colorado, zapote morado ( $3 \mathrm{r}$ it ish Honduras); sapotille, sapotillier (French) ; mispu, mispel, sapodille (Dutch West Indies): sapotille, sapatija, mispelboom (Surinam) ; sapotí, sapotilha (Brazil).

Botanical STNonyms.-Achras zapota L., Sapota achres Mill., Manithara zapotilla (Jacq.) Gilly.

Another species, wild-dilly (Manilkara jaimiqui (Wright) Dubard; synonyms Manilkara emargimata (L.) Britton \& Wilson, Achras emarginata (I.) Little), has been recorded from southwestern Puerto Rico, extending to Florida. It has smaller oblong leaves $11 / 4-4$ inches long, slightly notched at apex; flowers about $5 / 8$ inch long and broad, with light yellow corolla; and round inedible fruits 1-2 inches in diameter. 


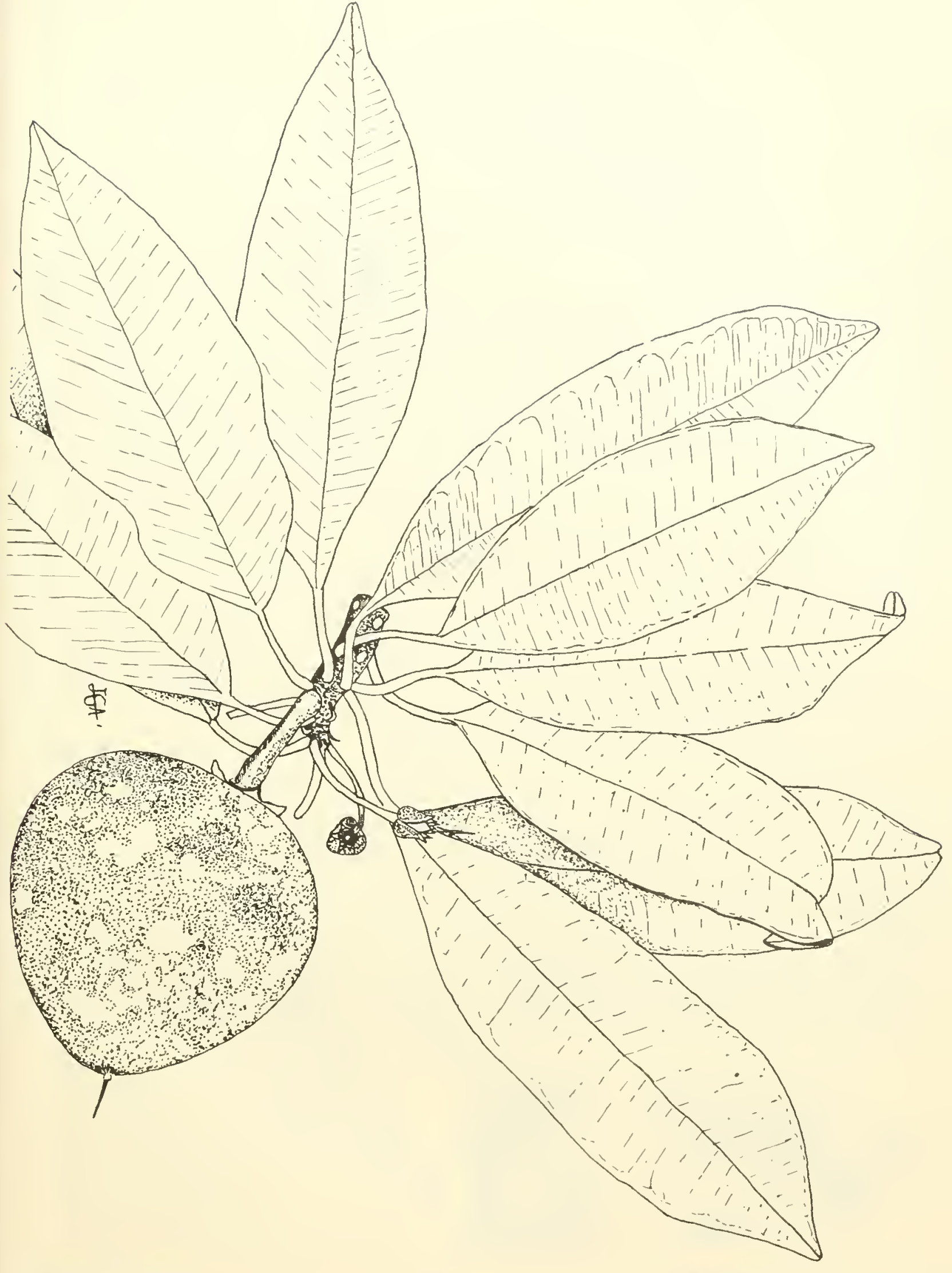




\section{SAPODILLA FAMILY (SAPOTACEAE)}

\section{Caimitillo}

A tree of monntain forests distinguished by the beautiful bronze or reddish-brown, finely silky hairy lower surfaces of the elliptic leares, which are 11/2-31/ inches long and 1-2 inches broad, and abruptly short-pointed at the apex. Other chalacteristies are: (1) small, bronze and greenish cupshaped flowers about $1 / 4$ inch long and broad, borne laterally; (2) elliptic berries $3 / 4-13 / 4$ inches long and $5 / 8$ inch or less in thickness; and (3) a small amount of milky sap.

Medimm-sized evergreen tree 30-60 feet in height and 2 feet in trunk diameter, with erect trunk and narrow dense crown of dark green foliage. The gray bark is smoothish. Inner bark is pinkish, tasteless or bitter. Twigs are bronze hairy when young, becoming dark gray and hairless.

The alternate leares have bronze hairy petioles $1 / 4-3 / 8$ inch long. Blades are short-pointed at base, thick and leathery, the upper surface dark green, hairless or nearly so, and slightly shiny, and the lower surface sometimes in age also nearly hairless.

The inconspicnous flowers are attached on bronze hairy stalks about $1 / 1$ inch long, usually $1-3$ (sometimes to 8 ) at the base of a leaf or on twig back of leaves. There are 5 bronze hairy sepals $1 / 8$ inch long; the yellowish-green corolla with tube and 5 short, rounded spreading lobes $1 / 4$ inch across: 5 small stamens on the corolla tube opposite the lobes and 1 short appendage (staminode) between each 2 lobes; and pistil with hairy 5-celled ovary and short style. One large elliptic brown seed is contained in the fleshy fruit. Flowering and fruiting nearly through the year.

The heartwood is uniform light yellowish brown and not readily separated from the lighter brown
Micropholis chrysophylloides Pierre

sapwood. The wood is hard, heary (specific gravity 0.68), strong, tongh, fine-textured, straightgrained, and with indistinct growth rings. It is susceptible to attack by dry-wood termites. The rate of air-seasoning is rapid, and the amount of degrade is minor. Machining characteristics are as follows: planing, turning, and mortising are good; shaping and boring are excellent; and sanding and resistance to screw splitting are fair. Sawing and machining are moderately difficult becanse silica in the wood dulls the saw teeth and cutting edges. However, the wood takes a high polish.

The wood is used sometimes for const ruction. It is snitable for furniture, cabinetwork, interior trim, flooring, paddles, farm implements, tool handles, veneer, plywood, and general carpentry.

In the forests of the upper monntains of Puerto Rico, widely distributed from east to west.

Public Forests.-Carite, Guilarte, Luquillo, Marica, Toro Negro.

MINICIPALTTES WIIERE ESPECIALLY COMMON.$1,17,19,27,35,45,52,54,62$.

Rixge.-Puerto Rico and Lesser Antilles from St. Kitts to Grenada.

Other common names.-mesa, leche prieta (Puerto Rico); pan mango (Nevis); wild mango (Montserrat); caimite (Dominica); feuille dorée (St. Iucia) ; wild star-apple (St. Vincent) ; bois (Grenada); caimitier bois (Guadeloupe, Martinique).

Botaxical synonyms.--Microphotis curvata (Pielre) T'rban, M. portoricensis Pierre var. curvata Pierre, Pouteria chrysophylloides (Pierre) Stehlé. 


\section{SAPODILLA FAMILY (SAPOTACEAE)}

\section{Caimitillo verde}

This tree found only in the eastern mountains of Plerto Rico is characterized by: (1) small elliptic leaves $11 / 4-21 / 2$ inches long and $3 / 4-13 / 4$ inches broad, stifl and leathery, rounded or slightly notched at apex, hairless or nearly so when mature, green on both surfaces, with numerous straight lateral veins very close together and parallel: (2) small greenish and rusty-brown cupshaped flowers about $3 / 16$ inch long and broad borne laterally on short stalks; (3) elliptic green fruits 1-1/2 inches long, pointerl at both ends and 5 -angled; and (4) a small amount of milky sap.

Small to medinn-sized evergreen tree $15-50$ feet ligh, with struight trunk to $1 \frac{1}{2}$ feet or more in diameter, huttressed at base when larere. The bark is smoothish or slightly fissured, brown or dark gray. Inner bark is reddish brown, slightly bitter, with small anount of white latex. The twigs are rusty-brown hair when young, becoming brown ol gray and finely fissured.

The alternate leaves have brown hairy petioles $1 / 8-3$ inch long. Leal blades are rounded at base, with edges turned muler, finely hairy when voung but becoming hairless or nealy so, dark green and shightly shiny on upper surface, and yelfow green on lower surface.

One to i flowers are borne at the base of a leaf on rusty-brown laairy stalks about $1 / 4$ inch long. Sepals $5,1 / 8$ incli long, rusty-brown hairy; the areen corolla with tube and 5 short, rounded, spreading lobes nearly $1 / 4$ inch across, hairless or with a few hairs on outside; 5 small stamens on the corolla tube opposite the lobes and 1 short appendage (staminode) between each 2 lobes; and pistil with hairy 5-celled ovary and short style.

\section{Micropholis garciniaefolia Pierre}

The berry has thin flesh and 5 or fewer pointed dark brown seeds :bout $3 / 4$ inch long. Flowering from. Tune to Norember, the fruits maturing in summer and fall.

The wood is very similar to that of the preceding species of caimitillo. The heartwood is uniform light yellowish brown, and the sapwood lighter brown and not clearly differentiated. The wood is hard, moderately heavy (specific glavity 0.64), strong, tough, fine-textured, straight-grined, and with indistinct growth rings. It is considered very susceptible to attack by dry-wood termites. The rate of air-seasoning is rapid, and the amount of degrade is moderate. Machining characteristics are as follows: planing, tuming, bol'ing, moltising, sanding, and resistance to screw splitting are good; and shaping is excellent. The wood is moderately difficult to saw and machine because siliea dulls teeth and cutting edges. However, it takes a high polish.

The wood is used for posts and in construction. It is suitable also for reneer, plywood, fumiture, cabinetmaking, turning, interior trim, flooring, farm implements, tool handles, and general cal"pentry.

In the upper mountain forests of eastern Puerto Rico, chiefly in the Luquillo Mountains.

Public forests.-Carite, Luquillo.

RANGE.-Known only from mountains of eastern Puerto Rico.

OTHER COMMON NAMES.-caimitillo cimarón, caimitillo (Puerto Rico).

Botaxical syony.-Pouteria garciniaefolia (Pierre) Baehni. 


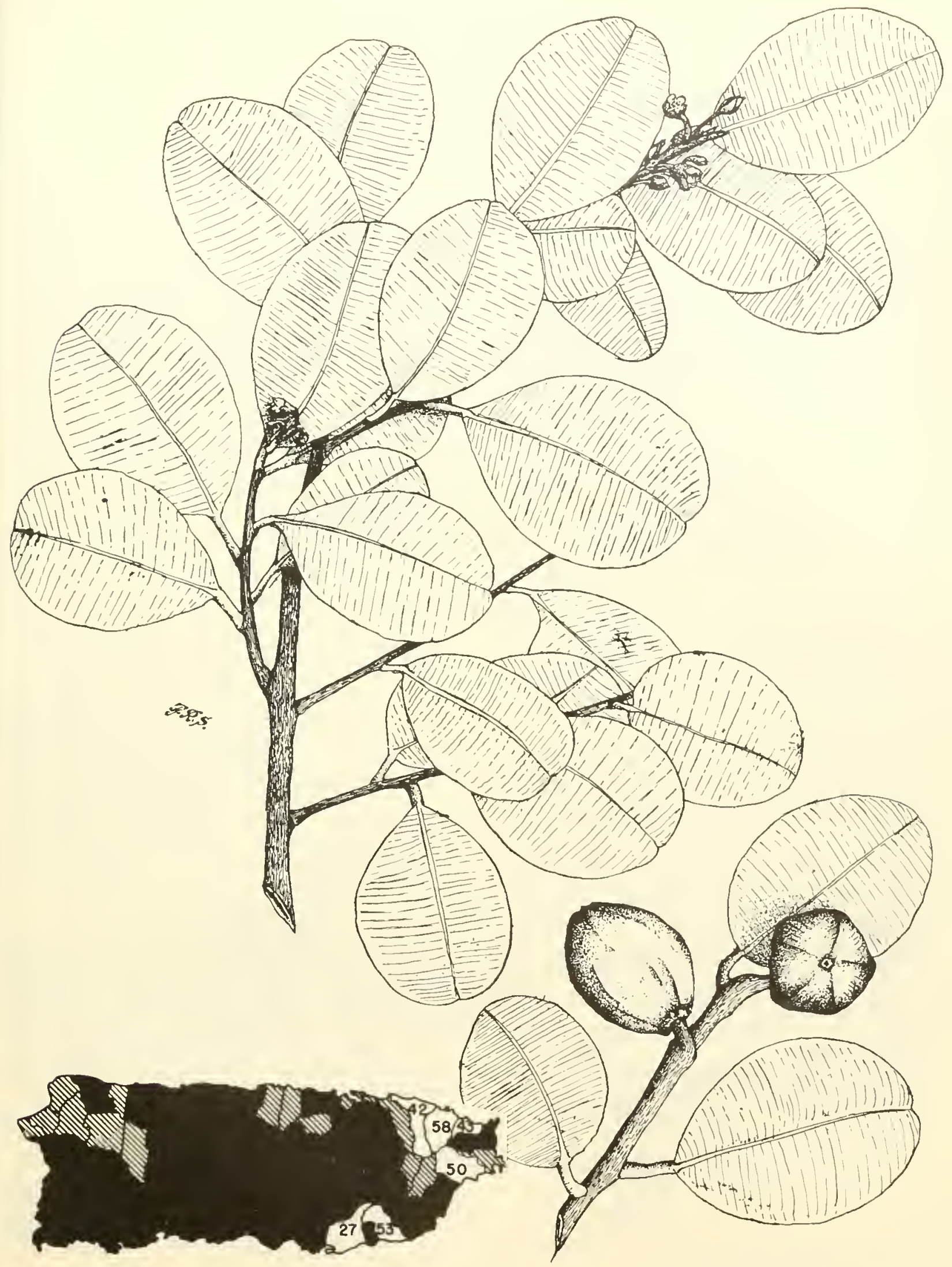

212. Caimitillo verde 


\section{SAPODILLA FAMILY (SAPOTACEAE)}

\section{Jácana}

This large tree with small amount of milky sap, found in moist forests, is distinguished by : (1) usmally large, narrowly elliptic dark green leaves $5-16$ inches long and $2-5$ inches broad, widest beyond middle, slightly thickened and leathery, with sunken lateral reins on upper surface; (2) the white to pinkish bell-shaped flowers $3 / 8$ inch long borne in lateral clusters along the twigs at leaf bases or back of leaves; and (3) orange-colored round or elliptic fruits $11 / 2-2$ inches long, which are edible but mealy and almost tasteless.

An evergreen tree $60-80$ feet in height and to $1 \frac{1}{2}$ feet in trunk dianeter, with wide crown of spreading and slightly drooping branches. Bark is much fissured, slightly rough, and brown. The innel bark is light pink, almost tasteless, and with a small quantity of white latex. The stont twigs are brown and minutely hairy when young, becoming gray.

The leaves are alternate but mostly close together on petioles $1 / 2-3 / 4$ inch long. Blades are usually short-pointed at apex, long- or shortpointed at base, not toothed on edges, hairless or nearly so, and beneatl green or yellow green with raised veins.

A few flowers are borne together on green, minutely hairy stalks $3 / 8$ inch long. There are 4 broad, rounded, overla ppiug, green sepals less than $1 / 4$ inch long, the onter 2 finely hairy; the white to pink corolla tubular, $3 / 8$ inch long and $1 / 4$ inch broad with generally 6 rounded lobes; there is 1 stamen on the corolla opposite each lobe and 1 appendage (staminode) between each 2 lobes; and pisti] with brown hairy 4- or 5-celled ovary and stout sty]e $1 / 4$ inch long.

The large soft berries have a slight mellow odor and an orange pulp, almost the color of an egg yolk. There is usually a single, very large, elliptic, shiny brown seed 1-11/2 inches long. Flowering from spring to fall, the fruit maturing nearly through the year.

The sapwood is light brown, and the heartwood is reddish brown. The wood is rery hard, very
Pouteria multiflora (A. DC.) Eyma

heavy (specific gravity 0.74), strong, fine-textured, with generally straight grain, and withont evident growth rings. It is susceptible to attack by dry-rood termites. Air-seasoning is slow, difficult, and with considerable degrade. Machining characteristics are as follows: planing and resistance to screw splitting are fair; shaping, turning, mortising, and sanding are good; and boring is excellent.

The wood is used principally for construction and also for fumiture. Uses elsewhere include heavy construction, house framing, bridgework, and posts.

Suitable for planting for shade and ormament. Fruits are eaten locally.

Moist coastal and limestone forests and lower mountain forests in Pnerto Rico. Seedlings sometimes are numerous in the shade of a parent tree. Also St. Croix and St. Thomas.

Purbic Forests.-Carite, Guilarte, Liquillo, Maricao, Río Abajo, Susúa, Toro Negro.

MUNICIPALTT WUERE ESPECIALLY COMMON.43.

Rasge.-Jamajca, Hispaniola (Dominican Repub]ic), Puerto Rico, St. Croix, St. Thomas, throngh Lesser Antilles from Saba and St. Kitts to Grenada, and Trinidad. Planted in Bermuda.

OTHER COMMON NaMES.-bully-tree, savannah bully-tree (Jamaica); choky-apple (St. Kitts, Nevis); pain d'épice (Dominica, Trinidad); penny-piece (Dominica, St. Vincent, Grenada, Trinidad); poinme pain, pain d'épice (Guadeloupe, Martinique). DC.

Botanical SYNONYM.-Lucuma multiflora A.

On limestone hills of northern Pnerto Rico there is another species (Pouteria dictyoneura (Griseb.) Radlk.; synonym Paralabatia portoricensis Britton \& Wilson ), found also in Hispaniola and Cuba. It has lance-shaped leaves $21 / 2-41 / 2$ inches long and $1-11 / 2$ inches wide, hairy beneath with long whitish hairs; smaller flowers $3 / 16$ inch long; and round or elliptic fruits $3 / 4-1$ inch long, 1 -seeded. 


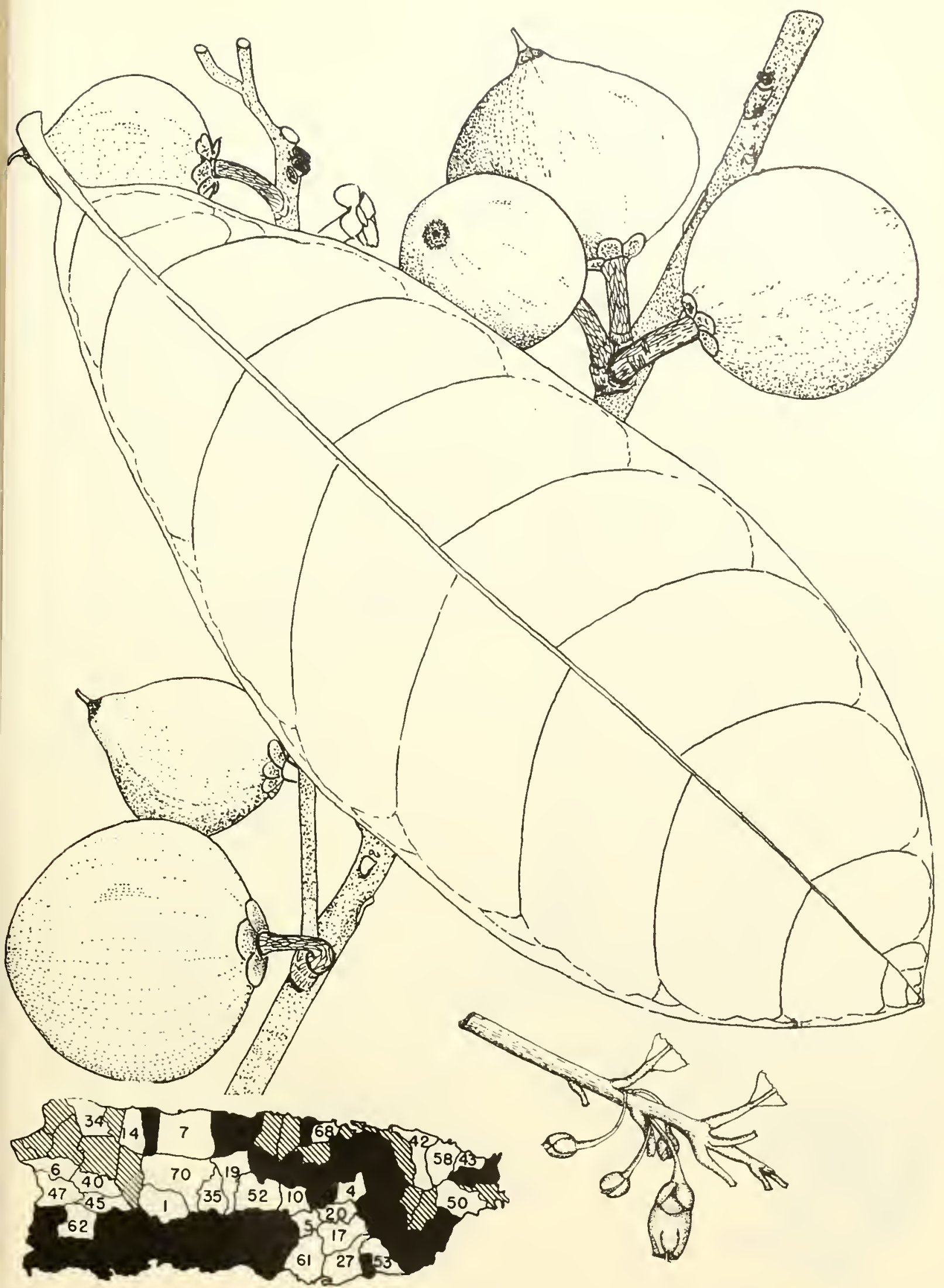

213. Jacana 


\section{SAPODILLA FAMILY (SAPOTACEAE)}

\section{Tortugo amarillo, false-mastic}

This tree with milky latex is characterized by: (1) ellipt ic to oblong, slightly shiny, yellow-grcen leaves appearing wavy or slightly wrinkled at edges, with long slender petioles and yellow midribs: (2) numerous small yellow flowers about 1/4 inch long and nearly :3/ inch across, widely spreading and 5- or 6-lobed, with somewhat unpleasant odor, crowded in clusters alongr twigs, mostly back of leaves: and (3) elliptic yellow sour fruits about $3 / 4-1$ inch long.

small to medium-sized evergreen tree with straight trumk and dense irregular crown, generally $15-50$ feet high and 4-12 inches in diameter, sometimes larger. Elsewhere reported to reach al maximum height of 80 feet and trunk diameter of more than 3 feet. Bark of small trunks is smoothish, with many small fissures and horizontal cracks, gray or light brown, on large trunks becoming thick, deeply furrowed, and splitting into plates. Inner bark is whitish and litter, with a small quantity of white latex. The twigs are brown and hairless, light green and minutely hainy when young.

The yellow-green petioles of the alternate leaves are $3 / 4-1 \frac{1 / 4}{4}$ incles long and often slightly winged toward apex. Blades are $21 / 2-41 / 2$ inches long and $7 / 8-21 / 4$ inches broad, blunt-pointed, rounded, or slightly notched at apex and short-pointed at base, very slightly thickened, hairless except when young, yellow green or a little paler beneath, and curved upward on both sides of the midrib.

The bright or pale yellow flowers are bome usnally sereral together, sometimes single, on slender stalks $1 / 4$ inch or less in length. Calyx consists of 5 or 6 rounded yellow-green overlapping sepals more than 1/16 inch long; the yellow corolla with short tube and 5 or 6 rounded widely spreading lobes $1 / 8$ inch long; as many yellow stamens erect at apex of corolla tube opposite the lobes and alternating with pointed deeply toothed appendages (staminodes); and greenish-yellow pistil 1/8 inch long with 5-celled ovity and short tapering style. The scientific name refers to the peculiar, strong, cheeselike odor of the flowers.

\section{Sideroxylon foetidissimum Jacq.}

Tsually 1 large brown seed is contained in the berry, which is shaped like an olive. Thongh edible and consumed by animals, the fruits have an umpleasant, gummy taste. Flowering and fruiting and fruiting at different times during the year lut not continuously.

The thick sapwood is yellowish and the heartwood is yellowish or orange. The wood is hard, heary (specific gravity 0.5), strong, and durable. The good timber is used for construction. Elsewhere it has been employed for boats, heary planking, furniture, and fenceposts.

Reported to be a fair honey plant and to be suitable as an ornamental for the clustered yellow flowers.

Coastal and moist limestone forests of Puerto Rico, probably common in the original forests but now searce because of demand for the wood. Also in Mona, St. Croix, St. Thomas, St. John, and Tortola.

Pıныс Forests.-Cambalche, Guajataca, Río Abajo.

R.xaE.-Central and southern Florida including Florida Key's and through West Indies from Bahamas and Cuba to Grenada and Barbados. A variety occurs also in Yucatán Peninsula of southeastem Mexico and in British Honduras.

OTHER COMMON NAMES.- tortugo colorado (Puerto Rico); mastwood, bully-mastic (Virgin lslands): ("ayal amarilla (Dominican Republic); jocuma, jocuma amarilla, jocuma blanca, jocuma lechera, caguaní (Cuba); false-mastic, mastic, mastic jungleplum (United States); mastic (Bahamas) : mastic-bully (Bahamas, Jamaica) ; mastwood (Antigua, St. Vincent); caimite acoma (Dominica); acoma (Grenadines); acomat (Haiti); acoma, acoma bâtard, acoma franc (Guadeloupe).

BOTANICAL srNoNrus.-Sideroxylon mastichodendron Jacq., S. portoricense Urban, Mastichodendron foetidissimum (Jacq.) Cronq. The generic name is sometimes spelled Sideroxylum. 


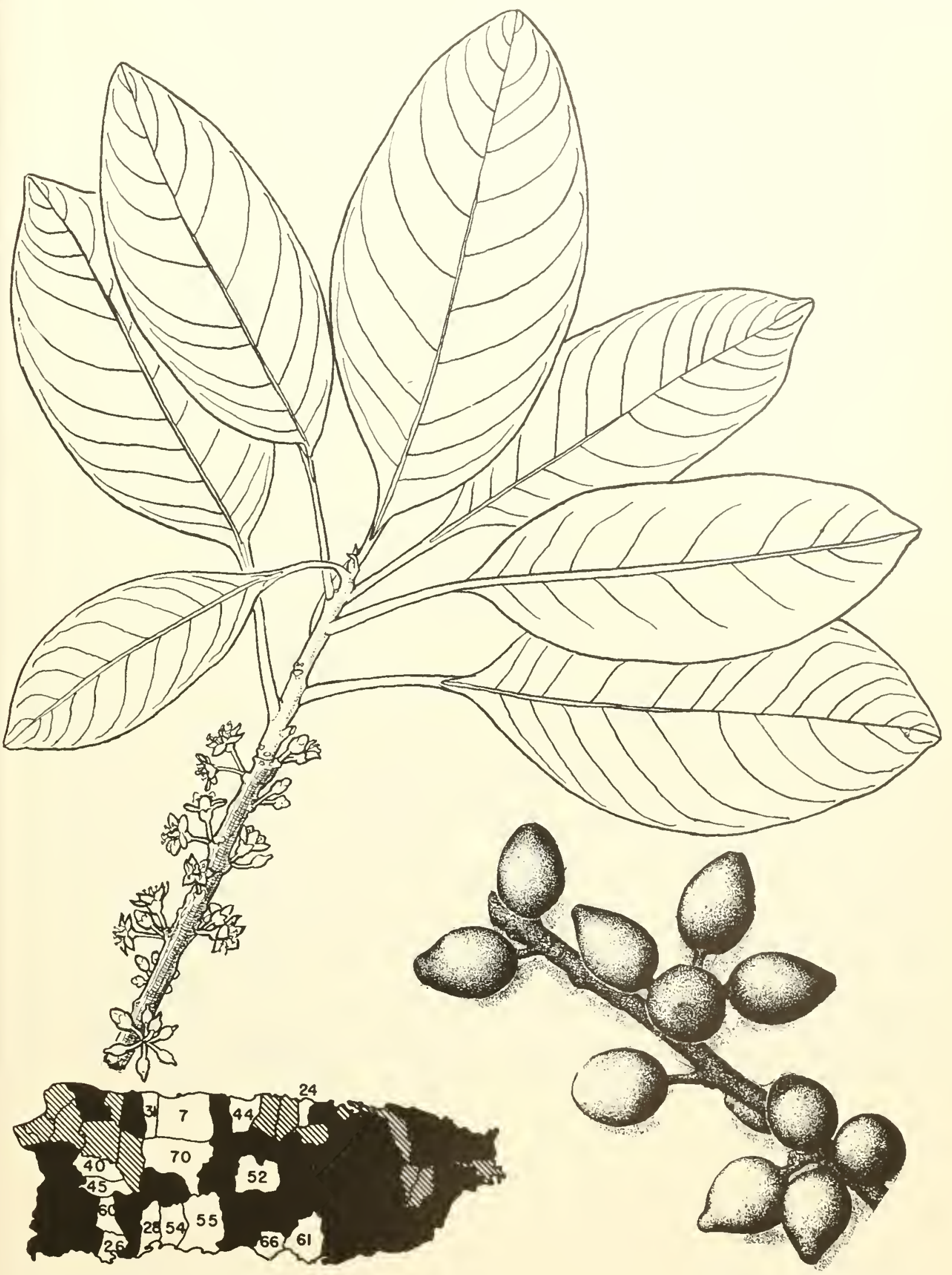

214. Tortugo amarillo, false-mastlc 


\section{SWEETLEAF FAMILY (SYMPLOCACEAE)}

\section{Aceituna blanca, candlewood}

A small to medium-sized tree characterized by: (1) shiny elliptic leaves $21 / 2-5$ inches long and 1-21/2 inches broald, abruptly short-pointed at apex and base, and with scattered inconspicuous wavy teeth along edges: (2) small 5-lobed white flowers nearly $1 / 2$ inch long and broad. a few to several together in chnster's at bases of leares; and (3) the oblong bluish-black fleshy fruits $5 / 8^{-3 / 4}$ inch long and 3/5 inch in diameter, with 5-lobed calyx remaining at apex.

An evergreen tree $20-30$ feet high and to 6 inches or more in trunk diameter, with spreading crown. Bark is smoothish or with small fissures, light gray to brown. Inner bark is pinkish and bitter. 'Twigs green and sometimes finely hairy when young, becoming light gray or brown.

The leaves are altermate on petioles $1 / 4^{-1 / 2}$ inch long. Blades are thin or slightly thickened, often turned upward at midrib, hairless, shiny green on npper surface and slightly paler beneath.

The fragrant flowers are attached a few to several together in short-stalked clusters (cymes). The green tubular base (hypanthium) is about $1 / 8$ inch long, with 5 rounded calyx lobes minntely hairy on edges; the white corolla $3 / 8^{-1 / 2}$ inch long and broad with a wide tube and 5 oblong spreading lobes; there are many stamens with flattened white filaments united to corolla tube and projecting $1 / 8$ inch beyond; and pistil with inferior 3-5-celled ovary, slender style $3 / 8$ inch long, and enlarged stigma.

Fruits are mostly single, green when immature, and contain usually 1 seed $5 \%$ inch long. In flower from late spring to fall and in fruit from summer to fall.

The rood with yellowish-brown sapwood is moderately heavy (specific gravity 0.8 ). Little used in Puerto Rico except for fuel, probably becanse of scarcity and generally small dimensions. Elsewhere a recorded use is for vehicles.

\section{Symplocos martinicensis Jacq.}

Widely distributed in moist to moderately dry forests at low to high elevations in Puerto Rico. Also in St. Thomas and Tortola.

Public forests.-Guajataca, Luquillo, Maricao. Raxee.-Jamaica, Puerto Rico, St. Thomas, Tortola, nearly thronghont Lesser Antilles from Saba to Grenada, and Trinidad and Tobago. Also Central America in British IIonduras, Guatemala, and Honduras, and in British Griana and French Guiana.

Other Cominon Names.--aceituma cimarrona (Puerto Rico): Martinique sweetleaf (English); white-box (St. Kitts) ; whitewood (Nevis); whitebeech (Montserrat); caca rat, bois bleu (St. Lncia): graines blenes (Dominica, Martinique, Guadeloupe); bois blanc (Grenada); blueberry (Salba, St. Eustatius).

Three related species of small trees are found only in Pnerto Rico. One called palo de cabra (Symplocos polyuntha Kirug \& Urban), rare and collected but once in Luquillo Mountains, has young twigs short hairy, elliptic leares $21 / 2-41 / 2$ inches long, hairless, and larger flower clusters about 2 inches long bearing many flowers with corolla $1 / 2$ inch long.

The other 2 species have twigs and petioles with long, stitf hairs. Níspero cimarrón (Symplocos lanitu Kring \& Urban), confined to mountain forests of the Central Cordillera, has the young twigs and petioles densely covered with long stiff reddish hairs; ellipt ic leaves $21 / 2-23 / 4$ inches long, hairy beneath, with petioles $1 / 8^{-1 / 4}$ inch long; and flowers with corolla about $3 / 1$ inch long.

The closely related species called aceitunillo (Symplocos micrentha Krug \& Trban), known only from monntain forests of eastern and central Pnerto Rico, differs in the young twigs and petioles less ha iry, the longer petioles $1 / 4-3 / 8$ inch long, and the slightly smaller flowers with corolla $1 / 8$ inch long. 


\section{OLIVE FAMILY (OLEACEAE)}

\section{Hueso blanco}

This small to medium-sized tree is characterized by: (1) an erect trunk which is usually deeply fluted near the base and covered with whitish bark; (2) opposite, narrowly elliptic, shightly leathery, pale green leaves $3-6$ inches long and $1-2$ inches broad, vely long-pointed at the base, slenderstalked: (3) flowel's with 4 very narrow white petals about $3 / 4$ inch long; and ( 4 ) slightly eggshaped and bonelike white fruits about $3 / 4$ inch long, with thin bitter flesh and 1 large stone, several in clusters and sometimes produced in large quantities.

An evergreen tree 15-60 feet high and to 1 foot in trunk diameter, with spreading crown. The bark is smoothish and thin. Inner bark is light brown, bitter, and slightly gritty. Twigs light mray, with prominent, nearly round, raised leaf sears.

The leaves have petioles $1 / 2-1$ inch long. Blades are not toothed on edges but sometimes slightly wrinkled, green to vellow green and hairless on upper' surface, paler and with minute tuft of hairs along midrib on lower surface.

The branched flower clusters (panicles) are terminal and lateral, 3 inches or less in length and width, at the end of long stalks or nearly stalkless, bearing many flowers 2 or 3 together at the end of slender branches. Calyx cup-shaped, more than $1 / 16$ inch long, 4-toothed, nearly hairless or with ninute lains around edges: the $t$ very narrow white petals $3 / 4$ inch or less in length and ouly 1/16 inch wide but slightly thickened and fleshy; the 2 stamens $1 / 1$ inch long borne at base of petals; and pistil less than $1 / 8$ inch long with 2 -celled ovary, short st $y$ le, and stigma.

The fruits (drupes) are about $5 / 8$ inch broad and $1 / 2$ inch thick, blunt-pointed, green when immature. The stone is angled and groored. Sometimes the fruits are so numerous and heary that they bend over the branches. Flowering from winter to summer, the fruits maturing from spring to fall,

The wood with light brown sapwood is hard, heary (specific orivity 0.9), and reported to be durable. Ised chiefly for posts in Puerto Rico, since it is not arailable in sufficient quantities or

\section{Linociera domingensis (Lam.) Knobl.}

large enough for other purposes. It takes a fine polish and has been made into ornamental objects and curiosities.

In the coastal, limestone, and lower mountain forests of Puerto Rico. Also St. Croix.

Prmac forests.-Cambalache, Carite, Guilarte, Luquillo, Marica, Susúa, Toro Negro.

R.snge-Cuba, Jamaica, Hispaniola, and Puerto Rico. Also in British Houduras and Guatemala.

Other common names.-palo de luueso, huesillo (Puerto Rica) : brojo (St. Croix) ; lirio, tárana (Dominican Republic); caney, huesillo, hueso, bayito, guaney (Cuba); white rosewond, ironwood (.Tamaica) : pine-ridge ironwood (British Honduras); cayepon (Haiti).

Botanical sronm.-Mayepea domingensis (Lam.) Krug \& Urban.

This genus has 3 more species of small trees in Puerto Rico. Avispillo (Linociera caribaea (.Jacq.) Knobl.; 'synonym Mayepea caribaea (Jacq.) Kuntze) is native in eastern Puerto Rico, Culebra, Vieques, St. Croix, St. Thomas, and other islands to Tenezuela. It has leaves with shorter petioles less than $5 / 8$ inch long and lateral flower clusters with several flowers.

The other 2 species luave thicker, leathery leaves. Linociera axilliflora Griseb. (Maye pea axilliflora (Griseb.) Krug \& [Trban), collected near Guanica and also west to Cuba, has oblong ol elliptic leaves $11 / 2-23 / 4$ inches long with petioles $1 / 4$ inch long; short, lateral flower clusters about $1 / 2$ inch long with few flowers about $1 / 4$ inch long; and furuits about $1 / 2$ inch long.

Linocieru holdridgii Camp \& Monachino, a small tree known only from dry forests of southwestern Puerto Rico, was first collected in 1938 by Leslie R. Holdridge, formerly of the United States Forest Service, and was named in 1939. It has ellipt ic leaves about 2 inches long and 1-11/4 inches wide, shiny on both sides, often hairy in vein angles beneath, with petioles less than $1 / 4$ inch long: lateral flower clusters $1 / 2-1$ inch long with few flowers about $3 / 16$ incl long; and black fruits about $1 / 4$ inch long. 


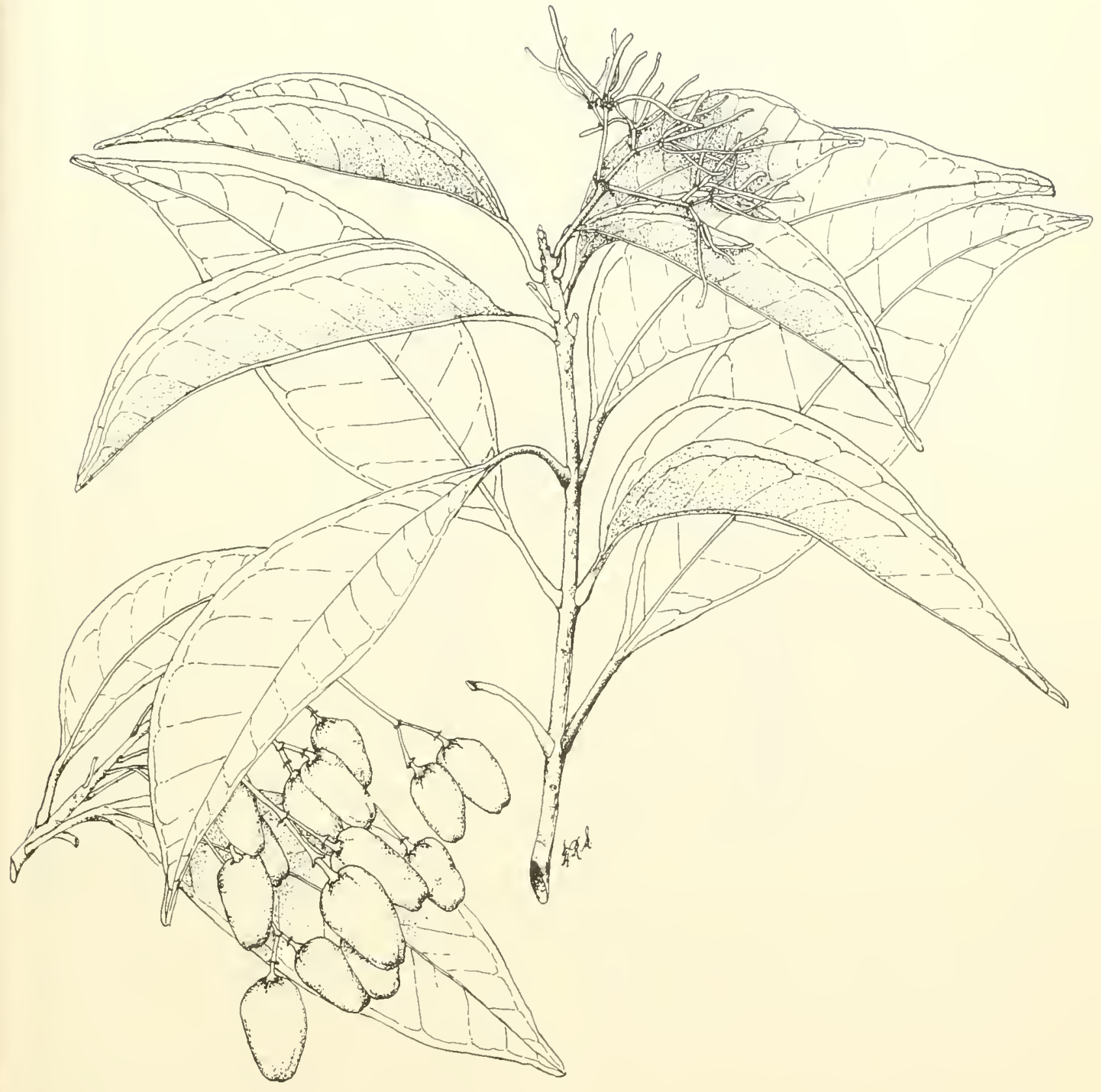




\section{DOGBANE FAMILY (APOCYNACEAE)}

A. Leaves alternate.

Key to the 3 species illustrated (Nos. 217-219)

B. Leaves narrowly lance-shaped, long-pointed, with edges tnrned under, the lower surface densely white hairy; Howers white-217. Plumeria alba.

BB. Leares elliptic, short-pointed, edges not turned under, lower surface often hairy; flowers red, yeliow, or white-218. Plumeria rubra.*

AA. Leares whorled, 4 of unequal size at a node-219. Rauvolfia nitida.

\section{Alelí, milktree}

This attractive wild tree, with milky juice or white latex which rums abundantly from cut parts, is easily distinguished by: (1) its peculiar shape without a crown of foliage but with a few stout soft and brittle branches ending in clusters of crowded spreading leaves: (2) the long narrow lance-shaped leaves $6-15$ inches long and $5 / 8-2$ inches broad, shiny green on upper surface and densely and minutely white hairy beneath; (3) the cluster's of showy and very fragrant, tubular and spreading, waxy, white flowers $11 / 2-2$ inches long and broad, with 5 overlapping elliptic corolla lohes; and ( 4 ) the paired brown pods $t-6$ inches long and about $1 / 2$ inch in diameter.

I small evergreen tree to 10-15 feet or more in height and $t$ inches in trunk diameter or shrubby, with hare branches. 'The smoothish bark is brownish gray. Inner bark is orange, slightly bitter, when crit yiekling much latex, which seportedly is poisonous. The twigs $1 / 2-3 / 4$ inch in diameter are greenish, becoming brownish gray, and have numerous nearly round leaf scars.

The leaves are alternate on petioles $3 / 4-11 / 2$ inches long. Blades are long-pointed at both ends, thick and leathery with edges turned under, and with many lateral veins spreading ont almost at right angles from the midrib, hairless on upper surface.

1 flower stalk 3-8 inches long, arising among the leares, bear's several to many short-stalked flowers in a compact, flattened cluster (cyme). The small calyx is about $1 / 8$ inch long, 5-lobed; corolla with narrow tube and 5 widely spreading lobes, waxy and white except for a yellow dot or "eye" at the base of each lobe: 5 small stamens inserted near base of corolla tube; and pistil of 2 separate ovaries about 1/s inclu long, partly inferior, with single short style.

Each fruit consists of 2 brown pods (follicles), long-pointed and widely spreading, containing
Plumeria alba L.

many flat winged seeds. Flowering and fruiting throughout the year in Puerto Rico.

The mood with light brown sapwood is hard, heary (specific gravity 0.8), and tough. A fuelwood in Puerto Rico but used also in carpentry where the tree grows to sufficient size.

This species apparently is not in cultivation though it shonld be a haddy ornamental for dry areas. The white-flowered alelí commonly grown for ormament belongs instead to the related introduced species, frangipani (Plumeria rubra L.*), which typically has red blossoms. White-flowered forms of the latter are distinguished by broader elliptic leaves greenish beneath and by more numerous larger blossoms.

Coastal thickets and limestone forests at low elevations and ascending in the western mountains of Pnerto Rico. Also Muertos, Icacos, Culebra, Vieques, St. Croix, St. Thomas, St. John, Tortola, Virgin Gorda, and Anegada.

Ptrildc forests.-Cambalache, Guánica, Maricao, Susha.

RANGE.-Puerto Rico and Virgin Islands and thronghout Lesser Antilles from Anguilla to Grenada.

Other common names.-alelí blanco, alelaila (Puerto Rico); milky-bush (Virgin Islands); jasmine (Barbuda); frangipanier saurage (Guadeloupe); white frangepane, pigeonwood (Dutch West Indies).

The generic name honoring the French botanist Charles Plumier is spelled also Plumiera and Plumieria.

Alelí cimarrón (Plumeria obtusa L.; synonyms $P$. Krugii Urban, $P$. portoricensis Urban) is a related species of dry areas of western Puerto Rico and Mona and west to Cuba and Bahamas. This small tree has oblong leaves $2 \frac{1}{2}-8$ inches long, rounded or notched at apex. 


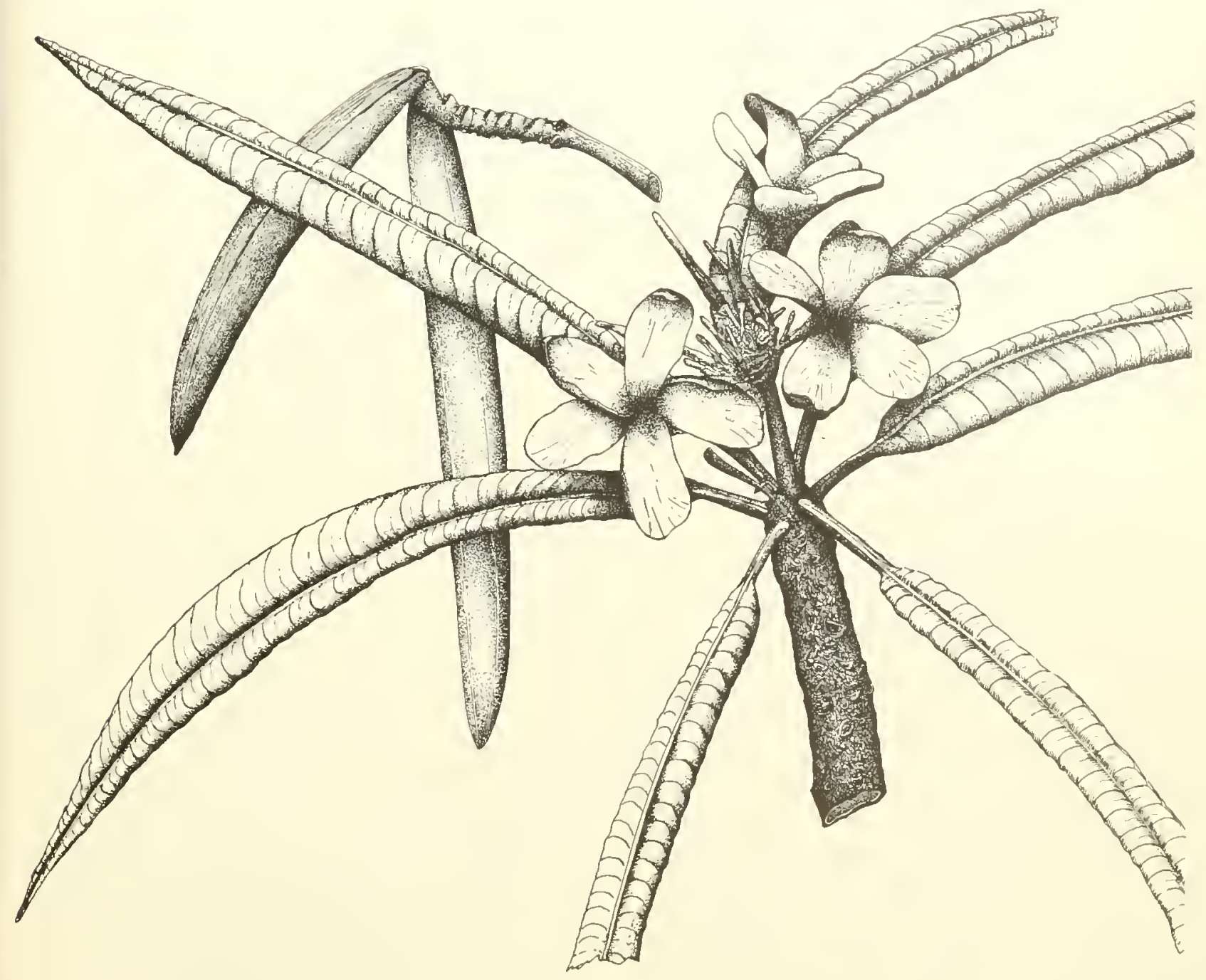




\section{Frangipani}

Frangipani is a small ornamental tree with milky juice, introdnced and commonly planted in gardens and parks for its beantiful clusters of very fragrant, lase, tubular, ged, vellow, or white flowers. Claracters for recognition include: (1) the few stout fleshy branches with whitish latex, bearing alternate but crowded leaves at ajex; (2) the large ellipt ic leaves 5-16 inches long and $11 / 2-5$ incles wide, shiny green above and often hairy beneath: (3) loose clusters of large wixy flowers 2-:3 inches across the 5 spreading, ovelapping corolla lobes: and (4) paired pods $5-10$ inclues long and $1 / 2-11 / 2$ inches in diameter.

'Tlis handsome small tree becomes $15-25$ feet tall, with very open crow of few thick spreading branches. larit is gray and smoothish. In l'verto Rico the trees are everoreen. but in areas with a long dry season they shed their leares and often flower when leatless.

Petioles are stout, mostly 1-21/2 inches long. B]ades are usually short-pointed at both ends, not toothed on edges, thick and leathery, with many parallel lateral reins almost at right angles to midrib.

The long-stalked flat-topped flower cluster (cyme) is terminal or appearing lateral, often 6-9 inches across. Many blossoms are borne on stout stalks $3-1$ inch long, buds in the center opening first. The flower has a 5 -lobed ealyx $1 / 8$ inch long; corolla with narrow tube $3 / 8-1$ inch long and less than 1/8 inch in diametel and witl 5 elliptic rounded lobes 1-2 inches long, 5 small stamens less than $1 / \mathrm{s}$ inch long inserted near base of corolla tube: and pistil of 2 separate ovaries partly inferior and a single short style.

The paired pods (follicles) from a flower spread widely apart, split, open on 1 side, and contain many winged seeds. Flowering and fruiting nearly through the year in Puerto Rico.

Flowers commonly have red, rose-colored, or purplish-tinged corollas, but some cultivated forms have yellow flowers ol' white with a yellow dot or eye at base of each lobe. I less frequent tricolored form has a white or pale yellow corolla with outer margin of lobes rose and usually with a yellow spot at base of lobes. The white-flowered garden form has been incorrectly referred to the native white-flowered species (Plumeria alba I.), which has narrow lance-shaped leaves densely white hairy beneath and also fewer, smaller blossoms.

The firm blossoms, which do not wither easily, are strung into chains and garlands and variously employed in decorations, often in churches. In the Pacific Islands the trees frequently are planted in cemeteries and sometimes called temple-flowers and grat veyard-flowers.

The caustic milky juice which flows freely from the cut trunks repoitedly is poisonous but has been employed in some regions in folk medicines. Frangipani, one of the common names, is said to be derived from the French word "frangipanier," coagulated milk, which is descriptive of the thick white rubbery latex.

Common as an ornamental in Puerto Rico, St. Thomas, St. Croix, St. John, and Tortola and occasionally escaping from cultivation. Plants are propagated easily from cuttings. It is reported that cuttings allowed to dry out for 2 weeks root readily. The trees will grow in dry, rocky, and windy aleas. In some areas planting is not recommended because large caterpillars caused repeated defoliation.

Radige.-Native of southern Mexico and Central America south to Costa Rica. Now widely int roduced through tropical and subtropical regions of the world. Planted in southern Florida and California, throngh the West Indies, and Sonth America soutl to Peru and Brazil. First described botanically from specimens collected in Jamaica.

Other common names.-alelí, alelí rojo (Puerto Rico); frangijaponie, red paucipan (Virgin Islands); ataiba rosada (Dominican Republic): lirio, lirio tricolor, frangipán (Cuba); cacalosochitl, cacalosúchil, súchil, flor de cuervo (Mexico); flor de la cruz, palo de cruz, flor de mayo, matuluna, nicte de monte (Guatemala); flor blanca, flor de la cruz, flor de ensarta, flor de mayo (El Salvador); flor de toro, sacuanjoche (Nicaragua) ; cacalojoche, flor blanca, juche, torito (Costa Rica); calacucha, cararucha blanea, palo de la cruz (Panama); amancayo (Colombia); amapola (Venezuela) ; carachuche (Peru) ; frangipani, red frangipani, white frangipani, nosegay frangipani, Mexican frangipani, nosegay (English); red jasmine (Bermuda, Jamaica); jessamine, Spanish jasmine (Bahamas); frangipanier (French); frangipanier rose (Haiti) ; frangipanier rouge, frangipanier blanc (Guadeloupe) ; red frangepane (Dutch West Indies).

Botanical syonyrs.-Plumeria acutifolia Poir., P. tricolor Ruiz \& Pav. 


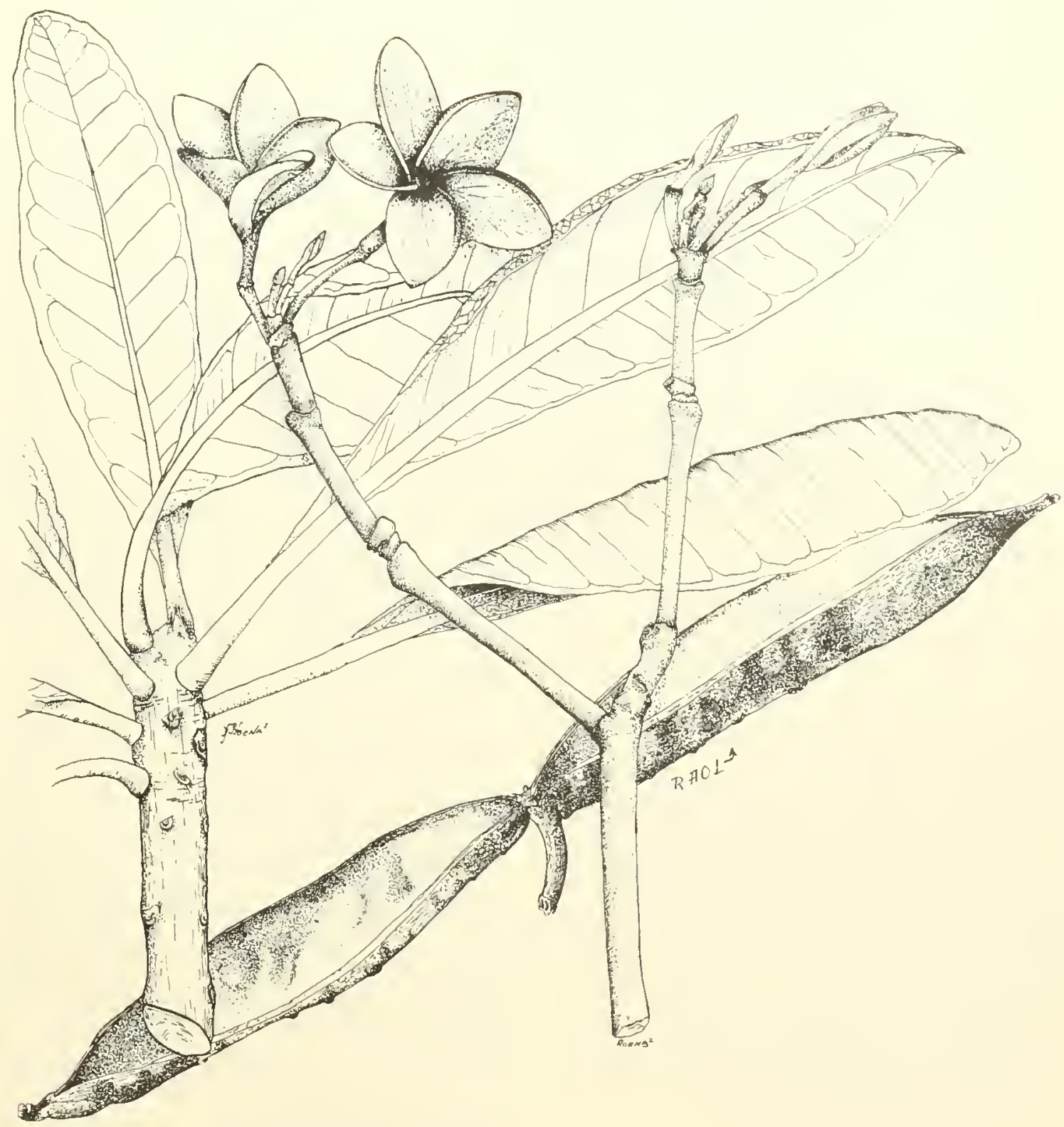




\section{DOGBANE FAMILY (APOCYNACEAE)}

\section{Palo amargo, bitter-ash}

This small tree or shrub with white latex is distinguished by its shiny yellow-green lance-shaped or narrowly elliptic leaves $21 / 2-6$ inches long and $3 / 4-13 / 4$ inches wide, long-pointed at apex and base, slightly turned under at edges, attached to the twig in groups of 4 of unequal size (whorled). The small whitish flowers are about $1 / 4$ inch across and the reddish to blackish rounded fruts about $3 / 8$ inch long and $1 / 4^{-1 / 2}$ inch broad.

Commonly a shrub or small tree to $20-40$ feet high and to $1 \frac{1}{2}$ feet in trunk diameter, evergreen with open rounded crown. The bark is smoothish, slightly fissured and warty, very light brown, and thim. Inner bark is light green and bitter. The twigs are bright green with raised brown dots (lenticels), enlarged at the nodes, and becoming brownish.

The slightly thickened leathery leaves have petioles $1 / 4^{-3 / 4}$ inch long and blades green or yellow green on upper surface and lighter yellow green beneath.

The small flower clusters (cymes) are terminal or lateral, branched, 1-11/2 inches long and broad, shorter than the leaves, with several to many flowers. The white and greenish flowers are tubular, about $3 / 8$ inch long, with 5 spreading lobes $1 / 4$ inch across; the green 5-lobed calyx is less than $1 / 8$ inch long; corolla has a narrow greenish tube $1 / 4$ inch long and 5 rounded white lobes; 5 minute stamens are inserted near mouth of corolla tube; and the pistil is composed of a 2 -lobed ovary with slender style and enlarged stigma.

The fleshy fruits, with milky juice, turn from green to reddish and blackish and contain 1 or 2 brownish seeds $5 / 16$ inch long. Flowering and fruiting nearly throughout the year.
Rauvolfa nitida Jacq.

The sapwood is light brown, and the heartwood clear yellow. The hard, lightweight wood is employed for posts in Prerto Rico. Elsewhere, use for furniture and musical instruments has been sugrested.

In the coastal and limestone forests and thickets of Puerto Rico, growing in the open and probably requiring light. Also in Mona, Vieques, St. Croix, st. Thomas, St. Jolnn, and Tortola.

Public forests.-Cambalache, Guánica.

Raxge.-Bahamas, Cuba, Jamaica, Hispaniola, Puerto Rico and Virgin Islands, St. Kítts, Guadeloupe, and Martinique. Also recorded long ago from st. Barthélemy.

Other common names.-palo de muñeco, cachimbo (Pnerto Rico) ; bitterbush, milkbush (Virgin Islands); palo de leche (Dominican Republic); huevo de gallo (Cuba); smooth rauvolfia (Bahamas) ; bois lait femelle (Haiti).

The name of a low shrub (Ruuvolfia tetraphylla L.) has been misapplied to this species.

The genus Rauvolfia (also spelled Rauwolfia) has attracted much attention in recent years because the root of a shrubby species in India has yielded a drug for the treatment of high blood pressure and certain mental illnesses. Related species are also under investigation.

Another native species is a shrub 3-10 feet high known as bitterbush (Rauvaltia viridis Roem. \& Schult.; synonym R. lamarckii A. DC.). It has slightly unequal leaves in groups of 4 (whorled), ovate to elliptic, mostly $1 \frac{1}{2}-4$ inches long, thin, dull green instead of shiny, and smaller blackish fruits about $1 / 4$ inch broad. It grows in coastal thickets of eastern Puerto Rico, Mona, Icacos, Culebra, Vieques, St. Croix, St. Thomas, St. John, and Virgin Gorda and other islands to Hispaniola and northern South America. 


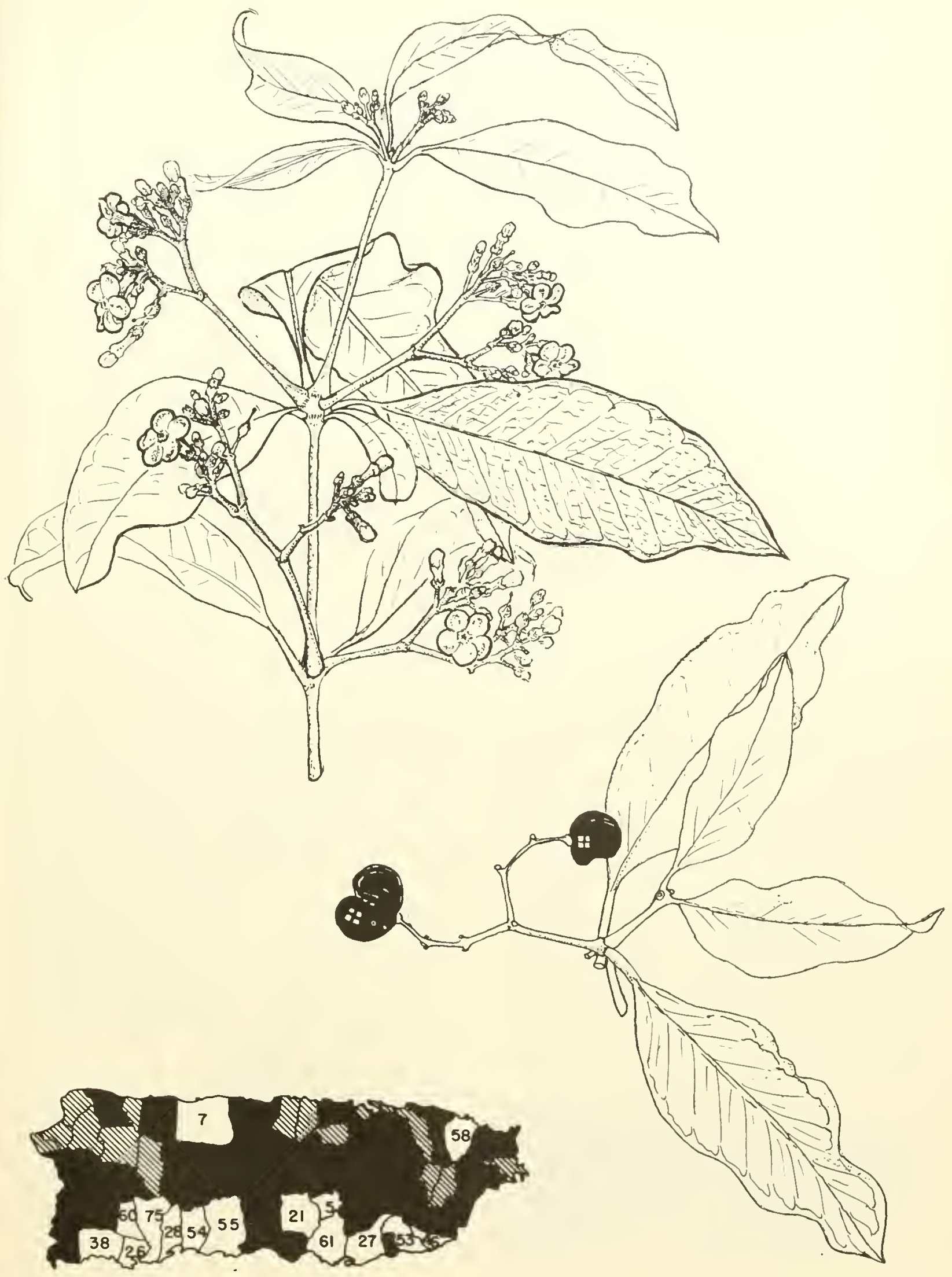

219. Palo amargo, bitter-ash 


\section{BORAGE FAMILY (BORAGINACEAE)}

Key to the 5 species illustrated (Nos. 220-224)

A. Flowers tubular, with narrow, tubular calyx and 5-lobed white corolla, turning brown; fruit a nutlet; leaves elliptic, long- or short-pointed, thin, hairy-221. Cordia alliodora.

Ad. Flowers spreading, mostly small and not shows, with white corolla; fruit a rounded drupe.

B. Leaves mostly rounded at apex, elliptic ; fruit orange red.

C. Leaves 11/2-5 inches long, slightly thickenerl; flowers about $1 / 2$ inch broad; fruit almost $1 / 2$ inch in diameter, slightly flattened-200. Bourreria succulenta.

CC. Leaves mostl, large, 3-10 inches long, thick and leathery, with prominent network of many raised veins; flowers about $1 / 4$ inch broad, fruit about $\% / 8$ inch in diameter, broader than long, oblique-222. Cordia borinquensis.

BB. Leaves short-or long-pointed at apex.

D. Leaves elliptic, $2-6$ inches long, very shing; flowers bell-shaped, $1 / 2-5 / 8$ inch across; fruit bright red, $1 / 2-5 / 8$ inch in diameter-223. Cordia nitida.

DD. Leaves large, ovate to elliptic, mostly 9-12 inches long, rough hairy on upper surface and soft hairy beneath; flowers $3 / 16$ inch broad; fruit whitish, $3 / 8$ inch in diameter-224. Cordia sulcata.

\section{Palo de vaca, pigeon-berry}

A small tree or shrub widely distributed in open areas at low elevations, characterized by: (1) elliptic leaves $1 \frac{1}{2}-\mathbf{5}$ inches long and $1-3$ inches broad, rounded or blunt-pointed or sometimes notched at apex and short-pointed at base, slightly thickened, green above and paler beneath, the under surface often finely hairy in dry regions; (2) many fragrant tubular white flowers $1 / 2$ inch across the 5 rounded spreading corolla lobes, in a much branched flat-topped terminal erect flower cluster; and (3) fleshy orange-red rounded fruit almost $1 / 2$ inch in diameter and slightly flattened.

Evergreen tree 12-25 feet high and $t$ inches or more in trunk diameter, or sometimes a shrub, with spreading or drooping branches. The bark is smooth and gray, sometimes becoming finely fissured and slightly rough and corky. Inner bark is light brown and slightly bitter. Twigs are green when young, turning to gray or light brown. Hairless in wet areas but in dry regions, such as southwestern Puerto Rico, a hairy form has the twigs, lower leaf surfaces, branches of flower clusters, and calyx finely soft hairy, and upper leaf surfaces and outside of corolla with a few hairs. Leaves are alternate on petioles $1 / 4-3 / 4$ inch long.

The flower clusters (cymes) are 2-8 inches across and high, and the short-stalked flowers about $3 / 8$ inch high. The light green bell-shaped tubular calyx $1 / 4$ inch long has 5 shightly unequal pointed lobes; the white corolla has a tube more than $1 / 4$ inch long with 5 rounded spreading lobes $3 / 16$ inch long, turning brown before shedding; 5 stamens $1 / 4$ inch long with white filaments and brown anthers, inserted on corolla tube and protruding; and pisti] 3/8 inch long, with light green 2-celled ovary, slender white style 2 -forked near apex, and flattened greenish stigmas.

The fruit (drupe) is broader than long, green to yellow when immature but turning orange red. Calys and often the dead style remain attached.
Bourreria succulenta Jacq.

Inside the flesh are 4 brown ridged bony nutlets. In flower and fruit nearly through the year.

The light brown, hard wood is used for fuel. Reported to be a good honey plant.

Coastal and limestone forests of Puerto Rico, especially in thickets and cutover forests. Also in Mona, Icacos, Culebra, Vieques, St. Croix, St. Thomas, St. John, Tortola, Virgin Gorda, and Anegada.

Punlic forests. - Cambalache, Guánica, Luquillo, Susúa.

MLNICIPALITIES WHERE ESPECHALY COMMON.$12,36,66$.

RANGE.-Throughont West Indies (except Bahamas) from Cuba, Cayman Islands, Jamaica, Hispaniola, and Turks Island to Grenada, Trinidad and Tobago, and Duteh West Indies. Also Panama to Tenezuela.

Other comsion Names.-doncella, cerecillo, roble de guayo (Puerto Rico) ; pigeon-wood, spoontree (Tirgin Islands) ; palo bobo (Dominican Republic); ateje de costa, roble guayo, fruta de catey, curaboca (Cuba); chinkswood (Antigua); cutlass (Grenadines); café marron, mapou gris (Haiti); acomat côte-lette, bois capri bâtard (Guadeloupe) ; goeaana, watakeeli, white-chank (Iutch West Indies).

Botanical synonym. - Bourreria succulenta var. conescens O. E. Schulz. The generic name is spelled also Beurerict.

A related species (Bourreria virgata (Sw.) G. Don) is a shrub or small tree of dry forests in southwestern Puerto Rico and west to Cuba. It has small elliptic leares mostly $3 / 4-2$ inches long, rongh abore, and small red fruits $1 / 4-3 / 8$ inch in diameter. Also recorded from the same area and from Vieques is a doubtfully distinct species ( $B$. domingensis (DC.) Griseb.), which differs from the last in the leaves smooth above. 
When in flower capí prieto is recognizable at a distance by the handsome masses of numerous white flowers over the tree. Other characters for identification are: (1) erect trunk with whorled branches appearing in horizontal layers; (2) elliptic or oblong, slightly shiny yellowish-green thin leaves, the lower surface paler and more or less finely hairy with minute star-shaped hairs, with odor of garlic when crushed; (3) the fragrant white flower's tubular, 5-lobed, and abont $1 / 2$ inch long and broad, crowded in large, showy, hranched terminal clusters, afterwards turning hrown; and (4) the fruits are mutlets $1 / 4$ inch long, with calyx and blown corolla remaining attached.

A medium-sized evergreen tree to 65 feet in height and $11 \%$ feet in trunk diameter. The gray or brown bark is fissured, becoming rough and thick. Inner bark is light brown, fibrous, and tasteless but has a slight odor of garlic, to which the scientific name refers. The twigs are green and with star-shaped hairs when young, becoming hrown.

The alternate leaves have hairy petioles $3 / 8^{-3}$ i inch long. Leaf blades are $21 / 2-6$ inches long and 1-13/4 inches broad, short-or long-pointed at apex and short-pointed at base, slightly thickened, the upper" surface with scattered star-shaped hairs or nearly hairless.

Flower clusters (panicles) are large and 4-12 inches broad, several spreading and almost stalkless at ends of widely forking hairy branches. The cylindrical gray-green calyx almost $1 / 4$ inch long is 10-ribbed, densely covered with minute star-shaped hairs, 5 -toothed; the expanded tubular corolla is $3 / 8$ inch high and $1 / 2$ inch across the 5 widely spreading, oblong, rounded lobes, white but fading to brown; 5 prominent erect white stamens inserted near month of corolla tube: and whitish pistil with ovary and slender style :2-forked near apex and each fork with 2 broad stigmas. The nutlet is oblong, 1-seeded, with attached corolla serving as wings in dispersal by wind. Flowering and fruiting irregularly through the year.

The thick light brown sapwood is not clearly marked. The heartwood when freshly cut is light greenish brown to olive brown with darker streaks and in seasoning becomes pale golden brown to brown with the darker streaks more prominent. Growth rings are shown by narrow dark lines of pores. The attractive mood is moderately soft, moderately heavy (specific qravity 0.57 ), moderately strong, tongh, of medium or time texture, and generally straight-grained. The rate of airseasoning and amount of degrade are moderate. Machining characteristics are as follows: planing, shaping, mortising, and sanding are good; turning and boring are excellent; and resistance to screw splitting is poor. The wood is easily worked and takes a fine polish. It is generally resistant to attack by dry-wood termites and is very durable in the ground.

This raluable wood is used extensively through the American tropics for furniture, cabinet work, millwork, and general construction. Various uses in different count ries include bridge timbers, flooring, ship decking, boat parts, truck parts, oars, and crossties.

The seeds and leaves have been used in home medicines. Also a grood honey plant.

Capá prieto has been planted for its wood and fol coffee shade and ornament. Propagated readily from seed, it grows very rapidly and requires nearly full sunlight. Entomologists report that insects sometimes attack and discolor the leaves, cansing leaf fall.

Forests in the moist limestone and lower mountain regions of Puerto Rico. Particularly common on soils derived from tuflaceous parent material. Also in Vieques, St. Croix. St. Thomas, St. John, and Tortola.

Publio Forests.-Cambalache, Carite, Guajataca, Guilarte, Luquillo, Río Abajo, Susúa, Toro Negro, Vega.

MUNIClPALITIES WIERE ESPECIALLY COMMON.-5, 8.

Raxge-Cuba, Hispaniola, Puerto Rico and Virgin Islands, throughout Lesser Antilles, and Trinidad and Tobago. Reported as introdnced in Tamaica. Also widely distributed in continental tropical America from central Mexico to Ecuador, Peln, Bolivia, and Brazil. Planted in southern Florida.

Other common Names.-capá, capá prieto, cruacimilla, capá de sabana, capá de olor (Dominican Republic) ; varia, varía prieta, varía colorada, varía amarilla (Cuba) ; hormiguero, bojón, tamhor hormiguero (Mexico); laurel (Central America) ; laurel blanco (Central America, commerce); bojón (Guatemala) ; laurel negro (Honduras, Nicaragua, Costa Rica); laurel macho (Nicaragua); solera, canalete, canalete de humo, laurel negro (Colombia); pardillo, tacuraí (Venezuela); laurel negro, laurel prieto, laurel macho, laurel (Ecuador); árbol del ajo (Peru); ajo (Bolivia); onion cordia (United States); spruce (Antigua); laurier cypre (Dominica); Spanish-elm (Jamaica); cypre, cyp (Trinidad); cypress (Tobago); salmwood, salaam, bohun, laurel blanco (British Honduras); brown silverballi (British Guiana); bois soumis, chêne caparo (Haiti); bois de rose, bois de Rhodes (Guadeloupe); Jouro, louro amarello, uruazeiro (Brazil).

Botanical sYNoNyM.-Cerdana alliodora Ruiz \& Pav.

This genus, formerly divided by a few authors into as many as 5, is represented by 7 native tree species, 4 of these illustrated here, 1 introduced ornamental tree, and 7 shrub species. 


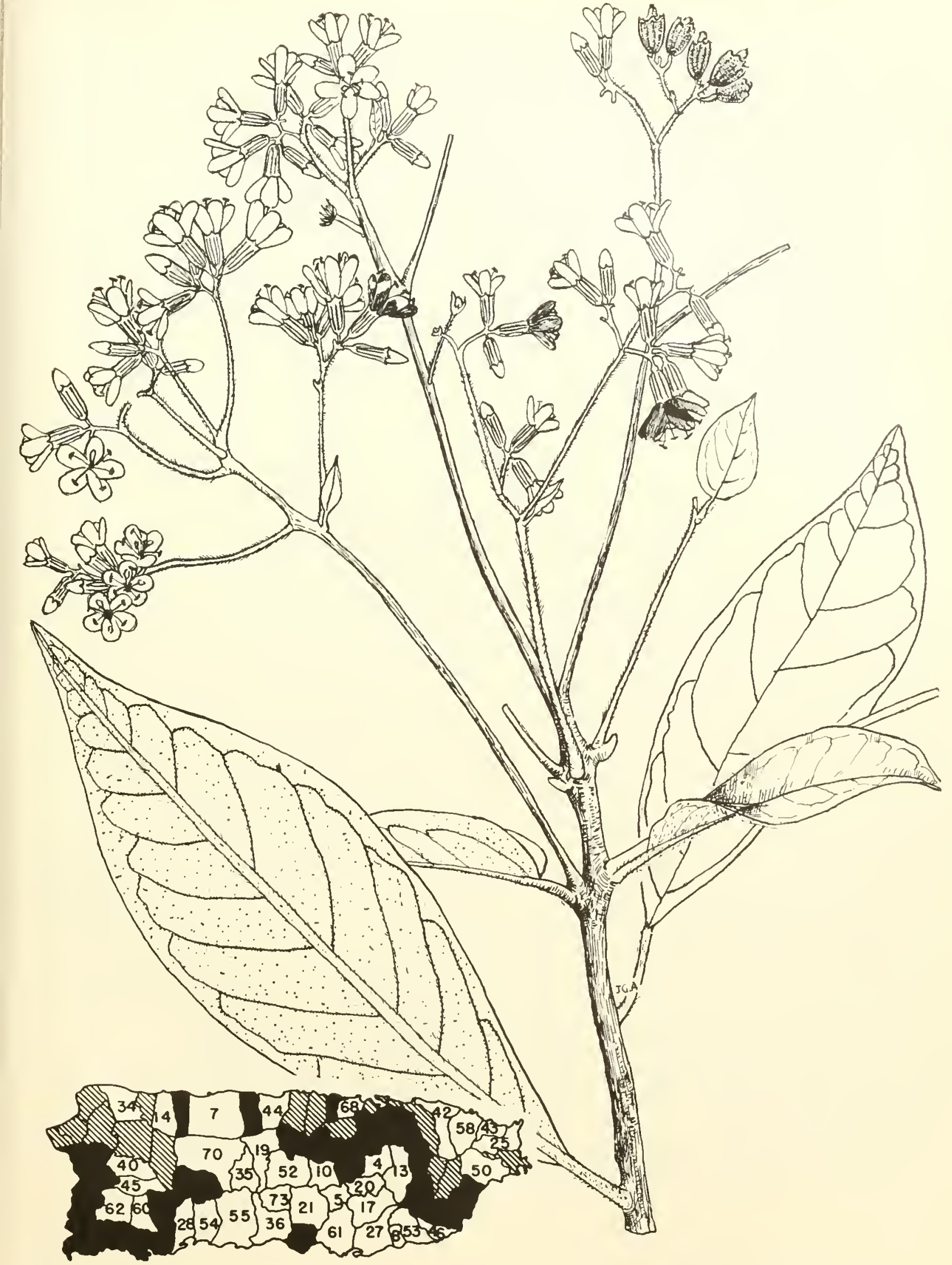


A shrub or small tree known as cerezas blancas and white manjack (rordiu dentatr Poir.; $C$. alba anth.o ("alyptruerordin alba anth.) is found in dry forests of southwestern Puerto Rico, St. Croix, and St. Thomas, through the West Indies, and from Mexico to Venezuela. It has elliptic leaves $11 / 2-$ 41's inches long, coilrsely toothel, rough hairy above; terminal branched clusters of numerons showy white Howers $5 / 8$ inch across: and elliptic whitish fruits about $1 / 2$ inch long.

The "- species below have very showy flower's 111/ inches long and loroad, with tubular orange corolla. Anaconda or Greiger-tree (Cordiu sebestena L.*; synonym Sebesten sebestena (L.)
Britton) is a popular planted ornamental along roadsides of Puerto Rico and the Virgin Islands but not native. It has orate thick leaves $31 / 2-8$ inches long, often toothed on edges, long-pointed at apex, rough on upper surface, and egg-shaped pointed white fruit $1-11 / 2$ inches long.

sian Bartolomé (Cordia rickiseckeri Millsp.; synonym sebesten ricksecheri (Millsp.) Britton) is a closely related small tree of coastal thickets native only in Puerto Rico, Culebra, Tieques, St. Thomas, and Tortola. It has elliptic leaves usually very rongh on upper surface, orange-red corolla, and yellow or orange fruit.

\section{BORAGE FAMILY (BORAGINACEAE)}

\section{Muñeco}

A small tree of wet forests mostly in mountains, known only from Puerto Rico, distinguished by: (1) erect axis with horizontal branching frequently in 3's; (2) thick and leathery, mostly large, elliptic or obovate, shiny green leaves with prominent network of many raised reins and veinlets on botls sides; (3) small white flowers more than 1/4 inch long and broar, with tubular 5-lobed corolla, several to many in branched flat-topped terminal clusters, male and female on different trees (dioecious); and (4) fleshy orange-red romnded fruit $3 / 5$ inch in diameter, broader than long, and oblique and swollen on side.

Usually about 20 feet tall and 5 inches in trunk diameter but recorded as becoming larger, sometimes flowering when only 5 feet high, evergreen. The gray bark is smooth with raiser dots (lenticels). whitish within, and tasteless. The stout twigs are green and minutely hairy when young, becoming brown.

Leaves are alternate, with stout green petioles $1 / 2-1$ inch long, grooved above, and minutely hairy. Blades are $3-10$ inches long and $1 \frac{1}{4}-41 / 2$ inches broad, rounded or short-pointed at both ends, green above and slightly lighter beneath, turning dull yellow before falling.

Flower clusters (panicles) are 1-31/2 inches broad and high, with slender curved nearly horizontal branches bearing almost stalkless flomers.

\section{Cordia borinquensis Urban}

The bell-shaped tubular calyx about $3 / 16$ inch long is mimutely hairy and has 5 pointed lobes, and the tubular white corolla hairy inside has 5 rounded lobes turning downward, becoming brown before shedding. Male flowers lave 5 stamens nearly 1/8 inch long, hairy at base, protruding from corolla tube, and a small pistil. Female flowers have slightly larger calyx, shorter sterile stamens, and larger pistil $1 / 4$ inch long. with 4 -celled ovary, 2 protruding styles, mited below and each forked above, ending in 4 flattened stigmas.

The shiny fruits (drupes) are green, turning to orange red at matmity, with greenish calyx remaining at base, broader than long, oblique and swollen on 1 side, with remains of style slightly on 1 side. Within the orange-red Hesh is a brown mutlet. Flowering and fruiting nearly through the year.

The whitish or light yellow wood is hard and heary (specific gravity 0.7 ). It is used for posts and tool handles.

In understory tree in the mountain forests of Pnerto Rico.

Prbuc fonests.-Carite, Luquillo, Maricao, Toro Negro.

R.inge.-Puerto Rico only.

Otiner COMmon Names.- capá, capá cimarrón (Puerto Rico). 


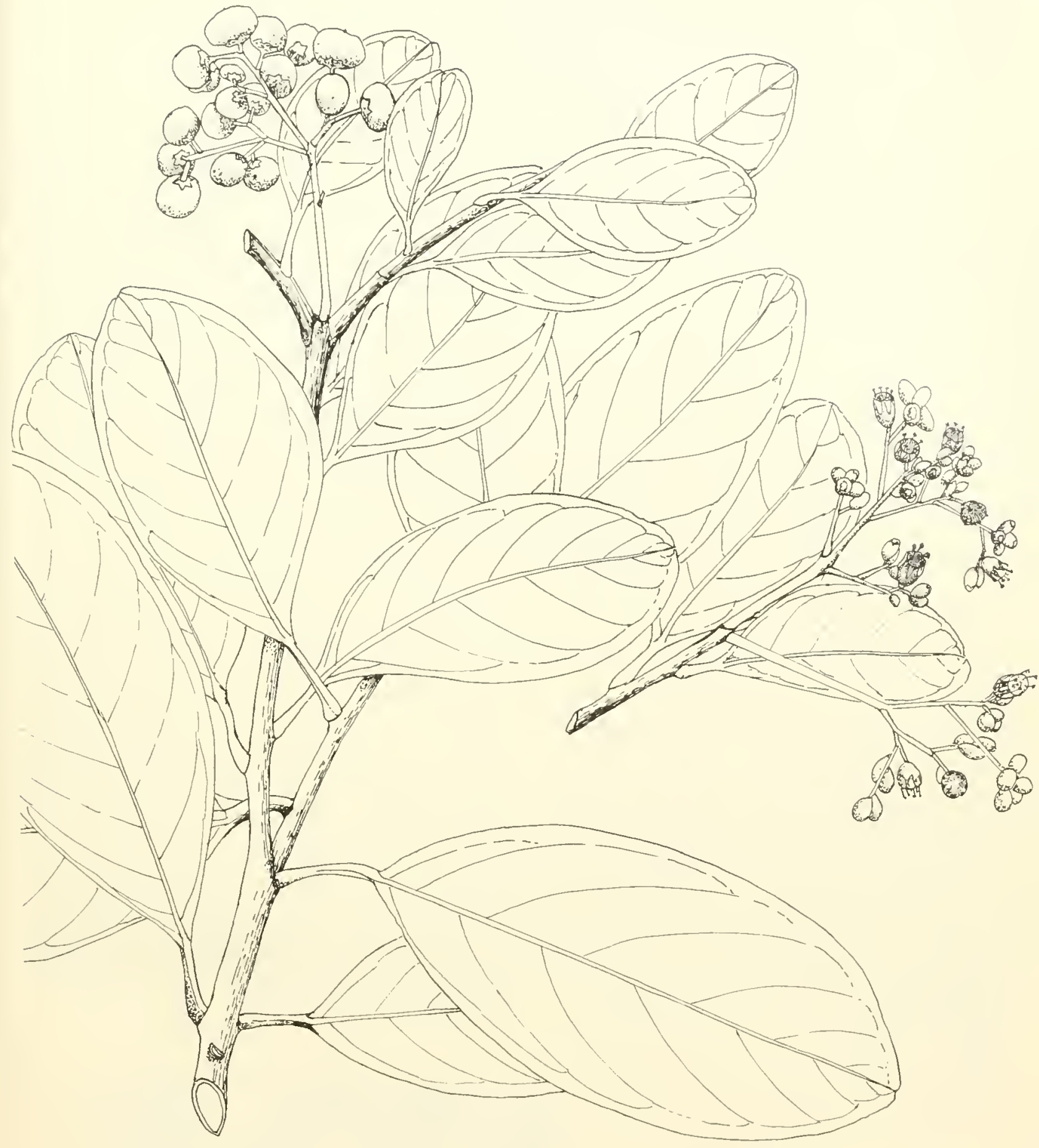




\section{BORAGE FAMILY (BORAGINACEAE)}

\section{Capá colorado, red manjack}

A handsome tree, generally small, distinguished by: (1) whorled branches appearing in horizontal layer's; (2) very shiny elliptic leaves, short-pointed at both ends, slightly leathery and stiff, bent up a little on both sides of midrib; (3) usually many bell-shaped white flowers $1 / 2-5 / 8$ inch across the 5 spreading corolla lobes, in an erect wide branching terminal flower cluster; and (4) clusters of fleshy, bright red, romnded frnits $1 / 2-5 / 8$ inch in diameter but slightly flattened.

An evergreen or decidnous tree $15-25$ feet high and to 1 foot in trunk diameter, reported to reach 65 feet, with dense rounded crown, or sometimes shrubby. The bark is gray, smoothish but becoming furrowed and thick. Inner bark is light brown, turning darker upon exposure, fibrons and almost tasteless. The twigs are light brown, green and finely hairy when young, often forking into 3 umequal twigs.

The alternate leaves have slender light green petioles $3 / 8^{-5 / 8}$ inch long. Blades are $2-6$ inclies long and 1-2 inches broad, hairless, above very shiny green with midrib and some lateral veins often slightly sunken, and beneath light green and only slightly shiny.

Flower clusters (panjeles) are 2-4 inches broad and high, the slender branches widely forking by 2's. The short-stalked flowers have a tubular whit ish calyx $1 / 4$ inch long, 3-5-toothed; the white corolla $1 / 4$ inch long has a short tube and 5 spreading lobes which become turned under before falling; 5 stamens hairy at base are inserted on corolla tube between the lobes and extend above; and the white pistil $5 / 16$ inch long has 4-celled ovary on an orange base and 2 styles united below and each forked above.

\section{Cordia nitida Vahl}

The fruit (drupe) retains the irregularly split greenish calyx at base. A light brown angled nutlet is imbedded in the slightly astringent reddish flesh. Flowering and fruiting irregnlarly through the year, frequently with quantities of finits.

The wood is used chiefly for posts. When cultivated, the trees make attractive ornamentals. I honey plant.

In thickets and forests of the coastal and limestone regions of Puerto Rico. Also in Mona, Vieques, St. Croix, St. Thomas, St. John, and Tortola. Originally named and described from St. Croix in 1793.

Punlic forests. - Cambalache, Guajataca, Guánica, Río Abajo, Susúa.

Municipality where especially common.-13.

Range.-Cuba, Jamajea, Hispaniola, and Puerto Rico and Virgin Islands. Also Central America from British Honduras to Costa Rica. Planted in sonthern Florida.

Other common nayes. - cerezo, cerezo del país, palo de goma, muñeco (Pnerto Rico); West-Indian-cherry, wild capa (Virgin Islands); cerezo, ateje de costa, ateje cimarrón, atejillo (Cuba); sombra de ternero (Houduras) ; buriogre amarillo, muñeco, buriogre de montaña (Costa Rica); bois paupit, bois poupée (Haiti).

Palo de muneca or manjack (Cordia collococca L.; synonym $C$. glabra auth., not L.), called also cerezo, is a related tree of Puerto Rico, Mona, Culebra, St. Croix, St. Thomas, St. John, and Tortola, also through West Indies and from Mexico to South America. It differ's in the leaves dull rather than shiny and the stalkless white flowers only $1 / 4$ inch across. 


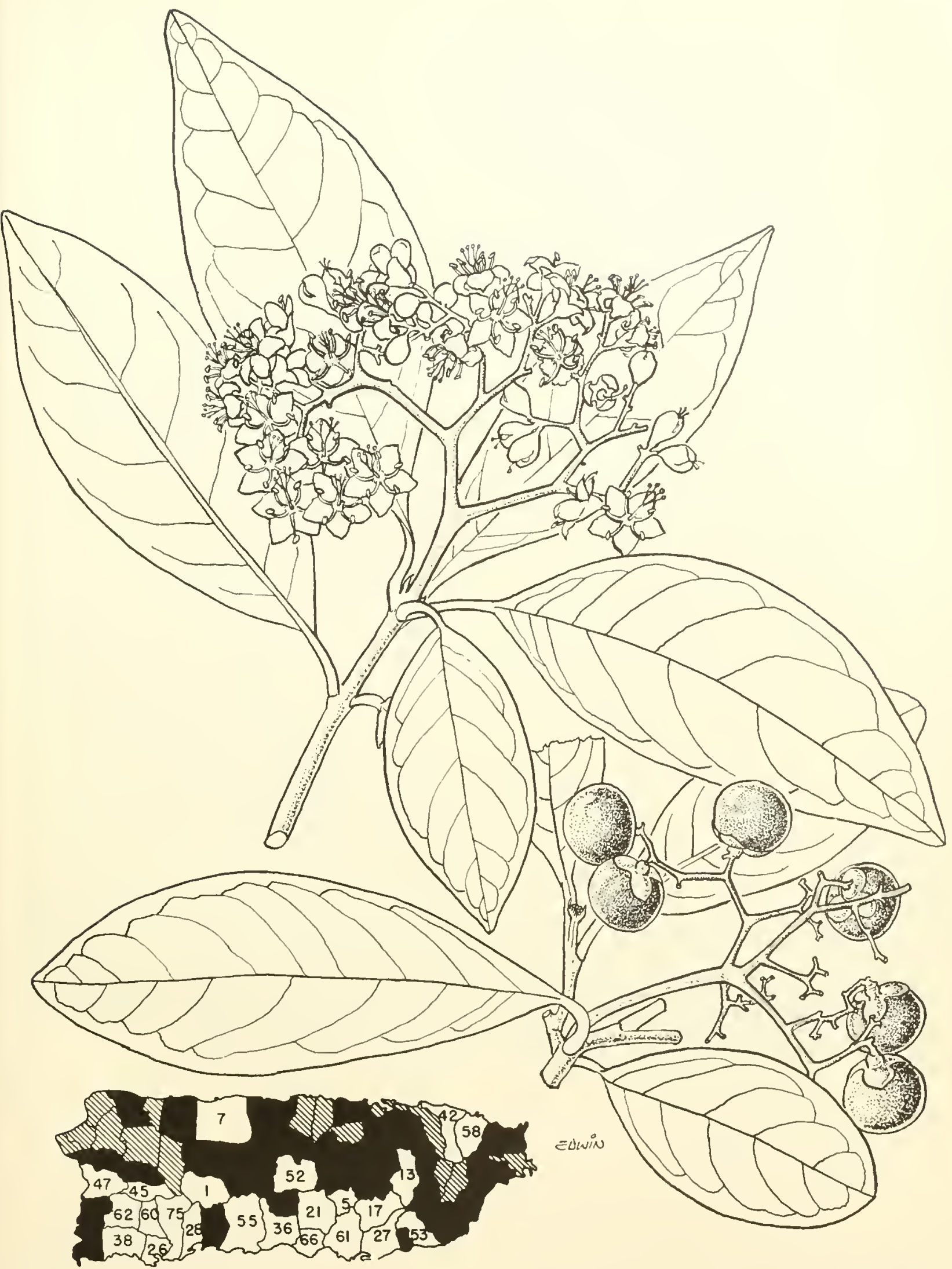

223. Capá colorado, red manjack Natural size. 


\section{BORAGE FAMILY (BORAGINACEAE)}

\section{Moral, white manjack}

This medium-sized tree of moist areas is easily recognized by its open spreading crown of a few widlely forking and often nearly horizontal hramches with large, rough hairy leaves, which are ovate to elliptic to nearly round, mostly 9-12 inrhes long and 5-8 inches wide and usually spaced apart on lateral branches forking at broad angles. Other distinguishing characteristies are the muchbranched flattened clusters of numerous small whitish flowers 1/4 inch long with tubular 5-lobed corolla and the round whit ish mucilaginous fruits 3 s incli in dianeter.

Deciduous tree 20-65 feet high and $11 / 2$ feet or more in trunk diameter. The bark is smooth and gray, becoming furrowed on harge trunks. Inner bark is light brown, slightly astringent. The twigs are finely hairy, green but becoming gray, slightly furrowed when roung, as the scientific name sugrests.

The alternate leaves have short stout petioles $1 / 4^{-1 / 2}$ inch long. Blades are short-pointed to rounded at apex and rounded or slightly heartshaped at base, the edges inconspicuonsly sawtoothed or withont teeth, slightly thickened, green to dark green, rough and finely hairy on upper surface, and paler and finely soft hairy on lower surface.

Flower clusters (panicles) are $4-6$ inches high and $t-10$ inches broad, terminal but becoming lateral at the base of 2 forking twigs. There are numerous fragrant small flower's $1 / 4$ inch long and $3 / 16$ inch across, stalkless. Calyx is tubular, 3-5toothed, green, and minutely hairy; the white corolla has a tube and 5 shorter lobes turned back; 5 stamens are inserted on the corolla tube; and the

\section{Cordia sulcata DC.}

pistil has an orange 4-celled orary with style twice forked.

The fruits (drupes) containing sticky flesh and a large iregrular-shaped stone are produced in abundance. Flowering from late spring to fall and with mature fruits nearly through the year.

The wood is light brown, soft, moderately lightweight (specific gravity 0.6), and easily worked but not durable. In use classed as roundwood. Elsewhere the wood has sometimes served for cooperage.

The trees have been planted along highways for shade and ornament.

Common and widespread in moist forests at all elevations in Puerto Rico. It is characteristic of openings and second-growth forests and probably is light-requiring. Mlso in Vieques, St. Thomas, St. John, and Tortola. Reported long ago from St. Croix.

Plizlic: ronests.-Cambalache, Carite, Guajataca, Luquillo, Maricao, Río Abajo, Susúa, Toro Negio.

MUNiCIPALITIES WHERE ESPECLALLY COMMON.-1, $29,42,50,51,59,64,68$.

RANGE, -Greater Antilles, Virgin Islands, and Lesser Antilles from Saba to St. Vincent and Barbados.

Other comaron vames.-moral de paz (Puerto Rico) ; mucilage manjack (Virgin Islands) ; ateje cimarrón, ateje macho, palo tabaco (Cuba); manjack (Jamaica, St. Kitts, Nevis, St. Vincent) ; bois bré (Dominica); wild clammy-cherry (Barbados) ; laylay, mapou, hairy laylay, bois laylay (Trinidad); parésol (Haiti); grand mapou, mahot grandes feuilles, mapou (Guadeloupe); manjack (Dutch West Indies). 


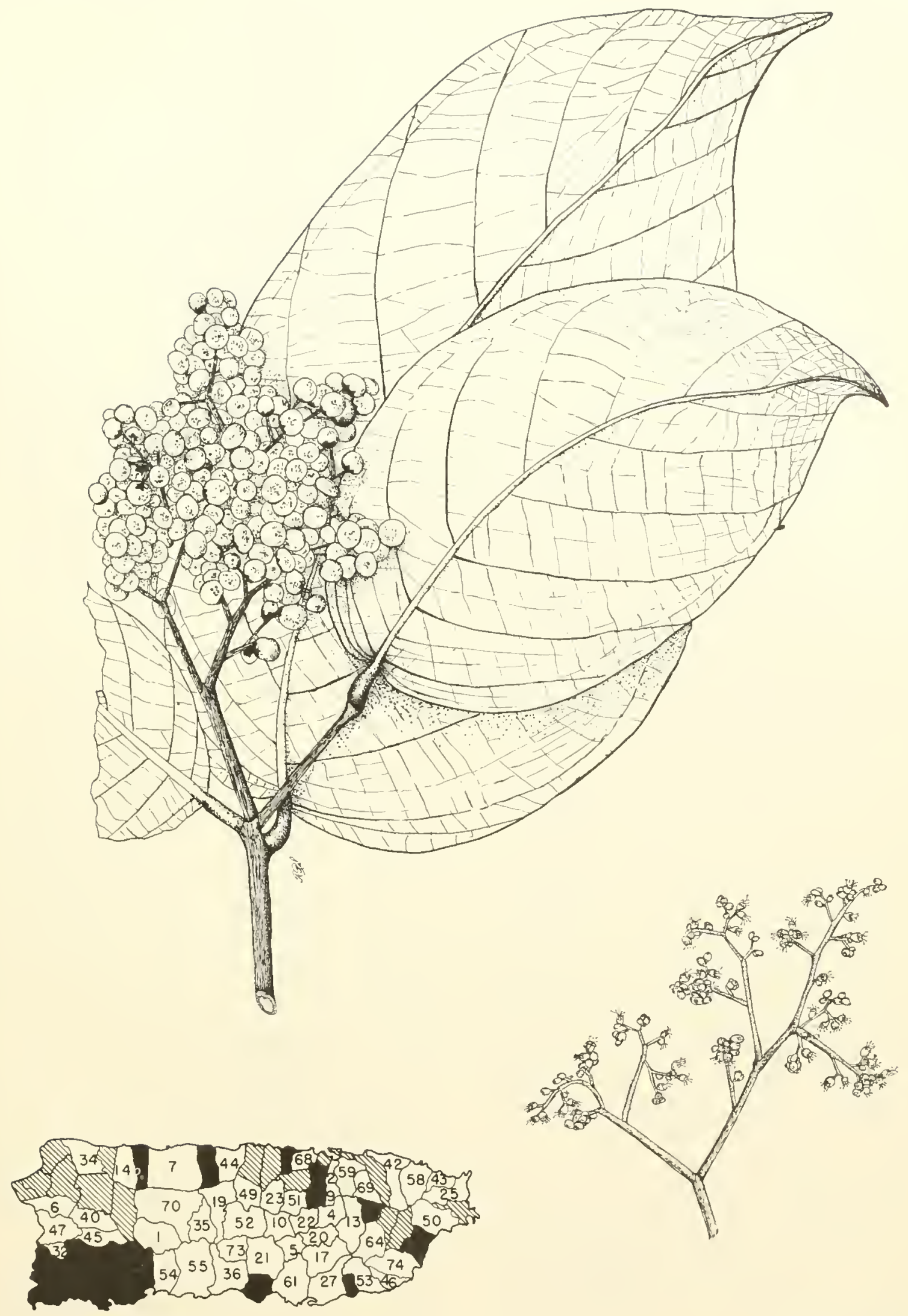




\section{VERBENA FAMILY (VERBENACEAE)}

Key to the 6 species illustrated (Nos. 225-230)

A. Leares simple.

B. Leares less than 6 inches long.

C. Leaves lance-shaped or narrowly elliptic, 2-41/2 inches long, lower surface gray green, hairy; trees of mangrove swamp forest-225. Aricennia nitida.

CC. Leaves elliptic; upland trees.

D. Petioles short, less than 1 inch long; leaf blades bairless or nearly so, the upper surface slightly shing.

E. Leares with few side reins; flowers with definite stalks-226. Citharexylum caudatum.

EF. Leares with prominent network of small reins when dry, turning red before falling, petiole pink or orange; flowers almost stalkless-2z7. Cilharexylum fruticosum.

DD. Petioles long, 1-21/2 inches long; leaf blades rough, lower surface pale yellow green, with minute seales and hairs and prominent veins-228. Petilia domingensis.

BB. Leaves very large, elliptic, 12-15 inches or more in length, thickened, leathery, and harsh, the upper surface rough, the lower surface soft hairy-22o. Tectona grandis.*

AA. Leares mostly compound with 3 elliptic leaflets, often only 1 or sometiues 2 , the end one largest-230. Vitex divarieata.

\section{Mangle prieto, black-mangrove}

This is 1 of the 4 kinds of mangrove trees which form swamp forests at sea level in salt water and brackish water along silty seashores. Mangle prieto is distinguished by: (1) opposite lanceshaped or narrowly elliptic leathery leaves $2-11 \%$ inches long and $1 / 2-13 / 4$ inches broad, the upper surfice yellow green and often shiny, the lower surface gray green with a coat of fine hairs giving a glayish color to the crown, and hoth surfaces often with scattered salt crystals and salty to the taste: (2) clusters of several rrowded stalkless white 4-lobed flowers about $1 / 4$ inch long and $3 / 8$ inch across: (3) elliptic flattened blunt-pointed seed capsules $1-1 \frac{1}{4}$ inches long and abont $3 / 4$ inch wide, yellow green and finely hairy, often splitting open into 2 parts; and (4) bright orange to yellow inmer bark.

Commonly a small tree or shrub $10-10$ feet high and attaining a trunk diameter of 1 foot in Puerto Rico, evergreen with rounded crown of spreading branches. Bark is smooth and dark gray or bown on small trunks but becomes dark brown, fissmred and scaly, and thick. The inner bark, brown deeper' within, has a slight salty taste. 'Twigs are gray or brown, finely hairy when young, with enla rged and ringed joints or nodes.

Often numerons fleshy pencillike projections (pnemmatophores) rise veltically from the long horizontal roots in the mud under a tree, perhaps aiding in bringing air to the roots. Masses of roots $1 / 2-11 / 2$ feet long sometimes hang in the air from the upper part of large trunks.

The short petioles are $1 / 8^{-1} / 2$ inch long. Blades are short-pointed or blunt at apex, short-pointed at base, and not toothed on edges.

Flower clusters (spikes or panicles) are terminal and lateral, erect on 4 -angled stalks $1 / 2-11 / 2$ inches long, and bear several finely hairy flowers. The gray-green calyx is cup-shaped, $3 / 16$ inch long, deeply 5 -lobed, with 3 smaller scales (bracts) outside; the corolla tube about the same length has 4 slightly unequal spreading romoted or notched lobes, white but yellowish at base; 4 stamens $3 / 16$ inch long are inserted on corolla tube near base;
Avicennia nitida Jacq.

and the pistil $3 / 16$ inch long has a 1 -celled ovary, slender style, and 2 -lobed stigma.

The fleshy seed capsule contains 1 large dark green seed which is an embryo plant without seedcoat. Often the seed germinates on the tree, splitting open the fruit. Upon falling, the young plant continues growth in the mud or may float and be transported by tide and currents. Flowering and fruiting nearly throughont the year.

The sapwood is light brown and thick. The heartwood is dark brown or blackish. The wood is very hard, very heavy (specific gravity 0.9), and strong. It has a coarse, uneven, interlocked grain and prominent growth rings and is very susceptible to ittack by äry-wood termites.

Seldom sawed into limmber, the wood is used primarily for posts in Puerto Rico. Timbers of larger size have been employed elsewhere for various purposes, such as piers, wharves, and other marine construction, as well as for telegraph and power poles and crossties. The wood is used also for fuel and charcoal, and the bark for tanning.

This is an important honey plant of coastal areas, producing clear white honey of high quality. The flowers are rich in nectar and attract bees. It is reported that the sprouting seeds are edible when cooked but poisonous raw. Salt for cooking or eating purposes can be obtained from the saltcoated foliage.

This species seems more hardy than the other 3 kinds of mangroves, to which it is not related. It penetrates farther inland along rivers and in the United States ranges farther northward, beyond the tropical zone. In Puerto Rico it appears to withstand prolonged flooding better than whitemangrove (Laguncularia racemosa). The adrancing thickets of mangroves with networks of roots collect and hold silt, thus building up the shores.

In mangrove forests in brackish water near prorected silty shores and at mouths of rivers around Puerto Rico, usually with other species of mangrove but rarely forming pure stands. Also Cule- 
bra, Vieques, St. Croix, St. Thomas, St. Jolnn, and Tortola.

Public Forests.-Aquirre, Boquerón, Ceiba, Guánica, and San Juan.

RANGE.-Very widely distributed along tropical silty seashores of Bermuda and throughout West Indies (except Dominica) from Bahamas and Cuba to Trinidad and Tobago and Bonaire and Curaçao. Coasts of Florida from northern part to Florida Keys, Mississippi, Lonisiana, and Texas in sontheastern Inited States and both coasts of Mexico sonth along ('entral Imerica to Ecuador, northwestern Peru, and Cralapagos Islands and to Brizil. Ilso west coast of $\mathrm{A}$ frica.

Other commox rames.-mangle negro, mangle bobo, siete cueros, salado (Puerto Rico); mangle prieto, mangle negro, mangle blanco (Spanish); black-mangrove, manglecito (commerce); puyeque (Mexico); palo de sal (Central America) ; istatén, árbol de sal (EI Salvador); culumate, mangle salado (Costa Rica); mangle salado, white-mangrove (Panama); iguanero (Colombia); mangle salado, mangle rosado, mangle prieto (Tenezuela) ; mangle iguanero (Ecuador); black - mangrove, honey - mangrove, saltbush (United States); black-mangrove (English); blackwood-bush (Bahamas); limewood (Trinidad) ; comrida, cruda (British Guiana) ; manglier noir, palétuvier (Haiti) ; palétuvier blanc, mangle blanc, chêne Guadeloupe, palétuvier (Guadeloupe); palétuvier blanc, manglier noir (French Guiana); mangel blancu, saltpond-tree (Dutch West Indies); parwa (Surinam); siriuba, seriba (Brazil).

Botanical symony.-Avicennia germinans L.

\section{VERBENA FAMILY (VERBENACEAE)}

\section{Péndula de sierra}

Shrub or tree of upper mountain forests characterized by: (1) opposite elliptic leaves blunt or rounded at apex and short-pointed at base, with few lateral veins; (2) marrow clusters of small white flowers $5 / 16$ inch across the 5 slightly umequal spreading corolla lobes and borne on short stalks $1 / 16$ inch long: and (3) shiny pear-shaped or elliptic fruits nearly $1 / 2$ inch long, turning from green to orange brown or black, with cuplike calyx at base.

This species differs from its widely distributed close relative péndula (Citharexylum fruticosum L.) in the leaves coarsely reined without a prominent network of small veins when dry, in the flowers definitely stalked instead of almost stalkless, and in its distribution in mountain forests at higlier elevations.

A small slender evergreen tree 15-30 feet ligh and to 8 inches in trunk diameter, or a shrub. The bark is smoothish and brown, inner bark light hrown and bitter. The long namow twigs are light gray brown, with prominent raised leaf scars.

Petioles are 1/4-3/4 inch long. Blades are 2-5 inches long and $3 / 4-21 / 4$ inches wide, slightly thickened and with edges sometimes tumed under a little, slightly shing green above and dull and paler beneath. On the lower surface are many minute inconspicuons dots visible with a lens.

Flower clusters (racenes) are $1 \frac{1}{2}-3$ inches long, terminal and lateral, bearing many slightly fracrant flowers. The bell-shaped ealyx is about $1 / 8$ inch long and broad, minutely 5 -toothed; the white finely hairy corolla with tube nearly $1 / 4$ inch long and 5 lobes $1 / 5$ inch long: 4 stamens nearly $1 / 8$ inch long inserted on corolla tube; and greenish pistil

\section{Citharexylum caudatum L.}

$3 / 16$ inch long with 2-celled orary, slender style, and slightly 2 -lobed stigma.

The tlesliy fruits (drupes) slightly 2 -lobed have cuplike calyx $1 / 8$ inch long remaining at base. They contain 2 ellipt ic shiny brown nut lets $3 / 8$ inch long, each 1-seeded. Flowering and fruiting nearly through the year.

The light brown, hard wood is used for posts and fuel. Nlso a honey plant.

Upper mountain forests and dwarf forests of mountain peaks in Puerto Rico.

Public forests.-Carite, Luquillo.

MUNicipality WHere especially COMMON.-22.

Range.-Bahamas, Greater Antilles, Leeward Islands, and Dominica. NIso Yucatán, Mexico, and Central America from British Honduras and Honduras to Panama and in Colombia. Planted in southern Florida.

Other connow Names.—café cimarrón, penda (Dominican Republic) ; penda, collarete (Cuba); roble amarillo (Nicaragua) : dama (Costa Rica); manglillo (Panama); fiddlewood (English); racemose fiddlewood (Bahamas); birdseed, pigeon-feed (British Honduras), café marron (Haiti).

The generic name (Citharexylum) is Greek for fiddlewood. The English name fiddlewood and similar ones in French and Spanish for related species refer to the use for violins, gruitars, and other musical instruments. The Spanish name péndula, meaning pendent, describes the long slender drooping or hanging clusters of flowers and fruits. 


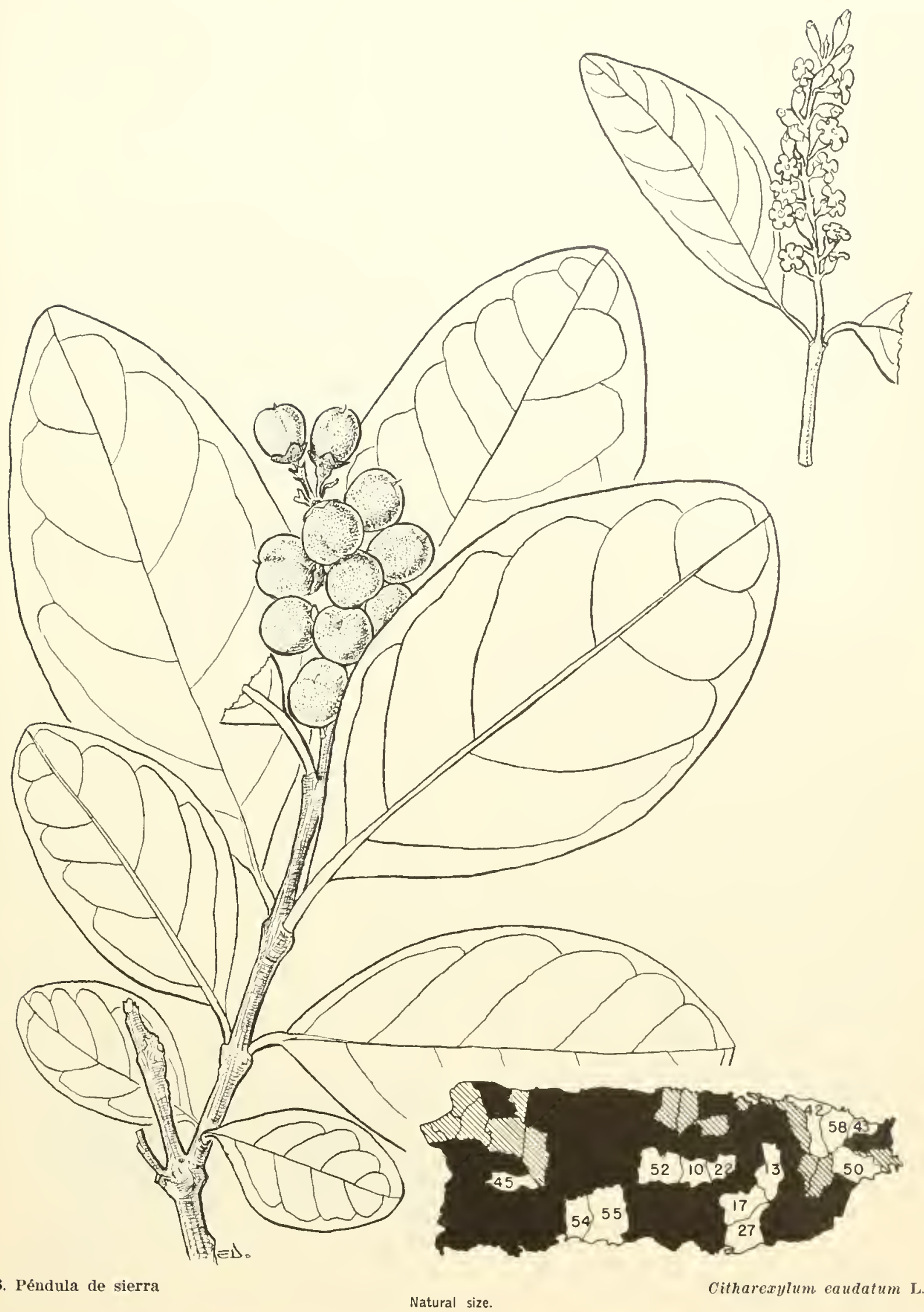




\section{VERBENA FAMILY (VERBENACEAE)}

\section{Péndula, pasture fiddlewood, Florida fiddlewood}

Citharexylum fruticosum $\mathrm{L}$.

This small tree is easily recognized by: (1) opposite, mostly elliptic, yellow-green leaves with conspicuons pink or orange petioles; (2) narrow clusters of small fragrant white flowers nearly $3 / 6$ inch across the 5 sliglitly unequal spreading corolla lobes, borne almost stalkless on narrow drooping axes: (3) nearly round, shiny, reddish-brown or black fruits $3 / 8$ incli or less in dianeter; and (4) rough, light brown bark, becoming much fissured and shredding in long narrow strips.

Evergreen shrmb or small slender tree 10-40 feet in height and to 1 foot in trumk diameter. The inner bark is whitish and tasteless. Young twigs are 4-angled and with faint rings at nodes, slender, light brown or green, becoming gray and finely fissured.

Petioles are $1 / 2-1$ inch long. Leaf blades are $3-\tau$ inches long and 1-21/2 inches broad, short - or longpointed at both ends or sometimes rounded or notched at apex, the edges rarely toothed on young shoots, thick and leathery, sometimes hairy on reins beneath, shing yellow green on upper surface and dull beneath, turning red before falling. They vary greatly in shape from lance-shaped to elliptic or obovate and when dry show a raised network of small veins on both sides. The midrib often is pinkish toward base.

Flower clusters (racemes) are 2-12 inches long, lateral and terminal, unbranched, bearing many white flowers abont 3/s inch long. The pale green calyx is marrowly tubular, $3 / 16$ inch long, mostly 5-toothed, hairless or hairy: the white tubular 5lobed corolla nearly $3 / 8$ inch long, hairy at throat: 4 stamens inserted on corolla tube: and pistil with 4-celled green ovary, slender style, and slightly 2lobed stigma.

The drooping clusters of the fleshy fruits (drupes), sometimes abundant, are reported to be sweet and eclible. Wach has a stone which separates into 2 2-seeded nutlets. Flowering and fruiting through the year.

The sapwood is light brown and thin, and the heartwood is reddish. The wood is very hard, heary (specific gravity 0.7), and strong. Considered il good fencepost in Puerto Rico. The wood of this and related species hats been used elsewhere for furniture, construction, and violins, guitars, and other musical instruments.

Sometimes planted along highways and fences and in gardens as an omamental. Also a honey plant. This species is subject to attacks by caterpillar's which fasten the leares together in bundles and canse leaf fall, reducing the value for ornament.

In thickets and forests of the coastal, limestone, and lower mountain regions of Puerto Rico. Also in Desecheo, Icacos, Culebra, Vieques, St. Croix, St. Thomas, St. John, Tortola, and Virgin Gorda.

Public forests. - A guirre, Cambalache, Carite, Guajataca, Guánica, Lnqquillo, Maricao, Río Abajo, Susúa.

Mi Nicipalities WHere especially COMMON.$21,31,32,36,42,66,69$.

RAxGe-Central and southern Florida including Florida Keys and through West Indies from Bahamas and Cuba to St. Vincent, Grenada, and Trinidad. Also Venezuela to Surinam in northerm South America. Widely planted for ormament.

Other conmox vames.-palo de guitarra, bálsamo (Puerto Rico); susanaleche (Virgin Islands) ; café cimarrón, penda, péndula (Dominican Republic); penda, canilla de venado, guayo blanco (Cuba); Florida fiddlewood, fiddlewood (United States): spicate fiddlewood, long-tom (Bahamas): fiddlewood (Jamaica, St. Vincent, Trinidad).

Minor botanical varieties differing ehiefly in lairiness and leat shape have been distinguished outside Puerto Rico.

A related tree species of péndula (Citharexylum spinosum L.), known also as susana, is wild and planted in St. Croix and St. Thomas and ranges southward to northem Sonth America. It has elliptic leaves 3-8 inches long, thin, hairless, and with prominent network of small veins when dry, and oblong shiny black fruits $3 / 8$ inch long. 


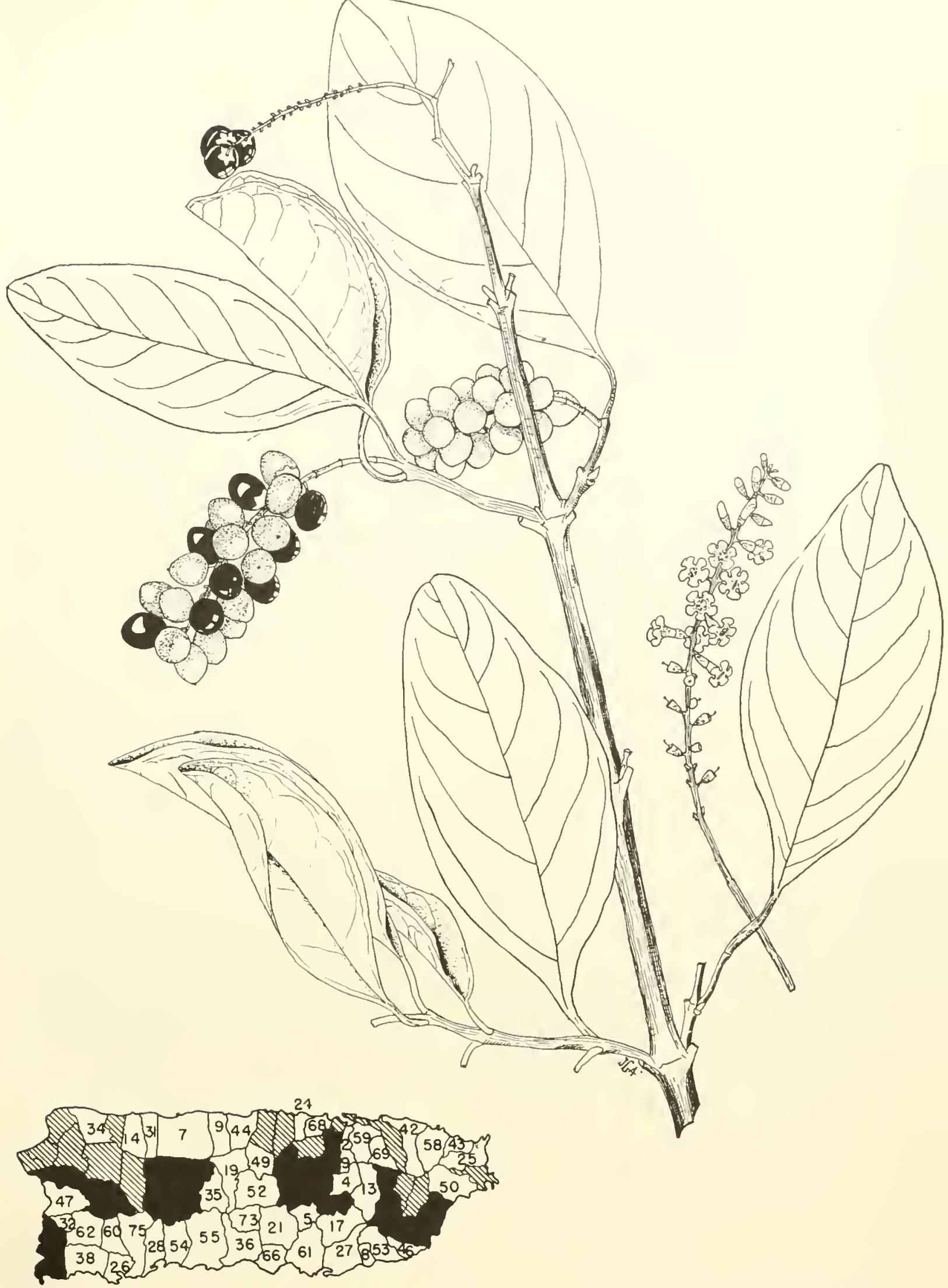




\section{VERBENA FAMILY (VERBENACEAE)}

\section{Capá blanco}

A small to medimm-sized tree characterized by: (1) the crown usually having a grayish color; (2) opposite long-stalked elliptic leaves with rough surfaces, green and almost hairless on upper surface, the lower surface pale yellow green and covered with minute scales and hairs and with prominent reins; (3) twigs t-angled, finely lairy, green but becoming brown; (4) numerons small white flowers about $1 / 8$ inch long and broad, with tubular t-lobed corollas, borne in long-stalked lateral branched chusters and forming round juicy fruits about 5/16 inch in cliameter, turning from green to red to black; and (5) gray bark slightly shreddy and separating into strips.

A tree 20-70 feet high and 1 foot or more in trunk diameter, with spreading open crown, evergreen or nearly so. The rough fissured bark has brown and tasteless inner lark. The young twigs, petioles, and flower stalks are minutely hairy.

Petioles are 1-21/2 inches long and blades 3-6 inclies long and $11 / 2-3$ inches broad, short-pointed at apex and rounded or short-pointed at base, slightly thickened, and withont teeth on edges.

Flower clusters (panicles) are $2-6$ inches long, including the long stalks, and bear many minutely hairy, slightly fragrant flowers. Calyx is bellshapeil, 4-toothed; the white tubular corolla with 4 spreading lobes; stamens 4, minnte, borne near mouth of corolla tube; and pistil with 2 -celled ovary, slender style, and 2-lobed stigma. The fruits (drupes) are 1-seeded. Flowering and fruiting through the year.

The light brown sapwood is not clearly separated from the very attractive light brown to medium brown heartwood, which frequently is variegated or marked by darker stripes. The wood is vely hard, heavy (specific gravity 0.66), tough, strong, fine-textured, with straight, wavy,

\section{Petitia domingensis Jacq.}

or interlocked grain, and withont growth rings. It is susceptible or moderately resistint to attack by dry-woor termites and moderately durable in contact with the ground. The rate of air-seasoning is rapid, and the amount of tegrade moderate. Machining characteristics are as follows: planing is fair: shaping, sanding, and resistance to screw splitting are good; and turning, boring, and mortising are excellent.

Uses include furniture, light and heavy construction. posts and piling, crossties, and jollers for coffee-lunlling mills. The wood is suitable also for cabinetmaking, turned articles, novelty items, interior paneling, farm implements, handles, and brictges.

On hillsides, thickets and woods, in the coastal, limestone, and lower mountain regions of Puerto Rico. Also reported long ago from St. Croix and St. Thomas.

This species is characteristic of openings in second-growth forests and probably is light-requiring. It is being tested in small plantations in Puerto Rico. The flower's attract bees.

Public rorests.-Cambalache, Carite, Guajataca, Luquillo, Maricao, Río Abajo, Susúa, Toro Negro.

MIticipultites Wiere especially CoMrmon.$32,34,38,46,47,49,69$.

Range.-Bahamas, Cuba, Cayman Islands, Jamaica, Hispaniola, and Puerto Rico. Also planted in sonthern Florida.

Otier common names.-capá amarillo, capá rosado, capá de sabana (Puerto Rico); capá de sabana. capá sabanero, capá blanco (Dominican Republic): roble guayo, guayo prieto (Cuba); petitia, bastard stopper (Bahamas); ficldlewood (Jamaica); bois d'ortie, chêne calebassier (Haiti). 


\section{VERBENA FAMILY (VERBENACEAE)}

\section{Teca, teak}

Teak, which has been introduced sparingly in plantations for its valuable timber and for ornament and shade, is easily identified by jts huge elliptic opposite leaves 12-15 inches long and 9-10 inches broad or larger, by its stont 4-angled twigs and few coarse branches, and by the bronze-colored young leaves which vield a reddish juice when crushed. The numerous small whitish flowers $1 / 4$ inch long and $3 / \varepsilon$ inch across the 6 spreading corolla lobes are borne in very large flower clusters. In enlarged thin egr-shaped calyx about 1 inch across encloses the fruit, which is a light brown ball about $1 / 2$ inch in diameter.

In its nat ive home this is a large tree to 150 feet tall, often with buttressed or fluted trunk. Trees of plantations in Puerto Rico have grown to 60 feet in height and 1 foot in trunk diameter within 20 years. They are decidnous. The light brown bark is much fissured and scaly and $1 / 2$ inch or more in thickness. Imer bark is soft, whitish, and almost tasteless. The spreading branches form an open crown of light gray twigs and few very large leaves. Young green twigs, foliage, and flower clusters are covered with fine gray-green star-shaped hairs.

Leaves are stalkless or short-petioled, mostly short-pointed at hoth apex and base, thickened, leathery, and harsh, the upper surface green and rough, and the lower surface light green and soft hairy. Very large leaves measure as much as 2 feet long and 16 inches broad.

Flower clusters (panicles) are terminal, erect and branched, about $11 / 2-2$ feet long and broad. The finely hairy flowers have a bell-shaped 6lobed gray calyx; the fumel-shaped whitish corolla has a short tube and 6 spreading lobes; 6 stamens are inserted on corolla tube; and the pistil has a 4 -celled orary, slender style, and 2-lobed stigma.

The light brown, finely hairy ball fuuit (drupe) has a liard stone containing 4 or fewer seeds $1 / 4$ inch long (600 fruits to the pound). Recorded in flower from August to December and with fruits persisting nearly through the year.

The sapwood is yellowish or whitish. The heartwood is olive green when freshly cut, turning golden brown upon seasoning. The wood is mod-
Tectona grandis L. f.*

erately hard, moderately leavy (specific gravity $0.55)$, strong, fine-textured, straight-grained, and has distinct annual growth rings, oily feel, and characteristic fracrance when freshly cut. Airseasoning is rapid with minor amomit of degrade and with low, uniform shrinkage. Machining characteristics are as follows: planing, shaping, boring, mortising, and resistance to screw splitting are good: turning is excellent; and sanding is very poor. The wood works easily but contains silica which dulls cutting edges. The heartwood is very resistant to attack by dry-wood termites, moderately resistant to subterranean termites, and very durable in the ground. However, the sapwood is susceptible to attack by termites and is not durable.

Teak, one of the world's best known and most valuable timbers, is important in shipbuilding, particularly for decking. Its many other uses include fine furniture, flooring, joinery, interior trim, franes, doors, paneling, carrings, turnery, tanks and vats, and laboratory fixtmes. Thinnings from plantations serve for posts and furniture.

Trees are cultivated occasionally in tropical countries as ornamentals for the large leaves and sprearling flower clusters. In Puerto Rico small experimental plantations have been made on Government forests to determine the practicability of growing teak commercially. The tree is irell adapted to deep soils at low elevation.

Grown experimentally or for ornament at low elevations in Puerto Rico and in St. Croix and Tortola.

Priblic forests.-Cambalache, Carite, Guajataca, Luquillo, Río Abajo.

RAxge.-Native of southern Asia from India to Malaya. Introduced and naturalized in Philippines and Java. Planted for timber or ormament and in botanical gardens in various tropical areas including the West Indies from Cuba and Jamaica to Trinidad and from Panama to Brazil. Grown in sonthern Florida.

Otuler comaron xumes.-teca (Spanish); teak (United States, English); teck (Guadeloupe, French). 


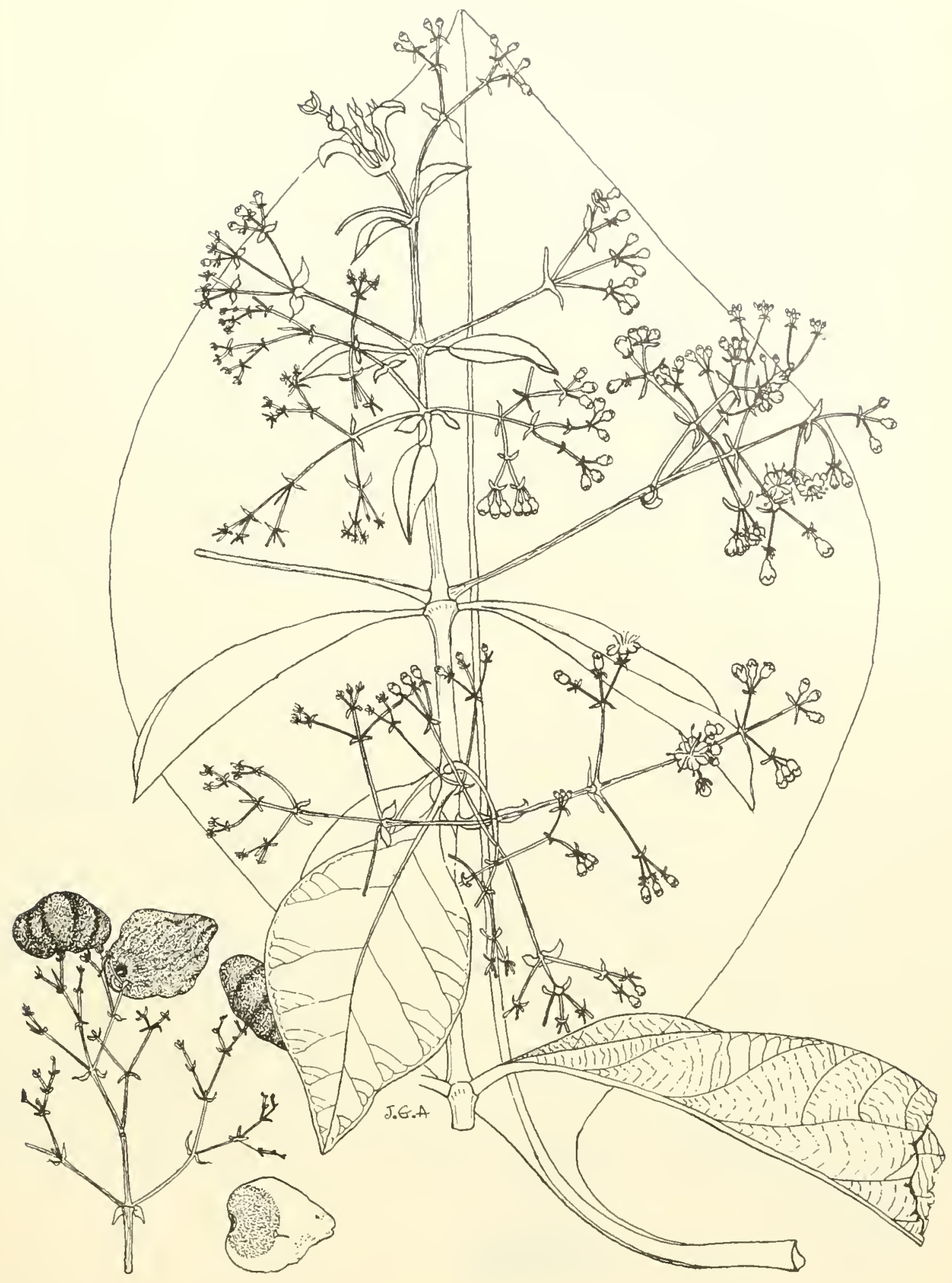




\section{VERBENA FAMILY (VERBENACEAE)}

\section{Higüerillo, white fiddlewood}

Snall to medium-sized tree with much-fissured light brown bark, rough and shreddy and separating in strips, further distinguished by: (1) opposite leaves mostly compound with 3 elliptic leaflets or often only 1 or sometimes 2, the end one larger than the others; (2) numerous showy pale purplish-blue flower's $3 / 8$ ineh long and $1 / 2-5 / 8$ inch aeross the 5 unequal corolla lobes, in lateral branehing elusters; and (3) black egg-shaped fleshy fruits $1 / 2$ inch long, with cuplike ealyx at base.

A decidnous tree 20-65 feet high and to $21 / 2$ feet in trunk diameter, with rounded erown. The inmer bark is light brown and slightly bitter. The twigs are greenish and minutely hairy when young, becoming gray or brown.

The slender green petioles are $3 / 4-23 / 4$ inches long, and the leaflet stalks $1 / 4$ inel or less in length. Leaflet blades are 2-6 inches long and $1 \frac{1}{4}-$ - $)$ inehes wide, mostly short-pointed at both ends, thin or slightly thiekened, above light green, beneath paler and hairy on veins.

Often the glound under a tree in flower has a bluish tinge from the numerous fallen corollas. Flower cluster's (ermes) 2-6 inehes long at base of leaves bear several to many slightly fragrant flowers on short slender stalks. The flower about $3 / 8$ inch long has a cuplike calyx less than $1 / 8$ ineh high and broad: pale blue or purplish-blue irregular finely hairy eorolla with narrow tube $1 / 4$ ineh long and 5 unequal, spreading, wavy-margined lobes, 1 much larger than the others; 4 stamens $1 / 4$ inch long in 2 pairs inserted on eorolla tube and slightly protruding: and pistil $3 / 5$ ineh long with 4-eelled ovary and slender style 2-forked at end.

The fruit (drupe) contains a large 4-eelled and 4-seeded stone. In maturing, fruits ehange color from yellow green to brownish and black. Observed in flower from February to July and in fruit from June to November.

The grayish sapwood turns light brown upon drying. The heartwood when freshly eut is tan to brown, generally variegated with darker shades,
Vitex divaricata Sw.

and afterwards becomes gray brown to deep brown. often with indistinct, narrow, lighter or darker bands. The wood is hard, heavy (specific gravity 0.62$)$, strong, tough, and fine-textured and has irregular, interlocked grain and well-defined growth rings. Air-seasoning is too slow to be praticable commereially. Amount of degrade is minor. Machining characteristies are as follows: planing and resistance to screw splitting are poor; shaping, boring, and mortising are good; turning is excellent; and sanding is fair. The wood works easily and takes a fine polish. It is moderately rosistant to dry-wood termites and is durable in contact with the ground.

The wood is used for framework of houses, fenceposts, construetion, cabinetwork, and elsewhere for shingles. It should be suitable also for sporting goods, tool handles, boats, and flooring.

Planting tests show this species to grow slowly and to require nearly full sunlight. The trees, which become eovered with flowers, are suitable for ornamentals also. They ean be propagated from cuttings and grow lapidly in open areas. A honey plant.

Widely distributed in coastal, limestone, and lower mountain regions of Puerto Rico. Also in St. Croix, St. Thomas, St. John, and Tortola.

Pcrulc roliests.-Cambalache, Carite, Guajataca, Guilarte, Luquillo, Maricao, Río Abajo, Susúa, Toro Negro.

MUNICIPALTIES WIERE ESPEClaLLY COMMON.46,50 .

Raxge.-Cuba, Hispaniola (Haiti), Puerto Rico and Tirgin Islands, and thronghout Lesser Antilles to Grenada and Trinidad and Tobago. Also in Tenezuela and Guianas.

Otuer comaros sumes.-péndula, péndula blanca (Puerto Rico); roble guayo, roble de olor, ofón eriollo (Cuba) ; totumillo (Venezuela) ; fiddlewood (St. Kitts, St. Vincent); white fiddlerood (Montserrat); bois lézard (Dominica); black fiddlewood (Trinidad); timber fiddlewood (Tobago) ; bois lézard, bois à agouti (Guadeloupe, Mart inique). 

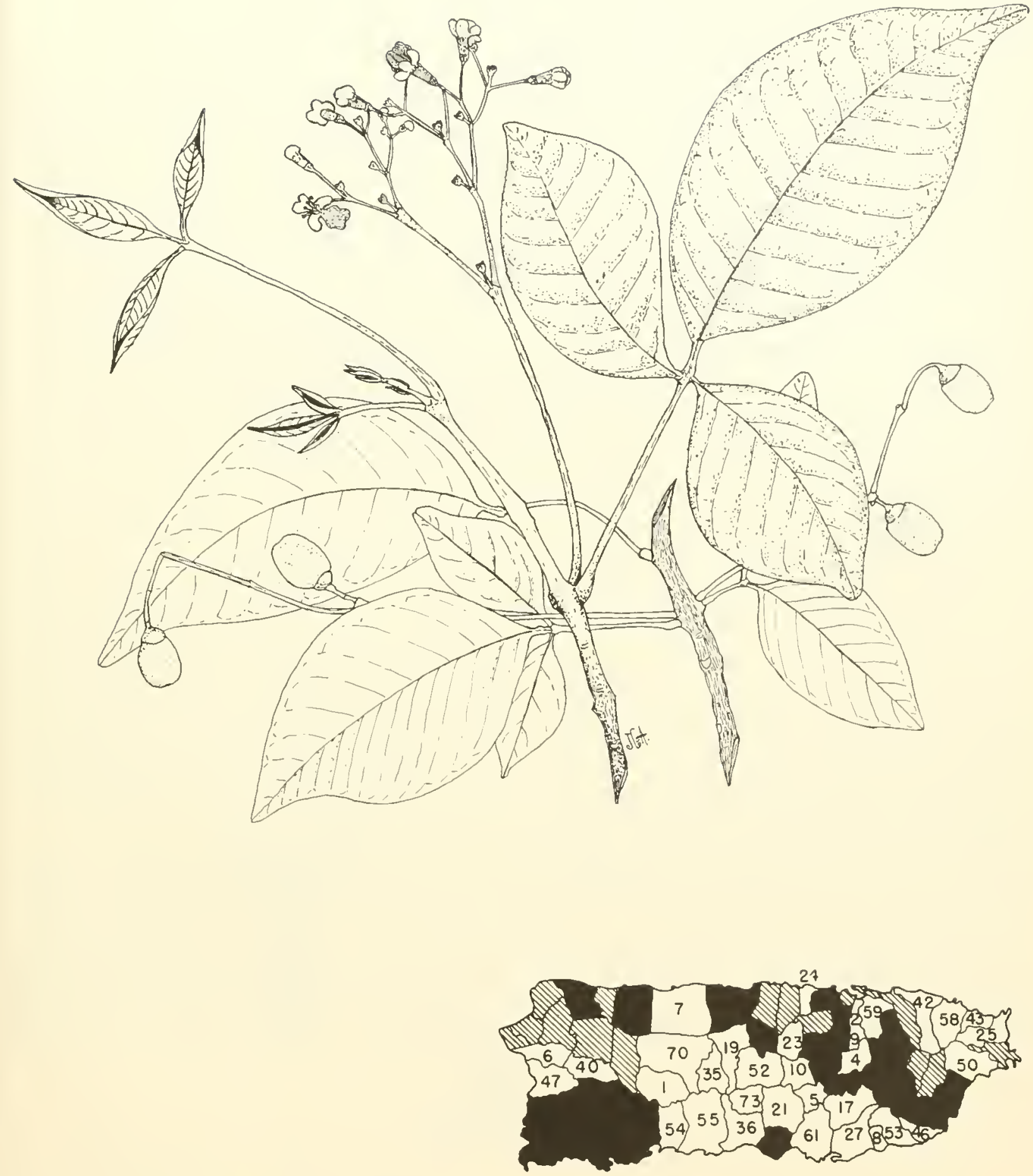


\section{NIGHTSHADE FAMILY (SOLANACEAE)}

\section{Tabacón}

A slunb or small tree characterized by: (1) large, thin, elliptic, altermate leaves long-pointed at alvex, the base also long-pointed and gradually narrowed into the long petiole, both surfaces slightly rough and bearing minute star-shaped hairs: (2) many widely spreading star-shaped white flowers $5 / 8$ inch across the 5 namow pointed lobes, borne in terminal flattened clusters; and (3) many round yellow berries $1 / 2$ inch in diameter, green when immature.

A spreading evergreen shrub or tree 12-15 feet high with trmak 2-3 inches in diameter, branching at wide angles. The light gray bark is smoothish and slightly warty, the immer bark soft, whitish, and slightly bitter. 'The greenish twigs bear many minute star-shaped hairs and are slightly rougli. Spineless thronghont, thongh many species of this genus are spiny.

The alternate leaves have long petioles $1 / 2-11 / 2$ inches long. appearing winged from the tapering leaf base. Blades are mostly 5-10 inches long and 24 inches broad, green abore and paler beneath, not tootlied on edges.

The long-stalked branching and flattened flower' clusters (corymbs) are 2-3 inches across. The short-stalked flowers have a bell-shaped tubular calyx $3 / 16$ inch long, densely hairy and with 5 pointed lobes; white corolla with short tube and 5 hairy lobes more than $1 / 4$ inch long. spreading like a star ; 5 stamens $3 / 16$ inch long, inserted on corolla, with large yellow anthers opening by pores at apex; and pistil with 2 -celled ovary more than $1 / 16$ inch in diameter and slender slightly curved style $5 / 16$ inch long. The berries have calyx at base and contain many small, rounded, flat, brown seeds $1 / 16$ inch in diameter. Flowering and fruiting through the year.

The whitish wood is soft and brittle.

In open areas, such as roadsides, thickets, plantations, and river banks in the moist coastal, limestone, and mountain forest regions of Puerto Rico.

Publ.rc forests.-Carite, Guajataca, Luquillo, Maricao, Toro Negro.

\section{Solanum rugosum Dunal}

R.nvge.-Hispaniola, Puerto Rico, Guadeloupe, Dominica, and Martinique. Also from Guatemala to Panama and from Colombia to Perru, Bolivia, Brazil, Guianas, and V'enezuela.

Otrier comion vasies.-tabacón áspero, sepí (Puerto Rico); tabacón (Dominican Republic); cncuna (Venezuela); caincúra (Brazil).

Botaxicas srxovra.-Solinum asperum Vahl, not L. C. Rich.

The large and widely distributed genus of nightshades (solumem) is represented in Puerto Rico and the Virgin Islands by about 15 native species of mostly spiny herbaceous weeds with some shrubs and vines. Also, tabacon and the 2 helow hecome small trees. The cultivated eggplant. (S. melongena. I.), potato (S. tuberosum L.), and a few other species planted for ormamental fruits belong to the same genus. The berries of some species are edible and of others poisonons.

Tabacion afelpado, wild tobacco, or mullein nightshade (Siolamum verbascifolium L.; S.erianthum D. Don), a spineless shrub and rarely a small tree, is found in l'nerto Rico, Míona, Muer. tos, Tieques, St. Croix, St. Thomas, St. John, and Tortola, also widespread in tropical America, and naturalized beyond to Florida. It has ovate to elliptic leares $4-12$ inches long, velvety hairy with minute star-shaped hairs, with petioles up to $21 / 2$ inches long and not winged; smaller white flowers about $1 / 2$ inch across; and round yellow berries $3 / s^{-3 / 4}$ inch in diameter.

Erubia (Solanum drymophilum O. E. Schultz), known only from mountain forests of Puerto Rico, is a spiny shrub or small tree with straight, yellow spines up to $3 / 8$ inch long; oblong to lanceshaped leaves 3-8 inches long with minute starshaped hairs denser beneath, with short petioles less than $3 / 8$ inch long; white flowers about $3 / 4$ inch across: and round black berries less than $1 / 4$ inch in diameter. 


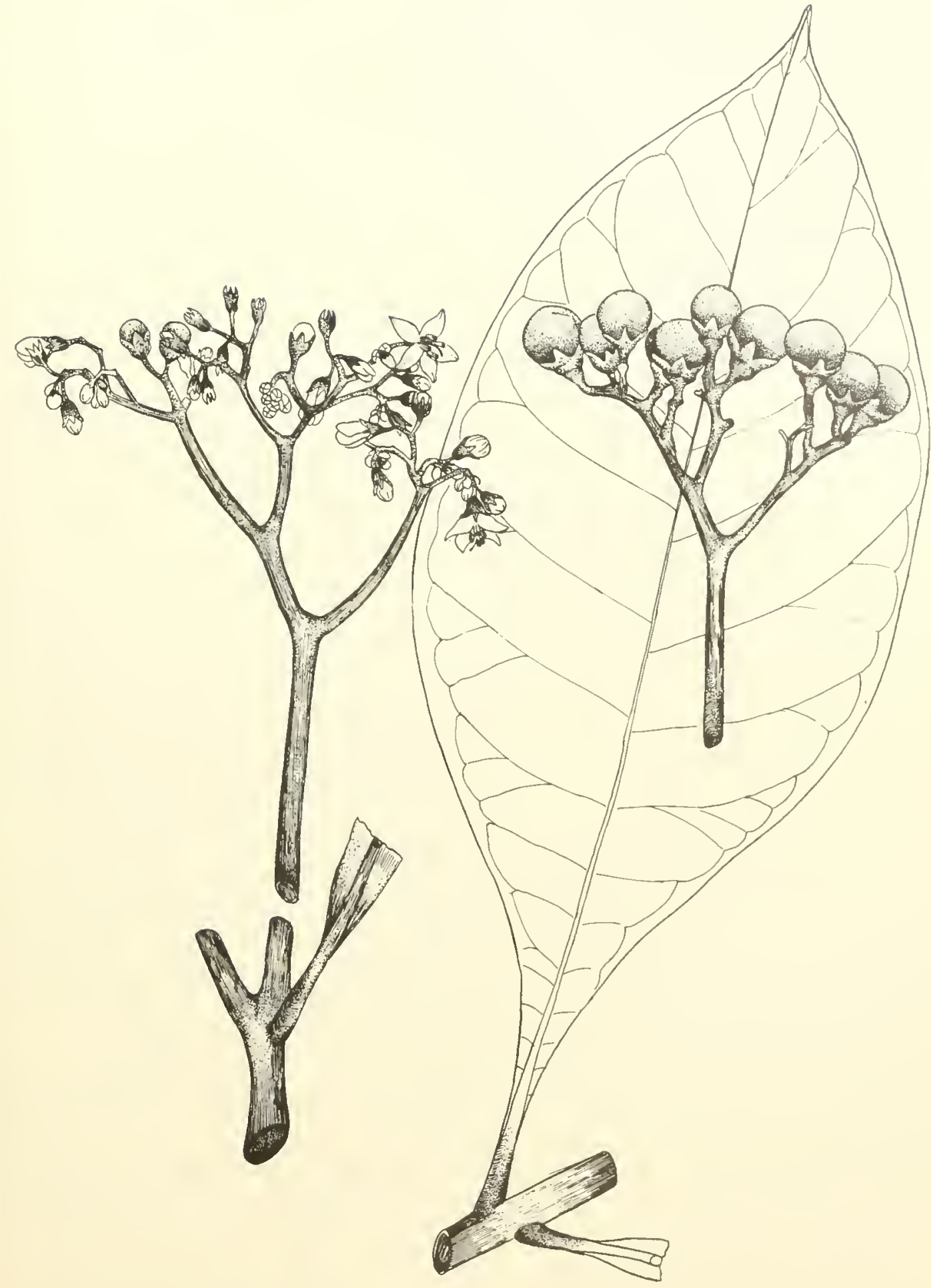




\section{BIGNONIA FAMILY (BIGNONIACEAE)}

Key to the 7 species illustrated (Nos. 232-238)

A. Leaves crowded in clusters of $3-5$ or more along the stout twigs, simple, spoon-shaped, 2-7 inches long, broadest near the roundel or short-pointed apex-"32. crescentia cujete.

A. Leaves opposite.

B. Leaves simple or digitate (palmatels compound) with 2-5 leaflets.

C. Elowers with dark red corolla.

D. Leaves witl 5 or 3 elliptic leaflets-23.. Tabebuia hacmantha.

DD. Leares simple, elliptic to ovate-237. Tabebuia rigina.

CC. Flowers with pink corolla : leaves with 5 or fewer (sometimes only 1) unequal elliptic leaflets-236. Tabebuia heterophylla.

BB. Leares pinnate or bipinnate.

E. Leares once pinnate.

F. Leaflets mostly 11-17, elliptic, not tootherl, abruptly slort-pointed-234. Spathodea campanulata.*

FF. Leaflets 5-13, lance-shaped to elliptic, saw-toothed, long-pointed-23s. Tecoma stans.

EE. Leares bipinnate, fernlike-233. Jacaranda mimosifolia.*

\section{Higüero, calabash-tree, common calabash-tree}

Crescentia cujete L.

This familiar small tree, planted and wild, is easily recognized by: (1) the few long spreading branches forming a broad open crown; (ㄹ) enlarged noles on the stout light brown or gray twigs: (3) the very large, hard, nearly romd (sometimes oval), irreen to brown fruits $1-12$ inches in diameter, resembling gourds: $(t)$ the spoon-shaped leaves $2-T$ inches long and $3 / 4-2$ jnches broad, arranged in clusters along the stout twigs: and (5) the light green bell-shaped flowers $2-21 / 2$ inches long, borne singly on the trunk and branches.

A tree $20-30$ feet or more in height and 1 foot or more in trunk diameter, evergreen or deciduous in areas with dry seasons. Bark on small trunks is smoothish or slightly scaly, becoming much fissured, light lnown or gray, and $1 / 2$ ineh thick. The imer bark is light brown, fibrous, and slightly bitter.

The leaves are mostly in clusters of $3-5$ or more (faseieled) on spurs (actually very short lateral branches) for several feet along the stout $t$ wigs but are also alternate near tips of slender twigs. Spoon-shaped (spatulate) or reverse lance-shaped (oblanceolate), the leares are broadest near the rounded apex (sometimes abruptly short-pointed) and gradually narrowed to the stalkless or shortstalked base, not toothed on edges, slightly thickened and with prominent midrib, green and slightly shiny on upper surface, paler beneath.

Flowers and fruits are unusual in being produced direetly on the trunk as well as on branches, borne singly on stout stalks $1 / 2-3 / 4$ inch long. The leathery gieen ealyx $5 / 8-1$ inch long splits deeply into usually 2 broad lobes; the large, light green, often purplish-streaked corolla is $2-21 / 2$ inches long, slightly thickened and fleshy, with a broad irregular swollen tube oddly folded on 1 side and with 5 short, wavy and irregularly toothed lobes $13 / 4$ inches across: the $t$ stamens are inserted in corolla tube in 2 pairs with large anthers visible; and the pistil on a disk has a 1-celled ovary, very slender style, and broad 2-lobed stigma. There is an unpleasant odor suggesting rotten cabbage.

The giant fruits (berries) have thin hard shells and whitish pulp and do not split open. The many seeds are dark brown, thin and flat, about $1 / 4$ inch long and hroad. Flowering and fruiting through the year.

The sapwood is pinkish to reddish brown, and the heartwood is light bromn. The wood is moderately hard, moderately heary (specific gravity 0.6$0.8)^{\circ}$, strong, and flexible. In Puerto Rico the timber is cut only for fuel. However, other uses are for tool handles, ox yokes, saddles, and vehicle parts.

Widely planted in Puerto Rico and througl the tropies for the fruits, from which bowls, cups, jugs, water containers, and other utensils, as well as ornaments and musical instruments, are fashioned, often with deenrations. Also classed as an ornamental. Elsewhere blocks of calabash bark and wood as well as the trees have been used fol growing orchids. The pulp of fruits is poisonous and has been employed in local medicines. It is said that the seeds are sometimes cooked and eaten.

Easily propagated from seeds or cuttings but slow growing. Through eultivation trees with larger fruits than the wild trees have been developed. It is reported that various shapes ean be obtained by tying and training the growing fruits.

Hillsides, pastures, roadsides, and around comntry homes in the coastal, limestone, and lower mountain regions of Puerto Rico, more eommonly in the drier areas. Probably more frequent as a planterl tree or an eseape than wild. Also Mona, Deseeheo, St. Croix, St. Thomas, St. John, and Tortola.

R.swa.-Widely distributed in tropical Ameriea, native, planted and escaping, propably spread somewhat through cultivation. Florida Keys, grown also in southern Florida and California, and introduced in Bermuda. 'Throughout West Indies from Bahamas and Cuba to Trinidad and Duteh West Indies. Also from southern Mexico to Peru and Brazil. Cultivated in the Old World tropies.

OTher comson vanes.-giiira, higiero (Dominjean Republic); giiira, calabasa (Cuba); cujete, cirián, tecomate, guaje (Mexico); jícaro, jicara (Central Ameriea): morro (Guatemala, Honduras); guacal (El Salvador); calabacero 

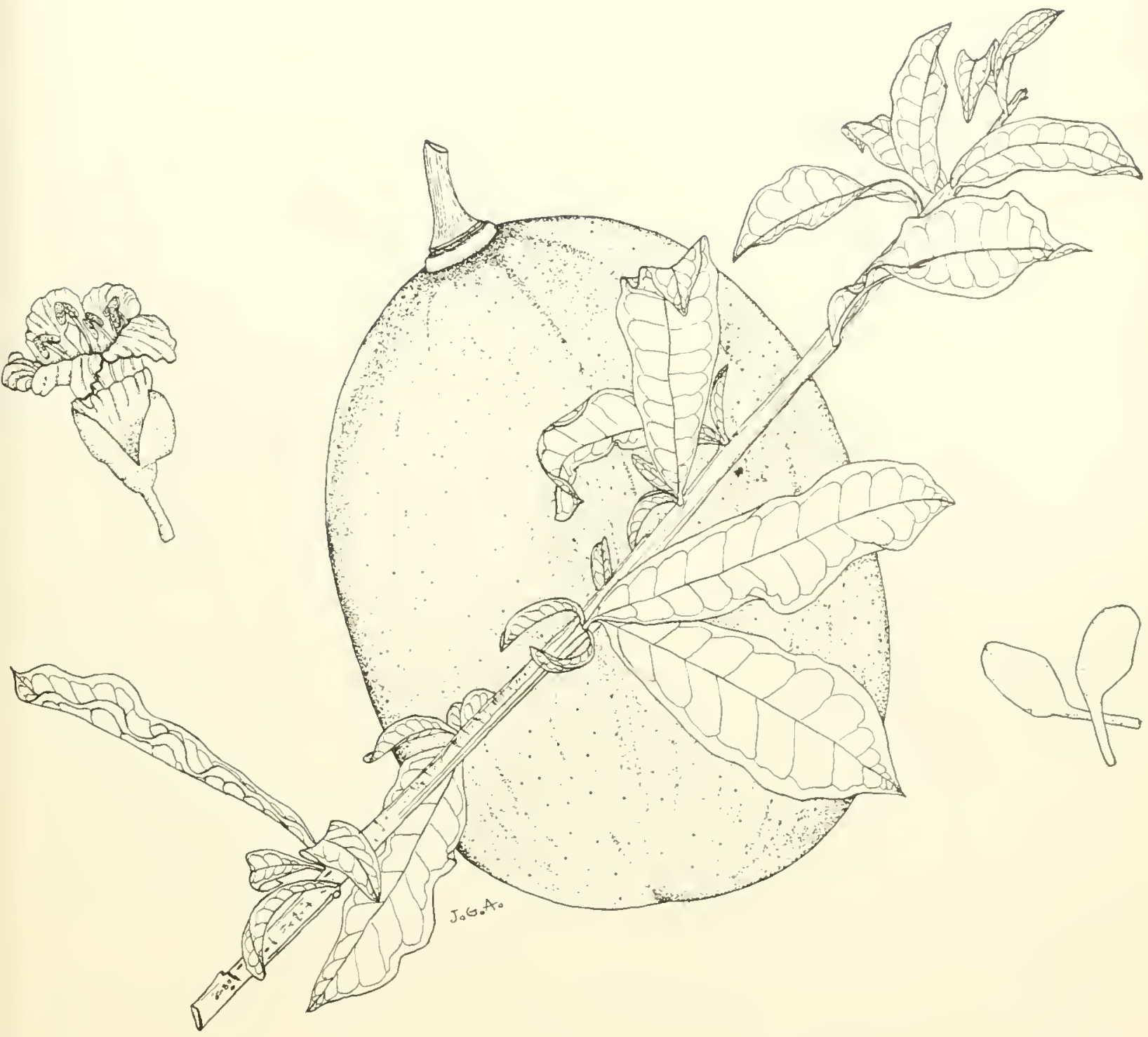
(Costa Rica) ; totumo, totumbo, calabazo (Panama, Colombia); totumo, taparo, camasa, giiire, cucharo (Tenezuela): mate, pilche (Ecuaclor): huingo, pati, cayiera, tutumo (Peru); common calabish-tree, calibash-tree, calabash (Trited States, English) ; calebasse, calebassier (French); callús, callás rondo (Dutch TTest Indies); kalebas, kalabassenboom (Surinam); cuité (Brazil).

Higüerito (Crescentia linearifolia Miers) is a related small tree of dry coastal areas mainly in southwestel'n Puerto Rico, St. Thomas, and St. John, and in St. Martin. It has nalrow, linear, shiny, stiff leaves $3 / 4-21 / 4$ inches long and less than 3 , inch wide, long-pointed and often spiny-tipped, clowled; greenish tubular flowers abont $11 / 2$ inches long: and ronnd or elliptic fruit $11,2-2$ inches long. The third native species is a vinelike shrub of western Puerto Rico.

\section{BIGNONIA FAMILY (BIGNONIACEAE)}

\section{Jacaranda}

This handsome introduced tree is occasionally planted for its large clusters of numerous beatiful blue-riolet hell-shaped flowers $11 / 4-13 / 4$ inches long and irregularly 5 -lobed, borne in spring. The attractive dark green fernlike leaves are opposite and twice pimate (bipimnate), about 9-18 inches long and 5-8 inches broad, with many small lanceshaped leaflets $3 / 8^{-1 / 2}$ inch long and bristle-tipped. Pods are dark brown, nearly rombl and flattened, about 2 inches long and $5 / 8$ inch thick, bordered by a narrow wing.

A deciduons medium-sized tree $25-40$ feet high and 8-12 inches in trunk diameter, with spreading crown of thin, delicate foliage. The bark is smonthish but becoming slightly fissured and rough, very light brown. Tmner bark is light brown, thin, and bitter. The stout $t$ wigs with light corky dots (lenticels) are green when young, turning light gray.

Leaves consist of a yellow-green axis and about 20-40 paired lateral axes (pinnae), each with about $19-45$ stalkless leaflets, also paired except for the larger end one. Leaflets are short-pointed at apex and oblique at base, not toothed on edges, dull dark green on upper surface and pale light green beneath.

The terminal, much branched flower clusters (panicles) are about 8-12 inches long and 6-8 inches across, with slender, forking branches. The spreading flowers have short stalks or none and are only faintly fragrant. Calyx is small, cuplike, greenish, $1 / 8$ inch long, and 5-toothed; the tubular blue-riolet corolla is swollen on 1 side and abruptly narrowed near base, about $11 / 4-13 / 4$ inches

\section{Jacaranda mimosifolia D. Don*}

long, with 5 unequal spreading wavy-margined lobes $3 / 4-1$ inch across, minutely hairy on outside and on lobes; 4 whitish cnrved stamens about $1 / 2$ inch long in 2 pairs of different. lengths and 1 longer sterile stamen inserted within corolla tube; and on a greenish disk the purplish pistil $7 / 8$ inch long, composed of 2-celled ovary, slender style, and 2-lobed stigma. One corolla lobe is much longer than the others and opposite a white spot inside the tube.

One or 2 pods (capsules) develop from a flower cluster. They split open along the edges and contain many very thin dark brown seeds, each about $3 / 4$ by $5 / 16$ incli in size, including the 2 transparent wings. Flowering from early spring to June, the fruits maturing in spring and early summer.

The sapwood is light brown and soft. The wood is not used locally.

This species is planted for ornament in Puerto Rico and St. Croix but is not common. Propagated by cuttings and seeds. It is a honey plant. Then the trees are not in flower, the foliage is also attractive.

Range.-Native of northwestem Argentina. Planted in West Indies, southem Florida and southern California, and from Mexico to Brazil.

Other Common NAMEs.-flamboyán aznl (Puerto Rico); fern-tree (Virgin Islands); jacaranda (Spanish); framboyán azul (Cuba); tarco (Bolivia): jacarandá, tarco (Argentina); jacaranda (United States, English); flamboyant bleu (Martinique).

BotaNICAL SYNoNYr.-Jacaranda acutifolia auth., not Humb. \& Bonpl. 


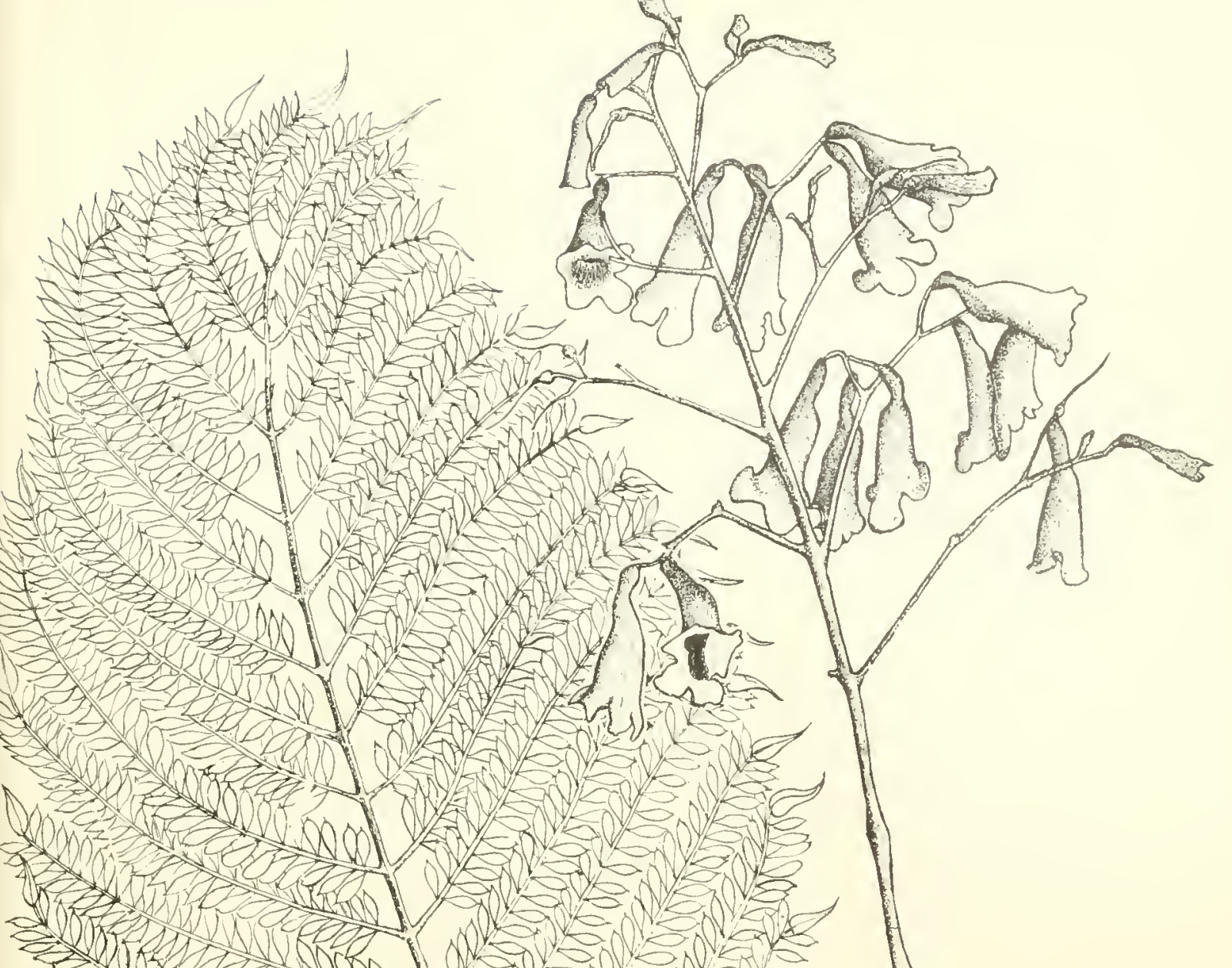
Q
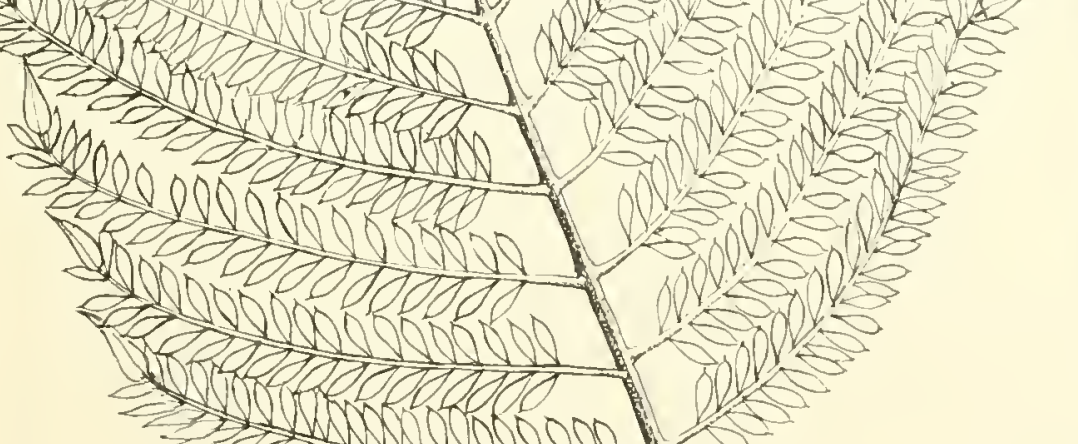


\section{BIGNONIA FAMILY (BIGNONIACEAE)}

\section{Tulipán africano, African tuliptree}

This handsome ornamental tree is planted for its masses of large brilliant orange-red to scarlet flowers. It is easily recognized by: (1) the tuliplike tubular flame-colored flowers 4 inches Jong and 3 inches across, in erect clusters mostly at the top of the crown; (2) the large erect green to dark brown pods 5-10 inches long, 11/2 inches wide, and $z$ inch thick, which point upward at the ends of the branches: and (3) the opposite large pinnate leaves 1-2 feet long with usually 11-17 (sometimes 5-19) opposite elliptic leaflets.

A large exotic tree becoming 50-80 feet high and 1-11/2 feet in trunk diameter, with a dense irregular crown of large spreading branches, evergreen or nearly deciduons. Big trunks develop tall narrow buttresses at base and are slightly broadened and grooved. The bark is very light brown, smoothish but becoming slightly fissured. Inner bark is about $1 / \mathrm{m}$ inch thick. whitish, and bitter. The stont grayish-brown $\mathrm{t}$ wigs are smooth except for corky warts (lenticels).

The large leares are opposite or sometimes in $3{ }^{`} \mathrm{~s}$, and the leaflets also opposite except for the end one. These leaflets are $3-6$ inches long and 11/23 inches broad, on short stalks 1/8 inch long, abruptly short-pointed, rounded and slightly oblique at base, a little thickened with edges a little turned under, almost hairless, the upper surface green to dark green with sunken veins and slightly shiny, the lower surface paler.

The terminal flower clusters (racemes) are about 4 inches high and 8 inches across. There are numerous crowded horn-shaped flower buds 1-2 inches long on stout greenish stalks of the same length, orange brown, curving inward to the center. Those around the outside open a few at a time and drop off about 2 days later. The flowers have a most unusual flattened shape, with light brown calyx 2-21/2 inches long, curved and pointed like a horn, splitting open on the onter side, minutely hairy and with longitudinal ridges. The tubular orange-red to scarlet corolla about 4 inches long and 2 by 3 inches broad has an enlarged irregular bell-shaped tube 2 inches across and curved downward and 5 broad unequal lobes with crisp wavy edges narrowly bordered with gold. There are 4 pale yellow stamens $2-21 / 2$ inches long, with dark brown anthers, inserted in corolla tube in 2
Spathodea campanulata Beauv.*

pairs and projecting barely beyond. The pistil on a disk consists of an oblong 2 -celled ovary $1 / 4$ inch long, a long. slender, curved, pale yellow style about 3 inches long, and a 2-lobed red stigma.

There are 1 to sevelal large lance-shaped or boat-shaped, slightly flattened pods (capsules) on stont stalks, long-pointed, splitting open on 1 side. The numerons very thin papery seeds, about 57,000 to a pound, have a light brown center bordered by a transparent wing $1 / 2-1$ inch across. Flowering and fruiting throughout the year but particularly from late winter to early summer.

The soft wood with whitish sapwood is not utilized in Pnerto Rico.

This ormamental and shade tree is propagated by seeds, cuttings, and root cuttings. It grows very rapidly bnt requires nearly full light. Measured trees in Prerto Rico increased in trunk diameter as much as 2 inches a year. As trees are broken by high winds and frequently become hollow and hazardous in age, planting near buildings or along roads is not advised. Also, the superficial root system makes this species undesirable for planting near houses and sidewalks. The trees produce sprouts from the roots, sometimes becoming like weeds. This species has been tried for coffee shade but is not recommended for that purpose.

Unopened flower buds contain water, ill smelling and tasting, which squirts out when the buds are squeezed, pinched, or pricked with a pin. Children play with these buds like water pistols. Old dry empty pods when widely open make very realistic toy boats, which, however, close up in water.

Cultivated for ornament and shade in Puerto Rico, growing in the coastal, limestone, and lower mountain regions. Also planted in St. Croix, St. Thomas, and Tortola.

Ravoe.-Native of tropical West Africa. Widely planted in tropical regions around the wolld. Southern Florida, West Indies, Central America, and South America.

Other coniron Names.-mampolo, amapola (Dominican Republic); espatodea (Cuba); tulipán africano (Colombia, Venezuela); African tuliptree (United States); African tuliptree, fountain-tree (English); immortel étranger (Haiti); tulpenboom (Dutch West Indies). 


\section{BIGNONIA FAMILY (BIGNONIACEAE)}

\section{Roble cimarrón}

This handsome small tree native only of Puerto Rico is characterized by: (1) opposite, digitate or palmately compound leaves with 5 or 3 elliptic stifl' and leathery leaflets and stout petioles; (2) showy, dark red or crimson flowers $11 / 4-2$ inches long, narrowly tubular and irregularly 5-lobed, several to many in erect terminal chinsters; and (3) narrow grooved seed pod $21 / 2-1$ inches long and less than $1 / 2$ inch in diameter.

[sually a smal] tree $10-20$ feet tall or often flowering as a shrub, evergreen. The gray bark is smoothish and slightly fissured, the mner bark whitish and slightly bitter. The light gray twigs are slightly flattened below nodes.

The leaves have petioles $1-2$ inches long and leaflet stalks $1 / 8^{-1}$ inch long. Leaflet blades are -2-6 inches long and $1 / 2-11 / 2$ inches broad, when 5 the lowest 2 much smaller than the others and netrly stalkless, the apex short-pointed or rounded and base rounded or slightly heart-shaped, with edges turned under slightly, hairless or minutely scaly hairy, the upper surface green and slightly shiny, and lower surface paler.

Flower clusters (panicles) have several to many flowers on slender spreading branches $3-6$ inches long and broad. The tubular dark red calyx $3 / 8-$ $5 / 8$ inch long has 2 or more short and unequal
Tabebuia haemantha (Bert.) DC.

rounded lobes at apex; the dark red or crimson corolla is $11 / 2-2$ inches long with long narrow tube and $5 / 8$ inch or more across the 5 short irregular lobes; there are 4 stamens in 2 pairs inserted near base of corolla with the long slender filaments projecting beyond; and pistil on a disk with conical 2-celled orary, slender style as long as corolla, and stigma with 2 flattened lobes.

The seed pod (capsule) retains the calyx at base and bears many 2 -winged seeds $3 / 4$ inch long. Probably flowering and fruiting nearly through the year:

The light brown, hard rood is little used becanse of the small size of the tree.

Perhaps of ornamental ralue for the showy flowers, from which the specific name, meaning blood flower, was derived. N. L. Britton called this one of the most elegant of the endemic species of Puerto Rico.

In dry forests and thickets in the southern foothills rising into the lower mountain region on the sonth slopes of the west end of the Central Cordillera of Puerto Rico.

Perlic forests.-Maricao, Susúa.

Rasge.-Known only from Puerto Rico.

OTHer CoMmon Nime.-roble colorado (Puerto Rico). 


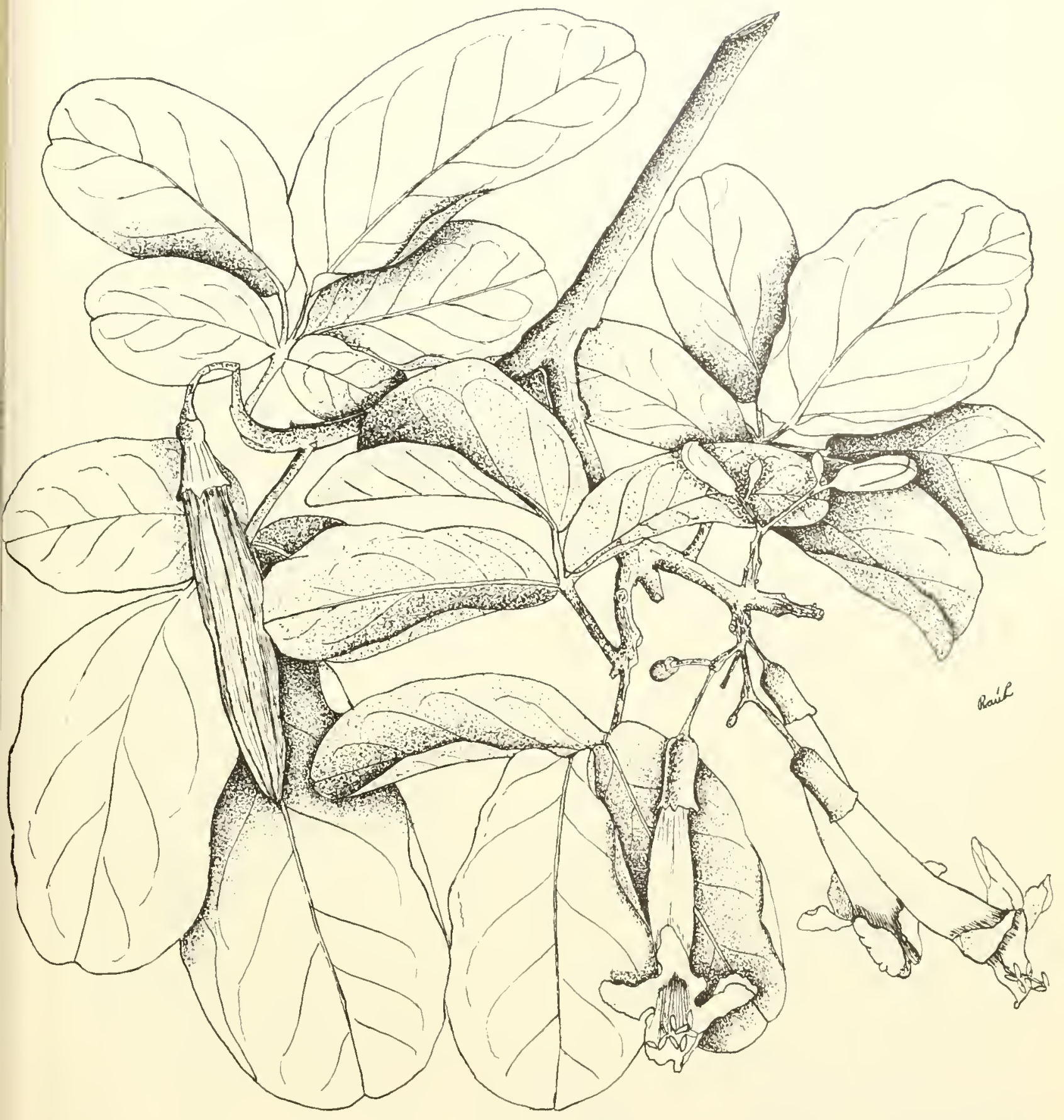

235. Roble cimarrón 


\section{BIGNONIA FAMILY (BIGNONIACEAE)}

236. Roble blanco, "white-cedar"

This valualle timber tree is distinguished by: (1) beatiful masses of showy pink tubular 5lobed flowers $2-31 / 2$ inches long, covering the tree in spring and making it stand out as an attractive feature of the landscape: (2) opposite palmate leares with $5 \mathrm{or}^{\text {fewer }}$ (sometimes only 1 ) unequal elliptic or oblanceolate leaflets: and (3) dark hrown cigarlike pods $3-8$ inches long and $1 / 4$ inch in riameter.

Roble blanco is a small to medinm-sized, mostly deciduous tree attaining 60 feet in height and $11 \%$ feet in diameter, with an erect axis and narrow columnal erown. The bark is rough and furrowed, grily to brown, about $1 / 4^{-3} / \mathrm{s}$ inch thick. Inner bark is light brown and slightly bitter. Twigs are green, tuming to brown, covered with tiny brown dotlike scales, with large nearly round leaf scars.

The leares typically are 6-12 inches long, including the petioles $2-5$ inches long and leatlets with slender stalks about $1 / 2-1$ inch long and blades $2-6$ inches long and 1-21/2 inches wide. However, in dry areas the leaves are smaller, only $11,6-5$ inches long, including the petioles $1 / 4-11 / 4$ inches long and the short-stalked or stalkless leaflets only $3 / 4-3$ inches long and as few as 1 . Leaflets are mostly broadest beyond middle and commonly bluntpointed at apex and base, the edres withont teeth and sometimes slightly turned under, slightly thickened, bairless except for tiny brown dotlike scales, green and slightly shiny on upper surface and paler beneath.

The large flowers are abundant over the crown, few to several together in terminal and lateral clusters (corymbs or panicles) or somet imes single on slender stalks $1 / 4^{-1}$ inch long. Calyx tubular, $3 / 8^{-1 / 2}$ inch long, 3-5-toothed, covered with dotlike scales; the tubular corolla funnel-shaped, 2-31/2 inches long with 5 slichtly mequal broad lobes $13 / 4-3$ inches across, deep pink or sometimes varying from whit ish to purplish : stamens $t$, in 2 pairs of different lengths inserted on the corolla ; and pistil on a disk, with 2 -celled orary, slender style, and 2-lobed stigma.

The pod (capsule) splits along 2 lines to shed the numerous thin light brown seeds $1 / 2^{-1}$ inch long with 2 white wings. The fresh seeds average about 21,000 to the pound. Flowering mainly in early spring but also sporadically through the year, and with mature fruits orer the year.

The heartwood is light brown with grayish or golden hue and fine brown lines, not easily separated from the similar sapwood. The rood is moderately hard, moderately heary (specific gravity 0.58), tough, strong, with medium to coarse texture, with straight to interlocked grain, and growth rings. The rate of air-seasoning is rapid, and amount of degrade is moderate. Machining claracteristics are as follows: planing and resist-
Tabebuia heterophylla (DC.) Britton

ance to screw splitting are fair; shaping, boring, mortising, and sanding are excellent ; and turning is grood. The wood takes a high polish. It is moderately durable in contact with the ground but very susceptible to attack by dry-wood termites.

The wood is important in Puerto Rico, classed as ronstruction timber, although now cut chiefly for posts and poles. Other uses mostly elsewhere are furniture, cabinetwork, interior trim, face veneer, flooring, paneling, boatbuilding, and ox yokes.

Extensively planted on the more humid public forest lands because of it a adaptability to soils degraded by farming. The abundant small trees found in many areas may in good weather be pulled up and successfully reestablished by planting elsewhere. Classed also as a honey plant.

Becanse of the numerous large pink flowers which cover the tree, often when nearly leafless, and which form a carpet on the ground upon falling, the trees are poprular for ornament and shade. Infortunately, some trees in Puerto Rico have been deformed by a witches"-broom disease. Also, in long dry periods, leafhoppers feed on these trees, defoliating them or causing the leares to turn yellow. Consequently, some authorities have sugrested that planting of this species for ornament be discontinned and have recommended the substitution of immune introduced species of the same genus.

Widespread in forests, abandoned pastures, secondary forests, forest plantations, and along roadsides and city streets throughont Pnerto Rico, with the exception of the upper. Luquillo and upper Cordillera forest regions. Also in Mona, Caja de Muertos, Culebra, Vieques, St. Croix, St. Thomas, St. John, Tortola, Virgin Gorda, and Anegada.

Ptblic foresrs.-A Anirre, Cambalache, Carite, Guajataca, Guánica, Guilarte, Luquillo, Maricao, Río Ibajo, Susúa, Toro Negro, Vega.

MINICIPALITIES WHERE ESPECIALLY COMMON.$13,17,20,24,26,28,29,31,32,47,50,53,58,59$, 68,74 .

Raxae.-Hispaniola, Puerto Rico and Virgin Islands, and throughout Lesser Antilles to Grenada and Barbados. Also naturalized in Bermuda and planted in sonthern Florida.

OTHer commos names.- roble, roble de yugo, roble prieto, prieto, roble de costa (Puerto Rico); pink manjack, pink-cedar, tooshe-flower (Virgin Islands); roble blanco (Spanish): roble (commerce); pink trumpet-tree (United States); white-cedar (Bermuda, St. Kitts to Gremada); poirier (St. Lucia); whitewood (Barbados); poiriel gris, poirier ronge, poirier blanc (Guadeloupe, French).

Botanical synonyas.-Tabebuia pentaphylla auth., not (L.) Hemsl., T. pallida (Lindl.) Miers, T. pallida subsp. heterophylla (DC.) Stehlé, $T$. 


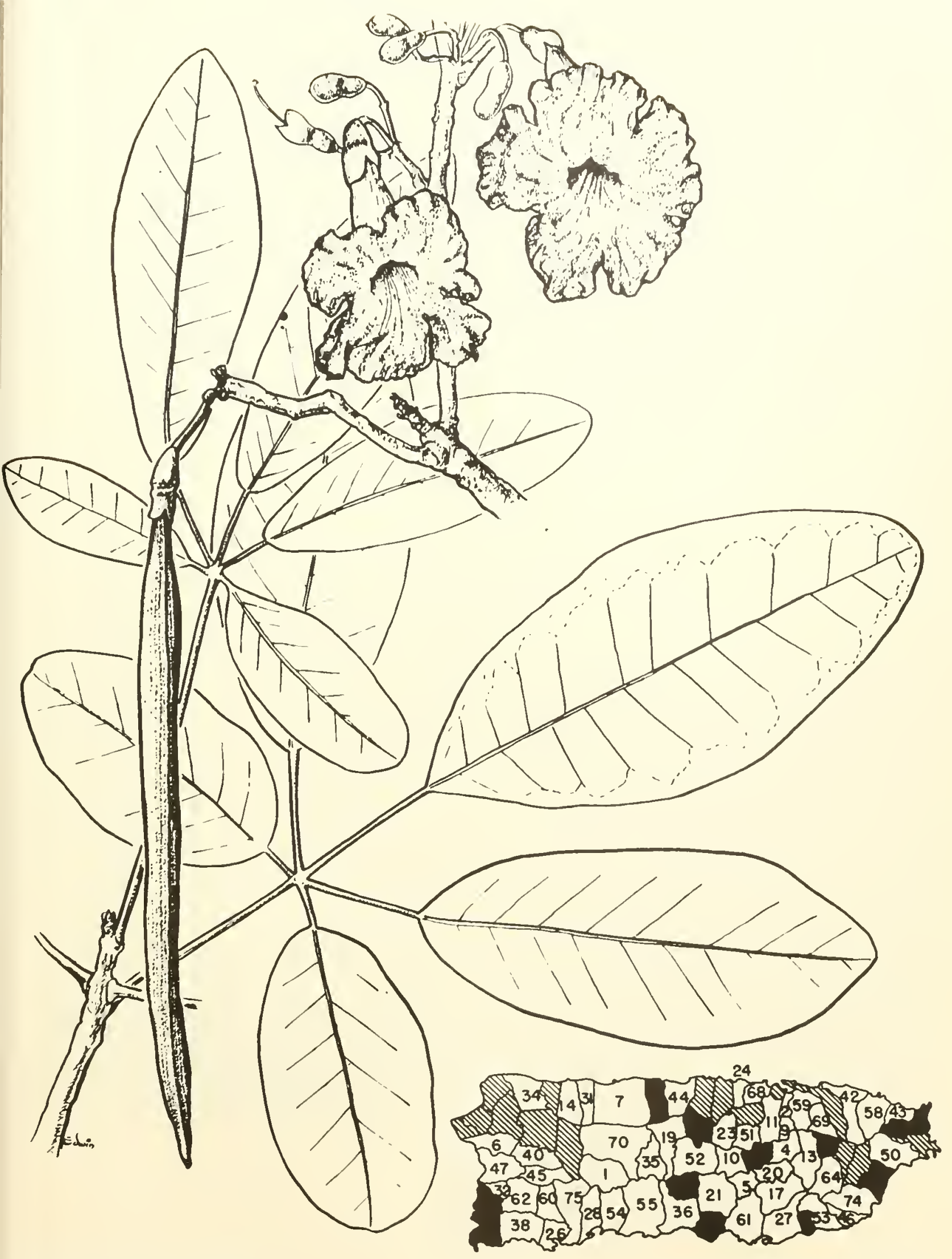

236. Roble blanco, "white-cedar" 
heterophylla subsp. pallida (Miers) Stehlé, $T$. dominicensis Urban, $T$. pallida subsp. dominirencis (Urban) Stehlé, T. Iucidla Britton.

The Spanish name roble blanco, meaning white oak, refers to the superficial resemblance of the wood to oak. The local English name "whitecedar" in the Virain Islands and Lesser Antilles is misleading, because the wood does not resemble that of the unrelated cedars. White tabebuia would be a more appropriate name.

This is a variable species whose variations have been distinguished as species or subspecies by some anthors, as the above synonymy indicates. The typical variation common throngh Puerto Rico except in the drier parts has leaves with 5 large leaflets. In dry areas and on coastal thickets in the Lesser Antilles the shorter trees, known as roble prieto, have smaller leaves with reduced leaflets as few as 1, fewer and mostly smaller flowers, shorter pods, and smaller seeds. A third variation present in Guadeloupe, Dominica, and Martinique is a lajge tree whose leaves generally have only 1 large broadly elliptic thicker blade or leaflet.

Some authors have united this West Indian species with another species ranging from Mexico through Central America to Colonbia and Venezuela and formerly known as Tabebuia pentaphylla, a name now rejected. The mainland species (T. rosea (Bertol.) DC.), called apamate in Venezuela and pink poui in Trinidad, is a larger tree readily distinguished by the 5 larger, longpointed, thinner, ovate leaflets.

\section{BIGNONIA FAMILY (BIGNONIACEAE)}

\section{Roble de sierra}

A small to medium-sized tree confined to the eastern mountains of Puetro Rico, distinguished by: (1) opposite, elliptic to ovate, stiff and leathery simple leaves $2-6$ inches long and $11 / 4-21 / 4$ inches wide, with edges curved under; (2) pink to dark red tubular 5 -lobed flowers $11 / 2-2$ inches long, 1 or few in terminal clusters; (3) dark brown, cigarlike pods 5-61/2 inches long and $3 / 8$ inch in diameter; and (4) 4-angled twigs.

Evergreen tree commonly 25-30 feet tall and 8 inches in trunk diameter, sometimes larger or shrubby. Crown open and spreading. The smootli, light brown bark is usually corered with mosses and similar small plants. Inner bark is whitish and bitter. Twigs becoming gray, with tiny brown dotlike scales.

Petioles are $3 / 8^{-1}$ inch long. Blades are shortpointed or rounded at apex and base, with tiny brown dotlike scales, green on upper surface and paler beneath.

Flowers have slender stalks 1-11/2 inches long. There is a tubular calyx $3 / 8^{-1 / 2}$ inch long, covered with dotlike scales; the tubulas corolla $11 \frac{1}{2}-2$

\section{Tabebuia rigida Urban}

inches long has 5 spreading lobes 1 inch across and is pink, turning to dark red; stamens 4 in 2 pairs of different lengths, inserted near base of corolla; and pistil on disk composed of 2-celled orary, slender style, and 2-lobed stigma.

The pod (capsule) splitting length wise releases numerous thin light brown seeds 1-11/4 inches long with 2 white wings. In flower and fruit nearly through the year:

The sapwood is hard and brown. Because of the small size and poor form of the trees, the wood is little used.

Upper mountain forest, including dwarf forest, in the Luquillo Mountains of Puerto Rico.

Public Forest.-Luquillo.

RAxGe.-Known only from eastern Puerto Rico.

Roble colorado (Tabebuia schumanniana Urban), known only from mountain forests of westem Puerto Rico, is a related species also with simple leares and red flowers. It differs in the leaves broadest toward apex (obovate or oblanceolate), $3-61 / 2$ inches long, and the usually longer flower stalks 1-2 inches long. 

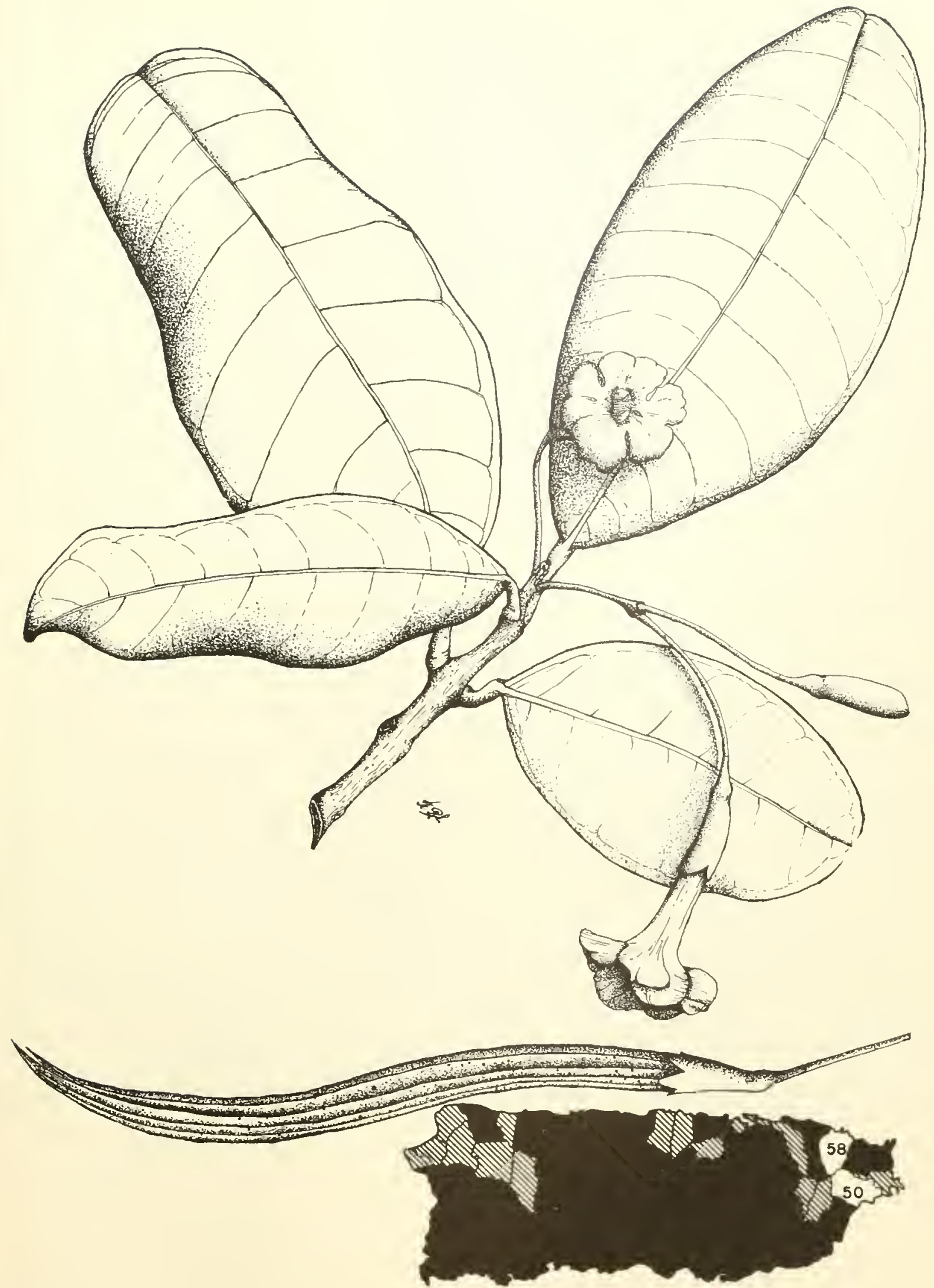


\section{BIGNONIA FAMILY (BIGNONIACEAE)}

\section{Roble amarillo, ginger-thomas}

The official flower of the United States Virgin Islands, this ornamental shrub or small tree is characterized by: (1) many large, showy, tubular, bell-shaped, :-lobed, yellow flower's $11 \% 2-2$ inches long; (2) large, narrow, dark brown, cigarlike porls $4-8$ inches long and $3 / 16$ inch in cliameter; and (3) opposite pinnate leaves 4-10 inches long with 5-13 lance-shaped to ellipt ic saw-toothed leaflets.

Having a great geographical range, this species is somewhat variable in shape of leaflets and other characters and has been divided into varieties. It is evergreen, 10-25 feet high, and to 3 inches or more in trunk diameter. The light gray bark is rough and much furrowed. Inner bark is brown, fibrous, and bjtter. Xomng twigs are green, turning brown.

The short-stalked or stalkless leaflets are $11 / 2-$ 4 inches long and 1/2-11/2 inches broad, longpointed at apex and short-pointed at base, thin, usually hairless, and green on both surfaces.

Several flowers are borne on short stalks in a terminal cluster (raceme). The calyx is $1 / 4 \mathrm{inch}$ long, tubular and 5 -t oothed; the bright vellow funnel-shaped or trumpet-shaped corolla $11 / 2-2$ inches long and $1 \frac{1}{4}$ inches across the 2 spreading lobes; stamens 4 , in 2 pairs of different lengths, inserted on the corolla: and on a disk the pistil with 2 -celled orary, long slender style, and 2 -lobed stigma.

The pod (capsule) splits open lengthwise to release many very thin light brown seeds, which are nearly 1 inch long inchuling the 2 whitish papery wings. Flowering and fruiting nearly throughout the year.

The sapwood is light brown and hard. The wood is seldom available in size large enough for use in Puerto Rico and the Virgin Islands but elsewhere has been employed in cabinetmaking, wood turning, and construction.
Tecoma stans (L.) H. B. K.

The principal local use is as an ornamental for the showy flowers, such as along roadsides and fences. The slightly fragrant flowers are a somree of honey. Flower buds will pop when squeezed. Bark, leares, and roots have been employed in home medicines.

Planted and on open hillsicles in the southern foothills of Puerto Rico. Also in Vieques, St. Croix, St. Thomas, St. John, and Tortola.

R.sxre.-Widely distributed in tropical America, including rarieties, and perhaps spread and naturalized from cultivation. Throughont West Indies from Bahamas and Cuba to Trinidad, and cultivated in Dutch West Indies. Also Florida (perhaps naturalized) and from southern Texas, sonthern New Mexico, and southern Arizona sonth throngh Mexico and Central America to Bolivia, northern Argentina, and Brazil.

OTher commox xumes.-sá́co amarillo, mibarba (Pnerto Rico): yellow-elder, yellow-cedar (Tirgin Islands) : saúco amarillo (Dominican Republic, Cuba) ; retama, tronadora, gloria (Mexico) : San Andrés, tagualaiste, marchucha, tasto, tache (El Salvador): sardinillo, San Andrés (Honduras); sardinillo, chilca, flor amarilla (Nicaragua); candelillo, carboncillo (Costa Rica) : copete (Panama) ; fresno americano, roble amarillo, chirlobirlos (Colombia); fresnillo (Teneznela) : cholán, fresno (Ecuador); huaranhua (Peru); toco-toco (Bolivia); guaranguay amarillo, guarán amarillo, guaranguay blanco, gnaranguarín (Argentina); yellow-trumpet, Florida yellow-trumpet, yellow trumpet-flower, yellow-elder (United States) ; coribee (Antigua); bois caraibe (Grenada) : Christmas-hope (Trinidad); cheralier (Haiti); bois fleurs jaunes (Guadeloupe, St. Lucia); kelki heel, yellowblossom (Dutch VTest Indies).

Botanical syxoxyas.-Stenolobium stans (L.) Seem., S. incisum Rose \& Standl., Tecoma tronodora (Loes.) Johnst. 


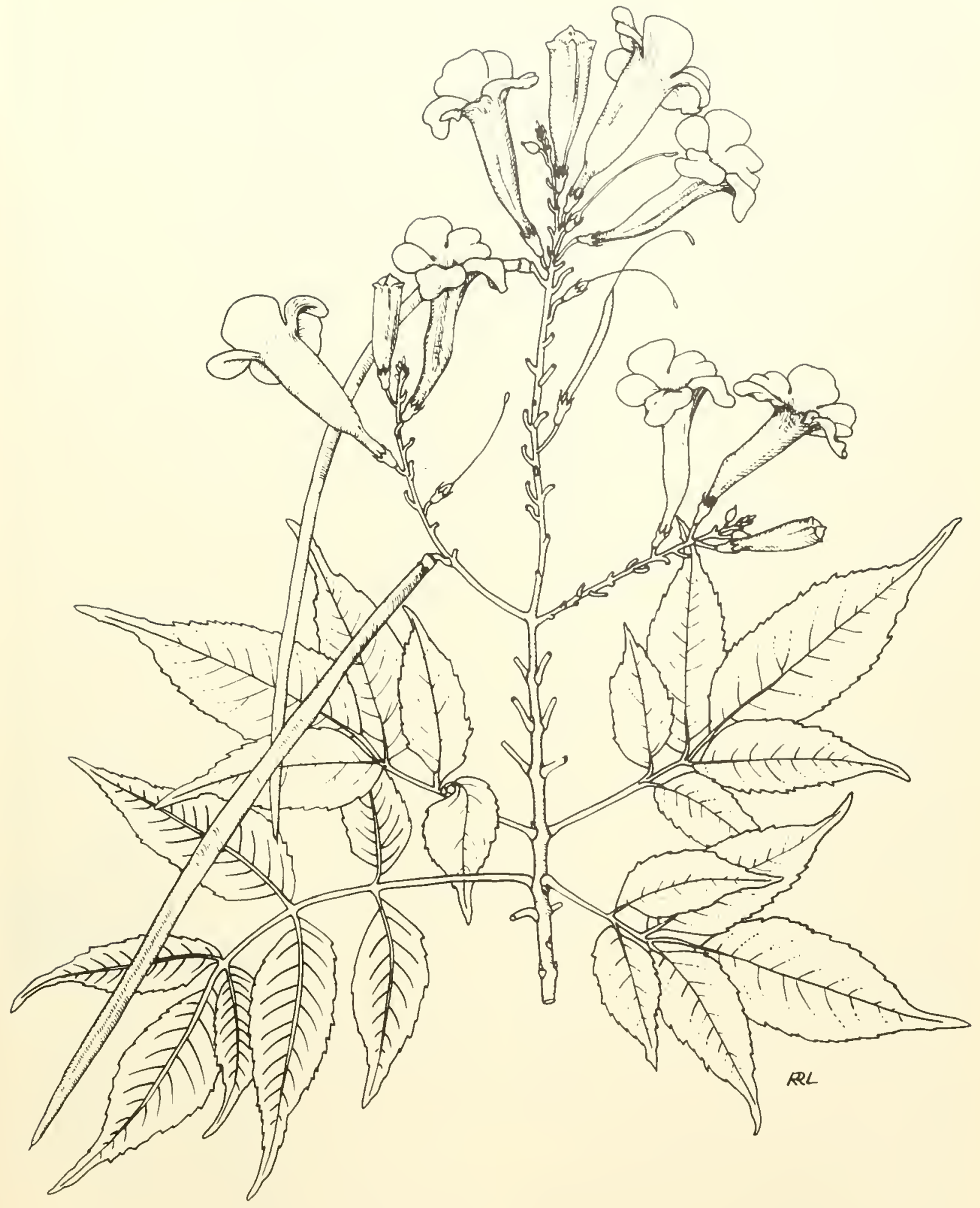




\section{MADDER FAMILY (RUBIACEAE)}

Kes to the 11 species illustrated (Nos. 239-249)

1. Twigs sping or with persistent bristlelike stipules: leaves small, mostls less than 2 inches long.

P. Twigs with paired gray slines: fowers 12 inch long, the white corrlia tubnlar, 5-lobed-247. Randia aculeata.

13B. Twigs witl narrow, bistlelike stipules furming rings back of leaves; flowers about 2 inches long, the corolla

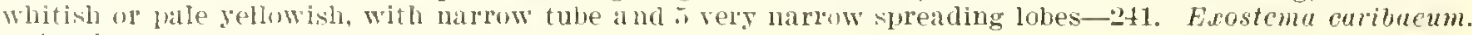
A. Twigs not spins.

C. Hlowers and fruits many, clusterel at nodes, short-stalked.

D. Flowers more than 1 inch across the 5 spreading white corolla lobes; fruits elliptic red berries (coffee lean - - -40. Coffea urubica.*

DD. Flowers th inch long, the corolla with very narrow reddish or pink tube and 4 or 5 short white lobes; fruits rounded red or pint berries-245. Ixora ferrea.

CC. Flowers and fruits variously arranged. not clustered at uodes.

E. Flowers few at the end of long, mostly slender stalks.

G. Flowers small, about $3 / 8$ inch long, several erect aloug borizontal forks, the corolla tubular, white.

H. Twigs, buds, and young leaves sticky or resinous; leares uarrowly elliptic, shiny green-249. Terebraria resinosu.

IIH. Twigs and other jarts hairless, not resinous; leaves ovate, rounded to beart-shaped at base, dull green-239. Antirhea obtusifolia.

GG. Flowers larger, nore than $5 / 8$ inch long.

f. Corolla with broad tube and 5 broad loles, pale yellow: fruit elliplic, yellow brown, about 4 inches long-243. Genipa americana.

II. Corolla narrowly tubular.

J. Flowers on slencler stalks, the white corolla will 4 narrow, widely spreading lobes; leaves hairless. turning blarkish upon drring-242. Faramea necidentalis.

JJ. Flowers stalkless, hairs. the white to brown corolla with 6-8 rounded lobes; leares very rough lairy on upper sirface-244. Gurttarda scabra.

EE. Flowers mans, about 16 inch long, the corolla tulular, white.

K. Flowers crowded in a short-stalked lall-like cluster (head); fruit elliptic, $3-4$ inches long, from many flowers, malolorous-24t. Morinda citrifolia.*

KK. Flowers in regularly spreading, branched clusters (panicles)-248. Rondeletia portoricensis.

\section{Quina}

Shruth or tree found only in mountain forests of eastern l'uerto Rico, characterized by: (1) opposite orate or elliptic dark green leaves, almost stalkless, rounded to heart-shaped at base and blunt-pointed at apex; (2) inner bark reddish; (3) many white, nawow, tubular, 4-lobed flowers about $3 \%$ inch long, elect and stalkless on upper side of nearly horizontal "urved paired forks of lateral branches: and (4) black, narrowly elliptic fruit $1 / 2-5 / 8$ inch long.

Evergreen shrub or tree 8-40 feet high and to 8 inches in trunk diameter. The gray bark is smoothish, the immer bark bitter. Twigs gray, slightly stout, ending in a pointed bud $3 / 16$ inch long, formed by a pair of srales (stipules) which soon shed and leave a faint ringed scar at each node.

Petioles are 1/8 inch long, and blades $2-6$ inches long and 1-31/4 inches wide, dull dark green above and green beneath.

Flower clusters (cymes) are 3-6 inches long and broad, the slender axis branching into 2 or more pairs of forks. The flowers have a tubular base (hypanthium) $1 / 16$ inch long enclosing the ovary and bearing $t$ minute calyx teeth; white nalrow corollat tube $1 / 4$ inch long and 4 spreading rounded lobes $1 / 8$ inch across: 4 stamens inserted inside corolla tube: and pistil of slenrler style with 2 -lobed stigma above the inferior ovary.

The black fruit (drupe) has minute calyx at apex and contains 2 narow seeds within the large ¿-celled stone. Flowering from May to August and fruiting from August to December.

The wood is light brown to reddish brown, hard, strong, and heary. Used mostly for posts.
Antirhea obtusifolia Urban

Mountain forests, mainly in understory, in eastern Puerto Rico.

Public forests.-Carite, Luquillo.

Range.-Restricted to eastem Puerto Rico.

Otuer CoMMon Nases.-quina roja, tort uguillo (Puerto Rico).

BotaniCaL SYNoxyM.- Stenostomum obtusifolium (Urban) Britton \& Wilson.

This genus, whose name is spelled also Antirhoeu, has 5 additional species of small trees or shrubs in Puesto Rico, known in part as quina. Quina or boje (Antirhea acutata (DC.) Urban; sylonym Stenostomum acutatum DC.), of dry forests of southwestern Puerto Rico, Mona, Vieques, Muertos, and ot her islands, has oblong leaves smalles than the other species, $3 / 4-21 / 2$ inches long. and longes white tubular flowers $5 / 8$ inch long.

Antirhea sintenisii Urban (synonym Stenostomum sintenisii (Urban) Britton \& Wilson), knowu only from moist forests of Puerto Rico, has oblong or lance-sluaped leaves $2-41$ in inches long, 3 to 5 times as long as wide, and cream-colored flowers about $3 / 8$ inch long.

The other' 3 species have bloader, ovate to elliptic leaves mostly 2-3 times as long as wide. Palo llorón (Antirhea lucida (Sw.) Benth. \& Hook. f.; synonym Stenostomum lucislum (Sw.) Gaertn. f.), rare in Puerto Rico and the Virgin Islands but in other West Indian islands and British Honduras, has elliptic leaves $11 / 2-6$ inches long, thin and shiny green above, and yellowish or white flowers about $1 / 4$ inch long.

Another species of quina or boje (Antirhea coriacea (Vahl) Ulban; synonym Stenostomum coriaceum (Vahl) Griseb.), of northern and north- 
western Pnerto Rico and other islands, has elliptic or" ovate leaves $2-5$ inches long, slightly thickened, dull green, with petioles about $1 / 2$ inch long, and white flowers about $3 / 8$ inch long.

A closely related rare species (Antirhea portori- censis (Britton \& Wilson) Standl.; synonym Stenostomum portoricense Britton \& Wilson), of northern Puerto Rico, differs in its petioles $1 / 8-3 / 8$ inch long and 4 -celled elliptic fruit $3 / 8$ inch long and $1 / 4$ inch in diameter.

\section{MADDER FAMILY (RUBIACEAE)}

\section{Café, coffee}

This familiar cultivated shrub, the source of one of the world's most popular beverages, sometimes becomes a small tree and is sufficiently common and important for inclusion here. Coffee is characterized by: (1) opposite, elliptic, shiny dark green leares, commonly long-pointed at apex and short-pointed at base, and with nndulating upper surface, the veins sunken, on long slender spreading and slightly drooping twigs: (2) white fragrant flowers $1 \frac{1}{4}$ iliches across the 5 long corolla lobes, several together and almost stalkless at leaf bases along a twig; and (3) elliptic red berries $1 / 2^{-5 / 8}$ inch long, containing usually 2 large brown seeds, the coflee beans.

Generally a compact shrub 5-10 feet high but in age and if not pruned back becoming a small tree 12-15 feet high and 2-3 inches in trunk diameter, evergreen with spreading foliage. The bark is light gray, thin, much fissured, and becoming rough. Inner bark is whitish and tasteless. From the main axis extend many twigs, green when young but changing to light brown, with paired long-pointed scales (stipnles) $3 / 16$ inch long at nodes.

Petioles are $1 / 4-1 / 2$ inch long, and blades $3-7$ inches long and $11 / 2-23 / 4$ inches broad, the edges often slightly wavy, a little thickened, hairless, paler green beneath.

Flowers are clustered on short stalks about $1 / 8$ inch long. The calyx consists of 5 minute teeth on the green tubular base (hypanthium) less than 1/8 inch long; the showy corolla has a narrow cylindrical tube $3 / 8^{-1 / 2}$ inch long and 5 widely spreading, narrow, pointed lobes $5 / 8$ inch long; there are 5 white stamens inserted in mouth of corolla tube; and pistil with 2 -celled inferior ovary and slender 2-forked white style.

The coffee berries have a thin fleshy pulp and 2 (sometimes 1) elliptic seeds or beans $5 / 16^{-1 / 2}$ inch long, flattened on the side where they join. There are about 1,000 seeds to a pound. Flowering mainly in spring from March to June and maturing fruits for harvest from September to December.

The wood is whitish, hard, heary, and tough. It is little used in Puerto Rico.

\section{Coffea arabica $\mathrm{L}^{*}$.}

Coffee is one of the most important agricultural products exported from tropical America. The shrubs are widely cultirated in tropical regions for their seeds, which contain caflein and are roasted and ground to produce the drink of the same name. This is the most widely grown of several species. There are many varieties. It is reported that in the New World coffee was introduced first into Surinam by the Dutch in 1714, into Jamaica in 1718, Martinique in 1720 , and Brazil in 1727.

In the mountainous areas of Puerto Rico, coffee is one of the principal crops. Coffee plantations are located in the momntains chiefly at elevations between 800 and 3,000 feet, on an area of about 175,000 arres. The shrubs are grown under shade trees, chiefly guaba (Inga vera Milld.) and guamá (Ingu laurina (Sw.) Willd.). These plantations protect the soil and reduce erosion on mountain slopes. Because of its many large flowers, coffee is also a honey plant, producing white honey with a characteristic flaror.

Planted and escaping from cultivation in Pnerto Rico. Also to a limited extent in St. Croix, St. Thomas, St. .John, and Tortola.

RANGE.-Native of Abyssinia but early introduced into Arabia (14th century) and extensively planted and escaping through the tropics. Cultivated and escaping or naturalized in Bermuda and most of West Indies from Cuba and Jamaica to Triniclad and Tobago. Also from Mexico and Central America south to Brazil. Grown as a novelty or ornamental shrub in southern Florida and southern California.

Other conlyon NAMEs.-café, cafeto (Spanish): coffee, Arabian coffee (English); café, caféier (French); koffie (Dutch); café (Brazil).

Other species and rarieties of coffee have been introdnced experimentally in Pnerto Rico. Dewerre coffee or café excelsa (Coffea dewevrei Wildem. \& T. Dur.*), sometimes planted, is a small tree 20 feet high and 4 inches in trunk diameter or larger unless prumed. It has large elliptic leaves $9-14$ inches long and $31 \%-6$ inches vide, leathery, dark green, and slightly shiny; white flowers with corolla of $5-7$ lobes; and reddish-yellow berries. 


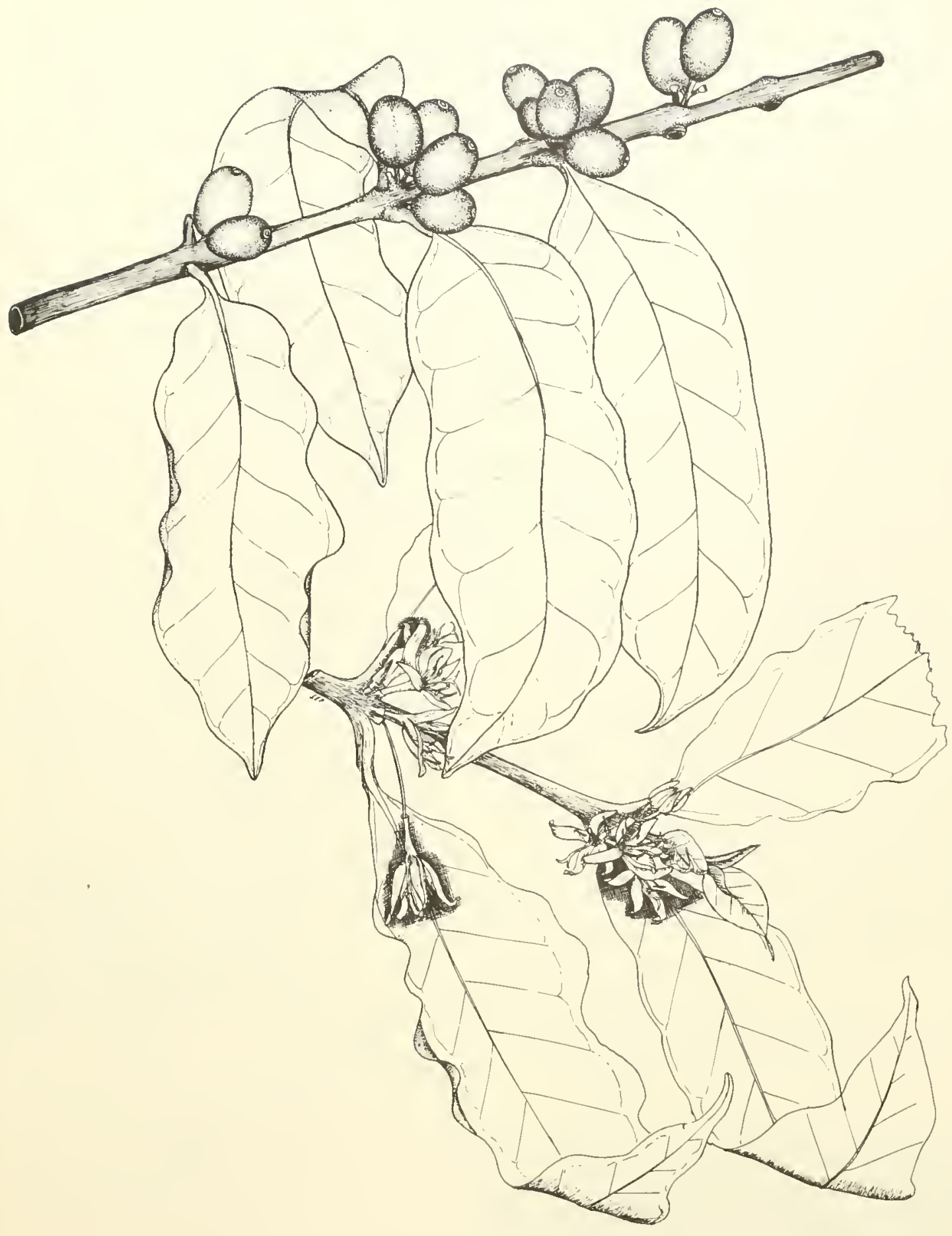




\section{MADDER FAMILY (RUBIACEAE)}

\section{Albarillo, Caribbean princewood}

This shrub or small tree of dry areas is distinguished by: (1) slender spreading branches sometimes without a definite crown of foliage; (2) opposite, small, thin, elliptic or ovate leaves, longor short-pointed with minute sharp point at apex and short-pointed at base, commonly curved upward on both sides of midrib; (3) Jarge whitish or pale yellowish flowers 2-21/2 inches long, with narrow corolla tube and 5 rery narrow spreading lobes, borne singly at leaf bases; and (4) dark brown elliptic seed capsules $3 / 8^{-5} / 8$ inch long.

Evergreen, 10-25 feet high and to 4 inches in trunk diameter. The bark is dark gray, smoothish with dots (lenticels), and thin, or becoming fissured. Imer bark is bitter and yellow, the cut surface turning orange. The slender gray twigs have leaves commonly crowded and a pair of pointed bristlelike scales (stipules) $1 / 8$ inch long forming a ring at each node. The nodes are mostly close together and bear old fruit stalks as well as scale rings back of the leaves.

The leares have slender petioles $1 / 8-3 / 8$ inch long and blades 1-3 inches long and $1 / 2-11 / 4$ inches broad, the edges not toothed, green to dark green on upper surface, lighter green and slightly hairy beneath. Sometimes the leaves are yellow spotted. perhaps from disease.

The lateral flowers, which are slightly fragrant, have slender stalks about $1 / 4$ inch long and are as much as 3 inches long in the bud. The narrow tubular base (hypanthium) 3/16 inch long bears a cup-shaped calyx 1/16 inch long with 5 teeth; the white or pale yellow corolla is composed of a narrow tube 11/4-11/2 inches long and 5 very narrow spreading lobes about 11/4 inches long: 5 stamens united at base and inserted at base of corolla tube and with rery slender yellow anther's extending 1 inch beyond tube: and pistil with 2 -celled inferior ovary and very long slender style about $21 / 2$ inches long.

The seed capsules split into 2 parts to release the many brown seeds, which are elliptic, $3 / 16$ inch long, thin, and bordered by a narrow ring. Flowering and fruiting irregularly through the year.

The saprood is yellow, and the heartwood is light brown with yellow streaks. The wood is hard, very heary (specific gravity 1.0), and strong. I durable fencepost. Elsewhere the wood has been utilized in cahinetmaking, wood turning, such as for canes, and inlaid work. The wood

\section{Exostema caribaeum (Jacq.) Roem. \& Schult.}

burns readily and has served for torehes, as a few common names indicate.

Formerly the bitter bark was used for treatment of fevers and as a substitute for cinchona bark, the sonrce of quinine, which is obtained from a ('losely related genus (C'inchona).

Common in open areas, clearings, thickets, and cutover dry forests near coasts and at lower and middle elevations in southern and western Puerto Rico. Also in Mona, Culebra, Vieques, Muertos, St. Croix, St. Thomas, St. John, Tortola, Virgin frorda, and Anegada.

Public forests.-Guajataca, Guánica, Maricao, Susúa.

M[NACIPAHTIES WHERE ESPECIALLY COMLMON.$12,26,54$.

Raxie.-Southern Florida including Florida Keys and through West Indies from Bahamas and Cuba to Cirenada. Also from central Mexico to Costa Rica.

Other common xames.-palo de Jazmín, teílla, cuero rle sapo, quina, palo de quina (Puerto Rico); yellow-torch (Virgin Islands); piñí-piñí, quina criolla (Dominican Republic); cerillo, lirio santana, carey de costa (Cuba); copalche (Mexico) ; hesito (Nicaragua); Caribbean princewood, princewood (United States): princewood (Bahamas) ; Caribbee bark-tree, Jamaica Jesuit-bark (Jamaica) ; ironwood (Antigua) ; chandelle Anglaise, quinquina pays (Haiti) ; tendre en gomme, quinquina caraibe, bois chandelle (Guadeloupe); quinquina piton (Martinique).

Two other species of this genus hare been collected once in Pnerto Rico, though present also on other islands. Plateado (Exostema ellipticum (rriseb.), found in the mountain forest of the Central Cordillera near Villalba, has elliptic leaves $13 / 4-31 / 4$ inches long and $1-13 / 4$ inches wide, rounded or short-pointed at both ends, with petioles about $1 / 4$ inch long; clnsters of few smaller flowers about 1-11/4 inches long, with corolla white, becoming rose; and cylindric seed capsules $5 / 8-11 / 4$ inches long.

Exostcma sanctae-Tuciae (Kentish) Britten, observed in the mountain forest near Maricao many year's ago, has larger oblong to elliptic leaves $+81 / 2$ inches long and about half as wide, shortpointed, shiny above, dull and with tufts of hairs in vein angles beneath, with petioles $1 / 2$ inch long or less; flower clusters terminal, flowers $1-11 / 2$ inches long, with red corolla; and cylindric seed capsules $3 / 8-3 / 4$ inch long. 


\section{MADDER FAMILY (RUBIACEAE)}

\section{Cafeíllo, false-coffee}

This shmb or small tree is dist inguished by : (1) very long lateral branches bearing nmmerous opposite leaves; (2) elliptic, shiny dark green leaves, abruptly loner-pointed at apex and short-pointed at base, and with a pair of bristle-tipped scales (stipules) $1 / 4$ inch or more in length between each 2 leaves; (3) fragrant white flowers with narrow tube about $5 / 8$ inch long and 4 widely spreading, narrow, pointed corolla lobes about $5 / 8$ inch long, in loosely branched terminal and lateral clusters; and (4) hard black fruits about $3 / 8$ inch in diameter, rounded but broader than long.

Evergreen shrub or small tree 10-30 feet or more in height and 3 inches or more in trunk diameter. The gray or brown bark is smoothish and slightly fissured. Inner bark is light brown, almost tasteless. Twigs are slender and green with rings at nodes.

The leaves have petioles $1 / 4^{-1 / 2}$ inch long and blades 3-6 inclues long and 1-3 inches broad, not toothed at edges, slightly thickened, and paler green beneath. The foliage darkens or becomes blackish upon drying.

Flower chusters (panicles) are 1-4 inches long, with few to several flowers on long slender stalks. The tubular base (hypanthium) 1/16 inch long bears a cup-shaped calyx more than $1 / 16$ inch long with 4 minute teeth: the white corolla has a nal'ow tube $5 / 8$ inch or less in length and 4 lobes; the 4 stamens are inserted in the montl of corolla tube; and the pistil has an inferior 1-celled ovary, slender style, and 2-forked stigma. Often flower buds are deformed as insect galls, the corolla enlarged near base and with very short lobes.
Faramea occidentalis (L.) A. Rich.

The fruits (drupes) have calyx remaining at apex and contain 1 la rge rounded brown seed with a depression on 1 side. Flowering in spring and summer, the fruits maturing in summer and fall.

The wood is light brown or yellow, hard, and moderately heary, and takes a good polish. Generally too small for other than fuelwood use in Puerto Rico but reported as used in carpentry elsewhere.

Understory tree or shrub in forests of moist limestone and lower mountain regions in Puerto Rico. Also in Vieques, St. Croix, St. Thomas, St. John, Tortola, and Tirgin Gorda.

Poblic Forests. - Luquillo, Guajataca, Río Abajo, Susúa.

Raxae.-Through West Indies from Cuba and Jamaica to Barbados and Trinidad and Tobago. Also from central Mexico through Central America to Ecuador, Peru, Brazil, and the Guianas.

Other common names.-palo de toro, café cimarrón (Puerto Rico) ; cafetillo (Dominican Republic) ; hiquillo, café cimarrón, júcaro, jújano, nabaco (Cuba) ; hueso (Mexico); cafecillo (Mexico, El Salvador) ; huesito (Panama) ; cafecillo, cafecillo de danta, jasmín de estrella (Tenezuela); jújamo, cafetillo de monte (Ecuador); wild-coffee (Jamaica, St. Kitts, Montserrat, St. Tincent, Barbados); café marron, bois flèche (Guadeloupe).

Botanical syonym.-Faramea odoratissima DC. 


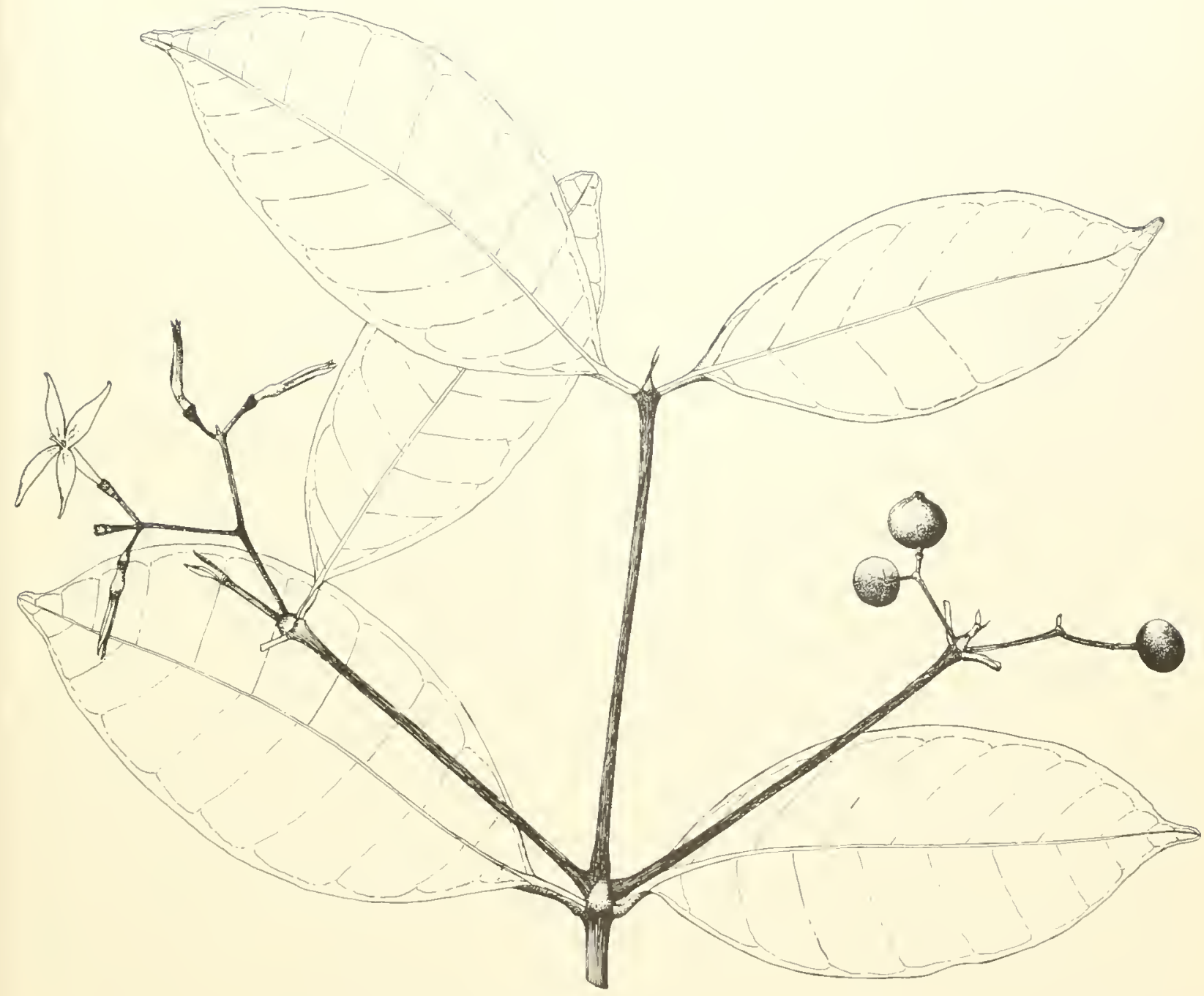




\section{MADDER FAMILY (RUBIACEAE)}

\section{Jagua, genipa}

Jagua or genipa, the source of a sour refreshing drink, is characterized by: (1) an erect trunk with leaves concentrated at the ends of the branches: (2) opposite, large, elliptic or obovate leaves, green or dark green, slightly shiny, t-12 inches long and 11/2-4 inches hroad, short-pointed at apex, longpointed at base, and broadest beyond middle: (3) large pale yellow flowers about 1 inch long and $11 / 2$ inches across the 5 lobes, few or sereral in short terminal chsters; and (4) large elliptic yellowbrown fruits $31 / 2-41 / 2$ inches fong and $21 / 2-31 / 2$ inches in diameter, with sour edible flesh, hanging down singly on long stalks.

This is a medium-sized deciduous tree to 60 feet high and $11 / 2$ feet in diameter or larger, with spreading crown of dense foliage. The bark is smooth, gray, and thick. Inner bark is light brown and almost tasteless. 'The stout twigs are green, turning brown, with ringed nodes close together. hairless or hairy.

The short petioles are $1 / 4-1 / 2$ inch long. Blades are without teeth on edges, slightly thickened. the lower surface paler green and hairless and often hairy. It the base of young leares are longr-pointed scales (stipules) $3 / s^{-5 / 8}$ inch long, which shed early. ITpon drying the leaf blades turn dark bluish green.

The branched flower clusters (cvmes) are shortstalked, $2-4$ inches long and broad, bearing large, slightly fragrant flowers. The funnel-shaped base (hypanthinm) and cylindrical tubular caly $\mathrm{x}$ without lohes are green, together $1 / 2$ inch long and 1/4 inch in diameter: the corolla has a tube about $1 / 2$ inch long with 5 broad lobes, which are widely spreading and turned back, pale yellow but brown at base inside, finely hairy; 5 stamens inserted on the corolla tube: and pistil with 2 -celled inferior ovary, slender style, and long thicker stigma.

Fruits (berries) are soft when mature, with strong sour odor, with leathery skin and yellowbrown pulp $1 / 2$ inch thick. Within are numerous flat yellowish seeds $3 / 8^{-1 / 2}$ inch long. Flowering and fruiting from spring to fall.

The sapwood is cream colored, and the heartwood very light yellowish brown, occasionally with slight pinkish- or purplish-blue overcast, with growth rings marked by narrow darker bands forming an attractive striped figure. The wood is hard. heavy (specific gravity 0.66), strong, resilient, fine-textured, and with straight to irregular grain. Rate of air-seasoning is slow, and amount of degrade is minor. Machining charac-
Genipa americana L.

teristics are as follows: planing, shaping, turning, boling, and mortising are excellent; and sanding and resistance to screw splitting are good. The wood works easily and with excellent results, better than most other Puerto Rican woods. It is very susceptible to attack by dry-wood termites, pinhole borers, and to decay.

['ses include tool handles, furniture, boxes, and carts. Elsewhere the wood is employed for shoe lists, plow beams, tool handles, barrel hoops, chests, rehicles, and shipbuilding. It is very suitable for cabinetwork, turnery, flooring, interior trim, and decorative reneer.

The trees are grown for shade and ormament as well as for the fruit and wood. An intoxicating beverage has been prepared from the fermented juice. The fruits sometimes are made into marmalade or preserves. Immature fruits contain a bluc-black juice which produces a lasting or indelible stain. It has been used as a dye and by the Indians in tattooing and in painting themselves as a protection against insect bites. A honey plant. Livestock eat the fruits.

Woodlands and pastures in the coastal, moist limestone, and lower mountain regions of Puerto Rico. Planted aromnd houses for the edible fruits. Also in Vieques, St. Thomas, and St. John.

Ptricic forests.-Cambalache, Carite, Luquillo, Maricao, Río Abajo, Susúa.

Ravie.-Cuba. Hispaniola, Puerto Rico and Tirgin Islands, Lesser Intilles from Guadeloupe to Grenada, and Triniclad and Tobago. Also from sonthern Mexico and Central America south to Ecliador, Peru, Bolivia, Argentina, and Brazil.

Other common names.-jagua (Spanish, commerce) : maluco (Mexico) ; irayol, irayol de loma (Cruatemala); irayol, tambor, tinadientes (El Salvador) ; tapaculo, gigualtí (Nicaragua) ; guaitil (Costa Rica); guaitil blanco, jagua amarilla, jagua blanea, jagua colorado, jagua de montaña. jagna negra (Panama) : caruto, caruto rebalsero (Venezuela) ; huito, vaco-huito, vito (Peru); bi (Bolivia): ñandipá (Argentina); genipap, marmalade-box (British VVest Indies); rose-marie (St. Lucia) ; resotu montagne (Dominica); juniper, genip (Trinidad); ibo-ink (Tobago); lana, geniptree, genipa (British Guiana); gêne-pas, génipayer (Haiti); genipa (Guadeloupe, French Guiani): taproepa, tapoeripa, arasaloe, sawa (Surinam) ; genipapo (Brazil).

Botanical styonyss.-Genipa caruto H. B. K., G. americuna var. caruto (H. B. K.) Schum. 

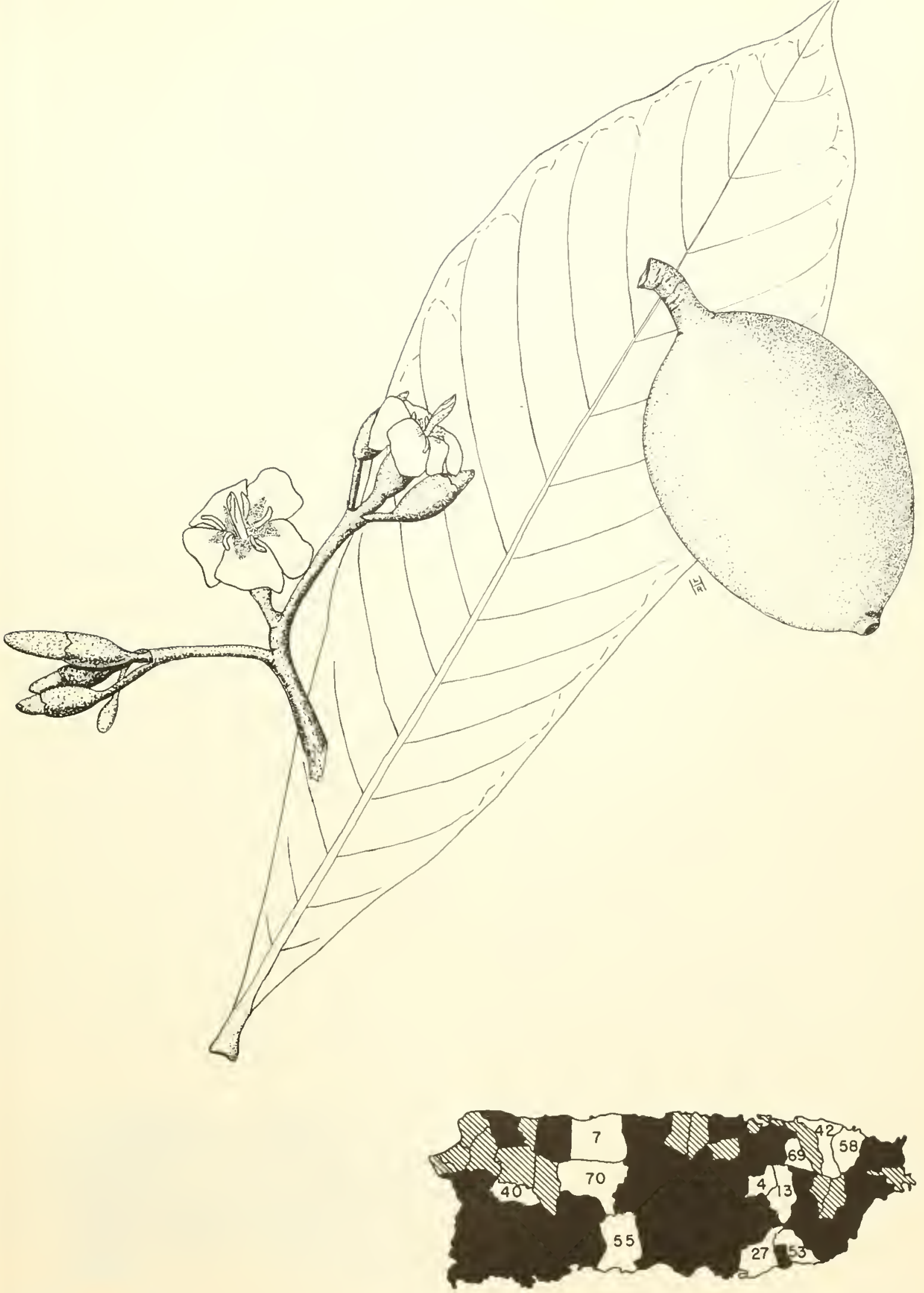


\section{MADDER FAMILY (RUBIACEAE)}

\section{Palo de cucubano, "greenheart," roughleaf velvetseed}

Guettarda scabra (L.) Vent.

This common small tree with rery rough leaves is recognized by : (1) opposite, small, elliptic or ovate leares which are thick and stiff, with edges turned under, very pough on upper surface, and finely hav' with very prominent raised network of small veins on lower surface; (2) narrow, hairy, white to hown flowers $3 / 4-1$ inch long, tubular and (i-8-lobed, sereral crowded together at end of a latera] stalk; and (:i) rounded, red, velvety hairy, fleshy fruits $1 / 4^{-1 / 2}$ inch in diameter.

Iin evergreen small tree $10-15$ feet or more in height and to $t$ inches in trunk diameter with open, spreading crown, or shrubby. The bark is gray, smooth, and thin, on larger trunks peeling off in small thin flakes and slightly mottled. Inner bark is whitish or light brown, almost tasteless or slightly bitter. The twigs are green and lrown hairy when young. becoming gray.

The leares have petioles $1 / 8-3 / 8$ inch long, hairy when young, and a pair of namow, pointed, hairy scales (stipules) 3/16 inch long at the base. Blades are 1-31/2 inches long and $5 / 8-2$ inches hroad, short pointed and with minute sharp point at apex, rounded or slightly heart-shaped at base. The upper surface is gleen, rough hairy (sonetimes nearly smooth), slightly shiny, and with veins a little sunken, and the lower surface is paler.

Isually several or a few fragrant flowers, hairy and stalkless, are borne on a headlike cluster (crme) at the end of an erect slender hairy flower stalk $3 / 4-3$ inches long. The short tubular base (lypanthium) and irregularly o-lobed alyx tube together are nearly $3 / 16$ inch long; the corolla has a narrow tube about $3 / 4$ inch long and $6-8$ spreading lobes $3 / 8$ inch across, white (sometimes pinkish) but turning to hrown: stamens as many as the corolla lolys, inserted almost stalkless inear mont hof tube: and pistil consists of inferior orary with usually $t-6$ rells, slencler style, and rounded stigma. Finits (drupes) are broader than long, with a large stome containing a few seeds. Flowering and fruiting irregularly through the year.

The sapwood is light brown and hard. I specifie armavity of about 0.8 has been recorded. I'sed only for stakes and fuel.

Common in open areas, clearings, and thickets in the coastal, moist limestone, and lower monntain regions of Pruerto Rico. Also in Vieques, St. ('oix, St. Thomas, St. John, Tortola, and Tirgin Gorda.

Public Forests.-Cambalache, Guajataca, Maricao, Río Abajo, Susúa. Yega.

Me Nicipalities WIERe Espectally COMMON.6. it.

Runge.-Sonthern Florida inchuling Florida Keys and throngh West Indies from Bahamas and
Cuba to Trinidad and Tobago, Margarita (Venezuela), and other islands ofl coast of Veneznela. Also recorded long ago from Jamaica.

Other common numes.-palo de dajao, serrasuela (Puerto Rico): "greenheart." (Virgin Islands): carapacho, chicharron de monte (Cuba); roughleaf relvetseed, rough relvetseed (United States); rough velvetseed, relvet-berry (Bahamas) : craw-wood (Barbuda); candlewood (Antigua); bois madame, bois noire (St. Lucia); juniper (Grenada); blue copper (Tobago); bois madame, goyavier bâtard (Guadeloupe); candlewoor, wild guare (St. Martin, Saba, St. Eustatins).

Though called "greenheart" in the Virgin Islands, this small tree is murelated to the valuable timber greenheart or Demerara greenheart (Ocotea rodicei (R. Schomb.) Mez), of British Guiana.

Five related species of trees all have the leaves smooth above. The first 3 below have flowers about $3 / 4$ inch long, and the last 2 have smaller flowers less than 1/2 inch long. Cucubano (Guettarda laces. Urban), known only from mountain forests of western Puerto Rico, has attractive useful wood described in "Puerto Rican Woods" and available in small sizes. It has broadly ovate to elliptic leaves $1 \frac{1}{2}-5$ inches long, slighitly thickened, hairless except for minute hairs on reins beneath, and petioles hairless or minutely hairy.

Gucttarda ovalifotia Urban, of central and western Puerto Rico, mostly in mountains, and also Hispaniola. has broadly ovate to elliptic leaves $-11 / 2$ inches long, thin, ipper surface nearly hairless and with veins in prominent network, lower surface hairy on veins, and petioles hairy.

Guettndic himgie. Urban, of coastal thickets of southwestern Puerto Rico and also Bahamas, has orate to ellipt ic leaves $1 \frac{1}{1}-4$ inches long, thick and leathery, hamless above, the lower surface densely hairy and with prominent network of veins.

Guettarda parvifiora. Tahl is found in southem Prerto Rico. Tieques, St. Croix, St. Thomas, St. John, Tortola, and Virgin Gorda, and Lesser Antilles south to northel'n South America. It has small oblong to elliptic leaves $3 / 4-11 / 4$ inches long, thin, shiny above, and hairless or nearly so beneath.

Gucttarda elliptica Sw. grows mostly in coastal thickets of southern and eastern Puerto Rico, St. Thomas, Muertos, Desecheo, and Mona, west to Florida, where known as Everglades dropseed: atso in Mexico and Venezuela. It has small elliptic leaves $3 / 4-23 / 4$ inches long, thin, dull and nearly hairless above, and beneath with fine, pressed, silky hairs. 

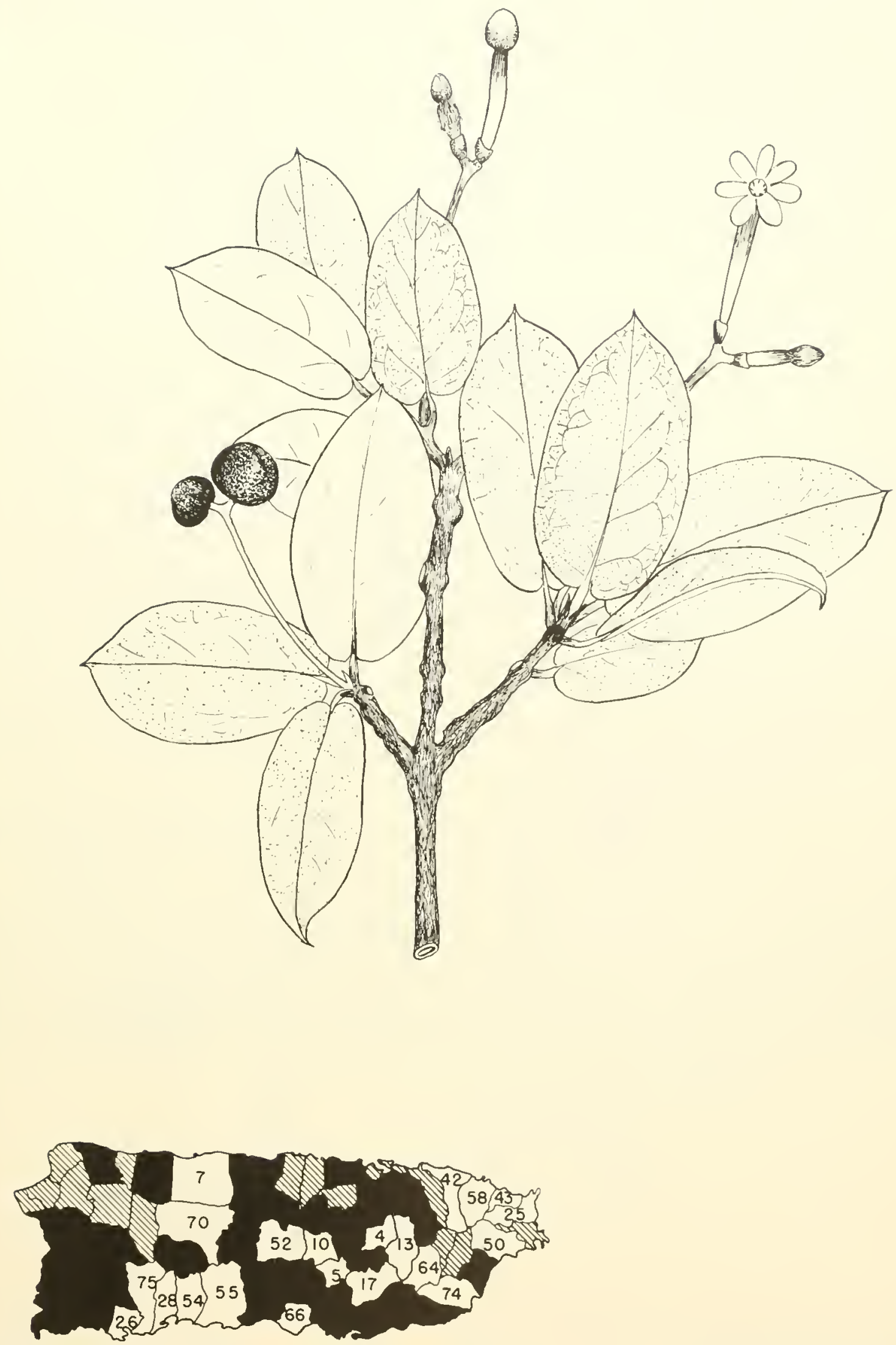

24t. Palo de cucubano, "greenheart," roughleaf velvetseed

Guettarda seabra (L.) Vent Natural size. 


\section{MADDER FAMILY (RUBIACEAE)}

\section{Cafeíllo}

Small tree or shrub characterized by: (1) twigs with prominent swollen nodes: (2) opposite narrowly elliptic leares long-pointed at both ends. with paired pointed scales (stipules) at base: (3) flowers $1 / 2$ inch long with very narrow reddish or pink tube and 4 or 5 white lobes, nearly stalkless in lateral clusters scattered along the larger wigs to $1 / 4$ inch in diameter mostly back of leaves; and (4) rounded red or pink berries about $3 / 8$ inch in diameter.

An evergreen spreatding shrub or small tree to 20 feet ligh and 3 inches or more in trunk diameter, hairless throughout. The dark brown bark is smoothish, slightly fissured, or scaly. Inner bark is light brown or pinkish and tasteless. Twigs are green, turning brown, with paired pointed scales (stipules) $1 / 8-1 / 4$ inch long at nodes.

Green petioles $1 / 4^{-1 / 2}$ inch long support the blades which are $3-71 / 2$ inches long and 1-3 inches broad, slighitly thickened, the upper surface green or dark green and slightly shiny, beneath light green.

Flower clusters (corymbs) are composed of a few fragrant flowers. The tubular base (hypanthium) ahout 1/16 inch long bears a short red calyx tube with 4 indistinct wavy teeth: the corolla has a very narrow reddish or pink tube $3 / 8^{-1 / 2}$ inch long and $1 / 32$ inch in diameter and 4 or 5 broad, widely spreading, white lobes $5 / 16$ inch across; there are 4 or 5 stamens at open end of tube; and the pistil

\section{Ixora ferrea (Jacq.) Benth.}

consists of inferior 2-celled ovary with slender style and 2-lobed stigma.

The ronnded berries are greenish or yellowish, turning to red or pink, fleshy, and contain 2 dark brown seeds $3 / 16$ inch long. In flower and fruit at different times during the year.

The wood with light brown sapwood is hard, heavy, strong, and tough. Reported as used elsewhere for fenceposts and in carpentry, but utilization in Puerto Rico is limited to fuelwood by small size of the trees.

Common in understory of forests in the moist limestone and lower mountain regions in Puerto Rico. Also in St. Thomas, St. John, and Tortola.

Public Forests.-Guajataca, Luquillo, Río Abajo.

Raxge-Cuba. Hispaniola, Puerto Rico and Vircin Islands, and through Lesser Antilles from St. Kitts and Montserrat to Grenada and Barbados. Also reported from Venezuela and British Guiana.

Otifer common names.-palo de dajao, palo de hierro (Puerto Rico); dajao (Dominican Rejublic): café cimarrón, cafetillo (Cuba); black candlewood (Montserrat) : bois crapaud (Dominica); wild-coffee (St. Vincent); café marron (Grenarla) ; café grand bois (St. Lucia); bois de fer rouge, bois jamne (Guadeloupe, Martinique). 


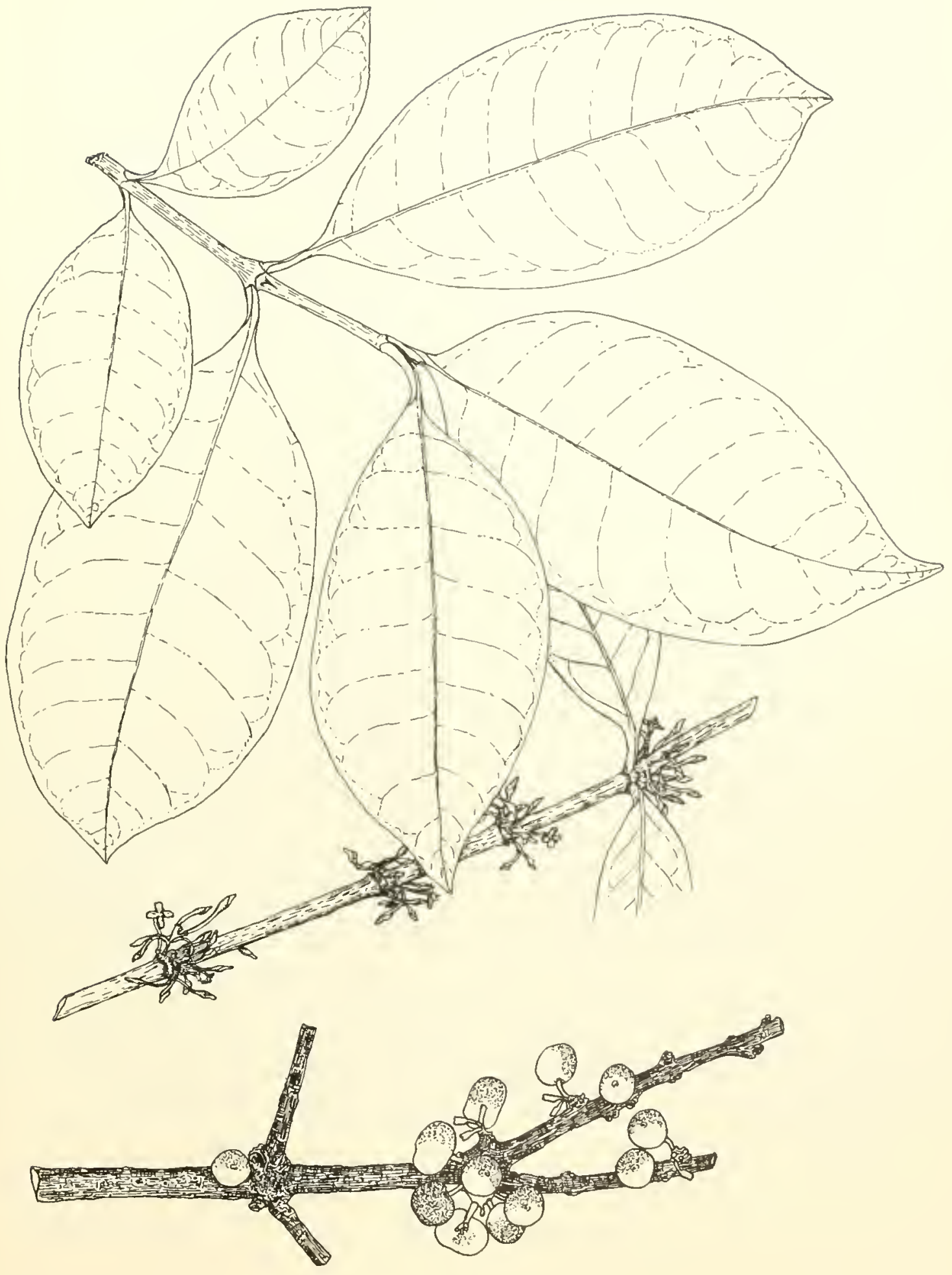




\section{MADDER FAMILY (RUBIACEAE)}

\section{Morinda, painkiller}

This small tree planted for ornament and naturlized on sandy coasts is characterized by: (1) large, thin, elliptic, dark green leaves with undulating surfaces, short-pointed at both ends, opposite on stout 4-angled twies: (2) twigs with paired rounded seales (stipules) about $1 / 4$ inch long at base of each pair of leaves, the scales leaving ring scars upon shedding; (3) white tubular 4-6-lobed flowers more than $1 / 2$ inch long, many in a lateral ball-like cluster on a short stalk; and (4) Whitish, green-tinged, elliptic mnltiple fruits $3-4$ inches long and about $21 / 2$ inches across, slightly resembling pineapples, fleshy and malodorons.

Small evergreen tree to 20 feet high and 5 inches in trunk dianeter, or shrubby. Twigs hairless. light green. The bark is gray or brown, smoothish and slightly warty or scaly, and soft. Inner bark is light brown and tasteless or slightly irritating.

The leaves have stont green petioles about $1 / 2$ inch long. Leaf blades are about 5-11 inches long and $21 / 2-61 / 2$ inches broad, not toothed on edges. slightly shiny dark green on upper surface, and the lower surface light green with small tufts of hairs in rein angles along midrib.

Flower chusters (heads) about 1 inch across are mostly single on stalks about $1 / 2$ inch long and are composed of many crowded flowers more than $1 / 2$ inch long rising from a light green rounded or elliptic mass. The light green base (hypanthium) more than $1 / 8$ inch long bears a very short light green calyx rim; the white corolla nearly $1 / 2$ inch long is tubular with $4-6$ lobes $3 / 8^{-1 / 2}$ inch across; 16 stamens $3 / 16$ inch long are inserted near mouth of corolla tube; and the pistil is composed of inferior 2-celled ovary with slender light green style and 2-lobed stigma.

\section{Morinda citrifolia $\mathrm{L}^{*}$}

From the flower head derelops a multiple fruit (syncalp), a compact, soft, juicy mass of fruits from individual flowers. These fruits, which have a cheeselike odor, reportedly are edible. The surface is inregular and warty, marked by the 4-6-sided individual fruits $1 \%$ inch across, each 2 -celled and 2 -seeded. The seeds are more than $1 / 8$ inch long. Flowering and fruiting nearly through the year.

The sapwood is yellow brown and soft.

I rerl dye has been obtained from the bark. The edible frmits are eaten also by hogs.

The English name painkiller refers to use of the leares in the Tirgin Islands, Trinidad, British Guiana, and probably elsewhere in alleviating pain. According to different directions, a hot leaf (heated over a fire) or wilted leaf is pressed anainst the body on painful swellings, a poultice of the leares is applied to wounds or to the head for headaches, or crushed leares in lard or camphor oil are put on the face for treatment of neuralgia or head colds.

Sometimes grown for ormament in Puerto Rico. Mlso planted or naturalized along sandy coasts of Puerto Rico, Vieques, St. Croix, St. Thomas, St. John, and Tortola.

R.AxaE.- Native of India, Malaya including East Indies, and tropical Australia and introduced into other tropical areas. Cultirated and in part naturalized through West Indies from Cuba and Jamaica to Barbados and Trinidad. Rarely planted at Key West, Florida, and grown also in Guianas.

OTIER COMmoN NAMES.-gardenia hedionda, noni (Puerto Rico): nigua, piña de puerto (Dominican Republic); Indian-mulberry, painkiller (English); douleur, fromagier (Haiti); thubarbe caraibe (Guadeloupe). 


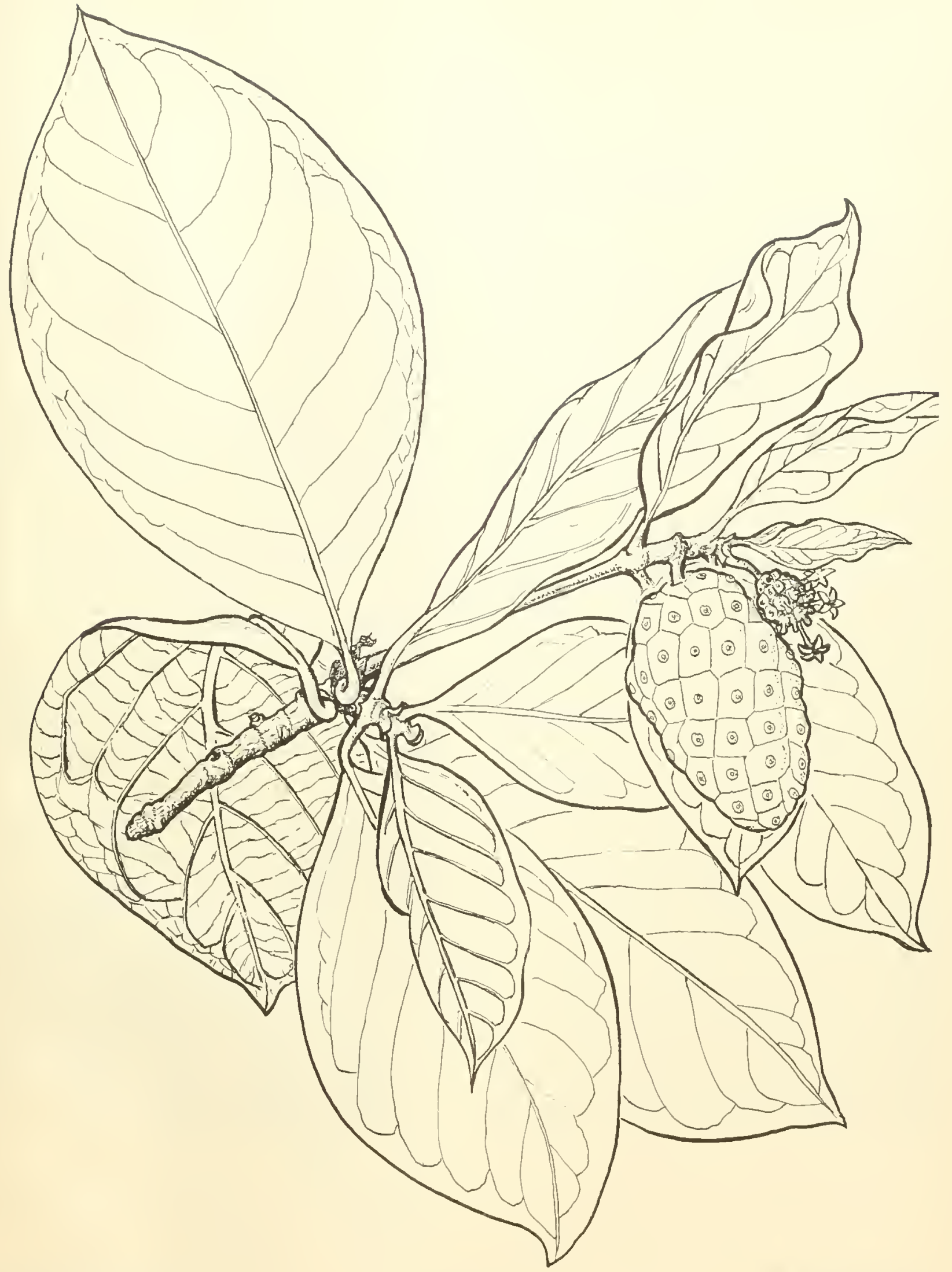

246. Morinda, painkiller

Morinda citrifolia $\mathbf{L}$. 


\section{MADDER FAMILY (RUBIACEAE)}

\section{Tintillo, box-briar}

A spiny shrub or small tree, mostly of dry areas, characterized by : (1) long, slender, stiff, horizontal branches with + rows of many paired short lateral twigs $3 / 4^{-2}$ inches long, usually ending in a pair of widely forking gray spines $1 / 4-3 / 4$ inch long; (2) leaves varying in shape from elliptic to nearly round to spoon-shaped (spatulate), $3 / 8-13 / 4$ inches long and 1/4-1 inch broad, almost stalkless, opposite ol elustered; (3) fragrant white flowers $1 / 4$ inch long, with short tube and 5 broad flat corolla lobes $5 / 8$ inch across, single and stalkless on twigs; and $(4)$ rounded berries $1 / 4^{-1 / 2}$ inch in diameter with calyx remaining at apex, green turning to white at maturity.

Deciduous shrub 5-10 feet high or small tree to 20 feet tall and 3 inches in trunk diameter, with erect axis and thin crown of many nearly holizontal spiny branches. The bark is gray and smoothish or slightly fissured. Inuer bark is light brown, slightly gritty and tasteless.

The leaves are opposite or often clustered 4 together at end of a short lateral twig, almost stalkless or with short petioles to $1 / 8$ inch long and brown scales (stipules) $1 / 16$ inch long at base. Blades are short-pointed at hase, rounded at apex, not toothed on edges, a little thickened, shiny green above, and beneath light green and slightly shiny.

The solitary flowers appearing lateral along the twigs actually are on rery short spur or lateral twigs abont $1 / 16$ inch long. The light green tubular base (hypanthimm) about $1 / 16$ inch long encloses the inferior 2 -celled ovary and bears a light green calyx tube about $1 / 16$ inch long with 5 narlow ealyx lobes $1 / 16$ inch long. The white corolla consists of a broad tube more than $1 / 8$ inch long and 5 elliptic lohes $5 / 16$ inch long, hairy at throat. It apex of tube are 5 stalkless light brown stamens about 1/16 inch long, alternating with the lobes. The pisti] with inferior ovary has a whitish style nearly $1 / 4$ inch long and broader, 2-lobed stigma. Flowers sometimes are small and with

\section{Randia aculeata L.}

4-lobed corolla. A berry contains several rounded seeds in blue or black pulp. Flowering and with green finits nearly through the year.

The light brown wood is hard and heavy. Fishing rods ale made from the rigid stems in the Tirgin Islands.

The names árbol de navidad and Christmas-tree refer to use of the tree as a Christmas decoration. I blue dye has been obtained from the berries, the source of the common names tintillo and inkberry. It is reported that the fruits can be eaten and also have been employed elsewhere in home remedies.

Thickets and open forests, mostly in dry areas, in the coastal, limestone, and lower mountain regrions of Puerto Rico. Also in Mona, Icacos, Tieques, St. Croix, St. Thomas, St. John, Tortola, and Anegada.

Prbicic forests.-Aguirre, Cambalache, Carite, Gruajataca, Guánica, Susúa.

RAvge.-Southern Florida including Florida Keys, Bermuda, and throughout West Indies from Bahamis and Cuba to Grenada and Barbados, Trinidad and Tobago, and Bonaire and Curaçao. Ilso in Mexico, Central America. Colombia, and Tenezuela.

Other comiron Nayes.-escambrón, eambrón, írbol de navidad, palo de navidad, palo de cotorra, sota caballo (Puerto Rico) : fishing-rod, Christmas-tree, inkberly (Virgin Islands); resnelesuele (Dominican Republic); café cimarıón (Cuba); espino cruz, crucete, clucilla, papachilla (Mexico) ; crueito, tintero (El Salvador) ; cruceto, maíz tostado, maría angola, corallero (Colombia) ; cruceto (Veneznela); box-briar (Bermuda, Bahamas, .Jamaica ) ; indigo-berry, inkberry, pricklebush (Jamaiea); fishing-rod (Antigua) ; inkberry (Barbados) ; peetsch-kitam (British Honduras); eroc-à-chien (Haiti) ; petit coco (St. Barthélemy, Guadeloupe); raboe die kabasi, wakoera, leele (Dutch West Indies).

Botanical srnonys.-Randia mitis L., R. aculeata var. mitis (L.) Griseb. 


\section{MADDER FAMILY (RUBLACEAE)}

\section{Juan tomás}

A small to medinm-sized tree or shrub of mountain forests, confined to Puerto Rico, characterized by: (1) opposite elliptic leares 3-7 inches long and 11/2-3 inches broad, short-pointed at both purls, with midrih pink or red on nnder side and sometimes also on nuprer side: (2) 2 broad and pointed ercen scilles (stipules) $3 / 16^{-1 / 4}$ inch long at the lase of each pair of leaves: (3) tubular white flowers 1 in inch long and with 5 lobes $3 / 8$ inch across, sevelal to many in lateral chusters; and (4) glay or brown seed capsules $1 / 4$ inch long, nealy romend but broader than long.

Generally a small tree $15-25$ feet high and to 6 inches in trunk liameter, sometimes larger, or a shrul, everereen. The rray bark is smoothish and slightly fismlert. Tnmel bark is pinkish outside ancl light bown within, slightly bitter. The twigs ale irlay and with rings at nodes, greenish and minutely hairy when yonng, the nodes partly r'owed and partly distant.

Petioles are 1 o- 1 inch long. green or tinged with pink, minutely hairy. Luaf b]ades are slightly thickener and slightly fleshy, with elges turned umler, green and hairless on upper surface, the lower surfare paler and with prominent minutely hairy midrib.

Flowro chusters (panicles) are branched, 1-21/2 inches long, with several to many fragrant flowers. The light green, finely bairy tubular base (hyp:unthimm) more than "1/6 inch long bears 5 calyx teeth nearly as long: the tulular white corolla $3 / s$ inch fong has 5 widely spreading lobes turned

\section{Rondeletia portoricensis Krug \& Urban}

back, minutely hairy: 5 stamens are inserted within corolla tube: and the pistil is composed of inferior 2 -celled ovary with hairy style and 2-lobed stigma.

Seed capsules are minutely hairy, splitting open into 4 parts, containing many tiny winged seeds $1 / 16$ inch long. Flowering in summer, and fruit maturing in fall.

Sapwood is light brown and hard. This tree is ordinarily small and not utilized.

TVidely distributed usually in the understory of momntain forests of Puerto Rico.

Perime Forests.-Imquillo, Maricao, Toro Negro.

Ringe.-Puerto Rico only.

Two related species are shrubs or small trees. Cordolancillo (Rondeletia inermis (Spreng.) Krug \& Urban) is widely distributed in Puerto Rico and also in Mnertos but not known elsewhere. It has opposite, linear to oblong or elliptic leaves $1 / 2-4$ inches long and $1 / 4-2$ inches wide and lateral clusters of 5 or fewer tubular flowers about $1 / 2$ inch long with 4 -lobed corolla yellow or white, cluanging to purple.

Rondeletia pilosa $\mathrm{SW}$. is found in coastal thickets of eastern and southeastern Puerto Rico, St. Croix, St. Thomas, St. John, Tortola, Virgin Gorda, and Montserrat. It has the twigs and under surfaces of leaves densely soft hairy; opposite elliptic leaves $11 \%-4$ inches long; and lateral clusters of usually 3 tubular flowers about $5 / 8$ inch long with 4 -lobed corolla. 


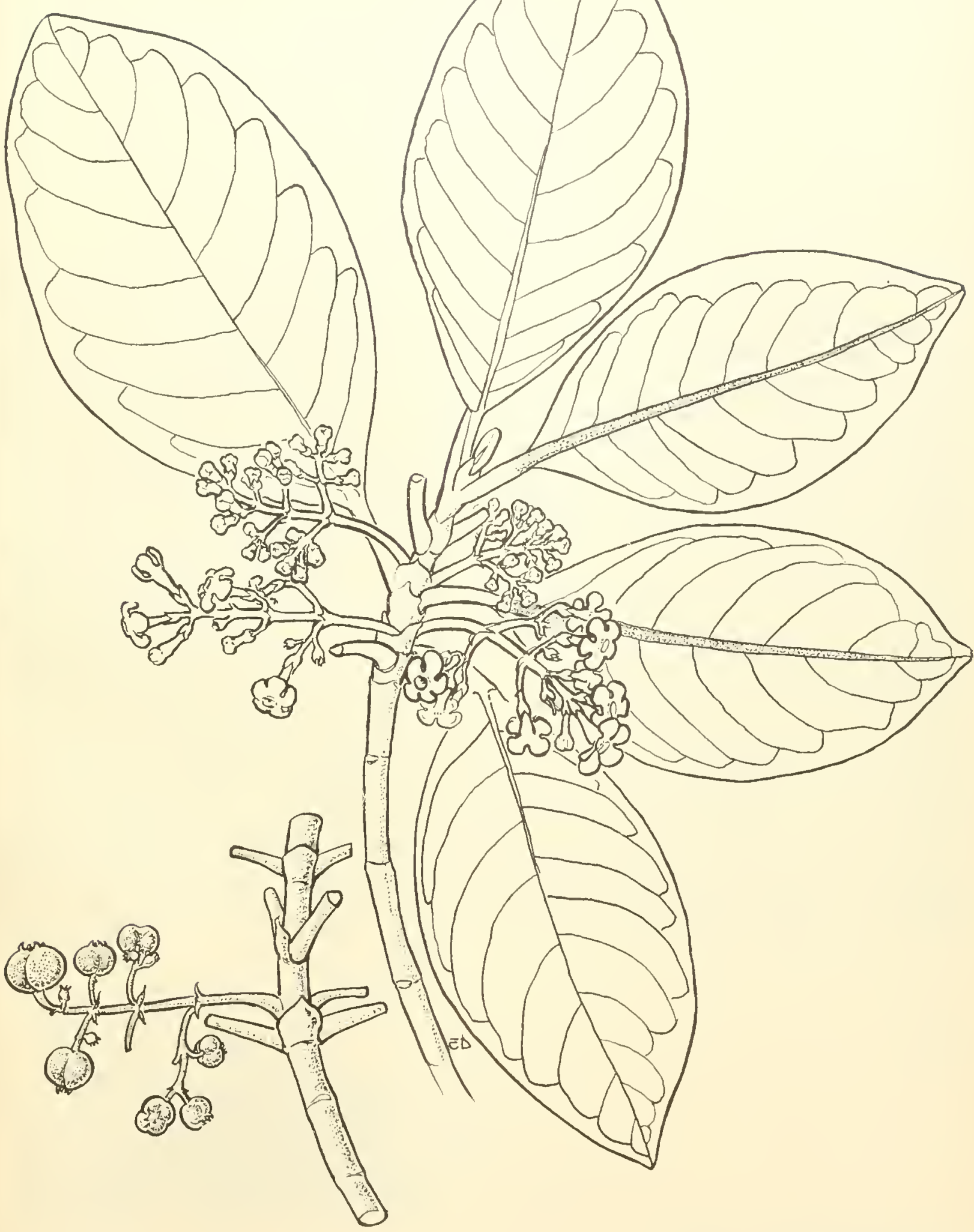




\section{MADDER FAMILY (RUBIACEAE)}

\section{Aquilón}

Easily recognized by the sticky or resinous buds, young twigs, young leaves, and flower clusters, the buds with a whitish mass of resin about $1 / 4$ inch across and 2 -pointed. Other distinguishing characters are: (1) a dense symmetrical and conical light green crown; (2) the opposite, narrowly elliptic or lance-shaped leaves, shiny green on upper surface as if varnished, especially when young: (3) small tubular white flowers about $3 / 8$ inch long, 5- or 4-lobed, stalkless along 2 horizontal forks of a slender lateral axis; and (4) the elliptic, brown or black, fleshy fruits $5 / 16$ inch long.

A small-or medium-sized evergreen tree $20-30$ feet high and to 1 foot in trunk diameter, or shrubby. The gray bark is smoothish, flaky and scaly, on large trunks becoming mottled as thin flakes peel off. Inner bark is pink and bitter. The twigs are green when young, turning light brown or gray, with hairy ringed scales (stipules) 1/8 inch high at nodes.

Petioles are $1 / 8^{-3} / 8$ inch long. Leaf blades are $2-41 / 2$ inches long and $5 / 8-11 / 8$ inches broad, mostly long-pointed at both ends, the edges turned under, slightly thickened and leathery, hairless, paler beneath.

Flower clusters (cymes) have a slender green stalk $11 / 2-2$ inches long with 2 horizontal forks $1 / 4^{-}$ $1 / 2$ inch long bearing several crowded stalkless flowers all on the npper side. Flowers about $3 / 8$ inch long are composed of a short green tubular

\section{Terebraria resinosa (Vahl) Sprague}

base (hypanthium) and cup-shaped hairy calyx, together more than 1/16 inch long; white corolla $5 / 16$ inch long, with narrow tube and 4 or 5 lobes $3 / 16$ inch across, minutely hairy; 4 or 5 stamens inserted on the corolla tube; and pistil of inferior 4- or 5-celled ovary, short style, and 4-or 5-lobed stigma.

The fruit (drupe) has a 4- or 5-celled stone and 5 or fewer brown seeds more than $1 / 8$ inch long. Flowering in spring and summer and maturing fruits from summer to winter.

The wood is hard and light brown, the saprood with specific gravity 0.8 . Used only as a post. Wood susceptible to attack by dry-wood termites. The resinons buds can be chewed bnt are tasteless.

In forests and openings in the moist limestone region and ascending into the lower mountain forests on the north side of the Cordillera in western Pnerto Rico.

Public forests.-Cambalache, Guajataca, Maricao, Río Abajo, Susúa, Vega.

MUNiCIPALITIES WHERE FSPECIALLY COMMON.$14,24,31,34,45,60$.

Range.-Bahamas, Cuba, Hispaniola, Puerto Rico, Lesser Antilles to St. Vincent, and Trinidad.

Botanical synonyms. - Laugeria resinosa Vahl, L. densiffora (Griseb.) Hitchc., Antirhea resinosa (Vahl) Cook \& Collins, Stenostomum densiftorum Griseb. 


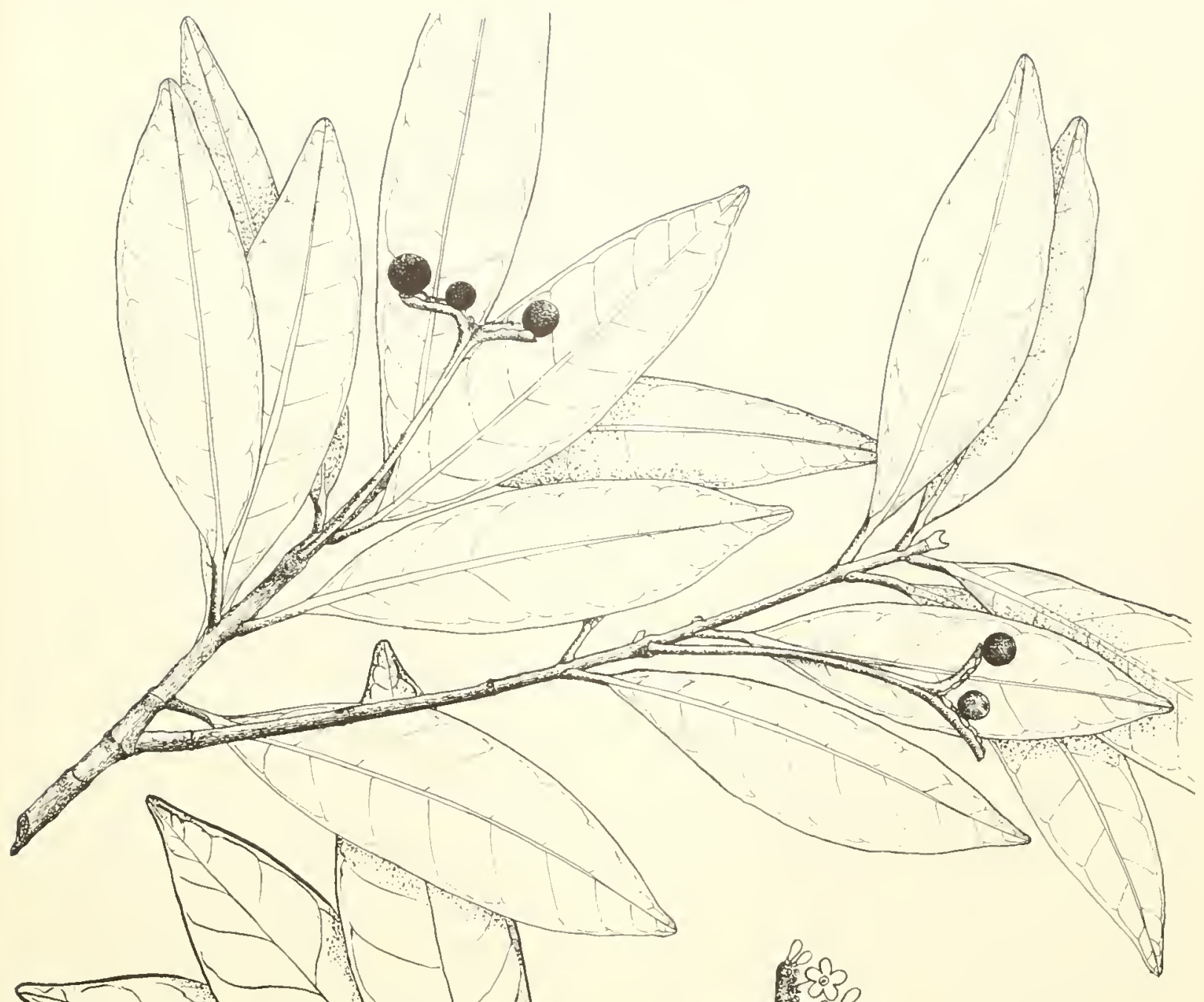




\section{COMPOSITE FAMILY (COMPOSITAE)}

\section{Carruzo}

Shrub or small tree with bristly hairy twigs easily recognized by the opposite long-stalked leaves with thin broadly ovate hlades long-pointed at both ends, the edges irregularly and doubly toothed with long and short teeth, green and rough hairy above, and wray green and soft hairy beneath. Other characters are: (1) bristly hairy stont areen to brown twigs: and (2) large terminal clusters with numerous greenish and white rounded flower heads about $1 / 4$ inch long and broad, each with many crowded tubular white flowel's.

A widely spreading and much branched evergreen shrub or small tree 10-20 feet or nore in height and to 3 inches or more in trunk diameter. The bark is gray and smoothish to stightly fissured. Inmer bark is yellowish and slightly bitter. The twig, are ringed at the nodes by 2 :3-lobed light. brown leaf scars.

Petioles are $1-t$ inches long, finely hairy, light ureen or purplish tinged, stont, at hase broad and slightly 3-lobed. Blades are $?-8$ inches long and 2-6 inches wide.

The much branched cluster's (corymbs) of numerous flower hearls are $t-6$ inches broad and have a slightly hiter odor. On the outside of each flower head are a few overlapping, hairy malrrined, greenish seales about 3/16 inch long with whitish points, enclosing many narow flowers $3 / 1 f^{-1 / 4}$ inch long and smaller light green seales. The marginal flowers are fertile and female, consisting of elliptic, flattened, green inferior orary hearing tubular white corolla minutely 5 -toothed at apex and the protruding 2 -forked white style. The other flowers are sterile and male, consisting of rudimentary pistil of narrow inferior ovary bearing unbranched style and the tubular white corolla, which is 5-toothed at apex and which has inside the tube 5 stamens united by the narrow dark brown anthers.

Several black seedlike fruits (akenes) about $1 / 8$ inch long, elliptic and flattened, are produced within the flower head, which also turns blackish.
Clibadium erosum (Sw.) DC.

Probably flowering and fruiting nearly throngh the rear".

The whitish wood is soft, and there is a large white pith.

In openings, cut over areas, and roadsides in forests of the lower and upper mountain legions of Puevto Rico including dwalf forest of the peaks. It is a light-requiring species mainly of disturbed areas. Ilso recorded from St. Thomas more than a century ago hut not found there since.

l'ruacic morests.-Carite, Luquillo, Toro Negro.

R.inge.-Pnerto Rico and in the Iesser Antilles on Saba, St. Kitts. Montserrat, Guadeloupe, Dominica, Martinique, and St. Vincent.

Othel comstow Nases.-cachimbo, tuchima (Puerto Rico); bois énivrant (Guadeloupe).

The composite family (Compositae), to which this small tree belongs, is easily recognized by the flowers crowded together in heads. What appears to be a single flower is found upon inspection to contain many small flowers, some frequently with strap-shaped corolla resembling a single petal and others in the center or disk witl tubular corolla of a diflerent color. The seedlike fruits (akenes) usually bear long hairs or scales at apex. The family is a very large one containing numerons species of herbs and some shrubs and in the tropies a few species of small trees.

Gnerrero (Eupatorium portoricense Lrban: synonym Critonia portoricensis (Urban) Britton \& Wilson) is the only other species of this family reaching tree size in Prerto Rico. This is a small tree or shrub 10-20 feet high, known only from northern, central, and western Puerto Rico and from Tieques but sometimes planted for its fragrant foliage. It has opposite elliptic leaves with petioles less than $5 / 8$ inch long and blades 3-6 inches long and 1-2 inches wide, thin, toothed on edges, hairless, with many gland dots and lines, and fragrant. The large terminal flower clusters contain many stalkless heads, each with about 5 tubular white flowers. The seedlike fruits have long hairs at apex. 


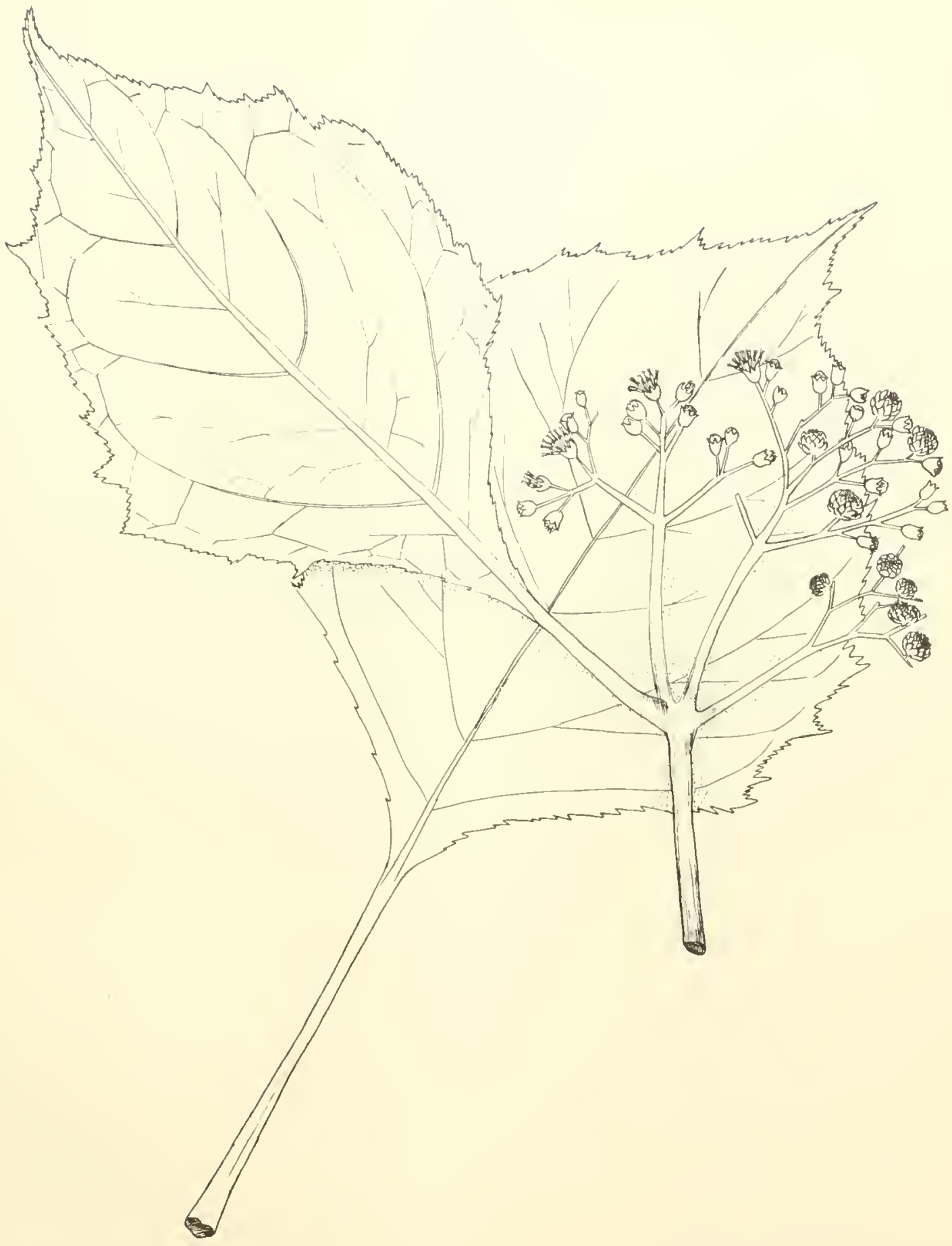

250. Carruzo

Two-thirds natural size.

Clibadium erosum (Sw.) DC. 



\section{INDEX OF COMMON AND SCIENTIFIC NAMES}

The preferred common names adopted in healings for the 250 tree species illustrated and the page mmbers where these descriptions begin are in heary (boldface) type. Other common mames appear in oldinary (roman) type. ('ommon names in the English language are indexed under the last word.

Acepted scientific names of the tree species illustrated are shown in heavy (boldface) italics, and the page numbers where these descriptions hegin are in heary (boldface) type. Other scientific names, including synonyms, are in italics. Family names, common and scientific, are shown in capitals.

abacate, 128

abacateiro, $12 s$

abey, $160, \geq 10$

abey heulira, 160,240

abeyuclo, 316

abricó do Pará, $3 \pi 4$

abricot, $35+4$

abricot de Saint-Domingue, 354

abricot des Antillex. 354

abricot pass. 354

abricoteiro. 354

abricotier, 354

abricotier d'Amériųue, 354

abricotier mandit, 35

a cacia, 144, 148, 150, 156, 176, 180

acacia amarilla, 146, 148

acacia, Anegada, 144

Acaria anrgadensis, 144

acacia de agiiijote, 180

acacia de Catarina, 168

acacia de los masones, 180

Acacia farnesiana, 142

Araria macracantha. 144

Acacia macracanthoides, 144

Acacia muricata, 144

Acacia nitotica, $1+4$

acracia mudosa, 144

acacia odorant, 144

acacia palida, $\mathbf{1 5 6}$

acacia rosada, 172

acacia, spineless, 144

acacia, steel, 144

leacia suma, 14

acacia, sweet, 142, 144

Acucia tortuosa, 14

acacia, twisted, 144

acajou, 24, 250, 288

acajon à muebles, 244

acrajou à pomme, 288

acajou amer, 244

acajou Amérique, 250

acajou de Saint Domingue, 252

acajon du Honduras, 250

acajou pays, 244

acajou rouge, 244

acajou senti, 244

acajú, 244

acaná, 414

aceite de maría, 350

aceitillo, 13, 228

aceituna blanca, 456

aceiluna cimarrona, $\mathbf{4 5 6}$

aceitunillo, 110,456

acero, 320

acletilio, 118

achiot, 358

achiote, 358

achiotillo, 262, 264

achote, 358

Achras cmarginatn, $\mathbf{4 6}$

Achras zapota, 446

acrma, 454

acoma batard, 454

acoma blanc, 372

acoma franc, 372,454

acoma hêtre, 372 acomat, 372, 454

acomat bâtard, 282,442

icomat coite-lette, 466

acomât rouge, $4+2$

Icrocomia aculcata, 34

Acrocom:a media, 13, 34

acrocomia, Puerto Rico, 34

. lerodiclidium jamaicensc. 11 t

lcoudiclitium salicifolium, 112

levodiclidium triandrum, 114

acuapar, 278

acurutü, 200

Adenanthera paronina, 142, 144

advocaat, 128

ifta colorada, 58

agati, 208

Agati grandiftora. 208

agati sesbania, 20 .

aguacate, 128

aguacate cimarrôn. 110

aguacatillo, $110,116,130,264,314$

aguano, 250

aguedita, 234

agiiijote, 160

annejote, 194

ahuijote, 194

AILANTHUS FAMILT, 234

Aiphanes acanthophylla, 13, 34, 36

a isegerina, 58

aité, 272

ajo, $\mathbf{4 6 s}$

ajuela ciruelo, 296

a junacto, 190

akira, 392

Aklema petiolare, 270

ธlamo, 330

\{lamo blanco. 330

alamo extranjero, 72

alas de ângel, 170

albarillo, 508

albizia, 148

albizia, lebbek, 148

Albizia lebbek, 15, 142, 146

Albizia procera, 142, 148

albizia, tall, 148, 150

Alibizzia, see Albizia, 146

albopín, 62

Alchornea latifolia, 14, 262, 264

Alchorneopsis portoricensis, 14, 262, 264

alciba, 94

alcornoque, 394

alelaila, $246,248,460$

aleli, $248,460,462$

aleli bianco, 460

alelí cimarrón, 460

alelí rojo, 462

alfiler, 228

algarrobo, 164, 168, 178, 180

algarrobo de las Antillas, 180

algarrobo de olor, 149

algarrobo del Brasil, 168

algarrobo del país, 164

algodón, 336

algodón de monte, 330

algodoncillo, 326 alilaila, 248

alligator-pear, 128

allspice, 414

almácigo, 236

almácigo blanco, 236

almácigo colorado, 236

almendra, 15, 394

almendrillo, 254, 256, 442

almendro, 190, 2-4, 394

almendro americano, 394

almendro cjmarrón, 190

almend ro de liı India, 394

almendro de río, 190

almendro macho, 190

aimendro montés, 190

almendro real, 190

almendro silvestre, 442

almendrón, 290, 394, 142

almond, 394

4lsophita, 28

amacey, 240

amanca 50,462

amanda, 394

a mandelboom, 394

amandier, 394

amandier de Cayenne, 394

amandier des Indes, 394

amandier-pays, 394

amandier tropica I, 394

amapola, $196,328,462,492$

amarillo, 356

amarillo boj. 386

amasisa, 194,196

amate, 68

amatillo, 432

ambarella, 292

ambay-guazú, 428

amendoeira, 394

Amomis caryophyllata, 414

Amomis caryophyltata var. grisca, $\mathbf{1 1 4}$

Amomis grisca, $\mathbf{4 1 4}$

amor platónico, 148

amortiguado, 282

Amyris balsamifera, 216

Amyris elemifera, 13, 216

amyris, sea, 216

amyris-wood, 216

anacaguita, 340

anachahuita, 340

$A T A C A R D I A C E A E, 286$

Anacardium occidentale, 286

ana conda, 470

Anamomis fragrans, 400

anatto, 358

ANATTO FAMILY, 358

anatto-tree, 358

anauca, 196

ananca immortelle, 196

analuco, 194

Andira inermis, 13, 14, 188

Andira jamaicensis, 190

anesita, 248

angela, 134

angelica-tree, 426

angelim, 190

angelim da varzea, 190 
angelim morcequeira, 190 angelin, 190 angelin, cabbage, 188, 190

angelin 1 a l miste, 190 angouchi des sables, 386 ancuilla, 400 anisillo, $\overline{0} 0$

annatto, 358

ANNONA FAIILY, 98

Ammona glabra, 98

Annona montana, 98

Annona muricata, 98, 100

Annona reticulata, 98, 102

Annona squamosa, 98, 104

$A N N_{O N A}{ }^{\prime} F A E, 98$

anón, 102, 304

anón de azúcar, 104

anón doméstico, 104

anón pelón, 102

Anona, see Anmona, 98

anona, 102

anoua colorada, 102

anona de Guatemala, 104

anona de redecilla, 102

anonillo, 94, 100, 428

Antirlica acutata, 504

Antirhea coriacca, 504

Antirifea lucida, 50

Antirhea oblusifolia, 504

Antirhea portoricensis, 500 i

Antirhea resinosa, 524

Antirhea sintenisii, 504

Antirrioca, see Antirhca. 504

ant tree. 86

anttree, long-john, 86

a pamate, 500

aperta ruão, 50

apes-earring, 162

$\triangle P O C Y N A C E A H, 462$

apomo panaco, 360

appelroos, 402

apple-bush, 104

apra, 438

apricot. 128,354

aques del chiquito, 410

aquilón, 524

arabo, 210

a rabo carbonero, 210

arabo jiba, 210

arabo real, 210

$A R A L I A C E A E, 426$

aralie, 352

aralie grande feuille, 352

arasaloe, 512

araticum apé, 98

araz\{-puitít, 416

arbol de ajo, 468

á rbol de fuego, 176

arbol de navidad, 520

árbol de pan, 62

árbol de sal, 478

árbol de violeta, 260

arbol del fuego, 176

árlol del hule, 64

arbre à graines réglisse, 146

a rbre à pain, 62

arbre à pluie. 166

arbre à réglisse, 146

arbre an diable, 278

arbre de Saint-Jean, 428

arbre véritable. 62

Ardisia glauciflora, 430

Ardisia guadalupensis, 430

Ardisia obovata, 430

areeiro. 278

arenillo, 138, 190

aroma, 142, 144, 148

aroma a marilla, 144 aroma americana, 168

aroma blanca, 156

aroma boba, 156

aroma francesa, 148

aroma mansa, 156

aromo, 14,168

arraijān, 412

arrạ̦án, 406, 432

a rra rån loboo, 432

arrête-boenf, 180

arriero, 4:s

arrogo, 3 ]4

Artocarpus altilis, 60

Artocarpus communis, 62

Artocarpus helerophyllus, 62

Artocarpus incisus, 62

Artocarpus integer, 62

Artocarpus integrifolius, 62

assacut, 278

assacú-rana, 194

Asterandra'grandifolia, 250

astromelia, 382

asubillo, 336

ata, 104

atadijo, 58

ataiba rosada, 46:2

a tapio, 246

a tauba, 246

a teje cima rron, 472,474

a teje de costa, $4(66,472$

ateje macho, 474

a tejillo. 472

atta, 3.s

Australian-pine, 48

a usú. 414

ausubo, 12, 444

aratí-timbatí, 370

Alircnnia germinans, 478

Avicennia nitida, 12,476

a rispillo, 116, 282, 458

avocado, 128

arocado, false, 122

avocado-rea r, 128

a vocat, 128

avocatier, 129

awacati, 128

axemaster, 320

a.

aรินีa amarilla, 230

azafrán, 52

azeitona hrava, 432

azeitona do matto, 432

azufaito 322

azulejo, 282

hacona, 264

Bactris acanthoplyulla, 36

háculo, 208

badana, 428

bádula, $430,432,434$

bala, 195

balata, 444

balata chien, 430

balata france 444

balata ronge, 411

balate, 444

balo, 198

balsa, $66,334,336$

halsa-wood, 336

balsam-tree, 238.352

bálsamo, 480

balso, 336

bamboe, 34

bamboo, 32, 34

bamboo, common, 32,34

bamboo, feathery. 34

Bambos, see Bambusa, 34 bambou, 34

bambú, 32,34

bambua. 34

bambulo, 206

Bambusa vulgaris, 32

bansau. wild, T0

barba de caliallero, 148

barba de jolote, 160

barba de leon, 156

barba di junkuman, 148

larba jolote, 160

barbasco, 362

baria. 350

bariaco, 254, 320

barillo, 350

bark-tree, Caribee, 508

bark, whitewood, 362

barka-locust 256

barredera, 370

barrehormo, 92

barril, 298

bastard-cedar, 340

batseed, 190

bauhinia, 168,170

bauhinia, Buddhist, 170

bauhinia, butterfly, 368, 170

Bauhinia kappleri, 170

Bauhinia monandra, 368

bauhinia, pink, 170

Baulinia variegata, 170

baujinia, 170

bay boom, 414

bay-cedar, 340

bay-cedar, wild, 58

barahon, 168

bayahonda, $15,166,168$

batarone, 168

basberry-tree, 414

bayberry, West Indian, 414

basito, 458

bayleaf, 414

bay-rum-tree, 414

baรúa, 230

bead-tree, 248

beadtree, sandal, 146

beautr-leaf, Brazil. 350

bebé, 206

bebé hoedoe, 206

beefrood, 48,92

beefwood, Australian, 48

beefwood, horsetail, 48

beera. 214

beetwood 298

Beilschmiedia pendula, 14, 130

bejuco inglés, 132

bella, 96

bellota, 340

ben, 134

ben oleifere, 134

benboom, 134

benzolirier, 134

Bequia-plum, 204

berraco, 58, 136

Beureria, see Bourreria, $\mathbf{4 6 6}$

bi, 512

bien restida, 198

bietahoedoe, 372

bigi boesie, 428

BIGNONYA FAMILT, 490

BIGNONIACEAE, 490

bija, 358

bijaguara, 316

bijote, 118

bilibili, 246

binorama, 144

birch, 238

birch-gum. 238

birchberry, 412 
birdseed, 478

birijagni, 316

biriji, 400

biritac, 50

bisenitwoud, 360

bilter-ash, 464

bitterbush, 234, 464

bitterbuslı, Florida, 234

hitters, 316

Bixa orellana, 358

BIX ACE.IE, 358

black-bircln, 412

black-cerlar, 122

hlack-ebony. 14s

black-ironwood, 320

black-mangroce, 476, 478

black-olive, 388

black-plum, 190

black-willow, 132

hlackbead, 162

blackbead, catclaw, 162

blackbead-t ree. 316

blackwood, Bombas, 174

blackwood-bush, 478

BLADDERNLT FAMILY, 300

bloodwood. 206. 298

bloodwood, swamp, 206

hlueberr' 5,456

hobbie, manja, 290

bocare, 194

boeloebarie, 214

bohum, 468

bois, 448

bois à agout i, 486

bois arada, 254

louis bale, 246

bois bleu, 456

bois blane, 4.56

bois butis, 430

bois bré, 474

bois cacá, 132

bois café. 268

bois canelle, $36^{\circ} 2$

hois canon, 68

hois capri battard, $466^{\circ}$

hois caraibe, 02

bois chandelle, 216,508

bois cIanclelle blanc, 216

hois chique, 112

bols cochon, 240

bois coton. 331

bois couclué. 298

bois crapand, 264, 511;

bois créole. 412

hois d'argent, 13:

bois d'Inde, 414

bois d'Inde Français, 414

hois d'oranger, 200

bois d'orme, 340

bois d'ortie, 482

bois de fer, $316,318,3: 0$

hois de fer ronge, 516

hois de hetre, $340,3 \% 2$

mois de l'ea u, 52

hois de liège, 326

bois de Rliodes. 46 i

buis de rose, $46 \mathrm{~S}$

bois de satanier, $30^{\circ}$

hois de soie, 58

bois diable, 282

hois doux, 120

bois doux jaune, 122

bois doux négresse. 116

bois doux noir, 116

bois doux piment, 122

bois du diable, 278

bois énivrant. 526

bois ferblanc, 316 hois fla mbea u, 216

hois fleche,, 10

hois fleurs jamnes, $50^{\circ}$

bois flot, 326,336

bois fourmi, 112

bois fragile, 52

bois galle, 158

hois gli-gli, 386, 38,

bois glu, 436

bois gri-gri, 386, 3s

bois gris-gris, $386,38 s$

bois immortel, 194, 196

buis jaune, 366,516

bois kaki, 436

bois lait femelle, 464

bois larlay, $47 \pm$

hois l'écorce, 158

hois lézald, 456

bois liège, 336

bois liêre, 336

bois-lolo, 156

bois mabel, 136

bois mabi, 316,318

hois madame, 514

bois marbre, 272

bois margot, $3 \$ 6$

bois mausseux, 308

hois montagne, 234

bois myrte, 406

bois négresse, 426

bois noir, 108, 132, 148, 444

hois noire, 514

bois noyer, 228, 232

bois olive, 190

bois olivier, $3 \$ 6$

bois nâle, 206

bois palmiste, 190

bois naulit, 472

hois pelé, 316

bois pine. 230

bois pini, 216

hois pistolet, 246

bois plomb, 432

hois poison, 234

bois noulée, 472

bois pripri, 336

bois ronge, 75,246

bois saint, 212

bois savanne, 432

buis savonette, 308

bis sẻnegal, 132

bois senti, 52

hois sitheur. 138

bois soumis, 468

buis $\tan , 256$

bois tan rouge, 138

hois trompette, 68

hois vache, 264

bois violet, 314

bois riolon, 116

boje, 504

hojón, 468

bolletrie 444

BOMBACACEAE, 332

BOMIBAX FAMIIY, 332

Bombax pentandrum, 334

bombilla, 62

bombón, 196, 360

hon ga rçon, 270

bonga, 334

bougo. 334

boniate, 116

boniato. 122

boniato Jaurel, 120

boonchi strena, 180

BORAGF, FAMILY. 466

IBORACINACESE, 466

boschkasjoe, 288 boschkatoen, 330

hoskoffe, 282

bospapaja, 68

bossoea, 232

bosi่, 232

bosน์a, 232

boszuurzak, 98

botija, 360

botoncillo, 390

bototillo, 360

bototito, 360

bototo, 360

botulo, 360

Bowreria domingensis, 466

Bourreria succulenta, 466

Bourreria succulcnta var. cancscens. 466

Bourreria virgata, 466

box-briar, 520

Brazilian-rose, 360

brazilleto, bastard, 138

brazilletto, wild, 138

bread-and-cheese, 162

breadf ruit, $60,62,404$

breaduut, 62

brenolli, 134

brésillette, 410

hribri, 152

brignolle, 400

brojo, 458

hroodboom, 62

broomstick, 252

broomwood. 254

browngum, 398

brucal, 192,196

bruca ro, 196

Brunellia comocladifolia, 14, 136

BRTNELLIA FANIILY, 136

BRI NELLI.1 CEAE, 136

hícar. 196

bucare, 192, 194, 196

bucare ellano, 190

lucare gigante, 196

bricaro, $19+$

bucago, 192

bucayo enano, 192

bucayo gigante, 15. 194

bucayo sin espinas, 192

Buccras bucida, 388

Buchenavia capitata, 14, 386

húcida, 388

Bucida buceras, 13, 388

Bucida capitata, 386

bucida, oxhorn, 388

huckbead, 146

BLCKTIIORN FAMILY, 316

BLCKWHEAT FAMILY, 76

buen pan, 62

indlet. 44

bulket-tree, 388

bulletwood, 14, 444

bulletwood, white, 442

bullock-luea rt, 102

lulltsre, 46

hull,

bull $r$-tree, $388,442,441,452$

bully-tree, savannah, 452

hullswood, 388

bumatell, 196

buriogre ama rillo, 472

buriogre de montaña, 472

Burma-rosewood, 204

hurro, 132

Iurro blanco, 132

burro mauricio, 94

burro prieto, 132

BIRSERA FAMILI, 236 
Bursera gummifera, $20 \mathrm{~s}$

Burstra olalifolia, 23 s

Bursera simaruba, 13, 236

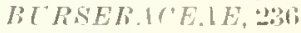

bustic, $41^{2}$

bustic, willow, 142

loutter-pea1", 1::

butterfig-flower, 170

button-mangrove, 390

huttonbush, $3 !)$

buttonwood, 390

buttonwood, white. 39$)^{\prime \prime}$

Byrsonima coriacea, 14, 256

Byrsonima coriurea var. swirata, 256

Byrsonima crassifolia, 2.06, 258

Bursonima cuncata, 2âti

Bursonima lorncana, 25fi

Byrsomima lucida, 256

Byrsonima oplilirola, 256;

Bursomima spicatu, 256i

Byrsonima uadsurorthii. 256

cabbage-bark, 190

cabellos de ángel. 148

cabimbo, 246

cabimo, 246,302

cabirma, 246

cabirma santa, $2+6$

cabo de hacha, 254

cabra, 5s, 136

cabrilla,

caca rat, 456

cacagua, 195

cacaguance, 198

cacaguillo, 340

cacaluanance, 198

racahuananche. 198

cacaillo, 122, 314, 321

cacaito, 340

cacalojoche, 462

cacalosichil, 4 (i)

cacalosochitl, 462

cacao, 104, 198, 342

cacao bobo, 314

cacao cimarrón, $314,3 * 4$

cacao motillo. 324

cacao rojo, $32 \%$

cacao roseta, 324

cacaotillo, 3:4

cacaoyer, 342

cacateiro, $34^{\circ}$

cachicamo, 350

cachiman cannelle, 104

cachiman coeur hoeuf, 10:

cachiman coeur-de-boenf, $10^{\circ}$

cachimbo, $196,46+5,520$

cachito de aromo, 144

CACTACEAE, 376

cactus, 376

CACTIS FAMILY, 376

(actuc, pipe-organ, 37 (i

cactus, tree. 378

cacri, 206

cadmia, $106^{\circ}$

Cacsalpinia ferruginca, 18:

cacsalpinia inrrmis, 15?

CAESALPIVIACE.IE, 16S

CAESALPITIOIDEAE, 16

café, 506

café cimarrón, $368,478,480,510,516$. 520

eafé de gallina, $36 \mathrm{~S}$

cafó excelsa, joci

café grand bois. 268, 516

(afé marron, $466,178,510,516$

"afé silvestre, 370

cafecillo, 510

cafecillo de danta, 510 cafèier, 506

cafeillo, 268, 36. 370,516

cafeillo cima rrón. $3 \bar{i} 0$

cafetillo, $368,510,516$

cafetillo de monte, 510

cafeto, 506

caguairán, 180

casuani, 454

caīmite, 438,448

caimite acoma, $\mathbf{4 5 4}$

cainuite marron, 440

caimitier, $\mathbf{4 3 8}$

cainitier bois, 436,448

caimitillo, $436,440,448,450$

caimitillo cima rrón, $\$ 50$

caimitillo de perro, 440

caimitillo verde, 450

caimito, 438,440

caimito blanco cimarrou, 436

caimito cima rrón, 140

caimito cocuro, 436

caimito (le perro, $\mathbf{4} 4$ )

caimito rerde, 436

caimo, $43 \mathrm{~s}$

caino morado, 435

cainit, 438

cainit, wild. 410

cainito, 498

caituco, 358

caiucára, 488

cajá, 294, 296

cajá manga, 292

ca jä-mirim, 294

cajá seira, 934

cajeta, 300

cajeto, 336

cajeton, 264

cajoba, 160

caju, 288

cajueiro, 288

(ajuil, 285

ca juilito sulimán. 404

calaba, $3 . \overline{0}$

calabacero, 400

calabasa, 490

calabash, 492

calabash-tree, 490,492

calabash-tree, common, 490, 492

calabazo, 492

calambreña, 81

calbás. 492

calbás rondo, $49^{\circ}$

(alebasse, 4 : 2

calebassier, $49^{\circ}$

Calophyllum antillanum, 35̈4

Calophyllum brasiliense, 12, 13, 348

caloplunlium brasilicnse var. antillanum, 350

Calophullum calaba, 350

Calophyllum jacquinii. 350

Calophullum lucidum, 350

CALTROP FAMIIL, 212

Calycogonium squamulosum, 1f, 418

Calyptracordia alba, 470

calyptranthes kiaershorii, 396

Calyptranthes krugit, 14, 396

Caluptrantiocs pallens, 396

Calyptranthes portoricensis, 398

Caluntranthes sintenisii, 336

Calyptranthes thomasiana, 398

camaguilla. 432,434

camajonduro, 340

cama jurú, $3 \pm 0$

camaron, 28

camaroncillo, 2

camaluca, 3.40

camasa, 492

camasey, 422 camasey blanco, 422

camasey cenizo, 424

canıasey de paloma, 420

camase jusillo, $\$ 18$

camasey negro, $\$ 18$

camasey peludo, 420

camba-acả, 340

cambagui, 370

cambrón, 111, 168, 180.520

cámbulo, 194, 196

came-marie, 350

camoruco, 310

campa ño. 164

canalete, $25 \pm, 468$

canalete de humo, 468

cananga, 106

Cananga blainii, 108

Cananga caribaea, 108

Cananga odorata, 106

Canangium odoratum, 106

candelillo, 502

candlewood, 216, 240,456, 514

candlemood, black, 120, 516

candlewood-tree, 302

caneel, 362

canéfice, 172

caléficier. 172

canela, 112, 118, 128, 362

canela blanca, 362

canela de la tierra, 362

canela del pais, 112

canelilla, 112, 36.

canelillo, 112, 11S, 126,414

canelito, 264

canella, 362

Canella alba, 362

canella, cinnamon, 362

CANELLA FA MIIY, 362

Canella winterana, 13, 362

CANELLACEAE, 362

canelle poirrée, 362

canellier bâtard, 362

canellier blanc, 362

canelón, 119, 434

canelón-puitá, 432

cane $\bar{x}, 458$

canilla de muerte, 50

canilla de renado, 480

canjuro, 148

cantagallo, 194

caña brara, 34

caña India, $3 \pm$

cañafistola, 170

cañafístula, 170

cañafistula cimarrona, 172

cañambú, 34

ca ีิaza, 34

caoba, 250,252

caoba americana, 250

caoba de Honduras, 250

caoba de Santo Domingo, 252

caoba del país, 30

caoba dominicana, 250

caoba hondurē̄a, 248, 250

caoba renezolana, 250

caobilla, 14, 30, 252

caoutchoue, 68

capa, 468,470

capá amarillo, 482

capá blanco, 482

caṕ cimarrón, 470

capá colorado, 472

capá de olor, 468

capá de sabana. 468,482

capá prieto, 468

capí rosado, 482

capá sabanero, 482

capá, wild, 472 
cape, 352

(al per, 132

('aper, liroadleaf, 132

(AI'ER FAMII, $13:$

caper, Jamaica, 132

cajer, limber, 132

capeltree. 132

('A 'P.LRIDACEAE, 132

Capparis buducea, 132

Capparix coceolobifolia, 132

Capparis cynophallophora, 13. 132

Capparis flcruosa, 132

Capparis intica, 132

Capparis jamaiccusis, 132

Cupparis portorice'usis, 132

(ด)

capulin, 58

capnlin blanco, 58

(afulin macho, 58

capulin montes, 5x

(apulin negro, 58

(apulin, white, 58

capulineillo, 58

carabalí, 161

(arabana, 436

carachuche, 462

('aracolî. 2:4

caracolillo, 254, 372

caractère des hommes, 170

(a racucha. 4 tid

(araicillo, 304

caramacate, 372

(ฉล raña, 236

(arapacho, :114

(ara ruclia hlanca, 462

rarate, 236

1:a ratero, 236

('a rboin, 168, 190

1:a rboncillo,, 02

('a rbonero. 132, 246.318

carbonero de costa, $31 \mathrm{~s}$

carbonero de sombrio, 148

cares de mota. 320,508

Carica papaya, 374

rARICA'EAE, 374

(i) rillo, 2S2

carue asada, 190

('arnestoleudas, 360

(arob, 180

"arolina, 442

(arrapeta, 254

iarreto, $\mathbf{1 6}$ is

carretón, 264

carruzo, 526

(:artahar, fi2

carubio, 232

(aruto, 512

'aruto rebalsero, 512

Caryophyllus jambos, 402

cascalata. 316

casca rilla, 322

cascarita, 364

cascarroya, 322

casco de mulo, 170

Caxentia aculeata, 364

Casearia arborea, 14, 364

Cuscuria bicolor. 364

Casearia decandra. 364,366

Casearia guianensis, 364, 368

Caseraria parrifora, 370

Cascaria ramifora, 308

Casearia sylvestris, 364,370

rasha, 144

cashar, 144, 168

cashew, 256, 288

(ashew-apple, 288

CASHEW FAMILY, 286 caslew-nut, 288

caslia, 144

eashu, 288

('isia, 17.

casia ama rillit. 148, 17t

casia de Siam, 174

casia rosada, 172

(asia siamea, 174

casita, 305

caspuroupsis monundra, 170

(assadia, 4 t:

cassada, wild, 112

(assadia-wood, 142

cassa veliout, 428

casse, 172

casse de Siam, 17

rasse-hubitant, 172

cassia, 141

cassia, apple-blossom, 172

Cassia fistula, 168, I70

Cassia grundis, 172

cassia, Jaranese, 172

Cassia jacanica, 168, 172

cassia, nodding, 172

Cassia nodosa. 172

cassia, pink, 172

cassia, pinkshower, 172

cassia, purging, 172

Cassia siamea, 168, 174

cassia, Siamese, 174

CASSIA SLBFAMILY, $16 \mathrm{G}$

cassia-stick-tree, 172

cassia, rellow, 174

cassie, 141

cassie-flower, 144

castaīa, 62, 394

castañeto, 278

eastaño, 62, 340

castaño del Malabar, 62

castañola. 394

Castilla elastica, 64

Castilla larlifua, 64

Castilla pannmensis, $6 t$

Castillou, see Castilla. 64

casu, 288

casuarina, 48

Casuarina equisetifolia, 48

CAST.ARIXA FAMILY, 48

casuarina, horsetail, 48

CASTARINACEAE, 4.

('asuarine, 48

catahua, 278

catalpa, 330

catamericucle. 360

catí uí, 278

catclaw, 162

eatoche, 100

catuche, 100

catzimec, 168

cauchera, 6 it

caucho, 64, 6s

caucho le la India. lix

caucho negro. G4

(aulote, 340

casa amarilla, 4.54

(a)a colorada. 442

(ayepon, 458

capiera, 492

(azabito, 254

cazuarina, 48

ceboruquillo, 312

Cecropia asperrima, is

Cecropia peltata, 14, 66

ceda, 105

cedar, 241

("eder, $24 t$

cèdre, 244

cèrłre espagnol, 24 celrela, cigarbox, 244

Celirela mericana, 244

Cedrela odorata, 13, 14, 242

Cedrcla sintenisii, 244

cedrillo, 246, 254, 300

certro, 244, 290

cedro amargo, 244

cedro amarillo, 24t

cedro blanco, 244

cedro caoba, 244

certro clavel, 244

cedro colorado, 241, 254

cedro de Castilla, 24t

cerlro del pais, 241

cedro dulce, 244,246

ceđro español, 244

cedro espino, 254

cedro hembra, 242, 24t, 300

cerlro heinbra del pais, 244 ,

cedro macho, 110, 244, 246. 278

certro mexicano, 244

cedro oloroso, 244

cedro prieto, 290

cedro real, 244

cellro vermelho, 244

ced rohs, 246

cedrón, 246

ceiba, $278,332,334$

Ceiba anfractuosa, 334

ceiba blanca, 278

Ceiba caribaca, 334

ceilua de Garzón, 334

ceiba de lana, 334, 336

ceiba de leche, 278

ceiba habillo, 278

Ceiba occidentalis, 334

Ceiba pentandra, 13, 332

Cciba pentandra rar. caribaea, 334

ceibo, 194, 196, 33t

ceibo amarillo, 278

ceibón botija, 336

cenícero, 164

cenizo, 230, 424

cenizoso, 422

Central-American-cedar, $24 t$

Cephalocereus royenii, 13,376

Ceratonia siliqua, 180

cerdant alliodora, 468

cerecillo, 466

cereus royenii, 376

celeza, 2s0, 372

cereza amarilla, 280

cerezas blancas, 470

cerezo, 366,472

cerezo agrio, 280

cerezo de Casena, 400

cerezo del pais, 472

cerillo, 508

ceriniva, 58

cerrillo, 314

ceuf de poule, 158

chabark. 160

chaca, 236, 238

chacalte, 250

chachá, 148

chichiga, 442

charlèque, 224

chagualito, 434

cliajada a marilla, 206

chancán, 162

chancaro blanco, 428

chandelle anglaise, 50 ,

changugo, 258

cliaparro, 258

chaparro de chinclie, 256

chaparro de sabana, 25.8

chaparro manteca, 258

chaparro manteco, 258 
chapéo de sol, 394

chapernillo, 150

"haperno, 190

chaquira, 316

chaquirillo, 282

chaquirio, 310

chataigue, 62

chatraignier, 62,324

châtaignier du pars, 62

châtaignier petit coco, 324

clusa. 35

checker-grape, 84

chêne calebassier, 482

chêne caparo, 468

chêne Guadeloupe, 394,47s

chenet, 306

cherry, 288

cherry-grape, 81

chevalier, 502

chi, 258

chic-chica, 236

chicha, 340

chicharro, 386

chicharrón. 340

chicharrón de monte. 514

chicle, 446

chicory-grape, 84

chicozapote, 446

chilca, 502

chilillo, 216

china, 220, 226

china dulce, 226

chinaberry, 246,248

chinaberrs, umbrella, 248

chinacahuite, 236

rhinacuite, 230

(dinatree, 248

chininango, 162

chinkswood, 466

(hino, 236

chino dulce, 226

chioué, 238

chirai, 190

chirimoya, 102, 104

chirlobirlos, 502

chirmosa, 104

CHLORANTIICEAE, 52

CHLORANTHES FAMILY, 52

cho, 360

(")ocho, $30 \mathrm{~s}$

CHOCOLATE FAMLY, 338

chocolate-tree, 342

choks-apple, 452

(holân, 502

(honcho, 208

rhorio, 5 t

chorote, 305

('hote, 264

(hou palmiste, 42

Christmas-hope, 502

Christ nas-tree, 48,520

Chrysophylluni argenteum, 436

Chrysophyllum bicolor, 440

Chrysophyllun cainito, 436, 438

Chrysophyllum eggersii. 440

chrysophyllum glabrum, 436

Chrysophyllum oliviforme, 436, 440

chrysophyllum paucifiorum, 43 i

chuchi copei, 352

chumbimbo, 308

elnumbino, 308

churrusco, 58

chuun, 360

ricca acida, 280

Cicen histicha, 2s0

rist ra, 218, 222

cieneguillo, 400, 410

cigarbox-cedar, 244 cigua, 116

cigua ama rilla, 110,116

cigua blanca, 116

cigua boba, 122

cigua laurel, 122

cigua prieta, 114

eiguamo, 320

ciguarayo, 132

cillament, pepper, 116

cilliment-bush, 362

elliment, wild, 414

cina-cina, 180

(incahuite, 392

rincho, 200

Cinchona, 508

cinnamomo, $24 \mathrm{~s}$

cinnamon, 414

cinnamon-bark, 362

einnamon. pepper. 362

cinnamon, wild, 362,414

ciprés, 48

ciralillo, 314

Circassian-bean, 146

Circassian-seed, 146

cirián. 490

ciroela, 294, 296

cirouelle, 296

cirtuela, 296

cirtlela amarilla, 204

ciruela campechana, 296

cirnela colorada, 296

ciruela de jobo, 294

ciruela de monte. 294

ciruela del país, 296

ciruela dulce, 292

cirvela morada, 296

cirtlela sanjuanera, 296

rirmelillo, 386

(ciruelo, 296

ciruelo colorado, 296

citara. 292

Citharexylum caudatum, 476, 478

Citharexyfum fruticosum, $13,476,47 \mathrm{~s}$, 480

Citharerylum spinasum, 480

cit ron, 218

rit ron commun, 218

cit ron doux. $21 \mathrm{~s}$

("it romier, 22!

citrus, 218

Citrus aurantifolia, 216. 218

Citrus aurantium, 216, 220, 226

Citrus bigaradia, 220

Citrus dopumana, 224

citrus gruntis. 218, 222, 224

c'itrus limu. 218

Citrus limette. 218

Citrus limon, 216, 222

Citrus limonir. 222

citrus limonum, 222

Citrus maxima, 222, 224

Citrus medica, 218

Citrus nobilis. 218

Citrus paradisi, 216, 224

Citrus roticulata, 218

Citrus sinensis, 216, 226

Citme vulgaris. 220

clammy-cherry, wild, 474

rlamor, 330

clavellina, 298

clavellino, 176

clawberrs, 282

clemón. 330

Clibadium erosum, 526

clusia, copey, 352

Clusin gundlnchii, 350

Clusia krugiana, 14, 348, 350

Clusia minor, 350
Clusia rosea, 13, 348, 352

coabanilla, 184

cóbana, 184

cóbana negra, 184

cóbano, 244

cobreque, 208

coca, 210,344

COCA FAHILY, 210

cocaina falsa, 210

Coccoloba borinquensis. so

Coccoloba costata, 78

Coccoloba diversifolia, 13, 76

Coccolobr grandifolia, 78

Coccoloba krugii, 80

Coccoloba laurifolia, 76

Coccoloba microstachya, 80

Coccoloba nivea, 84

Coccoloba obtusifolia, so

Coccoloba pubescens, 13, 76, 78

Coccoloba pyrifolia, 80

Coccoloba rugosa, is

Coccoloba rupicola, 78

Coccoloba sinterisii, 76

Coccoloba swartzii, 76,80

Coccoloba uvifera, 12, 76, 82

Coccoloba venosa, 13, 76,84

COCHLOSPERMACEAE, 360

cochlospermum, 360

COCHLOSPERMIJ FAMILY, 360

Cochlospermum hibiscoides, 360

Cochlospermum vitifolium, 360

cocito, 360

cock-tree, 194

coco, 40,340

coco da India, 40

coco de agma, 40

coco de Bahia, 40

cocoa, 342

cocoa-mamma, 196

cocoa-shade, Nicaragua, 19s

cocoa, wild, 314

cocoite, $19 \mathrm{~s}$

cocojoro, 130

coconut, 38,40

coconut-palm. 40

cocos, 40

Cocos nucifera, 34,38

rocospalm. 40

cocotero, 40

cocotier, 40

rocoser, 324

соси. 190

cocuso, 320

coeur de boeuf, 102

Coffea arabica, 506

Coffen acuerrei, 506

coffee, 196, 198, 506

coffee, Arabian, 506

roffee. Dewerre. 506

coffee-mamma, 196

coholoa, 158

roil, 392

cojoba, 158,160

Cojoba arborea. 160

cojóbana, 158, 160

(o) jobanilla, 160

cojobillo. 158

cojobo, 158

cojón, 350

cola de pavo, 254

colibri végétal, $20 \mathrm{~s}$

colla rete, 478

collier, 160

(')lorado, 298

Colubrina arborescens, 13, 316

colubrina, coffee, 316

Colubrina colubrina, 316

Colubrina ferruginosa, 316 
Colubrina reclinata, 316,318

('O.1I BRET 1CEAE, 386

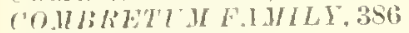

comecarí, 400, 412

comiual de culebra. 370

('0.1/POSTT.1 E, .

COMI' ISITE FAIILI, 5*6

concha de paneque, 232

congo, 190

(o)

Conocarpus erectus, 12,390

Consolea rubeserns, 378

contamal, 310

copal, 180

(')palcbe, 508

(roluete, 502

(a)e 352

copinol 180

copon, 236

copper, blue, 514

contueiro de Bahia, 40

corpuelicot, 146

coquemulle, 322

coraç̃o de boi, 102

coração de negro, 14 S

coracão de rainlsa, 100

corail végétal, $1+6$

coral, 146

coralbean. 192

(oralbean, common, 192

coralillo, $146,192,370$

(ora)iu, 146

coralitos, 146

corallero, 520

roraltree, 192

corazón, 102

corazón cimarrón, 98

corizón de pil loma, 316,372

corcho, 88,90,92, 336

corcho blanco, 88,90

corcho bobo, $\$ 8$

Corlia alba 470

Cordia alliodora, 14, 466, 468

Cordia borinquensis, 14, 466,470

rordia collocoeca. 472

Comlia dentata, t70

Cortia glabra, 472

Cordia nitida, 13, 466, 472

cordia, onion, 468

Corlia rickscekeri, 470

Corlia sebestena, 470

Cordia sulcata, 14, 466, 474

cordobán. t2s

cordoluncillo, , ri2n

corduncillo, 50

(ordoneillo blanco, 50

(')ribee, 502

cork-tree. 330

cork-tree, filse, 336

iorkwood. 206.336

corkwood-tree, Australian, 208

cornwood, 190

corolore, 1 so

coronel, 320

(orussol, 100

(orossol zombi, as

(orossolier, 100

corozo, 34

corta lingua, 370

costex, 316

costilla de rlanto, 428

coto. 200

coton fleurs, 336

coton marron, 326

cotorrelillo, 366

cotton-tree, 334,336

cotton, wild, 326 courbaril, 178, 180

conricla, 478

cow-t:1untind, 16 t

cowbush, 156

cowee, 206

cows-font, 50

roxté, 311 i

cosora, 36

coyore, 36

cosur, 98

corure. 36

crabo, 258

craboo. 258

craboo, wild, 258

crabwood, 272

crack-open, 370

crapemyrtle, common, $35^{\circ}$

crapemyrtle, queen, $35^{\circ}$

crapenyrtle, tree, 382

crapoo, 258

craw-wood, 514

cremón, 330

Crescentia cujete, 490

Crescentia linearifolia, 492

cresta de gallo, 208

Critonia portorictnsis, 526

(roc-ì-chien, 520

Croton poecilanthus, 14, 262, 266

crucete, 520

cruceto, 520

erucilla, 520

crucito, 520

cruda, 475

('uaba cle costa, 216

cuabllla, 216

cuajachole, 358

cuajo, 29.4

cuapaste, 200

cuapinol, 180

cucharo, $352,434,492$

cucheme, 236

cuchiú, 352

cucubano, 514

cucuna, 488

cueriduro, 265

cuerno de bues, 316

cuero de sapo, 508

enida, 168

cuilimbuca, 100

cuité, 492

cujete. 490

cuji, 168

euji a romo, 144

cuji carora, 168

(uji cimarrón, 144

cuji extranjero, 180

(uji nesro, 168

cuji saque, 168

cujinicuil, 150

culche, 244

culumate, $\$ 78$

CUNONIA FAMILY, 138

CUNONLACEA, 138

(1untich, 144

Cupania americana, 14, 302

Cupania triquelra, 302

cupeillo, 350

cupeillo de altura, 350

cupey, 352

cupes de altura, 350

cupes trepador, 350

cura, 128

curabara, 122

curaboca, 466

curavara, 110

cúrbana. 362

curbaril, 180

curtidor, 138 curuba, 1.58

custard-apple, 102

('utlass, 46 it)

curá, 44:

curis, 308

Cyathea arborea, 14, 25

Cyathca brittmiuna, 28

Cyathca pubeseens, 28

C Y $A T H E A C E A E, 28$

c.y), 468

cylire, $46 \mathrm{~s}$

cruress, 468

crrilla, American, $29 \mathrm{~s}$

cyrillu antillana. 298

CIIILLA FAMILY, 298

Cyrilla racemiftora, 14,298

cyrilla, swamp, 298

CYRILLACEAE, 298

crsba, 334

Dacryodes excelsa, 14, 238

Dacryodes hexandra, 240

dajao, 516

lakara, 434

dalemarie, 350

dam machu, 352

dama, 478

damage, 350

dama jagua, 320

Daplinopsis amcricana, 380

Daplmopsis amcricana subsp. caribaea. 380

Daphnopsis caribaca, 380

Daphnopsis helleriana, 380

Daphnopsis philippiana, 380

deux jumelles, 170

Delonix regia, 168,176

Dendropanax arboreus, 14, 426

Denilromana laurifolius. 426

Didymopanax morototoni, 14, 68, 426, 428

dildo, 376

dilenia, 344

dillenia, 344

DILLENIA FAMILY, 344

dillenia, India, 344

Dillenia indica, 344

$D I L L E N I$ CEAE, 344

dills, 446

dinner-bell, monkes, 278

Dipholis bellonis, 412

Dipholis cubensis, 442

Dipholis salicifolia, 13,442

Dipholis sintcnisiana, 442

doctor-bar, 234

dog-almond, 190

clog-plum, 190

DOGBANE FAMILI, 460

(logwood, 200

dogwood, swamp, 200

doifiesirie, 246

dombou, 254

doncela, 258

doncella, 256, 304, 460

dondequiera. 370

dormilon, 148, 164

double-coconut, 38

douleur, 518

dove-wood, 264

doveplum, 76

downtree, 336

drago, 206

dreifi, 82

dreifi di laman, 82

druif, $\$ 2$

drumstick-tree, 134

Drypcles alba, 268

Drypetes glauca, 14, 262, 268 
Drunetes iticifolia, 26s

Diendetes laterifora. 268

duckworkel, 123

East-Iudian-waInut, 148

elons, mountain. 316

elonv. wild, 316

ELAEOC'1RPAREAE, 321

EIAEOCARPIS FAIIIIV.3:4

Elawhrium simaruba, „3s

elder, is

eluel, spanish, 50

elerueme, 192

แha. Simanish. 50

ELII I 1 MIII, J6

ells, 50

emajagua, 15, 92, 326

enajagua brava, 340

enajagua de sierra, 350

emajagiiilla, 330

emperatriz de la selva, 360

encinilla, gis

encinillo, 138

endurece naiz, 132

enrubio, 232

Entcrolobium saman, 16ti

erutumal. $5 \mathrm{~S}$

erutia, 5s, 48S

Erythrina berteroana, 1Ss, 190

Erythrinu ruralloriculrum.192

Erythrina colorsii, 192

Erythrina glauca, 188, 192

Evuthrimu horrida, 192

Erythrina micropteryx, 196 .

Erythrina poeppigiana, 15, 18., 194

ERTTHROXILACE.1E, 210

Erythroxylon areolatum, 13, 210

Erythroxylon brexipes. 210

Erythroxylon cora, 210

Er!ythrosuton rotumifolium, 2I0

Eryitiroxylon rufum, 210

erytlroxylon, thin-leaf, 210

excambrón. .120

escamblón colorado, 16:2

escanjocote, 306

sxcoba, 304

("spadero, 432

expatollea, 494

exicjuelo, 320,442

asrinal, 114

espillillo. 144.150.226

"spino, 144, 162, $230,23,2$

expino Hlanco, 141, 232

espillo cruz $\div$ - 20

espino rubial, $228,230,232$

espino ruco. $14 t$

espinosa, 230

esponjeira. 144

ritribo, 92

eucalipto, 398

eucalipto acluatado. 39s

eucalipto común, 398

eltealirtu (le vantano, 398

eucalinto del alcanfor, 398

(4llealspt, $32 \mathrm{~s}$

eucalyntus. 398

eucalyptus, beakpod, 398

Encalyptus multifiora. $39 \mathrm{~s}$

Eucalyptus robusta, 396, 398

('ugenia. $\mathbf{4 0 0}$

Eugenia aeruginea, 396. 400

Eugenia arillaris, 400

Eugcnia bellonis, 400

Eugenia bifora, 400

Eugenia bouncronensis, 400

Eugenia borinquensis, 14, 400

elgenia, boxleaf, 400

Eugenia burifolia, 400
Eugenia confusa, 400

Engenia cordata, 400

Eugenia corozalcusis. 400

Eugcniu domingchsis, 400

Eurenia cagersii, 400

Eugcnia foribunda, 400

Eugchia fragrans, $4(x)$

Eugenia jambos, 1.̄, 396, 402

Enucnia lancea, 400

Eugenia ligustrina, 400

Eugenia malaccensis, 301, 404

Eugenia manticola, 400

Eugcnia murtoides, 400

Engcnia procera, 400

Euycnia uscuaopsiaium, 400

engenia, redbel's, 400

Eugenia rhombea, 396, 406

Eugenia serrasucla, 400

Eurrnia sessitifora, 400

Engchin sintenisii. 400

eugenia, spiceberry, 406

Eugenia stahlii, 396,408

Eugenia sterarlsonii. 400

Eugcria underumortii, 400

Eugchia unifora, 400

engenia, mbite-stopper, 400

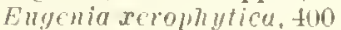

ellgerio. 300

Eupatorium portoricense, $5: 26$

Euphorbia petiolaris, 262, 270

EUPHOREI ICEAE, 202

Euterpe globosa, 14, 34, 40

Exostema caribaeum. $-104,508$

Exostema fliption, .50

Errostemu sanctar-luciac, 5ox

Eyscminaritia polyxtachy

$F+B A C E A E, 18 S$

Fu!lara caribaca, 228

Fandra fara. 2:s

Fa!nun matinicensis, 230

Fa!lara momophylla, 232

Fugara trifoliata, 208

false-colfee, 510

false-gl:ape, 81

false-mahogany, 100

false-maney, $3.0,352$

false-mastic, 454

Faramea occidentalis, 504,510

Faramea oduratissima, 510

terrl-tree, 492

feuille disepe, 448

Ficus brerifotia, 70

Firus citrifotia, to

Ficus cressincria, $\mathbf{7 0}$

Ficus elastica. 68

Ficus laevigata, 70

Firns luevigata var, brerifulia, To

Firns lacrigata var. lentiginosa, in

ficus lentivinnsa, in

Fieus nitila. T2

Ficus obtusifolin, i:-

Fiens perforata, $7 t$

Ficus nopuluca, to

Ficus populnca var. brerifolia. 70

Ficus retusa, 72

Ficus sintenisii, 74

Ficus stahlii, 70

Ficus trigonata, 70

Fires urbaniana, 72

fiddlemoon, 475, 480, 482, 4sti

fiddlewood, black. 486

fiddlewood, Florida, 480

fiddlewood, pasture, 480

tildlewnod, racennse, 478

fiddlewool, spicate, $4 \mathrm{SO}$

fiddlewood, timber, 486

fiddlewood, white, 486 fig, 72

fig, India-laurel, 72

fig, India-rubber, 68

fig, shortleaf, 70

fig, shortleaf, wild, 70

fig, white, 70

fig, wild, 70

figuier, 70

figuier banian, 70

figuler blanc, 70

tiguier marron, 352

figuier maudit, 70,352

figuier maudit cinarrou, 352

filao, 4

fishing-rod, 520

Fishlockia ancgadensis. 144

FLACOLRTIA FAMILY, 36-

FLACOLRTI.1CEAE. 364

flambollain amarillo, 174

flamboyán, 176

flamboyán amarillo, 182

flamboyan azul, 492

flamboyån blanco, 170

flamboyán colorado, 176

flamboyín cubano, 170

famboyin extranjero. 170

flamboyin rojo, 176

flamboyant, 176

flamborant bleu, 492

flamboyant-tree, 176

flamboy ant, yellow, 182

flame-tree, 176

flamingo-bill, 208

fleur-papillon, 208

flor amarilla, 502

flor blanca, 402

flor de cuervo, 462

flor de ellsarta, 462

flor de fuego, 176

flor de la cruz, 462

flor de la reina, 382

ffor de maso, 1SO, 462

flol de paraiso, 245

flor de paro, 176

for de raso, 180

fur de toro, 462

forestina, 148

forteventura, 200

fortuga, caspi, 366

fountain-tree, 494

FOUR-O'CLOCK FAMILY, SS

flambopán, 176

frambotán azul. 492

frangepane, red, 462

frangelane, white, 460

frangij:uponje, 462

frangipan, 402

frangipani, 460, 462

frangipani, Mexican, 462

frangipani, nosegay, 462

frangipani, red, 462

frangipani, white, 462

frangipanier, 462

frangipanier blanc, 462

frangipanier rose, 462

frangipanier rouge, 462

frangipanier saurage, 460

fransi mope, 202

French-easher, 404

frescura, 330

fresnillo, 502

fresno. 502

fresno americano, 502

frijol, 132

fúijolillo a marillo. 200

fromager, 334

fromager mapou, 336

fromagier, 518 
fructa pão, 62

fruit a pain, 62

fruta de conde, 104

fruta bomlua, 376

fruta de cater, 466

fruta de loro, 246

fruta tle paloma, 76,210

fivta de pan, 62

fuego, 316

fuelle "anelle, 434

fustic, 202

gaeta, 254

gaīac, 212

gaïac blanc, 211

ga ĩc femelle, 214

gaiac frane, 212

gaìc mâle, 212

gajigua, 254

galba, 350

galba odorant, 350

valipee, 426

gallimero, 162

gallitu, 192, 194, 208

gallito blanco, 208

gallito colorado, $20 \mathrm{~s}$

gamo de costa, 280

gilque, 352

garbancillo, 2it

gardenia hedionda, 518

gargorílu, 42s

garrocho, 336

gatillo, 336

Gaussia attenuata, 13, 34, 42

ga rilín, 428

Geiger-tree, 170

gemberhout, 356

gêne-pas, 512

genip, 306,512

genipa, 512

Genipa americana, 13, 504, 512

Genipa americana var, caruto, 512

Grnipa caruto, 512

genipap, 512

genipipo, 512

gévipayer, 512

genipt ree, 512

genizaro, 164

geno, 200

genogeno, 200

geo, 122

geo-geo, 122

Froffroyn inermis, 190

gia mausa, 366

giant, 176

giant-tree, 176

gigualti, 512

Gilibertia arborea, 426

ginep, 306

ginger-thomas, 502

GIXSENT FAMILY, 426

gitó, 246

gliceridia, 198

gliricidia, 195

Fliricidia maculata, 198

Gliricidia sepium, 188, 196

gloria, 502

goajiro, 180

gobiabiera, 416

goeaana. 460

gueanzona, 3 t)

goea jaaba, 416

goejaba, 416

goesberie, 280

goiaba, 416

golden-apple, 292

golden-shower, 170

soldenleaf, 438 goma, $6+$

gomil arnibiga, 144

goma elástica, $6 \mathrm{~S}$

goma elemi, 238

gombo-limbu, red, 238

gomme mombin, 238

gommier, $236,238,240$

gommier à canot, 240

gommier barrière, $23 \mathrm{~s}$

gommier blane, 235, 240

sommier, drf-land, 238

gommier encens, 240

yommier maudit, 228

gommier montagne, 240

nommier, peelinar-hark. $28 \mathrm{~S}$

nommier ruuge, 238

gongolí, 426

wroseherr, 250, 282, 44

yooseherr. false, 282

gooseherrs-tree, 280

gooseberry-tree, Otaheite, 280

zooseberry, wild, 2s0

gouannegoul, $166^{\circ}$

govare, 416

goparier, 410,416

goyavier à fruits. 416

moravier bîtard. 514

covarier queue-de-1'at, 410

graine canique, 308

graines bleues, 456

xraines rertes, 314

wraines violettes, 311

grains de lin pays, 1,if

grajo, 400

GRA IIINEAE, 32

granadillo, 386

gramadillo bobo, 156, 422

sranadillo de clavo. 372

irranadino, 156

granado, 295

graud mahot. 326

grantl mapom, 474

traple, 82

grapefruit, 224

GRASS FIMILY, :3:

gravióla, 100

grasumo hembra, 68

greenheart, 316.514

greenheart, Demerara, 514

gregre, 388

greif ruta, 224

gri-gri, 386,288

grignon, 388

grijze mangel, 390

gris-gris des montagnes, 388

gros mahaut, 330

grosella, 280

¿rosella blanca, 280

wrosella de Nien ragua, 280

gross grain, 211

guaba, 154, 312, 506

guaba del paîs, 154

suaba nativa, 154

guaca 1,490

gluacamaya, 176

guaca ma yo, 176,190

guacharaco, 302

guachimol, 162

guácima, 338

guácima cimarrona, 338

guácima de caballo, 33 .

guacimilla, 58,468

guacimilla boba. ER

guacimilla cimarroma, is

quacimillo, 340

guácimo, $33 \mathrm{~s}$

guácimo blanco, 340

guacimo de temero, 340 guaconejo, 216

guaguasi, 364

guaiaco, 50, 212

Guaiacum guatemalense, 214

Guaiacum officinale, 13, 212

Guaiacum sanctum, 13, 214

guaicaje, 282

guaira je, 406

guaita, 254

guaitil, 512

guaitil blinco, 512

Guajacum, see Guaiacum, :21.

guajanilla, 372

guaje. 156,490

guajón, 110

guamá, 150, 154, 506

guamá americano, 162

guamá de costa, 200

guamí de Puerto Rico, 150

guamí macho, 200

guami peludo, 152

guamá venezolano, 152

guamá zapatero, 294

guamacho, 162

guamo blanco, 162

guamo guarå, 302

guamo matias, 302

guamuche, 162

guamuchil, 162

guanaba, 100

guanábana, 98,100

guanábana cimarrona, 98

guanábana de loma, 98

guanábana de perro, 98

guallabano, 100

guanandi, 350

guaney, 458

guaugo, 164, 166

guano, 334, 336

guao de costa, 200

guapaste, 200

guapinal, 180

suapinol, 180

guara, 302, 304

guara blanca, 302

guara común, 302

guaraguaillo, 246

guaraguao, $244,386,388$

guaraguao macho, 246

guarín amarillo, 502

guárana, 302

guhrana hembra, 302

guárana macho, 302

guaranguarán, 502

guarangua, amarillo, 502

guaranguay hlanco, 502

guảrano, 302

guarapo, 8

guarataro, 282

guarda-sol, 394

Cuarea guara, 246

Guarea ramiftora, 246

Guarea trichilioides 14, 242, 244

guarema, 234

guarmuche, 148

guarumo, 68

guasábara, 400

guásara, 400

guxisima de pinares, 136

guasimilla, 56, 36t

guassatunga, 370

guatafer, 320

guatapaná, 168

Guatteria blainii, 14, 108

Guatteria caribaea, 108

guara, 272, 416

guava, common, 416

guava, serrette, 400 
guava, wild, 412, 416, 514

guave, 416

รัuavo, 150

guayaba, 274,416

guaraba perulera, 416

gua fabacos, 350

guayubacón, 254,400,410

gua yabilla de costa, 406

guayabillo, 316,370

gnarabito, 370

guatabo, 416

guayalo dulce, 416

gua, $7 a b o n, 76$

guayabota, 400,408

guasarote, 314

guayacán, 212, 214

guayacín blanco, 162, 212, 214

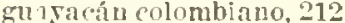

guayacín congo, 190

guasactil de playa, 212

guasacin de vera, 214

guayacín negro, 212

guayacneitio, 214

guafacanejo, 76

guaraco, 212

gua yara, 416

guayo blauco, 480

guaso prieto, 482

gua บuyo. 50

guasuro błanco, 50

guazatumba, 370

guazuma, $3+0$

Gua zuma gua $\approx m+340$

Gluasma tomentosa, 335,340

Guazuma ulmifolia, 13, 338

Guazuma ulmifolia rar. tomentosa. 340

guẻ-gué, $35 S$

gner'rero, 526

Guctlarda cllintica. 514

Guellarela krmgii, 514

ructaria lacris, 511

Guettarita oralifolia. 514

Guellarda parvifora, 514

Guettarda scabra, 13, 504, 514

Guianaplum, 268

guiliqueme, 194

guinda, 280

guira, 490

giiire, 492

giiirit, 308

guitarero, $42 \mathrm{~S}$

yum-alabic. 144

cum-elewi, 238

gumbo-limbo, 236, 238

gumtree, 235

GITTIFERAE, 348

guyaba. 416

Gymnanthes lucida, 13, 262. 272

haba. 278

habilla, 278

halbitlo, 278

II acmoch aris portoricensis, 346

luaiti-baiti, 330

laiti-haiti, purple, 328

lin rklis, fellow, 232

lat-palm, Puerto Rico, 46

hasa, 108

hata blanea, 108

haya minga, 108

hediondilla, 156

II du igia batsamifera, 240

Hedyosnum arborescens, 52

helecho, 2s

helecho á rbol, 28 helecho a rbóreo, 25

helecho gigante, 28

Hemitclia, 28

flercules, sellow, 230

HERNANIIA FAMILT, 130

Hermandiu guianensis, 130

IIernandia sonora, 13, 130

HERNANDILEAE, 130

besito, 508

IIeterotrichum cymosum, 14, 418, 420

lêtre gris, 340

liêtre vert, 340

Her"ea, 64. 68

lnibiscus, Chinese, 328

Ilibiscus clat 11,826

Hibiseus eseulentus, 328

hibiscus, linden, 326

libiseus rosa-sinensis, 328

hibiscus, sea, 326

Hibiscus tiliaceus, 15,326

hibiscus, tree, $3 \geq 0$

hicrquillo, 140

hicha. 256

II ieron!ma, see 11 ycromima, 278

hierro negro, 210

higuera, 68

higuerete, 428

higüierillo, 486

higiterito, 492

higuiero, 490

higuillo, 50, 70, 252

higuillo hoja menuda, su

higuillo prieto, 74

Hippomane mancinella, 202, 274

bieluillo, 510

Hirtella rugosa, 14, 140

II irtella triamira. I 40

hoba, 294

hobo, 29t

hobo eolorado, 296

hoe-stick-woorl, 84

hogberry, 250

hog-herry, bastard, 28?

hogplum, 294. 296

hoja tamal, 130

hoịa menuda, $400,406,412$

hojancha, 78, 12.

hojita larga, 432

holia. 256

hollyhock, 256

Homulium liemistulum, 37:?

Homalim leiogymm, 372

Homalium blciandrum, 372

IIonalium racemosum, 14, 364, 372

Honduras-cedar, 244

hones-mangrove, 478

honey-tree, wild, 366

hooboo, 294

hom-tree, 248

lori, 258

hormiguero, 468

horsebean, 180

horseradish-tree, 134

HORSERAIISH-TREE FAIILY, 134

horsetail-tree, 48

huacimaro-chico, 164

huampo, 336

luaranga, 144

luvaranhua, 502

lutbu. 294

huesillo, 458

luesito, 368, 510

hueso, 234, 265, 458, 510

hueso blanco. 458

luneso de tortuga, 320

huevo de gallo, 464

II"felamilia pendula, 110

huimba, 360 buingo, 492

buira-palto, 128

huiril, $30 \mathrm{~s}$

huisiche, 144

huito. 512

hukup, 23.9

hule. 64,6 s

liura, 276, 278

II ura crepitans, 262,276

II ra polyuntra, $27 \mathrm{~S}$

hura-wond, 278

huria, 255

Ilyeronima raribaca, 278

Hyeromima clusioides, 13, 262, 278

Hyrronima jumnicensis, $27 \mathrm{~s}$

Hymenaea courbaril, 13, 16S, 178

ibbi-hanaru, 412

iho-ink, 512

Iracorea ylawcifora, 430

learoren guadulupensis, 430

icaquillo, 140

igarata, 68

iguaneco, 478

ilán-ilán, 106

ilang-ilang, 106

imbuzeiro, 292, 2966

immortel blane, 194

immortel étranger. 494

immortel jaune, 196

immortelle, locare, 194

immortelle, wois, 194, 196

immortelle, mountain, 194, 19;

immortelle, swamp, 192

immortelle, water, 194

incense-l ree, 238

indano, 205\%

inclano colorido, 256

Indian-almond, 394

Indian-laurel, 72

Indian-mulberry, 518

indien nue, 238

indigo-berry, 520

indio, 210

indio desnudo, 236, 270

indju, 16.8

inga dulce, 162

Inga fastussa, 152

lnga inga, 154

Inga laurina, 14, 142, 150, 500

Inga quaternata, 142. 152

Inga roussoviana, 152

Inga speriosissima, 152

Inga cera, 142, 154, 506

inkbers, 520

irasol. 512

irayol de loma. 512

ironberrs, 320

ironwood, $320,458,508$

ironwnod, pine-ridge, $\mathbf{4 5 8}$

istaten. 478

iumanasi, 340

Ixora ferrea, 504, 516

jabilla, 278

jabillo, 278

jabon-ché, 308

jaboncillat. 308

jaboncillo, 308

jaca, 62

jácana, 452

jacaranda, 492

Jacaranda acutifolia. 492

Jacaranda mimosifolia, 492

jaca re-\{́ba, 350

jacatirão, 422

jacinto, 134,248 
Jack. 62

jackfruit, 62

jack-iu-the-beanstalk, $20 \mathrm{~s}$

jack-in-the-box, 130

jacocalalu, 335,340

jacocalalı, false, 58

jagua, 512

jagua amarilla, 512

jagua blanca, 512

jagua colorado, 512

jagua de montaña, 512

jagua negra, 512

jaguar. 162

jagijeicillo, 70

jagiteillo, 70

jagiierillo, 280

jagilex, $70,72,74$

jagüey blanco, 70

jagiiey colorado, 74

jagizer macho, to

jagiier prieto, 74

jagiiilla, 94

Januica-plum, 296

Jamaican-cedar, 244

jambeiro, 402, 404

jambo anarello, 102

jambo encarnado, 404

Jambos jambos. 402

Jambosa malacecnsis, 404

Jambosa rulgaris, 402

jambosier, 402

f.melac, 404

jaqueca, 330

jaqueira, 62

jaquier, 62

jasmin de estrella, 62,510

jasmine, 460

jาsmine, red, 462

jasmine, Spanish, 462

jatobá, 180

jarilla. 278

jayajabico, 318

jazmin francés, 134

jelse, 200

jele, 300

jeneguite, 236

jeretón. 428

Jerusalem, 180

Jerusalem-date, 170

Jerusalem-thorn, 180

jessamine, 462

Jesuit-bark, Jamaica, 508

jía amarilla, 368

iia colorada, 370

jiba, 210

jicaquillo, 140

jicara, 490

jicarillo. 360

jicaro, 490

jigiierillo, 70

jimbay, 156

jimbling, 280

jina, 150

jin̄icuite, 236

jin̄ocuาbo, 236

jiñocuaro, 236

jiñote, 236

jiote, 236

jique, 364

jisotoủbo, 308

jobillo, 294, 296

johito, 296

jobo, 294, 296

jobo blanco, 294

jobo colorado, 294

fobo de castilla, 294

joho de indio, 292

jobo de la India, 292 jubo de perro, 294

jubo de juerco, 294

jobo francés. 296

joho gusanero, 294

joho hembra, 294

jobo jocote, 294

jobo macho de tierra fria, 136

jolno pelón, 236

jobo rano, 294

jobohín, 2994

jurote, 294, 296

jucote conun, 296

juente de invierno, 296

jucote de jobo, 294

jocote jobo, 296

jocote marañón, 288

joente montanero, 294

jocotillo, 254

joctuma, 386,454

jocuma ama rilla, 454

jocnma blanca, 454

jocuma lechera, $\mathbf{4 5}$

John-Bull-tree, 330

jointwood, 172

jojobán, 254

josefina, 176

juan tomas, 522

juanilla, 140

juba rompehueso, 370

jubabán, 254

jubilla, 442

jucarillo, 396, $38 \mathrm{~s}$

jucaro, 38s, 510

juicaro amarillo, 386

jucaro mastelero, 386

júcaro negro, 388

juche, 462

juco, 58

judio, 122

jújึmo, 510

jujano. 510

jujul, 336

July-tree, 176

jumas, 254

jumbie-apple, 366

jumbie-bead, 144, 146

jumbie-bean, 156

junco marino, 180

jumgleplum, mastic, 454

juniper, 512, 514

jurupe, 308

jusillo, 418

jutahy, 180

kaddo bakkoe, 334

kaimit, 438

kaimit, wild, 436

kajanna manja, 290

kalabarie, $22 \mathrm{~S}$

kalahassenboom, 492

kalebas, 492

kauakuchiballi, 360

ka neelappel, 104

kankantrie, 334

kapok. 334

kapokboom, 334

kapokier, 334

karaba-balli, 246

ka rohoro, 428

kasabahoedoe, 428

kasjoe, 288

kasjoema, 102

kassod-tree, 174

katoelima, 386

katoenboom, 334

katunbom, 33

kaubaati, 232

kaway, 206 kawaร, swamp, 206

kayuwa, 326

kelki heel, 50)

kenepa, 306

kenepier, 306

kibihidan, 365

kidneywood, 204

kinep, 306

king-of-flowers, 38:

kinnup-tree, 306

klapperboom, 40

knippen, 300

kvelarie, 350

koerahara, 350

koesoewee, $35 \mathrm{~s}$

koffie, 506

koko, 148

konaparan, 434

konorlépie, 422

kopijk, 352

koraro, 190

kre-kre, 424

Krugiodendron ferreum, 316, 320

kufa, 352

kuigi, 168

kumaka, 334

kurana, 244

laburum, Indian, 170

lagarto, 232

lagarto amarillo, 232

lagarto-caspi blanco, 350

lagarto negro, 232

Lagerstroemia flos-rcginae, 382

Lagerstroemia indica, 392

Lagerstroemia speciosa, 382

Laguncularia racemosa, 12, 386, 392, 476

lagumero, 206

lamoentsji, 222

lamunchi, 218

lamunchi dushi, 222

lana, 336,512

lancewood, 116, 200

landi, 350

lanero, 336

lanilla, 336

Laplacen portoricensis, 346

lara, 164

laraha, 220

laraha zier, 220

laranja amarga, 220

laranja cla terra, 220

latapi. 246

latapi-caspi, 246

Laugeria densiflora, 524

Laugeria resinosa, 524

$L A T A C E \& E, 110$

laurel, $72,116,118,120,122,46 \mathrm{~s}$

laurel amarillo, 116

laurel avispillo, 116, 118

laurel blanco, $114,120,468$

lanrel cauelón, 116, 118

laurel cigua, 116

laurel de la India, 72

laurel de loma, 114

laurel de paloma, 118

laurel espada, 120

LAUREL FAMILY, 110

laurel geo, 122

laurel geo-geo, 122

laurel macho, 116, 468

laurel negro, 468

laurel prieto, $116,46 \mathrm{~s}$

laurel roseta, 116

laurel sabino, 94, 96

laurelillo, 116

laurier, 122 
Iatrier blanc, IIf

linurier crpre, 468

taurier tine, 122

lituritu jaune, 114

liturier madame, 110, 12

laurier marbré, IIf

baurier noir, 12*3

laurier pront, 120

laurier-rose, 30

lavapén, 62

laslas, 474

laslay, hairy, $47 \pm$

leadtree, 156

leadwood, 320

leather-coat-tree, is

leatherwoor, 295

leatherworod, southern, wis

lehbek, 146, 148

lebisa, $1 \mathrm{i} 4,116,120$

leche prieta, 448

Jechecillo, 284, 436, 440

lechosa, 374,376

lecle, 520

l'église, 146

LECIIIE FAMILY, I12

LEGT MINONA $F, 142$

leli, 244

lemoen, 218

lemon, 222

lemon, Canton, 222

lengua de mujer. 148

lengua de vaca, 426

lengua viperina, I48

l'epine, 230

l'epine gommier, 230

lépine jaune, 230, 232

l'opinet, 230

lépinellx jaune, 230

lépuni jaune, 230,232

Leucaena glauca, 156

Lrucacna leucoccphala, 156

leviza, 114

libertad, 134

licaria, Gulf, 114

Licaria jamaiconsis, 114

Licaria salicifolia, 13, 110, 112

Licaria triandra, 110, 114

licorice, 164

lidflower, 396

lidflower, pale, 396

lignum nephriticum, 204

lignumvitae, 212,214

lignumvitae, common, 212

lignumvitae, false, 272

lignumvitae, holywood, 214

lignumvitae, roughbark, 214

lila, 248

lilac, 248

lilaila, 248

lilas, 248

lilas des Indes, 248

lilas du pass, 248

lilas étranger, 248

lilayo, 248,300

lima, 218

lima agria, 218

lima boba, 218

lima chica, 218

lime, 218

lime-leaf-plant, 218

lime, sweet, 218

lime, West Indian, 218

limewood, 478

limón, 218, 222

limón agrio, 218, 222

limón criollo, 218, 222

limón común, 222

limón de cabro, 222 limòn dulce, 218

limon france, 222

limón francés. 222

limón real, 222

limón sutil, 218

limoneaspi, 366

limoncillo, 210, 276, 306, 308, 368, 396, 4 It

limoncillo del monte, 396,410

limonero, 222

linguam, 132

lino, 156

lino criollo, 156

Linocicra axillifiora, 458

Linocicra caribaca, 458

Linociera domingensis, 14, 458

Linocicra hollrilgii, 4 is

lirio, 455,462

lirio santana, 508

lirio tricolor, 462

llagrumo, 68

Ilaj 1 s, 364

llorón, 28?

1lorona, 298

llume-palm, I'uerto Rico, t?

Iluvia de oro, Iso

loblolly, 90

locus, 180

locust, 178, 180

locust-berrs, 25 ;

locust-tree, 2.07

Lodoicea maldivica, 38

loksi. 150

Lonchorarpus domingensis, 13, 200

Lonchocarpus gla ucifolius, 200

Lonchocarpus latifolius, 188, 198

long-tom, 480

LOOSESTRIFE FAMILI, 352

lorito, $13 \mathrm{~s}$

loro, 138

LOTOIDEAE, 188

louro, 468

louro ama rello, $46 \mathrm{~s}$

Lucuma multiflora, 452

LYTHRACEAE, 382

mabí, 318

maca colorado, 190

macanabo, 436,440

macaprein, 294

macata, 156

maca ta blanca, 156

maca $\%, 190$

machacomo, 366

marbete, 192

machette, 190

machetillos, 192

inacoi, 330

macoutouca, 42

macurije. 304

madam naiz, 180

madam Fass, 180

IIADLER FAMILY, 504

madera negra, 198

madiera, 252

Madras-thorn, 162

madre de caca o, 194, 198

madre de flecha, 162

madriado, 19s

madrial, 198

madura, 198

maduraverde, 438

maga, 130,328

maga colorada, 328

II ana grandiflor, 328

mageniel, black, 270

IAGNOLIA FAMILY, 94

Magnolia portoricensis, 14, 94
Magnolia splendens, 14, 94, 96 IACIOLIACEAE, 94

mago, 130

mahajo, 370

mahaudeme, 336

mahault de Londres, 330

mabaut franc, 326

wahaut piment, 56

in aho, 326,330

maho, beach, 330

mahoe, 326

mahoe, bombast, 336

mahoe, seaside, 326,330

mahogans, 13, 248, 250, 252

mahogan 5 , biglea, 250

mahogany, Brazilian, 250

malogany, British Honduras, 250

mahogan, broadleaf, 250

mahogans, Central American, 250

mahogany, Dominican, 17, 250

mahogany du navs, 252

MAHOGANY FAMILY, 242

mahogany, Honduras, 248,250

mahogany, mediumleaf, 250

maliogany, Perurian, 250

mahogan. petites feuilles, 2:2

malogany, small-leaf, 252

mahogans, Spanish, 252

mahogans, Venezuelan, 250

mahogany, West Indies, 250, 25\%

mahogans, West-Indian, 252

mahok, 252

mahomo, 200

mahoni, 252

wahot, 326

mahot bord-de-mer, 330

mahot gombo, 326

mahot grandes feuilles, 474

mahot-hêtre, 340

mahout, 380

mai das aryores, 334

maiz tostado, 520

majagua, $56,92,326$

majagua brava, 380

majagua colorada, 58

majagua de Florida, 330

majagua de mona, 92

majagua de sierra, 380

majagua de toro, 340

majagua gallina, 190

majagua hembra, 326

majagua quemadora, 380

majagiiilla, 330

majao, 326

majoe, seaside, 326

makka nruim, 296

malagueta, 414

malambo, 362

Malay-apple, 404

malcaconier, 202

MALLOW FAMILY, 326

maloko, 134

MALPIGHIA FAMILY, 250

IILPIGHIACEAE, 256

maluco, 512

IALY ACEAE, 326

mamaja, 354

mamão, 376

mamaya, 354

mambee, 318

mamee, 354

mamey, 354

mamey amarillo, 354

mamey de Cartagena. 354

mamey de Santo Domingo, 354

mameycillo, 434

mameyuelo, $430,434,444$

mami, 354 
mamie, 351

mamieboom, 351

Mammea americana, 13, 348, 354

mammee-apple, 351

uamıi, 351

mameeiro, 376

maıón. $102,306,376$

manón de Cartagena, 306

mamoncillo, 306

mampolo, 494

mampoo, 90

mampoo, black, 92

mampoo, water, 90

manacla, 42

manca-caballo, 168

mancenillier, 290

manchineel, 274, 276

manclioneel, 276

mancinillier, 276

mandarina, 218

mandioqueira, 428

manero, 258

manga, 290

mangabé. 428

mangel, 390, 392

mangel blancu, 390,478

mangel tan. 384

mangeniel, 276

manggaboom, 290

manggel cora, 320

mangro, 290

Mangifera indica, 2\$6, 288

mangle, 384, 390,392

mangle amarillo, 392

mangle hlanc, 392,478

mangle blanco, 12, 392, 478

mangle bobo, 392,478

mangle botón, 12, 390

mangle botoncillo, 390

mangle caballero, 384

mangle colorado, 12. 354

mangle de chifle. 384

mangle garbancillo, 390

mangle gateador, $\mathbf{3 8 1}$

uangle gris, 390

mangle iquanero. 478

mangle injerto, 34

mangle jeli, 390

mangle lloroso, 390

mangle marequita, 390,392

mangle médaille, 206

mangle negro, $12,390,478$

wangle noir. 354

mangle piñuelo. 390

mangle prieto. $390,392.476,478$

mangle rojo. 381

mangle rosado, 478

mangle rouge, 381

mangle salado, 384,478

mangle torcido, 390

mangle zapatero, 381

manglecito. 478

manglier, 394,390

manglier blanc, 392

manglier chandelle, 384

manglier gris, 390

manglier nolr, $47 \mathrm{~s}$

manglier rouge, 384

manglillo. 432

mango, 288, 290

mangn, wild. 448

MA VGOSTEEN FAM ILY, 349

manoot, 290

mangotine, 290

mangro. 384

mangrove, 384,476

mangrore, black. 384

MANGROVE FAMILT, 384 mangrore, red, 384

mallgue, $290,390,392$

mangue branco, 390,392

mangue de butāo, 390

mangue sapateiro, 394

mangue vermelho, 384

mangueira, 290

manguel, 394

manguier. 290

mani kwaha, 350

Manila-tamarind, 1 (i2

Wanilhara balata, 441

Mamilkara bidentata, 12, 13, 14, 436 , 444

Tanilkara cmarginata, 446

ILamilkara duplicata. 44

Ianillara jaimiqui, 446

If anilkara nitida, 444

IIanilhara plecana, $1 \pm 1$

Manilkara riedlema. 441

Manilkara zapota, 436, 446

Ir anillaru sapotillu, 446

manja, 290

manjack, 472.474

manjack, mucilage, 474

manjack, link, $49 \mathrm{~s}$

manjack, red, 472

manjack, white, 474

mannie botieie. 434

mano de león, 130,426

mano de 0 so, 420;

manteco, $256,258,432$

manteco blanco, 432,434

manteco lle agua, 256

manteco merex, "zs

manteco sabanero, 256

mantequero, 432,434

mantequito, 432

manu. 246

manzaliuja, 276

manzana, 402,404

manzana de Faiti, 404

manzana de oro, 29?

manzana de otahiti, 292

manzana malaya, 404

manzana rosa, 402

manzanilla, 276 ;

man zanillo, 274, 284

manzanillo de costa, 276

manzanillo de plasa, 276

manzanita de rosa, 102

mapabnite, 254

malén, 62

mapola, 196

majoo, 92

mapou, 20, 334, 474

mapou gris, 9. 466

mappoo, 90

napnrito, 232

ma ra, 236,350

maranga calalú, 134

maranuey. 30

maratión, 288

inarañón de Curacao, 40 -

marañón japonés, 404

ma rafuil, $30^{\circ}$

marcluncha, 502

ma requito, 390

marfil, 372

Jargaritaria nobilis, 282

Ifargaritaria nobilis rar. antillana, 282

maría, 12, 348. 350

maría angola, 520

marlberry, Guadeloupe, 430

maricao, 256,346

maricao cimarrón, 258

maricao verde, 258, $\mathbf{3 4 6}$
Marie Jeanne, 254

mario, 350

mariposa, 168

marmalade-box. 512

marupá, 428

masa, 240

masaquilla, $5 \mathrm{~S}$

mastate blanco, 64

mastic, 454

mastic-bully, 454

mastic-tree, 238

Masticllorlendron foctidissimum, 454

mast wond, 154

mata caimán, 192

mata de chiro. 308

mata piojo, 254

niata-ratón, 196, 198

mata-serramo, 354

matabos, 200

mataburro, 180

matakki, 386

matapal, 352

matatauba, 428

Matayba domingensis, 14, 304

Latayba oppositifolia, 304

matchwood, 428

mate, 492

matico falso, 50

matillo, 202

mato, 202

mato colorado, 146

matuhua, 462

mauricef, 256

Iarimilianca ritifolia, 360

maximilier, 276

Mallepen axillifiora. 458

Ilavepca caribaca, 458

laycpea domingensis, 458

mazapån, 62

meerilang, 112

IFLASTOJATACEAE, 418

MELASTOMIE FAMIII, 418

Melia azedarach, 242, 246

IIELIACE. $\perp E, 242$

Mclicorea bijuga, 306

Melicoccus bijugatus, 302, 306

Metiosma herbertii, 14. 314

Meliosma obtusifolia, 314

melôn, 216

melón zajюte, 376

memiso, 58

memiso de paloma, 58

memizo cimarrón, 56,58

memizo de majagua, 56

mereke, $28 S$

nerey, 258, 288

merisier, 406

merisier petites feuilles, 412

merisier rouge, 406

mesa, 448

uespel, 146

mespel, wild, 412

mesquit-tree, 168

mesquite, 166,168

mestizo, 246

Metopium toxiferum, 286. 290

Mexican-cedar, 241

MEZEREON FAMILY. 380

mezquite, 168

miche, 192

II conia forcolata. 422

Ificonia impetiolaris, 422

Iiconia lacvigata, 422

Ifieonia lanata, 422

Iiconia microcarpa, 422

II iconia ottoschulii, 422

Irconia pachyphylla, 422

Miconia prasina, 418,422 
Iricomia yunctata, 422

Miramia llyenoncura, $\downarrow^{\text {ban }}$

Miconia raremosa, 1*2)

Wi(comia rubiginusa, t:o)

.liconia sintrnisii, 42.3

Hirmaia subrarymbosa. 122

Wicomia tefrandra, 422

Miconia thomaviama, 4:2

Micropholis chrysophylloides, 14,448

Mierouholis curvatu, 44 S

Micropholis garciniaefolia, 14, 450

Micropholis portariecusis var. curlata. 448

mije, 106

mijico, 442

unilkbush, 164

milktree, 460

MILKWORT FAMILY, 260

milky-bush, $\$ 60$

milks-iron, 436

mille branches, 28

millerwood, 336

millo, 282

mimbre, 54

mimosa, 156

MIMOSA SLPFAMILY, 142

minosa, West Indies, 156

mimosa, wild, 156;

MIJOSACEAE, 112

UIMONOI/F, $E, 142$

I Imusops balata, 44

Iimusops bidentata, $\mathbf{1 4}$

Jimusops domingensis, 414

Jimusops ricalcana, $\mathbf{1 4}$

IImusops sicheri, 111

misanteca, Gulf, 114

Misanteca triandra, 114

misanteco. 114

mispel, 446

mispelboom, $\mathbf{1 4 6}$

inispur, 46

moca, 188, 190

moca blanca, 190

mochigiiste, 162

mocinasn, 331

moeleri, 256

molno, blue, 326

molinillo, 276, 336

luonbin, 294

mombin bâtard, 254

mombin espagnol, 292

mombin franc, 294

mombin fruits jaunes, 294

mombin, purple, 294, 296

mombin, red, 296

nombin ronge, 296

mombin. vellow, 294

monbe, 294

moubin, 294

monbinier, 294

mondururu preto, 422

mongollano, $16^{\circ}$

monkes-apple, $3 \sin ^{2}$

inonker-goblet, 352

monkey-pistol, $27 \mathrm{~s}$

monkesjod, 166

Honte ama grandifore. 32S

Montezuma speciosissinia, 13, 326, 328 monval. 156

mopé, 294

moppé, 224

WORACEAE, 60

moral, 474

noral de naz, 474

moralón, 78

moriengo, 134

morinda, 518

Morinda citrifolia, 50 t, moringa, 134

IIoringa mominga, 134

Moringa oleifera, 134

Inoringa pteryusperma, 134

JORIAGACEAE, 134

morototó, 128

morro, 490

noruro, 160

moruro jrieto, 160

unoruro rojo, 160

mostacilla, 13

mother-of-cocoa, 196

motillo, 324

motön, 190

mountain-cabbage, $4 t$

mountain-palm, 42

unoutoucli de savane, 206

wuche, 148

muchichilann, 58

mucutela, 206

inuerto, 210

mulato, 110, 236

MILBERRY FAMILY, 60

inullaca coloralo, 422

mullu caspi, 42 .

mulungí, 196

muñeco, 470, 17 ?

uurta, 400

Inüsico, 148

muskwood, Anterican, 244

inutamba, 340

inututs, 206

nusozapot, $\$ 16$

Myrcia berberis, $\mathbf{1 1 0}$

Vurcia citrifolia, 110

Myrcia deflexa, 14, 396, 410

Myrcia ferruginca, $\$ 10$

Iyrcia 7eprorlada, 410

II Ureia paganii, 410

Myrcia splendens, 412

nis robalane, 294

IYREIVACEAE, 130

myrsine, 434

MIRSINE FAMILY, 430

If YRT ACE-IE, 396

mirte, 406

IIRTIE FAMILY, 396

llabaco, 510

nacascol, 168

Jancia coriacea. 30

lakerl-boy, 238

naked-Indian, 238

naked-wood, 316, 318

nanre, $25 \mathrm{~s}$

nance acrio, 258

nance rerde, $25 \mathrm{~S}$

nanche, $25 \mathrm{~s}$

nancite, 258

nancito, 258

nิandiท์, 512

naranga, 220

naranja, 226

naranja ácida, 200

narania agria, 220

naranja cajera, 220

naranja de Clina, 226

naranja dulce, 226

naranjo. 226

naranjo amargo, 220

naranjo común, 226

naseherry, 146

uazareno, 180

Nectandra antillana, 116

Nectandra coriacea, 13, 110, 116

nectandra, Jamaica, 116

Neclandra krugii, 116

Vectandra membranacea, 116
Tectandra patens, 116

Iectantra sintenisii, 116

negra lora, 10s, 304

Teltuma julifora, 168

nemocá, 124

nemocá cimarrón, 12t;

nemocá macho, 126

nettle-tree, Jamaican, 58

nicte de monte, 46 ?

niglitshade, 488

NIGHTSHADE FAMII,Y, 4\$8

niglitshade, mullein, 488

nigua, 518

niño de cota. 346

niopa, 158

Niopa peregrina, 158

niopo, 158

nispero, 446

uispero cimarrón, 456

uistamal, 282

njoe fodoe, 360

noba, 296

noix d'acajou, 288

noix de coco, 40

noni, 518

noro, 258

uosegay, $\mathbf{4 6 2}$

noser, 228

nuez moscada, 124

nuez moscada cimarrona, 124

nuez moscada del pais, 124

nuez moscada macho, 124, 126

nune, 278

NYCTAGINACEAE, S8

ñandipá, 512

ochohô, 278

Ochroma bicolor, 336

ochroma boliviana, 336

ochroma grandifora, 336

Ochroma lagopus, 336

Ochroma lagopus var. bicolor, 336

Ochroma limonensis, 336

ochroma obtusa, 336

Ochroma perumiana, 336

Ochroma pyram idale. 13, 14, 334

ochroma tomentosa, 336

Ochroma telutina, 336

Ocotea caiesbyana, 116

ocotea coriacca, 116

Ocotea cuneata, 110, 118

Ocotea foribunda, 110, 120

ocolca foeniculacea, 118

ncotea, Jamaica, 116

Ocotea leucoxylon, 14, 110, 122

Ocotea moschata, 14, 110, 124

Ocotea portoricensis. 118

Ocotea rodiaei, 514

Ocotea spathulata, 14, 110, 126

Orotea urightii, 118

ocuje. 350

ocuje colorado, 350

ofôn criollo, 486

ohia, 404

okra, 326

ocuje, 350

$O L E A C E A E, 458$

olive-bark-tree, $38 s$

OLIVE FAMILY, 458

olice, wild, 386,114

oliviel grand bois, 386

olivier montagne, 298

olivier, rellow, 386

olivo, 132

onotillo, 358

moto. 358

opoponax, 111

Opuntia rubescens, 13,378 
orange, 226

brange amere, 220

orange, hirarade، 220

wrange, hitter, 220

oralige lource, $22^{*} 6^{\circ}$

orange grossic-pen 11, 220

orange, mandarin, 218

orange, seville. 2:0

orange, sour, 220, 226

orange sûre, 220

orange, sweet, 220,226

orchid, poor man's 170

orchidlree, pink, 170

oreganillo, 138

orengga, 134

orme d'Amérique, 340

orme petites fenilles, $\mathbf{5 6}$

Ormosia krugii. 14, 185, 200

oronoque, 194

orselli, 134

ortegón, Ts, S0, 94

orumo macho, 425

orri, $2 \mathrm{sS}$

otaheita, 330

Otaheite-apule, 202,404

Otalieite-gonseberry, 280

Otaheite-plum, 292

oysterwood, 272

usterwod. sliny, 272

เฉน́a, 414

liablıe sieja doesji, 238

parloe siej 1 ma: tsjoe. $23 \mathrm{~s}$

Jilbito. 370

paca 5.190

Puchulobus hexandrus, 240

jatcon, 308

yacón curus. 308

jelcun, $30 \mathrm{~s}$

padauk, 204

Hidauk, lirmit-coast. 204

padauk, India, 204

padero, 428

bain d"epice, 452

pain-in-back, in

painkiller, 518

pa jarobobo, 54

pajuil, 286

[ualal, 1.50

lalétuvier. $206,390,392,478$

baléturier blane. 47s

jaléturier gris, 3!m

laléturier rouge. 384

palinguin. 132

malissindre, 18:

I'ALWI HA.III,Y, 34

palm, prickly, 34

palm, sierra, 14, 40

yal 1 a boba, 12

palma de abmico. 46

palma de coco, 38,40

jalma de (oogollo, 46

patma de corozo, 34

malma de costa. 44

palma de coyor, 36

palma de lluvia, 42

pralma de manacla, 42

palma de sierra, 40

palma de sombrero, 46

lalma de saguiss, 44

inlma justa, 42

palma real, 34,44

$P A L U H E, 34$

lialmera de coco, 40

palmera sin espinas, $2 \mathrm{~A}$

balmet to, Bermula, 46

palmetto, Puerto Rico, 46

palmilla, 28 jalmiste a chapelet. 42

palmiste blane, 42

palmiste franc, 42

jaluniste montiane, 42

palo amargo, 2. $4,252,308,318,461$

palo amarillo, 30is

palo blanco, 26t $, 366,368,370$

palo bobo, $90.136,1 ! 4,360,466$

fillo chino, 236, 235

palo colorado, 298

falo de abejas 134

palo de aceite. "24)

fralo de aceituna, 268

palo le anastasio, 254

palo de balsa, 330

palude boza, 196

falo de burlo, 190, 426

lalo de culva, 55,456

palo de cabrilla, 56

lalin de cachumba, 426

yalo de corcho, ?'

lialo de cotona, 370

palu de cotorra. $21,4,520$

palo de cruz, 356,462

palo de cucubano, 514

fralo de la jao. 514,510

ralo de danti1, 426

palo de doncella, 256

palo de gallina, 264

palo de Earrocha, 336

palo de goma, $64,68,472$

palo de guitarra, 480

palo de hierro, 198, $210,320,516$

palo ale hueso, 272,458

palo de inciensu, 236

palo de jaqueca, 330

palo de Jazmil, 508

palo de la cruz, 368,462

palo le lana, 30

lis lo de leche, 270,464

palo de maria, 350

balo cle mato. 146

palo de matos, 200

palo de millo. 282

palo de misanteco, 114

palo de muleta, 400

palo de muñeca, 472

palo de muñeco, 464

lah) de navidad, 520

palo de orquíleas, 170

palo de pan, 62

lalo tle peje, 234

palo be verico, 92

palo de prenonía. 202

palo de veronfas, 202

palucle prez, 234

palo de pollo, 206, 424

palo de pollo negro, 426

balo de quina, jos

palo de rayo, 180

palo de sabana, 432

palo de sable, 428

palo de sal, 392.478

falo de seca, 140

palo de tea, 216

palo cle toro, 510

palo le tortuga, 260

palo de vaca, $268,426,466$

palo de violeta, 260

palo de yagu:, 364

palo de yuca, 270

palo diablo, 132, 320

yalo guitaro, 426

balo hetliondn, 200

palo-jabón, 308

palo jeringa, 1:34

palo jiote, 238

palo llorón. 504 palo nuaria, 350

palo misinuteco, 114

palo mujer, : $26-4$

palo mulato, $2: 36$

14alo-[nolvora, ins

palo pulato, :30;

palo prieto, 194

yalo rajador, 370

palo retinto, 236

palo rubio, 232

palo salvaje, 364

palo santo, 115, 194, 21:2, 214, 4:6

jal lo seco, 200

nalo tabaco, 474

flaloma, 20s

paloverde, 1 so

baluverde, Mexican, 180

fralta, $12 \mathrm{~s}$

palto, 1:s

palu di rashupete, 28s

jalu di frut "i pan, 62

palu santu, 330

pama, 426

manashto, 444

pamplemousse, 224

pan, (i)

pan cle fruta, 62

pan de trigo, 254

pan mango, 445

jana, 62

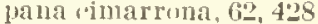

pana de pepitas, 60

lana forastera, 62

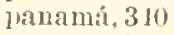

panama-tree, 340

panapéu, 60

panelu, 156

paneque, $2: 32$

papachilla, 520

pap:ı jahoedoe, 425

Javico, 376

papเat urro, 82

papaturro extranjero, 82

papan, 376

paplaw, wild, 68

papay, 376

papaya, 374,376

PAPAYA FAMILY, 374

paraye, 376

papayer, 376

papayillo, 340

papayo, 290,376

paparo ea lentano, $37 t$

papason, 428

papayote, 360

papelile, 370

papillon, 208

paradise-tree, 248

paraíso, 134, 248

paraiso blanco, 134

paraíso de España, 134

laraíso francéx. 134

Paralabatia portoricensis, 450

parajairo, 30 s

parata, 444

jardillo, $46 \mathrm{~s}$

parésol, 474

Iral'icí, 158

pariti, 326

Parilium tiliareum. 326

Parkinsonia aculeata, 168, 180

parrot-apple, 352

parwa, 478

pasilla, 245

lrata de danta, $3+0$

fata le raca, 170,254

patabin. 392

patabin de monte, 122 
[aiternillo. 1:0

pati, $4 ! ! 2$

[nitillo, 30!

pilte lapis, 330

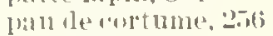

[1:11 sat110, 212

lian tentu, 146

pancipan, red, 462

In:1 11ji, 144, 180

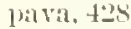

movilla. 428

1):

P'EA SIPFAIILT, 1 SS

peatrie, 12, 19s

vear, 128

pear-tree, 128

peetselh-kitam, 520

pelí. 144

pelleju de indio, 236

pelufo, 100

peltophorum, 182

Peltophorum forrugineum, 1:52

Peltophorum inerme, 16n, 182

Peltophorum roxburghii, 1 s2

pelia, 420

penda, 478, 480

prendare, 444

péndula, 47s, 480, 456

féndula banca, 486

péndula de sierra, 478

penny-piece, 452

peonia. 146

peper mortelboom, 134

leiv, $80 \mathrm{~s}$

I'FPPER FAIIILY, 50

pera, 404

peraleja, 2 is

perilejo, $2,6,258$

peralej , hlaneo, 258

peralejo de pinar, 2.56

peralejา de sabana. 258

perico, 02

perlas, 134

pernilla de casa, 192

peronia, $20: 2$

peronías, 144

)ronias chatas, 146

beromilla. 192

peronio, 192

Persea americana, 110, 128

Persea oratissima, 128

Persea hrugii, 128

Persen pelsea, 12s

pessegueiro bravo, $2 \pi f i$

letit bouis, 436

petit caimite, 436 ;

pet it coen, 324. 520

petit merisier, 41 ?

petite-feuille, 410

petites raquettes, 378

vetitia, 4,82

Petitia domingensis, 13, 476, 482

peuplier, 54

Phanera variegata, 170

Phlebotacuia courellii, 260

Plocbe clongata 116

Phyllanthus acidus, 262.2, 280

Phyllanthus antillanus, 282

Pliullanthus disfichus, 280

Phyllanthus grandifolits. 280

l'hillanthus juglandifolius, 250

Phyllanthus nobilis, 262, 252

Phyllanthus nobitis var. antillanus. 282

pica-pica, 362

pichones, 62

piro de tlamenco, 208

Picramnia pentandra, 234
Pictetia aculeata, 13, 202

pigeon-berry, 466

pigeon-feed, $4 \pi \mathrm{s}$

pigeon-plum. 76

pigeon-womel, $340,460,46$ iti

piginio, 2ito

pij, 272

pilche, 492

Pitocerells royenii, 376

pilon. 190

Pimenta ureris, 414

Pimenta acris var. grisca, $\mathbf{4 1 4}$

Pimenta diesiea, $\$ 14$

Pinchta reffieinalis, 414

Pinchta pimcntu, 414

Pimenta racemosa, 39f, 414

Pimenta racemosu val. grisea, 414

fimienta. $216.2-2(), 414$

pinienta de Tabasco, 414

pin d'Anstralie, $4 \mathrm{~S}$

yine, will. 30

pine, wild piteh, 30

pinlıa, 104

vinipinine. 276

link-redar. 498

billo, 48

viun aust raliano, 48

vino de Australia. 48

fino mat)

Jint jo, 422

pinturero, 28:2

viña de merto. 51s

piñîpiñí, ธo8

vin̄on, 192

jiñon a moroso, 198

piñon de cerca. 192

viñon de Cuba, 198

piñon de pito, 192

piñón de sombra, 196

piñon del canto, 194

piñón espinoso, 192

piñón florirlo, 198

piñon francés, 194

piñon violento, 198

piojillo, 298

pioiito. 298

Piper aduncum, 50

PIPERACEAE. .0

pinewoud, 36 if. 368

Piptadenia peregrina, 158

piricua. 210

písamo, 194, 196

jisano colentarlo, 194

Pisonia albida, 13.88

Pisonia framans. 02

Pisonia subcordala. 90

pisquin, 148

pistache des Indes, 340

pitanga, 400

pitangueira, 400

pitarrillo, 296

pitrll-ample. 352

Pithecellobium arboreum, 14, 142, 160

Pithecellobium dulce, 142, 162

Pithecellobium saman, 142, 164

Pithecellobium unguis-rati. 162

Pithreolobium, see Pithecellobium, 160

jito, 34, 192, 194

pito de meronilla, 102

lito extranjero, $19 f$;

pito gigante. 190

piton. 192

vivija 5,72

pixoy, 340

plateadn, 508

platinillo de Cuba, 50

plum-bush, 294 plum-rose, 402

jlun, St. Vincent, 198

flume, Napoleon's, 170

Plumeria ncutifolit, 462

Plumeria alba, 13,460, 462

Plumeria krugii, 460

Plumeria obtusa, 460

Plumeria portoricensis, 460

Plumeria rubra, 460, 462

Plumeria tricolor, 462

Plmmiera, see Plumeria, 460

Plumieria, see Plumcria, 460

plumillo, 160

prehote, $264,334,360$

podocarp, 30

podoearpus, 30

Podocarpus coriaceus, 14,30

poinciana, 176

Poineiana regia, 176

puinciana, royal, 176

poinciana, sellow, 182

poirier, 210,498

poirier blane, 498

poirier gris, 198

poirier rouge. $\mathbf{4 9 8}$

juis doux, 150, 15t

pois doux ì paille, 154

pois duix blane, 150

pois donx poilu, 1.it

pois suerin, 154

pois vallier, 208

poison-guava. 276

poison lasinette, 160

poison-ivy, $2 \%$

loison-oak, 290

poisont ree, 290

poisontree, Florida, 290

poisontree. West Indies, 290

poisonwood, 290

pokbout. 212

polak. 336

polisand ro, 184

pollo, 426

Polygala conellii, 13,260

$P O L Y G+L A C^{\prime} E A E, 260$

POLYGOXACEAE, 76

pomagada, 404

yomagás, 404

pomarrosa, 15, 402

pomarrosa de Malaca, 404

pomarrosa malaya, 404

pomelo, 218, 224

pomerac, 404

pomme cajou, 288

pomme cannelle, 104

pomme cythère, 292

pomme d'acajon, 288

pomme de Cythère, 292

pomme de Ma la isie, 404

pomme de Tahiti. 404

pomme malac, 404

pomme pain, 452

pomme rose, 402

pemme surelle, 280

pommerak, 404

pommeroos, 402

pommier d'acajon, 288

pommier rose, 402

yomo, 402

pomshock, 150

pond-apple, 98

pop-a-gun, 68

popinac, white, 156

Poponax macraeanthoides, 144

Poponax tortuosa, 144

poró, 194

poroporo, 360

portiatree, 330 
possenlrie, 278

mossumt ree, $27 \mathrm{~s}$

possumwood, 278

poui, pink, 500

Pouteria chrysophylloiles, 448

Poutcria dictyoneura, 452

Poutcria garciniacfolia 4 to

Pouteria multiflora, 452

prickle-busl, 520

prickly-ash, Martinique, 230

prickly-ash, yellow, 232

prickly-ash, gellonheart, 228

prickly-yellow, 230

pricklypear, 378

pride-of China. 248

pride-of-1ndia, 248,382

prieto, 290

princewood, 508

princewood, Caribbean, 508

probado, 428

Prosopis chilensis, 16 s

Prosopis julifora, 15, 166

prune ('r thère, 292

prune d'Espagne, 296

prume du Chili, 296

prune jaune, 296

vrune mombin, 294

prune 11 probolan, 294

prune rouge, 296

prunier nombin, 294

Psidium guajal'a, 13, 396, 416

pterocarpus, 204

Pterocarpus draco, 20;

Pterocarpus indicus, 188, 204

Pterocarpus officinalis, 13, 188, 206

pucti, 388

pudding-pine-tree, 170

pulnmelo, 215, 224

рumı, 360

pumpumjuche, 360

pnmpwod, 68

punehberr, 412

punta de ral, 308

punteral, 370

jurguo, 444

purio fangar, 108

murio prieto, 108

purple-plum. 296

pureque, 478

pyinma, 382

Quararibaea turbinata, 336

quebrarha, 312

quebracho, 310,320

rueen-flower, 382

queen-of-flowers, 382

quenepa, 306

quénépe, 306

quenette, 306

quenettier, 306

qui, 168

quick-stick, 198

quiebra-hacha, 312,320

quiebrahaca, 400

quillo-sisa, 360

quina, 504, 508

quina eriolla, 508

quina del pais, 234

quina roja, 504

quinilla, $4+4$

quinilla colorada, 444

quinquina caraibe, 508

quinquina pass, 508

quinquina piton, 508

quira, 190

quisache, $1+4$ rabo ratón, 364

rabo junco, $36+$

raboe die kabasi, 5:0

rainlree, 164

raisin bork-cle-mer, s'

raisin la mer, 82

raisin marron, 76

raisinier bord-de-mer. 82

raisinier grandes-feuilles, of

raisinier montague. 30

rami menuda, 412

ramón. 272

ramon de caballo, 426

ramon de costa, 426

rimon de vaca, 426

ramon marho, 282

ramoncillo, 254

Randia aculeata, 13, 504, 520

Rantia aculeata var. milis, 520

Ranlia mitis, 520

Rapanea ferruginea, 430,432

rapanea, Guiana, 434

Rapanea guianensis, 430, 434

rascaso, 270

raspador, 58

rat-bean, 132

ratón, 210,304

ratonera, 198

Raurolfia lamarckit, $t 64$

Raurolfia nitida, 13, 460, 464

rauvelfia, smooth, 464

Tauloolfia tetraph!llu, 464

lialleolfia viridis. 464

Raurolfia. see Raurolfia, tfit

red-birch, 238

redcedar, 244,254

reddie, 190

redplum, 296

redwood, 210,246

redword, ridge, 210

redwood, swamp, 210

réglisse, 146

reina de las flores, 382

requia, 246

resbalo mono, 236

resedá, 134

resotu montagne, 512

resuelesuele, 520

retama, $180,198,502$

retamo, 254

RHAWNACEAE, 316

Rhecdia acuminała, 356

hhecdill hessii, 3 in 6

Rheedia portoricensis, 346,356

Rhizophora mangle, 12, 384

Rhizophora mangle var. samoensis, $3 \mathrm{St}$

Rhizophara samornsis, 384

RHIZOPHORACEAE, 384

rhubarbe caraibe, 518

Rhus, 290

Ribcs grossularia, 280

rima, 62

robe, 292

roble, 12,498

roble agalla, 234

roble amarillo, 478,502

roble blanco, 428,498

roble cimarrón, 496

roble colorado, $496,5(x)$

roble de costa, 498

roble de gua yo, 466

roble de olor, 456

roble de sierra, 500

roble de $y$ ugo, 495

roble guayo, $466,482,486$

roble güira, 300 roble prieto, 500

rode kabbes, 190

rode locus, 1 so

rodwood, 406

rodwood, red, 412

roldan, 216

rolón, 162

Rondeletia inrmis, niz:

Rondiletia pilosa, 522

Rondeletia portoricensis, 504, 522

rosa amarilla, 30

rosa china, 360

rosa de Maximiliano, 360

rosa imperial, 360

ROSACEAE, 140

rose-apple, 402

ROSE FAMILY, 140

rose-marie, 512

rose-of-Peru. 360

rose-of-Sharon, 360

roselle, 280

roseta, 324

rosew ood, 204, 25f

rosewood, white, $45 \mathrm{~s}$

roucom, 358

roncourel, 358

royalpalm, 44

royalpalm, Cuban, 44

royalpalm, Puerto Rico, 44

Roystonea borinquena, 34,44

Roystonca regia, 44

rubber, 64

rubber, castilla, 64

rubber, castilloa, 64

rubber, Central American, 64

rubber. Pari, 64, 68

rubber-plant, $6 \mathrm{~s}$

rubber-plant, India, 68

rubber-tree, India, 68

rubia, 232

RUBIACEAE, 504

ruen, 358

RI'E FAMILY, 216

ruffle-palm, co5ure, 36

ruiba rba, 502

ruri, 354

$R U T A C E A E, 216$

Sabal bermudana, 46

Sabal blachburnianum, 46

Sabal causiarum, 34, 46

sabana kwari moeleidan, 258

sabana kwarie, 256

sabana mango, 258

SABIA FAMILY, 314

SABIACEAE, 314

sabicú, 160

sabicu de pinares, 138

sabicú ma rañón, 138

sabicú moruro, 160

sabina macho, 298

sabino, 96

sabinón, 266

sablier, 278

sablito, 428

saboeiro, 308

saboneteiro, 308

sabroso, 206

sacha-uva, 428

sackrsae, 150

sacmuda, 370

sacuanjoche, 462

saffron-tree, 440

saibo, 196

saijhan, 134

Saint John, 134 
saisai, $13 \mathrm{~S}$

saivo, 196

salaam, 468

salado, 478

salaster, 134

salgueiro, 54

SILIC.ACEAE, 54

Salix chilensis, 54

Salix humboldtiana. 54

salmwond. 468

sitso, 54

salthush, 478

saltpond-tree, $4 \pi \mathrm{s}$

salvadera, 278

samaguare, 164

samán, 148, 164, 166

samana, 166

samanca arborca, 160

Samanca samum, 166

San Andrés, 502

San Bartolomé, 470

sandalwood, red, 146

sandbox, 276, 278

sandbox-tree, 278

sandcoker, 194

sanders, yellow, 386

siang dragon, 206

salngre, 206

sangre de drago, 206

sangregado, 206

sangrillo, 206

sangrito, 206

sanguinaria, 442

santa maria, 330,350

santa-maria, 348,350

santo, 420

saona eimar rona, 302

saona de pueroo, 32:

sapatija, 446

SAI'IDDAR'EAE, 30'

Sapindus saponaria, 302, 308

Sapium laurocerasus, 13, 14, 262, 264

sapo, 132

sapodilla, 446

SAPODILLA FAMIIY, 436

sapodille, 446

sapota achras, 446

S.APOTACE.IE, 436

sapote, 446

saljoti, 446

sa jotilha, 446

saputille, 446

saputillier, $\mathbf{4 4 6}$

sapotillier marron, $44_{2}^{\circ}, 44$

sapotillier noir, $4+4$

sa ramuya, 104

Sorenmplialus romingensis, 32.)

Sarcomphalus reticulatus, $13,316.322$

sarcomphalus taulorii, 322

sardine, 422

sardinillo, $\overline{302}$

sarnilla, 370

sasafrás, 118

satinleaf, 440

satinwood, 228

satinwood, Jamajcan, 228

satiuwood. Test Indian, 228

sauce, $48,54,180$

sance amargo, it

sauce blaneo, 54

sauce chileno, 54

sauce colorado, 54

sance criollo, 54

sauce espino, 180

ธล น์่อ ล marillo, 502

saúco cimarrón, 300

sanle, 54

sa uquillo, 300 sal vonetapel, 308

savonette, 200

savonette grand bois, 201

savonette ja une, 200

wa vonet te mon tagne, 308

sa ronet te monsscuse, 308

silvonet te pars, 308

savonette. white, 200

savonettier, 308

savonier, $: 308$

sa vonnette grandes fenilles, 200

savonnette rivière, 200

sawa, 512

Striacassia siamea, 174

sorplappel. 104

Scotch-at torney, 352

Scotchmin, 352

seagrape, 82

seagrape, grandleaf, Ti

seigrape, jigeon, 76

seaside-grape, 82

Nebesten ricksecheri, 4 it)

sebesten sebestena, 470

sebucán, 376,470

selele bélétére. t’2

semna, apple-blossom, 172

semna, golden-shower, 170

senna, jointwood, 172

selna, Siamese, 174

sepi. 488

seriba, 478

seplina, 170

serrasuela, $310,312,514$

serrazueli, 100

serrette, 250

selrette, sa vamna, 258

serucho, 300

Seslan, see Se'slania, 200

Sesbania grandiflora, 18\$, 208

shack-shack, 148, 156

shaddock, 218, 22t

shaluuar, 162

shambu, 3.58

shellseed, 360

shimbillo, 152

shower-of-gold, 170

shower, pink-and-wbite, 172

shower, Siamese, 174

slumpí raí, 246

Sideroxylon foetidissinum, 12, 13, 436 , 454

Sidcraxylon mastichadendron, 454

siderorylon portoriense, 454

siderorylum, see sidlerorylon, 4.it

siejat blanko, 238

siempre-viva. 180

sipte-cueros, 282. 478

sicuir ril 5a, 116,254

silk-cotton-tree, 332,334

silverhalli, brown, 468

SIMAROTE.ACEAE. 234

simiri, 180

sinaasaplels, 226

singer-tree, 148

síris-tree, 148

siris, white, 150

sinuba, 478

sloanea amygdalina, 324

Sloanea berteriana, 14, 324

slog-wood, 110

slug-wood, 110

small-leaf, 412

small-leaf-grape, 84

snake-bark, commun, 316

snake-bark, smootb, 31s

snake-wood, 68,316

soap-tree, 308

soapberry, 308
NOAPBERRY FAMILT, 302

soapberry, wingleaf, 308

soanseed, 308

soaliseed-tree, 308

SOLANACHAE, 488

solunum asperum, 488

Solanum drymophilum, 488

Solonum crianthum. 488

Salanum melongcna, 488

Solanum rugosum, 488

Solonum tuberosum, 488

Solanum verlaseifolium, 4.88

soldierwood, 318

solera, $46 \mathrm{~s}$

sombra de armado, 370

sombra de conejo, 370

sombra de ternero, 472

sopa ipo, 32 ?

sopo sirie, 308

sorsaka, 100

sota eaballo, 520

soursap, 100

soursop, 100

soursop, mountain, 98

soursop, wild, 98

South-American-cedar, 244

Spanish-cedar, 242, 244

Spanish-cork, 330

Spanish-elm, 468

Spanish-lime, 306

Spanish-oali, 150

Spanish-plum, 296

Spalhodea campanulata, 15, 490, 494

Spondias cirouclla, 296

spondias cytherea, 292

Spondias dulcis, 2\$6, 292

Spondias lutea, 294

Spondias mombin, 256, 294, 296

Spondias purpurea, 2\$6, 294, 296

Spondias purpurca forma lutea, 296

spoon-tree, 466

spruce, 468

spurge, brondleaf, 270

SPURGE FAMILY, 262

Stahlia maritima, 184

Stahlia monosperma, 13, 168, 184

STAPHYLEACEAE, 300

star-apple, 436,438

star-apple, wild, 448

star-gooseberry, 280

Stculobium incisum, 502

Stenolobium stans, 502

Stcrostomum acutatum, 504

Stchostomum coriacem, 504

stenostomum densifiorum, 524

stenostomum lucidum, 504

stchostomum obtusifolium, 504

Sitchostomum portoricensc, 506

stenostomum sintenisii, 504

sterapluel, 438

Sterculia apetala, 338, 340

Sterculia carlliaginensis, 3 to

STERCTLIACEAE, 338

stinking-toe, $\mathbf{1 8 0}$

stopper, 400,406

stopper, bastard, 482

stopper, red, 406

strangler-fig. 352

subin, 144

subinche, 144

súchil, 462

sucrier, 154

sucrin, 154

sugar-apple, 104

sugary-grape, 84

suiña, 194

sulfatillo, 180 
sulfato, 180

sulluco, 308

suma-catechu, 144

sumauma, 334

sun-suin, 340,428

sureati, 50

surelle, 280

Surinam-cherrs, 400,412

susana. 480

susanaleche, 480

swamł-1nahogany, 398

SWEETLEAF FANILY, 4 î

sweetleaf, Martinique, 456

sweetpea, 150

sweetsup, 1nt

sweetwood, 114, 116, 442

sweetwond, black, 120

sweetwool, cap-berry, 116

sneetwood, loblolls, 122

sweetwood, small-leared, 116

Sretetnia belizensis, 250

Suctenia candollei, 250

Srictcria krukorii. 250

Swietenin macrophylla, 242, 248

Swictenit macrophylla $\times$ mahagoni, 250

Sivietenia mahagoni, 13, 15, 17, 242 , 250

Suctenia tessmannii. 250

swizzle-stick-tree, 336

srbilline. 280

SYMPLOCACEAE. 456

Simmlocos lanatu, 456

Symplocos martinicensis, $\mathbf{4 5 6}$

Sumplaros mierantha, 456

symploces polyantha, 456

Suzuqium jambos, 402

syzygium malaecense, 404

tabaco, $2 \pi 2$

tabacón, 272, 488

labacón afelpado, 488

tabacón aspero, $\mathbf{4 8 8}$

tabaiba, 284

Tabeluia dominicensis, 500

Tabebuia haemantha, 490, 496

Tabebuia heterophylla, 12, 13, 14, 490, 498

Tabcbuia helcropllylla subsp. pallida, 495

Tabebuir Tucida, 500

Tabebuiu pallida, $4: 1 \mathrm{~s}$

Tabebuia pallida sulsp. dominicensis. sino

Tabebuia pallida subsp. heterophylla. $49 \mathrm{~s}$

Tabebuia pentaphylla, 498,500

Tabebuia rigida, $14,490,500$

Tabchuia rosra, 504

Tabcbuia schumanniana, 500

tabelunia, white, 500

tabloncillo, 442

tablote. 338

tabouluco, 238

tabuchín. 176

tacasito, 370

tache, 502

tachuelo, 202

tacurai, 468

tagualaiste, 502

talantrón, 364

Talauma splendens, 96

taman, 186

taman, wild, 156

tamarandillo, 160

tamarijn, 186

tamarin, 186

tamarind, 186 tamarind, black, 160

tama rimd, French, 166

tamarind, red, 160

tama rind, wild, 156, 160

tamarindade, 186

tamarinde, 186

tama rinclier, 186

tama rindillo, 156

tamarindo, 160, 186

tama rindo de loma, 138

tamarindo silvest re, 144

Tamarindus indica, 165, 1S6

tamarinier, 186

tambor, 130, 264, 465, 512

ta nubor hormignero, 468

tampaco, 352

tangerine, 218

tantan, 156

tapaculo, $340,366,512$

tapal, 2.58

taparo, 492

taray, 216

tapoeripa, 512

taproepa, 512

tirana. 458

tareo, 492

tasto, 502

$T A X \perp C E+E .30$

teha-tcha, 148

tea, 216

tea cimarrona, 304

TEA FAMILY, 346

teak, 484

teberinto, 134

teca, 484

teck, 484

Tecoma stans, 502

Tecoma tronodora, 502

tecomasuche, 360 )

tecomasúchil, 360

tecomate, 490

tecomatillo, 360

Tectona grandis, 476,484

teilla. 216, 50s

tendre en gomme, , 08

tento carolina, 146

tercionelo, 420

terebinto. I34

Terebraria resinosa, 13, 504, 524

Tcrminalia buceras, $3 \searrow 6,385$

Terminalia calappa, 15, 3\$6, 394

Tetragastris balsamitera, 14,240

Tetragaslris balsamifera var. lanceifolia, 240

Tetrasygia anyustifolia. 424

Tetrazygia elaeagnoides, 13, 118,424

$T H E_{i}$ CE $A E_{i}, 3+$ i

Theobronia cacao, 338,342

Thesyesia grandiflora, 328

Thespesia populnea, 326, 330

Thouinia portoricensis, 13, 310

Thouinin slriata, 13, 310, 312

Thyana portoricensis, 302,310

Thyana striala, 302, 312

THYWHLA EA CEAE. 980

ti caïmite, 436

ti feuilles, 412

tibet, 15,146

tibet, giant, 161

tilief-tree, 148

tie-tongue, 80

tiger-tongue, 208

tinacio, 252

tinajero, 412, 428

tinta, 300

tintero,, 720

tintillo, $\mathbf{5 2 0}$

tiñadientes, 512 tira-jala, 64

tiraco, 160

titi. 298

titi, white, 295

tobacco, wild, 4S8

tolililo, 280

tocu-toco, 502

twekoeli, 386

tooshe-flower, 498

(o) $), 336$

toporite, 130

torreh, blatck, 116

torch. white, 216

torchwoud, 216,236

trrchwood, sweet, 116

torito, 462

toronja, 224

Torruluia discolor, 92

Torrubia fragrans, 92

tortolero, 58

tortolito, 370

tortugo amarillo, 12, 454

tortugo colorado, 454

tort tiguero, 260

tortuguillo 504

tostado, 366, 372

totumbo, 492

tot umillo, 486

tot umo, 492

Traxicudendron, 290

tree-fern, 28

TREE-FERN FAMILY, 29

trema, Florida, 58

trema, Lamarck, 56

Trema lamarekiana, 56

Trema micrantha, 58

trema, West Indies, 56

trible-grape, 84

Trichilia hirta, 242, 252

Trichilia pallida, 14, 242, 254

Trichilia spondioines, $2 \pi 4$

Trichiliu Iriucantha, 254

triplaris, 86

Triplaris americana, 76, 86

Triplaris caracasana, 86

Triplaris cumingiana, 86

tromleto, 246

trompillo, 190. 246, 2.54

tronador, 278

tronadora, 502

tropicat-almond, 394

trumpet-flower, 5ellow, 50:

trumpet, mountain, 428

irumpet-tree, 66,68

trumpet-tree, pink, 498

trumpet-tree, shield-shaped, 6 \% trumpet-wood, 68

trupilto, 16s

tuchima. 526

tuctumo, 336

tulipán africano, 15, 494

tulipán clel .Jajón, 328

tuliptree, 330

tuliptree, African, 494

tulpenboom, 494

tumbarabu, 1 iv 6

tuna. 378

tuna de petate, 378

tuna de yagua, 378

turagua, 98

turpentine-tree, 236,238

Turpinia paniculata, 14, 300

turtle-bough, green, 392

tutumo, 492

uaxim, 156

úcar, 388

ucariviro, 282 
ule, (it

ule-ule, $6 t$

$\left.I^{r} L W+r^{\prime} E.\right] E, 56$

unbrella-tree, 248

una de calora, 144

uña de gato, 162

urape, 170

urelo, 16it

uruazeiro, 406

urucni, 3.5

11 $16,5,82$

ura caleta, 82

uva cinarrona. 76

ura de mar. 8:3

ura de jaloma, 7 (i

uva de playa, 12, 82

uvera, so

lverillo, 76,80

uvero, 82

urero de monte, 76

uvilla, 76,80

uvilla de sierra. 76

urillon, 80

Taclellia farnesiama, 144

raillant garçon, 234

vaquero, 426

rara blanea, 58

varia, 468

varía colorada, 468

varia colorado, 468

varia prieta, 465

vario, 3.50

varital, 268

varital variable, 170

relvet-berr., .514

relvet, blark, 316

velvetseed, rough, 514

velvetseed, roughleaf, 514

renaco, is

vencedor, 118

veri. 214

VERBENA FAMILY, 476

I"ERPENACEAE,476

rerdecito, 372

verdiseco, 424

vi-apple, 292

ribona, 426

vibora, 426

vicho caspi, 412

vielle fille, 148

violet-tree, 260

violet-tree, Puerto lican, 2000

violeta, 248,260

Vitex divaricata, 14, 476,486

vito, 512

vinderbloem, 170

vonit, buck, 246

wata gre-gwe, 206

waiki-pine, 216

Wijakaa maatsjoe, 214

wakoera, 520

wanasoro, 68

waraia, 422 warimiri, 298

watakeeli, 466

wat rabebé. 206

พryacã, 212

wayaka shiıarón, 214

weedee, 30

Weinmannia pinuata. 14, 138

West-1udian-alnond. 394

West-1ndian-birch, 23 ?

West-Indin-cherrs, 470

Test-Indian-elm, 340

West-Indian-gooseherry, 280

West-1ndian-lilac, "24s

West-Indian-locust, 178, 180

West-1ndian-sumac, 136;

West-Indies-cedar, 244

West-Indies-elon, 148

whistling-bean. 148

whistling-pine, 48

white-beech 456

white-box, 456

white-cedar, 498

white-cliank, 466

wlite-grape, 81

white-mangrove, $392,476,478$

white-prickle, 230

whitewood, 1202, 4.) 4,498

Wickstroemia portoriennsis. 346

wild-cherry, 25: 30 (fi

wild-coffee, $234,316,368,370,510,516$

wild-cotton, 360

wild-dilly, 446

wild-fig, 352

wild guave, 514

wild-mamee, 3.50

wild-mammee, 352

wild-plum, 280, 294, 29,

wild-sage, 370

wilde amandel, 394

willow, it

W11LOW FAMITY, 54

willow, Humboldt, 54

willow, weeping, 48

llintrana cancila, 362

witte mangel, 390

woman's-tongue. 148

wonder-tree, 180

xilc-chum, 442

Finthroxylum, see Zanthoxylum, 22s

хауан, 358

ralua, 190

ralia colorada, 190

rabo, 180

raci de cuero, 58

yaco-huito, 512

vacure, 162

Tagruma, 68

vagruma bembra, fos

Fagrume, 428

xagrumo, 68

yagrumo hembra, 66,68

yagrumo macho, 68,428

yaiti, 272

xiา magua, 246
Famao, 246

yana, 390

rana-caspi, 58

yanilla, 298

Finue, $16 \mathrm{~s}$

sares, 46

yalumero, 428

ya $5 \mathrm{a}, 108$

гaรo, 282

rellow-blossom, 502

sellow-cedar, 502

Fellow-elder, 502

yellowheart, 228

Yellow-plum, 294

yellow-prickle, 230, 232

Fellow-prickly, 232

yellow-sanders, 228

rellow-torch, $50 \mathrm{~s}$

yellow-trumpet, 502

sellow-trumpet, Florida, 502

yelowwood, 228

requiti, 30s

Jerbil di tonka, 198

YEW FAHILY, 30

ylang-ylang, 106

roke, sarannah, 158

I0100, 158

51100, 2.5

yuco rínonn, 136

suquillo, 252

zaboca, 128

zambo cedro, 246

Zamin, 30

zandkokerboom, 278

zanmande, 394

Zanthoxylum caribarmm, 228

Zanthoxylum flavum, 13, 216, 228

Zanthoxylum martinicense, 13, 216 230

Zanthoxylum monophyllum, 216, 232

zanlhorylum punctatum, 22s

zaxpatero, $182,30^{\circ}$

zaplo ton, 428

zilpatón blanco, 208

zatpatón rojo, $20 \mathrm{~s}$

zalpote, 446

zapote blanco, 208

zapote chico, 446

zajote colorado, 446

zapote namey, 354

zapote de costa. 44

zalpote de niño, 354

zapote de Santo Domingo, 354

zajote morado, $\mathbf{H 6}$

zapotillo, 46

zoracosa, 390

zarcilla, 156

zehrawood, 132

zeedleifi, 82

zoedruif, 82

zic, 132

zopilote, 160

zorra. $16 t$

zuurzak. 100

ZYGOPHYLLACEAE, 214 



